\title{
Environmental Monitoring Report
}

Quarterly Report (January - March 2014)

April 2014

\section{VIE: Greater Mekong Subregion Kunming-Hai Phong Transport Corridor Noi Bai- Lao Cai Highway Project}

Prepared by Getinsa for the Vietnam Expressway Corporation, the Ministry of Transport, the Government of Viet Nam, and the Asian Development Bank 


\section{CURRENCY EQUIVALENTS}

(as of 1 April 2014)

$\begin{array}{rll}\text { Currency unit } & - & \text { dong }(D) \\ \text { D1.00 } & = & \$ 0.0000474 \\ \$ 1.00 & = & D 21,080\end{array}$

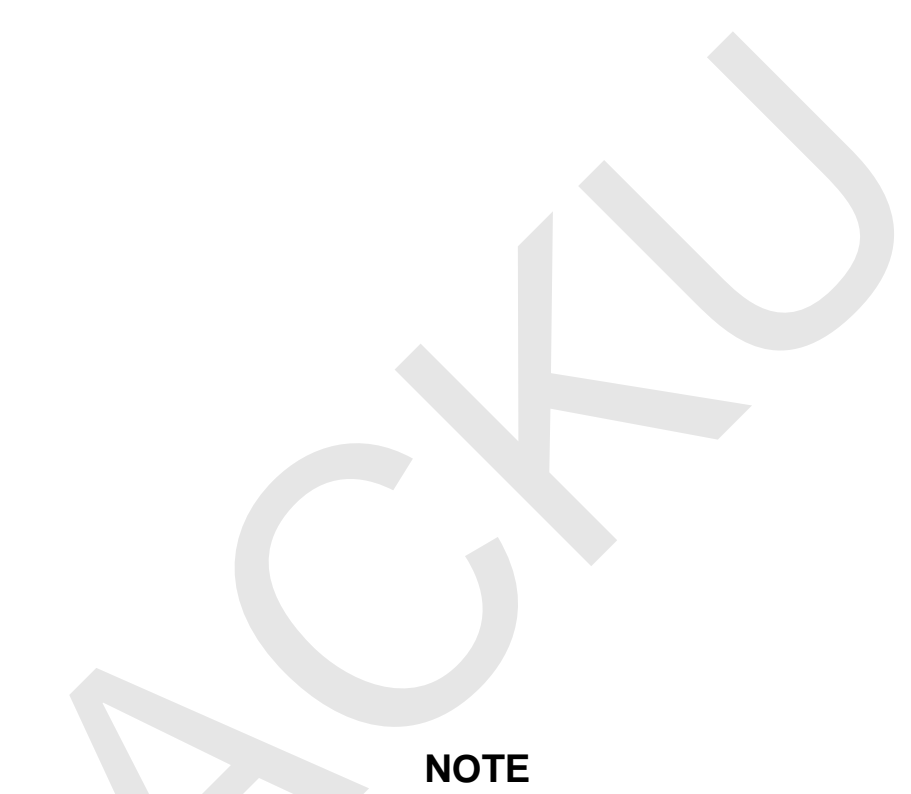

In this report, "\$" refers to US dollars unless otherwise stated.

This environmental monitoring report is a document of the borrower. The views expressed herein do not necessarily represent those of ADB's Board of Directors, Management, or staff, and may be preliminary in nature.

In preparing any country program or strategy, financing any project, or by making any designation of or reference to a particular territory or geographic area in this document, the Asian Development Bank does not intend to make any judgments as to the legal or other status of any territory or area. 
Loan 2391/2392 - VIE: GMS Kunming - Hai Phong Transport Corridor Noi Bai - Lao Cai Highway Project

\section{ENVIRONMENTAL, HEALTH AND SAFETY QUARTERLY REPORT}
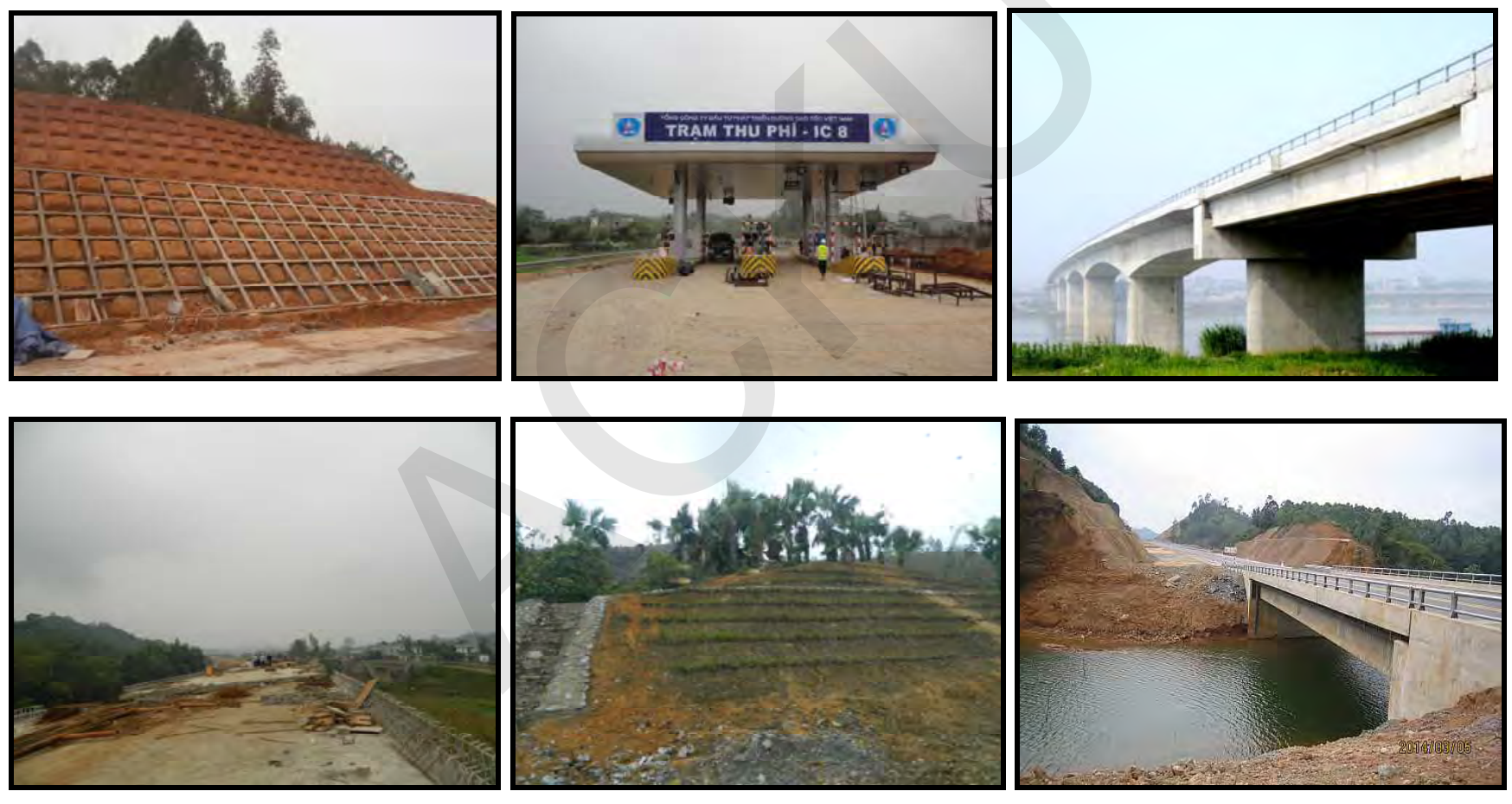

JANUARY - MARCH 2014 
getinsa

ER

Loan 2391/2392 - VIE: GMS Kunming - Mai Phony Transport Corridor No Bail - Lao Cai Highway Project 


\begin{tabular}{|c|c|c|}
\hline getinsa & $\begin{array}{c}\text { Loan 2391/2392 - VIE: GMS Kunming - Hai Phong Transport Corridor } \\
\text { Noi Bai - Lao Cai Highway Project }\end{array}$ & GETCT-TR- \\
& EN \\
\hline
\end{tabular}

\title{
ENVIRONMENTAL, HEALTH AND SAFETY QUARTERLY REPORT
}

\author{
JANUARY - MARCH 2014
}

\begin{tabular}{|l} 
Written by: Sergio Mata Gallego \\
\hline Approved by: Francisco Javier de Bonifaz
\end{tabular}

GETINSA INGENIERÍA S.L.

April 2014 
getinsa

TDEISTRADA ISO IAOO1

Loan 2391/2392 - VIE: GMS Kunming - Hai Phong Transport Corridor Noi Bai - Lao Cai Highway Project

1 
Loan 2391/2392 - VIE: GMS Kunming - Hai Phong Transport Corridor Noi Bai - Lao Cai Highway Project

\section{INDEX}

0. SUMMARY

1. INTRODUCTION. FRAMEWORK OF THE REPORT 7

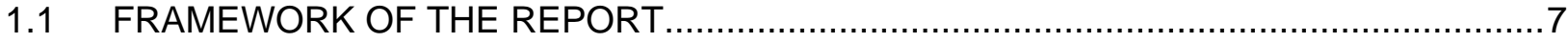

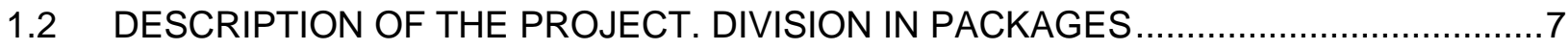

2. CONSTRUCTION WORKS PROGRESS DURING THE PERIOD 11

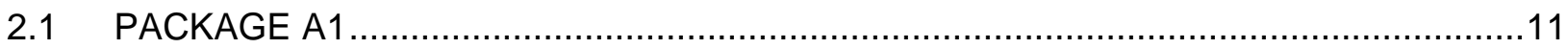

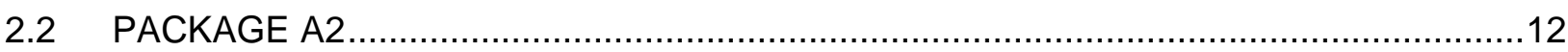

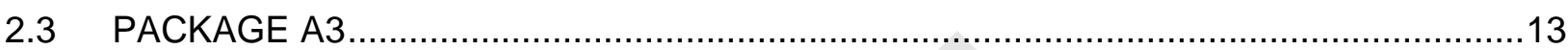

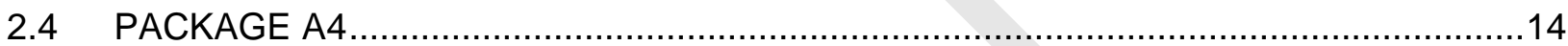

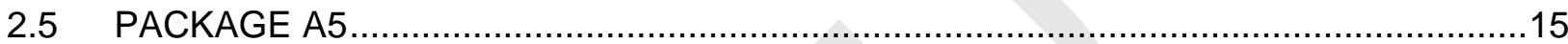

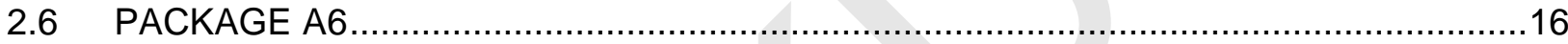

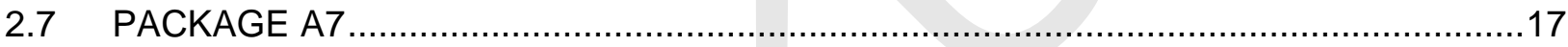

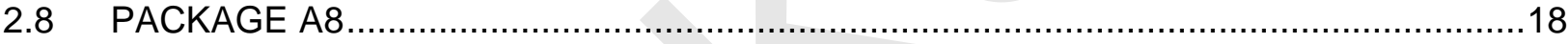

3. CARRIED OUT TASKS DURING THE PERIOD 19

4. ENVIRONMENTAL MONITORING RESULTS. COMPLEMENTARY MEASURES TO BE APPLIED

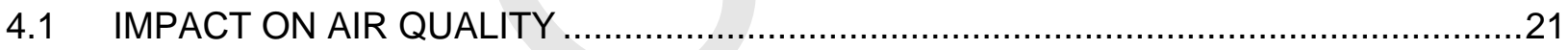

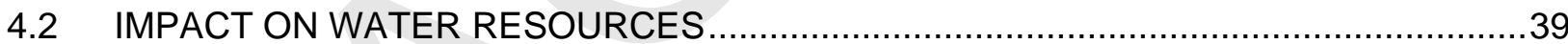

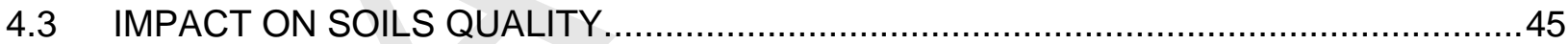

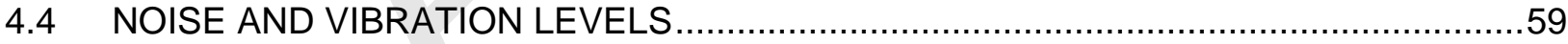

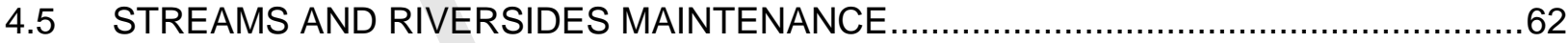

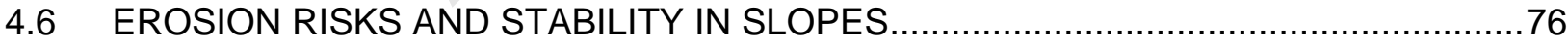

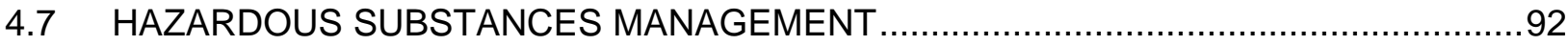

4.8 UNSUITABLE MATERIAL DISPOSALS AND BORROW PITS ….............................103

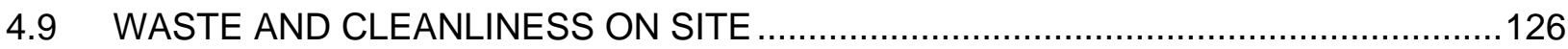

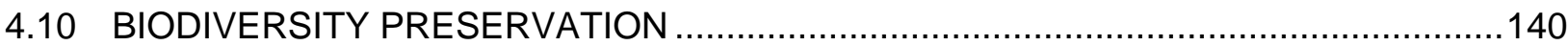

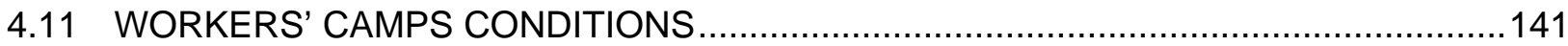

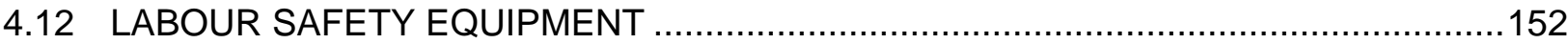

4.13 TRAFFIC CONDITIONS AND SIGNPOSTING IN ROADS ....................................169

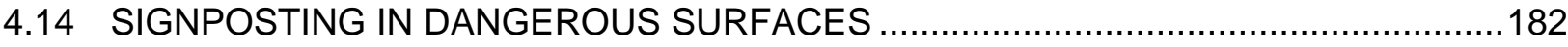

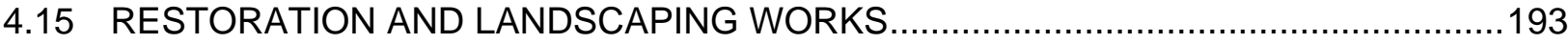

4.16 ACCIDENTS DUE TO THE LACK OF SAFETY MEASURES. RESPONSIBLES..........195 


\section{Loan 2391/2392 - VIE: GMS Kunming - Hai Phong Transport Corridor Noi Bai - Lao Cai Highway Project}

4.17 CONTRACTORS' ENVIRONMENTAL AND SAFETY SPECIALISTS MOBILIZATION 196

5. REFERENCE DOCUMENTS RELATIVE TO ENVIRONMENT, HEALTH AND SAFETY ISSUES 198

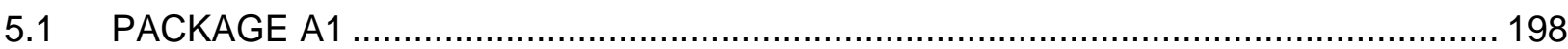

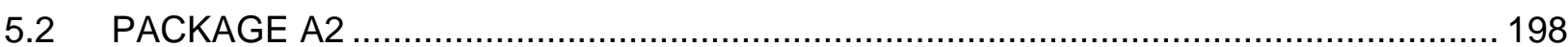

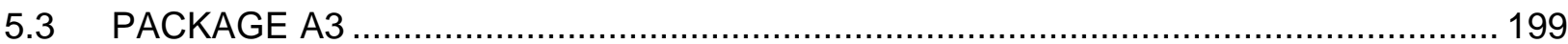

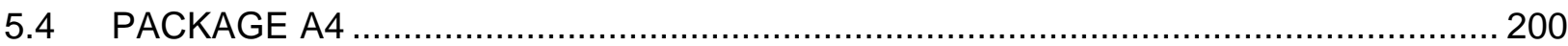

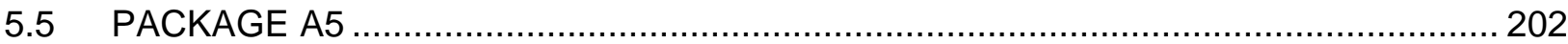

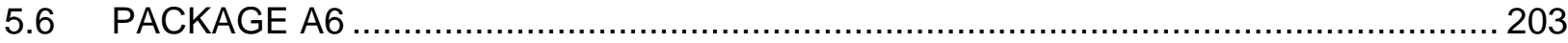

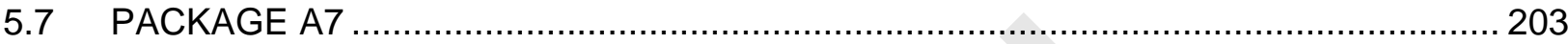

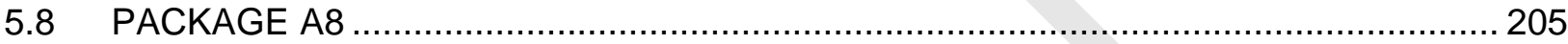

6. GRIEVANCE INTAKES. PUBLIC CONSULTATION 206

ANNEX 1: COMPLAINTS OF LOCAL PEOPLE. SUMMARY TABLE 208

ANNEX 2: DATA OF ENVIRONMENTAL QUALITY PARAMETERS ANALYSIS 224

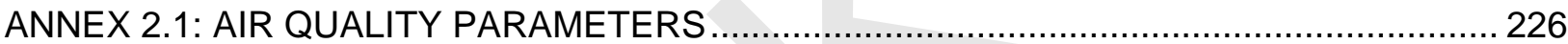

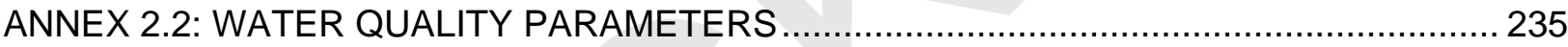

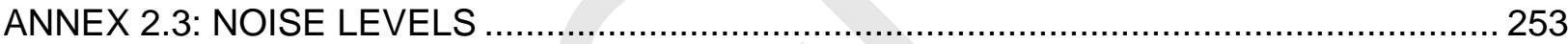

ANNEX 3: DOCUMENTATION RECEIVED FROM CONTRACTORS DURING THE PERIOD 266 ANNEX 4: STATUS OF THE DOCUMENTATION RELATED TO BORROW PITS, QUARRIES, SOIL DISPOSALS AND CONCRETE BATCHING PLANTS 272

ANNEX 5: SUMMARY TABLE OF IMPOSED PENALTIES

ANNEX 6: RESTORATION PLANS AT DISPOSALS 190+420, 195+500, 208+890 AND 209+800. PACKAGE A7

ANNEX 7: SLOPE PROTECTION AND RESTORATION PLAN AT STRETCH KM 195+350 KM 195+500. PACKAGE A7

ANNEX 8: RESTORATION PLANS FOR XUAN PHUONG AND TAN LOI RIVERS. SECOND PROPOSAL. PACKAGE A1

ANNEX 9: DOCUMENTATION RELATED TO COMPLAINTS AND COMPENSATION ACTIVITIES DUE TO SOCIAL IMPACTS 
Loan 2391/2392 - VIE: GMS Kunming - Hai Phong Transport Corridor Noi Bai - Lao Cai Highway Project

\section{ABBREVIATIONS}

\begin{tabular}{|l|l|}
\hline ADB & Asian Development Bank \\
\hline EIA & Environmental Impact Assessment \\
\hline EPMU & Expressway Project Management Unit \\
\hline EHSMR & Environmental, Health and Safety Monthly Report \\
\hline EHSQR & Environmental, Health and Safety Quarterly Report \\
\hline EHSWIR & Environmental, Health and Safety Weekly Inspection Report \\
\hline MONRE & Ministry of Natural Resources and Environment \\
\hline MOT & Ministry of Transport \\
\hline NB-LC & Noi Bai - Lao Cai \\
\hline NS & National Specialist (environmental) \\
\hline PPE & Personal Protection Equipment \\
\hline PSC & Project Supervision Consultant \\
\hline SMR & Safety Monitoring Report \\
\hline TOR & Terms Of Reference \\
\hline VEC & Vietnam Expressway Corporation \\
\hline KPH & Not detected \\
\hline
\end{tabular}




\section{SUMMARY}

Environmental, Health and Safety Control and Protection: Environmental, Health and Safety inspections continued being regularly carried out in weekly basis to monitor impacts due to works and the implementation of mitigation measures. Specific monthly reports, which are submitted to EPMU, and a quarterly report, which is submitted to the Client and to ADB, were prepared for all packages concerning the supervision and control of the above mentioned issues, as regular reporting procedure established by the PSC, increasing the duties specified in our Contract in order to improve the monitoring and control processes. Also, short weekly check lists are prepared after each inspection on site in order to maintain the information constantly updated.

The general main problems and impacts on site along the entire Project this first quarter 2014 have been very similar to the previous periods, and may be summarized as below:

\section{Cleanliness, healthy conditions}

- Lack of cleanliness at some construction sites. Waste materials are not generally properly stored. However, in the last three months it has been noticed some improvements in the management of this matter by the contractors.

- This quarter, most of worker camps were improving, little by little, the cleanliness and the sanitary conditions. In any case, they must continue in this line. Packages A3, A4 and $A 6$ must clearly improve this issue.

Noise \& Air Pollution

- Due to the dry season, much dust was generated on site and local roads. The causes are: not enough water spraying activities and trucks for earthworks operating without being covered. In Packages A2, A5, A6, A7 and A8 some watering trucks were regularly seen spraying water. Packages $A 3, A 4, A 5$ and $A 6$ must clearly improve this issue. The Engineer continually requests contractors to improve these activities.

- Mitigation measures to alleviate the increase of noise level were introduced in some locations, avoiding noisy night works near houses. 


\section{Loan 2391/2392 - VIE: GMS Kunming - Hai Phong Transport Corridor Noi Bai - Lao Cai Highway Project}

Soil pollution and erosive processes. Hazardous substances management

- Soil landslide continued happening in some slopes and several riverbanks, due to the rain water and the lack of protection for the new surfaces at many locations. Specially, in packages $A 2, A 3$ and $A 4$, soil landslide happened in some sections. Currently, Contractor almost solved this problem satisfying local people and authorities.

- In package $\mathrm{A} 1$, Contractor planted grass in more than $80 \%$ of planting areas and the plantations are kept in good maintenance. Contractor in Package A3 planted grass in more than $70 \%$ of cutting slope areas. In package A6, planting works are very advanced. In package A7, Contractor planted grass in more than $80 \%$ of planting areas. Contractor in Package A8 has planted grass in more than 50\% of embankment slope areas. The Engineer has requested to increase the grassing works, suggesting contractors the most adequate method to do it.

- The storage and management of oil, fuel, waste oil and other hazardous substances is showing some deficiencies, although the impact on soils due to spills may be recognized that is lower than in previous quarters. However, oil and waste oil was seen on the ground at store place at Km 209+800 (package A7). Package A7 must clearly improve this issue.

Rivers protection, water quality

- According to the results of the water quality monitoring activities, it can be considered, in general, that Contractors are taking care of this matter despite some punctual affectations. Water quality is not being significantly affected by the project activity, according to the results of the monthly analytics. Especially, Contractor did not provide any septic tank in the toilet at the workers' camp at Km209 + 800 (Package A7). However, the Contractor has demobilized this workers' camp since February, 2014.

- Some riversides, especially in package A1 (Tan Loi and Xuan Phuong bridges, present erosion processes due to temporary crossing accesses or piers construction. Until now, Consultant has approved the restoration plans of Contractor for these cases. But Contractor delays restoration works. At the unauthorized disposal places that are near the Red river such as Km165+500 in package A6; Chau Que Thuong bridge, Km190+420; Km195+500; Km208+890 and Km209+800 in package A7 the Engineer 
Loan 2391/2392 - VIE: GMS Kunming - Hai Phong Transport Corridor Noi Bai - Lao Cai Highway Project

has approved the restoration and slope protection plans and the Contractor will start the correction work in next months.

\section{Cement Batching Plants}

- CBPs were improved in this Quarter, installing or improving settling ponds and other protective measures. In the first quarter of 2014, settling ponds of Cement Batching Plants were well dredged regularly.

\section{Safety conditions}

During this Quarter remained some of common issues in safety, including:

- Workers do not use full PPEs at work in some locations such as Km 46+900, $\mathrm{Km} 36+700$ and $\mathrm{Km} 45+500$ (A2); Km52+100, IC8 bridge and IC8 bridge (A3); Km98+239, Ngoi Van bridge (A4); Up-box culvert Km129, Ngoi Rao bridge, Up-box culvert Km146, Km136, Ngoi Gua bridge (A5); Km199+960, Km209+690, Km195+800, Km202+700, Km199+900, Km207+936, Km209+690, Km199+000 (A7), Km236+900, $\mathrm{Km} 244+300, \mathrm{Km} 231+800$ (A8).

- At some locations, fences are missed or deteriorated and endangers the road users such as Red river bridge, TL325B bridge (A3), TL321C Bridge, Km94+340, Km109+100 (A4), Km191+100, Km195+500, Km204+400 and Tan Tien Bridge Km209+329 (A7).

- Some existing roads are flooded with mud and dirtiness such as TL325B bridge (A3), TL321C bridge, QL32C, Ngoi Lao bridge (A4), Km131, Km156 (A5), Km195+500 (A7).

Specific safety problems at specific locations include:

- Lack of safety net under launched girders and safety work way in Ngoi Gianh and Ngoi Van Bridges.

- Risk of landslide on slopes such as at Km42+400 Km43+000 (A2), Km53+150 (A3), $\mathrm{Km} 80+750, \mathrm{Km} 82+000$ (A4), Km215+200 (A7), Km228+100 (A8).

- At fuel stocking areas, usually no safety fences and signboards, although fire extinguishers were provided in many storages. 
Loan 2391/2392 - VIE: GMS Kunming - Hai Phong Transport Corridor Noi Bai - Lao Cai Highway Project

However, also some improvements should be remarked in this report, as below:

- Electric system is maintained in safety condition.

- In the most dangerous locations, such as structures, workers are mostly provided with safety equipment (PPE).

- Scaffolds in piers were improved as well as safety nets were installed in several bridges, as the Engineer required, improving safety in high works.

Several fences and warning signals were installed in sites when the working surfaces are beside local roads and sensitive locations. However, there are locations where no signalling has been installed yet. The Consultant has requested the contractors to fully complete the safety signalling. 


\section{Loan 2391/2392 - VIE: GMS Kunming - Hai Phong Transport Corridor Noi Bai - Lao Cai Highway Project}

\section{INTRODUCTION. FRAMEWORK OF THE REPORT}

\subsection{FRAMEWORK OF THE REPORT}

Within the framework of the Environmental Control Plans proposed by the contractors and the duties of the Consultant (PSC) in this matter contained in the Consulting Services Contract, the environmental team of national specialists (NS) in charge of inspecting the environmental conditions of the works for the new highway, have done weekly inspections along the sites and surroundings of all the Packages which nowadays are all with construction activities, checking the environmental measures applied by the constructors and detecting any impacts that could be generated by the building works during the period of reference of this quarterly report, that means, January, February and March 2014.

The results were already included in the environmental, health and safety weekly inspection reports (EHSWIR) and the corresponding monthly reports for each package (EHSMR). The Weekly Reports have been included in the corresponding Monthly Reports. So, it's considered not necessary or useful to include again that information in this document.

As the environmental team, therefore under its responsibility, is also in charge of monitoring the healthy and safety conditions in site, specialists in site offices also have made weekly inspections in all packages. Their results have been being included in the mentioned monthly reports, as nowadays all these issues have been joined in only one report. Therefore these issues are also included in this quarterly report.

So, this document is defined as Environmental, Health and Safety Monitoring Quarterly Report (hereinafter called EHSQR). It will be submitted to the Client, Vietnam Expressway Corporation (VEC), through the Expressway Project Management Unit (EPMU) and following the Terms of Reference (ToR) of the Consultant's Contract, also to Asian Development Bank (ADB).

\subsection{DESCRIPTION OF THE PROJECT. DIVISION IN PACKAGES}

Noi Bai - Lao Cai (NB-LC) Highway is a part of Kunming - Hai Phong Transport Corridor, which has been studied with a total length of $865 \mathrm{Km}$ passing Yunnan province of China and Lao Cai, Yen Bai, Phu Tho, Vinh Phuc, Ha Noi, Bac Ninh, Hai Duong, Quang Ninh and Hai Phong provinces of Vietnam. 


\section{Loan 2391/2392 - VIE: GMS Kunming - Hai Phong Transport Corridor Noi Bai - Lao Cai Highway Project}

Vietnam Expressway Corporation, which is a state owner company, is the proposer of this project. Its executing agency is the Ministry of Transport (MOT), and it's being financed by Asian Development Bank (ADB) and the Government of Vietnam.

According to original design, NB - LC Highway has a total length of about $262.4 \mathrm{~km}$, passing through 72 communes and 18 districts of provinces and cities as Ha Noi, Vinh Phuc, Phu Tho, Yen Bai and Lao Cai.

The construction of project is divided into two phases, in which the first phase will construct 244 km with 4 lanes from Ha Noi to Yen Bai and 2 lanes from Yen Bai to Lao Cai. The second phase will be the widen section of the former with 6 lanes from $\mathrm{Ha}$ Noi to Yen Bai and 4 lanes from Yen Bai to Lao Cai (Chinese border, $262 \mathrm{~km}$ ).

Construction of the whole project, first phase, is divided into 8 packages including $A 1, A 2, A 3$, A4, A5, A6, A7 and A8. All of them have already begun their construction activities. The length, location and the status of works in each package at the end of the period are described in the following paragraphs and tables.

- $\quad$ Package A1 is about $26.630 \mathrm{~km}$ of length with start point at station $\mathrm{Km} \mathrm{0+070} \mathrm{and}$

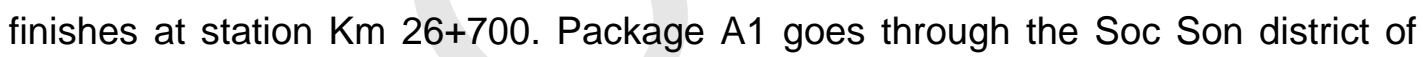
Hanoi City and Vinh Phuc province.

- Package A2 is about $22.120 \mathrm{~km}$ of length and goes through the Vinh Phuc province and a little of Phu Tho province. Package A2 has start point at station Km 26+700 and finishes at station $\mathrm{Km} \mathrm{48+820.} \mathrm{It} \mathrm{must} \mathrm{cross} \mathrm{over} \mathrm{Lo} \mathrm{River,} \mathrm{with} \mathrm{a} \mathrm{long} \mathrm{bridge.}$

- $\quad$ Package A3 is about $32.240 \mathrm{~km}$ of length with start point at station $\mathrm{Km} 48+360$ and ending point at station $\mathrm{Km} \mathrm{80+00.} \mathrm{Package} \mathrm{A3} \mathrm{goes} \mathrm{through} \mathrm{the} \mathrm{Phu} \mathrm{Tho} \mathrm{province.}$ The most significant structure is the bridge to cross over Red River.

- $\quad$ Package A4 has start point at Km 80+000 in Cam Khe district, Phu Tho province and ending point at $\mathrm{Km} 109+750$ in Tran Yen district, Yen Bai province. Its total length is $29.750 \mathrm{~km}$.

- Package A5 has start point at Km109+750 in Tran Yen district, Yen Bai province and ending point at Km150+900 in Van Yen district, Yen Bai province. Its total length is $41.150 \mathrm{~km}$. 
Loan 2391/2392 - VIE: GMS Kunming - Hai Phong Transport Corridor Noi Bai - Lao Cai Highway Project

- Package A6 lengthens from start point Km150+900 of Van Yen district, Yen Bai province to Km190+420 in Van Ban district, Lao Cai province. Its total length is $39.520 \mathrm{~km}$. Almost alignment goes through high mountains in Yen Bai and Lao Cai province and crosses over natural streams by 18 bridges. This section also includes 1 tunnel under range of mountain at Km186+500.

- Package A7 lengthens from start point $\mathrm{Km190+420} \mathrm{in} \mathrm{Van} \mathrm{Ban} \mathrm{district} \mathrm{to} \mathrm{Km}$ 218+040 in Bao Thang district, Lao Cai province. Almost alignment also goes through high mountains and 18 bridges are needed. Its total length is $27,620 \mathrm{~m}$. Khe Sang bridge with a length of $287 \mathrm{~m}$ is the biggest one.

- Package A8 begins at station $\mathrm{Km} \mathrm{218+040} \mathrm{in} \mathrm{Bao} \mathrm{Thang} \mathrm{district} \mathrm{and} \mathrm{finishes} \mathrm{at} \mathrm{Km}$ $244+155$ in Bao Thang district, Lao Cai province. Its total length is $26,115 \mathrm{~m}$. Suoi Trat bridge with a length of $374.8 \mathrm{~m}$ is the biggest one.

Table 1.1: Current status of the works at the end of this quarter (\%)

\begin{tabular}{||l|c|c|c|c||}
\hline \multicolumn{1}{|c|}{ Activity } & A1 & A2 & A3 & A4 \\
\hline Site clearing & 100 & 100 & 100 & 93,41 \\
\hline Earthworks & 100 & 99,19 & 100 & 84,56 \\
\hline Drainage & 88,99 & 50,88 & 62,55 & 58,40 \\
\hline Structures (1) & 100 & 100 & 100 & 91,96 \\
\hline Steel works & 100 & 89,89 & 53,42 & -- \\
\hline Asphalt & 99,99 & 92,94 & 27,58 & -- \\
\hline Grassing & 97,28 & 64,67 & 94,81 & 6,32 \\
\hline Overall progress & 99,72 & 93,22 & 83,54 & 58,53 \\
\hline \multicolumn{1}{|c|}{ Activity } & A5 & A6 & A7 & A8 \\
\hline Site clearing & 100 & 93,09 & 100 & 100 \\
\hline Earthworks & 76,34 & 98,37 & 99,49 & 99,27 \\
\hline Drainage & 65,91 & 53,95 & 90,84 & 81,60 \\
\hline Structures (1) & 84,66 & 98,80 & 100 & 100 \\
\hline Steel works & -- & 25,53 & 62,43 & 100 \\
\hline Asphalt & 1,19 & 22,76 & 100 & 90,91 \\
\hline Grassing & Unknown & 19,39 & 91,81 & 9,53 \\
\hline Tunnel Construction & -- & 82,76 & -- & -- \\
\hline Overall progress & 56,63 & 83,62 & 97,66 & 96,13 \\
\hline
\end{tabular}

(1) Concrete works 


\section{Loan 2391/2392 - VIE: GMS Kunming - Hai Phong Transport Corridor Noi Bai - Lao Cai Highway Project}

(data expressed in percentage of the total planned in the project, related to the contract quantities).

Currently, 2 packages, Package A1 and Package A8, were already opened to traffic, although some works are still pending. Also, it's foreseen that on April $1^{\text {st }} 2014$, Package A7 will be open to public use. Finally, on April $6^{\text {th }}$, a forth stretch will be open, Package A2 and first part of A3 until interchange IC8 to connect with national road.

The environmental monitoring program is carried out in compliance with regulations of Vietnam Government and ADB safeguard policy in order to control environmental impacts and to ensure that the environment in the surroundings of the project area is well preserved. The VEC proponent should perform environmental protection measures stated in the EIA report as well as requirements written in the approval decision made by MONRE. In accordance with article 23 of the Environmental Protection Law and article 15 of Decree 80/2006/ND-CP, MONRE will organize, direct, and monitor the environmental protection measures performed by VEC as stated in the EIA report approved.

At present, this environmental monitoring program is being undertaken by Environmental specialists of Getinsa hired by Vietnam Expressway Corporation. EPMU, the Project Manager, with the Consultant's support, monitors the environmental protection measures applied by the contractors during the development of their works, incompliance with the environmental control and protection plans proposed by contractors and already approved by the PSC. Consultant reports to EPMU-VEC as the main involved authority in the project.

In addition to that, during the monitoring process, the environmental specialists and contractors will try to find out and mitigate unanticipated environmental impacts arising from the project construction process. 
Loan 2391/2392 - VIE: GMS Kunming - Hai Phong Transport Corridor Noi Bai - Lao Cai Highway Project

\section{CONSTRUCTION WORKS PROGRESS DURING THE PERIOD}

In this chapter, they are included all the works already done or in process during the period, in each package and detailing the section where the works are developed.

\section{$2.1 \quad$ PACKAGE A1}

\begin{tabular}{|c|c|}
\hline \multicolumn{2}{|c|}{ January - February - March } \\
\hline Sec 1: Km 0+900 Km 4+350 & Finished \\
\hline $\begin{array}{l}\text { Sec 2: } \mathrm{Km} \mathrm{0+080} \sim \mathrm{Km} 1+000 \& \mathrm{Km} \\
4+350 \sim \mathrm{Km} \mathrm{7+661}\end{array}$ & Finished \\
\hline Sec 3: Km 7+661 Km 10+771 & Finished \\
\hline Sec 4: Km 10+771 Km15+030 & Finished \\
\hline Sec 5: Km 15+030 Km 18+400 & Finished \\
\hline Sec 6: Km 18+400 Km 21+900 & Finished \\
\hline Sec 7: Km 21+900 Km 23+900 & Finished \\
\hline Sec 8: Km 23+900 Km 26+700 & Finished \\
\hline Underpass NH2 & Finished \\
\hline Kim Anh bridge (Km 1+901.05) & Finished \\
\hline TL402 bridge ( $\mathrm{Km} \mathrm{3+053.55)}$ & Finished \\
\hline Trung Kien bridge (Km 4+491.00) & Finished \\
\hline Dai Duong bridge (Km 7+392.65) & Finished \\
\hline Xuan Phuong bridge (Km 7+660.05) & Finished \\
\hline NTT bridge $(\mathrm{Km} 7+854.7)$ & Finished \\
\hline TL301 bridge (Km 8+761.55) & Finished \\
\hline Tan Loi bridge (Km 10+695.00) & Finished \\
\hline Ba Thien bridge ( $\mathrm{Km} \mathrm{14+026.00)}$ & Finished \\
\hline I.C 3 bridge $(\mathrm{Km} \mathrm{14+590.00)}$ & Finished \\
\hline Bon bridge $(\mathrm{Km} \mathrm{15+107.00)}$ & Finished \\
\hline TL302B bridge (Km 15+825.00) & Finished \\
\hline TL-TK bridge (Km 19+120.05) & Finished \\
\hline TL302CI bridge (Km 19+740.05) & Finished \\
\hline Cam I bridge (Km 21+910.05) & Finished \\
\hline Cam II bridge (Km 21+910.05) & Finished \\
\hline TL302CII bridge (Km 22+480.05) & Finished \\
\hline Army I bridge (Km 23+855.45) & Finished \\
\hline NH2B bridge (Km 24+946.00) & Finished \\
\hline
\end{tabular}


Loan 2391/2392 - VIE: GMS Kunming - Hai Phong Transport Corridor Noi Bai - Lao Cai Highway Project

Currently, some works to round off are ongoing, such as small works on the pavement. Also pending the construction of some toll points

\subsection{PACKAGE A2}

\begin{tabular}{|c|c|}
\hline \multicolumn{2}{|c|}{ January } \\
\hline Army II Bridge (Km 27+015.00) & Finished \\
\hline Army III Bridge (Km 28+010.00) & Finished \\
\hline TL310 Bridge (Km 29+201.00) & Finished \\
\hline Ben Tre Bridge (Km 31+068.00) & Finished \\
\hline Tan Dung Bridge (Km 31+245.05) & Finished \\
\hline Muong Noi Bridge (Km 31+504.50) & Finished \\
\hline TL306I Bridge (Km 33+181.55) & Finished \\
\hline Muong Dao Bridge (Km 33+295.00) & Finished \\
\hline Ben Gao Bridge (Km 35+211.05) & Finished \\
\hline TL305 Bridge (Km 37+951.55) & Finished \\
\hline Song Dao Bridge (Km 38+450.05) & Finished \\
\hline Phung Nguyen Bridge (Km 39+188.00) & Finished \\
\hline Xuan Quang Bridge (Km 41+480.00) & Finished \\
\hline TL306II Bridge (Km 45+834.05) & Finished \\
\hline Lo river Bridge (Km 48+181.30) & Finished \\
\hline Sec 1: Km 26+700 Km 32+700 & Embankment work \\
\hline Sec 2: Km 32+700 Km 35+300 & Embankment work \\
\hline Sec 3: Km 35+300 Km36+910 & Embankment work \\
\hline Sec 4: Km 36+910 Km 39+850 & Embankment work \\
\hline Sec 5: Km 39+580 Km 40+690 & Embankment work \\
\hline Sec 6: Km 40+690 Km 43+400 & Embankment work \\
\hline Sec 7: Km 43+400 Km 45+300 & Embankment work \\
\hline Sec 8: Km 45+300 Km 47+660 & Embankment work \\
\hline \multicolumn{2}{|c|}{ February } \\
\hline Sec 1: Km 26+700 Km 32+700 & Pavement \\
\hline Sec 2: Km 32+700 Km 35+300 & Pavement \\
\hline Sec 3: Km 35+300 Km36+910 & Pavement \\
\hline Sec 4: Km 36+910 Km 39+850 & Pavement \\
\hline Sec 5: Km 39+580 Km 40+690 & Pavement \\
\hline Sec 6: Km 40+690 Km 43+400 & Pavement \\
\hline Sec 7: Km 43+400 Km 45+300 & Pavement \\
\hline Sec 8: Km 45+300 Km 47+660 & Pavement \\
\hline
\end{tabular}


Loan 2391/2392 - VIE: GMS Kunming - Hai Phong Transport Corridor Noi Bai - Lao Cai Highway Project

\begin{tabular}{||l|c||}
\hline \multicolumn{2}{||}{ March } \\
\hline Sec $1: \mathrm{Km} 26+700 \sim \mathrm{Km} 32+700$ & Finished \\
\hline Sec $2: \mathrm{Km} \mathrm{32+700 \sim Km} \mathrm{35+300}$ & Finished \\
\hline Sec 3: Km 35+300 Km36+910 & Pavement \\
\hline Sec $4: \mathrm{Km}$ 36+910 Km 39+850 & Finished \\
\hline Sec 5: Km 39+580 Km 40+690 & Finished \\
\hline Sec 6: Km 40+690 Km 43+400 & Finished \\
\hline Sec 7: Km 43+400 Km 45+300 & Pavement \\
\hline Sec 8: Km 45+300 Km 47+660 & Pavement \\
\hline Army II Bridge $(\mathrm{Km} \mathrm{27+015.00)}$ & Finished \\
\hline Army III Bridge $(\mathrm{Km} \mathrm{28+010.00)}$ & Finished \\
\hline
\end{tabular}

Some small works are still pending on the pavement in several stretches, such as planting in the medium strip, grassing in some slopes and restoration works in external areas.

\subsection{PACKAGE A3}

\section{Bridges:}

\begin{tabular}{|l|l|}
\hline \multicolumn{2}{|c|}{ January } \\
\hline TL 325 B & Drilling bored piles A1 \\
\hline Bai Bang bridge & Parapet and deck slap \\
\hline Cam Phu bridge & Finished \\
\hline Lung Thuong bridge & Finished \\
\hline TL 320 B & Finished \\
\hline HCM IC & Parapet and deck slap \\
\hline Xuan Thanh bridge & Finished \\
\hline TL 315 B & Finished \\
\hline TL 323B & Finished \\
\hline Phai Din bridge & Finished \\
\hline TL 320C & Finished \\
\hline RW Flyover & Casting pier column;casting pier head \\
\hline Red River bridge & Finished \\
\hline IC8 & Launching girder \\
\hline IC10 & Deck slap and parapet \\
\hline CV QL2 & Parapet \\
\hline Phong Chau bridge & Finished \\
\hline \hline
\end{tabular}


Loan 2391/2392 - VIE: GMS Kunming - Hai Phong Transport Corridor Noi Bai - Lao Cai Highway Project

\begin{tabular}{|l|l||}
\hline New Bai Bang (pipe flyover) & Finished \\
\hline \multicolumn{2}{|l||}{ February-March } \\
\hline TL 325 B & Drilling bored piles A1 \\
\hline Bai Bang & Parapet and deck slap \\
\hline HCM IC & Parapet and deck slap \\
\hline RW Flyover & Casting pier column;casting pier head \\
\hline IC8 & Launching girder \\
\hline IC10 & Deck slap and parapet \\
\hline CV QL2 & Parapet \\
\hline
\end{tabular}

Highway:

\begin{tabular}{|c|c|}
\hline \multicolumn{2}{|c|}{ January-February } \\
\hline Section 1: Km48+360-Km54+000 & Subbase; base and asphalt \\
\hline Section 2: Km54+000-Km59+600 & Subbase; base and asphalt \\
\hline Section 3: Km59+600-Km65+390 & Earth work; Subbase \\
\hline Section 4: Km65+390-Km69+070 & Subbase and Base works \\
\hline Section 5: Km69+070-Km73+070 & Subbase and Base works \\
\hline Section 6: Km73+070-Km77+620 & Subbase and Base works \\
\hline Section 7: Km77+620-Km80+000 & Subbase and base works \\
\hline \multicolumn{2}{|c|}{ March } \\
\hline Section 1: Km48+360-Km54+000 & Asphalt \\
\hline Section 2: Km54+000-Km59+600 & Asphalt \\
\hline Section 3: Km59+600-Km65+390 & Subbase and Base works \\
\hline Section 4: Km65+390-Km69+070 & Subbase and Base works \\
\hline Section 5: Km69+070-Km73+070 & Subbase and Base works \\
\hline Section 6: Km73+070-Km77+620 & Subbase and Base works \\
\hline Section 7: Km77+620-Km80+000 & Subbase and base works \\
\hline
\end{tabular}

\subsection{PACKAGE A4}

\section{Bridges:}

\begin{tabular}{||l|l||}
\hline \multicolumn{2}{|c|}{ January } \\
\hline Ngoi Lao bridge $-\mathrm{Km} 97+100$ & Pier Cap working \\
\hline QL32C bypass bridge $-\mathrm{Km} 107+533$ & Prepair for Launching PC slab grider \\
\hline Ngoi Van bridge $-\mathrm{Km} 108+960$ & Pier Cap working \\
\hline
\end{tabular}


Loan 2391/2392 - VIE: GMS Kunming - Hai Phong Transport Corridor Noi Bai - Lao Cai Highway Project

\begin{tabular}{|c|c|}
\hline Dam Nang bridge $-\mathrm{Km} 108+287$ & Foundation, stemwall working \\
\hline TL321C bridge $-\mathrm{Km} 84+400$ & Foundation working \\
\hline Ngoi Gianh bridge - Km88+760 & Pier cap, stemwall working \\
\hline \multicolumn{2}{|c|}{ February-March } \\
\hline Ngoi Lao bridge - Km97+100 & Pier Cap working \\
\hline QL32C bypass bridge $-\mathrm{Km} 107+533$ & Prepair for Launching PC slab grider \\
\hline Ngoi Van bridge - Km108+960 & Pier Cap working \\
\hline Dam Nang bridge $-\mathrm{Km} 108+287$ & Foundation, stemwall working \\
\hline TL321C bridge $-\mathrm{Km} 84+400$ & Foundation working \\
\hline Ngoi Gianh bridge - Km88+760 & Pier cap, stemwall working \\
\hline
\end{tabular}

Highway:

\begin{tabular}{|l|l|}
\hline \multicolumn{2}{|c|}{ January-February-March } \\
\hline Section 1: Km80+000 $-\mathrm{Km85+000}$ & Earth work; Subbase \\
\hline Section 2: Km85+000 $-\mathrm{Km} 89+600$ & Earth work; Subbase \\
\hline Section 3: Km89+600 $-\mathrm{Km} 96+200$ & Earth work; Subbase \\
\hline Section 4: Km96+200 - Km100+000 & Earth work; Subbase \\
\hline Section 5: Km100+000 - Km105+000 & Earth work; Subbase \\
\hline Section 6: Km105+000 $-\mathrm{Km} 109+750$ & Earth work; Subbase \\
\hline
\end{tabular}

\subsection{PACKAGE A5}

\begin{tabular}{|c|c|c|}
\hline \multicolumn{3}{|c|}{ January-February-March } \\
\hline Van Phu bridge $-\mathrm{Km} 114+100.05$ & Structure work & \\
\hline Hop Minh My bridge - Km118+920.05 & Structure work & \\
\hline Ngoi Lau bridge - Km120+615.85 & Structure work & \\
\hline QL 37 bridge $-\mathrm{Km} 121+433.05$ & Structure work & \\
\hline Ngoi Gua bridge - Km128+665.46 & Structure work & \\
\hline Ngoi Rao bridge - Km130+916.30 & Structure work & \\
\hline Ngoi Thu bridge - Km136+108.35 & Structure work & \\
\hline Ngoi Thap bridge - Km138+447.15 & Structure work & \\
\hline Ngoi Vien bridge - Km140+788.50 & Structure work & \\
\hline Xuan Thu bridge $-\mathrm{Km} 141+483.55$ & Structure work & \\
\hline Ngoi Thia bridge - Km145+434.05 & Structure work & \\
\hline Ngoi Buc bridge - Km 150+704.65 & Structure work & \\
\hline $\begin{array}{l}12^{\text {th }} \text { floor, Ocean Park Bu } \\
\text { Huu Thu Hamlet, Kim Lo } \\
\text { Calle Ramón de Aguinag }\end{array}$ & $\begin{array}{l}\text { g Da Distric } \\
\text { hhPhuc Province }\end{array}$ & 15 \\
\hline
\end{tabular}




\section{Loan 2391/2392 - VIE: GMS Kunming - Hai Phong Transport Corridor Noi Bai - Lao Cai Highway Project}

\begin{tabular}{||l|c|}
\hline Section 1: $\mathrm{Km} 109+750-\mathrm{Km} 115+800$ & Excavation \& sub-base work \\
\hline Section 2: $\mathrm{Km} 115+800-\mathrm{Km} 120+000$ & Excavation \& sub-base work \\
\hline Section 3: $\mathrm{Km} 120+000-\mathrm{Km} 125+000$ & Excavation \& filling work \\
\hline Section 4: $\mathrm{Km} 125+000-\mathrm{Km} 130+000$ & Excavation \& filling work \\
\hline Section 5: $\mathrm{Km} 130+000-\mathrm{Km} 136+400$ & Excavation \& filling work \\
\hline Section 6: $\mathrm{Km} 136+400-\mathrm{Km} 142+000$ & Excavation, filling \& sub-base work \\
\hline Section 7: $\mathrm{Km} 142+000-\mathrm{Km} 148+000$ & Excavation \& sub-base work \\
\hline Section 8: $\mathrm{Km} 148+000-\mathrm{Km} 150+900$ & Excavation \& sub-base work \\
\hline
\end{tabular}

\subsection{PACKAGE A6}

\section{January-February}

\begin{tabular}{|c|c|}
\hline Khe Chuong bridge $-\mathrm{Km153+355.05}$ & Structure work \\
\hline Ngoi That bridge - Km155+971.55 & Structure work \\
\hline Ngoi Rom bridge- Km157+517.05 & Structure work \\
\hline Ngoi Cong bridge - Km159+207.85 & Structure work \\
\hline Ngoi Giam I bridge - Km162+896.35 & Structure work \\
\hline Ngoi Giam II bridge - Km163+126.00 & Structure work \\
\hline Ngoi Hut bridge - Km165+110.50 & Structure work \\
\hline Ngoi Chac bridge - Km169+412.00 & Structure work \\
\hline Ngoi Pha bridge - Km170+312.50 & Structure work \\
\hline Suoi Quan bridge - Km173+434.00 & Structure work \\
\hline Ngoi Nhuoc bridge - Km176+661.85 & Structure work \\
\hline Lang Nhay bridge $-\mathrm{Km} 182+164.00$ & Structure work \\
\hline Lang Lau bridge $-\mathrm{Km} 184+057.95$ & Structure work \\
\hline Ngoi Don bridge - Km185+077.75 & Structure work \\
\hline Dai Viet bridge - Km186+902.05 & Structure work \\
\hline Van Xuan bridge $-\mathrm{Km} 187+141.55$ & Structure work \\
\hline Suoi Nau bridge $-\mathrm{Km} 188+766.00$ & Structure work \\
\hline Lang Nheo flyover - Km173+929 & Structure work \\
\hline Section 1: Km150+900 - Km156+000 & Embankment and sub-base work \\
\hline Section 2: Km156+000 - Km162+000 & Base and sub-base work \\
\hline Section 3: Km162+000 - Km165+000 & Embankment and sub-base work \\
\hline Section 4: Km165+000 - Km168+000 & Embankment and sub-base work \\
\hline Section 5: Km168+000 - Km172+000 & Excavation \& filling work \\
\hline Section 6: Km172+000 - Km176+713 & Excavation \& filling work \\
\hline
\end{tabular}


Loan 2391/2392 - VIE: GMS Kunming - Hai Phong Transport Corridor Noi Bai - Lao Cai Highway Project

\begin{tabular}{|c|c|}
\hline Section 7: Km176+713- Km182+214 & Excavation \& filling work \\
\hline Section 8: Km182+214 - Km186+200 & Embankment and sub-base work \\
\hline Section 9: Km186+730 - Km190+420 & Embankment and sub-base work \\
\hline Tunnel (Km 186+200 - Km 186+730) & Electric system works \\
\hline \multicolumn{2}{|c|}{ March } \\
\hline Section 1: Km150+900 - Km156+000 & Embankment and sub-base work \\
\hline Section 2: Km156+000 - Km162+000 & Base and sub-base work \\
\hline Section 3: Km162+000 - Km165+000 & Embankment and sub-base work \\
\hline Section 4: Km165+000 - Km168+000 & Embankment and sub-base work \\
\hline Section 5: Km168+000 - Km172+000 & Embankment and sub-base work \\
\hline Section 6: Km172+000 - Km176+713 & Base and sub-base work \\
\hline Section 7: Km176+713 - Km182+214 & Embankment and sub-base work \\
\hline Section 8: Km182+214 - Km186+200 & Embankment and sub-base work \\
\hline Section 9: Km186+730 - Km190+420 & Embankment and sub-base work \\
\hline Tunnel (Km 186+200 - Km 186+730) & Electric system works \\
\hline
\end{tabular}

\subsection{PACKAGE A7}

\begin{tabular}{|l|c|}
\hline \multicolumn{2}{|c|}{ January } \\
\hline Khe Sang Brdge & On going complete \\
\hline Khe Can Bridge & On going complete \\
\hline Tan Tien Bridge & On going complete \\
\hline Thin Thung I Bridge & On going complete \\
\hline Tan An Bridge & On going complete \\
\hline Xom Danh Bridge & On going complete \\
\hline Ram All Bridge & On going complete \\
\hline Xom Cam Bridge & On going complete \\
\hline Ngoi Bong Bridge & On going complete \\
\hline Tan Thuong Bridge & On going complete \\
\hline Khe Hong Bridge & On going complete \\
\hline Cam Con Bridge & On going complete \\
\hline Chau Que Rhuong Bridge & On going complete \\
\hline Ram B Bridge & On going complete \\
\hline Section1: Km190+420-Km201+000 & On going complete \\
\hline Section2: Km201+000-Km207+000 & Construction asphalt layers; Aggregate \\
\hline
\end{tabular}


Loan 2391/2392 - VIE: GMS Kunming - Hai Phong Transport Corridor Noi Bai - Lao Cai Highway Project

\begin{tabular}{||l|c||}
\hline Section3: Km207+000-Km218+040 & $\begin{array}{c}\text { Construction asphalt layers; Aggregate } \\
\text { subbase; Aggregate base }\end{array}$ \\
\hline Section1: $\mathrm{Km} 190+420-\mathrm{Km} 201+000$ & $\begin{array}{c}\text { February-March } \\
\text { Subbase; Aggregate base }\end{array}$ \\
\hline Section2: $\mathrm{Km} 201+000-\mathrm{Km} 207+000$ & On going complete \\
\hline Section3: $\mathrm{Km} 207+000-\mathrm{Km} 218+040$ & $\begin{array}{c}\text { Construction asphalt layers; Aggregate } \\
\text { subbase; Aggregate base }\end{array}$ \\
\hline
\end{tabular}

\subsection{PACKAGE A8}

\begin{tabular}{||l|c||}
\hline \multicolumn{2}{|c|}{ January, February-March } \\
\hline IC18 Bridge & On going complete \\
\hline Suoi Trat Bridge & On going complete \\
\hline Ngoi Bo Bridge & On going complete \\
\hline Suoi Nhu Bridge & On going complete \\
\hline Lang Tra Bridge & On going complete \\
\hline IC17 Bridge & On going complete \\
\hline Son Ha Bridge & On going complete \\
\hline Son Hai Bridge & On going complete \\
\hline Xuan Giao Bridge & On going complete \\
\hline Section1: Km218+080-Km223+000 & Deploy the Asphalt concrete, signpost and cleaning \\
\hline Section2: $\mathrm{Km} 223+000-\mathrm{Km} 225+000$ & Deploy the Asphalt concrete, signpost and cleaning \\
\hline Section3: $\mathrm{Km} 225+000-\mathrm{Km} 229+000$ & Deploy the Asphalt concrete, signpost and cleaning \\
\hline Section4: $\mathrm{Km} 229+000-\mathrm{Km} 232+000$ & Deploy the Asphalt concrete, signpost and cleaning \\
\hline Section5: $\mathrm{Km} 232+000-\mathrm{Km} 235+000$ & Deploy the Asphalt concrete, signpost and cleaning \\
\hline Section6: $\mathrm{Km} 235+000-\mathrm{Km} 238+000$ & Deploy the Asphalt concrete, signpost and cleaning \\
\hline Section7: $\mathrm{Km} 238+000-\mathrm{Km} 241+000$ & Deploy the Asphalt concrete, signpost and cleaning \\
\hline Section8: $\mathrm{Km} 241+000-\mathrm{Km} 243+000$ & Deploy the Asphalt concrete, signpost and cleaning \\
\hline Section9: $\mathrm{Km} 243+000-\mathrm{Km} 244+000$ & Deploy the Asphalt concrete, signpost and cleaning \\
\hline RAM IC18: $\mathrm{Km} 244+000-\mathrm{Km} 244+570$ & Deploy the Asphalt concrete \\
\hline
\end{tabular}




\section{CARRIED OUT TASKS DURING THE PERIOD}

During the period of reference for this quarterly report, the environmental tasks carried out by the specialists in their site offices and for each package were the following (see table below).

In some cases, weather conditions difficulted so much the movement along the alignment, therefore may be any week it was not possible the access to site. In other cases, the progress and distribution of the works in the packages, have conditioned especialists to carry out punctual inspections instead of general ones.

\begin{tabular}{|c|c|c|c|c|c|c|c|c|c|c|c|c|c|c|c|}
\hline \multirow{2}{*}{ Package } & \multicolumn{3}{|c|}{ General Inspection $^{1}$} & \multicolumn{3}{|c|}{ Punctual Inspection² } & \multicolumn{3}{|c|}{$\begin{array}{l}\text { Weekly Report } \\
\text { Submission }\end{array}$} & \multicolumn{3}{|c|}{$\begin{array}{c}\text { Letter/Notification } \\
\text { Submission }\end{array}$} & \multicolumn{3}{|c|}{$\begin{array}{c}\text { Weekly, Monthly and } \\
\text { Specific Meeting }\end{array}$} \\
\hline & Jan & Feb & Mar & Jan & Feb & Mar & Jan & Feb & Mar & Jan & Feb & Mar & Jan & Feb & Mar \\
\hline A1 & 7,14 & 28 & 17 & & & & & & & $\begin{array}{c}3,9 \\
15,21 \\
24\end{array}$ & & & & & \\
\hline A2 & $\begin{array}{l}8,10 \\
16,22\end{array}$ & $\begin{array}{c}10,17 \\
25\end{array}$ & $\begin{array}{l}4,12 \\
17,25\end{array}$ & 2,3 & 13,14 & & $\begin{array}{l}4,11 \\
18,25\end{array}$ & $\begin{array}{c}15,22 \\
28\end{array}$ & $\begin{array}{c}8,22 \\
29\end{array}$ & $\begin{array}{c}3,17 \\
23\end{array}$ & $\begin{array}{c}6,10 \\
13\end{array}$ & $\begin{array}{c}5,11 \\
27\end{array}$ & & & 27 \\
\hline A3 & $\begin{array}{l}01 ; 08 ; \\
15 ; 22\end{array}$ & $\begin{array}{c}07 ; 14 \\
21\end{array}$ & $\begin{array}{l}05 ; 12 ; \\
19 ; 26\end{array}$ & & 25 & & $\begin{array}{l}\text { 06; 13; } \\
20\end{array}$ & $\begin{array}{l}03 ; 10 \\
17 ; 24\end{array}$ & $\begin{array}{l}03 ; 10 \\
17 ; 24 \\
\quad 31\end{array}$ & $\begin{array}{l}07 ; 09 \\
10 ; 14 \\
22\end{array}$ & $\begin{array}{l}07 ; 24 ; \\
25 ; 26\end{array}$ & $\begin{array}{c}11 ; 25 \\
27\end{array}$ & $06 ; 20$ & $08 ; 15$ & $15 ; 28$ \\
\hline A4 & $\begin{array}{l}02 ; 09 \\
16 ; 23\end{array}$ & $\begin{array}{l}06 ; 13 ; \\
20 ; 27\end{array}$ & $\begin{array}{l}06 ; 13 ; \\
20 ; 27\end{array}$ & & & & $\begin{array}{l}06 ; 13 ; \\
20 ; 27\end{array}$ & $\begin{array}{l}03 ; 10 ; \\
17 ; 24\end{array}$ & $\begin{array}{l}03 ; 10 \\
17 ; 24 ; \\
\quad 31\end{array}$ & $\begin{array}{l}09 ; 14 \\
23 ; 25\end{array}$ & $\begin{array}{c}19 ; 25 \\
26\end{array}$ & $26 ; 27$ & $11 ; 18$ & $18 ; 25$ & $08 ; 22$ \\
\hline A5 & $\begin{array}{c}7,20 \\
28\end{array}$ & 7,17 & $\begin{array}{c}3,12 \\
28\end{array}$ & 2,5 & $\begin{array}{c}14,25 \\
28 \\
\end{array}$ & $\begin{array}{c}5,18 \\
21\end{array}$ & $\begin{array}{l}10,17 \\
24,31\end{array}$ & 15,22 & $\begin{array}{l}8,15 \\
22,29 \\
\end{array}$ & 14,16 & $\begin{array}{c}20,25 \\
28\end{array}$ & $\begin{array}{l}14,19 \\
26,27\end{array}$ & 16,23 & 13,27 & 6,20 \\
\hline
\end{tabular}

Hanoi office:

VinhPhuc office:

Madrid head office:

$12^{\text {th }}$ floor, Ocean Park Building, Dao Duy Anh Street, Dong Da Distric

19

Huu Thu Hamlet, Kim Long Ward, Tam Duong Distric, VinhPhuc Province

Calle Ramón de Aguinaga 8, 28028 Madrid, Spain 


\section{Loan 2391/2392 - VIE: GMS Kunming - Hai Phong Transport Corridor} Noi Bai - Lao Cai Highway Project

\begin{tabular}{|c|c|c|c|c|c|c|c|c|c|c|c|c|c|c|c|}
\hline \multirow[t]{2}{*}{ Package } & \multicolumn{3}{|c|}{ General Inspection ${ }^{1}$} & \multicolumn{3}{|c|}{ Punctual Inspection ${ }^{2}$} & \multicolumn{3}{|c|}{$\begin{array}{l}\text { Weekly Report } \\
\text { Submission }\end{array}$} & \multicolumn{3}{|c|}{$\begin{array}{l}\text { Letter/Notification } \\
\text { Submission }\end{array}$} & \multicolumn{3}{|c|}{$\begin{array}{c}\text { Weekly, Monthly and } \\
\text { Specific Meeting }\end{array}$} \\
\hline & Jan & Feb & Mar & Jan & Feb & Mar & Jan & Feb & Mar & Jan & Feb & Mar & Jan & Feb & Mar \\
\hline A6 & 3,15 & $\begin{array}{c}10,16 \\
26\end{array}$ & 4,17 & $\begin{array}{l}21,25 \\
30\end{array}$ & 8,15 & 1,25 & $\begin{array}{l}10,17 \\
24,31\end{array}$ & 15,22 & $\begin{array}{l}8,15 \\
22,29\end{array}$ & 16,23 & 26,28 & 10,14 & 16,23 & 13,27 & 6,20 \\
\hline A7 & 7,14 & 12,25 & 4,13 & $\begin{array}{c}10,20 \\
21\end{array}$ & 20 & 12,19 & $\begin{array}{c}11,18 \\
25\end{array}$ & $\begin{array}{c}15,22 \\
28\end{array}$ & $\begin{array}{l}8,15 \\
22\end{array}$ & $\begin{array}{c}2,3,6 \\
8,21 \\
22\end{array}$ & $\begin{array}{l}11,12 \\
19,28\end{array}$ & $\begin{array}{l}17,26 \\
28\end{array}$ & 2 & & \\
\hline A8 & 7 & 12,26 & 5,14 & 15 & 19,28 & 12,20 & 11, 18 & $\begin{array}{c}15,22 \\
28\end{array}$ & $\begin{array}{l}8,15 \\
22\end{array}$ & $\begin{array}{c}7,8 \\
10,22 \\
25\end{array}$ & $\begin{array}{c}11,21 \\
28\end{array}$ & $\begin{array}{l}7,13 \\
24,28\end{array}$ & 2 & & \\
\hline
\end{tabular}

1. Inspections along the whole package or, at least, most of its main stations

2 : Inspections in one or few locations, generally because of any specific matter or problem 
Loan 2391/2392 - VIE: GMS Kunming - Hai Phong Transport Corridor Noi Bai - Lao Cai Highway Project

4. ENVIRONMENTAL MONITORING RESULTS. COMPLEMENTARY MEASURES TO BE APPLIED

\subsection{IMPACT ON AIR QUALITY}

As Annex 2.1 there are included the results of the air quality monitoring carried out during the period of this quarterly report.

Related with the measurement of the parameter PM10, it's necessary to clarify that there were taken 3 samples along the day, for a period of 40 minutes each one. Although the standard value is expressed for a period of 24 hours, the National Technical Regulation on Ambient Air Quality allows, in point 1.2.3, to consider the "average value" to compare with the standard. Also, it must be mentioned that as the maximum value measured is lower than the standard for 24 hours, it may be consider that the results of this parameter are under the standards.

So, even the comparation between a punctual measurement and a continous 24 hours measurement is not available to get exact data for this parameter (PM10), it was considered that, since it is monitored by the specialists, it could be a good approximation to the real value and, specially, to the real impact or effect.

It must be also mentioned that there is not a homogeneous methodology between packages, as the companies which carry out the monitoring of these parameters are different ones in some of them.

\subsubsection{Package A1}

At the present, at package A1, the Contractor has finished all construction works. 


\section{Loan 2391/2392 - VIE: GMS Kunming - Hai Phong Transport Corridor Noi Bai - Lao Cai Highway Project}

\subsubsection{Package A2}

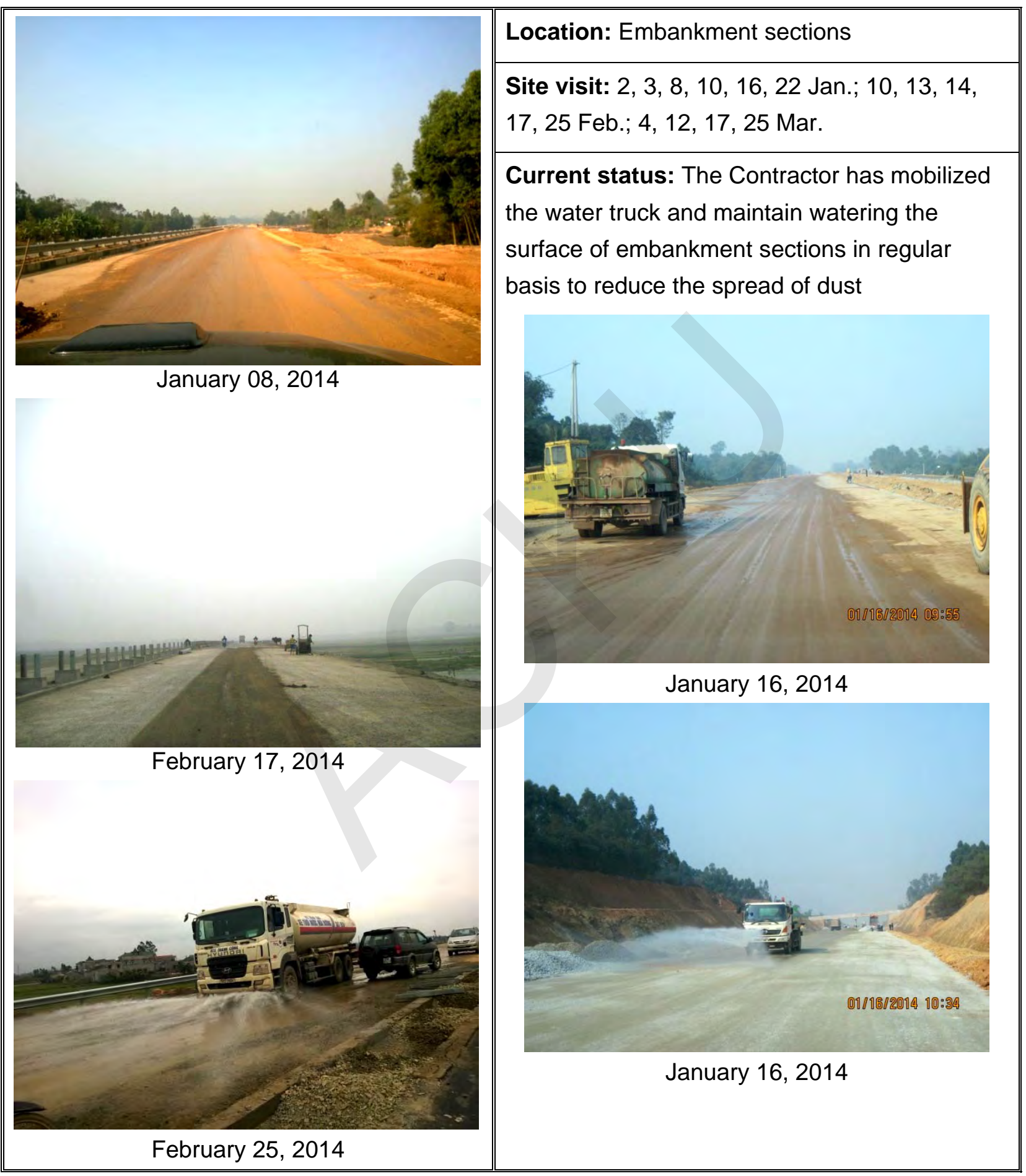




\section{Loan 2391/2392 - VIE: GMS Kunming - Hai Phong Transport Corridor Noi Bai - Lao Cai Highway Project}

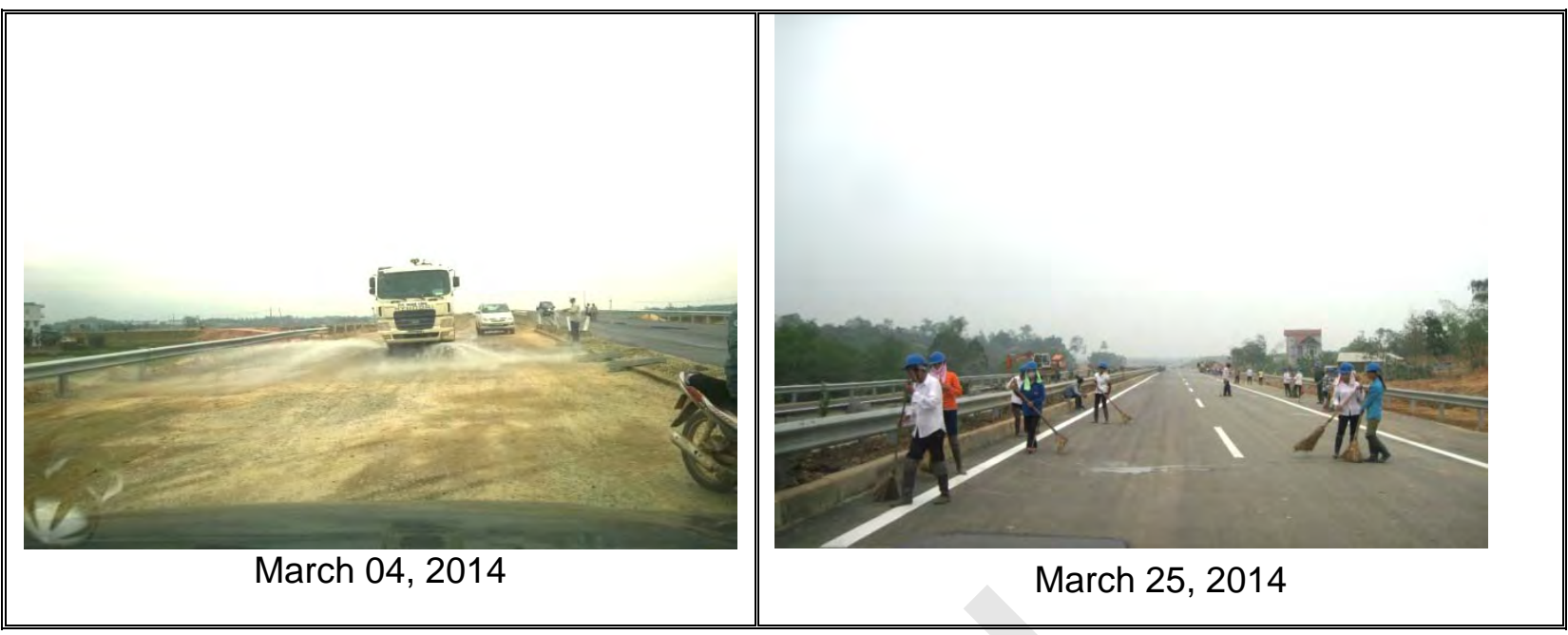

\subsubsection{Package A3}
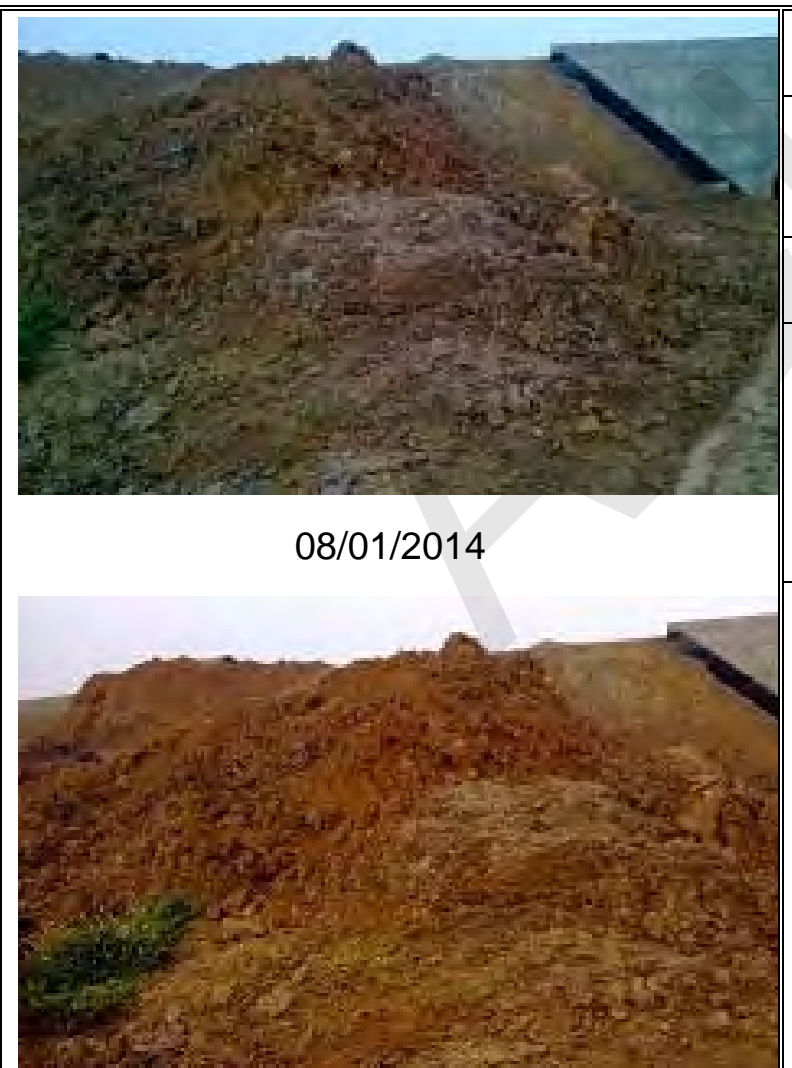

$07 / 2 / 2014$

\section{Location: $\mathrm{Km79+050}$}

Site visit: $01,08,15,22 / 01 / 2014 ; 07,14,21$, 25/2/2014

Date first observed: $13 / 6 / 2013$

Problems description and cause: Contractor dumped soils beside local road. Soil overflowed on the surface of the road. Thus, there is much dust in the sunny days.

\section{Recommendation and Action taken by} Engineer: The contactor is requested to clean the surface of the road and to spray water frequently in order to decrease dust concentration on the exist road. Refer to the letters GET2-POS-A3-1982; GET2-POS-A31985; GET2-POS-A3-2169; GET2-POS-A32181; GET2-POS-A3-2224C; GET2-POS-A32253; GET2-POS-A3-2232A.

\section{Responsible Party: Posco}

Deadline: Daily

Current status: Not yet improved 


\section{Loan 2391/2392 - VIE: GMS Kunming - Hai Phong Transport Corridor Noi Bai - Lao Cai Highway Project}

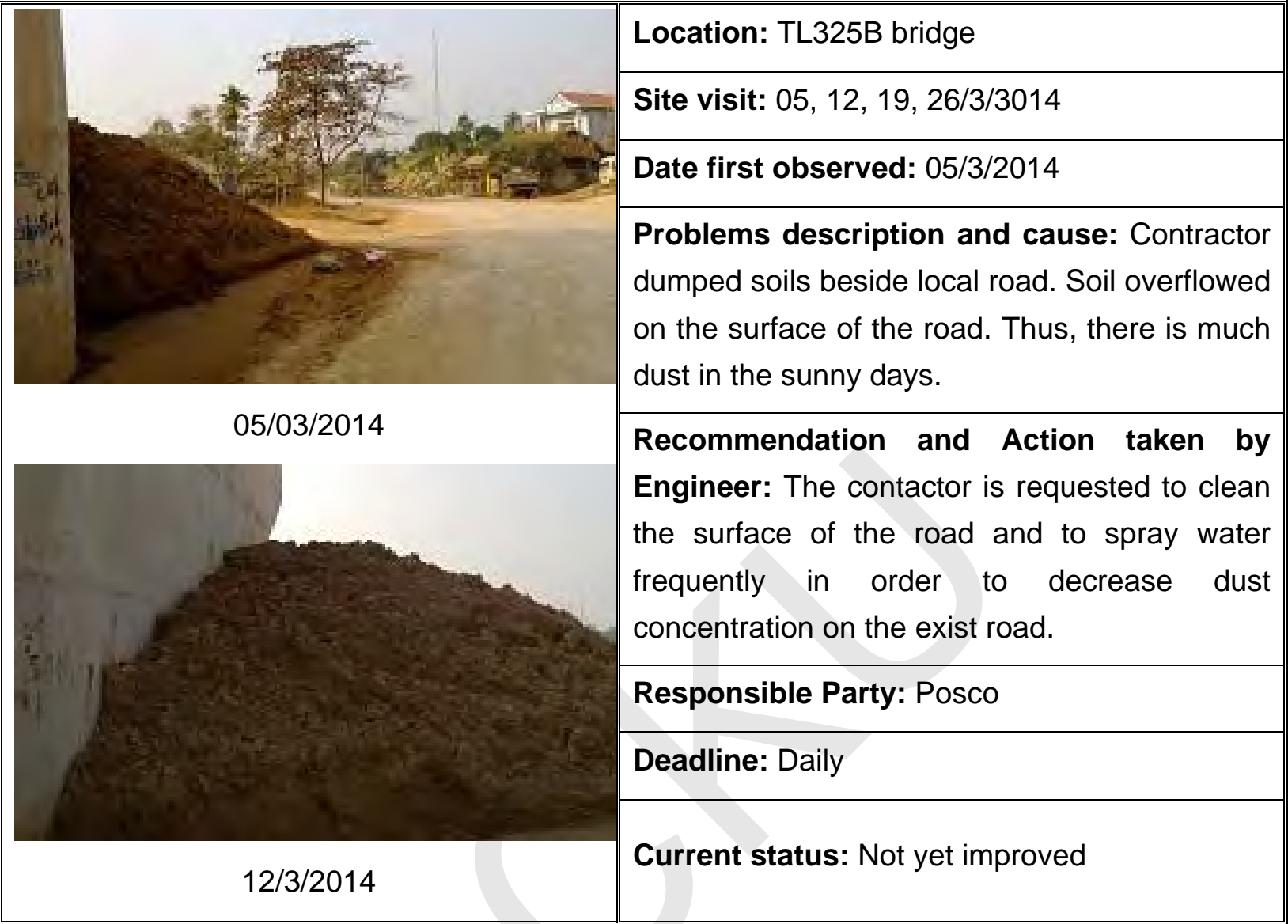

\subsubsection{Package A4}

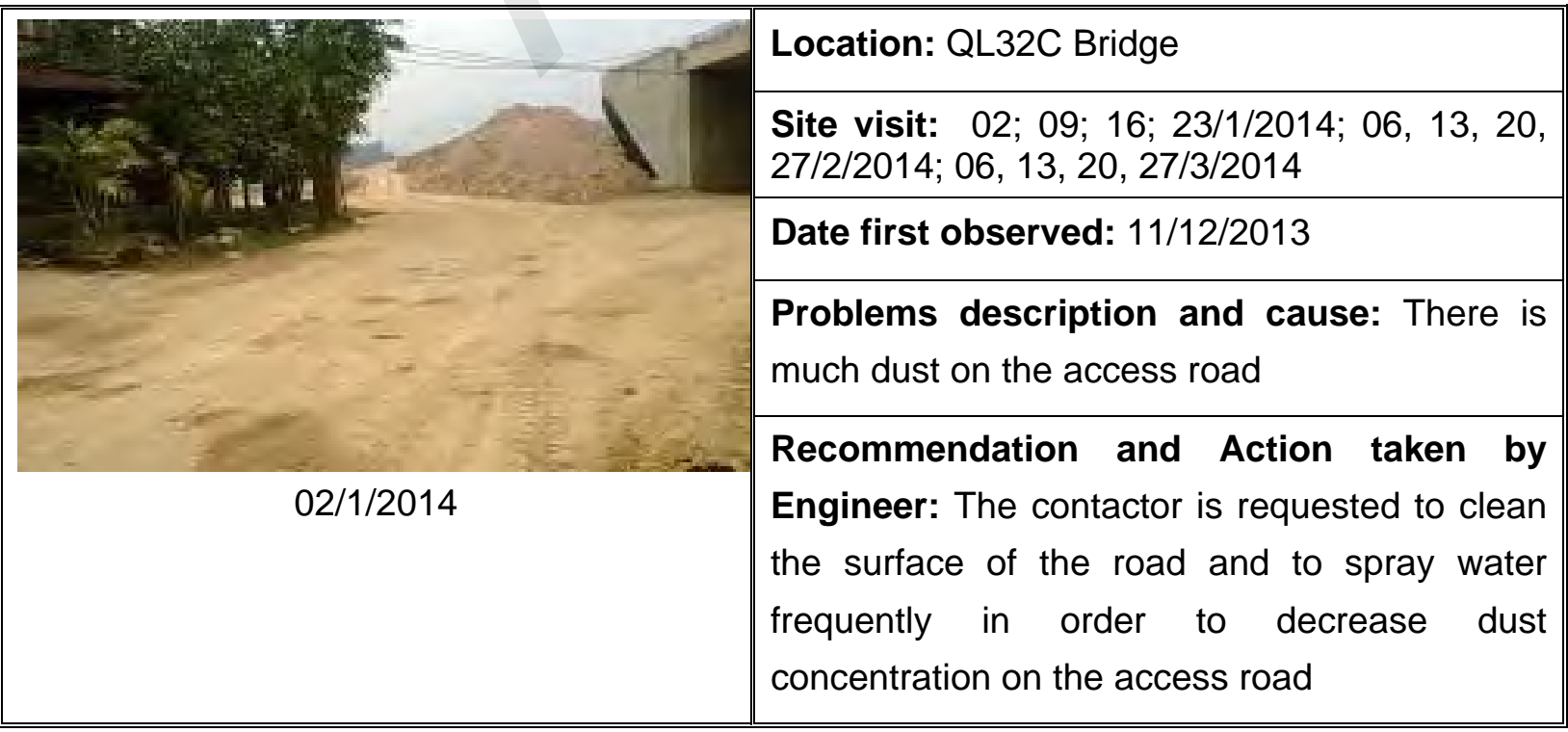




\section{Loan 2391/2392 - VIE: GMS Kunming - Hai Phong Transport Corridor Noi Bai - Lao Cai Highway Project}

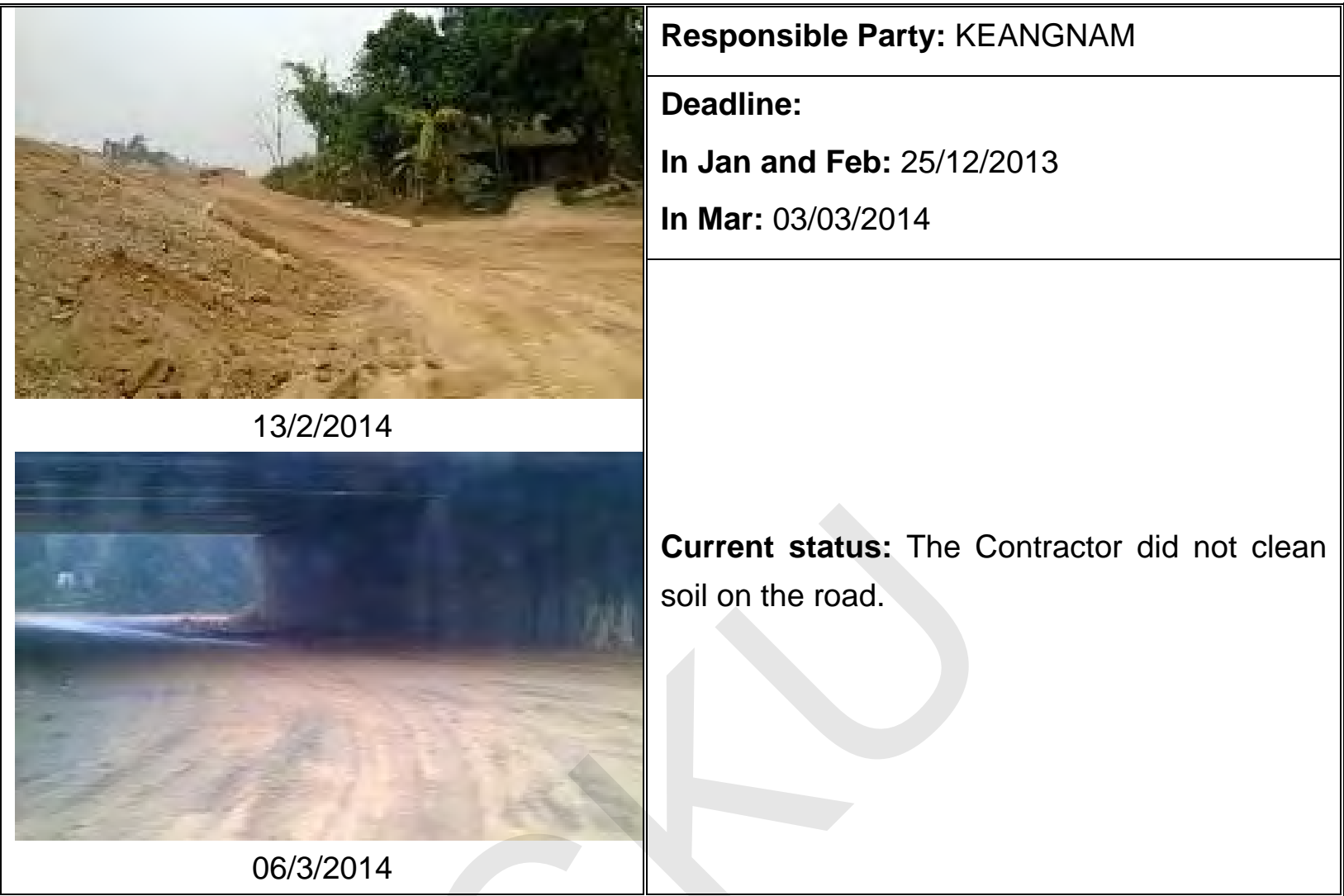

\begin{tabular}{|c|c|}
\hline & Location: Ngoi Lao Bridge \\
\hline & Site visit: $13 / 2 ; 06,13,20,27 / 3 / 2014$ \\
\hline & Date first observed: $11 / 12 / 2013$ \\
\hline & $\begin{array}{l}\text { Problems description and cause: There is } \\
\text { much dust on the access road. This can cause } \\
\text { the dust in the sunny day and impact on air } \\
\text { quality }\end{array}$ \\
\hline \multirow{3}{*}{$13 / 2 / 2014$} & $\begin{array}{l}\text { Recommendation and Action taken by } \\
\text { Engineer: The contactor is requested to clean } \\
\text { the surface of the road and to spray water } \\
\text { frequently in order to decrease dust } \\
\text { concentration on the access road }\end{array}$ \\
\hline & Responsible Party: KEANGNAM \\
\hline & Deadline: 03/03/2014 \\
\hline
\end{tabular}




\section{Loan 2391/2392 - VIE: GMS Kunming - Hai Phong Transport Corridor Noi Bai - Lao Cai Highway Project}

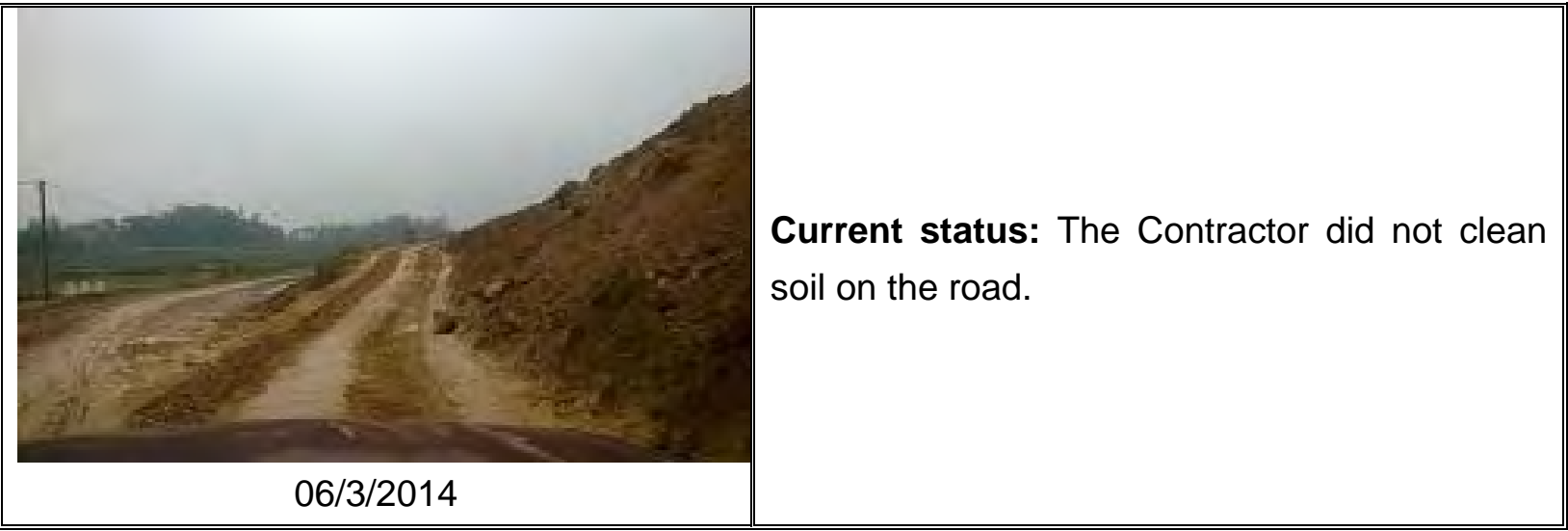

\subsubsection{Package A5}

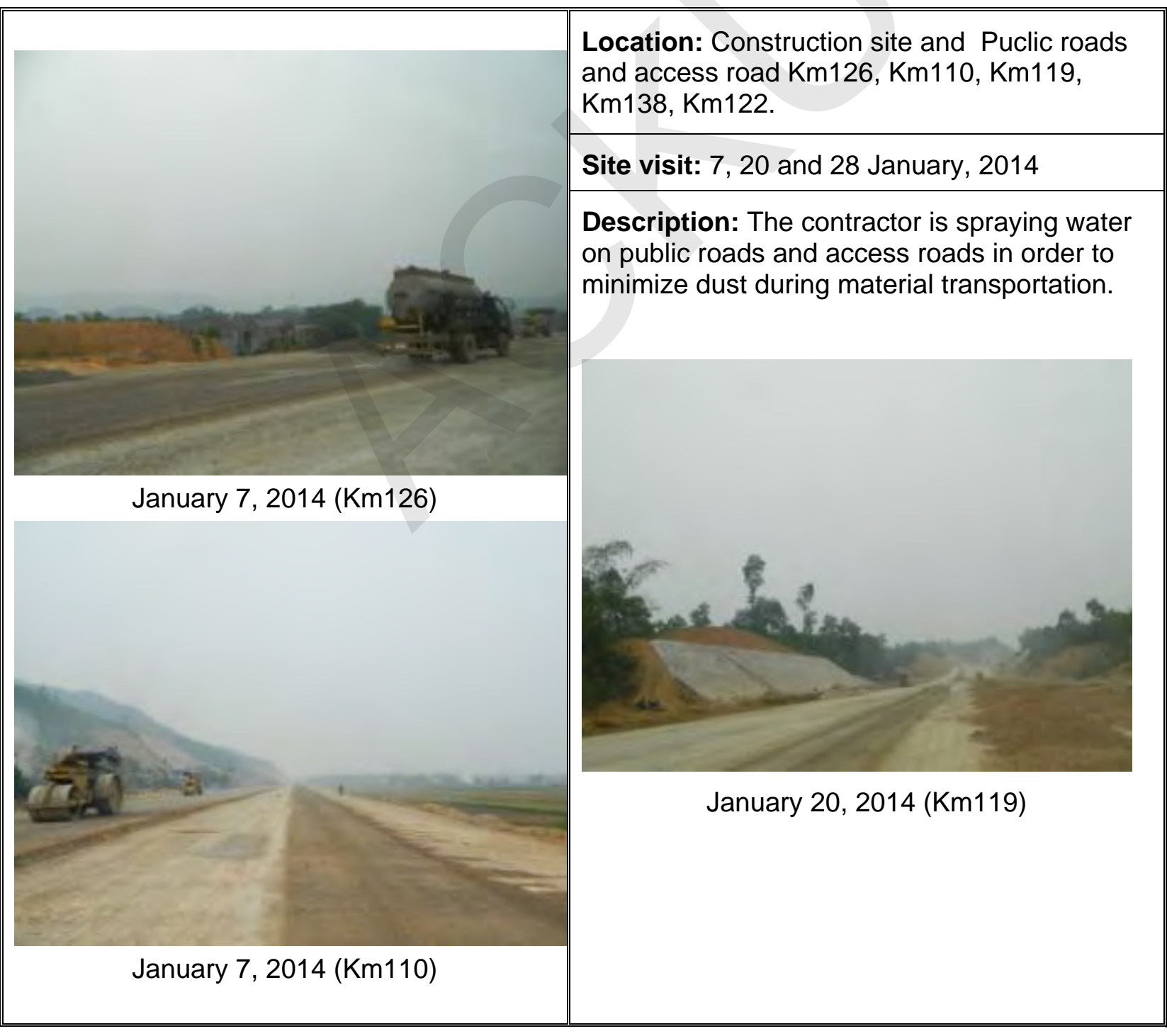




\section{Loan 2391/2392 - VIE: GMS Kunming - Hai Phong Transport Corridor Noi Bai - Lao Cai Highway Project}
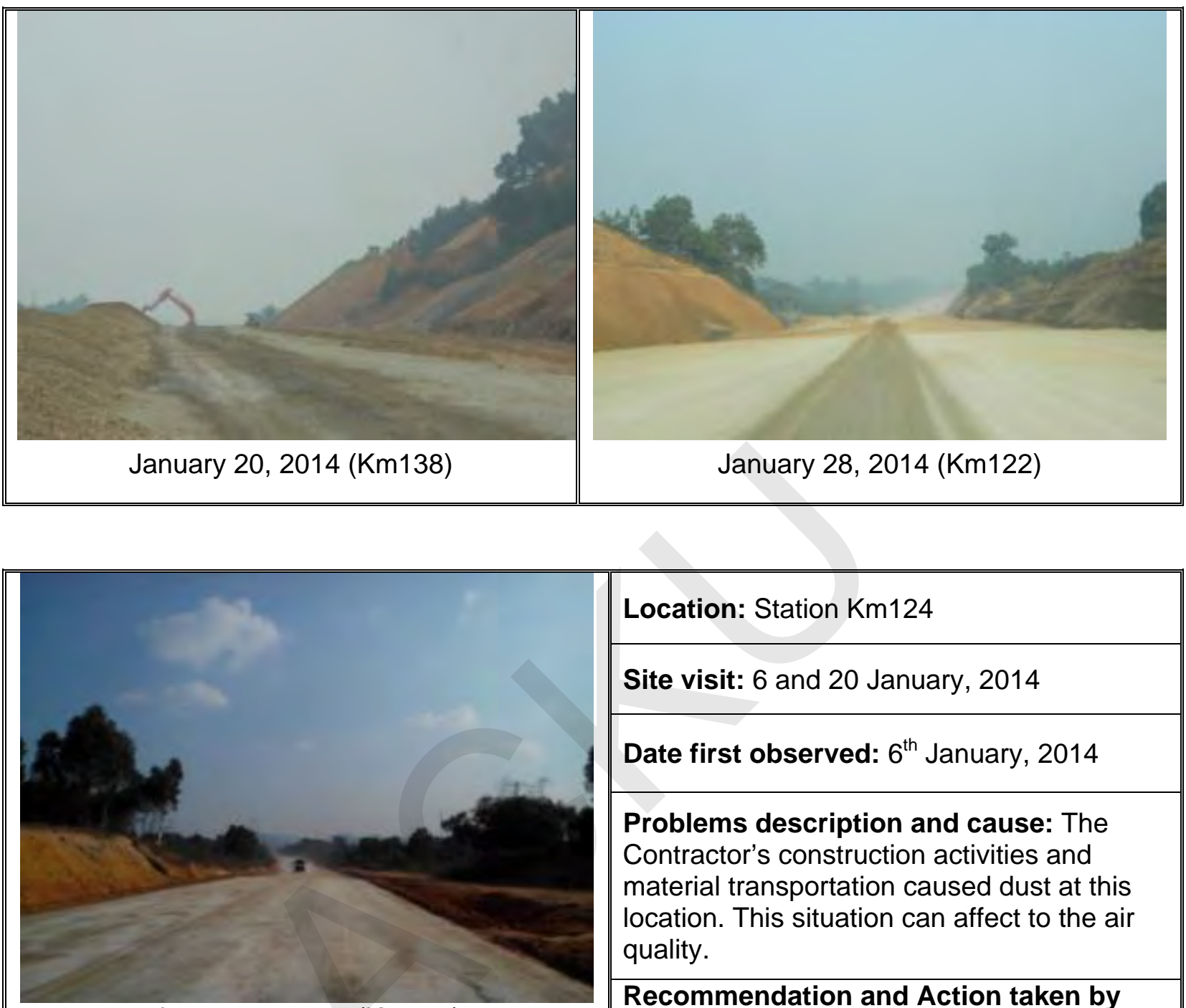

Location: Station $\mathrm{Km} 124$

Site visit: 6 and 20 January, 2014

Date first observed: $6^{\text {th }}$ January, 2014

Problems description and cause: The

Contractor's construction activities and material transportation caused dust at this location. This situation can affect to the air quality.

January 6, $2014(\mathrm{Km} 124)$

Recommendation and Action taken by Engineer: The Engineer requested the Contractor to apply the suitable measures in order to minimize dust during the construction and material transportation.

Responsible Party: Keangnam Contractor

Deadline: 15-Januaryr-2014

Current status: The contractor is spraying water on public roads and access roads in order to minimize dust during the material transportation. 


\section{Loan 2391/2392 - VIE: GMS Kunming - Hai Phong Transport Corridor Noi Bai - Lao Cai Highway Project}

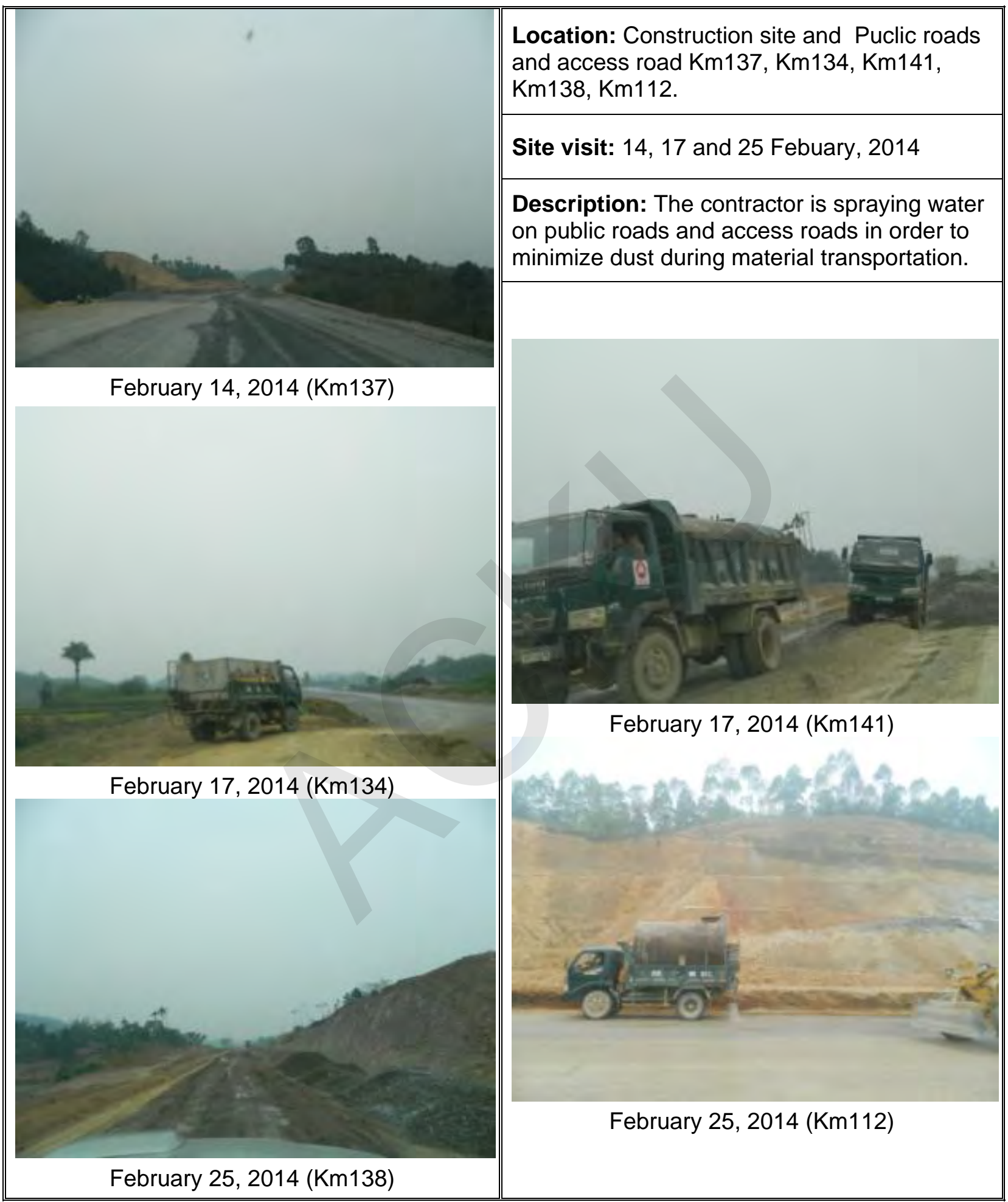


Loan 2391/2392 - VIE: GMS Kunming - Hai Phong Transport Corridor Noi Bai - Lao Cai Highway Project

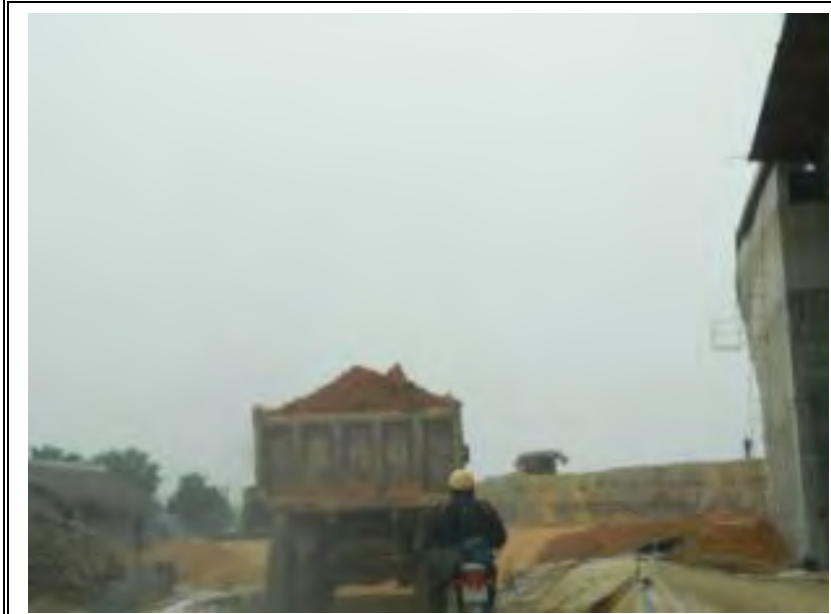

February 14, $2014(\mathrm{Km} 128)$

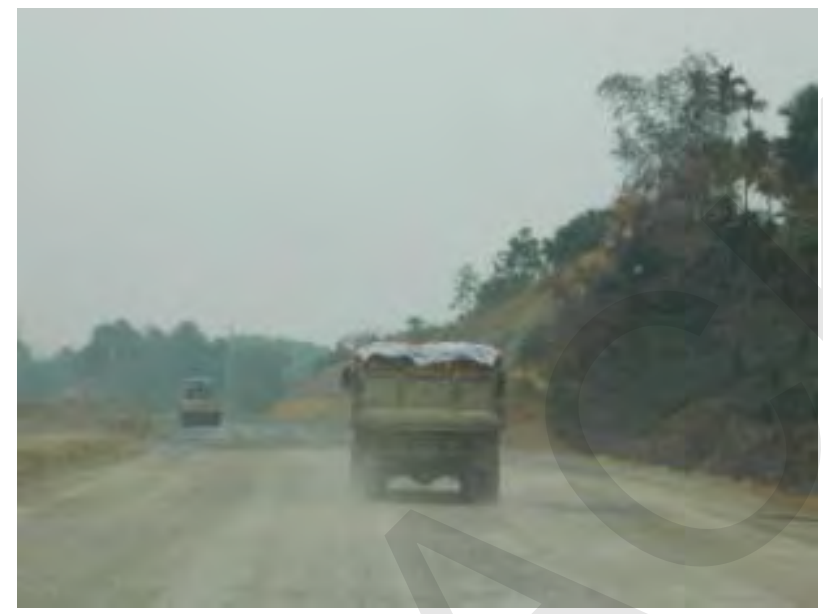

February 25, 2014 (Km128)
Location: Construction site $\mathrm{Km} 125$

Site visit: 14 and 25 February, 2014

Date first observed: $14^{\text {th }}$ February, 2014

Problems description and cause: The Contractor's trucks were not covered by canvas during the material transportation. This situation caused the dust.

\section{Recommendation and Action taken by} Engineer: The whole contractor's trucks must be covered by canvas during the material transportation. At the same time, the Contractor must apply the suitable measures in order to minimize the dust during material transportation.

Responsible Party: KeangnamContractor

Deadline: 20-Feb-2014

Current status: Some trucks were covered by canvas during material transportation.

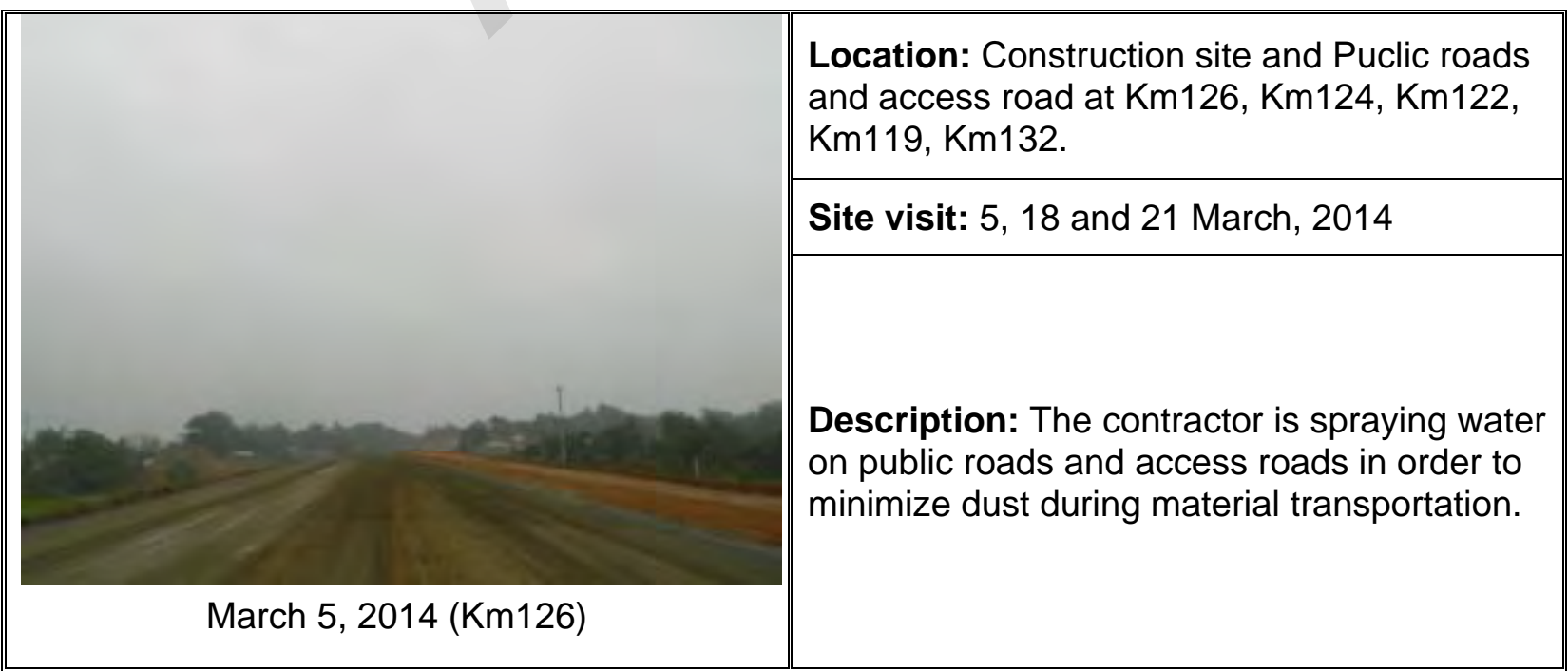




\section{Loan 2391/2392 - VIE: GMS Kunming - Hai Phong Transport Corridor Noi Bai - Lao Cai Highway Project}

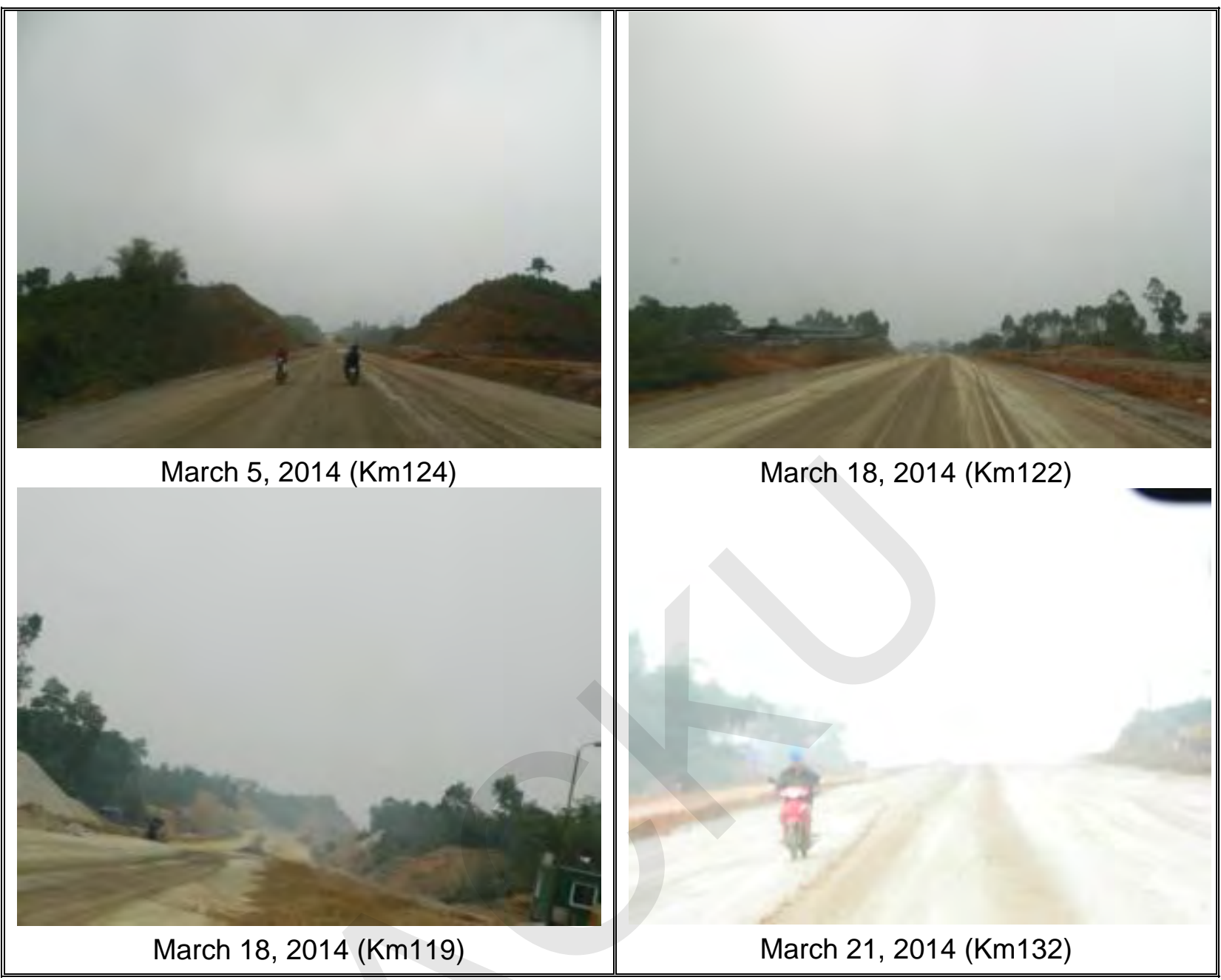

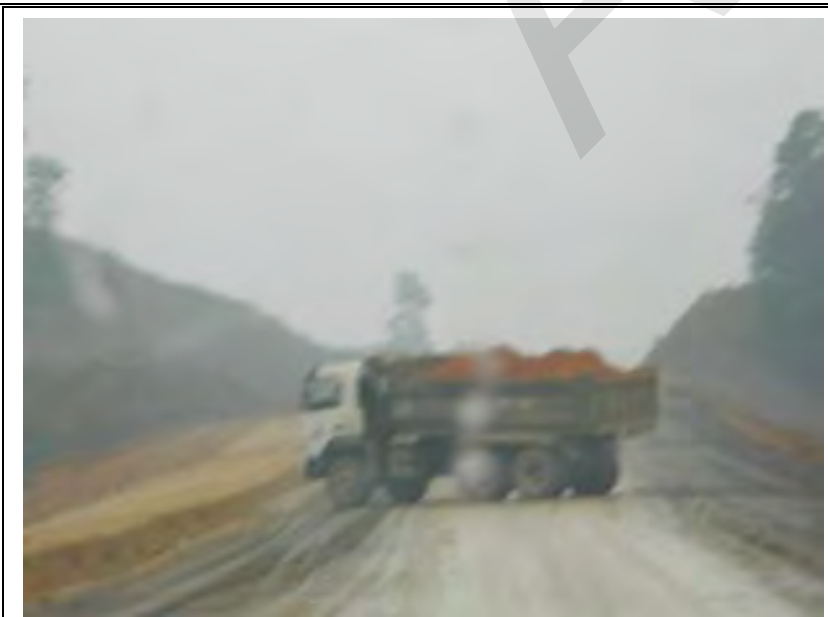

March 5, 2014 (Km131)
Location: Construction site at $\mathrm{Km} 131$

Site visit: 5 and 18 March, 2014

Date first observed: $14^{\text {th }}$ March, 2014

Problems description and cause: The Contractor's trucks were not covered with canvas during material transportation. This situation caused the airborne dust.

\section{Recommendation and Action taken by} Engineer: The Contractor has to cover the whole of trucks with canvas during material transportation. At the same time, the Contractor must apply the suitable measures in order to minimize the airborne dust during material transportation. 


\section{Loan 2391/2392 - VIE: GMS Kunming - Hai Phong Transport Corridor Noi Bai - Lao Cai Highway Project}

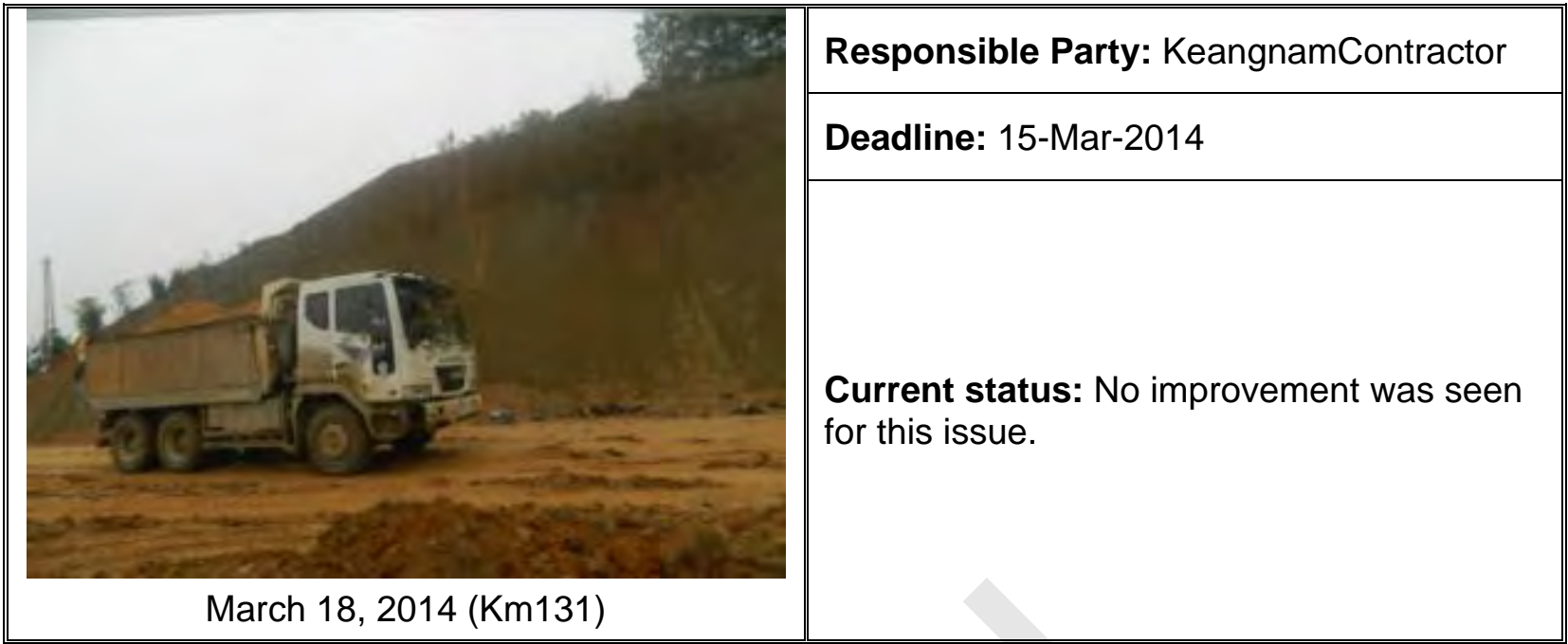

\subsubsection{Package A6}

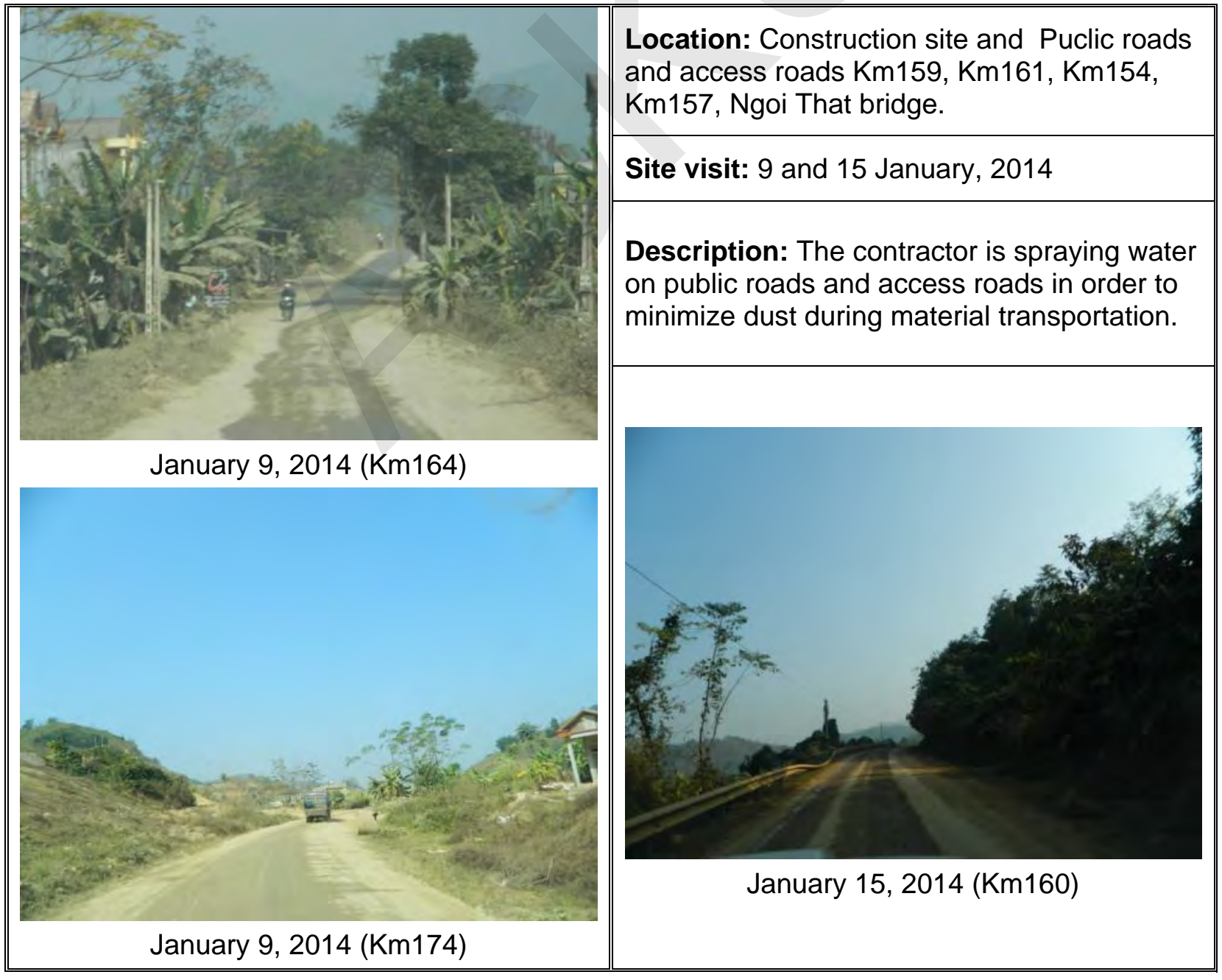




\section{Loan 2391/2392 - VIE: GMS Kunming - Hai Phong Transport Corridor Noi Bai - Lao Cai Highway Project}

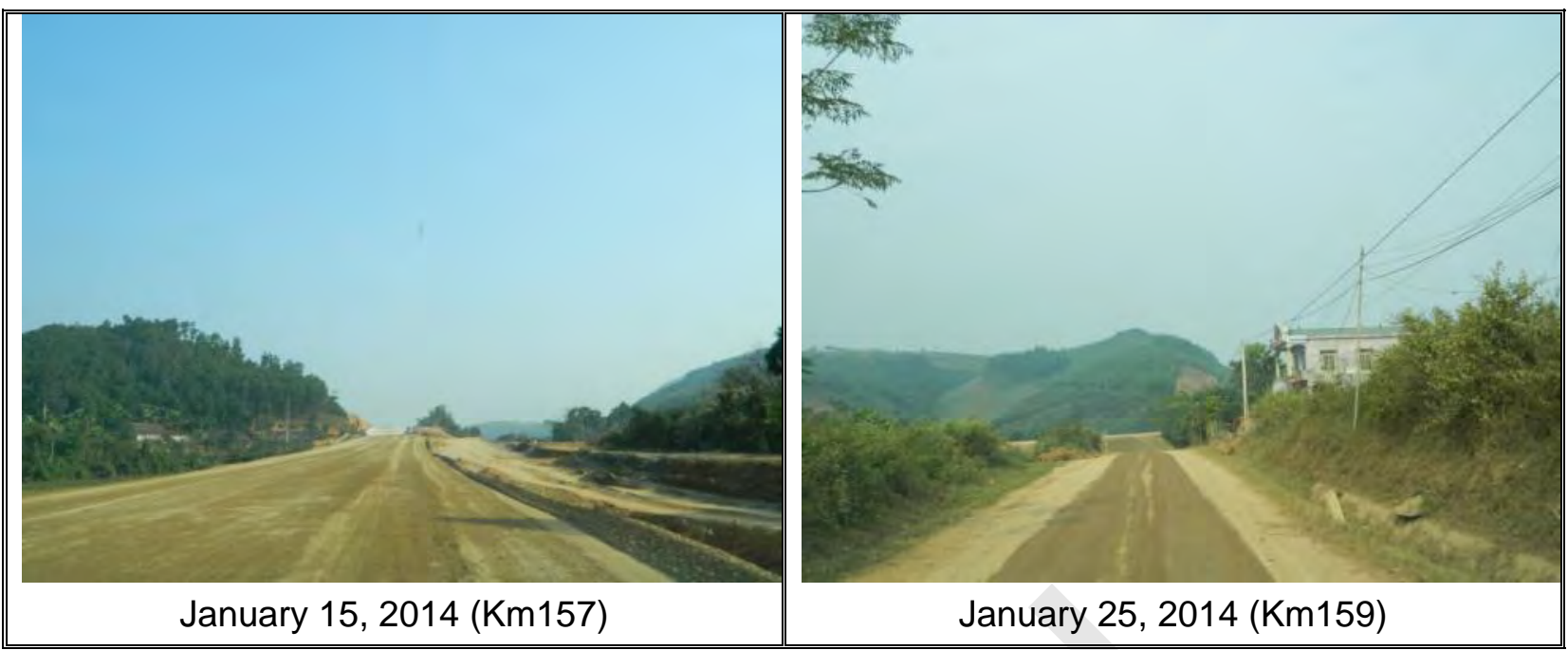

\begin{tabular}{|c|c|}
\hline \multirow{10}{*}{ January 9, 2014 (Km156) } & Location: Station Km156 \\
\hline & Site visit: 9 and 15 January, 2014 \\
\hline & Date first observed: $9^{\text {th }}$ January, 2014 \\
\hline & $\begin{array}{l}\text { Problems description and cause: The } \\
\text { Contractor's construction activities and } \\
\text { material transportation caused dust at this } \\
\text { location. This situation can affect air quality. }\end{array}$ \\
\hline & $\begin{array}{l}\text { Recommendation and Action taken by } \\
\text { Engineer: The Engineer requested the }\end{array}$ \\
\hline & Contractor to apply measures in order to \\
\hline & material transportation. \\
\hline & Responsible Party: Doosan Contractor \\
\hline & Deadline: 15-January-2014 \\
\hline & $\begin{array}{l}\text { Current status: The contractor is spraying } \\
\text { water on public roads and access roads in } \\
\text { order to minimize dust during material } \\
\text { transportation. }\end{array}$ \\
\hline January 15, 2014 (Km156) & \\
\hline
\end{tabular}




\section{Loan 2391/2392 - VIE: GMS Kunming - Hai Phong Transport Corridor Noi Bai - Lao Cai Highway Project}

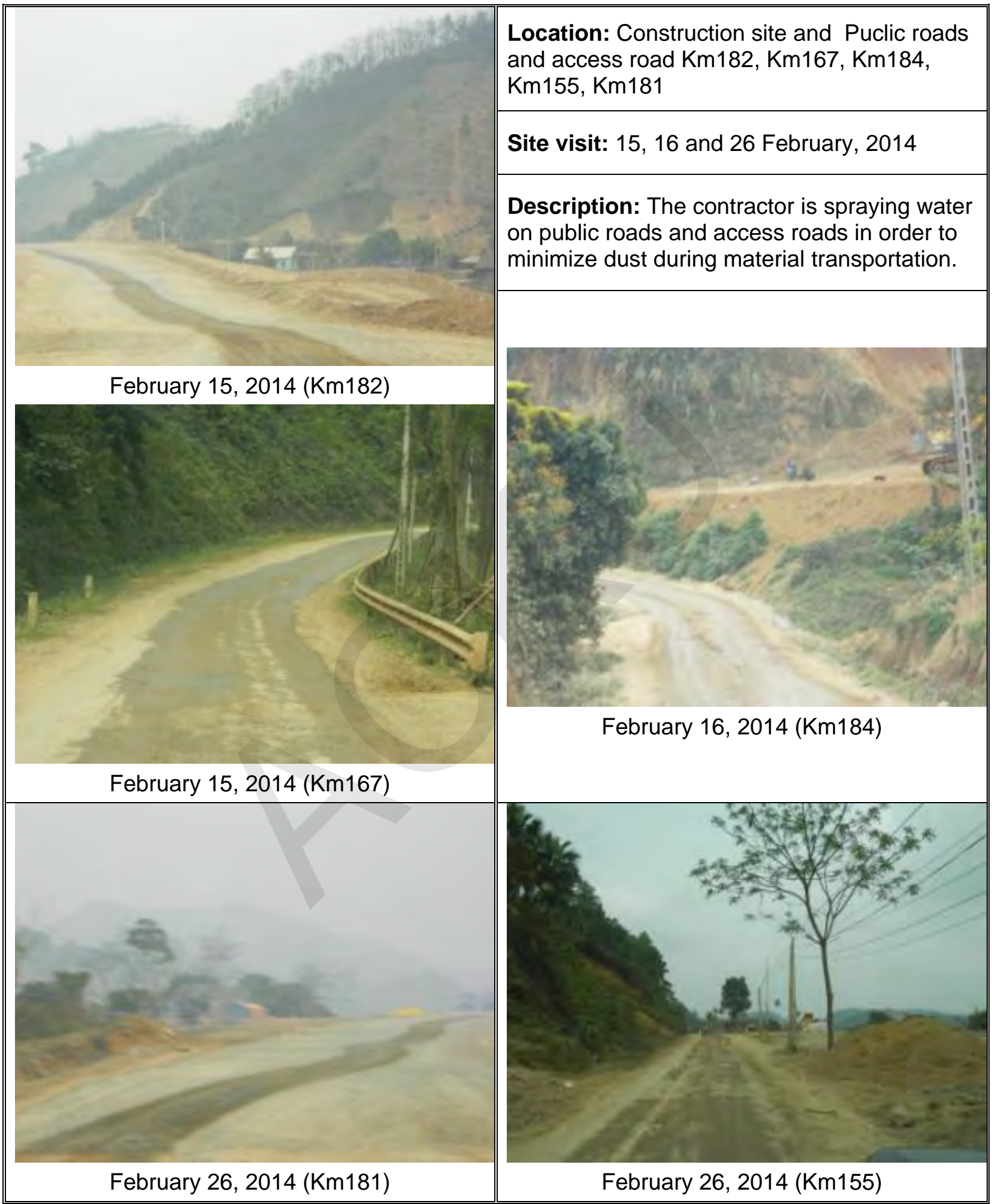


Loan 2391/2392 - VIE: GMS Kunming - Hai Phong Transport Corridor Noi Bai - Lao Cai Highway Project

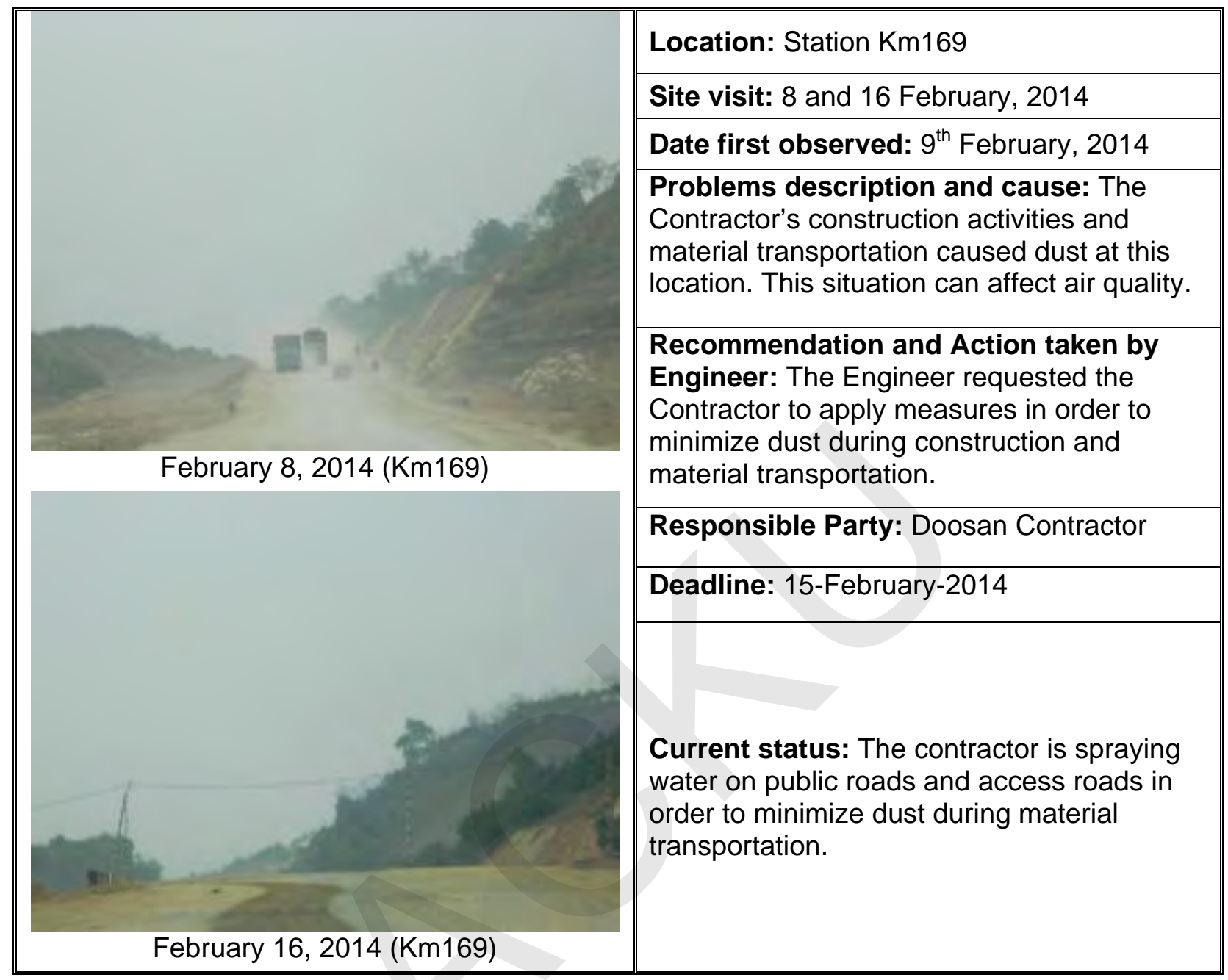

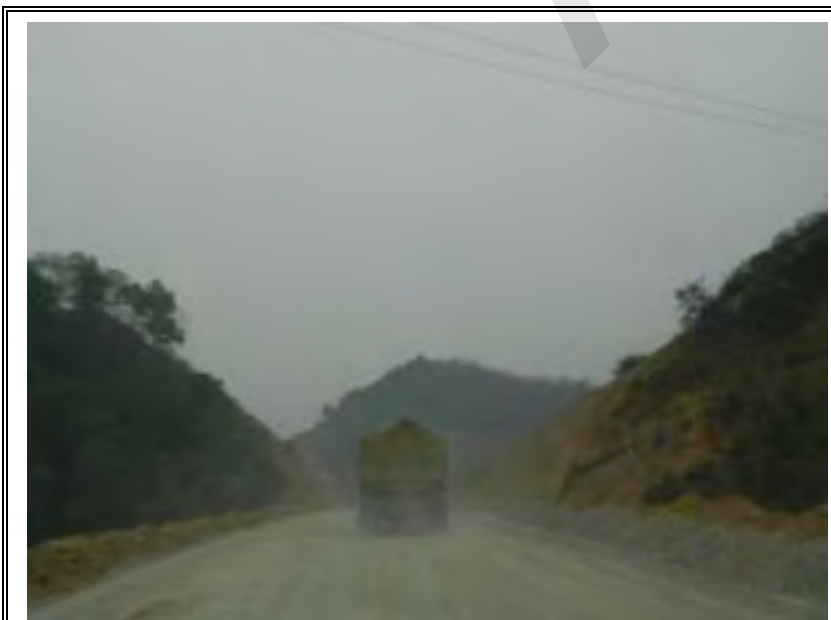

February 16, 2013 (Km187)
Location: Construction site $\mathrm{Km} 187$

Site visit: 16 and 26 February, 2014

Date first observed: $16^{\text {th }}$ February, 2014

Problems description and cause: The

Contractor's trucks were not covered with canvas during material transportation. This situation caused the dust.

Recommendation and Action taken by Engineer: All of the contractor's trucks have to be covered with canvas during material transportation. At the same time, the Contractor must apply suitable measures in order to minimize dust during material transportation. 


\section{Loan 2391/2392 - VIE: GMS Kunming - Hai Phong Transport Corridor Noi Bai - Lao Cai Highway Project}

\begin{tabular}{|l|l||}
\hline \multirow{2}{*}{} & Responsible Party: KeangnamContractor \\
\cline { 2 - 3 } & Deadline: 22-Feb-2014 \\
\cline { 2 - 2 } & \\
\hline February 26, $2013(\mathrm{Km} 187)$ & Current status: Not yet implemented \\
\hline
\end{tabular}

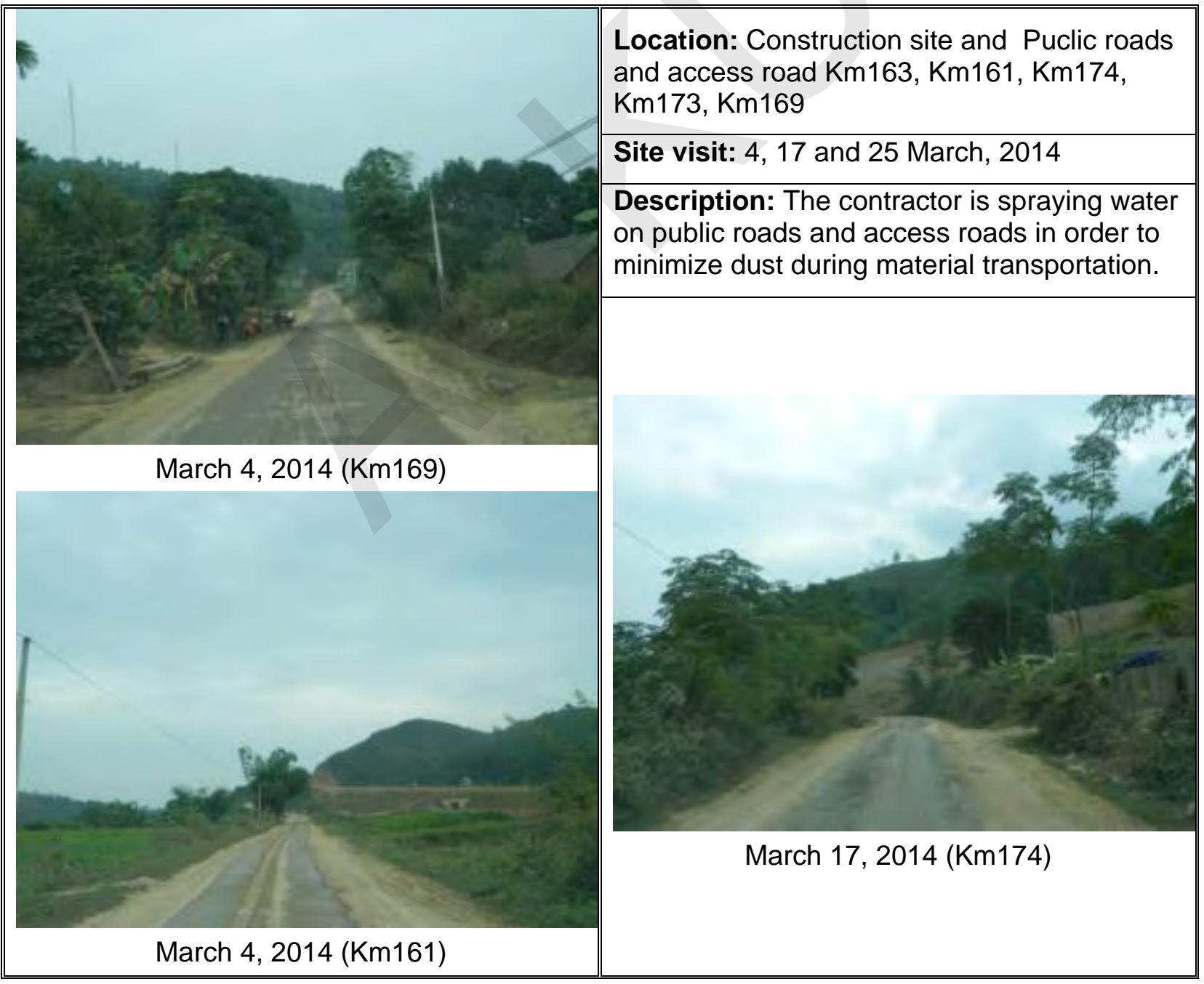




\section{Loan 2391/2392 - VIE: GMS Kunming - Hai Phong Transport Corridor Noi Bai - Lao Cai Highway Project}

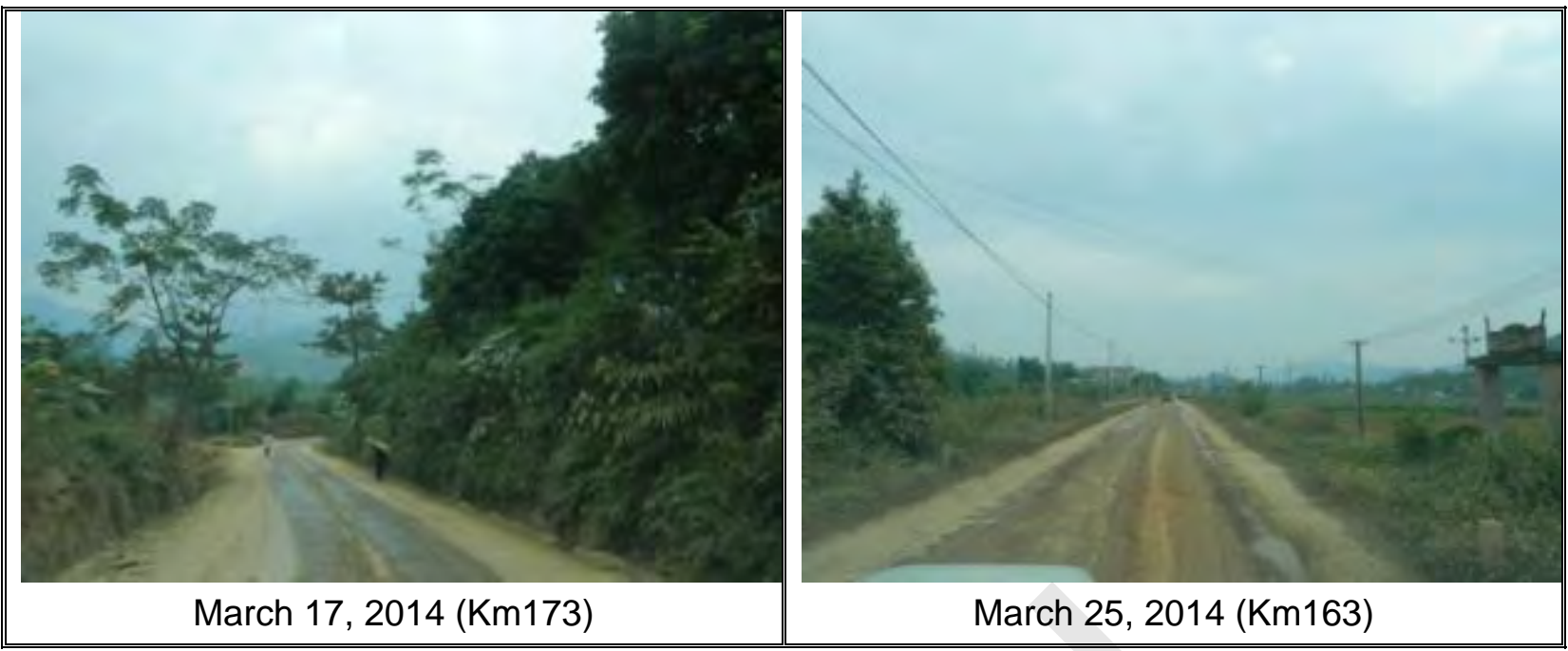

\subsubsection{Package A7}

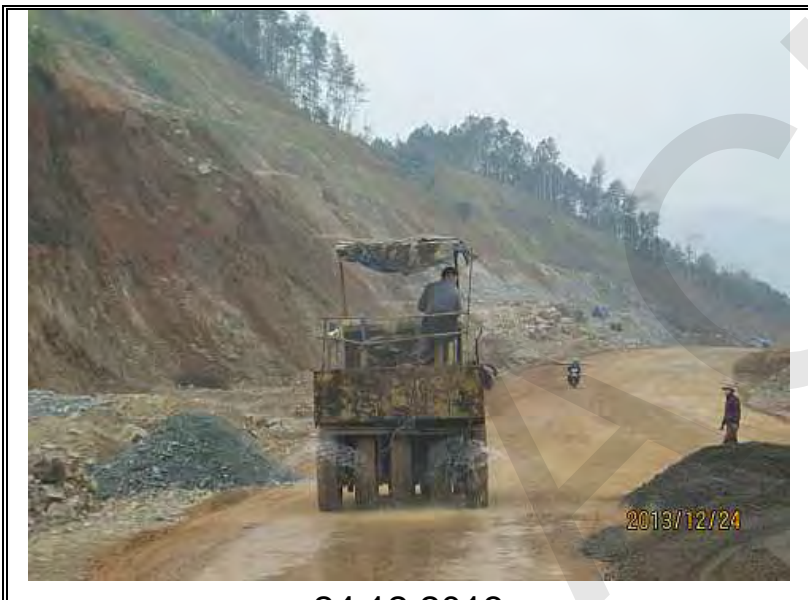

Location: Km209+329

Site visit: $7.1 .2014 ; 26.2 .2014 ; 31.3 .2014$

Date first observed: 13.8 .2013

Problems description and cause: There is a lot of dust on the exist road

Recommendation and Action taken by Engineer: The contactor is requested to spray water frequently (2 times/day) in order to decrease dust concentration on the exist road

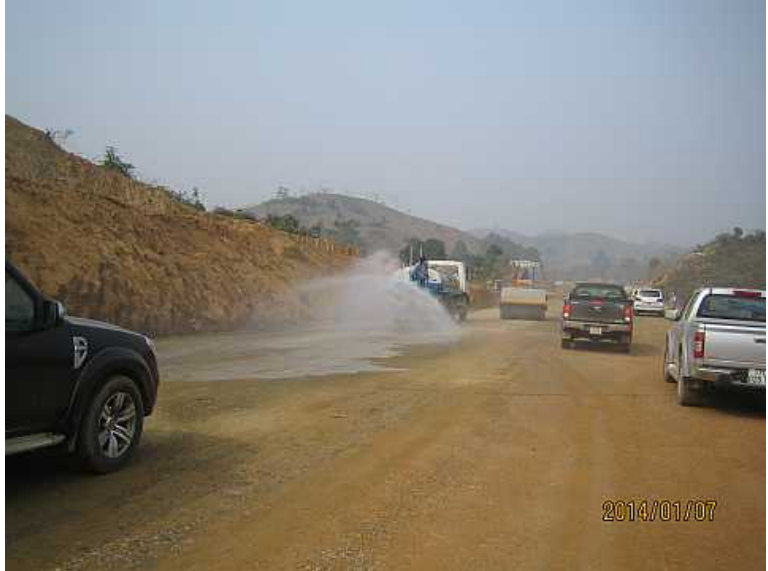

Deadline: Immediately

Current status: The contractor had sprayed water frequently on exist road 


\section{Loan 2391/2392 - VIE: GMS Kunming - Hai Phong Transport Corridor Noi Bai - Lao Cai Highway Project}

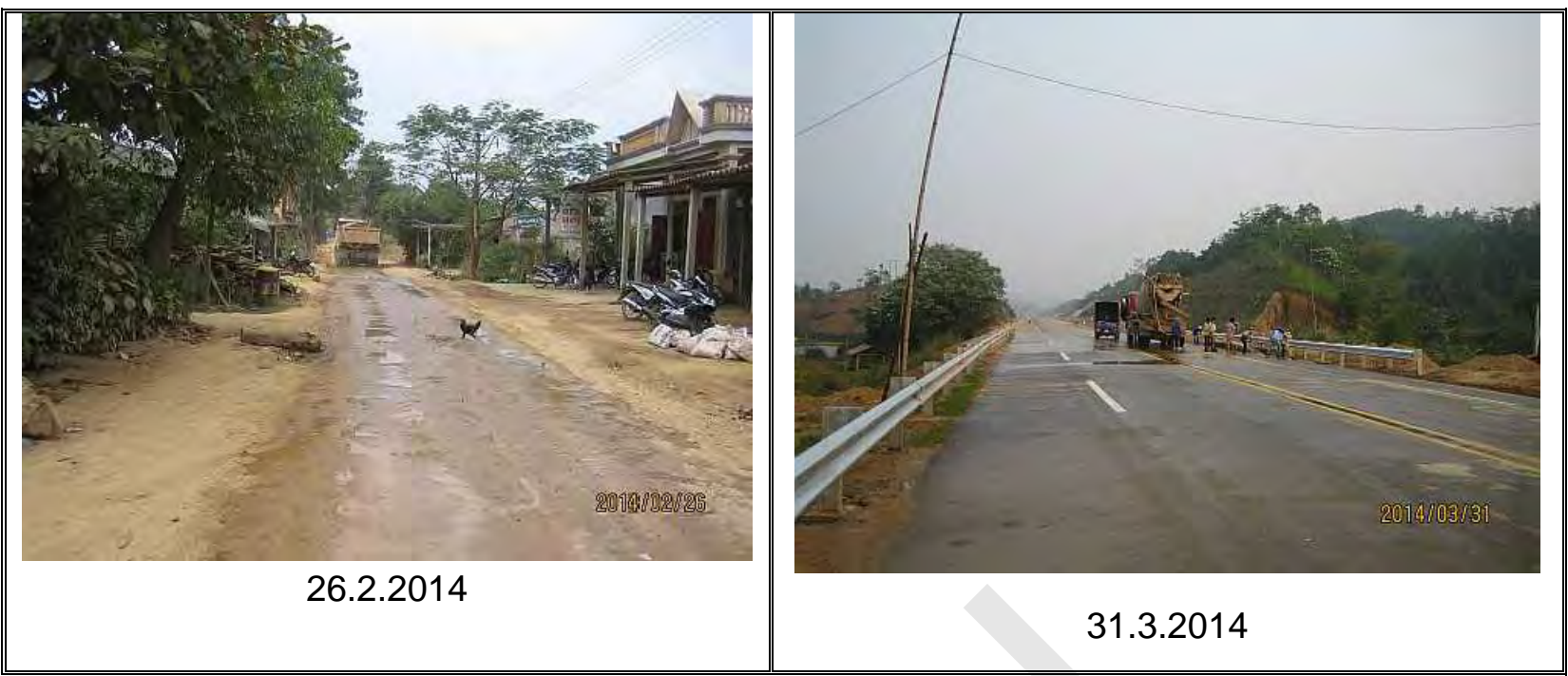

\subsubsection{Package A8}

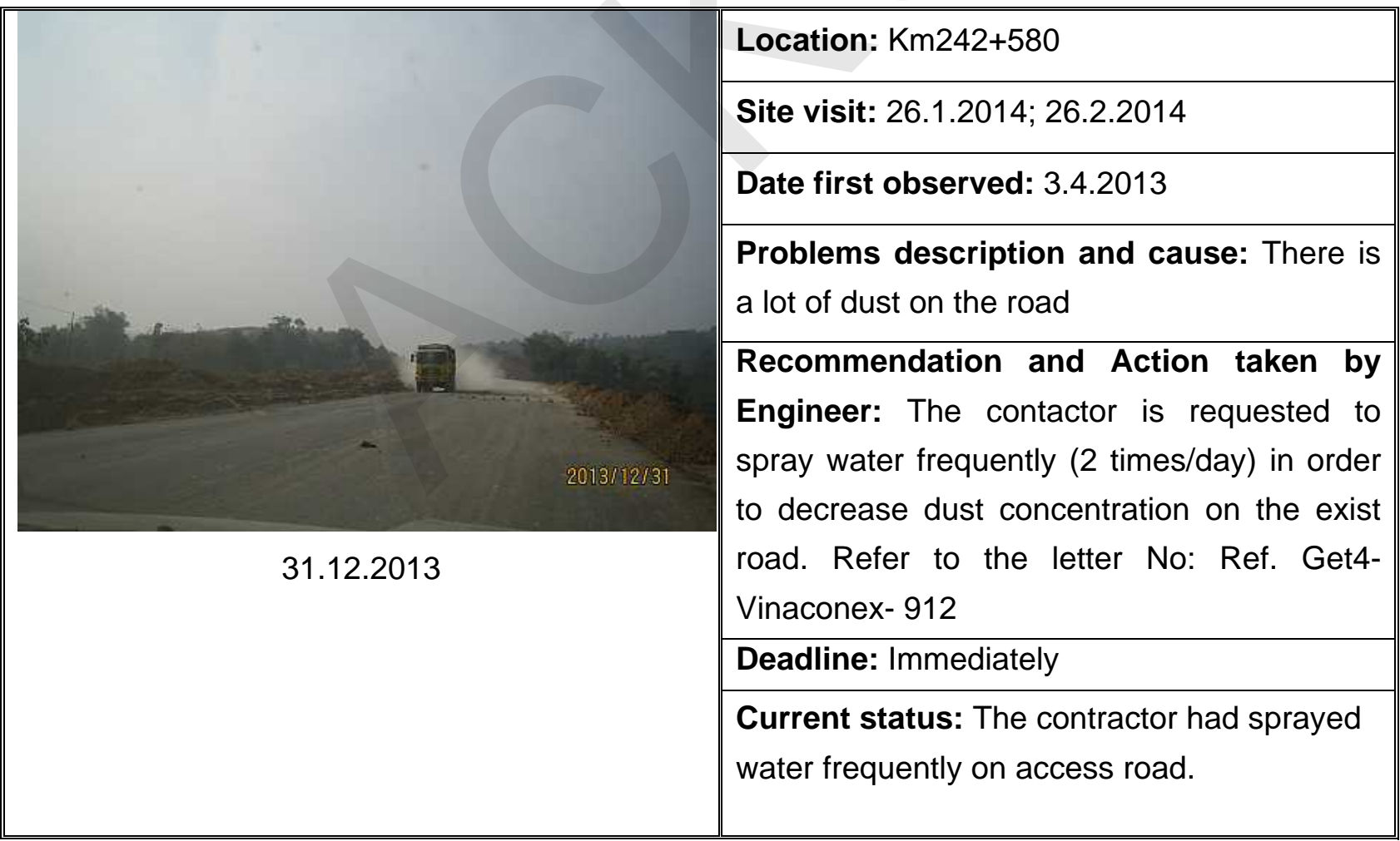




\section{Loan 2391/2392 - VIE: GMS Kunming - Hai Phong Transport Corridor Noi Bai - Lao Cai Highway Project}
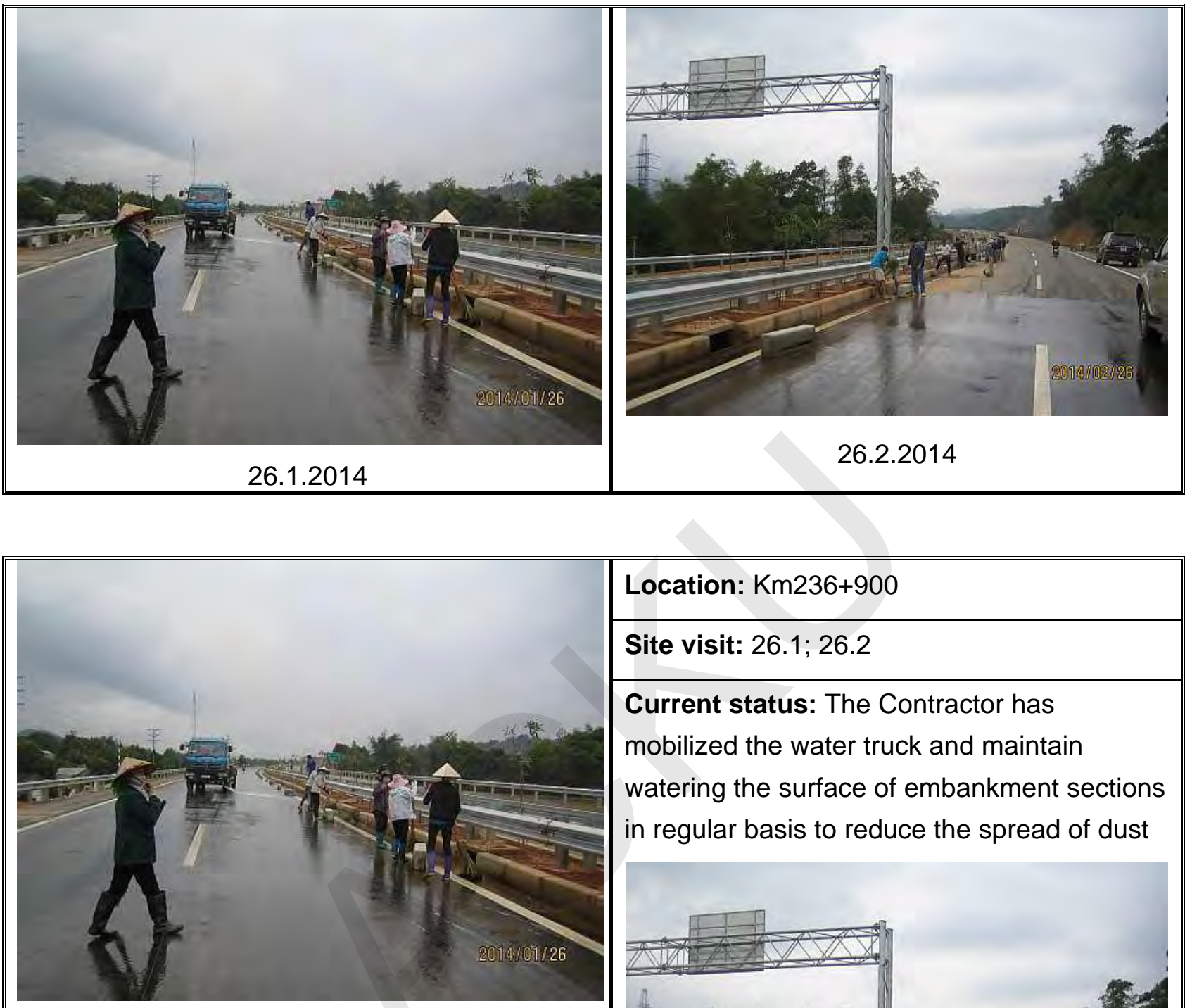

Location: $\mathrm{Km} 236+900$

Site visit: $26.1 ; 26.2$

Current status: The Contractor has mobilized the water truck and maintain watering the surface of embankment sections in regular basis to reduce the spread of dust

26.1.2014 tại Km236+900

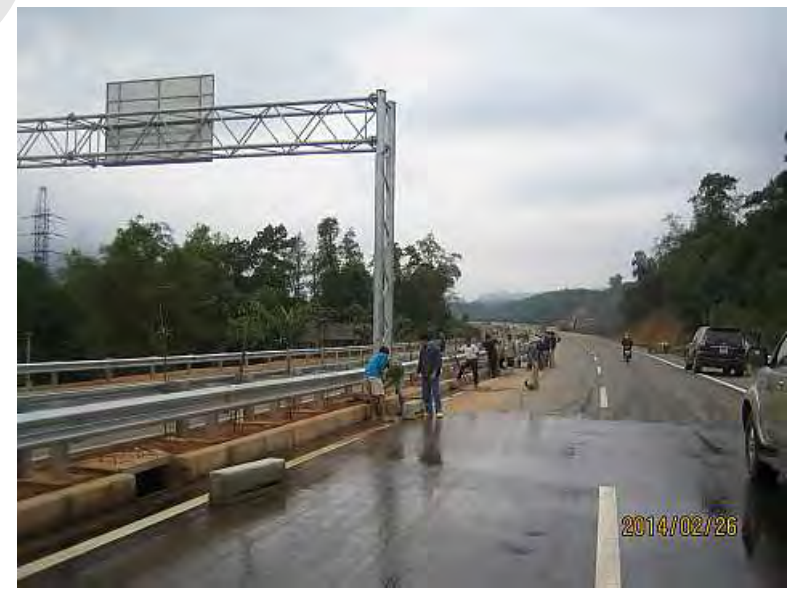

26.2.2014 tại Km236+900 
Loan 2391/2392 - VIE: GMS Kunming - Hai Phong Transport Corridor Noi Bai - Lao Cai Highway Project

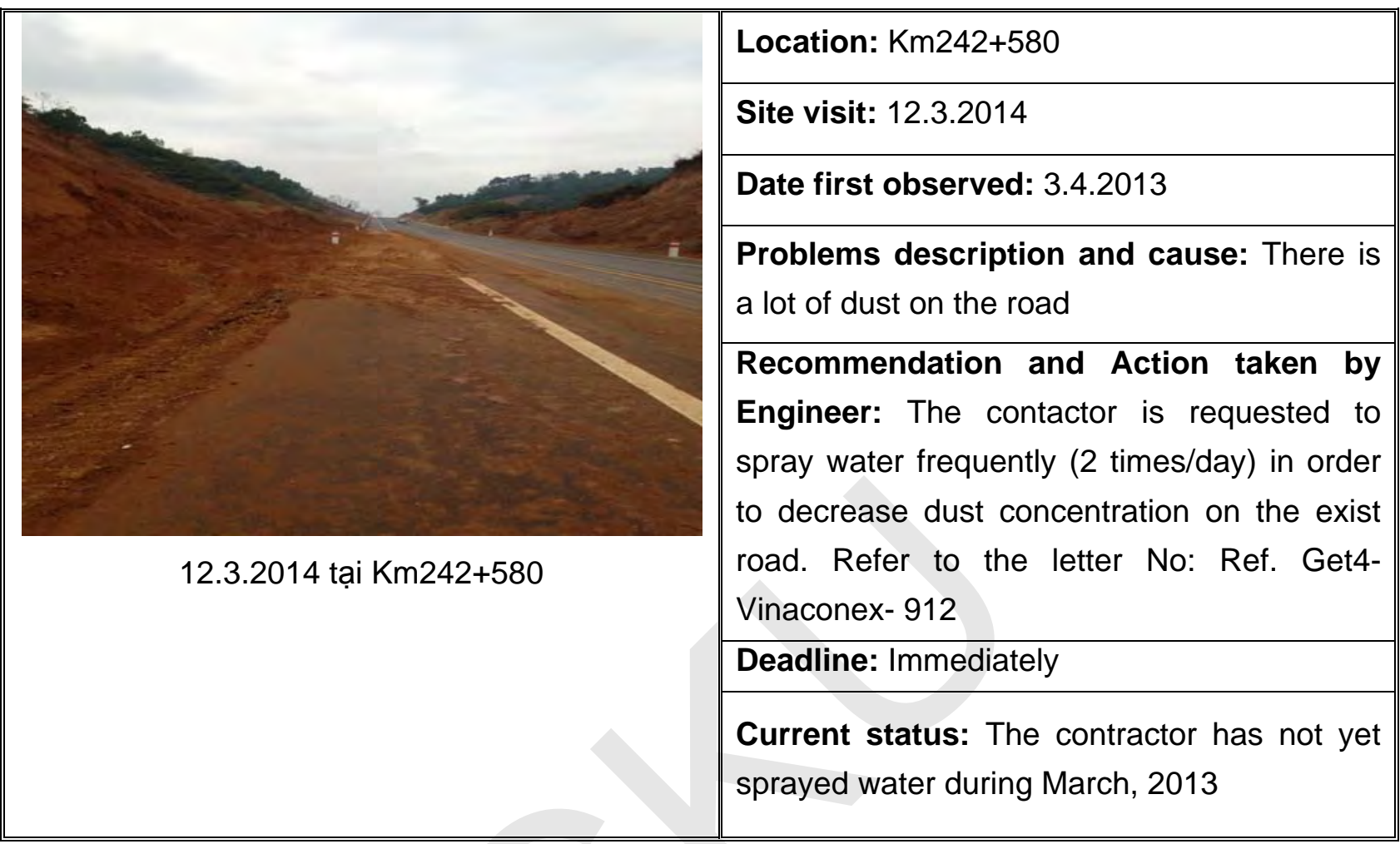

\section{$4.2 \quad$ IMPACT ON WATER RESOURCES}

As Annex 2.2 there are included the results of the water quality monitoring carried out during the period of this quarterly report.

\subsubsection{Package A1}

At the present, at package A1, the Contractor has finished all construction works.

\subsubsection{Package A2}

Up to now, all construction activities over the main water sources such as river/stream have already been completed. While carrying out the construction works of the Contractor, the Engineer also did not detect the pollution to be discharged into water sources. 
Loan 2391/2392 - VIE: GMS Kunming - Hai Phong Transport Corridor Noi Bai - Lao Cai Highway Project

\subsubsection{Package A3}

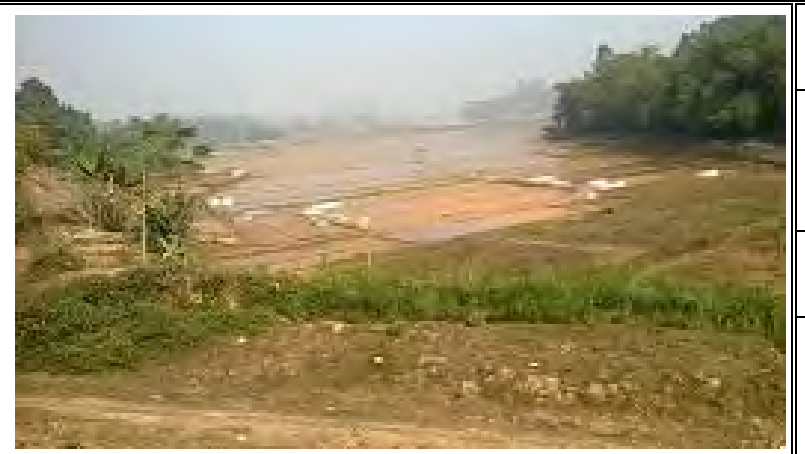

$15 / 1 / 2014$

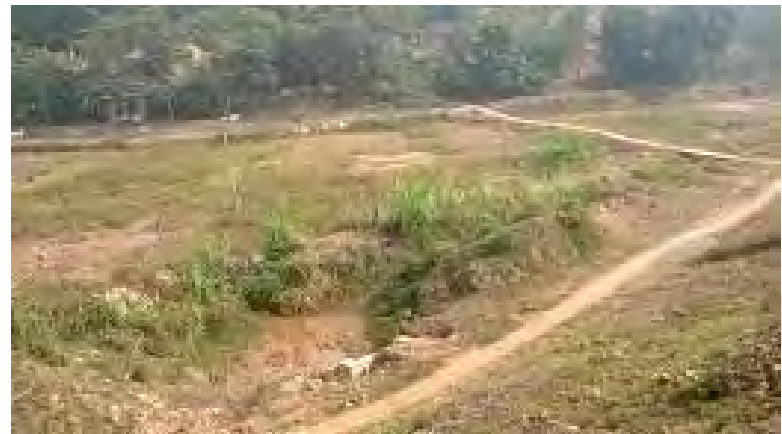

$07 / 2 / 2014$

Location: $\mathrm{Km} 53+150$

Site visit: $01,08,15,22 / 01 / 2014 ; 07,14,21$ $25 / 2 / 2014$

Date first observed: $15 / 5 / 2013$

Problems description and cause: Soil slides on agricultural lands and irrigation canals. This can affect to the water quality

Recommendation and Action taken by Engineer: The Contractor must remove all soil and dispose it into the approved disposals as well as reinforce the embankment slope.

\section{Responsible Party: Posco Contractor}

\section{Deadline: $10 / 3 / 2014$}

Current status: The compensation has been paid to the affected persons whose farmlands have been damaged due to erosion and landslides from road embankment but Contractor does not implement the suitable measures (e.g., slope stabilization, installation of adequate drainage, etc) to ensure that such impacts will be avoided.

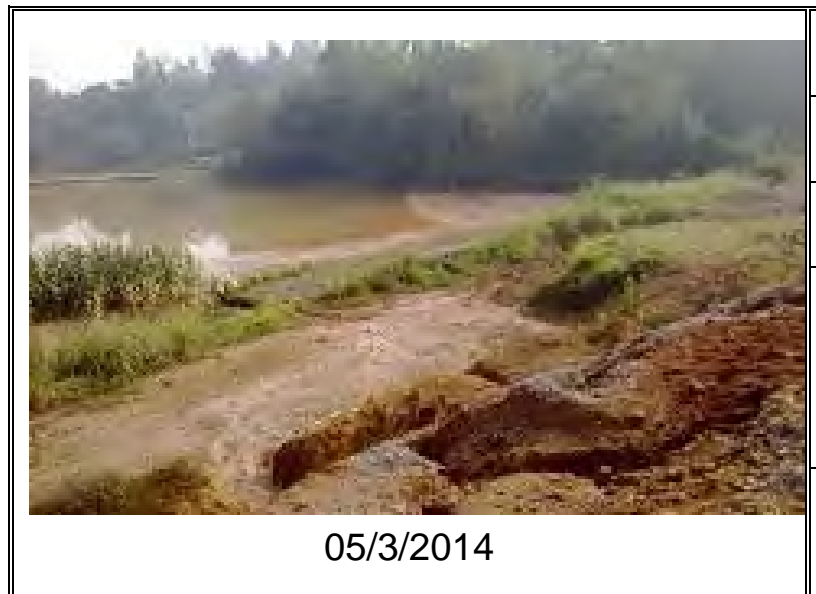

Location: $\mathrm{Km} 51+375$

Site visit: $05,12,19,26 / 3 / 3014$

Date first observed: $21 / 12 / 2013$

Problems description and cause: Soil slides on agricultural lands and irrigation canals. This can affect to the water quality

Recommendation and Action taken by Engineer: The Contractor must remove all soil 


\section{Loan 2391/2392 - VIE: GMS Kunming - Hai Phong Transport Corridor Noi Bai - Lao Cai Highway Project}

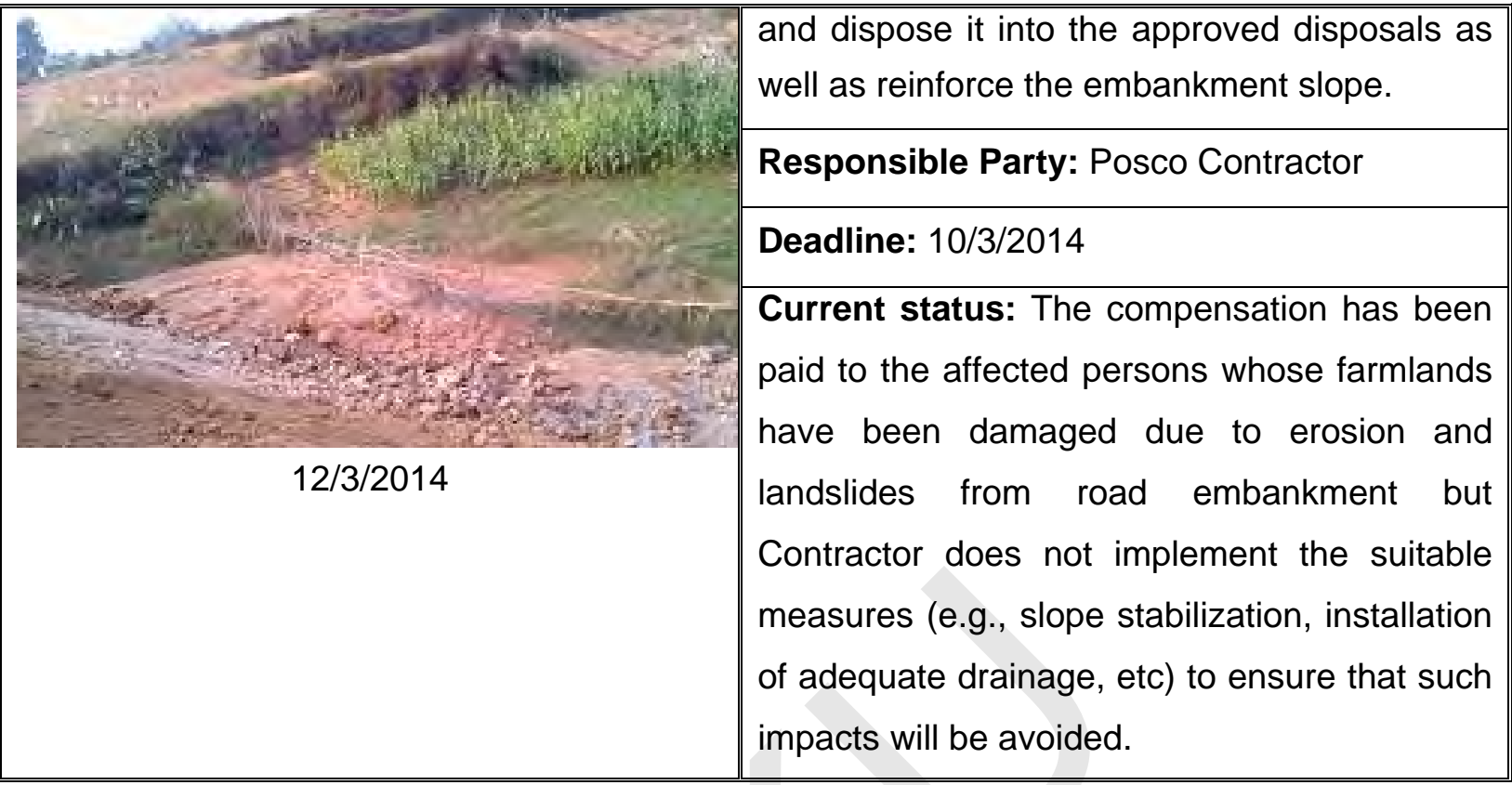

\subsubsection{Package A4}

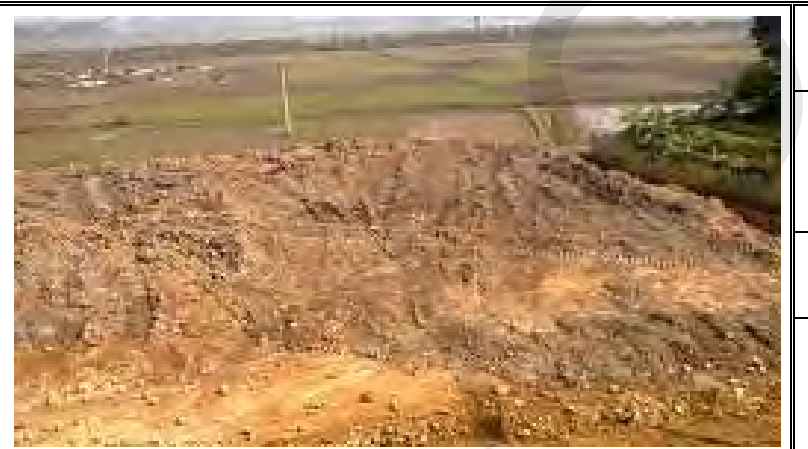

$09 / 1 / 2014$

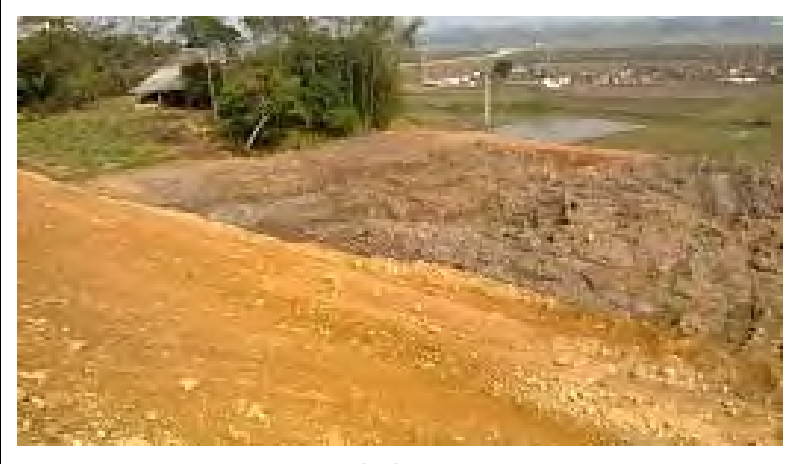

$06 / 2 / 2014$
Location: Km89+450

Site visit: $02 ; 09 ; 16 ; 23 / 1 / 2014 ; 06,13,20$, $27 / 2 / 2014 ; 06,13,20,27 / 3 / 2014$

Date first observed: $13 / 7 / 2013$

Problems description and cause: The Contractor dumped the unsuitable soil near the agricultural lands. These areas are not approved by Consultant. The soil overflowed on the surface of the agricultural lands. This can affect to the water quality as well as lead to the fall in production of these agricultural lands

Recommendation and Action taken by Engineer: GET2-KEA-A4-1377; GET2-KEAA4-1455B; GET2-KEA-A4-1508; GET2-KEAA4-1526.

Responsible Party: Keangnam 


\section{Loan 2391/2392 - VIE: GMS Kunming - Hai Phong Transport Corridor Noi Bai - Lao Cai Highway Project}

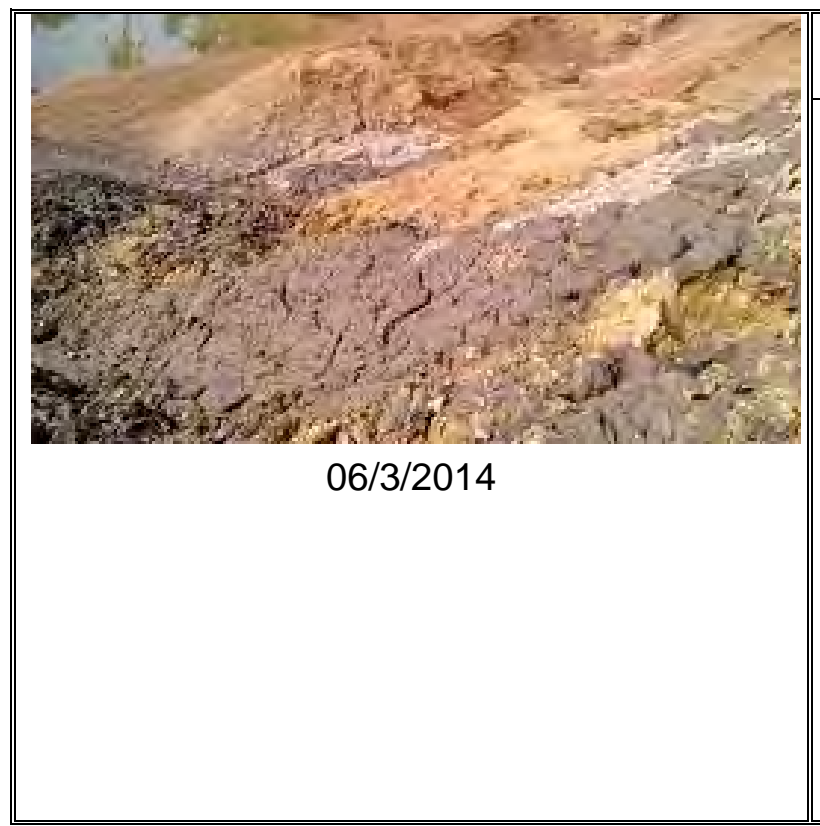

Deadline: $20 / 12 / 2013$

Current status: The Contractor did not

remove all soil to approved disposal areas

with correct approved quantity

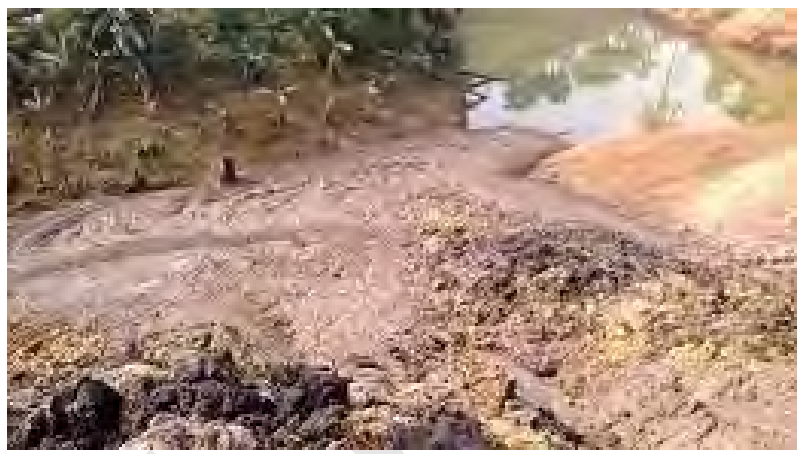

$13 / 3 / 2014$

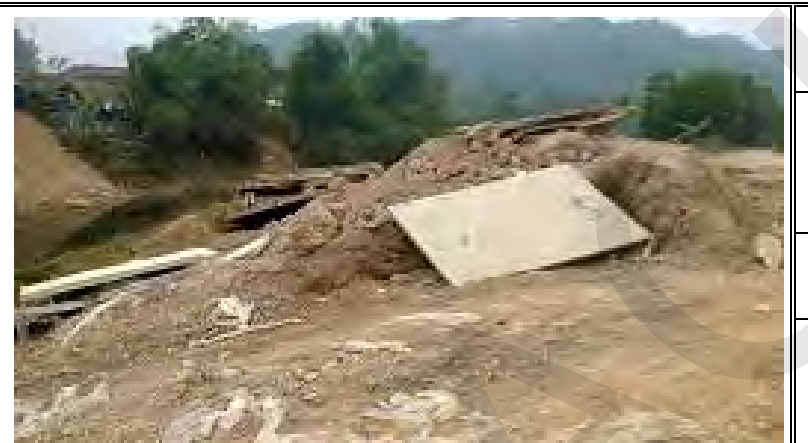

Location: Ngoi Van Bridge

Site visit: $02 ; 09 ; 16 ; 23 / 1 / 2014 ; 06,13,20$, $27 / 2 / 2014 ; 06,13,20,27 / 3 / 2014$

Date first observed: $11 / 10 / 2012$

Problems description and cause: The Contractor dumped soil into riverbed for the construction works. But the restoration works

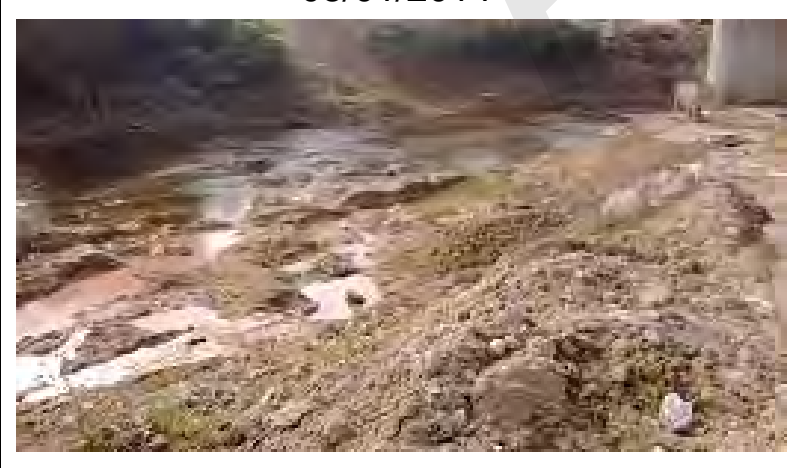
were not implemented by Contructor. This affected to the water quality

Recommendation and Action taken by Engineer: Restore the river bank by removing accumulated soil from construction works and stabilize the slope of river bank.

$20 / 02 / 2014$

Responsible Party: Keangnam

Deadline: 05/12/2013

Current status: The Contractor has not yet removed all soil to the approved disposal areas as well as implemented the restoration works. 


\section{Loan 2391/2392 - VIE: GMS Kunming - Hai Phong Transport Corridor Noi Bai - Lao Cai Highway Project}

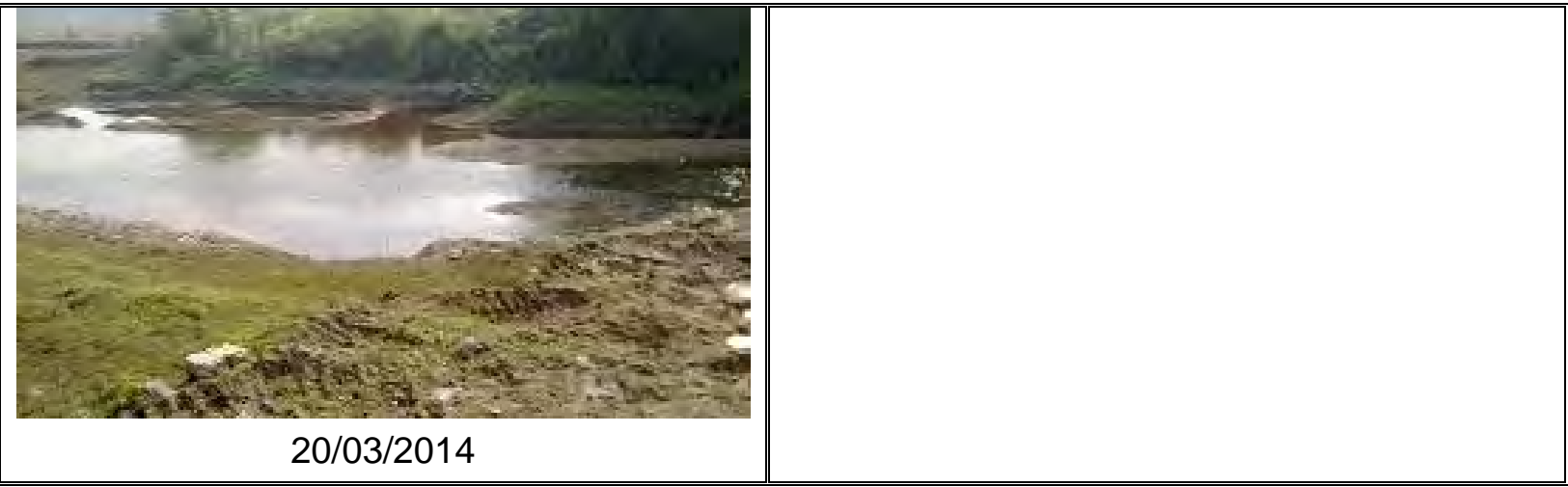

\begin{tabular}{|c|c|}
\hline \multicolumn{2}{|r|}{ Location: Km93+150 } \\
\hline & Site visit: $06,13,20,27 / 3 / 2014$ \\
\hline & Date first observed: 06/3/2014 \\
\hline $27 / 3 /$ & $\begin{array}{l}\text { Problems description and cause: The } \\
\text { Contractor dumped the unsuitable soil near } \\
\text { the agricultural lands. These areas are not } \\
\text { approved by Consultant. The soil overflowed } \\
\text { on the surface of the agricultural lands. This } \\
\text { can affect to the water quality as well as lead } \\
\text { to the fall in production of these agricultural } \\
\text { lands }\end{array}$ \\
\hline & $\begin{array}{l}\text { Recommendation and Action taken by } \\
\text { Engineer: GET2-KEA-A4-1526. }\end{array}$ \\
\hline & Responsible Party: Keangnam \\
\hline & Deadline: 20/4/2014 \\
\hline $27 / 3 / 2014$ & $\begin{array}{l}\text { Current status: The Contractor did not } \\
\text { remove all soil to approved disposal areas } \\
\text { with correct approved quantity }\end{array}$ \\
\hline
\end{tabular}

\subsubsection{Package A5}

By observations during site inspections in this quarter, we have not found any serious problem that arises from construction activity of the project affecting the water resources quality. 


\section{Loan 2391/2392 - VIE: GMS Kunming - Hai Phong Transport Corridor Noi Bai - Lao Cai Highway Project}

\subsubsection{Package A6}

By observations during site inspections in this quarter, we have not found any serious problem that arises from construction activity of the project affecting the water resources quality.

\subsubsection{Package A7}

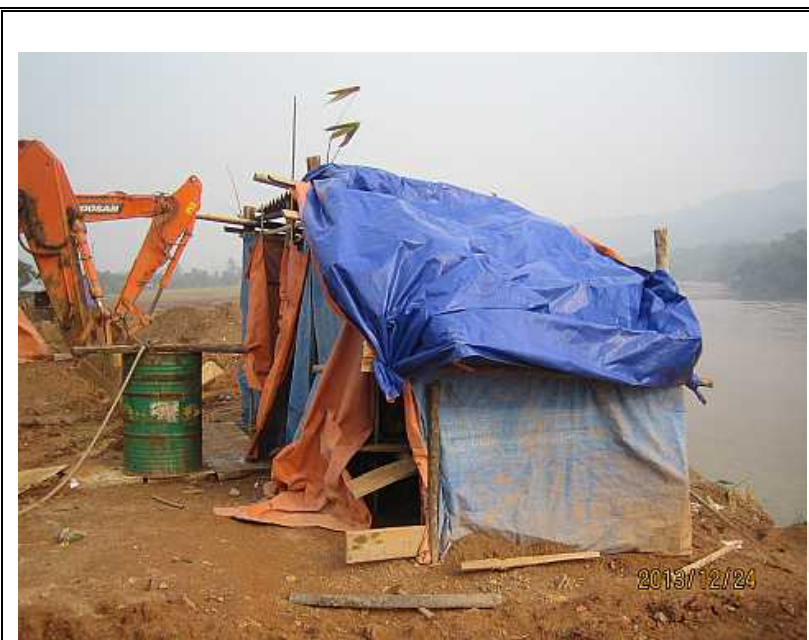

24.12.2013

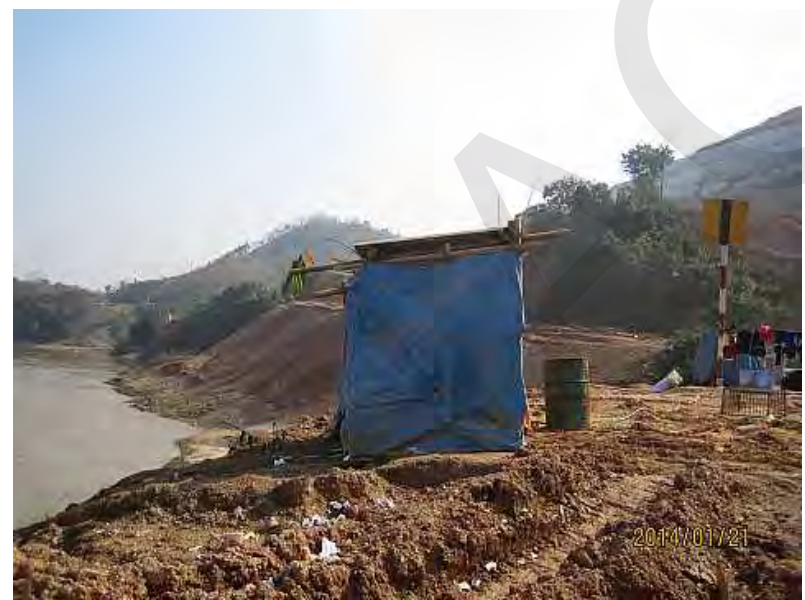

21.1.2014
Location: Worker camps at Km209+800

Site visit: $21.1 .2014 ; 25.2 .2014 ; 31.3 .2014$

Date first observed: 13.8 .2013

Problems description and cause: There is not any rubbish bin and any septic tank in the toilet at the workers' camp

Recommendation and Action taken by

Engineer: The contractor is requested to provide a rubbish bin and septic tank for toilet. Because this can affect to the surrounding water source. Reffer to the letter No: Ref. Get4- GRBCC-979

Deadline: 20.9 .2013

\section{Current status:}

In Jan: The contractor has not yet provided any rubbish bin and any septic tank for toilet. In Feb and Mar: The contractor has not yet provided any rubbish bin and any septic tank for toilet. However, the Contractor had demobilized this workers' camp. 


\section{Loan 2391/2392 - VIE: GMS Kunming - Hai Phong Transport Corridor Noi Bai - Lao Cai Highway Project}

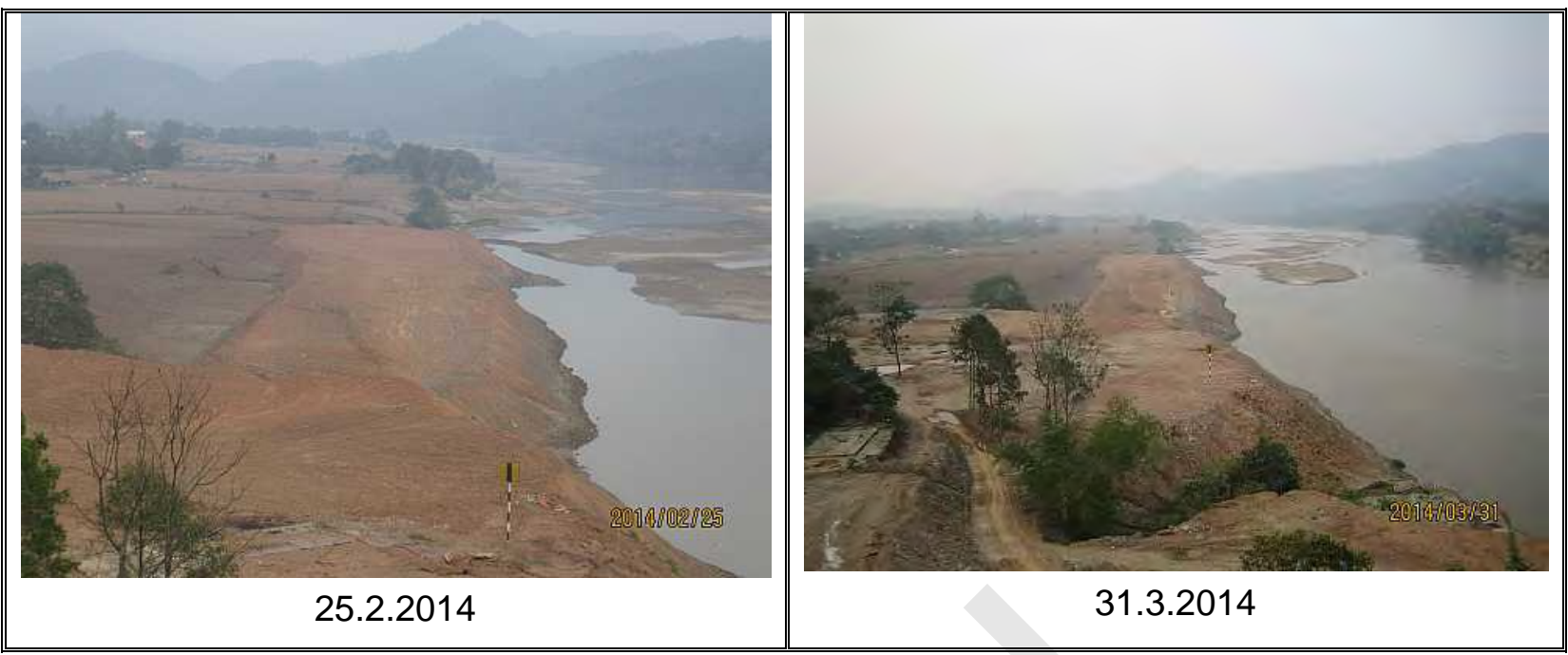

\subsubsection{Package A8}

At present, the construction works at Ngoi Bo Bridge, Suoi Nhu Bridge and Suoi Trat Bridge have been completed. So, the construction activities at these locations did not affect to the water quality.

\subsection{IMPACT ON SOILS QUALITY}

\subsubsection{Package A1}

At the present, at package A1, the Contractor has finished all construction works.

\subsubsection{Package A2}

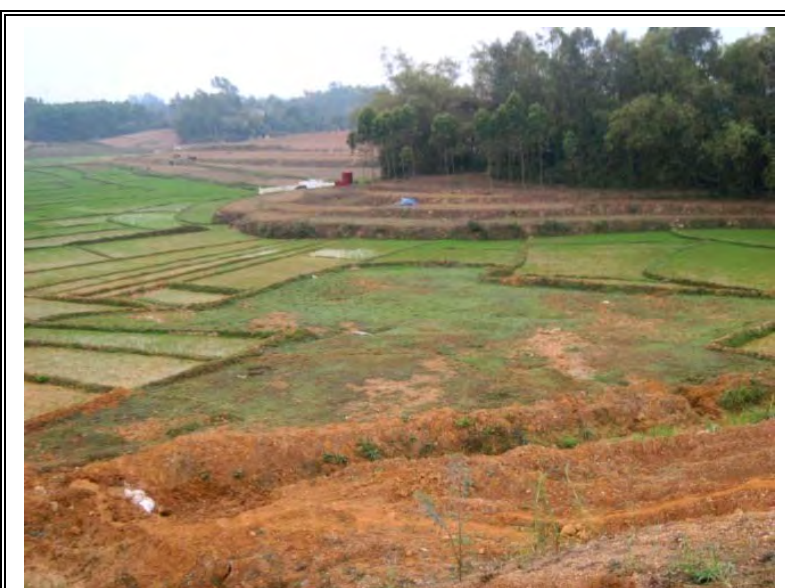

January 08, 2014
Location: $\mathrm{Km} \mathrm{42+400} \mathrm{Km} \mathrm{44+900}$

Site visit: 8, 10, 16, 22 Jan; 10, 17, 25 Feb; 4, 12, 17, 25 Mar

Date first observed: 05-June-2013

Problems description and cause:

Uncontrolled erosion leaded sediment into croplands and damaged the crop of local people; restoration work is being carried out slowly
Hanoi office:

VinhPhuc office: Madrid head office $12^{\text {th }}$ floor, Ocean Park Building, Dao Duy Anh Street, Dong Da Distric 


\section{Loan 2391/2392 - VIE: GMS Kunming - Hai Phong Transport Corridor Noi Bai - Lao Cai Highway Project}

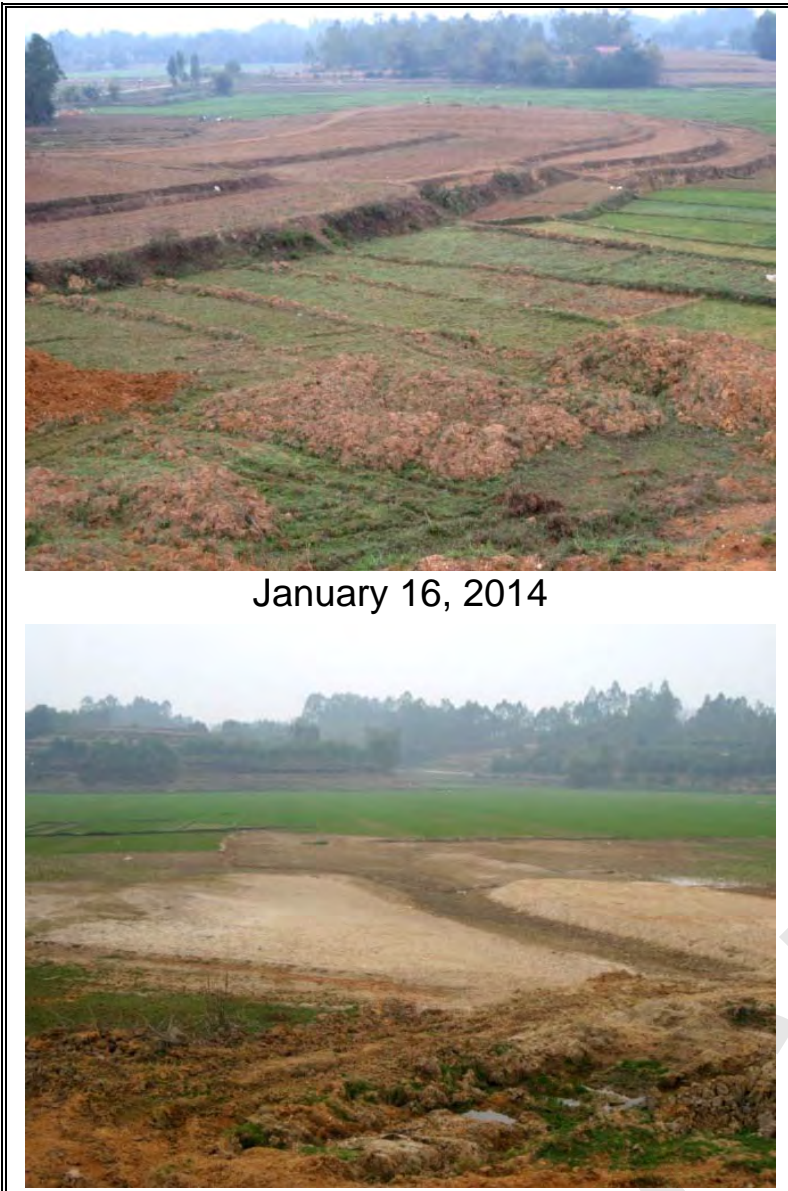

February 17, 2014

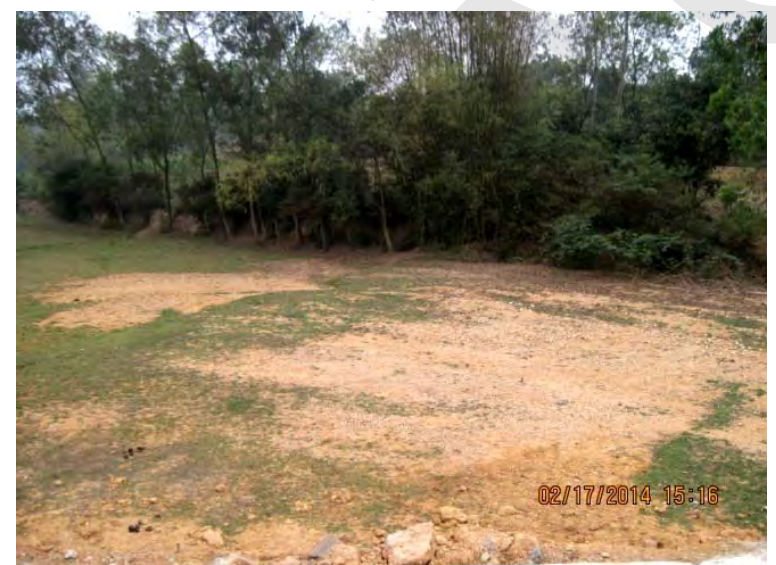

February 17, 2014

\section{Recommendation and Action taken by}

Engineer: Apply erosion and sediment control measures; contact local people and authority to negotiate to compensate for the damaged assets and restore affected areas. Refer to letter GET1/POS/A2/2090, 2101, 2176, 2315; GET/MISC/361, 363; The Engineer also warned the Project Manager of the Contractor of his negative attitude in cooperation to deal with problem; refer to letter GET1/POS/A2/2266; 2362, 2450

Responsible Party: POSCO

\section{Deadline:}

In Jan.: 20-Jan-2014

In Feb and Mar: By 31-Mar-2014

\section{Current status:}

In Jan and Feb: The Contractor has mobilized equipment to restore the affected areas but the progress is slowly; besides, the negotiation for damaged assets compensation has not been implemented due to the stagnancy of the Contractor.

In March: The Contractor is carrying out the compensation for local people who have affected cropland.

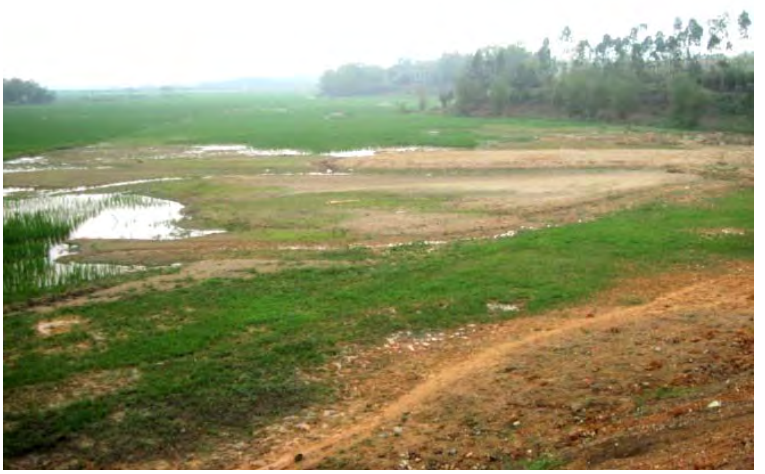




\section{Loan 2391/2392 - VIE: GMS Kunming - Hai Phong Transport Corridor Noi Bai - Lao Cai Highway Project}

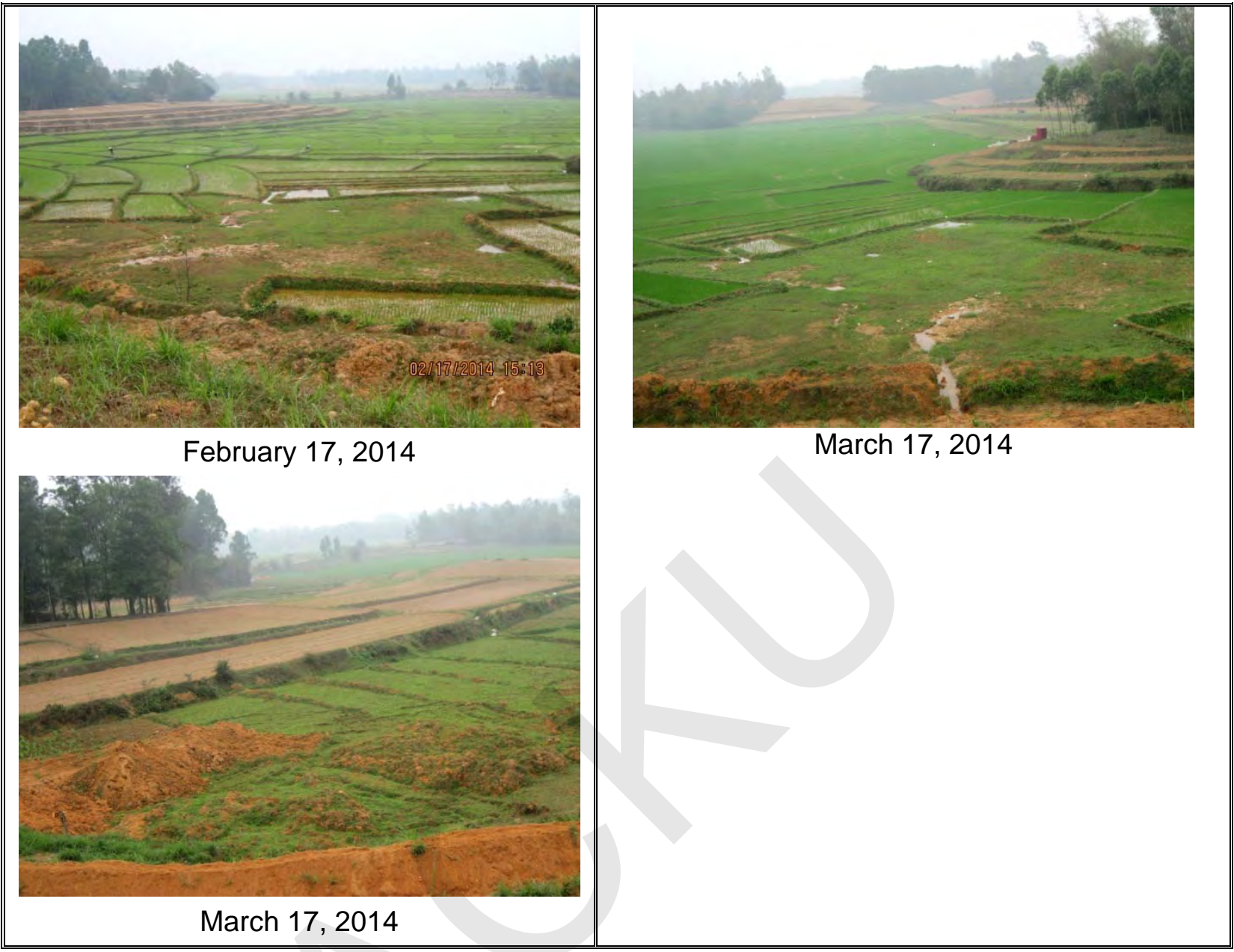

\subsubsection{Package A3}

\begin{tabular}{|c|c|}
\hline & Location: Km53+150 \\
\hline & $\begin{array}{l}\text { Site visit: } 01,08,15,22 / 01 / 2014 ; 07,14,21 \text {, } \\
25 / 2 / 2014\end{array}$ \\
\hline & Date first observed: $15 / 5 / 2013$ \\
\hline 4 & $\begin{array}{l}\text { Problems description and cause: Soil slides } \\
\text { on agricultural lands and irrigation canals. This } \\
\text { cause the fall in production of the households }\end{array}$ \\
\hline $6 x=$ & Recommendation and Action taken by \\
\hline $15 / 1 / 2014$ & $\begin{array}{l}\text { Engineer: The Contractor must remove soil } \\
\text { and dispose it into the approved disposals as }\end{array}$ \\
\hline
\end{tabular}




\section{Loan 2391/2392 - VIE: GMS Kunming - Hai Phong Transport Corridor Noi Bai - Lao Cai Highway Project}

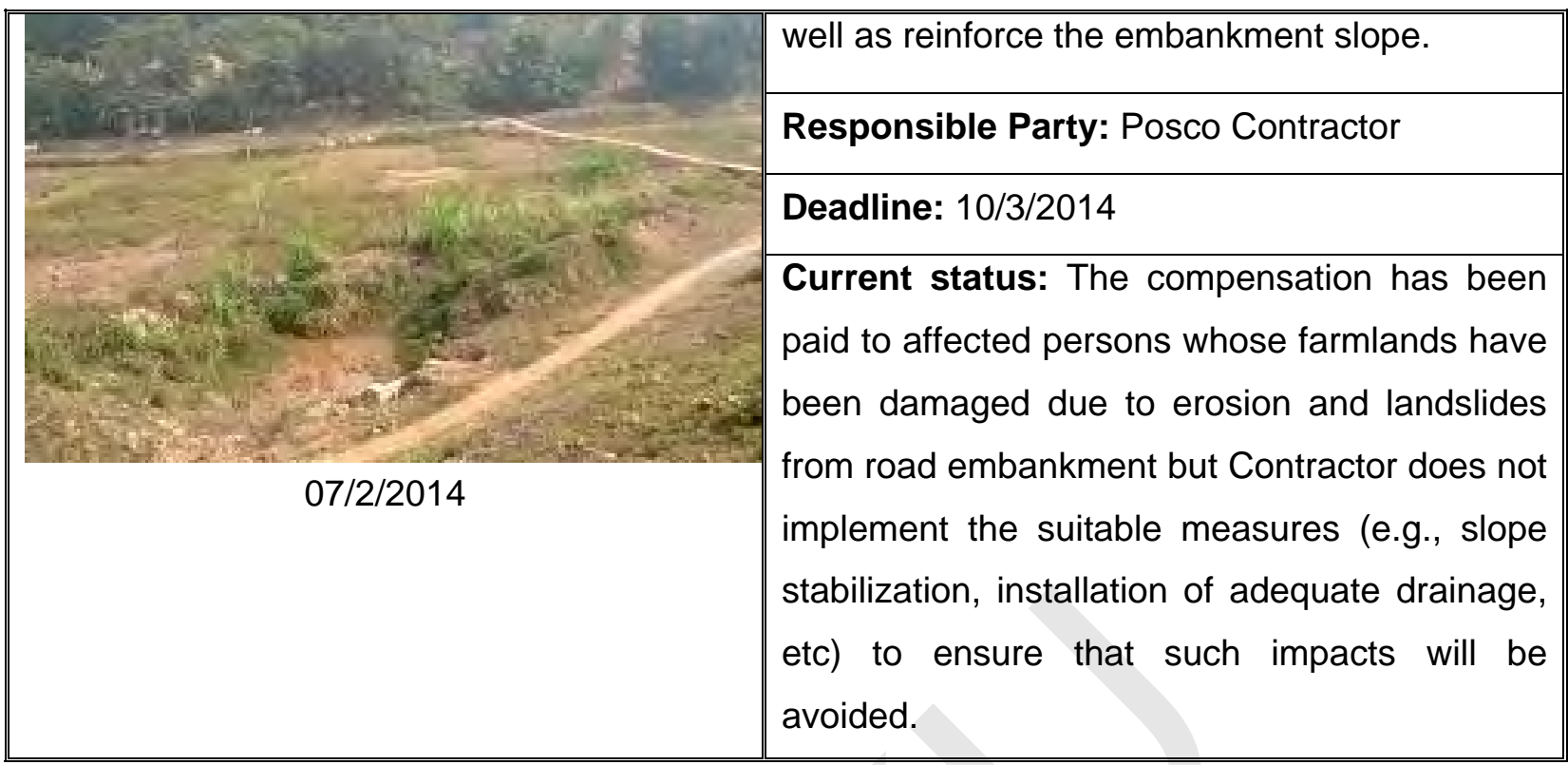

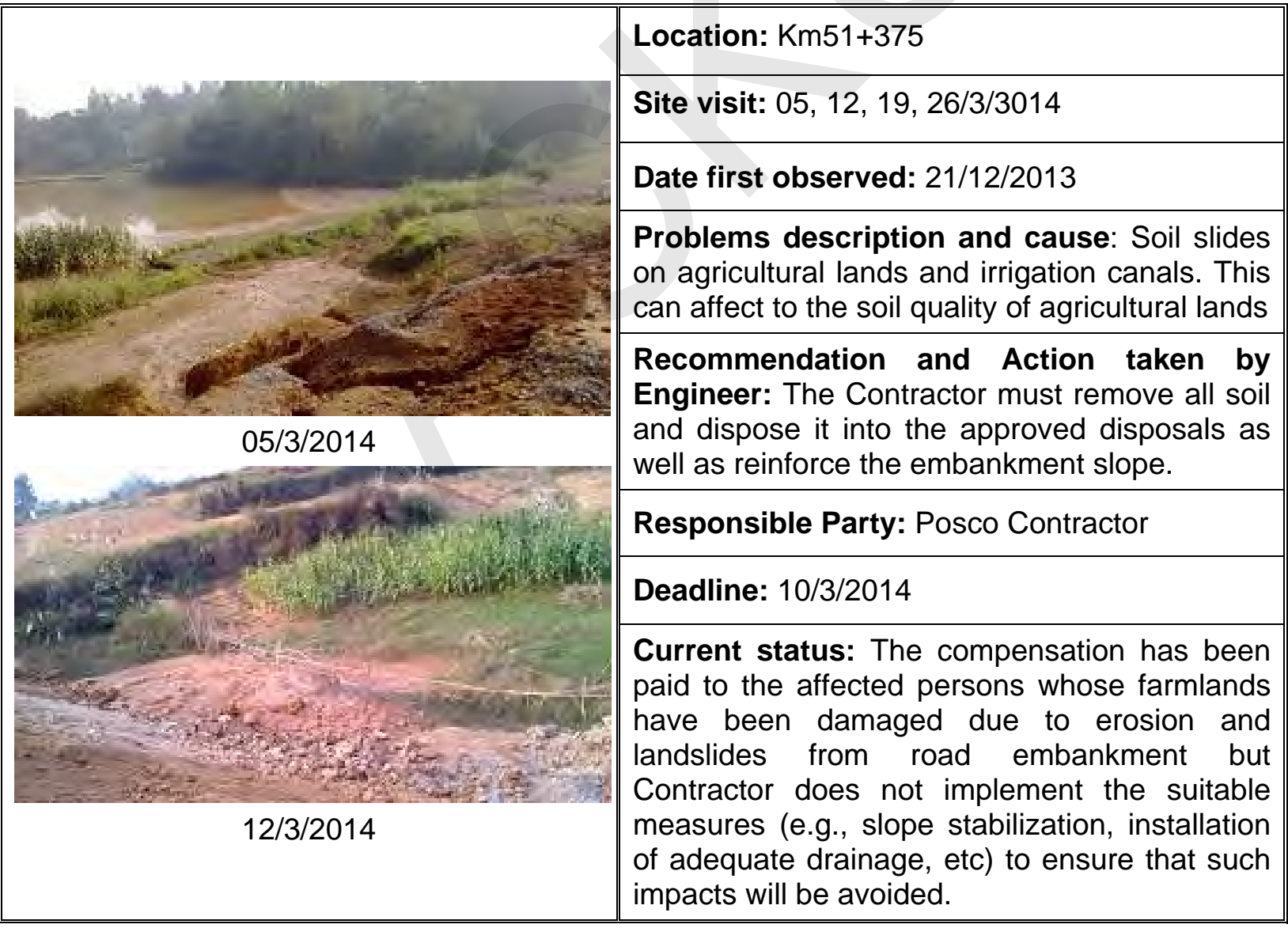




\section{Loan 2391/2392 - VIE: GMS Kunming - Hai Phong Transport Corridor Noi Bai - Lao Cai Highway Project}

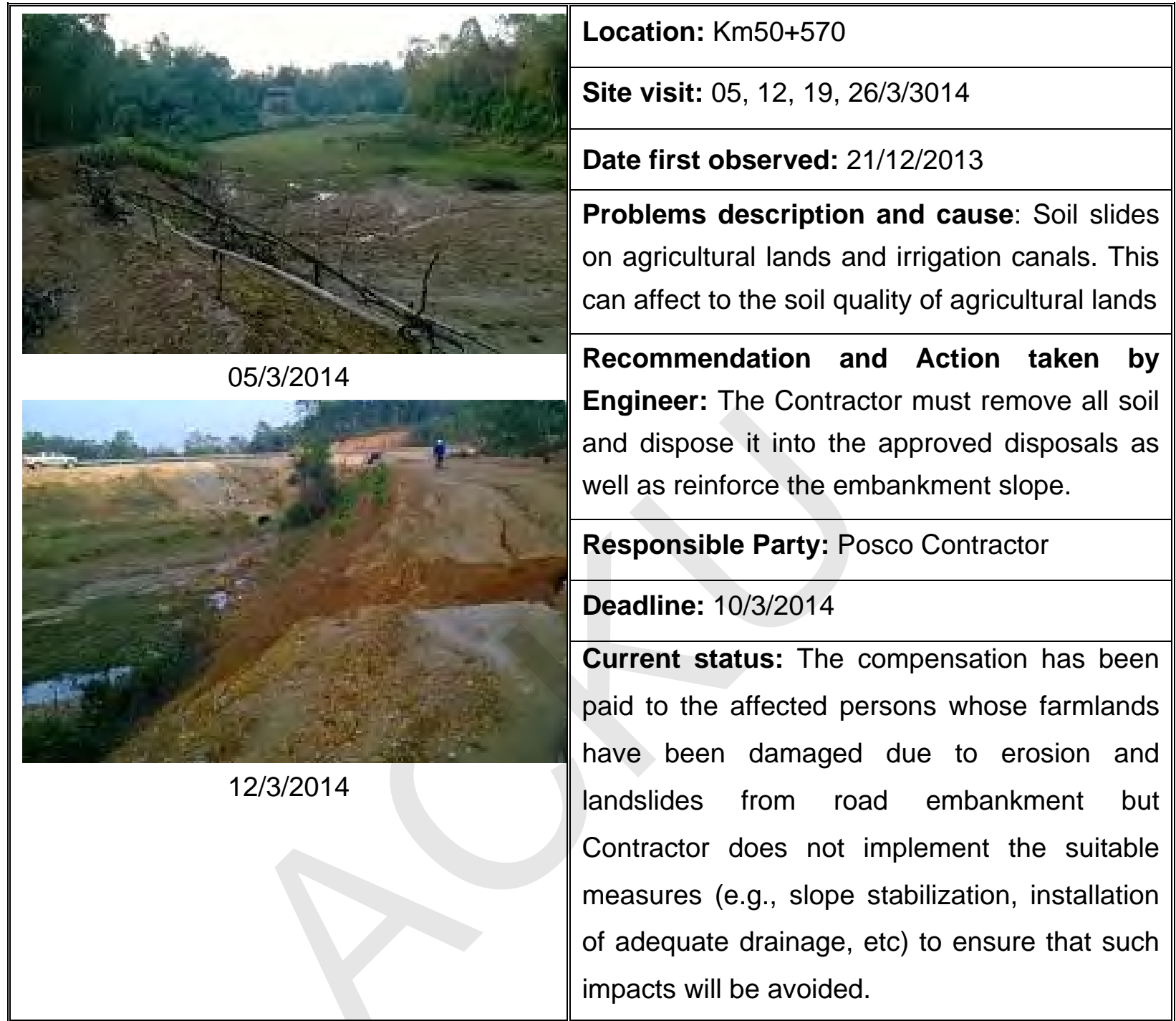

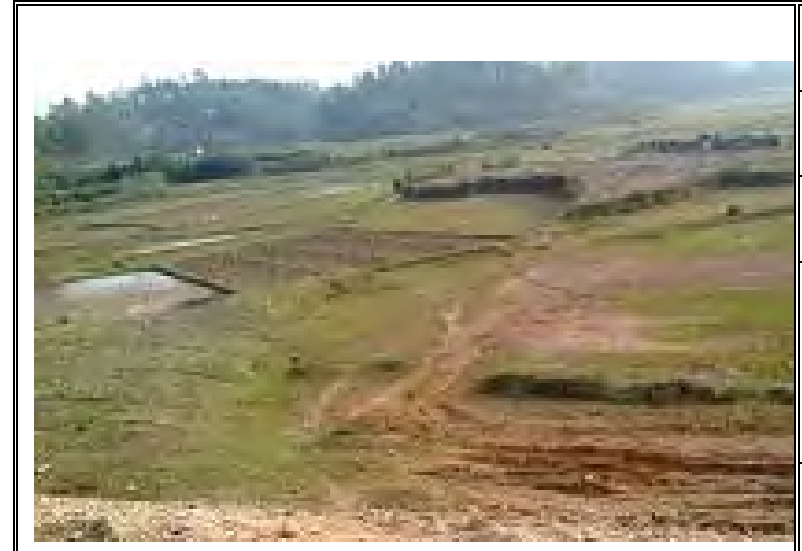

Location: Km62+570

Site visit: $05,12,19,26 / 3 / 3014$

Date first observed: $21 / 12 / 2013$

Problems description and cause: Soil slides on agricultural lands and irrigation canals. This can affect to the soil quality of agricultural lands

Recommendation and Action taken by $05 / 3 / 2014$

Engineer: The Contractor must remove all soil and dispose it into the approved disposals as 


\section{Loan 2391/2392 - VIE: GMS Kunming - Hai Phong Transport Corridor Noi Bai - Lao Cai Highway Project}

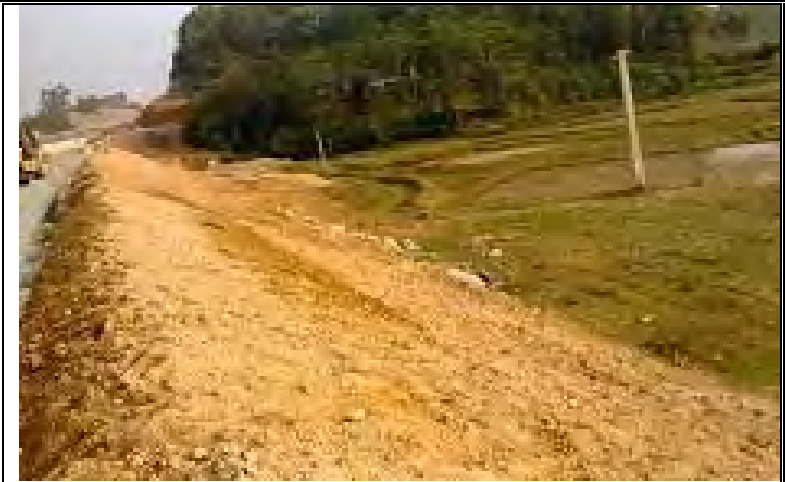

$12 / 3 / 2014$ well as reinforce the embankment slope.

Responsible Party: Posco Contractor

Deadline: $10 / 3 / 2014$

Current status: The compensation has been paid to the affected persons whose farmlands have been damaged due to erosion and landslides from road embankment but Contractor does not implement the suitable measures (e.g., slope stabilization, installation of adequate drainage, etc) to ensure that such impacts will be avoided.

\subsubsection{Package A4}

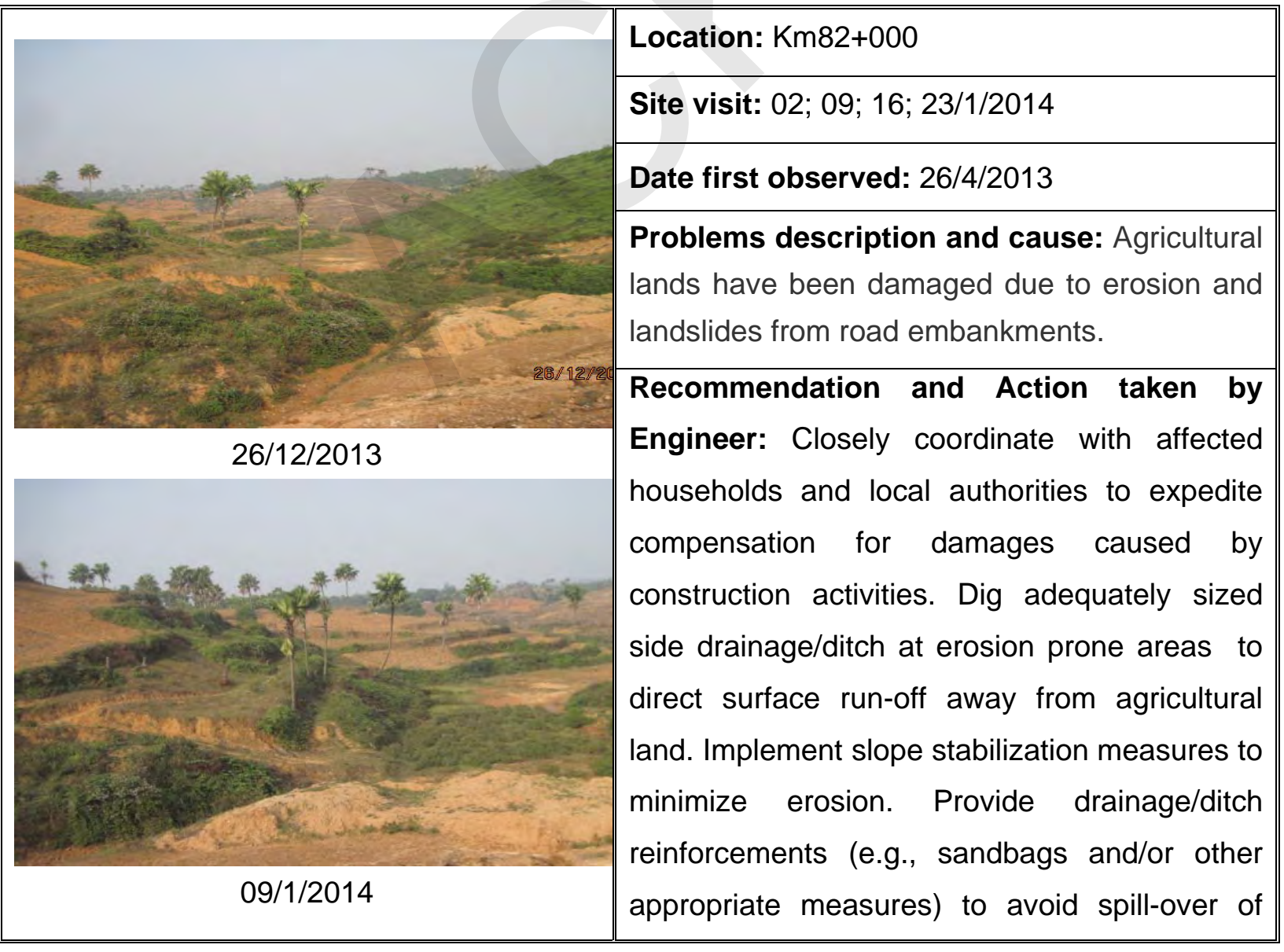


Loan 2391/2392 - VIE: GMS Kunming - Hai Phong Transport Corridor Noi Bai - Lao Cai Highway Project

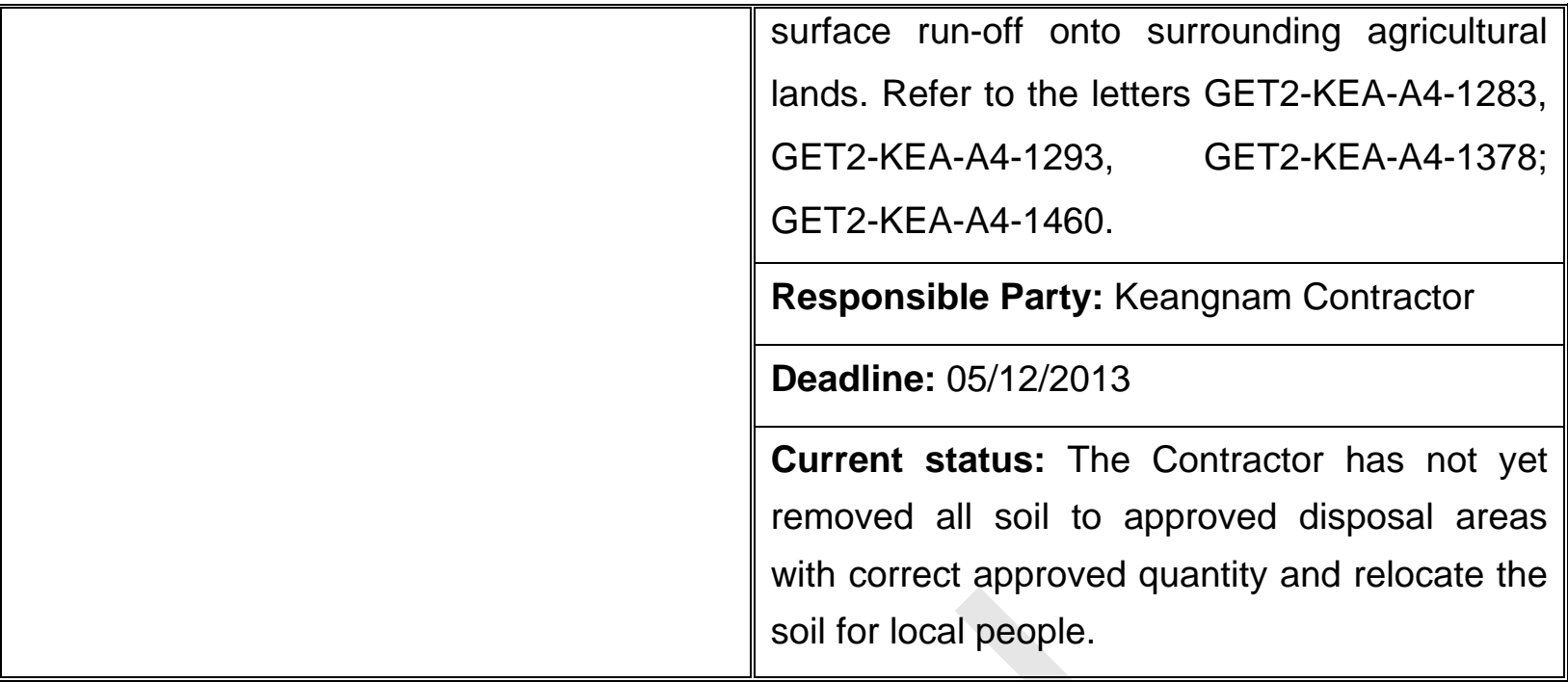
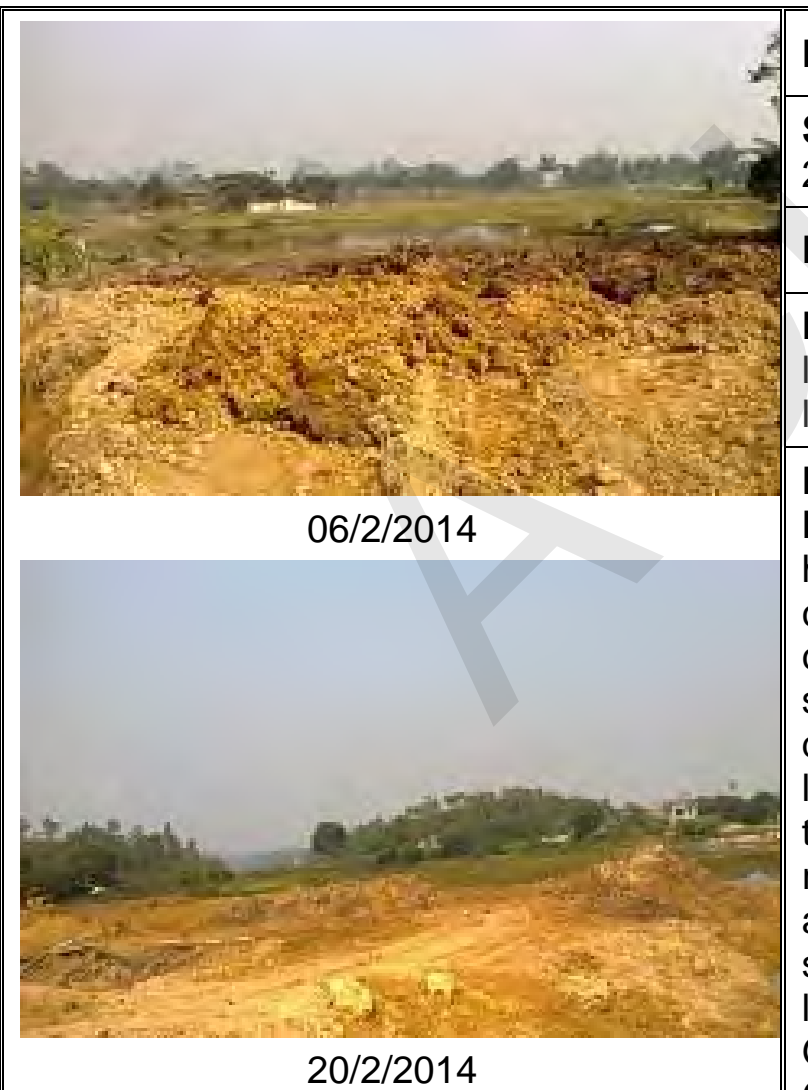

Hanoi office:

VinhPhuc office:

Madrid head office:
Location: Km92+260

Site visit: $06,13,20,27 / 2 / 2014 ; 06,13,20$, $27 / 3 / 2014$

Date first observed: $26 / 4 / 2013$

Problems description and cause: Agricultural lands have been damaged due to erosion and landslides from road embankments.

Recommendation and Action taken by Engineer: Closely coordinate with affected households and local authorities to expedite compensation for damages caused by construction activities. Dig adequately sized side drainage/ditch at erosion prone areas to direct surface run-off away from agricultural land. Implement slope stabilization measures to minimize erosion. Provide drainage/ditch reinforcements (e.g., sandbags and/or other appropriate measures) to avoid spill-over of surface run-off onto the surrounding agricultural lands. Refer to the letters GET2-KEA-A4-1283, GET2-KEA-A4-1293, GET2-KEA-A4-1378; GET2-KEA-A4-1460, GET2-KEA-A4-1509; GET2-KEA-A4-1526.

Responsible Party: Keangnam Contractor

Deadline:

In Feb: 05/12/2013

In Mar: 05/4/2014 


\section{Loan 2391/2392 - VIE: GMS Kunming - Hai Phong Transport Corridor Noi Bai - Lao Cai Highway Project}

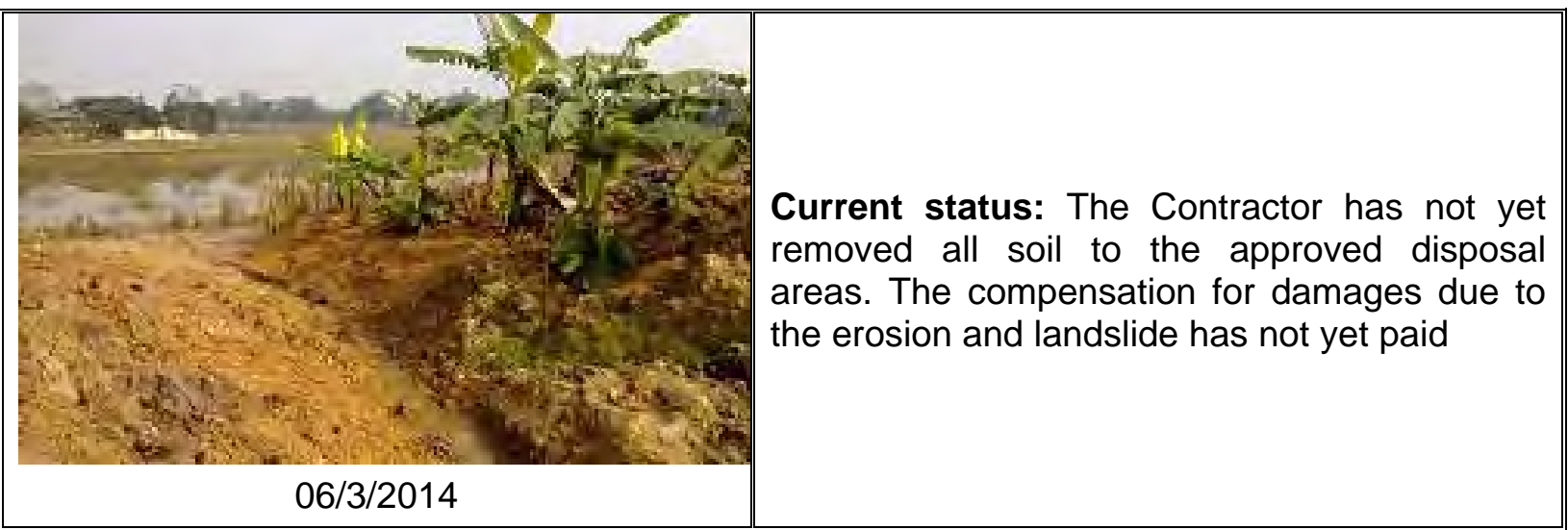

\subsubsection{Package A5}

\begin{tabular}{|c|c|}
\hline & Location: Ngoi Thu bridge's construction site \\
\hline & Site visit: 6 January, 2014 \\
\hline & Date first observed: $4^{\text {th }}$ November,2013 \\
\hline & $\begin{array}{l}\text { Problems description and cause: Fuel } \\
\text { storage tanks are not well controlled. Fuel } \\
\text { tanks were placed directly on the ground. This } \\
\text { situation caused the leak of oil and soil } \\
\text { pollution. }\end{array}$ \\
\hline & $\begin{array}{l}\text { Recommendation and Action taken by } \\
\text { Engineer: The Engineer required the }\end{array}$ \\
\hline \multirow{5}{*}{ December 3, 2013 (Ngoi Thu bridge) } & Contractor to improve fuel control at this \\
\hline & provided the instruction for these issues. \\
\hline & Responsible Party: Keangnam Contractor \\
\hline & Deadline: $12-$ Nov-2013 \\
\hline & $\begin{array}{l}\text { Current status: } \\
-6^{\text {th }} \text { January, 2014: Not yet improved }\end{array}$ \\
\hline January 6, 2014 (Ngoi Thu bridge) & \\
\hline
\end{tabular}




\section{Loan 2391/2392 - VIE: GMS Kunming - Hai Phong Transport Corridor Noi Bai - Lao Cai Highway Project}

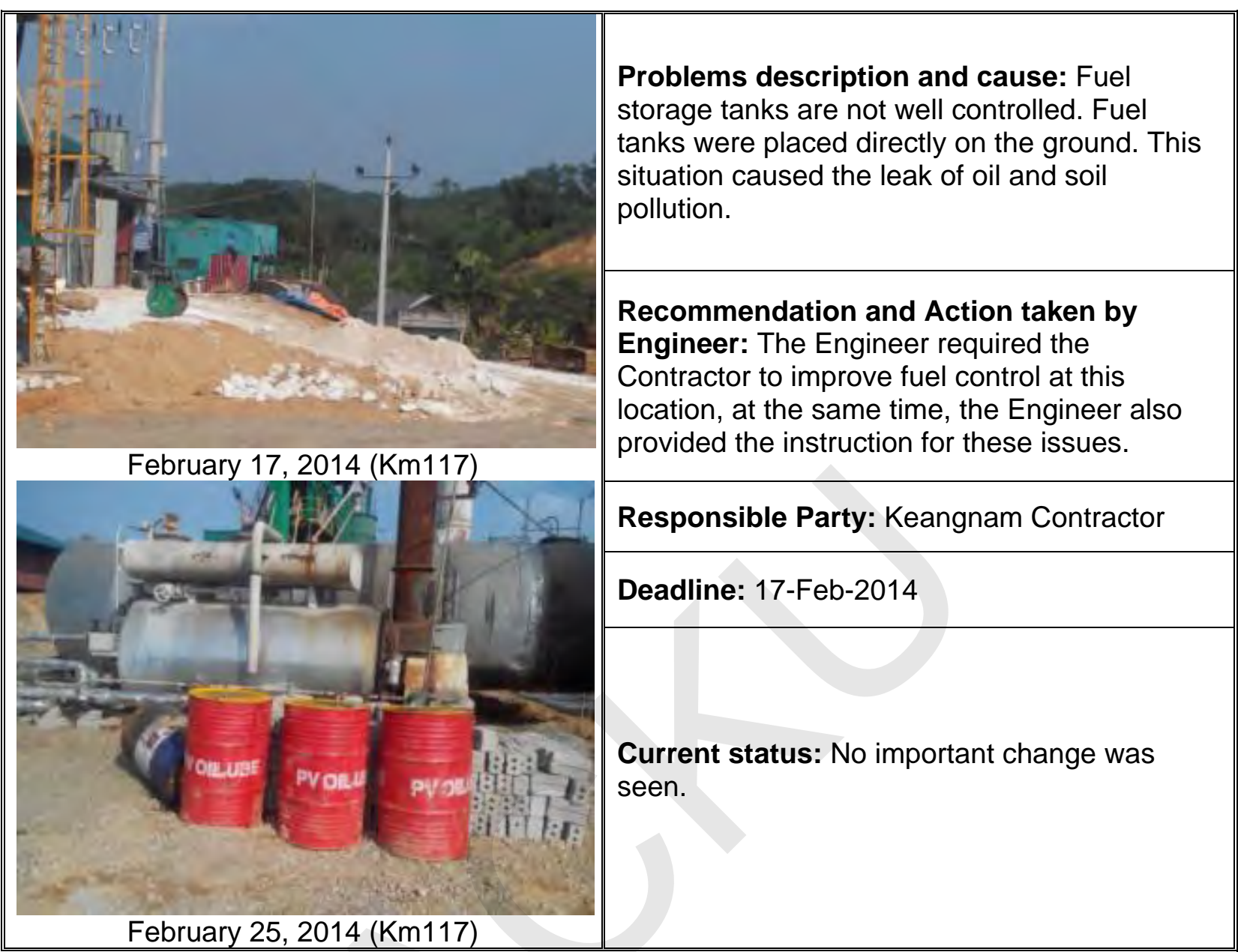

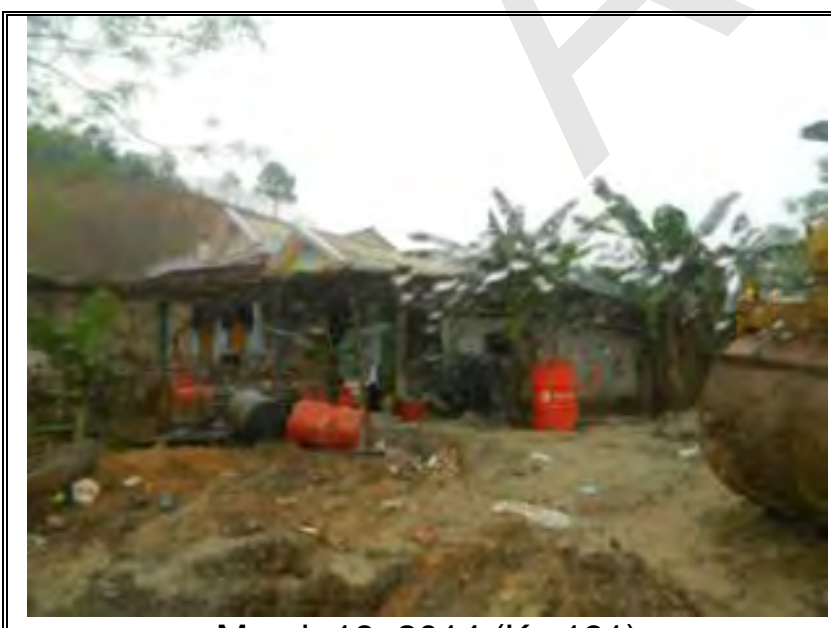

March 18, 2014 (Km131)
Location: $\mathrm{Km} 130+900$

Site visit: 18 and 28 March, 2014

Date first observed: $18^{\text {th }}$ March, 2014

Problems description and cause: The Contractor did not control well the fuel management. Haphazard placement of waste oil and oil drums was observed on site. This can cause the spills/leaks of oil on the ground and affect to the soil quality.

Recommendation and Action taken by Engineer: The Engineer required the Contractor to improve the fuel management at this location. At the same time, the Engineer also provided the instruction for this issues. 
Loan 2391/2392 - VIE: GMS Kunming - Hai Phong Transport Corridor Noi Bai - Lao Cai Highway Project

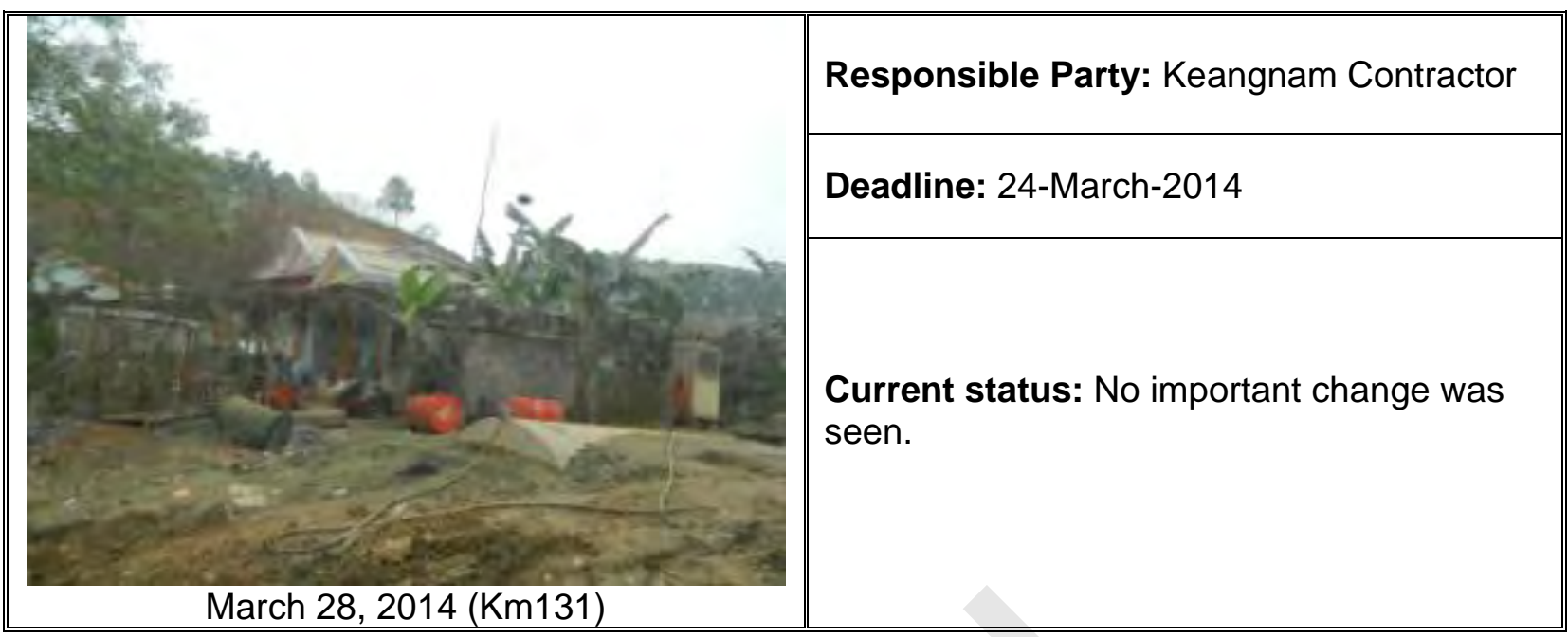

\subsubsection{Package A6}

In January, during inspection and supervision on construction site, the Engineer did not detect any serious problem that arose from construction activities of the project affecting to the soil quality.

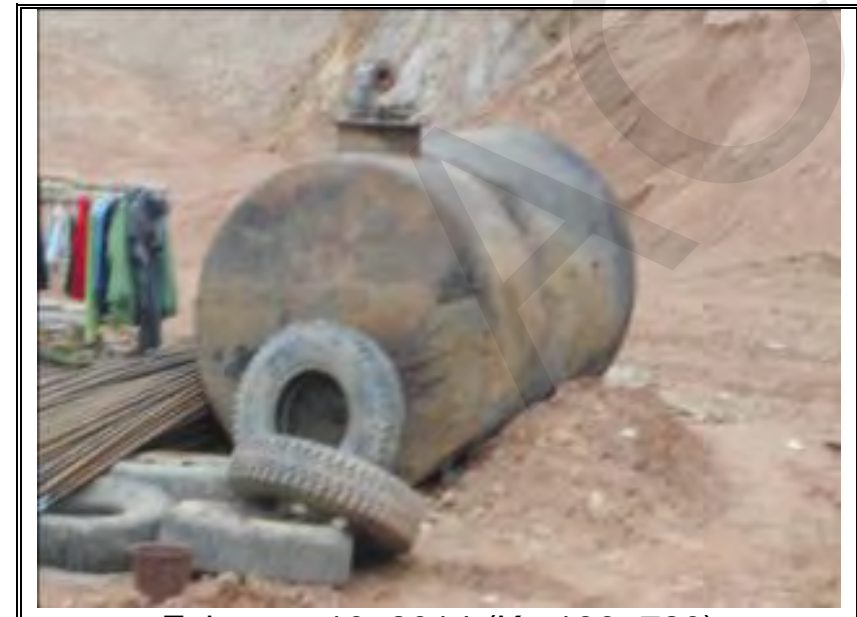

February 10, $2014(\mathrm{Km} 186+720)$
Location: $\mathrm{Km} 186+720$

Site visit: 10 and 26 February; 4 March, 2014

Date first observed: $10^{\text {th }}$ February, 2014

Problems description and cause: The Contractor did not control well the management of fuel storage. Fuel tanks are placed directly on the ground. This situation can cause the leak of oil and soil pollution.

Recommendation and Action taken by Engineer: The Engineer required the Contractor to improve fuel control at this location. At the same time, the Engineer also provided some instructions for this issue.

Responsible Party: Doosan Contractor

Deadline: 17- Feb-2014 


\section{Loan 2391/2392 - VIE: GMS Kunming - Hai Phong Transport Corridor Noi Bai - Lao Cai Highway Project}
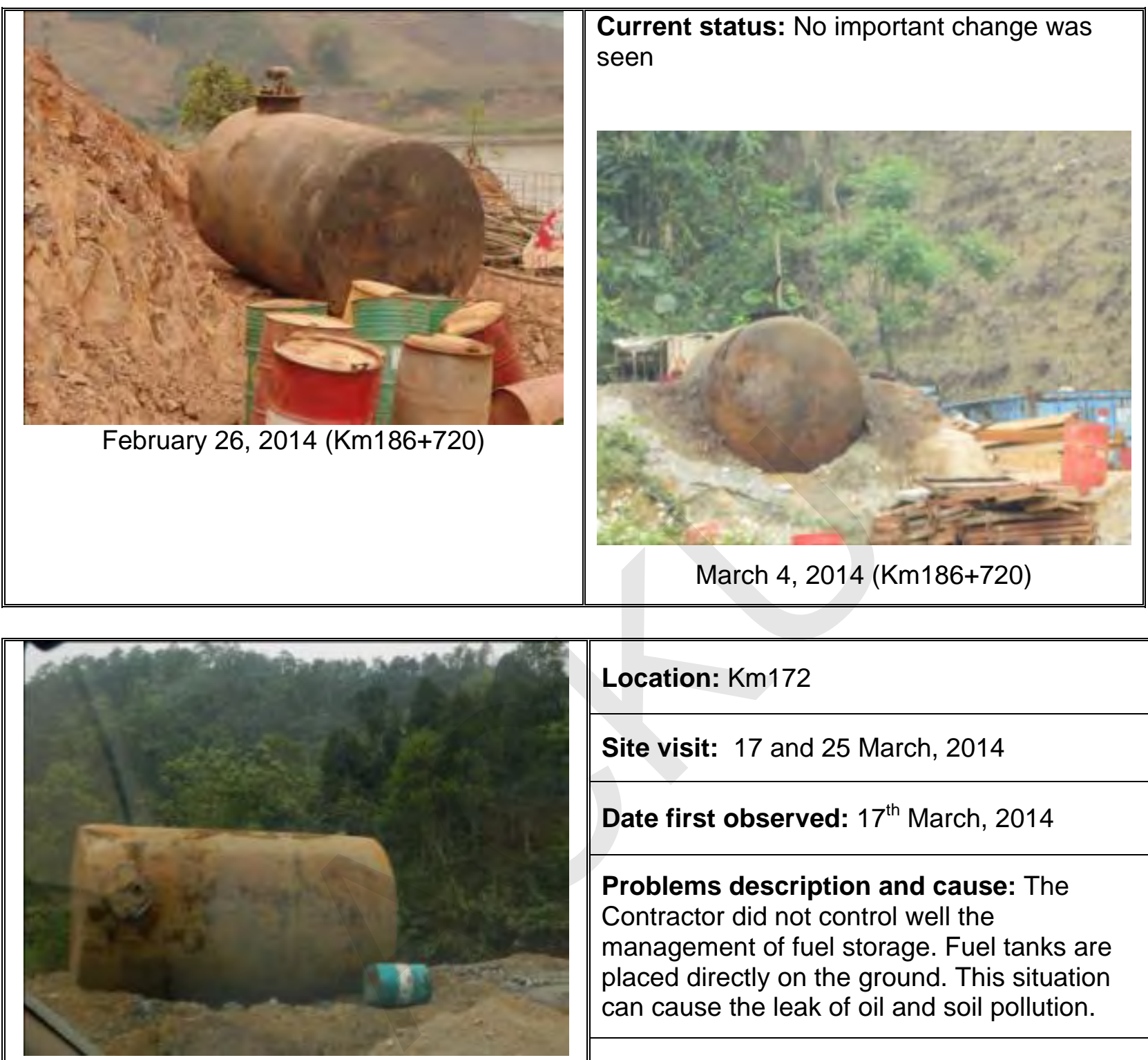

Location: $\mathrm{Km} 172$

Site visit: 17 and 25 March, 2014

Date first observed: $17^{\text {th }}$ March, 2014

Problems description and cause: The

Contractor did not control well the

management of fuel storage. Fuel tanks are placed directly on the ground. This situation can cause the leak of oil and soil pollution.

Recommendation and Action taken by

Engineer: The Engineer required the Contractor to improve fuel control at this location. At the same time, the Engineer also provided some instructions for this issue.

Responsible Party: Doosan Contractor

Deadline: 25 - Mar - 2014

Current status: No important change was seen

March 25, 2014 (Km172) 


\section{Loan 2391/2392 - VIE: GMS Kunming - Hai Phong Transport Corridor Noi Bai - Lao Cai Highway Project}

\subsubsection{Package A7}

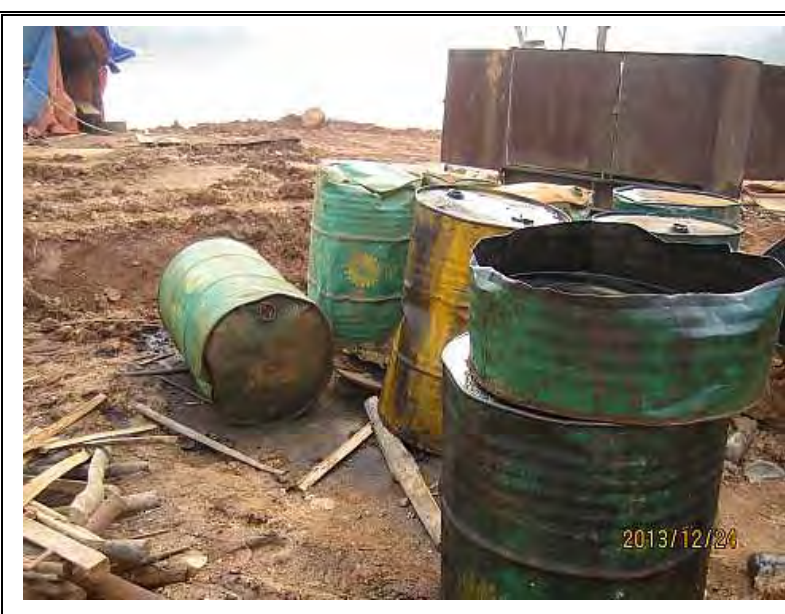

24.12.2013

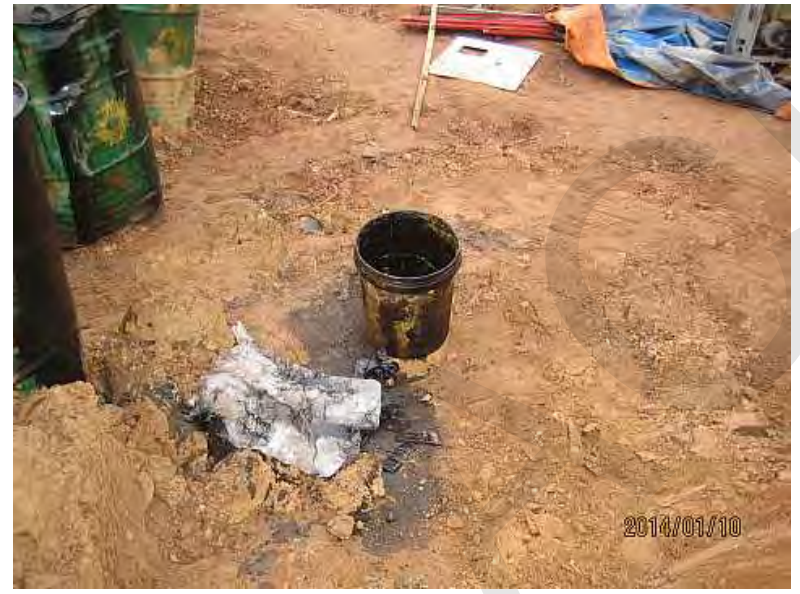

10.1.2014

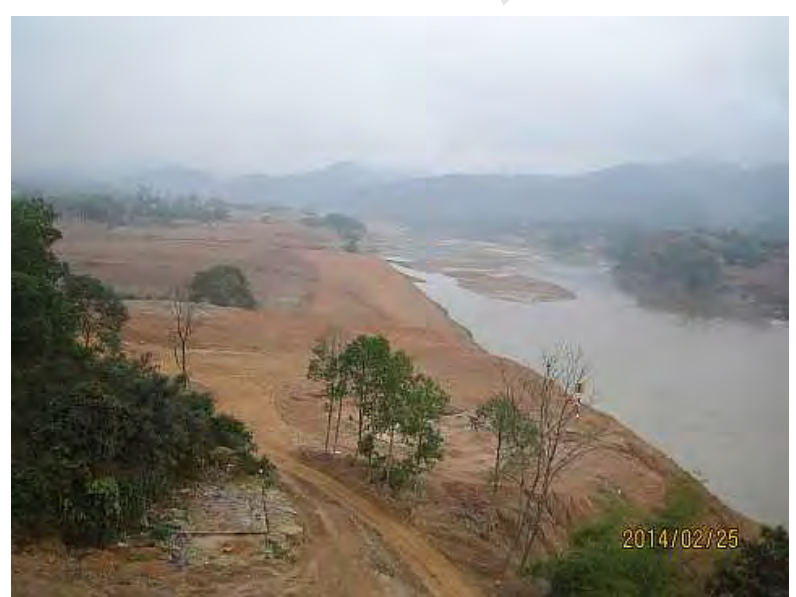

25.2.2014
Location: Store place Km209+800

Site visit: $10.1 .2014 ; 25.2 .2014 ; 31.3 .2014$

Date first observed: 10.9 .2013

Problems description and cause: Oil and waste oil tanks are put directly on the ground. This can affect soil quality

Recommendation and Action taken by Engineer: Required the contractor to put oil and waste oil tanks inside the store with floor concreted. Consultant had issued many letters to the contractor such as: Get4- GRBCC- 952, 979 and GET- GUA- 107, 112, 125

Deadline: 20.9.2013

\section{Current status:}

In Jan: Not yet improved

In Feb and Mar: Not yet improved. However, the contractor had demobilized this workers' camp.

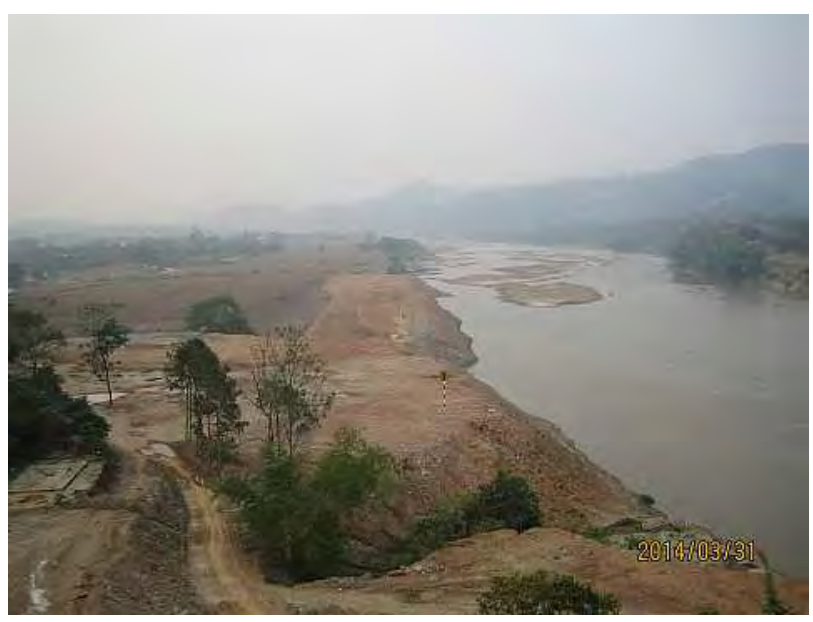

31.3.2014 


\section{Loan 2391/2392 - VIE: GMS Kunming - Hai Phong Transport Corridor Noi Bai - Lao Cai Highway Project}

\subsubsection{Package A8}

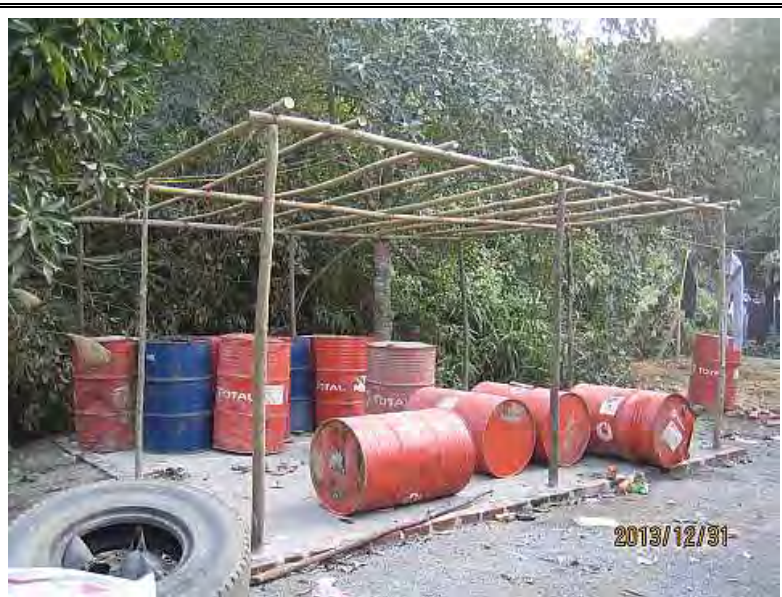

31.12 .2013

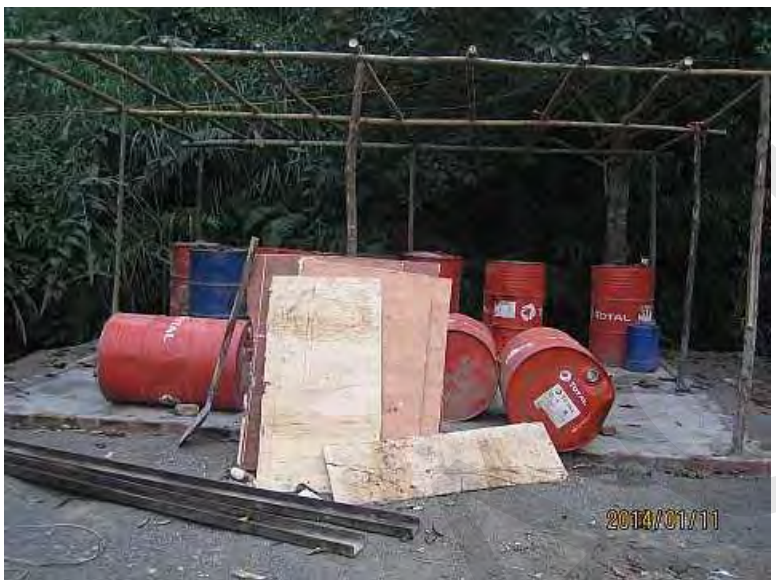

11.1.2014

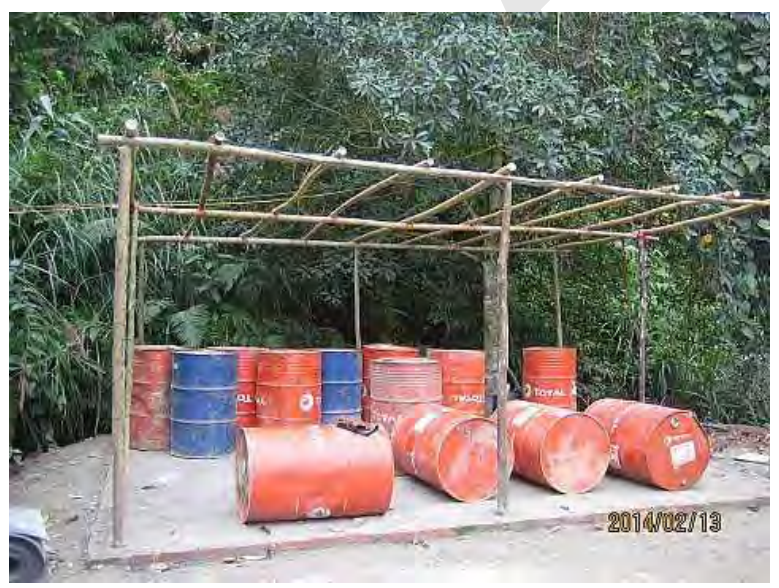

13.2.2014
Location: Store place oil and waste oil $\mathrm{Km} 230+800$

Site visit: $11.1 .2014 ; 13.2 .2014$

Date first observed: 6.9 .2013

Problems description and cause: Oil and waste oil barrels are put directly on the ground. This can affect to soil quality

Recommendation and Action taken by Engineer: Required the contractor to keep oil and waste oil barrels on the concrete floor and into the store according to the letter No: Ref. Get4Vinaconex- 859

Deadline: 20.9.2013

Current status: The contractor had improved this issue but not satisfied the Engineer 's requirement 


\section{Loan 2391/2392 - VIE: GMS Kunming - Hai Phong Transport Corridor Noi Bai - Lao Cai Highway Project}

In March, at package A8, the Contractor has finished all construction works. The technical traffic opening ceremony was organized on March $2^{\text {nd }}, 2014$.

\subsection{NOISE AND VIBRATION LEVELS}

As Annex 2.3 there are included the results of the noise and vibration levels monitored during the period of this quarterly report.

\subsubsection{Package A1}

In January: In January 06, 2014 we, together with the EPMU and the Contractor has worked with the local authority of Huong Son commune to find the solution to deal with the problem of local people complaining about cracking houses. At this time the Contractor has the compensation approach based on the calculation of the independent audit company VAE and the local authority will convinces local people to comply with regulations of compensation.

In Nam Viem commune $(\sim \mathrm{Km} 8+700)$, there are 9 households complained about vibration affecting their houses. The Contractor has specified the status of 3 houses, remaining houses has not been verified due to the household's owner's absence.

In Kim Long commune $(\sim \mathrm{Km} 26+600)$, there are 42 households complained about vibration cracking their houses. The Contractor has verified and compensated for 33 households, 9 remaining households are being considered solving.

The Engineer has requested the Contractor to contact local authorities and people to deal with these issues and submitted the report by letters GET1/POS/A1/2356, 2359; however, up to now we have not received the reports yet.

In February: For the impact of vibration during construction period, up to now the Contractor has finished the compensation for impacted households, including the 19 remaining households in Huong Son commune (Km 19+120 Km 19+740), 3 impacted households in Nam Viem commune $(\mathrm{Km} \mathrm{8+700)}$ and 9 remaining households in Kim Long commune $(\mathrm{Km}$ $26+600)$. At this time, there is no grievance of local people or authorities on vibration impact.

In March: For the impact of vibration during construction period, up to now the Contractor has finished the compensation for impacted households since February, 2104. 


\section{Loan 2391/2392 - VIE: GMS Kunming - Hai Phong Transport Corridor Noi Bai - Lao Cai Highway Project}

\subsubsection{Package A2}

By environmental monitoring in this period, we have perceived that the construction work does not cause the noise exceeding the standard at the sensitive areas.

For the vibration impact, we, together with EPMU and the Contractor, contacted local authorities to deal with the obstruction of local people during verifying the problem. At the present, the Contractor and VAE are specifying the impacted houses and the damage. After finishing verifying, the compensation will be carried out.

In March, the Contractor is carrying out the compensation for affected households.

\subsubsection{Package A3}

By environmental monitoring, we perceived that the construction work did not cause the noise exceeding the standard at sensitive areas in this period.

For the vibration impact, we, together with the EPMU and the Contractor, contacted local authorities to deal with the obstruction of local people during verifying the problem. At the present, the Contractor and VAE are specifying the impacted houses and the damage. After finishing verifying, the compensation will be carried out.

\subsubsection{Package A4}

By environmental monitoring, we perceived that the construction work did not cause the noise exceeding the standard at sensitive areas in this period.

For the vibration impact at QL32C bridge, the Consultant has requested the Contractor several times to contact with the local authorities and the household whose houses was impacted by the construction activity of Contractor in order to deal with the obstruction of local people during verifying the problem.

\subsubsection{Package A5}

In this quarter, the Consultant found that the Contractor's construction activities have not caused serious effects of noise and vibration to the surrounding areas.

The construction activities and operation of the batching plants and transportation of raw materials during the period from $10 \mathrm{pm}$ to 7 am were also minimized by the Contractor. 


\subsubsection{Package A6}

Through site check and supervision in this period, the Consultant found that the Contractor's construction activities have not caused serious effects of noise and vibration to the surrounding areas.

\subsubsection{Package A7}

The construction of road base operations, transportation of materials can also cause impacts on noise and vibration but the impacts are appraised to be acceptable and in accordance with standards noise and vibration levels.

\subsubsection{Package A8}

Currently the batching plant of some bridge as: Suoi Nhu Bridge, Suoi Trat Bridge, IC18 Bridge and Ngoi Bo Bridge did not cause impacts on noisy and vibration because the location of construction of the bridge away from residential areas and sensitive areas.

In addition, the construction of road base operations, transportation of materials can also cause impacts on noise and vibration but the impacts are appraised to be acceptable and in accordance with standards noise and vibration levels. However, the consultant always reminds the contractor to limit even forbid construction activities to create noisy and violence in the early morning, noontime or middle night. 


\section{Loan 2391/2392 - VIE: GMS Kunming - Hai Phong Transport Corridor Noi Bai - Lao Cai Highway Project}

\subsection{STREAMS AND RIVERSIDES MAINTENANCE}

\subsubsection{Package A1}

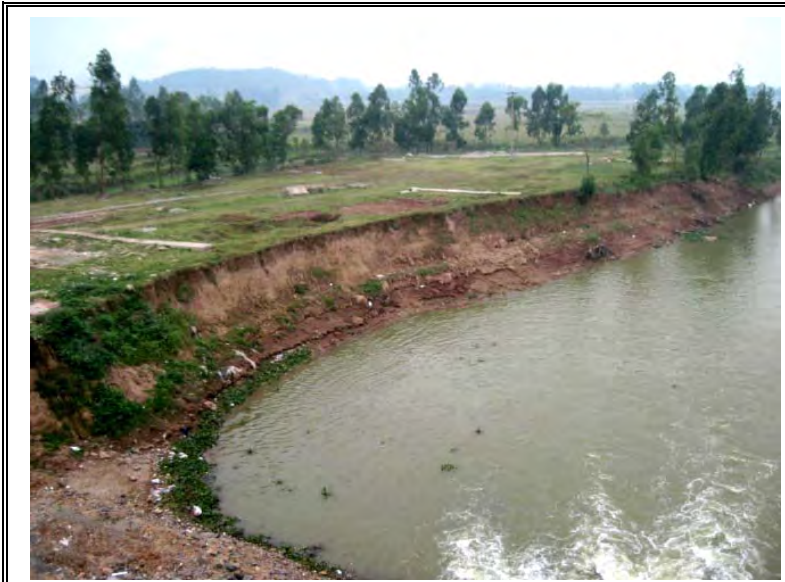

January 14, 2014 (Xuan Phuong Bridge)

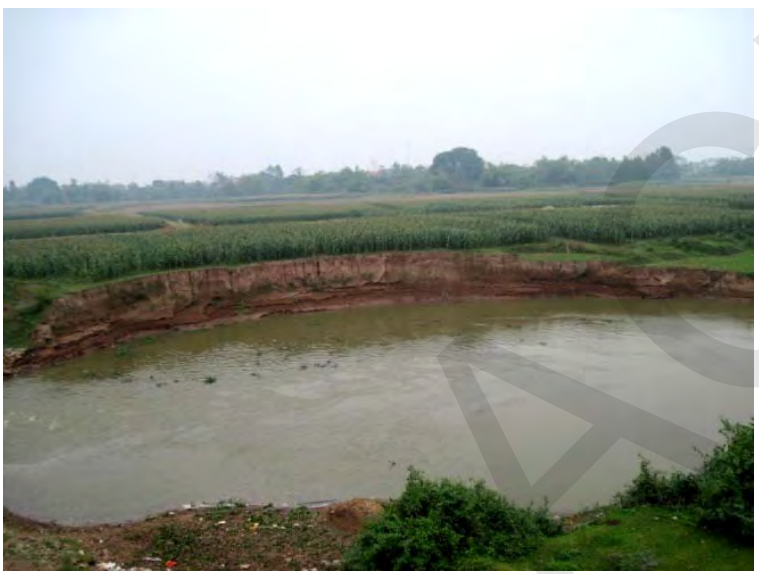

January 14, 2014 (Tan Loi Bridge)

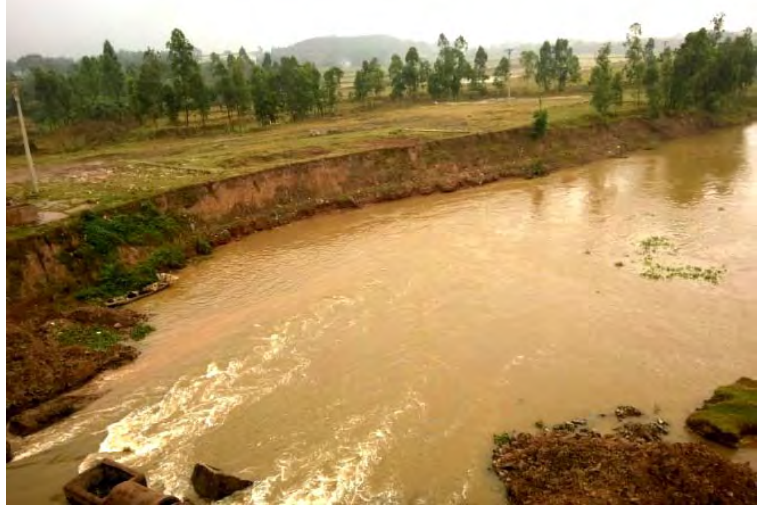

Feb 28, 2014 (Xuan Phuong Bridge)
Location: Tan Loi Bridge, Xuan Phuong Bridge

Site visit: 7, 14 Jan; 28 Feb; 17 Mar

Date first observed:

Problems description and cause: landslide happened on riversides because the Contractor didn't comply with Engineer's instruction during carrying out construction work in these areas; besides, the water flows in these sections are being blocked due to temporary stream crossing. Up to now, the main construction works in these areas already finished; however, the Contractor has not begun the restoration works yet

\section{Recommendation and Action taken by} Engineer: The Engineer has requested the Contractor to submit the detail restoration schedule as well as the working method statement basing on the approved restoration plans. Refer to letter GET1/POS/A1/2269 Due to the Contractor doesn't comply with requirements of the Engineer in order to restore affected areas so the Engineer is going to retain VND 10,000,000,000 (VND ten billion) until he finishes restoration work. Refer to letter GET1/POS/A1/2306, 2314, 2317

\section{Responsible Party: POSCO}

Deadline: Immediately

Current status: The Contractor has restored the water flow at Xuan Phuong Bridge but the remaining works have not been started to 


\section{Loan 2391/2392 - VIE: GMS Kunming - Hai Phong Transport Corridor Noi Bai - Lao Cai Highway Project}

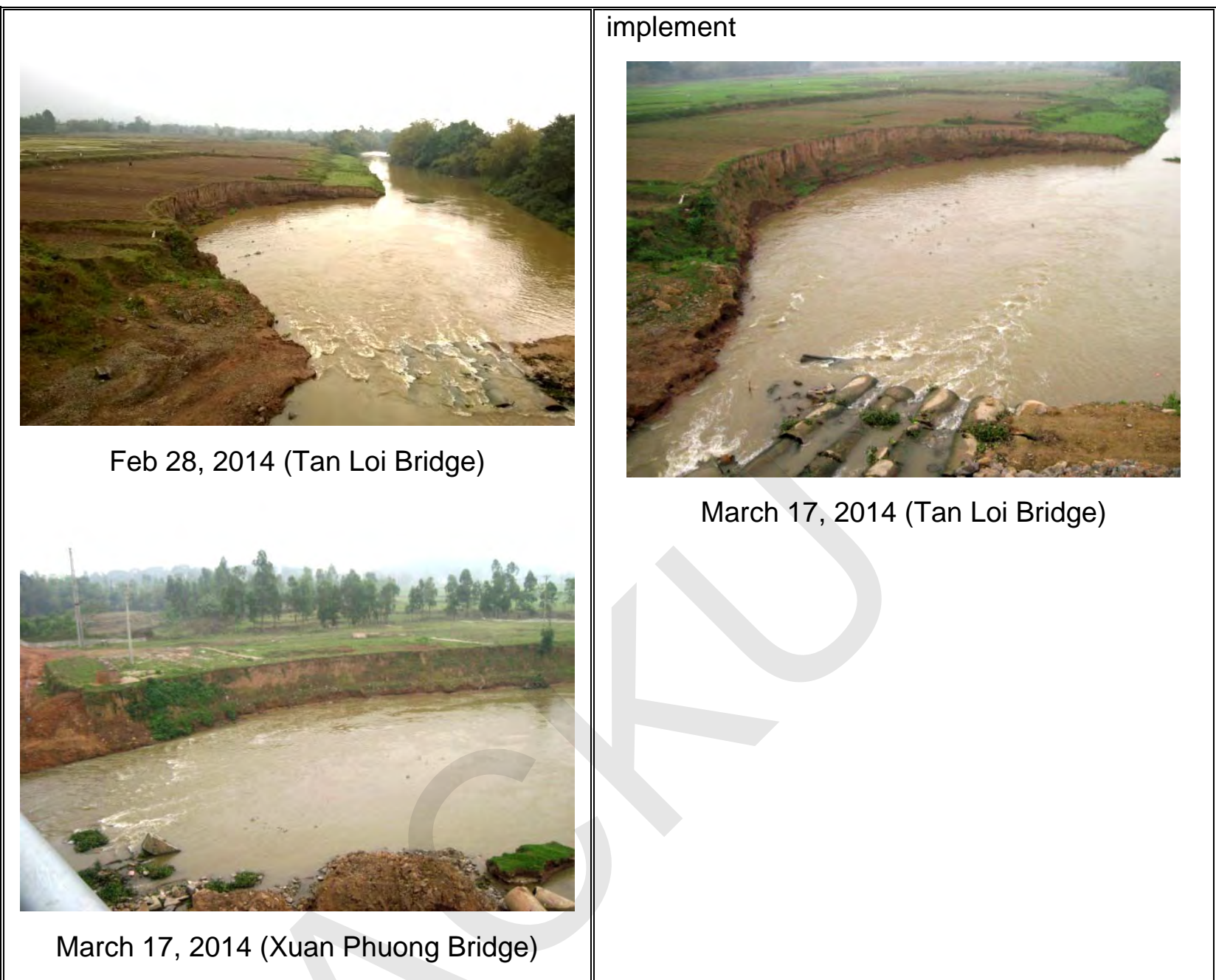

\subsubsection{Package A2}

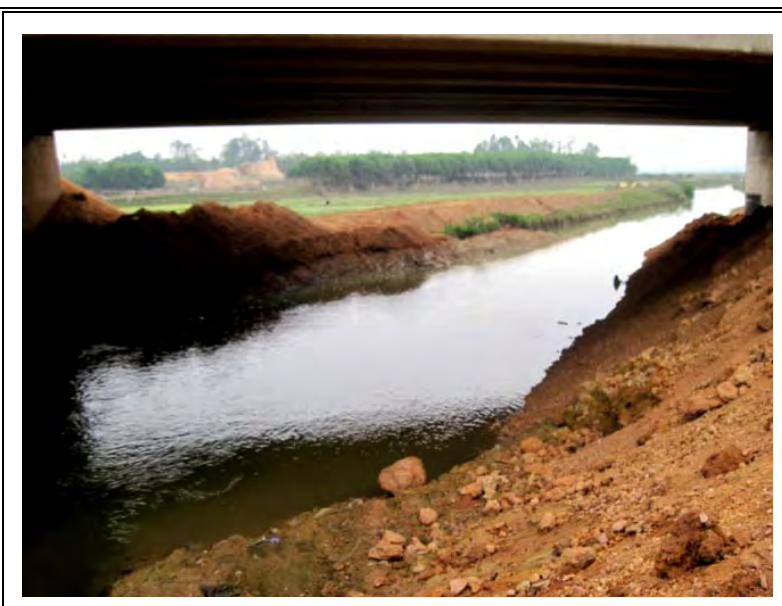

January 16, 2014

\section{Location: Muong Dao Bridge}

Site visit: 8, 10, 16, 22 Jan; 10, 13, 17, 25 Feb.

Date first observed: 28-Aug-2013

Problems description and cause: Water flow is still being blocked due to the Contractor has not finished restoration work because of lacking equipment

\section{Recommendation and Action taken by}

Engineer: The Engineer has orally requested $12^{\text {th }}$ floor, Ocean Park Building, Dao Duy Anh Street, Dong Da Distric

Huu Thu Hamlet, Kim Long Ward, Tam Duong Distric, VinhPhuc Province Calle Ramón de Aguinaga 8, 28028 Madrid, Spain 


\section{Loan 2391/2392 - VIE: GMS Kunming - Hai Phong Transport Corridor Noi Bai - Lao Cai Highway Project}

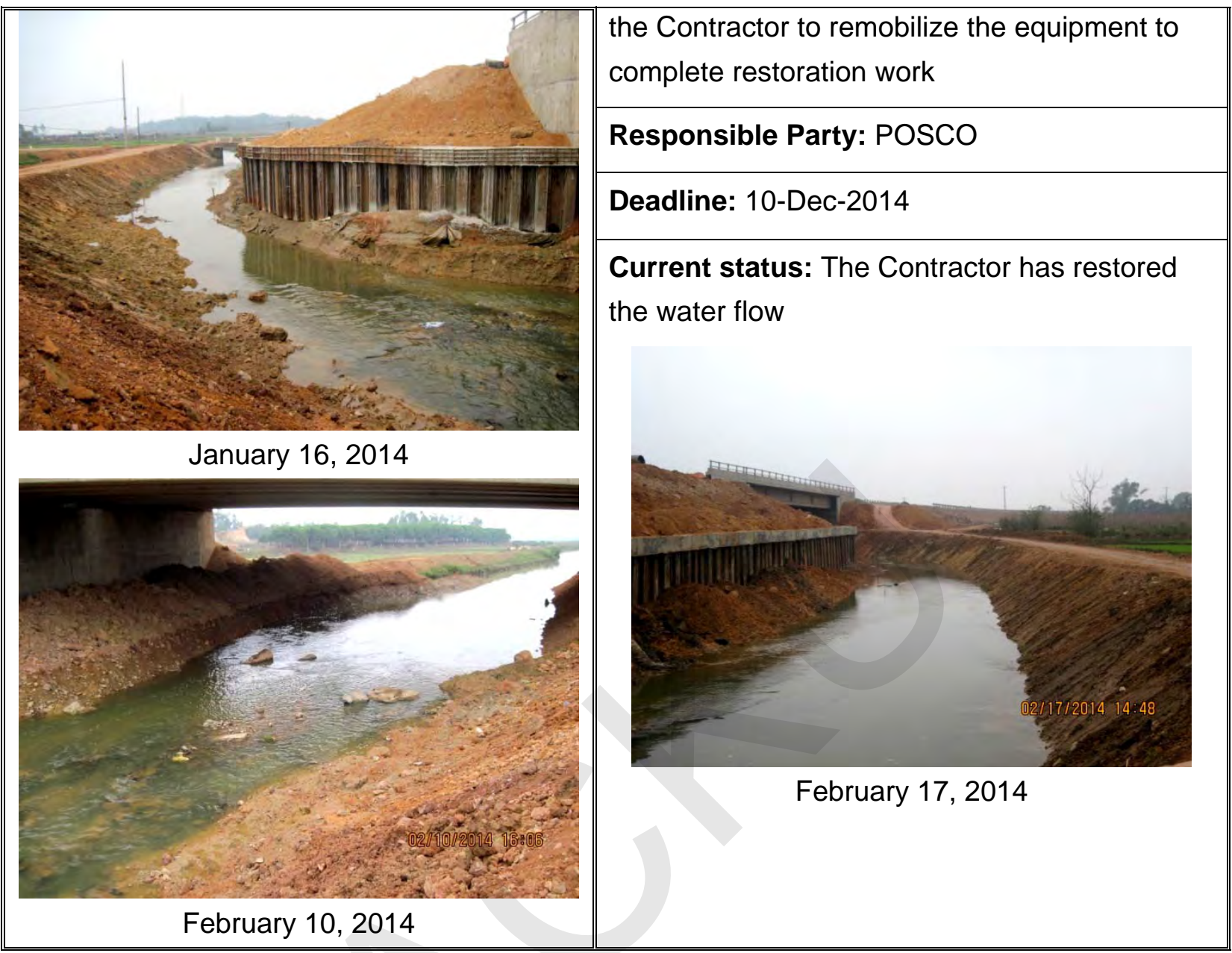

By observation during March, we perceived that the construction works no longer impact on stream, canal, drainage and their banks.

\subsubsection{Package A3}

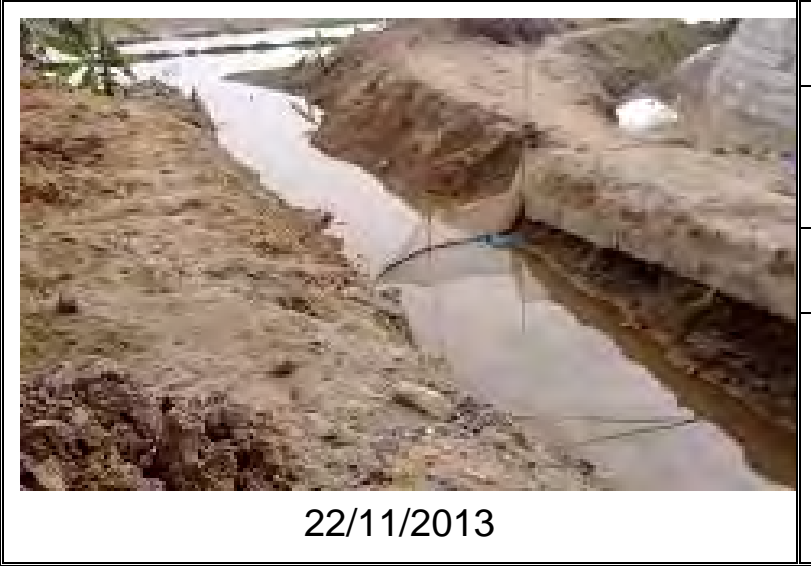

Location: A2, Red river bridge

Site visit: $01,08,15,22 / 01 / 2014 ; 07,14,21$, 25/2/2014; 05, 12, 19, 26/3/3014

Date first observed: 05/09/2013

Problems description and cause: The Contractor is carrying out construction of Quarter cone. The unsuitable soil overflowed into the irrigation canal so that it blocked 


\section{Loan 2391/2392 - VIE: GMS Kunming - Hai Phong Transport Corridor Noi Bai - Lao Cai Highway Project}

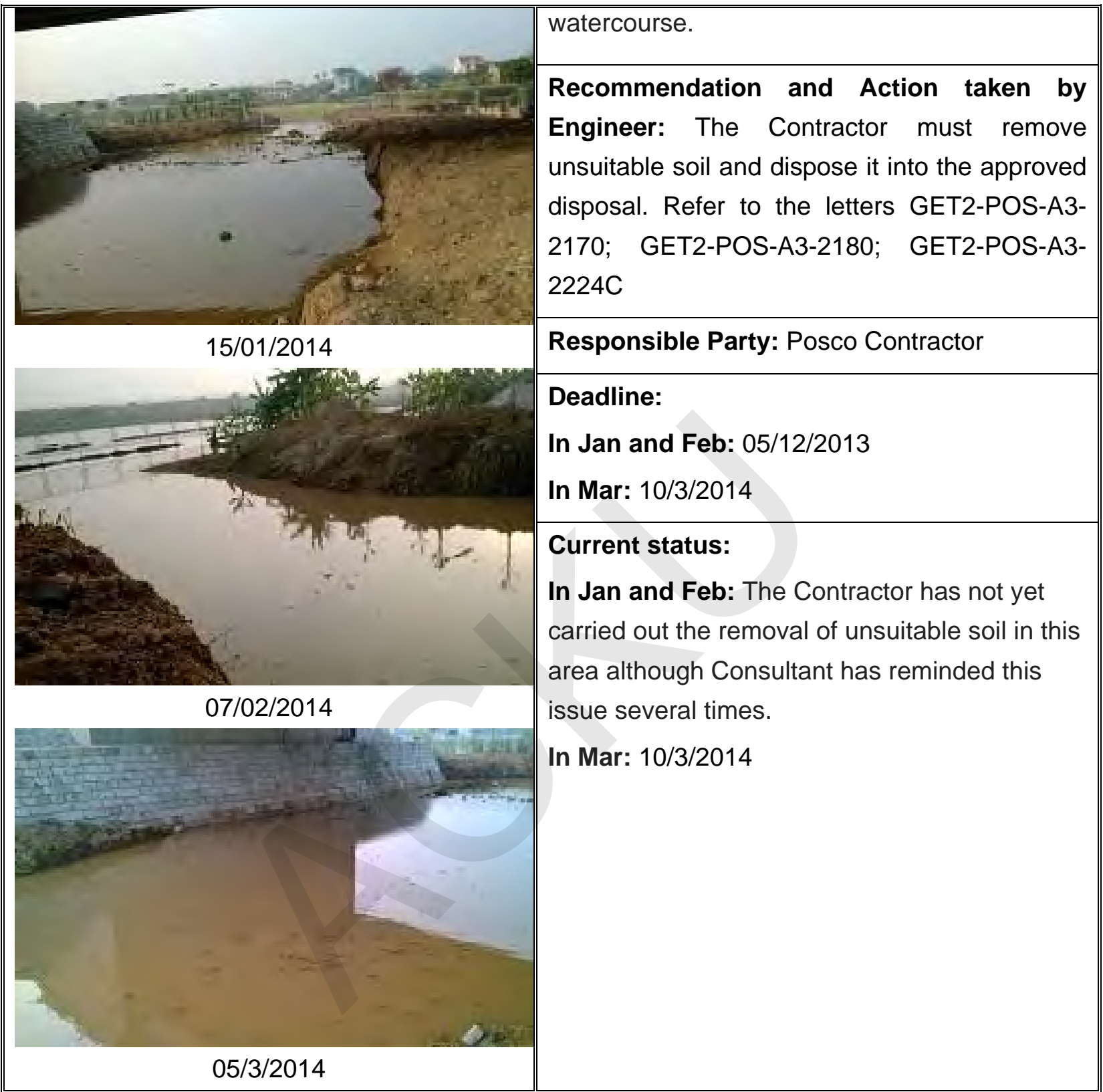




\section{Loan 2391/2392 - VIE: GMS Kunming - Hai Phong Transport Corridor Noi Bai - Lao Cai Highway Project}

\subsubsection{Package A4}

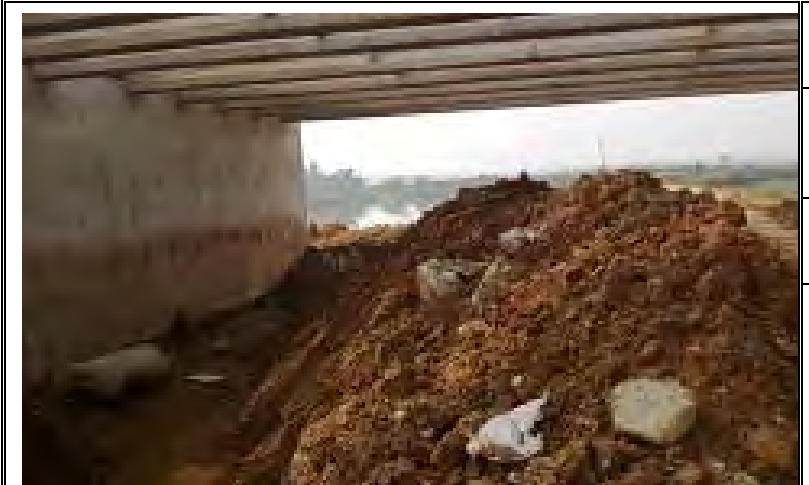

Location: Ngoi Gianh Bridge

Site visit: $02 ; 09 ; 16 ; 23 / 1 / 2014 ; 06,13,20$, $27 / 2 / 2014$

Date first observed: $24 / 6 / 2013$

Problems description and cause: The unsuitable soil was discharged near irrigation canal. The soil was overflowed to the surrounding drainage canal

$02 / 1 / 2014$

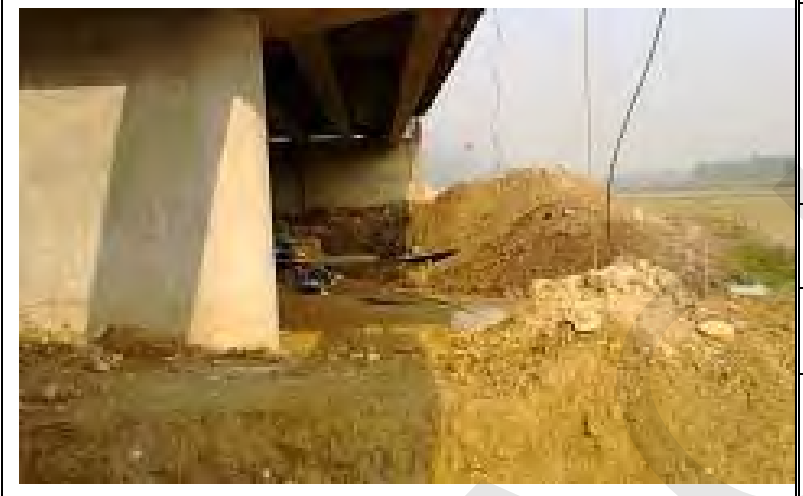

Recommendation and Action taken by Engineer: Require contractor to remove all waste mud in riverbed to ensure the water flow

Responsible Party: KEANGNAM

Deadline: 20/12/2013

Current status: The Contractor has not yet $06 / 2 / 2014$ removed all soil to the approved disposals

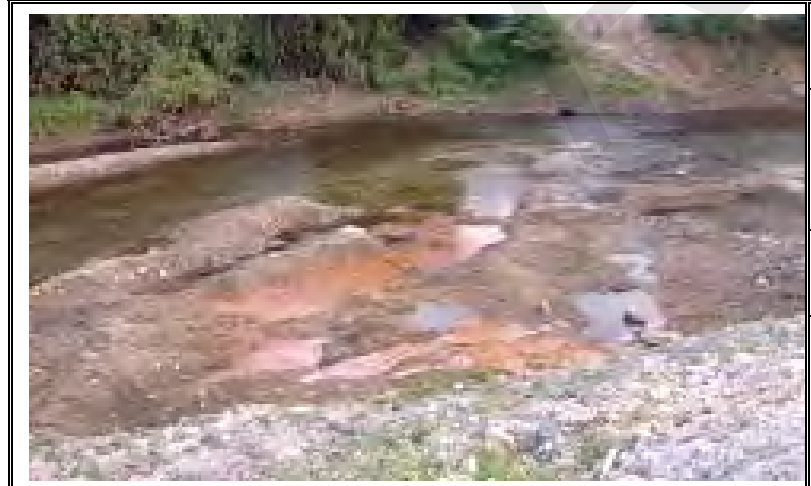

$20 / 11 / 2013$
Location: Ngoi Van Bridge

Site visit: $02 ; 09 ; 16 ; 23 / 1 / 2014 ; 06,13,20$, 27/2/2014; 06, 13, 20, 27/3/2014

Date first observed: 11/10/2012

Problems description and cause: The Contractor dumped soil into riverbed for the construction works. But the restoration works were not implemented by Contructor. This affected to the water quality

Recommendation and Action taken by Engineer: Restore the river bank by removing accumulated soil from construction works and stabilize the slope of river bank. 


\section{Loan 2391/2392 - VIE: GMS Kunming - Hai Phong Transport Corridor Noi Bai - Lao Cai Highway Project}
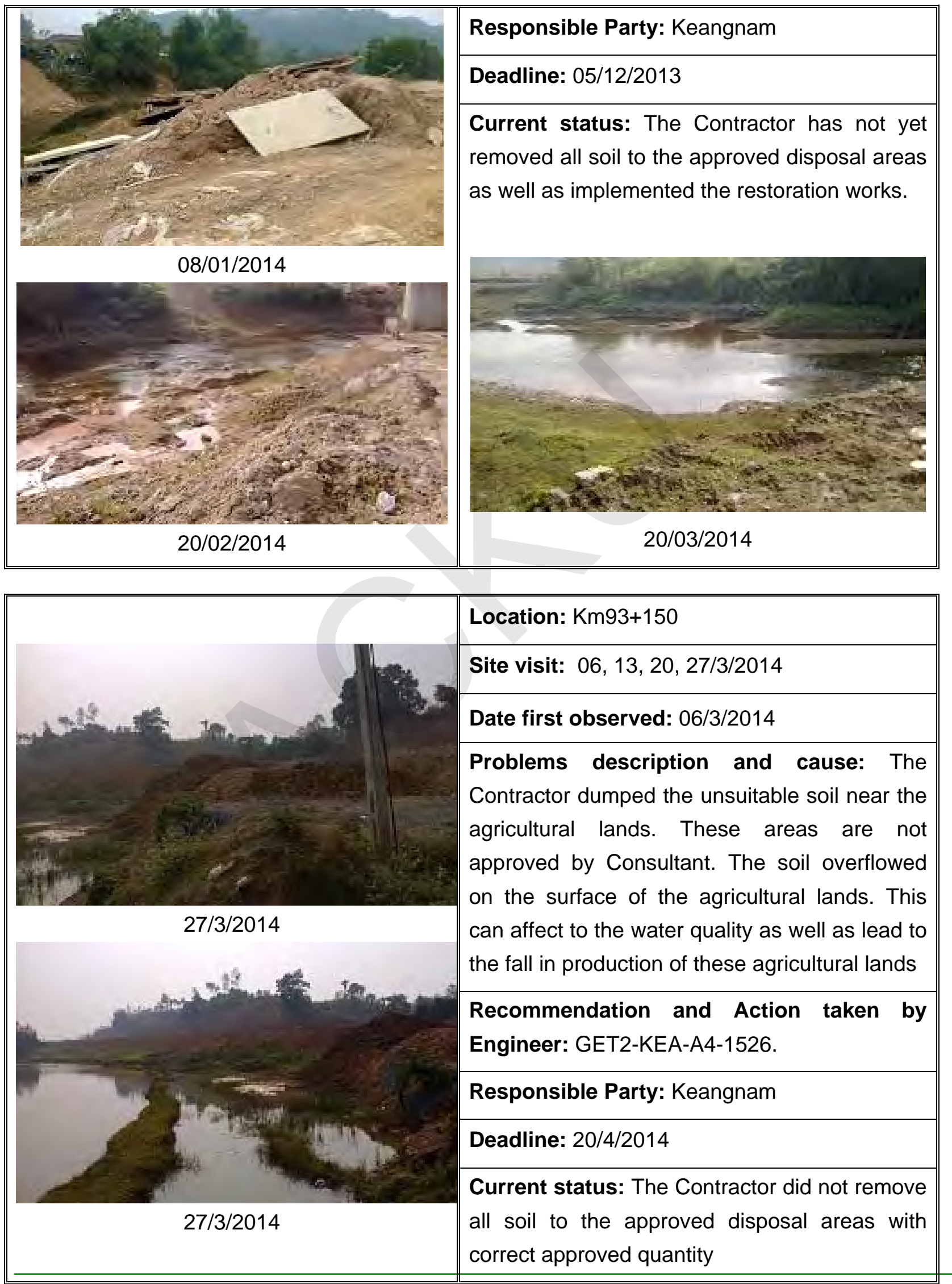


\section{Loan 2391/2392 - VIE: GMS Kunming - Hai Phong Transport Corridor Noi Bai - Lao Cai Highway Project}

\subsubsection{Package A5}

During the inspection and supervision on construction site in January, the Consultant found that the Contractor's construction activities have not caused any serious effect to the maintenance of the stream and riverside at the surrounding areas.

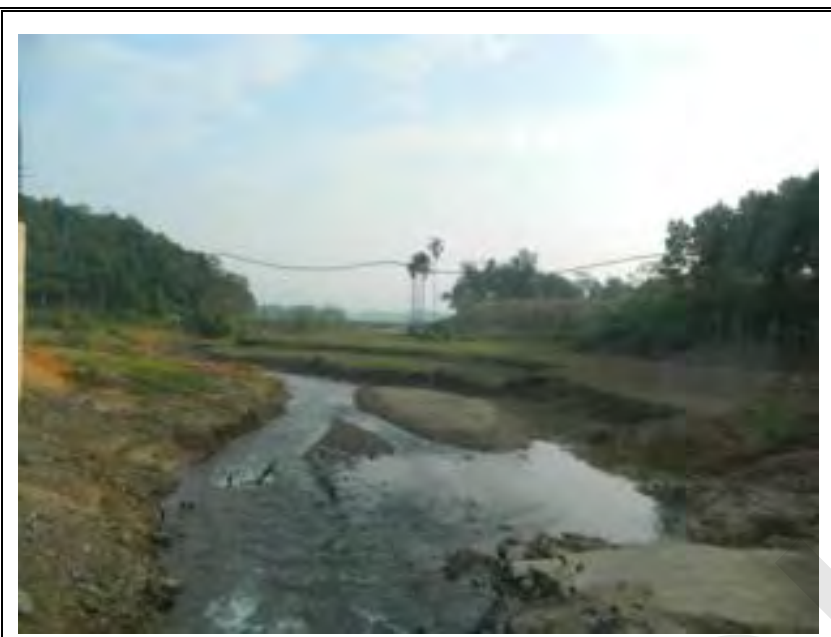

December 4, 2013 (Ngoi Vien bridge)

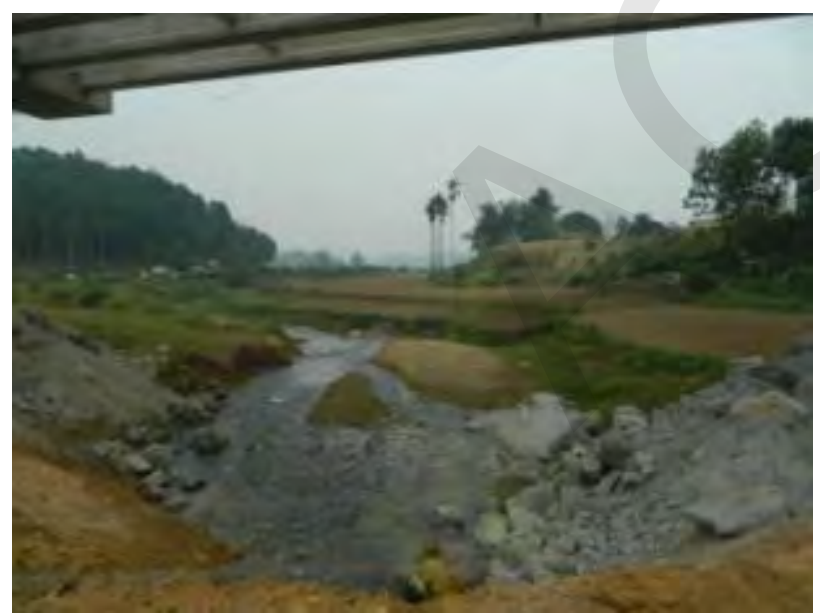

February 25, 2014 (Ngoi Vien bridge)
Location: Ngoi Vien bridge's construction site

Site visit: 25 February; 5 March, 2014

Date first observed: $4^{\text {th }}$ December, 2013

Problems description and cause: The flow of the watercourse was impacted by the Contractor's construction activities.

Recommendation and Action taken by Engineer: The Engineer requested the Contractor to implement the tasks as follows: 1.Remove all excavated soil from the stream/riverbed; 2 .Undertake regularly clearing of the channel section affected by construction;

3. Undertake the restoration of channel/stream.

Responsible Party: Keangnam Contractor

Deadline: 28 December, 2013

Current status: Not yet implemented 


\section{Loan 2391/2392 - VIE: GMS Kunming - Hai Phong Transport Corridor Noi Bai - Lao Cai Highway Project}

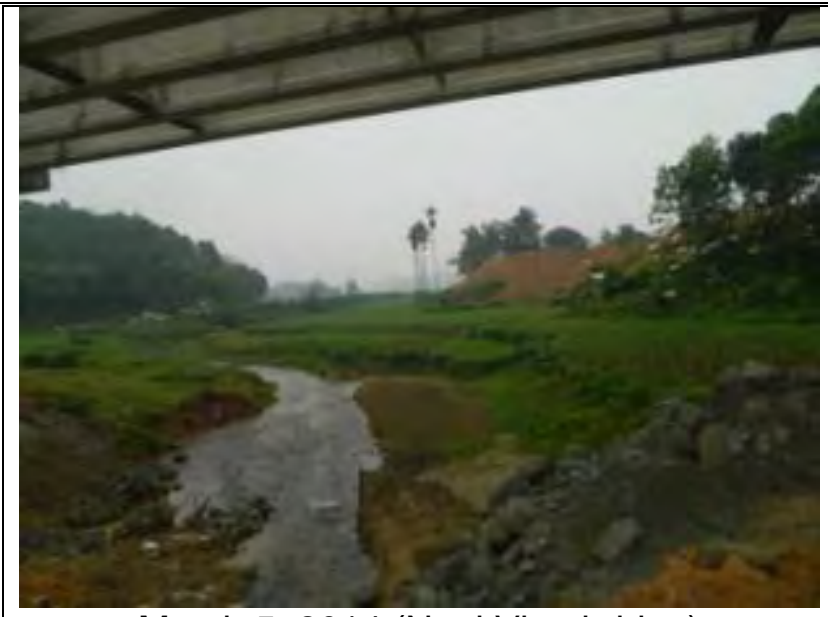

March 5, 2014 (Ngoi Vien bridge)

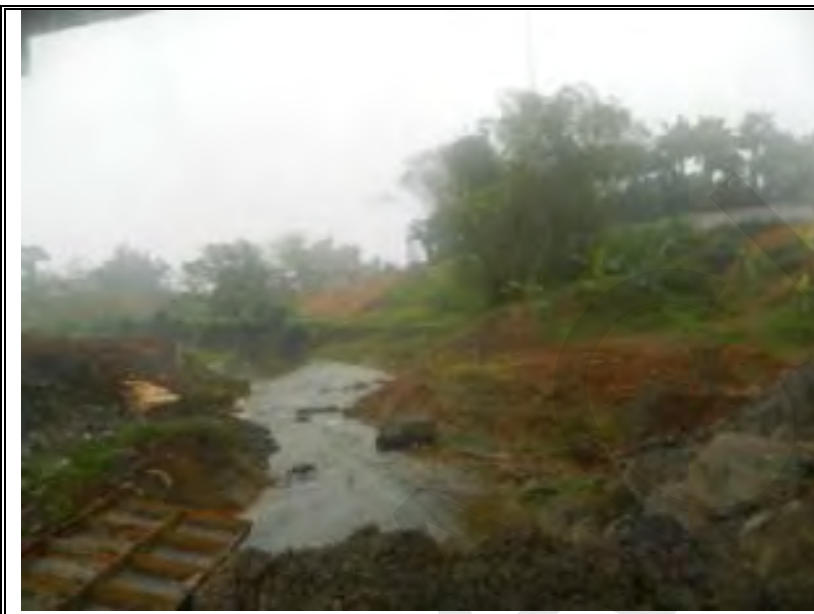

Location: Ngoi Gua bridge's construction site

Site visit: 5 and 18 March, 2014

Date first observed: $5^{\text {th }}$ March, 2014

Problems description and cause: The Contractor's construction activities blocked the watercourse of the river.

March 5, 2013 (Ngoi Gua bridge)

Recommendation and Action taken by Engineer: The Engineer requested the Contractor to implement the tasks as follows: 1. Remove all the excavated soil from the stream/riverbed; 2 . Undertake regularly the clearing of the channel section affected by construction; 3 . Undertake the restoration of channel/stream.

Responsible Party: Keangnam Contractor

Deadline: 15 - Mar - 2013

Current status: Not yet implemented March 18, 2014 (Ngoi Gua bridge) 


\section{Loan 2391/2392 - VIE: GMS Kunming - Hai Phong Transport Corridor Noi Bai - Lao Cai Highway Project}

\subsubsection{Package A6}

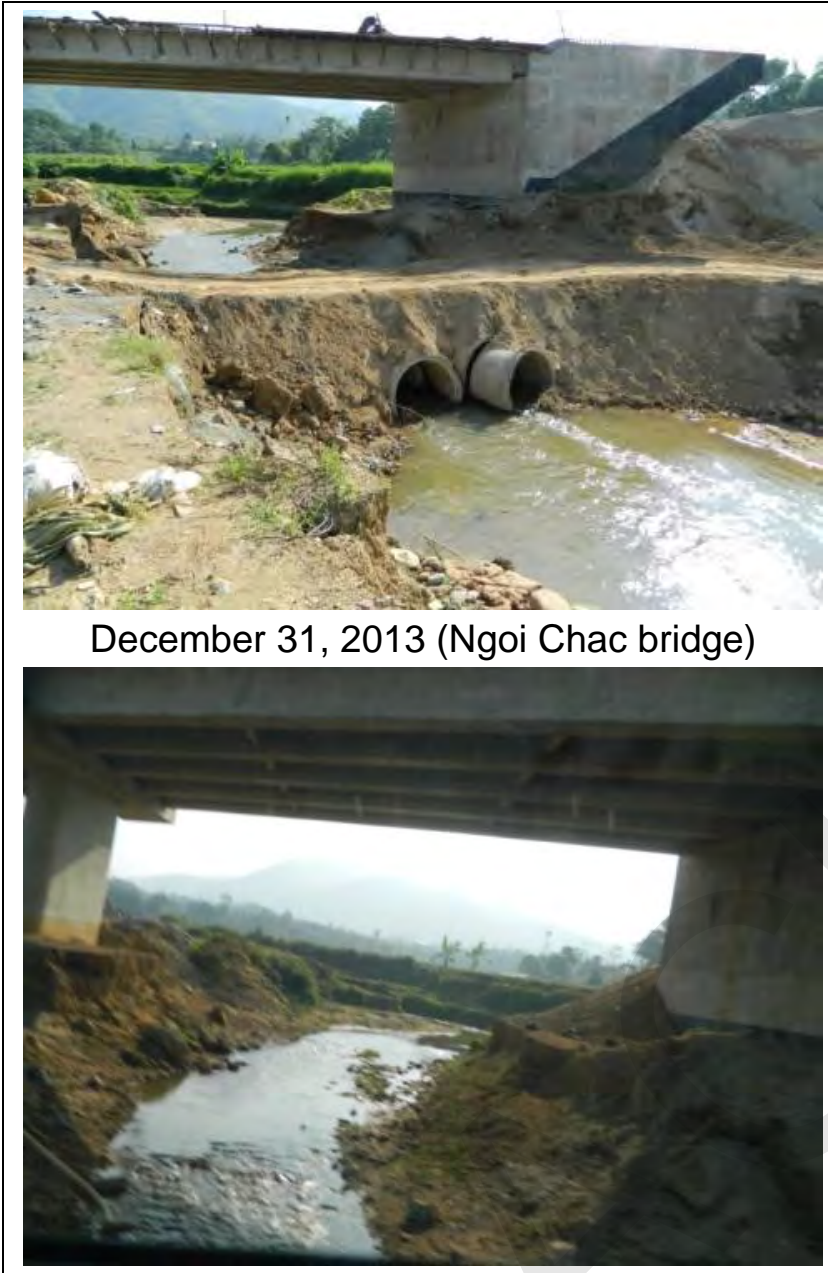

January 25, 2014 (Ngoi Chac bridge)
Location: Ngoi Chac bridge's construction site

Site visit: 31 December, 2013 25 January, 2014

Date first observed: $31^{\text {st }}$ December, 2013

Problems description and cause: The Contractor built the service road at bridge's construction site. Currently, some items of this bridge have already been completed and the Contractor need not use this access road. But the Contractor has not yet removed dumped soil from the stream/river and undertake restoration of the stream. This situation has partially obstructed the water flow of the stream.

Recommendation and Action taken by Engineer: The Engineer requested the Contractor to implement the tasks as follows: 1. Remove dumped soil from the stream/river at bridge site to ensure the watercourse of the stream/river; 2. Undertake regular clearing of the stream/river affected by construction activity; 3. Undertake restoration of stream/river at all bridge sites.

Responsible Party: Doosan Contractor

Deadline: 20-January-2014

Current status: The Contractor is applying some measures in order to improve this issue. 


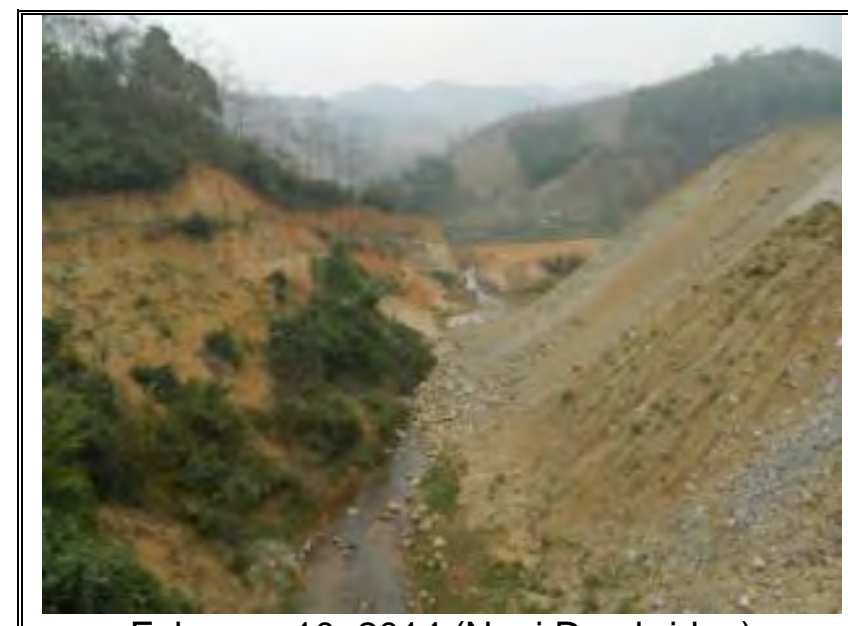

February 10, 2014 (Ngoi Don bridge)

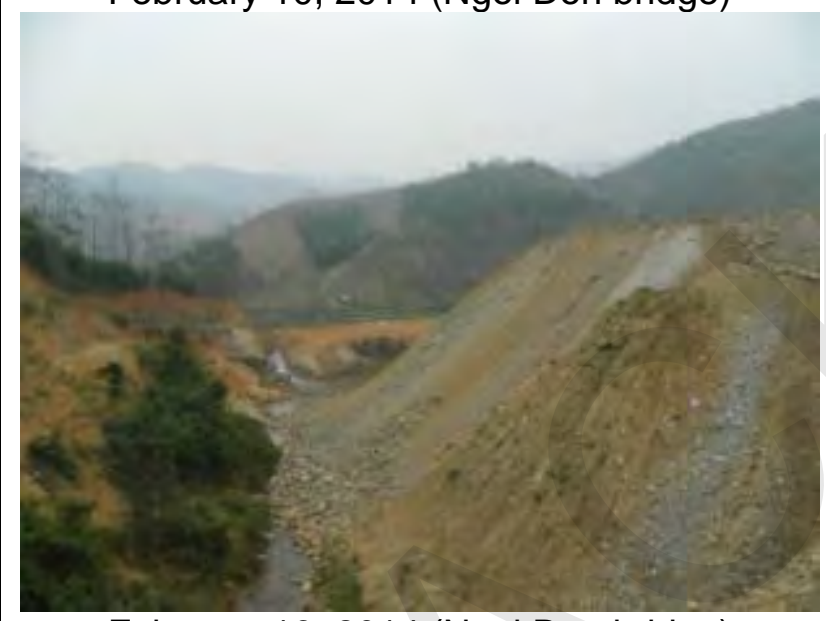

February 16, 2014 (Ngoi Don bridge)
Location: Ngoi Don bridge's construction site

Site visit: 10 and 16 February, 2014

Date first observed: $10^{\text {th }}$ February, 2014

Problems description and cause: The Contractor built the service road at bridge's construction site. Currently, some items of this bridge have already been completed and the Contractor need not use this access road. But the Contractor has not yet removed dumped soil from the stream/river and undertake restoration of the stream. This situation has partially obstructed the water flow of the stream.

\section{Recommendation and Action taken by}

Engineer: The Engineer requested the Contractor to implement the tasks as follows: 1. Remove dumped soil from the stream/river at bridge site to ensure the watercourse of the stream/river; 2. Undertake regular clearing of the stream/river affected by construction activity; 3. Undertake restoration of stream/river at all bridge sites.

Responsible Party: Doosan Contractor

Deadline: 17-February-2014

Current status: Not yet implemented

Location: Suoi Quan bridge's construction site

Site visit: 10 and 16 Febuary, 2014 $14^{\text {th }}$ March, 2014

Date first observed: $10^{\text {th }}$ February, 2014

Problems description and cause: At Suoi Quan bridge's construction site, excavated soil from on-going bridge works has partially obstructed water flow of the stream

February 10, 2014 (Suoi Quan bridge) 


\section{Loan 2391/2392 - VIE: GMS Kunming - Hai Phong Transport Corridor Noi Bai - Lao Cai Highway Project}

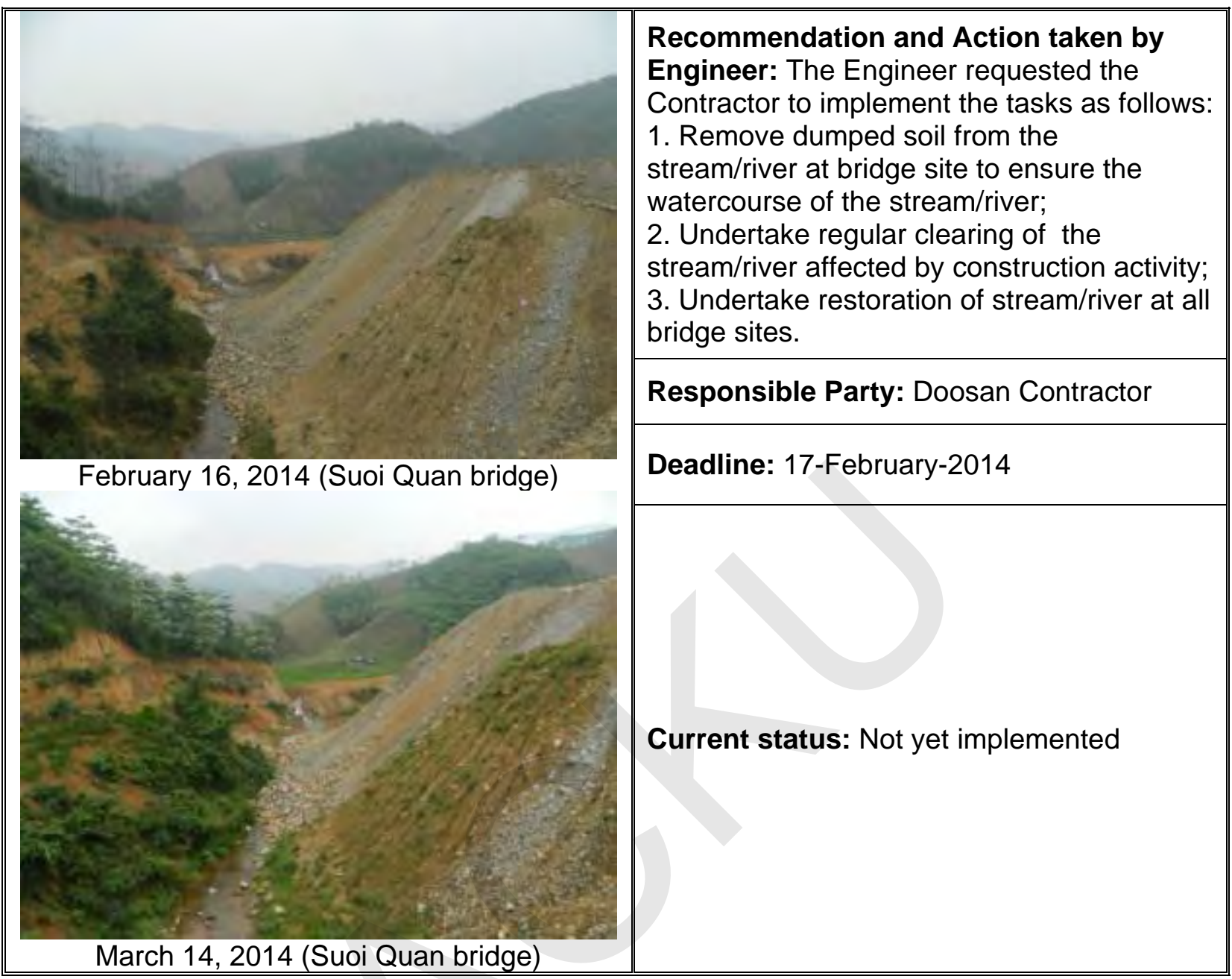

\subsubsection{Package A7}

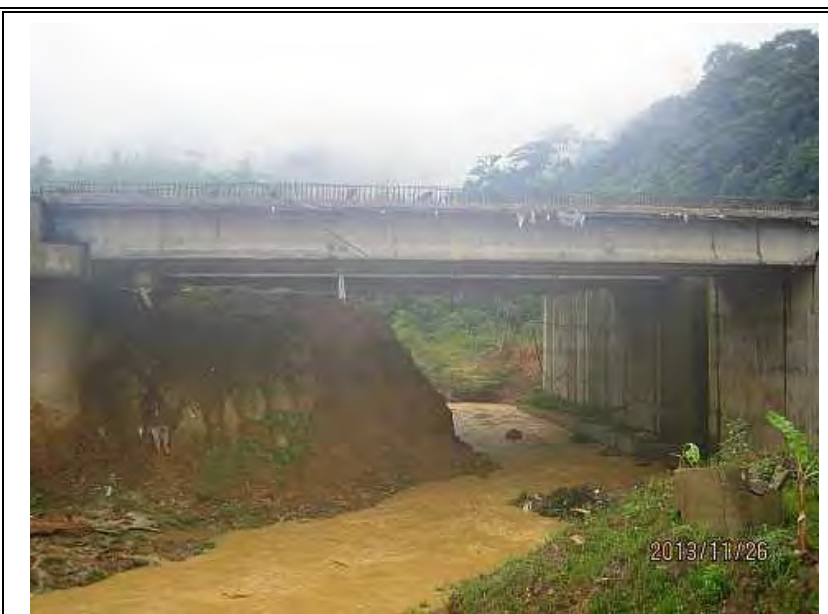

26.11 .2013
Location: Km199+050

Site visit: 7.1 and 14.1.2014

Date first observed: 4.9 .2013

Problems description and cause: The flow of watercourse has become narrower because of landslide of unsuitable soil

Recommendation and Action taken by

Engineer: Required the contractor to unblock and to restore the natural flow of watercourse according to the letter No: Ref. $12^{\text {th }}$ floor, Ocean Park Building, Dao Duy Anh Street, Dong Da Distric 


\section{Loan 2391/2392 - VIE: GMS Kunming - Hai Phong Transport Corridor Noi Bai - Lao Cai Highway Project}

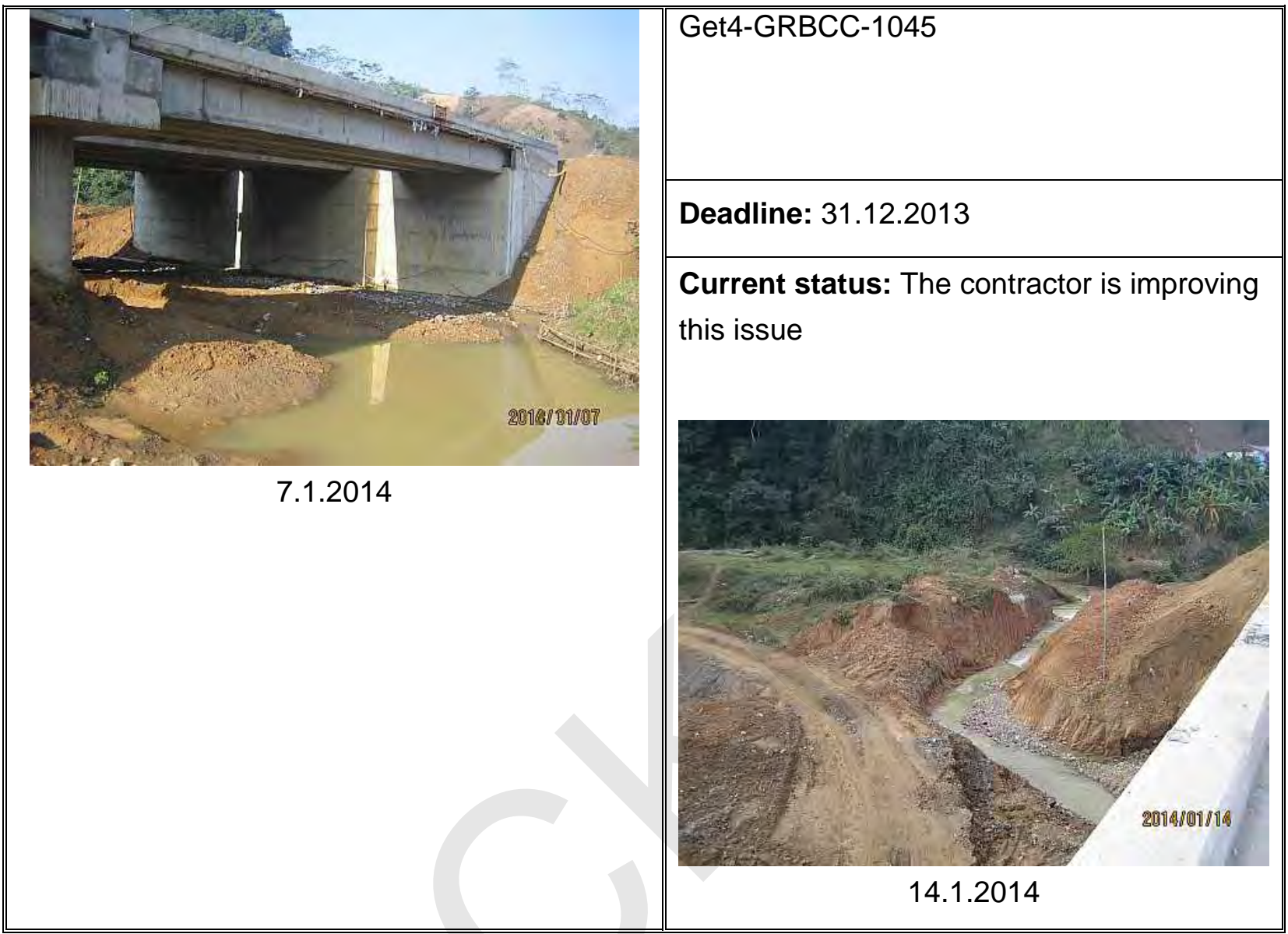

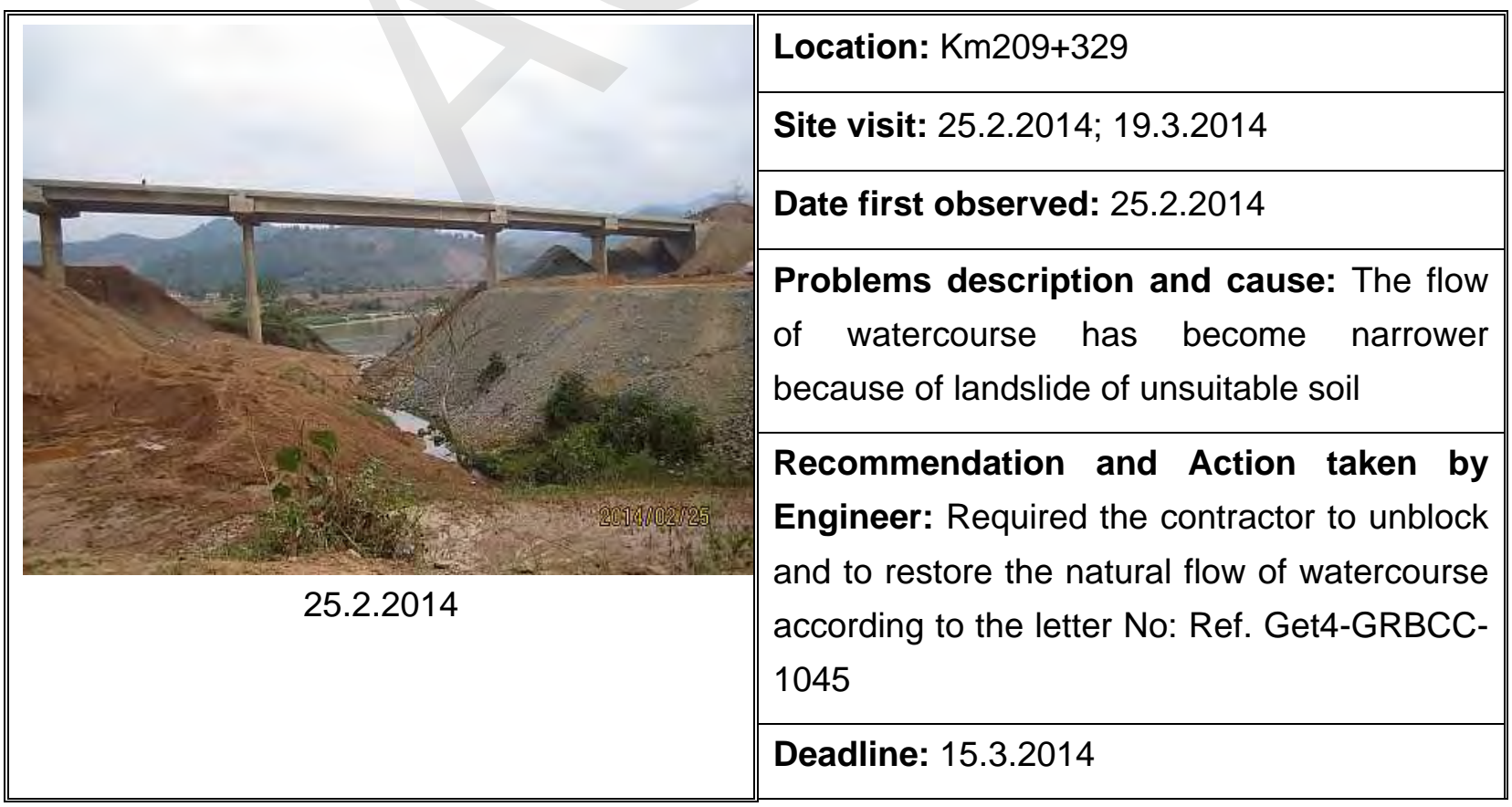




\section{Loan 2391/2392 - VIE: GMS Kunming - Hai Phong Transport Corridor Noi Bai - Lao Cai Highway Project}

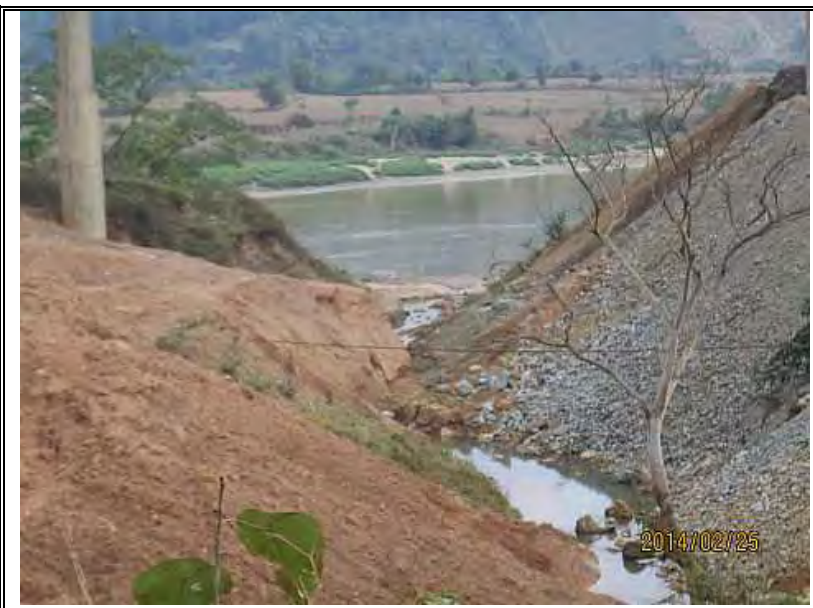

25.2.2014

Current status: Not yet improved
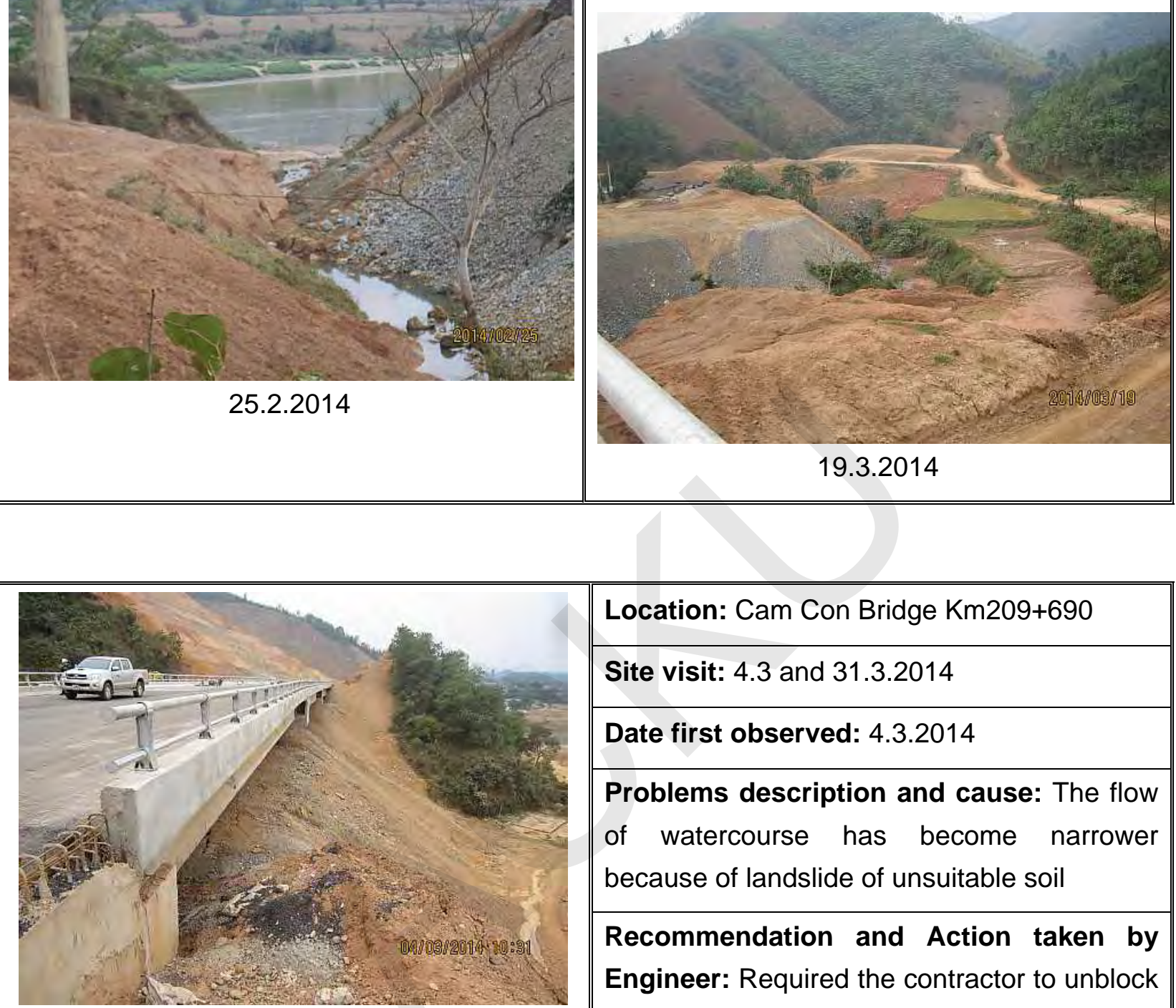

Location: Cam Con Bridge Km209+690

Site visit: 4.3 and 31.3 .2014

Date first observed: 4.3 .2014

Problems description and cause: The flow of watercourse has become narrower because of landslide of unsuitable soil

Recommendation and Action taken by Engineer: Required the contractor to unblock and to restore the natural flow of watercourse according to the letter No: Ref. Get4GRBCC-1045

Deadline: 15.3 .2014

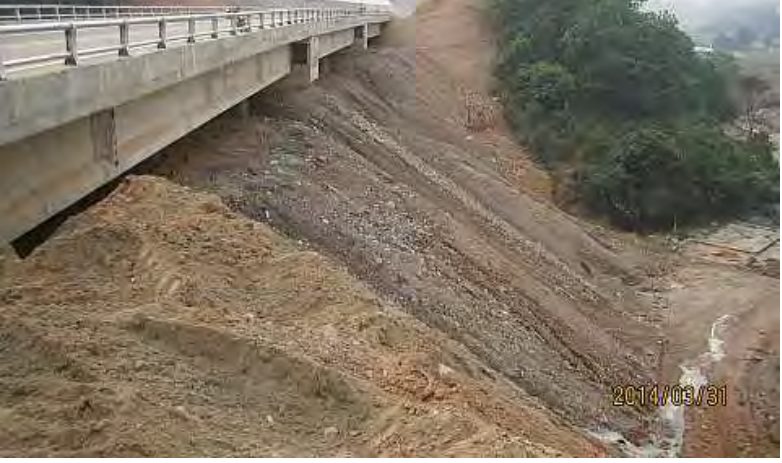

Current status: Not yet improved

31.3.2014 


\section{Loan 2391/2392 - VIE: GMS Kunming - Hai Phong Transport Corridor Noi Bai - Lao Cai Highway Project}

\subsubsection{Package A8}

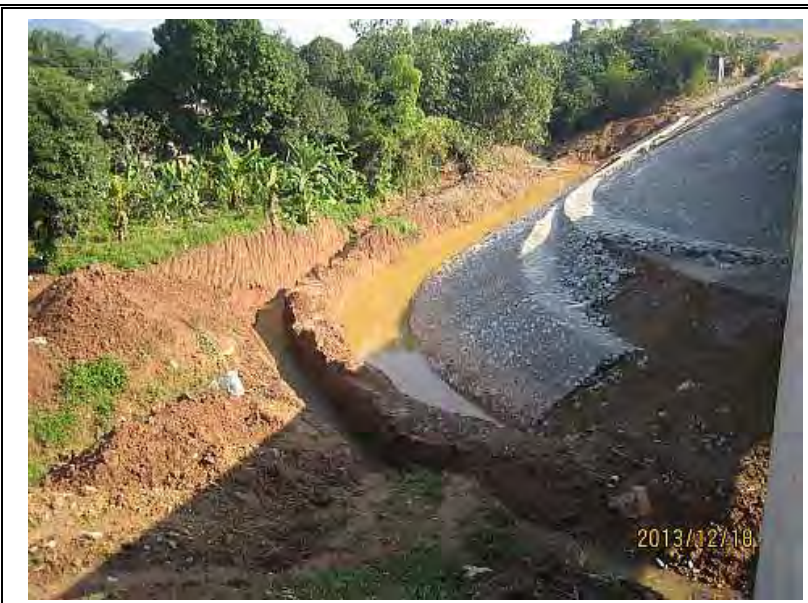

Location: Son Ha Bridge Km224+369

Site visit: $12.1 .2014 ; 28.2 .2014 ; 20.3 .2014$

Date first observed: 22.5 .2013

Problems description and cause: The canal was blocked by earth and stone fallen during time construction works

Recommendation and Action taken by Engineer: The contractor had been requested 18.12.2013

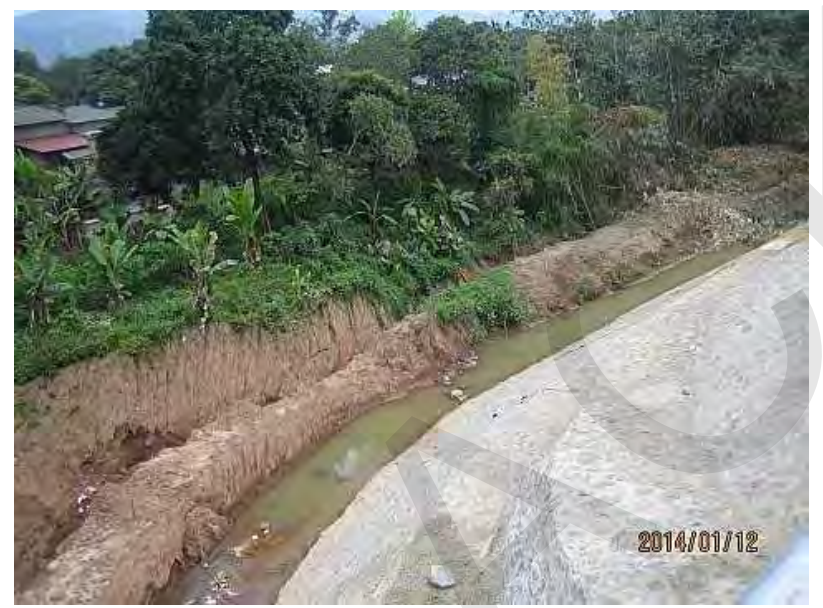
to remove all earths and rock to avoid the watercourse according to the letter No: Ref. Get4- Vinaconex- 912

Deadline: 31.12 .2013

Current status: The contractor is improving this issue

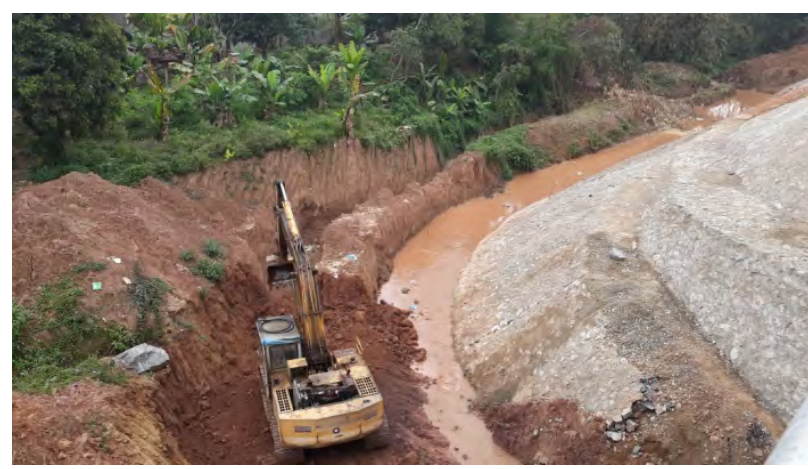

28.2.2014 


\section{Loan 2391/2392 - VIE: GMS Kunming - Hai Phong Transport Corridor Noi Bai - Lao Cai Highway Project}

\subsection{EROSION RISKS AND STABILITY IN SLOPES}

\subsubsection{Package A1}

At the present, at package A1, the Contractor has finished all construction works.

\subsubsection{Package A2}

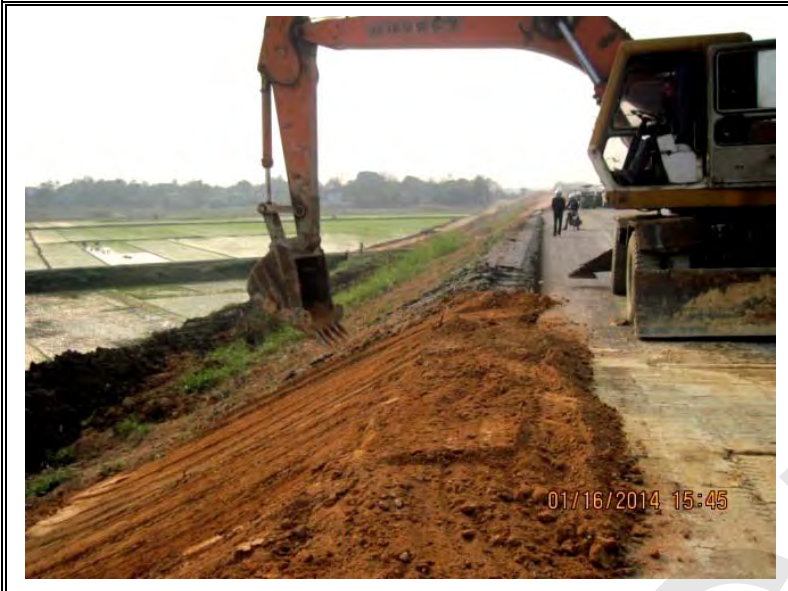

Location: $\mathrm{Km} \mathrm{42+400} \mathrm{Km} \mathrm{43+000}$

Site visit: 8, 10, 16, 22 Jan; 10, 13, 17, 25

Feb.; 4, 12, 17, 25 Mar.

Date first observed: 18-July-2013

Problems description and cause: Heavy rain caused erosion on unprotected slopes

Recommendation and Action taken by

Engineer: Apply erosion control measures at unprotected slope areas; restore affected slopes. Refer to letter GET1/POS/A2/2098; 2295

Responsible Party: POSCO

Deadline: Before carrying out sodding work

Current status: Mitigation measure is being implemented

January 10, 2014

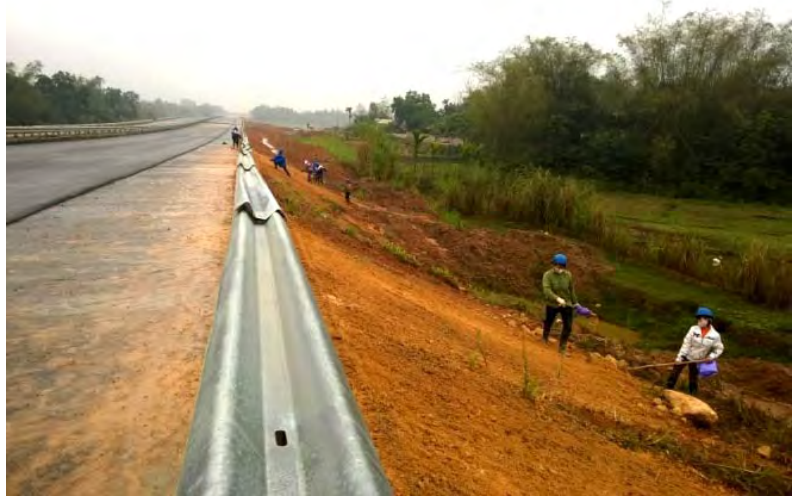

February 25, 2014 


\section{Loan 2391/2392 - VIE: GMS Kunming - Hai Phong Transport Corridor} Noi Bai - Lao Cai Highway Project

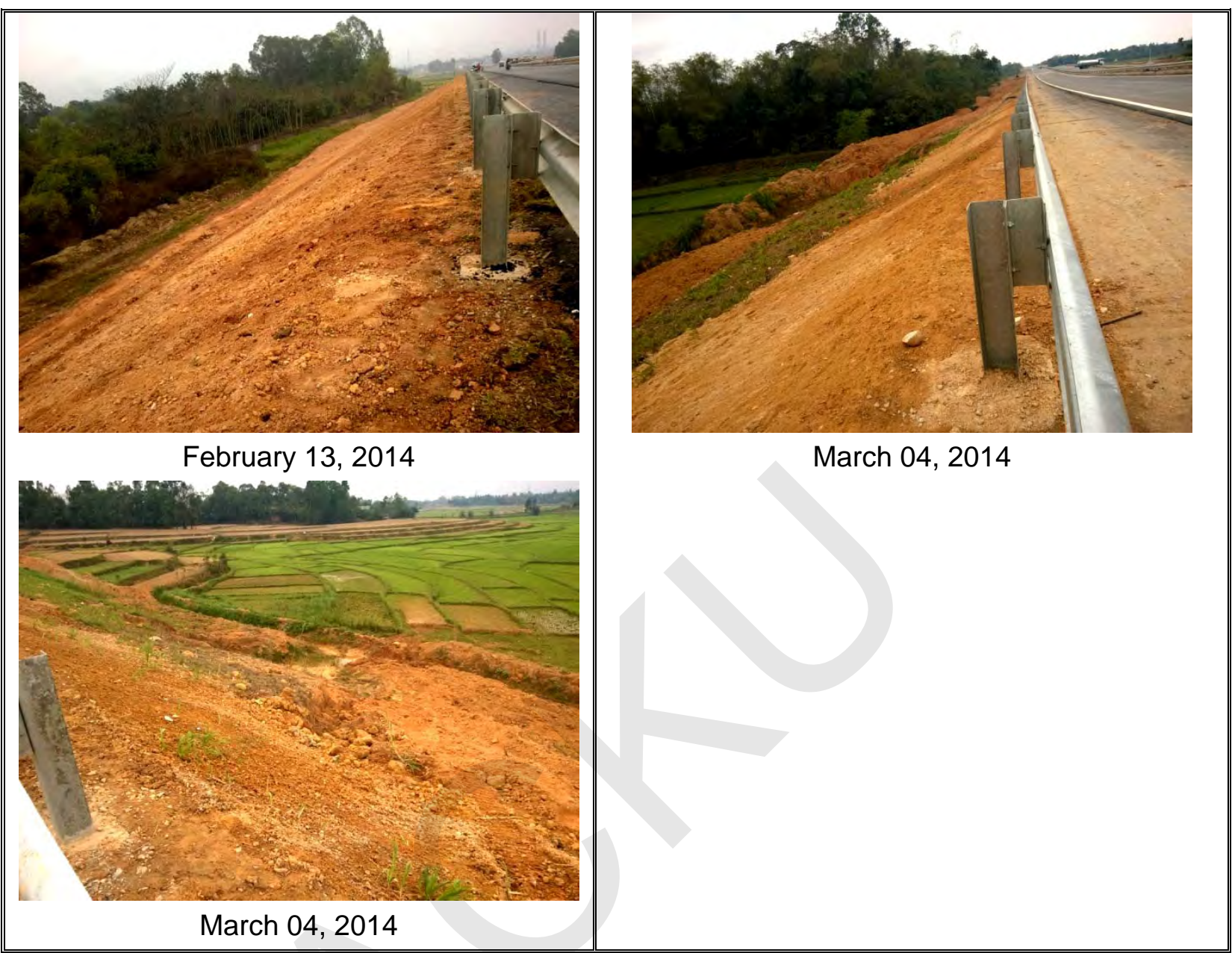

\subsubsection{Package A3}

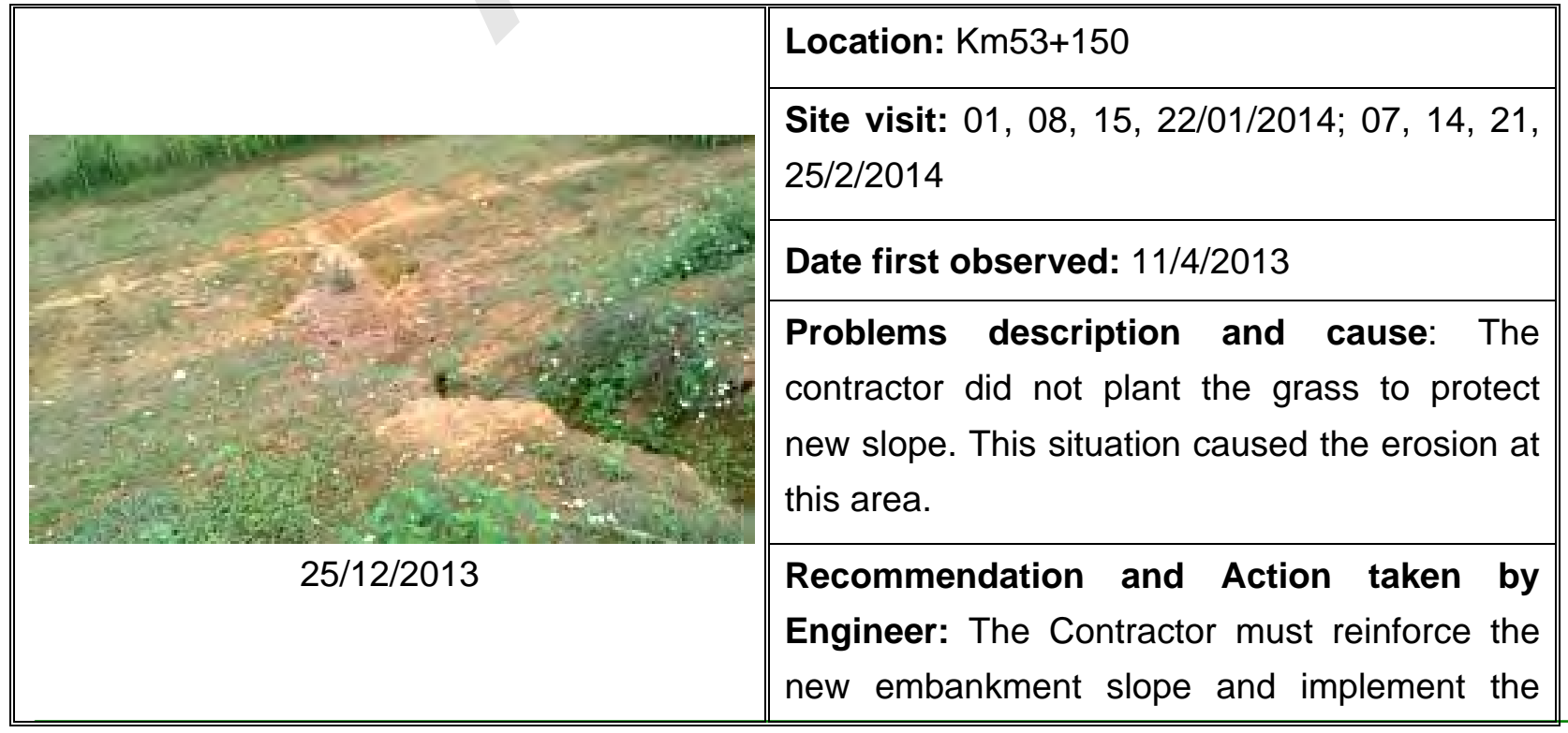




\section{Loan 2391/2392 - VIE: GMS Kunming - Hai Phong Transport Corridor Noi Bai - Lao Cai Highway Project}

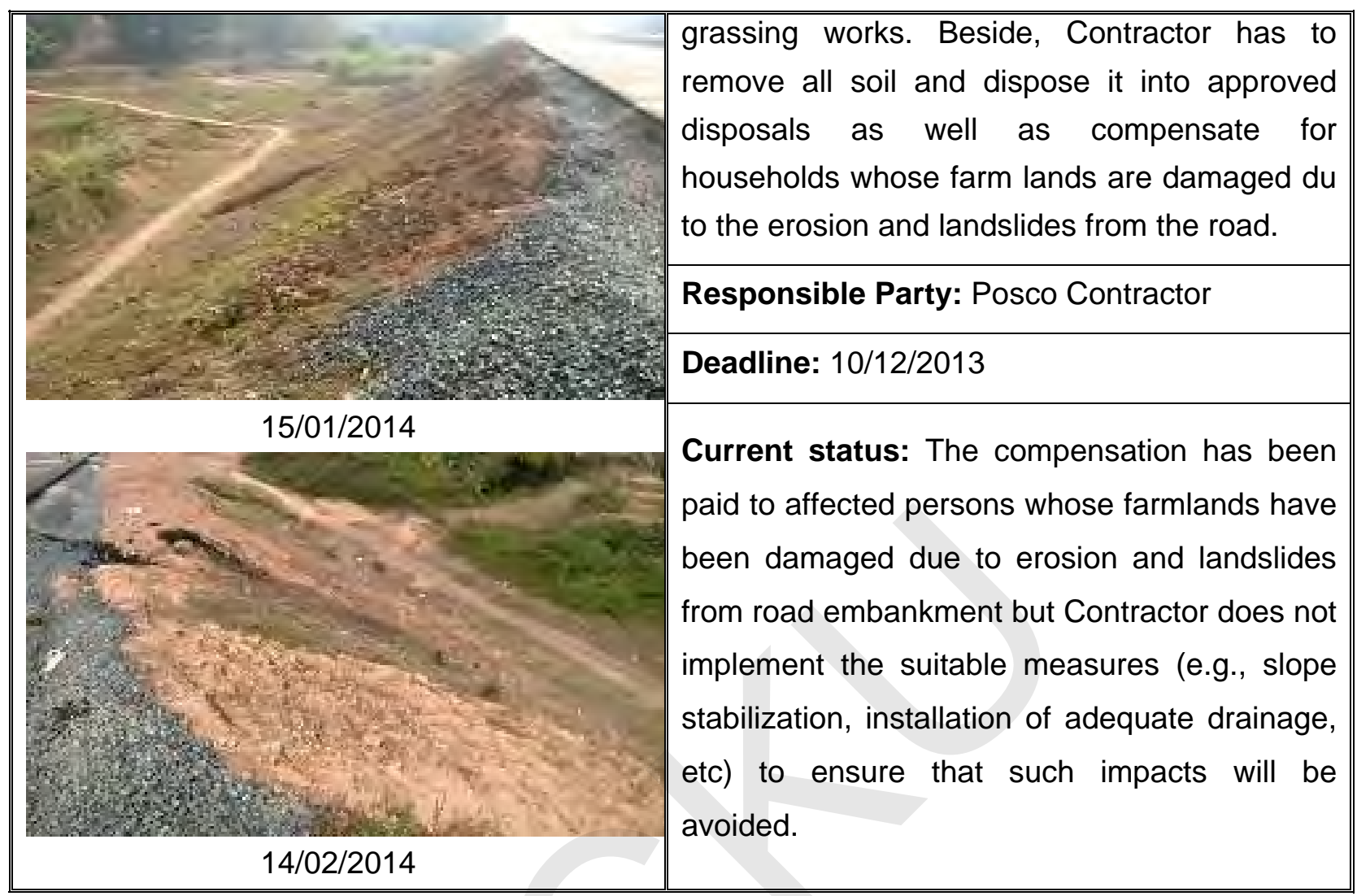

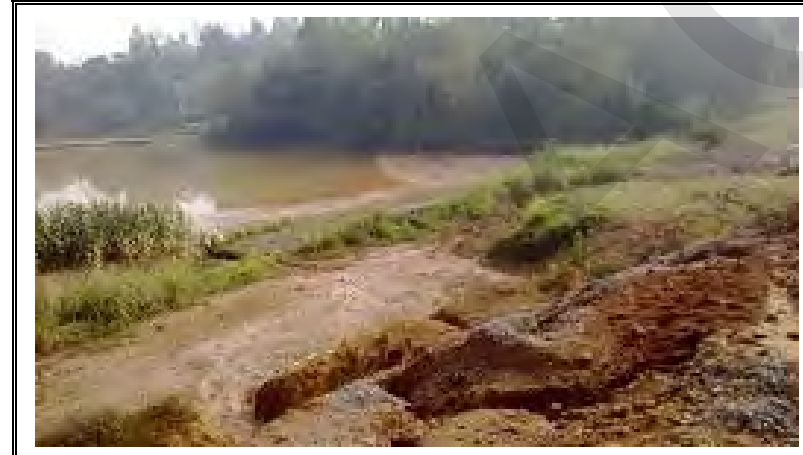

$05 / 3 / 2014$

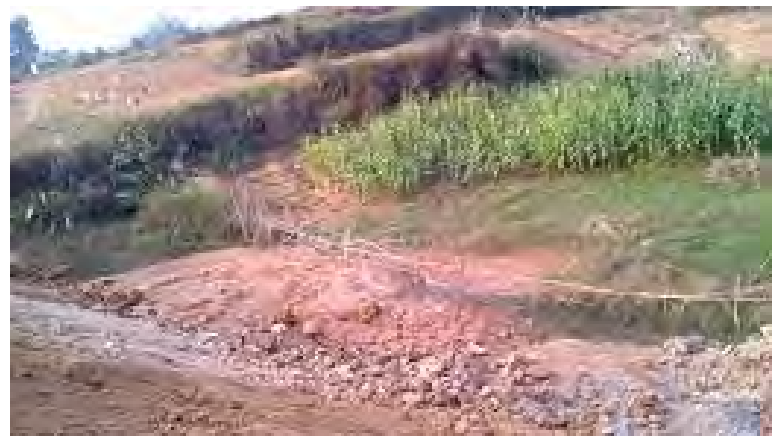

$12 / 3 / 2014$
Location: Km51+375

Site visit: $05,12,19,26 / 3 / 3014$

Date first observed: $11 / 4 / 2013$

Problems description and cause: The contractor did not plant the grass to protect new slope. This situation caused the erosion at this area.

Recommendation and Action taken by Engineer: The Contractor must reinforce the new embankment slope and immediately implement the grassing works to protect it. Beside, Contractor has to remove all soil and dispose it into approved disposals as well as compensate for households whose farm lands are damaged du to the erosion and landslides 
Loan 2391/2392 - VIE: GMS Kunming - Hai Phong Transport Corridor Noi Bai - Lao Cai Highway Project

\begin{tabular}{|l||l||}
\hline \hline \multirow{2}{*}{\multicolumn{1}{|l|}{}} & from the road. \\
\cline { 2 - 3 } & Responsible Party: Posco Contractor \\
\cline { 2 - 3 } & Deadline: $10 / 3 / 2014$ \\
\cline { 2 - 3 } & $\begin{array}{l}\text { Current status: The compensation has been } \\
\text { paid to affected persons whose farmlands have } \\
\text { been damaged due to erosion and landslides } \\
\text { from road embankment but Contractor does not } \\
\text { implement the suitable measures (e.g., slope } \\
\text { stabilization, installation of adequate drainage, } \\
\text { etc) to ensure that such impacts will be } \\
\text { avoided. }\end{array}$ \\
\hline
\end{tabular}

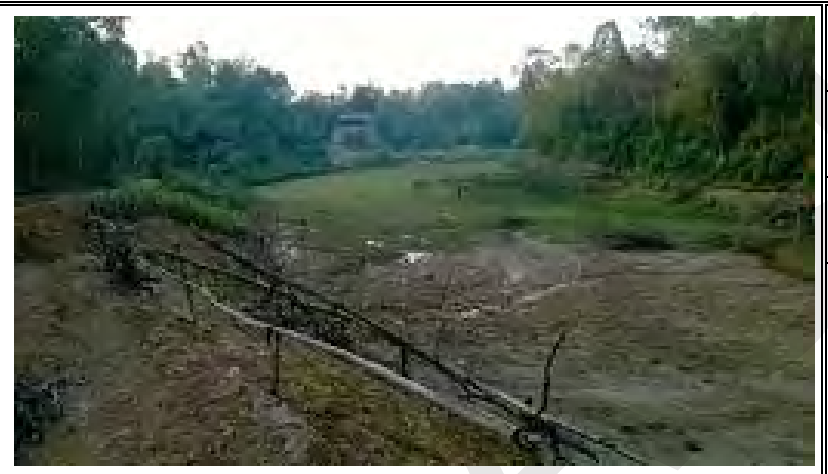

$05 / 3 / 2014$

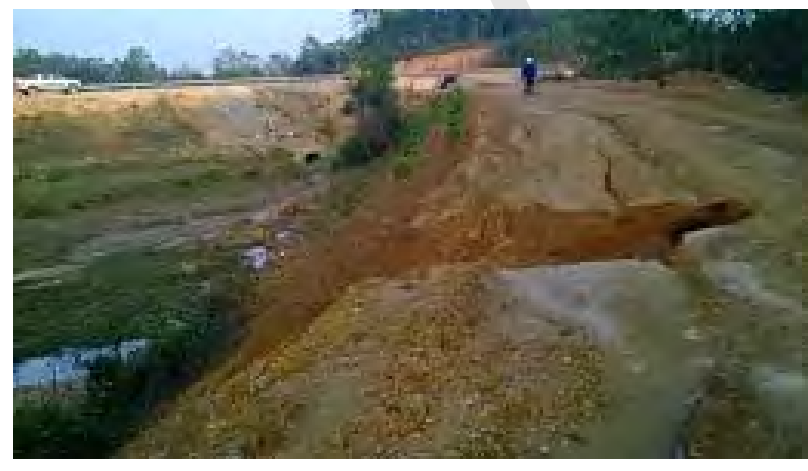

$12 / 3 / 2014$
Location: Km50+570

Site visit: $05,12,19,26 / 3 / 3014$

Date first observed: $21 / 12 / 2013$

Problems description and cause: The contractor did not plant the grass to protect new slope. This situation caused the erosion at this area.

Recommendation and Action taken by Engineer: The Contractor must reinforce the new embankment slope and immediately implement the grassing works to protect it. Beside, Contractor has to remove all soil and dispose it into approved disposals as well as compensate for households whose farm lands are damaged du to the erosion and landslides from the road.

Responsible Party: Posco Contractor

Deadline: $10 / 3 / 2014$

Current status: The compensation has been 


\section{Loan 2391/2392 - VIE: GMS Kunming - Hai Phong Transport Corridor Noi Bai - Lao Cai Highway Project}

\begin{tabular}{|l||l|}
\hline \hline & $\begin{array}{l}\text { paid to affected persons whose farmlands have } \\
\text { been damaged due to erosion and landslides } \\
\text { from road embankment but Contractor does not } \\
\text { implement the suitable measures (e.g., slope } \\
\text { stabilization, installation of adequate drainage, } \\
\text { etc) to ensure that such impacts will be } \\
\text { avoided. }\end{array}$ \\
\hline
\end{tabular}

\subsubsection{Package A4}

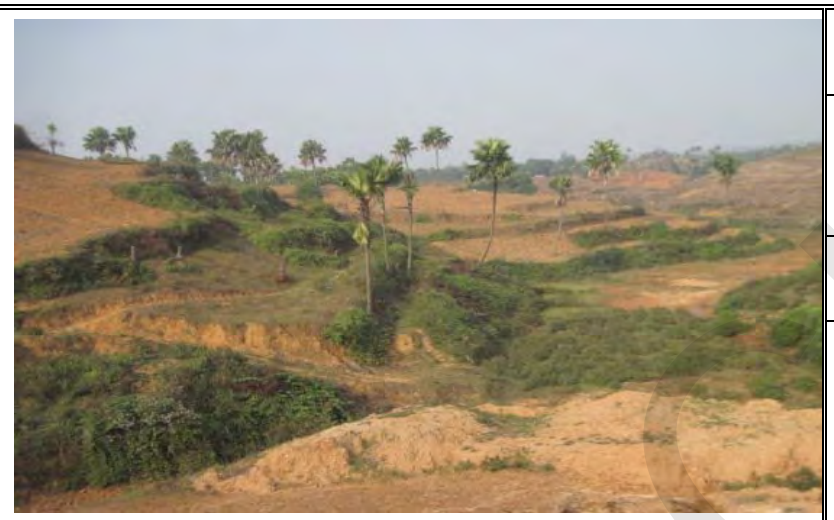

Location: Km82+000

Site visit: $02 ; 09 ; 16 ; 23 / 1 / 2014 ; 06,13,20$, 27/2/2014; 06, 13, 20, 27/3/2014

Date first observed: $26 / 4 / 2013$

Problems description and cause: Agricultural lands have been damaged due to erosion and landslides from road embankments.

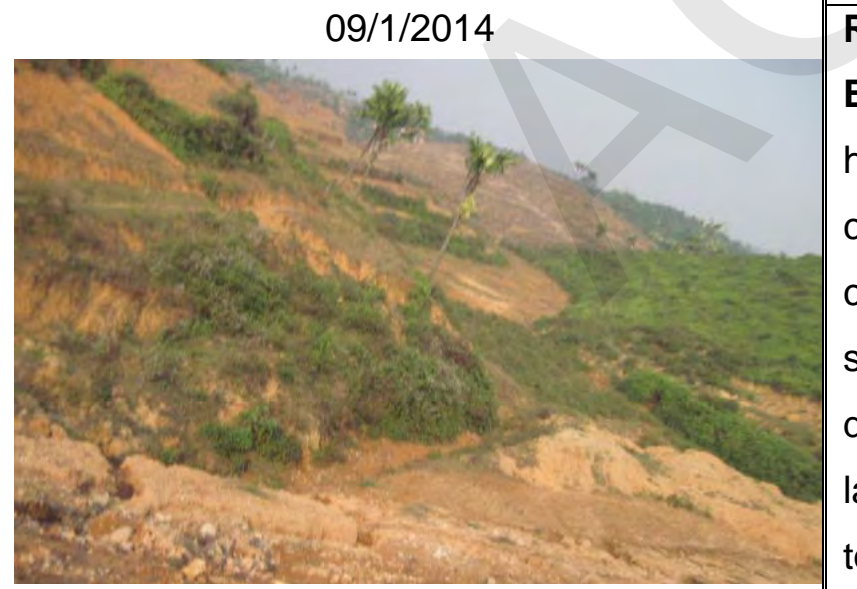

Recommendation and Action taken by Engineer: Closely coordinate with affected households and local authorities to expedite compensation for damages caused by construction activities. Dig adequately sized side drainage/ditch at erosion prone areas to direct surface run-off away from agricultural land. Implement slope stabilization measures to minimize erosion. Provide drainage/ditch reinforcements (e.g., sandbags and/or other appropriate measures) to avoid spill-over of surface run-off onto surrounding agricultural lands. Refer to the letters GET2-KEA-A4-1283, GET2-KEA-A4-1293， GET2-KEA-A4-1378; GET2-KEA-A4-1460, GET2-KEA-A4-1509. 
Loan 2391/2392 - VIE: GMS Kunming - Hai Phong Transport Corridor Noi Bai - Lao Cai Highway Project

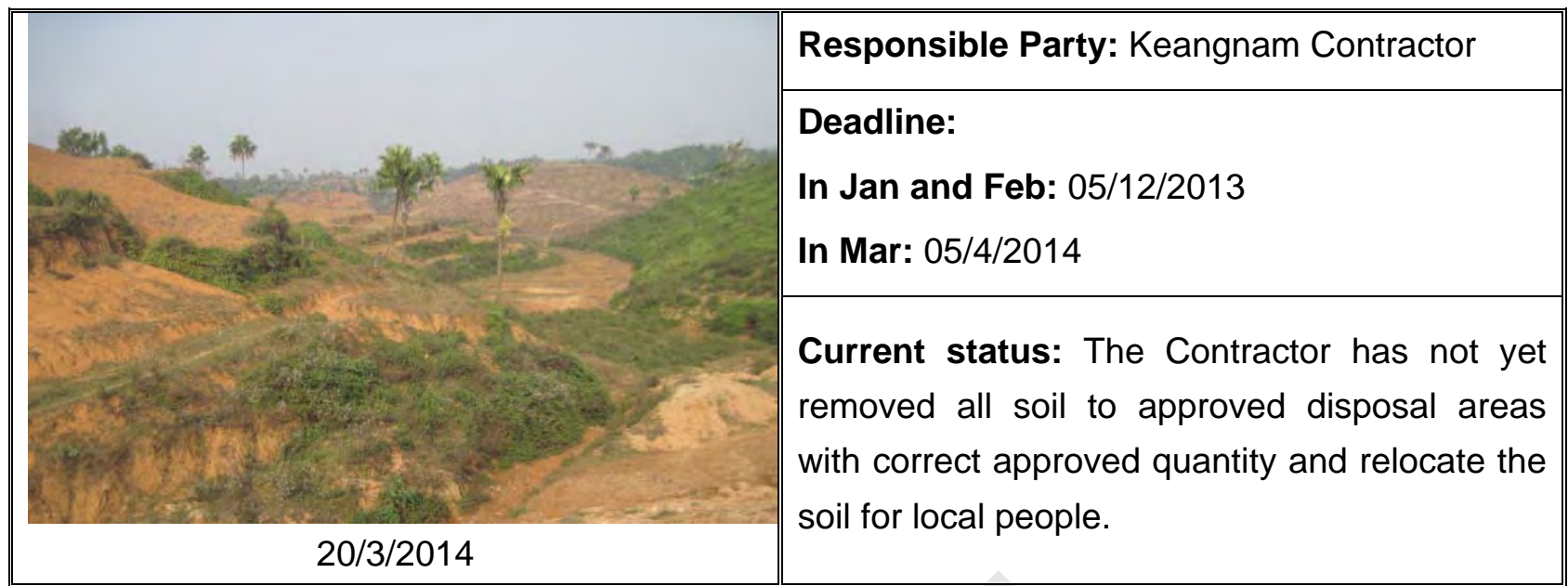

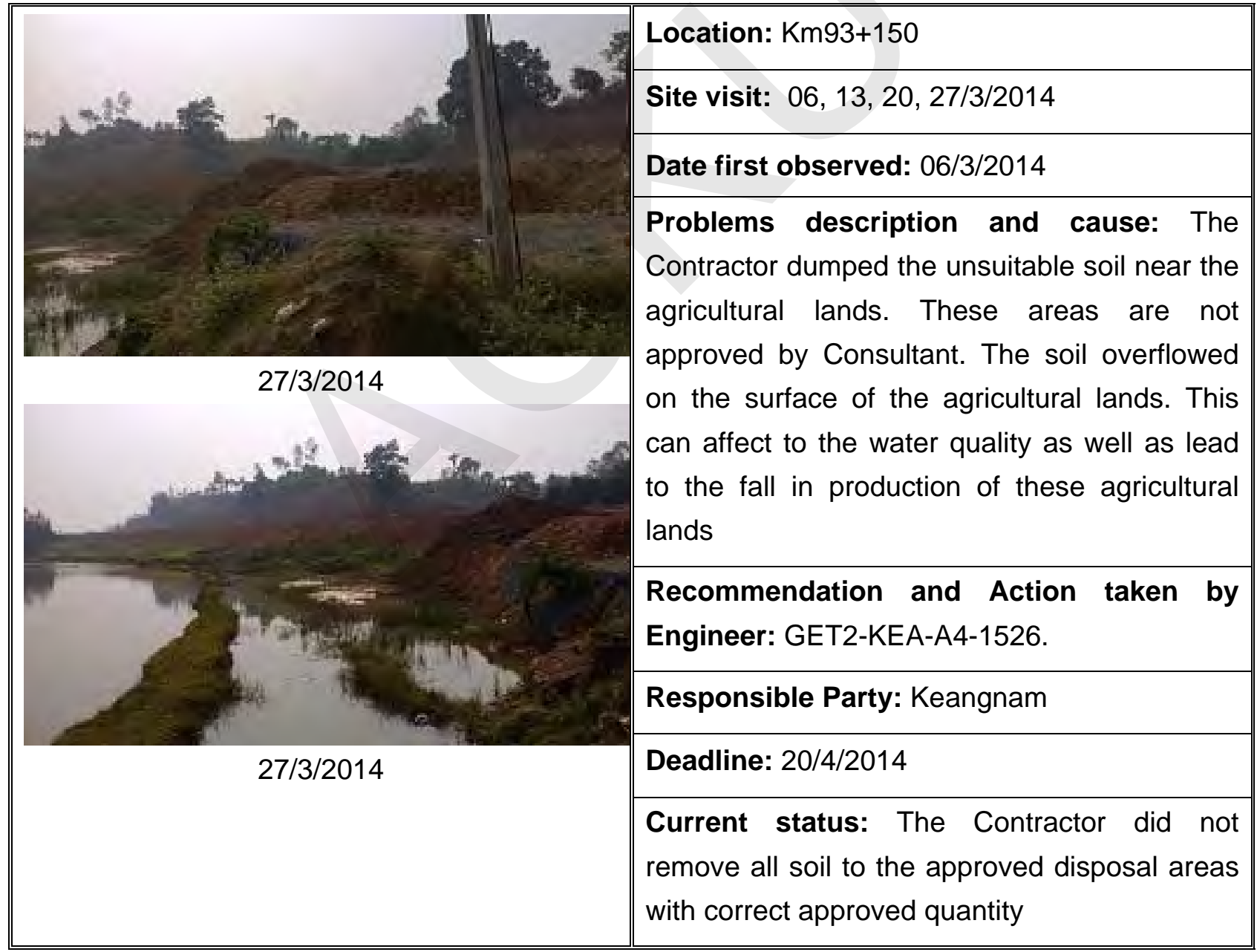




\section{Loan 2391/2392 - VIE: GMS Kunming - Hai Phong Transport Corridor Noi Bai - Lao Cai Highway Project}

\subsubsection{Package A5}

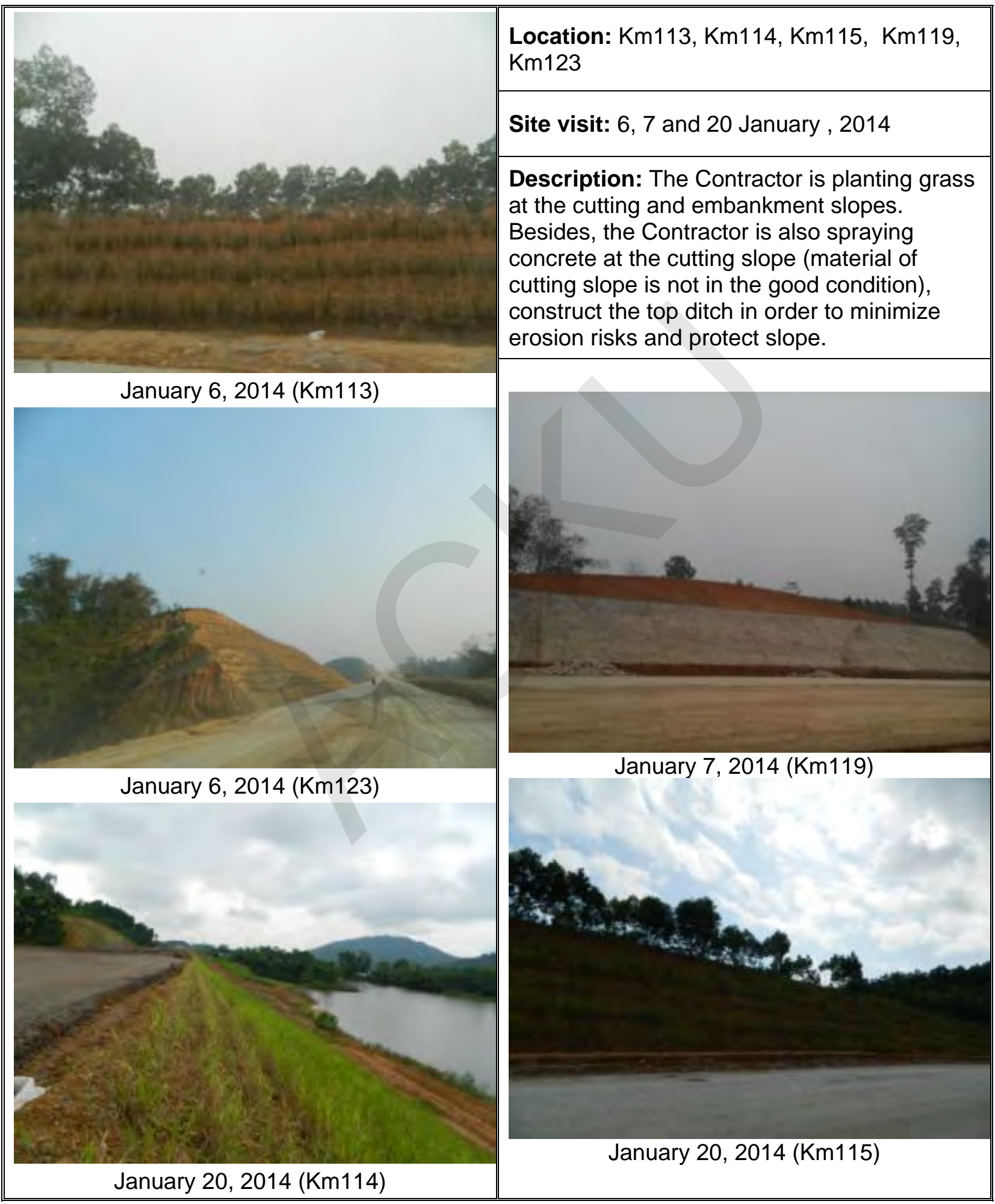




\section{Loan 2391/2392 - VIE: GMS Kunming - Hai Phong Transport Corridor Noi Bai - Lao Cai Highway Project}

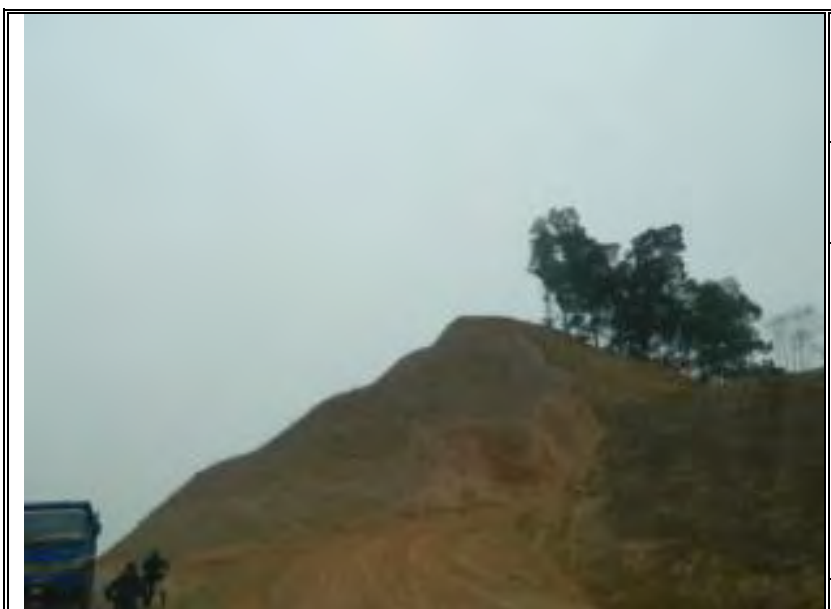

Location: $\mathrm{Km} 122, \mathrm{Km} 120, \mathrm{Km} 135, \mathrm{Km} 134$, Km126

Site visit: 4, 17 and 25 February , 2014

Description: The Contractor is planting grass at the cutting and embankment slopes. Besides, the Contractor is also spraying concrete at the cutting slope (material of cutting slope is not in the good condition), construct the top ditch in order to minimize erosion risks and protect slope.

February 4, 2014 (Km122)
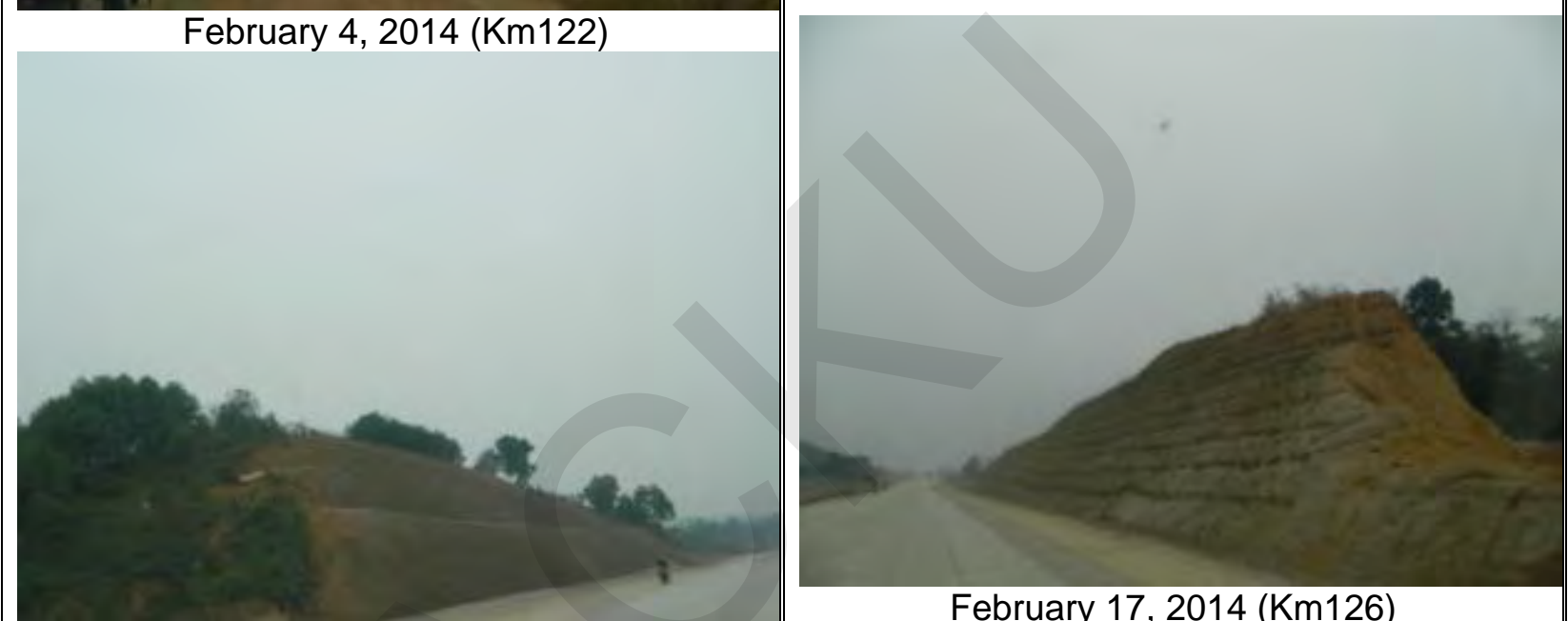

February 4, 2014 (Km124)

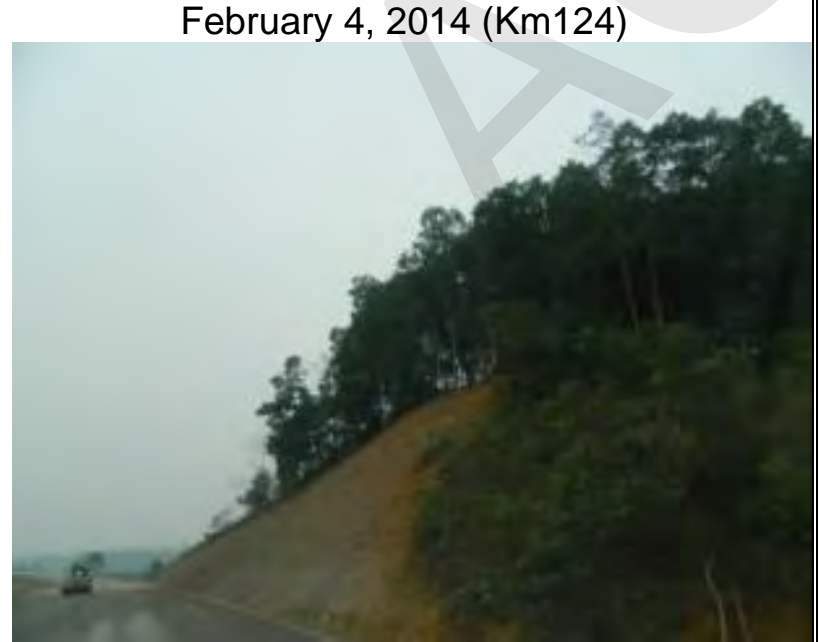

February 25, 2014 (Km135)

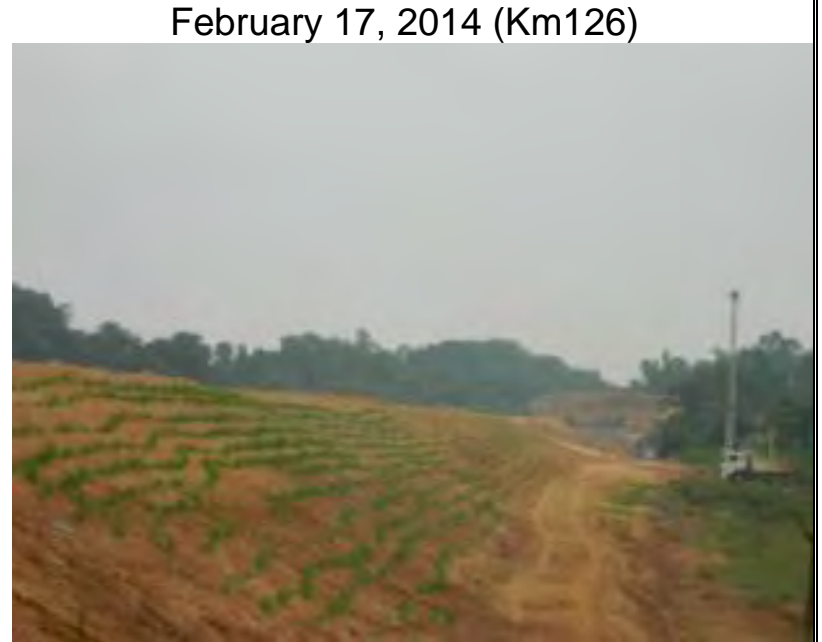

February 25, 2014 (Km120) 


\section{Loan 2391/2392 - VIE: GMS Kunming - Hai Phong Transport Corridor Noi Bai - Lao Cai Highway Project}

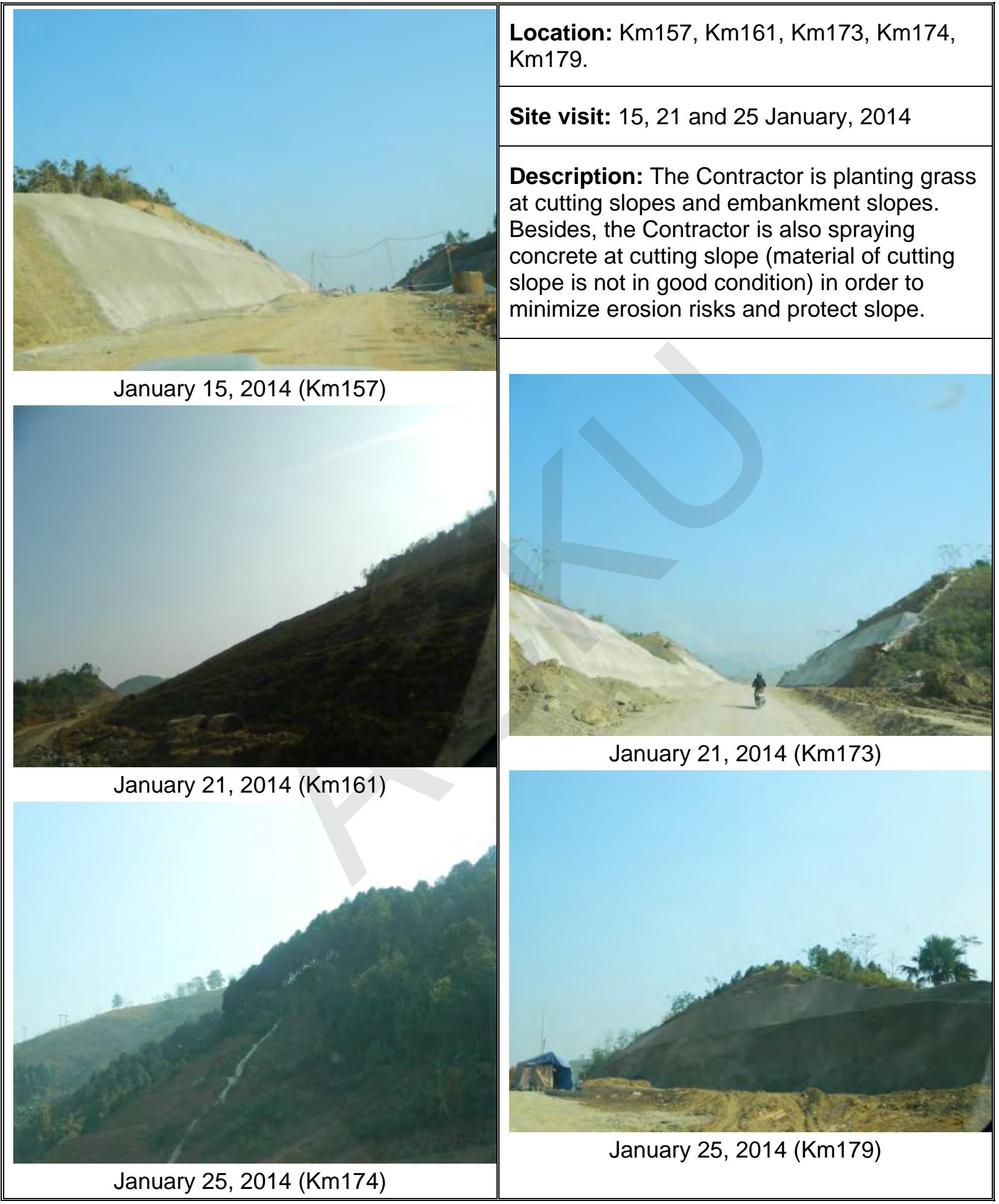




\section{Loan 2391/2392 - VIE: GMS Kunming - Hai Phong Transport Corridor Noi Bai - Lao Cai Highway Project}

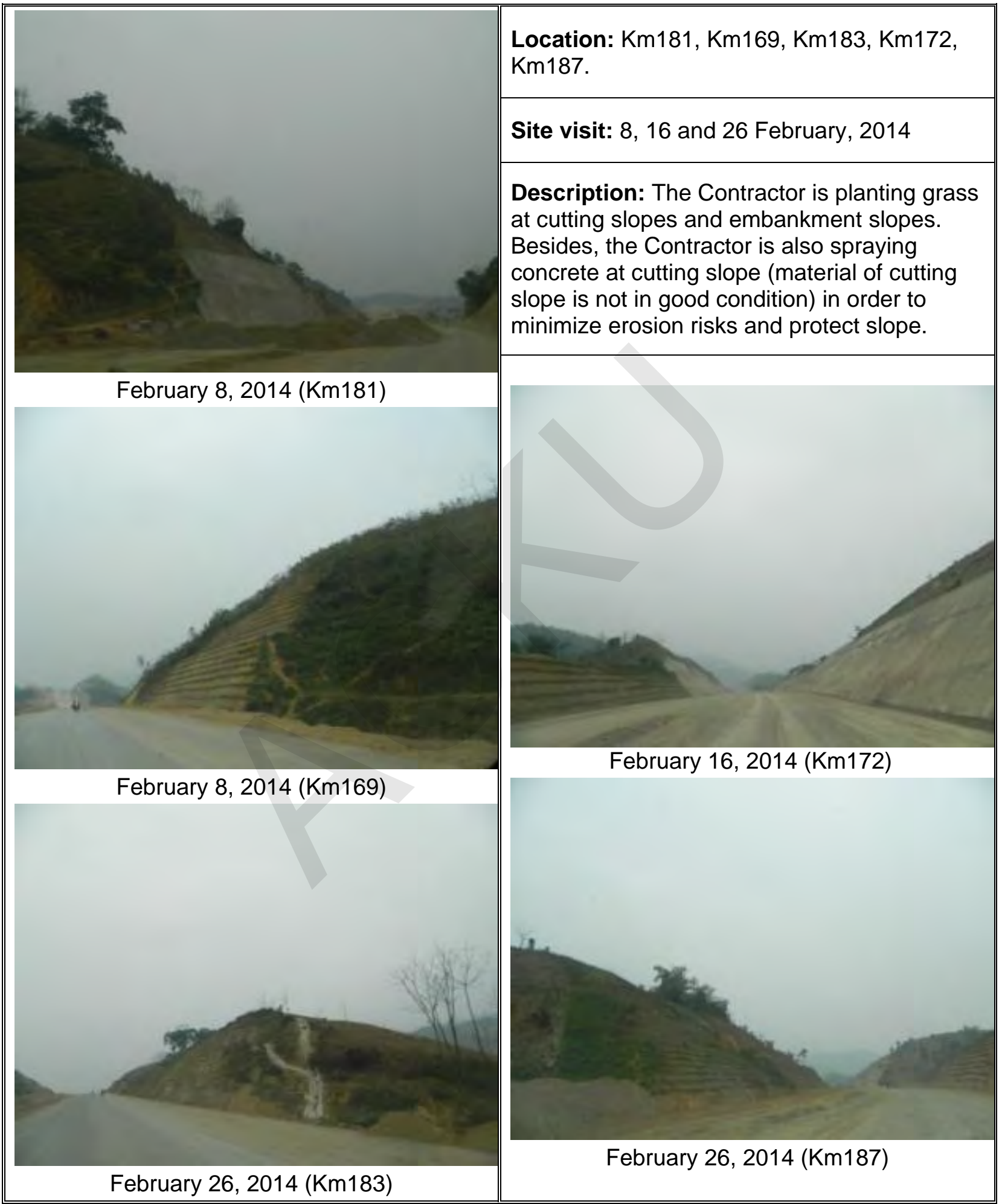




\section{Loan 2391/2392 - VIE: GMS Kunming - Hai Phong Transport Corridor Noi Bai - Lao Cai Highway Project}

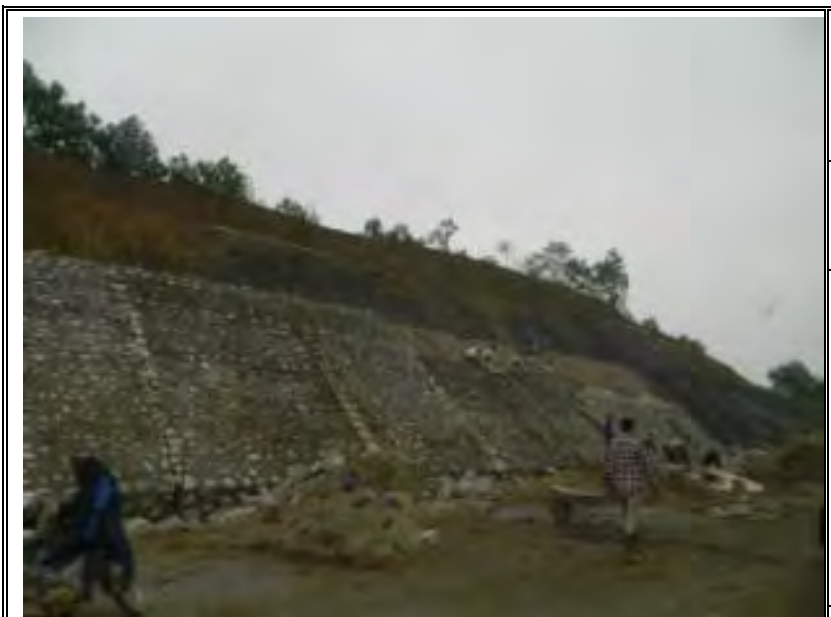

Location: $\mathrm{Km} 136, \mathrm{Km} 130, \mathrm{Km} 119, \mathrm{Km} 118$, $\mathrm{Km} 123$

Site visit: 3, 12 and 18 March, 2014

Description: The Contractor is planting grass at the cutting slopes and the embankment slopes. Besides, the Contractor also built the stone wall at some cutting slopes (material of cutting slope is not in the good condition), construct the top ditch in order to minimize the erosion risks and protect the slope.
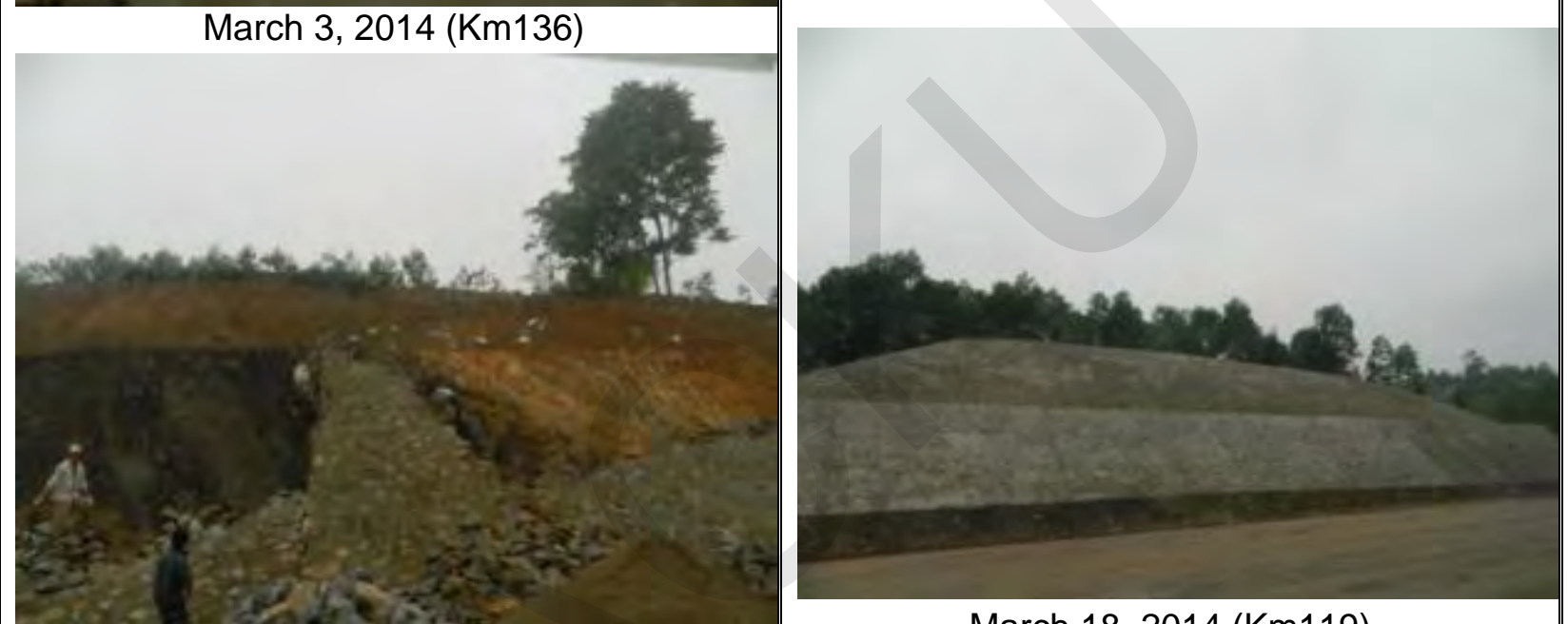

March 12, 2014 (Km130)

March 18, 2014 (Km119)

March 18, 2014 (Km123)

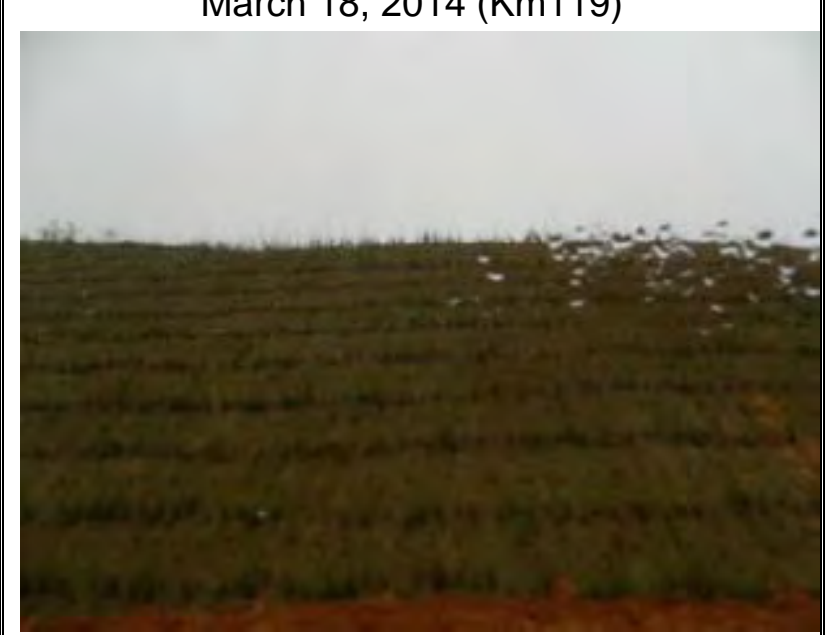

March 12, 2014 (Km118) 


\section{Loan 2391/2392 - VIE: GMS Kunming - Hai Phong Transport Corridor Noi Bai - Lao Cai Highway Project}

\subsubsection{Package A6}

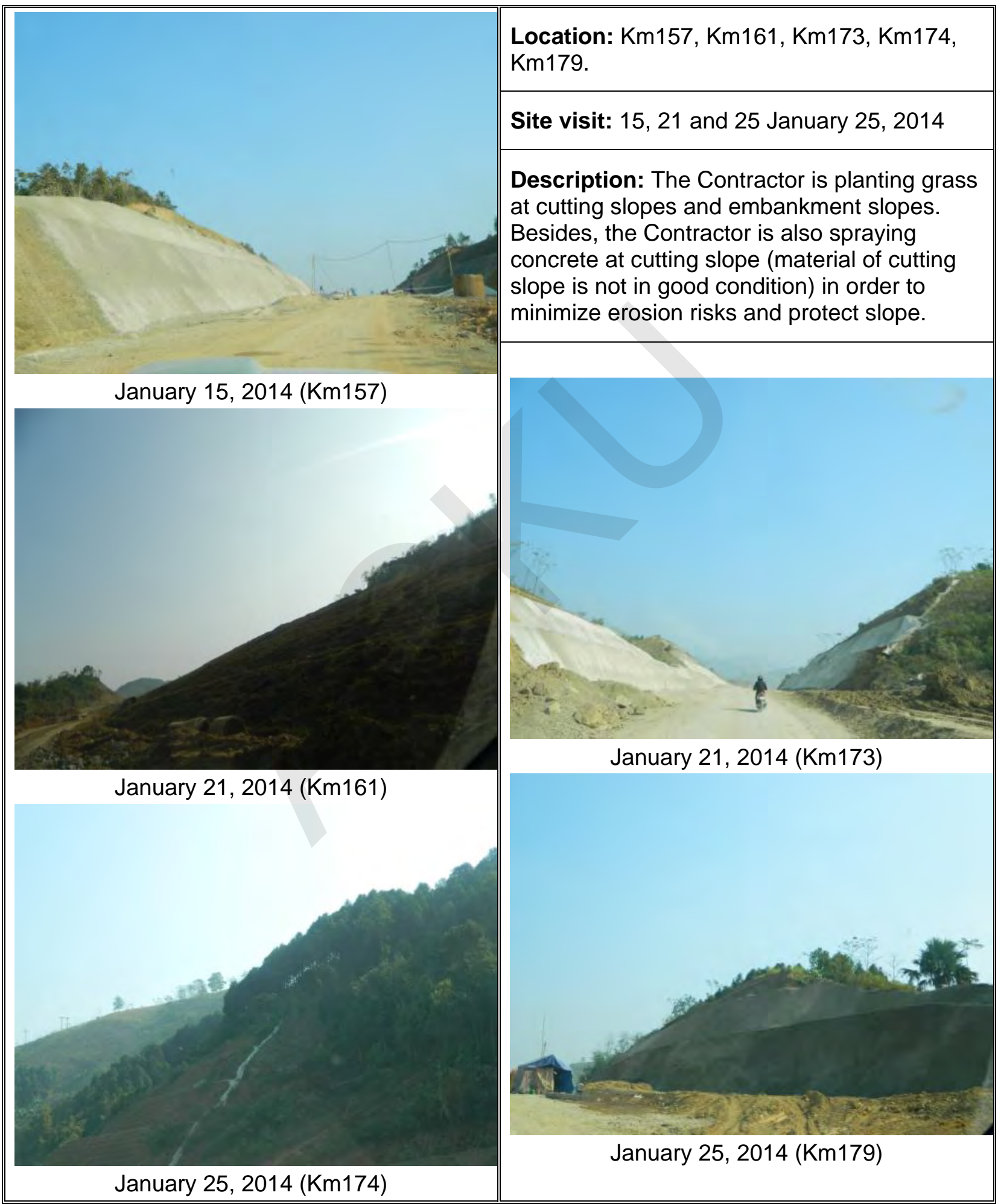




\section{Loan 2391/2392 - VIE: GMS Kunming - Hai Phong Transport Corridor Noi Bai - Lao Cai Highway Project}

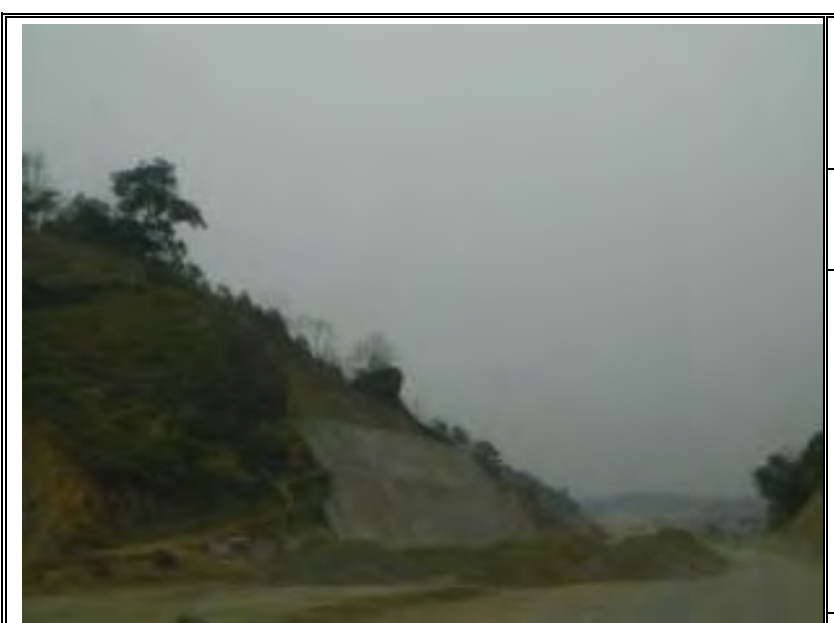

Location: Km181, Km169, Km183, Km172, Km187.

Site visit: 8,16 and 26 February, 2014

Description: The Contractor is planting grass at cutting slopes and embankment slopes. Besides, the Contractor is also spraying concrete at cutting slope (material of cutting slope is not in good condition) in order to minimize erosion risks and protect slope.

February 8, 2014 (Km181)

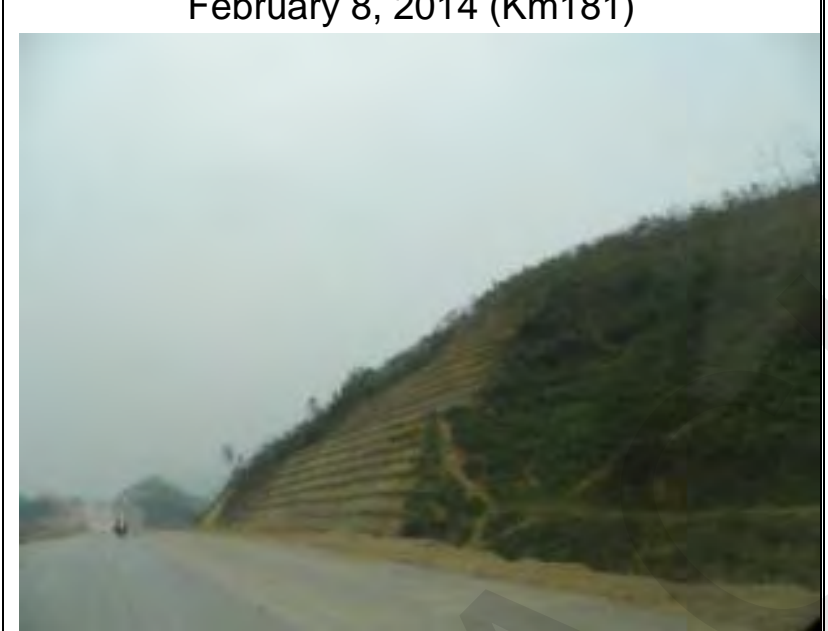

February 8, 2014 (Km169)

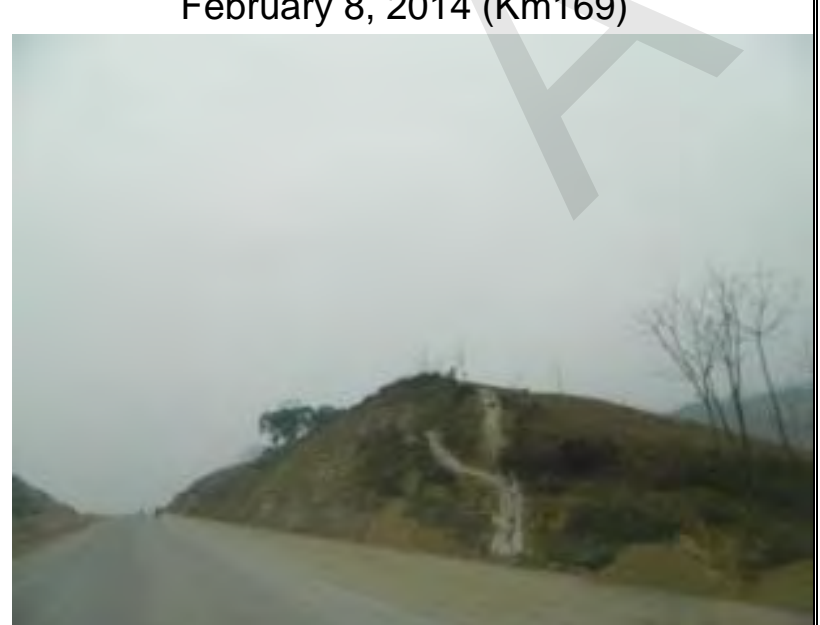

February 26, 2014 (Km183)

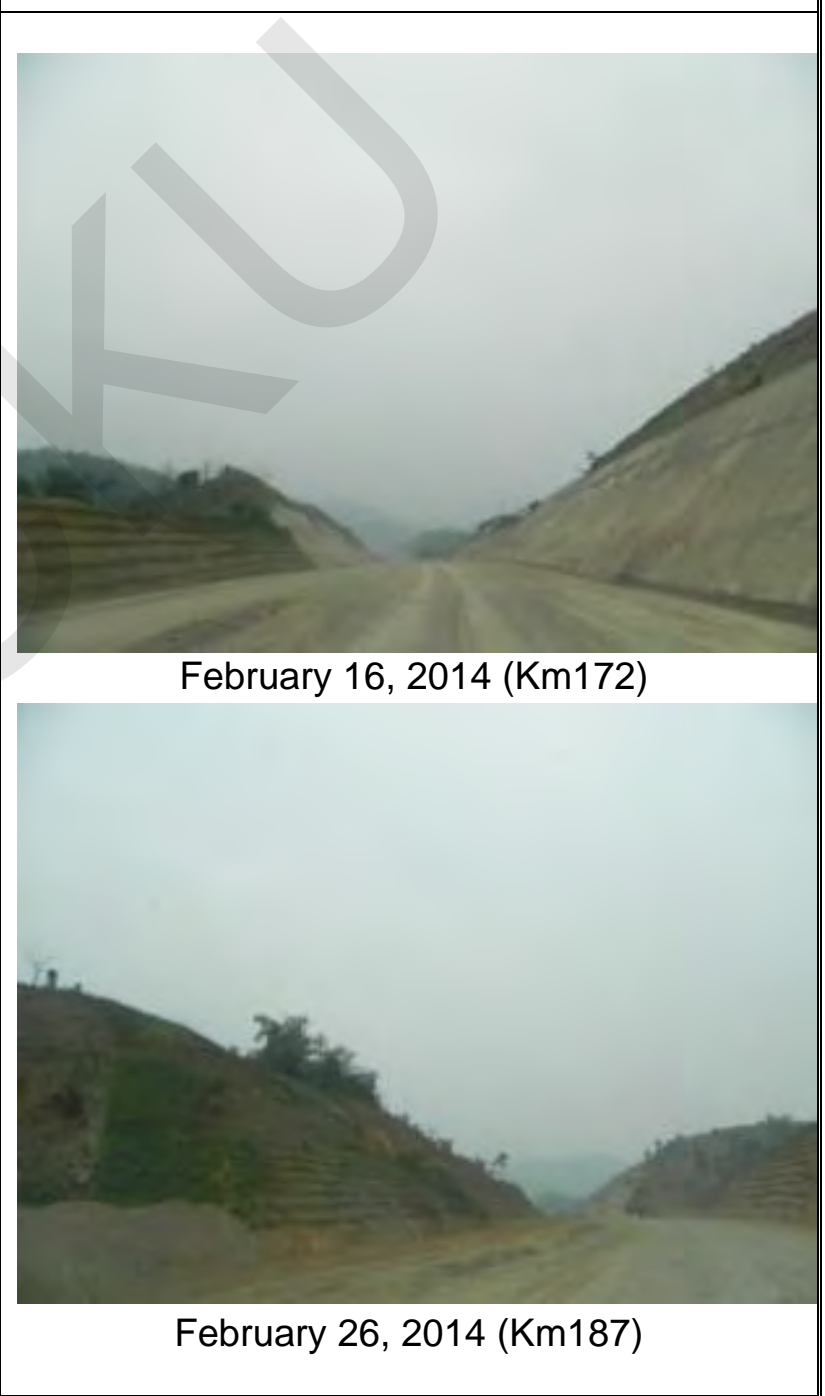




\section{Loan 2391/2392 - VIE: GMS Kunming - Hai Phong Transport Corridor Noi Bai - Lao Cai Highway Project}

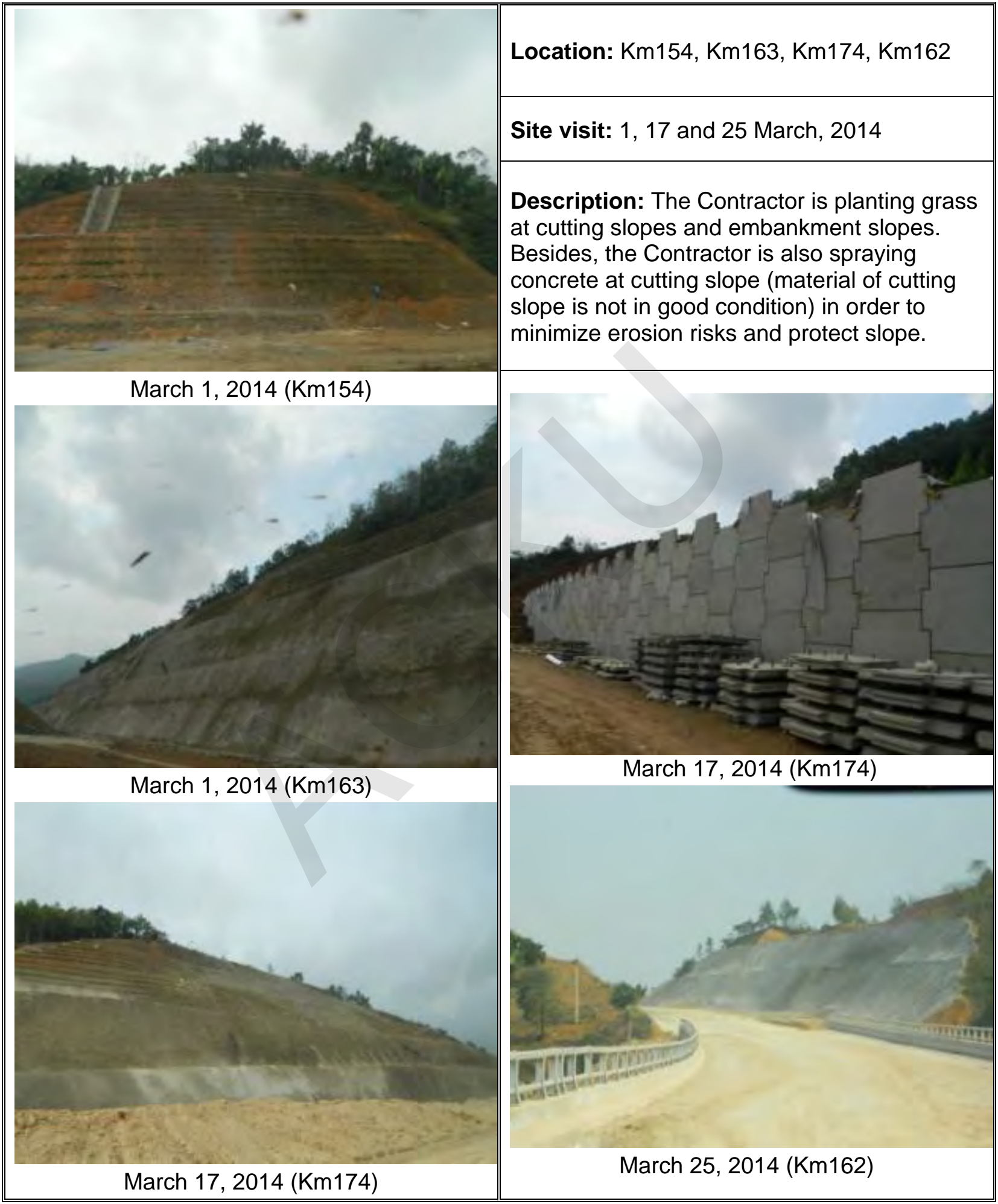




\section{Loan 2391/2392 - VIE: GMS Kunming - Hai Phong Transport Corridor Noi Bai - Lao Cai Highway Project}

\subsubsection{Package A7}

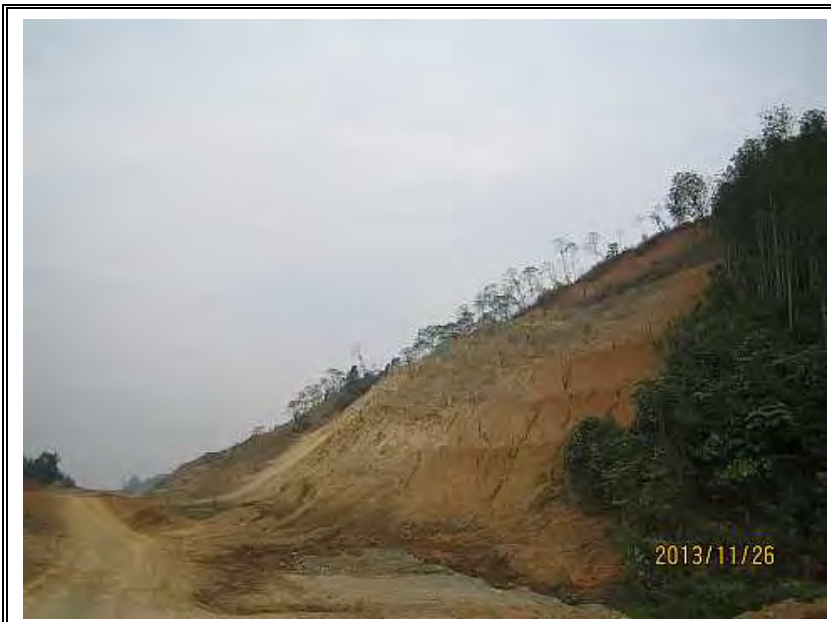

Location: Excavation slope $\mathrm{Km} 215+200$

Site visit: $21.1 .2014 ; 25.2 .2014 ; 19.3 .2014$

Date first observed: 21.5 .2013

Problems description and cause: Slope had landside and erosion due to heavy rains

Recommendation and Action taken by Engineer: Required the contractor to set up safety fences and signposts surrounding landside and erosion areas, after that apply the slope protection method to overcome as soon as possible.

Deadline: As soon as possible

Current status: The contractor is improving this issue

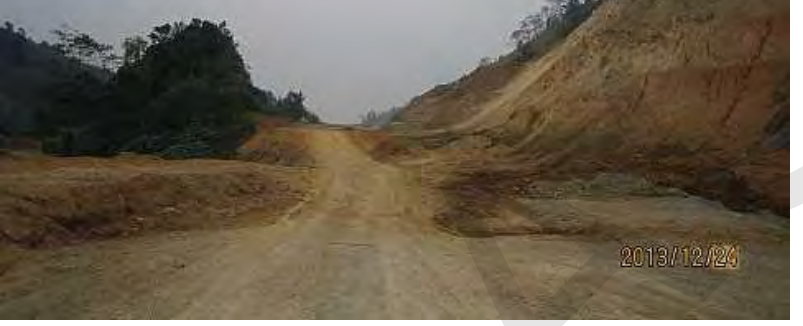

24.12 .2013
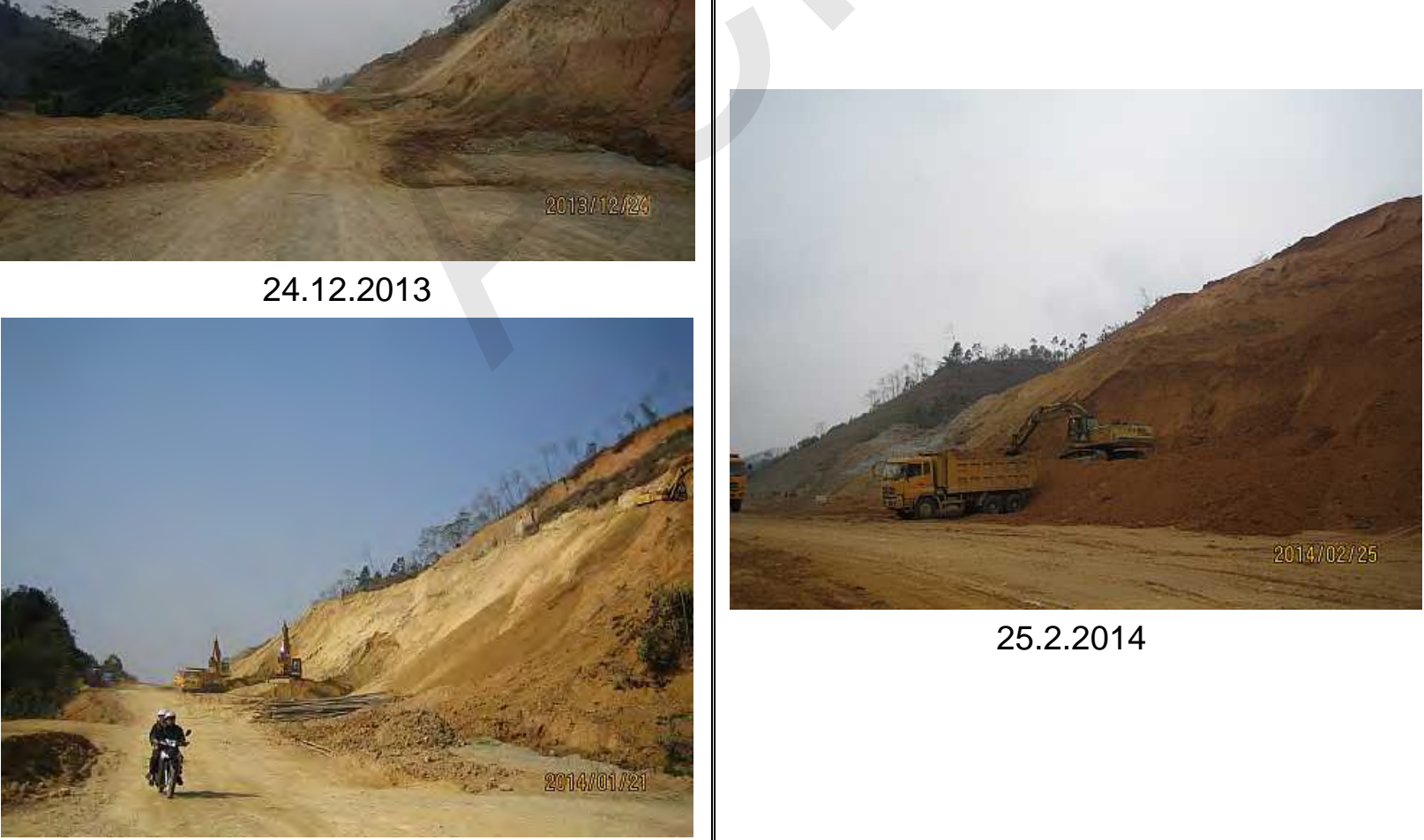

25.2.2014

21.1.2014 


\section{Loan 2391/2392 - VIE: GMS Kunming - Hai Phong Transport Corridor Noi Bai - Lao Cai Highway Project}

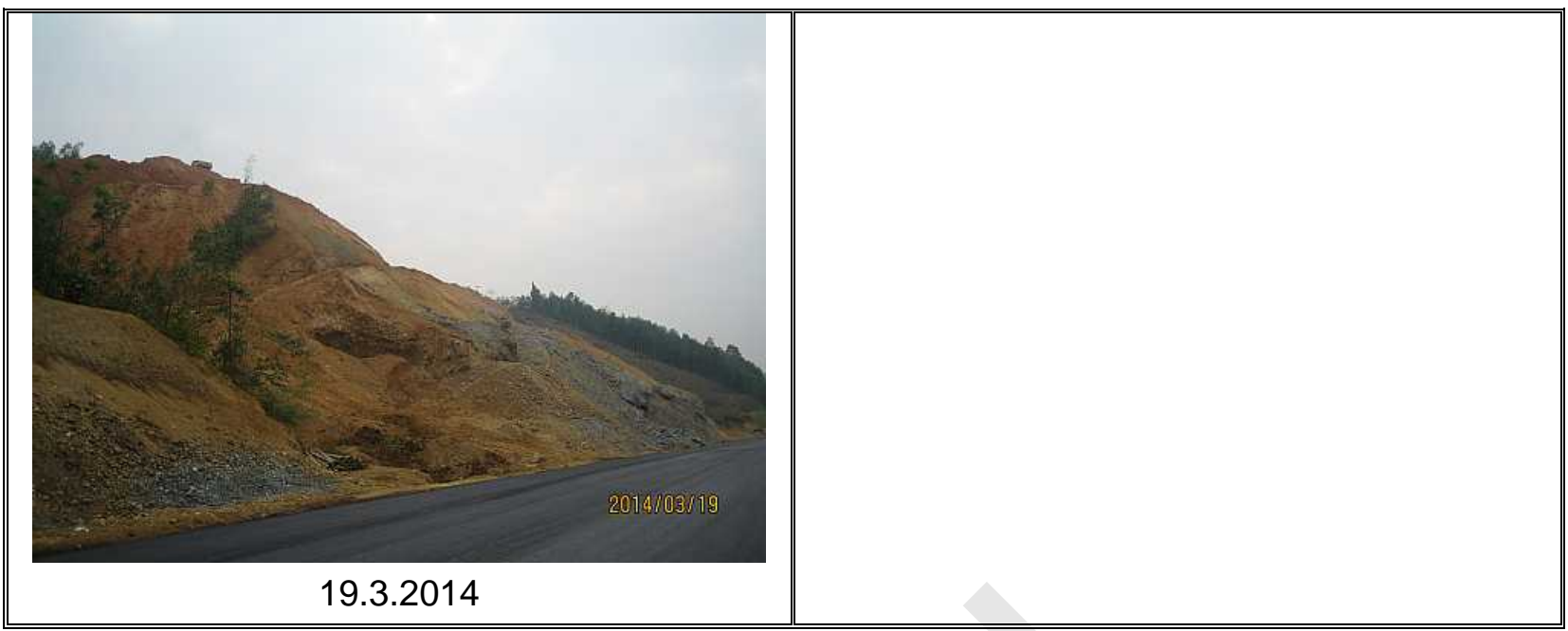

\subsubsection{Package A8}

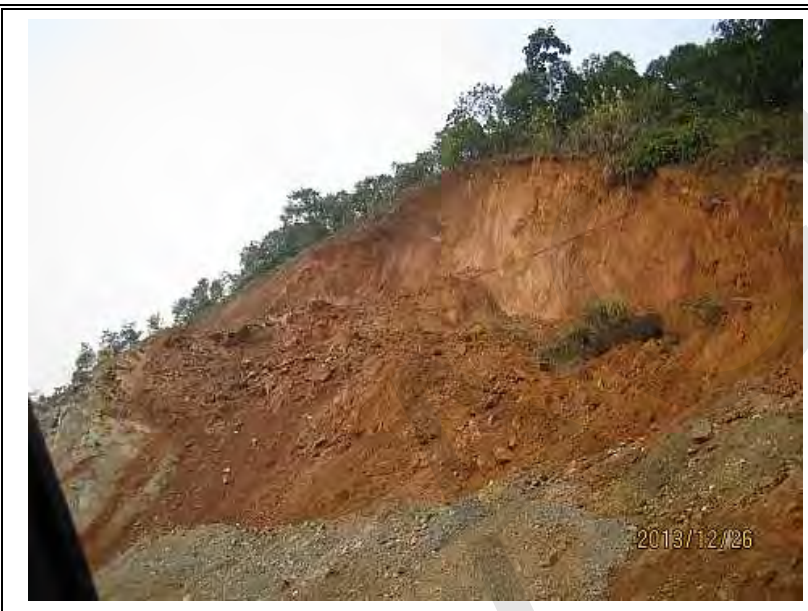

26.12.2013

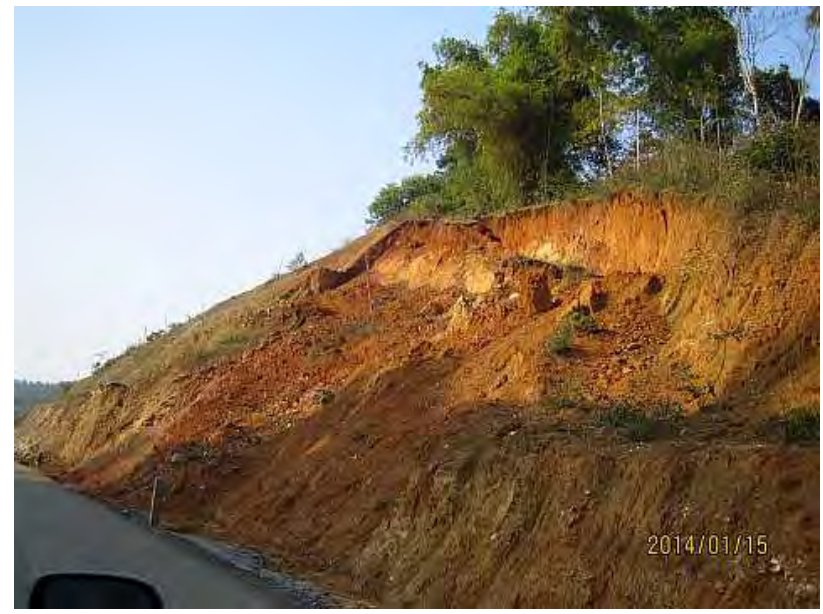

15.1 .2014
Location: Excavation slope $\mathrm{Km} 228+100$

Site visit: $12.1 .2014 ; 26.2 .2014 ; 26.3 .2014$

Date first observed: 22.5 .2013

Problems description and cause: Slope had landside and erosion due to heavy rains

Recommendation and Action taken by Engineer: Required the contractor to set up safety fence and signpost surrounding landside and erosion areas, after that apply the slope protection method to overcome as soon as possible.

Deadline: As soon as possible

Current status: The contractor is going to solve by reducing the high level and applying the slope protections method. 
Loan 2391/2392 - VIE: GMS Kunming - Hai Phong Transport Corridor Noi Bai - Lao Cai Highway Project

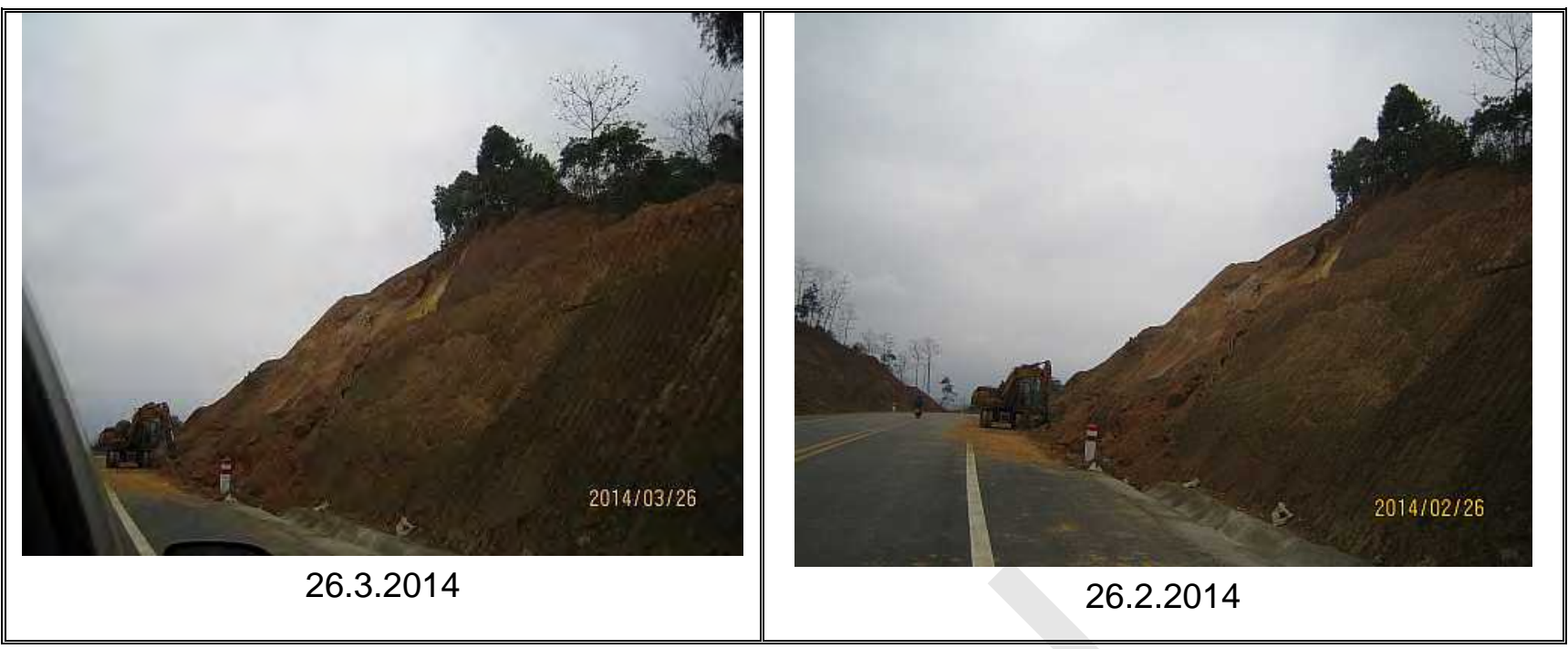

\subsection{HAZARDOUS SUBSTANCES MANAGEMENT}

\subsubsection{Package A1}

At the present, at package A1, the Contractor has finished all construction works.

\subsubsection{Package A2}

During the site inspection in this period, we did not detect any serious problem regarding to hazardous substance management.

\subsubsection{Package A3}

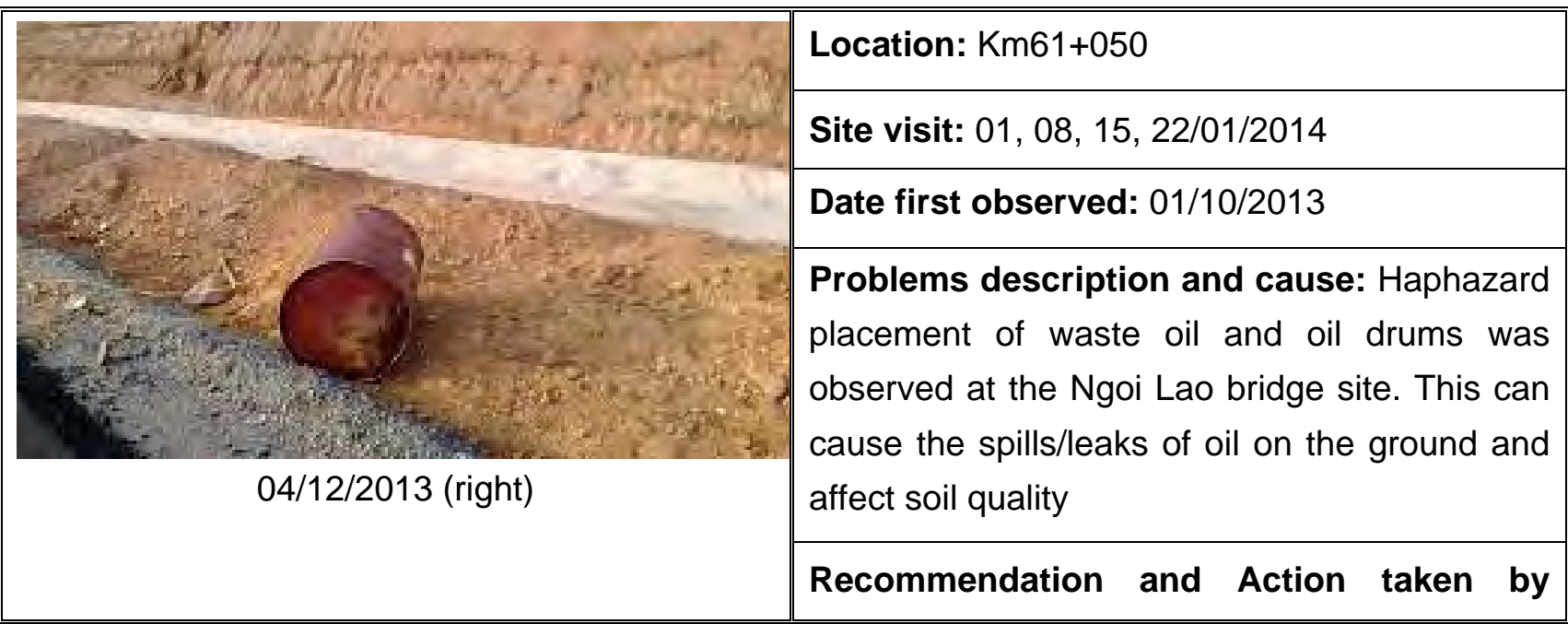




\section{Loan 2391/2392 - VIE: GMS Kunming - Hai Phong Transport Corridor Noi Bai - Lao Cai Highway Project}

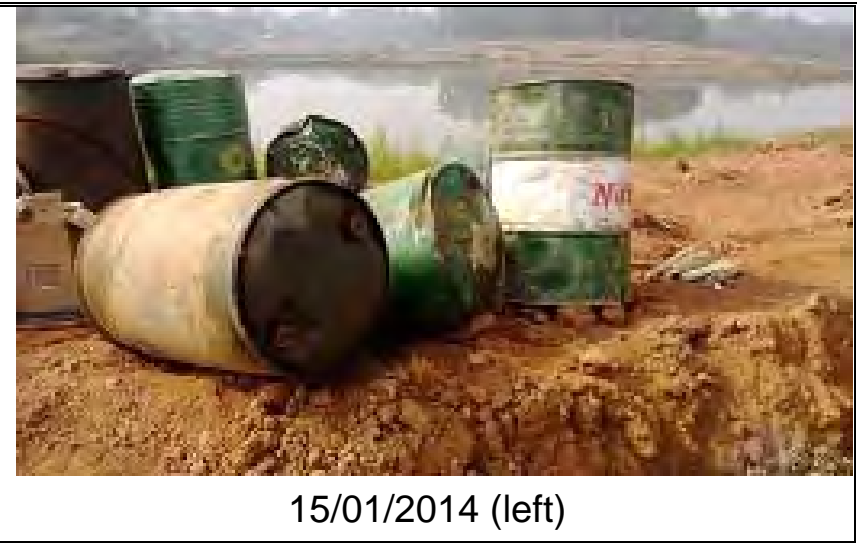

Engineer: The fuel storage tanks should be provided with roof and concrete floor with bund to minimize the risk of spills/leaks of oil.

Responsible Party: POSCO

Deadline: Immediately

Current status: The Contractor has not yet implemented the Consultant's instructions

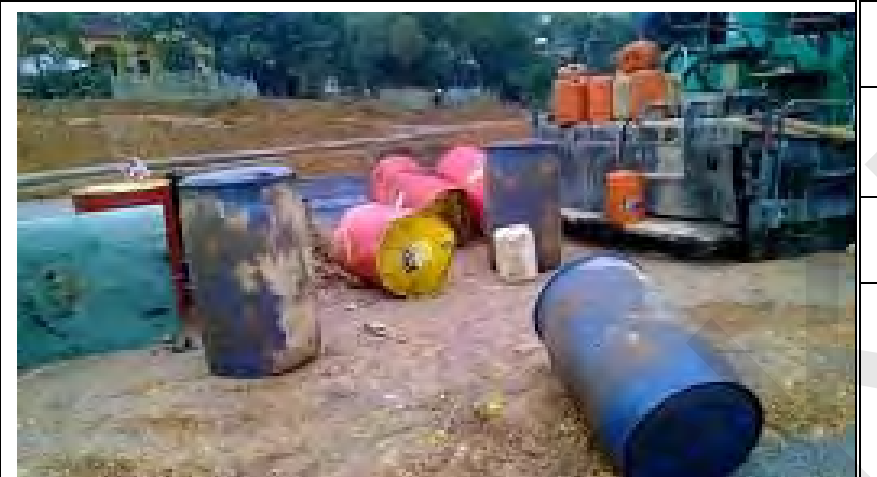

Location: Km62+150

Site visit: $07,14,21,25 / 2 / 2014 ; 05,12,19$, 26/3/3014

Date first observed: $07 / 2 / 2014$

Problems description and cause: Haphazard placement of waste oil and oil drums was observed on site. This can cause the spills/leaks of oil on the ground and affect to the soil quality

Recommendation and Action taken by Engineer: The fuel storage tank should be provided with roof and concrete floor with bund to minimize the risk of spills/leaks of oil.

Responsible Party: POSCO

Deadline: Immediately

\section{$14 / 2 / 2014$}

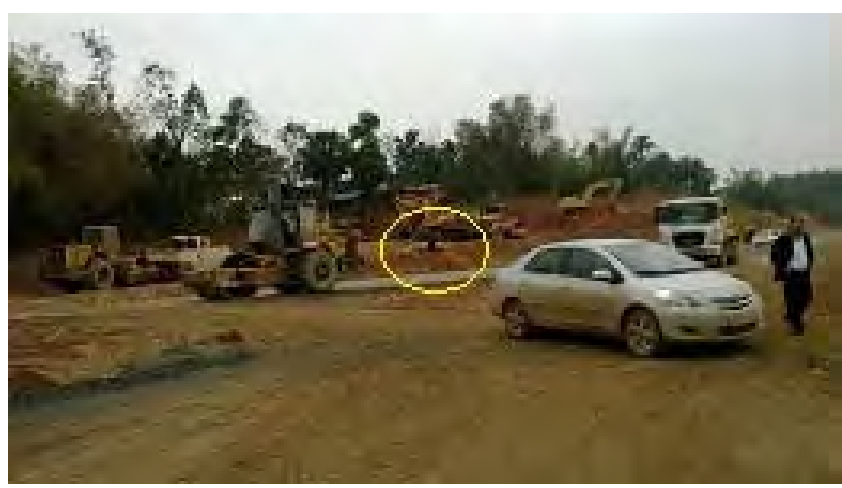

$05 / 3 / 2014$

Current status: The Contractor has not yet implemented the Consultant 's instructions 


\section{Loan 2391/2392 - VIE: GMS Kunming - Hai Phong Transport Corridor Noi Bai - Lao Cai Highway Project}

\subsubsection{Package A4}

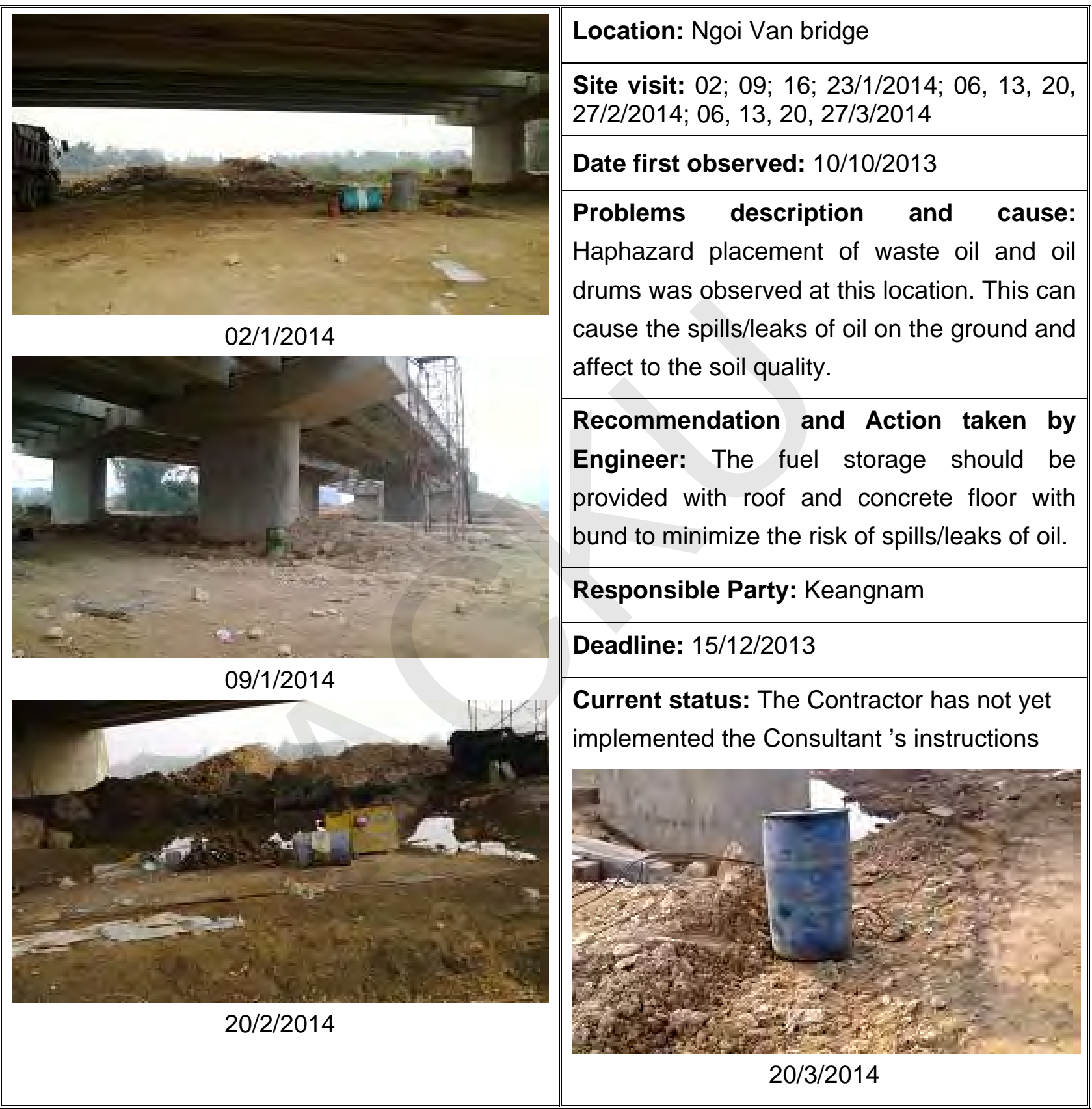




\section{Loan 2391/2392 - VIE: GMS Kunming - Hai Phong Transport Corridor Noi Bai - Lao Cai Highway Project}

\begin{tabular}{|c|c|}
\hline & Location: Ngoi Gianh Bridge \\
\hline & Site visit: $02 ; 09 ; 16 ; 23 / 1 / 2014$ \\
\hline & Date first observed: $10 / 10 / 2013$ \\
\hline 7 & $\begin{array}{l}\text { Problems description and cause: } \\
\text { Haphazard placement of waste oil and oil } \\
\text { drums was observed at this location. This can } \\
\text { cause the spills/leaks of oil on the ground and } \\
\text { affect soil quality. }\end{array}$ \\
\hline & $\begin{array}{l}\text { Recommendation and Action taken by } \\
\text { Engineer: The fuel storage tank should be } \\
\text { provided with roof and concrete floor with } \\
\text { bund to minimize the risk of spills/leaks of oil. }\end{array}$ \\
\hline & Responsible Party: Keangnam \\
\hline & Deadline: 10/12/2013 \\
\hline 09/1/2014 & $\begin{array}{l}\text { Current status: The Contractor has yet not } \\
\text { removed drums in upright position in this area }\end{array}$ \\
\hline
\end{tabular}

\subsubsection{Package A5}

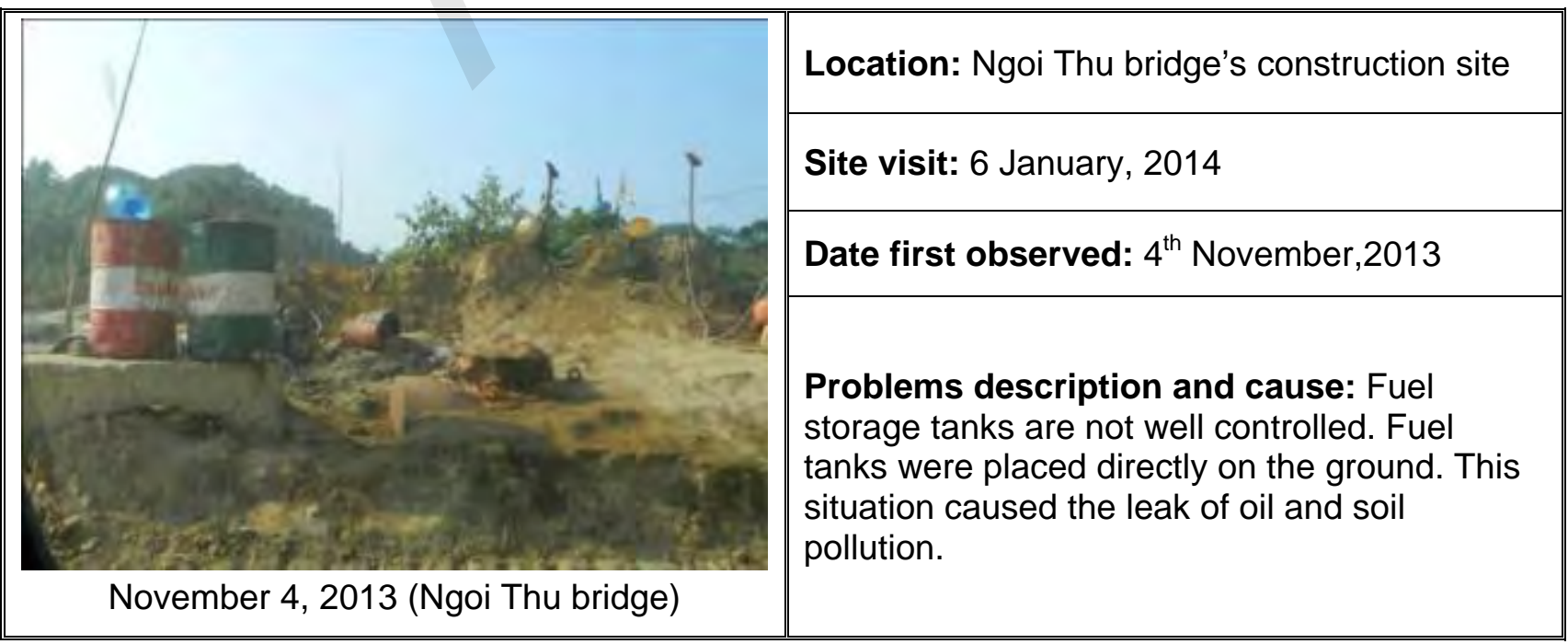




\section{Loan 2391/2392 - VIE: GMS Kunming - Hai Phong Transport Corridor Noi Bai - Lao Cai Highway Project}

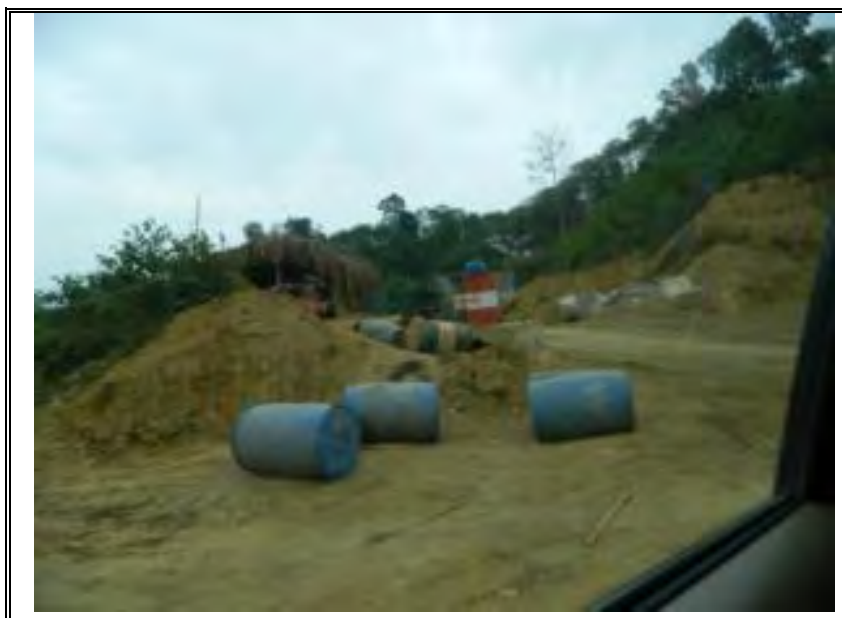

\section{Recommendation and Action taken by}

Engineer: The Engineer required the

Contractor to improve fuel control at this

location, at the same time, the Engineer also

provided the instruction for these issues.

November 19, 2013 (Ngoi Thu bridge)

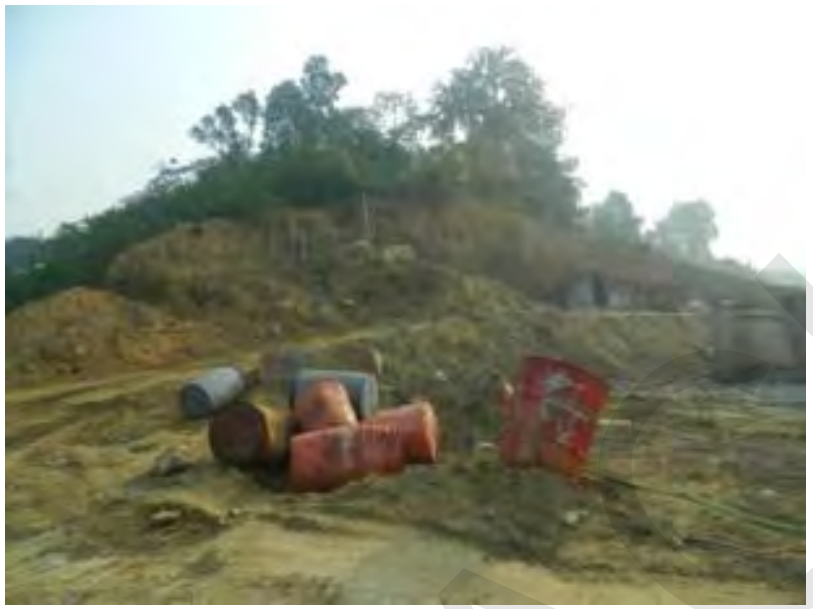

December 3, 2013 (Ngoi Thu bridge)

\section{Responsible Party: Keangnam Contractor}

Deadline: 12-Nov-2013

\section{Current status:}

\section{- $6^{\text {th }}$ January, 2014: Not yet improved}

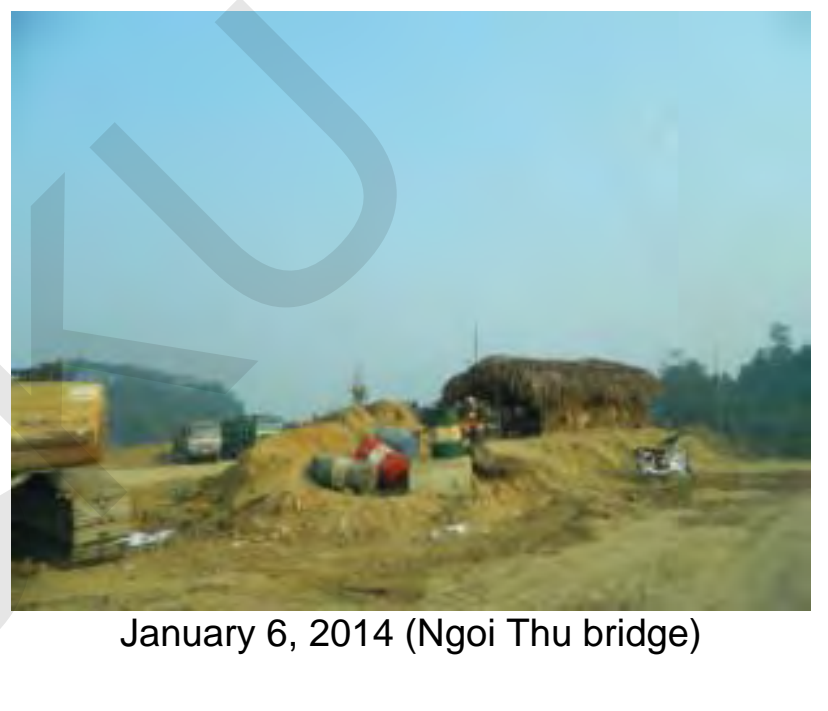

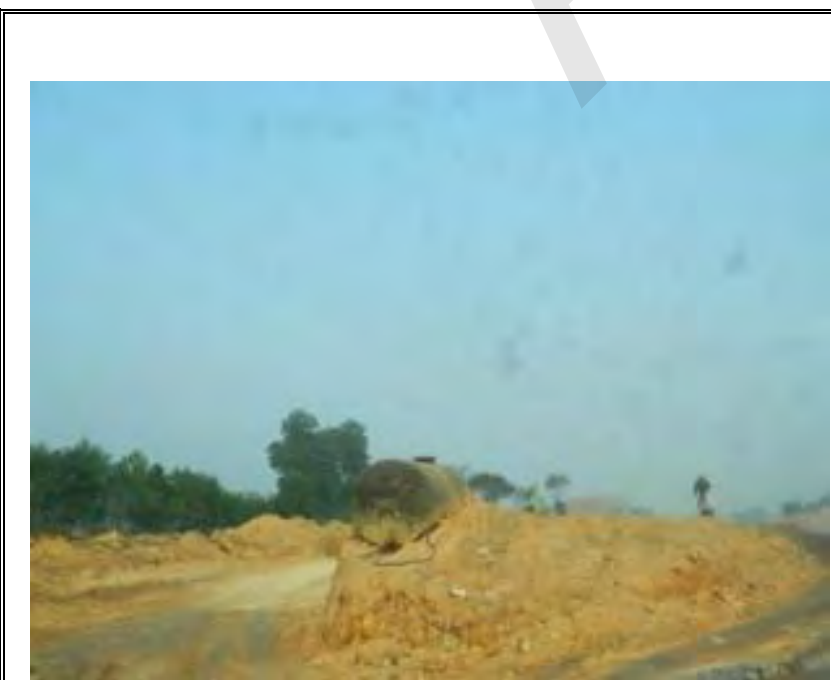

December 13, 2013 (Km126)
Location: $\mathrm{Km} 126$

Site visit: 20 January, 2014

Date first observed: $3^{\text {rd }}$ December,2013

Problems description and cause: Fuel storage tanks are not well controlled. Fuel tanks were placed directly on the ground. This situation caused the leak of oil and soil pollution. 


\section{Loan 2391/2392 - VIE: GMS Kunming - Hai Phong Transport Corridor Noi Bai - Lao Cai Highway Project}

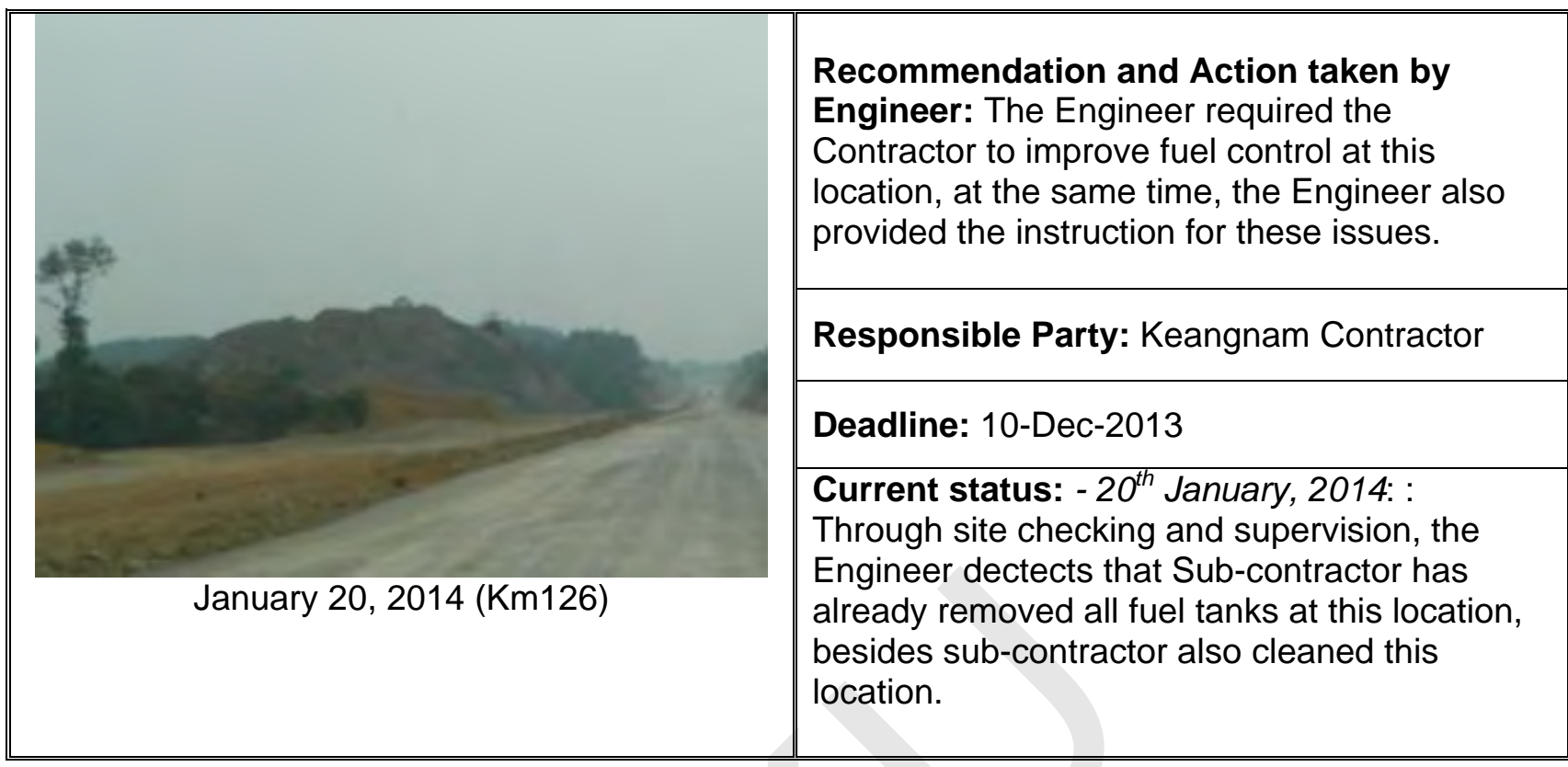

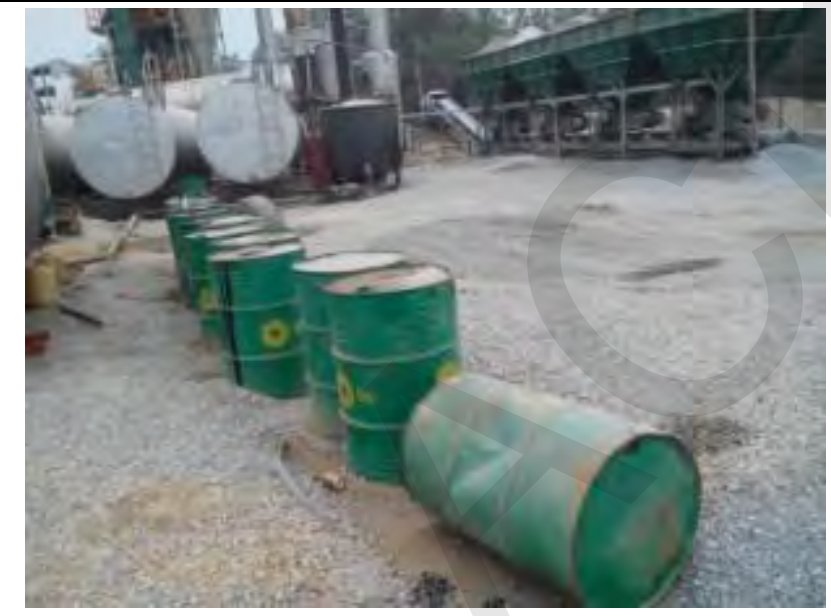

February 17, 2014 (Km117)

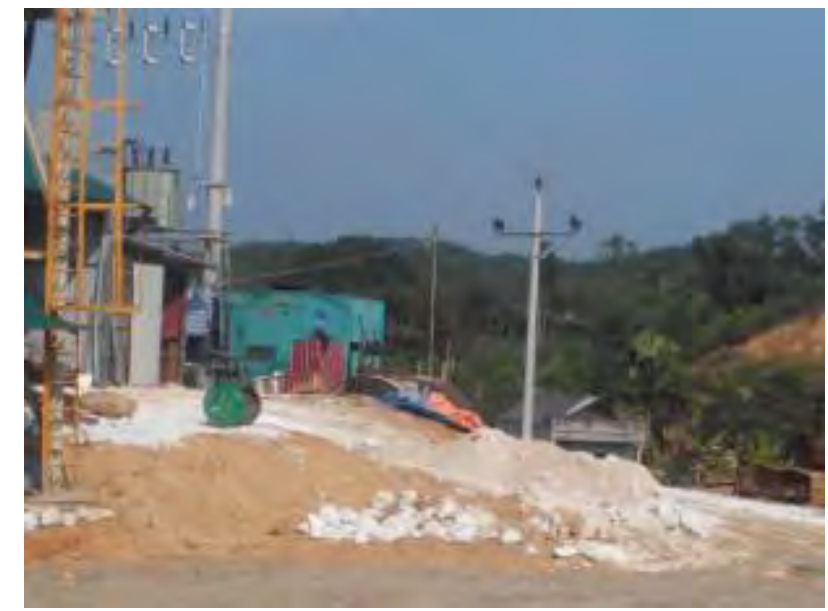

February 17, 2014 (Km117)
Location: Asphast concrete batching plant $\mathrm{Km} 117$

Site visit: 17 and 25 February, 2014

Date first observed: $17^{\text {th }}$ February, 2014

Problems description and cause: Fuel storage tanks are not well controlled. Fuel tanks were placed directly on the ground. This situation caused the leak of oil and soil pollution.

\section{Recommendation and Action taken by} Engineer: The Engineer required the Contractor to improve fuel control at this location, at the same time, the Engineer also provided the instruction for these issues.

Responsible Party: Keangnam Contractor

Deadline: 17-Feb-2014

Current status: No important change was seen. 


\section{Loan 2391/2392 - VIE: GMS Kunming - Hai Phong Transport Corridor Noi Bai - Lao Cai Highway Project}

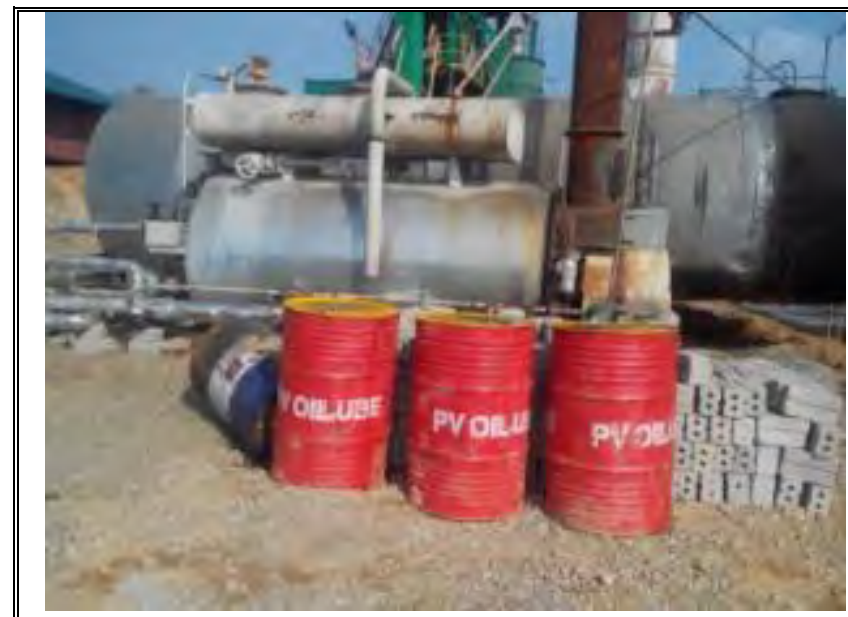

February 25, 2014 (Km117)

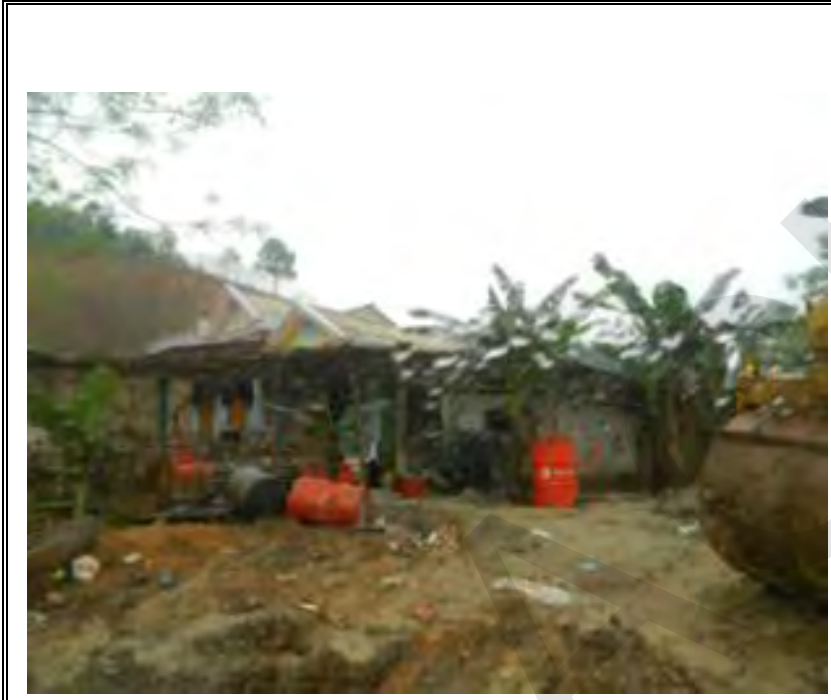

March 18, 2014 (Km131)

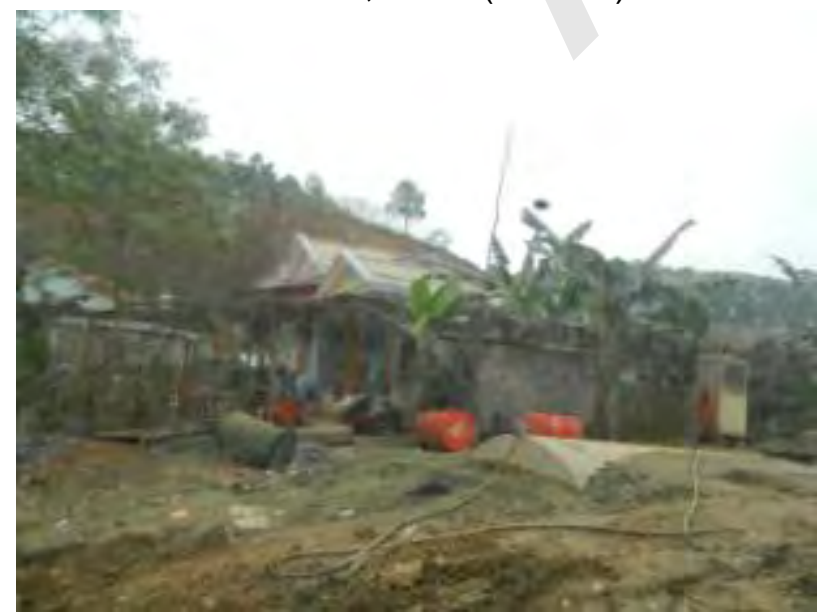

Site visit: 18 and 28 March, 2014

Date first observed: $18^{\text {th }}$ March, 2014

Problems description and cause: The Contractor did not implement well the fuel management. Haphazard placement of waste oil and oil drums was observed on site. This can cause the spills/leaks of oil on the ground and affect to the soil quality. Besides, there is lack of safety measures for fire and explosive preventive issues at this location.

Recommendation and Action taken by Engineer: The Engineer required the Contractor to improve the fuel management at this location. At the same time, the Engineer also provided the instruction for this issues.

Responsible Party: Keangnam Contractor

Deadline: 24-March-2014

Current status: No important change was seen. 


\subsubsection{Package A6}

Through site checking and supervision in January, the Consultant found that the Contractor's hazardous substance management has not caused any serious effect to the surrounding areas.

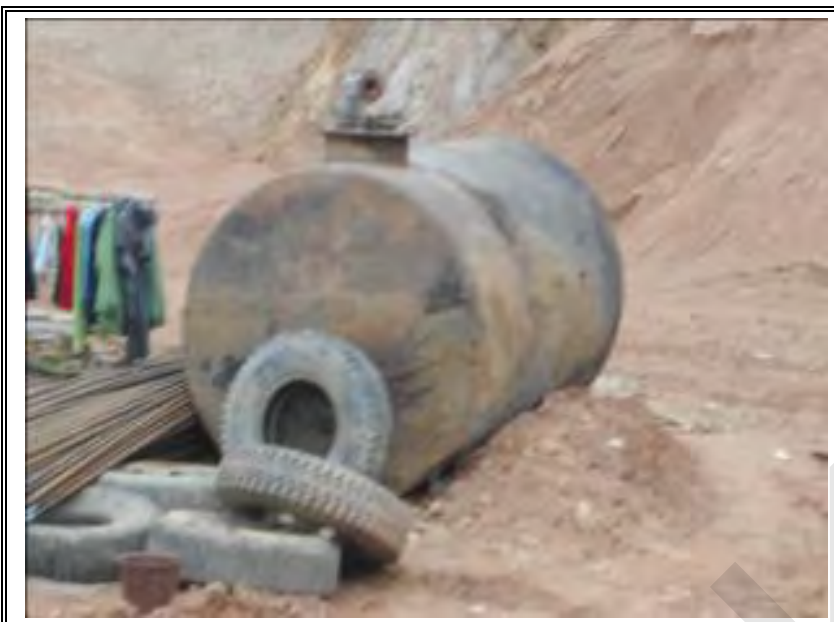

February 10, $2014(\mathrm{Km} 186+720)$

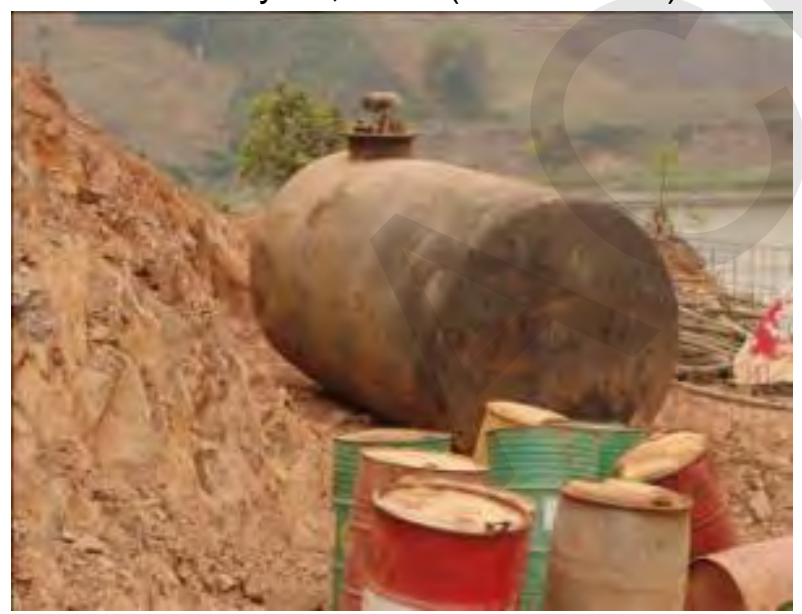

February 26, $2014(\mathrm{Km} 186+720)$
Location: $\mathrm{Km} 186+720$

Site visit: 10 and 26 February, 4 March, 2014

Date first observed: $10^{\text {th }}$ February, 2014

Problems description and cause: Fuel management is not well performed by contractor. The fuel tanks were placed directly on the ground. There is lack of safety fence and signboard at fuel storage area.

Recommendation and Action taken by Engineer: The Engineer required the Contractor to improve the fuel management at this location. At the same time, the Engineer also provided the instruction for this issue.

Responsible Party: Doosan Contractor

Deadline: 17- Feb-2014

Current status: Not yet improved 


\section{Loan 2391/2392 - VIE: GMS Kunming - Hai Phong Transport Corridor Noi Bai - Lao Cai Highway Project}

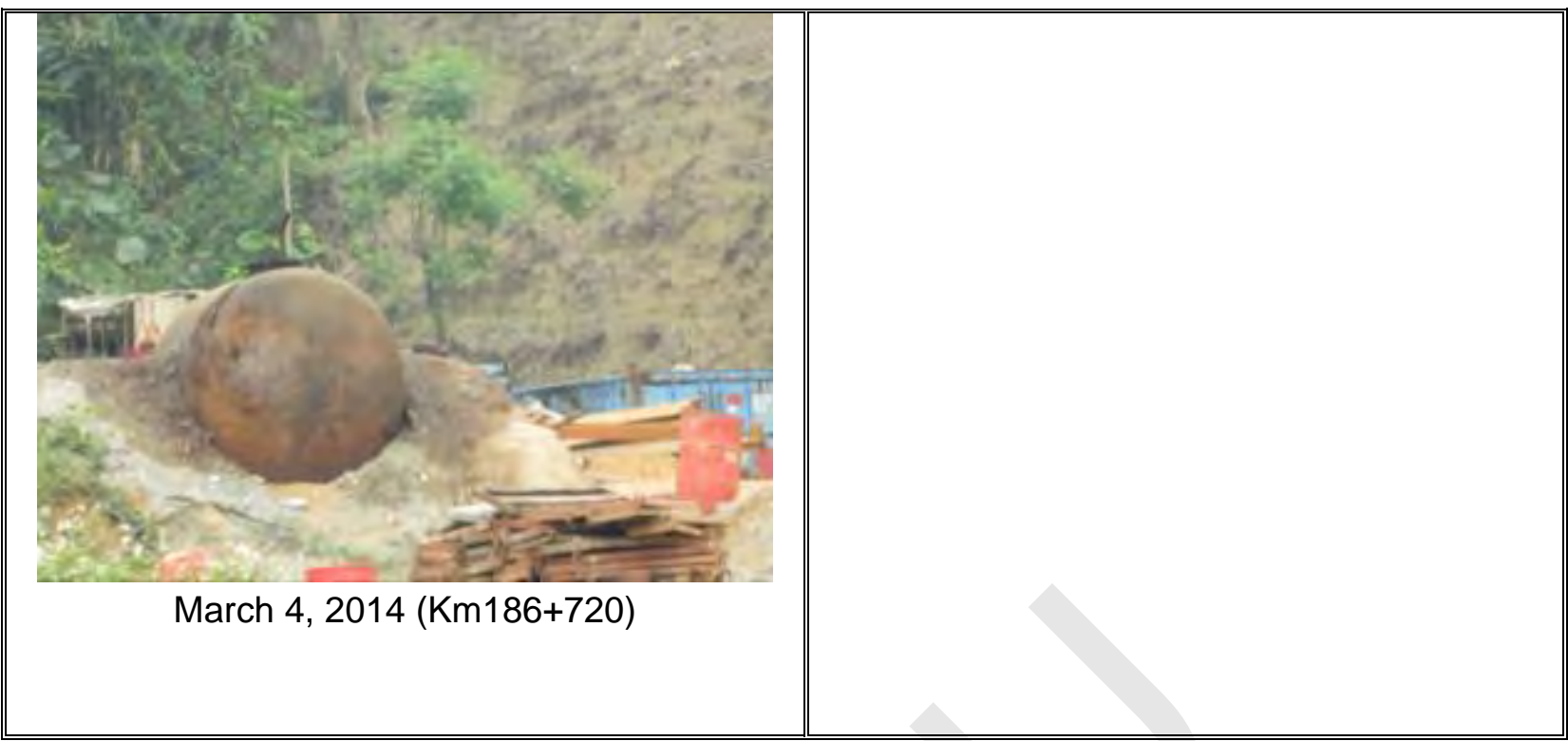

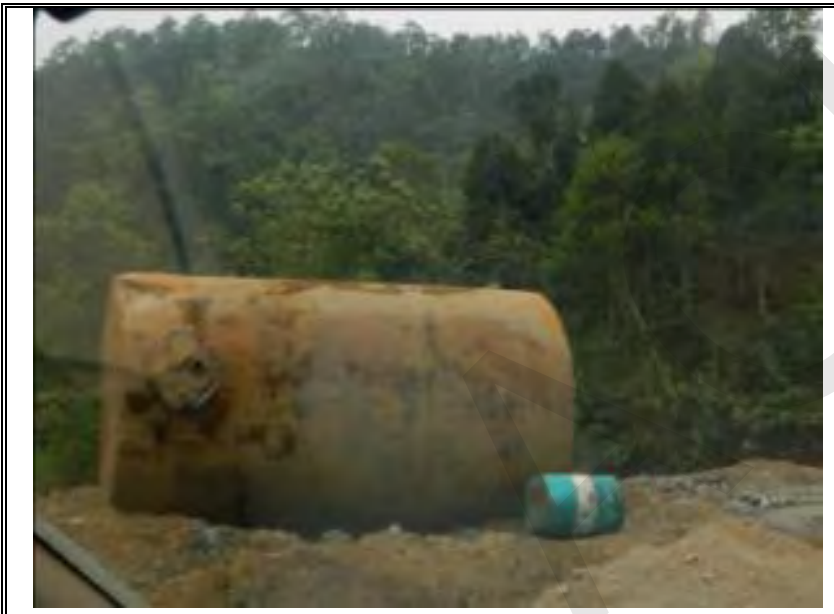

March 17, 2014 (Km172)

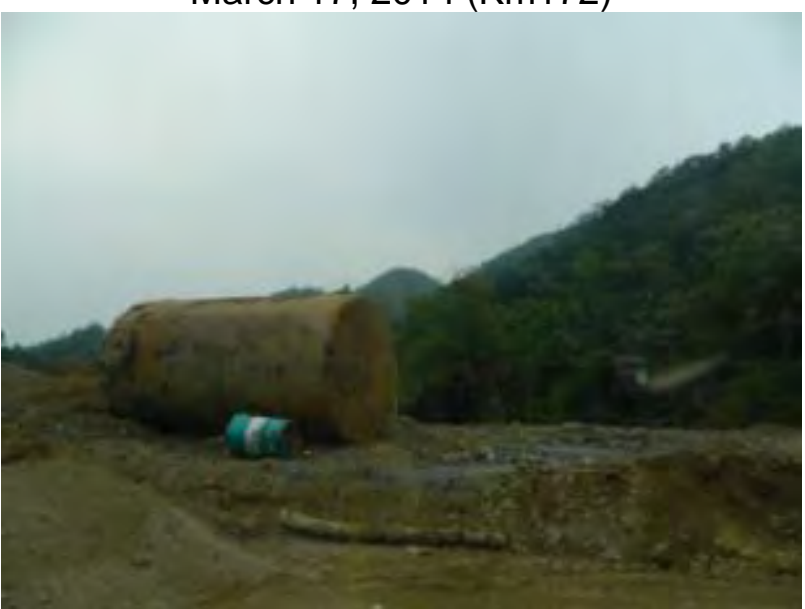

March 25, $2014(\mathrm{Km} 172)$
Location: $\mathrm{Km} 172$

Site visit: 17 and 25 March, 2014

Date first observed: $17^{\text {th }}$ March, 2014

Problems description and cause: Fuel management is not well performed by contractor. The fuel tanks were placed directly on the ground. There is lack of safety fence and signboard at fuel storage area.

\section{Recommendation and Action taken by}

Engineer: The Engineer required the Contractor to improve the fuel management at this location. At the same time, the Engineer also provided the instruction for this issue.

Responsible Party: Doosan Contractor

Deadline: 25 - Mar - 2014

Current status: Not yet improved 


\section{Loan 2391/2392 - VIE: GMS Kunming - Hai Phong Transport Corridor Noi Bai - Lao Cai Highway Project}

\subsubsection{Package A7}

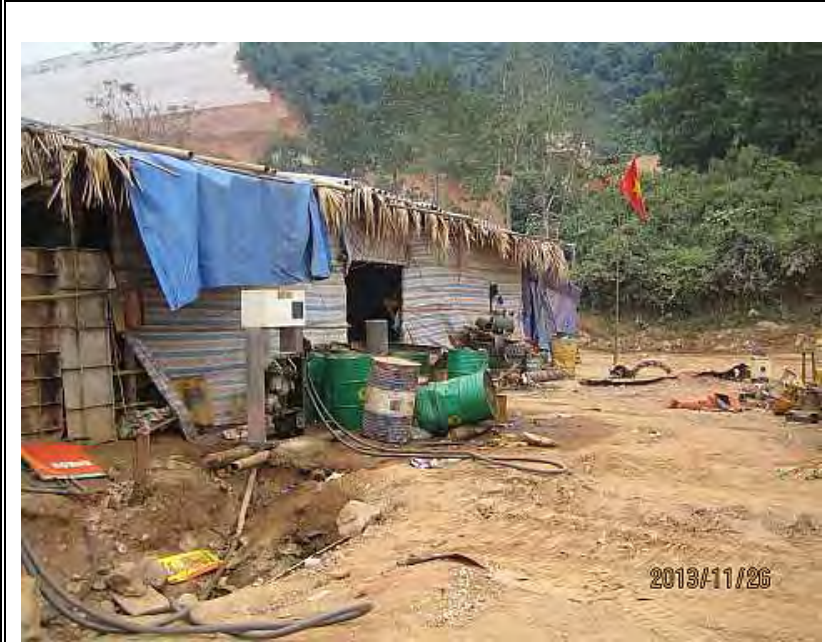

26.11.2013

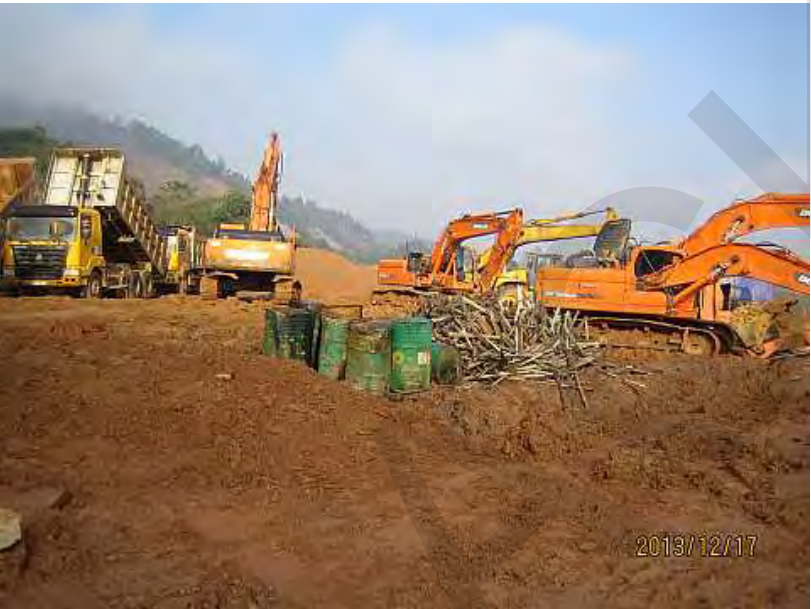

17.12 .2013

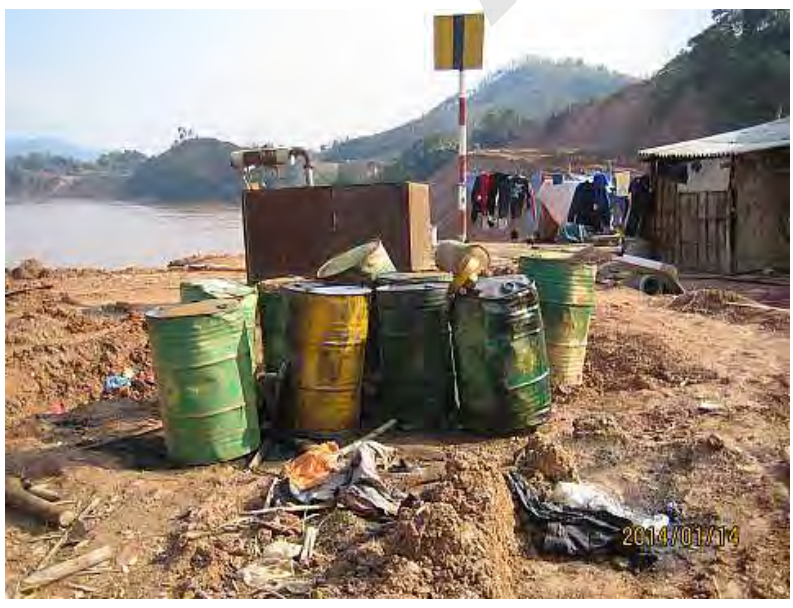

14.1.2014
Location: Store place Km209+800

Site visit: $14.1 .2014 ; 20.2 .2014 ; 19.3 .2014$

Date first observed: 10.9 .2013

Problems description and cause: Oil and waste oil tanks are put directly on the ground.

This can affect soil quality

\section{Recommendation and Action taken by}

Engineer: Required the contractor to put oil and waste oil tanks inside store with floor concreted. Consultant had issued many letters to the contractor such as: Get4GRBCC- 952. 979 and GET- GUA- 107, 112, 125

Deadline: 20.9.2013

\section{Current status:}

In Jan: Not yet improved

In Feb and Mar: Not yet improved. However, the contractor had demobilized this workers' camp.

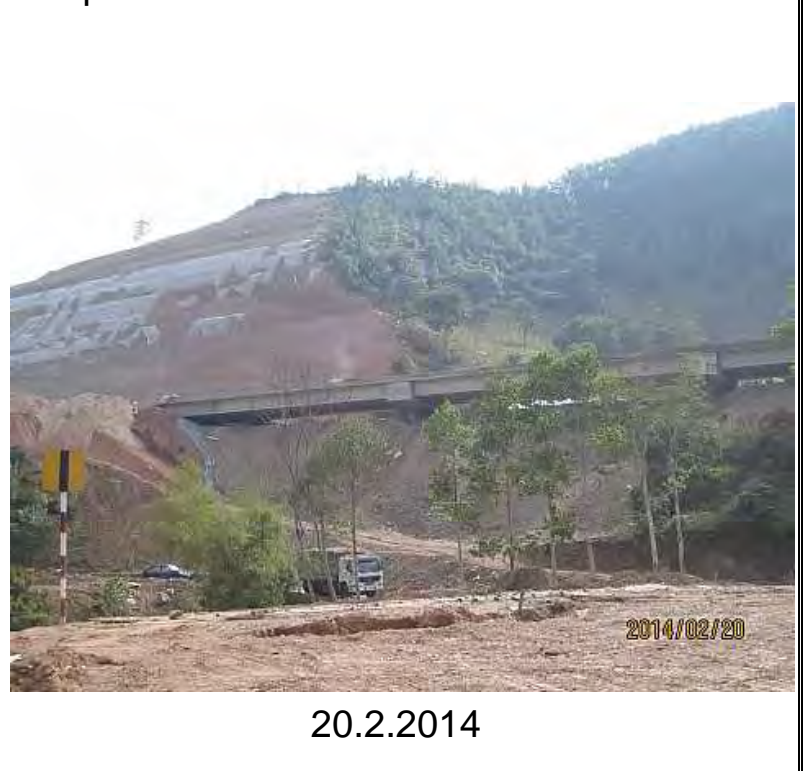




\section{Loan 2391/2392 - VIE: GMS Kunming - Hai Phong Transport Corridor Noi Bai - Lao Cai Highway Project}

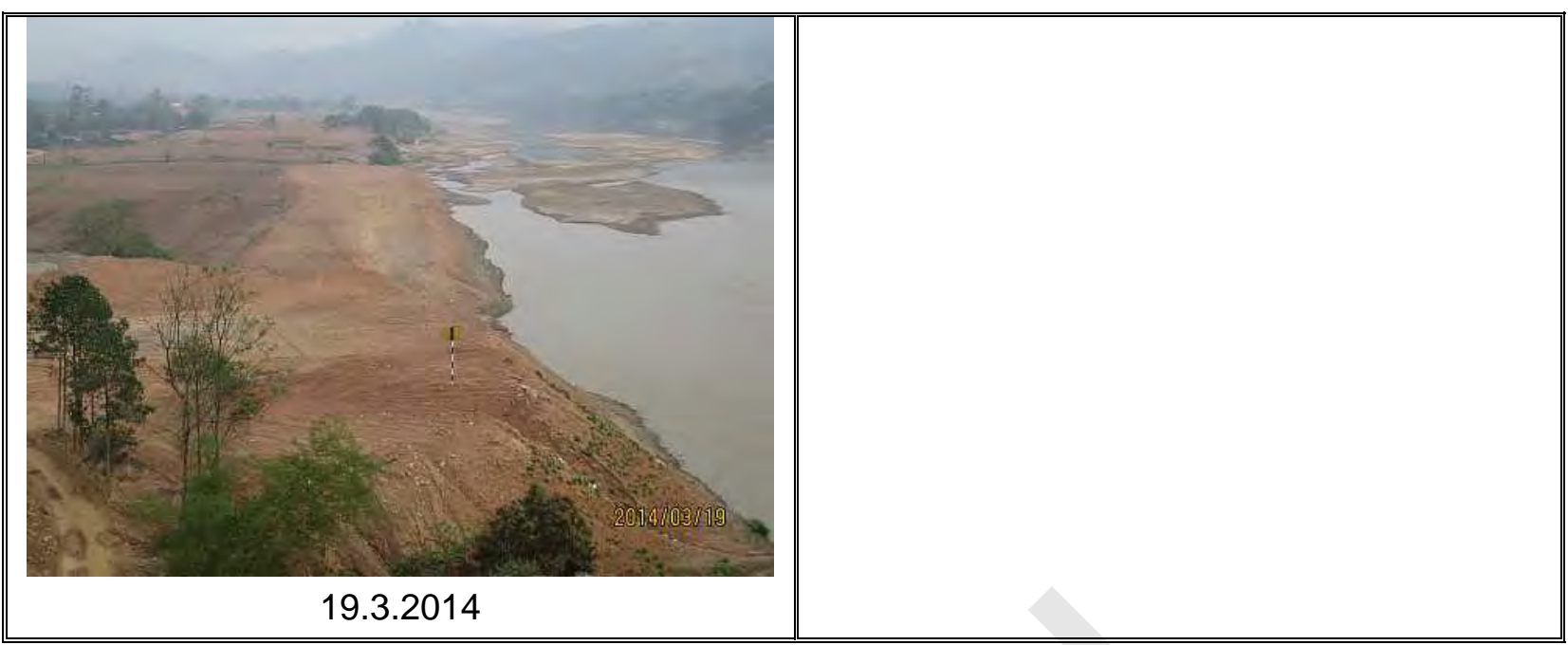

\subsubsection{Package A8}

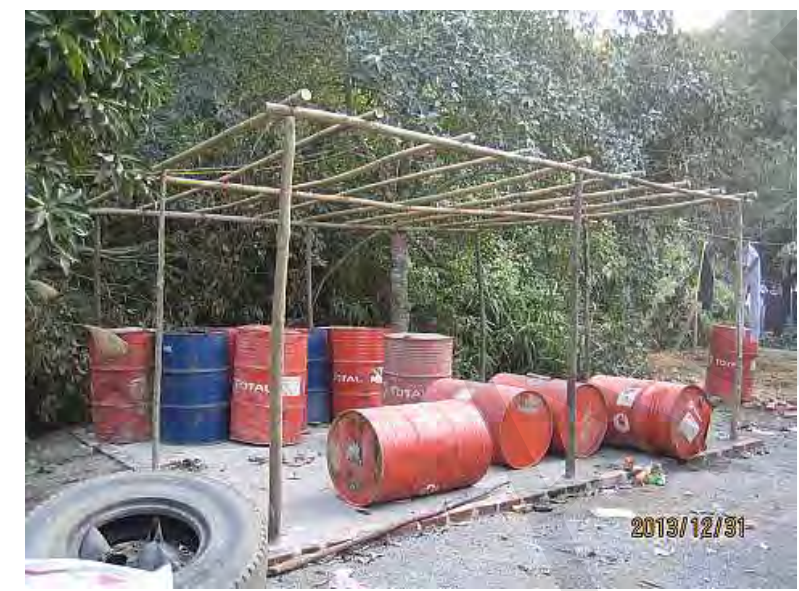

31.12 .2013

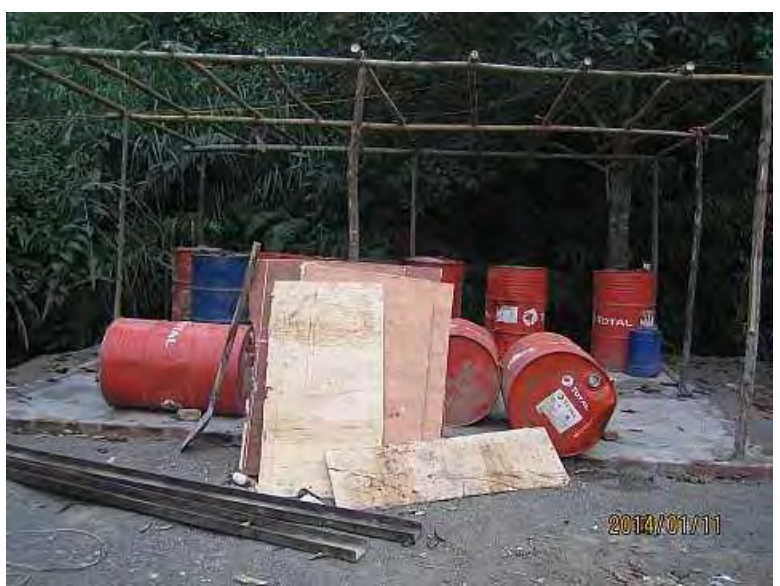

11.1.2014
Location: Store place oil and waste oil $\mathrm{Km} 230+800$

Site visit: $11.1 .2014 ; 13.2 .2014$

Date first observed: 6.9 .2013

Problems description and cause: Oil and waste oil barrels are kept directly on the ground. This can affect to soil quality

Recommendation and Action taken by Engineer: Required the contractor to keep oil and waste oil barrels on the concrete floor and into the store according to the letter No: Ref. Get4Vinaconex- 859

Deadline: 20.9.2013

Current status: The contractor had improved this issue but not satisfied the Engineer 's requirement $12^{\text {th }}$ floor, Ocean Park Building, Dao Duy Anh Street, Dong Da Distric 
Loan 2391/2392 - VIE: GMS Kunming - Hai Phong Transport Corridor Noi Bai - Lao Cai Highway Project

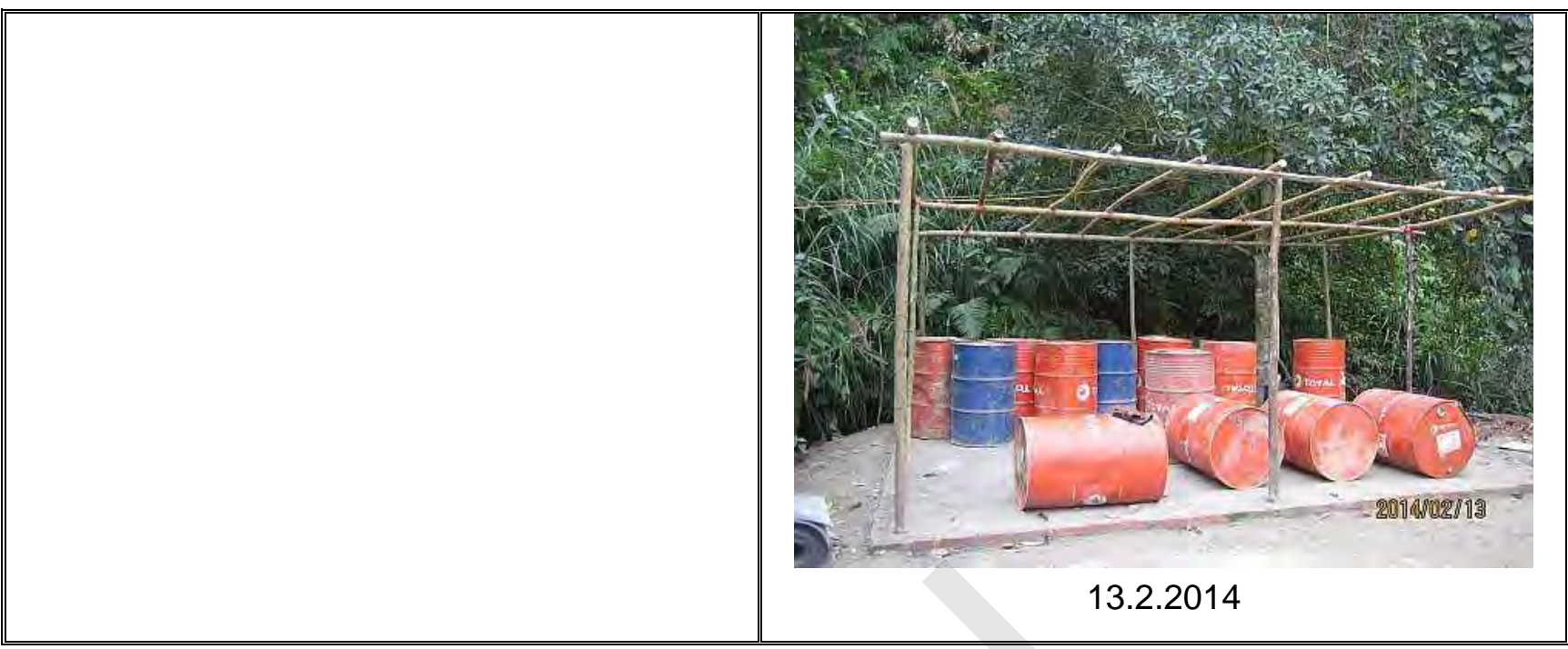

In March, at package A8, the Contractor has finished all construction works.

\subsection{UNSUITABLE MATERIAL DISPOSALS AND BORROW PITS}

\subsubsection{Package A1}

At the present, at package A1, the Contractor has finished all construction works.

\subsubsection{Package A2}

By observation in the site inspections in January, we did not detect any problem relating to unsuitable material disposal. It's also noted that there is no borrow pit submitted by the Contractor during this month. 


\section{Loan 2391/2392 - VIE: GMS Kunming - Hai Phong Transport Corridor Noi Bai - Lao Cai Highway Project}

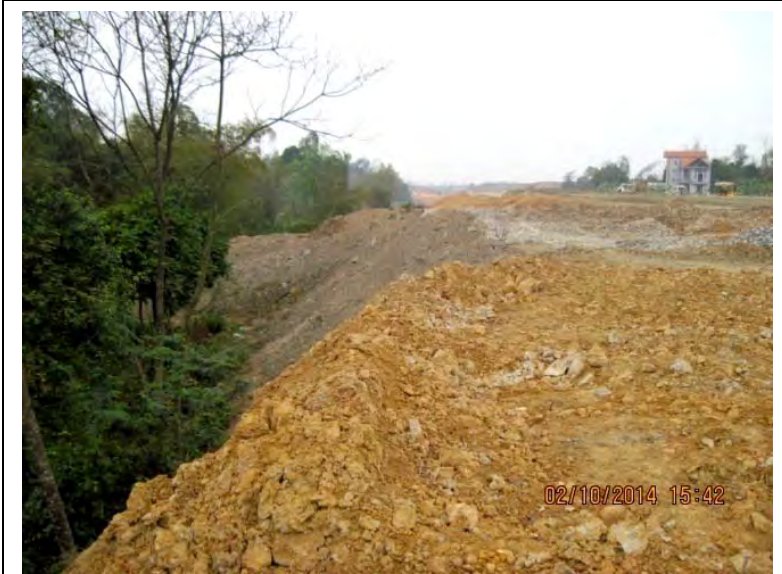

February 10, 2014

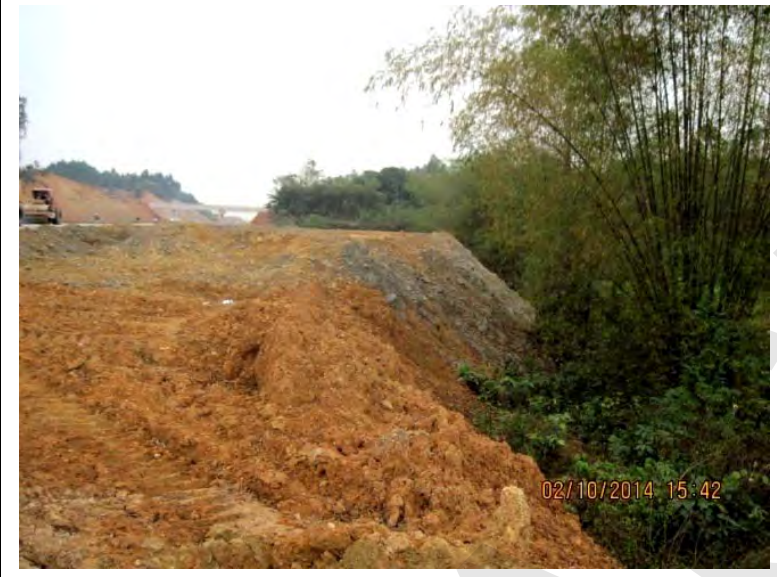

February 10, 2014

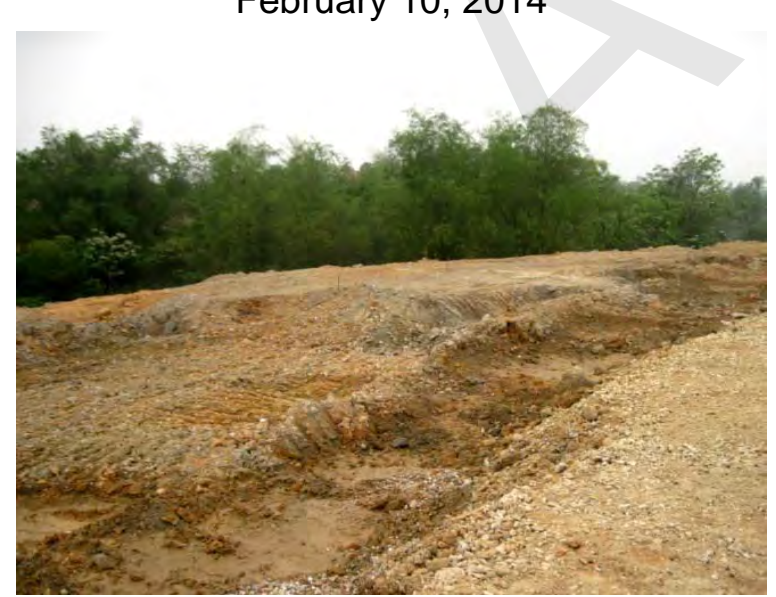

March 25, 2014
Location: $\mathrm{Km} \mathrm{45+500}$

Site visit: 10, 13, 17, 25 Feb.; 10, 13, 17, 25

Mar.

Date first observed: $17-J a n-2014$

Problems description and cause: Unsuitable material is disposed along throughway

\section{Recommendation and Action taken by}

Engineer: The Contractor is requested to find out and submit disposal place for this material; unsuitable material must be removed to disposal place right after the approval of the Engineer for disposal area. Refer to letter GET1/POS/A2/2388

Responsible Party: POSCO

Deadline: 24-Jan-2014

Current status: Mitigation measure has not been implemented

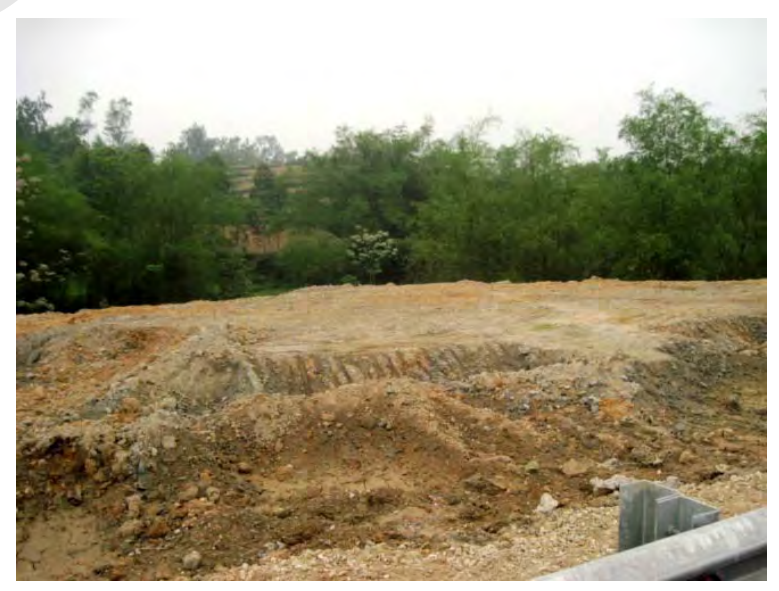

March 25, 2014 


\section{Loan 2391/2392 - VIE: GMS Kunming - Hai Phong Transport Corridor Noi Bai - Lao Cai Highway Project}

\subsubsection{Package A3}

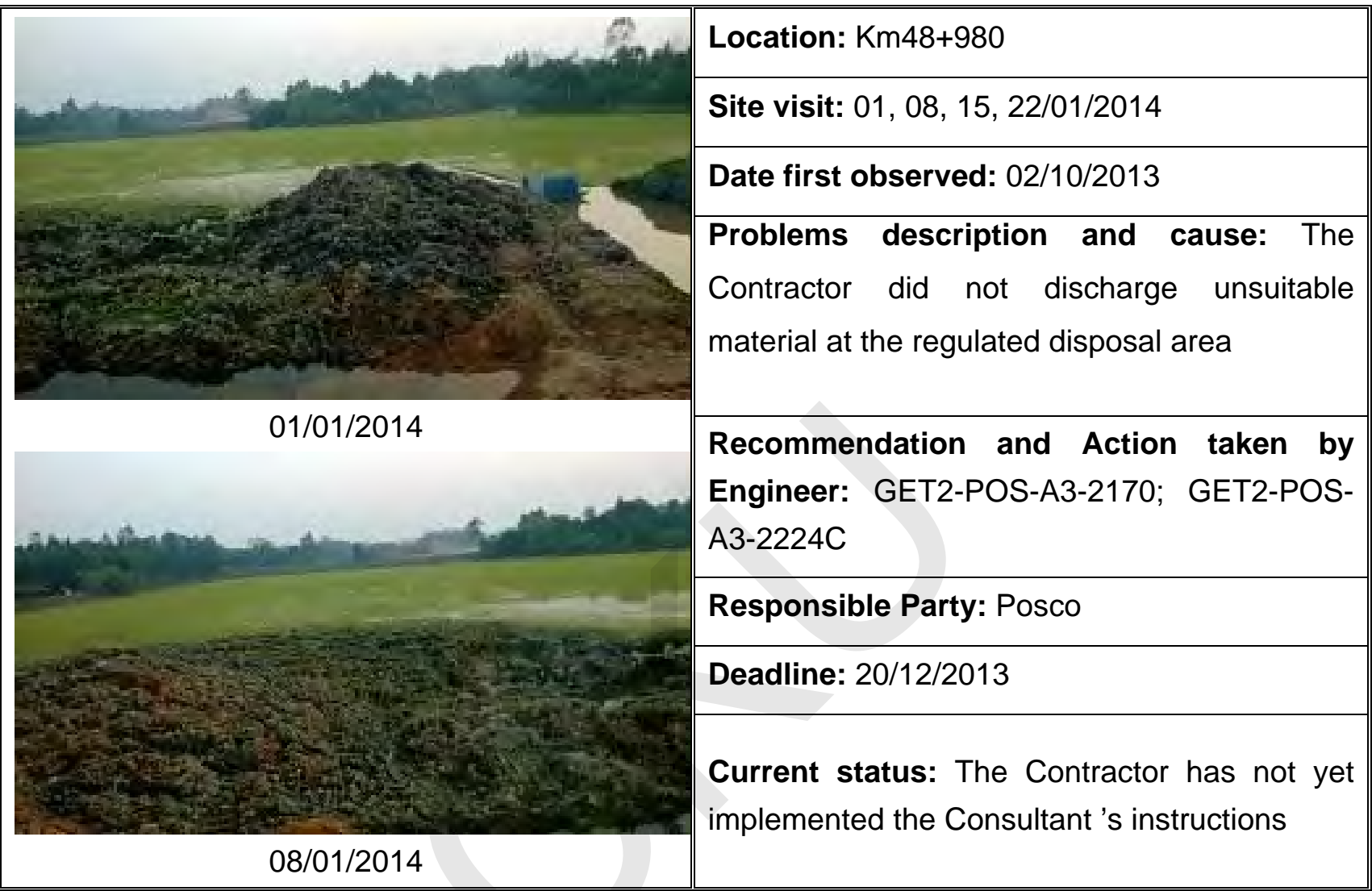

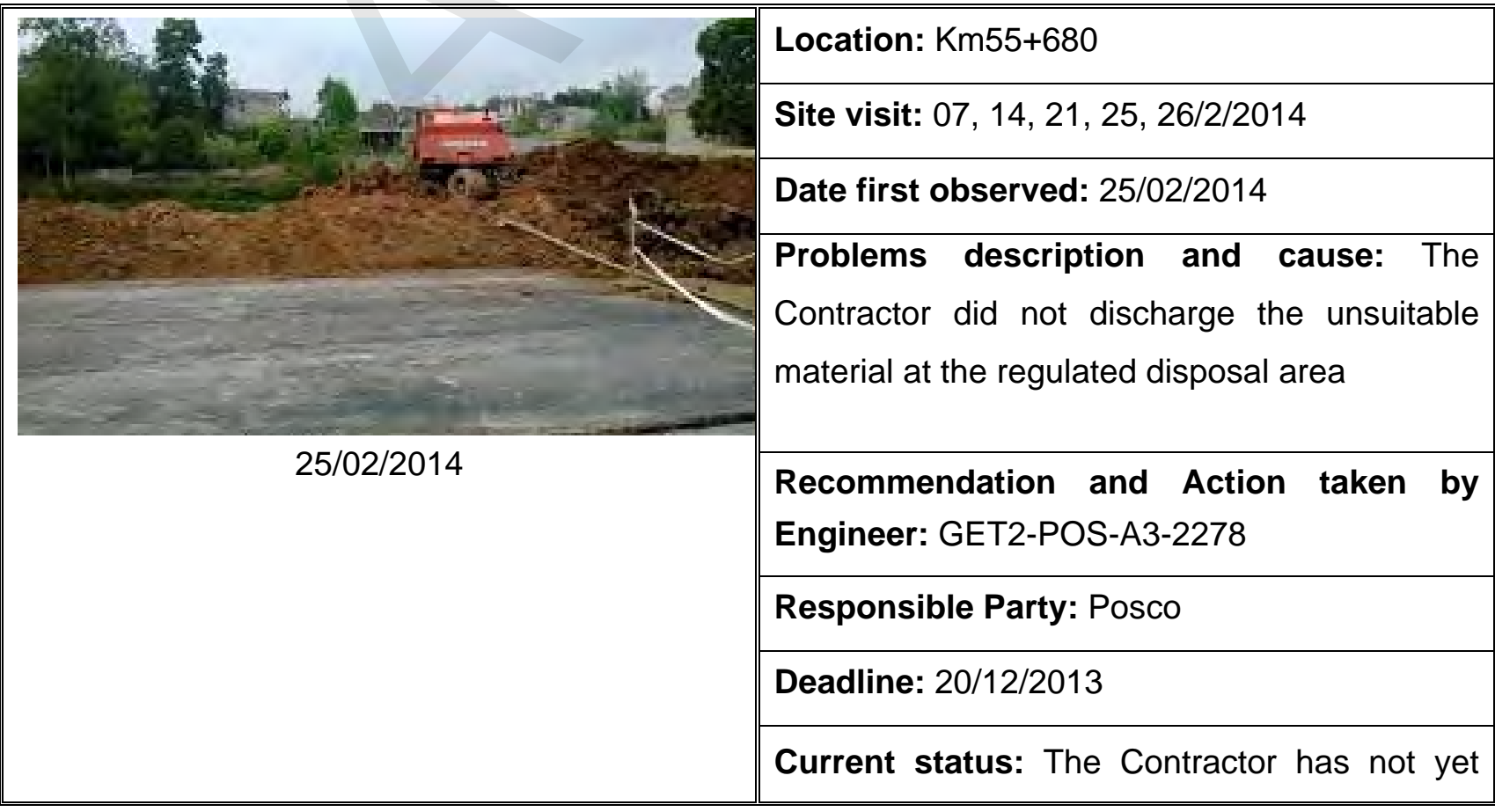




\section{Loan 2391/2392 - VIE: GMS Kunming - Hai Phong Transport Corridor Noi Bai - Lao Cai Highway Project}

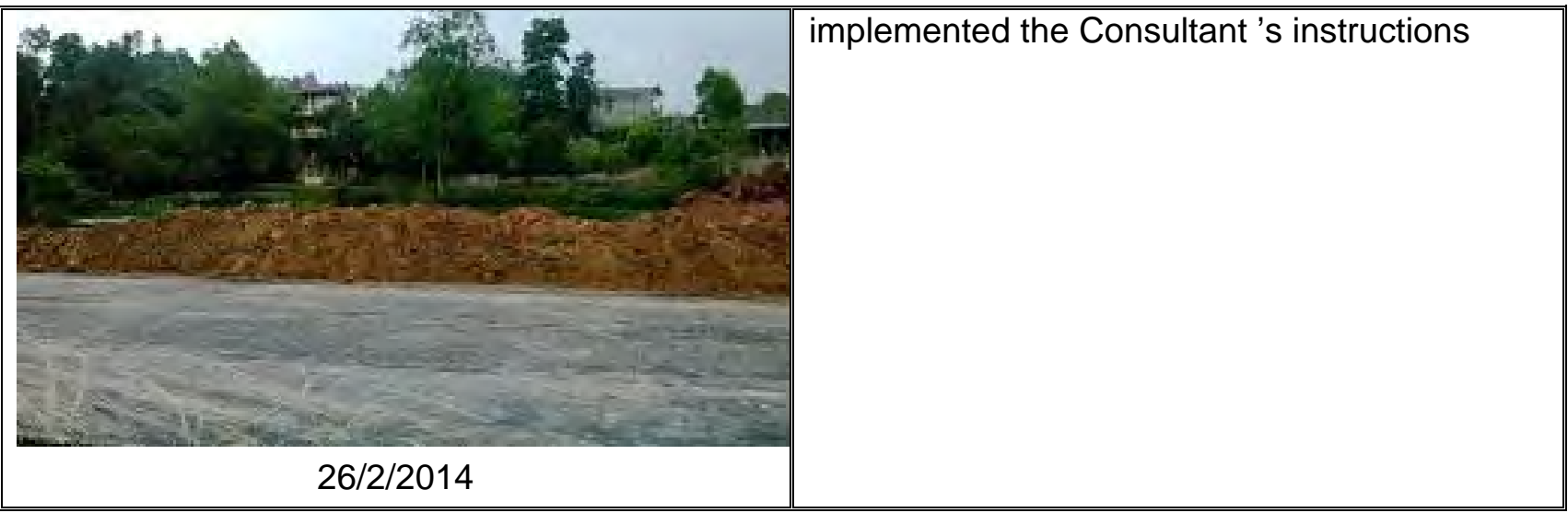

\begin{tabular}{|c|c|}
\hline & Location: Km53+150 (left site) \\
\hline & Site visit: $05,12,19,26 / 3 / 3014$ \\
\hline & Date first observed: $05 / 3 / 2014$ \\
\hline$\theta$ & $\begin{array}{l}\text { Problems description and cause: The } \\
\text { Contractor did not discharge the unsuitable } \\
\text { material at the disposal areas approved by } \\
\text { Consultant }\end{array}$ \\
\hline & $\begin{array}{l}\text { Recommendation and Action taken by } \\
\text { Engineer: GET2-POS-A3- } 2308\end{array}$ \\
\hline & Responsible Party: Posco \\
\hline & Deadline: 20/03/2013 \\
\hline $26 / 3 / 201$ & $\begin{array}{l}\text { Current status: The Contractor has yet } \\
\text { implemented the Consultant 's instructions }\end{array}$ \\
\hline
\end{tabular}




\section{Loan 2391/2392 - VIE: GMS Kunming - Hai Phong Transport Corridor Noi Bai - Lao Cai Highway Project}

\subsubsection{Package A4}

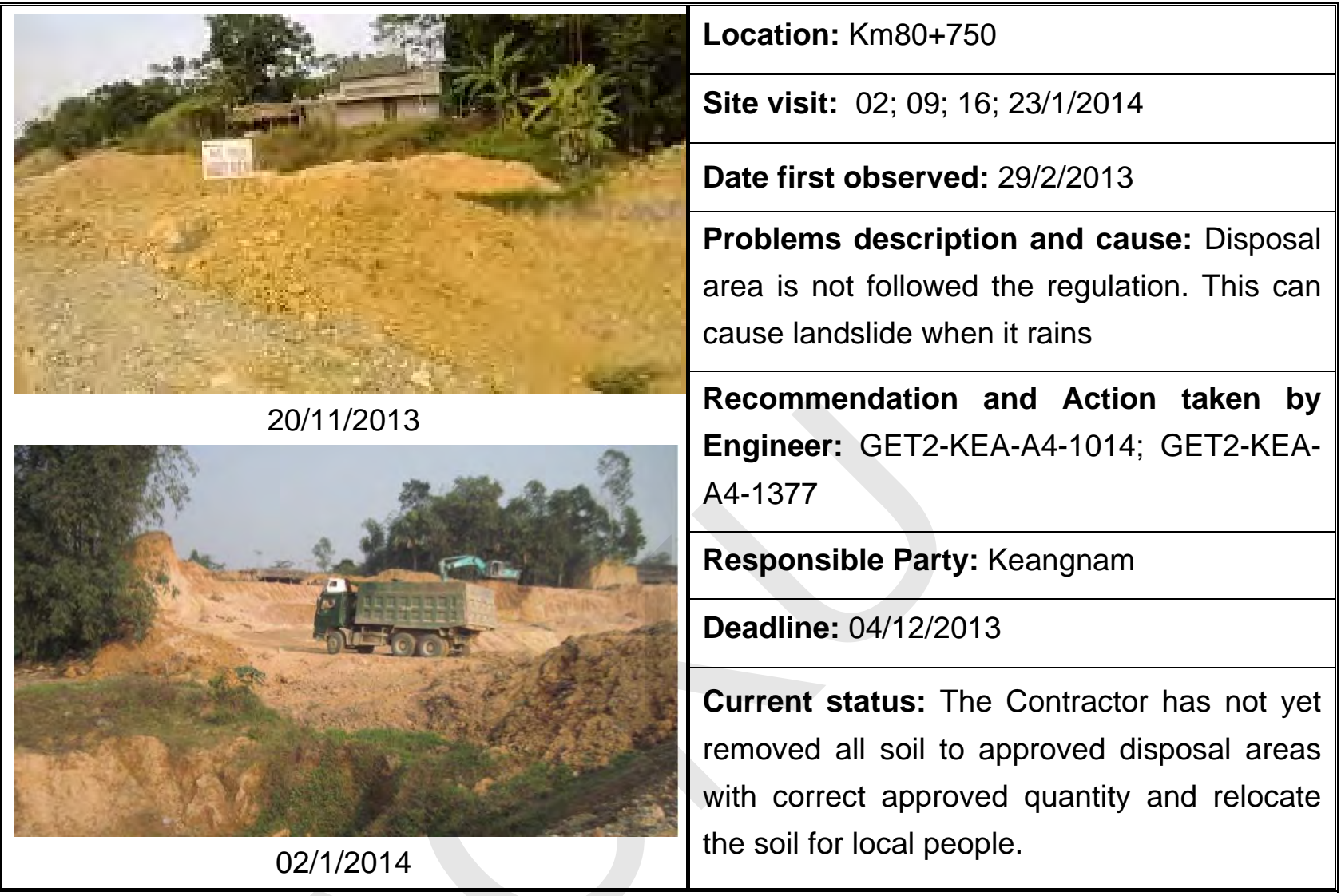

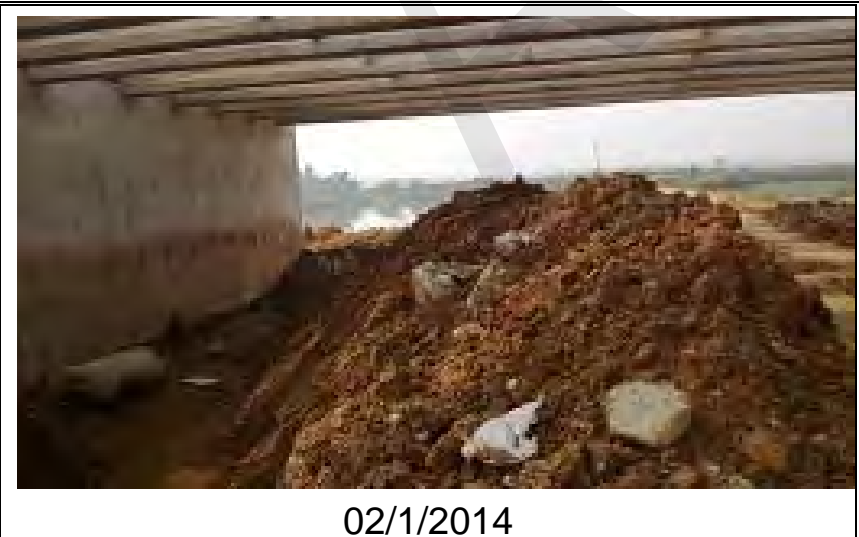

Location: Ngoi Gianh Bridge

Site visit: $02 ; 09 ; 16 ; 23 / 1 / 2014 ; 06,13,20$, $27 / 2 / 2014$

Date first observed: $24 / 6 / 2013$

Problems description and cause: The unsuitable soil was discharged near irrigation canal. The soil was overflowed to the surrounding drainage canal

Recommendation and Action taken by Engineer: Require contractor to remove all waste mud in riverbed to ensure the water flow

Responsible Party: KEANGNAM 


\section{Loan 2391/2392 - VIE: GMS Kunming - Hai Phong Transport Corridor Noi Bai - Lao Cai Highway Project}

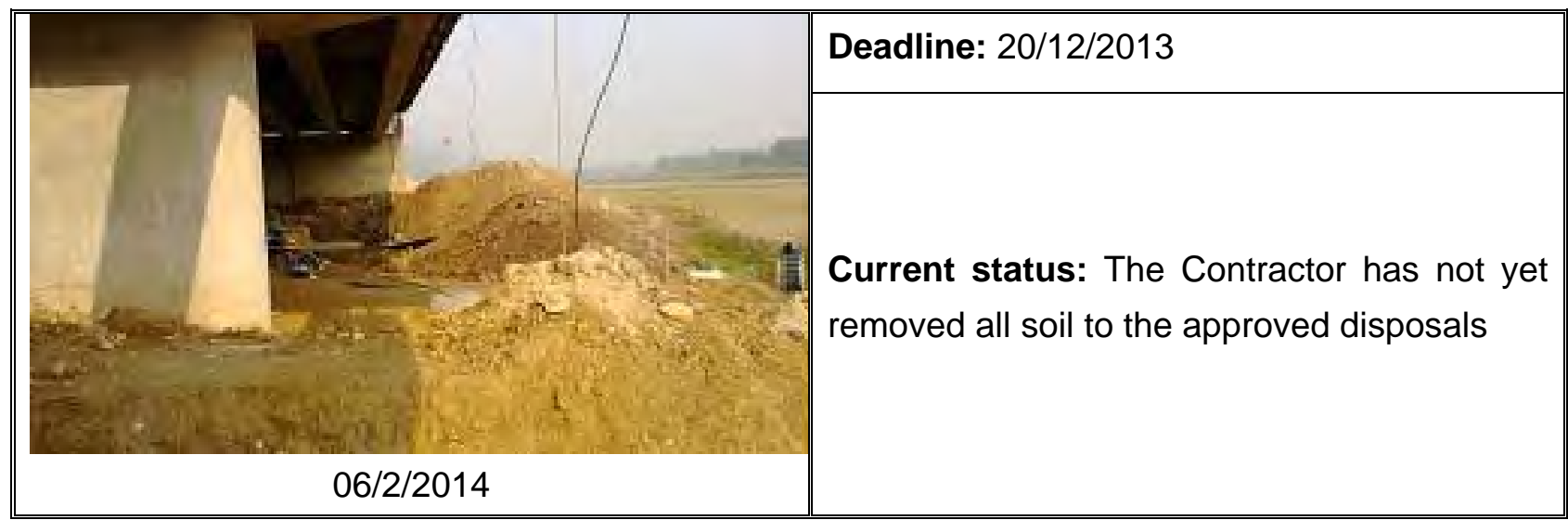

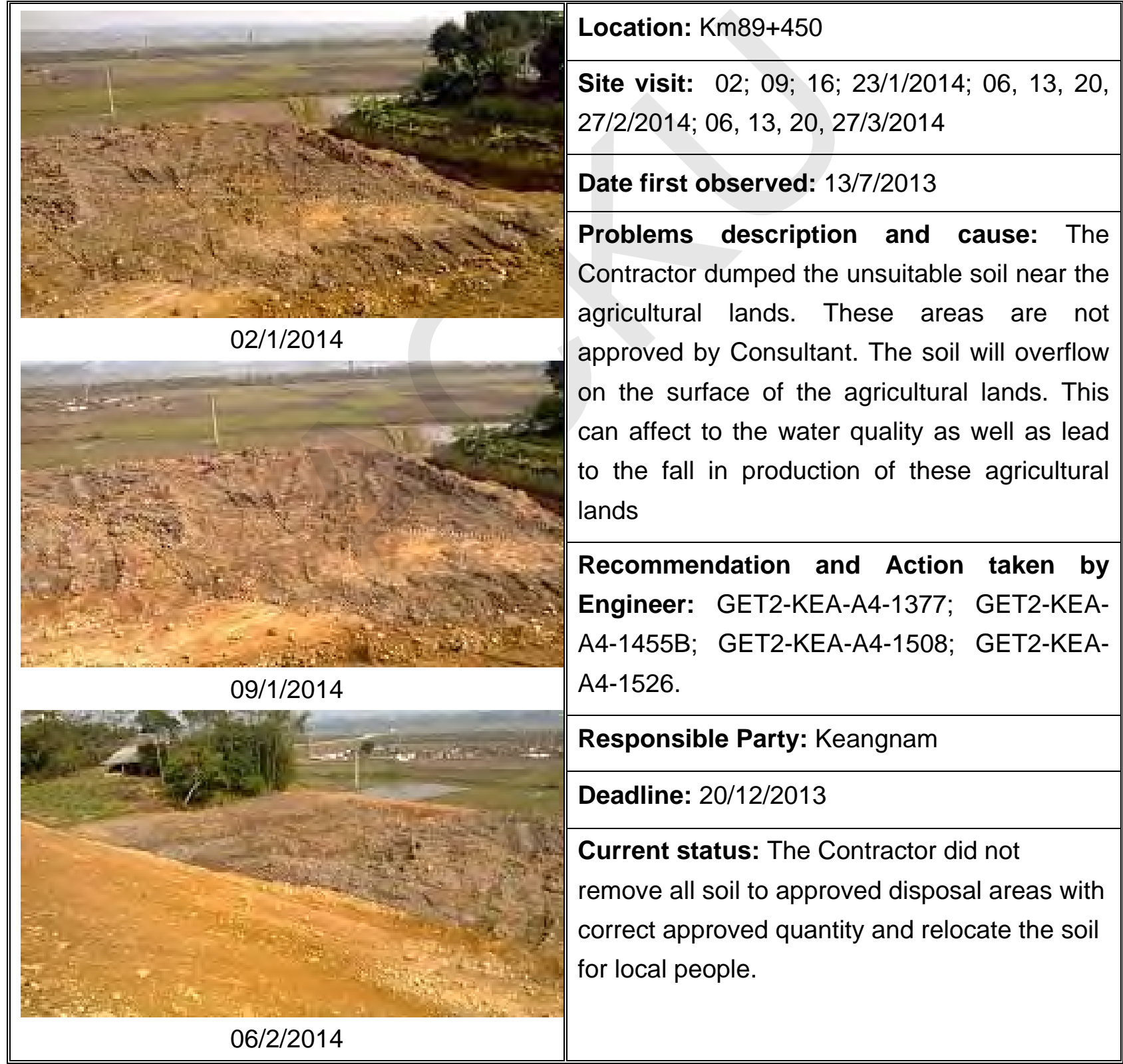




\section{Loan 2391/2392 - VIE: GMS Kunming - Hai Phong Transport Corridor Noi Bai - Lao Cai Highway Project}

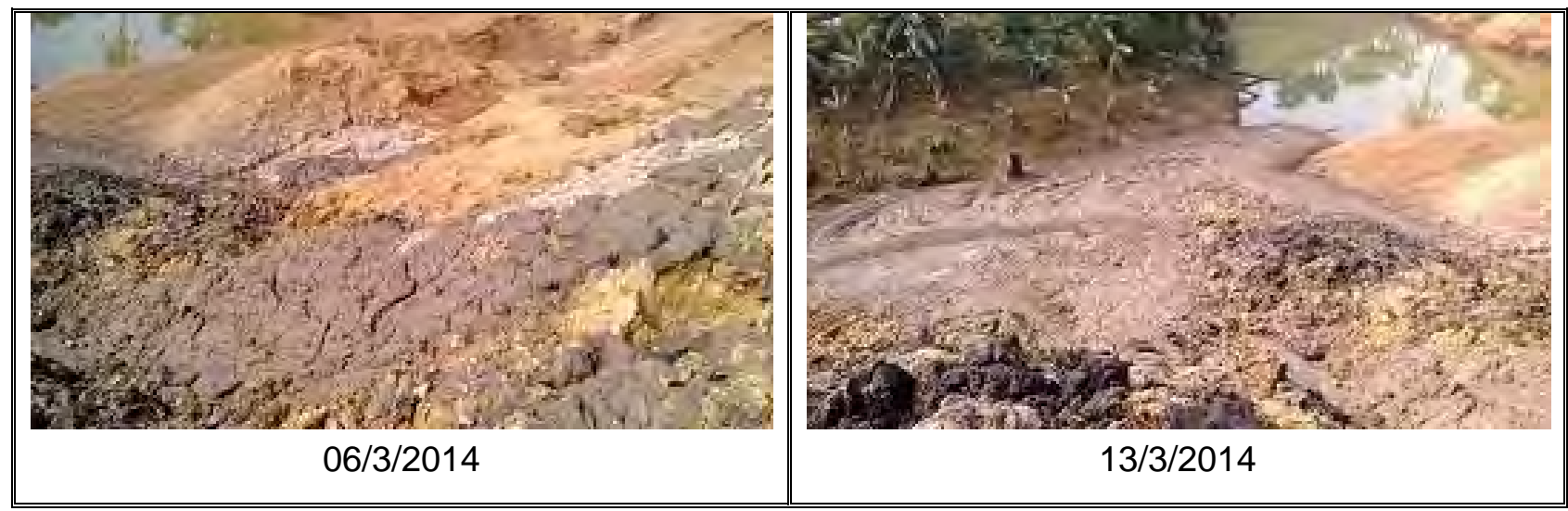

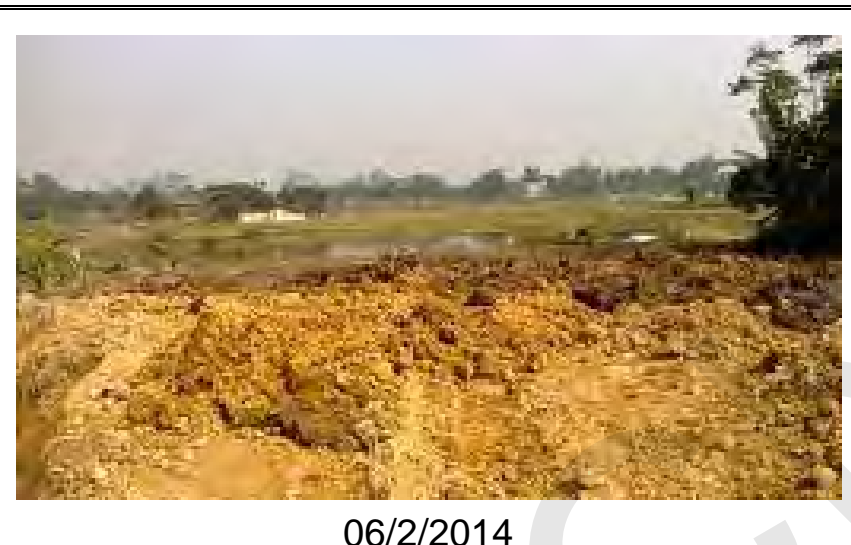

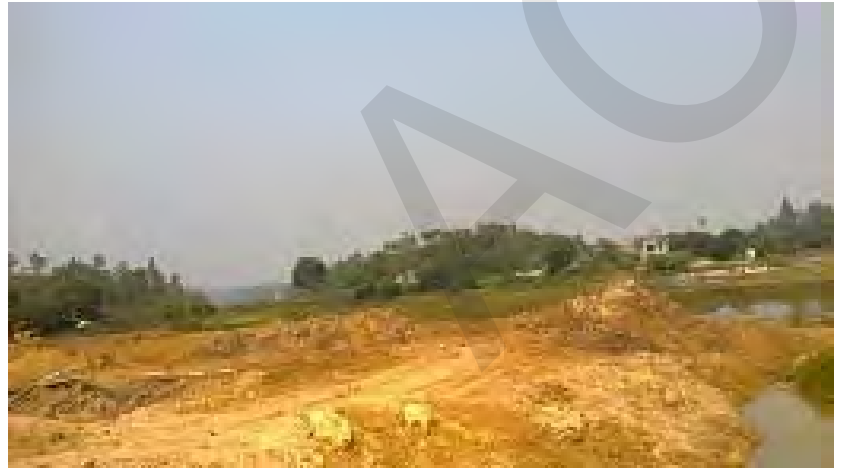

$20 / 2 / 2014$

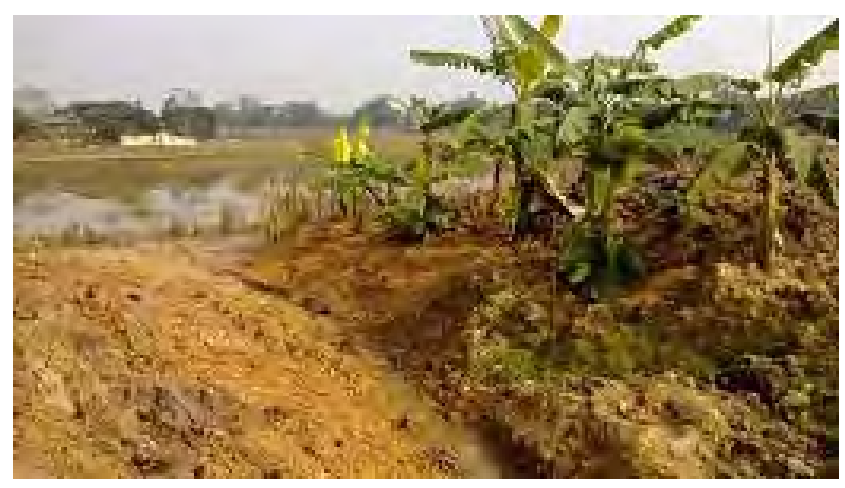

$06 / 3 / 2014$

\section{Location: Km92+260}

Site visit: $06,13,20,27 / 2 / 2014 ; 06,13,20$, $27 / 3 / 2014$

Date first observed: $26 / 4 / 2013$

Problems description and cause:

Agricultural lands have been damaged due to erosion and landslides from road embankments.

\section{Recommendation and Action taken by}

Engineer: Closely coordinate with affected households and local authorities to expedite compensation for damages caused by construction activities. Dig adequately sized side drainage/ditch at erosion prone areas to direct surface run-off away from agricultural land. Implement slope stabilization measures to minimize erosion. Provide drainage/ditch reinforcements (e.g., sandbags and/or other appropriate measures) to avoid spill-over of surface run-off onto the surrounding agricultural lands. Refer to the letters GET2KEA-A4-1283, GET2-KEA-A4-1293， GET2KEA-A4-1378; GET2-KEA-A4-1460， GET2KEA-A4-1509; GET2-KEA-A4-1526. $12^{\text {th }}$ floor, Ocean Park Building, Dao Duy Anh Street, Dong Da Distric 
Loan 2391/2392 - VIE: GMS Kunming - Hai Phong Transport Corridor Noi Bai - Lao Cai Highway Project

\begin{tabular}{|l||l|}
\hline \multicolumn{1}{|l||}{} & Responsible Party: Keangnam Contractor \\
\cline { 2 - 3 } & $\begin{array}{l}\text { Deadline: } \\
\text { In Feb: } 05 / 12 / 2013 \\
\text { In Mar: 05/4/2014 }\end{array}$ \\
\cline { 2 - 2 } & $\begin{array}{l}\text { Current status: The Contractor has not yet } \\
\text { removed all soil to the approved disposal } \\
\text { areas. The compensation for damages due to } \\
\text { the erosion and landslide has not yet paid }\end{array}$ \\
\hline
\end{tabular}

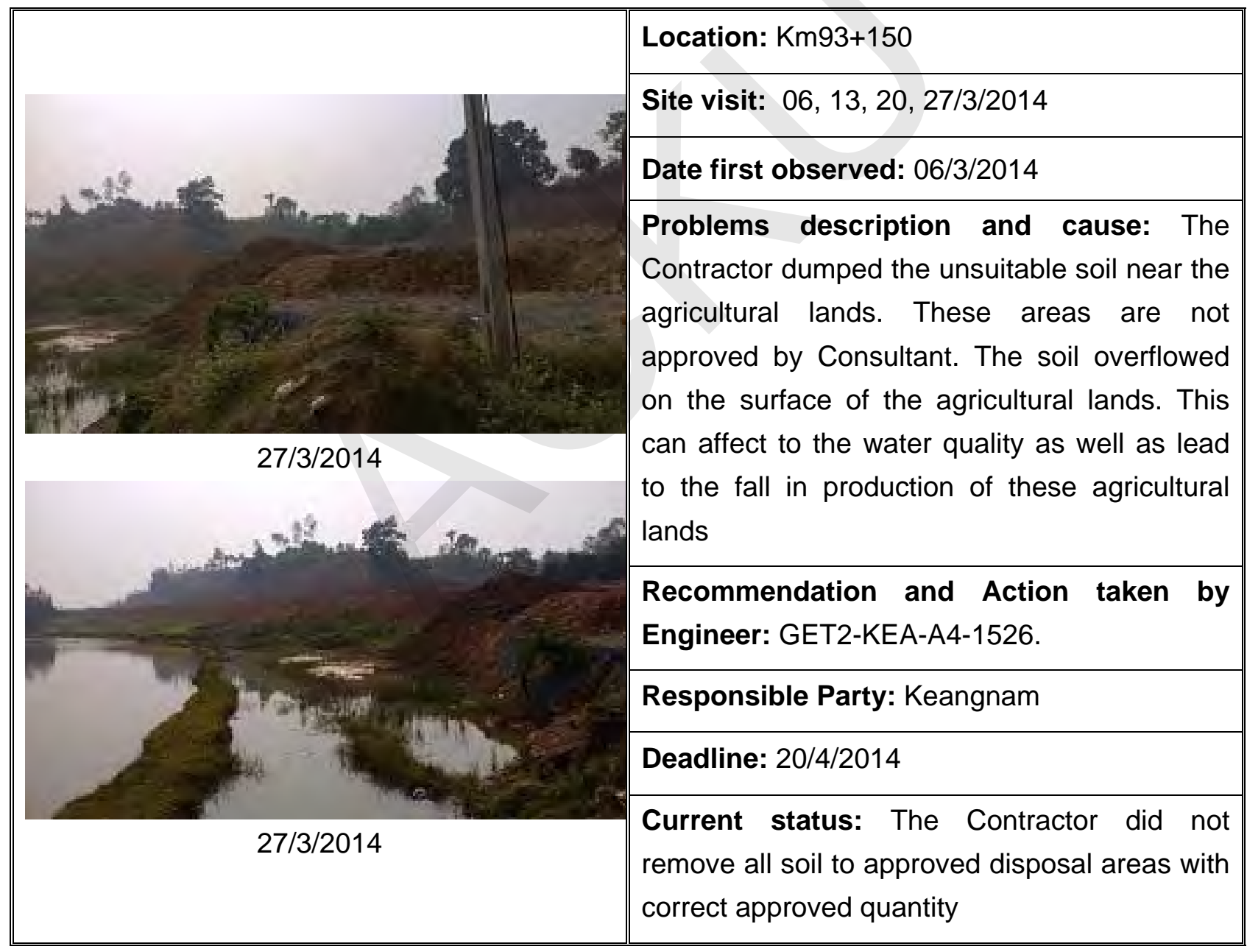




\subsubsection{Package A5}

In this period, through the inspection and supervision on site, the Consultant found that there was no serious problem of environment and safety from the disposal areas approved by the Consultant.

\subsubsection{Package A6}

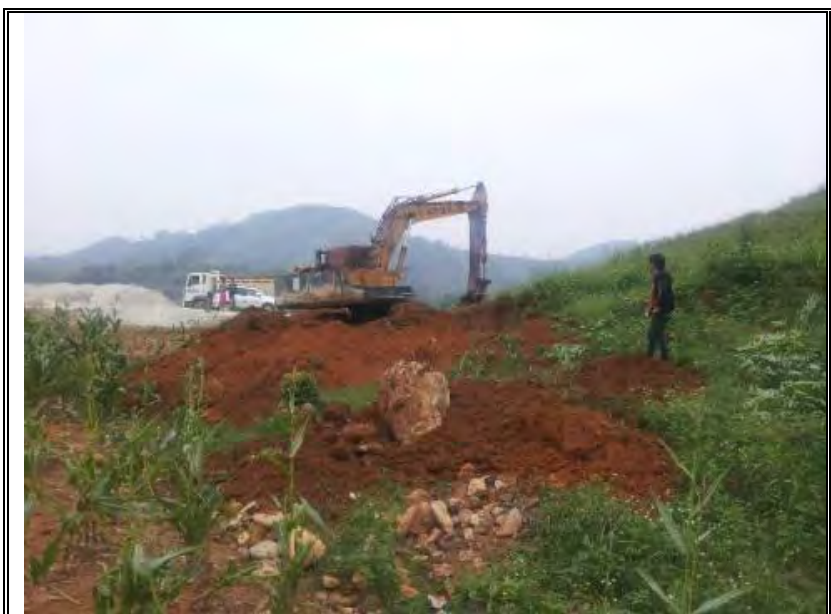

P1: $29^{\text {th }}$ October, $2013(\mathrm{Km} 166+860)$

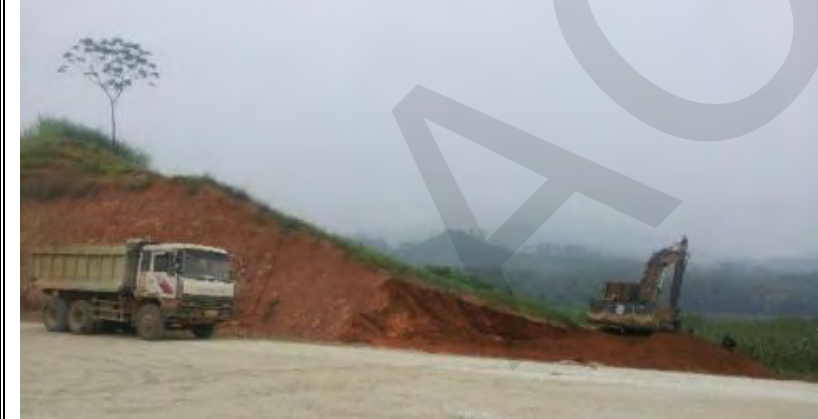

P2: $29^{\text {th }}$ October, $2013(\mathrm{Km} 166+860)$
Location: Km166+860

Site visit: $8^{\text {th }}$ and $21^{\text {st }}$ January, 2014

Equipment mobilized: So far, no equipments and manpower for this work.

Volume of unsuitable material already removed: The unsuitable soil that had been removed was actually checked by survey equipment and the removed volume is 4,915 $\mathrm{m}^{3}$ of unsuitable soil.

Impact caused: The contractor dumped unsuitable material from excavation near Red River and on the riverbank, affecting the slope and the riverbed. This disposal was not approved by Engineer.

The Contractor coordinated with local people at $\mathrm{Km} 166+860$ in order to get the agreement with verification of local authority on disposal area that details as bellows: length $100 \mathrm{~m}$, width $54,82 \mathrm{~m}$ and height: $3,8 \mathrm{~m}$. Thus, the maximum volume of this disposal area is $21,030.0 \mathrm{~m}^{3}$.

Up to date $29^{\text {th }}$ October, 2013 , the Contractor, according to information provided by them, dumped about $4,894.13 \mathrm{~m}^{3}$ of unsuitable soil on this disposal area, with length $50,19 \mathrm{~m}$, width $16,46 \mathrm{~m}$ and height: $5,92 \mathrm{~m}$.

Authorized disposals: The Contractor has already submitted new disposal area (Km166+520L) where the Contractor will use to dump the removed material. Besides, the Engineer has already approved this new 


\section{Loan 2391/2392 - VIE: GMS Kunming - Hai Phong Transport Corridor Noi Bai - Lao Cai Highway Project}

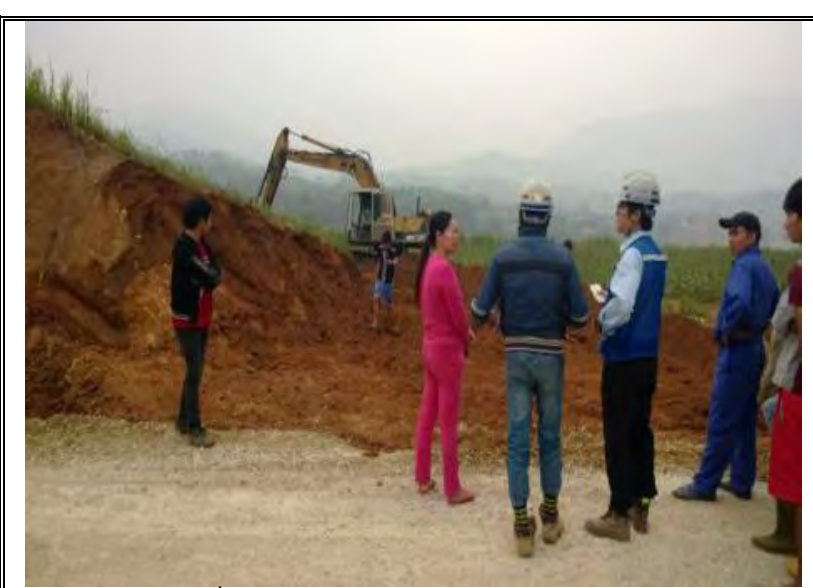

P3: $29^{\text {th }}$ October, $2013(\mathrm{Km} 166+860)$

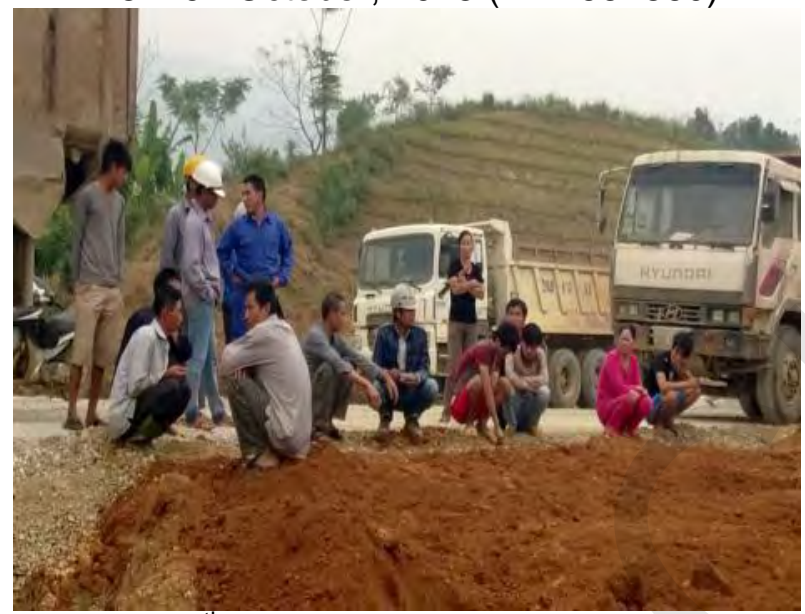

P4: $29^{\text {th }}$ October, $2013(\mathrm{Km} 166+860)$

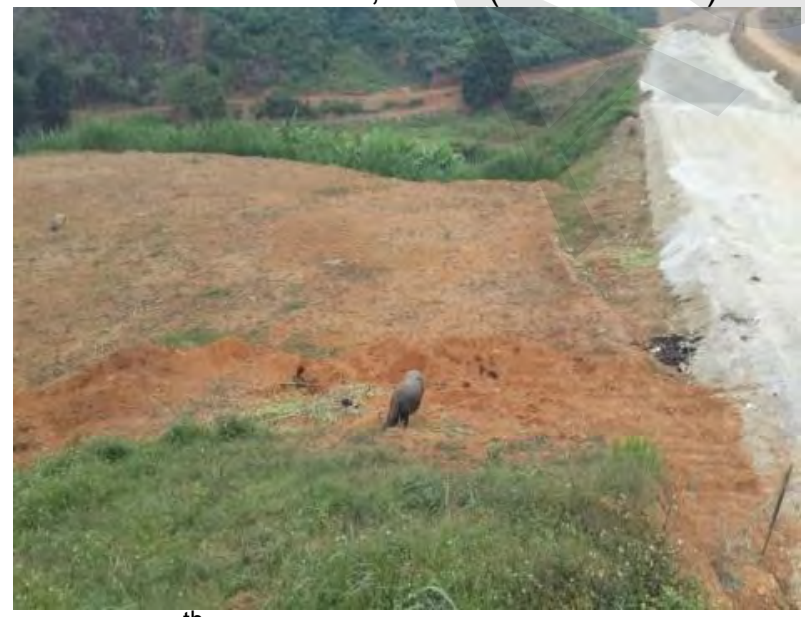

P5: $10^{\text {th }}$ November, $2013(\mathrm{Km} 166+860)$ disposal area (referring to the Engineer's letter No. Ref. GET3-DOOSAN-13-A6-547 dated on $17^{\text {th }}$ September, 2013).

Current status: The contractor had mobilized some equipment and manpower to start removing the unsuitable materials in order to install access road for transport activities on $29^{\text {th }}$ and $30^{\text {th }}$ October, 2013. Contractor could remove about $95 \mathrm{~m}^{3}$ of soil until local people began to cause an obstruction for the Contractor's activities (see attached pictures) because they want the situation remains as it's now at this location. As well, local people have planted some trees on the surface.

The Engineers from the Consultant and the Contractor discussed with local people in order to remove all unsuitable soil, according to the instructions received. Local people did not agree with the Contractor's activities concerning on removing soil; therefore local people are still continuing to cause an obstruction for the Contractor's activities.

Besides, according to the Nation Centre for Hydro-Meteorological Forecasting, storm $\mathrm{N}^{0} .14$ (Haiyan storm) will influence the large area in the north of Vietnam in the first two weeks in November. Therefore, the Contractor stopped all works related to removing unsuitable soil in order to ensure safety issues as well as avoid landslide and erosion at this disposal area while excavators may be working (see previous bimonthly report).

On November $20^{\text {th }}, 2013$, once again, the Contractor mobilized the equipments and manpower in order to remove unsuitable soil at disposal area Km166+860, but local people have got strongly actions in order to obstruct the Contractor's removal work. In order to keep safety for the sub-contractor's workers and the Contractor's Engineers, the Consultant and Contractor had to delay removal work at this location until an 


\section{Loan 2391/2392 - VIE: GMS Kunming - Hai Phong Transport Corridor Noi Bai - Lao Cai Highway Project}

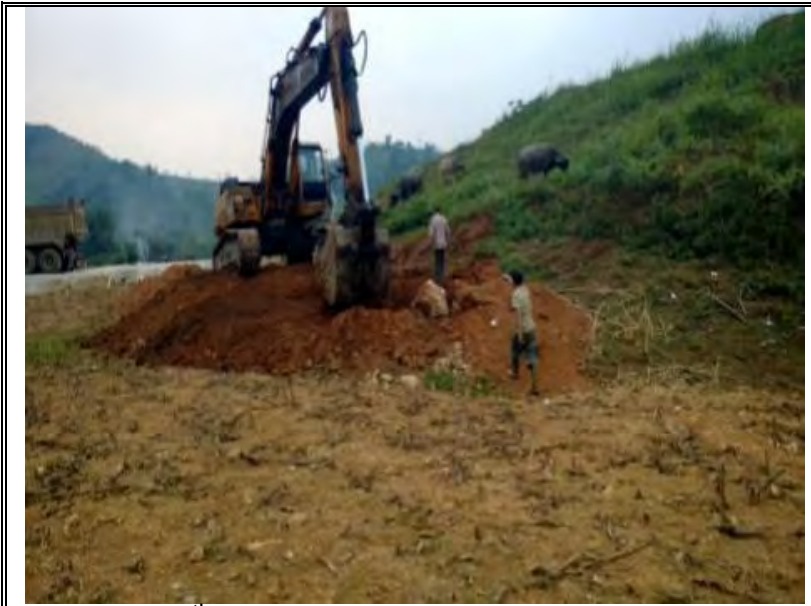

P6: $20^{\text {th }}$ November, $2013(\mathrm{Km} 166+860)$

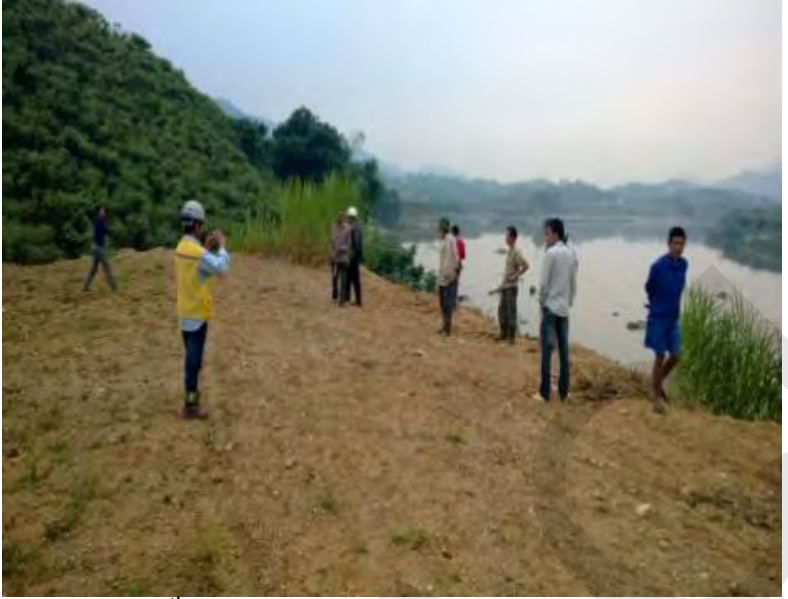

P7: $20^{\text {th }}$ November, $2013(\mathrm{Km} 166+860)$

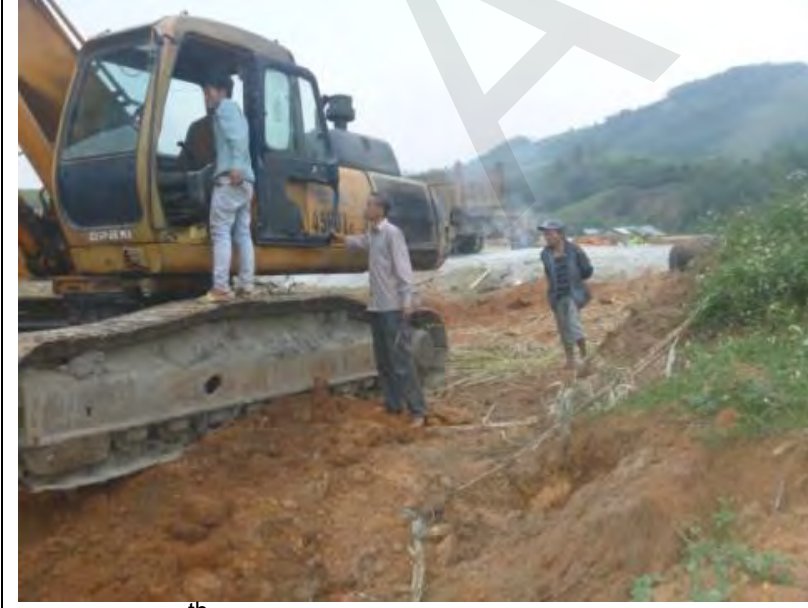

P8: $20^{\text {th }}$ November, $2013(\mathrm{Km} 166+860)$ agreement could be reached between parts involved.

On $25^{\text {th }}$ November, 2013, the Consultant requested the Contractor to arrange a meeting between the Contractor, subcontractor and local people in order to absolutely solve the obstacle. The Engineer also requested the Contractor to compensate local people for damaged property, although the property was the new surface created by the disposal, in order to continue removing unsuitable soil at this location. After Contractor reached an agreement and compensated local people, again the equipment and the manpower were mobilized to restart the removal works.

By November $24^{\text {th }}, 2013$, the Contractor could finally restart these works.

On November $27^{\text {th }}, 2013$, the Contractor has already removed $4,915.52 \mathrm{~m}^{3}$ unsuitable soil, according to the information given by the Contractor, to the disposal area approved by Consultant at $\mathrm{Km} 166+520$.

On $4^{\text {th }}$ December, 2013, the Engineers of EPMU, the Consultant, Contractor and SubContractor, checked jointly the actual situation of this unauthorized disposal area (see Picture 12). Removed unsuitable soil was measured by survey machinery and the result was $4,915 \mathrm{~m}^{3}$ unsuitable soil have been already removed at this location. (See Annex 4 - Site Minute).

After removed $4,915.52 \mathrm{~m}^{3}$ of unsuitable soil at this location, the Contractor stopped removal works. As it is shown in the pictures $\mathrm{P} 10$ to $\mathrm{P} 13$, most part of the disposal remains at this location, so, the Engineer required the Contractor to explain this issue by official letter.

On site, the explanation given by Contractor and Sub-contractor was that local people, owners of the land, said that from this project all dumped soil was already removed. When 


\section{Loan 2391/2392 - VIE: GMS Kunming - Hai Phong Transport Corridor Noi Bai - Lao Cai Highway Project}

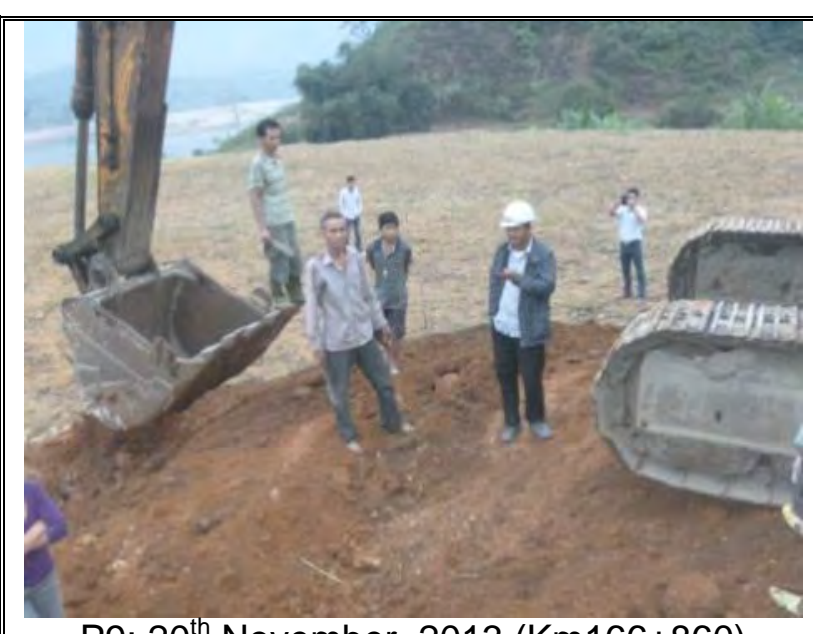

P9: $20^{\text {th }}$ November, $2013(\mathrm{Km} 166+860)$

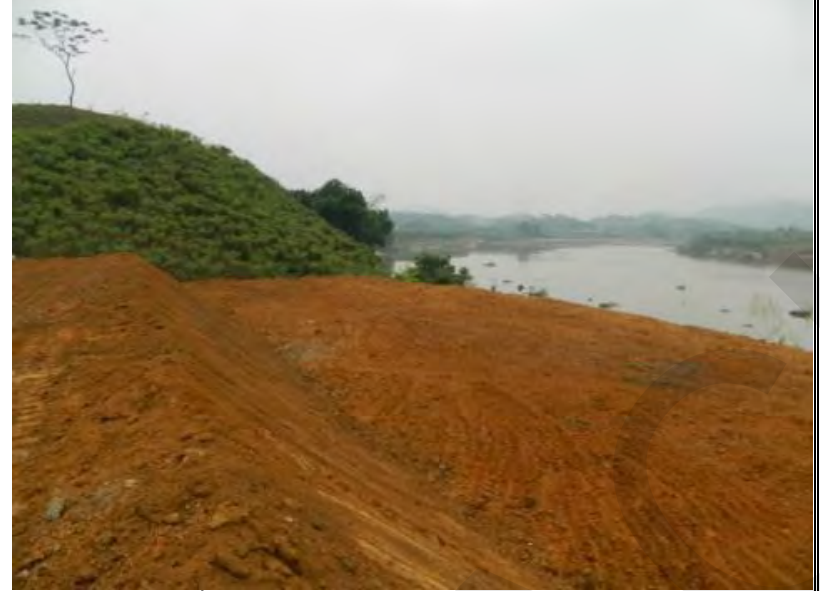

P10: $27^{\text {th }}$ November, $2013(\mathrm{Km} 166+860)$

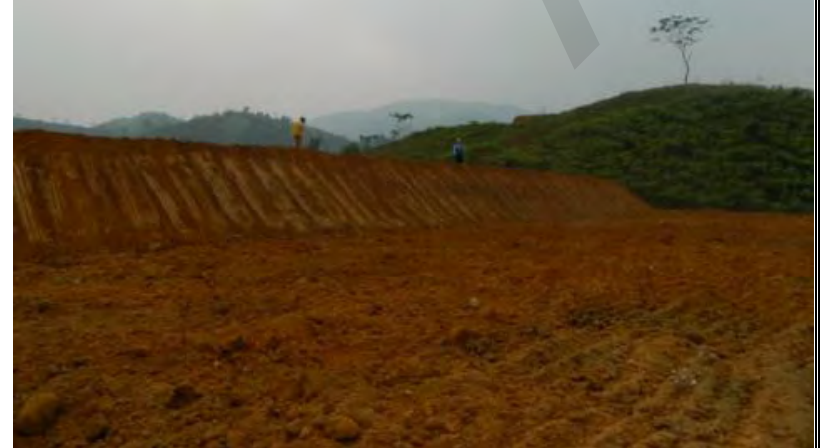

P11: $27^{\text {th }}$ November, $2013(\mathrm{Km} 166+860)$
Consultant asked about the soil remaining in the riverbank, the answer from local people was that it came from another part and that they were not going to allow to remove any more.

Besides, the Engineer required the Contractor to prepare the plan for the restoration works of unauthorized disposal area (referring to the letter $\mathrm{N}^{0}$. GET-DOO-123 dated on $9^{\text {th }}$ December, 2013 regarding to "The restoration works in unauthorized disposal area at Km166+860)" in order to ensure the environmental issues at this location and avoid erosion and landslides in the future.

The Contractor has already submitted Plan on restoration works of unauthorized disposal area (mentioned in the letter No. DHIC-13SET-071). The Engineer has checked this plan, which is related to the current situation on site.

Besides, in order to avoid erosion and landslide can be happened at this location, the Contractor is starting to plant tree and grass at cutting slope at this location.

The Contractor also has got the explanation for issues of disposal area Km166+860 by official letter (referring to the Contractor's letter No.DHIC-13-SET-075 dated on $30^{\text {th }}$ December, 2013).

On $21^{\text {st }}$ January, 2014, the Contractor has not got any action for this work.

After the last ADB mission, in which some unauthorized disposals were finally approved in Package $A 7$ attending to the claims expressed by local people, and after analyzing the current situation of the disposal at $\mathrm{km} 166+860$ and because of the rainy season is coming, Consultant estimates convenience and therefore recommends to apply the same criteria for this disposal and to proceed to the approved restoration works as soon as possible, especially now that the flow level in the Red river is low and works can be 


\section{Loan 2391/2392 - VIE: GMS Kunming - Hai Phong Transport Corridor Noi Bai - Lao Cai Highway Project}

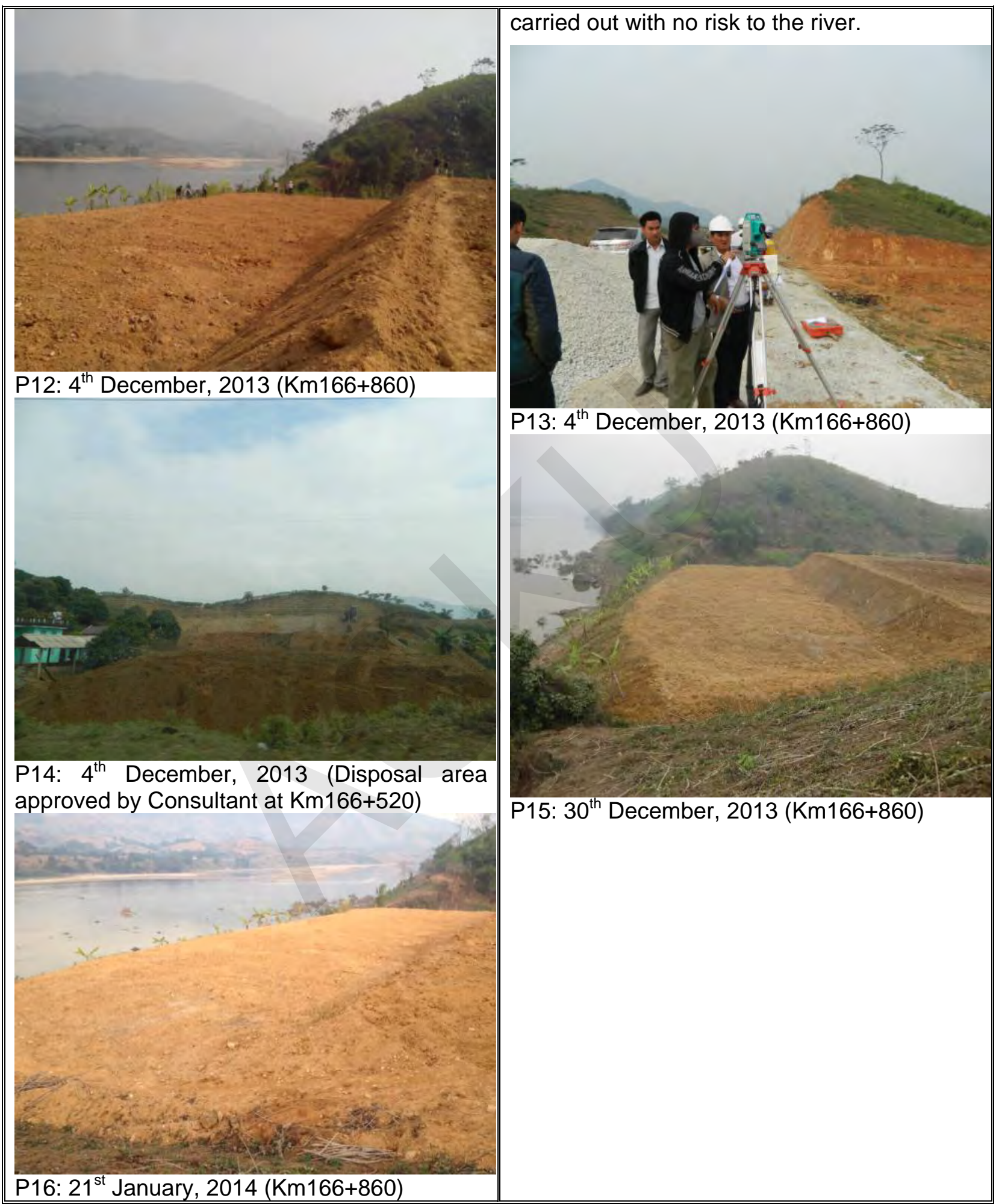




\section{Loan 2391/2392 - VIE: GMS Kunming - Hai Phong Transport Corridor Noi Bai - Lao Cai Highway Project}

The site checking and supervision in February and March, the Consultant found that there was no serious problem of environment and safety from the disposal areas approved by the Consultant.

\subsubsection{Package A7}

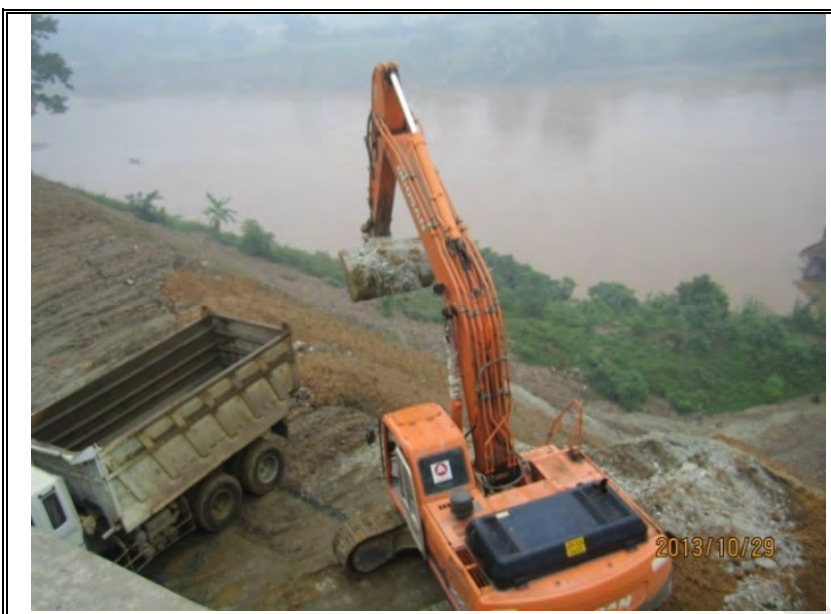

29.10.2013

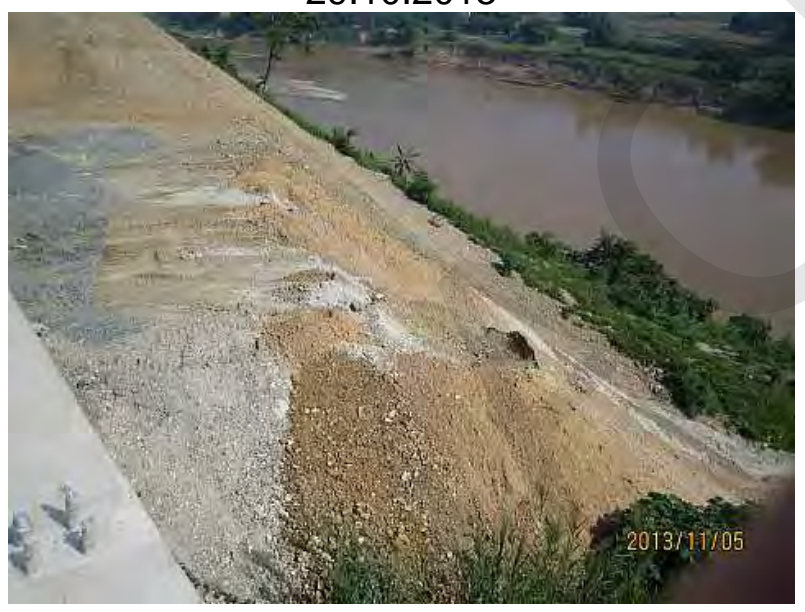

5.11 .2013
Location: Km190+420

Site visit: 29/10/2013; 05/11/2013; 28/11/2013; 11/12/2013; 17/12/2013; 24/12/2013; 21/1/2014; 25/2/2014; 31.3.2014

Equipment mobilized: According to the picture on November $28^{\text {th }}, 2013$, some equipments were mobilized

Volume of unsuitable material already removed: The contractor started to remove the unsuitable material on 29.10.2013 but from 29.10.2013 to 28.11.2013 the volume of unsuitable material that had really been removed is almost equal to Zero.

From 28.11.2013 to 11.12.2013, the Contractor removed about $500 \mathrm{~m} 3$ of unsuitable soil.

From 11.12 .2013 to 24.12 .2013 , the Contractor removed $100 \mathrm{~m} 3$ of unsuitable soil.

From 24.12.2013 to 21.1.2014, the Contractor stopped removal the unsuitable material

Impact caused: The contractor dumped about $24.813,04 \mathrm{~m}^{3}$ of unsuitable material from excavation near Red River and on the 


\section{Loan 2391/2392 - VIE: GMS Kunming - Hai Phong Transport Corridor Noi Bai - Lao Cai Highway Project}

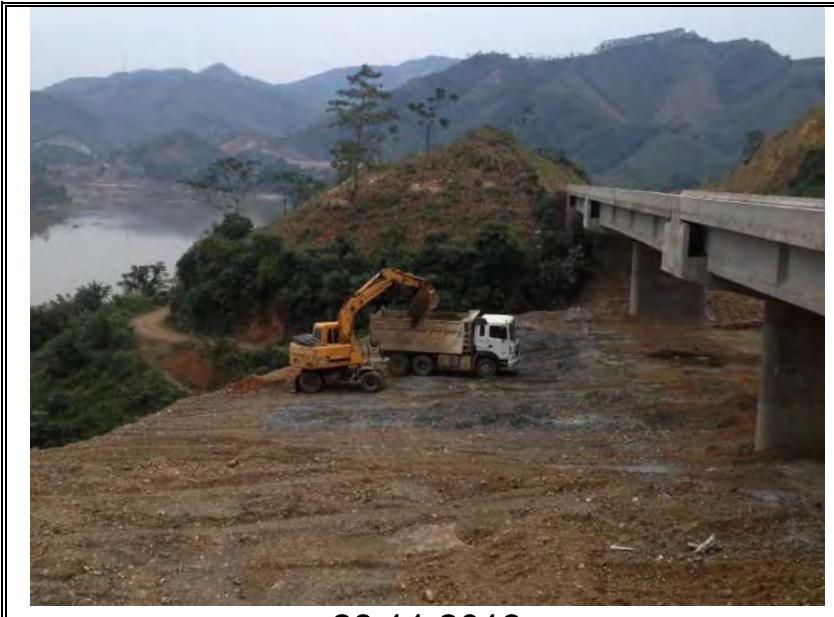

28.11 .2013

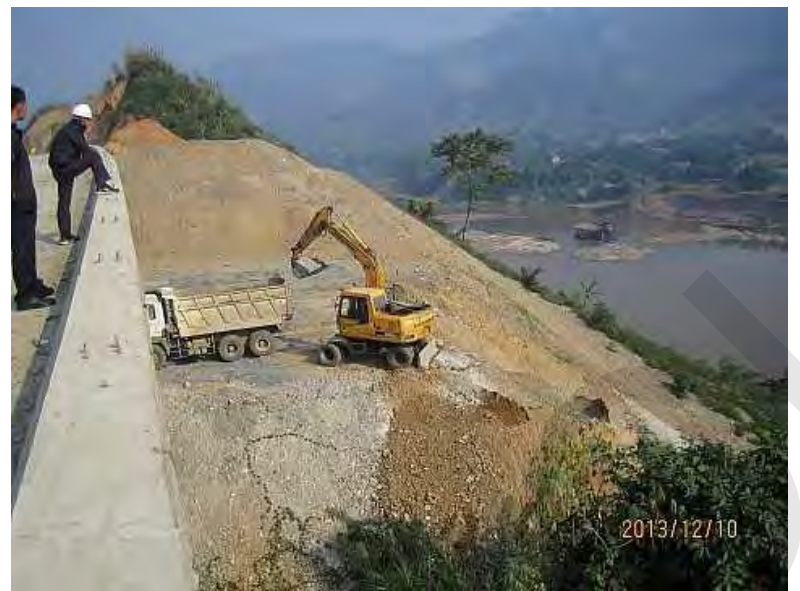

10.12 .2013

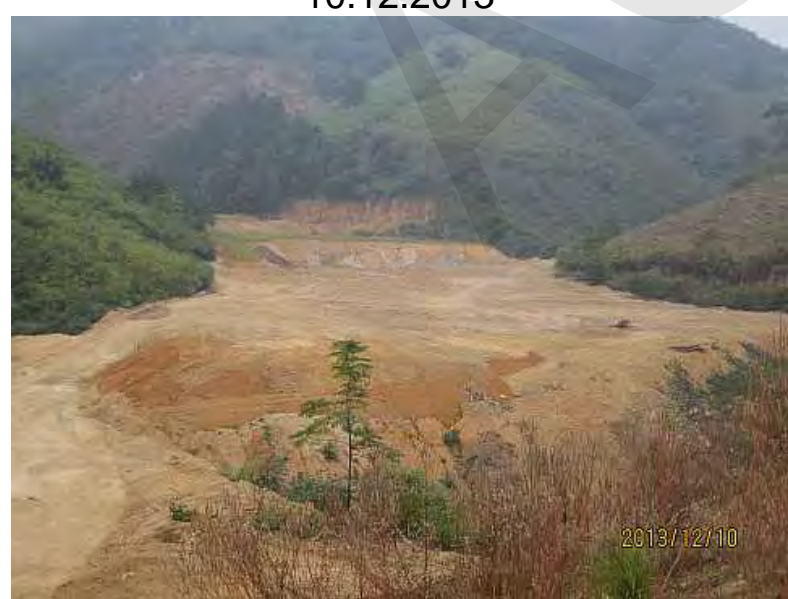

10.12.2013 (Authorized disposal Km189+700) riverbank, affecting the slope of riverbank and the riverbed. This disposal was not approved by Engineer.

Note: The number of $24.813,04 \mathrm{~m}^{3}$ is the volume defined as maximum capacity according to the restoration plan that had been approved on November $08^{\text {th }}, 2013$ But the exact volume will be determined on site after the contractor removes the surface layers

Authorized disposals: The contractor proposed to use the unsuitable material disposal at $\mathrm{Km} 189+700$ in order to dump the removed unsuitable material. The unsuitable material disposal at $\mathrm{Km} 189+700$ was approved by Consultant

Current status: On 29.10.2013 the contractor started to remove the unsuitable material and after that the contractor stopped works until 28.11.2013. On that date, the contractor has started again operations and continued removing the unsuitable material from the unauthorized disposal.

Up to date 10.12.2013, the Contractor continued removing the unsuitable material to authorized disposal $\mathrm{Km} 198+700$ but the real volume of unsuitable soil that has already been removed is about $500 \mathrm{~m} 3$. But From 17.12.2013 to 24.12.2013 the contractor removed only $100 \mathrm{~m} 3$ of unsuitable soil 


\section{Loan 2391/2392 - VIE: GMS Kunming - Hai Phong Transport Corridor Noi Bai - Lao Cai Highway Project}

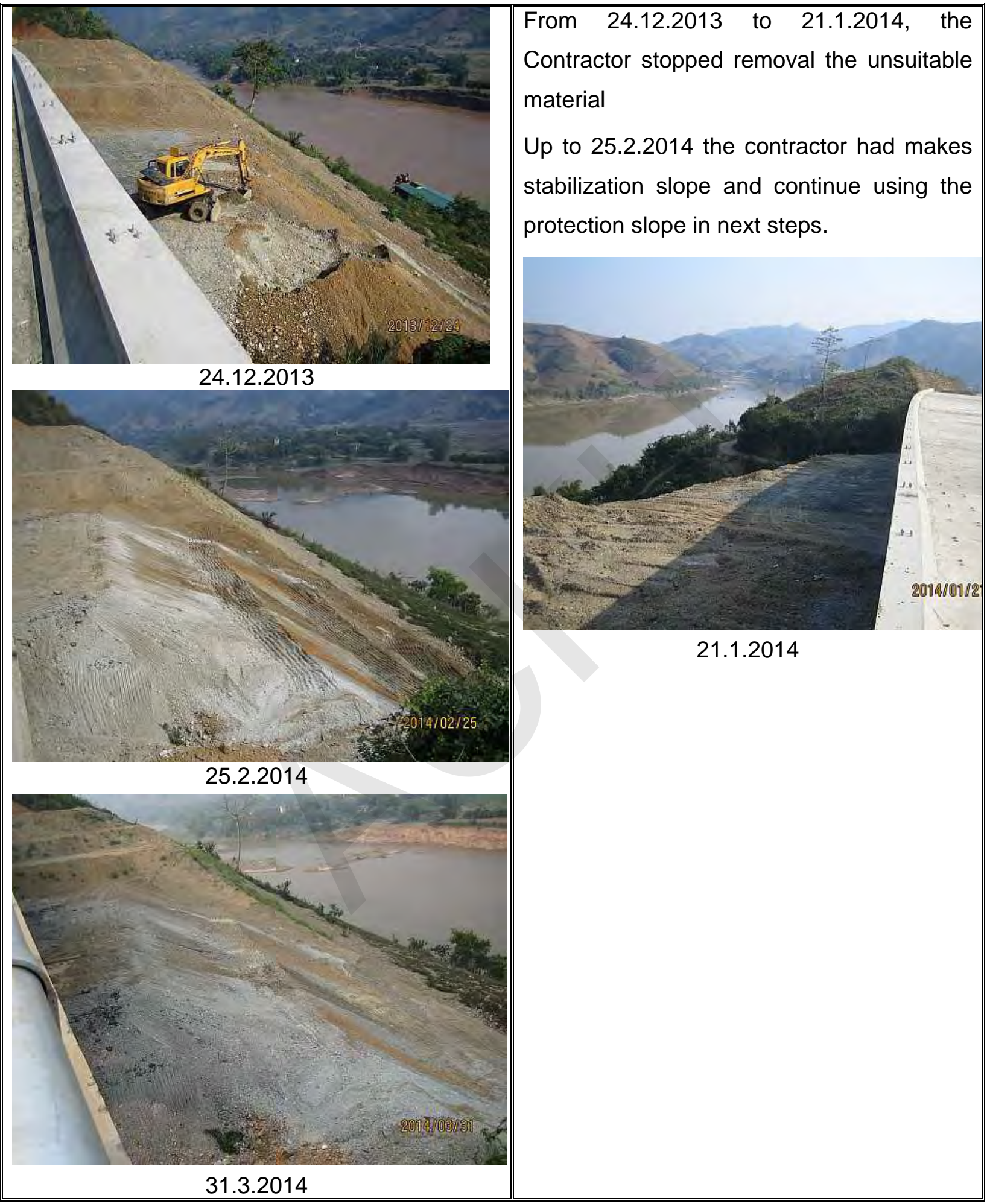




\section{Loan 2391/2392 - VIE: GMS Kunming - Hai Phong Transport Corridor Noi Bai - Lao Cai Highway Project}

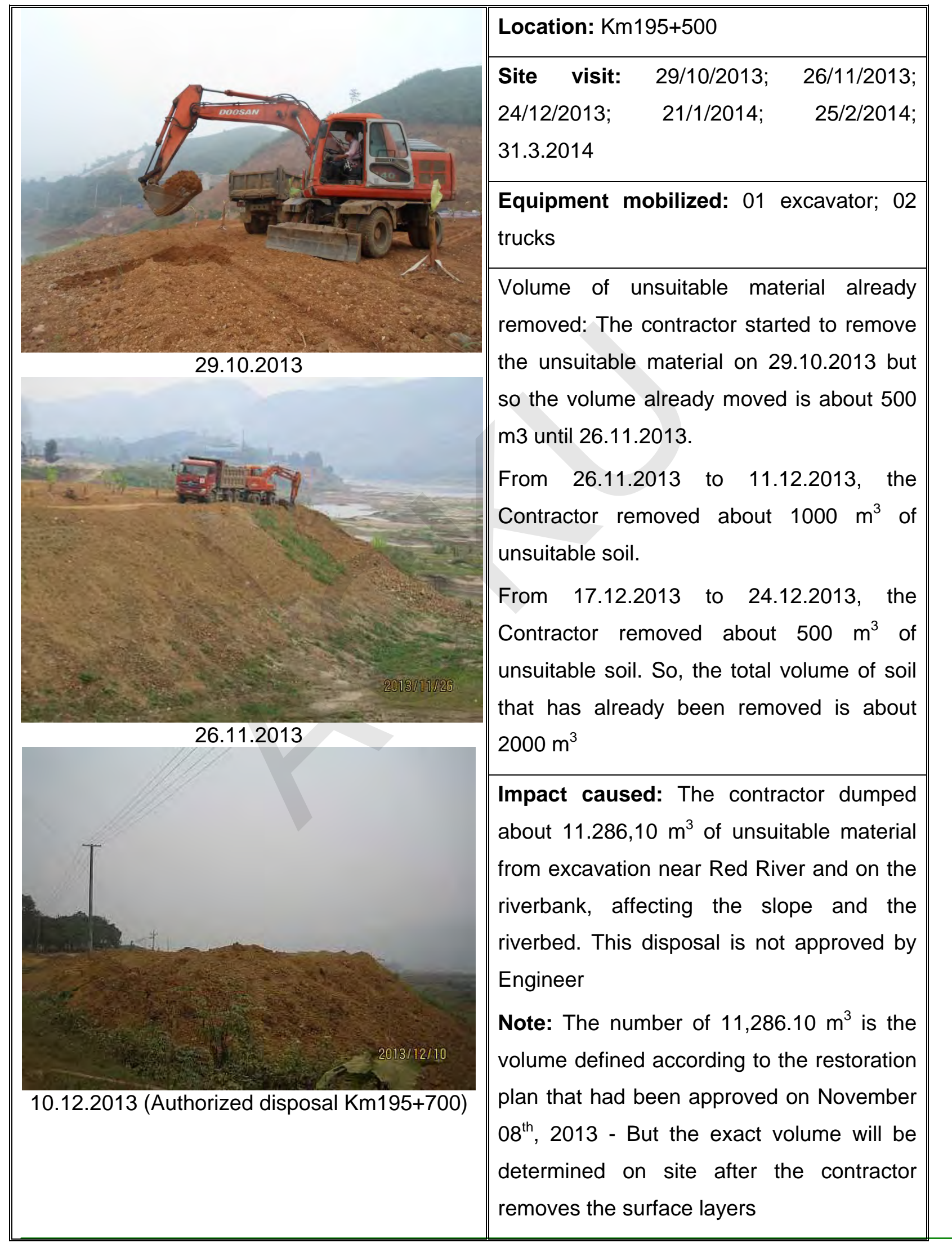




\section{Loan 2391/2392 - VIE: GMS Kunming - Hai Phong Transport Corridor Noi Bai - Lao Cai Highway Project}

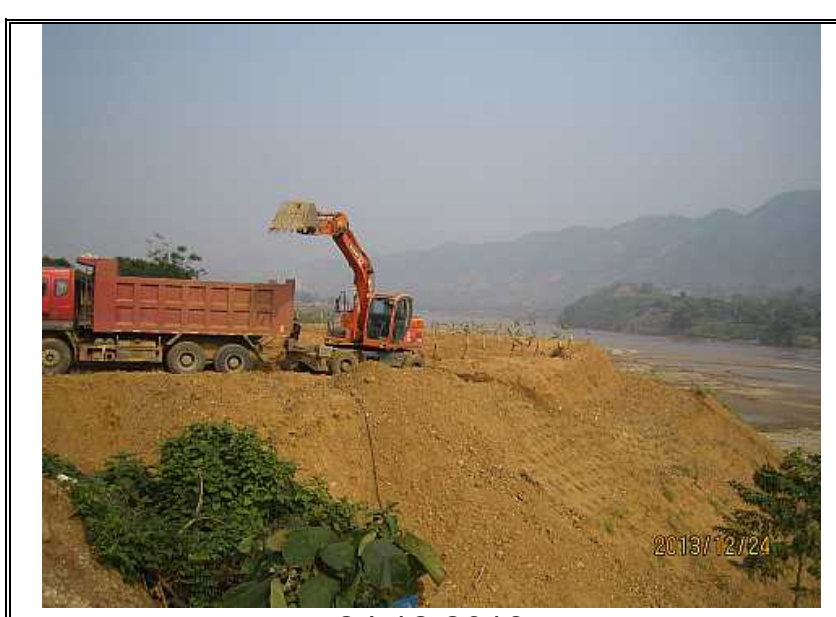

24.12.2013

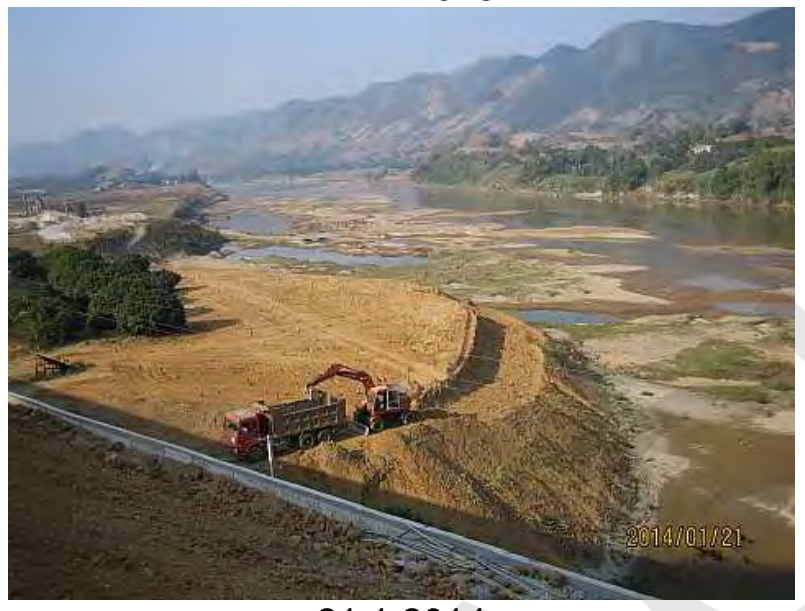

21.1.2014

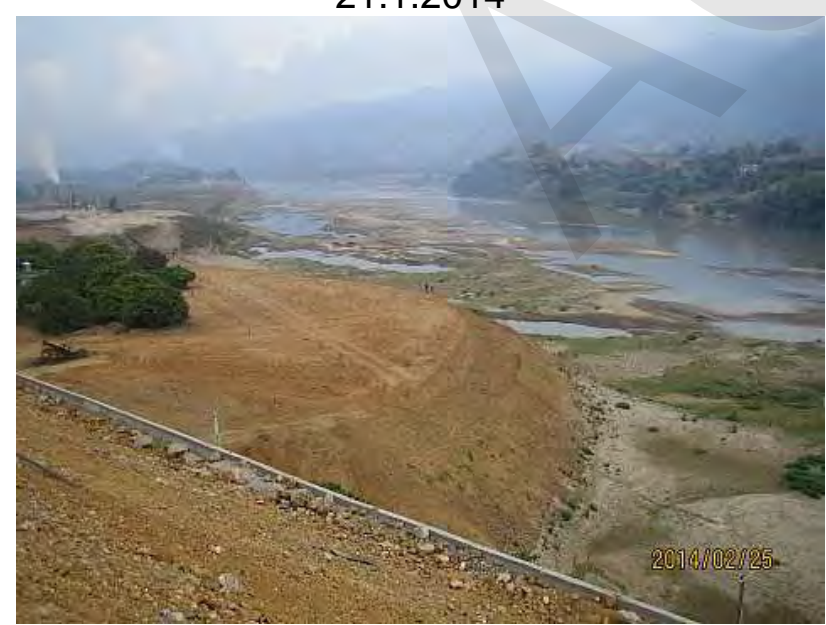

25.2.2014
Authorized disposals: The contractor proposed to use the unsuitable material disposal at $\mathrm{Km} 195+700$ in order to dump the removed unsuitable material. The unsuitable material disposal at $\mathrm{Km} 195+700$ was approved by Consultant

Current status: On 29.10.2013 the contractor started to remove the unsuitable material (only some $\mathrm{m}^{3}$ ) and after that the contractor stopped works until 12.11.2013. On that date, Contractor could continue removing about $500 \mathrm{~m}^{3}$ of soil. But in the same day, the removal works had to stop because the local people caused an obstruction according to the explanations given by letter $\mathrm{N}^{0}$ : Ref. GRBCC- GETINSAA7-1809 dated November $13^{\text {th }} 2013$.

On 26.11.2013 the contractor had reached an agreement with local people, with the support of the Client and Tan An commune. On that date, the contractor has restarted operations and continued removing the unsuitable material from the unauthorized disposal.

Up to 21.1.2014 the Contractor continued removing the unsuitable material to authorized disposal $\mathrm{Km} 195+700$ but the total volume of soil that has already been removed is about $2100 \mathrm{~m} 3$ Up to now the contractor stopped and waiting the MOU between VEC and ADB mission 


\section{Loan 2391/2392 - VIE: GMS Kunming - Hai Phong Transport Corridor Noi Bai - Lao Cai Highway Project}

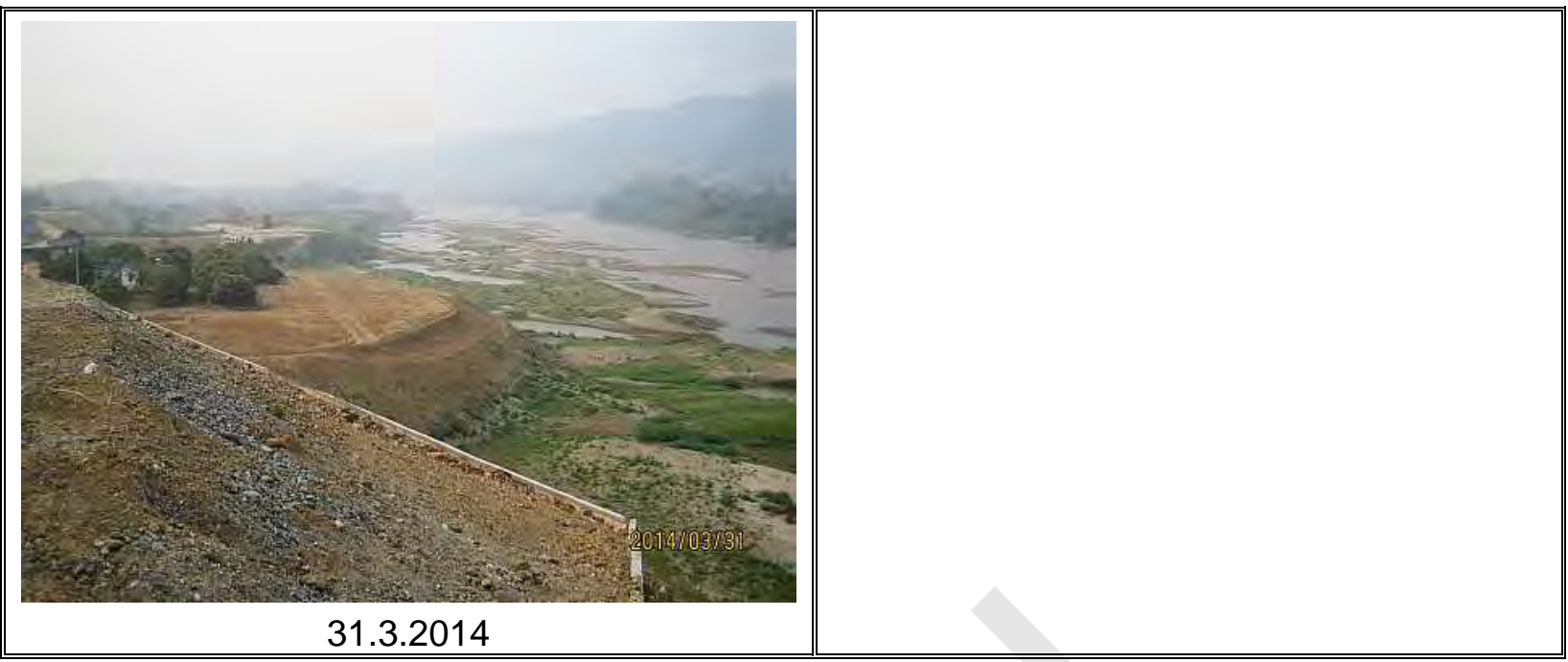

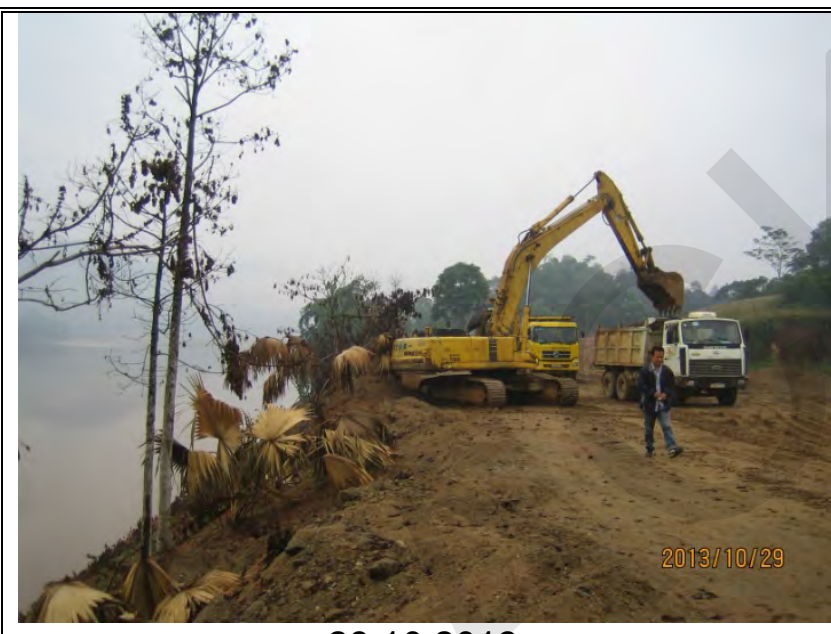

29.10 .2013

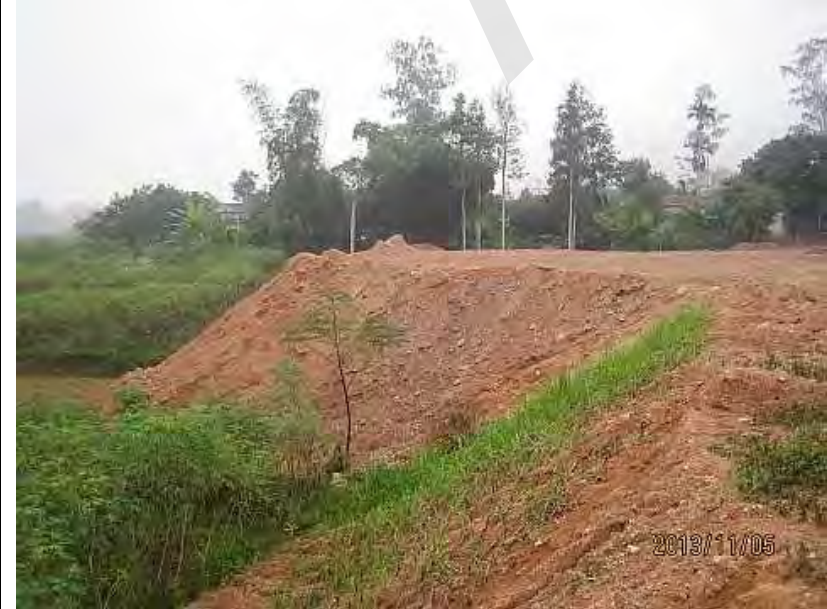

05.11.2013 (Authorized disposal area at $\mathrm{Km} 210+400)$
Location: $\mathrm{Km} 208+890$

Site visit: 29/10/2013; 26/11/2013;

24/12/2013; 21/1/2014; 25/2/2014; 31.3.2014

Equipment mobilized: According to the picture on October $29^{\text {th }}, 2013$, some equipments were mobilized

Volume of unsuitable material already removed: The contractor started to remove the unsuitable material on 29.10 .2013 but so far the volume of unsuitable material that had been removed is almost equal to Zero

Impact caused: The contractor dumped about $10,377.28 \mathrm{~m}^{3}$ of unsuitable material from excavation near Red River and on the riverbank, affecting the slope of riverbank and the riverbed. This disposal was not approved by Engineer.

Authorized disposals: At first, the contractor proposed to use the unsuitable material disposal at $\mathrm{Km} 210+400$ (this authorized 


\section{Loan 2391/2392 - VIE: GMS Kunming - Hai Phong Transport Corridor Noi Bai - Lao Cai Highway Project}

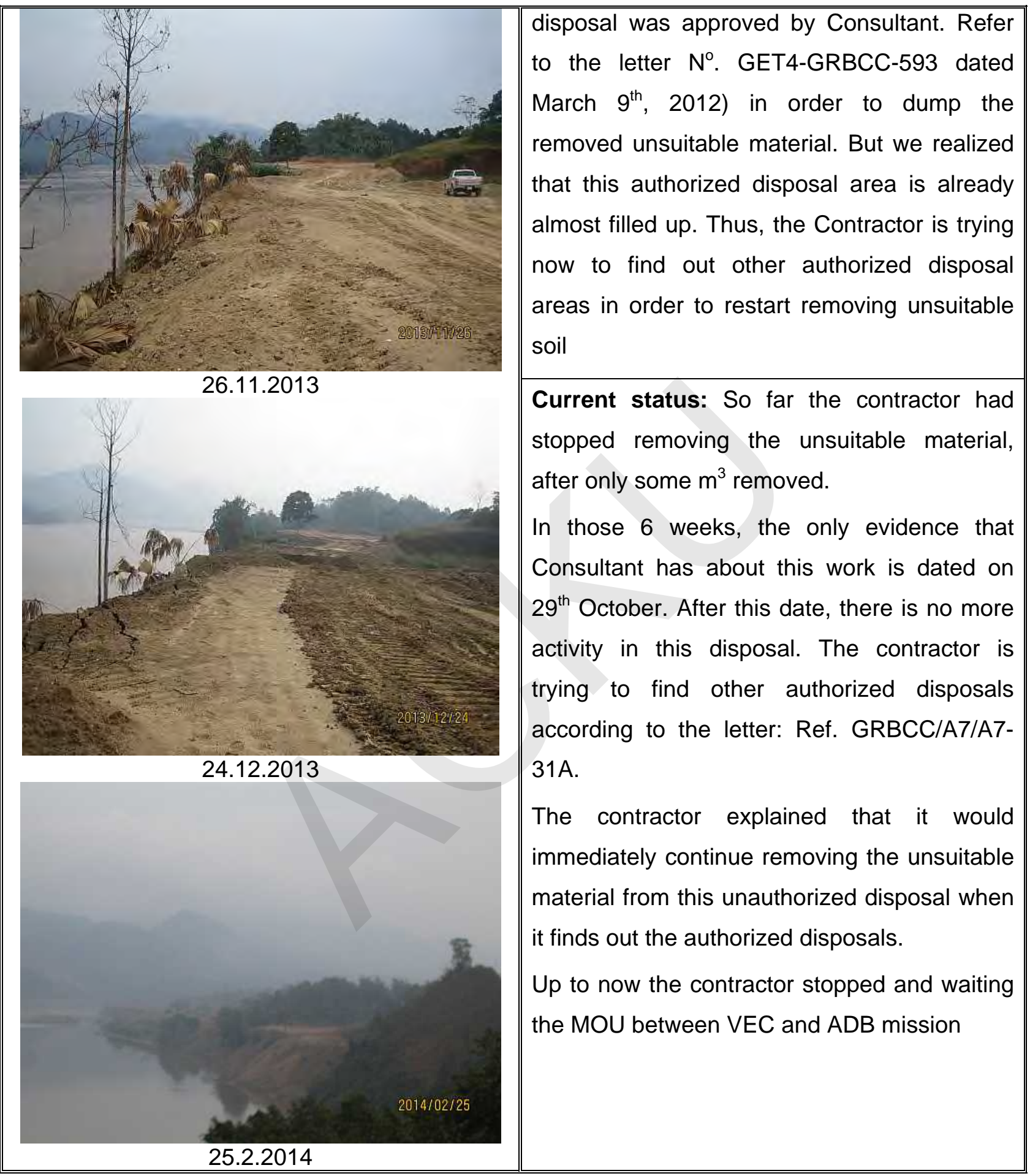




\section{Loan 2391/2392 - VIE: GMS Kunming - Hai Phong Transport Corridor Noi Bai - Lao Cai Highway Project}

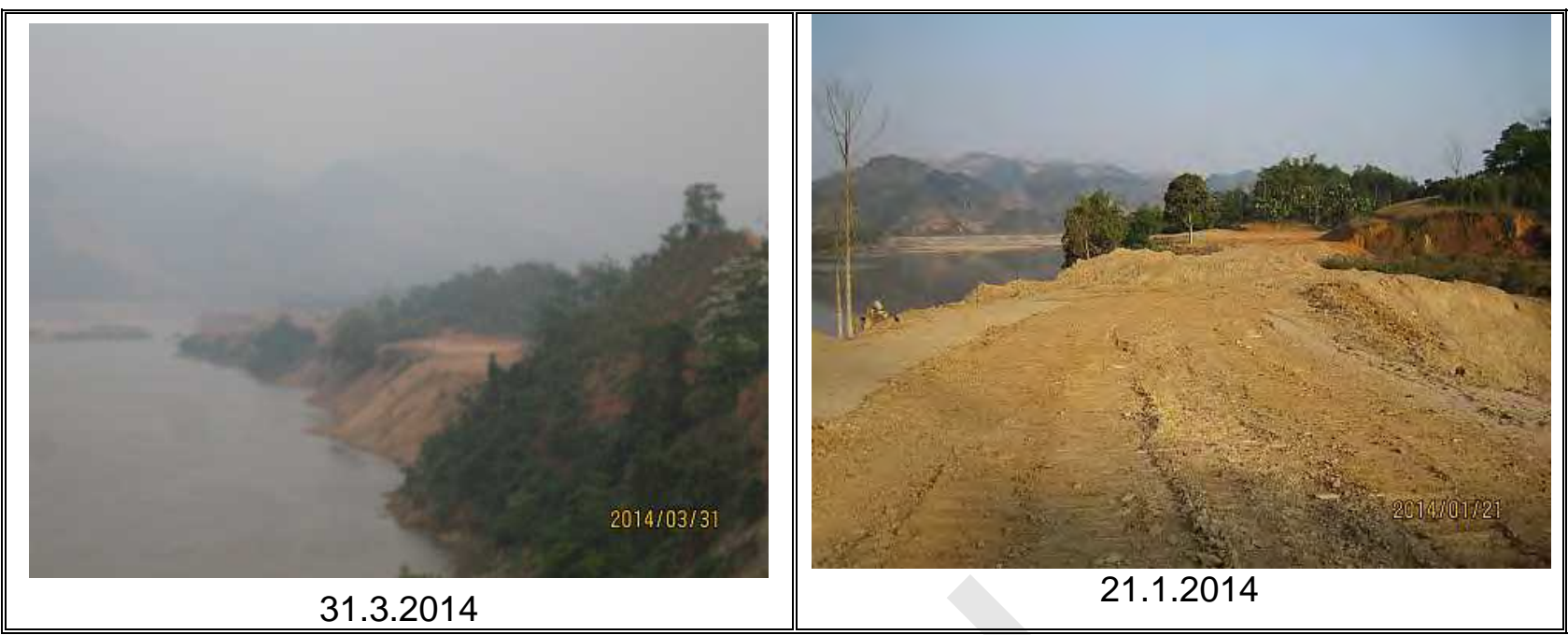

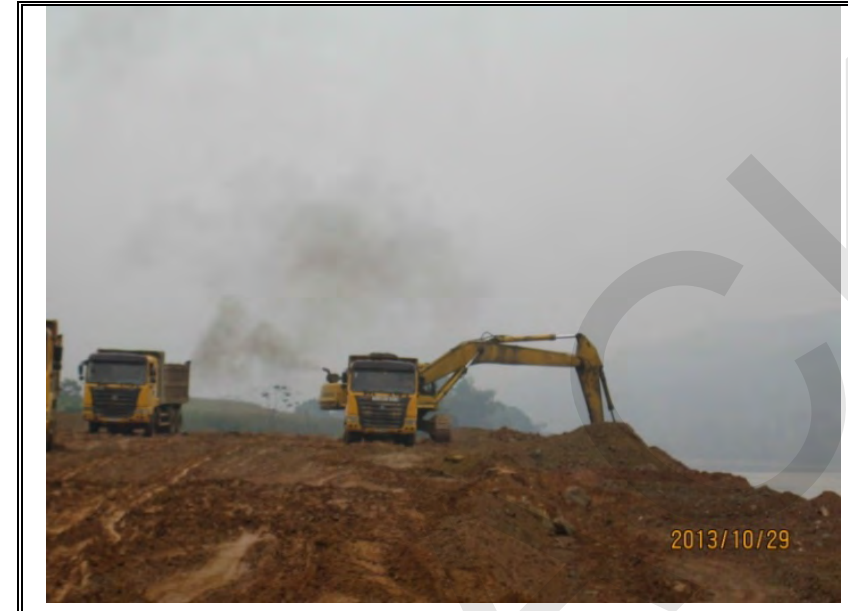

29.10 .2013

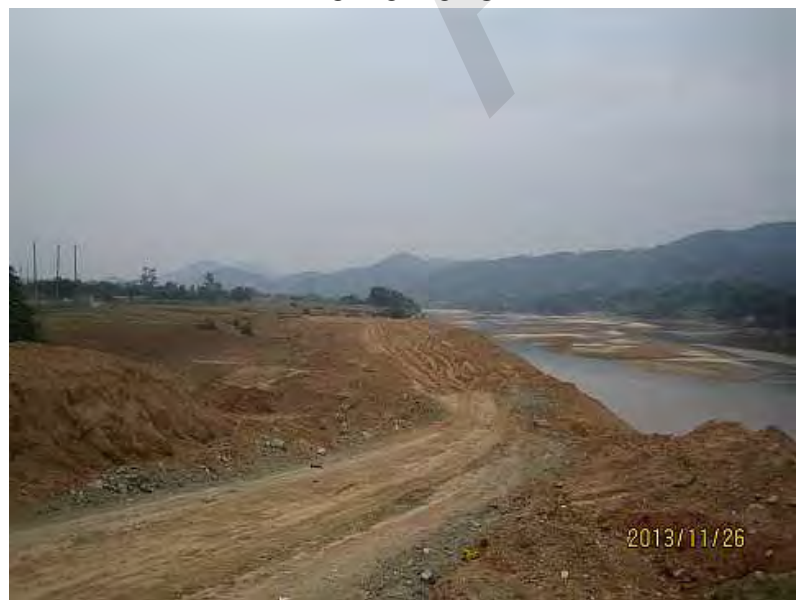

26.11 .2013
Location: $\mathrm{Km} 209+800$

Site visit: 29/10/2013; 26/11/2013;

24/12/2013; 21/1/2014; 25/2/2014; 31.3.2014

Equipment mobilized: According to the picture on October $29^{\text {th }}, 2013$, some equipments were mobilized

Volume of unsuitable material already removed: The contractor started to remove the unsuitable material on 29.10 .2013 but so far the volume of unsuitable material that had been removed is almost equal to Zero

Impact caused: The contractor dumped about $24,169.00 \mathrm{~m}^{3}$ of unsuitable material from excavation near Red River and on the riverbank, affecting the slope and the riverbed. This disposal area was not approved by Engineer. However, the other authorized areas are almost filled up. Thus, the Contractor is trying to find out other authorized disposal areas in order to restart removing unsuitable soil at this unauthorized disposal 


\section{Loan 2391/2392 - VIE: GMS Kunming - Hai Phong Transport Corridor Noi Bai - Lao Cai Highway Project}
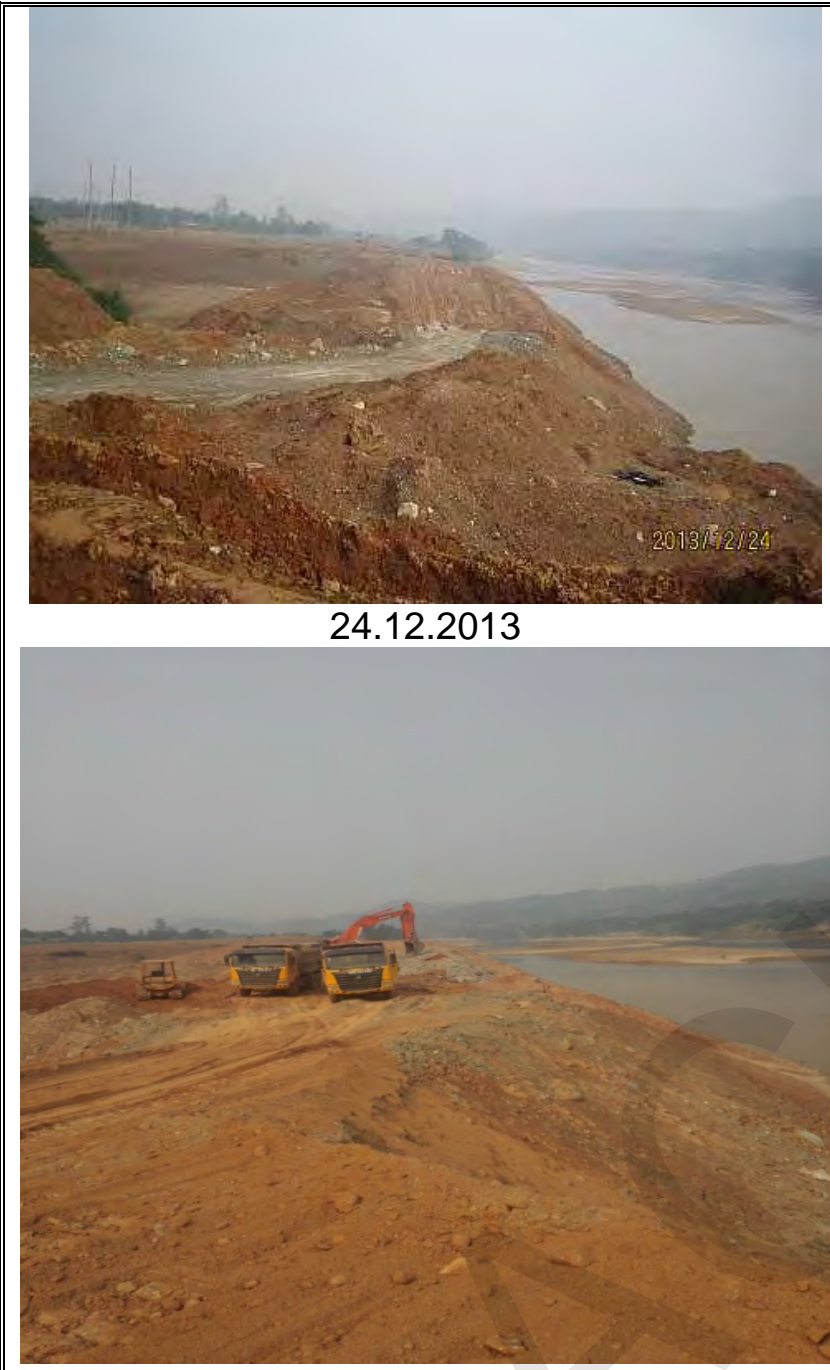

21.1.2014

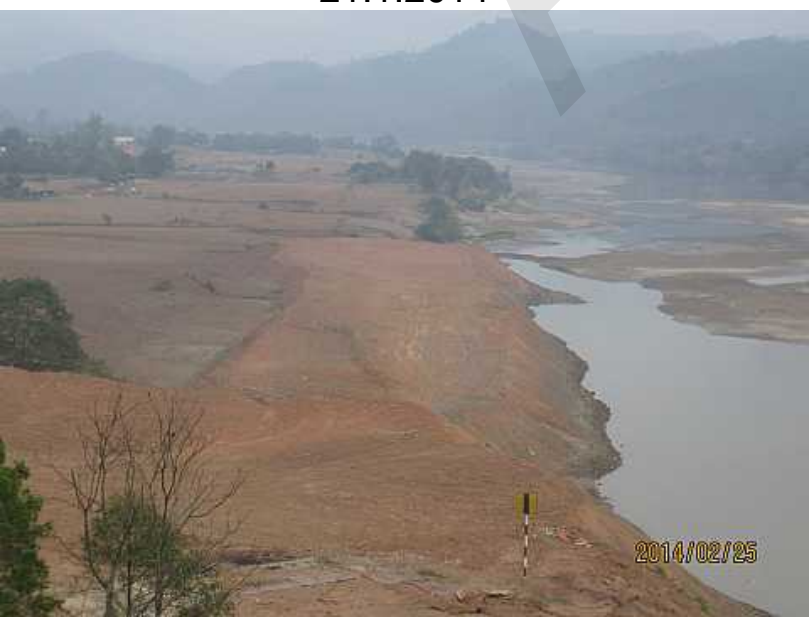

25.2.2014 area.

Authorized disposals: At first, the contractor also proposed to use the unsuitable material disposal at $\mathrm{Km} 210+400$ (same as for unauthorized disposal at $\mathrm{km} 208+890$. This authorized disposal was approved by Consultant. Refer to the letter $\mathrm{N}^{0}$. GET4GRBCC-593 dated March $9^{\text {th }}, 2012$ ) in order to dump the removed unsuitable material. As this authorized disposal area is already almost filled up, the Contractor has to find out other authorized disposal areas in order to restart removing unsuitable soil from this location

Current status: So far the contractor had stopped removing the unsuitable material, after only some $\mathrm{m}^{3}$ removed.

In these 6 weeks, the only evidence that Consultant has about this work is dated on $29^{\text {th }}$ October. After this date, there is no more activity in this disposal. The contractor is trying to find other authorized disposals according to the letter: Ref. GRBCC/A7/A7$31 \mathrm{~A}$.

The contractor explained that it would immediately continue removing the unsuitable material from this unauthorized disposal when it finds out the authorized disposals.

Up to now the contractor stopped and waiting the MOU between VEC and ADB mission 


\section{Loan 2391/2392 - VIE: GMS Kunming - Hai Phong Transport Corridor Noi Bai - Lao Cai Highway Project}

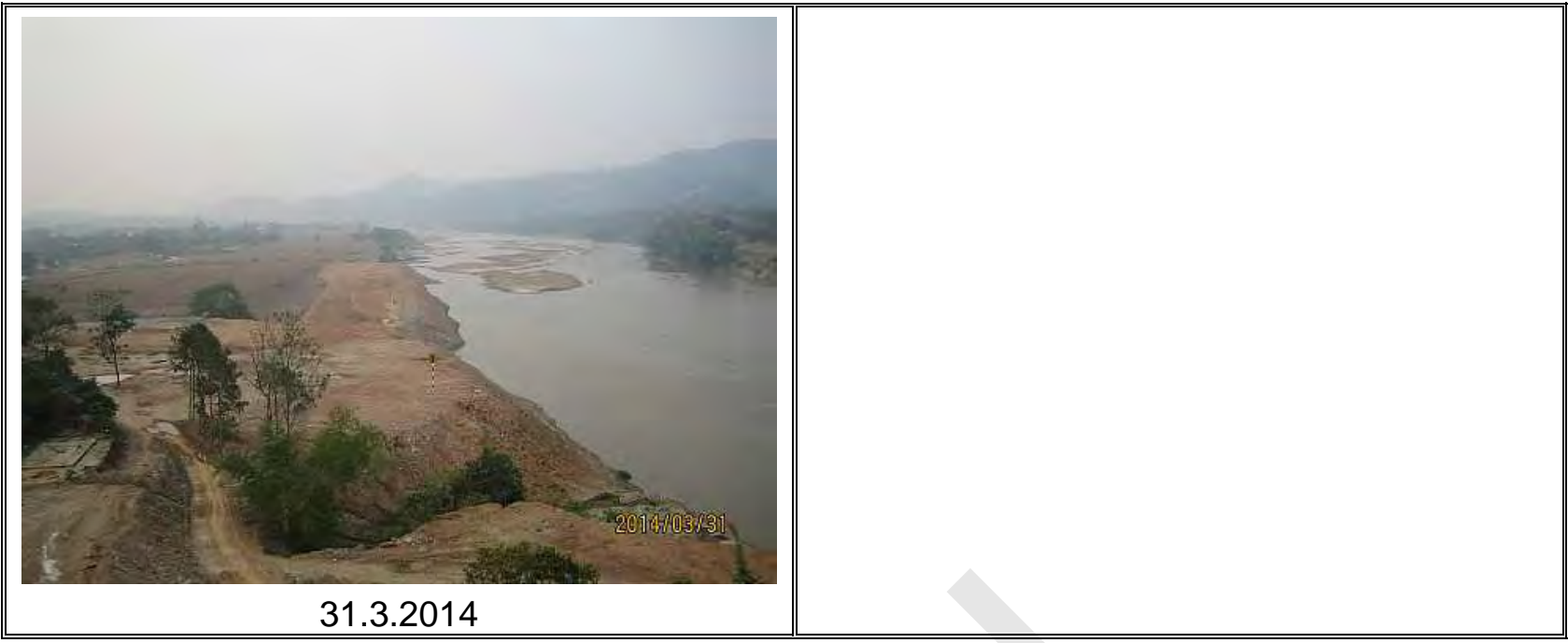

\subsubsection{Package A8}

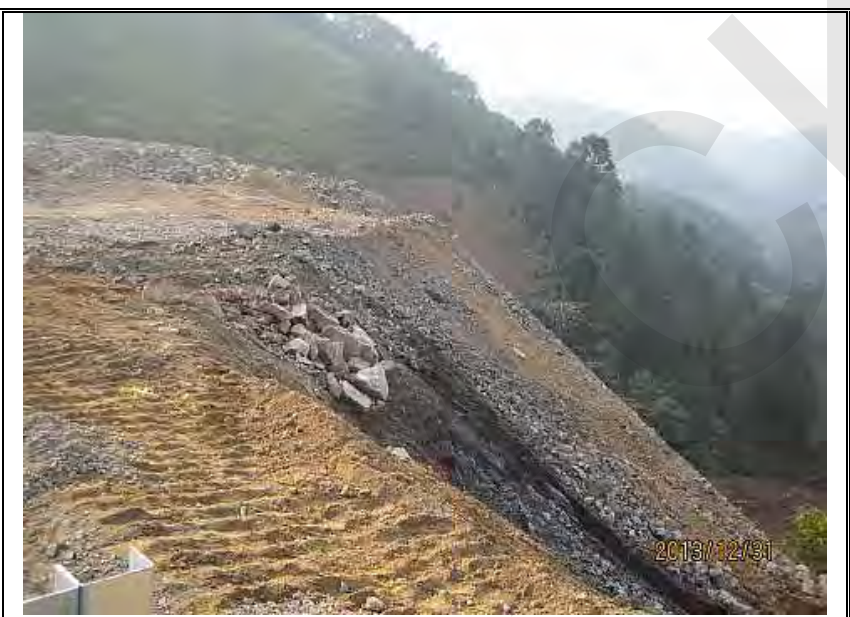

31.12 .2013

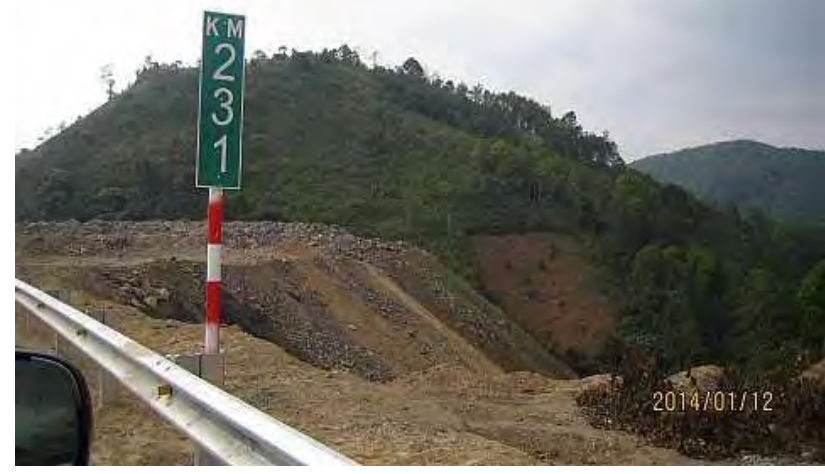

12.1.2014
Location: $\mathrm{Km} 231+100$

Site visit: $12.1 .2014 ; 26.2 .2014 ; 5.3 .2014$

Date first observed: 22.8 .2013

Problems description and cause: The contractor dumped soil on the place where the Consultant does not approve.

Recommendation and Action taken by Engineer: The contractors are required to supply the documents related to waste disposal and plant grass to avoid erosion and landside according to the letter No: Ref. Get4Vinaconex- 859

Deadline: 31.8.2013

Current status: The contractor has not yet deployed according to consultant's instructions yet. 


\section{Loan 2391/2392 - VIE: GMS Kunming - Hai Phong Transport Corridor Noi Bai - Lao Cai Highway Project}

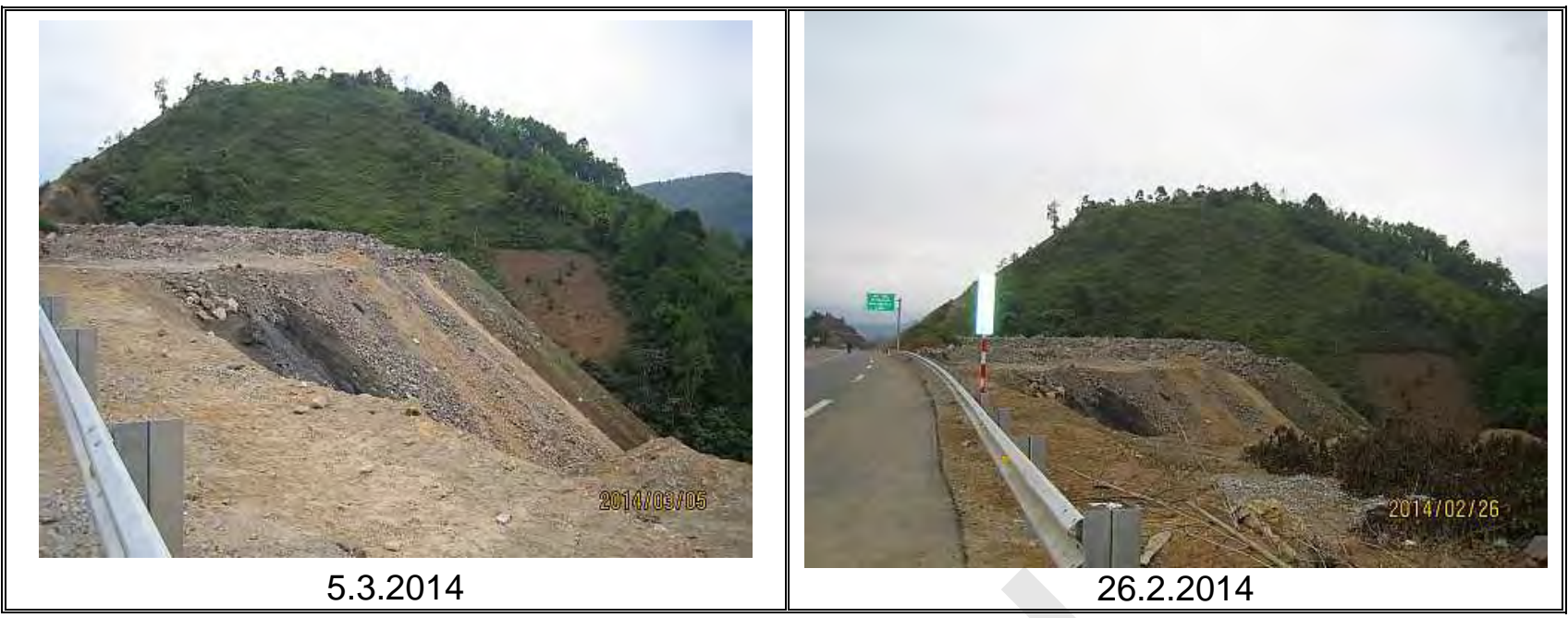

\subsection{WASTE AND CLEANLINESS ON SITE}

\subsubsection{Package A1}

At the present, at package A1, the Contractor has finished all construction works.

\subsubsection{Package A2}

\begin{tabular}{|c||l||}
\hline \multirow{2}{*}{} & Location: whole package \\
\cline { 2 - 3 } & $\begin{array}{l}\text { Site visit: 2, 3, 8, 10, 16, 22 Jan; 10, 13, 17, } 25 \\
\text { Feb.; 4, 12, 17, 25 Mar }\end{array}$ \\
\cline { 2 - 3 } & $\begin{array}{l}\text { Current status: } \\
\text { In Jan and Feb: All the sites are kept in } \\
\text { tidiness and cleanliness condition } \\
\text { In Mar: The Contractor has mobilized the } \\
\text { manpower to clean the debris and trash onsite }\end{array}$ \\
\hline January 02, 2014 & \\
\hline
\end{tabular}




\section{Loan 2391/2392 - VIE: GMS Kunming - Hai Phong Transport Corridor} Noi Bai - Lao Cai Highway Project

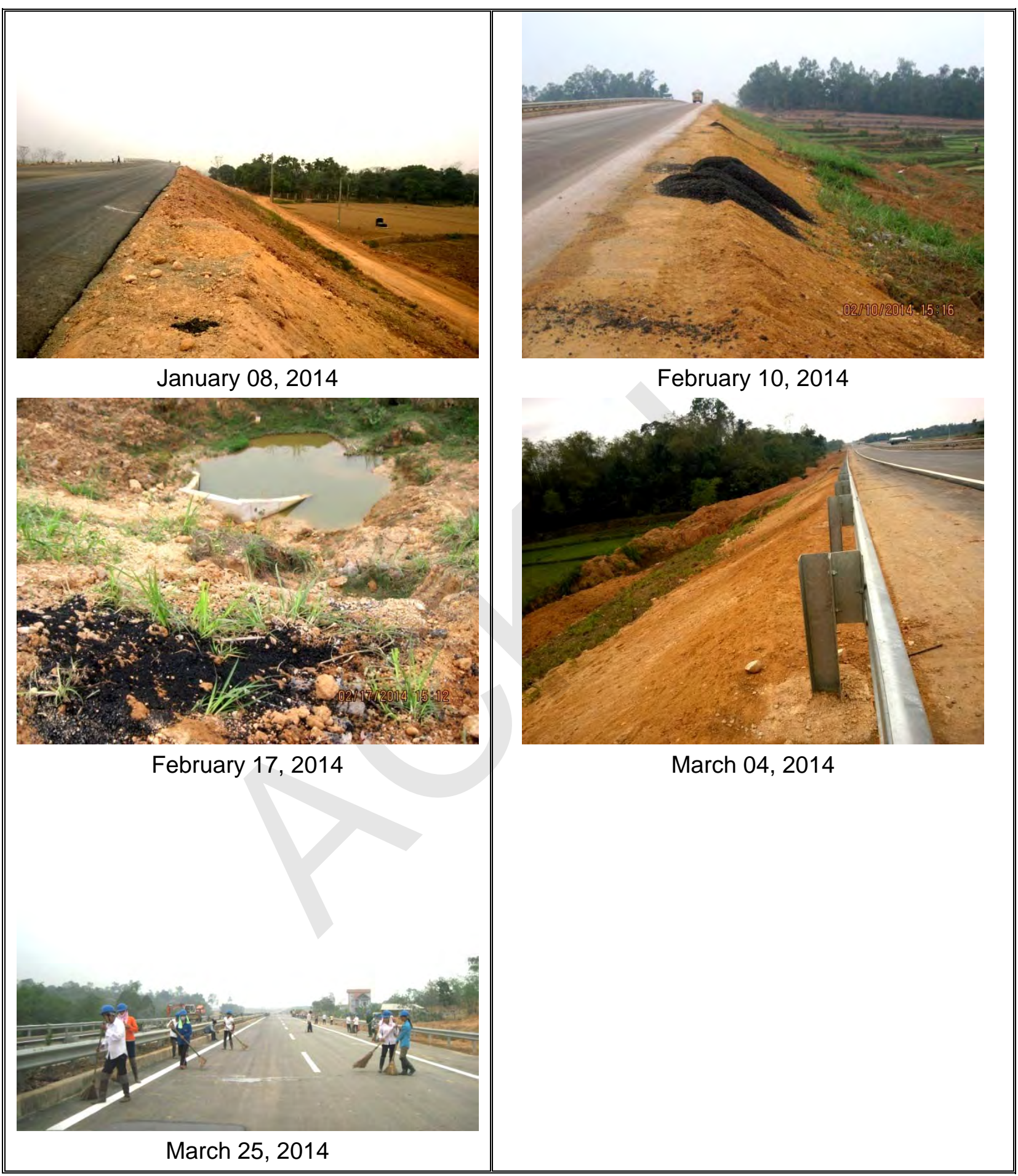




\section{Loan 2391/2392 - VIE: GMS Kunming - Hai Phong Transport Corridor Noi Bai - Lao Cai Highway Project}

\subsubsection{Package A3}

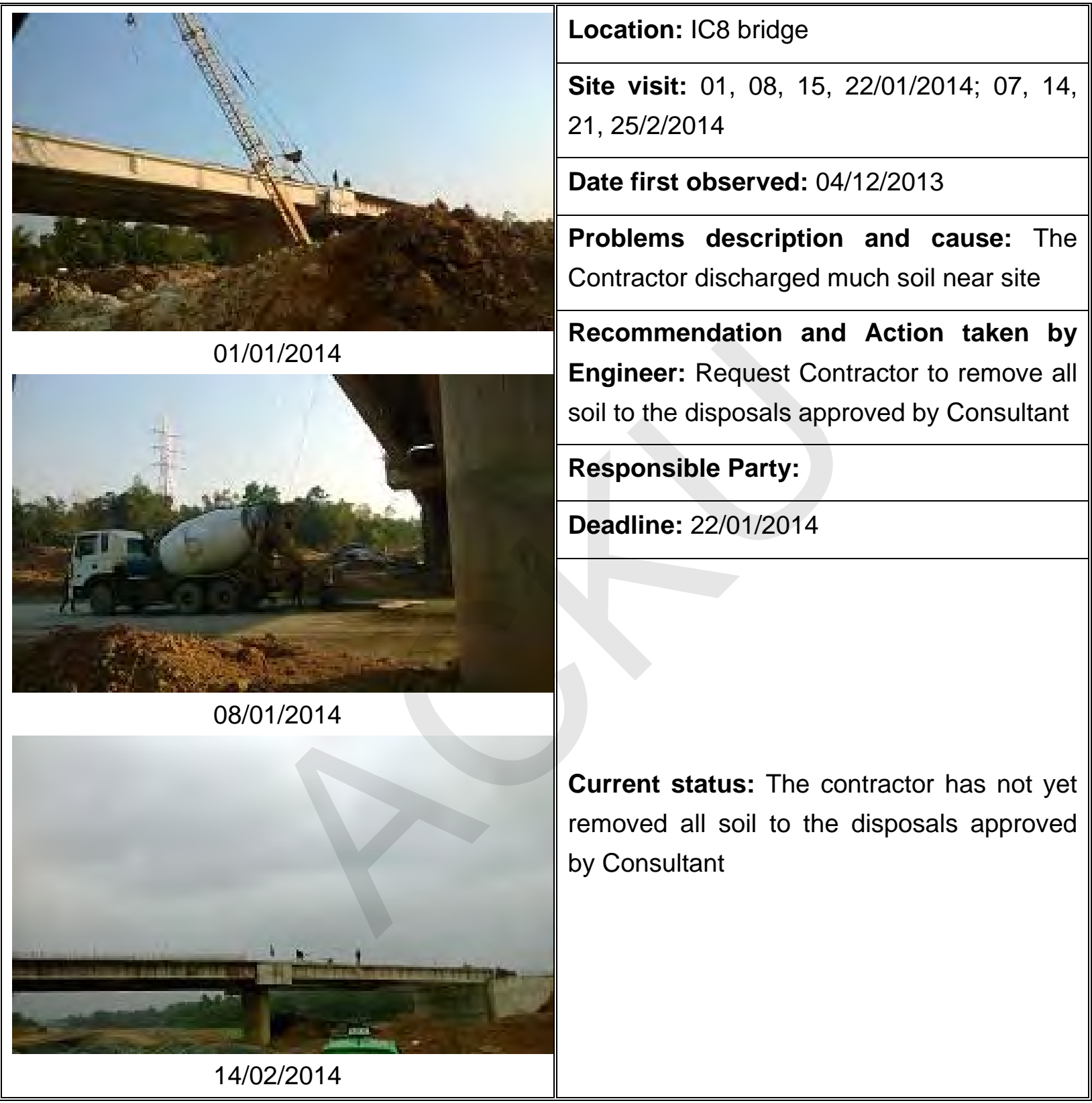




\section{Loan 2391/2392 - VIE: GMS Kunming - Hai Phong Transport Corridor Noi Bai - Lao Cai Highway Project}

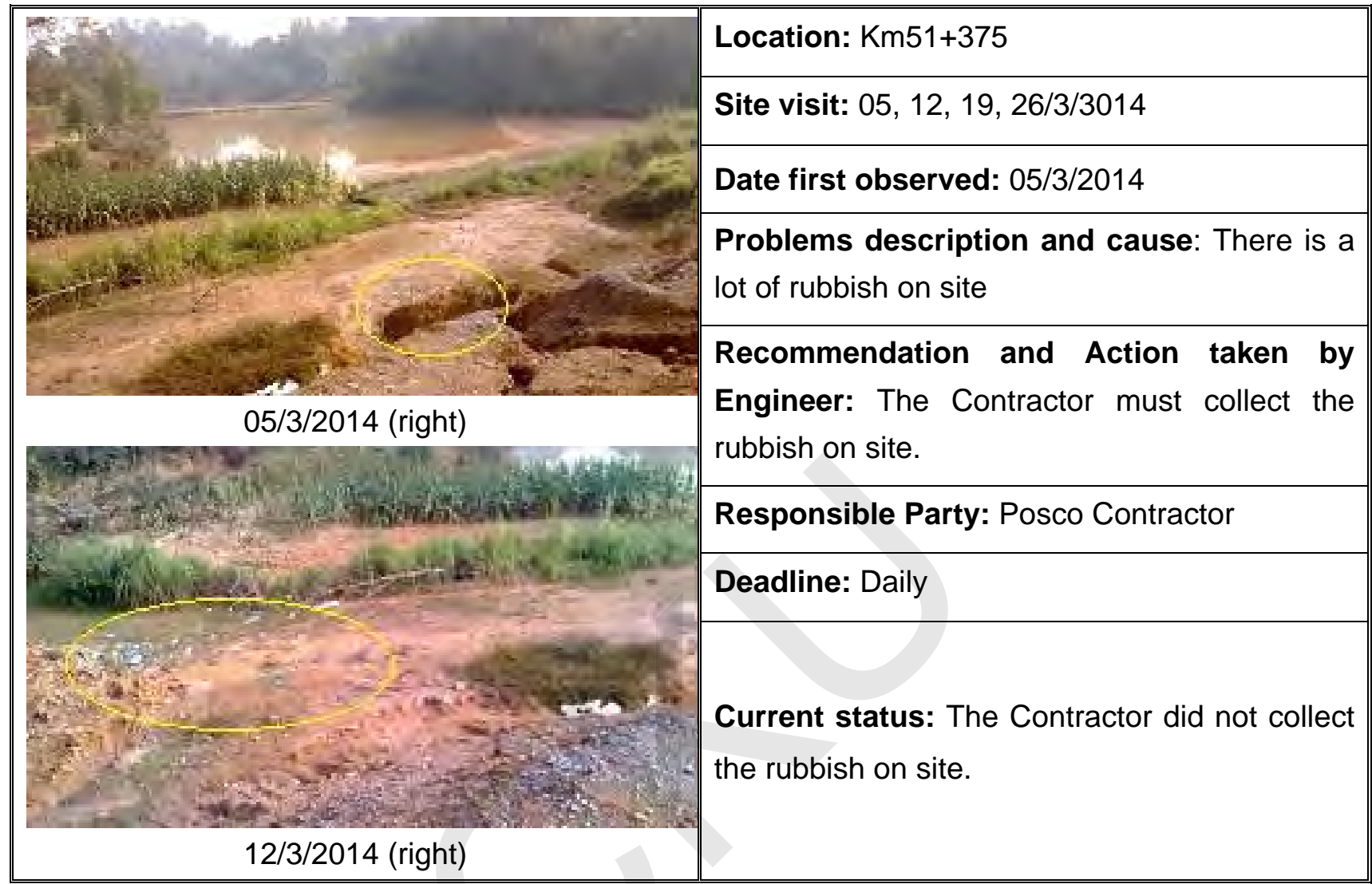

\subsubsection{Package A4}

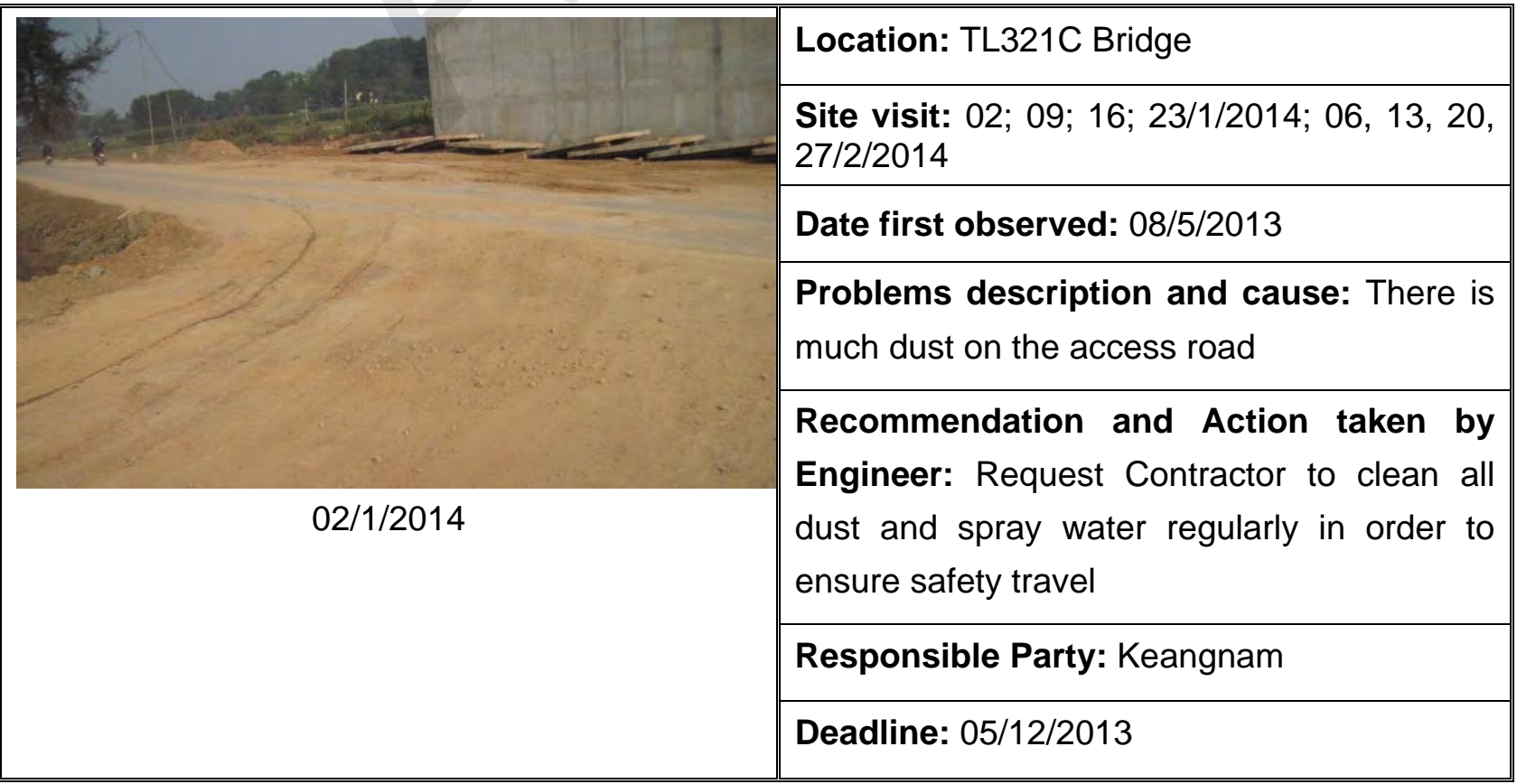




\section{Loan 2391/2392 - VIE: GMS Kunming - Hai Phong Transport Corridor Noi Bai - Lao Cai Highway Project}
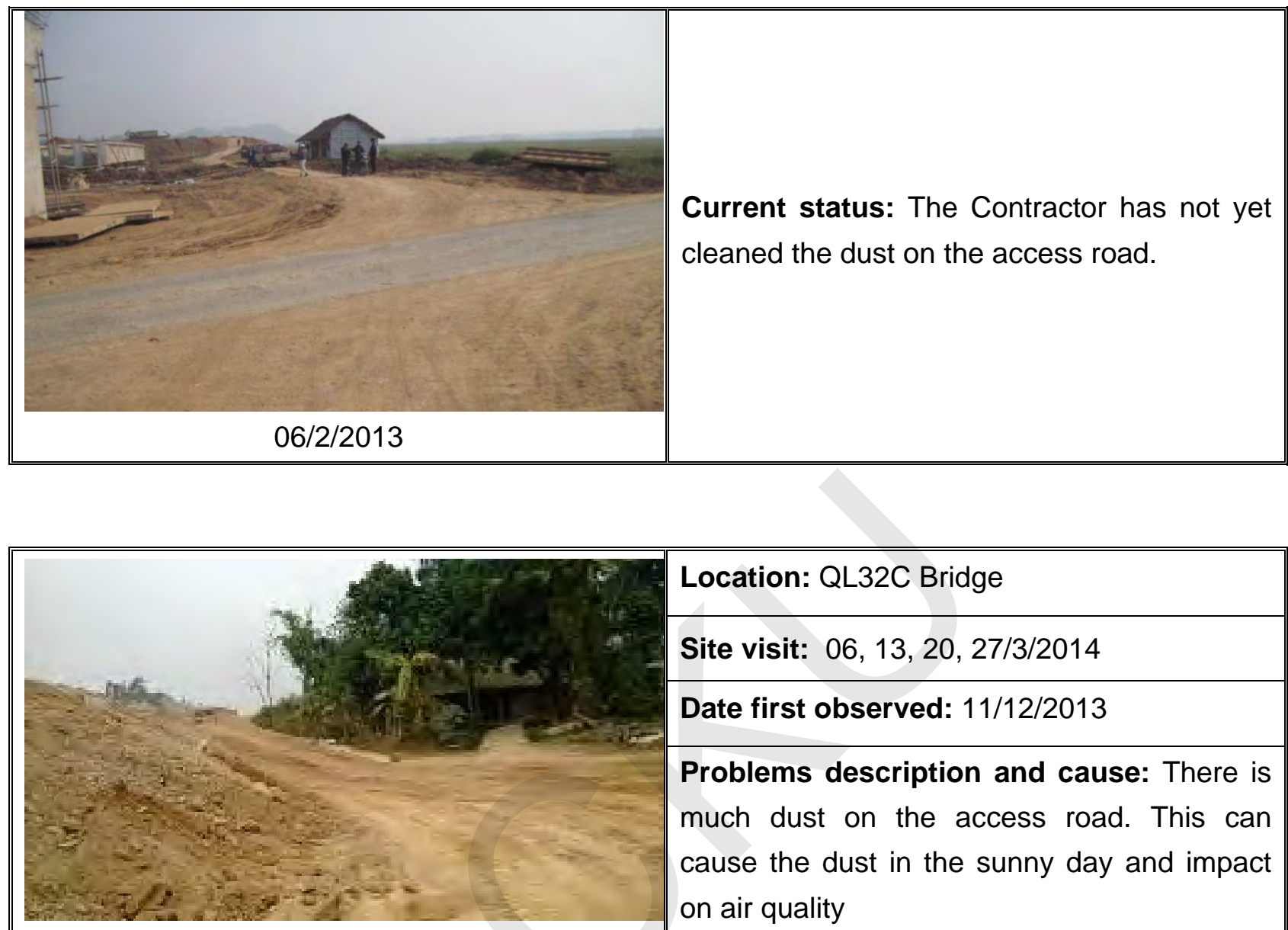

Location: QL32C Bridge

Site visit: $06,13,20,27 / 3 / 2014$

Date first observed: $11 / 12 / 2013$

Problems description and cause: There is much dust on the access road. This can cause the dust in the sunny day and impact on air quality

$13 / 2 / 2014$

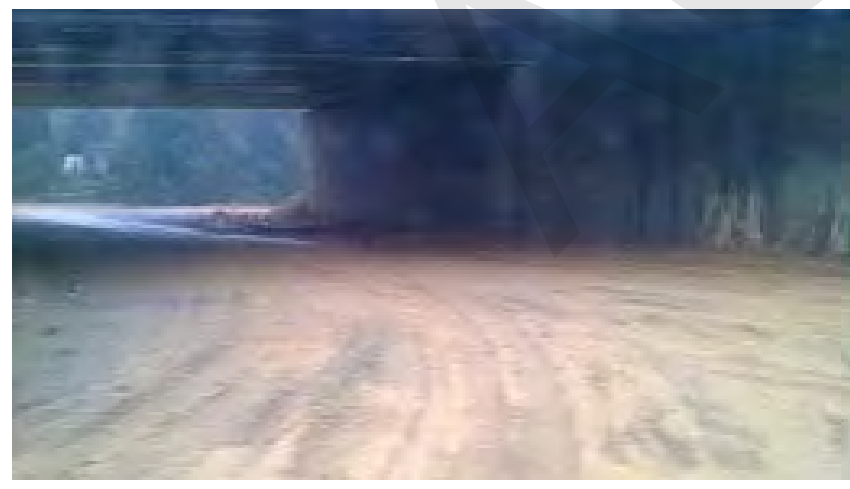

Recommendation and Action taken by

Engineer: The contactor is requested to clean the surface of the road and to spray water frequently in order to decrease dust concentration on the access road

Responsible Party: KEANGNAM

Deadline: 03/03/2014

$06 / 3 / 2014$

Current status: The Contractor did not clean soil on the road. 


\section{Loan 2391/2392 - VIE: GMS Kunming - Hai Phong Transport Corridor Noi Bai - Lao Cai Highway Project}

\subsubsection{Package A5}

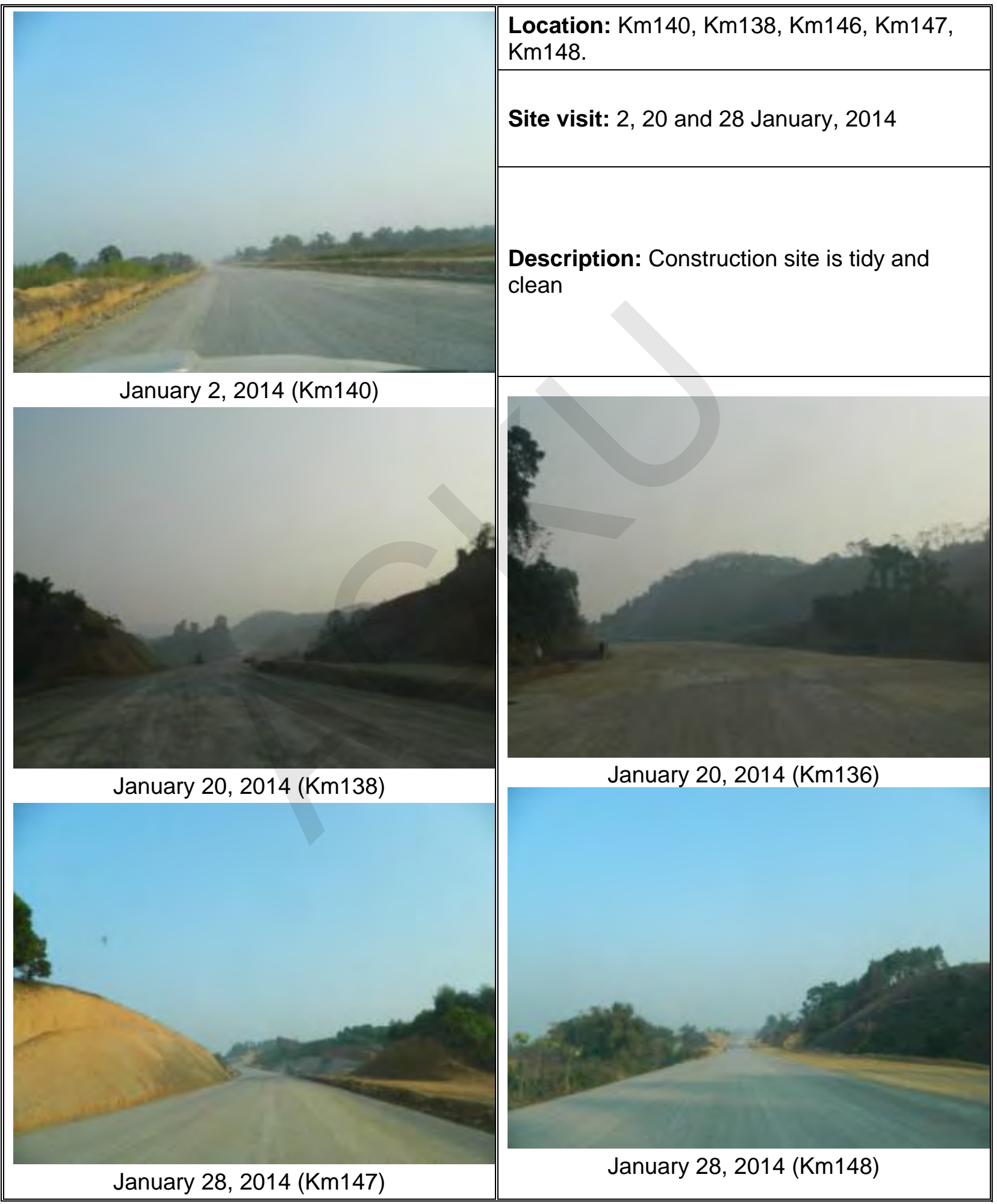




\section{Loan 2391/2392 - VIE: GMS Kunming - Hai Phong Transport Corridor Noi Bai - Lao Cai Highway Project}

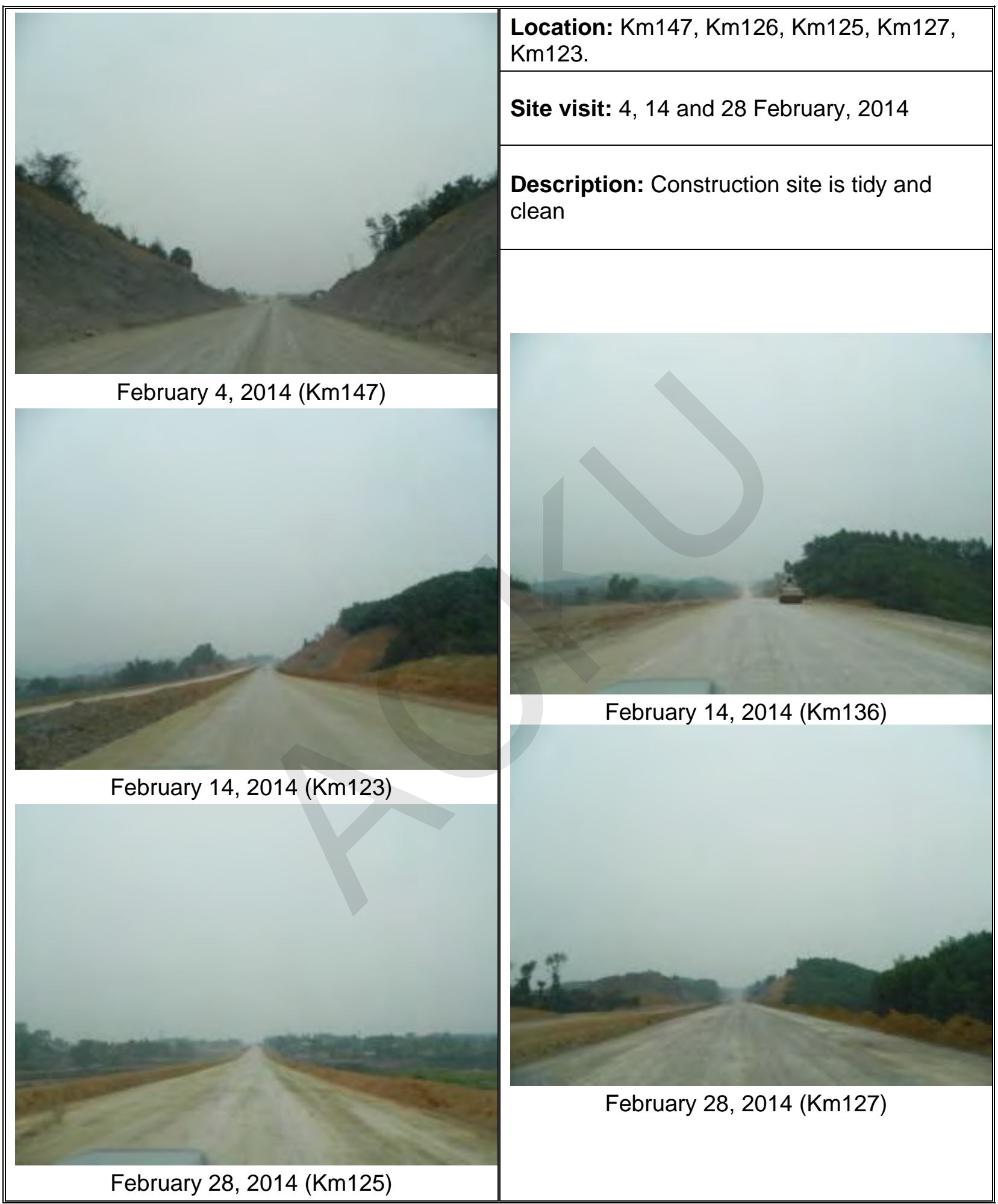




\section{Loan 2391/2392 - VIE: GMS Kunming - Hai Phong Transport Corridor Noi Bai - Lao Cai Highway Project}

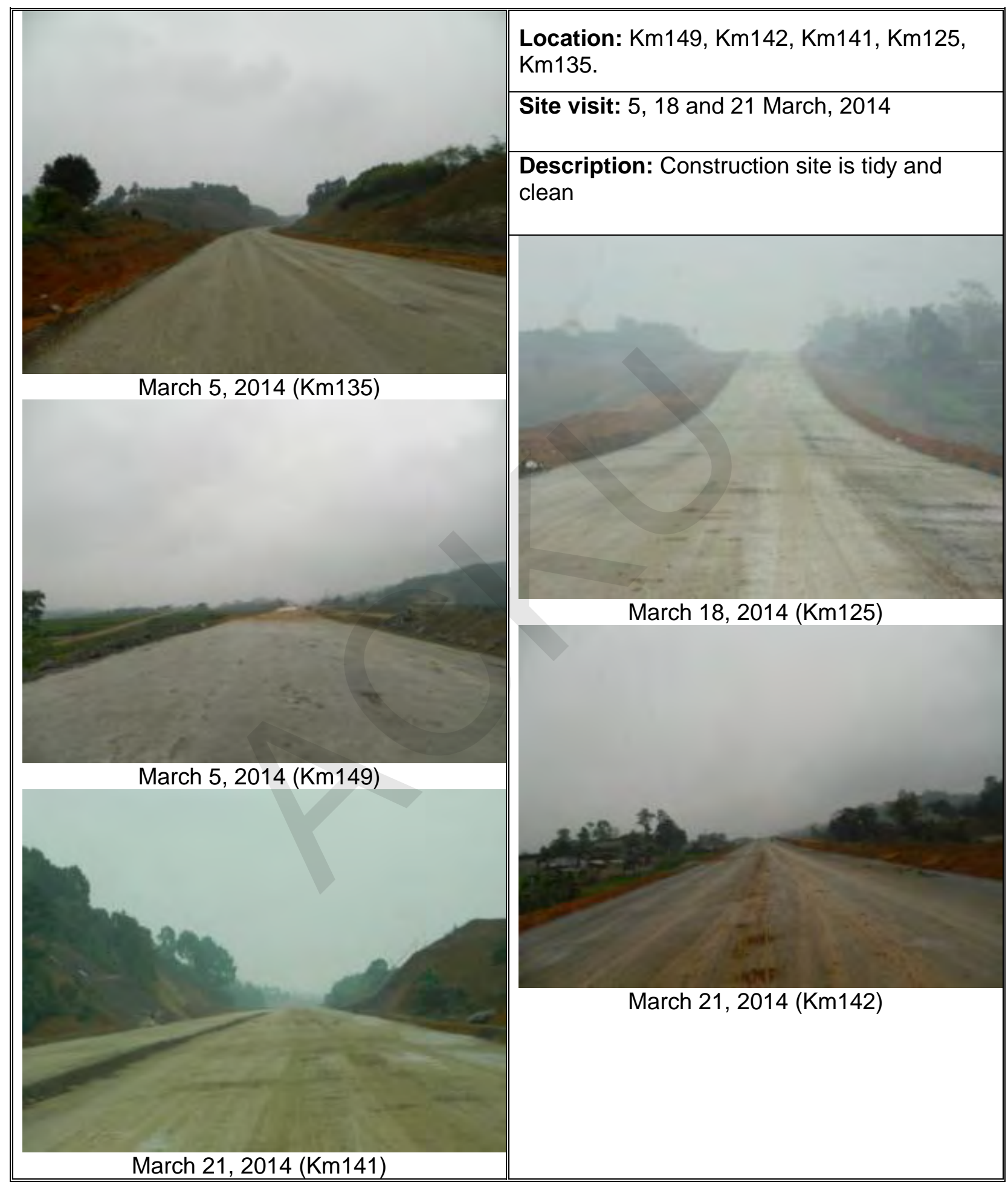




\section{Loan 2391/2392 - VIE: GMS Kunming - Hai Phong Transport Corridor Noi Bai - Lao Cai Highway Project}

\subsubsection{Package A6}

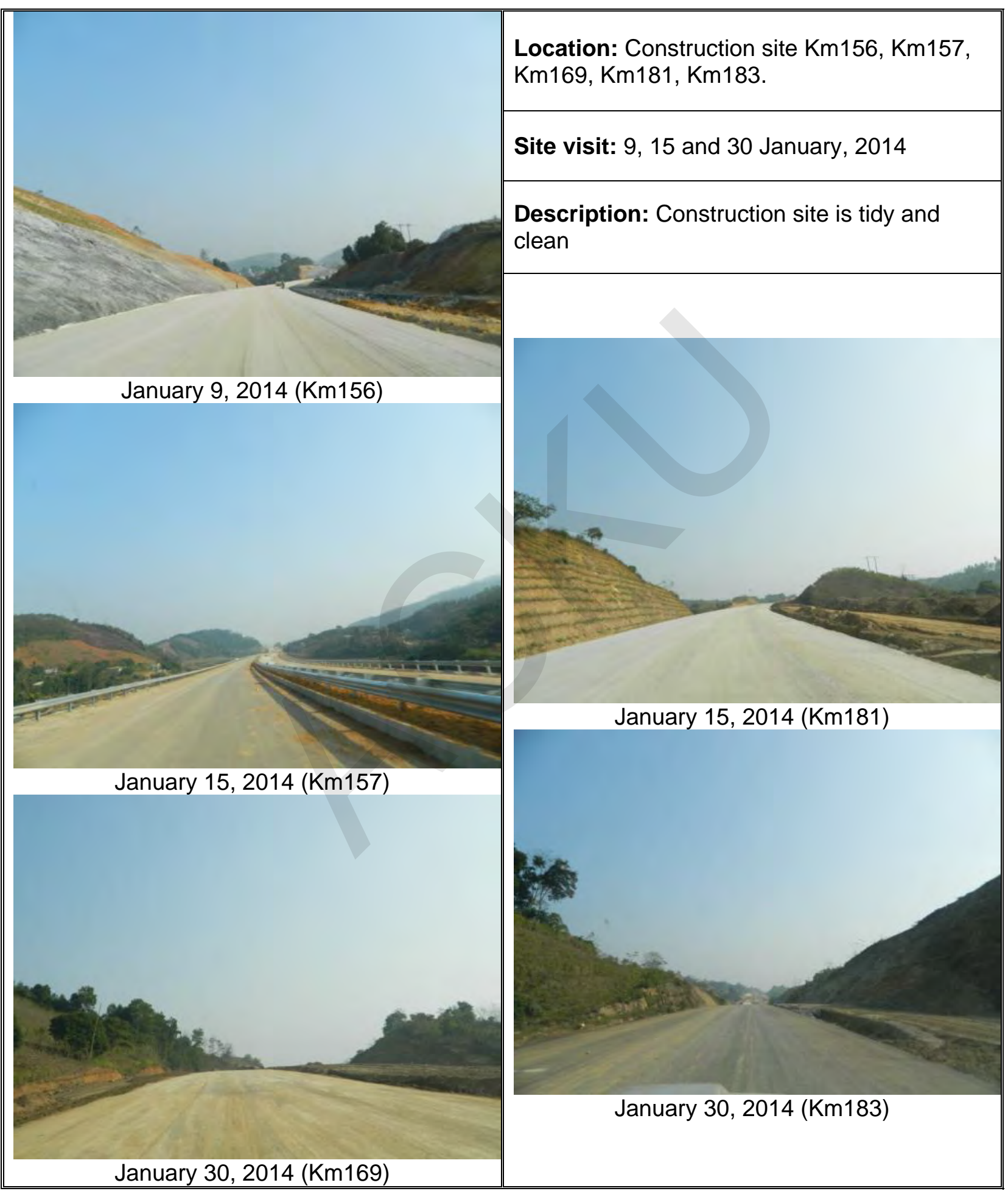




\section{Loan 2391/2392 - VIE: GMS Kunming - Hai Phong Transport Corridor Noi Bai - Lao Cai Highway Project}

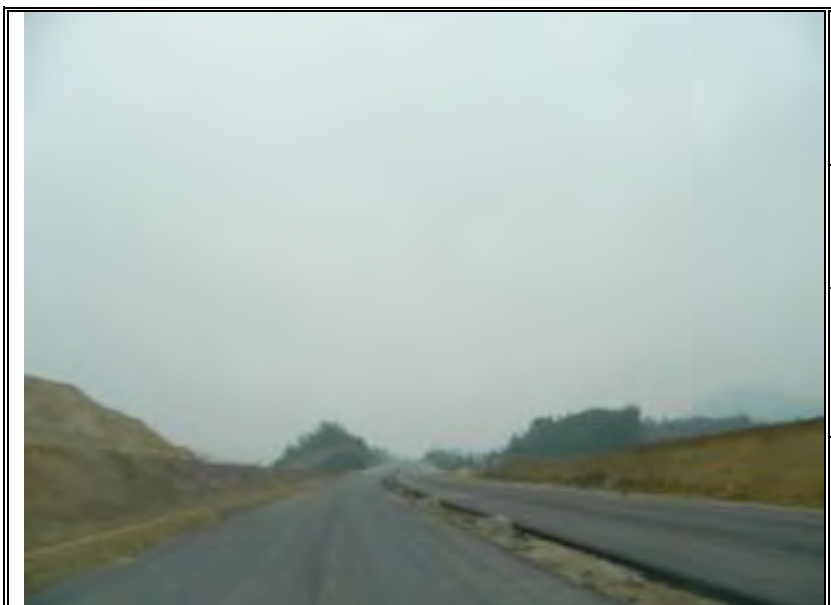

Location: Construction site $\mathrm{Km} 171, \mathrm{Km} 170$, Km174, Km176, Km168.

Site visit: 8, 10 and 16 February, 2014

Description: Construction site is tidy and clean

February 8, 2014 (Km171)
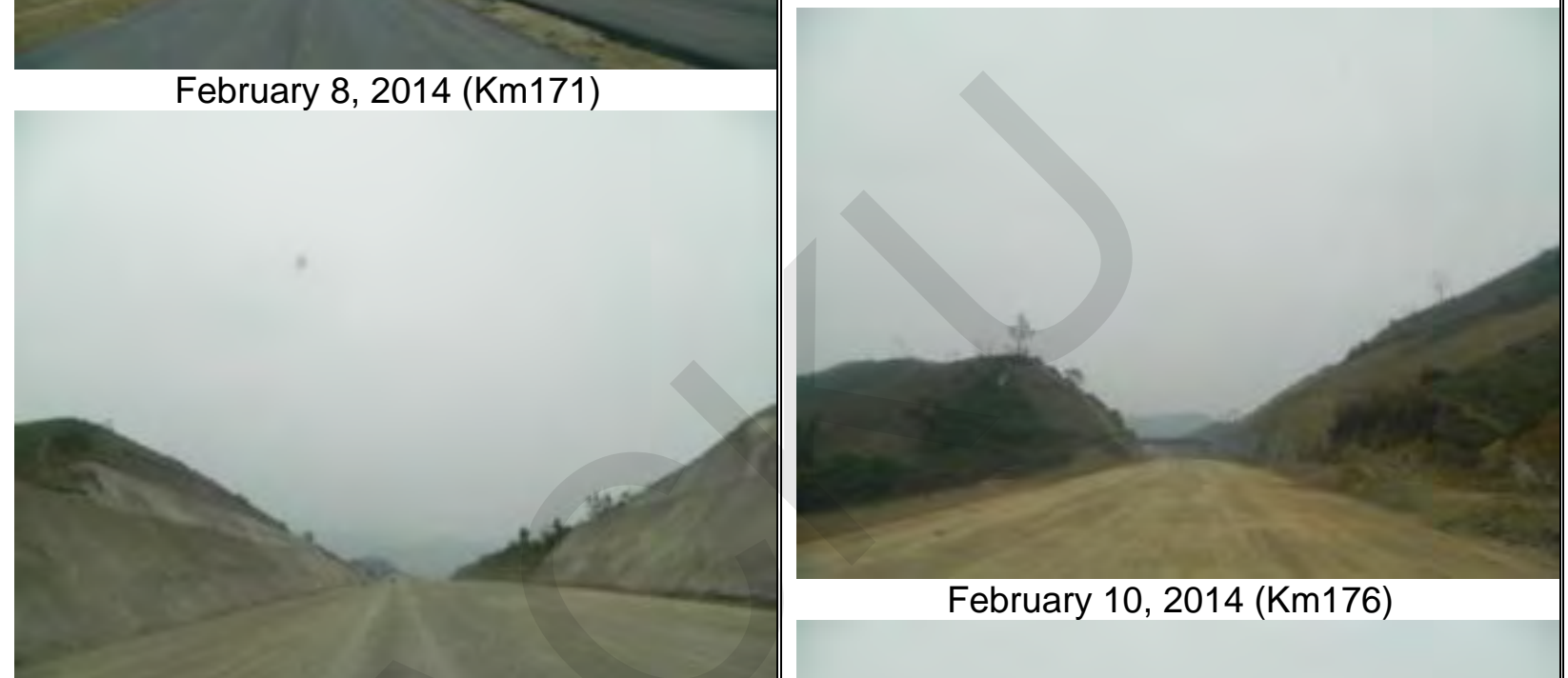

February 10, 2014 (Km170)

February 10, 2014 (Km176)
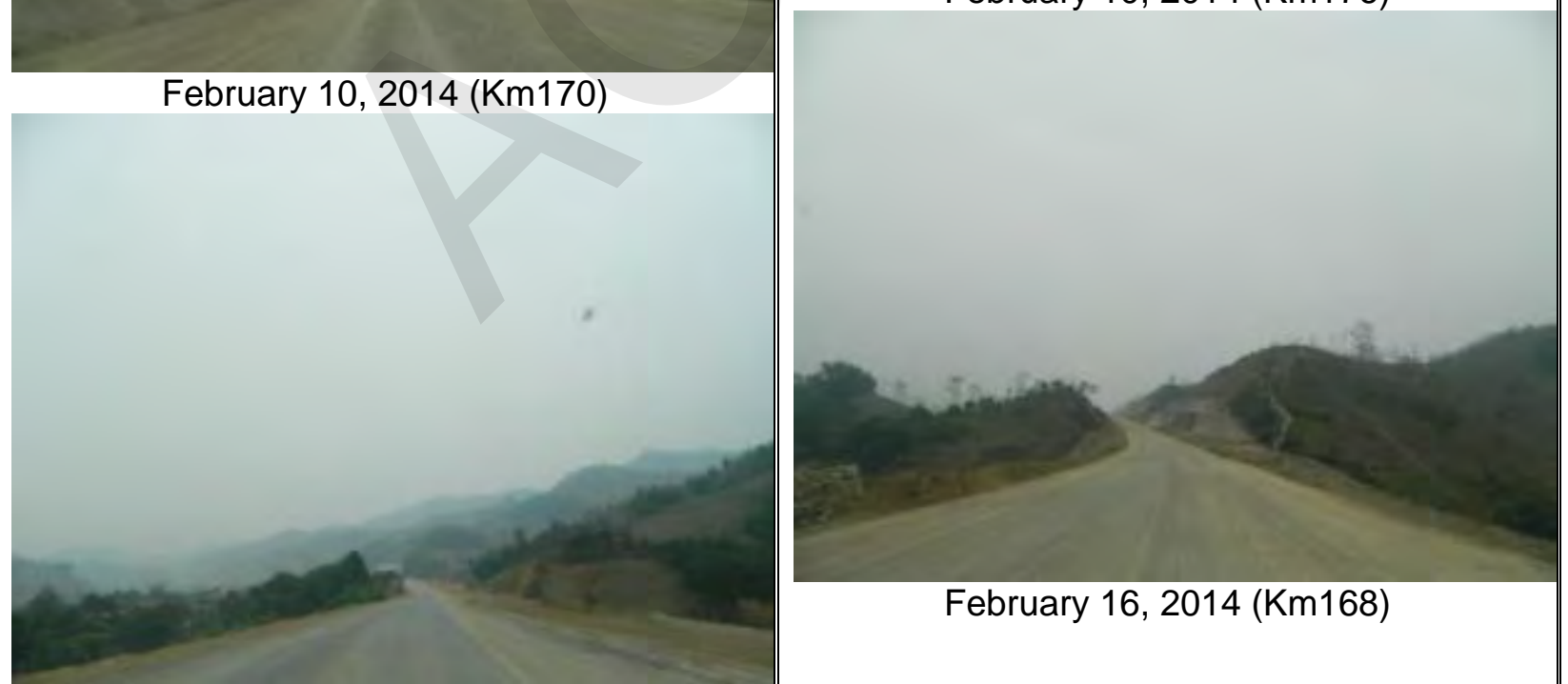

February 16, 2014 (Km168)

February 16, 2014 (Km174) 


\section{Loan 2391/2392 - VIE: GMS Kunming - Hai Phong Transport Corridor Noi Bai - Lao Cai Highway Project}

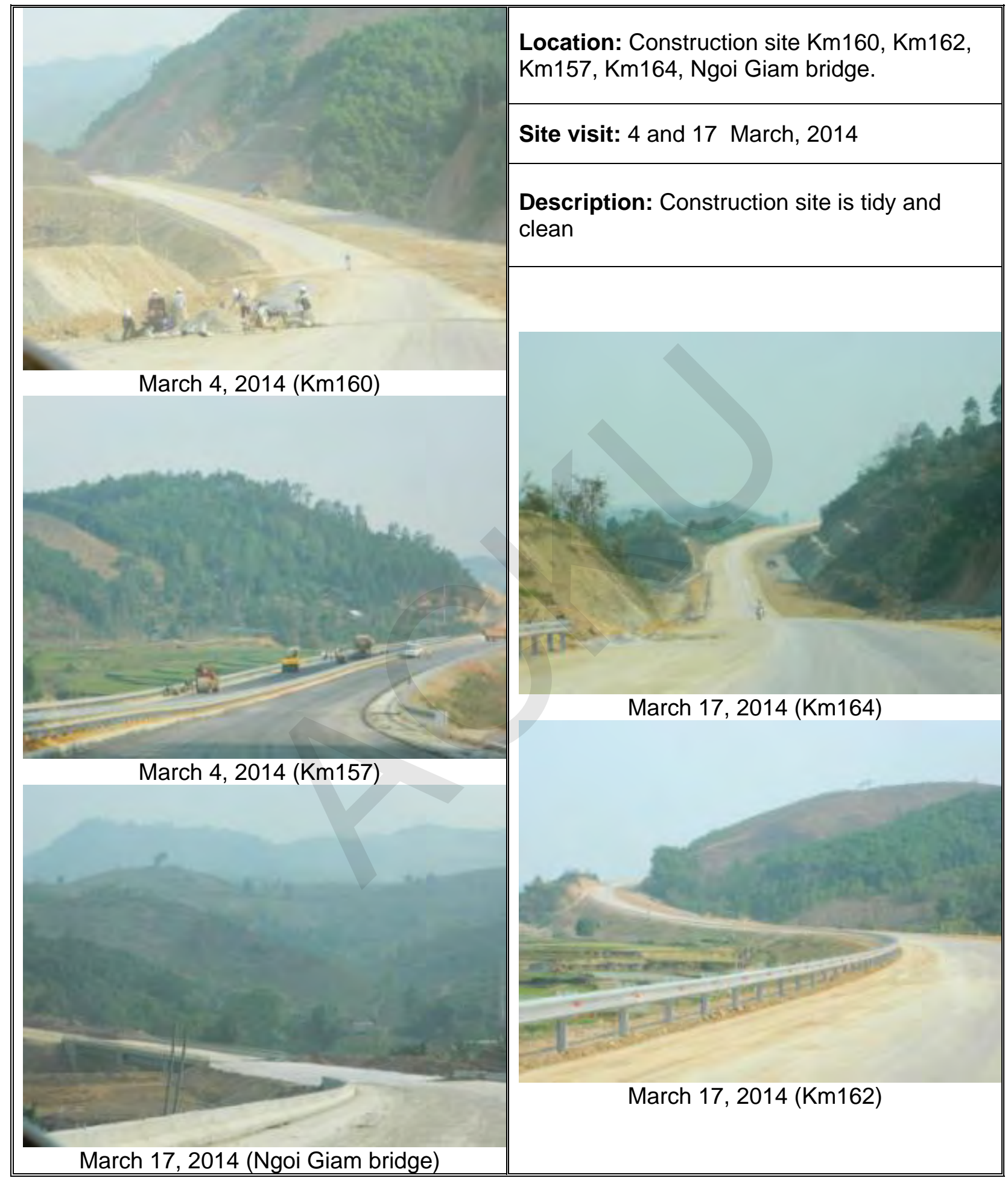




\section{Loan 2391/2392 - VIE: GMS Kunming - Hai Phong Transport Corridor Noi Bai - Lao Cai Highway Project}

\subsubsection{Package A7}

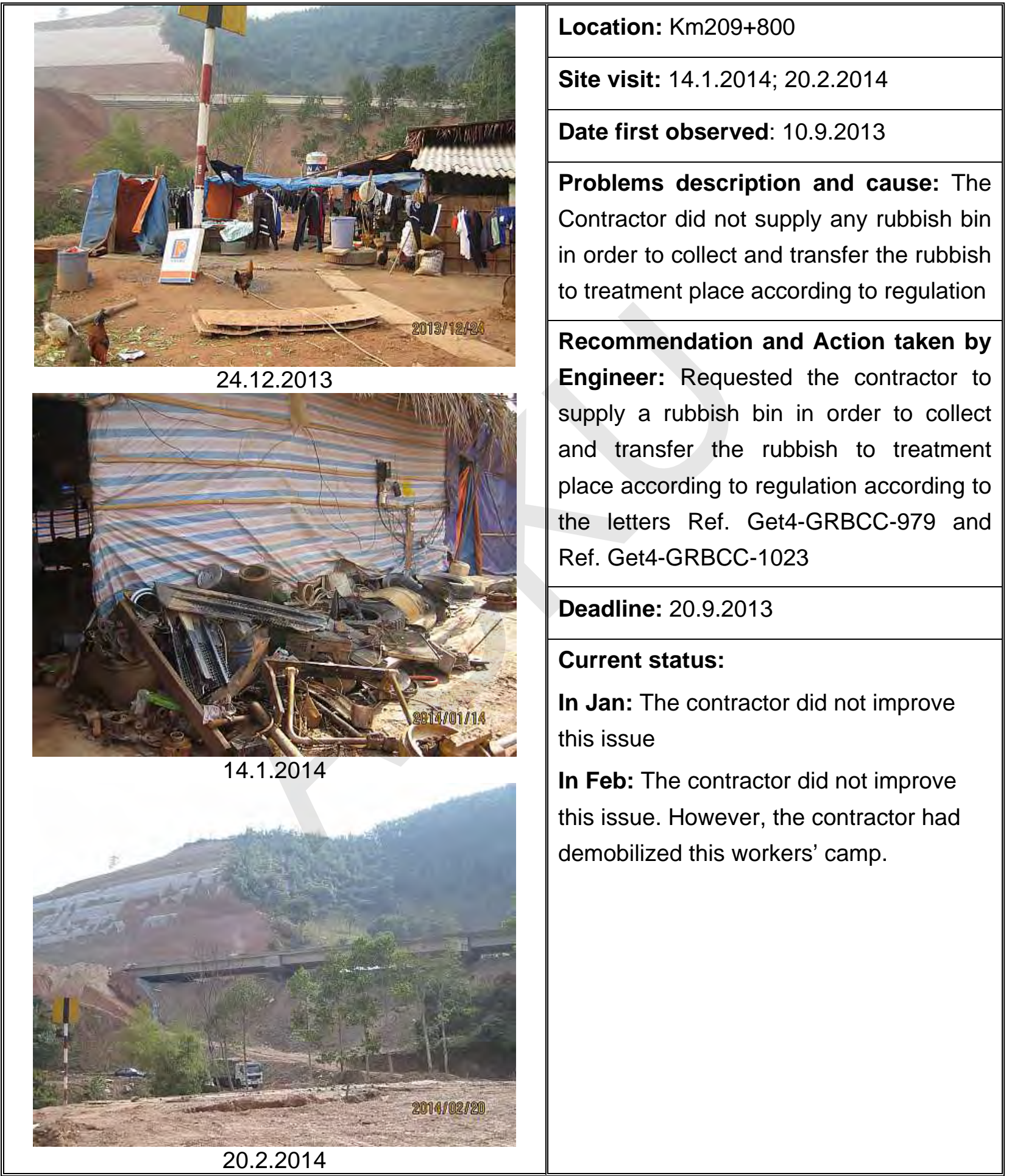




\section{Loan 2391/2392 - VIE: GMS Kunming - Hai Phong Transport Corridor Noi Bai - Lao Cai Highway Project}

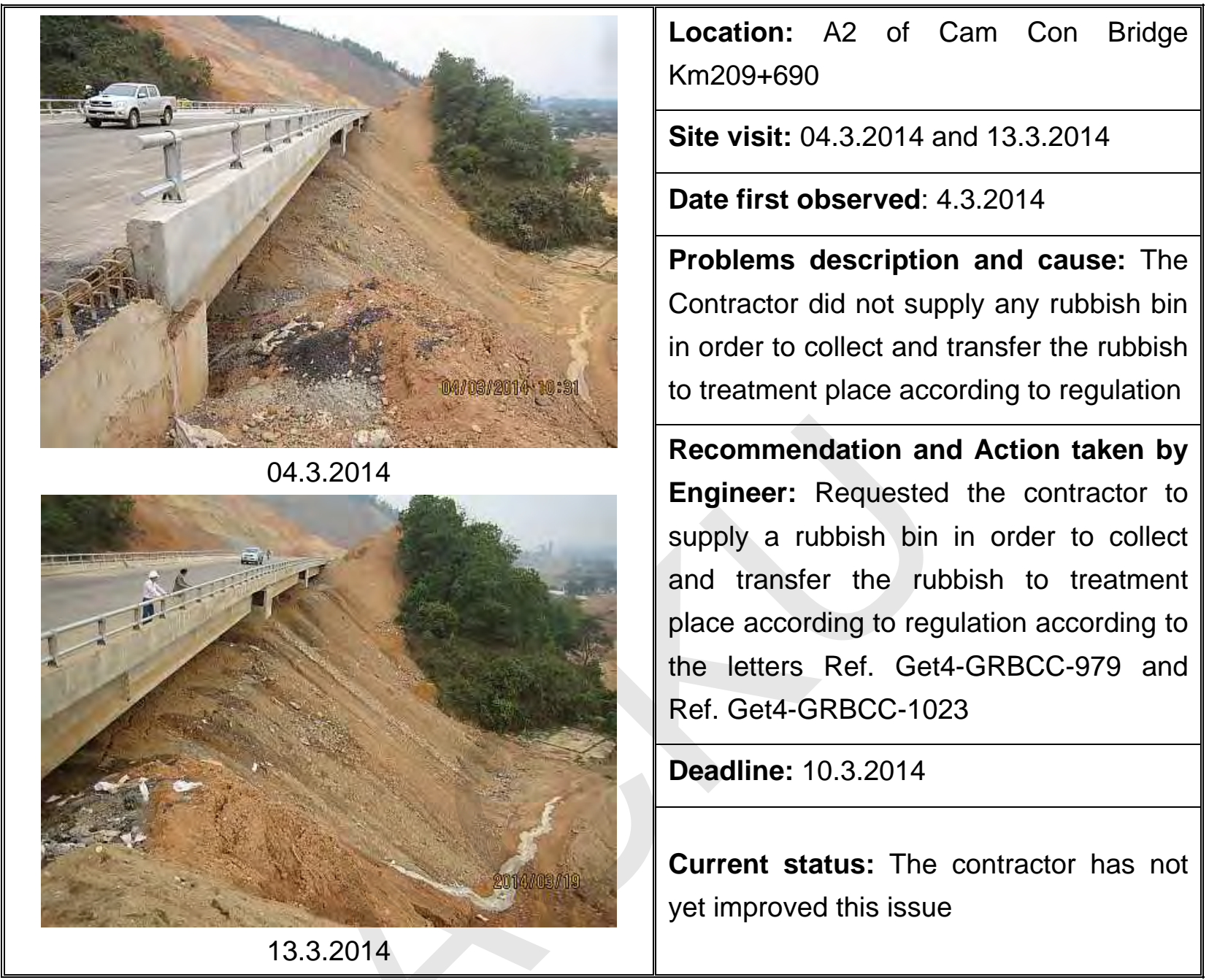




\section{Loan 2391/2392 - VIE: GMS Kunming - Hai Phong Transport Corridor Noi Bai - Lao Cai Highway Project}

\subsubsection{Package A8}

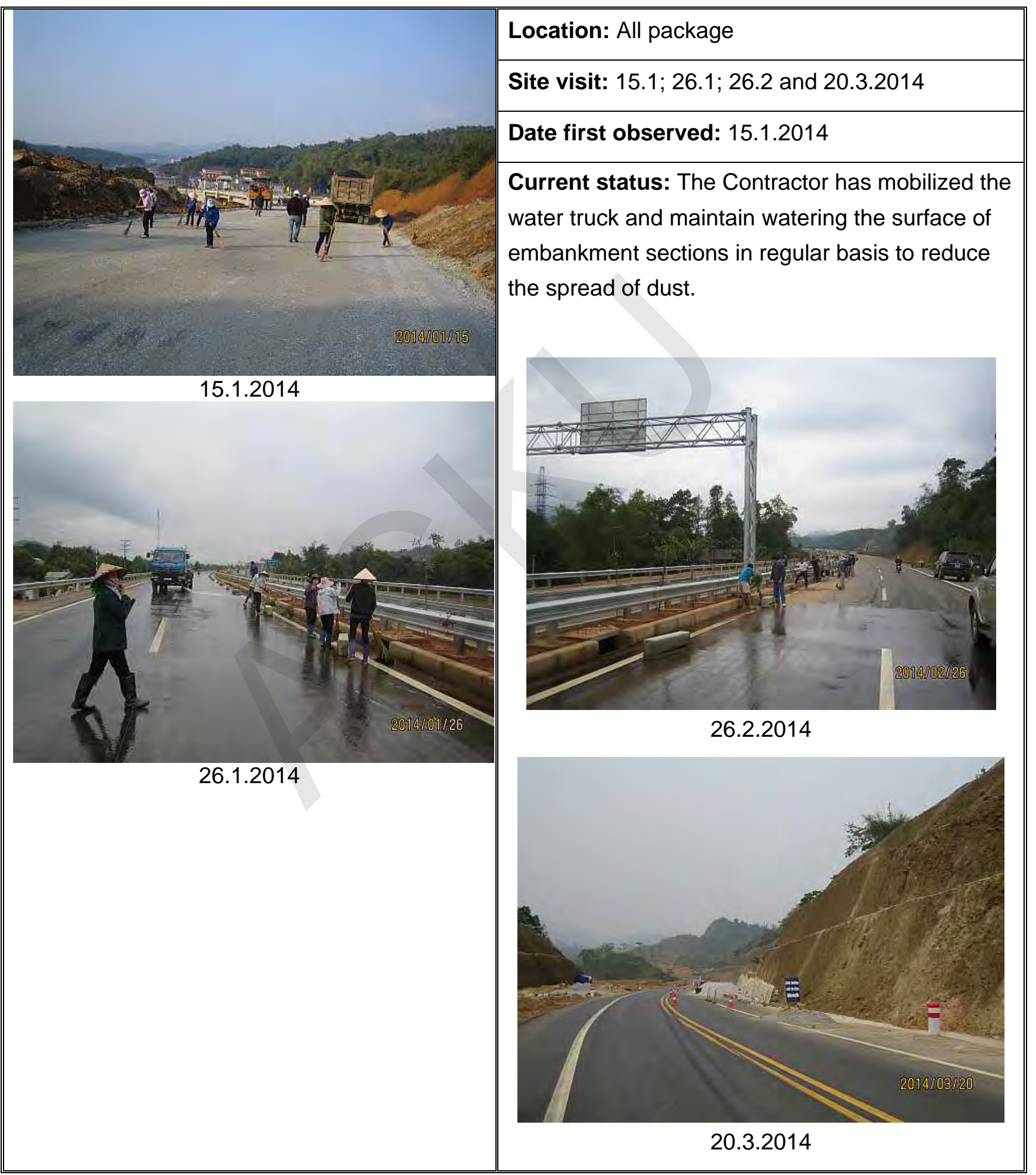


Loan 2391/2392 - VIE: GMS Kunming - Hai Phong Transport Corridor Noi Bai - Lao Cai Highway Project

\subsection{BIODIVERSITY PRESERVATION}

\subsubsection{Package A1}

At the present, at package A1, the Contractor has finished all construction works.

\subsubsection{Package A2}

In this period, during the site inspections, we did not find any serious impacts, which arise from construction activities of the project, on biodiversity preservation.

\subsubsection{Package A3}

In this period, according to the observations and based on the monitoring results of analysis the environmental air quality, noise and surface water in this quarter shows that ecosystems and the resident activities of the local community people around of construction area are still normally, not detected any bad impact from the construction activities on them. Until now, The Consultant has not received report about plants and animals died by machinery or vehicle operations inside the limits of construction zone or in the close sorroundings.

\subsubsection{Package A4}

In this period, according to the observations and based on the monitoring results of analysis the environmental air quality, noise and surface water in this quarter shows that ecosystems and the resident activities of the local community people around of construction area are still normally, not detected any bad impact from the construction activities on them. Until now, The Consultant has not received report about plants and animals died by machinery or vehicle operations inside the limits of construction zone or in the close sorroundings.

\subsubsection{Package A5}

During inspection and supervision on construction site in this period, the Consultant found that the Contractor's construction activities have not caused any serious impact to the fauna and flora at the region. However, to ensure the regional environment, the Consultant has frequently required the Contractor to comply with Method Statement, Environment Control and Protection Plan to prevent adverse impacts to the regional fauna and flora. 


\subsubsection{Package A6}

In this period, through the inspection and supervision on site this month, the Consultant found that the Contractor's construction activities have not caused serious impacts on the fauna and flora of the region. However, to ensure the environment of the area, the Consultant has frequently required the Contractor to comply with Method Statement, Environmental Control and Protection Plan to prevent adverse impacts on the regional fauna and flora.

In addition, in the inspections on site and weekly meetings, the Consultant has also recommended the Contractor to hold propaganda for workers and engineers to raise the awareness of biodiversity protection in the project's construction process.

\subsubsection{Package A7}

In this period, the clearing and grubbing had finished along of package A7 from Km190+420 to $\mathrm{Km} 218+040$. And during construction work didn't have animal extinct or damage by construction work of the contractor, this showing in monthly report of the contractor.

\subsubsection{Package A8}

Up to now the activities of the Contractor didn't cause negative effect to animal and plan and biodiversity preservation in area as well as. However, consultant always reminded the contractor to apply some methods to mitigate impact to environment in general and living being particularly on the construction site.

\subsection{WORKERS' CAMPS CONDITIONS}

\subsubsection{Package A1}

At the present, at package A1, the Contractor has finished all construction works.

\subsubsection{Package A2}

At this time, there is no worker's camp maintained onsite. 


\section{Loan 2391/2392 - VIE: GMS Kunming - Hai Phong Transport Corridor Noi Bai - Lao Cai Highway Project}

\subsubsection{Package A3}

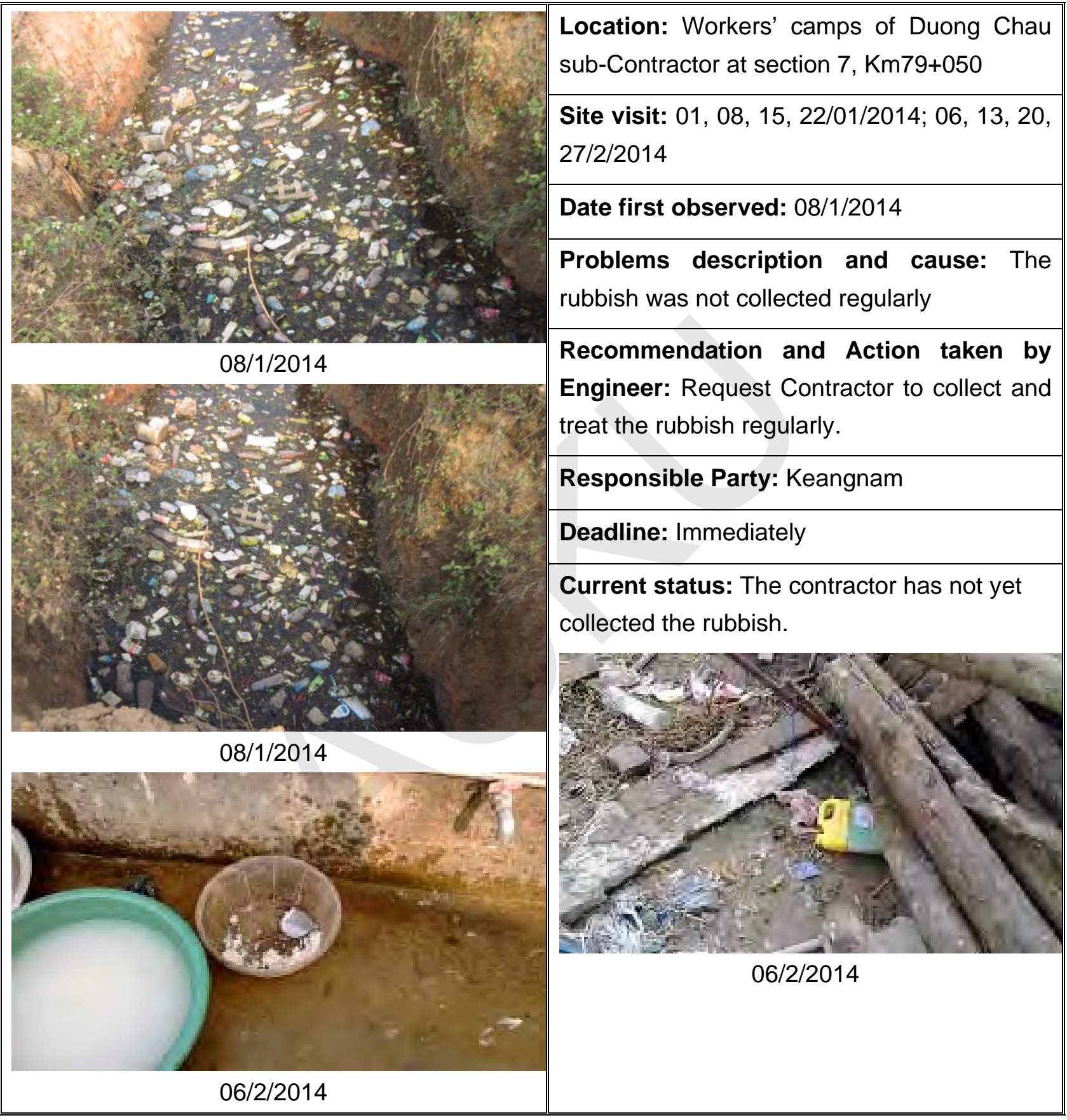

In March, all workers' camps have been equipped with rubbishes, fire extinguishers and first aid kids in package A3. The workers' camp of Duong Chau Sub-Contractor at section 7 has been removed to the local people's house. 
Loan 2391/2392 - VIE: GMS Kunming - Hai Phong Transport Corridor Noi Bai - Lao Cai Highway Project

\begin{tabular}{||l|l|}
\hline & Location: Workers' Camp at Km79+050 \\
\cline { 2 - 2 } & Site visit: $12 / 3 / 2014$ \\
\hline & Date first observed: \\
\hline & Problems description and cause: \\
\hline & $\begin{array}{l}\text { Recommendation and Action taken by } \\
\text { Engineer: }\end{array}$ \\
\hline & Responsible Party: POSCO \\
\hline $12 / 3 / 2014$ & Deadline: \\
\hline & Current status: \\
\hline
\end{tabular}

\subsubsection{Package A4}

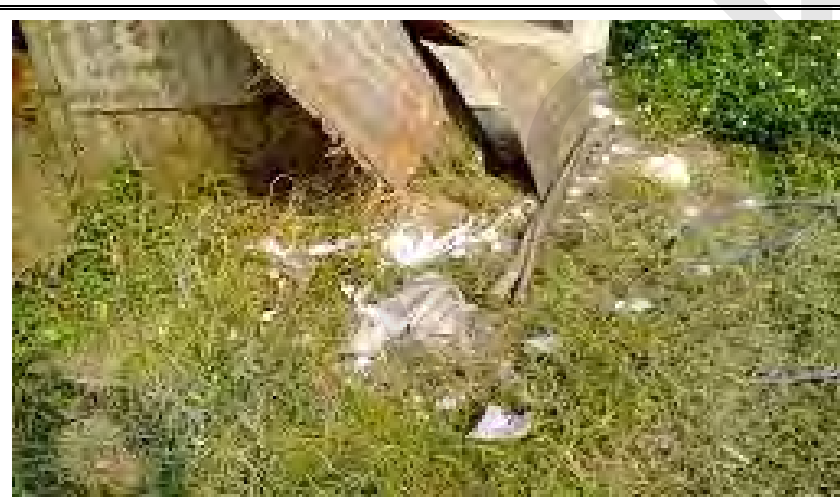

$19 / 12 / 2013$

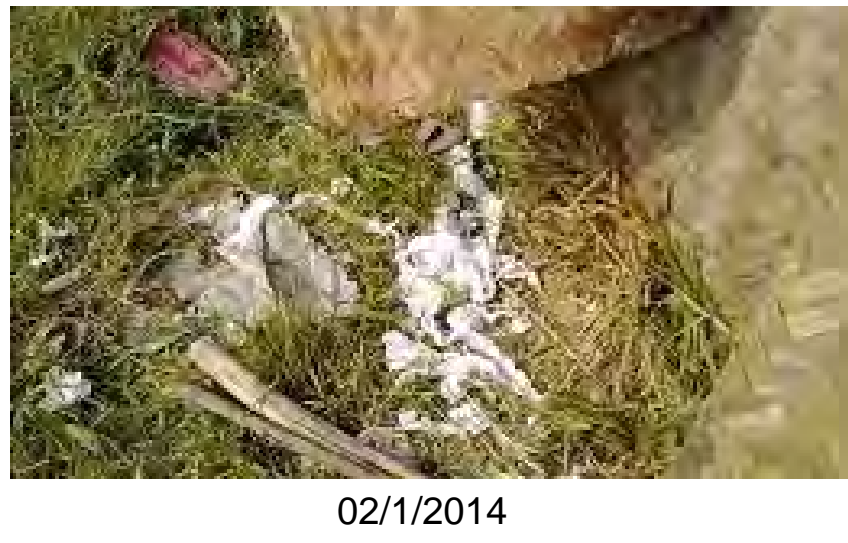

Location: Workers' camps at Ngoi Gianh Bridge

Site visit: $02 ; 09 ; 16 ; 23 / 1 / 2014 ; 06,13,20$, $27 / 2 / 2014$

Date first observed: $07 / 3 / 2013$

Problems description and cause: Rubbish was not collected regularly

Recommendation and Action taken by Engineer: Request Contractor to collect and treat the rubbish regularly according to the Consultant 's instruction.

Responsible Party: Keangnam

Deadline: Immediately

Current status: The contractor has not yet collected the rubbish. 
Loan 2391/2392 - VIE: GMS Kunming - Hai Phong Transport Corridor Noi Bai - Lao Cai Highway Project

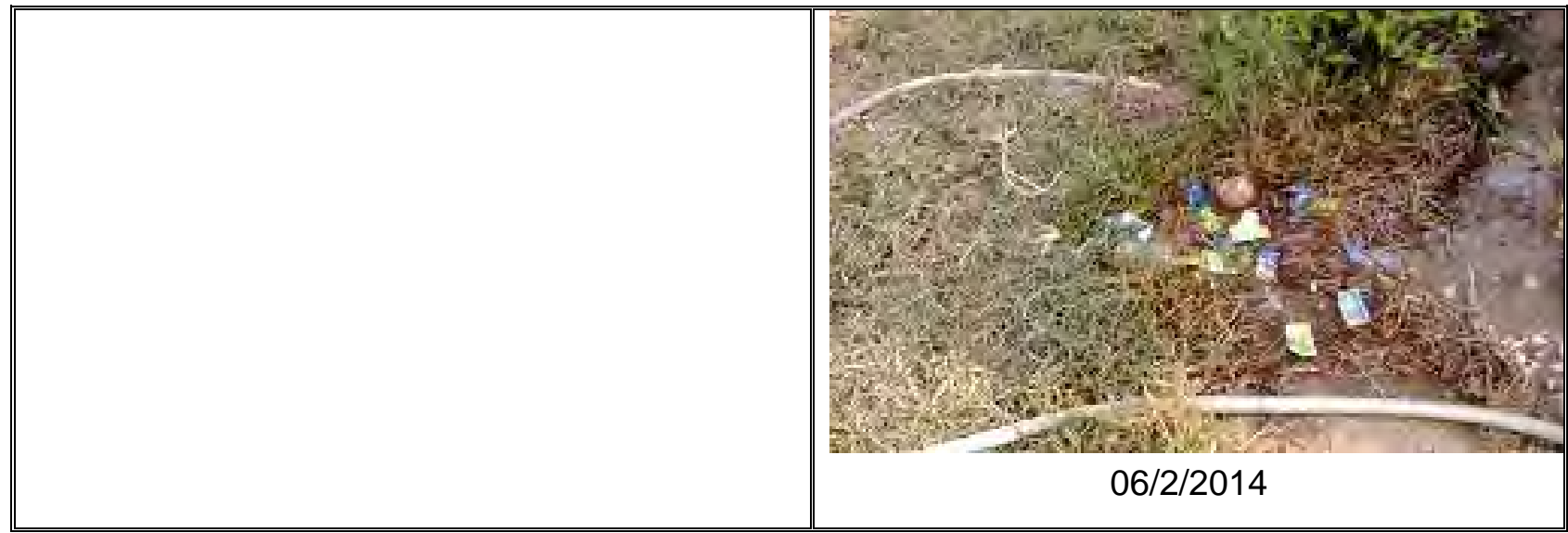

The Workers' camps of Sub-Contractor at Ngoi Van bridge has been removed to the local people's house.

\begin{tabular}{|c|c|}
\hline & Location: TL321C Bridge \\
\hline & Site visit: $13 / 3 / 2014$ \\
\hline & Date first observed: \\
\hline & Problems description and cause: \\
\hline & $\begin{array}{l}\text { Recommendation and Action taken by } \\
\text { Engineer: }\end{array}$ \\
\hline & Responsible Party: KEANGNAM \\
\hline & Deadline: \\
\hline & Current status: \\
\hline
\end{tabular}


Loan 2391/2392 - VIE: GMS Kunming - Hai Phong Transport Corridor Noi Bai - Lao Cai Highway Project

\subsubsection{Package A5}

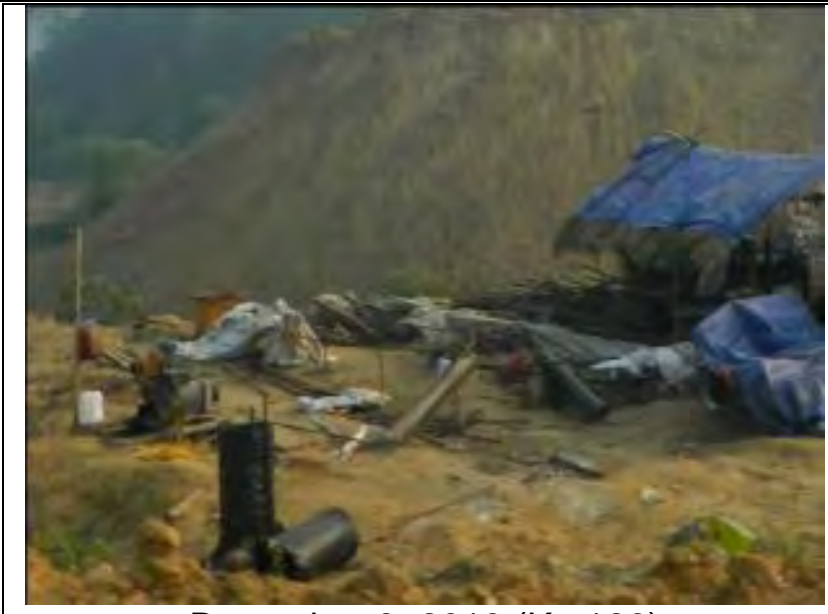

December 3, 2013 (Km126)

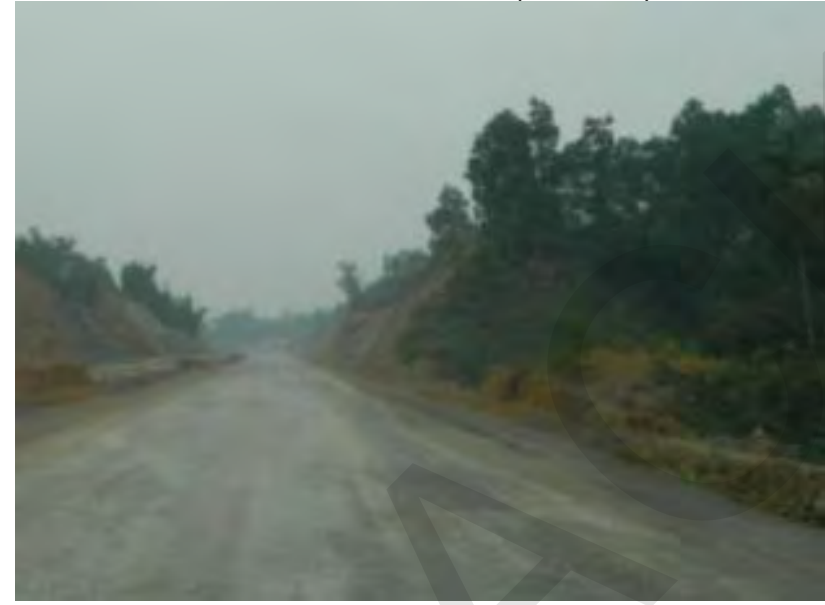

January 7, 2014 (Km126)
Location: The worker's camp at Km126

Site visit: 7 January, 2014

Date first observed: $11^{\text {th }}$ November, 2013

Problems description and cause: This camp has not been maintained in the good condition by the Contractor (e.g. 1.Rubbish is not collected in order to treat regularly; 2 . Lack of dustbin and first-aid kits, 3 . The workers' camp is dirty, 4 . Construction materials are not tidy).

Recommendation and Action taken by Engineer: The Engineer requested the Contractor to improve the living and working condition at this camp.

Responsible Party: Keangnam Contractor

Deadline: 18-Nov-2013

\section{Current status:}

- $7^{\text {th }}$ January, 2014: Most item of this Up-box culvert were completed by sub-contractor, therefore all workers did not live at this camp. The Contractor is starting remove and clean this location. 


\section{Loan 2391/2392 - VIE: GMS Kunming - Hai Phong Transport Corridor Noi Bai - Lao Cai Highway Project}

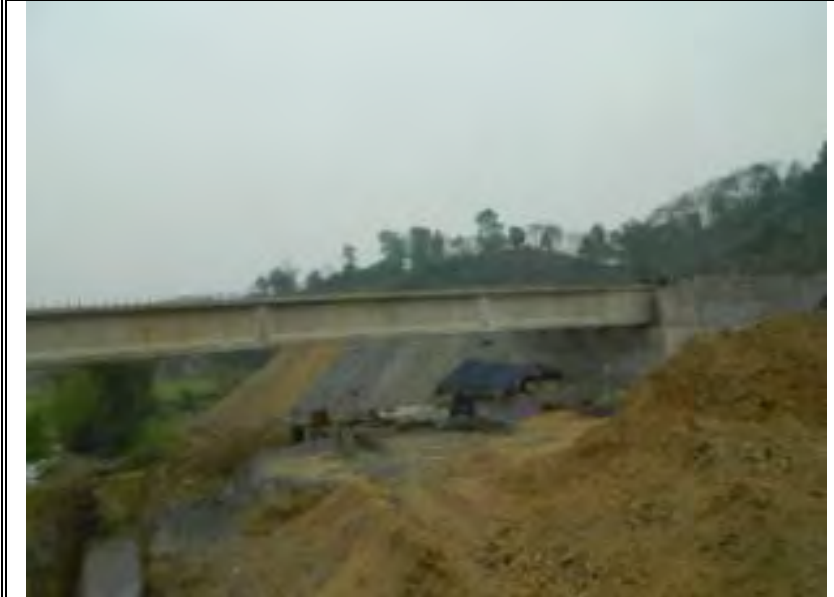

February 14, 2014 (Ngoi Thu bridge)

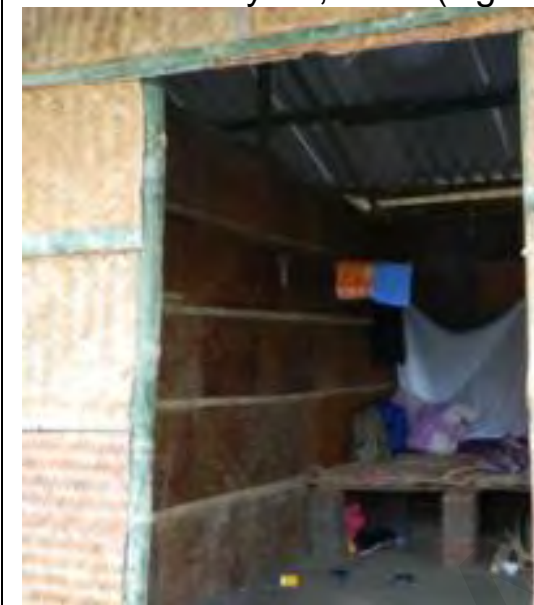

February 28, 2013 (Ngoi Thu bridge)

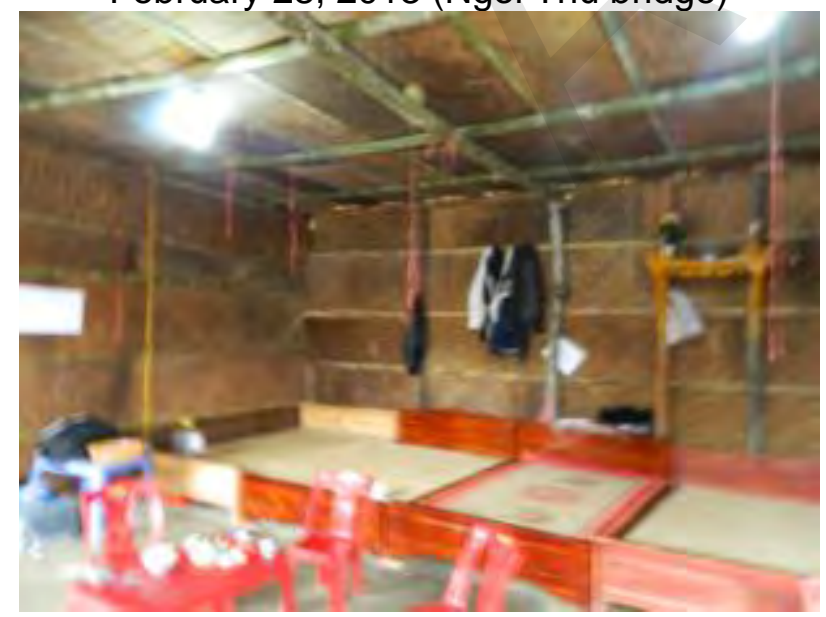

March 12, 2014 (Ngoi Thu bridge)
Location: The worker's camp at Ngoi Thu bridge

Site visit: 14 and 28 February; 12 March 2014

Date first observed: $14^{\text {th }}$ February, 2014

Problems description and cause: This camp has not been maintained in the good condition by the Contractor (e.g. 1.Rubbish is not collected in order to treat regularly; 2 . Lack of dustbin and first-aid kits, 3 . The workers' camp is dirty, 4. Construction materials are not tidy).

Recommendation and Action taken by Engineer: The Engineer requested the Contractor to improve the living and working condition at this camp.

Responsible Party: Keangnam Contractor

Deadline: 25-Feb-2014

\section{Current status:}

In Feb: No improvement was seen for this problem.

On $12^{\text {th }}$ March, 2014: Sub-contractor has already cleaned this workers' camp but dustbins and first-aid kits still have not been provided at this location. 


\subsubsection{Package A6}

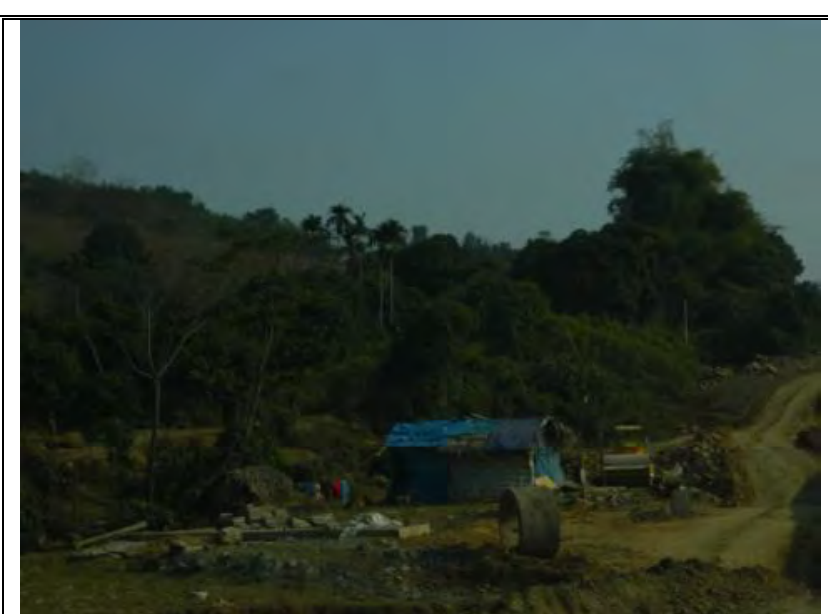

December 23, 2013 (Ngoi Chac bridge)

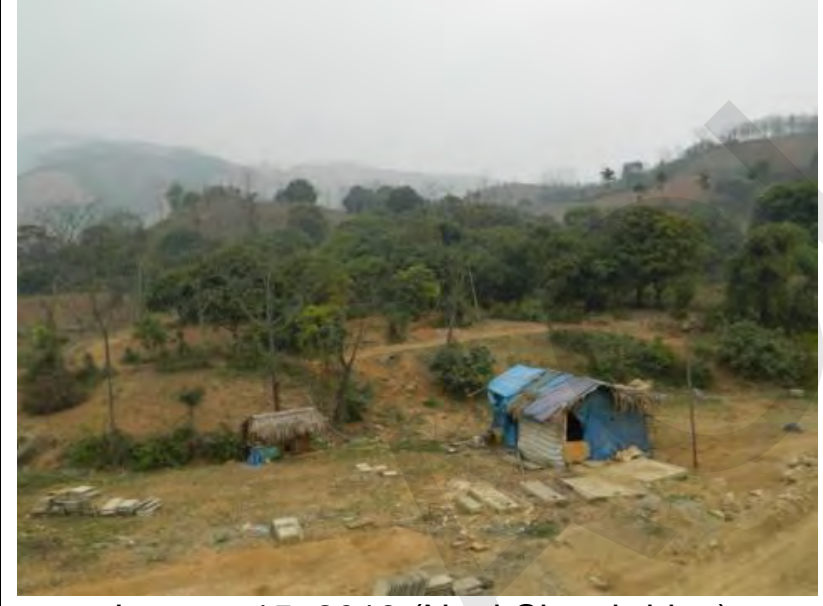

January 15, 2013 (Ngoi Chac bridge)
Location: The worker's camp at Ngoi Chac bridge

Site visit: 15 January, 2014

Date first observed: $19^{\text {th }}$ November, 2013

Problems description and cause: This camp has not been maintained in good condition by the Contractor (e.g. 1.Rubbish is not collected in order to treat; 2 . Lack of dustbin and first-aid kits 3. The workers' camp is dirty).

\section{Recommendation and Action taken by} Engineer: The Engineer requested the Contractor to improve living and working condition at this camp.

Responsible Party: Doosan Contractor

Deadline: 30- November-2013

\section{Current status:}

- 10 January, 2014: The Contractor is starting to remove the workers' camp and to clean this location. 


\section{Loan 2391/2392 - VIE: GMS Kunming - Hai Phong Transport Corridor Noi Bai - Lao Cai Highway Project}

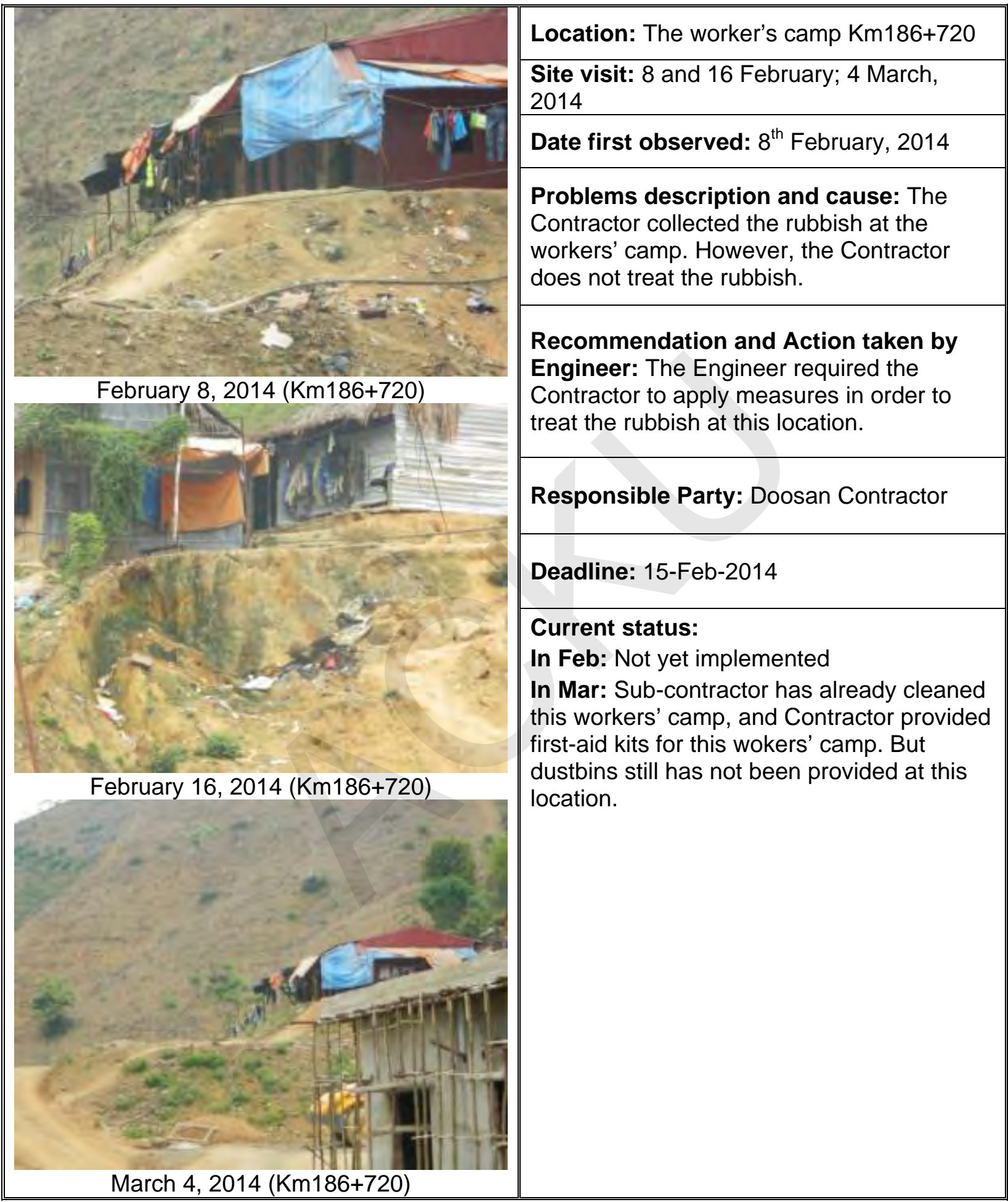


Loan 2391/2392 - VIE: GMS Kunming - Hai Phong Transport Corridor Noi Bai - Lao Cai Highway Project

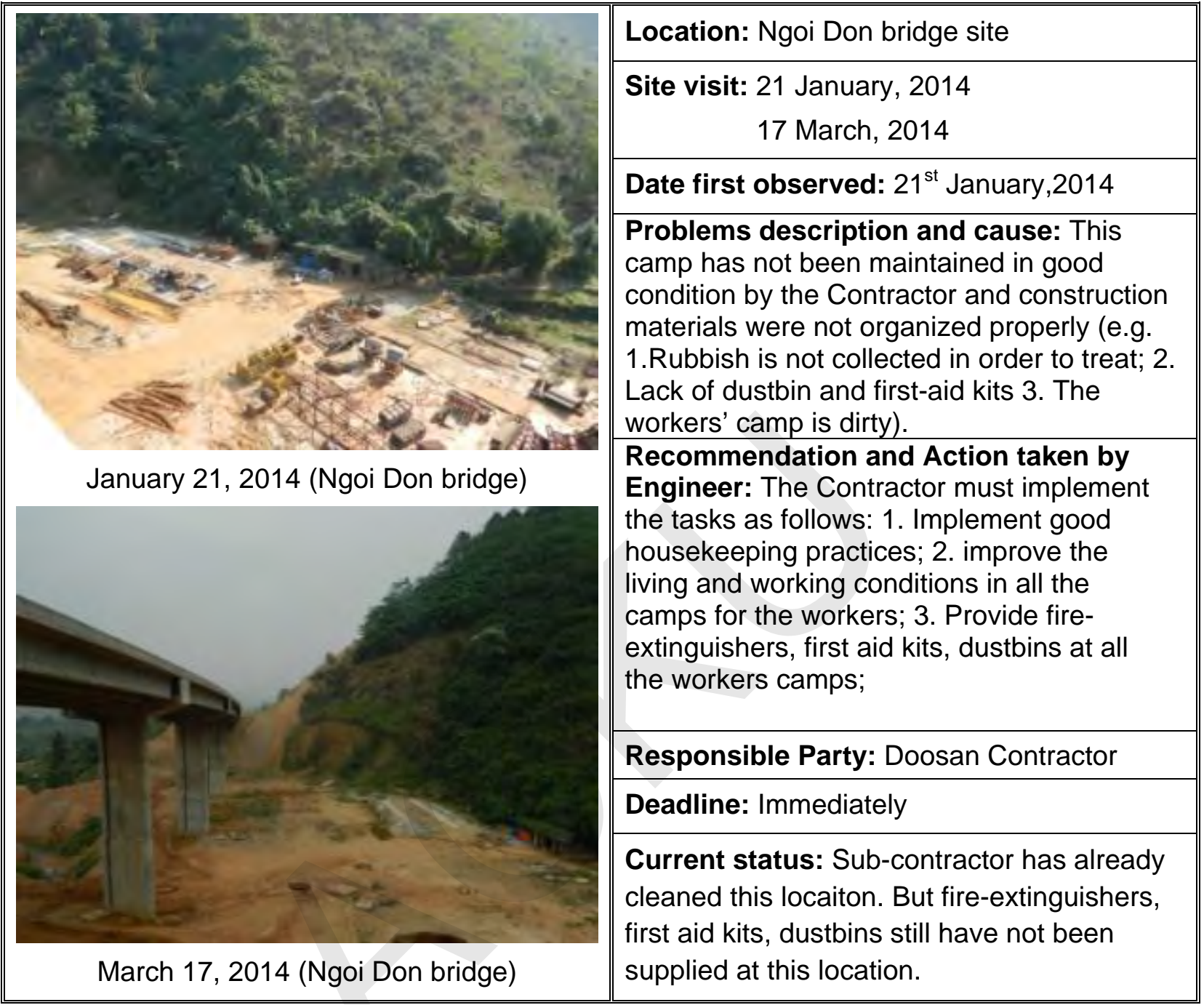




\section{Loan 2391/2392 - VIE: GMS Kunming - Hai Phong Transport Corridor Noi Bai - Lao Cai Highway Project}

\subsubsection{Package A7}

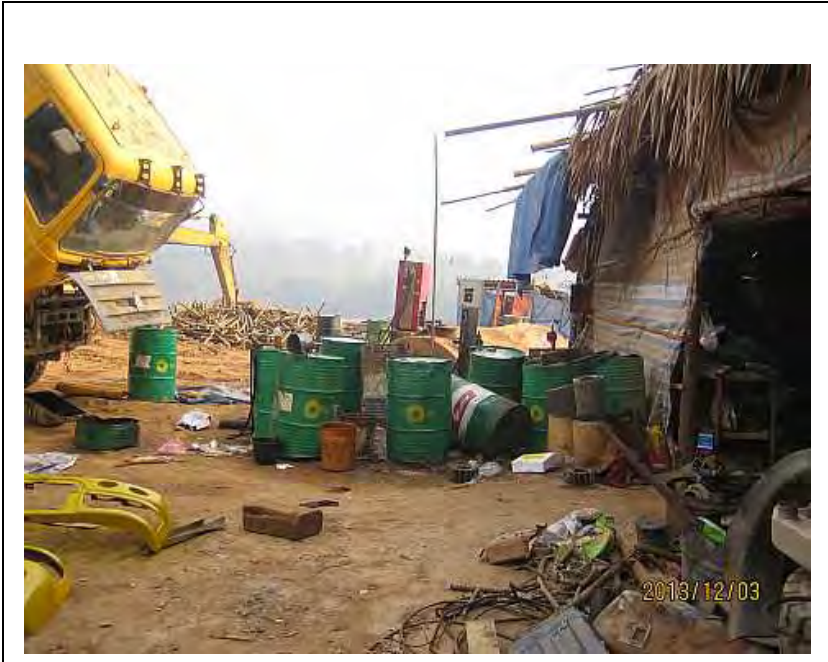

3.12 .2013

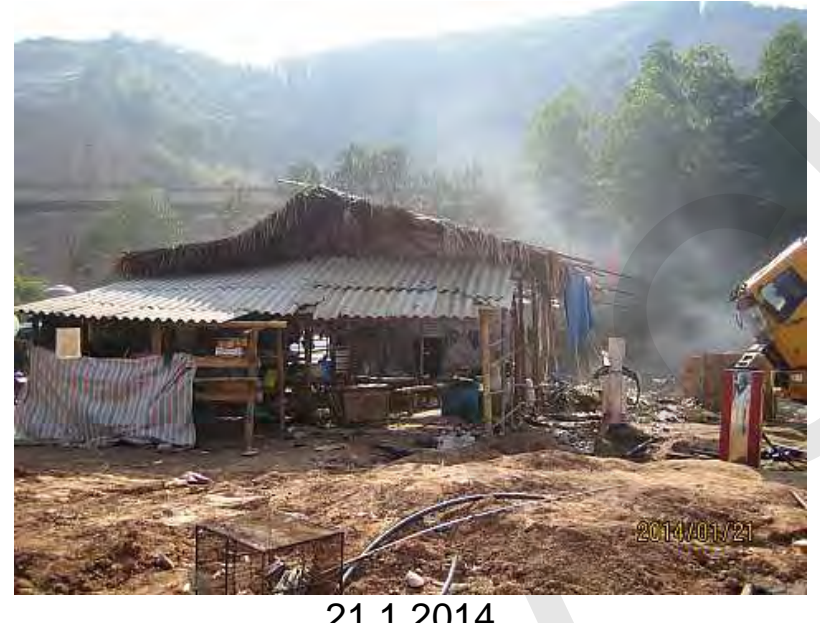

21.1.2014

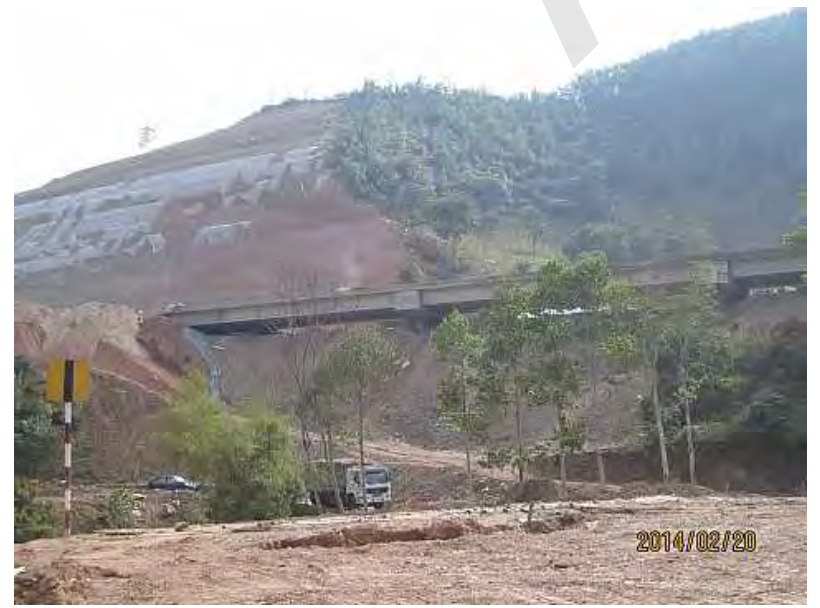

20.2.2014
Location: Worker camps at Km209+800

Site visit: $21.1 .2014 ; 20.2 .2014 ; 31.3 .2014$

Date first observed: 13.8 .2013

Problems description and cause: There is not any rubbish bin and any septic tank in the toilet at the workers' camp

\section{Recommendation and Action taken by}

Engineer: The contractor is required to provide a rubbish bin and septic tanks for toilet. Because this can affect water source around. Refer to the letter No: Ref. Get4GRBCC-979

Deadline: Immediately

\section{Current status:}

In Jan: The contractor has not yet provided a rubbish bin and a septic tank for toilet

In Feb and Mar: The contractor has not yet provided any rubbish bin and any septic tank for toilet. However, the contractor had demobilized this workers' camp.

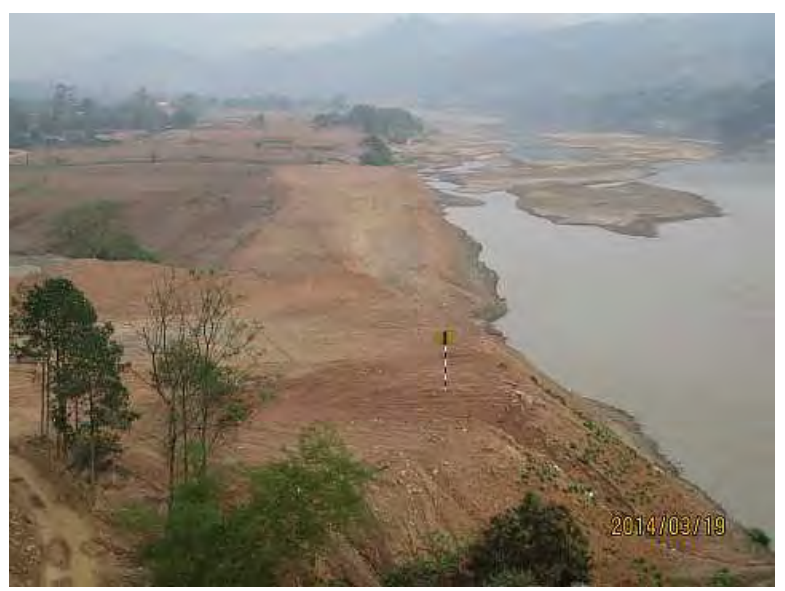

31.3.2014 


\section{Loan 2391/2392 - VIE: GMS Kunming - Hai Phong Transport Corridor Noi Bai - Lao Cai Highway Project}

\subsubsection{Package A8}

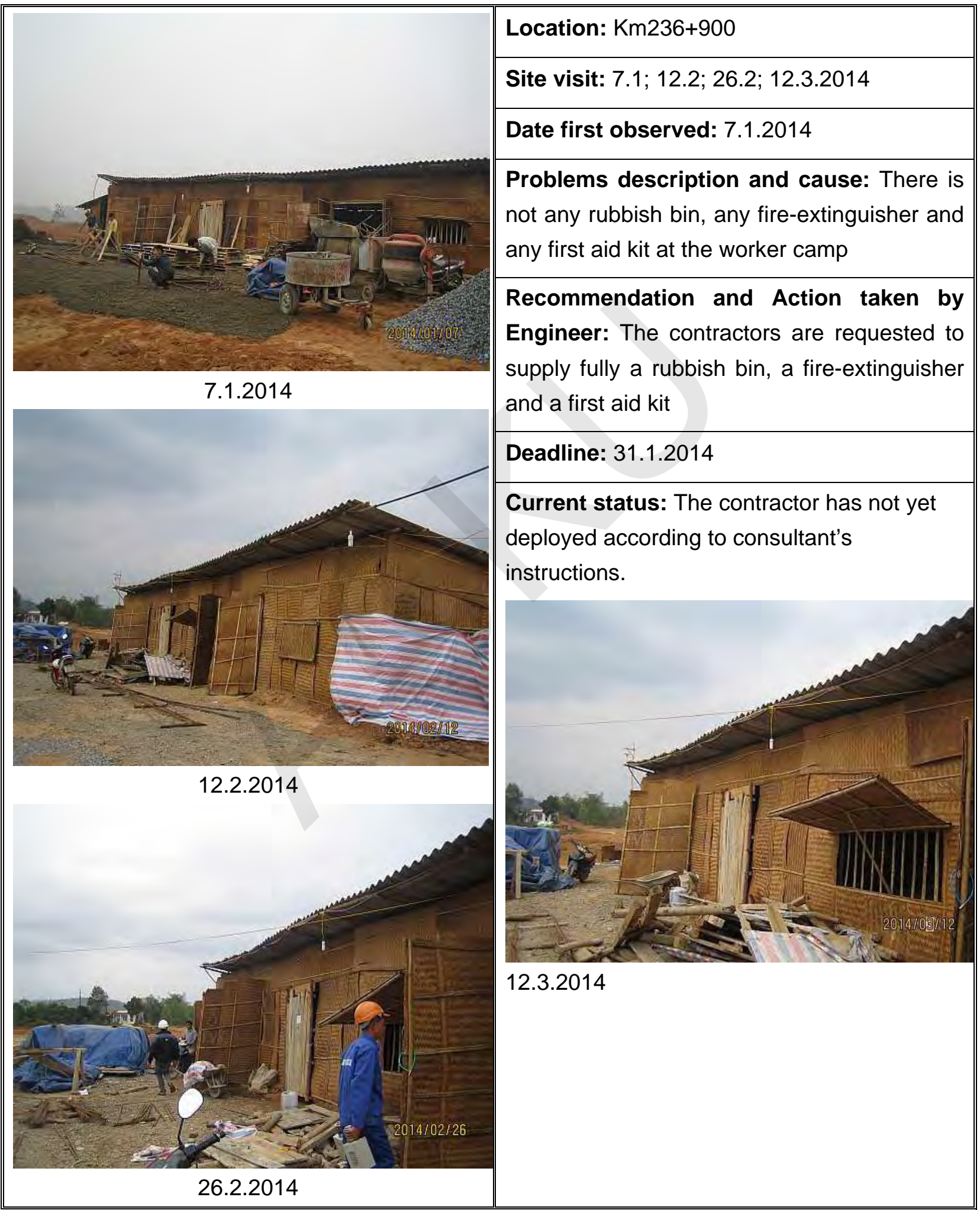




\section{Loan 2391/2392 - VIE: GMS Kunming - Hai Phong Transport Corridor Noi Bai - Lao Cai Highway Project}

\subsection{LABOUR SAFETY EQUIPMENT}

\subsubsection{Package A1}

At the present, at package A1, the Contractor has finished all construction works.

\subsubsection{Package A2}

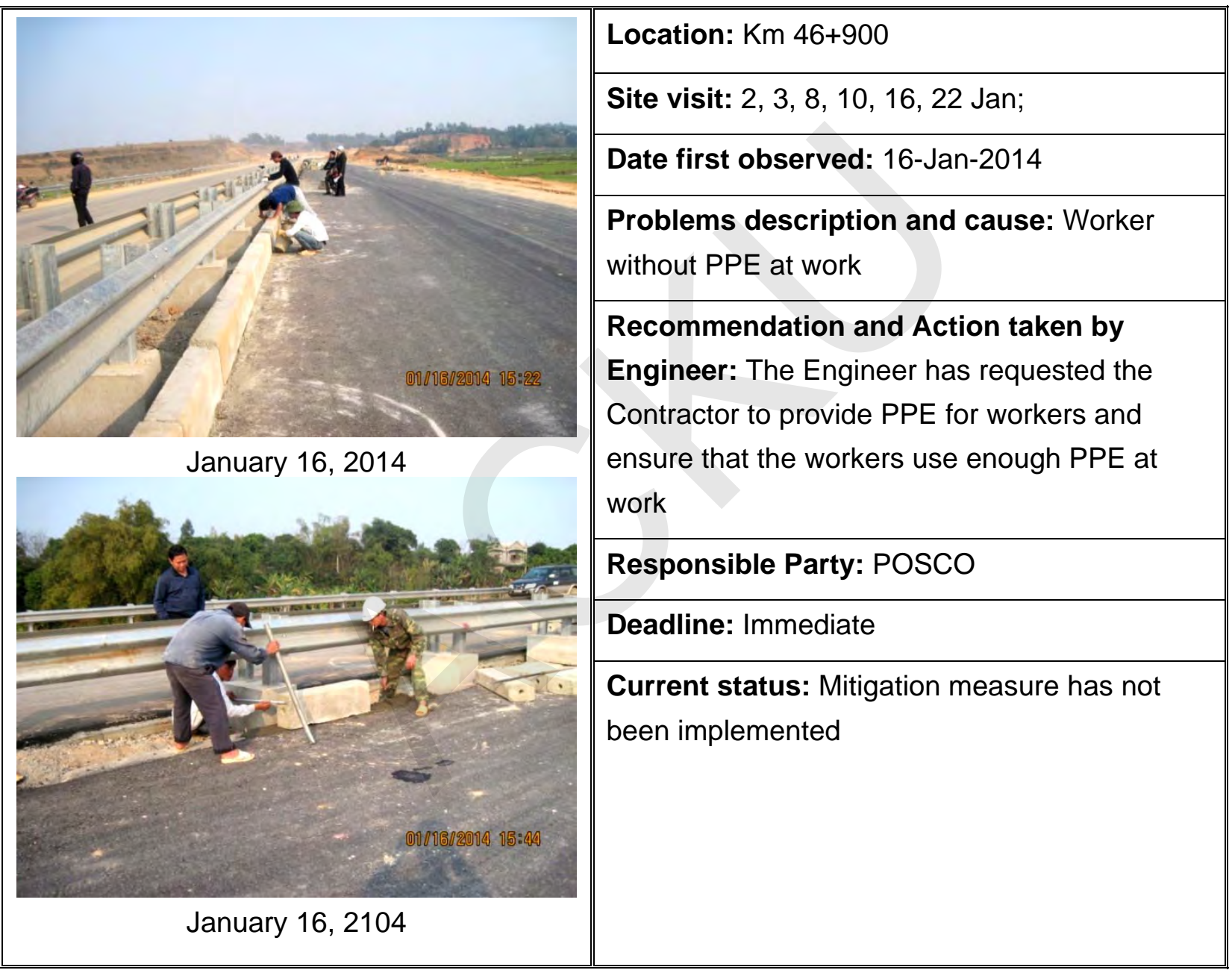

\begin{tabular}{|c|c|}
\hline & Location: $\mathrm{Km} \mathrm{36+700} \mathrm{and} \mathrm{Km} \mathrm{45+500}$ \\
\hline & Site visit: 10, 13, 17, 25 Feb.; \\
\hline & Date first observed: 17-Feb-2014 \\
\hline & $\begin{array}{l}\text { Problems description and cause: Worker } \\
\text { without PPE at work }\end{array}$ \\
\hline
\end{tabular}




\section{Loan 2391/2392 - VIE: GMS Kunming - Hai Phong Transport Corridor Noi Bai - Lao Cai Highway Project}

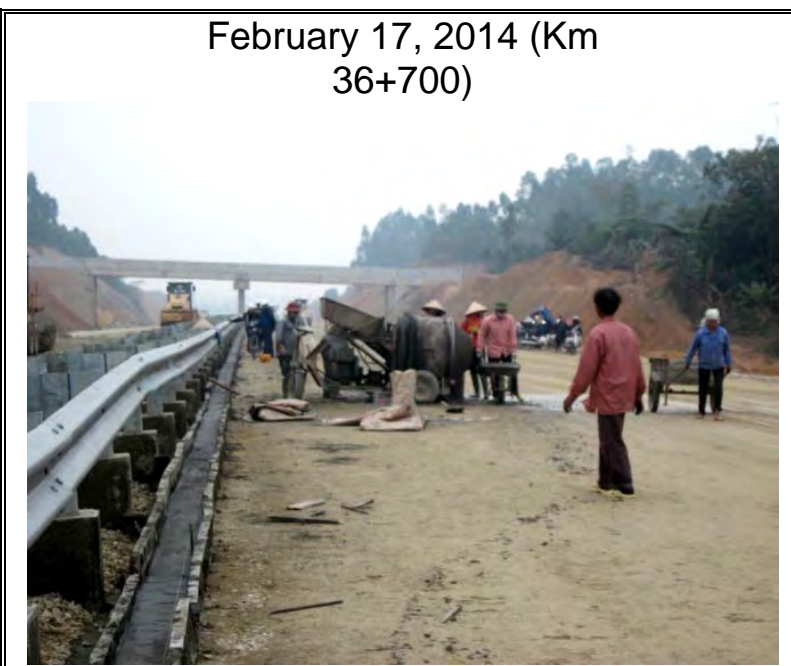

\section{Recommendation and Action taken by}

Engineer: The Engineer has requested the

Contractor to provide PPE for workers and ensure that the workers use enough PPE at work

\section{Responsible Party: POSCO}

Deadline: Immediate

Current status: The Contractor has provided PPE for workers

February 17, 2104 (Km 45+500)
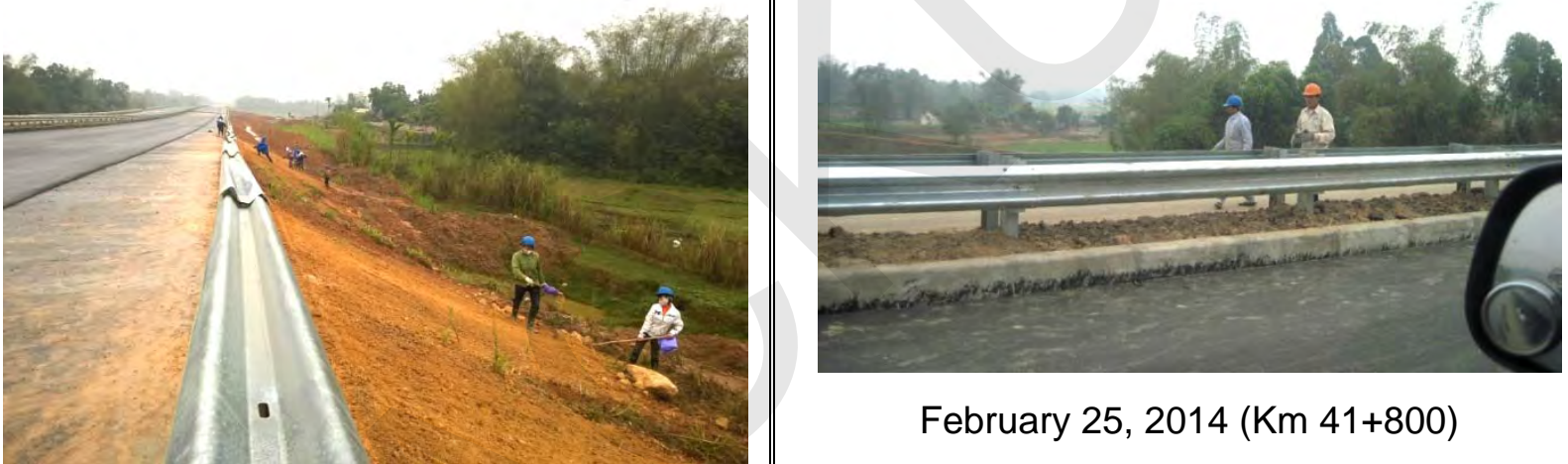

February 25, 2014 (Km 41+800)

February 25, 2014 (Km 42+400)

Location: whole package

Site visit: 4, 12, 17, 25 Mar 


\section{Loan 2391/2392 - VIE: GMS Kunming - Hai Phong Transport Corridor Noi Bai - Lao Cai Highway Project}

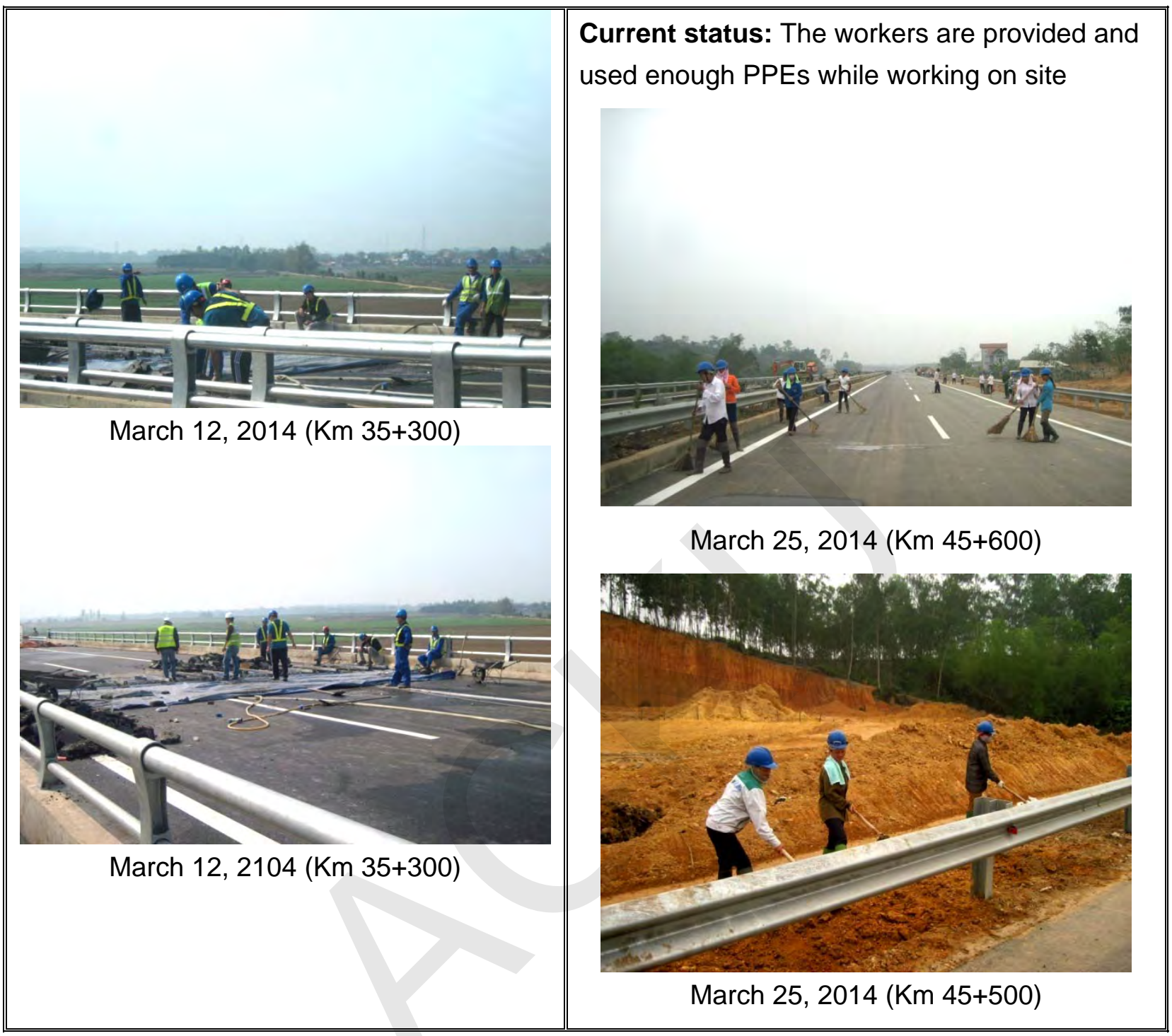

\subsubsection{Package A3}

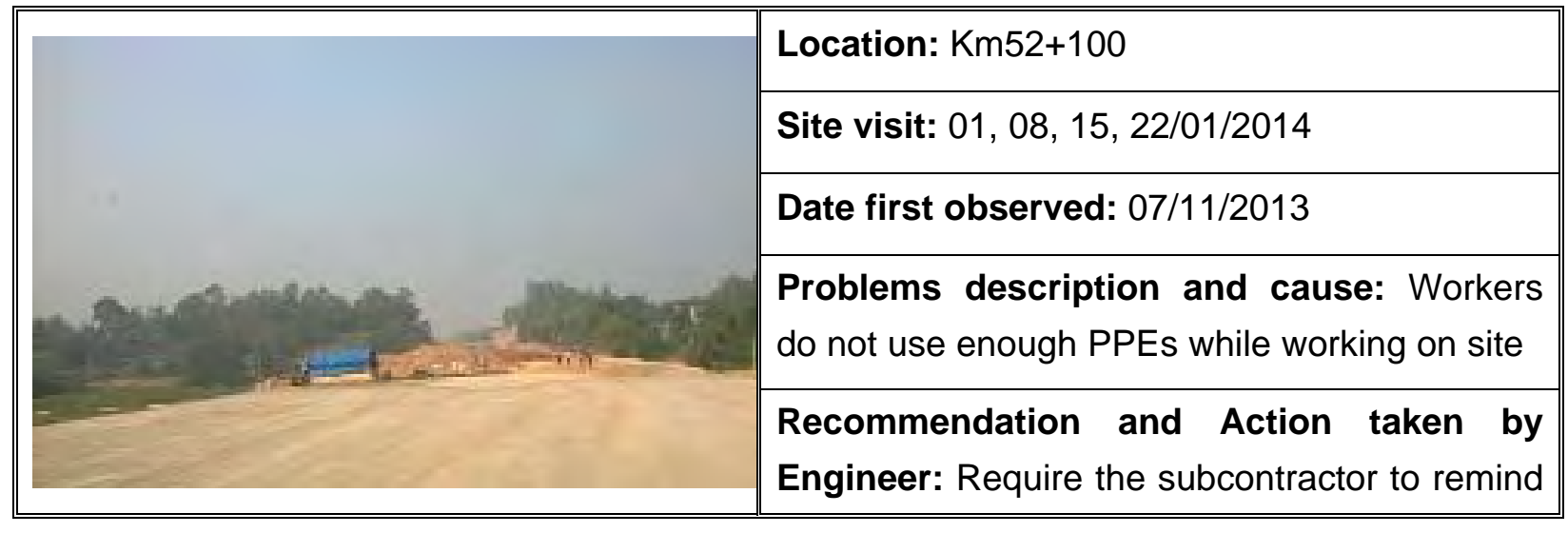




\section{Loan 2391/2392 - VIE: GMS Kunming - Hai Phong Transport Corridor Noi Bai - Lao Cai Highway Project}

\begin{tabular}{|c|c|}
\hline $01 / 01 / 2014$ & $\begin{array}{l}\text { and supply workers with enough PPEs. If any } \\
\text { worker continues to violate the regulation, he } \\
\text { will be fired. }\end{array}$ \\
\hline & Responsible Party: Posco \\
\hline & Deadline: Daily \\
\hline 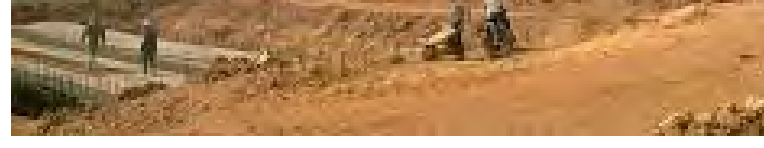 & $\begin{array}{l}\text { Current status: Workers have not yet used } \\
\text { enough PPEs while working on site. }\end{array}$ \\
\hline & \\
\hline
\end{tabular}

\begin{tabular}{|c|c|}
\hline & Location: IC8 bridge \\
\hline & Site visit: $07,14,21,25 / 2 / 2014$ \\
\hline & Date first observed: $07 / 11 / 2013$ \\
\hline & $\begin{array}{l}\text { Problems description and cause: } \\
\text { Workers do not use enough PPEs while } \\
\text { working on site }\end{array}$ \\
\hline $07 / 02 / 2014$ & $\begin{array}{l}\text { Recommendation and Action taken by } \\
\text { Engineer: Require the Contractor to } \\
\text { remind and supply enough PPEs for all } \\
\text { workers. If any worker continues to violate } \\
\text { the regulation, he will be fired. }\end{array}$ \\
\hline & Responsible Party: Posco \\
\hline 70 & Deadline: Daily \\
\hline $14 / 02 / 2014$ & $\begin{array}{l}\text { Current status: Workers have not yet used } \\
\text { enough PPEs while working on site. }\end{array}$ \\
\hline
\end{tabular}

In March, almost workers used enough PPEs while working on site except for site at Km67+175. 


\section{Loan 2391/2392 - VIE: GMS Kunming - Hai Phong Transport Corridor Noi Bai - Lao Cai Highway Project}

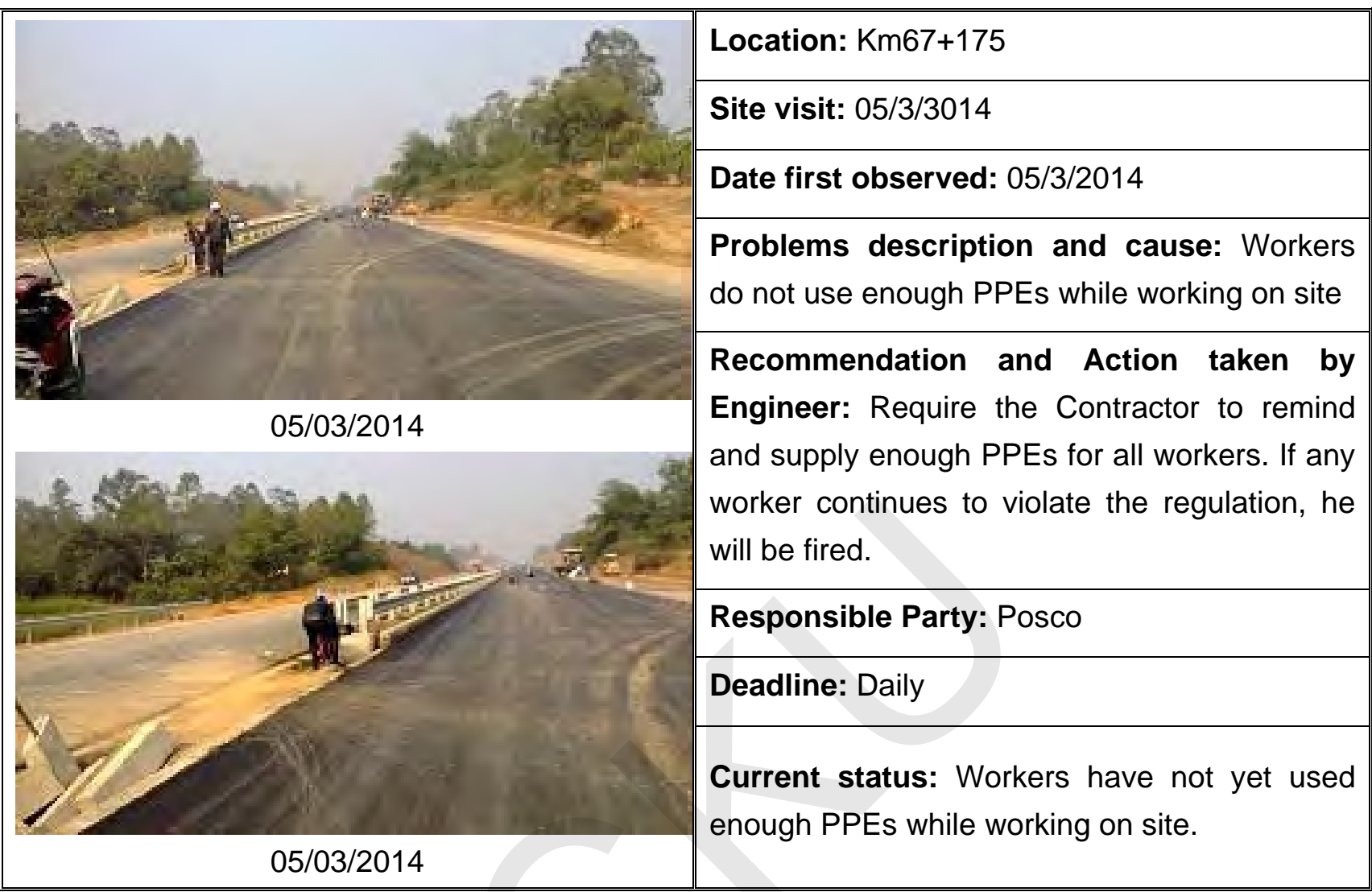

\subsubsection{Package A4}

\begin{tabular}{|c|c|}
\hline \multirow{6}{*}{ 23/1/2014 } & Location: Km98+239 \\
\hline & Site visit: $02 ; 09 ; 16 ; 23 / 1 / 2014$ \\
\hline & Date first observed: $06 / 11 / 2013$ \\
\hline & $\begin{array}{l}\text { Problems description and cause: } \\
\text { Workers do not use enough PPEs while } \\
\text { working on site }\end{array}$ \\
\hline & $\begin{array}{l}\text { Recommendation and Action taken by } \\
\text { Engineer: Require the subcontractor to } \\
\text { remind and supply workers with enough } \\
\text { PPEs. If any worker continues to violate the } \\
\text { regulation, he will be fired. }\end{array}$ \\
\hline & Responsible Party: Keangnam \\
\hline
\end{tabular}




\section{Loan 2391/2392 - VIE: GMS Kunming - Hai Phong Transport Corridor Noi Bai - Lao Cai Highway Project}

\begin{tabular}{|l|l|l|}
\hline & Deadline: Daily \\
\hline & Current status: Workers have not yet used \\
enough PPEs while working on site.
\end{tabular}

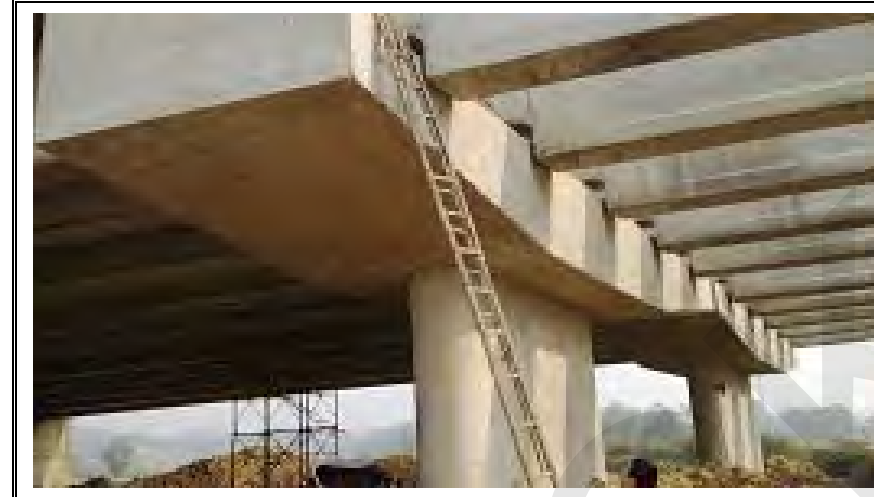

$19 / 12 / 2013$
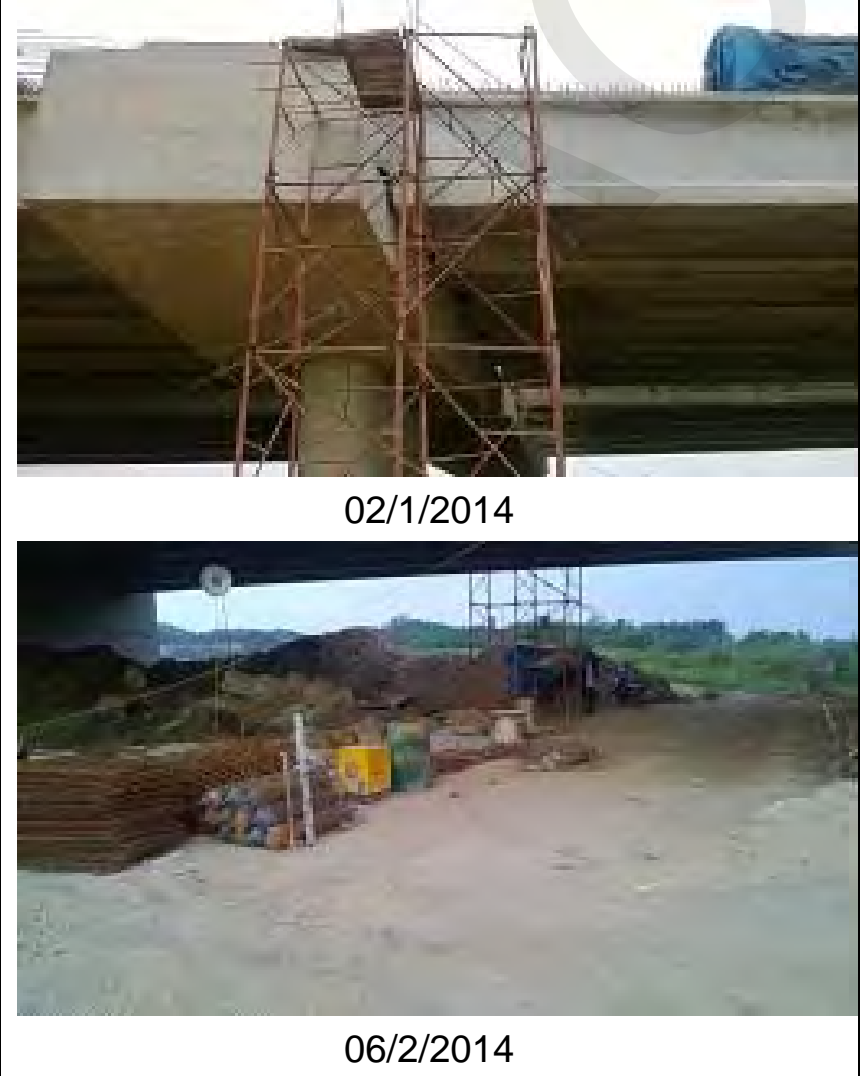

Location: Ngoi Van bridge

Site visit: $02 ; 09 ; 16 ; 23 / 1 / 2014 ; 06,13$, $20,27 / 2 / 2014 ; 06,13,20,27 / 3 / 2014$

\section{Date first observed:}

Problems description and cause: scaffoldings were not safe enough for users.

\section{Recommendation and Action taken by} Engineer: The Consultant requested the Contractor to stop construction activities and to overcome the safety matters of scaffoldings to ensure safety during construction process. Until Contractor ensures the safety of scaffolding, it can continue construction activities. Besides, the Contractor is requested to force the workers to use enough PPEs when working on site.

\section{Responsible Party:}

Deadline: Daily

Current status: The Contractor has not yet overcomed the safety matters of scaffoldings 


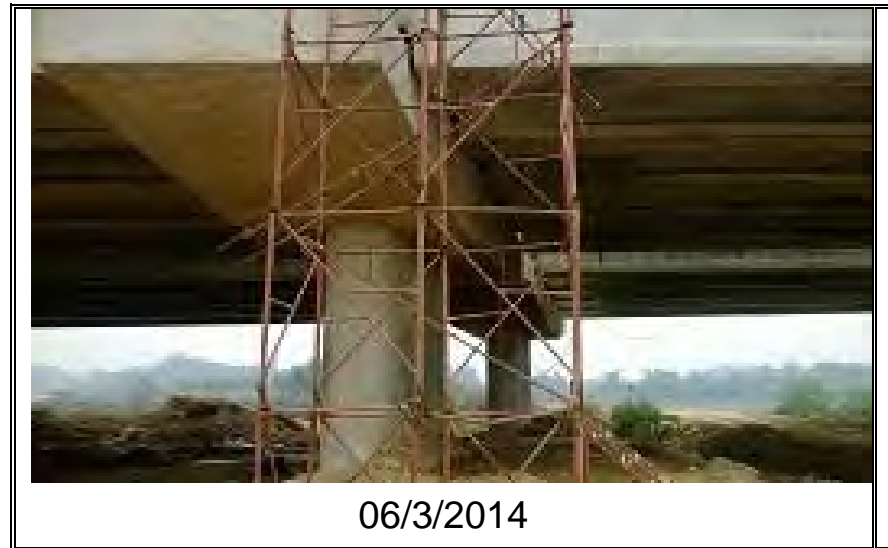

\subsubsection{Package A5}
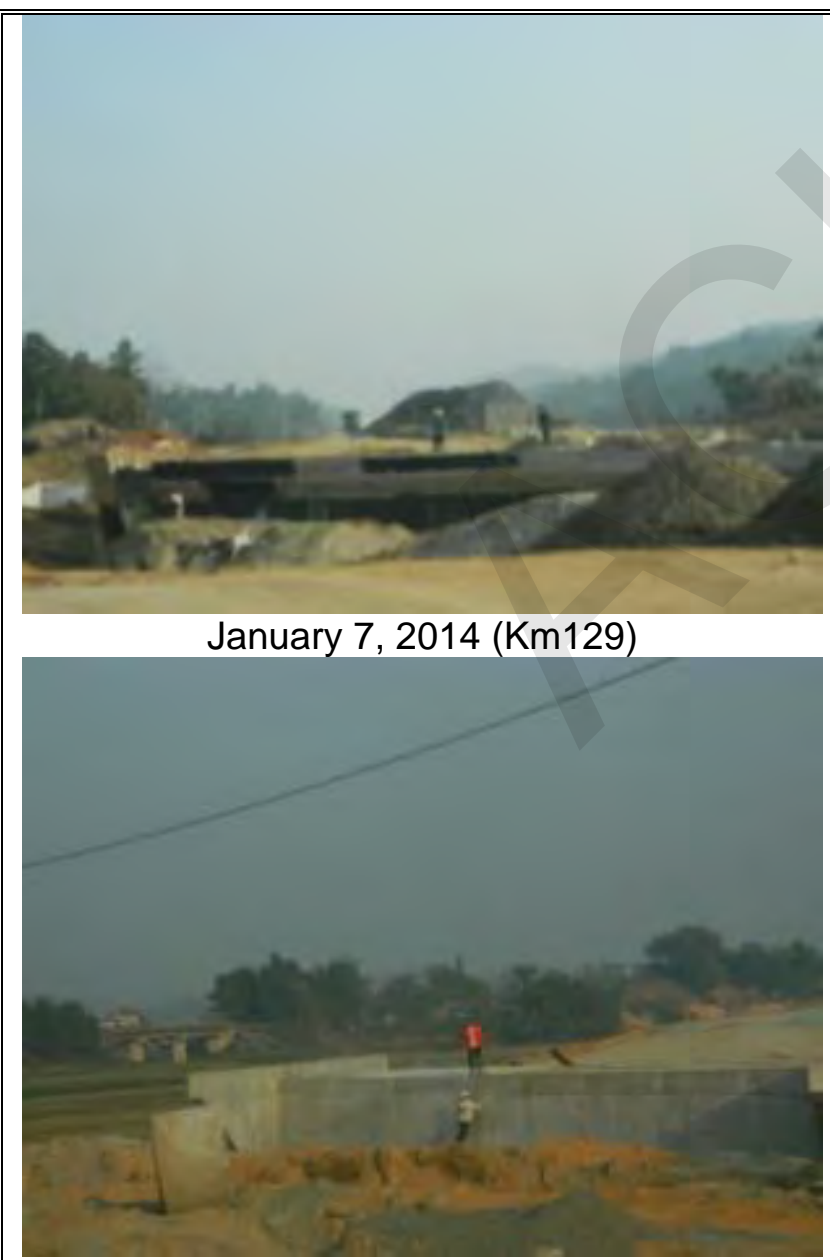

January 20, $2014(\mathrm{Km} 129)$
Location: Up-box culvert Km129

Site visit: 7 and 20 January, 2014

Date first observed: 7 January , 2014

Problems description and cause: The workers did not use fully PPEs during work on the site. This could not ensure the safety issue.

Recommendation and Action taken by Engineer: The Contractor must implement the tasks as follows:

1. Ensure that all workers are provided with full PPEs and that these workers are worn at all times while working on site.

2. Install scaffoldings that are safe enough for using.

Responsible Party: Keangnam Contractor

Deadline: Immediate

Current status: The workers still do not use fully PPEs during working at this location.

\section{Location: Ngoi Rao bridge's construction} site 


\section{Loan 2391/2392 - VIE: GMS Kunming - Hai Phong Transport Corridor Noi Bai - Lao Cai Highway Project}

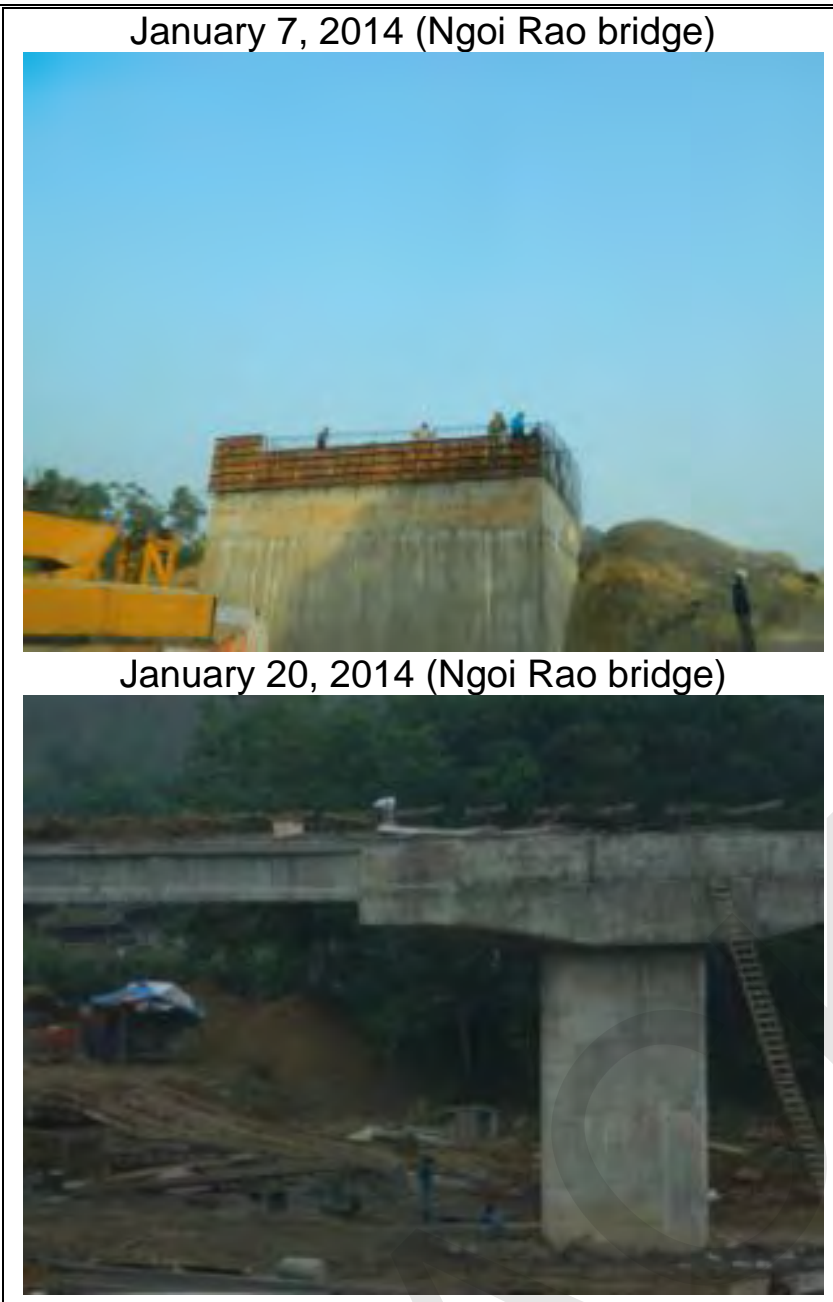

Site visit: 7 and 20 January; 14 February, 2014

Date first observed: 7 January , 2014

Problems description and cause: The workers did not use fully PPEs during work on the site. This could not ensure the safety issue.

Recommendation and Action taken by Engineer: The Contractor must implement the tasks as follows:

1. Ensure that all workers are provided with full PPEs and that these workers are worn at all times while working on site.

2. Install scaffoldings that are safe enough for using.

Responsible Party: Keangnam Contractor

Deadline: Immediately

Current status: The workers still do not use fully PPEs during working at this location.

February 14, 2014 (Ngoi Rao bridge)

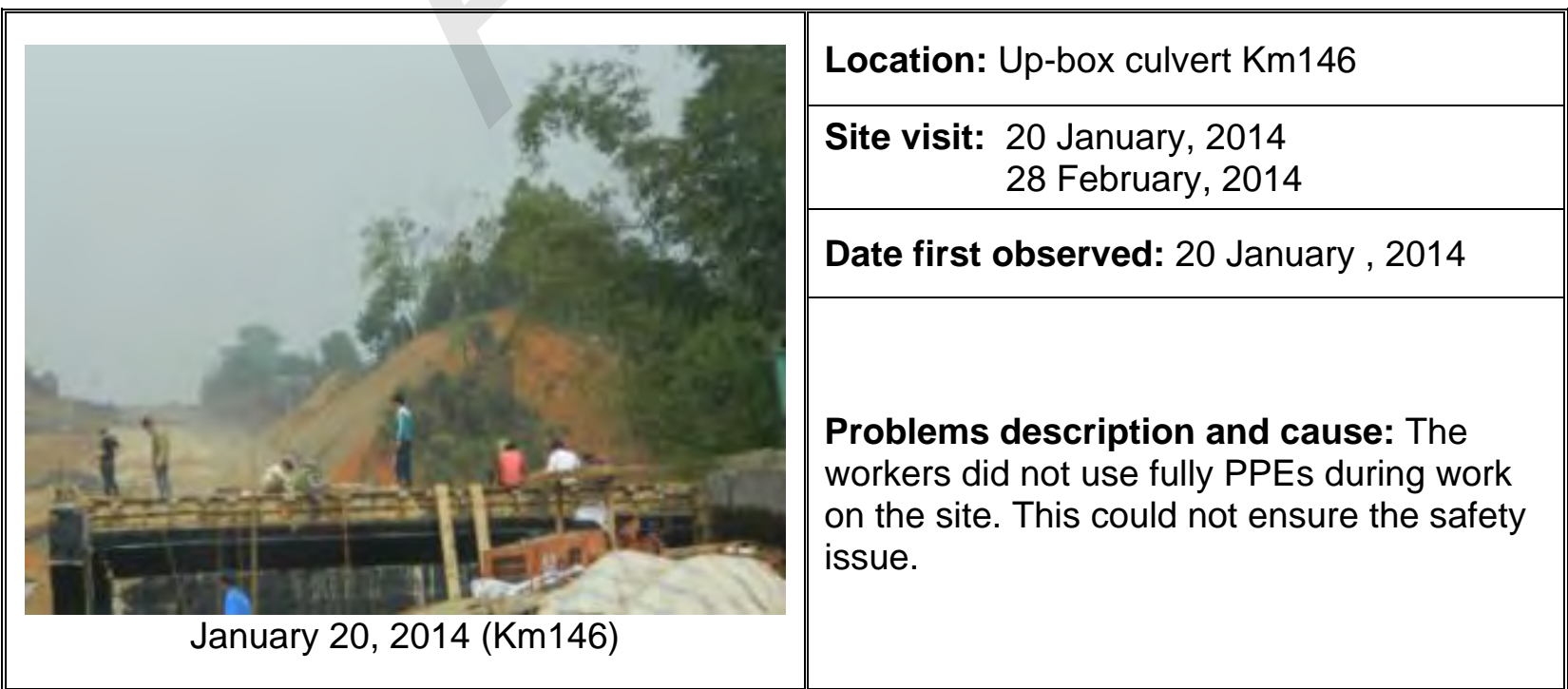


Loan 2391/2392 - VIE: GMS Kunming - Hai Phong Transport Corridor Noi Bai - Lao Cai Highway Project

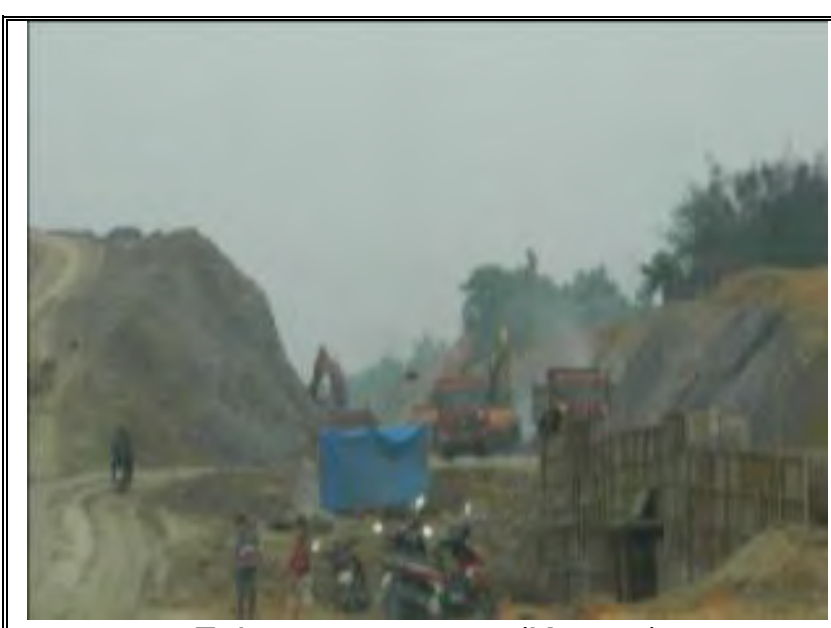

February 28, 2014 (Km146)
Recommendation and Action taken by Engineer: The Contractor must implement the tasks as follows:

1. Ensure that all workers are provided with full PPEs and that these workers are worn at all times while working on site.

2. Install scaffoldings that are safe enough for using.

Responsible Party: Keangnam Contractor

Deadline: Immediately

Current status: The workers still do not use fully PPEs during work at this location.

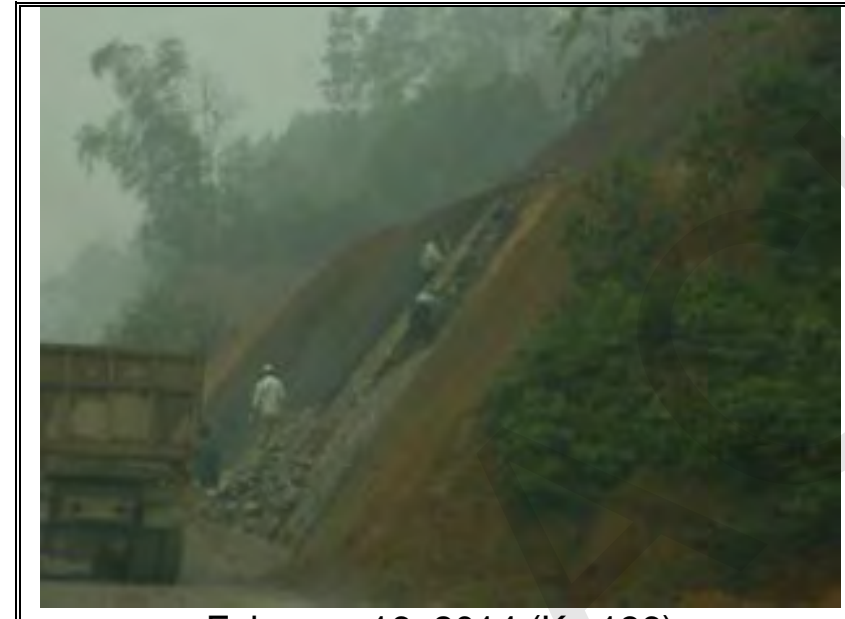

February 16, 2014 (Km136)

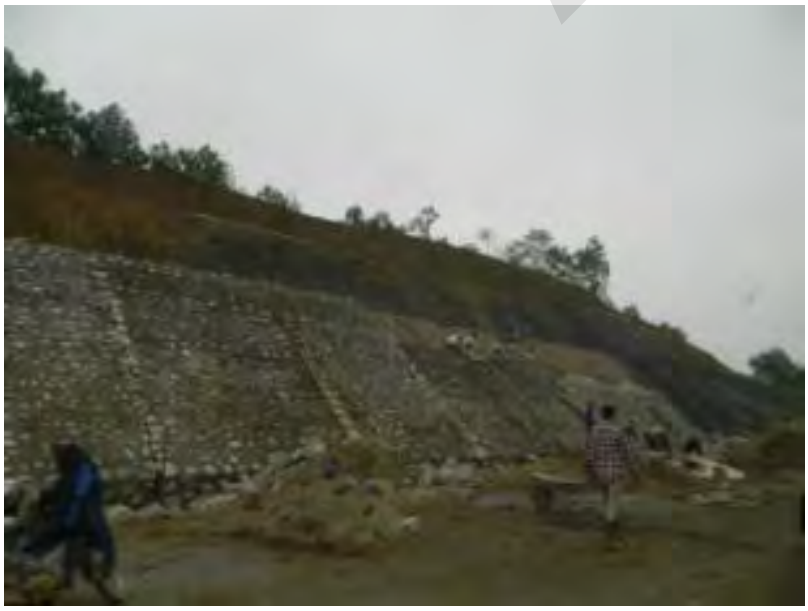

March 3, 2014 (Km136)
Location: Construction site $\mathrm{Km} 136$

Site visit: 16 February, 2014 3 March, 2014

Date first observed: 16 February, 2014

Problems description and cause: The workers did not use enough PPEs while working on the site. This did not ensure the safety issues.

Recommendation and Action taken by Engineer: The Contractor must implement the tasks as follows:

1. Ensure that all workers are provided with PPEs and that these are worn at all times where necessary.

2. Install scaffoldings that are stable and has fall prevention provisions.

Responsible Party: Keangnam Contractor

Deadline: Immediate

Current status: The workers still did not use enough PPEs while working on site 
Loan 2391/2392 - VIE: GMS Kunming - Hai Phong Transport Corridor Noi Bai - Lao Cai Highway Project

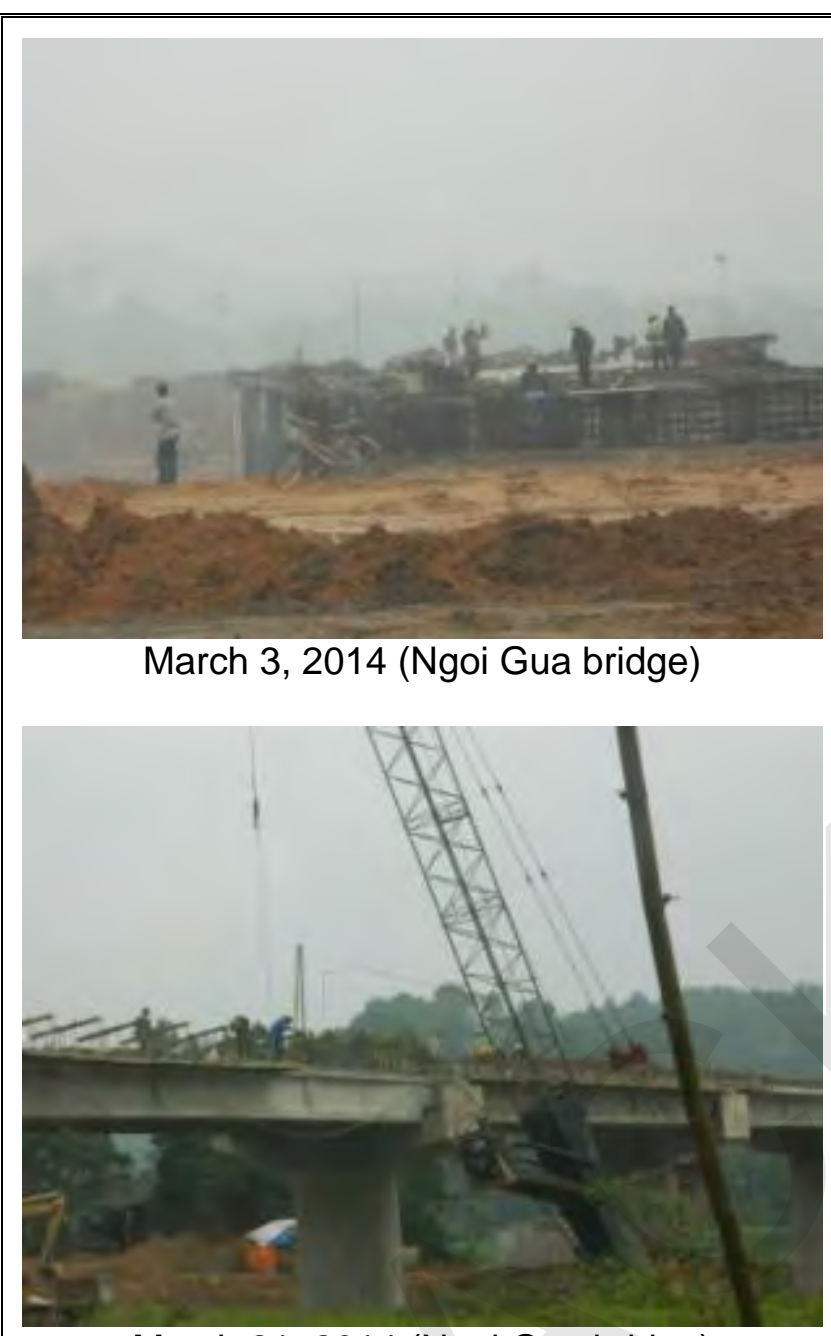

March 21, 2014 (Ngoi Gua bridge)
Location: Ngoi Gua bridge's construction site

Site visit: 3 and 21 March, 2014

Date first observed: 3 March, 2014

Problems description and cause: The workers did not use enough PPEs while working on the site. This did not ensure the safety issues.

Recommendation and Action taken by Engineer: The Contractor must implement the tasks as follows:

1. Ensure that all workers are provided with PPEs and that these are worn at all times where necessary.

2. Install scaffoldings that are stable and has fall prevention provisions.

Responsible Party: Keangnam Contractor

Deadline: Immediate

Current status: The workers still don't use enough PPEs during work at this location.

\subsubsection{Package A6}

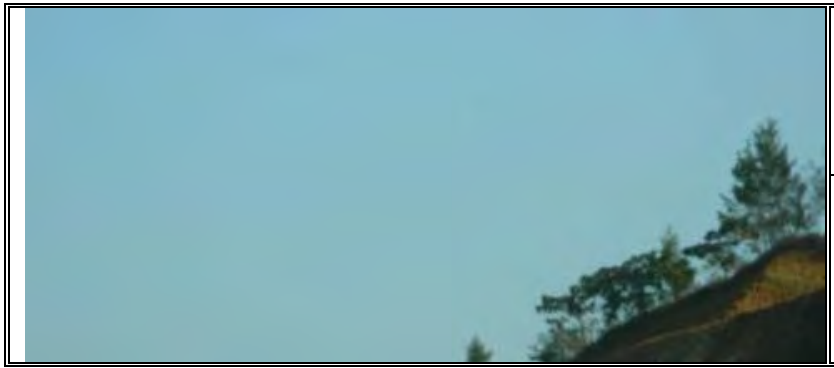

Location: Ngoi Giam bridge, Km158, Km154, Ngoi Nhuoc bridge, Ngo Cong bridge

Site visit: 15, 25 and 30 January, 2014 


\section{Loan 2391/2392 - VIE: GMS Kunming - Hai Phong Transport Corridor Noi Bai - Lao Cai Highway Project}
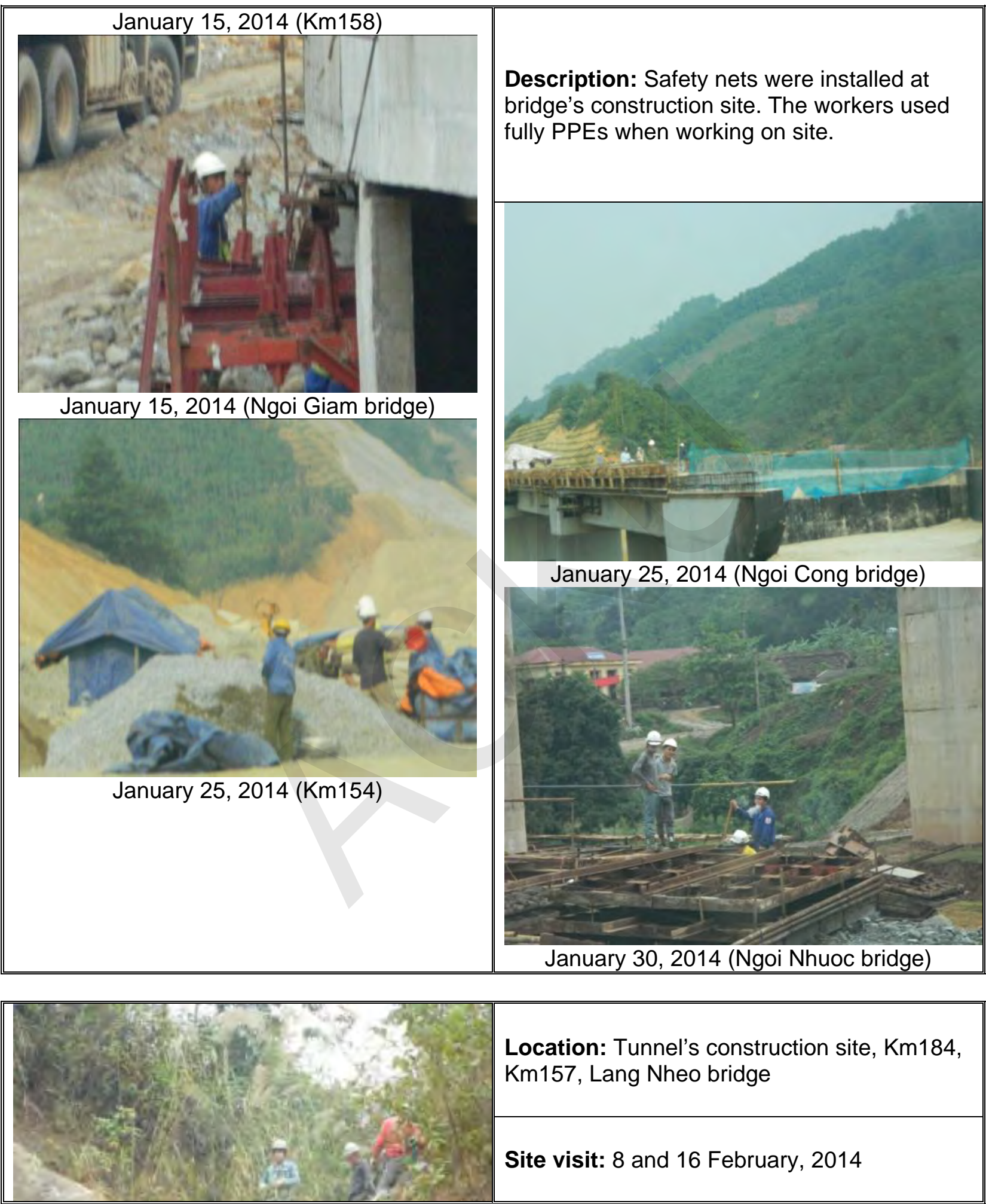

Location: Tunnel's construction site, $\mathrm{Km} 184$, Km157, Lang Nheo bridge

Site visit: 8 and 16 February, 2014 


\section{Loan 2391/2392 - VIE: GMS Kunming - Hai Phong Transport Corridor Noi Bai - Lao Cai Highway Project}

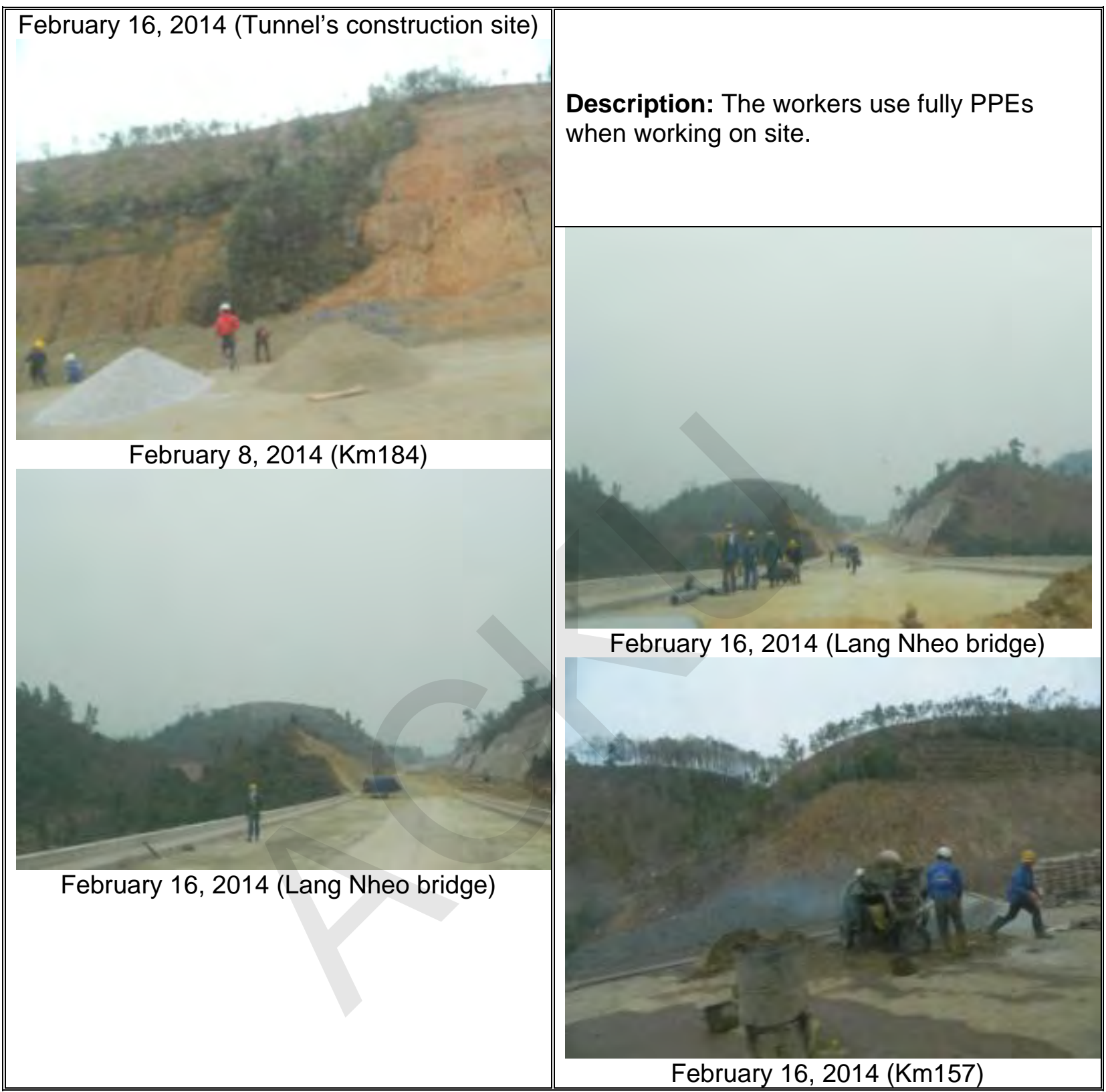

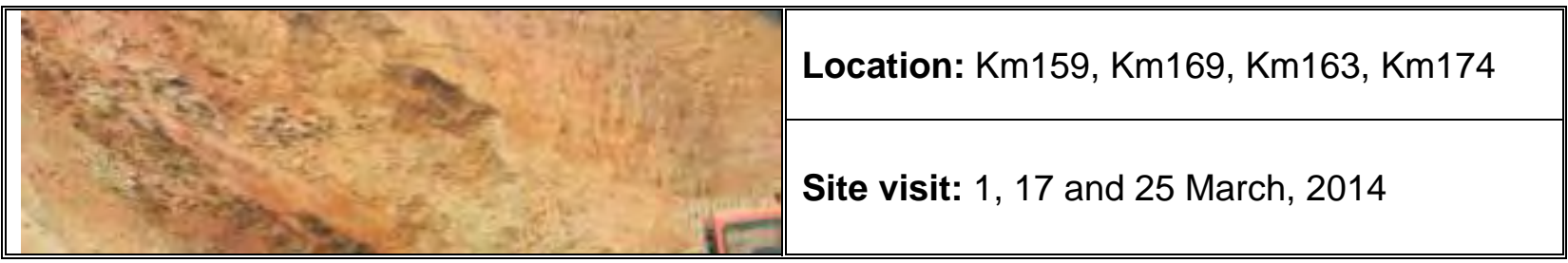




\section{Loan 2391/2392 - VIE: GMS Kunming - Hai Phong Transport Corridor} Noi Bai - Lao Cai Highway Project

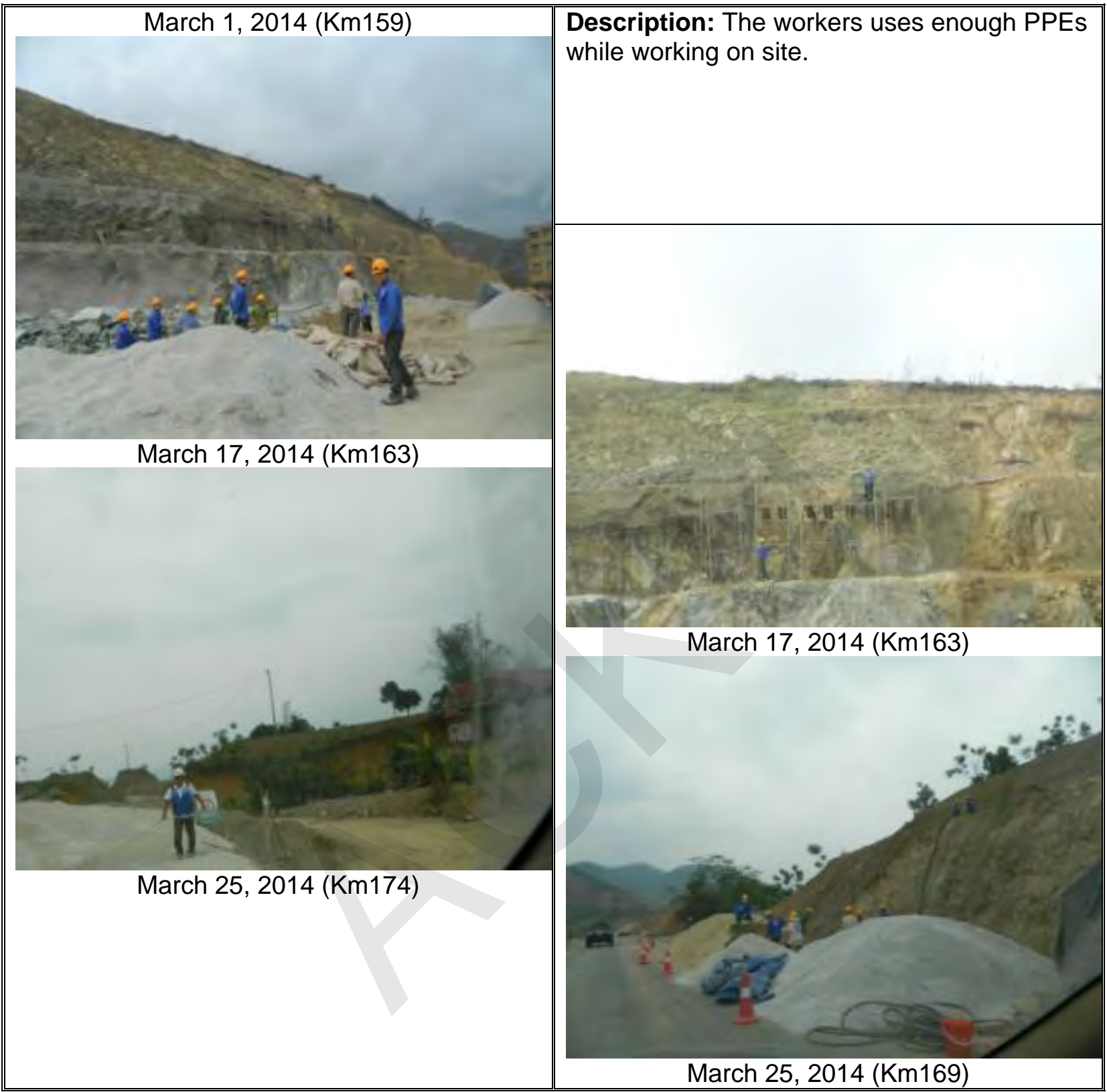

\subsubsection{Package A7}

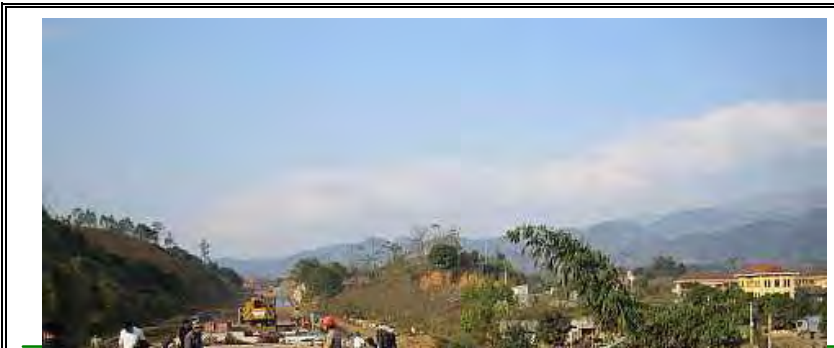

Location: Km199+960

Site visit: 14.1 .2014

First observed: 21.6 .2013

Problems description and cause: The 
Loan 2391/2392 - VIE: GMS Kunming - Hai Phong Transport Corridor Noi Bai - Lao Cai Highway Project

\begin{tabular}{|c|c|}
\hline \multirow[t]{4}{*}{ 14.1.2014 at $\mathrm{Km} 199+960$} & $\begin{array}{l}\text { workers are not supplied enough PPEs } \\
\text { during the working time }\end{array}$ \\
\hline & $\begin{array}{l}\text { Recommendation and Action taken by } \\
\text { Engineer: Require the subcontractor to } \\
\text { remind and propose labour safety for } \\
\text { workers. If any worker continues to violate } \\
\text { the regulation, he will be fired. Consultant } \\
\text { had issued many letters to the contractor } \\
\text { such as: Get4- GRBCC- } 952 \text {. } 979 \text { and } \\
\text { GET- GUA- } 107,119,125\end{array}$ \\
\hline & Deadline: Immediately \\
\hline & Current status: Not yet improved \\
\hline
\end{tabular}

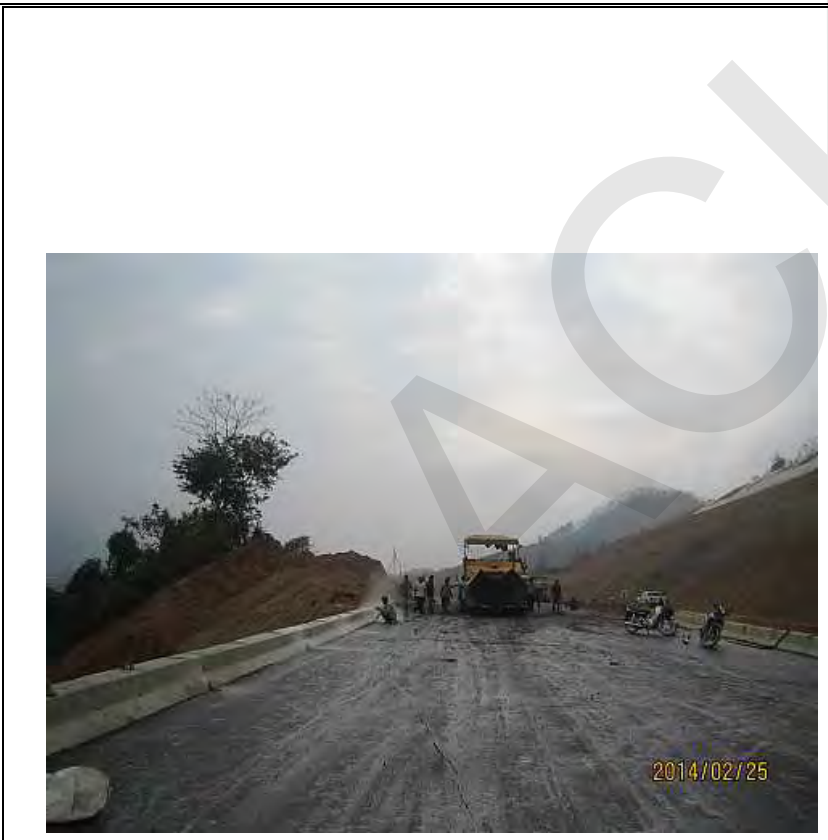

25.2.2014 at $\mathrm{Km} 209+690$
Location: Km209+690

Site visit: 25.2 .2014

First observed: 21.6 .2013

Problems description and cause: The workers are not supplied with enough PPEs during the working time

Recommendation and Action taken by Engineer: Require the subcontractor to remind and propose labour safety for workers. If any worker continues to violate the regulation, he will be fired. Consultant had issued many letters to the contractor such as: Get4-GRBCC- 952. 979 and GETGUA- 107, 119, 125

Deadline: Immediately

Current status: Not yet improved 


\section{Loan 2391/2392 - VIE: GMS Kunming - Hai Phong Transport Corridor Noi Bai - Lao Cai Highway Project}

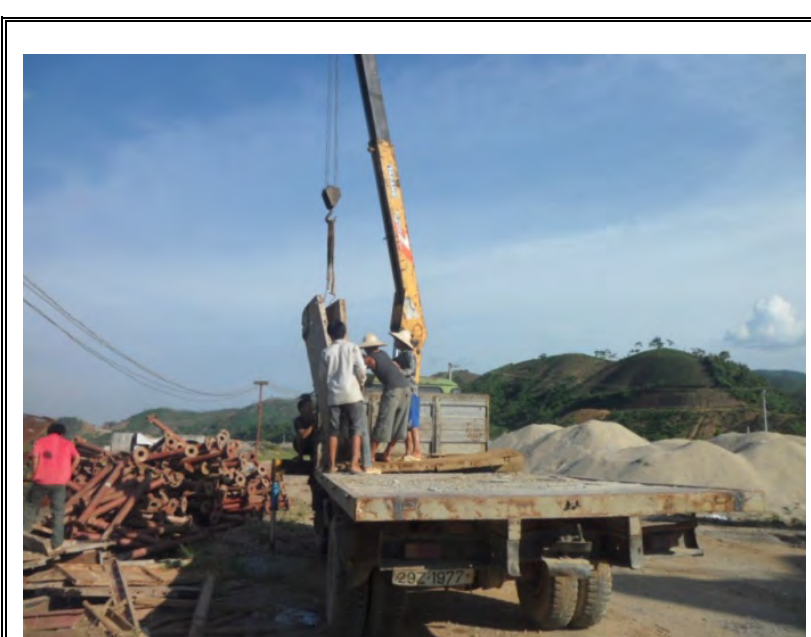

21.6.2013 at $\mathrm{Km} 195+800$

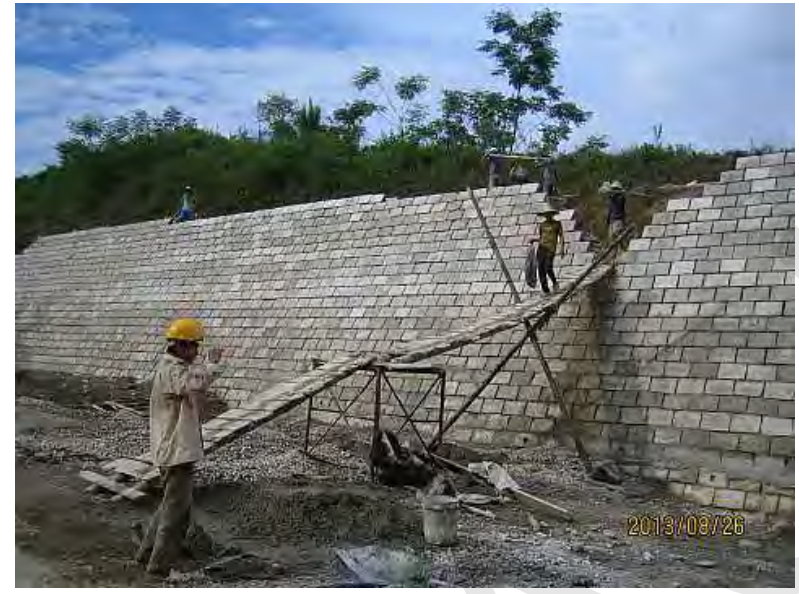

26.8.2013 at $\mathrm{Km} 202+700$

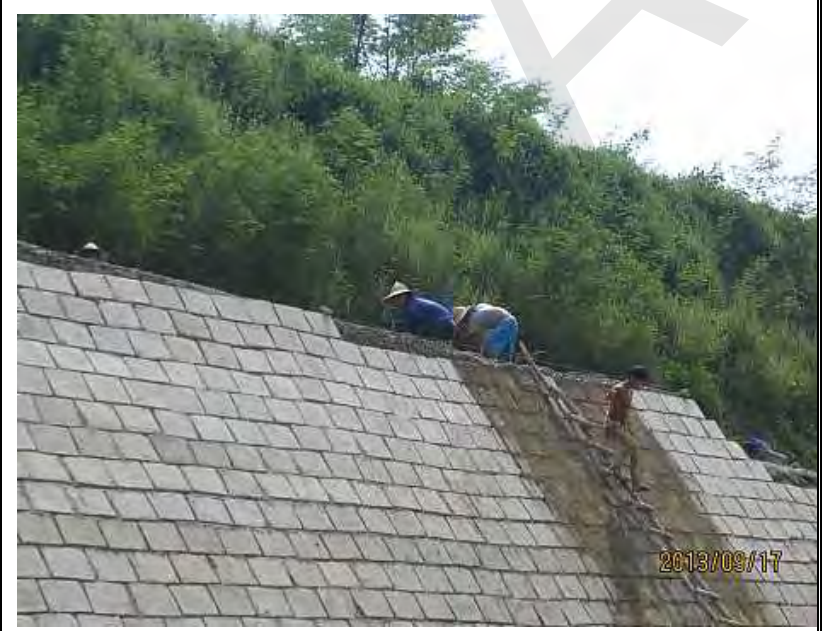

17.9.2013 at $\mathrm{Km} 202+700$

$\begin{array}{lll}\text { Location: } & \text { Km195+800; } & \text { Km202+700; } \\ \text { Km199+900; } & \text { Km207+936; } & \text { Km209+690; } \\ \text { Km199+000 } & & \\ & & \end{array}$

Site visit: $21.6 ; 26.8 ; 17.9 ; 22.10 ; 26.11$; 24.12; 14.1 and 25.2.2014

First observed: 21.6 .2013

Problems description and cause: The workers are not supplied with enough PPEs while working on site

\section{Recommendation and Action taken by} Engineer: The consultant had issued letter No: Ref. GET-EPMU-2617 with contents: "Proposed to reject the Safety manager and Environment Manager of Package A7" and Consultant had issued many letters to the contractor such as: Get4-GRBCC- 952. 979 and GET- GUA- 107, 119, 125

Deadline: Immediately

Current status: During March, the contractor has not yet improved this issue.

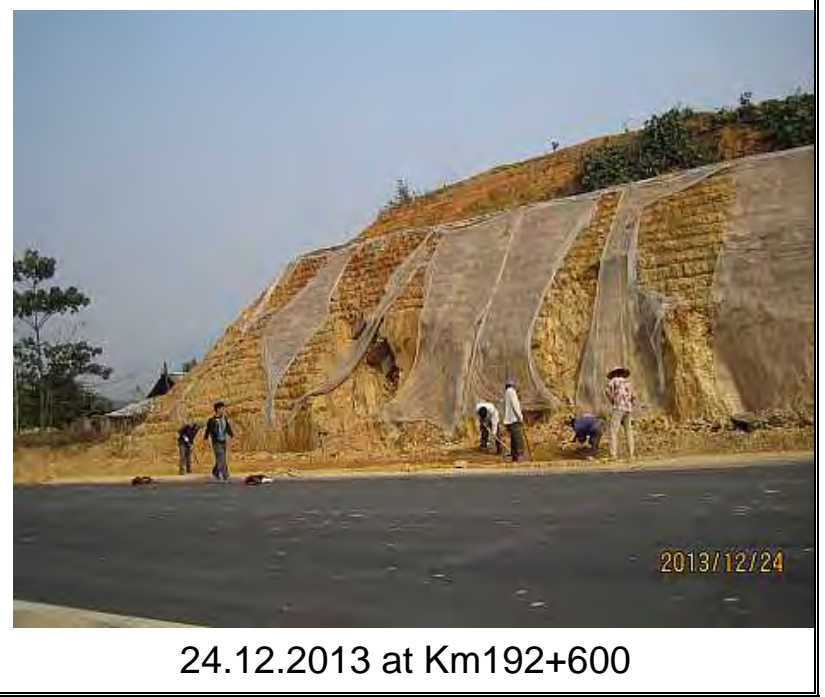




\section{Loan 2391/2392 - VIE: GMS Kunming - Hai Phong Transport Corridor} Noi Bai - Lao Cai Highway Project
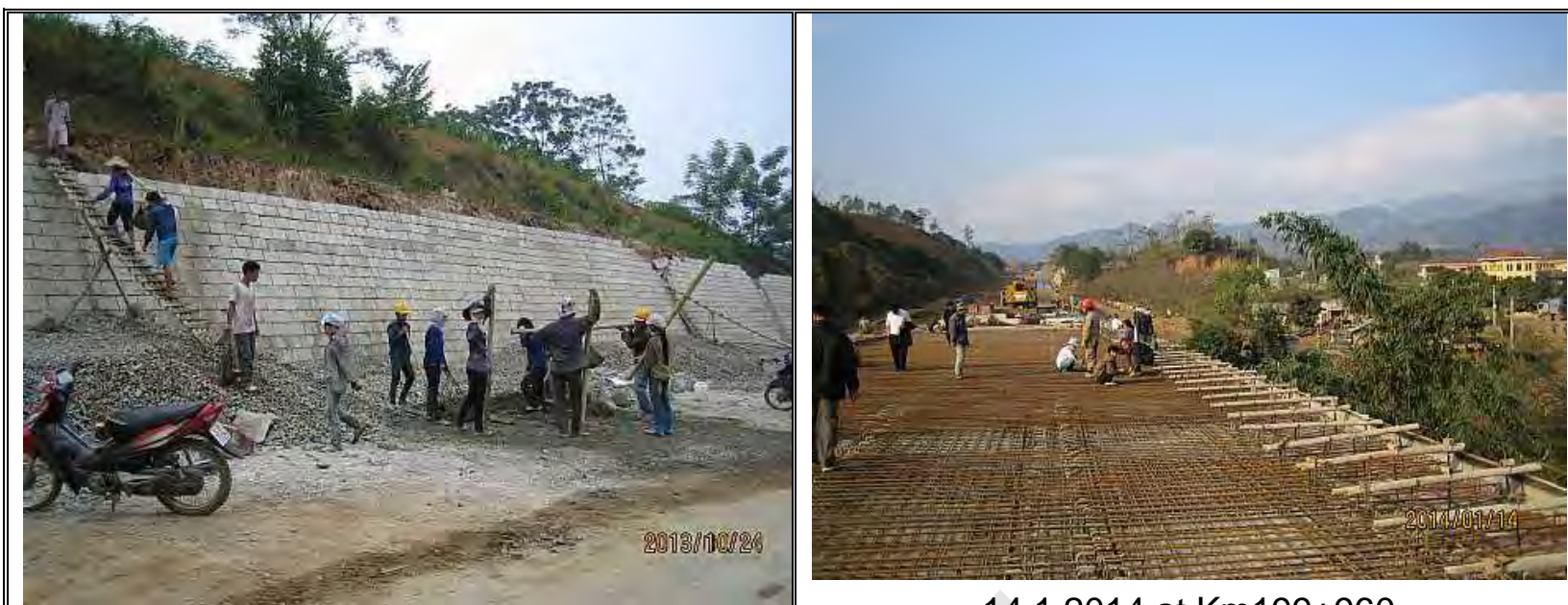

22.10.2013 at $\mathrm{Km} 199+900$

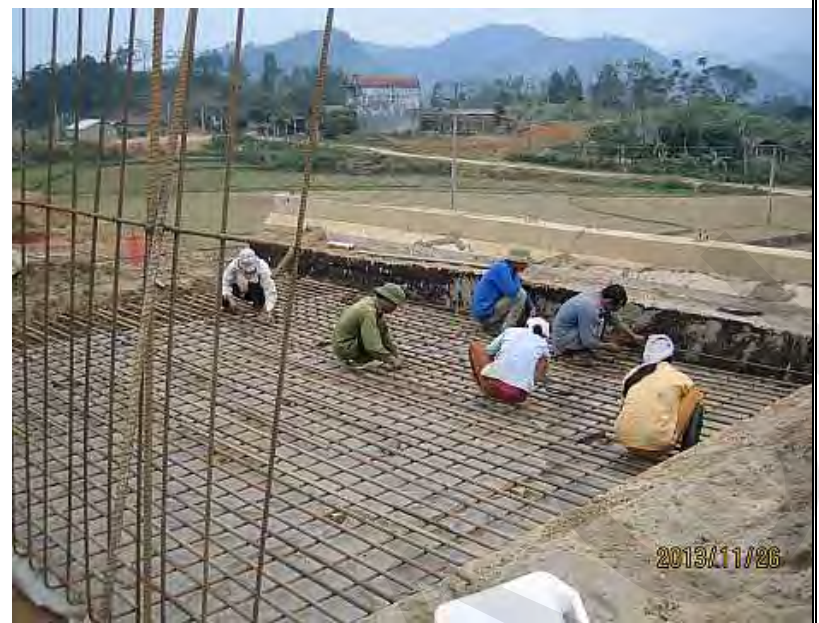

14.1.2014 at $\mathrm{Km} 199+960$

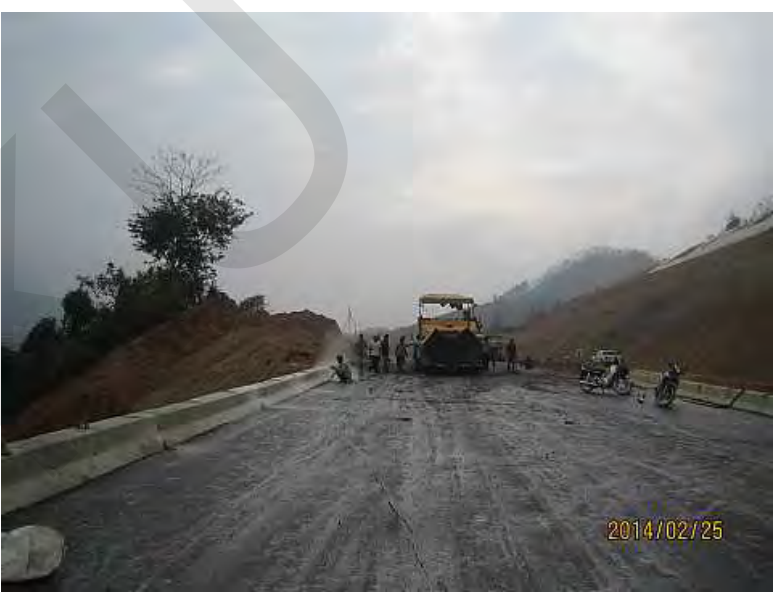

25.2.2014 at $\mathrm{Km} 209+690$

26.11.2013 at $\mathrm{Km} 207+936$

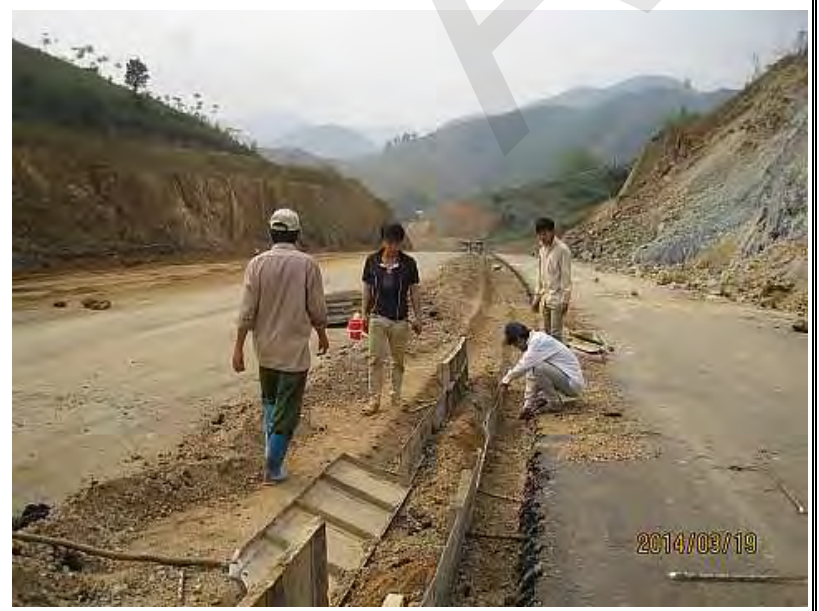

19.3.2014 at $\mathrm{Km} 199+000$ 


\section{Loan 2391/2392 - VIE: GMS Kunming - Hai Phong Transport Corridor Noi Bai - Lao Cai Highway Project}

\subsubsection{Package A8}

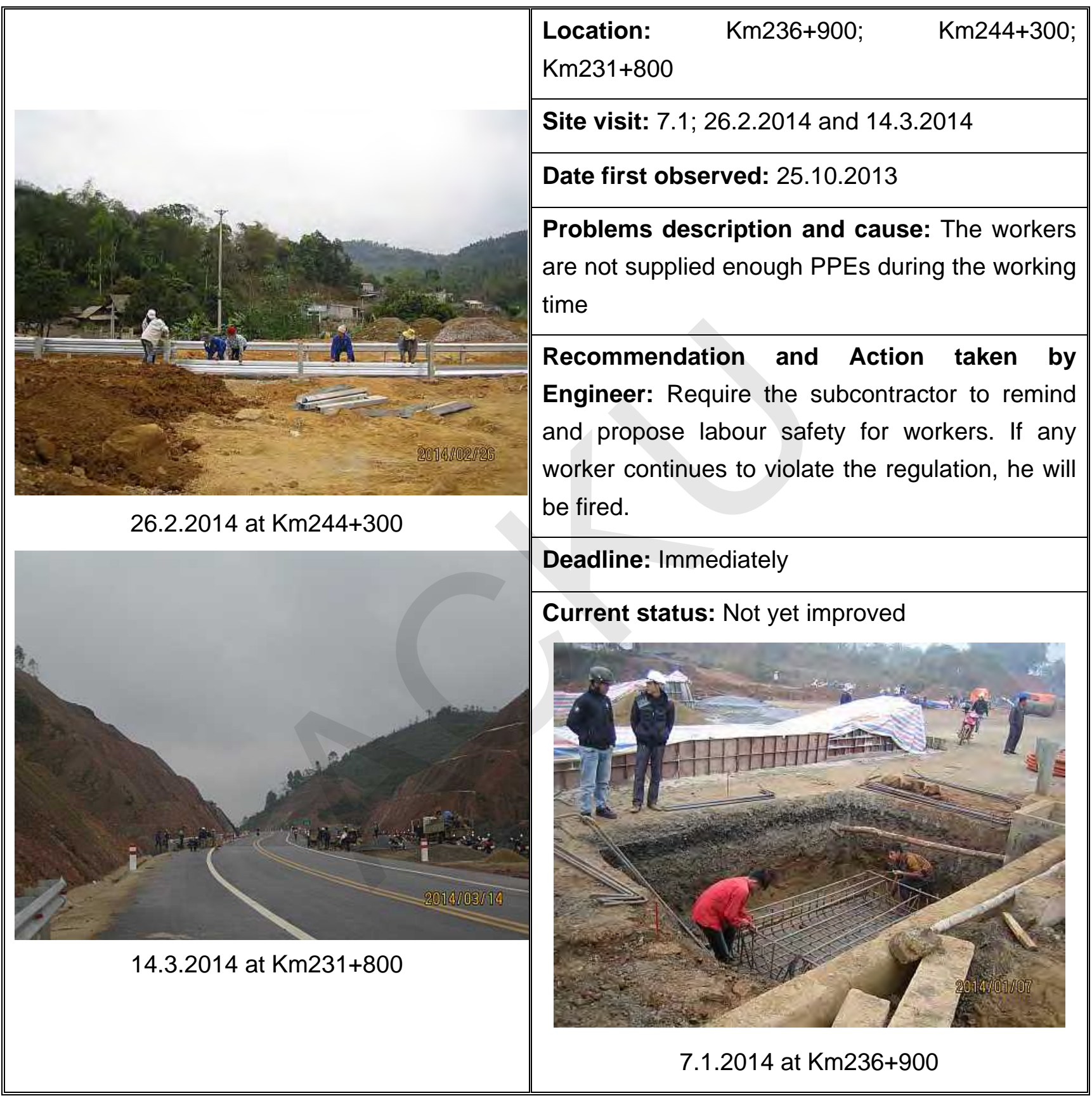




\section{Loan 2391/2392 - VIE: GMS Kunming - Hai Phong Transport Corridor Noi Bai - Lao Cai Highway Project}

\subsection{TRAFFIC CONDITIONS AND SIGNPOSTING IN ROADS}

\subsubsection{Package A1}

At the present, at package A1, the Contractor has finished all construction works.

\subsubsection{Package A2}

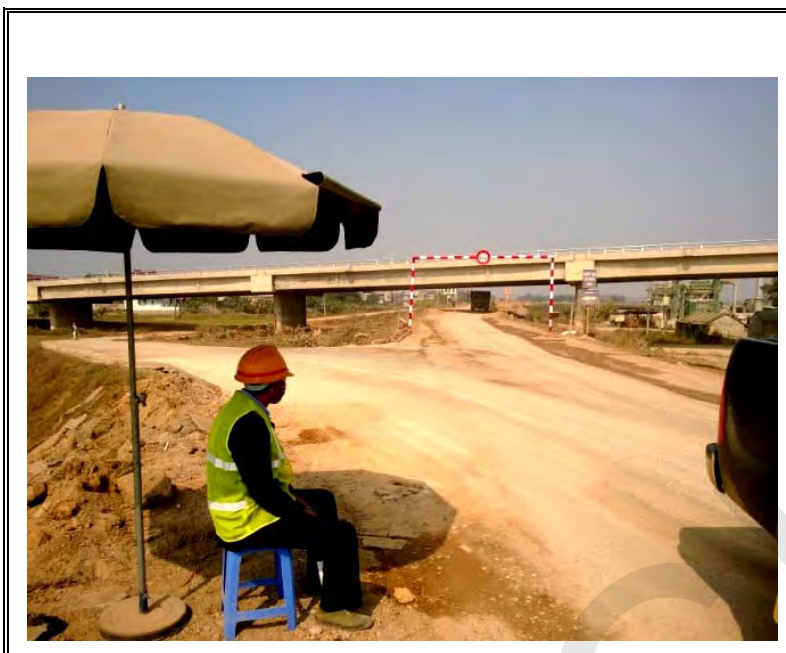

January 16, 2014 (Lo River Bridge)

January 16, 2014 (Lo River Bridge)
Location: Intersect with public roads points

Site visit: 8, 10, 26, 22 Jan; 10, 13, 14, 17, 25

Feb.; 4, 12, 17, 25 Mar.

Current status: The Contractor is maintaining the signboard systems and traffic guide at intersect areas

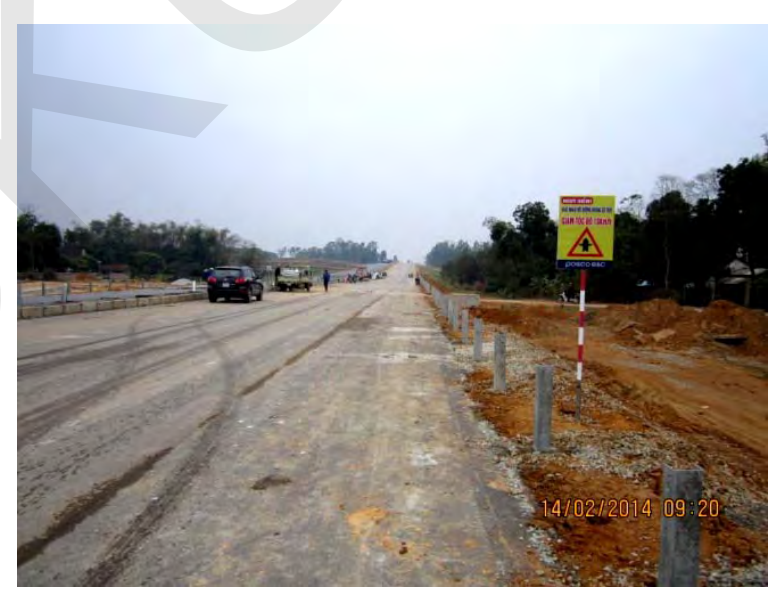

February 14, 2014 (Km 42+100)

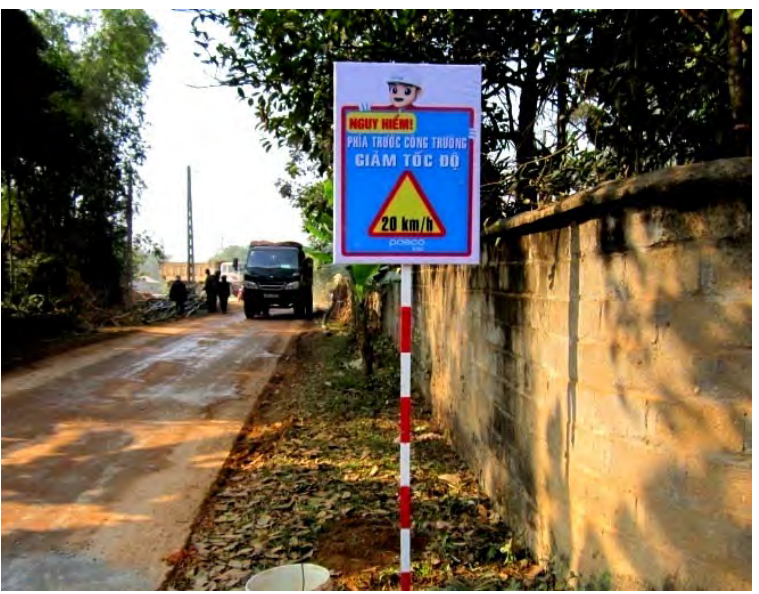

February 25, 2014 (Km 42+200) 


\section{Loan 2391/2392 - VIE: GMS Kunming - Hai Phong Transport Corridor} Noi Bai - Lao Cai Highway Project

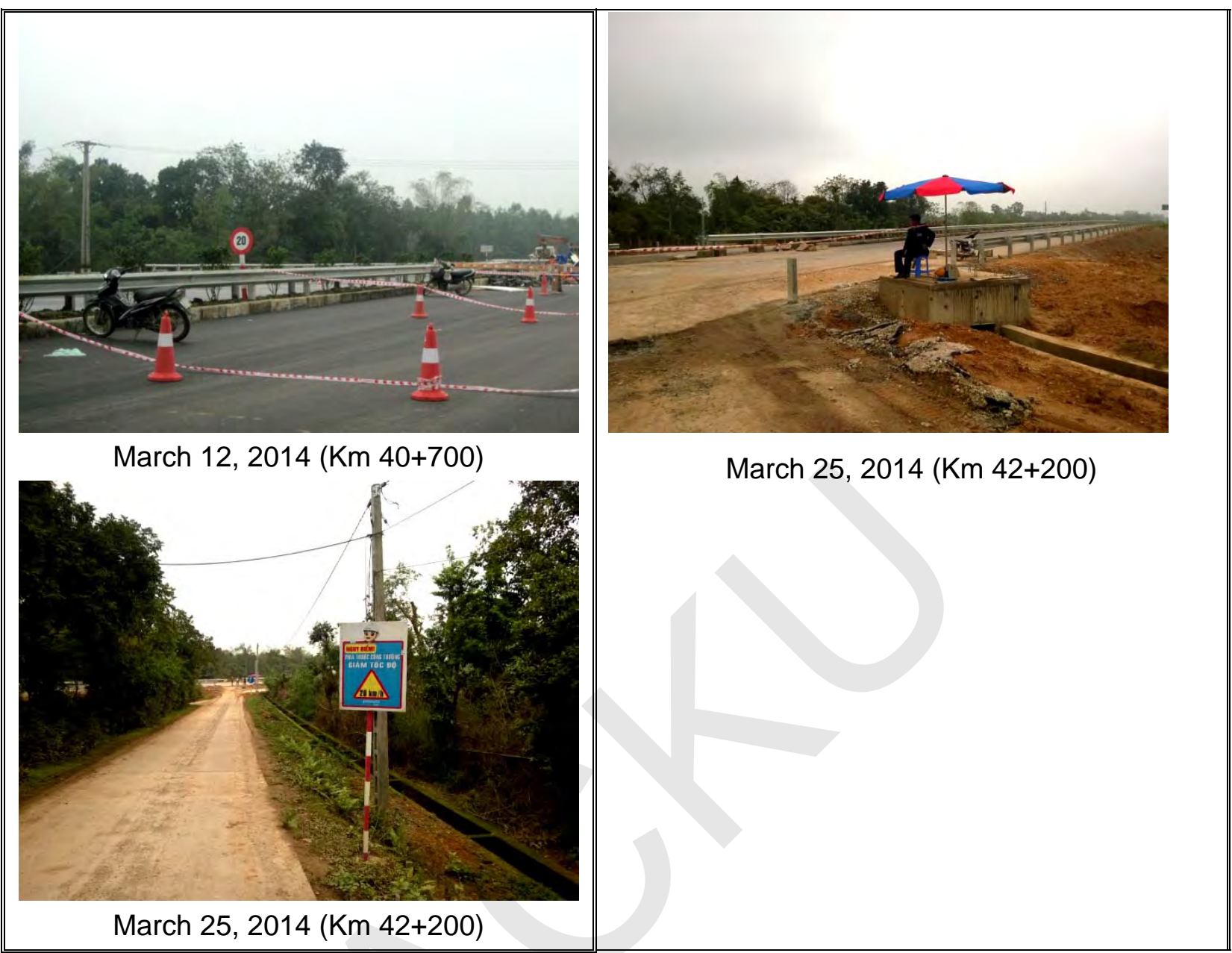

\subsubsection{Package A3}

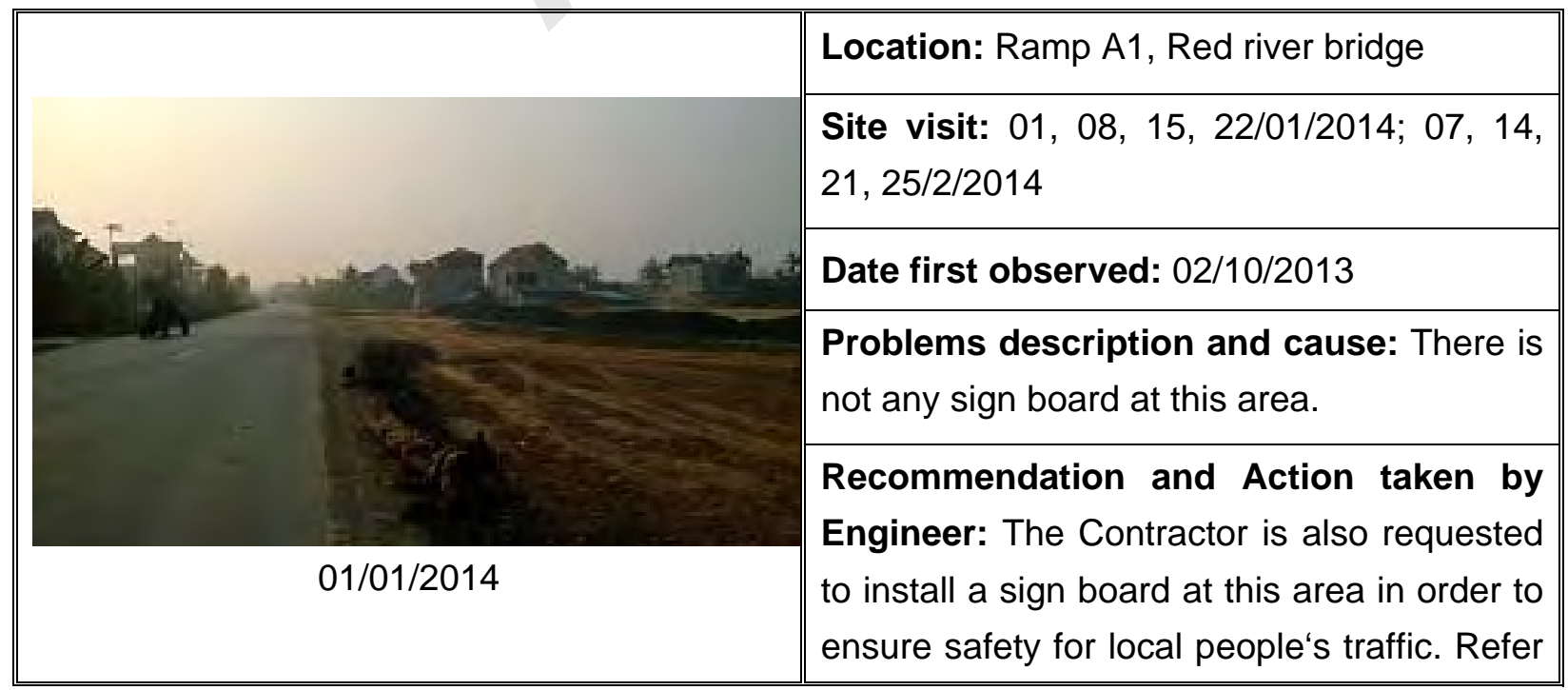




\section{Loan 2391/2392 - VIE: GMS Kunming - Hai Phong Transport Corridor Noi Bai - Lao Cai Highway Project}

\begin{tabular}{|c|c|}
\hline & $\begin{array}{l}\text { to the letters GET2-POS-A3-2170; GET2- } \\
\text { POS-A3-2228 }\end{array}$ \\
\hline & Responsible Party: \\
\hline & Deadline: immediately \\
\hline & $\begin{array}{l}\text { Current status: The contractor has not yet } \\
\text { installed a sign board at this area in order to } \\
\text { ensure safety for local people 's traffic. }\end{array}$ \\
\hline 07/2/2014 & \\
\hline
\end{tabular}

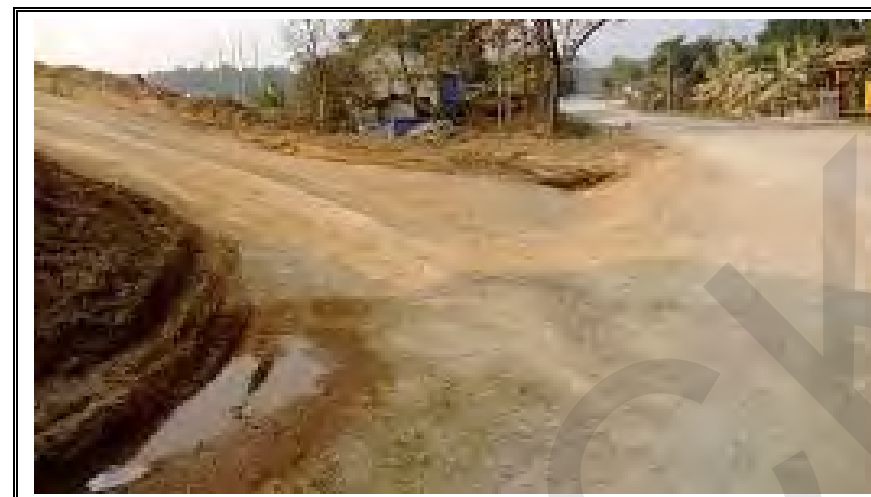

05/03/2014 (left site)

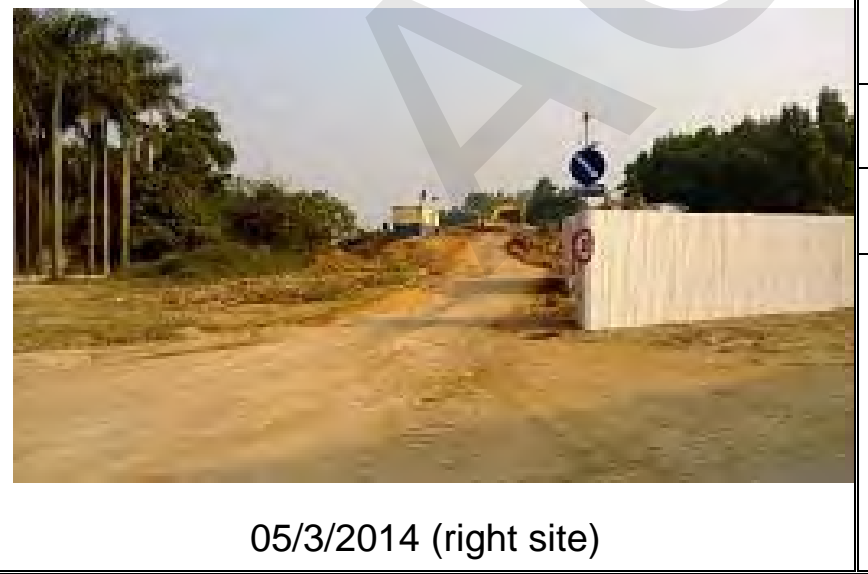

Location: TL325B bridge

Site visit: 05/3/3014

Date first observed: $05 / 03 / 2014$

Problems description and cause: There is not any signpost.

Recommendation and Action taken by Engineer: The Contractor is also requested to install a signpost in this area in order to ensure safety for local people 's traffic.

\section{Responsible Party:}

Deadline: immediately

Current status: The contractor has yet installed any signpost in this area in order to ensure safety for local people 's traffic. 


\section{Loan 2391/2392 - VIE: GMS Kunming - Hai Phong Transport Corridor Noi Bai - Lao Cai Highway Project}

\subsubsection{Package A4}

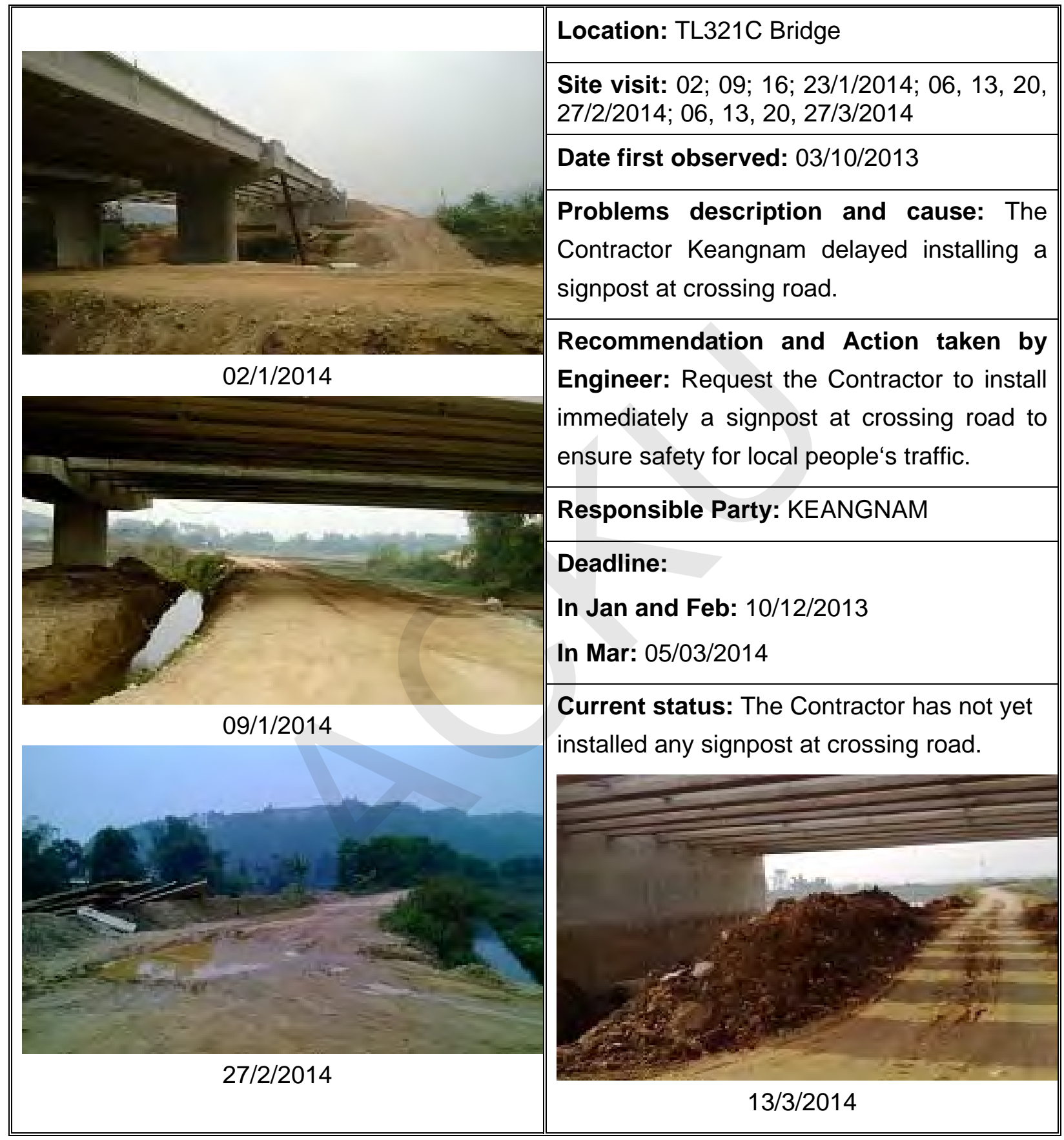




\section{Loan 2391/2392 - VIE: GMS Kunming - Hai Phong Transport Corridor Noi Bai - Lao Cai Highway Project}

\subsubsection{Package A5}

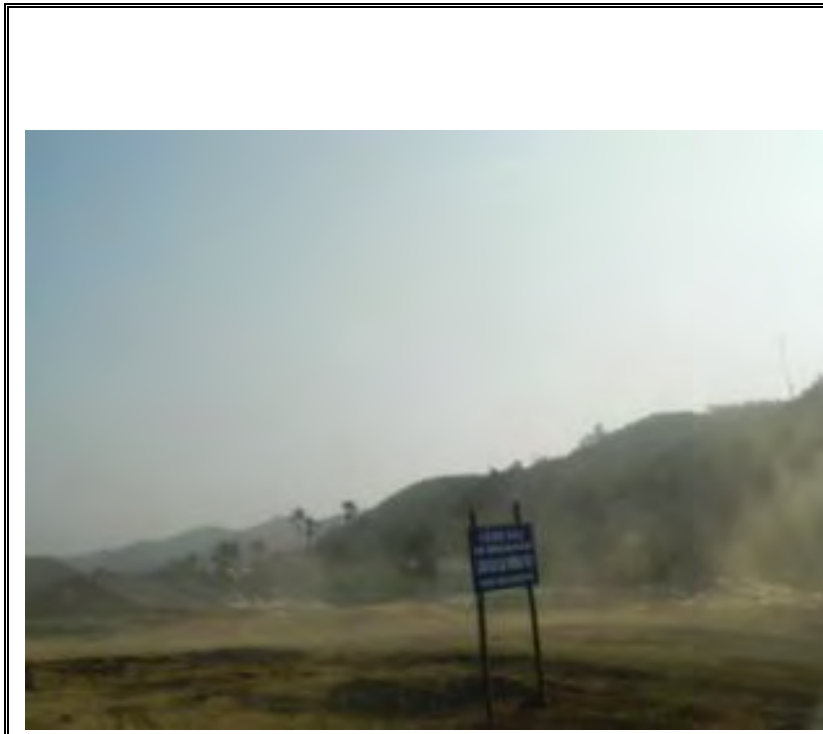

Location: Km142, Km123, Km111

Site visit: 7 and 20 January, 2014

January 7, $2014(\mathrm{Km} 142)$

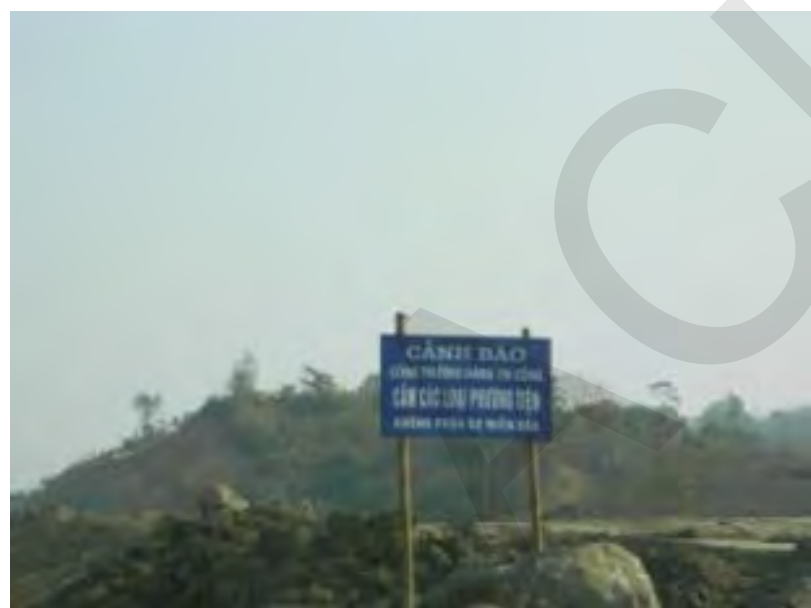

Description: The Contractor installed safety signboard in roads. Besides, the The Contractor is installing safety fence at access roads in order to keep the Project's safety.

January 7, $2014(\mathrm{Km} 111)$

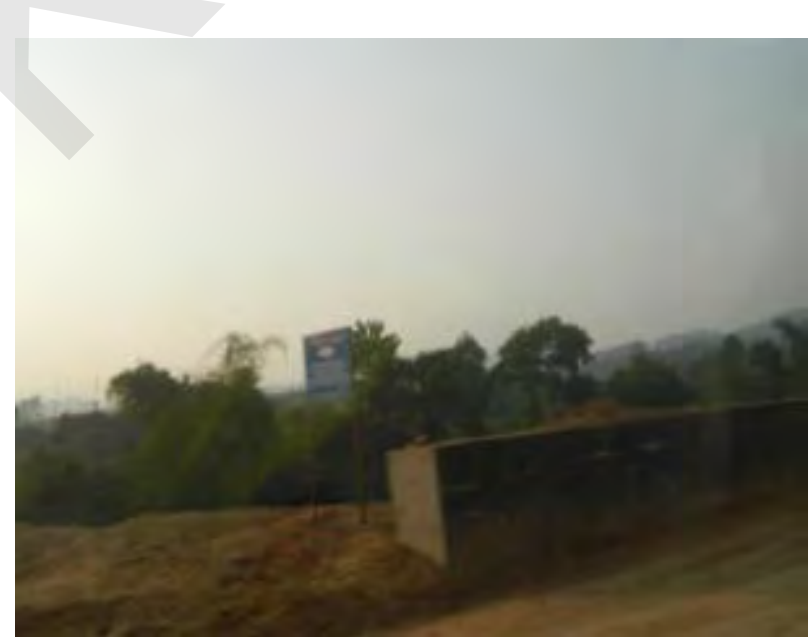

January 20, 2014 (Km123)

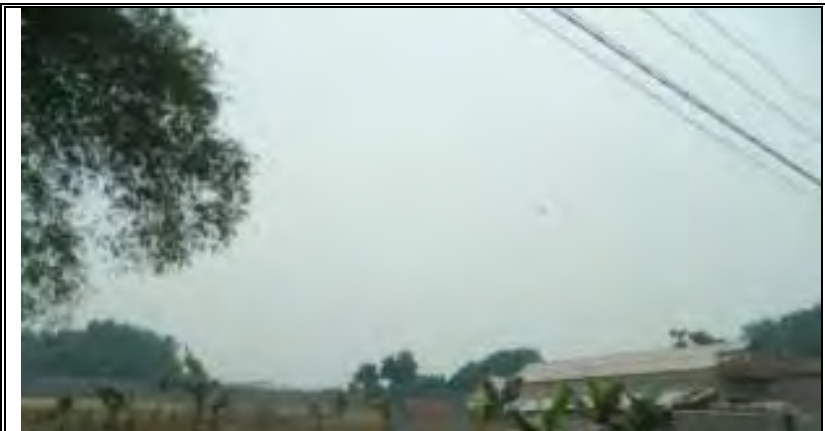

Location: Km131, NR37 bridge, Hop Minh My bridge

Site visit: 14 and 17 February, 2014 


\section{Loan 2391/2392 - VIE: GMS Kunming - Hai Phong Transport Corridor Noi Bai - Lao Cai Highway Project}

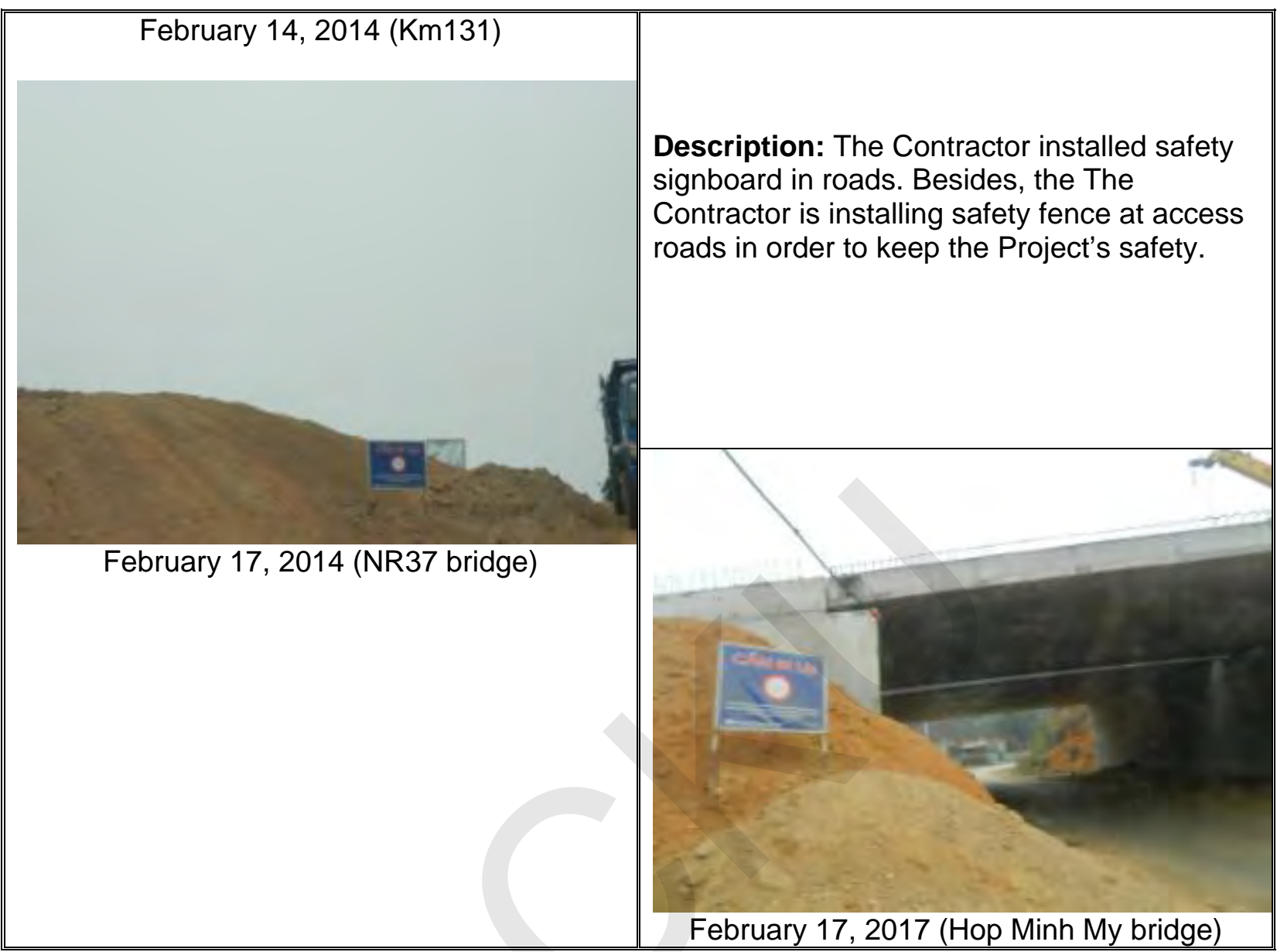

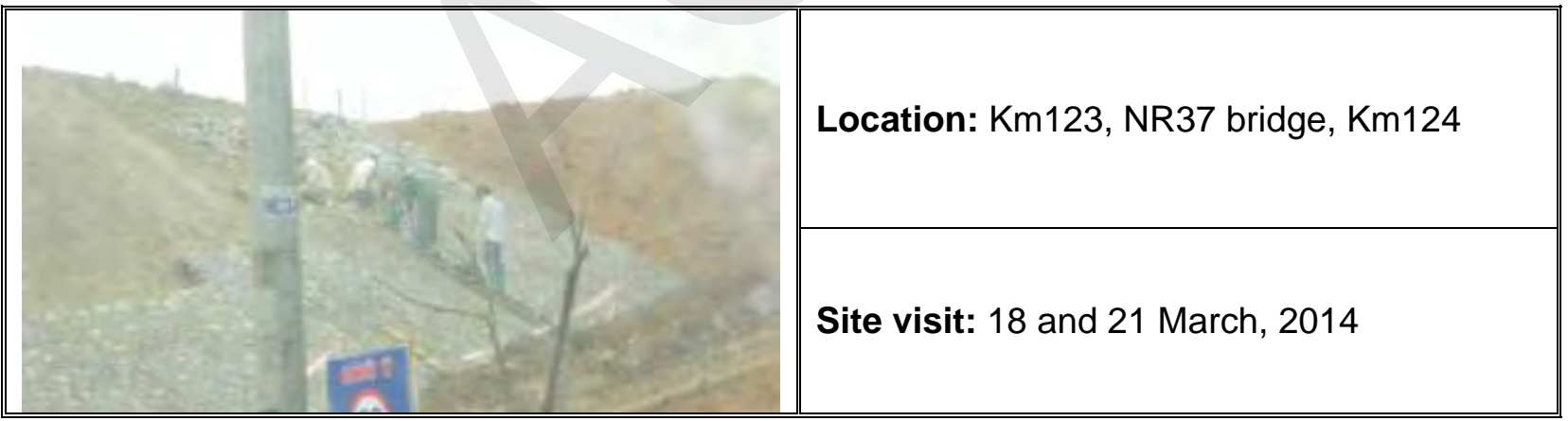




\section{Loan 2391/2392 - VIE: GMS Kunming - Hai Phong Transport Corridor Noi Bai - Lao Cai Highway Project}

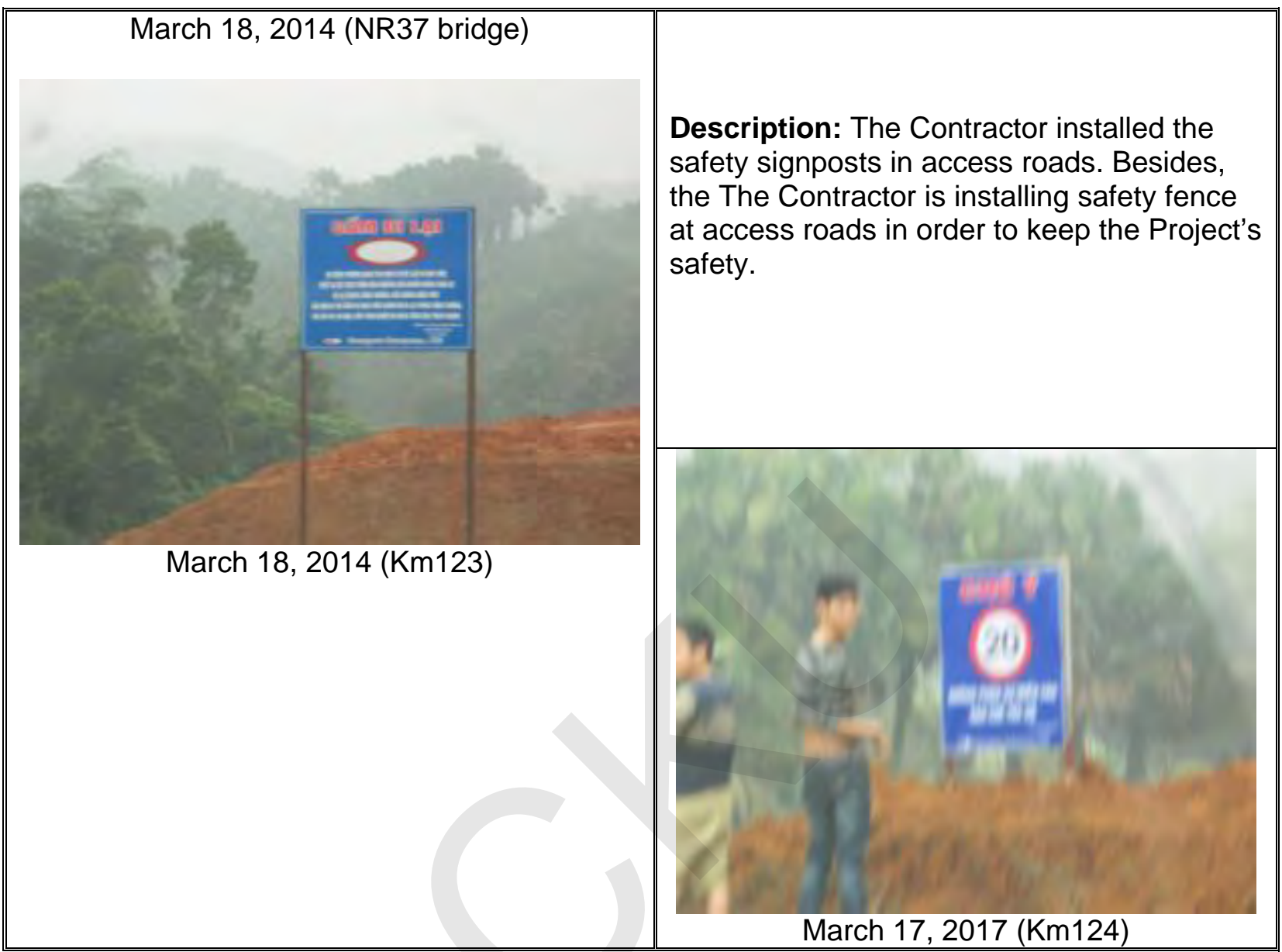

\subsubsection{Package A6}

\begin{tabular}{|l|l|l|}
\hline & Location: $\mathrm{Km} 174, \mathrm{Km} 176, \mathrm{Km} 156$ \\
\hline
\end{tabular}




\section{Loan 2391/2392 - VIE: GMS Kunming - Hai Phong Transport Corridor Noi Bai - Lao Cai Highway Project}
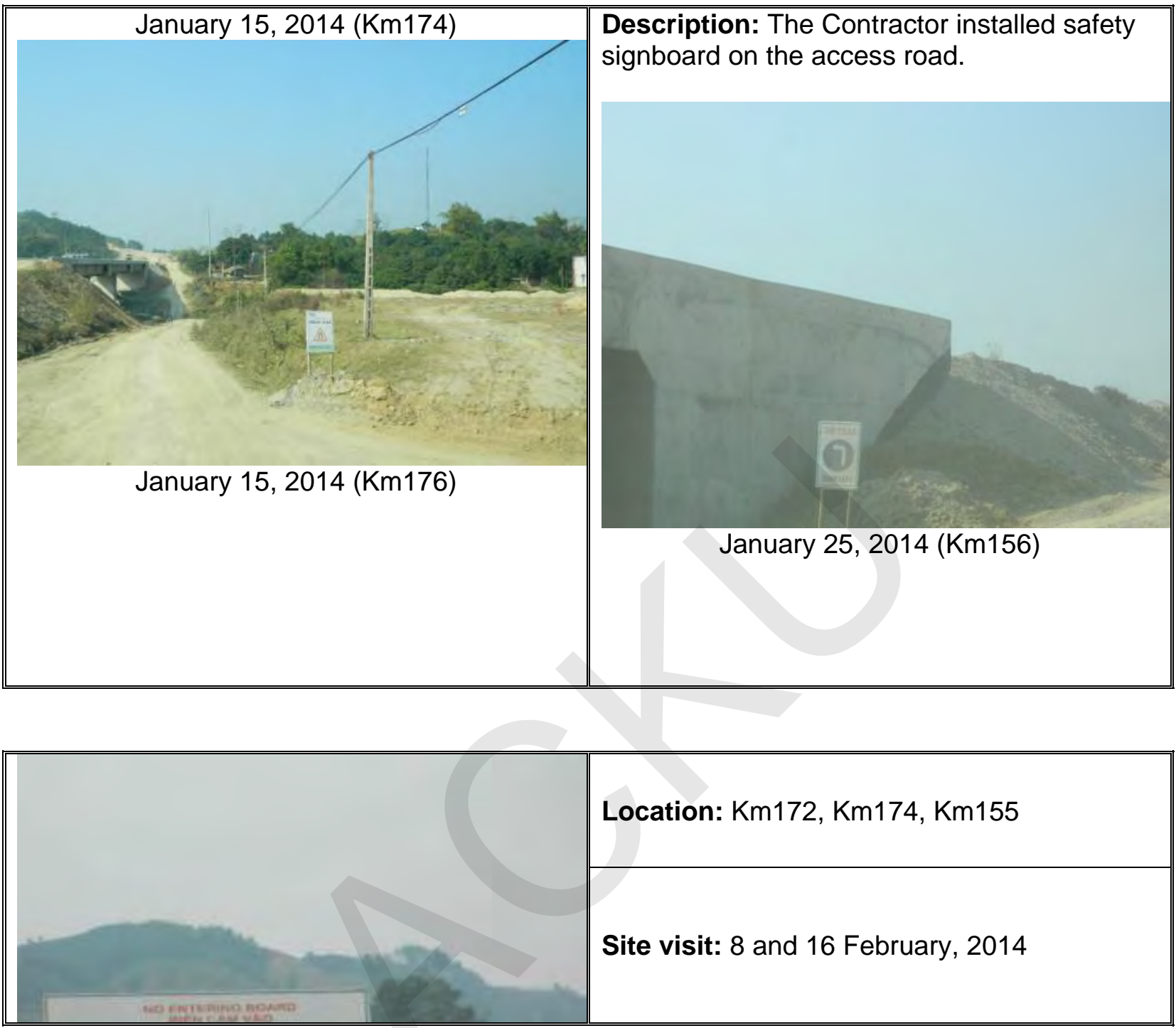


\section{Loan 2391/2392 - VIE: GMS Kunming - Hai Phong Transport Corridor Noi Bai - Lao Cai Highway Project}

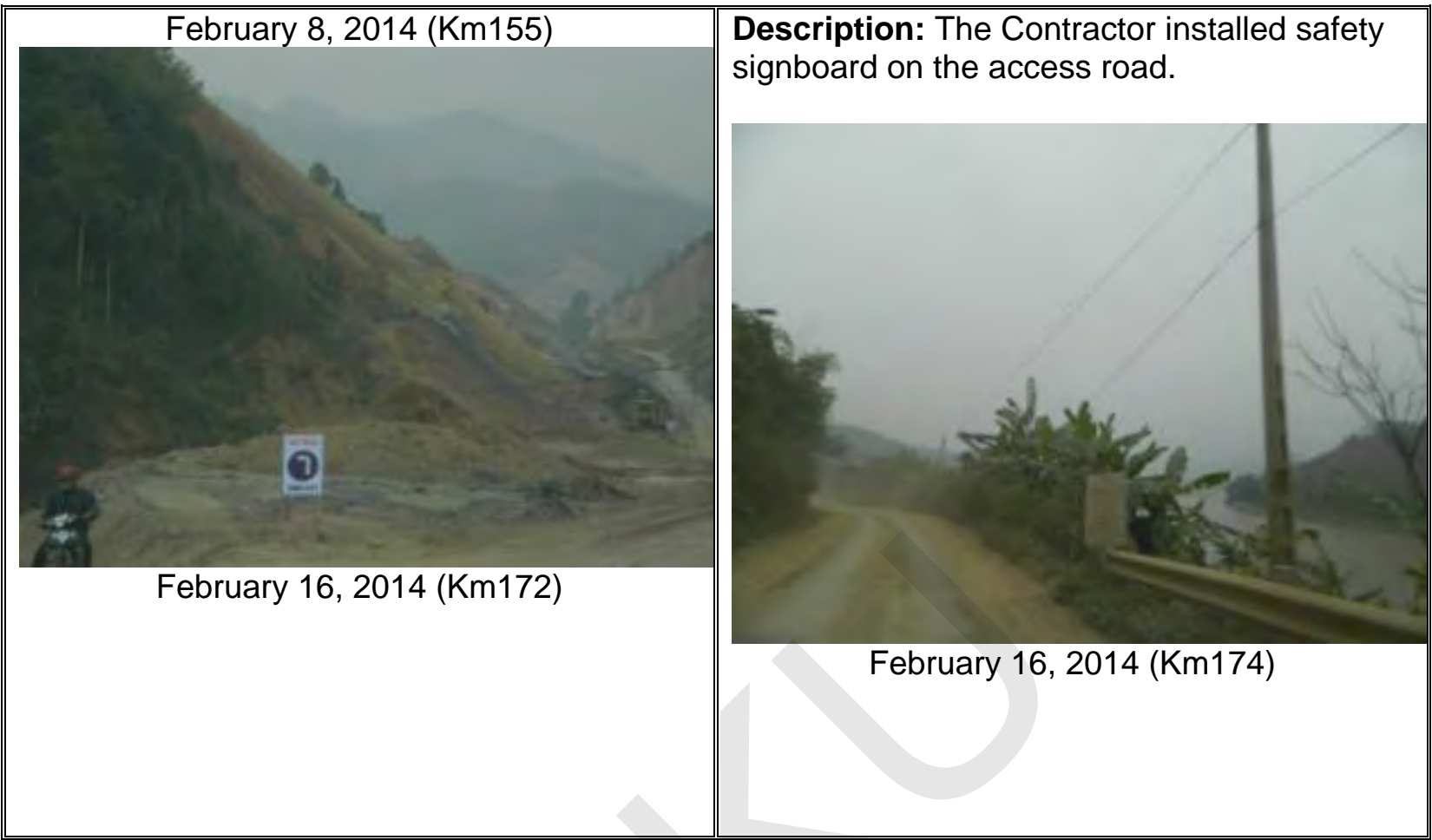

\begin{tabular}{|c|c|}
\hline & Location: Km169, Km154, Km160 \\
\hline & Site visit: 1 and 25 March, 2014 \\
\hline & $\begin{array}{l}\text { Description: The Contractor installed safety } \\
\text { signpostsat access roads. }\end{array}$ \\
\hline March 1, 2014 (Km160) & \\
\hline
\end{tabular}




\section{Loan 2391/2392 - VIE: GMS Kunming - Hai Phong Transport Corridor Noi Bai - Lao Cai Highway Project}

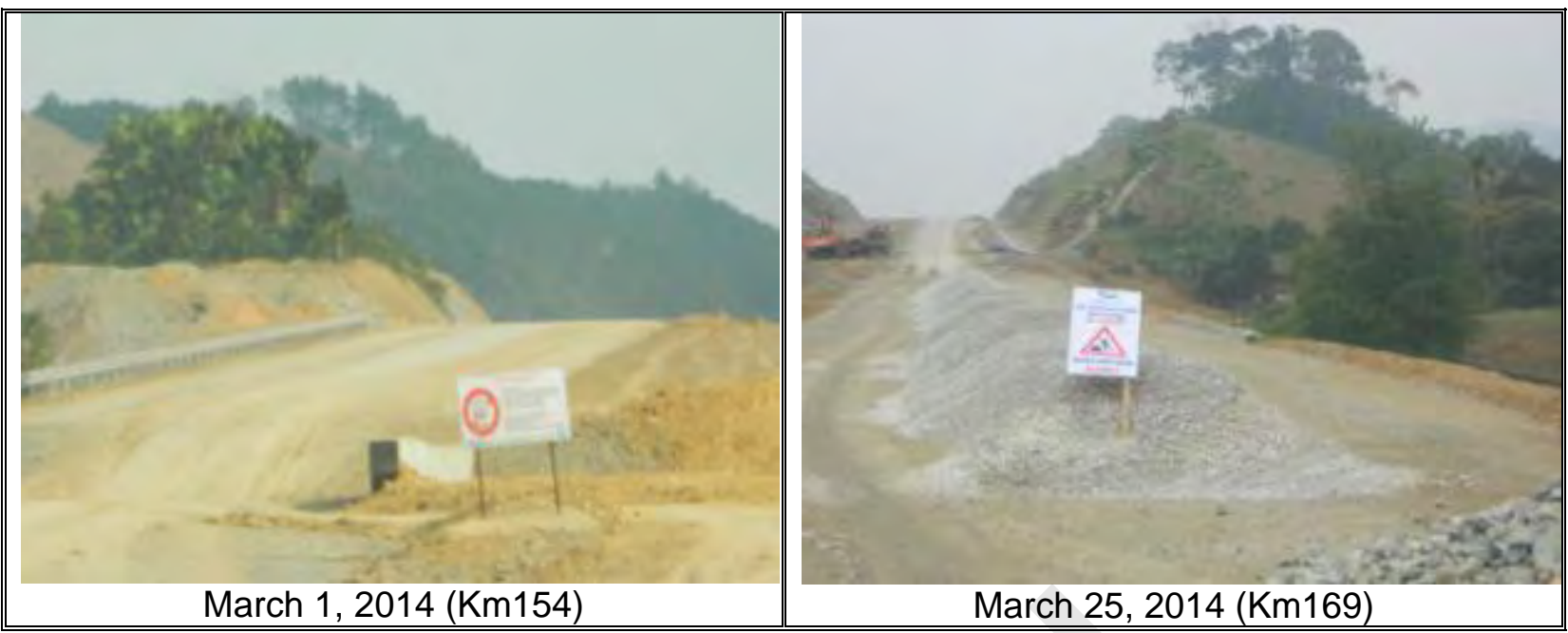

\subsubsection{Package A7}

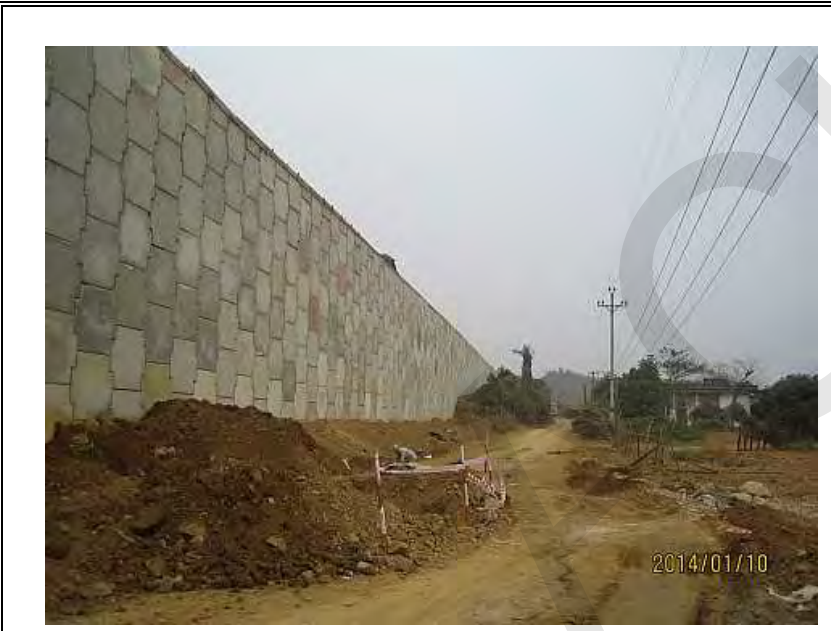

10.1.2014

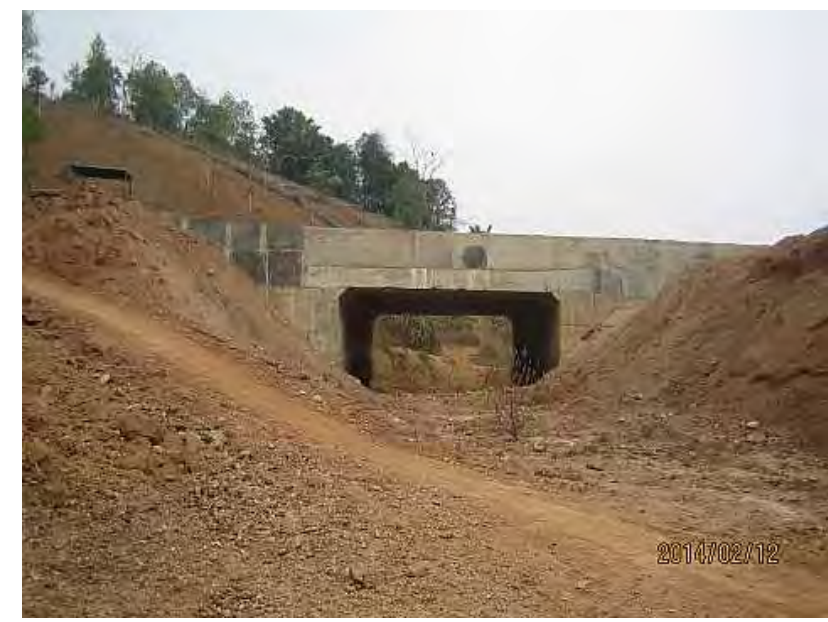

12.2 .2014
Location: Exist road at Km195+500

Site visit: $10.1 .2014 ; 20.2$ and 25.2 .2014

Date first observed: 12.2 .2014

Problems description and cause: The access roads are full of mud and it is very difficult for travel

Recommendation and Action taken by

Engineer: The contractor is required to repair and consolidate the road surface to convenient traffic for local people according to the letters No: Ref. Get4- GRBCC-1042 and 1056

Deadline: 28.2.2014

Current status: The contractor is improving this issue 


\section{Loan 2391/2392 - VIE: GMS Kunming - Hai Phong Transport Corridor Noi Bai - Lao Cai Highway Project}
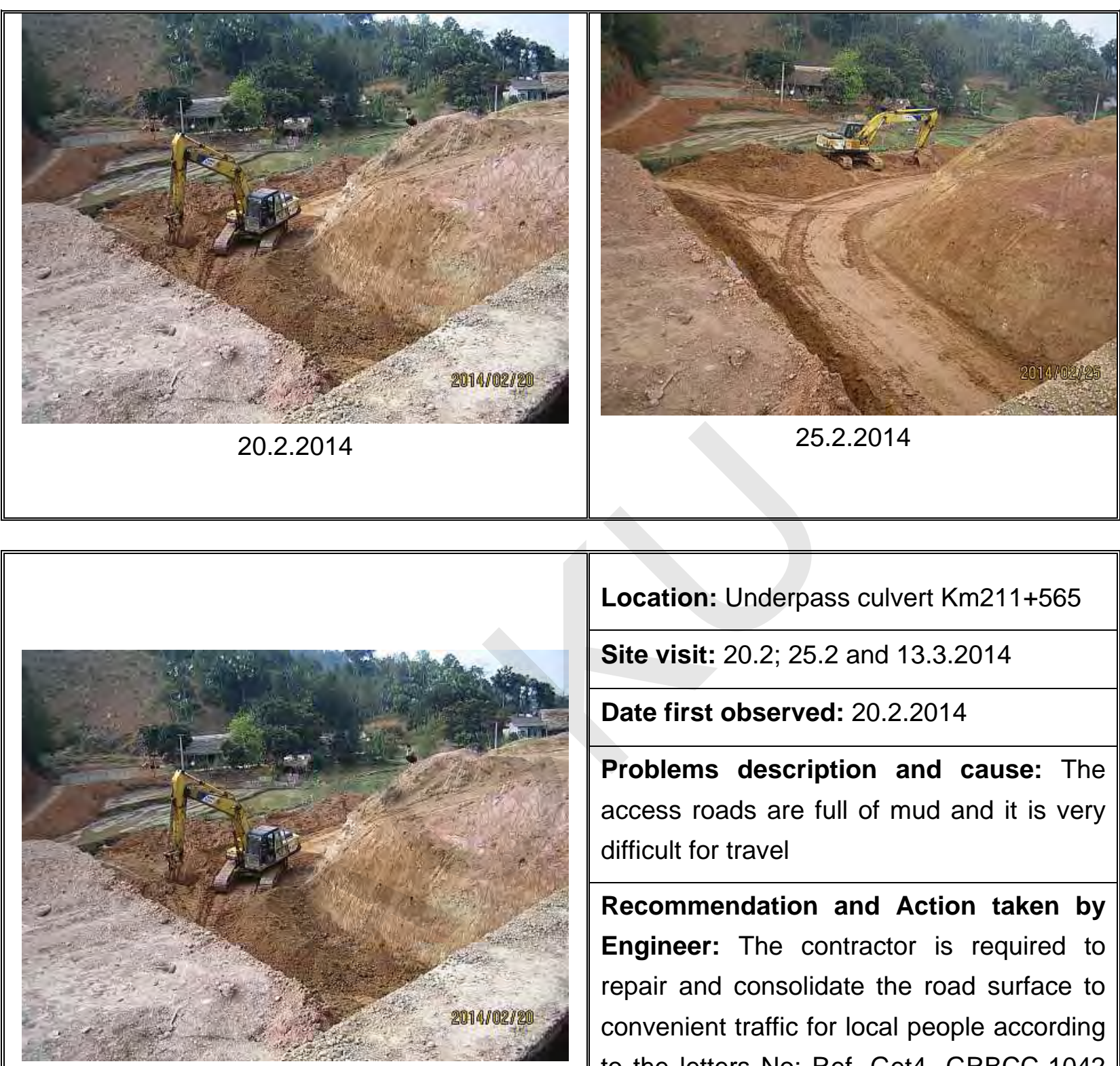

Location: Underpass culvert Km211+565

Site visit: $20.2 ; 25.2$ and 13.3 .2014

Date first observed: 20.2 .2014

Problems description and cause: The access roads are full of mud and it is very difficult for travel

Recommendation and Action taken by Engineer: The contractor is required to repair and consolidate the road surface to convenient traffic for local people according to the letters No: Ref. Get4- GRBCC-1042 and 1056

Deadline: 28.2 .2014 


\section{Loan 2391/2392 - VIE: GMS Kunming - Hai Phong Transport Corridor Noi Bai - Lao Cai Highway Project}

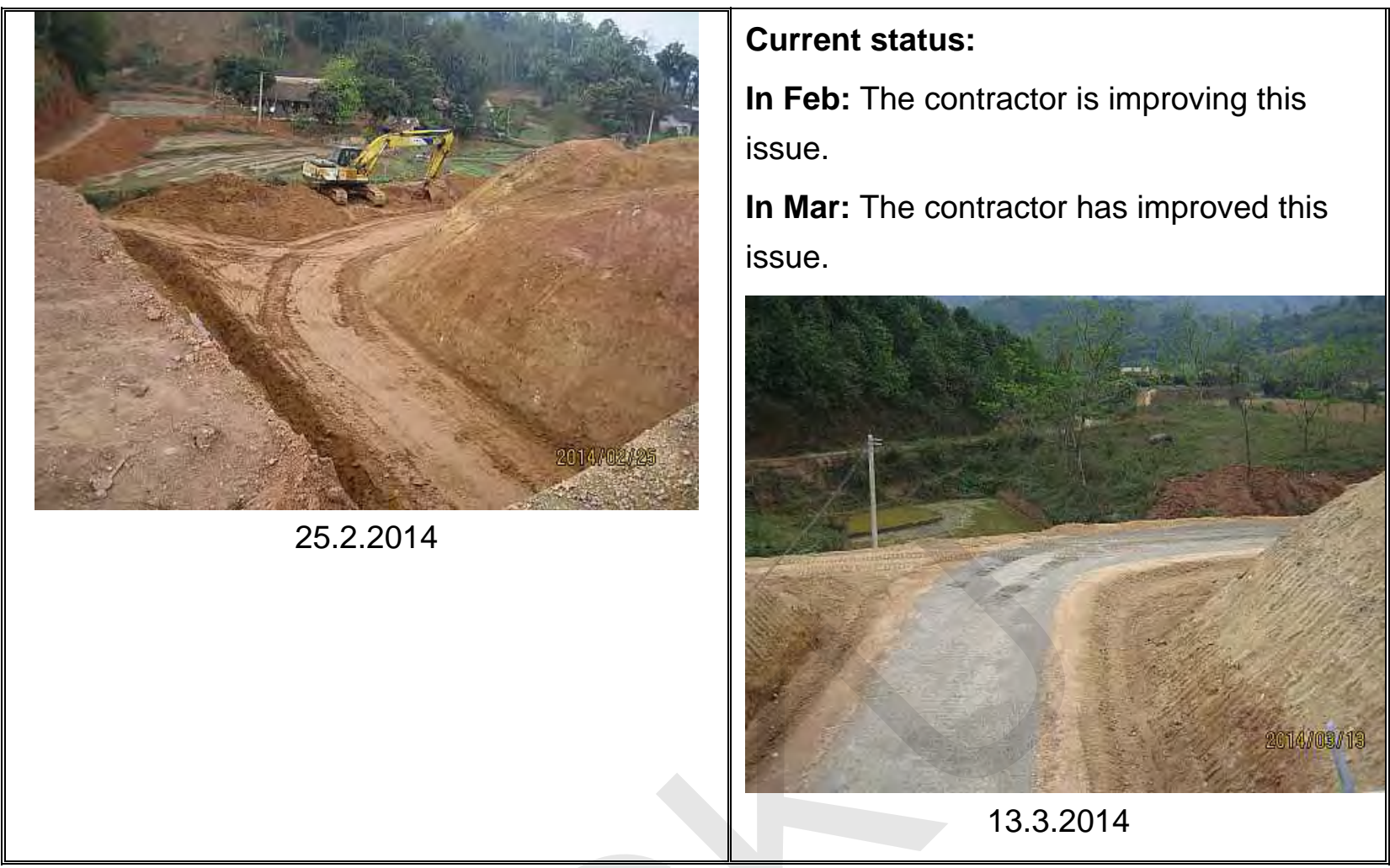

\subsubsection{Package A8}

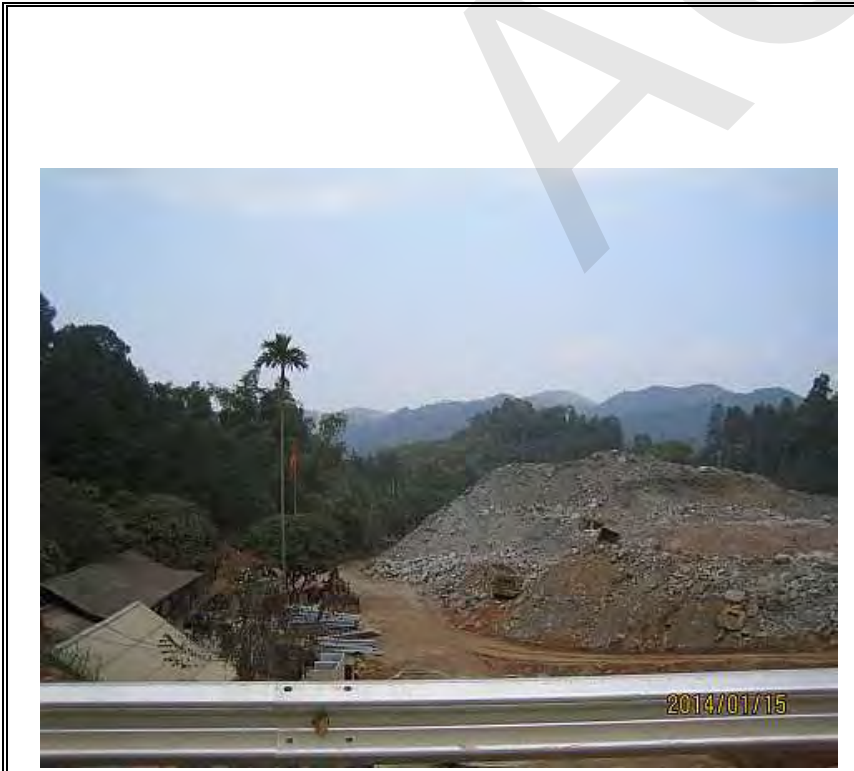

15.1.2014

Location: Underpass box culvert
Km218+160

Site visit: 15.1 .2014

Date first observed: 15.4 .2013

Problems description and cause: The access roads are full of mud and it is very difficult for travel

Recommendation and Action taken by Engineer: Require the contractor to repair this road in order to ensure local people's traffic according to the letter No: Ref. Get4Vinaconex- 912 and No: 230/EPMUNBLC- A8

Deadline: 31.12.2013 


\section{Loan 2391/2392 - VIE: GMS Kunming - Hai Phong Transport Corridor Noi Bai - Lao Cai Highway Project}

\begin{tabular}{|l||l|}
\hline & $\begin{array}{l}\text { Current status: The contractor had } \\
\text { repaired the access road in order to make } \\
\text { the good condition for traffic of local people }\end{array}$ \\
\hline
\end{tabular}

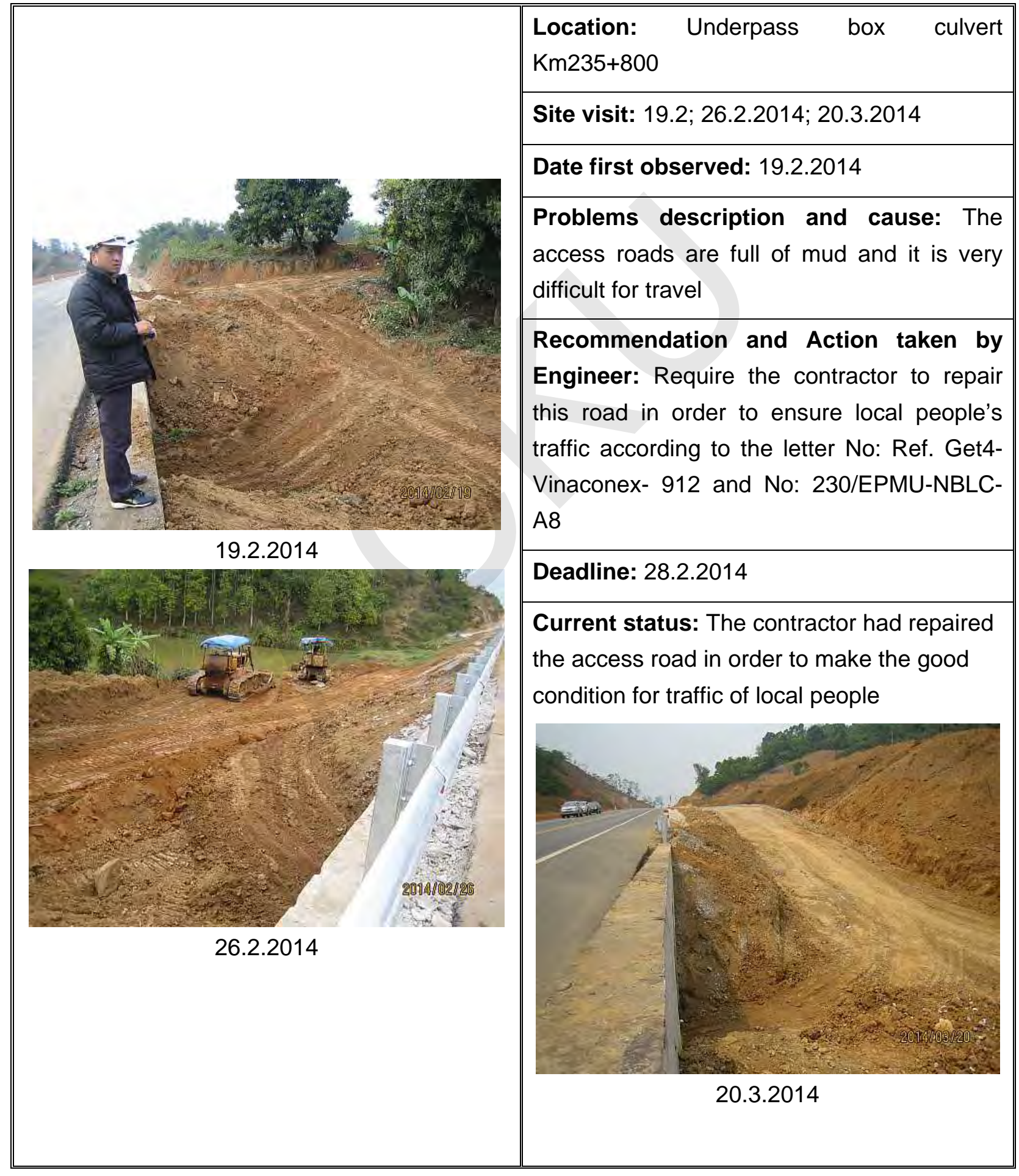




\section{Loan 2391/2392 - VIE: GMS Kunming - Hai Phong Transport Corridor Noi Bai - Lao Cai Highway Project}

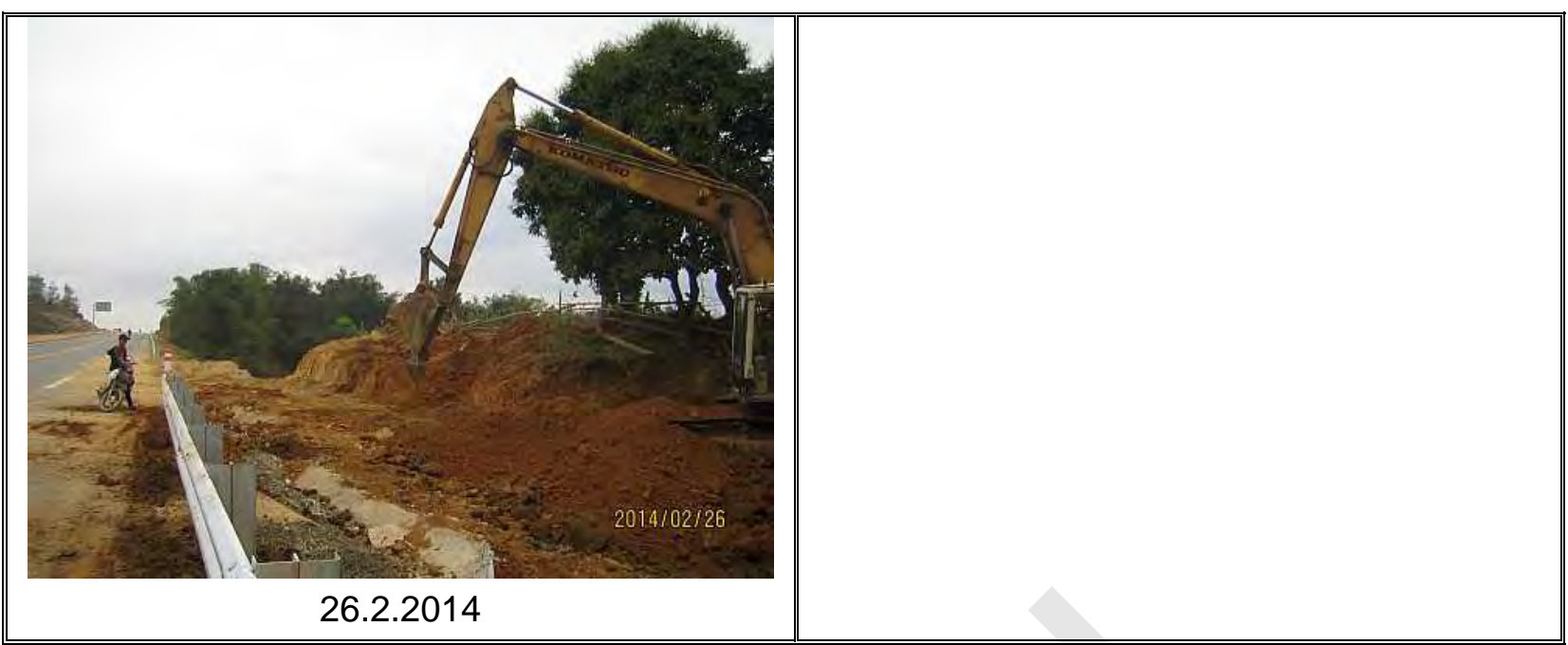

\subsection{SIGNPOSTING IN DANGEROUS SURFACES}

\subsubsection{Package A1}

At the present, at package A1, the Contractor has finished all construction works.

\subsubsection{Package A2}

By site inspections in this period, we did not detect any problem on the sites in this period. However, the Engineer also recommended the Contractor to pay attention to this issue if it happens and the necessary countermeasures must be applied to prevent accident happening.

\subsubsection{Package A3}

\begin{tabular}{|l|l|}
\hline \multirow{4}{*}{} & Location: QL2 bridge \\
\hline & $\begin{array}{l}\text { Site visit: 01, 08, 15, 22/01/2014; 07, 14, 21, } \\
25 / 2 / 2014\end{array}$ \\
\hline & Date first observed: 02/10/2013 \\
\hline & $\begin{array}{l}\text { Problems description and cause: There is } \\
\text { not any signpost at this area. }\end{array}$ \\
\hline $25 / 12 / 2013$ & $\begin{array}{l}\text { Recommendation and Action taken by } \\
\text { Engineer: The Contractor is also requested }\end{array}$ \\
\hline
\end{tabular}




\section{Loan 2391/2392 - VIE: GMS Kunming - Hai Phong Transport Corridor Noi Bai - Lao Cai Highway Project}

\begin{tabular}{|l|l|}
\hline & $\begin{array}{l}\text { to install a signpost in this area in order to } \\
\text { ensure safety for local people's traffic. }\end{array}$ \\
\hline & Desponsible Party: \\
\hline &
\end{tabular}

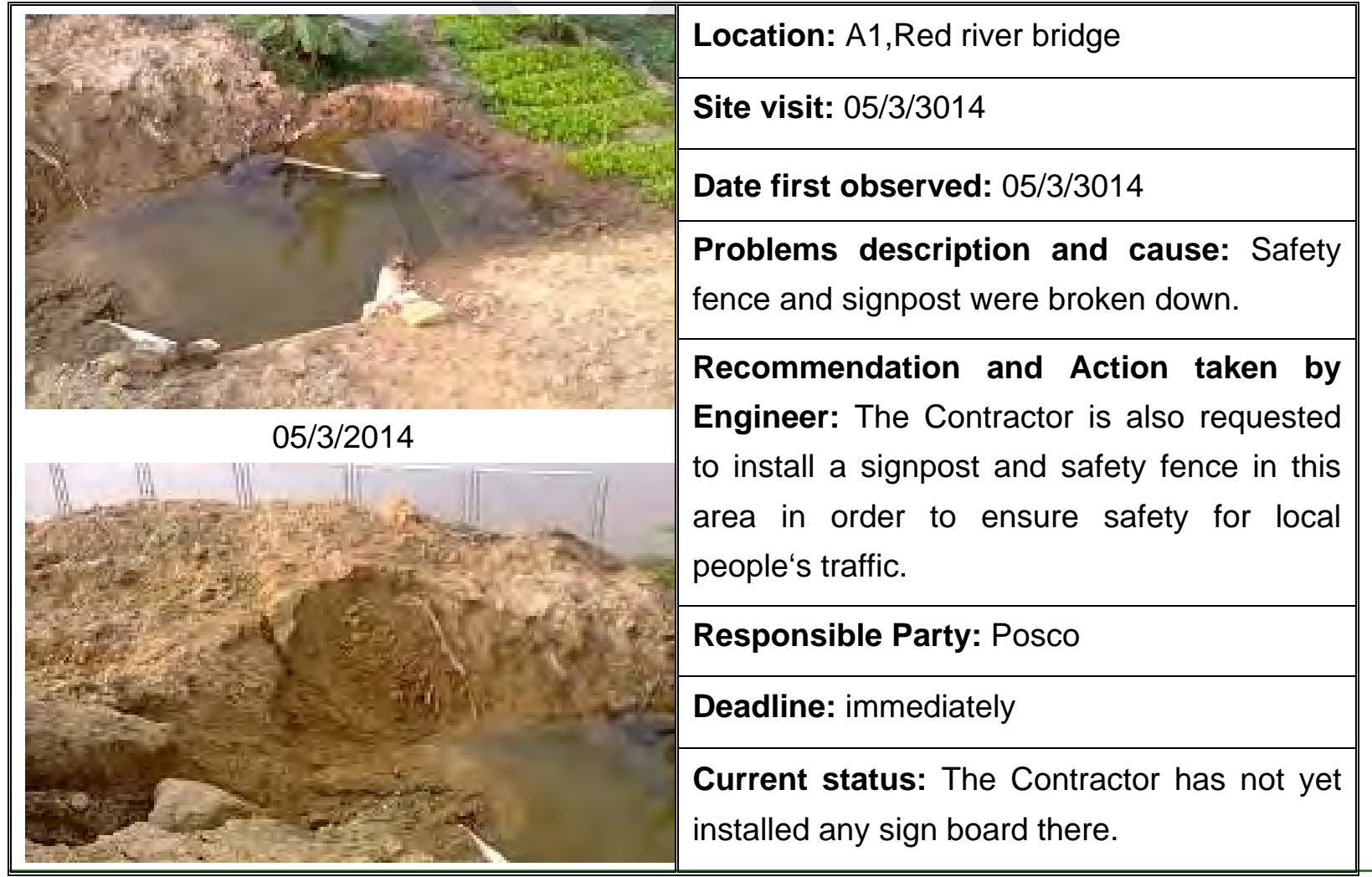


Loan 2391/2392 - VIE: GMS Kunming - Hai Phong Transport Corridor Noi Bai - Lao Cai Highway Project

\begin{tabular}{|l|l|}
\hline $05 / 3 / 2014$ & \\
\hline
\end{tabular}

\subsubsection{Package A4}

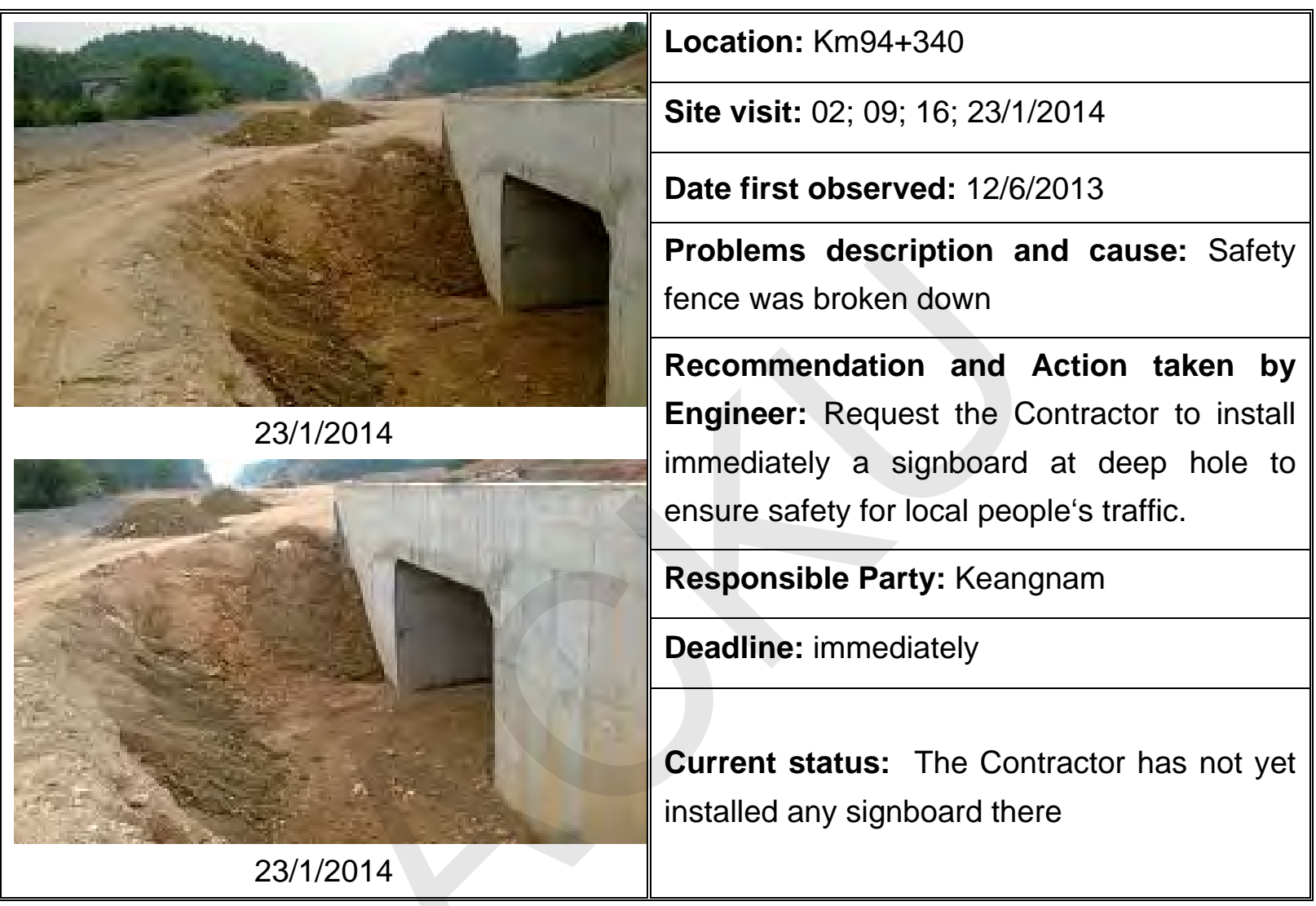

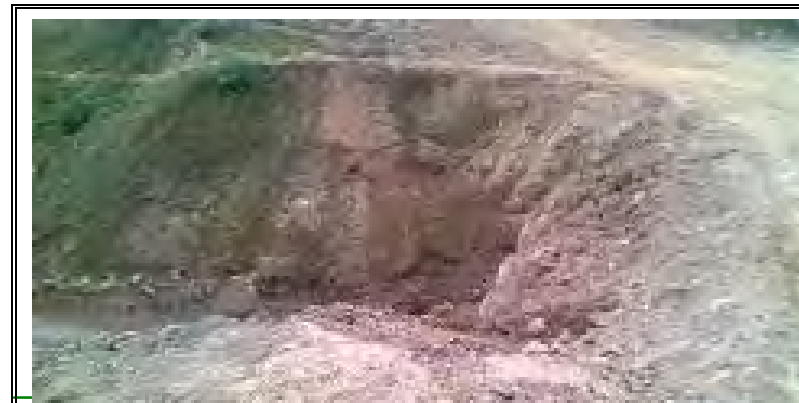

Location: Km109+100

Site visit: $06,13,20,27 / 2 / 2014 ; 06,13,20$, $27 / 3 / 2014$

Date first observed: $12 / 6 / 2013$ 


\section{Loan 2391/2392 - VIE: GMS Kunming - Hai Phong Transport Corridor Noi Bai - Lao Cai Highway Project}

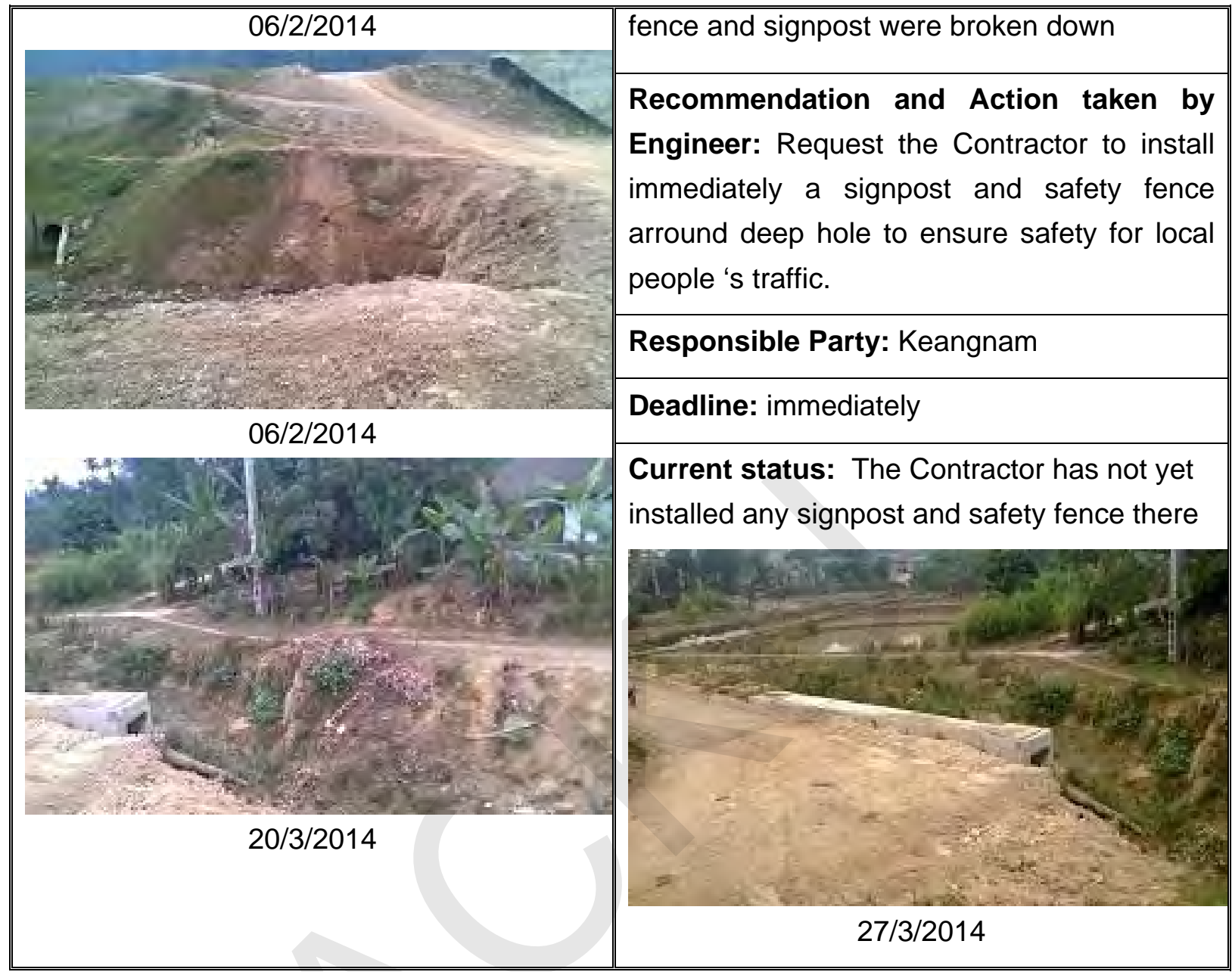

\subsubsection{Package A5}

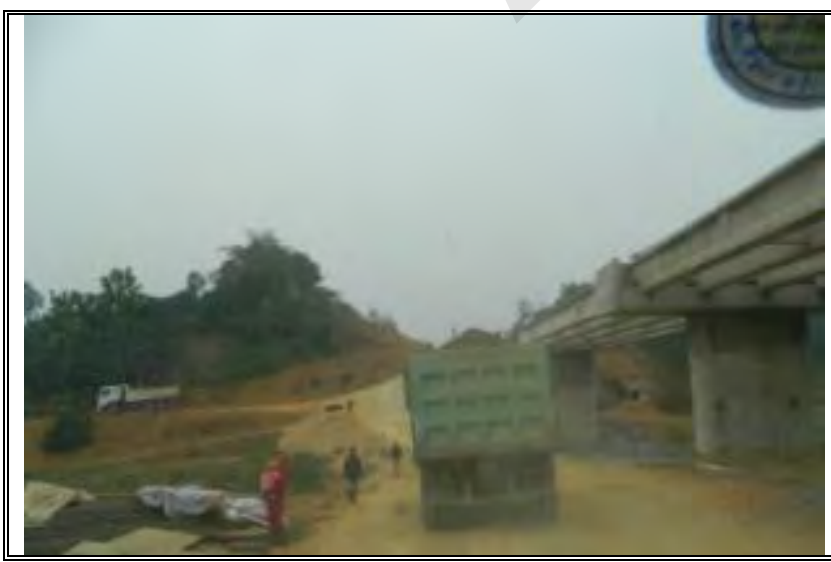

Location: Ngoi Thap bridge's construction site

Site visit: 7 and 20 January; 28 February; 5 March, 2014

Date first observed: $7^{\text {th }}$ January, 2014

Problems description and cause: This construction site is intersecting with public road, but safety fences and signboards were not installed at this location. This situation is unsafe. 


\section{Loan 2391/2392 - VIE: GMS Kunming - Hai Phong Transport Corridor Noi Bai - Lao Cai Highway Project}
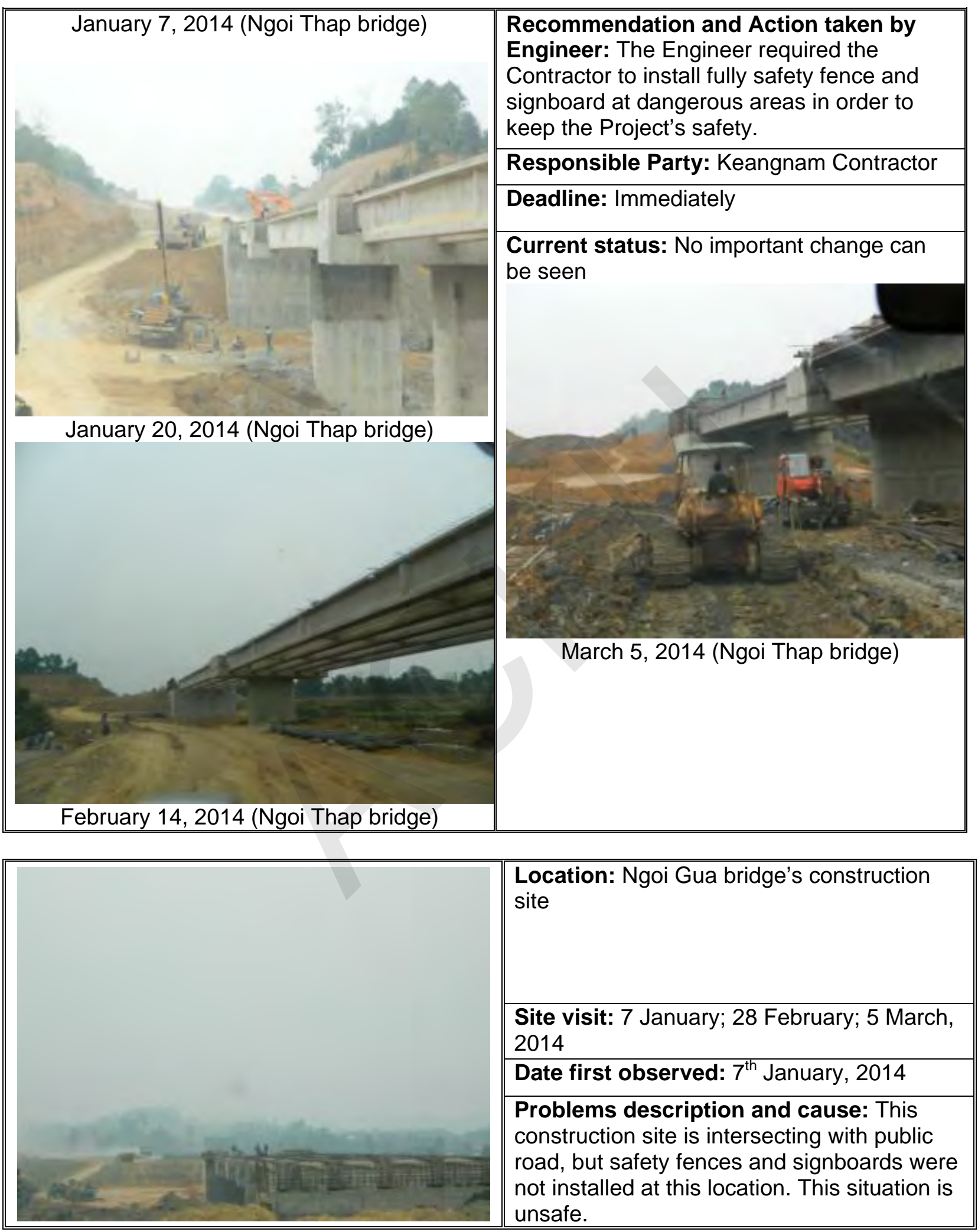
Loan 2391/2392 - VIE: GMS Kunming - Hai Phong Transport Corridor Noi Bai - Lao Cai Highway Project

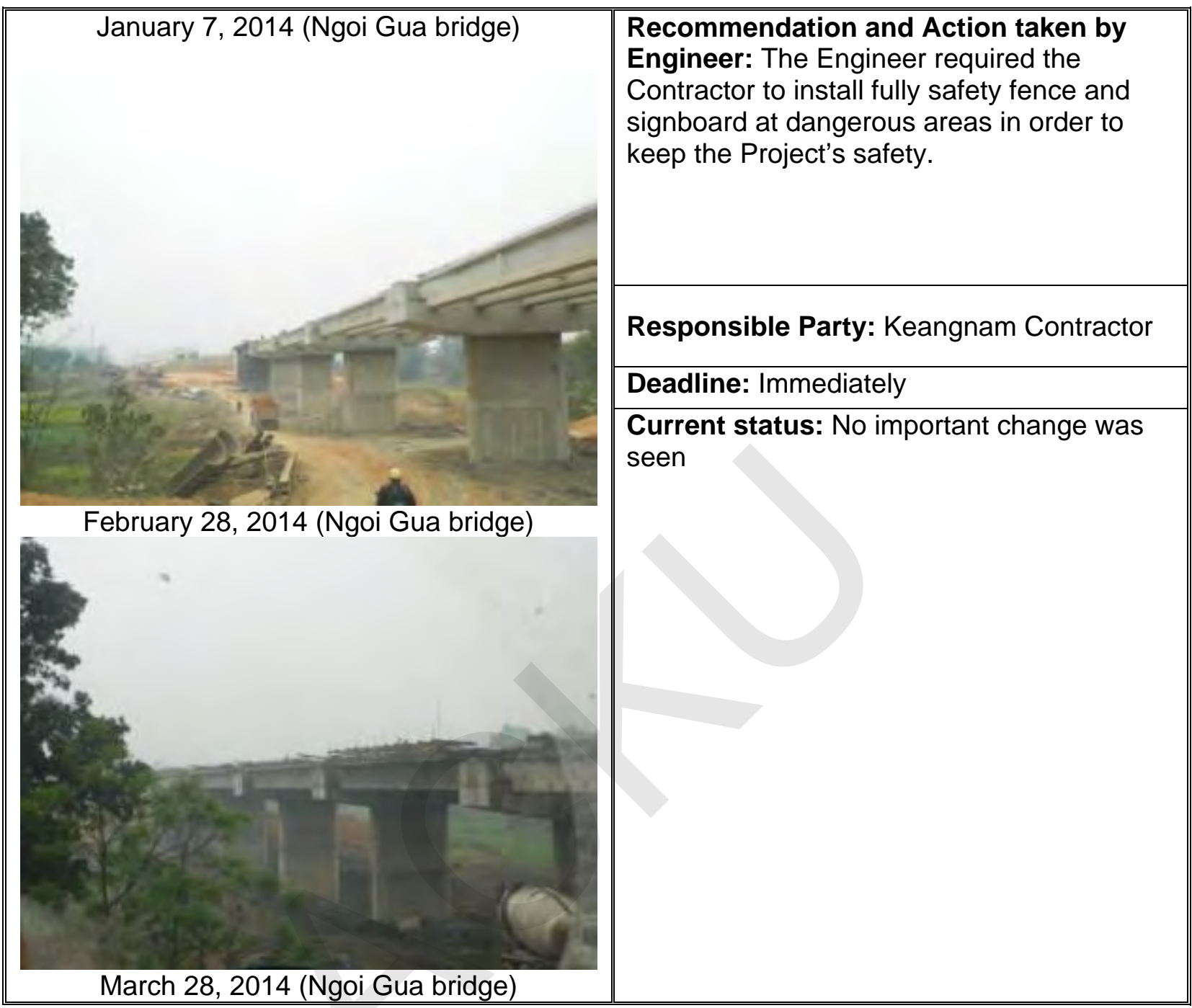

\subsubsection{Package A6}

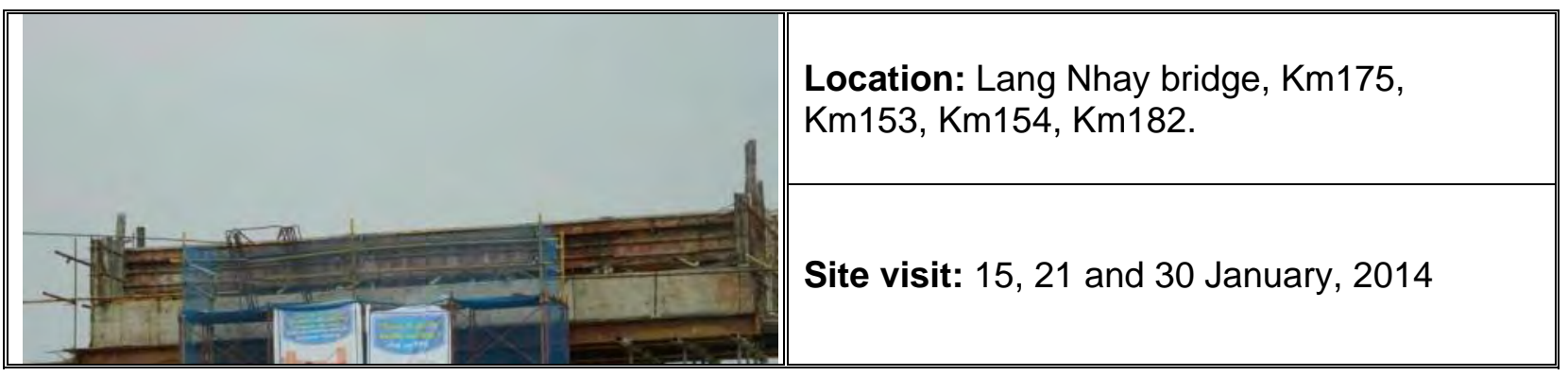




\section{Loan 2391/2392 - VIE: GMS Kunming - Hai Phong Transport Corridor Noi Bai - Lao Cai Highway Project}
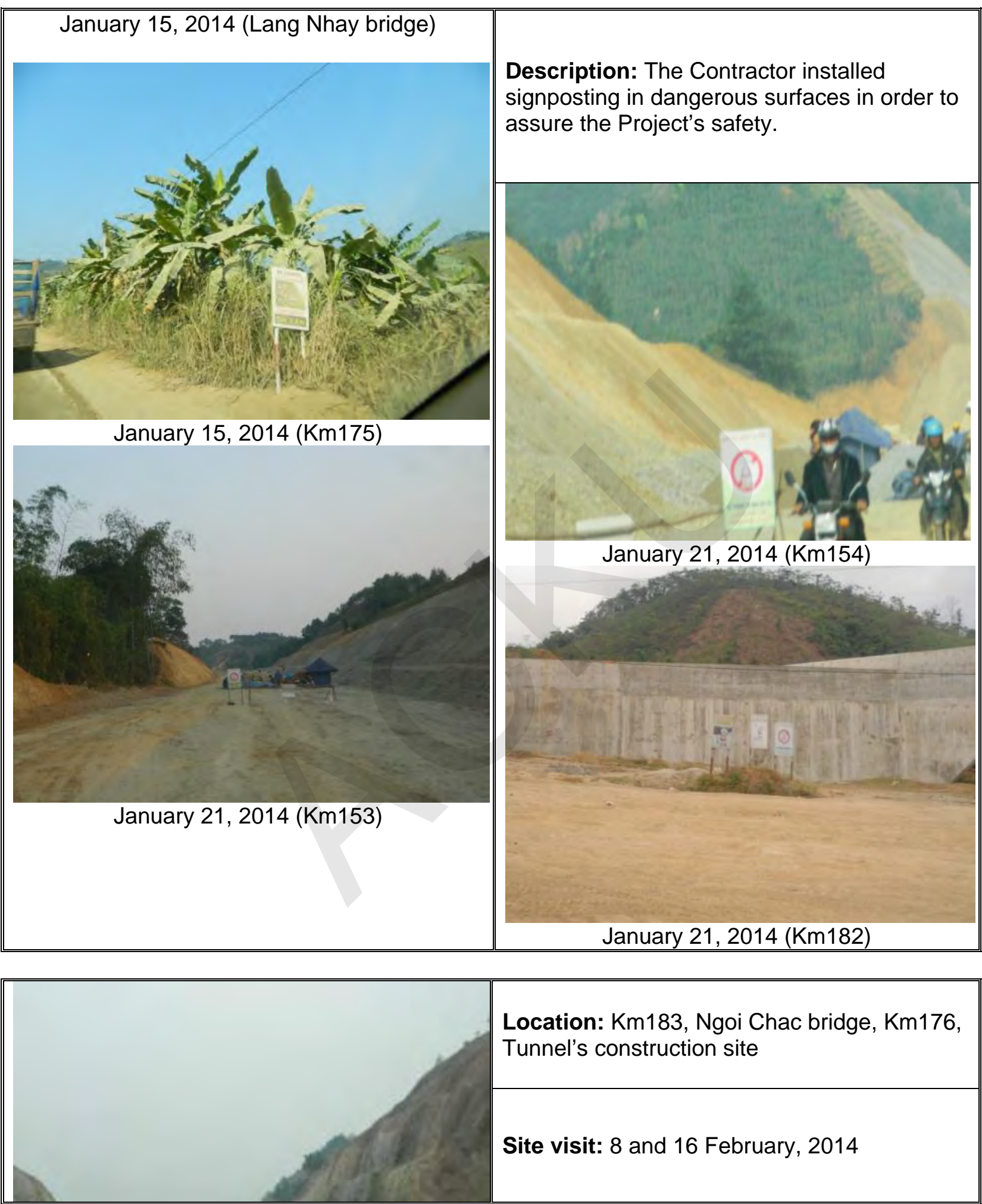


\section{Loan 2391/2392 - VIE: GMS Kunming - Hai Phong Transport Corridor Noi Bai - Lao Cai Highway Project}
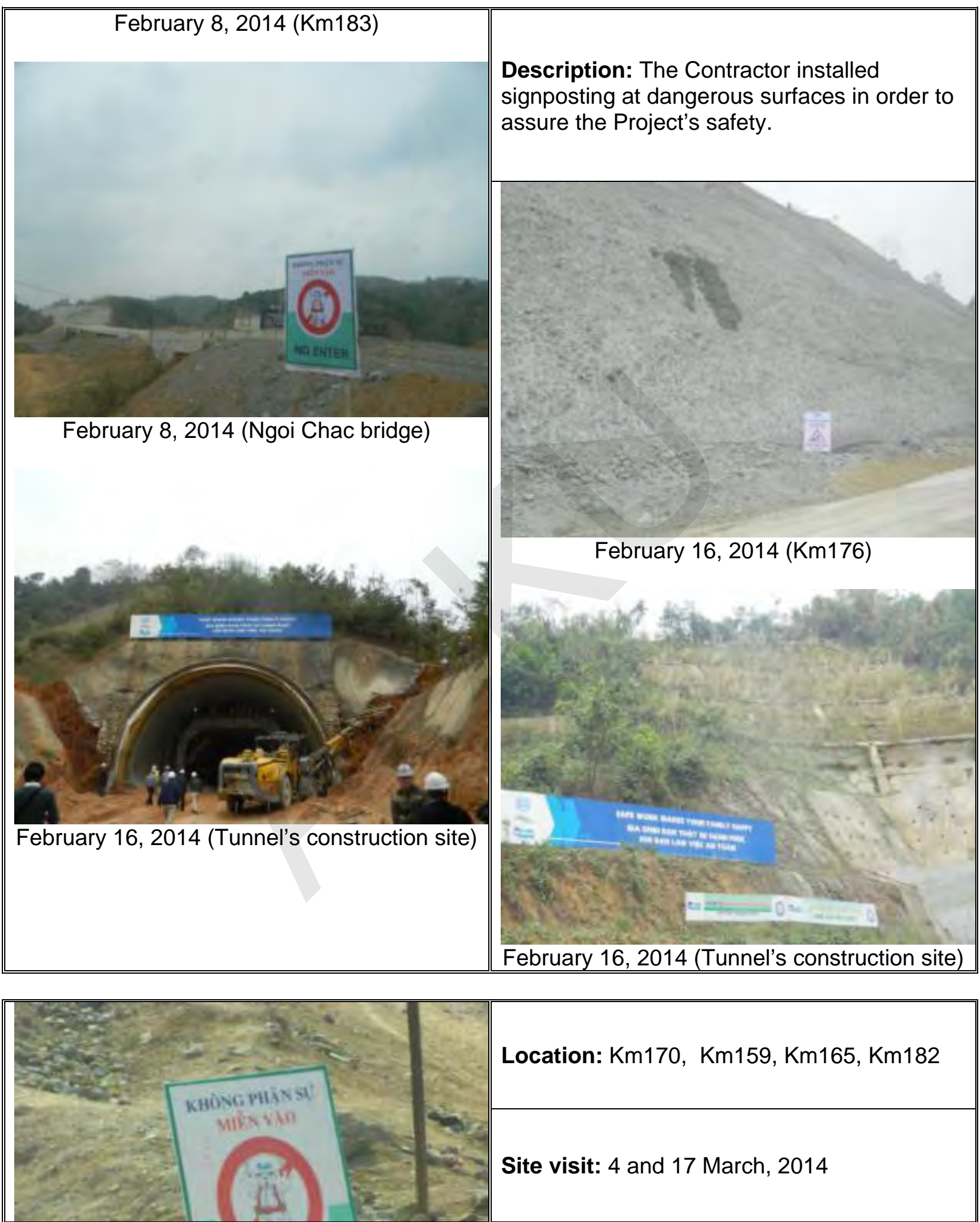

Location: Km170, Km159, Km165, Km182

Site visit: 4 and 17 March, 2014 


\section{Loan 2391/2392 - VIE: GMS Kunming - Hai Phong Transport Corridor Noi Bai - Lao Cai Highway Project}

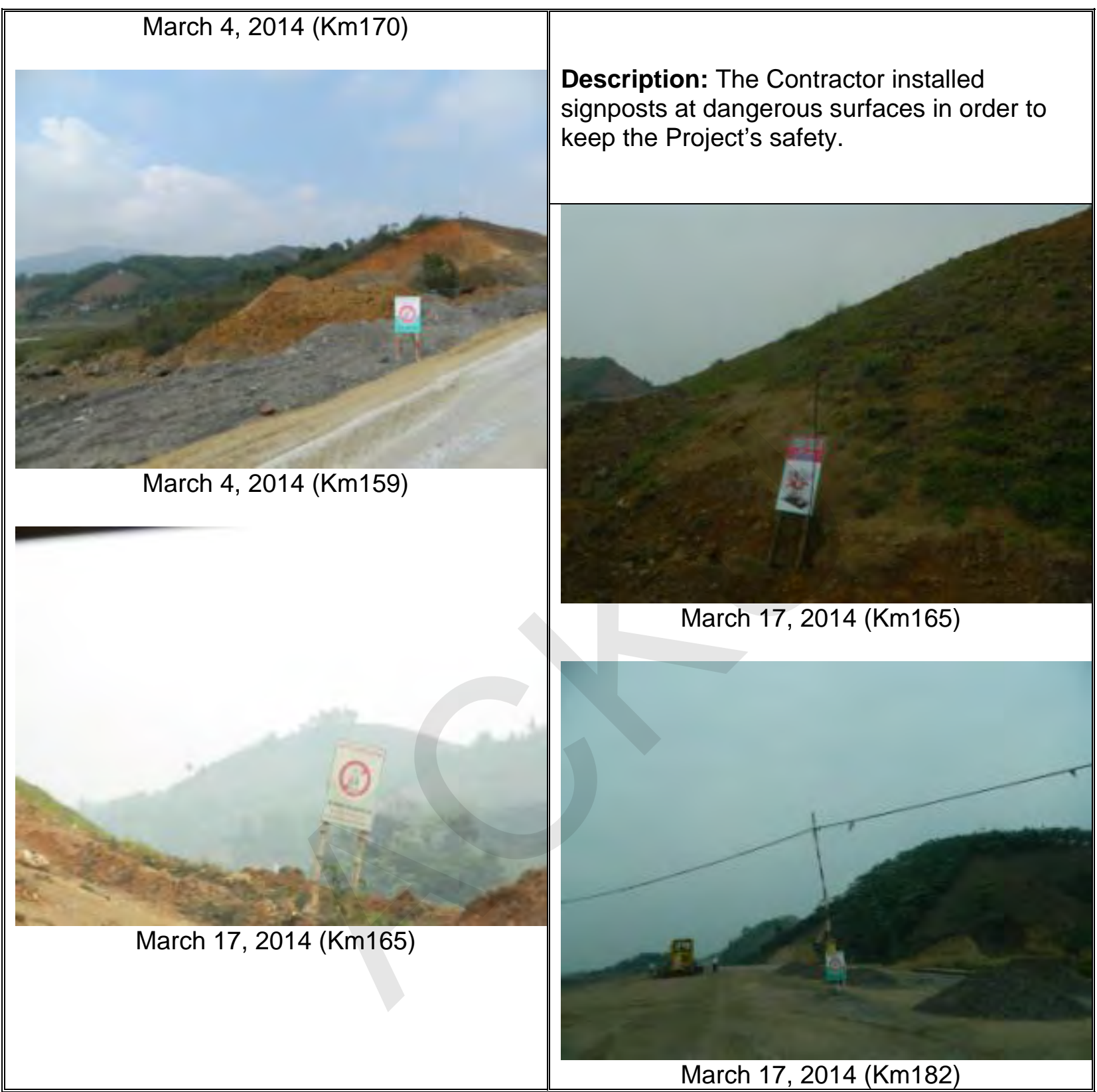

\subsubsection{Package A7}

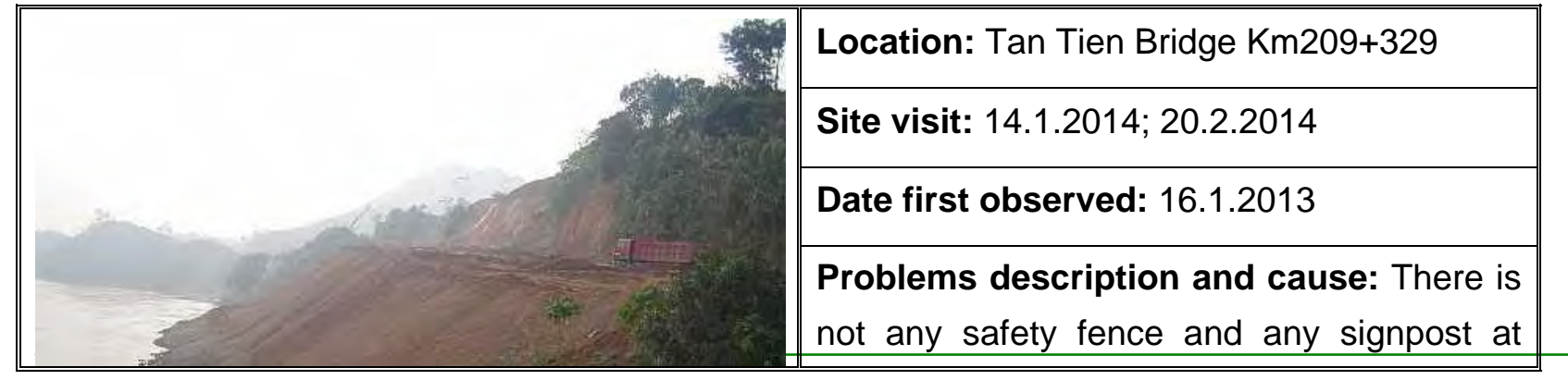




\section{Loan 2391/2392 - VIE: GMS Kunming - Hai Phong Transport Corridor Noi Bai - Lao Cai Highway Project}

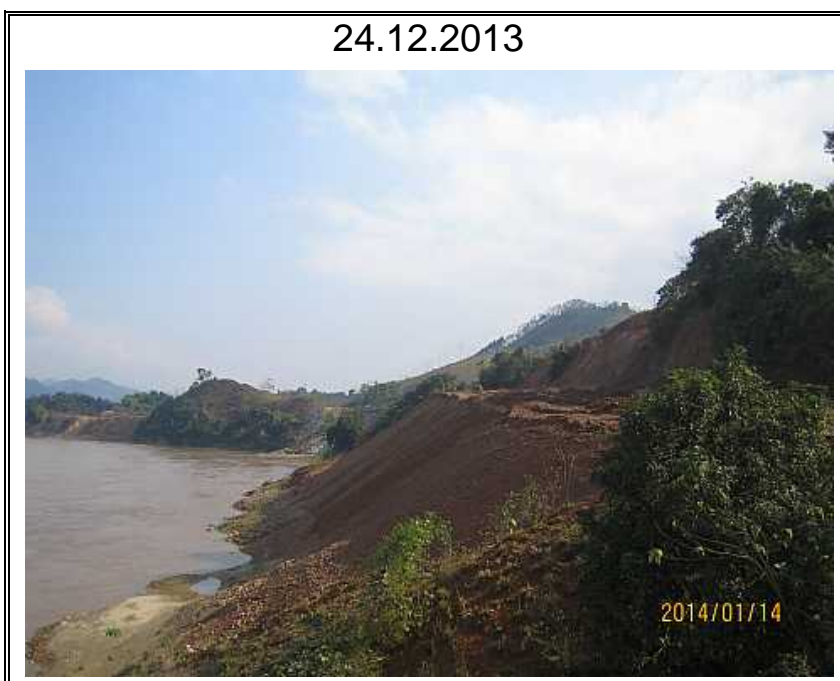

dangerous areas

Recommendation and Action taken by

Engineer: Required the contractor to install the safety fences and signposts at dangerous position according to the letters No: Ref. Get4-GRBCC-1042 and 1056

Deadline: Immediately

Current status: The contractor has not yet improved this issue

14.1.2014

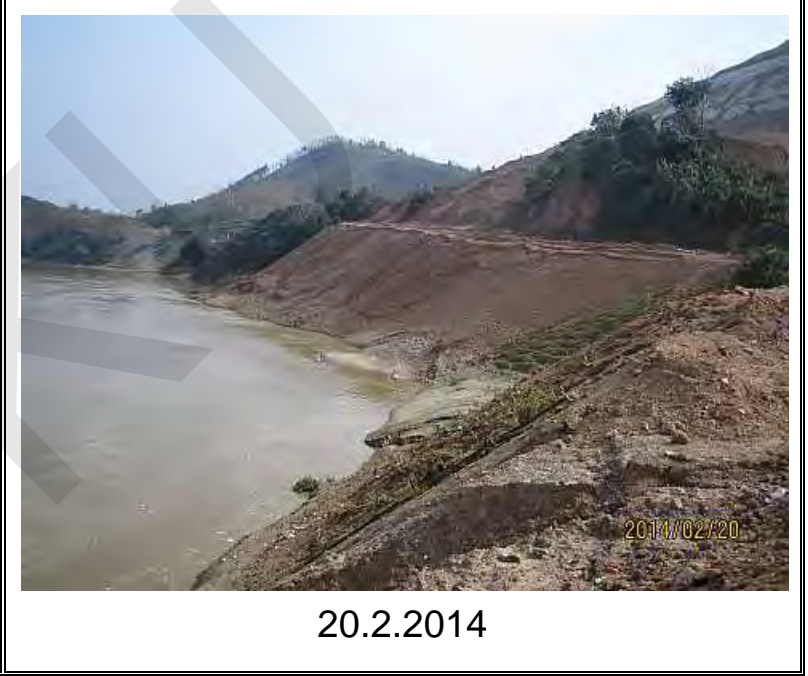

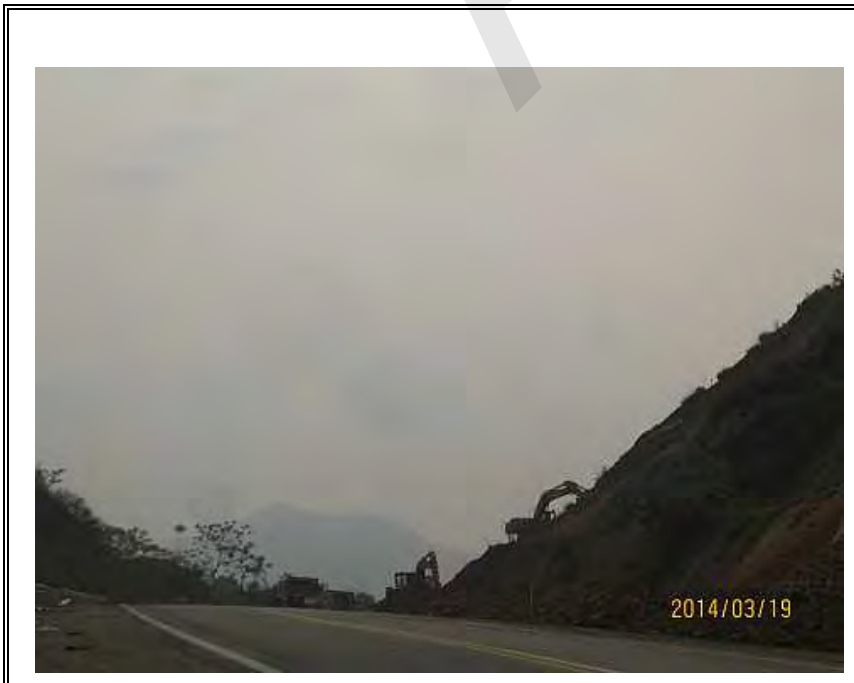

19.3.2014 at $\mathrm{Km} 204+400$
Location: Km204+400 and Km191+100

Site visit: 19.3 .2014

Date first observed: 19.3 .2014

Problems description and cause: There is not any safety fence and any signpost at dangerous areas

\section{Recommendation and Action taken by} Engineer: Required the contractor to install the safety fences and signposts at dangerous position according to the letters No: Ref. Get4-GRBCC-1042 and 1056 


\section{Loan 2391/2392 - VIE: GMS Kunming - Hai Phong Transport Corridor Noi Bai - Lao Cai Highway Project}

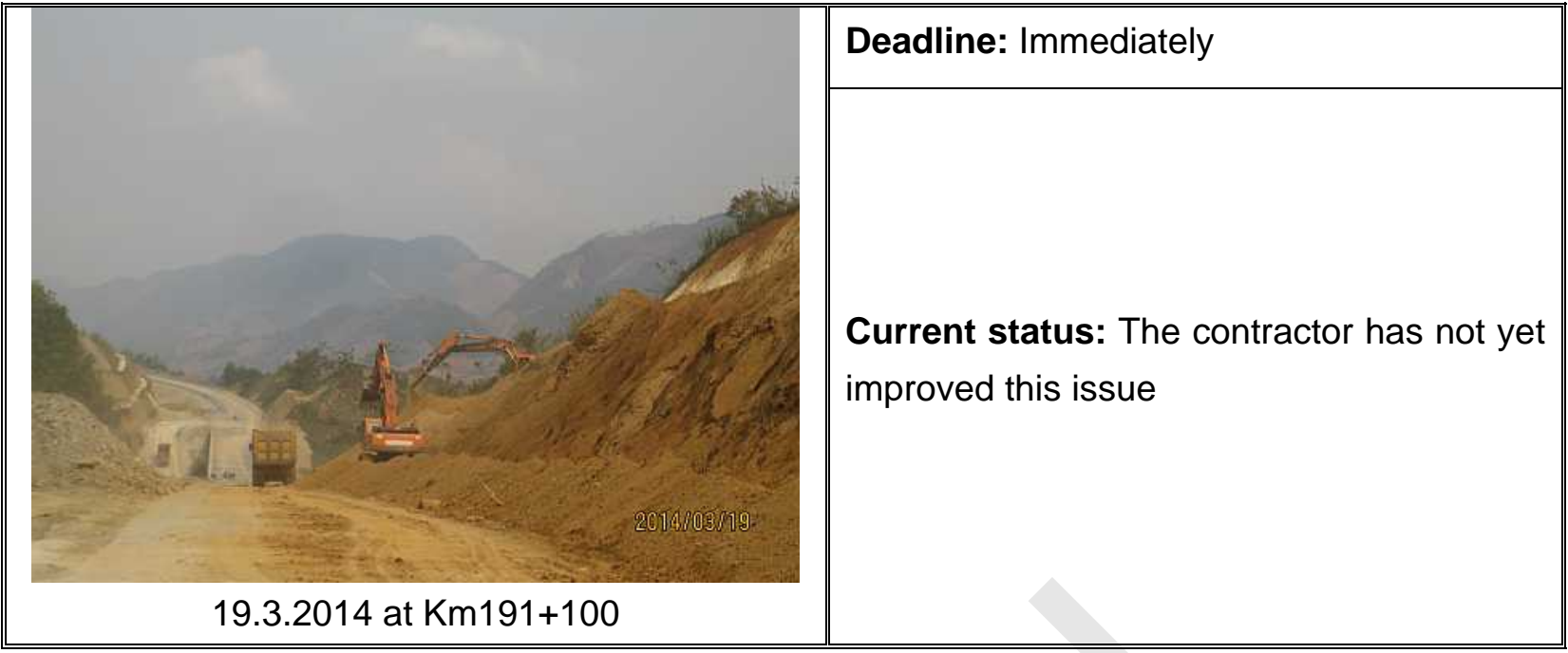

\subsubsection{Package A8}

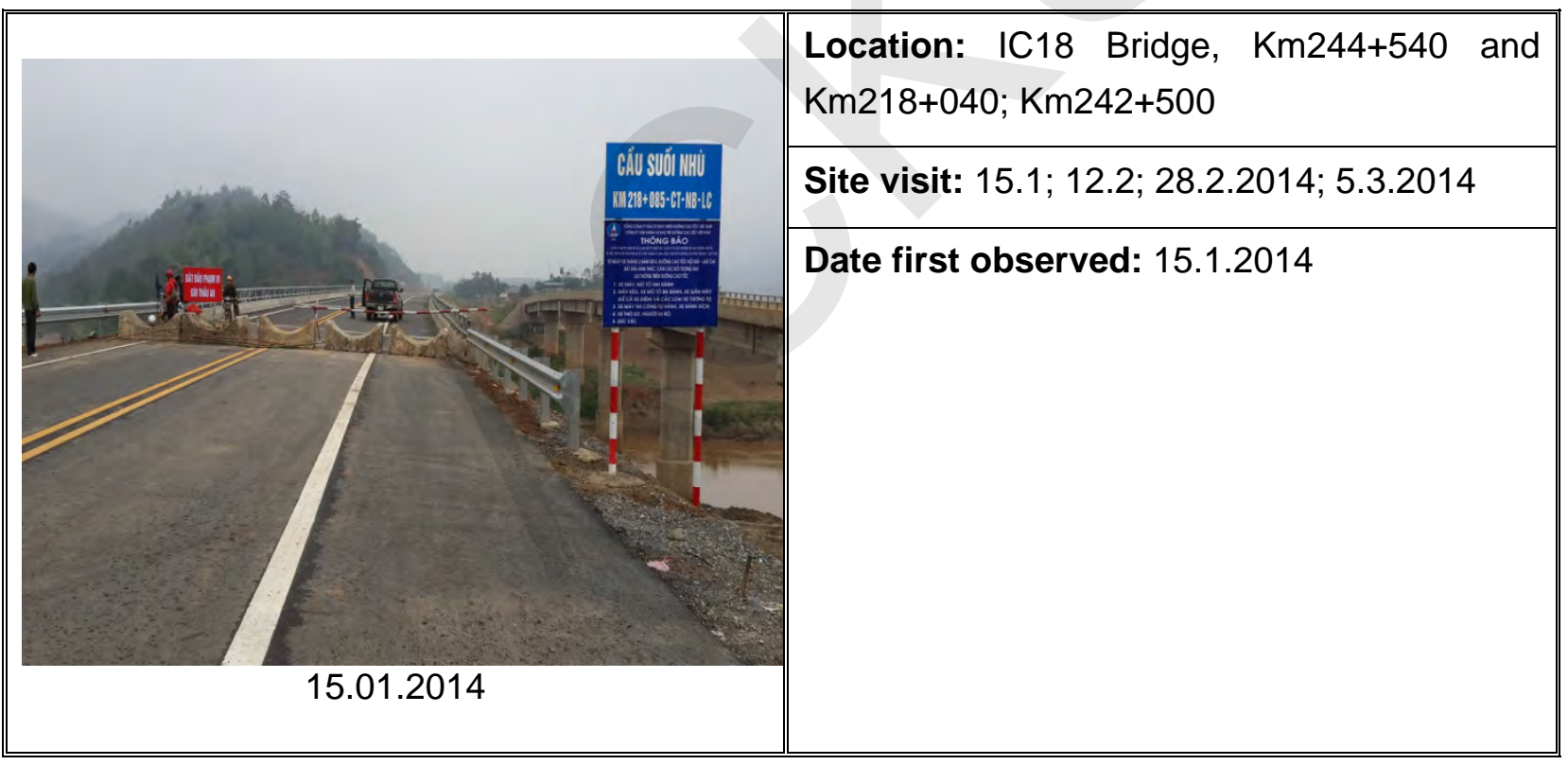




\section{Loan 2391/2392 - VIE: GMS Kunming - Hai Phong Transport Corridor Noi Bai - Lao Cai Highway Project}

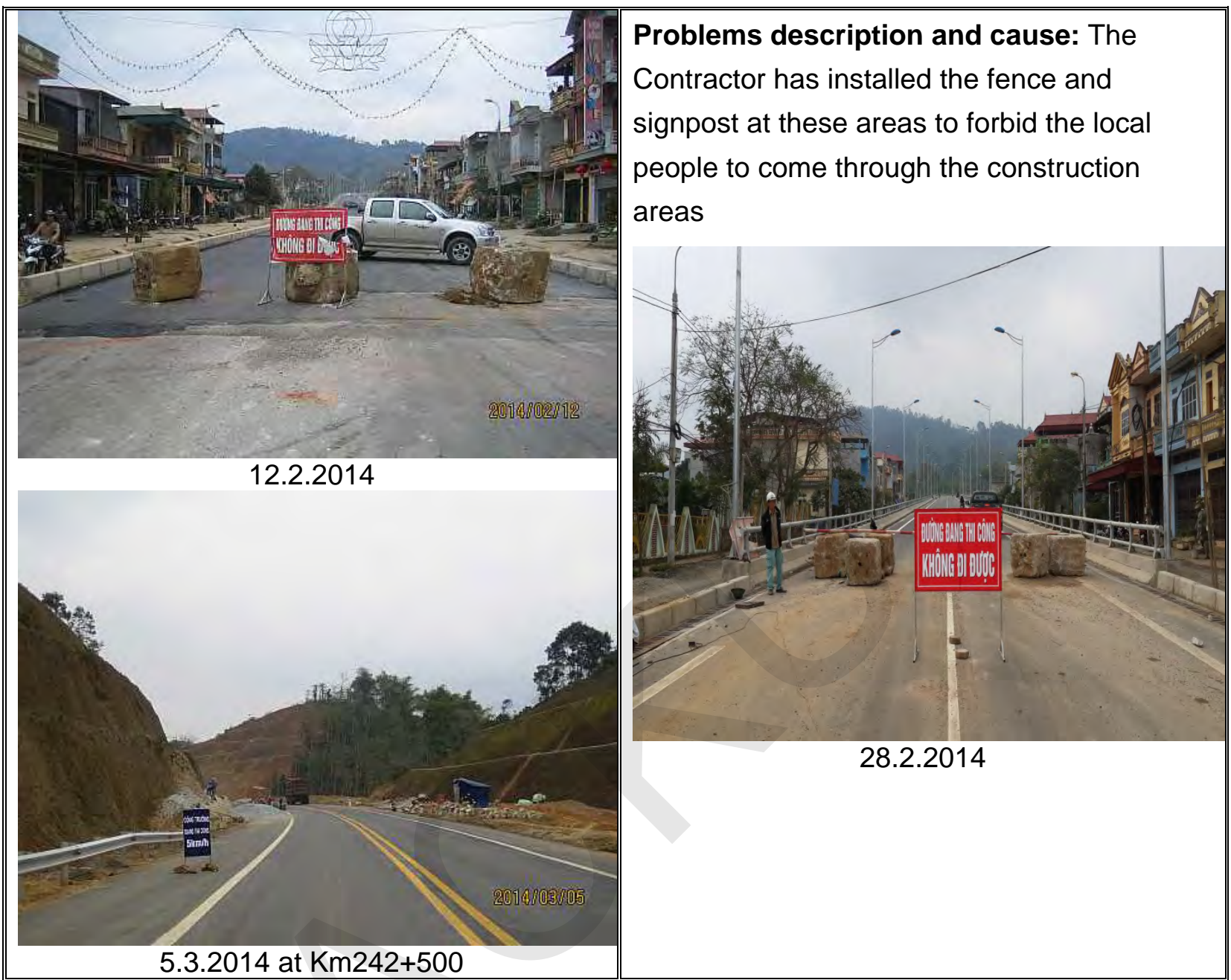

\subsection{RESTORATION AND LANDSCAPING WORKS}

\subsubsection{Package A1}

The Contractor has finished the planting anti-flare and landscaping trees in median and toll plazas. Planting grass on slopes of embankment to protect slopes from erosion also has been completed.

\subsubsection{Package A2}

Till the end of March 2014, the Contractor has completed planting anti-flare and landscaping trees in median. Twenty kilometers of embankment slopes has been planted with grass to protect slopes from erosion. 


\section{Loan 2391/2392 - VIE: GMS Kunming - Hai Phong Transport Corridor Noi Bai - Lao Cai Highway Project}

\subsubsection{Package A3}

The Contractor has already planted the anti-flare and landscaping tree in median from the beginning of the package A3 to IC8 bridge.

\subsubsection{Package A4}

At present, the Contractor continues all construction items of bridges, filling works and subbase works. Therefore, the landscaping works (Anti-glare trees, trees and shrubs, etc) still have not yet been started. The restoration and landscaping works will be implemented in the future.

\subsubsection{Package A5}

At this moment, the Contractor is constructing bridge items, filling works and sub-base works, therefore landscaping works (Anti-glare trees, trees and shrubs, etc) still have not yet been started. The restoration and landscaping works will be implemented next time. The Engineer required the Contractor to submit the Method Statement for landscaping work ASAP for review and approval.

\subsubsection{Package A6}

The Contractor has already submitted Method Statement for landscaping work (mentioned in the letter $\mathrm{N}^{0}$. DHIC-14-CT-02), in order to ensure the requirements from the Project's technical specification, the Engineer has commented this Method Statement. This month, the Contractor is reparing Method Statement for landscaping work in order to implement this work next time.

\subsubsection{Package A7}

The Contractor has already submitted Restoration plant for Unauthorized disposals at Km190+420; Km208+890; Km209+800 and Km195+350- Km195+500 on March 28th 2014. Engineer reviewed and proposed to VEC and ADB to checking and approval. So now the contractor was waiting opinion of ADB mission and will carry out according to ADB mission mentions.

About the Method statement for Landscaping works the contractor has not yet submitted it up to now. 
Loan 2391/2392 - VIE: GMS Kunming - Hai Phong Transport Corridor Noi Bai - Lao Cai Highway Project

\subsubsection{Package A8}

About the Method statement for Landscaping works, the contractor has not yet submitted it up to now.

\subsection{ACCIDENTS DUE TO THE LACK OF SAFETY MEASURES. RESPONSIBLES}

During this period, the first quarter 2014, through the inspection and supervision on site, Consultant did not notice about any serious accident happened due to lack of safety measures. Also, Consultant did not receive any report regarding significant accidents in any package.

However, the Consultant has often required the contractors to comply with the Methods Statement as well as the project's Safety Plan and to improve the management and control of safety issues to ensure the project's safety during construction process and prevent unfortunate accidents in the future. 


\section{Loan 2391/2392 - VIE: GMS Kunming - Hai Phong Transport Corridor} Noi Bai - Lao Cai Highway Project

\subsection{CONTRACTORS' ENVIRONMENTAL AND SAFETY SPECIALISTS MOBILIZATION}

As this issue is one of the most important ones for the right implementation of the contractors' ECP and ECAP, here is presented a summary table of the currently situation, updated until September 2013, in each package about the mobilization of contractors' environmental and safety managers. Some remarks are also considered inside the table.

\begin{tabular}{|c|c|c|c|c|c|c|}
\hline \multirow{2}{*}{ PACKAGE } & \multicolumn{6}{|c|}{ CURRENT STATUS } \\
\hline & POSITION & PROPOSED & APPROVED & MOBILIZED & NAME & REMARKS \\
\hline \multirow{2}{*}{ A1 } & Environmental manager & & & Yes & Shin Seung Sik & $\begin{array}{l}\text { Assigned by Engineer. } \\
\text { Package already opened to traffic }\end{array}$ \\
\hline & Safety manager & Yes & Yes & Yes & Le Dinh Quyen & Package already opened to traffic \\
\hline \multirow{2}{*}{ A2 } & Environmental manager & Yes & Yes & Yes & Kim Nam Young & \\
\hline & Safety manager & Yes & Yes & Yes & Kim Jeong Ho & \\
\hline \multirow[t]{2}{*}{ A3 } & Environmental manager & Yes & Yes & Yes & Kim Su Han & $\begin{array}{l}\text { Currently demobilized since } 2013 \text {. } \\
\text { Contractor did not propose any } \\
\text { other one. Consultant assigned the } \\
\text { environmental tasks to Mr. Cong, } \\
\text { Safety Manager }\end{array}$ \\
\hline & Safety manager & Yes & Yes & Yes & $\begin{array}{l}\text { Nguyen Thanh } \\
\text { Cong }\end{array}$ & \\
\hline \multirow[b]{2}{*}{ A4 } & Environmental manager & No & No & No & & Requested to be mobilized \\
\hline & Safety manager & Yes & Yes & Yes & $\begin{array}{l}\text { Nguyen Danh } \\
\text { Nam }\end{array}$ & \\
\hline
\end{tabular}


Loan 2391/2392 - VIE: GMS Kunming - Hai Phong Transport Corridor Noi Bai - Lao Cai Highway Project

\begin{tabular}{|c|c|c|c|c|c|c|}
\hline \multirow{2}{*}{ PACKAGE } & \multicolumn{6}{|c|}{ CURRENT STATUS } \\
\hline & POSITION & PROPOSED & APPROVED & MOBILIZED & NAME & REMARKS \\
\hline \multirow{2}{*}{ A5 } & Environmental manager & Yes & Yes & Yes & Cho, Han Sun & \\
\hline & Safety manager & Yes & Yes & Yes & Nguyen Van Phuc & \\
\hline \multirow{2}{*}{ A6 } & Environmental manager & Yes & Yes & Yes & Song, HwaSeo & \\
\hline & Safety manager & Yes & Yes & Yes & Kwon, Oh Lin & \\
\hline \multirow[b]{2}{*}{ A7 } & Environmental manager & Yes & Yes & Yes & Li Sheng Guang & \multirow{2}{*}{$\begin{array}{l}\text { EPMU approved by letter No: } 1562 \\
\text { /EPMU-NBLC-KH } \\
\text { These managers, after have beer } \\
\text { approved, were never mobilized, }\end{array}$} \\
\hline & Safety manager & Yes & Yes & Yes & Lai Jian Hong & \\
\hline \multirow{2}{*}{ A8 } & Environmental manager & Yes & Yes & Yes & Tran Van Dinh & Package already opened to traffic \\
\hline & Safety manager & Yes & Yes & Yes & Mai Xuan Lap & Package already opened to traffic \\
\hline
\end{tabular}


Loan 2391/2392 - VIE: GMS Kunming - Hai Phong Transport Corridor Noi Bai - Lao Cai Highway Project

5. REFERENCE DOCUMENTS RELATIVE TO ENVIRONMENT, HEALTH AND SAFETY ISSUES

\subsection{PACKAGE A1}

\begin{tabular}{|c|l|c|l|}
\hline $\mathbf{N}^{\mathbf{0}}$ & Document reference & Date & \multicolumn{1}{|c|}{ Remark } \\
\hline $\mathbf{1}$ & GET1/POS/A1/2350 & Jan 03,2014 & $\begin{array}{l}\text { Report on Environmental Monitoring } \\
\text { and Analysis - December, 2013 }\end{array}$ \\
\hline $\mathbf{2}$ & GET1/POS/A1/2353 & Jan 09,2014 & $\begin{array}{l}\text { Request to complete sodding and } \\
\text { supplement organic soil in median }\end{array}$ \\
\hline $\mathbf{3}$ & GET1/POS/A1/2353 & Jan 15, 2013 & $\begin{array}{l}\text { Request to deal with local people's } \\
\text { grievances }\end{array}$ \\
\hline $\mathbf{4}$ & GET1/POS/A1/2359 & Jan 21, 2014 & $\begin{array}{l}\text { Request to deal with local people's } \\
\text { grievances }\end{array}$ \\
\hline $\mathbf{5}$ & GET1/POS/A1/2361 & Jan 24, 2014 & $\begin{array}{l}\text { Plants Quality Control at Toll Plaza - } \\
\text { Km 6+000 }\end{array}$ \\
\hline $\mathbf{6}$ & GET1/POS/A1/2362 & Feb 06, 2014 & $\begin{array}{l}\text { Report on Environmental Monitoring } \\
\text { and Analysis - January, 2013 }\end{array}$ \\
\hline $\mathbf{7}$ & GET-POS-A1-251 & April 01, 2014 & $\begin{array}{l}\text { Instructions to modify the restoration } \\
\text { plans for Xuan Phuong and Tan Loi } \\
\text { rivers }\end{array}$ \\
\hline
\end{tabular}

\subsection{PACKAGE A2}

\begin{tabular}{|c|l|c|l||}
\hline $\mathbf{N}^{\mathbf{0}}$ & Document reference & Date & \multicolumn{1}{|c|}{ Remark } \\
\hline \hline $\mathbf{1}$ & GET1/POS/A2/2374 & Jan 03, 2014 & $\begin{array}{l}\text { Report on Environmental Monitoring } \\
\text { and Analysis - December, 2013 }\end{array}$ \\
\hline $\mathbf{2}$ & GET1/POS/A2/2388 & Jan 17, 2014 & Unsuitable Material Disposal \\
\hline $\mathbf{3}$ & GET1/POS/A2/2398 & Jan 23, 2014 & Project safety on holiday \\
\hline $\mathbf{4}$ & GET1/POS/A2/2403 & Feb 06, 2014 & $\begin{array}{l}\text { Report on Environmental Monitoring } \\
\text { and Analysis - January, 2013 }\end{array}$ \\
\hline $\mathbf{5}$ & GET1/POS/A2/2407 & Feb 10, 2014 & $\begin{array}{l}\text { Request to submit the report of } \\
\text { problems settlement }\end{array}$ \\
\hline $\mathbf{6}$ & GET1/POS/A2/2413 & Feb 13, 2014 & $\begin{array}{l}\text { Km 42+190: Request for Traffic } \\
\text { Protection }\end{array}$ \\
\hline $\mathbf{7}$ & GET1/POS/A2/2431 & Mar 05, 2014 & $\begin{array}{l}\text { Report on Environmental Monitoring } \\
\text { and Analysis - February, 2013 }\end{array}$ \\
\hline
\end{tabular}


Loan 2391/2392 - VIE: GMS Kunming - Hai Phong Transport Corridor Noi Bai - Lao Cai Highway Project

\begin{tabular}{|c|l|c|l|}
\hline $\mathbf{8}$ & GET1/POS/A2/2435 & Mar 11, 2014 & Safety Control \\
\hline $\mathbf{9}$ & GET1/POS/A2/2450 & Mar 27, 2014 & $\begin{array}{l}\text { Request to deal with the problems } \\
\text { persists }\end{array}$ \\
\hline
\end{tabular}

\subsection{PACKAGE A3}

\begin{tabular}{|c|c|c|c|}
\hline $\mathbf{N}^{\circ}$ & Document reference & Date & Remark \\
\hline 1 & GET2-POS-A3-2231 & 07/01/2014 & $\begin{array}{l}\text { Request the Contractor to ensure } \\
\text { safety in QL2 (Phu Tho) flyover }\end{array}$ \\
\hline 2 & GET2-POS-A3-2232A & 09/01/2014 & $\begin{array}{l}\text { Remind Managers of Environment, } \\
\text { Safety and Construction of POSCO } \\
\text { E\&C }\end{array}$ \\
\hline 3 & GET2-POS-A3-2232 & 09/01/2014 & $\begin{array}{l}\text { Request the Contractor to provide } \\
\text { information Package A3 }\end{array}$ \\
\hline 4 & GET2-POS-A3-2234 & $10 / 01 / 2014$ & $\begin{array}{l}\text { Remind for absence of Environment } \\
\text { Manager of POSCO E\&C }\end{array}$ \\
\hline 5 & GET2-POS-A3-2238 & $14 / 01 / 2014$ & $\begin{array}{l}\text { Approve environmental monitoring } \\
\text { and observation services report in } \\
\text { Nov } 2013\end{array}$ \\
\hline 6 & GET2-POS-A3- 2250 & $14 / 01 / 2014$ & $\begin{array}{l}\text { Aproval for the disposal area of } \\
\text { section } 2.1 \text { of Package } A 3\end{array}$ \\
\hline 7 & GET2-POS-A3-2253 & 22/01/2014 & $\begin{array}{l}\text { Request to ensurre safety at } \\
\text { construction site on Tet holiday }\end{array}$ \\
\hline 8 & GET2-POS-A3-2252 & 22/01/2014 & $\begin{array}{l}\text { Report on enviromental mornitoring } \\
\text { and observational service - Package } \\
\text { A3.final }\end{array}$ \\
\hline 9 & GET2-POS-A3-2231 & 07/01/2014 & $\begin{array}{l}\text { Request the Contractor to ensure } \\
\text { safety in QL2 (Phu Tho) flyover }\end{array}$ \\
\hline 10 & GET2-POS-A3-2258 & $07 / 2 / 2014$ & $\begin{array}{l}\text { Approve Environmental monitoring } \\
\text { and Observation services report in } \\
\text { December } 2013 \text { - Package A3. }\end{array}$ \\
\hline 11 & GET2-POS-A3-2273 & $25 / 2 / 2014$ & $\begin{array}{l}\text { Approve Environmental monitoring } \\
\text { and Observation services report in } \\
\text { January } 2014 \text { - Package A3. }\end{array}$ \\
\hline 12 & GET2-POS-A3-2277A & $25 / 2 / 2014$ & $\begin{array}{l}\text { Request to ensure safety at IC8 } \\
\text { Bridge-Package A3 }\end{array}$ \\
\hline 13 & GET2-POS-A3-2278 & $26 / 2 / 2014$ & $\begin{array}{l}\text { Request the Contractor to remove } \\
\text { spoil and submit document of } \\
\text { disposal area section Km55+300- }\end{array}$ \\
\hline
\end{tabular}


Loan 2391/2392 - VIE: GMS Kunming - Hai Phong Transport Corridor Noi Bai - Lao Cai Highway Project

\begin{tabular}{|c|c|c|c|}
\hline $\mathbf{N}^{0}$ & Document reference & Date & Remark \\
\hline & & & Package A3. \\
\hline 14 & GET2-POS-A3-2280 & $26 / 2 / 2014$ & $\begin{array}{l}\text { Remind Enviroment manager, safety } \\
\text { manager and construction manager } \\
\text { of Package } A 3\end{array}$ \\
\hline 15 & GET2-POS-A3-2281 & $26 / 2 / 2014$ & $\begin{array}{l}\text { Request the Contractor to } \\
\text { compensate landsilde in Hung Lo } \\
\text { Commune, Viet tri city- Package A3 }\end{array}$ \\
\hline 16 & GET2-POS-A3-2282 & $26 / 2 / 2014$ & $\begin{array}{l}\text { Request the Contractor POSCO E\&C } \\
\text { to complete compensation for local } \\
\text { people due to landslide at Km61+070 } \\
\sim \mathrm{Km} 61+600 \text {. }\end{array}$ \\
\hline 17 & GET2-POS-A3-2283 & $26 / 2 / 2014$ & $\begin{array}{l}\text { Request the Contractor to solve } \\
\text { landslide in Kim Duc Commune, Viet } \\
\text { Tri City. }\end{array}$ \\
\hline 18 & GET2-POS-A3-2258 & $07 / 2 / 2014$ & $\begin{array}{l}\text { Approve Environmental monitoring } \\
\text { and Observation services report in } \\
\text { December } 2013 \text { - Package A3. }\end{array}$ \\
\hline 19 & GET2-POS-A3-2301 & $11 / 3 / 2014$ & $\begin{array}{l}\text { Request the Contractor to solve } \\
\text { landslide in Phu Ninh- Hung Lo-Kim } \\
\text { Duc- Viet Tri City. }\end{array}$ \\
\hline 20 & GET2-POS-A3-2309 & $25 / 3 / 2014$ & $\begin{array}{l}\text { Request the Contractor to remove } \\
\text { soil and submit document of disposal } \\
\text { area section } \mathrm{Km} 55+300 \text { - Package A3 } \\
\text { (second time). }\end{array}$ \\
\hline 21 & GET2-POS-A3-2310 & $25 / 3 / 2014$ & $\begin{array}{l}\text { Remind Environment Manager, } \\
\text { Safety Manager and Construction } \\
\text { Manager of POSCO E\&C - Package } \\
\text { A3. }\end{array}$ \\
\hline 22 & GET2-POS-A3-2311 & $25 / 3 / 2014$ & $\begin{array}{l}\text { Request the Contractor to } \\
\text { compensate landslide in Hung Lo } \\
\text { commune, Viet Tri city - Package A3. }\end{array}$ \\
\hline 23 & GET2-POS-A3-2312 & $25 / 3 / 2014$ & $\begin{array}{l}\text { Request the Contractor to solve } \\
\text { landslide in Kim Duc Commune, Viet } \\
\text { Tri City. }\end{array}$ \\
\hline 24 & GET2-POS-A3-2316 & $27 / 3 / 2014$ & $\begin{array}{l}\text { Request the Contractor to provide } \\
\text { information - Package } A 3 \text {. }\end{array}$ \\
\hline
\end{tabular}

\subsection{PACKAGE A4}

\begin{tabular}{|l|c|c|c|}
\hline \hline \multicolumn{1}{|c|}{$\mathbf{N}^{\mathbf{0}}$} & Document reference & Date & Remark \\
\hline Hanoi office: & $12^{\text {th }}$ floor, Ocean Park Building, Dao Duy Anh Street, Dong Da Distric \\
VinhPhuc office: & Huu Thu Hamlet, Kim Long Ward, Tam Duong Distric, VinhPhuc Province \\
Madrid head office: & Calle Ramón de Aguinaga 8, 28028 Madrid, Spain
\end{tabular}


Loan 2391/2392 - VIE: GMS Kunming - Hai Phong Transport Corridor Noi Bai - Lao Cai Highway Project

\begin{tabular}{|c|c|c|c|}
\hline $\mathbf{N}^{\circ}$ & Document reference & Date & Remark \\
\hline 1 & GET2-KEA-A4-1474 & 09/1/2014 & $\begin{array}{l}\text { Request the Contractor to provide } \\
\text { information Package A4 }\end{array}$ \\
\hline 2 & GET2-KEA-A4-1477 & $14 / 1 / 2014$ & $\begin{array}{l}\text { Approve environmental monitoring } \\
\text { and observation services report in } \\
\text { Nov } 2013\end{array}$ \\
\hline 3 & GET2-KEA-A4-1485 & $23 / 1 / 2014$ & Reply for ref. KNEA4-GET-2014013. \\
\hline 4 & GET2-KEA-A4-1486 & 23/1/2014 & $\begin{array}{l}\text { Request to ensure the enviroment at } \\
\text { QL32C Bridge-Package A4 }\end{array}$ \\
\hline 5 & GET2-KEA-A4-1487 & 23/1/2014 & $\begin{array}{l}\text { Request to ensure safety at } \\
\text { construction site on Tet holiday }\end{array}$ \\
\hline 6 & GET2-KEA-A4-1489 & $23 / 1 / 2014$ & $\begin{array}{l}\text { Request the Contractor to solve the } \\
\text { impacts due to construction activities } \\
\text {-Package A4 }\end{array}$ \\
\hline 7 & GET2-KEA-A4-1490 & $23 / 1 / 2014$ & $\begin{array}{l}\text { Request the Contractor to solve } \\
\text { landslide in Sai Nga and Son Nga } \\
\text { commune - Cam Khe district, Phu } \\
\text { Tho province. }\end{array}$ \\
\hline 8 & GET2-KEA-A4-1491 & $23 / 1 / 2014$ & $\begin{array}{l}\text { Remind the Contractor about } \\
\text { disposing the soil to unregulated } \\
\text { area at Km82+500-600 }\end{array}$ \\
\hline 9 & GET2-KEA-A4-1492 & $25 / 1 / 2014$ & $\begin{array}{l}\text { Request the Contractor to ensure } \\
\text { safety on site }\end{array}$ \\
\hline 10 & GET2-KEA-A4-1502 & 19/2/2104 & $\begin{array}{l}\text { Request the Contractor to ensure } \\
\text { safety in construction area of } \\
\text { T1321C and Ngoi Gianh bridge- } \\
\text { Package A4EN-.docx }\end{array}$ \\
\hline 11 & GET2-KEA-A4-1503 & $25 / 2 / 2104$ & $\begin{array}{l}\text { Approve Enviromental monitoring } \\
\text { and Observation services report in } \\
\text { January 2014- Package A4 }\end{array}$ \\
\hline 12 & GET2-KEA-A4-1505 & $26 / 2 / 2104$ & $\begin{array}{l}\text { Approve Capacity profile of Green } \\
\text { nature JSC- Package A4 }\end{array}$ \\
\hline 13 & GET2-KEA-A4-1508 & $26 / 2 / 2104$ & $\begin{array}{l}\text { Request the Contractor to submit } \\
\text { disposal area document for soft soil } \\
\text { treatment from Km82+810 - } \\
\text { Km83+360 - Package A4 }\end{array}$ \\
\hline 14 & GET2-KEA-A4-1509 & $26 / 2 / 2104$ & $\begin{array}{l}\text { Request the Contractor to solve } \\
\text { landslide in Sai Nga and Son Nga } \\
\text { commune - Cam Khe district, Phu } \\
\text { Tho province. }\end{array}$ \\
\hline 15 & GET2-KEA-A4-1526 & $26 / 03 / 2014$ & $\begin{array}{l}\text { Remind Project Manager of the } \\
\text { Contractor of disposal not following }\end{array}$ \\
\hline
\end{tabular}




\section{Loan 2391/2392 - VIE: GMS Kunming - Hai Phong Transport Corridor Noi Bai - Lao Cai Highway Project}

\begin{tabular}{|c|l|c|l|}
\hline $\mathbf{N}^{\mathbf{0}}$ & Document reference & Date & \multicolumn{1}{c|}{ Remark } \\
\hline \hline 16 & GET2-KEA-A4-1527 & $26 / 03 / 2014$ & $\begin{array}{l}\text { the regulations at Section 1, 3 and 6, } \\
\text { in Ngoi Van and Ngoi Gianh bridge - } \\
\text { Package A4.. }\end{array}$ \\
\hline 17 & GET2-KEA-A4-1528 & $26 / 03 / 2014$ & $\begin{array}{l}\text { Request the Contractor to ensure } \\
\text { safety in construction area of } \\
\text { TL321C and Ngoi Gianh bridge - } \\
\text { Package A4. }\end{array}$ \\
\hline 18 & GET2-KEA-A4-1529 & $\begin{array}{l}\text { Request the Contractor to submit } \\
\text { disposal area document for soft soil } \\
\text { treatment from Km82+810 - } \\
\text { Km83+360 - Package A4 }\end{array}$ \\
\hline 19 & GET2-KEA-A4-1531 & $26 / 03 / 2014$ & $\begin{array}{l}\text { Request the Contractor to solve } \\
\text { landslide in Sai Nga and Son Nga } \\
\text { commune - Cam Khe district, Phu } \\
\text { Tho province. }\end{array}$ \\
\hline
\end{tabular}

\subsection{PACKAGE A5}

\begin{tabular}{|c|c|c|c|}
\hline $\mathbf{N}^{\circ}$ & Document reference & Date & Remark \\
\hline 1 & $\begin{array}{l}\text { Ref. GET3-KEANGNAM- } \\
\text { 14-A5-018 }\end{array}$ & $\begin{array}{c}\text { January } 14 \\
2014\end{array}$ & $\begin{array}{l}\text { Approval with comments on Asphalt } \\
\text { Concrete Batching Plant }\end{array}$ \\
\hline 2 & $\begin{array}{l}\text { Ref. GET3-KEANGNAM- } \\
\text { 13-A5-024 }\end{array}$ & $\begin{array}{l}\text { January } 16 \\
2014\end{array}$ & $\begin{array}{l}\text { Approval of Report on Environmental } \\
\text { Monitoring for December } 2013\end{array}$ \\
\hline 3 & $\begin{array}{l}\text { Ref. GET3-KEANGNAM- } \\
\text { 14-A5-046 }\end{array}$ & $\begin{array}{l}\text { February 20, } \\
2014\end{array}$ & $\begin{array}{l}\text { Approval of Supplement Method } \\
\text { statement for grassing at } \\
\text { embankment slope }\end{array}$ \\
\hline 4 & $\begin{array}{l}\text { Ref. GET3-KEANGNAM- } \\
\text { 13-A5-050 }\end{array}$ & $\begin{array}{l}\text { February } 25 \\
2014\end{array}$ & $\begin{array}{l}\text { Reminding the Contractor on safety } \\
\text { issues }\end{array}$ \\
\hline 5 & $\begin{array}{l}\text { Ref. GET3-KEANGNAM- } \\
\text { 13-A5-052 }\end{array}$ & $\begin{array}{c}\text { February } 28 \\
2014\end{array}$ & $\begin{array}{l}\text { Approval of Report on Environmental } \\
\text { Monitoring for January } 2014\end{array}$ \\
\hline 6 & $\begin{array}{l}\text { Ref. GET3-KEANGNAM- } \\
\text { 14-A5-078 }\end{array}$ & March 14, 2014 & $\begin{array}{l}\text { Approval of Report on Environmental } \\
\text { Monitoring for February } 2014\end{array}$ \\
\hline 7 & $\begin{array}{l}\text { Ref. GET3-KEANGNAM- } \\
\text { 13-A5-080 }\end{array}$ & March 19, 2014 & $\begin{array}{l}\text { Comment on the documents of } \\
\text { Asphalt Concrete Batching Plant at } \\
\mathrm{Km} 135+700\end{array}$ \\
\hline 8 & $\begin{array}{l}\text { Ref. GET3-KEANGNAM- } \\
13-A 5-081\end{array}$ & March 19, 2014 & $\begin{array}{l}\text { Comment on the documents of } \\
\text { Asphalt Concrete Batching Plant }\end{array}$ \\
\hline
\end{tabular}


Loan 2391/2392 - VIE: GMS Kunming - Hai Phong Transport Corridor Noi Bai - Lao Cai Highway Project

\begin{tabular}{|c|l|c|l|}
\hline $\mathbf{N}^{\mathbf{0}}$ & Document reference & Date & \multicolumn{1}{c|}{ Remark } \\
\hline \hline $\mathbf{9}$ & $\begin{array}{l}\text { Ref. GET3-KEANGNAM- } \\
\text { 13-A5-096 }\end{array}$ & March 26, 2014 & $\begin{array}{l}\text { Reminding Contractor on Personal } \\
\text { Protection Equipment of workers }\end{array}$ \\
\hline $\mathbf{1 0}$ & $\begin{array}{l}\text { Ref. GET3-KEANGNAM- } \\
13-\text { A5-098 }\end{array}$ & March 26, 2014 & $\begin{array}{l}\text { Require the Contractor to ensure the } \\
\text { living and working conditions in the } \\
\text { workers' camps }\end{array}$ \\
\hline
\end{tabular}

\subsection{PACKAGE A6}

\begin{tabular}{|c|c|c|c|}
\hline $\mathbf{N}^{\circ}$ & Document reference & Date & Remark \\
\hline 1 & $\begin{array}{l}\text { Ref. GET3-DOOSAN-14- } \\
\text { A6-009 }\end{array}$ & $\begin{array}{l}\text { January } 16 \\
2014\end{array}$ & $\begin{array}{l}\text { Approval of Report on Environmental } \\
\text { Monitoring for December } 2013\end{array}$ \\
\hline 2 & $\begin{array}{l}\text { Ref. GET3-DOOSAN-13- } \\
\text { A6-021 }\end{array}$ & $\begin{array}{l}\text { January } 22 \\
2014\end{array}$ & $\begin{array}{l}\text { Request for support to solve } \\
\text { obstruction at km 165+700- } \\
166+000\end{array}$ \\
\hline 3 & $\begin{array}{l}\text { Ref. GET3-DOOSAN-14- } \\
\text { A6-037 }\end{array}$ & $\begin{array}{l}\text { February 26, } \\
2014\end{array}$ & $\begin{array}{l}\text { Comment on Method Statement for } \\
\text { landscaping work, package A6 }\end{array}$ \\
\hline 4 & $\begin{array}{l}\text { Ref. GET3-DOOSAN-13- } \\
\text { A6-039 }\end{array}$ & $\begin{array}{l}\text { February 28, } \\
2014\end{array}$ & $\begin{array}{l}\text { Official Certificate for } \\
\text { environmental } \quad \text { monitoring } \\
\text { activities - package A6 }\end{array}$ \\
\hline 5 & $\begin{array}{l}\text { Ref. GET3-DOOSAN-14- } \\
\text { A6-044 }\end{array}$ & March 10, 2014 & $\begin{array}{l}\text { Environmental monitoring } \\
\text { activities - package A6 }\end{array}$ \\
\hline 6 & $\begin{array}{l}\text { Ref. GET3-DOOSAN-13- } \\
\text { A6-046 }\end{array}$ & March 14, 2014 & $\begin{array}{l}\text { Approval with comments on } \\
\text { Disposal area }\end{array}$ \\
\hline
\end{tabular}

\subsection{PACKAGE A7}

\begin{tabular}{|c|l|l|l|}
\hline $\mathbf{N}^{\mathbf{0}}$ & Document reference & \multicolumn{1}{|c|}{ Date } & \multicolumn{1}{c|}{ Remark } \\
\hline $\mathbf{1}$ & $\begin{array}{l}\text { Ref. GET4-GRBCC- } \\
1041\end{array}$ & $2 / 1 / 2014$ & $\begin{array}{l}\text { Repair and maintain the exist } \\
\text { road from Km209+300 to } \\
\text { Km209+800 }\end{array}$ \\
\hline $\mathbf{2}$ & $\begin{array}{l}\text { Ref. GRBCC/ } \\
\text { GETINSA/A7/1881 }\end{array}$ & $3 / 1 / 2014$ & $\begin{array}{l}\text { Re- Submit the restoration plan } \\
\text { of unauthorized disposal- A7 }\end{array}$ \\
\hline $\mathbf{4}$ & $\begin{array}{l}\text { Ref. GET4-GRBCC- } \\
1058\end{array}$ & $6 / 1 / 2014$ & $\begin{array}{l}\text { Invitation meeting for } \\
\text { Environment manager and safety } \\
\text { manager of Package A7 }\end{array}$ \\
\hline
\end{tabular}


Loan 2391/2392 - VIE: GMS Kunming - Hai Phong Transport Corridor Noi Bai - Lao Cai Highway Project

\begin{tabular}{|c|c|c|c|}
\hline $\mathbf{N}^{\circ}$ & Document reference & Date & Remark \\
\hline & & & $\begin{array}{l}\text { disposal sites Km195+500 and } \\
\text { Km190+420- Package A7 with } \\
\text { condition: The old nature line will } \\
\text { be determined by Engineer } \\
\text { accordingly to actually on site }\end{array}$ \\
\hline 5 & $\begin{array}{l}\text { Ref. GET4-GRBCC- } \\
1070\end{array}$ & 21/1/2014 & $\begin{array}{l}\text { Approval the New restoration } \\
\text { plan of unauthorized spoil } \\
\text { disposal sites Km195+500 and } \\
\text { Km190+420- Package A7 }\end{array}$ \\
\hline 6 & $\begin{array}{l}\text { Ref. GET4-GRBCC- } \\
1071\end{array}$ & 22/1/2014 & $\begin{array}{l}\text { Project safety on Lunar Tet } \\
\text { holiday } 2014\end{array}$ \\
\hline 7 & $\begin{array}{l}\text { Ref. GET4-GRBCC- } \\
1074\end{array}$ & $11 / 2 / 2014$ & $\begin{array}{l}\text { Invitation meeting for Environment } \\
\text { manager and safety manager of } \\
\text { Package A7- Second time }\end{array}$ \\
\hline 8 & $\begin{array}{l}\text { Ref. GET4-GRBCC- } \\
1075\end{array}$ & $11 / 2 / 2014$ & $\begin{array}{l}\text { Ensure safety and clean on site- } \\
\text { Package A7 }\end{array}$ \\
\hline 9 & $\begin{array}{l}\text { Ref. GRBCC/ } \\
\text { GETINSA/A7/1892A }\end{array}$ & $12 / 2 / 2014$ & $\begin{array}{l}\text { Commit to carry out the restoration } \\
\text { plan of unauthorized spoil site at } \\
\text { Km190+420; } \\
\text { Km208+890; Km209+800 }\end{array}$ \\
\hline 10 & $\begin{array}{l}\text { Ref. GET4-Core team- } \\
284\end{array}$ & $19 / 2 / 2014$ & $\begin{array}{l}\text { Propose to replace the Environment } \\
\text { Manager and Safety Manager - } \\
\text { Package A7 }\end{array}$ \\
\hline 11 & Ref. GET- GUA-151 & $19 / 2 / 2014$ & $\begin{array}{l}\text { Complete Removal of Unauthorized } \\
\text { disposal area at } \mathrm{Km} 190+420\end{array}$ \\
\hline 12 & $\begin{array}{l}\text { Ref. GRBCC/ } \\
\text { GETINSA/Core } \\
\text { team/A7/47 }\end{array}$ & 28/2/2014 & $\begin{array}{l}\text { Summiting traffic control within the } \\
\text { site }\end{array}$ \\
\hline 13 & $\begin{array}{l}\text { Ref. GET4-GRBCC- } \\
1091\end{array}$ & $17 / 3 / 2014$ & $\begin{array}{l}\text { Request the contractor to submit the } \\
\text { document relate to the Unauthorized } \\
\text { disposals at Km195+500; } \\
\text { Km208+890 and Km209+800 }\end{array}$ \\
\hline 14 & $\begin{array}{l}\text { Ref. GET4-GRBCC- } \\
1099\end{array}$ & 20/3/2014 & $\begin{array}{l}\text { Request the contractor to submit the } \\
\text { document relate to the slope } \\
\text { protection of unauthorized disposal } \\
\text { at } \mathrm{Km} 195+500\end{array}$ \\
\hline 15 & $\begin{array}{l}\text { Ref. GET4-Core team- } \\
291\end{array}$ & $28 / 3 / 2014$ & $\begin{array}{l}\text { Propose to review and given } \\
\text { comments about the Document } \\
\text { relate to the disposals and } \\
\text { stabilization method of the soil } \\
\text { disposed } \\
\text { Km209+800 }\end{array}$ \\
\hline 16 & Ref. GET4-Core team- & $28 / 3 / 2014$ & Propose to review and given \\
\hline
\end{tabular}


Loan 2391/2392 - VIE: GMS Kunming - Hai Phong Transport Corridor Noi Bai - Lao Cai Highway Project

\begin{tabular}{|c|l|l|l||}
\hline $\mathbf{N}^{\mathbf{0}}$ & Document reference & Date & \multicolumn{2}{|c|}{ Remark } \\
\hline & 292 & & $\begin{array}{l}\text { comments about the Correcting } \\
\text { slope protection } \\
\text { site Km190+420 }\end{array}$ \\
\hline
\end{tabular}

\subsection{PACKAGE A8}

\begin{tabular}{|c|c|c|c|}
\hline $\mathrm{N}^{\circ}$ & Document reference & Date & Remark \\
\hline 1 & No: 07/EPMUNBLC-KT & 03/1/2014 & $\begin{array}{l}\text { Slide treatment at } \mathrm{Km} 240+940- \\
\mathrm{Km} 241+020 \text { (Right) - Package A8 }\end{array}$ \\
\hline 2 & No: 08/EPMUNBLC-KT & 03/1/2014 & $\begin{array}{l}\text { Slide treatment at } \mathrm{Km} 241+660- \\
\mathrm{Km} 241+740 \text { (Right) - Package A8 }\end{array}$ \\
\hline 3 & Ref. Get- MIS-390 & $10 / 1 / 2014$ & $\begin{array}{l}\text { Official certificate for Environmental } \\
\text { monitoring activities }\end{array}$ \\
\hline 4 & $\begin{array}{l}\text { Ref. Get4- Vinaconex- } \\
942\end{array}$ & $22 / 1 / 2014$ & $\begin{array}{l}\text { Project safety on Lunar Tet holiday } \\
2014\end{array}$ \\
\hline 5 & $\begin{array}{l}\text { Ref. Get4- Vinaconex- } \\
946\end{array}$ & $11 / 2 / 2014$ & $\begin{array}{l}\text { Ensure safety and clean on site- } \\
\text { Package A8 }\end{array}$ \\
\hline 6 & Ref. Get- MIS-395 & $21 / 2 / 2014$ & Ensuring traffic control within the site \\
\hline 7 & A8- LC-140228-01 & $28 / 2 / 2014$ & Ensuring traffic control within the site \\
\hline 8 & $\begin{array}{l}\text { Ref. Get4- Vinaconex- } \\
965\end{array}$ & $7 / 3 / 2014$ & $\begin{array}{l}\text { Ensure safety and clean on site after } \\
\text { technical open - Package A8 }\end{array}$ \\
\hline 9 & $\begin{array}{l}\text { Ref. Get4- Vinaconex- } \\
968\end{array}$ & $13 / 3 / 2014$ & $\begin{array}{l}\text { Returning the Additional disposal site } \\
\text { profile- Package A8 }\end{array}$ \\
\hline 10 & $\begin{array}{l}\text { Ref. Get4- Vinaconex- } \\
969\end{array}$ & $13 / 3 / 2014$ & $\begin{array}{l}\text { Ensure safety and clean on site after } \\
\text { technical open - Package A8- } \\
\text { second time }\end{array}$ \\
\hline 11 & $\begin{array}{l}\text { Ref. Get4- Vinaconex- } \\
977\end{array}$ & $24 / 3 / 2014$ & $\begin{array}{l}\text { Require to clearance the current flow } \\
\text { and moving the unsuitable material } \\
\text { out of the unauthorized disposals- } \\
\text { Package A8 }\end{array}$ \\
\hline 12 & $\begin{array}{l}\text { Ref. Get4- Vinaconex- } \\
980\end{array}$ & $28 / 3 / 2014$ & $\begin{array}{l}\text { Returning the Additional disposal site } \\
\text { profile- Package A8- Second time }\end{array}$ \\
\hline
\end{tabular}




\section{GRIEVANCE INTAKES. PUBLIC CONSULTATION}

As Annex 1 we include a summary table with references about complaints which were expressed by local people affected by the construction works, to the environmental or social impact specialists.

It's supposed that these are not the only existing complaints, but the only ones received or collected by Consultant.

On the other hand, after being implemented in some packages the system to collect complaints by the contractors, the Consultant has not received any information from contractors. 
getinso

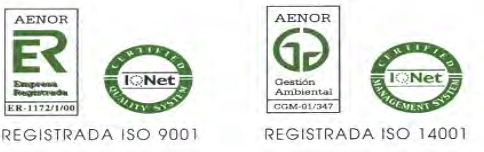

Loan 2391/2392 - VIE: GMS Kunming - Mai Phony Transport Corridor No Bail - Lao Cai Highway Project

207 
Loan 2391/2392 - VIE: GMS Kunming - Hai Phong Transport Corridor Noi Bai - Lao Cai Highway Project

7. ANNEX 1: COMPLAINTS OF LOCAL PEOPLE. SUMMARY TABLE 
getinso

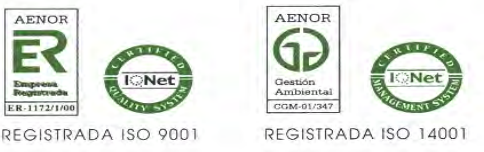

Loan 2391/2392 - VIE: GMS Kunming - Mai Phony Transport Corridor No Bail - Lao Cai Highway Project

209 


\section{Loan 2391/2392 - VIE: GMS Kunming - Hai Phong Transport Corridor}

Noi Bai - Lao Cai Highway Project

\begin{tabular}{|c|c|c|c|c|c|c|}
\hline PACK. & LOCATION & COMPLAINT DESCRIPTION & DATE & EXECUTED ACTIONS & CURRENT STATUS & DOCUMENT. \\
\hline $\mathrm{A} 2$ & $\begin{array}{c}\mathrm{Km} \mathrm{42+300} \\
\mathrm{Km} \mathrm{44+180}\end{array}$ & $\begin{array}{l}\text { Erosion leads the soil into } \\
\text { croplands and cause the } \\
\text { lost for } 35 \text { households. } \\
\text { Local authority (Song Lo's } \\
\text { DPC) has finished } \\
\text { calculating the damaged } \\
\text { and requested the } \\
\text { Contractor to compensate }\end{array}$ & $\begin{array}{l}\text { 15-Mar- } \\
2014\end{array}$ & & $\begin{array}{l}\text { The Contractor is } \\
\text { preparing money for } \\
\text { compensation. } \\
\text { Expectation of } \\
\text { completion by April 15, } \\
2014\end{array}$ & $\begin{array}{l}\text { Consultant's } \\
\text { report }\end{array}$ \\
\hline A2 & $\begin{array}{c}\mathrm{Km} \mathrm{36+500} \\
\mathrm{Km} \mathrm{37+900}\end{array}$ & $\begin{array}{l}\text { There are } 67 \text { households } \\
\text { who complain that their } \\
\text { houses were impacted } \\
\text { due to vibration during } \\
\text { carrying out construction } \\
\text { work of the project. The } \\
\text { Contractor has finished } \\
\text { the verifying work and the } \\
\text { local people requested the } \\
\text { Contractor to compensate } \\
\text { for damaged assets }\end{array}$ & $\begin{array}{l}\text { 20-Mar- } \\
2014\end{array}$ & & $\begin{array}{l}\text { The Contractor has } \\
\text { carried out } \\
\text { compensation for } \\
\text { damaged assets }\end{array}$ & $\begin{array}{l}\text { Consultant's } \\
\text { report }\end{array}$ \\
\hline A2 & $\mathrm{Km} \mathrm{39+400}$ & $\begin{array}{l}\text { There are } 7 \text { households } \\
\text { impacted due to vibration } \\
\text { during carrying out } \\
\text { construction work of the } \\
\text { project. The Contractor } \\
\text { has issued the } \\
\text { compensation method; } \\
\text { one household agree with } \\
\text { compensation level and } \\
\text { received money, the } \\
\text { others don't agree with }\end{array}$ & $\begin{array}{l}\text { 27-Mar- } \\
2014\end{array}$ & & $\begin{array}{l}\text { The Contractor } \\
\text { committed to carry out } \\
\text { the reassessment in } \\
\text { April } 07,2014\end{array}$ & $\begin{array}{l}\text { Consultant's } \\
\text { report }\end{array}$ \\
\hline
\end{tabular}


Loan 2391/2392 - VIE: GMS Kunming - Hai Phong Transport Corridor

Noi Bai - Lao Cai Highway Project

\begin{tabular}{|c|c|c|c|c|c|c|}
\hline PACK. & LOCATION & COMPLAINT DESCRIPTION & DATE & EXECUTED ACTIONS & CURRENT STATUS & DOCUMENT. \\
\hline & & $\begin{array}{l}\text { compensation level and } \\
\text { required the Contractor to } \\
\text { re-assess }\end{array}$ & & & & \\
\hline A2 & $\begin{array}{l}\text { Song Lo } \\
\text { district }\end{array}$ & $\begin{array}{l}\text { Request the Contractor to } \\
\text { compensate impacted } \\
\text { household for damaged } \\
\text { assets due to flooding } \\
\text { which was caused by } \\
\text { construction work of the } \\
\text { project }\end{array}$ & $\begin{array}{l}\text { 25-Mar- } \\
2014\end{array}$ & & $\begin{array}{l}\text { We has requested the } \\
\text { Contractor to contact } \\
\text { local authority (Song } \\
\text { Lo's DPC) to come to } \\
\text { an agreement on } \\
\text { compensation level and } \\
\text { prepare money to } \\
\text { compensate }\end{array}$ & $\begin{array}{l}\text { Consultant's } \\
\text { report }\end{array}$ \\
\hline A3 & $\begin{array}{l}\text { Km 53+560 } \\
\text { Resident area }\end{array}$ & $\begin{array}{l}\text { Soil slide down pipe culvert } \\
\text { saffecting the irrigation } \\
\text { system }\end{array}$ & $05 / 01 / 2014$ & $\begin{array}{l}\text { Closely coordinate with } \\
\text { affected } \mathrm{HH} \text { and local } \\
\text { authorities to expedite } \\
\text { compensation for damages } \\
\text { caused by construction } \\
\text { activities. }\end{array}$ & $\begin{array}{l}\text { 1- Dig adequately sized } \\
\text { side drainage/ditch at } \\
\text { erosion prone areas to } \\
\text { direct surface run-off } \\
\text { away from agricultural } \\
\text { land. } \\
\text { 2- Implement slope } \\
\text { stabilization measures to } \\
\text { minimize erosion. }\end{array}$ & Consultant's reports \\
\hline A3 & $\begin{array}{l}\text { Km51+375 } \\
\text { Resident area }\end{array}$ & $\begin{array}{l}\text { 1- Soil and mud is usually } \\
\text { tracked onto public road. } \\
\text { 2- Not enough water is } \\
\text { sprayed on dusty surfaces so } \\
\text { airborne dust level is high. }\end{array}$ & $26 / 09 / 2013$ & Watering activities & $\begin{array}{l}\text { 1- Public roads continue } \\
\text { covered by soil and mud } \\
\text { 2- Surfaces are regularly } \\
\text { watered }\end{array}$ & Consultant's reports \\
\hline A3 & $\begin{array}{l}\text { Km50+570 } \\
\text { Resident area }\end{array}$ & $\begin{array}{l}\text { Soil slide down pipe culverts } \\
\text { affecting the irrigation system }\end{array}$ & $12 / 10 / 2013$ & $\begin{array}{l}\text { Closely coordinate with } \\
\text { affected } \mathrm{HH} \text { and local } \\
\text { authorities to expedite } \\
\text { compensation for damages } \\
\text { caused by construction } \\
\text { activities. }\end{array}$ & $\begin{array}{l}\text { 1- Dig adequately sized } \\
\text { side drainage/ditch at } \\
\text { erosion prone areas to } \\
\text { direct surface run-off } \\
\text { away from agricultural } \\
\text { land. }\end{array}$ & Consultant's reports \\
\hline
\end{tabular}


Loan 2391/2392 - VIE: GMS Kunming - Hai Phong Transport Corridor

Noi Bai - Lao Cai Highway Project

\begin{tabular}{|c|c|c|c|c|c|c|}
\hline PACK. & LOCATION & COMPLAINT DESCRIPTION & DATE & EXECUTED ACTIONS & CURRENT STATUS & DOCUMENT. \\
\hline & & & & & $\begin{array}{l}\text { 2- Implement slope } \\
\text { stabilization measures to } \\
\text { minimize erosion. }\end{array}$ & \\
\hline A3 & $\begin{array}{l}\text { Km53+150 } \\
\text { Resident area }\end{array}$ & $\begin{array}{l}\text { 1- Soil and mud is usually } \\
\text { tracked onto public road. } \\
\text { 2- Not enough water is } \\
\text { sprayed on dusty surfaces so } \\
\text { airborne dust level is high. }\end{array}$ & $25 / 2 / 2014$ & Watering activities & $\begin{array}{l}\text { 1- Public roads continue } \\
\text { covered by soil and mud } \\
\text { 2- Surfaces are regularly } \\
\text { watered }\end{array}$ & Consultant's reports \\
\hline A3 & $\begin{array}{l}\text { Km62+570 } \\
\text { Resident area }\end{array}$ & $\begin{array}{l}\text { Soil slide down pipe culverts } \\
\text { affecting the irrigation system }\end{array}$ & $21 / 12 / 2013$ & $\begin{array}{l}\text { Closely coordinate with } \\
\text { affected } \mathrm{HH} \text { and local } \\
\text { authorities to expedite } \\
\text { compensation for damages } \\
\text { caused by construction } \\
\text { activities. }\end{array}$ & $\begin{array}{l}\text { 1- Dig adequately sized } \\
\text { side drainage/ditch at } \\
\text { erosion prone areas to } \\
\text { direct surface run-off } \\
\text { away from agricultural } \\
\text { land. } \\
\text { 2- Implement slope } \\
\text { stabilization measures to } \\
\text { minimize erosion. }\end{array}$ & Consultant's reports \\
\hline A4 & $\begin{array}{l}\mathrm{Km} 81+700 \\
\text { Resident area }\end{array}$ & $\begin{array}{l}\text { 1- Soil and mud is usually } \\
\text { tracked onto public road. } \\
2-\quad \text { Not enough water is } \\
\text { sprayed on dusty surfaces so } \\
\text { airborne dust level is high. }\end{array}$ & $16 / 07 / 2013$ & Watering activities & $\begin{array}{l}\text { 1- Public roads continue } \\
\text { covered by soil and mud } \\
\text { 2- Surfaces are regularly } \\
\text { watered }\end{array}$ & Consultant's reports \\
\hline A4 & $\begin{array}{l}\text { Km107+533 } \\
\text { (QL32C bridge) } \\
\text { Resident area }\end{array}$ & $\begin{array}{l}\text { 1- Soil and mud is usually } \\
\text { tracked onto public road. } \\
2-\quad \text { Not enough water is } \\
\text { sprayed on dusty surfaces so } \\
\text { airborne dust level is high. }\end{array}$ & $11 / 12 / 2013$ & Watering activities & $\begin{array}{l}\text { 1- Public roads continue } \\
\text { covered by soil and mud } \\
2 \text { - Surfaces are regularly } \\
\text { watered }\end{array}$ & Consultant's reports \\
\hline A4 & $\begin{array}{l}\mathrm{Km} 82+000 \\
\text { Resident area }\end{array}$ & $\begin{array}{l}\text { Soil slide down pipe culverts } \\
\text { affecting the irrigation system }\end{array}$ & $15 / 6 / 2013$ & $\begin{array}{l}\text { Closely coordinate with } \\
\text { affected } \mathrm{HH} \text { and local } \\
\text { authorities to expedite } \\
\text { compensation for damages } \\
\text { caused by construction }\end{array}$ & $\begin{array}{l}\text { 1- Dig adequately sized } \\
\text { side drainage/ditch at } \\
\text { erosion prone areas to } \\
\text { direct surface run-off } \\
\text { away from agricultural }\end{array}$ & Consultant's reports \\
\hline
\end{tabular}


Loan 2391/2392 - VIE: GMS Kunming - Hai Phong Transport Corridor

Noi Bai - Lao Cai Highway Project

\begin{tabular}{|c|c|c|c|c|c|c|}
\hline PACK. & LOCATION & COMPLAINT DESCRIPTION & DATE & EXECUTED ACTIONS & CURRENT STATUS & DOCUMENT. \\
\hline & & & & activities. & $\begin{array}{l}\text { land. } \\
\text { 2- Implement slope } \\
\text { stabilization measures to } \\
\text { minimize erosion. }\end{array}$ & \\
\hline A5 & $\begin{array}{l}\text { Hop Minh My } \\
\text { bridge, NR37 } \\
\text { bridge, Km145, } \\
\text { Km142 }\end{array}$ & $\begin{array}{l}\text { The Contractor's construction } \\
\text { activities and material } \\
\text { transportation were caused } \\
\text { dusty at this location. This } \\
\text { situation is caused impact to } \\
\text { air quality. }\end{array}$ & $13 / 01 / 2014$ & $\begin{array}{l}\text { 1-Apply fully measures in } \\
\text { order to minimize dust during } \\
\text { project implementation; } \\
\text { 2-Comply with Environmental } \\
\text { Control and Protection Plant } \\
\text { approved by the Engineer; } \\
\text { 3-Implement strictly the } \\
\text { Engineer's instruction and } \\
\text { requirements. }\end{array}$ & $\begin{array}{l}\text { Hop Minh My bridge, } \\
\text { NR37 bridge, Km145, } \\
\text { Km142 }\end{array}$ & $\begin{array}{l}\text { The Contractor's } \\
\text { construction } \\
\text { activities and } \\
\text { material } \\
\text { transportation were } \\
\text { caused dusty at this } \\
\text { location. This } \\
\text { situation is caused } \\
\text { impact to air quality. }\end{array}$ \\
\hline A5 & $\mathrm{Km} 121, \mathrm{Km} 122$ & $\begin{array}{l}\text { The Contractor is } \\
\text { constructing earth works with } \\
\text { high vibration level, this } \\
\text { situation is causing impact to } \\
\text { structure of local people's } \\
\text { house. }\end{array}$ & $14 / 02 / 2014$ & $\begin{array}{l}\text { 1-Comply with the Project's } \\
\text { requirements as well as } \\
\text { Environmental Control and } \\
\text { Protectionr; } \\
\text { 2-Comply with Method } \\
\text { Statements approved by the } \\
\text { Engineer during project } \\
\text { implementation. }\end{array}$ & $\begin{array}{l}\text { The Contractor is } \\
\text { combining with local } \\
\text { people and local } \\
\text { authorities in order to } \\
\text { solve this problem }\end{array}$ & Consultant's reports \\
\hline A5 & $\begin{array}{l}\text { Ngoi That } \\
\text { bridge, Ngoi } \\
\text { Rao bridge, }\end{array}$ & $\begin{array}{l}\text { The Contractor built some } \\
\text { service roads at these bridge } \\
\text { construction sites. But the } \\
\text { Contractor did not install fully } \\
\text { pipe culvert at these location, } \\
\text { this situation has partially } \\
\text { obstructed the water flow of } \\
\text { the stream / river. }\end{array}$ & $5 / 03 / 2014$ & $\begin{array}{l}\text { 1-Remove dumped soil from } \\
\text { the stream / river at bridge } \\
\text { site, ensure the water flow of } \\
\text { the stream / river; } \\
\text { 2-Undertake regular clearing } \\
\text { of the stream / river affected } \\
\text { by construction; } \\
\text { 3-Undertake restoration of } \\
\text { stream / river at all bridge } \\
\text { sites. }\end{array}$ & $\begin{array}{l}\text { This issue still has not } \\
\text { been solved absolutely by } \\
\text { the Contractor }\end{array}$ & Consultant's reports \\
\hline A6 & Km165, Km167, & Much soil have been fallen & $14 / 01 / 2014$ & 1-Ensure that all trucks are & 1-Some dumped trucks & Consultant's reports \\
\hline
\end{tabular}




\section{Loan 2391/2392 - VIE: GMS Kunming - Hai Phong Transport Corridor}

Noi Bai - Lao Cai Highway Project

\begin{tabular}{|c|c|c|c|c|c|c|}
\hline PACK. & LOCATION & COMPLAINT DESCRIPTION & DATE & EXECUTED ACTIONS & CURRENT STATUS & DOCUMENT. \\
\hline & & $\begin{array}{l}\text { on the public road during the } \\
\text { Contractor's material } \\
\text { transportation, this situation } \\
\text { is causing impact to the } \\
\text { region's environment and } \\
\text { traffic. }\end{array}$ & & $\begin{array}{l}\text { fully covered with canvas } \\
\text { during material } \\
\text { transportation; } \\
\text { 2-Implement fully instructions } \\
\text { and requirements from the } \\
\text { Engineer; } \\
\text { 3-Comply with the Project's } \\
\text { requirements as well as } \\
\text { Environmental Control and } \\
\text { Protection. }\end{array}$ & $\begin{array}{l}\text { were covered with canvas } \\
\text { during material } \\
\text { transportation; } \\
\text { 2-The Contractor repaired } \\
\text { and cleaned some public } \\
\text { roads; } \\
\text { 3-The Contractor is } \\
\text { spraying water on public } \\
\text { roads in order to minimize } \\
\text { dusty during material } \\
\text { transportation. }\end{array}$ & \\
\hline A6 & Km159, Km165 & $\begin{array}{l}\text { The Contractor's activities } \\
\text { construction and materials } \\
\text { transportation are cause } \\
\text { impact to quality of public } \\
\text { road, difficultly to vehicles } \\
\text { travelling through this } \\
\text { location, }\end{array}$ & $15 / 02 / 2014$ & $\begin{array}{l}\text { 1- Repair damaged road in } \\
\text { order to ensure the region's } \\
\text { traffic. } \\
\text { 2- Comply with Traffic } \\
\text { Control Plan in the whole } \\
\text { process of project } \\
\text { implementation; } \\
\text { 3- Stop repeat similar case, }\end{array}$ & $\begin{array}{l}\text { Contractor is applying } \\
\text { some of the measures in } \\
\text { order to repair damaged } \\
\text { roads in order to ensure } \\
\text { the region's traffic. }\end{array}$ & Consultant's reports \\
\hline A6 & Km155, Km175 & $\begin{array}{l}\text { The Contractor's construction } \\
\text { activities and material } \\
\text { transportation were caused } \\
\text { dusty at this location. This } \\
\text { situation is caused impact to } \\
\text { air quality. }\end{array}$ & $17 / 03 / 2014$ & $\begin{array}{l}\text { 1-Apply fully measures in } \\
\text { order to minimize dust during } \\
\text { project implementation; } \\
\text { 2-Comply with Environmental } \\
\text { Control and Protection Plant } \\
\text { approved by the Engineer; } \\
\text { 3-Implement strictly the } \\
\text { Engineer's instruction and } \\
\text { requirements. }\end{array}$ & $\begin{array}{l}\text { The Contractor is } \\
\text { spraying water at this } \\
\text { location in order to } \\
\text { minimize dusty during } \\
\text { project implementation. }\end{array}$ & Consultant's reports \\
\hline A7 & $\mathrm{Km} 193+242$ & $\begin{array}{l}\text { Household don't way to in } \\
\text { and out because construction } \\
\text { works of Noi Bai- Lao Cai } \\
\text { highway }\end{array}$ & $30 / 12 / 2011$ & $\begin{array}{l}\text { Required to revoked this } \\
\text { house or make the way } \\
\text { (UNDERPASS CULVERT) to } \\
\text { in and out }\end{array}$ & $\begin{array}{l}\text { EPMU had revoked this } \\
\text { house }\end{array}$ & Consultant's reports \\
\hline
\end{tabular}


Loan 2391/2392 - VIE: GMS Kunming - Hai Phong Transport Corridor

Noi Bai - Lao Cai Highway Project

\begin{tabular}{|c|c|c|c|c|c|c|}
\hline PACK. & LOCATION & COMPLAINT DESCRIPTION & DATE & EXECUTED ACTIONS & CURRENT STATUS & DOCUMENT. \\
\hline A7 & $\mathrm{Km} 209+200$ & $\begin{array}{l}\text { While construction the earth } \\
\text { overflow in fields }\end{array}$ & $\begin{array}{l}13 / 1 / 2012 \\
25 / 9 / 2012\end{array}$ & $\begin{array}{l}\text { Request the contractor to } \\
\text { dredging or compensation }\end{array}$ & $\begin{array}{l}\text { The contractor had } \\
\text { coordinate with Local } \\
\text { Authorities and EPMU to } \\
\text { compensate for } \\
\text { household }\end{array}$ & Consultant's reports \\
\hline A7 & Km199+100 & $\begin{array}{l}\text { While construction the earth } \\
\text { overflow in fields }\end{array}$ & $\begin{array}{l}13 / 2 / 2012 \\
14 / 8 / 2012\end{array}$ & $\begin{array}{l}\text { Request the contractor to } \\
\text { dredging or compensation }\end{array}$ & $\begin{array}{l}\text { The contractor had } \\
\text { coordinate with Local } \\
\text { Authorities and EPMU to } \\
\text { compensate for } \\
\text { household }\end{array}$ & Consultant's reports \\
\hline A7 & $\mathrm{Km} 193+700$ & $\begin{array}{l}\text { While construction the earth } \\
\text { overflow in fields }\end{array}$ & $\begin{array}{l}\text { 24/3/2012; } \\
17 / 7 / 2012\end{array}$ & $\begin{array}{l}\text { Request the contractor to } \\
\text { dredging or compensation }\end{array}$ & $\begin{array}{l}\text { The contractor had } \\
\text { coordinate with Local } \\
\text { Authorities and EPMU to } \\
\text { compensate for } \\
\text { household }\end{array}$ & Consultant's reports \\
\hline A7 & $\mathrm{Km} 201+540$ & $\begin{array}{l}\text { While construction the earth } \\
\text { overflow in fields }\end{array}$ & $24 / 4 / 2012$ & $\begin{array}{l}\text { We suggest the contractor to } \\
\text { compensate for the filed } \\
\text { areas are filled by earth, and } \\
\text { apply the slope protection's } \\
\text { method to avoid erosion and } \\
\text { landsides when heavy } \\
\text { raining }\end{array}$ & $\begin{array}{l}\text { The contractor had } \\
\text { coordinate with Local } \\
\text { Authorities and EPMU to } \\
\text { compensate for } \\
\text { household }\end{array}$ & Consultant's reports \\
\hline A7 & $\mathrm{Km} 191+350$ & $\begin{array}{l}\text { Earth from embankment road } \\
\text { overflow into filed, }\end{array}$ & $28 / 5 / 2012$ & $\begin{array}{l}\text { Request the contractor to } \\
\text { dredging or compensation }\end{array}$ & $\begin{array}{l}\text { The contractor had } \\
\text { coordinate with Local } \\
\text { Authorities and EPMU to } \\
\text { compensate for } \\
\text { household }\end{array}$ & Consultant's reports \\
\hline A7 & $\mathrm{Km} 211+764$ & $\begin{array}{l}\text { Earth from embankment road } \\
\text { overflow into pond, }\end{array}$ & $7 / 6 / 2012$ & $\begin{array}{l}\text { Request the contractor to } \\
\text { dredging or compensation }\end{array}$ & $\begin{array}{l}\text { The contractor had } \\
\text { coordinate with Local } \\
\text { Authorities and EPMU to } \\
\text { compensate for } \\
\text { household }\end{array}$ & Consultant's reports \\
\hline
\end{tabular}




\section{Loan 2391/2392 - VIE: GMS Kunming - Hai Phong Transport Corridor}

Noi Bai - Lao Cai Highway Project

\begin{tabular}{|c|c|c|c|c|c|c|}
\hline PACK. & LOCATION & COMPLAINT DESCRIPTION & DATE & EXECUTED ACTIONS & CURRENT STATUS & DOCUMENT. \\
\hline A7 & Km204+307 & $\begin{array}{l}\text { The follow rate in down tream } \\
\text { of pipe culvert flow into fileds }\end{array}$ & $\begin{array}{l}\text { 15/11/2012; } \\
3 / 12 / 2012\end{array}$ & $\begin{array}{l}\text { Client coordinated with } \\
\text { household inorder to revoke } \\
\text { land }\end{array}$ & $\begin{array}{l}\text { Untill 03/12/2012 the } \\
\text { client not yet pay monney } \\
\text { for household. EPMU had } \\
\text { revoked this fields and } \\
\text { payment money for this } \\
\text { household }\end{array}$ & Consultant's reports \\
\hline A7 & $\mathrm{Km} 211+000$ & $\begin{array}{l}\text { While construction the earth } \\
\text { in the down stream of pile } \\
\text { culvert overflow in fields }\end{array}$ & $4 / 1 / 2013$ & $\begin{array}{l}\text { Request the contractor to } \\
\text { dredging or compensation }\end{array}$ & $\begin{array}{l}\text { The contractor had } \\
\text { coordinate with Local } \\
\text { Authorities and EPMU to } \\
\text { compensate for } \\
\text { household }\end{array}$ & Consultant's reports \\
\hline A7 & Km209+300 & $\begin{array}{l}\text { Exist road through her house } \\
\text { many dust during time } \\
\text { construction work. }\end{array}$ & $27 / 2 / 2013$ & $\begin{array}{l}\text { Request the contractor to } \\
\text { watering at least } 02 \text { times/ } \\
\text { day in order to air pollution } \\
\text { mitigate during time } \\
\text { construction work }\end{array}$ & $\begin{array}{l}\text { The contractor had } \\
\text { mobilize the watering car } \\
\text { inorder to watering at this } \\
\text { location but not satisfies }\end{array}$ & Consultant's reports \\
\hline A7 & $\mathrm{Km} 192+800$ & $\begin{array}{l}\text { He said that his house was } \\
\text { affected by the blasting rock } \\
\text { using for embankment } \\
\text { construction work }\end{array}$ & 4/3/2013 & $\begin{array}{l}\text { Request the contractor to } \\
\text { compensate household in } \\
\text { order to continue } \\
\text { construction work on site }\end{array}$ & $\begin{array}{l}\text { The contractor had } \\
\text { coordinate with Local } \\
\text { Authorities and EPMU to } \\
\text { compensate for } \\
\text { household }\end{array}$ & Consultant's reports \\
\hline A7 & $\mathrm{Km} 210+200$ & $\begin{array}{l}\text { While construction the earth } \\
\text { in the down stream of pile } \\
\text { culvert overflow in fields }\end{array}$ & $9 / 4 / 2013$ & $\begin{array}{l}\text { Request the contractor to } \\
\text { compensate household in } \\
\text { order to continue } \\
\text { construction work on site }\end{array}$ & $\begin{array}{l}\text { The contractor had } \\
\text { coordinate with Local } \\
\text { Authorities and EPMU to } \\
\text { compensate for } \\
\text { household }\end{array}$ & Consultant's reports \\
\hline A7 & $\mathrm{Km} 215+200$ & $\begin{array}{l}\text { While construction the earth } \\
\text { from embankment slope } \\
\text { overflow in fields }\end{array}$ & $3 / 5 / 2013$ & $\begin{array}{l}\text { Request the contractor to } \\
\text { dredging or compensation }\end{array}$ & $\begin{array}{l}\text { The contractor had } \\
\text { coordinate with Local } \\
\text { Authorities and EPMU to } \\
\text { compensate for } \\
\text { household }\end{array}$ & Consultant's reports \\
\hline
\end{tabular}




\section{Loan 2391/2392 - VIE: GMS Kunming - Hai Phong Transport Corridor}

Noi Bai - Lao Cai Highway Project

\begin{tabular}{|c|c|c|c|c|c|c|}
\hline PACK. & LOCATION & COMPLAINT DESCRIPTION & DATE & EXECUTED ACTIONS & CURRENT STATUS & DOCUMENT. \\
\hline A7 & $\mathrm{Km} 209+329$ & $\begin{array}{l}\text { The exist road on the front of } \\
\text { household very dirty in dry } \\
\text { season and slippery in } \\
\text { raining day } \\
\text { While construction the earth } \\
\text { in the exist road overflow in } \\
\text { fields at Km209+329 }\end{array}$ & $\begin{array}{l}21 / 1 / 2013 \\
11 / 6 / 2013 \\
22 / 10 / 2013 \\
23 / 7 / 2013\end{array}$ & $\begin{array}{l}\text { Request the contractor to } \\
\text { watering at least } 02 \text { times/ } \\
\text { day in order to air pollution } \\
\text { mitigate during time } \\
\text { construction work } \\
\text { Request the contractor to } \\
\text { compensate household in } \\
\text { order to continue } \\
\text { construction work on site }\end{array}$ & $\begin{array}{l}\text { The contractor had } \\
\text { mobilize the watering car } \\
\text { inorder to watering at this } \\
\text { location but not satisfies } \\
\text { The contractor had } \\
\text { coordinate with Local } \\
\text { Authorities and EPMU to } \\
\text { compensate for } \\
\text { household }\end{array}$ & Consultant's reports \\
\hline A7 & $\mathrm{Km} 212+100$ & $\begin{array}{l}\text { While construction the earth } \\
\text { in the down stream of pile } \\
\text { culvert overflow in fields at } \\
\mathrm{Km} 212+100\end{array}$ & $13 / 8 / 2013$ & $\begin{array}{l}\text { Request the contractor to } \\
\text { compensate household in } \\
\text { order to continue } \\
\text { construction work on site }\end{array}$ & $\begin{array}{l}\text { The contractor had } \\
\text { coordinate with Local } \\
\text { Authorities and EPMU to } \\
\text { compensate for } \\
\text { household }\end{array}$ & Consultant's reports \\
\hline A7 & $\mathrm{Km} 215+000$ & $\begin{array}{l}\text { While construction the earth } \\
\text { in the down stream of pile } \\
\text { culvert overflow in fields at } \\
\mathrm{Km} 215+000\end{array}$ & $17 / 9 / 2013$ & $\begin{array}{l}\text { Request the contractor to } \\
\text { compensate household in } \\
\text { order to continue } \\
\text { construction work on site }\end{array}$ & $\begin{array}{l}\text { The contractor had } \\
\text { coordinate with Local } \\
\text { Authorities and EPMU to } \\
\text { compensate for } \\
\text { household }\end{array}$ & Consultant's reports \\
\hline A7 & $\mathrm{Km} 211+500$ & $\begin{array}{l}\text { Earth from embankment road } \\
\text { overflow into pond, }\end{array}$ & $26 / 11 / 2013$ & $\begin{array}{l}\text { Request the contractor to } \\
\text { dredging or compensation }\end{array}$ & $\begin{array}{l}\text { The contractor had } \\
\text { coordinate with Local } \\
\text { Authorities and EPMU to } \\
\text { compensate for } \\
\text { household }\end{array}$ & Consultant's reports \\
\hline A7 & $\mathrm{Km} 209+500$ & $\begin{array}{l}\text { While construction the earth } \\
\text { in the exist road overflow in } \\
\text { fields at } \mathrm{Km} 209+500\end{array}$ & $17 / 12 / 2013$ & $\begin{array}{l}\text { Request the contractor to } \\
\text { compensate household in } \\
\text { order to continue } \\
\text { construction work on site }\end{array}$ & $\begin{array}{l}\text { The contractor had } \\
\text { coordinate with Local } \\
\text { Authorities and EPMU to } \\
\text { compensate for } \\
\text { household }\end{array}$ & Consultant's reports \\
\hline
\end{tabular}




\section{Loan 2391/2392 - VIE: GMS Kunming - Hai Phong Transport Corridor}

Noi Bai - Lao Cai Highway Project

\begin{tabular}{|c|c|c|c|c|c|c|}
\hline PACK. & LOCATION & COMPLAINT DESCRIPTION & DATE & EXECUTED ACTIONS & CURRENT STATUS & DOCUMENT. \\
\hline A7 & Km207+834 & $\begin{array}{l}\text { Living road of Underpass } \\
\text { culvert very dirty and can not } \\
\text { throught wighle the highway } \\
\text { is closed }\end{array}$ & $25 / 2 / 2014$ & $\begin{array}{l}\text { The contractor is requested } \\
\text { to repair to ensure the local } \\
\text { people can using this road } \\
\text { for traffict }\end{array}$ & $\begin{array}{l}\text { The contractor on going } \\
\text { repair }\end{array}$ & Consultant's reports \\
\hline A7 & $\mathrm{Km} 211+565$ & $\begin{array}{l}\text { Living road of Underpass } \\
\text { culvert very dirty and can not } \\
\text { throught wighle the highway } \\
\text { is closed }\end{array}$ & $19 / 3 / 2014$ & $\begin{array}{l}\text { The contractor is requested } \\
\text { to repair to ensure the local } \\
\text { people can using this road } \\
\text { for traffict }\end{array}$ & $\begin{array}{l}\text { The contractor on going } \\
\text { repair }\end{array}$ & Consultant's reports \\
\hline A7 & $\mathrm{Km} 193+242$ & $\begin{array}{l}\text { Household don't way to in } \\
\text { and out because construction } \\
\text { works of Noi Bai- Lao Cai } \\
\text { highway }\end{array}$ & $30 / 12 / 2011$ & $\begin{array}{l}\text { Required to revoked this } \\
\text { house or make the way } \\
\text { (UNDERPASS CULVERT) to } \\
\text { in and out }\end{array}$ & $\begin{array}{l}\text { EPMU had revoked this } \\
\text { house }\end{array}$ & Consultant's reports \\
\hline A7 & $\mathrm{Km} 209+200$ & $\begin{array}{l}\text { While construction the earth } \\
\text { overflow in fields }\end{array}$ & $\begin{array}{l}13 / 1 / 2012 \\
25 / 9 / 2012\end{array}$ & $\begin{array}{l}\text { Request the contractor to } \\
\text { dredging or compensation }\end{array}$ & $\begin{array}{l}\text { The contractor had } \\
\text { coordinate with Local } \\
\text { Authorities and EPMU to } \\
\text { compensate for } \\
\text { household }\end{array}$ & Consultant's reports \\
\hline A7 & Km199+100 & $\begin{array}{l}\text { While construction the earth } \\
\text { overflow in fields }\end{array}$ & $\begin{array}{l}13 / 2 / 2012 \\
14 / 8 / 2012\end{array}$ & $\begin{array}{l}\text { Request the contractor to } \\
\text { dredging or compensation }\end{array}$ & $\begin{array}{l}\text { The contractor had } \\
\text { coordinate with Local } \\
\text { Authorities and EPMU to } \\
\text { compensate for } \\
\text { household }\end{array}$ & Consultant's reports \\
\hline A8 & $\mathrm{Km} 232+070$ & $\begin{array}{l}\text { The fields at downstream of } \\
\text { pile culvert at, it can flood. }\end{array}$ & $30 / 12 / 2011$ & $\begin{array}{l}\text { Required to revoked this } \\
\text { fields }\end{array}$ & $\begin{array}{l}\text { EPMU had revoked this } \\
\text { fields }\end{array}$ & Consultant's reports \\
\hline A8 & $\begin{array}{l}\mathrm{Km} 200+00- \\
\mathrm{Km} 200+100\end{array}$ & $\begin{array}{l}\text { The exits road was broken by } \\
\text { trucks or any vehicles which } \\
\text { usually through this roads }\end{array}$ & $10 / 1 / 2012$ & $\begin{array}{l}\text { Require to repair and } \\
\text { maintenance the exist road }\end{array}$ & $\begin{array}{l}\text { The contractor had repair } \\
\text { and didn't go through this } \\
\text { road from May } 2012\end{array}$ & Consultant's reports \\
\hline A8 & $\mathrm{Km} 230+480$ & $\begin{array}{l}\text { While construction the earth } \\
\text { overflow in fields }\end{array}$ & $22 / 2 / 2012$ & $\begin{array}{l}\text { Request the contractor to } \\
\text { dredging or compensation }\end{array}$ & $\begin{array}{l}\text { The contractor had } \\
\text { coordinate with Local } \\
\text { Authorities and EPMU to } \\
\text { compensate for }\end{array}$ & Consultant's reports \\
\hline
\end{tabular}




\section{Loan 2391/2392 - VIE: GMS Kunming - Hai Phong Transport Corridor}

Noi Bai - Lao Cai Highway Project

\begin{tabular}{|c|c|c|c|c|c|c|}
\hline PACK. & LOCATION & COMPLAINT DESCRIPTION & DATE & EXECUTED ACTIONS & CURRENT STATUS & DOCUMENT. \\
\hline & & & & & household & \\
\hline A8 & $\mathrm{Km} 238+465$ & $\begin{array}{l}200 m \text { canal are obstructed by } \\
\text { construction works but the } \\
\text { contractor didn't overcome }\end{array}$ & $21 / 3 / 2012$ & $\begin{array}{l}\text { Request the contractor to } \\
\text { dredging to ensure irrigation } \\
\text { system for farmer }\end{array}$ & $\begin{array}{l}\text { The contractor had dredg } \\
\text { to ensure irrigation } \\
\text { system for farmer }\end{array}$ & Consultant's reports \\
\hline A8 & $\mathrm{Km} 238+800$ & $\begin{array}{l}400 m \text { canal are obstructed } \\
\text { by construction works }\end{array}$ & $25 / 4 / 2012$ & $\begin{array}{l}\text { Request the contractor to } \\
\text { dredging to ensure irrigation } \\
\text { system for farmer }\end{array}$ & $\begin{array}{l}\text { The contractor had dredg } \\
\text { to ensure irrigation } \\
\text { system for farmer }\end{array}$ & Consultant's reports \\
\hline A8 & $\begin{array}{l}\mathrm{Km} 230+527- \\
\mathrm{Km} 230+660\end{array}$ & $\begin{array}{l}\text { Earth from embankment road } \\
\text { overflow into pond }\end{array}$ & $29 / 5 / 2012$ & $\begin{array}{l}\text { Request the contractor and } \\
\text { EPMU make a cannal } \\
\text { through household to guide } \\
\text { the water to drainage system }\end{array}$ & $\begin{array}{l}\text { The contractor had make } \\
\text { a box culvert through } \\
\text { household to guide the } \\
\text { water to drainage system }\end{array}$ & Consultant's reports \\
\hline A8 & $\mathrm{Km} 227+065$ & $\begin{array}{l}\text { Erarth overflow into Hai Tien } \\
\text { Lake due to construction } \\
\text { works of the contractor }\end{array}$ & $10 / 6 / 2012$ & $\begin{array}{l}\text { Request the contractor to } \\
\text { dredging or compensation }\end{array}$ & $\begin{array}{l}\text { The contractor had } \\
\text { coordinate with Local } \\
\text { Authorities and EPMU to } \\
\text { compensate for } \\
\text { household }\end{array}$ & Consultant's reports \\
\hline A8 & $\mathrm{Km} 230+295$ & $\begin{array}{l}\text { While construction the earth } \\
\text { overflow in house, garden } \\
\text { and pond }\end{array}$ & $\begin{array}{l}25 / 7 / 2012 \\
26 / 10 / 2012\end{array}$ & $\begin{array}{l}\text { Request the contractor and } \\
\text { EPMU make a cannal } \\
\text { through household to guide } \\
\text { the water to drainage system }\end{array}$ & $\begin{array}{l}\text { The contractor had make } \\
\text { a box culvert through } \\
\text { household to guide the } \\
\text { water to drainage system }\end{array}$ & Consultant's reports \\
\hline A8 & $\mathrm{Km} 230+450$ & $\begin{array}{l}\text { While construction the earth } \\
\text { overflow in households, } \\
\text { garden and pond }\end{array}$ & $22 / 8 / 2012$ & $\begin{array}{l}\text { Request the contractor to } \\
\text { dredging or compensation }\end{array}$ & $\begin{array}{l}\text { The contractor had } \\
\text { coordinate with Local } \\
\text { Authorities and EPMU to } \\
\text { compensate for } \\
\text { household }\end{array}$ & Consultant's reports \\
\hline A8 & $\begin{array}{l}\mathrm{Km} 222+700- \\
\mathrm{Km} 222+800\end{array}$ & $\begin{array}{l}\text { While construction the earth } \\
\text { overflow in canal cause } \\
\text { obstructed flow rate and } \\
\text { decrease the crop } \\
\text { productivity }\end{array}$ & $3 / 10 / 2012$ & $\begin{array}{l}\text { Request the contractor to } \\
\text { dredging or compensation }\end{array}$ & $\begin{array}{l}\text { The contractor had } \\
\text { coordinate with Local } \\
\text { Authorities and EPMU to } \\
\text { compensate for } \\
\text { household }\end{array}$ & Consultant's reports \\
\hline A8 & $\mathrm{Km} 218+040$ & Washing water of Concrete & $14 / 11 / 2012$ & Required the contractor to & The contractor had dig a & Consultant's reports \\
\hline
\end{tabular}




\section{Loan 2391/2392 - VIE: GMS Kunming - Hai Phong Transport Corridor}

Noi Bai - Lao Cai Highway Project

\begin{tabular}{|c|c|c|c|c|c|c|}
\hline PACK. & LOCATION & COMPLAINT DESCRIPTION & DATE & EXECUTED ACTIONS & CURRENT STATUS & DOCUMENT. \\
\hline & & $\begin{array}{l}\text { batching plant could osmose } \\
\text { into well, it effect to water } \\
\text { quality using for family life. }\end{array}$ & & $\begin{array}{l}\text { dig a trench to guide the } \\
\text { washing water into settling } \\
\text { pond }\end{array}$ & $\begin{array}{l}\text { trench to guide the } \\
\text { washing water into } \\
\text { settling pond }\end{array}$ & \\
\hline A8 & $\mathrm{Km} 237+150$ & $\begin{array}{l}\text { While construction the earth } \\
\text { in the down stream of pile } \\
\text { culvert overflow in fields and } \\
\text { pond }\end{array}$ & $7 / 12 / 2012$ & $\begin{array}{l}\text { Request the contractor to } \\
\text { dredging or compensation }\end{array}$ & $\begin{array}{l}\text { The contractor had } \\
\text { coordinate with Local } \\
\text { Authorities and EPMU to } \\
\text { compensate for } \\
\text { household }\end{array}$ & Consultant's reports \\
\hline A8 & $\mathrm{Km} 231+120$ & $\begin{array}{l}\text { While construction the earth } \\
\text { in the down stream of pile } \\
\text { culvert overflow in fields }\end{array}$ & $10 / 1 / 2013$ & $\begin{array}{l}\text { Request the contractor to } \\
\text { dredging or compensation }\end{array}$ & $\begin{array}{l}\text { The contractor had } \\
\text { coordinate with Local } \\
\text { Authorities and EPMU to } \\
\text { compensate for } \\
\text { household }\end{array}$ & Consultant's reports \\
\hline A8 & $\mathrm{Km} 219+150$ & $\begin{array}{l}\text { While construction the earth } \\
\text { in the down stream of pile } \\
\text { culvert overflow in fields }\end{array}$ & $28 / 2 / 2013$ & $\begin{array}{l}\text { Request the contractor to } \\
\text { dredging or compensation }\end{array}$ & $\begin{array}{l}\text { The contractor had } \\
\text { coordinate with Local } \\
\text { Authorities and EPMU to } \\
\text { compensate for } \\
\text { household }\end{array}$ & Consultant's reports \\
\hline A8 & $\mathrm{Km} 222+300$ & $\begin{array}{l}\text { While construction the earth } \\
\text { in the down stream of pile } \\
\text { culvert overflow in fields }\end{array}$ & $20 / 3 / 2013$ & $\begin{array}{l}\text { Request the contractor to } \\
\text { dredging or compensation }\end{array}$ & $\begin{array}{l}\text { The contractor had } \\
\text { coordinate with Local } \\
\text { Authorities and EPMU to } \\
\text { compensate for } \\
\text { household }\end{array}$ & Consultant's reports \\
\hline A8 & $\mathrm{Km} 237+900$ & $\begin{array}{l}\text { Household effected } \\
\text { (household was cracked due } \\
\text { to vibration) by the using } \\
\text { machines (roller, } \\
\text { excavations) for embankment } \\
\text { construction work of the } \\
\text { contractor }\end{array}$ & $10 / 4 / 2013$ & $\begin{array}{l}\text { Request the contractor to } \\
\text { compensate for household }\end{array}$ & $\begin{array}{l}\text { The contractor had } \\
\text { coordinate with Local } \\
\text { Authorities and EPMU to } \\
\text { compensate for } \\
\text { household }\end{array}$ & Consultant's reports \\
\hline A8 & $\mathrm{Km} 237+200$ & $\begin{array}{l}\text { Household effected } \\
\text { (household was cracked due }\end{array}$ & $3 / 5 / 2013$ & $\begin{array}{l}\text { Request the contractor to } \\
\text { compensate for household }\end{array}$ & $\begin{array}{l}\text { The contractor had } \\
\text { coordinate with Local }\end{array}$ & Consultant's reports \\
\hline
\end{tabular}




\section{Loan 2391/2392 - VIE: GMS Kunming - Hai Phong Transport Corridor}

Noi Bai - Lao Cai Highway Project

\begin{tabular}{|c|c|c|c|c|c|c|}
\hline PACK. & LOCATION & COMPLAINT DESCRIPTION & DATE & EXECUTED ACTIONS & CURRENT STATUS & DOCUMENT. \\
\hline & & $\begin{array}{l}\text { to vibration) by the using } \\
\text { machines (roller, } \\
\text { excavations) for embankment } \\
\text { construction work of the } \\
\text { contractor }\end{array}$ & & & $\begin{array}{l}\text { Authorities and EPMU to } \\
\text { compensate for } \\
\text { household }\end{array}$ & \\
\hline A8 & $\mathrm{Km} 234+500$ & $\begin{array}{l}\text { While construction the earth } \\
\text { in the down stream of pile } \\
\text { culvert overflow in fields }\end{array}$ & $12 / 6 / 2013$ & $\begin{array}{l}\text { Request the contractor to } \\
\text { compensate for household }\end{array}$ & $\begin{array}{l}\text { The contractor had } \\
\text { coordinate with Local } \\
\text { Authorities and EPMU to } \\
\text { compensate for } \\
\text { household }\end{array}$ & Consultant's reports \\
\hline A8 & $\mathrm{Km} 236+700$ & $\begin{array}{l}\text { While construction the earth } \\
\text { in the down stream of pile } \\
\text { culvert overflow in fields at } \\
\mathrm{Km} 236+700\end{array}$ & $25 / 7 / 2013$ & $\begin{array}{l}\text { Request the contractor to } \\
\text { compensate for household }\end{array}$ & $\begin{array}{l}\text { The contractor had } \\
\text { coordinate with Local } \\
\text { Authorities and EPMU to } \\
\text { compensate for } \\
\text { household }\end{array}$ & Consultant's reports \\
\hline A8 & $\mathrm{Km} 222+000$ & $\begin{array}{l}\text { While construction the earth } \\
\text { in the down stream of pile } \\
\text { culvert overflow in fields at } \\
\mathrm{Km} 222+000\end{array}$ & $8 / 8 / 2013$ & $\begin{array}{l}\text { Request the contractor to } \\
\text { compensate for household }\end{array}$ & $\begin{array}{l}\text { The contractor had } \\
\text { coordinate with Local } \\
\text { Authorities and EPMU to } \\
\text { compensate for } \\
\text { household }\end{array}$ & Consultant's reports \\
\hline A8 & $\mathrm{Km} 240+100$ & $\begin{array}{l}\text { While construction the earth } \\
\text { in the down stream of pile } \\
\text { culvert overflow in fields at } \\
\mathrm{Km} 240+100\end{array}$ & 6/9/2013 & $\begin{array}{l}\text { Request the contractor to } \\
\text { compensate for household }\end{array}$ & $\begin{array}{l}\text { The contractor had } \\
\text { coordinate with Local } \\
\text { Authorities and EPMU to } \\
\text { compensate for } \\
\text { household }\end{array}$ & Consultant's reports \\
\hline A8 & $\mathrm{Km} 237+700$ & $\begin{array}{l}\text { Household effected } \\
\text { (household was cracked due } \\
\text { to vibration) by the using } \\
\text { machines (roller, } \\
\text { excavations) for embankment } \\
\text { construction work of the } \\
\text { contractor }\end{array}$ & 25/10/2013 & $\begin{array}{l}\text { Request the contractor to } \\
\text { compensate for household }\end{array}$ & $\begin{array}{l}\text { The contractor had } \\
\text { coordinate with Local } \\
\text { Authorities and EPMU to } \\
\text { compensate for } \\
\text { household }\end{array}$ & Consultant's reports \\
\hline
\end{tabular}




\section{Loan 2391/2392 - VIE: GMS Kunming - Hai Phong Transport Corridor}

Noi Bai - Lao Cai Highway Project

\begin{tabular}{|c|c|c|c|c|c|c|}
\hline PACK. & LOCATION & COMPLAINT DESCRIPTION & DATE & EXECUTED ACTIONS & CURRENT STATUS & DOCUMENT. \\
\hline A8 & $\mathrm{Km} 232+437$ & $\begin{array}{l}\text { While construction the earth } \\
\text { in the down stream of pile } \\
\text { culvert overflow in fields at } \\
\mathrm{Km} 232+437\end{array}$ & $13 / 11 / 2013$ & $\begin{array}{l}\text { Request the contractor to } \\
\text { compensate for household }\end{array}$ & $\begin{array}{l}\text { The contractor had } \\
\text { coordinate with Local } \\
\text { Authorities and EPMU to } \\
\text { compensate for } \\
\text { household }\end{array}$ & Consultant's reports \\
\hline A8 & $\mathrm{Km} 241+100$ & $\begin{array}{l}\text { Earth from embankment road } \\
\text { overflow into pond, }\end{array}$ & $11 / 12 / 2013$ & $\begin{array}{l}\text { Request the contractor to } \\
\text { dredging or compensation }\end{array}$ & $\begin{array}{l}\text { The contractor had } \\
\text { coordinate with Local } \\
\text { Authorities and EPMU to } \\
\text { compensate for } \\
\text { household }\end{array}$ & Consultant's reports \\
\hline A8 & $\mathrm{Km} 234+050$ & $\begin{array}{l}\text { Living road of Underpass } \\
\text { culvert very dirty and can not } \\
\text { throught wighle the highway } \\
\text { is closed }\end{array}$ & $15 / 1 / 2014$ & $\begin{array}{l}\text { The contractor is requested } \\
\text { to repair to ensure the local } \\
\text { people can using this road } \\
\text { for traffict }\end{array}$ & $\begin{array}{l}\text { The contractor on going } \\
\text { repair }\end{array}$ & Consultant's reports \\
\hline A8 & $\mathrm{Km} 235+800$ & $\begin{array}{l}\text { Living road of Underpass } \\
\text { culvert very dirty and can not } \\
\text { throught wighle the highway } \\
\text { is closed }\end{array}$ & $26 / 2 / 2014$ & $\begin{array}{l}\text { The contractor is requested } \\
\text { to repair to ensure the local } \\
\text { people can using this road } \\
\text { for traffict }\end{array}$ & $\begin{array}{l}\text { The contractor on going } \\
\text { repair }\end{array}$ & Consultant's reports \\
\hline A8 & $\mathrm{Km} 242+900$ & $\begin{array}{l}\text { Living road of Underpass } \\
\text { culvert very dirty and can not } \\
\text { throught wighle the highway } \\
\text { is closed }\end{array}$ & $20 / 3 / 2014$ & $\begin{array}{l}\text { The contractor is requested } \\
\text { to repair to ensure the local } \\
\text { people can using this road } \\
\text { for traffict }\end{array}$ & $\begin{array}{l}\text { The contractor on going } \\
\text { repair }\end{array}$ & Consultant's reports \\
\hline
\end{tabular}


getinsa

ER

Loan 2391/2392 - VIE: GMS Kunming - Mai Phon Transport Corridor No Bail - Lao Cai Highway Project

223 
Loan 2391/2392 - VIE: GMS Kunming - Hai Phong Transport Corridor Noi Bai - Lao Cai Highway Project

8. ANNEX 2: DATA OF ENVIRONMENTAL QUALITY PARAMETERS ANALYSIS 
getinso

6D)

R-1172/1100
REGISTRADA ISO 9001 CGM-01/347

Loan 2391/2392 - VIE: GMS Kunming - Hai Phong Transport Corridor Noi Bai - Lao Cai Highway Project

225 
Loan 2391/2392 - VIE: GMS Kunming - Hai Phong Transport Corridor Noi Bai - Lao Cai Highway Project

8.1 ANNEX 2.1: AIR QUALITY PARAMETERS 
getinso

(7)

REGISTRADA ISO 9001

बत्या

Loan 2391/2392 - VIE: GMS Kunming - Hai Phong Transport Corridor Noi Bai - Lao Cai Highway Project

227 


\section{Loan 2391/2392 - VIE: GMS Kunming - Hai Phong Transport Corridor}

Noi Bai - Lao Cai Highway Project

\section{PACKAGE A1}

Technical traffic opening ceremony was organized in December, 2013. The Contractor stopped monitoring the air quality parameters on that month.

\section{PACKAGE A2}

\begin{tabular}{|c|c|c|c|c|c|c|c|c|c|c|c|c|c|c|c|c|c|}
\hline \multirow{3}{*}{ Station } & \multirow{3}{*}{$\begin{array}{c}\text { Sensitive } \\
\text { Receptors }\end{array}$} & \multirow{3}{*}{$\begin{array}{l}\text { Sampling } \\
\text { Date \& Time }\end{array}$} & \multicolumn{15}{|c|}{ PARAMETERS, $\mu \mathrm{g} / \mathrm{m}^{3}$} \\
\hline & & & \multicolumn{3}{|c|}{$\mathrm{SO}_{2}$} & \multicolumn{3}{|c|}{$\mathrm{CO}$} & \multicolumn{3}{|c|}{$\mathrm{NO}_{\mathrm{x}}$} & \multicolumn{3}{|c|}{ TSP } & \multicolumn{3}{|c|}{ PM10 } \\
\hline & & & Jan & Feb & Mar & Jan & Feb & Mar & Jan & Feb & Mar & Jan & Feb & Mar & Jan & Feb & Mar \\
\hline $\mathrm{Km} 34+780$ & $\begin{array}{l}\text { Resident } \\
\text { area }\end{array}$ & $\begin{array}{l}\text { Jan } \\
\text { Feb } \\
\text { Mar }\end{array}$ & 28 & 27 & & 6,700 & 6,800 & & 28 & 27 & & 290 & 270 & & 130 & 120 & \\
\hline $\mathrm{Km} 36+500$ & $\begin{array}{l}\text { Resident } \\
\text { area }\end{array}$ & $\begin{array}{l}\text { Jan } \\
\text { Feb } \\
\text { Mar }\end{array}$ & 27 & 26 & & 6,900 & 6,700 & & 29 & 28 & & 280 & 260 & & 120 & 110 & \\
\hline \multirow[t]{2}{*}{$\mathrm{Km} \mathrm{39+130}$} & $\begin{array}{l}\text { Resident } \\
\text { area }\end{array}$ & $\begin{array}{l}\text { Jan } \\
\text { Feb } \\
\text { Mar }\end{array}$ & 26 & 28 & & 6,800 & 6,900 & & 27 & 29 & & 260 & 280 & & 120 & 130 & \\
\hline & \multicolumn{2}{|c|}{ QCVN 05:2009/BTNMT } & \multicolumn{3}{|c|}{350 (1-hr) } & \multicolumn{3}{|c|}{30,000 (1-hr) } & \multicolumn{3}{|c|}{200 (1-hr) } & \multicolumn{3}{|c|}{300 (1-hr) } & \multicolumn{3}{|c|}{150 (24-hr) } \\
\hline
\end{tabular}




\section{getinso}

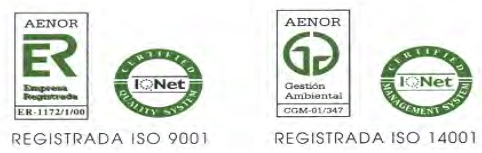

\section{Loan 2391/2392 - VIE: GMS Kunming - Hai Phong Transport Corridor}

Noi Bai - Lao Cai Highway Project

\section{PACKAGE A3}

\begin{tabular}{|c|c|c|c|c|c|c|c|c|c|c|c|c|c|c|c|c|c|}
\hline \multirow{3}{*}{ Station } & \multirow{3}{*}{$\begin{array}{l}\text { Sensitive } \\
\text { Receptors }\end{array}$} & \multirow{3}{*}{$\begin{array}{c}\text { Sampling } \\
\text { Date \& } \\
\text { Time, } \\
\text { weather } \\
\text { condition }\end{array}$} & \multicolumn{15}{|c|}{ PARAMETERS, $\mu \mathrm{g} / \mathrm{m}^{3}$} \\
\hline & & & \multicolumn{3}{|c|}{$\mathrm{SO}_{2}$} & \multicolumn{3}{|c|}{$\mathrm{CO}$} & \multicolumn{3}{|c|}{$\mathrm{NO}_{\mathrm{x}}$} & \multicolumn{3}{|c|}{ TSP } & \multicolumn{3}{|c|}{ PM10 } \\
\hline & & & Jan & Feb & Mar & Jan & Feb & Mar & Jan & Feb & Mar & Jan & Feb & Mar & Jan & Feb & Mar \\
\hline $\mathrm{Km} 48+500$ & $\begin{array}{l}\text { Residential } \\
\text { area }\end{array}$ & $\begin{array}{l}14 / 1 / 2014 \\
14 / 2 / 2014\end{array}$ & 51 & 55 & & 2675 & 2689 & & 23 & 26 & & 232 & 213 & & 143 & 129 & \\
\hline $\mathrm{Km} 55+500$ & $\begin{array}{l}\text { Residential } \\
\text { area }\end{array}$ & $\begin{array}{l}14 / 1 / 2014 \\
14 / 2 / 2014\end{array}$ & 39 & 41 & & 3,22 & 3134 & & 16 & 19 & & 159 & 137 & & 111 & 109 & \\
\hline $\mathrm{Km} 67+700$ & $\begin{array}{l}\text { Residential } \\
\text { area }\end{array}$ & $\begin{array}{l}14 / 1 / 2014 \\
14 / 2 / 2014\end{array}$ & 50 & 52 & & 3319 & 3322 & & 14 & 17 & & 217 & 211 & & 77 & 68 & \\
\hline \multirow[t]{2}{*}{$\mathrm{Km} 78+900$} & Street & $\begin{array}{l}14 / 1 / 2014 \\
14 / 2 / 2014\end{array}$ & 42 & 45 & & 3049 & 3059 & & 50 & 53 & & 277 & 251 & & 119 & 108 & \\
\hline & \multicolumn{2}{|c|}{ QCVN 05:2009/BTNMT } & \multicolumn{3}{|c|}{350 (1-hr) } & \multicolumn{3}{|c|}{30,000 (1-hr) } & \multicolumn{3}{|c|}{200 (1-hr) } & \multicolumn{3}{|c|}{300 (1-hr) } & \multicolumn{3}{|c|}{150 (24-hr) } \\
\hline
\end{tabular}




\section{Loan 2391/2392 - VIE: GMS Kunming - Hai Phong Transport Corridor}

Noi Bai - Lao Cai Highway Project

\section{PACKAGE A4}

\begin{tabular}{|c|c|c|c|c|c|c|c|c|c|c|c|c|c|c|c|c|c|}
\hline \multirow{3}{*}{ Station } & \multirow{3}{*}{$\begin{array}{l}\text { Sensitive } \\
\text { Receptors }\end{array}$} & \multirow{3}{*}{$\begin{array}{c}\text { Sampling } \\
\text { Date \& } \\
\text { Time, } \\
\text { weather } \\
\text { condition }\end{array}$} & \multicolumn{15}{|c|}{ PARAMETERS, $\mu \mathrm{g} / \mathrm{m}^{3}$} \\
\hline & & & \multicolumn{3}{|c|}{$\mathrm{SO}_{2}$} & \multicolumn{3}{|c|}{$\mathrm{CO}$} & \multicolumn{3}{|c|}{$\mathrm{NO}_{\mathrm{x}}$} & \multicolumn{3}{|c|}{ TSP } & \multicolumn{3}{|c|}{ PM10 } \\
\hline & & & Jan & Feb & Mar & Jan & Feb & Mar & Jan & Feb & Mar & Jan & Feb & Mar & Jan & Feb & Mar \\
\hline $\mathrm{Km} 91+150$ & School & $\begin{array}{l}16 / 1 / 2014 \\
21 / 2 / 2014\end{array}$ & 159 & 164 & & 3146 & 3157 & & 25 & 164 & & 234 & 224 & & 136 & 127 & \\
\hline Km95+100 & $\begin{array}{l}\text { Residential } \\
\text { area }\end{array}$ & $\begin{array}{l}16 / 1 / 2014 \\
21 / 2 / 2014\end{array}$ & 132 & 137 & & 3435 & 3441 & & 56 & 137 & & 139 & 128 & & 129 & 119 & \\
\hline $\begin{array}{l}\text { CPB } \\
\text { TanThanh }\end{array}$ & $\begin{array}{l}\text { Residential } \\
\text { area }\end{array}$ & $\begin{array}{l}16 / 1 / 2014 \\
21 / 2 / 2014\end{array}$ & 219 & 221 & & 3196 & 3207 & 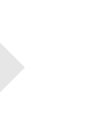 & 72 & 221 & & 246 & 234 & & 141 & 132 & \\
\hline $\mathrm{Km} 88+300$ & $\begin{array}{l}\text { Residential } \\
\text { area }\end{array}$ & $\begin{array}{l}16 / 1 / 2014 \\
21 / 2 / 2014\end{array}$ & 136 & 146 & & 3754 & 3769 & & 62 & 146 & & 238 & 215 & & 140 & 129 & \\
\hline Km104+900 & $\begin{array}{l}\text { Residential } \\
\text { area }\end{array}$ & $\begin{array}{l}16 / 1 / 2014 \\
21 / 2 / 2014\end{array}$ & 135 & 141 & & 3549 & 3564 & & 65 & 141 & & 137 & 126 & & 96 & 83 & \\
\hline Km106+500 & $\begin{array}{l}\text { Residential } \\
\text { area }\end{array}$ & $\begin{array}{l}16 / 1 / 2014 \\
21 / 2 / 2014\end{array}$ & 136 & 142 & & 3549 & 3554 & & 16 & 142 & & 197 & 181 & & 139 & 127 & \\
\hline Km106+800 & School & $\begin{array}{l}16 / 1 / 2014 \\
21 / 2 / 2014\end{array}$ & 143 & 154 & & 3386 & 3397 & & 65 & 154 & & 165 & 142 & & 134 & 134 & \\
\hline \multicolumn{3}{|c|}{ QCVN 05:2009/BTNMT } & \multicolumn{3}{|c|}{350 (1-hr) } & \multicolumn{3}{|c|}{30,000 (1-hr) } & \multicolumn{3}{|c|}{200 (1-hr) } & \multicolumn{3}{|c|}{300 (1-hr) } & \multicolumn{3}{|c|}{150 (24-hr) } \\
\hline
\end{tabular}




\section{Loan 2391/2392 - VIE: GMS Kunming - Hai Phong Transport Corridor}

Noi Bai - Lao Cai Highway Project

\section{PACKAGE A5}

According to Environmental Monitoring Plan approved by the Engineer through the letter Ref. GET3-KEANGNAM-11-A5-037 dated 28 ${ }^{\text {th }}$ March, 2011, the contractor carries out the Environment monitoring with frequency: 1 time / 1 month. Include some indications: $\mathrm{SO}_{2}, \mathrm{CO} \mathrm{NO}_{\mathrm{x}}, \mathrm{TSP}$, $\mathrm{PM}_{10}$

Weather condition: $-15^{\text {th }}$ January, 2014: Cloudy, average temperature $16.1 \mathrm{C}$, windy speed $0.48 \mathrm{~m} / \mathrm{s}$. North - East windy direction - $25^{\text {th }}$ February, 2014: Cloudy, average temperature $20.8 \mathrm{C}$, windy speed $0.29 \mathrm{~m} / \mathrm{s}$. South-East windy direction - $17^{\text {th }}$ March, 2014: Sunny, average temperature of 21.5 , windy speed $0.62 \mathrm{~m} / \mathrm{s}$. North-East windy direction

\begin{tabular}{|c|c|c|c|c|c|c|c|c|c|c|c|c|c|c|c|c|c|}
\hline \multirow{3}{*}{ Station } & \multirow{3}{*}{$\begin{array}{l}\text { Sensitive } \\
\text { Receptors }\end{array}$} & \multirow{3}{*}{ Date } & \multicolumn{15}{|c|}{ PARAMETERS, $\mu \mathrm{g} / \mathrm{m}^{3}$} \\
\hline & & & \multicolumn{3}{|c|}{$\mathrm{SO}_{2}$} & \multicolumn{3}{|c|}{$\mathrm{CO}$} & \multicolumn{3}{|c|}{$\mathrm{NO}_{\mathrm{x}}$} & \multicolumn{3}{|c|}{ TSP } & \multicolumn{3}{|c|}{$\mathrm{HC}$} \\
\hline & & & Jan & Feb & Mar & Jan & Feb & Mar & Jan & Feb & Mar & Jan & Feb & Mar & Jan & Feb & Mar \\
\hline Km117+050 & A1 & $\begin{array}{l}15 / 01 / 2014 \\
25 / 02 / 2014 \\
17 / 03 / 2014 \\
\end{array}$ & 163 & 152 & 172 & 1780 & 1510 & 1690 & 156 & 141 & 163 & 168 & 142 & 156 & - & - & - \\
\hline Km117+050 & A1 & $\begin{array}{l}15 / 01 / 2014 \\
25 / 02 / 2014 \\
17 / 03 / 2014\end{array}$ & 159 & 141 & 159 & 1920 & 1740 & 1850 & 169 & 148 & 158 & 194 & 167 & 179 & - & - & - \\
\hline Km117+050 & A1 & $\begin{array}{l}15 / 01 / 2014 \\
25 / 02 / 2014 \\
17 / 03 / 2014\end{array}$ & 167 & 149 & 142 & 1750 & 1560 & 1710 & 172 & 150 & 166 & 237 & 196 & 192 & - & - & - \\
\hline $\mathrm{Km} 118+820$ & $\mathrm{~A} 2$ & $15 / 01 / 2014$ & 292 & 274 & 304 & 3950 & 3710 & 3890 & 183 & 152 & 238 & 254 & 221 & 122 & - & - & - \\
\hline
\end{tabular}


Loan 2391/2392 - VIE: GMS Kunming - Hai Phong Transport Corridor Noi Bai - Lao Cai Highway Project

\begin{tabular}{|c|c|c|c|c|c|c|c|c|c|c|c|c|c|c|c|c|c|}
\hline \multirow{3}{*}{ Station } & \multirow{3}{*}{$\begin{array}{l}\text { Sensitive } \\
\text { Receptors }\end{array}$} & \multirow{3}{*}{ Date } & \multicolumn{15}{|c|}{ PARAMETERS, $\mu \mathrm{g} / \mathrm{m}^{3}$} \\
\hline & & & \multicolumn{3}{|c|}{$\mathrm{SO}_{2}$} & \multicolumn{3}{|c|}{$\mathrm{CO}$} & \multicolumn{3}{|c|}{$\mathrm{NO}_{\mathrm{x}}$} & \multicolumn{3}{|c|}{ TSP } & \multicolumn{3}{|c|}{$\mathrm{HC}$} \\
\hline & & & Jan & Feb & Mar & Jan & Feb & Mar & Jan & Feb & Mar & Jan & Feb & Mar & Jan & Feb & Mar \\
\hline & & $\begin{array}{l}25 / 02 / 2014 \\
17 / 03 / 2014\end{array}$ & & & & & & & & & & & & & & & \\
\hline Km118+820 & A2 & $\begin{array}{l}15 / 01 / 2014 \\
25 / 02 / 2014 \\
17 / 03 / 2014\end{array}$ & 279 & 261 & 282 & 3440 & 3570 & 3320 & 179 & 165 & 244 & 269 & 234 & 139 & - & - & - \\
\hline Km118+820 & A2 & $\begin{array}{l}15 / 01 / 2014 \\
25 / 02 / 2014 \\
17 / 03 / 2014\end{array}$ & 268 & 253 & 275 & 3580 & 3410 & 3670 & 170 & 143 & 251 & 281 & 256 & 161 & - & - & - \\
\hline Km121+433 & A3 & $\begin{array}{l}15 / 01 / 2014 \\
25 / 02 / 2014 \\
17 / 03 / 2014\end{array}$ & 315 & 288 & 291 & 4350 & 4310 & 4820 & 188 & 154 & 252 & 261 & 240 & 114 & - & - & - \\
\hline Km121+433 & A3 & $\begin{array}{l}15 / 01 / 2014 \\
25 / 02 / 2014 \\
17 / 03 / 2014\end{array}$ & 345 & 302 & 297 & 4420 & 4080 & 4340 & 176 & 165 & 248 & 248 & 232 & 127 & - & - & - \\
\hline \multirow[t]{2}{*}{$\mathrm{Km} 121+433$} & A3 & $\begin{array}{l}15 / 01 / 2014 \\
25 / 02 / 2014 \\
17 / 03 / 2014\end{array}$ & 308 & 276 & 281 & 4780 & 4140 & 4510 & 187 & 169 & 242 & 269 & 239 & 124 & - & - & - \\
\hline & & $\begin{array}{l}\text { QCVN } \\
05: 2009 / B T N M T\end{array}$ & \multicolumn{3}{|c|}{350 (1-hr) } & \multicolumn{3}{|c|}{30,000 (1-hr) } & \multicolumn{3}{|c|}{200 (1-hr) } & \multicolumn{3}{|c|}{300 (1-hr) } & \multicolumn{3}{|c|}{5000 (1-hr) } \\
\hline
\end{tabular}

\section{Notes:}

A1, A2, A3: Sampling points are close to Bao Long Church area (Km117+050): (GPS: N 21.40.269; E 104.53.057)

A4, A5, A6: Sampling points are close to Hop Minh My bridge construction site (Km118+820): (GPS: N 21.40.801; E 104.52.259) 


\section{Loan 2391/2392 - VIE: GMS Kunming - Hai Phong Transport Corridor \\ Noi Bai - Lao Cai Highway Project}

A7, A8, A9: Sampling points are close to National Road bridge construction site (Km121+433): (GPS: N 21.41.609; E 104.51.171)

\section{PACKAGE A6}

According to Environmental Monitoring Plan approved by the Engineer through the letter Ref. Ref. GET3-DOOSAN-11-A6-139 dated $16^{\text {th }}$ April, 2011, the contractor carries out the Environment monitoring with frequency: 1 time / 3 month. Include some indications: SO${ }_{2}, \mathrm{CO} \mathrm{NO}_{\mathrm{x}}, \mathrm{TSP}_{\text {, }}$ $\mathrm{PM}_{10}$

Weather condition: cloudy, breeze

\begin{tabular}{|c|c|c|c|c|c|c|c|c|c|c|c|c|c|c|c|c|c|}
\hline \multirow{3}{*}{ Station } & \multirow{3}{*}{$\begin{array}{l}\text { Sensitive } \\
\text { Receptors }\end{array}$} & \multirow{3}{*}{ Date } & \multicolumn{15}{|c|}{ PARAMETERS, $\mu \mathrm{g} / \mathrm{m}^{3}$} \\
\hline & & & \multicolumn{3}{|c|}{$\mathrm{SO}_{2}$} & \multicolumn{3}{|c|}{$\mathrm{CO}$} & \multicolumn{3}{|c|}{$\mathrm{NO}_{\mathrm{x}}$} & \multicolumn{3}{|c|}{ TSP } & \multicolumn{3}{|c|}{ HC } \\
\hline & & & Jan & Feb & Mar & Jan & Feb & Mar & Jan & Feb & Mar & Jan & Feb & Mar & Jan & Feb & Mar \\
\hline Km155+360 & A6/K1 & $11 / 03 / 2014$ & - & - & 175 & - & - & 2150 & - & - & 61 & - & - & 250 & - & - & - \\
\hline $\mathrm{Km} 155+360$ & $\mathrm{~A} 6 / \mathrm{K} 2$ & $11 / 03 / 2014$ & - & - & 172 & - & - & 1810 & - & - & 66 & - & - & 230 & - & - & - \\
\hline Km155+360 & A6/K3 & $11 / 03 / 2014$ & - & - & 165 & - & - & 1840 & - & - & 63 & - & - & 220 & - & - & - \\
\hline $\mathrm{Km} 159+400$ & $\mathrm{~A} 6 / \mathrm{K} 4$ & $11 / 03 / 2014$ & - & - & 186 & - & - & 2250 & - & - & 74 & - & - & 260 & - & - & - \\
\hline Km159+400 & A6/K5 & $11 / 03 / 2014$ & - & - & 172 & - & - & 2110 & - & - & 65 & - & - & 270 & - & - & - \\
\hline $\mathrm{Km} 159+400$ & A6/K6 & $11 / 03 / 2014$ & - & - & 151 & - & - & 2010 & - & - & 54 & - & - & 220 & - & - & - \\
\hline $\mathrm{Km} 162+800$ & $\mathrm{~A} 6 / \mathrm{K} 7$ & 11/03/2014 & - & - & 181 & - & - & 2670 & - & - & 83 & - & - & 270 & - & - & - \\
\hline $\mathrm{Km} 162+800$ & A6/K8 & $11 / 03 / 2014$ & - & - & 186 & - & - & 2420 & - & - & 86 & - & - & 280 & - & - & - \\
\hline $\mathrm{Km} 162+800$ & A6/K9 & $11 / 03 / 2014$ & - & - & 154 & - & - & 1890 & - & - & 54 & - & - & 240 & - & - & - \\
\hline $\mathrm{Km} 165+300$ & $\mathrm{~A} 6 / \mathrm{K} 10$ & $11 / 03 / 2014$ & - & - & 195 & - & - & 2560 & - & - & 87 & - & - & 240 & & & - \\
\hline Km165+300 & A6/K11 & $11 / 03 / 2014$ & - & - & 183 & - & - & 2440 & - & - & 71 & - & - & 260 & - & - & - \\
\hline $\mathrm{Km} 165+300$ & A6/K12 & $11 / 03 / 2014$ & - & - & 165 & - & - & 2010 & - & - & 68 & - & - & 220 & - & - & - \\
\hline
\end{tabular}




\section{getinso}

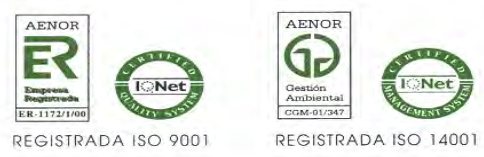

Loan 2391/2392 - VIE: GMS Kunming - Hai Phong Transport Corridor Noi Bai - Lao Cai Highway Project

\begin{tabular}{|c|c|c|c|c|c|c|c|c|c|c|c|c|c|c|c|c|c|}
\hline \multirow{3}{*}{ Station } & \multirow{3}{*}{$\begin{array}{c}\text { Sensitive } \\
\text { Receptors }\end{array}$} & \multirow{3}{*}{ Date } & \multicolumn{15}{|c|}{ PARAMETERS, $\mu \mathrm{g} / \mathrm{m}^{3}$} \\
\hline & & & \multicolumn{3}{|c|}{$\mathrm{SO}_{2}$} & \multicolumn{3}{|c|}{$\mathrm{CO}$} & \multicolumn{3}{|c|}{$\mathrm{NO}_{\mathrm{x}}$} & \multicolumn{3}{|c|}{ TSP } & \multicolumn{3}{|c|}{$\mathrm{HC}$} \\
\hline & & & Jan & Feb & Mar & Jan & Feb & Mar & Jan & Feb & Mar & Jan & Feb & Mar & Jan & Feb & Mar \\
\hline & & $\begin{array}{l}\text { QCVN } \\
\text { 05:2009/BTNMT }\end{array}$ & \multicolumn{3}{|c|}{350 (1-hr) } & \multicolumn{3}{|c|}{30,000 (1-hr) } & \multicolumn{3}{|c|}{200 (1-hr) } & \multicolumn{3}{|c|}{300 (1-hr) } & \multicolumn{3}{|c|}{5000 (1-hr) } \\
\hline
\end{tabular}

\section{Notes:}

A6/K1, A6/K2, A6/K3: Sampling points are close to Tan Hop Church area (Km155+360) - X (m): $2.423 .253-Y(m): 461.635$ A6/K4, A6/K5, A6/K6: Sampling points are close to Tan Hop Primary School area (Km159+400) - X (m): 2.425.610 - Y (m): 458.440 A6/K7, A6/K8, A6/K9: Sampling points are close to Vinasan's concrete station (Km162+800) - X (m): 2.428.188 - Y (m): 456.100 A6/K10, A6/K11, A6/K12: Sampling points are close to White stone vina's concrete station (Km165+300) - X (m): 2.430.266 - Y (m): 455.303

\section{PACKAGE A7}

Contractor stopped monitoring activities in November 2013 adducing that the contract was finished, although the technical opening ceremony was not celebrated until $1^{\text {st }}$ April 2014.

\section{PACKAGE A8}

Contractor stopped monitoring activities in December 2013 adducing that the contract was finished, although the technical opening ceremony was not celebrated until $2^{\text {nd }}$ March 2014, and only the last 11 kilometers of the package. 
Loan 2391/2392 - VIE: GMS Kunming - Hai Phong Transport Corridor Noi Bai - Lao Cai Highway Project

\subsection{ANNEX 2.2: WATER QUALITY PARAMETERS}


getinsa

6D)

Loan 2391/2392 - VIE: GMS Kunming - Hai Phong Transport Corridor Noi Bai - Lao Cai Highway Project

236 


\section{Noi Bai - Lao Cai Highway Project}

Loan 2391/2392 - VIE: GMS Kunming - Hai Phong Transport Corridor

\section{PACKAGE A1}

Technical traffic opening ceremony was organized in December, 2013. The Contractor stopped monitoring the water quality parameters.

\section{PACKAGE A2}

\section{January}

\begin{tabular}{|c|c|c|c|c|c|c|c|}
\hline \multicolumn{2}{|c|}{ Location } & \multirow{2}{*}{$\frac{\text { pH }}{}$} & \multirow{2}{*}{$\begin{array}{c}\begin{array}{c}\text { TSS } \\
(\mathrm{mg} / \mathrm{l})\end{array} \\
45\end{array}$} & \multirow{2}{*}{$\begin{array}{c}\begin{array}{c}\text { Total Fecal } \\
\text { Coliform } \\
\text { (MPN/100ml) }\end{array} \\
33\end{array}$} & \multirow{2}{*}{$\begin{array}{c}\begin{array}{c}\text { Total } \\
\text { Coliform } \\
\text { (MPN/100ml) }\end{array} \\
3,300\end{array}$} & \multirow{2}{*}{$\begin{array}{c}\begin{array}{c}\text { Petrolium } \\
(\mathrm{mg} / \mathrm{l})\end{array} \\
0.066\end{array}$} & \multirow{2}{*}{$\begin{array}{c}\begin{array}{c}\mathrm{DO} \\
(\mathrm{mg} / \mathrm{l})\end{array} \\
6.11\end{array}$} \\
\hline Lo River - & Upstream & & & & & & \\
\hline Central point & Downstream & 7.71 & 43 & 34 & 3,100 & 0.064 & 6.14 \\
\hline \multirow{2}{*}{$\begin{array}{l}\text { Lo River - } \\
\text { Right side }\end{array}$} & Upstream & 7.66 & 42 & 31 & 3,000 & 0.056 & 6.13 \\
\hline & Downstream & 7.45 & 46 & 34 & 3,200 & 0.058 & 6.09 \\
\hline \multirow{2}{*}{$\begin{array}{l}\text { Lo River - } \\
\text { Left side }\end{array}$} & Upstream & 6.97 & 44 & 32 & 3,400 & 0.057 & 6.12 \\
\hline & Downstream & 7.46 & 47 & 35 & 3,500 & 0.054 & 6.15 \\
\hline \multirow{2}{*}{$\begin{array}{l}\text { Tan Dung } \\
\text { Bridge }\end{array}$} & Upstream & 6.32 & 45 & 33 & 2,800 & 0.056 & 5.59 \\
\hline & Downstream & 7.45 & 46 & 30 & 3,300 & 0.059 & 5.57 \\
\hline \multirow{2}{*}{$\begin{array}{l}\text { Muong Dao } \\
\text { Bridge }\end{array}$} & Upstream & 6.78 & 44 & 28 & 2,900 & 0.055 & 5.96 \\
\hline & Downstream & 7.96 & 46 & 26 & 3,200 & 0.058 & 5.83 \\
\hline \multirow{2}{*}{$\begin{array}{l}\text { Ben Gao } \\
\text { Bridge }\end{array}$} & Upstream & 7.34 & 47 & 29 & 3,400 & 0.053 & 6.14 \\
\hline & Downstream & 6.99 & 45 & 27 & 3,500 & 0.056 & 5.98 \\
\hline \multirow{2}{*}{$\begin{array}{l}\text { Song Dao } \\
\text { Bridge }\end{array}$} & Upstream & 6.83 & 48 & 26 & 2,800 & 0.059 & 6.17 \\
\hline & Downstream & 7.26 & 46 & 29 & 2,700 & 0.053 & 6.13 \\
\hline \multicolumn{2}{|c|}{$\begin{array}{c}\text { QCVN 08:2008/BTNMT } \\
\text { Column B1 }\end{array}$} & $5.5 \sim 9$ & 50 & 100 & 7,500 & 0.10 & $\geq 4$ \\
\hline
\end{tabular}

\section{February}

\begin{tabular}{|l|l|c|c|c|c|c|c||}
\hline \multicolumn{2}{|c|}{ Location } & pH & $\begin{array}{c}\text { TSS } \\
(\mathrm{mg} / \mathrm{l})\end{array}$ & $\begin{array}{c}\text { Total Fecal } \\
\text { Coliform } \\
(\text { MPN/100ml) }\end{array}$ & $\begin{array}{c}\text { Total } \\
\text { Coliform } \\
(\text { MPN/100ml) }\end{array}$ & $\begin{array}{c}\text { Petrolium } \\
(\mathrm{mg} / \mathrm{l})\end{array}$ & $\begin{array}{c}\text { DO } \\
(\mathrm{mg} / \mathrm{l})\end{array}$ \\
\hline \hline \multirow{2}{*}{$\begin{array}{l}\text { Lo River - } \\
\text { Central point }\end{array}$} & Upstream & 6.91 & 42 & 32 & 3,100 & 0.063 & 6.13 \\
\cline { 2 - 8 } & Downstream & 7.76 & 45 & 33 & 3,200 & 0.068 & 6.15 \\
\hline \multirow{2}{*}{$\begin{array}{l}\text { Lo River - } \\
\text { Right side }\end{array}$} & Upstream & 7.62 & 44 & 35 & 3,300 & 0.055 & 6.16 \\
\cline { 2 - 8 } & Downstream & 7.48 & 43 & 36 & 3,400 & 0.057 & 6.07 \\
\hline
\end{tabular}


Loan 2391/2392 - VIE: GMS Kunming - Hai Phong Transport Corridor Noi Bai - Lao Cai Highway Project

\begin{tabular}{|c|c|c|c|c|c|c|c|}
\hline \multicolumn{2}{|c|}{ Location } & \multirow{2}{*}{$\begin{array}{c}\text { pH } \\
6.95\end{array}$} & \multirow{2}{*}{$\begin{array}{c}\begin{array}{c}\text { TSS } \\
(\mathrm{mg} / \mathrm{l})\end{array} \\
46\end{array}$} & \multirow{2}{*}{$\begin{array}{c}\begin{array}{c}\text { Total Fecal } \\
\text { Coliform } \\
\text { (MPN/100ml) }\end{array} \\
34\end{array}$} & \multirow{2}{*}{$\begin{array}{c}\begin{array}{c}\text { Total } \\
\text { Coliform } \\
\text { (MPN/100ml) }\end{array} \\
3,100\end{array}$} & \multirow{2}{*}{$\begin{array}{c}\begin{array}{c}\text { Petrolium } \\
(\mathrm{mg} / \mathrm{l})\end{array} \\
0.053\end{array}$} & \multirow{2}{*}{$\begin{array}{c}\begin{array}{c}\text { DO } \\
(\mathrm{mg} / \mathrm{l})\end{array} \\
6.13\end{array}$} \\
\hline Lo & Upstream & & & & & & \\
\hline Left side & Downstream & 7.43 & 43 & 36 & 3,600 & 0.051 & 6.12 \\
\hline \multirow{2}{*}{$\begin{array}{l}\text { Tan Dung } \\
\text { Bridge }\end{array}$} & Upstream & 6.36 & 44 & 32 & 2,900 & 0.059 & 5.56 \\
\hline & Downstream & 7.49 & 43 & 31 & 3,000 & 0.054 & 5.59 \\
\hline \multirow{2}{*}{$\begin{array}{l}\text { Muong Dao } \\
\text { Bridge }\end{array}$} & Upstream & 6.71 & 44 & 29 & 2,800 & 0.056 & 5.92 \\
\hline & Downstream & 7.94 & 45 & 27 & 3,100 & 0.057 & 5.85 \\
\hline \multirow{2}{*}{$\begin{array}{l}\text { Ben Gao } \\
\text { Bridge }\end{array}$} & Upstream & 7.38 & 48 & 28 & 3,300 & 0.054 & 6.12 \\
\hline & Downstream & 6.92 & 42 & 25 & 3,400 & 0.059 & 5.94 \\
\hline \multirow{2}{*}{$\begin{array}{l}\text { Song Dao } \\
\text { Bridge }\end{array}$} & Upstream & 6.88 & 45 & 24 & 2,900 & 0.057 & 6.15 \\
\hline & Downstream & 7.29 & 46 & 26 & 2,800 & 0.055 & 6.18 \\
\hline \multicolumn{2}{|c|}{$\begin{array}{c}\text { QCVN 08:2008/BTNMT } \\
\text { Column B1 }\end{array}$} & $5.5 \sim 9$ & 50 & 100 & 7,500 & 0.10 & $\geq 4$ \\
\hline
\end{tabular}

\section{March}

\begin{tabular}{|c|c|c|c|c|c|c|c|}
\hline \multicolumn{2}{|c|}{ Location } & \multirow[t]{2}{*}{$\mathrm{pH}$} & \multirow[t]{2}{*}{$\begin{array}{l}\text { TSS } \\
(\mathrm{mg} / \mathrm{l})\end{array}$} & \multirow{2}{*}{$\begin{array}{l}\text { Total Fecal } \\
\text { Coliform } \\
\text { (MPN/100ml) }\end{array}$} & \multirow{2}{*}{$\begin{array}{c}\text { Total } \\
\text { Coliform } \\
\text { (MPN/100ml) }\end{array}$} & \multirow{2}{*}{$\begin{array}{l}\text { Petrolium } \\
\text { (mg/l) }\end{array}$} & \multirow{2}{*}{$\begin{array}{c}\text { DO } \\
(\mathrm{mg} / \mathrm{l})\end{array}$} \\
\hline \multirow{2}{*}{$\begin{array}{l}\text { Lo River - } \\
\text { Central point }\end{array}$} & Upstream & & & & & & \\
\hline & Downstream & & & & & & \\
\hline \multirow{2}{*}{$\begin{array}{l}\text { Lo River - } \\
\text { Right side }\end{array}$} & Upstream & 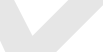 & & & & & \\
\hline & Downstream & & & & & & \\
\hline \multirow{2}{*}{$\begin{array}{l}\text { Lo River - } \\
\text { Left side }\end{array}$} & Upstream & $V$ & & & & & \\
\hline & Downstream & & & & & & \\
\hline \multirow{2}{*}{$\begin{array}{l}\text { Tan Dung } \\
\text { Bridge }\end{array}$} & Upstream & & & & & & \\
\hline & Downstream & & & & & & \\
\hline \multirow{2}{*}{$\begin{array}{l}\text { Muong Dao } \\
\text { Bridge }\end{array}$} & Upstream & & & & & & \\
\hline & Downstream & & & & & & \\
\hline \multirow{2}{*}{$\begin{array}{l}\text { Ben Gao } \\
\text { Bridge }\end{array}$} & Upstream & & & & & & \\
\hline & Downstream & & & & & & \\
\hline \multirow{2}{*}{$\begin{array}{l}\text { Song Dao } \\
\text { Bridge }\end{array}$} & Upstream & & & & & & \\
\hline & Downstream & & & & & & \\
\hline \multicolumn{2}{|c|}{$\begin{array}{l}\text { QCVN 08:2008/BTNMT } \\
\text { Column B1 }\end{array}$} & $5.5 \sim 9$ & 50 & 100 & 7,500 & 0.10 & $\geq 4$ \\
\hline
\end{tabular}


Loan 2391/2392 - VIE: GMS Kunming - Hai Phong Transport Corridor Noi Bai - Lao Cai Highway Project

\section{PACKAGE A3}

January

\begin{tabular}{|c|c|c|c|c|c|}
\hline Order & $\begin{array}{l}\text { Monitoring } \\
\text { Items }\end{array}$ & $\begin{array}{l}\text { Max. value } \\
(\mathrm{mg} / \mathrm{l})\end{array}$ & $\begin{array}{l}\text { Min. value } \\
(\mathrm{mg} / \mathrm{l})\end{array}$ & $\begin{array}{c}\text { Average } \\
\text { Value }(\mathrm{mg} / \mathrm{l})\end{array}$ & $\begin{array}{c}\text { QCVN 08:2008/BTNMT } \\
\text { Column B1 } \\
\end{array}$ \\
\hline \multirow{9}{*}{$\mathrm{Km} \mathrm{67+000}$} & $\mathrm{pH}$ & 6,14 & 6,07 & 6,11 & $5,5-9$ \\
\hline & TSS & 33 & 29 & 31 & 50 \\
\hline & Fecal Coliform & 35 & 31 & 33 & 100 \\
\hline & Total Coliform & 6.700 & 6.600 & 6.650 & 7.500 \\
\hline & Petroleum & $\mathrm{KPH}$ & $\mathrm{KPH}$ & $\mathrm{KPH}$ & 0,1 \\
\hline & BOD & 14 & 14 & 14 & 15 \\
\hline & COD & 22,8 & 21,2 & 22 & 30 \\
\hline & \begin{tabular}{|l|} 
Total Nitrogen \\
\end{tabular} & 1,67 & 1,63 & 1,65 & - \\
\hline & Total Phosphor & 0,76 & 0,74 & 0,75 & - \\
\hline \multirow{9}{*}{$\mathrm{Km} 78+000$} & $\mathrm{pH}$ & 6,19 & 6,15 & 6,17 & $5,5-9$ \\
\hline & TSS & 31 & 27 & 29 & 50 \\
\hline & Fecal Coliform & 39 & 37 & 38 & 100 \\
\hline & Total Coliform & 6.600 & 6.500 & 6.550 & 7.500 \\
\hline & Petroleum & $\mathrm{KPH}$ & $\mathrm{KPH}$ & $\mathrm{KPH}$ & 0,1 \\
\hline & BOD & 14 & 12 & 13 & 15 \\
\hline & COD & 22,2 & 19,8 & 21 & 30 \\
\hline & Total Nitrogen & 1,43 & 1,39 & 1,41 & - \\
\hline & Total Phosphor & 1,63 & 1,61 & 1,62 & - \\
\hline
\end{tabular}

\section{February}

\begin{tabular}{|c|c|c|c|c|c|}
\hline Order & $\begin{array}{l}\text { Monitoring } \\
\text { Items }\end{array}$ & $\begin{array}{l}\text { Max. value } \\
(\mathrm{mg} / \mathrm{l})\end{array}$ & $\begin{array}{l}\text { Min. value } \\
(\mathrm{mg} / \mathrm{l})\end{array}$ & $\begin{array}{c}\text { Average } \\
\text { Value }(\mathrm{mg} / \mathrm{l})\end{array}$ & $\begin{array}{c}\text { QCVN 08:2008/BTNMT } \\
\text { Column B1 }\end{array}$ \\
\hline \multirow{9}{*}{$\mathrm{Km} \mathrm{67+000}$} & $\mathrm{pH}$ & 6,23 & 6,19 & 6,21 & $5,5-9$ \\
\hline & TSS & 35 & 31 & 33 & 50 \\
\hline & Fecal Coliform & 37 & 33 & 35 & 100 \\
\hline & Total Coliform & 6.700 & 6.600 & 6.650 & 7.500 \\
\hline & Petroleum & $\mathrm{KPH}$ & $\mathrm{KPH}$ & $\mathrm{KPH}$ & 0,1 \\
\hline & BOD & 14 & 14 & 14 & 15 \\
\hline & COD & 26,2 & 24,8 & 25 & 30 \\
\hline & Total Nitrogen & 1,75 & 1,71 & 1,73 & - \\
\hline & Total Phosphor & 0,83 & 0,79 & 0,81 & - \\
\hline \multirow{2}{*}{$\mathrm{Km} 78+000$} & $\mathrm{pH}$ & 6,28 & 6,22 & 6,25 & $5,5-9$ \\
\hline & TSS & 33 & 29 & 31 & 50 \\
\hline
\end{tabular}


Loan 2391/2392 - VIE: GMS Kunming - Hai Phong Transport Corridor Noi Bai - Lao Cai Highway Project

\begin{tabular}{|c|l|c|c|c|c||}
\hline \multirow{2}{*}{ Order } & \multicolumn{1}{|c|}{$\begin{array}{c}\text { Monitoring } \\
\text { Items }\end{array}$} & $\begin{array}{c}\text { Max. value } \\
(\mathrm{mg} / \mathrm{l})\end{array}$ & $\begin{array}{c}\text { Min. value } \\
(\mathrm{mg} / \mathrm{l})\end{array}$ & $\begin{array}{c}\text { Average } \\
\text { Value }(\mathrm{mg} / \mathrm{l})\end{array}$ & $\begin{array}{c}\text { QCVN 08:2008/BTNMT } \\
\text { Column B1 }\end{array}$ \\
\hline \hline \multirow{7}{*}{} & Fecal Coliform & 42 & 38 & 40 & 100 \\
\cline { 2 - 6 } & Total Coliform & 6.700 & 6.500 & 6.600 & 7.500 \\
\cline { 2 - 6 } & Petroleum & $\mathrm{KPH}$ & $\mathrm{KPH}$ & $\mathrm{KPH}$ & 0,1 \\
\cline { 2 - 6 } & $\mathrm{BOD}$ & 15 & 13 & 14 & 15 \\
\cline { 2 - 6 } & $\mathrm{COD}$ & 27,5 & 15,5 & 26 & 30 \\
\cline { 2 - 6 } & Total Nitrogen & 1,62 & 1,60 & 1,61 & - \\
\cline { 2 - 6 } & Total Phosphor & 1,77 & 1,73 & 1,75 & - \\
\hline \hline
\end{tabular}

March

\begin{tabular}{|c|c|c|c|c|c|}
\hline Order & $\begin{array}{l}\text { Monitoring } \\
\text { Items }\end{array}$ & $\begin{array}{c}\text { Max. value } \\
(\mathrm{mg} / \mathrm{l})\end{array}$ & $\begin{array}{c}\text { Min. value } \\
(\mathrm{mg} / \mathrm{l})\end{array}$ & $\begin{array}{c}\text { Average } \\
\text { Value }(\mathrm{mg} / \mathrm{l})\end{array}$ & $\begin{array}{c}\text { QCVN 08:2008/BTNMT } \\
\text { Column B1 }\end{array}$ \\
\hline \multirow{9}{*}{$\mathrm{Km} 67+000$} & $\mathrm{pH}$ & & & & $5,5-9$ \\
\hline & TSS & & & s & 50 \\
\hline & Fecal Coliform & & 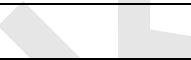 & & 100 \\
\hline & Total Coliform & & & 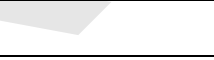 & 7.500 \\
\hline & Petroleum & & & & 0,1 \\
\hline & BOD & & 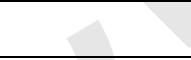 & & 15 \\
\hline & COD & & & & 30 \\
\hline & Total Nitrogen & & & & - \\
\hline & Total Phosphor & & 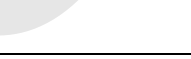 & & - \\
\hline \multirow{9}{*}{$\mathrm{Km} \mathrm{78+000}$} & $\mathrm{pH}$ & 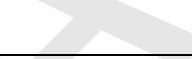 & & & $5,5-9$ \\
\hline & TSS & 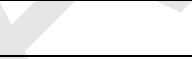 & & & 50 \\
\hline & Fecal Coliform & & & & 100 \\
\hline & Total Coliform & $P$ & & & 7.500 \\
\hline & Petroleum & & & & 0,1 \\
\hline & BOD & & & & 15 \\
\hline & COD & & & & 30 \\
\hline & \begin{tabular}{|l|} 
Total Nitrogen \\
\end{tabular} & & & & - \\
\hline & Total Phosphor & & & & - \\
\hline
\end{tabular}


Loan 2391/2392 - VIE: GMS Kunming - Hai Phong Transport Corridor Noi Bai - Lao Cai Highway Project

\section{PACKAGE A4}

January

\begin{tabular}{|c|c|c|c|c|c|}
\hline Order & $\begin{array}{l}\text { Monitoring } \\
\text { Items }\end{array}$ & $\begin{array}{l}\text { Max. value } \\
\quad(\mathrm{mg} / \mathrm{l})\end{array}$ & $\begin{array}{l}\text { Min. value } \\
(\mathrm{mg} / \mathrm{l})\end{array}$ & $\begin{array}{c}\text { Average } \\
\text { Value }(\mathrm{mg} / \mathrm{l})\end{array}$ & $\begin{array}{c}\text { QCVN 08:2008/BTNMT } \\
\text { Column B1 }\end{array}$ \\
\hline \multirow{9}{*}{$\mathrm{Km} \mathrm{88+700}$} & $\mathrm{pH}$ & 6,64 & 6,60 & 6,62 & $5,5-9$ \\
\hline & TSS & 39 & 37 & 38 & 50 \\
\hline & Fecal Coliform & 11 & 9 & 10 & 100 \\
\hline & Total Coliform & 4.400 & 4.100 & 4.300 & 7.500 \\
\hline & Petroleum & $\mathrm{KPH}$ & $\mathrm{KPH}$ & $\mathrm{KPH}$ & 0,1 \\
\hline & BOD & 9,0 & 8,4 & 8,7 & 15 \\
\hline & COD & 16,6 & 16,0 & 16,3 & 30 \\
\hline & Total Nitrogen & 1,27 & 1,21 & 1,24 & - \\
\hline & Total Phosphor & 0,78 & 0,74 & 0,76 & - \\
\hline \multirow{9}{*}{$\mathrm{Km} \mathrm{97+500}$} & $\mathrm{pH}$ & 6,67 & 6,63 & 6,65 & $5,5-9$ \\
\hline & TSS & 42 & 36 & 39 & 50 \\
\hline & Fecal Coliform & 18 & 12 & 15 & 100 \\
\hline & Total Coliform & 5.500 & 4.700 & 5.100 & 7.500 \\
\hline & Petroleum & $\mathrm{KPH}$ & $\mathrm{KPH}$ & $\mathrm{KPH}$ & 0,1 \\
\hline & BOD & 6,9 & 6,1 & 6,5 & 15 \\
\hline & COD & 13,6 & 12,4 & 13,0 & 30 \\
\hline & Total Nitrogen & 0,80 & 0,72 & 0,76 & - \\
\hline & Total Phosphor & 0,32 & 0,27 & 0,27 & - \\
\hline \multirow{9}{*}{$\begin{array}{l}\mathrm{Km} 101+000 \text { to } \\
\mathrm{Km} 101+900\end{array}$} & $\mathrm{pH}$ & 6,40 & 6,34 & 6,37 & $5,5-9$ \\
\hline & TSS & 42 & 38 & 40 & 50 \\
\hline & Fecal Coliform & 14 & 10 & 12 & 100 \\
\hline & Total Coliform & 4.300 & 4.100 & 4.200 & 7.500 \\
\hline & Petroleum & $\mathrm{KPH}$ & $\mathrm{KPH}$ & $\mathrm{KPH}$ & 0,1 \\
\hline & BOD & 6,90 & 6,70 & 6,80 & 15 \\
\hline & COD & 14,8 & 14,0 & 14,4 & 30 \\
\hline & Total Nitrogen & 0,77 & 0,71 & 0,74 & - \\
\hline & Total Phosphor & 0,42 & 0,36 & 0,39 & - \\
\hline \multirow{7}{*}{$\mathrm{Km} \mathrm{109+000}$} & $\mathrm{pH}$ & 6,89 & 6,83 & 6,86 & $5,5-9$ \\
\hline & TSS & 41 & 37 & 39 & 50 \\
\hline & Fecal Coliform & 12 & 10 & 11 & 100 \\
\hline & Total Coliform & 4.600 & 4.000 & 4.300 & 7.500 \\
\hline & Petroleum & $\mathrm{KPH}$ & $\mathrm{KPH}$ & $\mathrm{KPH}$ & 0,1 \\
\hline & BOD & 9,1 & 8,3 & 8,7 & 15 \\
\hline & COD & 15,6 & 15,0 & 15,3 & 30 \\
\hline
\end{tabular}


Loan 2391/2392 - VIE: GMS Kunming - Hai Phong Transport Corridor Noi Bai - Lao Cai Highway Project

\begin{tabular}{|c|c|c|c|c|c|}
\hline Order & $\begin{array}{l}\text { Monitoring } \\
\text { Items }\end{array}$ & $\begin{array}{l}\text { Max. value } \\
\quad(\mathrm{mg} / \mathrm{l})\end{array}$ & $\begin{array}{l}\text { Min. value } \\
\quad(\mathrm{mg} / \mathrm{l})\end{array}$ & $\begin{array}{c}\text { Average } \\
\text { Value }(\mathrm{mg} / \mathrm{l})\end{array}$ & $\begin{array}{c}\text { QCVN 08:2008/BTNMT } \\
\text { Column B1 }\end{array}$ \\
\hline & Total Nitrogen & 1,68 & 1,60 & 1,64 & - \\
\hline & Total Phosphor & 0,55 & 0,51 & 0,52 & - \\
\hline \multirow{9}{*}{$\mathrm{Km} \mathrm{108+227}$} & $\mathrm{pH}$ & 6,40 & 6,34 & 6,37 & $5,5-9$ \\
\hline & TSS & 41 & 39 & 40 & 50 \\
\hline & Fecal Coliform & 12 & 8 & 10 & 100 \\
\hline & Total Coliform & 4.800 & 3.900 & 4.300 & 7.500 \\
\hline & Petroleum & $\mathrm{KPH}$ & $\mathrm{KPH}$ & $\mathrm{KPH}$ & 0,1 \\
\hline & BOD & 8,4 & 7,8 & 8,1 & 15 \\
\hline & COD & 15,6 & 14,4 & 15,0 & 30 \\
\hline & Total Nitrogen & 0,98 & 0,94 & 0,96 & - \\
\hline & Total Phosphor & 0,48 & 0,46 & 0,47 & - \\
\hline
\end{tabular}

\section{February}

\begin{tabular}{|c|c|c|c|c|c|}
\hline Order & $\begin{array}{l}\text { Monitoring } \\
\text { Items }\end{array}$ & $\begin{array}{l}\text { Max. value } \\
\quad(\mathrm{mg} / \mathrm{l})\end{array}$ & $\begin{array}{l}\text { Min. value } \\
(\mathrm{mg} / \mathrm{l})\end{array}$ & $\begin{array}{c}\text { Average } \\
\text { Value }(\mathrm{mg} / \mathrm{l})\end{array}$ & $\begin{array}{c}\text { QCVN 08:2008/BTNMT } \\
\text { Column B1 }\end{array}$ \\
\hline \multirow{9}{*}{$\mathrm{Km} \mathrm{88+700}$} & $\mathrm{pH}$ & 6,48 & 6,46 & 6,47 & $5,5-9$ \\
\hline & TSS & 42 & 40 & 41 & 50 \\
\hline & Fecal Coliform & 14 & 12 & 13 & 100 \\
\hline & Total Coliform & 4.450 & 4.450 & 4.450 & 7.500 \\
\hline & Petroleum & $\mathrm{KPH}$ & $\mathrm{KPH}$ & $\mathrm{KPH}$ & 0,1 \\
\hline & BOD & 9,4 & 9,0 & 9,2 & 15 \\
\hline & COD & 17,8 & 17,4 & 17,6 & 30 \\
\hline & Total Nitrogen & 1,42 & 1,28 & 1,35 & - \\
\hline & Total Phosphor & 0,83 & 0,79 & 0,81 & - \\
\hline \multirow{9}{*}{$\mathrm{Km} \mathrm{97+500}$} & $\mathrm{pH}$ & 6,45 & 6,39 & 6,42 & $5,5-9$ \\
\hline & TSS & 47 & 43 & 45 & 50 \\
\hline & Fecal Coliform & 18 & 16 & 17 & 100 \\
\hline & Total Coliform & 5.300 & 5.100 & 5.200 & 7.500 \\
\hline & Petroleum & $\mathrm{KPH}$ & $\mathrm{KPH}$ & $\mathrm{KPH}$ & 0,1 \\
\hline & BOD & 8,9 & 8,1 & 8,5 & 15 \\
\hline & COD & 17,1 & 16,7 & 16,9 & 30 \\
\hline & Total Nitrogen & 0,99 & 0,95 & 0,97 & - \\
\hline & Total Phosphor & 0,44 & 0,40 & 0,42 & - \\
\hline \multirow{3}{*}{$\begin{array}{l}\mathrm{Km} 101+000 \text { to } \\
\mathrm{Km} \mathrm{101+900}\end{array}$} & $\mathrm{pH}$ & 6,28 & 6,24 & 6,26 & $5,5-9$ \\
\hline & TSS & 45 & 41 & 43 & 50 \\
\hline & Fecal Coliform & 15 & 13 & 14 & 100 \\
\hline
\end{tabular}


Loan 2391/2392 - VIE: GMS Kunming - Hai Phong Transport Corridor Noi Bai - Lao Cai Highway Project

\begin{tabular}{|c|c|c|c|c|c|}
\hline Order & $\begin{array}{l}\text { Monitoring } \\
\text { Items }\end{array}$ & $\begin{array}{l}\text { Max. value } \\
(\mathrm{mg} / \mathrm{l})\end{array}$ & $\begin{array}{l}\text { Min. value } \\
(\mathrm{mg} / \mathrm{l})\end{array}$ & $\begin{array}{c}\text { Average } \\
\text { Value }(\mathrm{mg} / \mathrm{l})\end{array}$ & $\begin{array}{c}\text { QCVN 08:2008/BTNMT } \\
\text { Column B1 }\end{array}$ \\
\hline & Total Coliform & 4.400 & 4.360 & 4.380 & 7.500 \\
\hline & Petroleum & $\overline{\mathrm{KPH}}$ & $\mathrm{KPH}$ & $\mathrm{KPH}$ & 0,1 \\
\hline & BOD & 8,90 & 8,10 & 8,5 & 15 \\
\hline & COD & 15,9 & 15,5 & 15,7 & 30 \\
\hline & Total Nitrogen & 0,86 & 0,78 & 0,82 & - \\
\hline & Total Phosphor & 0,55 & 0,47 & 0,51 & - \\
\hline \multirow{9}{*}{ Km 109+000 } & $\mathrm{pH}$ & 6,64 & 6,58 & 6,61 & $5,5-9$ \\
\hline & TSS & 43 & 41 & 42 & 50 \\
\hline & Fecal Coliform & 15 & 11 & 13 & 100 \\
\hline & Total Coliform & 4.400 & 4.300 & 4.350 & 7.500 \\
\hline & Petroleum & $\mathrm{KPH}$ & $\mathrm{KPH}$ & $\mathrm{KPH}$ & 0,1 \\
\hline & BOD & 9,8 & 9,2 & 9,5 & 15 \\
\hline & COD & 17,1 & 16,7 & 16,9 & 30 \\
\hline & Total Nitrogen & 1,75 & 1,69 & 1,72 & - \\
\hline & Total Phosphor & 0,70 & 0,66 & 0,68 & - \\
\hline \multirow{9}{*}{$\mathrm{Km} \mathrm{108+227}$} & $\mathrm{pH}$ & 6,32 & 6,24 & 6,28 & $5,5-9$ \\
\hline & TSS & 45 & 31 & 43 & 50 \\
\hline & Fecal Coliform & 16 & 14 & 15 & 100 \\
\hline & Total Coliform & 4.340 & 4.300 & 4.320 & 7.500 \\
\hline & Petroleum & $\mathrm{KPH}$ & $\mathrm{KPH}$ & $\mathrm{KPH}$ & 0,1 \\
\hline & BOD & 9,4 & 9,2 & 9,3 & 15 \\
\hline & COD & 17,1 & 16,3 & 16,7 & 30 \\
\hline & Total Nitrogen & 1,10 & 1,02 & 1,06 & - \\
\hline & Total Phosphor & 0,68 & 0,66 & 0,67 & - \\
\hline
\end{tabular}

March

\begin{tabular}{||c|l|c|c|c|c|}
\hline \multirow{2}{*}{ Order } & \multicolumn{1}{|c|}{$\begin{array}{c}\text { Monitoring } \\
\text { Items }\end{array}$} & $\begin{array}{c}\text { Max. value } \\
(\mathrm{mg} / \mathrm{l})\end{array}$ & $\begin{array}{c}\text { Min. value } \\
(\mathrm{mg} / \mathrm{l})\end{array}$ & $\begin{array}{c}\text { Average } \\
\text { Value (mg/l) }\end{array}$ & $\begin{array}{c}\text { QCVN 08:2008/BTNMT } \\
\text { Column B1 }\end{array}$ \\
\hline \hline \multirow{5}{*}{$\mathrm{km} 88+700$} & & & & $5,5-9$ \\
\cline { 2 - 6 } & $\mathrm{pH}$ & & & & 50 \\
\cline { 2 - 6 } & TSS & & & & 100 \\
\cline { 2 - 6 } & Tecal Coliform & & & & 7.500 \\
\cline { 2 - 6 } & Petal Coliform & & & & 0,1 \\
\cline { 2 - 6 } & BOD & & & & 30 \\
\cline { 2 - 6 } & COD & & & & - \\
\cline { 2 - 6 } & Total Nitrogen & & & & 30 \\
\hline
\end{tabular}


Loan 2391/2392 - VIE: GMS Kunming - Hai Phong Transport Corridor Noi Bai - Lao Cai Highway Project

\begin{tabular}{|c|c|c|c|c|c|}
\hline Order & $\begin{array}{l}\text { Monitoring } \\
\text { Items }\end{array}$ & $\begin{array}{l}\text { Max. value } \\
\quad(\mathrm{mg} / \mathrm{l})\end{array}$ & $\begin{array}{l}\text { Min. value } \\
(\mathrm{mg} / \mathrm{l})\end{array}$ & $\begin{array}{c}\text { Average } \\
\text { Value }(\mathrm{mg} / \mathrm{l})\end{array}$ & $\begin{array}{c}\text { QCVN 08:2008/BTNMT } \\
\text { Column B1 }\end{array}$ \\
\hline & Total Phosphor & & & & - \\
\hline \multirow{9}{*}{$\mathrm{Km} 97+500$} & $\mathrm{pH}$ & & & & $5,5-9$ \\
\hline & TSS & & & & 50 \\
\hline & Fecal Coliform & & & & 100 \\
\hline & Total Coliform & & & & 7.500 \\
\hline & Petroleum & & & & 0,1 \\
\hline & BOD & & & & 15 \\
\hline & COD & & & & 30 \\
\hline & Total Nitrogen & & & & - \\
\hline & Total Phosphor & & & 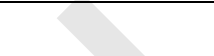 & - \\
\hline \multirow{9}{*}{$\begin{array}{l}\mathrm{Km} 101+000 \text { to } \\
\mathrm{Km} \mathrm{101+900}\end{array}$} & $\mathrm{pH}$ & & & & $5,5-9$ \\
\hline & TSS & & 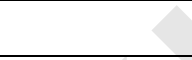 & & 50 \\
\hline & Fecal Coliform & & & & 100 \\
\hline & Total Coliform & & & 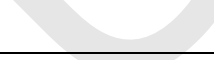 & 7.500 \\
\hline & Petroleum & & & & 0,1 \\
\hline & BOD & & & $z$ & 15 \\
\hline & COD & & 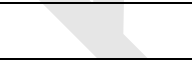 & & 30 \\
\hline & Total Nitrogen & & 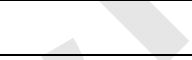 & & - \\
\hline & Total Phosphor & & & & - \\
\hline \multirow{9}{*}{$\mathrm{Km} \mathrm{109+000}$} & $\mathrm{pH}$ & & & & $5,5-9$ \\
\hline & TSS & - & 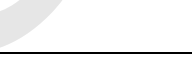 & & 50 \\
\hline & Fecal Coliform & 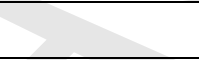 & & & 100 \\
\hline & Total Coliform & 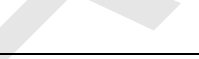 & & & 7.500 \\
\hline & Petroleum & & & & 0,1 \\
\hline & BOD & & & & 15 \\
\hline & COD & & & & 30 \\
\hline & Total Nitrogen & & & & - \\
\hline & Total Phosphor & & & & - \\
\hline \multirow{9}{*}{$\mathrm{Km} \mathrm{108+227}$} & $\mathrm{pH}$ & & & & $5,5-9$ \\
\hline & TSS & & & & 50 \\
\hline & Fecal Coliform & & & & 100 \\
\hline & Total Coliform & & & & 7.500 \\
\hline & Petroleum & & & & 0,1 \\
\hline & BOD & & & & 15 \\
\hline & COD & & & & 30 \\
\hline & Total Nitrogen & & & & - \\
\hline & Total Phosphor & & & & - \\
\hline
\end{tabular}


Loan 2391/2392 - VIE: GMS Kunming - Hai Phong Transport Corridor Noi Bai - Lao Cai Highway Project

\section{PACKAGE A5}

According to Environmental Monitoring Plan approved by the Engineer through the letter Ref. GET3-KEANGNAM-11-A5-037 dated $28^{\text {th }}$ March, 2011, the contractor carryied out the Environment monitoring with frequency: 1 time / 1 month. Include some indications: pH, DO, TSS, COD, $\mathrm{BOD}_{5}$, Surfactant, Oil and grease, Fecal coliform, total coliform.

\section{January}

\begin{tabular}{|c|c|c|c|c|c|c|c|c|c|c|}
\hline \multirow{2}{*}{$\begin{array}{c}\text { Sensitive } \\
\text { Receptors }\end{array}$} & \multirow[t]{2}{*}{ Date } & $\mathrm{pH}$ & DO & TSS & COD & $\begin{array}{l}\mathrm{BOD}_{5} \\
\left(20^{\circ} \mathrm{C}\right)\end{array}$ & Surf. & $\begin{array}{l}\text { Oil and } \\
\text { Grease }\end{array}$ & $\begin{array}{c}\text { Fecal } \\
\text { Coliform }\end{array}$ & $\begin{array}{c}\text { Total } \\
\text { Coliform }\end{array}$ \\
\hline & & - & $\mathrm{mg} / \mathrm{l}$ & $\mathrm{mg} / \mathrm{l}$ & $\mathrm{mg} / \mathrm{l}$ & $\mathrm{mg} / \mathrm{l}$ & $\mathrm{mg} / \mathrm{l}$ & $\mathrm{mg} / \mathrm{l}$ & MPN/100ml & MPN/100ml \\
\hline W1 & $15 / 01 / 2014$ & 6.7 & 5.5 & 35 & 9 & $<5$ & $<0,1$ & $<0,1$ & 85 & 1520 \\
\hline w2 & $15 / 01 / 2014$ & 6.6 & 6.0 & 33 & 7 & $<5$ & $<0,1$ & $<0,1$ & 75 & 1490 \\
\hline W3 & $15 / 01 / 2014$ & 6.7 & 5.7 & 37 & 8 & $<5$ & $<0,1$ & $<0,1$ & 90 & 930 \\
\hline W4 & $15 / 01 / 2014$ & 6.8 & 6.2 & 41 & 6 & $<5$ & $<0,1$ & $<0,1$ & 80 & 1120 \\
\hline W5 & $15 / 01 / 2014$ & 7.2 & 5.9 & 39 & 9 & $<5$ & $<0,1$ & $<0,1$ & 90 & 1050 \\
\hline W6 & $15 / 01 / 2014$ & 7.1 & 6.1 & 32 & 5 & $<5$ & $<0,1$ & $<0,1$ & 85 & 1010 \\
\hline W7 & $15 / 01 / 2014$ & 7.4 & 6.0 & 34 & 7 & $<5$ & $<0,1$ & $<0,1$ & 60 & 990 \\
\hline W8 & $15 / 01 / 2014$ & 7.4 & 6.3 & 41 & 8 & $<5$ & $<0,1$ & $<0,1$ & 65 & 950 \\
\hline W9 & $15 / 01 / 2014$ & 6.8 & 5.8 & 42 & 22 & 11 & 0.34 & 0.08 & 640 & 5700 \\
\hline W10 & $15 / 01 / 2014$ & 6.8 & 6.2 & 49 & 25 & 15 & 0.38 & 0.09 & 710 & 6100 \\
\hline W11 & $15 / 01 / 2014$ & 6.9 & 5.9 & 47 & 19 & 12 & 0.32 & 0.06 & 770 & 6900 \\
\hline W12 & $15 / 01 / 2014$ & 6.6 & 6.1 & 44 & 24 & 14 & 0.31 & 0.05 & 950 & 7200 \\
\hline $\mathrm{QCV}$ & N08:08 & $5,5-9$ & $\geq 4$ & 50 & 30 & 15 & 0,4 & 0,1 & 100 & 7500 \\
\hline
\end{tabular}

\section{February}

\begin{tabular}{|c|c|c|c|c|c|c|c|c|c|c|}
\hline \multirow{2}{*}{$\begin{array}{l}\text { Sensitive } \\
\text { Receptors }\end{array}$} & \multirow[t]{2}{*}{ Date } & pH & DO & TSS & COD & $\begin{array}{l}\mathrm{BOD}_{5} \\
\left(20^{\circ} \mathrm{C}\right)\end{array}$ & Surf. & $\begin{array}{l}\text { Oil and } \\
\text { Grease }\end{array}$ & $\begin{array}{l}\text { Fecal } \\
\text { Coliform }\end{array}$ & $\begin{array}{c}\text { Total } \\
\text { Coliform }\end{array}$ \\
\hline & & - & $\mathrm{mg} / \mathrm{l}$ & $\mathrm{mg} / \mathrm{l}$ & $\mathrm{mg} / \mathrm{l}$ & $\mathrm{mg} / \mathrm{l}$ & $\mathrm{mg} / \mathrm{l}$ & $\mathrm{mg} / \mathrm{l}$ & MPN/100ml & MPN/100ml \\
\hline W1 & $25 / 02 / 2014$ & 6.8 & 5.8 & 28 & 7 & $<5$ & $<0,1$ & $<0,1$ & 72 & 1130 \\
\hline W2 & $25 / 02 / 2014$ & 6.4 & 6.2 & 29 & 6 & $<5$ & $<0,1$ & $<0,1$ & 68 & 1010 \\
\hline W3 & $25 / 02 / 2014$ & 6.9 & 5.9 & 31 & 7 & $<5$ & $<0,1$ & $<0,1$ & 55 & 620 \\
\hline W4 & $25 / 02 / 2014$ & 6.5 & 6.0 & 35 & 5 & $<5$ & $<0,1$ & $<0,1$ & 60 & 980 \\
\hline
\end{tabular}


Loan 2391/2392 - VIE: GMS Kunming - Hai Phong Transport Corridor Noi Bai - Lao Cai Highway Project

\begin{tabular}{|c|c|c|c|c|c|c|c|c|c|c|}
\hline \multirow{2}{*}{$\begin{array}{l}\text { Sensitive } \\
\text { Receptors }\end{array}$} & \multirow[t]{2}{*}{ Date } & pH & DO & TSS & COD & $\begin{array}{l}\mathrm{BOD}_{5} \\
\left(20^{\circ} \mathrm{C}\right)\end{array}$ & Surf. & $\begin{array}{l}\text { Oil and } \\
\text { Grease }\end{array}$ & $\begin{array}{l}\text { Fecal } \\
\text { Coliform }\end{array}$ & $\begin{array}{c}\text { Total } \\
\text { Coliform }\end{array}$ \\
\hline & & - & $\mathrm{mg} / \mathrm{l}$ & $\mathrm{mg} / \mathrm{l}$ & $\mathrm{mg} / \mathrm{l}$ & $\mathrm{mg} / \mathrm{l}$ & $\mathrm{mg} / \mathrm{l}$ & $\mathrm{mg} / \mathrm{l}$ & \multicolumn{2}{|c|}{ MPN/100mlMPN/100ml } \\
\hline W5 & $25 / 02 / 2014$ & 7.0 & 6.1 & 34 & 8 & $<5$ & $<0,1$ & $<0,1$ & 75 & 820 \\
\hline W6 & $25 / 02 / 2014$ & 6.9 & 6.1 & 36 & 6 & $<5$ & $<0,1$ & $<0,1$ & 70 & 920 \\
\hline W7 & $25 / 02 / 2014$ & 7.3 & 5.8 & 32 & 6 & $<5$ & $<0,1$ & $<0,1$ & 65 & 840 \\
\hline W8 & $25 / 02 / 2014$ & 7.1 & 6.2 & 37 & 7 & $<5$ & $<0,1$ & $<0,1$ & 60 & 860 \\
\hline W9 & $25 / 02 / 2014$ & 6.3 & 5.9 & 39 & 18 & 10 & 0,24 & 0.03 & 520 & 5400 \\
\hline W10 & $25 / 02 / 2014$ & 6.2 & 5.7 & 41 & 22 & 13 & 0.27 & 0.05 & 610 & 5600 \\
\hline W11 & $25 / 02 / 2014$ & 6.7 & 6.0 & 38 & 20 & 12 & 0.29 & 0.03 & 580 & 5900 \\
\hline W12 & $25 / 02 / 2014$ & 6.5 & 5.8 & 40 & 21 & 13 & 0.30 & 0.02 & 630 & 6600 \\
\hline \multicolumn{2}{|c|}{ QCVN08:08 } & $5,5-9$ & $\geq 4$ & 50 & 30 & 15 & 0,4 & 0,1 & 100 & 7500 \\
\hline
\end{tabular}

March

\begin{tabular}{|c|c|c|c|c|c|c|c|c|c|c|}
\hline \multirow[t]{2}{*}{$\begin{array}{c}\text { Sensitive } \\
\text { Receptors }\end{array}$} & \multirow[t]{2}{*}{ Date } & pH & DO & TSS & COD & $\begin{array}{l}\mathrm{BOD}_{5} \\
\left(20^{\circ} \mathrm{C}\right)\end{array}$ & Surf. & $\begin{array}{l}\text { Oil and } \\
\text { Grease }\end{array}$ & $\begin{array}{c}\text { Fecal } \\
\text { Coliform }\end{array}$ & $\begin{array}{c}\text { Total } \\
\text { Coliform }\end{array}$ \\
\hline & & - & $\mathrm{mg} / \mathrm{l}$ & $\mathrm{mg} / \mathrm{l}$ & $\mathrm{mg} / \mathrm{l}$ & $\mathrm{mg} / \mathrm{l}$ & $\mathrm{mg} / \mathrm{l}$ & $\mathrm{mg} / \mathrm{l}$ & \multicolumn{2}{|c|}{ MPN/100mlMPN/100ml } \\
\hline W1 & $17 / 03 / 2014$ & 6.4 & 5.5 & 32 & 6 & $<5$ & $<0,1$ & $<0,1$ & 85 & 1210 \\
\hline W2 & $17 / 03 / 2014$ & 6.5 & 6.1 & 34 & 5 & $<5$ & $<0,1$ & $<0,1$ & 75 & 1040 \\
\hline W3 & $17 / 03 / 2014$ & 6.7 & 5.7 & 36 & 6 & $<5$ & $<0,1$ & $<0,1$ & 65 & 750 \\
\hline W4 & $17 / 03 / 2014$ & 6.6 & 6.3 & 39 & 7 & $<5$ & $<0,1$ & $<0,1$ & 78 & 940 \\
\hline W5 & $17 / 03 / 2014$ & 6.9 & 6.2 & 40 & 7 & $<5$ & $<0,1$ & $<0,1$ & 84 & 870 \\
\hline W6 & $17 / 03 / 2014$ & 7.1 & 5.9 & 38 & 5 & $<5$ & $<0,1$ & $<0,1$ & 82 & 910 \\
\hline W7 & $17 / 03 / 2014$ & 6.8 & 5.7 & 31 & 8 & $<5$ & $<0,1$ & $<0,1$ & 74 & 890 \\
\hline W8 & $17 / 03 / 2014$ & 7.0 & 6.1 & 33 & 6 & $<5$ & $<0,1$ & $<0,1$ & 84 & 830 \\
\hline W9 & $17 / 03 / 2014$ & 6.1 & 6.2 & 40 & 21 & 12 & 0.28 & 0.06 & 550 & 5100 \\
\hline W10 & $17 / 03 / 2014$ & 6.0 & 5.9 & 43 & 19 & 12 & 0.35 & 0.07 & 670 & 5800 \\
\hline W11 & $17 / 03 / 2014$ & 5.8 & 5.7 & 39 & 17 & 11 & 0.32 & 0.04 & 660 & 6300 \\
\hline W12 & $17 / 03 / 2014$ & 5.7 & 5.4 & 44 & 22 & 14 & 0.33 & 0.06 & 740 & 7100 \\
\hline \multicolumn{2}{|c|}{ QCVN08:08 } & $5,5-9$ & $\geq 4$ & 50 & 30 & 15 & 0,4 & 0,1 & 100 & 7500 \\
\hline
\end{tabular}




\section{Notes:}

W1: Ngoi Thia river (Km145+500) - The bridge pier (N21 ${ }^{\circ} 50^{\prime} 961^{\prime \prime}$; E104 $\left.{ }^{\circ} 42^{\prime} 500^{\prime \prime}\right)$

W2: Ngoi Thia river $(\mathrm{Km} 145+500)$ - 50m from the bridge pier (toward upstream) (N21050'960"; E104²42'483')

W3: Ngoi Thia river (Km145+500 - $200 \mathrm{~m}$ from the bridge pier (toward downstream) (N21050'982"; E104²4'521")

W4: Ngoi Thia river (Km145+500 - $400 \mathrm{~m}$ from the bridge pier (toward downstream) (N21050'998"; E104²42'539")

W5: Y Can lake (Km126+000) - Surface water sample at position No. 1 (N21 ${ }^{\circ} 44^{\prime} 038^{\prime \prime} ;$ E104 $\left.{ }^{\circ} 49^{\prime} 496^{\prime \prime}\right)$

W6: Y Can lake $(\mathrm{Km} 126+000)$ - Surface water sample at position No. 2 (N2144'046"; E104 49 '503")

W7: Y Can lake (Km126+000) - Surface water sample at position No. 3 (N21 ${ }^{\circ} 44^{\prime} 067^{\prime \prime}$; $\left.\mathrm{E} 104^{\circ} 45^{\prime} 553^{\prime \prime}\right)$

W8: Y Can lake $(\mathrm{Km} 126+000)$ - Surface water sample at position No. 4 (N21 ${ }^{\circ} 44^{\prime} 079$ '; E104 $\left.45^{\prime} 571^{\prime \prime}\right)$

W9: Nuoc Mat lake (Km122+000) - Surface water sample at position No. 1 (N21 ${ }^{\circ} 44^{\prime} 741^{\prime \prime}$; $\mathrm{E} 104^{0} 50$ '492")

W10: Nuoc Mat lake $(\mathrm{Km} 122+000)$ - Surface water sample at position No. 2 (N21044'711"; E10405'935')

W11: Nuoc Mat lake $(\mathrm{Km} 122+000)$ - Surface water sample at position No. 3 (N21044'726"; E10400'955")

W12: Nuoc Mat lake $(\mathrm{Km} 122+000)$ - Surface water sample at position No. 4 (N21044'725"; E10405'965")

* Nuoc Mat lake (W9, W10, W11 and W12) has a small area and locates in the residential area with dense population density. The area of lake tends to be smaller because of site clearance as well as encroachment by inhabitants. Because domestic wastewater from residential areas discharges into Nuoc Mat lake, water quality of the lake in polluted partly although the measured values are within acceptable limits in QCVN 08:2008 - column B1. 


\section{Loan 2391/2392 - VIE: GMS Kunming - Hai Phong Transport Corridor}

Noi Bai - Lao Cai Highway Project

\section{PACKAGE A6}

According to Environmental Monitoring Plan approved by the Engineer through the letter Ref. Ref. GET3-DOOSAN-11-A6-139 dated 16 ${ }^{\text {th }}$ April, 2011. The contractors carry out the Environment monitoring with frequency: 1 time / 1 month. Include some indications: $\mathrm{pH}$, DO, TSS, COD, $\mathrm{BOD}_{5}$, Surfactant, Oil and grease, Fecal coliform, total coliform.

\section{January}

\begin{tabular}{|c|c|c|c|c|c|c|c|c|c|c|c|}
\hline \multirow{2}{*}{ Station } & \multirow{2}{*}{$\begin{array}{l}\text { Sensitive } \\
\text { Receptors }\end{array}$} & \multirow{2}{*}{ Date } & pH & DO & TSS & COD & $\begin{array}{l}\mathrm{BOD}_{5} \\
\left(20^{\circ} \mathrm{C}\right)\end{array}$ & Surf. & $\begin{array}{l}\text { Oil and } \\
\text { Grease }\end{array}$ & $\begin{array}{l}\text { Fecal } \\
\text { Coliform }\end{array}$ & $\begin{array}{c}\text { Total } \\
\text { Coliform }\end{array}$ \\
\hline & & & - & $\mathrm{mg} / \mathrm{l}$ & $\mathrm{mg} / \mathrm{l}$ & $\mathrm{mg} / \mathrm{l}$ & $\mathrm{mg} / \mathrm{l}$ & $\mathrm{mg} / \mathrm{l}$ & $\mathrm{mg} / \mathrm{l}$ & MPN/100ml & MPN/100ml \\
\hline $\mathrm{Km} 165+100$ & NM1 & $10 / 01 / 2014$ & 6.6 & 6.1 & 37 & 7.2 & 4.1 & 0.005 & 0.03 & 58 & 623 \\
\hline Km165+100 & NM2 & $10 / 01 / 2014$ & 7.1 & 6.4 & 40 & 6.1 & 3.8 & 0.003 & 0.06 & 62 & 531 \\
\hline $\mathrm{Km} 165+100$ & NM3 & $10 / 01 / 2014$ & 7.4 & 5.7 & 41 & 8.5 & 4.5 & 0.004 & 0.04 & 33 & 456 \\
\hline Km165+100 & NM4 & $10 / 01 / 2014$ & 7.2 & 6.3 & 43 & 8.3 & 4.9 & 0.004 & 0.05 & 37 & 504 \\
\hline $\mathrm{Km} 186+200$ & NM7 & $10 / 01 / 2014$ & 7.2 & 6.2 & 36 & 5.5 & 3.2 & 0.005 & 0.04 & 41 & 557 \\
\hline $\mathrm{Km} 186+200$ & NM8 & $10 / 01 / 2014$ & 7.2 & 6.6 & 35 & 5.8 & 2.9 & 0.003 & 0.03 & 30 & 542 \\
\hline $\mathrm{Km} 186+730$ & NM9 & $10 / 01 / 2014$ & 7.1 & 6.3 & 32 & 7.4 & 3.3 & 0.004 & 0.05 & 32 & 536 \\
\hline $\mathrm{Km} 186+730$ & NM10 & $10 / 01 / 2014$ & 7.0 & 6.7 & 39 & 7.2 & 3.8 & 0.006 & 0.07 & 29 & 495 \\
\hline $\mathrm{Km} 186+730$ & NM11 & $10 / 01 / 2014$ & 7.2 & 6.4 & 35 & 8.6 & 4.6 & 0.003 & 0.06 & 31 & 537 \\
\hline
\end{tabular}




\section{February}

\begin{tabular}{|c|c|c|c|c|c|c|c|c|c|c|c|}
\hline \multirow{2}{*}{ Station } & \multirow{2}{*}{$\begin{array}{l}\text { Sensitive } \\
\text { Receptors }\end{array}$} & \multirow{2}{*}{ Date } & $\mathrm{pH}$ & DO & TSS & COD & $\begin{array}{l}\mathrm{BOD}_{5} \\
\left(20^{\circ} \mathrm{C}\right)\end{array}$ & Surf. & $\begin{array}{l}\text { Oil and } \\
\text { Grease }\end{array}$ & $\begin{array}{c}\text { Fecal } \\
\text { Coliform }\end{array}$ & $\begin{array}{c}\text { Total } \\
\text { Coliform }\end{array}$ \\
\hline & & & - & $\mathrm{mg} / \mathrm{l}$ & $\mathrm{mg} / \mathrm{l}$ & $\mathrm{mg} / \mathrm{l}$ & $\mathrm{mg} / \mathrm{l}$ & $\mathrm{mg} / \mathrm{l}$ & $\mathrm{mg} / \mathrm{l}$ & MPN/100ml & MPN/100ml \\
\hline $\mathrm{Km} 165+100$ & NM1 & $11 / 02 / 2014$ & 7.0 & 6.8 & 12 & 5.4 & 2.6 & 0.002 & 0.04 & 34 & 427 \\
\hline $\mathrm{Km} 165+100$ & NM2 & $11 / 02 / 2014$ & 7.1 & 6.2 & 17 & 6.2 & 3.5 & 0.003 & 0.03 & 48 & 472 \\
\hline Km165+100 & NM3 & $11 / 02 / 2014$ & 7.1 & 5.9 & 21 & 8.4 & 4.7 & 0.005 & 0.03 & 39 & 470 \\
\hline $\mathrm{Km} 165+100$ & NM4 & $11 / 02 / 2014$ & 7.0 & 6.1 & 25 & 8.6 & 5.1 & 0.003 & 0.06 & 39 & 512 \\
\hline $\mathrm{Km} 186+200$ & NM5 & $11 / 02 / 2014$ & 6.9 & 6.3 & 16 & 4.6 & 2.4 & 0.002 & 0.04 & 47 & 483 \\
\hline Km186+200 & NM6 & $11 / 02 / 2014$ & 6.5 & 6.6 & 20 & 5.1 & 2.8 & 0.004 & 0.06 & 52 & 495 \\
\hline Km186+200 & NM7 & $11 / 02 / 2014$ & 6.9 & 5.4 & 24 & 5.8 & 3.3 & 0.003 & 0.04 & 38 & 505 \\
\hline $\mathrm{Km} 186+200$ & NM8 & $11 / 02 / 2014$ & 6.7 & 5.1 & 26 & 5.3 & 2.7 & 0.004 & 0.03 & 45 & 521 \\
\hline $\mathrm{Km} 186+730$ & NM9 & $11 / 02 / 2014$ & 7.0 & 6.0 & 15 & 10.4 & 5.7 & 0.006 & 0.08 & 41 & 592 \\
\hline $\mathrm{Km} 186+730$ & NM10 & $11 / 02 / 2014$ & 7.1 & 5.8 & 22 & 13.4 & 6.7 & 0.009 & 0.06 & 52 & 627 \\
\hline $\mathrm{Km} 186+730$ & NM11 & $11 / 02 / 2014$ & 7.0 & 5.4 & 26 & 17.1 & 8.3 & 0.008 & 0.09 & 73 & 821 \\
\hline $\mathrm{Km} 186+730$ & NM12 & $11 / 02 / 2014$ & 7.1 & 5.6 & 27 & 18.2 & 9.4 & 0.009 & 0.07 & 66 & 724 \\
\hline \multicolumn{3}{|c|}{ QCVN08:08 } & $5,5-9$ & $\geq 4$ & 50 & 30 & 15 & 0,4 & 0,1 & 100 & 7500 \\
\hline
\end{tabular}




\section{Loan 2391/2392 - VIE: GMS Kunming - Hai Phong Transport Corridor}

Noi Bai - Lao Cai Highway Project

\section{March}

\begin{tabular}{|c|c|c|c|c|c|c|c|c|c|c|c|}
\hline \multirow{2}{*}{ Station } & \multirow{2}{*}{$\begin{array}{l}\text { Sensitive } \\
\text { Receptors }\end{array}$} & \multirow{2}{*}{ Date } & pH & DO & TSS & COD & $\begin{array}{l}\mathrm{BOD}_{5} \\
\left(20^{\circ} \mathrm{C}\right)\end{array}$ & Surf. & $\begin{array}{l}\text { Oil and } \\
\text { Grease }\end{array}$ & $\begin{array}{l}\text { Fecal } \\
\text { Coliform }\end{array}$ & $\begin{array}{c}\text { Total } \\
\text { Coliform }\end{array}$ \\
\hline & & & - & $\mathrm{mg} / \mathrm{l}$ & $\mathrm{mg} / \mathrm{l}$ & $\mathrm{mg} / \mathrm{l}$ & $\mathrm{mg} / \mathrm{l}$ & $\mathrm{mg} / \mathrm{l}$ & $\mathrm{mg} / \mathrm{l}$ & MPN/100ml & MPN/100ml \\
\hline $\mathrm{Km} 165+100$ & NM1 & $10 / 03 / 2014$ & 7.3 & 6.1 & 37 & 7.9 & 4.1 & 0.006 & 0.06 & 37 & 579 \\
\hline Km165+100 & NM2 & $10 / 03 / 2014$ & 7.2 & 6.0 & 42 & 7.3 & 3.9 & 0.005 & 0.04 & 58 & 582 \\
\hline Km165+100 & NM3 & $10 / 03 / 2014$ & 7.2 & 5.7 & 44 & 7.7 & 4.2 & 0.007 & 0.07 & 41 & 495 \\
\hline $\mathrm{Km} 165+100$ & NM4 & $10 / 03 / 2014$ & 7.2 & 5.5 & 46 & 8.7 & 4.6 & 0.004 & 0.05 & 39 & 451 \\
\hline Km186+200 & NM7 & $10 / 03 / 2014$ & 7.2 & 4.6 & 44 & 6.1 & 3.3 & 0.005 & 0.08 & 67 & 489 \\
\hline $\mathrm{Km} 186+200$ & NM8 & $10 / 03 / 2014$ & 7.3 & 4.1 & 46 & 7.5 & 4.9 & 0.004 & 0.04 & 62 & 472 \\
\hline $\mathrm{Km} 186+730$ & NM9 & $10 / 03 / 2014$ & 7.0 & 5.9 & 45 & 9.6 & 5.1 & 0.007 & 0.06 & 44 & 583 \\
\hline $\mathrm{Km} 186+730$ & NM10 & $10 / 03 / 2014$ & 6.7 & 5.3 & 42 & 8.9 & 4.9 & 0.009 & 0.02 & 35 & 558 \\
\hline Km186+730 & NM11 & $10 / 03 / 2014$ & 7.0 & 4.6 & 48 & 9.7 & 5.5 & 0.002 & 0.05 & 48 & 494 \\
\hline
\end{tabular}

\section{Notes:}

NM1: Ngoi Hut bridge area (Km165+100) - Upper layer of water samples (time 1) - X (m): 2.430.208 - Y (m): 455.312

NM2: Ngoi Hut bridge area (Km165+100) - Upper layer of water samples (time 2) - X (m): 2.430.208 - Y (m): 455.312

NM3: Ngoi Hut bridge area (Km165+100) - Under layer of water samples (time 1) - X (m): 2.430.208 - Y (m): 455.312 


\section{getinso}

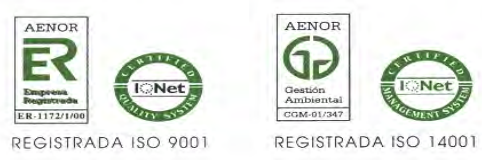

\section{Loan 2391/2392 - VIE: GMS Kunming - Hai Phong Transport Corridor}

Noi Bai - Lao Cai Highway Project

NM4: Ngoi Hut bridge area (Km165+100) - Under layer of water samples (time 2) - X (m): 2.430.208 - Y (m): 455.312

NM5: Tunnel's south portal area (Km186+200) - Upper layer of water samples (time 1) - X (m): $2.444 .056-Y(m): 441.293$

NM6: Tunnel's south portal area (Km186+200) - Upper layer of water samples (time 2) - X (m): $2.444 .056-Y(m): 441.293$

NM7: Tunnel's south portal area (Km186+200) - Under layer of water samples (time 1) - X (m): $2.444 .056-Y(m): 441.293$

NM8: Tunnel's south portal area (Km186+200) - Under layer of water samples (time 2) - X (m): $2.444 .056-Y(m): 441.293$

NM9: Tunnel's north portal area (Km186+730) - Upper layer of water samples (time 1) - X (m): $2.444 .379-\mathrm{Y}(\mathrm{m}): 440.636$

NM10: Tunnel's north portal area (Km186+730) - Upper layer of water samples (time 2) - X (m): 2.444.379-Y (m): 440.636

NM11: Tunnel's north portal area $(\mathrm{Km} 186+730)$ - Under layer of water samples (time 1) - X (m): 2.444.379-Y (m): 440.636

NM12: Tunnel's north portal area $(\mathrm{Km} 186+730)$ - Under layer of water samples (time 2) - X (m): $2.444 .379-\mathrm{Y}(\mathrm{m}): 440.636$

\section{PACKAGE A7}

Contractor stopped monitoring activities in November 2013 adducing that the contract was finished, although the technical opening ceremony was not celebrated until $1^{\text {st }}$ April 2014.

\section{PACKAGE A8}

Contractor stopped monitoring activities in December 2013 adducing that the contract was finished, although the technical opening ceremony was not celebrated until $2^{\text {nd }}$ March 2014, and only the last 11 kilometers of the package. 
getinsa

ER

Loan 2391/2392 - VIE: GMS Kunming - Mai Phon Transport Corridor No Bail - Lao Cai Highway Project

252 
getinso

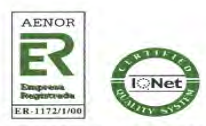

REGISTRADA ISO 9001

$G_{\text {Gestión }}^{\text {AENOR }}$

Ambiantai

REGISTRADA. ISO 14001

Loan 2391/2392 - VIE: GMS Kunming - Hai Phong Transport Corridor Noi Bai - Lao Cai Highway Project

8.3 ANNEX 2.3: NOISE LEVELS

253 
getinsa

6D)

Loan 2391/2392 - VIE: GMS Kunming - Hai Phong Transport Corridor Noi Bai - Lao Cai Highway Project

254 


\section{PACKAGE A1}

Technical traffic opening ceremony was organized in December, 2013. The Contractor stopped monitoring the noise levels.

\section{PACKAGE A2}

\section{January}

\begin{tabular}{|c|c|c|c|c|}
\hline \multicolumn{5}{|c|}{ Noise Monitoring Result } \\
\hline \multirow{2}{*}{ Location } & \multicolumn{2}{|c|}{ Monitoring value (dBA) } & \multicolumn{2}{c|}{ Standard value (dBA) } \\
\cline { 2 - 5 } & $6 \mathrm{~h}-21 \mathrm{~h}$ & $21 \mathrm{~h}-6 \mathrm{~h}$ & $6 \mathrm{~h}-21 \mathrm{~h}$ & $21 \mathrm{~h}-6 \mathrm{~h}$ \\
\hline $\mathrm{Km} \mathrm{34+780}$ & 52 & 43 & 55 & 45 \\
\hline $\mathrm{Km} \mathrm{36+500}$ & 63 & 53 & 70 & 55 \\
\hline $\mathrm{Km} \mathrm{39+130}$ & 65 & 53 & 70 & 55 \\
\hline
\end{tabular}

\section{February}

\begin{tabular}{|c|c|c|c|c|}
\hline \multicolumn{5}{|c|}{ Noise Monitoring Result } \\
\hline \multirow{2}{*}{ Location } & Monitoring value (dBA) & \multicolumn{2}{c|}{ Standard value (dBA) } \\
\cline { 2 - 5 } & $6 \mathrm{~h}-21 \mathrm{~h}$ & $21 \mathrm{~h}-6 \mathrm{~h}$ & $6 \mathrm{~h}-21 \mathrm{~h}$ & $21 \mathrm{~h}-6 \mathrm{~h}$ \\
\hline \hline $\mathrm{Km} \mathrm{34+780}$ & 53 & 42 & 55 & 45 \\
\hline $\mathrm{Km} 36+500$ & 64 & 54 & 70 & 55 \\
\hline $\mathrm{Km} 39+130$ & 63 & 52 & 70 & 55 \\
\hline
\end{tabular}

\section{March}

\begin{tabular}{|c|c|c|c|c|}
\hline \multicolumn{5}{|c|}{ Noise Monitoring Result } \\
\hline \multirow{2}{*}{ Location } & \multicolumn{2}{|c|}{ Monitoring value (dBA) } & \multicolumn{2}{c|}{ Standard value (dBA) } \\
\cline { 2 - 5 } & $6 \mathrm{~h}-21 \mathrm{~h}$ & $21 \mathrm{~h}-6 \mathrm{~h}$ & $6 \mathrm{~h}-21 \mathrm{~h}$ & $21 \mathrm{~h}-6 \mathrm{~h}$ \\
\hline $\mathrm{Km} \mathrm{34+780}$ & & & 55 & 45 \\
\hline $\mathrm{Km} \mathrm{36+500}$ & & & 70 & 55 \\
\hline $\mathrm{Km} \mathrm{39+130}$ & & & 70 & 55 \\
\hline
\end{tabular}




\section{PACKAGE A3}

January

Noise measuring

\begin{tabular}{|c|c|c|c|c|}
\hline \multirow{2}{*}{ Station } & \multicolumn{3}{|c|}{ Monitoring Value (dBA) } & Standard Value (dBA) \\
\cline { 2 - 5 } & $6 \mathrm{~h}-10 \mathrm{~h}$ & $10 \mathrm{~h}-14 \mathrm{~h}$ & $14 \mathrm{~h}-18 \mathrm{~h}$ & $6 \mathrm{~h}-21 \mathrm{~h}$ \\
\hline \hline $\mathrm{Km} \mathrm{48+500}$ & 56 & 49 & 54 & 55 \\
\hline $\mathrm{Km} \mathrm{55+550}$ & 69 & 59 & 66 & 70 \\
\hline $\mathrm{Km} \mathrm{67+700}$ & 67 & 55 & 64 & 70 \\
\hline $\mathrm{Km} 78+900$ & 68 & 59 & 65 & 70 \\
\hline
\end{tabular}

\section{Vibration measuring}

\begin{tabular}{|c|c|c|c|c|}
\hline Station & $\begin{array}{c}\text { Max. Value } \\
\left(\mathbf{m g} / \mathbf{m}^{\mathbf{3}}\right)\end{array}$ & $\begin{array}{c}\text { Min. Value } \\
\left(\mathbf{m g} / \mathbf{m}^{\mathbf{3}}\right)\end{array}$ & $\begin{array}{c}\text { Average. } \\
\text { Value }\left(\mathbf{m g} / \mathbf{m}^{3}\right)\end{array}$ & $\begin{array}{c}\text { Standard Value } \\
\left(\mathbf{m g} / \mathbf{m}^{\mathbf{3}}\right)\end{array}$ \\
\hline \hline$K m 48+500$ & 0,030 & 0,026 & 0,028 & 0,055 \\
\hline$K m 55+550$ & 0,054 & 0,046 & 0,050 & 0,055 \\
\hline$K m 67+700$ & 0,059 & 0,053 & 0,056 & 0,055 \\
\hline$K m 78+900$ & 0,050 & 0,044 & 0,047 & 0,055 \\
\hline
\end{tabular}

\section{February}

\section{Noise measuring}

\begin{tabular}{|c|c|c|c|c||}
\hline & \multicolumn{3}{|c|}{ Monitoring Value (dBA) } & Standard Value (dBA) \\
\hline Station & $6 \mathrm{~h}-10 \mathrm{~h}$ & $10 \mathrm{~h}-14 \mathrm{~h}$ & $14 \mathrm{~h}-18 \mathrm{~h}$ & $18 \mathrm{~h}-21 \mathrm{~h}$ \\
\hline \hline $\mathrm{Km} \mathrm{48+500}$ & 57 & 50 & 55 & 55 \\
\hline $\mathrm{Km} \mathrm{55+550}$ & 69 & 61 & 67 & 70 \\
\hline $\mathrm{Km} \mathrm{67+700}$ & 68 & 57 & 65 & 70 \\
\hline $\mathrm{Km} 78+900$ & 68 & 60 & 66 & 70 \\
\hline
\end{tabular}

Vibration measuring

\begin{tabular}{|c|c|c|c|c||}
\hline Station & $\begin{array}{c}\text { Max. Value } \\
\left(\mathbf{m g} / \mathbf{m}^{\mathbf{3}}\right)\end{array}$ & $\begin{array}{c}\text { Min. Value } \\
\left(\mathbf{m g} / \mathbf{m}^{\mathbf{3}}\right)\end{array}$ & $\begin{array}{c}\text { Average. } \\
\text { Value }\left(\mathbf{m g} / \mathbf{m}^{\mathbf{3}}\right)\end{array}$ & $\begin{array}{c}\text { Standard Value } \\
\left(\mathbf{m g} / \mathbf{m}^{\mathbf{3}}\right)\end{array}$ \\
\hline \hline $\mathrm{Km} \mathrm{48+500}$ & & & & 0,055 \\
\hline $\mathrm{Km}$ 55+550 & & & & 0,055 \\
\hline $\mathrm{Km} \mathrm{67+700}$ & & & & 0,055 \\
\hline $\mathrm{Km} 78+900$ & & & & 0,055 \\
\hline
\end{tabular}


March

Noise measuring

\begin{tabular}{|c|c|c|c|c|}
\hline \multirow{2}{*}{ Station } & \multicolumn{3}{|c|}{ MonitoringValue (dBA) } & Standard Value (dBA) \\
\cline { 2 - 5 } & $6 \mathrm{~h}-10 \mathrm{~h}$ & $10 \mathrm{~h}-14 \mathrm{~h}$ & $14 \mathrm{~h}-18 \mathrm{~h}$ & $18 \mathrm{~h}-21 \mathrm{~h}$ \\
\hline \hline $\mathrm{Km} \mathrm{48+500}$ & & & & 55 \\
\hline $\mathrm{Km} \mathrm{55+550}$ & & & & 70 \\
\hline $\mathrm{Km} \mathrm{67+700}$ & & & & 70 \\
\hline $\mathrm{Km} 78+900$ & & & 70 \\
\hline
\end{tabular}

Vibration measuring

\begin{tabular}{|c|c|c|c|c|}
\hline Station & $\begin{array}{c}\text { Max. } \\
\text { Value }\left(\mathbf{m g} / \mathbf{m}^{3}\right)\end{array}$ & Min. Value $\left(\mathbf{m g} / \mathbf{m}^{3}\right)$ & $\begin{array}{c}\text { Average. } \\
\text { Value }\left(\mathbf{m g} / \mathbf{m}^{3}\right)\end{array}$ & $\begin{array}{c}\text { Standard Value } \\
\left(\mathbf{m g} / \mathbf{m}^{\mathbf{3}}\right)\end{array}$ \\
\hline $\mathrm{Km} \mathrm{48+500}$ & & & & 0,055 \\
\hline $\mathrm{Km} 55+550$ & & & & 0,055 \\
\hline $\mathrm{Km} 67+700$ & & & & 0,055 \\
\hline $\mathrm{Km} 78+900$ & & & & 0,055 \\
\hline
\end{tabular}

PACKAGE A4

January

Noise measuring

\begin{tabular}{|c|c|c|c|c|}
\hline & \multicolumn{3}{|c|}{ MonitoringValue (dBA) } & Standard Value (dBA) \\
\hline Station & $6 h-10 h$ & $10 h-14 h$ & $14 h-18 h$ & $6 h-21 h$ \\
\hline $\mathrm{Km} 91+150$ & 53 & 48 & 50 & \multirow{7}{*}{70} \\
\hline $\mathrm{Km} \mathrm{95+100}$ & 66 & 63 & 67 & \\
\hline Tan ThanhCBP & 67 & 64 & 65 & \\
\hline $\mathrm{Km} 88+300$ to $\mathrm{Km} 88+500$ & 70 & 66 & 68 & \\
\hline $\mathrm{Km} 104+900$ to $\mathrm{Km} 105+350$ & 65 & 61 & 67 & \\
\hline $\mathrm{Km} 106+500$ to $\mathrm{Km} 107+600$ & 66 & 59 & 68 & \\
\hline $\mathrm{Km} 106+800$ & 45 & 46 & 49 & \\
\hline
\end{tabular}


Loan 2391/2392 - VIE: GMS Kunming - Hai Phong Transport Corridor Noi Bai - Lao Cai Highway Project

Vibration measuring

\begin{tabular}{|c|c|c|c|c|}
\hline Station & Min. Value & Max. Value & Average Value & $\begin{array}{c}\text { Standard Value } \\
\left(\mathrm{mg} / \mathrm{m}^{3}\right)\end{array}$ \\
\hline $\mathrm{Km} \mathrm{91+150}$ & 0,041 & 0,039 & 0,040 & \multirow{7}{*}{0,055} \\
\hline $\mathrm{Km} \mathrm{95+100}$ & 0,042 & 0,039 & 0,041 & \\
\hline Tan ThanhCBP & 0,052 & 0,048 & 0,050 & \\
\hline $\mathrm{Km} 88+300$ to $\mathrm{Km} 88+500$ & 0,045 & 0,043 & 0,044 & \\
\hline $\mathrm{Km} 104+900$ to $\mathrm{Km} 105+350$ & 0,054 & 0,047 & 0,051 & \\
\hline $\mathrm{Km} 106+500$ to $\mathrm{Km} 107+600$ & 0,044 & 0,040 & 0,042 & \\
\hline Km106+800 & 0,040 & 0,034 & 0,037 & \\
\hline
\end{tabular}

February

Noise measuring

\begin{tabular}{|c|c|c|c|c|}
\hline \multirow[b]{2}{*}{ Station } & \multicolumn{3}{|c|}{ MonitoringValue (dBA) } & \multirow{2}{*}{$\begin{array}{c}\text { Standard Value (dBA) } \\
6 \mathrm{~h}-21 \mathrm{~h} \\
\end{array}$} \\
\hline & $6 h-10 h$ & $10 h-14 h$ & $14 h-18 h$ & \\
\hline Km 91+150 & 64 & 59 & 61 & \multirow{7}{*}{70} \\
\hline Km 95+100 & 67 & 62 & 65 & \\
\hline Tan ThanhCBP & 67 & 61 & 64 & \\
\hline $\mathrm{Km} 88+300$ to $\mathrm{Km} 88+500$ & 69 & 64 & 67 & \\
\hline $\mathrm{Km} 104+900$ to $\mathrm{Km105+350}$ & 66 & 59 & 65 & \\
\hline $\mathrm{Km} 106+500$ to $\mathrm{Km} 107+600$ & 67 & 59 & 66 & \\
\hline Km106+800 & 64 & 55 & 63 & \\
\hline
\end{tabular}

Vibration measuring

\begin{tabular}{|c|c|c|c|c|}
\hline Station & Min. Value & Max. Value & Average Value & $\begin{array}{l}\text { Standard Value } \\
\left(\mathrm{mg} / \mathrm{m}^{3}\right)\end{array}$ \\
\hline Km 91+150 & 0,040 & 0,036 & 0,038 & \multirow{7}{*}{0,055} \\
\hline Km 95+100 & 0,041 & 0,039 & 0,040 & \\
\hline Tan ThanhCBP & 0,048 & 0,044 & 0,046 & \\
\hline $\mathrm{Km} 88+300$ to $\mathrm{Km} 88+500$ & 0,042 & 0,040 & 0,041 & \\
\hline $\mathrm{Km} 104+900$ to $\mathrm{Km} 105+350$ & 0,042 & 0,038 & 0,040 & \\
\hline $\mathrm{Km} 106+500$ to $\mathrm{Km} 107+600$ & 0,042 & 0,036 & 0,039 & \\
\hline Km106+800 & 0,040 & 0,034 & 0,037 & \\
\hline
\end{tabular}




\section{March}

Noise measuring

\begin{tabular}{|c|c|c|c|c|}
\hline \multirow[b]{2}{*}{ Station } & \multicolumn{3}{|c|}{ MonitoringValue (dBA) } & \multirow{2}{*}{$\begin{array}{c}\text { Standard Value (dBA) } \\
6 \mathrm{~h}-21 \mathrm{~h} \\
\end{array}$} \\
\hline & $6 h-10 h$ & $10 h-14 h$ & $14 h-18 h$ & \\
\hline Km 91+150 & & & & \multirow{7}{*}{70} \\
\hline Km 95+100 & & & & \\
\hline Tan ThanhCBP & & & & \\
\hline $\mathrm{Km} 88+300$ to $\mathrm{Km} 88+500$ & & & & \\
\hline $\mathrm{Km} 104+900$ to $\mathrm{Km} 105+350$ & & & & \\
\hline $\mathrm{Km} 106+500$ to $\mathrm{Km} 107+600$ & & & & \\
\hline Km106+800 & & & 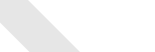 & \\
\hline
\end{tabular}

Vibration measuring

\begin{tabular}{|c|c|c|c|c|}
\hline Station & Min. Value & Max. Value & Average Value & $\begin{array}{l}\text { Standard Value } \\
\left(\mathrm{mg} / \mathrm{m}^{3}\right)\end{array}$ \\
\hline $\mathrm{Km} \mathrm{91+150}$ & 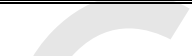 & 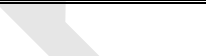 & & \multirow{7}{*}{0,055} \\
\hline $\mathrm{Km} 95+100$ & & 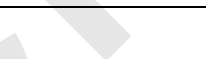 & & \\
\hline Tan ThanhCBP & & & & \\
\hline $\mathrm{Km} 88+300$ to $\mathrm{Km} 88+500$ & & & & \\
\hline $\mathrm{Km} 104+900$ to $\mathrm{Km} 105+350$ & se & & & \\
\hline $\mathrm{Km} 106+500$ to $\mathrm{Km} 107+600$ & & & & \\
\hline Km106+800 & & & & \\
\hline
\end{tabular}




\section{getinso}

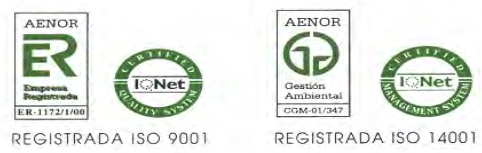

Loan 2391/2392 - VIE: GMS Kunming - Hai Phong Transport Corridor

Noi Bai - Lao Cai Highway Project

\section{PACKAGE A5}

\section{January}

\begin{tabular}{|c|c|c|c|c|c|c|c|c|}
\hline \multirow{3}{*}{ Station } & \multirow{3}{*}{$\begin{array}{l}\text { Sensitive } \\
\text { Receptors }\end{array}$} & \multirow{3}{*}{ Date } & \multicolumn{2}{|c|}{ Result (dB) (average) } & \multicolumn{2}{|c|}{ QCVN 26:2010 } & \multicolumn{2}{|c|}{ Exceeding value } \\
\hline & & & \multicolumn{6}{|c|}{ Working shift } \\
\hline & & & $6 h-21 h$ & $21 h-6 h$ & $6 h-21 h$ & $21 h-6 h$ & $6 h-21 h$ & $21 h-6 h$ \\
\hline $\mathrm{Km} \mathrm{117+050}$ & N 1 & $15 / 01 / 2014$ & 53.6 & 43.4 & 55 & 45 & - & - \\
\hline \multicolumn{9}{|c|}{$\begin{array}{l}\text { - The value of noise level referred to standards applied for extremely quiet areas (QCVN 26:2010/BTNMT) } \\
\text { - Noise primarily generated from the vehicle the vehicles or motorbike but constructional equipment }\end{array}$} \\
\hline
\end{tabular}

\begin{tabular}{|c|c|c|c|c|c|c|c|c|}
\hline \multirow{3}{*}{ Station } & \multirow{3}{*}{$\begin{array}{l}\text { Sensitive } \\
\text { Receptors }\end{array}$} & \multirow{3}{*}{ Date } & \multicolumn{2}{|c|}{ Result (dB) (average) } & \multicolumn{2}{|c|}{ QCVN 26:2010 } & \multicolumn{2}{|c|}{ Exceeding value } \\
\hline & & & \multicolumn{6}{|c|}{ Working shift } \\
\hline & & & $6 h-21 h$ & $21 h-6 h$ & $6 h-21 h$ & $21 h-6 h$ & $6 h-21 h$ & $21 h-6 h$ \\
\hline $\mathrm{Km} 118+820$ & $\mathrm{~N} 2$ & 15 / 01 / 2014 & 66.8 & 53.5 & 70 & 55 & & \\
\hline $\mathrm{Km} 121+433$ & N 3 & 15 / 01 / 2014 & 68.6 & 54.1 & 70 & 55 & - & - \\
\hline \multicolumn{9}{|c|}{$\begin{array}{l}\text { - The value of noise level referred to standards applied for commerce, office, industry area. } \\
\text { - Noise primarily generated }\end{array}$} \\
\hline
\end{tabular}




\section{getinso}

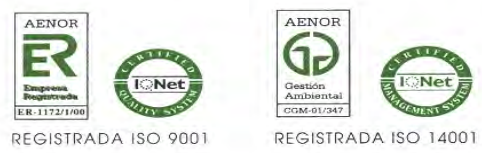

Loan 2391/2392 - VIE: GMS Kunming - Hai Phong Transport Corridor

Noi Bai - Lao Cai Highway Project

\section{February}

\begin{tabular}{|c|c|c|c|c|c|c|c|c|}
\hline \multirow{3}{*}{ Station } & \multirow{3}{*}{$\begin{array}{l}\text { Sensitive } \\
\text { Receptors }\end{array}$} & \multirow{3}{*}{ Date } & \multicolumn{2}{|c|}{ Result (dB) (average) } & \multicolumn{2}{|c|}{ QCVN 26:2010 } & \multicolumn{2}{|c|}{ Exceeding value } \\
\hline & & & \multicolumn{6}{|c|}{ Working shift } \\
\hline & & & $6 h-21 h$ & $21 h-6 h$ & $6 h-21 h$ & $21 h-6 h$ & $6 h-21 h$ & $21 h-6 h$ \\
\hline Km 117+050 & N 1 & 25 / 02 / 2014 & 49.8 & 37.2 & 55 & 45 & - & - \\
\hline \multicolumn{9}{|c|}{$\begin{array}{l}\text { - The value of noise level referred to standards applied for extremely quiet areas (QCVN 26:2010/BTNMT) } \\
\text { - Noise primarily generated from the vehicle the vehicles or motorbike but constructional equipment }\end{array}$} \\
\hline
\end{tabular}

\begin{tabular}{|c|c|c|c|c|c|c|c|c|}
\hline \multirow{3}{*}{ Station } & \multirow{3}{*}{$\begin{array}{l}\text { Sensitive } \\
\text { Receptors }\end{array}$} & \multirow{3}{*}{ Date } & \multicolumn{2}{|c|}{ Result (dB) (average) } & \multicolumn{2}{|c|}{ QCVN 26:2010 } & \multicolumn{2}{|c|}{ Exceeding value } \\
\hline & & & \multicolumn{6}{|c|}{ Working shift } \\
\hline & & & $6 h-21 h$ & $21 h-6 h$ & $6 h-21 h$ & $21 h-6 h$ & $6 h-21 h$ & $21 h-6 h$ \\
\hline $\mathrm{Km} 118+820$ & N 2 & 25 / 02 / 2014 & 58.6 & 48.3 & 70 & 55 & & \\
\hline $\mathrm{Km} 121+433$ & N 3 & 25 / 02 / 2014 & 64.0 & 49.7 & 70 & 55 & - & - \\
\hline \multicolumn{9}{|c|}{$\begin{array}{l}\text { - The value of noise level referred to standards applied for commerce, office, industry area. } \\
\text { - Noise primarily generated }\end{array}$} \\
\hline
\end{tabular}




\section{getinso}

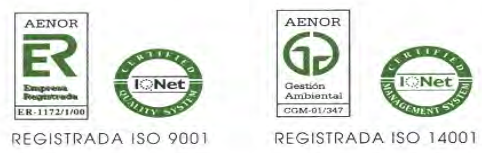

Loan 2391/2392 - VIE: GMS Kunming - Hai Phong Transport Corridor

Noi Bai - Lao Cai Highway Project

\section{March}

\begin{tabular}{|c|c|c|c|c|c|c|c|c|}
\hline \multirow{3}{*}{ Station } & \multirow{3}{*}{$\begin{array}{l}\text { Sensitive } \\
\text { Receptors }\end{array}$} & \multirow{3}{*}{ Date } & \multicolumn{2}{|c|}{ Result (dB) (average) } & \multicolumn{2}{|c|}{ QCVN 26:2010 } & \multicolumn{2}{|c|}{ Exceeding value } \\
\hline & & & \multicolumn{6}{|c|}{ Working shift } \\
\hline & & & $6 h-21 h$ & $21 h-6 h$ & $6 h-21 h$ & $21 h-6 h$ & $6 \mathrm{~h}-21 \mathrm{~h}$ & $21 h-6 h$ \\
\hline $\mathrm{Km} \mathrm{117+050}$ & N 1 & 17 / 03 / 2014 & 50.4 & 39.1 & 55 & 45 & - & - \\
\hline \multicolumn{9}{|c|}{$\begin{array}{l}\text { - The value of noise level referred to standards applied for extremely quiet areas (QCVN 26:2010/BTNMT) } \\
\text { - Noise primarily generated from the vehicle the vehicles or motorbike but constructional equipment }\end{array}$} \\
\hline
\end{tabular}

\begin{tabular}{|c|c|c|c|c|c|c|c|c|}
\hline \multirow{3}{*}{ Station } & \multirow{3}{*}{$\begin{array}{l}\text { Sensitive } \\
\text { Receptors }\end{array}$} & \multirow{3}{*}{ Date } & \multicolumn{2}{|c|}{ Result (dB) (average) } & \multicolumn{2}{|c|}{ QCVN 26:2010 } & \multicolumn{2}{|c|}{ Exceeding value } \\
\hline & & & \multicolumn{6}{|c|}{ Working shift } \\
\hline & & & $6 h-21 h$ & $21 h-6 h$ & $6 h-21 h$ & $21 h-6 h$ & $6 h-21 h$ & $21 h-6 h$ \\
\hline $\mathrm{Km} 118+820$ & N 2 & 17 / 03 / 2014 & 64.5 & 51.9 & 70 & 55 & & \\
\hline $\mathrm{Km} 121+433$ & N 3 & 17 / 03 / 2014 & 66.8 & 53.3 & 70 & 55 & - & - \\
\hline \multicolumn{9}{|c|}{$\begin{array}{l}\text { - The value of noise level referred to standards applied for commerce, office, industry area. } \\
\text { - Noise primarily generated }\end{array}$} \\
\hline
\end{tabular}




\section{getinso}

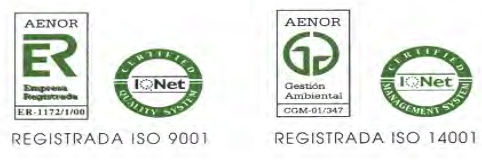

\section{Loan 2391/2392 - VIE: GMS Kunming - Hai Phong Transport Corridor}

Noi Bai - Lao Cai Highway Project

\section{Notes:}

According to Environmental Monitoring Plan approved by the Engineer through the letter Ref. GET3-KEANGNAM-11-A5-037 dated 28 ${ }^{\text {th }}$ March, 2011, the contractor carries out the Environment monitoring with frequency: 1 time / 1 month.

N1: $\quad$ Sampling points are close to Bao Long Church area (Km117+050): (GPS: N 21.40.269; E 104.53.057)

N2: $\quad$ Sampling points are close to Hop Minh My bridge construction site (Km118+820): (GPS: N 21.40.801; E 104.52.259)

N3: $\quad$ Sampling points are close to National Road bridge construction site (Km121+433): (GPS: N 21.41.609; E 104.51.171)

\section{PACKAGE A6}

\section{March}

\begin{tabular}{|c|c|c|c|c|c|c|c|c|}
\hline \multirow{3}{*}{ Station } & \multirow{3}{*}{$\begin{array}{l}\text { Sensitive } \\
\text { Receptors }\end{array}$} & \multirow{3}{*}{ Date } & \multicolumn{2}{|c|}{ Result (dB) (average) } & \multicolumn{2}{|c|}{ QCVN 26:2010 } & \multicolumn{2}{|c|}{ Exceeding value } \\
\hline & & & \multicolumn{6}{|c|}{ Working shift } \\
\hline & & & $6 h-21 h$ & $21 h-6 h$ & $6 h-21 h$ & $21 h-6 h$ & $6 h-21 h$ & $21 h-6 h$ \\
\hline $\mathrm{Km} 155+360$ & N1/A6 & 11 / 03 / 2014 & 54.7 & 43.2 & 55 & 45 & - & - \\
\hline $\mathrm{Km} \mathrm{159+400}$ & N2/A6 & $11 / 03 / 2014$ & 54.2 & 42.9 & 55 & 45 & - & - \\
\hline \multicolumn{9}{|c|}{$\begin{array}{l}\text { - The value of noise level referred to standards applied for extremely quiet areas (QCVN 26:2010/BTNMT) } \\
\text { - Noise primarily generated }\end{array}$} \\
\hline
\end{tabular}




\section{getinso}

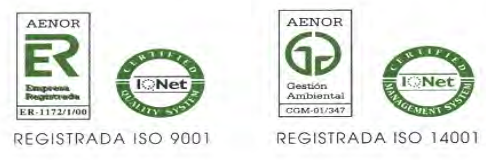

Loan 2391/2392 - VIE: GMS Kunming - Hai Phong Transport Corridor Noi Bai - Lao Cai Highway Project

\begin{tabular}{|c|c|c|c|c|c|c|c|c|}
\hline \multirow{3}{*}{ Station } & \multirow{3}{*}{$\begin{array}{l}\text { Sensitive } \\
\text { Receptors }\end{array}$} & \multirow{3}{*}{ Date } & \multicolumn{2}{|c|}{ Result (dB) (average) } & \multicolumn{2}{|c|}{ QCVN 26:2010 } & \multicolumn{2}{|c|}{ Exceeding value } \\
\hline & & & \multicolumn{6}{|c|}{ Working shift } \\
\hline & & & $6 \mathrm{~h}-21 \mathrm{~h}$ & $21 h-6 h$ & $6 \mathrm{~h}-21 \mathrm{~h}$ & $21 h-6 h$ & $6 h-21 h$ & $21 h-6 h$ \\
\hline $\mathrm{Km} 162+800$ & N3/A6 & 11 / 03 / 2014 & 69.2 & 50.1 & 70 & 55 & & \\
\hline $\mathrm{Km} 165+300$ & N4/A6 & 11 / 03 / 2014 & 67.5 & 52.7 & 70 & 55 & - & - \\
\hline \multicolumn{9}{|c|}{$\begin{array}{l}\text { - The value of noise level referred to standards applied for commerce, office, industry area. } \\
\text { - Noise primarily generated }\end{array}$} \\
\hline
\end{tabular}

\section{Notes:}

According to Environmental Monitoring Plan approved by the Engineer through the letter Ref. Ref. GET3-DOOSAN-11-A6-139 dated $16^{\text {th }}$ April, 2011, the contractor carries out the Environment monitoring with frequency: 1 time / 3 month.

N1: $\quad$ Sampling points are close to Tan Hop Church area $(\mathrm{Km} 155+360)-\mathrm{X}(\mathrm{m}): 2.423 .253-\mathrm{Y}(\mathrm{m}): 461.635$

N2: $\quad$ Sampling points are close to Tan Hop Primary School area $(\mathrm{Km} 159+400)-X(\mathrm{~m}): 2.425 .610-\mathrm{Y}(\mathrm{m}): 458.440$

N3: $\quad$ Sampling points are close to Vinasan's concrete station $(\mathrm{Km} 162+800)-X(\mathrm{~m}): 2.428 .188-\mathrm{Y}(\mathrm{m}): 456.100$

N4: $\quad$ Sampling points are close to White stone vina's concrete station $(\mathrm{Km} 165+300)-X(\mathrm{~m}): 2.430 .266-\mathrm{Y}(\mathrm{m}): 455.303$ 


\section{PACKAGE A7}

Contractor stopped monitoring activities in November 2013 adducing that the contract was finished, although the technical opening ceremony was not celebrated until $1^{\text {st }}$ April 2014.

\section{PACKAGE A8}

Contractor stopped monitoring activities in December 2013 adducing that the contract was finished, although the technical opening ceremony was not celebrated until $2^{\text {nd }}$ March 2014, and only the last 11 kilometers of the package. 
Loan 2391/2392 - VIE: GMS Kunming - Hai Phong Transport Corridor Noi Bai - Lao Cai Highway Project

9. ANNEX 3: DOCUMENTATION RECEIVED FROM CONTRACTORS DURING THE PERIOD 
getinso

(7)

REGISTRADA ISO 9001

बत्या

Loan 2391/2392 - VIE: GMS Kunming - Hai Phong Transport Corridor Noi Bai - Lao Cai Highway Project

267 
Loan 2391/2392 - VIE: GMS Kunming - Hai Phong Transport Corridor

Noi Bai - Lao Cai Highway Project

\begin{tabular}{|c|c|c|c|c|c|}
\hline \multicolumn{6}{|c|}{ DOCUMENTS RECEIVED FROM CONTRACTORS DURING THE FOURTH QUARTER 2013} \\
\hline PACKAGE & CONTRACTOR & REFERENCE & DESIGNATION & REV & APPROVED \\
\hline A1 & POSCO & POS151-2014 & $\begin{array}{l}\text { Proposal to modify the already approved restoration plans } \\
\text { for Xuan Phuong and Tan Loi rivers }\end{array}$ & 1 & NO \\
\hline A1 & POSCO & $\begin{array}{l}\text { POS-A1-SS- } \\
048 / 2014\end{array}$ & $\begin{array}{l}\text { Final method of restoration plans for Xuan Phuong and Tan } \\
\text { Loi rivers, after receiving instructions from the Engineer }\end{array}$ & 1 & YES \\
\hline A1 & POSCO & $\begin{array}{l}\text { POS-A1-SS- } \\
409 / 2013\end{array}$ & $\begin{array}{l}\text { Report on Environmental Monitoring and Analysis - } \\
\text { January, } 2014\end{array}$ & 1 & Yes \\
\hline A2 & POSCO & $\begin{array}{l}\text { POS-A2-SS- } \\
038 / 2014\end{array}$ & $\begin{array}{l}\text { Report on Environmental Monitoring and Analysis - } \\
\text { January, } 2014\end{array}$ & 1 & Yes \\
\hline $\mathrm{A} 2$ & POSCO & $\begin{array}{l}\text { POS-A2-SS- } \\
061 / 2014\end{array}$ & $\begin{array}{l}\text { Report on Environmental Monitoring and Analysis - } \\
\text { February, } 2014\end{array}$ & 1 & Yes \\
\hline A3 & POSCO & $\begin{array}{l}\text { POSA3-SS- } \\
030 / 2014\end{array}$ & Environmental monitoring report in January - 2014 & 1 & Yes \\
\hline A3 & POSCO & \begin{tabular}{|l|} 
POSA3-SS- \\
092/2014
\end{tabular} & Environmental monitoring report in February - 2014 & 1 & Yes \\
\hline A3 & POSCO & \begin{tabular}{|l|} 
POSA3-SS- \\
$116 / 2014$ \\
\end{tabular} & Environmental monitoring report in March - 2013 & 1 & Yes \\
\hline A3 & POSCO & $\begin{array}{l}\text { POSA3-SS- } \\
434 / 2013\end{array}$ & Submit disposal area for section 2-1 & 1 & Yes \\
\hline A4 & KEANGNAM & $\begin{array}{l}\text { KNEA4-GET- } \\
2014 / 061\end{array}$ & Environmental monitoring report in January - 2014 & 1 & Yes \\
\hline A4 & KEANGNAM & $\begin{array}{l}\text { KNEA4-GET- } \\
2014 / 101\end{array}$ & Environmental monitoring report in February - 2014 & 1 & Yes \\
\hline
\end{tabular}


Loan 2391/2392 - VIE: GMS Kunming - Hai Phong Transport Corridor Noi Bai - Lao Cai Highway Project

\begin{tabular}{|c|c|c|c|c|c|}
\hline \multicolumn{6}{|c|}{ DOCUMENTS RECEIVED FROM CONTRACTORS DURING THE FOURTH QUARTER 2013} \\
\hline PACKAGE & CONTRACTOR & REFERENCE & DESIGNATION & REV & APPROVED \\
\hline A4 & KEANGNAM & \begin{tabular}{|l|} 
KNEA4-GET- \\
$2014 / 157$ \\
\end{tabular} & Environmental monitoring report in March - 2014 & 1 & Yes \\
\hline A4 & KEANGNAM & \begin{tabular}{|l|} 
KNEA4-GET- \\
$060 / 2014$
\end{tabular} & $\begin{array}{l}\text { Submission of Capacity profile of Carpet grass supplier } \\
\text { serving for seeding on cutting slope - Package A4 }\end{array}$ & 1 & Yes \\
\hline A5 & KEANGNAM & $\begin{array}{l}\text { KNE-NBLC5- } \\
\text { VEC\&GET-13-923 }\end{array}$ & $\begin{array}{l}\text { Submission for approval of asphalt plant at location hamlet } \\
\text { 4, Hop Minh commune, Tran Yen District, Yen Bai province }\end{array}$ & 1 & Yes \\
\hline A5 & KEANGNAM & $\begin{array}{l}\text { KNE-NBLC5- } \\
\text { VEC\&GET-14-15 }\end{array}$ & Report on Environmental Monitoring for December 2013 & 0 & Yes \\
\hline A5 & KEANGNAM & PLA-14-036 & $\begin{array}{l}\text { Supplement Method statement for grassing at embankment } \\
\text { slope }\end{array}$ & 1 & Yes \\
\hline A5 & KEANGNAM & $\begin{array}{l}\text { KNE-NBLC5- } \\
\text { VEC\&GET-14-064 }\end{array}$ & Report on Environmental Monitoring for January 2014 & 0 & Yes \\
\hline A5 & KEANGNAM & $\begin{array}{l}\text { KNE-NBLC5- } \\
\text { VEC\&GET-14-132 }\end{array}$ & Report on Environmental Monitoring for February 2014 & 0 & Yes \\
\hline A5 & KEANGNAM & $\begin{array}{l}\text { KNE-NBLC5- } \\
\text { VEC\&GET-14-087 }\end{array}$ & $\begin{array}{l}\text { Submission for approval of asphalt concrete batching plant } \\
\text { profile - package A5 }\end{array}$ & 0 & No \\
\hline A5 & KEANGNAM & $\begin{array}{l}\text { KNE-NBLC5- } \\
\text { VEC\&GET-14-003 }\end{array}$ & $\begin{array}{l}\text { Submission for approval of asphalt concrete batching plant } \\
\text { at Dong Quyet Hamlet, Bao Hung commune, Tran Yen } \\
\text { district, Yen Bai province - package A5 }\end{array}$ & 0 & No \\
\hline A6 & DOOSAN & DHIC-13-SET-072 & Documents of disposal areas at Km173+800 (Package A6) & 1 & Yes \\
\hline A6 & DOOSAN & DHIC-14-SET-001 & Official certificate for environmental monitoring activities & 0 & No \\
\hline A6 & DOOSAN & DHIC-14-SET-002 & $\begin{array}{l}\text { Submission of environmental monitoring report in January } \\
2014\end{array}$ & 0 & Yes \\
\hline
\end{tabular}


Loan 2391/2392 - VIE: GMS Kunming - Hai Phong Transport Corridor Noi Bai - Lao Cai Highway Project

\begin{tabular}{|c|c|c|c|c|c|}
\hline \multicolumn{6}{|c|}{ DOCUMENTS RECEIVED FROM CONTRACTORS DURING THE FOURTH QUARTER 2013} \\
\hline PACKAGE & CONTRACTOR & REFERENCE & DESIGNATION & REV & APPROVED \\
\hline A6 & DOOSAN & DHIC-14-SET-003 & Environmental monitoring plan in February 2014 & 0 & Yes \\
\hline A6 & DOOSAN & DHIC-14-SET-004 & $\begin{array}{l}\text { Submission of environmental monitoring report in February } \\
2014\end{array}$ & 0 & Yes \\
\hline A6 & DOOSAN & DHIC-14-SET-005 & Environmental monitoring plan in March 2014 & 0 & Yes \\
\hline A6 & DOOSAN & DHIC-14-SET-006 & Report of safe traffic control on the site & 0 & Yes \\
\hline A6 & DOOSAN & DHIC-14-SET-009 & $\begin{array}{l}\text { Submission of environmental monitoring report in March } \\
2014\end{array}$ & 0 & Yes \\
\hline A6 & DOOSAN & DHIC-14-SET-010 & Environmental monitoring plan in April 2014 & 0 & Yes \\
\hline A6 & DOOSAN & DHIC-14-CT-02 & Method Statement for landscaping work, package A6 & 0 & No \\
\hline A6 & DOOSAN & DHIC-14-SET-007 & Official certificate for environmental monitoring activities & 1 & Yes \\
\hline A7 & GRBCC & $\begin{array}{l}\text { Ref. } \\
\text { GRBCC/GETINSA/ } \\
\text { A7/1873 }\end{array}$ & $\begin{array}{l}\text { Submitting the Restoration of unauthorized spoil disposal } \\
\text { sites } \mathrm{Km} 208+890 \text { and } \mathrm{Km} 209+800\end{array}$ & A1 & $\begin{array}{l}\text { Approved with } \\
\text { conditions }\end{array}$ \\
\hline A7 & GRBCC & $\begin{array}{l}\text { Ref. } \\
\text { GRBCC/GETINSA/ } \\
\text { A7/1881 }\end{array}$ & $\begin{array}{l}\text { Re-submit the Restoration of unauthorized spoil disposal } \\
\text { sites } \mathrm{Km} 190+420 \text { and } \mathrm{Km} 195+500\end{array}$ & A1 & $\begin{array}{l}\text { Approved with } \\
\text { conditions }\end{array}$ \\
\hline A7 & GRBCC & $\begin{array}{l}\text { Ref.GRBCC/GETI } \\
\text { NSA/A7/1958 }\end{array}$ & $\begin{array}{l}\text { Propose to review and given comments about the } \\
\text { Correcting slope protection } \\
\text { Km190+420 }\end{array}$ & A1 & $\begin{array}{l}\text { Send to Core } \\
\text { team }\end{array}$ \\
\hline $\mathrm{A} 7$ & GRBCC & $\begin{array}{l}\text { Ref.GRBCC/GETI } \\
\text { NSA/A7/1978 }\end{array}$ & $\begin{array}{l}\text { Submitting the "Document relate to the disposals and } \\
\text { stabilization method of the soil disposed } \mathrm{Km} 208+890 \text { and } \\
\mathrm{Km} 209+800\end{array}$ & A1 & $\begin{array}{l}\text { Send to Core } \\
\text { team }\end{array}$ \\
\hline
\end{tabular}


Loan 2391/2392 - VIE: GMS Kunming - Hai Phong Transport Corridor Noi Bai - Lao Cai Highway Project

\begin{tabular}{|c|l|c|c|c|c||}
\hline \multicolumn{7}{|c|}{ DOCUMENTS RECEIVED FROM CONTRACTORS DURING THE FOURTH QUARTER 2013 } \\
\hline PACKAGE & CONTRACTOR & REFERENCE & DESIGNATION & REV & APPROVED \\
\hline A8 & VINACONEX & A8/LC/140306-03 & Submit the Additional disposal site profile & A1 & $\begin{array}{c}\text { Returning the } \\
\text { contractor }\end{array}$ \\
\hline A8 & VINACONEX & A8/LC/140321-01 & Submit the Additional disposal site profile- Version A2 & $\begin{array}{c}\text { A2 } \\
\text { Returning the } \\
\text { contractor }\end{array}$ \\
\hline
\end{tabular}


Loan 2391/2392 - VIE: GMS Kunming - Hai Phong Transport Corridor Noi Bai - Lao Cai Highway Project

10. ANNEX 4: STATUS OF THE DOCUMENTATION RELATED TO BORROW PITS, QUARRIES, SOIL DISPOSALS AND CONCRETE BATCHING PLANTS 
getinso

(7)

REGISTRADA ISO 9001

बत्या

Loan 2391/2392 - VIE: GMS Kunming - Hai Phong Transport Corridor Noi Bai - Lao Cai Highway Project

273 


\section{Loan 2391/2392 - VIE: GMS Kunming - Hai Phong Transport Corridor}

Noi Bai - Lao Cai Highway Project

Note:

a - For public lands, indicate whether it is the property of the commune, district, province, etc.

b - Indicate the beneficial use of the property before it was acquired for the project (e.g., rice field, acacia plantation, etc.). If none, provide a short description, e.g., grassland, abandoned/idle farm lot, etc.

c - Specify which government agency (e.g., District People's Committee) issued the approval, including any written agreement between the contractor and the land owner

\section{Package A1}

\begin{tabular}{|c|c|c|c|c|c|c|c|c|c|c|c|}
\hline \multicolumn{12}{|c|}{ BORROW PITS } \\
\hline \multirow{2}{*}{$\begin{array}{c}\text { Package } \\
\text { /Borrow Pit } \\
\text { No. }\end{array}$} & \multirow[b]{2}{*}{ Location } & \multirow{2}{*}{$\begin{array}{l}\text { Approved } \\
\text { Area }\left(m^{2}\right)\end{array}$} & \multirow{2}{*}{$\begin{array}{c}\text { Approved } \\
\text { Volume } \\
\left(\mathrm{m}^{3}\right)\end{array}$} & \multicolumn{2}{|c|}{ Ownership $^{a}$} & \multirow{2}{*}{$\begin{array}{c}\text { Prior Land } \\
\text { Use }^{\mathbf{b}}\end{array}$} & \multicolumn{2}{|c|}{ Approval } & \multicolumn{3}{|c|}{ Operation Schedule } \\
\hline & & & & Name & Contact Info & & $\begin{array}{c}\text { Local } \\
\text { Authorities }\end{array}$ & PSC & Start & $\begin{array}{l}\text { Estimated } \\
\text { Completion }\end{array}$ & $\begin{array}{c}\text { Actual } \\
\text { Completion }\end{array}$ \\
\hline A1/BP6 & $\begin{array}{l}\text { Minh Tri and Minh } \\
\text { Phu Commune, } \\
\text { Soc Son District, } \\
\text { Hanoi city }\end{array}$ & & 832,862 & & & $\begin{array}{l}\text { Industrial } \\
\text { crop land }\end{array}$ & & 31-Aug-09 & 31-Aug-09 & & Closed 2013 \\
\hline A1/BP16 & $\begin{array}{l}\text { La Mai Hill, Huong } \\
\text { Son Commune, } \\
\text { Binh Xuyen District, } \\
\text { Vinh Phuc Province }\end{array}$ & & 606,590 & & & $\begin{array}{l}\text { Industrial } \\
\text { crop land }\end{array}$ & 27-Apr-10 & 06-May-10 & 06-May-10 & 27-May-13 & Closed 2013 \\
\hline A1/BP17 & $\begin{array}{l}\text { Go De Hill, Huong } \\
\text { Son Commune, } \\
\text { Binh Xuyen District, } \\
\text { Vinh Phuc Province }\end{array}$ & & 263,290 & & & $\begin{array}{l}\text { Industrial } \\
\text { crop land }\end{array}$ & 27-Apr-10 & 06-May-10 & 06-May-10 & 27-May-13 & Closed 2013 \\
\hline A1/BP21 & $\begin{array}{c}\text { Dong Mo Hill, Nam } \\
\text { Son Commune, } \\
\text { Soc Son District, } \\
\text { Hanoi City }\end{array}$ & & 492,800 & & & $\begin{array}{l}\text { Industrial } \\
\text { crop land }\end{array}$ & 01-Nov-10 & 25-Mar-11 & 25-Mar-11 & 30-Nov-15 & Closed 2013 \\
\hline A1/SG1 & $\begin{array}{l}\text { Go De Hill, Huong } \\
\text { Son Commune, } \\
\text { Binh Xuyen District, } \\
\text { Vinh Phuc Province }\end{array}$ & & 100,000 & & & $\begin{array}{l}\text { Industrial } \\
\text { crop land }\end{array}$ & 27-Apr-10 & 13-Jan-11 & 13-Jan-11 & 27-May-13 & Closed 2013 \\
\hline
\end{tabular}


Loan 2391/2392 - VIE: GMS Kunming - Hai Phong Transport Corridor Noi Bai - Lao Cai Highway Project

\begin{tabular}{|c|c|c|c|c|c|c|c|c|c|c|c|}
\hline \multicolumn{12}{|c|}{ BORROW PITS } \\
\hline \multirow{2}{*}{$\begin{array}{c}\text { Package } \\
\text { /Borrow Pit } \\
\text { No. }\end{array}$} & \multirow[b]{2}{*}{ Location } & \multirow{2}{*}{$\begin{array}{l}\text { Approved } \\
\text { Area }\left(\mathrm{m}^{2}\right)\end{array}$} & \multirow{2}{*}{$\begin{array}{c}\text { Approved } \\
\text { Volume } \\
\left(\mathrm{m}^{3}\right)\end{array}$} & \multicolumn{2}{|c|}{ Ownership $^{a}$} & \multirow{2}{*}{$\begin{array}{c}\text { Prior Land } \\
\text { Use }^{b}\end{array}$} & \multicolumn{2}{|c|}{ Approval } & \multicolumn{3}{|c|}{ Operation Schedule } \\
\hline & & & & Name & Contact Info & & $\begin{array}{c}\text { Local } \\
\text { Authorities }\end{array}$ & PSC & Start & $\begin{array}{l}\text { Estimated } \\
\text { Completion }\end{array}$ & $\begin{array}{c}\text { Actual } \\
\text { Completion }\end{array}$ \\
\hline A1/SG4 & $\begin{array}{c}\text { Dong Giang Hill, } \\
\text { Trung My } \\
\text { Commune, Binh } \\
\text { Xuyen District, Vinh } \\
\text { Phuc Province }\end{array}$ & & 90,000 & & & $\begin{array}{l}\text { Industrial } \\
\text { crop land }\end{array}$ & 27-Apr-10 & 22-Mar-12 & 22-Mar-12 & 27-May-13 & Closed 2013 \\
\hline
\end{tabular}

\begin{tabular}{|c|c|c|c|c|c|c|c|c|c|c|c|}
\hline \multicolumn{12}{|c|}{ QUARRIES } \\
\hline \multirow{2}{*}{$\begin{array}{c}\text { Package } \\
\text { IQuarry No. }\end{array}$} & \multirow[b]{2}{*}{ Location } & \multirow{2}{*}{$\begin{array}{l}\text { Approved } \\
\text { Area }\left(m^{2}\right)\end{array}$} & \multirow{2}{*}{$\begin{array}{c}\text { Approved } \\
\text { Volume } \\
\left(\mathrm{m}^{3}\right)\end{array}$} & \multicolumn{2}{|c|}{ Ownership $^{a}$} & \multirow{2}{*}{$\begin{array}{l}\text { Prior Land } \\
\text { Use }^{b}\end{array}$} & \multicolumn{2}{|c|}{ Approval } & \multicolumn{3}{|c|}{ Operation Schedule } \\
\hline & & & & Name & Contact Info & & $\begin{array}{c}\text { Local } \\
\text { Authorities }\end{array}$ & PSC & Start & $\begin{array}{l}\text { Estimated } \\
\text { Completion }\end{array}$ & $\begin{array}{c}\text { Actual } \\
\text { Completion }\end{array}$ \\
\hline A1/Q1 & $\begin{array}{c}\text { Quang Son } \\
\text { commune, Lap } \\
\text { Thach dist, Vinh } \\
\text { Phuc }\end{array}$ & 123,000 & $2,611,729$ & & & $\begin{array}{l}\text { Rock- } \\
\text { mine }\end{array}$ & 08-Apr-10 & 13-Dec-11 & 13-Dec-11 & 17-Apr-13 & $\begin{array}{l}\text { Closed } \\
2013\end{array}$ \\
\hline A1/Q2 & $\begin{array}{c}\text { Trung Mau } \\
\text { commune, Binh } \\
\text { Xuyen dist, Vinh } \\
\text { Phuc }\end{array}$ & 640,000 & $\begin{array}{c}75,187,00 \\
0\end{array}$ & & & $\begin{array}{l}\text { Rock- } \\
\text { mine }\end{array}$ & 21-Jul-04 & 13-Dec-11 & 13-Dec-11 & 30-Jun-14 & $\begin{array}{l}\text { Closed } \\
2013\end{array}$ \\
\hline
\end{tabular}

\begin{tabular}{|c|c|c|c|c|c|c|c|c|c|c|c|}
\hline \multicolumn{12}{|c|}{ BATCHING PLANTS } \\
\hline \multirow{2}{*}{$\begin{array}{l}\text { Packagel } \\
\text { CBP No. }\end{array}$} & \multirow[b]{2}{*}{ Location } & \multirow{2}{*}{$\begin{array}{c}\text { Appropriate } \\
\text { settling pond }\end{array}$} & \multirow{2}{*}{$\begin{array}{c}\text { Noise and } \\
\text { dust } \\
\text { measures }\end{array}$} & \multicolumn{2}{|c|}{ Ownership $^{a}$} & \multirow{2}{*}{$\begin{array}{c}\text { Prior Land } \\
\text { Use }^{\mathbf{b}}\end{array}$} & \multicolumn{2}{|c|}{ Approval } & \multicolumn{3}{|c|}{ Operation } \\
\hline & & & & Name & Contact Info & & $\begin{array}{c}\text { Local } \\
\text { Authorities }\end{array}$ & PSC & Start & Est. End & $\begin{array}{c}\text { Actual } \\
\text { End }\end{array}$ \\
\hline $\mathrm{A} 1 / \mathrm{CBP} 1$ & Underpass $\mathrm{NH} 2$ & Yes & Yes & $\begin{array}{l}\text { Evernew } \\
\text { Holding., } \\
\text { JSC }\end{array}$ & $\begin{array}{c}\text { A24-BT4, My } \\
\text { Dinh commune, } \\
\text { Tu Liem dist, } \\
\text { Hanoi }\end{array}$ & Unidentified & Unidentified & 10-May-11 & 10-May-11 & & Dec 2013 \\
\hline A1/CBP2 & Underpass NH2 & Yes & Yes & $\begin{array}{l}\text { Ngoc Mai } \\
\text { Construct. }\end{array}$ & $\begin{array}{c}\text { Tho Dan village, } \\
\text { Kim No }\end{array}$ & Unidentified & Unidentified & 29-Jun-11 & 29-Jun-11 & & Dec 2013 \\
\hline
\end{tabular}

$$
275
$$


Loan 2391/2392 - VIE: GMS Kunming - Hai Phong Transport Corridor Noi Bai - Lao Cai Highway Project

\begin{tabular}{|c|c|c|c|c|c|c|c|c|c|c|c|}
\hline \multicolumn{12}{|c|}{ BATCHING PLANTS } \\
\hline \multirow{2}{*}{$\begin{array}{l}\text { Packagel } \\
\text { CBP No. }\end{array}$} & \multirow[b]{2}{*}{ Location } & \multirow{2}{*}{$\begin{array}{l}\text { Appropriate } \\
\text { settling pond }\end{array}$} & \multirow{2}{*}{$\begin{array}{c}\text { Noise and } \\
\text { dust } \\
\text { measures }\end{array}$} & \multicolumn{2}{|c|}{ Ownership $^{a}$} & \multirow{2}{*}{$\begin{array}{l}\text { Prior Land } \\
\text { Use }\end{array}$} & \multicolumn{2}{|c|}{ Approval } & \multicolumn{3}{|c|}{ Operation } \\
\hline & & & & Name & Contact Info & & $\begin{array}{c}\text { Local } \\
\text { Authorities }\end{array}$ & PSC & Start & Est. End & $\begin{array}{l}\text { Actual } \\
\text { End }\end{array}$ \\
\hline & & & & JSC & $\begin{array}{c}\text { commune, } \\
\text { Dong Anh dist, } \\
\text { Hanoi }\end{array}$ & & & & & & \\
\hline A1/CBP3 & $\mathrm{Km} \mathrm{13+500}$ & Yes & Yes & POSCO & $\begin{array}{c}\text { POSCO E\&C - } \\
\text { Noi Bai - Lao } \\
\text { Cai Highway } \\
\text { project - Huu } \\
\text { thu village, Kim } \\
\text { Long commune, } \\
\text { Tam Duong } \\
\text { dist, Vinh Phuc }\end{array}$ & Pond & 05-May-08 & 27-Jan-10 & 27-Jan-10 & & Dec 2013 \\
\hline A1/CBP4 & $\mathrm{Km} \mathrm{25+000}$ & Yes & Yes & POSCO & $\begin{array}{c}\text { POSCO E\&C - } \\
\text { Noi Bai - Lao } \\
\text { Cai Highway } \\
\text { project - Huu } \\
\text { thu village, Kim } \\
\text { Long commune, } \\
\text { Tam Duong } \\
\text { dist, Vinh Phuc }\end{array}$ & $\begin{array}{l}\text { Long term } \\
\text { cropland }\end{array}$ & 05-May-08 & 27-Jan-10 & 27-Jan-10 & & Dec 2013 \\
\hline
\end{tabular}

\begin{tabular}{|c|c|c|c|c|c|c|c|c|}
\hline \multicolumn{9}{|c|}{ SPOILS DISPOSAL AREAS } \\
\hline \multirow{2}{*}{$\begin{array}{c}\text { Package I } \\
\text { SD No. }\end{array}$} & \multirow[b]{2}{*}{ Location } & \multirow{2}{*}{$\begin{array}{c}\text { Approved } \\
\text { Area } \\
\left(\mathrm{m}^{2}\right)\end{array}$} & \multirow{2}{*}{$\begin{array}{c}\text { Approved } \\
\text { Capacity } \\
\left(\mathrm{m}^{3}\right)\end{array}$} & \multicolumn{2}{|c|}{ Ownership $^{a}$} & \multicolumn{2}{|c|}{ Approval } & \multirow[b]{2}{*}{ Operation } \\
\hline & & & & Name & Contact Info & $\begin{array}{c}\text { Local } \\
\text { Authorities }\end{array}$ & PSC & \\
\hline A1/SD1 & $\begin{array}{l}\text { Trung Mau } \\
\text { village, Trung } \\
\text { My commune, } \\
\text { Binh Xuyen } \\
\text { district, Vinh } \\
\text { Phuc province }\end{array}$ & $200,000 \mathrm{~m} 2$ & $200,000 \mathrm{~m}^{3}$ & $\begin{array}{l}\text { Hoang Chi } \\
\text { Thanh } \\
\text { Hoang Van } \\
\text { Ngoc }\end{array}$ & $\begin{array}{l}\text { Dong Ich } \\
\text { Hamlet, Trung } \\
\text { My commune, } \\
\text { Binh Xuyen } \\
\text { dist, Vinh } \\
\text { Phucs }\end{array}$ & 06-Dec-10 & 20-Dec-10 & \\
\hline
\end{tabular}


Loan 2391/2392 - VIE: GMS Kunming - Hai Phong Transport Corridor

Noi Bai - Lao Cai Highway Project

Package A2

\begin{tabular}{|c|c|c|c|c|c|c|c|c|c|c|c|}
\hline \multicolumn{12}{|c|}{ BORROW PITS } \\
\hline \multirow{2}{*}{$\begin{array}{l}\text { Package } \\
\text { /Borrow } \\
\text { Pit No. }\end{array}$} & \multirow[b]{2}{*}{ Location } & \multirow{2}{*}{$\begin{array}{l}\text { Approved } \\
\text { Area }\left(\mathrm{m}^{2}\right)\end{array}$} & \multirow{2}{*}{$\begin{array}{c}\text { Approved } \\
\text { Volume } \\
\left(\mathrm{m}^{3}\right)\end{array}$} & \multicolumn{2}{|c|}{ Ownership $^{a}$} & \multirow{2}{*}{$\begin{array}{l}\text { Prior Land } \\
\text { Use }^{b}\end{array}$} & \multicolumn{2}{|c|}{ Approval } & \multicolumn{3}{|c|}{ Operation Schedule } \\
\hline & & & & Name & Contact Info & & $\begin{array}{c}\text { Local } \\
\text { Authorities }\end{array}$ & PSC & Start & $\begin{array}{l}\text { Estimated } \\
\text { Completion }\end{array}$ & $\begin{array}{c}\text { Actual } \\
\text { Completion }\end{array}$ \\
\hline A2/BP4 & $\begin{array}{l}\text { Chay Hill, Vinh Phu } \\
\text { village, Hop Hoa } \\
\text { town, Tam Duong } \\
\text { District, Vinh Phuc } \\
\text { Province }\end{array}$ & & 327,167 & & & $\begin{array}{l}\text { Industrial } \\
\text { crop land }\end{array}$ & 29-Dec-09 & 01-Apr-10 & 01-Apr-10 & 29-Dec-12 & March 2014 \\
\hline A2/BP5 & $\begin{array}{c}\text { Rung Nen hill, Thanh } \\
\text { Van-Dao Tu } \\
\text { Commune, Tam } \\
\text { Duong District, Vinh } \\
\text { Phuc Province }\end{array}$ & & 508,467 & & & $\begin{array}{l}\text { Industrial } \\
\text { crop land }\end{array}$ & 23-Mar-10 & 01-Apr-10 & 01-Apr-10 & 30-Apr-13 & March 2014 \\
\hline A2/BP7 & $\begin{array}{c}\text { Nhon Huc \& Go Bep } \\
\text { Hill, Tu Yen } \\
\text { Commune, Song Lo } \\
\text { District, Vinh Phuc } \\
\text { Province }\end{array}$ & & 941,590 & & & $\begin{array}{l}\text { Industrial } \\
\text { crop land }\end{array}$ & 01-Oct-10 & 15-Nov-10 & $15-N o v-10$ & 01-Oct-13 & March 2014 \\
\hline A2/BP11 & $\begin{array}{c}\text { Quan Hill, Phu Ninh } \\
\text { Commune, Phu Ninh } \\
\text { District, Phu Tho } \\
\text { Province }\end{array}$ & & 297,000 & & & $\begin{array}{l}\text { Industrial } \\
\text { crop land }\end{array}$ & 19-May-10 & 01-Jun-12 & 01-Jun-12 & 19-May-12 & March 2014 \\
\hline $\begin{array}{c}\text { A2/BPS } \\
\text { G1 }\end{array}$ & $\begin{array}{l}\text { Rung Nen hill, Thanh } \\
\text { Van-Dao Tu } \\
\text { Commune, Tam } \\
\text { Duong District, Vinh } \\
\text { Phuc Province }\end{array}$ & & 508,467 & & & $\begin{array}{l}\text { Industrial } \\
\text { crop land }\end{array}$ & 23-Mar-10 & 19-May-12 & $\begin{array}{l}\text { 19-May- } \\
12\end{array}$ & 30-Apr-13 & March 2014 \\
\hline $\begin{array}{l}\text { A2/BPS } \\
\text { G5 }\end{array}$ & $\begin{array}{l}\text { Dinh Chua Hill, Tien } \\
\text { Lu Commune, Lap } \\
\text { Thach District, Vinh } \\
\text { Phuc Province }\end{array}$ & & 623,837 & & & $\begin{array}{l}\text { Industrial } \\
\text { crop land }\end{array}$ & 18-Oct-10 & 09-Jul-12 & 09-Jul-12 & 18-Oct-12 & March 2014 \\
\hline
\end{tabular}


Loan 2391/2392 - VIE: GMS Kunming - Hai Phong Transport Corridor Noi Bai - Lao Cai Highway Project

\begin{tabular}{|c|c|c|c|c|c|c|c|c|c|c|c|}
\hline \multicolumn{12}{|c|}{ QUARRIES } \\
\hline \multirow{2}{*}{$\begin{array}{c}\text { Package } \\
\text { IQuarry No. }\end{array}$} & \multirow[b]{2}{*}{ Location } & \multirow{2}{*}{$\begin{array}{l}\text { Approved } \\
\text { Area }\left(\mathrm{m}^{2}\right)\end{array}$} & \multirow{2}{*}{$\begin{array}{c}\text { Approved } \\
\text { Volume } \\
\left(\mathrm{m}^{3}\right)\end{array}$} & \multicolumn{2}{|c|}{ Ownership $^{a}$} & \multirow{2}{*}{$\begin{array}{l}\text { Prior Land } \\
\text { Use }\end{array}$} & \multicolumn{2}{|c|}{ Approval } & \multicolumn{3}{|c|}{ Operation Schedule } \\
\hline & & & & Name & $\begin{array}{c}\text { Contact } \\
\text { Info }\end{array}$ & & $\begin{array}{c}\text { Local } \\
\text { Authorities }\end{array}$ & PSC & Start & $\begin{array}{l}\text { Estimated } \\
\text { Completion }\end{array}$ & $\begin{array}{c}\text { Actual } \\
\text { Completion }\end{array}$ \\
\hline A2/Q1 & $\begin{array}{c}\text { Quang Son } \\
\text { commune, Lap } \\
\text { Thach dist, Vinh } \\
\text { Phuc }\end{array}$ & 123,000 & $2,611,729$ & & & Rock-mine & 13-Dec-11 & 08-Apr-10 & 13-Dec-11 & 17-Apr-25 & March 2014 \\
\hline $\mathrm{A} 2 / \mathrm{Q} 2$ & $\begin{array}{c}\text { Trung Mau } \\
\text { commune, Binh } \\
\text { Xuyen dist, Vinh } \\
\text { Phuc }\end{array}$ & 640,000 & $75,187,000$ & & & Rock-mine & 13-Dec-11 & 21-Jul-04 & 13-Dec-11 & 30-Jun-14 & March 2014 \\
\hline
\end{tabular}

\begin{tabular}{|c|c|c|c|c|c|c|c|c|}
\hline \multicolumn{9}{|c|}{ SPOILS DISPOSAL AREAS } \\
\hline \multirow{2}{*}{$\begin{array}{l}\text { Package } \\
\text { I SD No. }\end{array}$} & \multirow[b]{2}{*}{ Location } & \multirow{2}{*}{$\begin{array}{c}\text { Approved } \\
\text { Area } \\
\left(\mathrm{m}^{2}\right)\end{array}$} & \multirow{2}{*}{$\begin{array}{c}\text { Approved } \\
\text { Capacity } \\
\left(\mathrm{m}^{3}\right)\end{array}$} & \multicolumn{2}{|c|}{ Ownership $^{a}$} & \multicolumn{2}{|c|}{ Approval } & \multirow[b]{2}{*}{ Operation } \\
\hline & & & & Name & Contact Info & \begin{tabular}{c|} 
Local \\
Authorities
\end{tabular} & PSC & \\
\hline A2/SD1 & $\begin{array}{l}\text { Fields } 99 \text { and } 99^{(1)} \text {, } \\
\text { map No. 21, Cau } \\
\text { hamlet, Hoang Dan } \\
\text { commune, Tam } \\
\text { Duong district, } \\
\text { Vinh Phuc province }\end{array}$ & $9,110 \mathrm{~m}^{2}$ & $30,000 \mathrm{~m}^{3}$ & $\begin{array}{l}\text { Hoa Hung } \\
\text { Co.,Ltd }\end{array}$ & $\begin{array}{l}\text { Hoang Dan } \\
\text { commune, Tam } \\
\text { Duong dist, } \\
\text { Vinh Phuc }\end{array}$ & 09-Jul-10 & 12-Jul-10 & \\
\hline A2/SD2 & $\begin{array}{l}\text { Tu Du commune, } \\
\text { Lap Thach district, } \\
\text { Vinh Phuc province }\end{array}$ & $60,000 \mathrm{~m}^{2}$ & $60,000 \mathrm{~m}^{3}$ & $\begin{array}{l}\text { Tu Du } \\
\text { commune }\end{array}$ & $\begin{array}{l}\text { Tu Du CPC, } \\
\text { Lap Thach dist, } \\
\text { Vinh Phuc }\end{array}$ & March-10 & 04-Jun-10 & \\
\hline A2/SD3 & $\begin{array}{l}\text { Dong Go area, } \\
\text { map No. 07, Tien } \\
\text { Lu commune, Lap } \\
\text { Thach district, Vinh } \\
\text { Phuc province }\end{array}$ & $2,000 \mathrm{~m}^{2}$ & $4,000 \mathrm{~m}^{3}$ & $\begin{array}{l}\text { Tien Lu } \\
\text { commune }\end{array}$ & $\begin{array}{l}\text { Tien Lu CPC, } \\
\text { Lap Thach dist, } \\
\text { Vinh Phuc }\end{array}$ & 28-May-10 & 04-Jun-10 & \\
\hline A2/SD4 & $\begin{array}{l}\text { Dong Ai area, map } \\
\text { No. } 19 \text {, Tien Lu }\end{array}$ & $12,000 \mathrm{~m}^{2}$ & $24,000 \mathrm{~m}^{3}$ & $\begin{array}{l}\text { Tien Lu } \\
\text { commune }\end{array}$ & $\begin{array}{l}\text { Tien Lu CPC, } \\
\text { Lap Thach dist, }\end{array}$ & 28-May-10 & 04-Jun-10 & \\
\hline
\end{tabular}


Loan 2391/2392 - VIE: GMS Kunming - Hai Phong Transport Corridor

Noi Bai - Lao Cai Highway Project

\begin{tabular}{|c|c|c|c|c|c|c|c|c|}
\hline \multicolumn{9}{|c|}{ SPOILS DISPOSAL AREAS } \\
\hline \multirow{2}{*}{$\begin{array}{l}\text { Package } \\
\text { I SD No. }\end{array}$} & \multirow[b]{2}{*}{ Location } & \multirow{2}{*}{$\begin{array}{c}\text { Approved } \\
\text { Area } \\
\left(\mathrm{m}^{2}\right)\end{array}$} & \multirow{2}{*}{$\begin{array}{c}\text { Approved } \\
\text { Capacity } \\
\left(\mathrm{m}^{3}\right)\end{array}$} & \multicolumn{2}{|c|}{ Ownership $^{\mathrm{a}}$} & \multicolumn{2}{|c|}{ Approval } & \multirow[b]{2}{*}{ Operation } \\
\hline & & & & Name & Contact Info & \begin{tabular}{c|} 
Local \\
Authorities
\end{tabular} & PSC & \\
\hline & $\begin{array}{l}\text { commune, Lap } \\
\text { Thach district, Vinh } \\
\text { Phuc province }\end{array}$ & & & & Vinh Phuc & & & \\
\hline A2/SD5 & $\begin{array}{l}\text { Field No. 155, map } \\
\text { No. 12, Phu Thinh } \\
\text { village, Tu Yen } \\
\text { commune, Song } \\
\text { Lo district, Vinh } \\
\text { Phuc province }\end{array}$ & $5,566 \mathrm{~m}^{2}$ & $11,132 \mathrm{~m}^{3}$ & $\begin{array}{l}\text { Tu Yen } \\
\text { commune }\end{array}$ & $\begin{array}{l}\text { Tu Yen CPC, } \\
\text { Song Lo dist, } \\
\text { Vinh Phuc }\end{array}$ & 11-May-10 & 20-May-10 & \\
\hline A2/SD6 & $\begin{array}{l}\text { Map No. 38, Khan } \\
\text { Tat hill, Dao Tu } \\
\text { commune, Tam } \\
\text { Duong district, } \\
\text { Vinh Phuc province }\end{array}$ & $10,300 \mathrm{~m}^{2}$ & $10,300 \mathrm{~m}^{3}$ & Ly Van Hung & $\begin{array}{c}\text { Dao Tu } \\
\text { commune, Tam } \\
\text { Duong, Vinh } \\
\text { Phuc }\end{array}$ & 25-Mar-10 & 31-Mar-10 & \\
\hline A2/SD7 & $\begin{array}{l}\text { Field No. 1, map } \\
\text { No. 3, Bo U hill, } \\
\text { Dao Tu commune, } \\
\text { Tam Duong } \\
\text { district, Vinh Phuc } \\
\text { province }\end{array}$ & $9,400 \mathrm{~m}^{2}$ & $9,400 \mathrm{~m}^{3}$ & $\begin{array}{l}\text { Nguyen Anh } \\
\text { Chien }\end{array}$ & $\begin{array}{c}\text { Dao Tu } \\
\text { commune, Tam } \\
\text { Duong, Vinh } \\
\text { Phuc }\end{array}$ & 25-Mar-10 & 31-Mar-10 & \\
\hline A2/SD8 & $\begin{array}{l}\text { Field No. 185, } \\
\text { Dong Ich } \\
\text { commune, Lap } \\
\text { Thach district, Vinh } \\
\text { Phuc province }\end{array}$ & $30,560 \mathrm{~m}^{2}$ & $30.560 \mathrm{~m}^{3}$ & $\begin{array}{l}\text { Dong Ich } \\
\text { commune }\end{array}$ & $\begin{array}{l}\text { Dong Ich CPC, } \\
\text { Lap Thach dist, } \\
\text { Vinh Phuc }\end{array}$ & 08-Mar-10 & 17-Mar-10 & \\
\hline A2/SD9 & $\begin{array}{l}\text { Field No. 613, } \\
\text { Dong Ich } \\
\text { commune, Lap } \\
\text { Thach district, Vinh } \\
\text { Phuc province }\end{array}$ & $10,345 \mathrm{~m}^{2}$ & $10,345 \mathrm{~m}^{3}$ & $\begin{array}{l}\text { Dong Ich } \\
\text { commune }\end{array}$ & $\begin{array}{l}\text { Dong Ich CPC, } \\
\text { Lap Thach dist, } \\
\text { Vinh Phuc }\end{array}$ & 08-Mar-10 & 17-Mar-10 & \\
\hline $\mathrm{A} 2 / \mathrm{SD} 10$ & $\begin{array}{l}\text { Field No. 78, Gian } \\
\text { village, Cao Phong } \\
\text { commune, Song } \\
\text { Lo district, Vinh }\end{array}$ & $3,268 \mathrm{~m}^{2}$ & $6,536 \mathrm{~m}^{3}$ & $\begin{array}{c}\text { Nguyen Van } \\
\text { Luu }\end{array}$ & $\begin{array}{l}\text { Cap Phong } \\
\text { commune, Song } \\
\text { Lo dist, Vinh } \\
\text { Phuc }\end{array}$ & 20-Mar-10 & 25-Mar-10 & \\
\hline
\end{tabular}


Loan 2391/2392 - VIE: GMS Kunming - Hai Phong Transport Corridor Noi Bai - Lao Cai Highway Project

\begin{tabular}{|c|c|c|c|c|c|c|c|c|}
\hline \multicolumn{9}{|c|}{ SPOILS DISPOSAL AREAS } \\
\hline \multirow{2}{*}{$\begin{array}{l}\text { Package } \\
\text { I SD No. }\end{array}$} & \multirow[b]{2}{*}{ Location } & \multirow{2}{*}{$\begin{array}{c}\text { Approved } \\
\text { Area } \\
\left(\mathrm{m}^{2}\right)\end{array}$} & \multirow{2}{*}{$\begin{array}{c}\text { Approved } \\
\text { Capacity } \\
\left(\mathrm{m}^{3}\right)\end{array}$} & \multicolumn{2}{|c|}{ Ownership $^{a}$} & \multicolumn{2}{|c|}{ Approval } & \multirow[b]{2}{*}{ Operation } \\
\hline & & & & Name & Contact Info & $\begin{array}{c}\text { Local } \\
\text { Authorities } \\
\end{array}$ & PSC & \\
\hline & Phuc province & & & & & & & \\
\hline A2/SD11 & $\begin{array}{l}\text { Fields No. 337, } \\
475,481, \text { Dong } \\
\text { Hang Phien village, } \\
\text { Dong Thinh } \\
\text { commune, Song } \\
\text { Lo district, Vinh } \\
\text { Phuc province } \\
\end{array}$ & $13,863 \mathrm{~m}^{2}$ & $100,000 \mathrm{~m}^{3}$ & $\begin{array}{c}\text { Dong Thinh } \\
\text { commune }\end{array}$ & $\begin{array}{l}\text { Dong Thich } \\
\text { CPC, Dong } \\
\text { Thinh } \\
\text { commune, Song } \\
\text { Lo dist, Vinh } \\
\text { Phuc }\end{array}$ & Mar-10 & 18-Mar-10 & \\
\hline $\mathrm{A} 2 / \mathrm{SD} 12$ & $\begin{array}{l}\text { Long Son village, } \\
\text { Dao Tu commune, } \\
\text { Tam Duong } \\
\text { district, Vinh Phuc } \\
\text { province }\end{array}$ & $2,250 \mathrm{~m}^{2}$ & $5,500 \mathrm{~m}^{3}$ & $\begin{array}{l}\text { Lai Xuan } \\
\text { Diem }\end{array}$ & $\begin{array}{l}\text { Long Son } \\
\text { village, Dao Tu } \\
\text { commune, Tam } \\
\text { Duong district, } \\
\text { Vinh Phuc } \\
\text { province }\end{array}$ & 07-Mar-13 & 30-May-13 & \\
\hline
\end{tabular}

\begin{tabular}{|c|c|c|c|c|c|c|c|c|c|c|c|}
\hline \multicolumn{12}{|c|}{ BATCHING PLANTS } \\
\hline \multirow{2}{*}{$\begin{array}{l}\text { Packagel } \\
\text { CBP No. }\end{array}$} & \multirow[b]{2}{*}{ Location } & \multirow{2}{*}{$\begin{array}{l}\text { Appropriate } \\
\text { settling pond }\end{array}$} & \multirow{2}{*}{$\begin{array}{c}\text { Noise and } \\
\text { dust } \\
\text { measures }\end{array}$} & \multicolumn{2}{|c|}{ Ownership $^{a}$} & \multirow{2}{*}{$\begin{array}{l}\text { Prior Land } \\
\text { Use }^{b}\end{array}$} & \multicolumn{2}{|c|}{ Approval } & \multicolumn{3}{|c|}{ Operation } \\
\hline & & & & Name & Contact Info & & $\begin{array}{c}\text { Local } \\
\text { Authorities }\end{array}$ & PSC & Start & Est. End & $\begin{array}{l}\text { Actual } \\
\text { End }\end{array}$ \\
\hline A2/CBP1 & $\mathrm{Km} \mathrm{39+118}$ & Yes & Yes & $\begin{array}{l}\text { Vinh Sinh } \\
\text { Co.,Ltd }\end{array}$ & $\begin{array}{c}160-\text { Dinh } \\
\text { Dong - Le Chan } \\
\text { dist, Hai Phong } \\
\text { City }\end{array}$ & $\begin{array}{l}\text { Agricultural } \\
\text { land }\end{array}$ & Unidentified & 17-Nov-10 & 17-Nov-10 & & $\begin{array}{c}\text { March } \\
2014\end{array}$ \\
\hline A2/CBP2 & Lo River Bridge & Yes & Yes & POSCO & $\begin{array}{l}\text { POSCO E\&C - } \\
\text { Noi Bai - Lao } \\
\text { Cai Highway } \\
\text { project - Huu } \\
\text { thu village, Kim } \\
\text { Long commune, } \\
\text { Tam Duong } \\
\text { dist, Vinh Phuc }\end{array}$ & $\begin{array}{l}\text { Agricultural } \\
\quad \text { land }\end{array}$ & 05-May-08 & 15-Jun-11 & 15-Jun-11 & & $\begin{array}{c}\text { March } \\
2014\end{array}$ \\
\hline
\end{tabular}


Loan 2391/2392 - VIE: GMS Kunming - Hai Phong Transport Corridor Noi Bai - Lao Cai Highway Project

\begin{tabular}{|c|c|c|c|c|c|c|c|c|c|c|c|}
\hline \multicolumn{12}{|c|}{ BATCHING PLANTS } \\
\hline \multirow{2}{*}{$\begin{array}{l}\text { Packagel } \\
\text { CBP No. }\end{array}$} & \multirow[b]{2}{*}{ Location } & \multirow{2}{*}{$\begin{array}{l}\text { Appropriate } \\
\text { settling pond }\end{array}$} & \multirow{2}{*}{$\begin{array}{c}\text { Noise and } \\
\text { dust } \\
\text { measures }\end{array}$} & \multicolumn{2}{|c|}{ Ownership $^{a}$} & \multirow{2}{*}{$\begin{array}{c}\text { Prior Land } \\
\text { Use }^{b}\end{array}$} & \multicolumn{2}{|c|}{ Approval } & \multicolumn{3}{|c|}{ Operation } \\
\hline & & & & Name & Contact Info & & $\begin{array}{c}\text { Local } \\
\text { Authorities }\end{array}$ & PSC & Start & Est. End & $\begin{array}{l}\text { Actual } \\
\text { End }\end{array}$ \\
\hline A2/CBP3 & Lo River Bridge & Yes & Yes & POSCO & $\begin{array}{c}\text { POSCO E\&C - } \\
\text { Noi Bai - Lao } \\
\text { Cai Highway } \\
\text { project - Huu } \\
\text { thu village, Kim } \\
\text { Long commune, } \\
\text { Tam Duong } \\
\text { dist, Vinh Phuc }\end{array}$ & Wild land & 05-May-08 & 25-Jun-11 & 25-Jun-11 & & $\begin{array}{l}\text { March } \\
2014\end{array}$ \\
\hline
\end{tabular}

\section{Package A3}

\begin{tabular}{|c|c|c|c|c|c|c|c|c|c|c|c|}
\hline \multicolumn{12}{|c|}{ BORROW PITS } \\
\hline \multirow[b]{2}{*}{$\begin{array}{c}\text { Package } \\
\text { I Borrow } \\
\text { Pit No. }\end{array}$} & \multirow[b]{2}{*}{ Location } & \multirow{2}{*}{$\begin{array}{c}\text { Approve } \\
\text { d } \\
\text { Area } \\
\left(\mathrm{m}^{2}\right)\end{array}$} & \multirow{2}{*}{$\begin{array}{c}\text { Approve } \\
\text { d } \\
\text { Volume } \\
\left(\mathrm{m}^{3}\right)\end{array}$} & \multicolumn{2}{|c|}{ Ownership $^{a}$} & \multirow[b]{2}{*}{$\begin{array}{l}\text { Prior Land } \\
\text { Use }^{\mathbf{b}}\end{array}$} & \multicolumn{2}{|c|}{ Approval } & \multicolumn{3}{|c|}{ Operation Schedule } \\
\hline & & & & Name & Contact Info & & Date & Agency $^{c}$ & Start & $\begin{array}{l}\text { Estimated } \\
\text { Completion }\end{array}$ & $\begin{array}{c}\text { Actual } \\
\text { Completio } \\
n\end{array}$ \\
\hline 1 & Km 52+500 (Section 1) & & $\begin{array}{c}90,000 \mathrm{~m}^{3} \\
/ 1 \text { year }\end{array}$ & TGT Group & 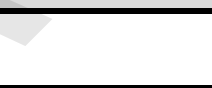 & Hill land & & $\begin{array}{l}\text { Phu Tho } \\
\text { Province }\end{array}$ & $\begin{array}{l}\text { 02-Jul- } \\
12\end{array}$ & 30-Aug-13 & Not yet \\
\hline 2 & Km 53+700 (Section 1) & & $\begin{array}{c}90,000 \mathrm{~m}^{3} \\
/ 1 \text { year }\end{array}$ & TGT Group & & Hill land & & $\begin{array}{l}\text { Phu Tho } \\
\text { Province }\end{array}$ & $\begin{array}{l}\text { 02-Jul- } \\
12\end{array}$ & 30-Aug-13 & Not yet \\
\hline 3 & Km 54+000 (Section 1) & & $\begin{array}{c}90,000 \mathrm{~m}^{3} \\
/ 1 \text { year }\end{array}$ & TGT Group & & Hill land & & $\begin{array}{l}\text { Phu Tho } \\
\text { Province }\end{array}$ & $\begin{array}{l}\text { 02-Jul- } \\
12\end{array}$ & 30-Aug-13 & Not yet \\
\hline 4 & $\begin{array}{l}\text { Km } 54+000 \text { (Section } \\
3 \text { ) }\end{array}$ & & 328,295 & Long Vuong & & Hill land & & $\begin{array}{l}\text { Phu Tho } \\
\text { Province }\end{array}$ & $\begin{array}{l}\text { 15-Aug- } \\
11\end{array}$ & 14-Jun-13 & Not yet \\
\hline 5 & Km $76+400$ (Section 6) & & 264,527 & VINASHIN & & Hill land & & $\begin{array}{l}\text { Phu Tho } \\
\text { Province }\end{array}$ & $\begin{array}{l}10-F e b- \\
12\end{array}$ & 31-Aug-13 & Not yet \\
\hline
\end{tabular}


Loan 2391/2392 - VIE: GMS Kunming - Hai Phong Transport Corridor Noi Bai - Lao Cai Highway Project

\begin{tabular}{|c|c|c|c|c|c|c|c|c|c|c|c|}
\hline \multicolumn{12}{|c|}{ BORROW PITS } \\
\hline \multirow[b]{2}{*}{$\begin{array}{c}\text { Package } \\
\text { I Borrow } \\
\text { Pit No. }\end{array}$} & \multirow[b]{2}{*}{ Location } & \multirow{2}{*}{$\begin{array}{c}\text { Approve } \\
\text { d } \\
\text { Area } \\
\left(\mathrm{m}^{2}\right)\end{array}$} & \multirow{2}{*}{$\begin{array}{c}\text { Approve } \\
\text { d } \\
\text { Volume } \\
\left(\mathrm{m}^{3}\right)\end{array}$} & \multicolumn{2}{|c|}{ Ownership $^{a}$} & \multirow[b]{2}{*}{$\begin{array}{l}\text { Prior Land } \\
\text { Use }^{b}\end{array}$} & \multicolumn{2}{|c|}{ Approval } & \multicolumn{3}{|c|}{ Operation Schedule } \\
\hline & & & & Name & Contact Info & & Date & Agency $^{c}$ & Start & $\begin{array}{l}\text { Estimated } \\
\text { Completion }\end{array}$ & $\begin{array}{c}\text { Actual } \\
\text { Completio } \\
n\end{array}$ \\
\hline 6 & Km $81+000$ (Section 7) & & 805,000 & Posco E\&C & & Hill land & & $\begin{array}{l}\text { Phu Tho } \\
\text { Province }\end{array}$ & & & Not yet \\
\hline
\end{tabular}

\begin{tabular}{|c|c|c|c|c|c|c|c|c|c|c|c|}
\hline \multicolumn{12}{|c|}{ QUARRIES } \\
\hline \multirow{2}{*}{$\begin{array}{l}\text { Package } \\
\text { I Quarry } \\
\text { No. }\end{array}$} & \multirow[b]{2}{*}{ Location } & \multirow{2}{*}{$\begin{array}{l}\text { Approved } \\
\text { Area }\left(\mathrm{m}^{2}\right)\end{array}$} & \multirow{2}{*}{$\begin{array}{l}\text { Approved } \\
\text { Volume } \\
\left(\mathrm{m}^{3}\right)\end{array}$} & \multicolumn{2}{|c|}{ Ownership $^{a}$} & \multirow{2}{*}{$\begin{array}{c}\text { Prior Land } \\
\text { Use }^{\mathbf{b}}\end{array}$} & \multicolumn{2}{|c|}{ Approval } & \multicolumn{3}{|c|}{ Operation Schedule } \\
\hline & & & & Name & Contact Info & & Date & Agency $^{c}$ & Start & $\begin{array}{l}\text { Estimated } \\
\text { Completion }\end{array}$ & $\begin{array}{c}\text { Actual } \\
\text { Completion }\end{array}$ \\
\hline 1 & $\begin{array}{c}\text { Phu Man comm. } \\
\text { Quoc Oai dist. Ha Noi } \\
\text { Capital }\end{array}$ & & & $\begin{array}{c}\text { Sunway- } \\
\text { Hataco JSC }\end{array}$ & & & & & & & \\
\hline 2 & $\begin{array}{c}\text { Phu Man comm. } \\
\text { Quoc Oai dist. Ha Noi } \\
\text { Capital }\end{array}$ & & & Vimeco JSC & & $y$ & & & $1-O c t-13$ & 30-Jan-14 & \\
\hline 3 & $\begin{array}{l}\text { Ngoc Lap comm. Yen } \\
\text { Lap dist. Phu Tho } \\
\text { pro. }\end{array}$ & & & $\begin{array}{c}\text { Phu Tho } \\
\text { forest \& } \\
\text { mineral } \\
\text { product JSC }\end{array}$ & & & & & & & \\
\hline 4 & $\begin{array}{l}\text { Phuc Ung comm. } \\
\text { Son duong dist., } \\
\text { Tuyen Quang pro. }\end{array}$ & & & $\begin{array}{c}\text { Tuyen } \\
\text { Quang } \\
\text { forest \& } \\
\text { mineral } \\
\text { product JSC }\end{array}$ & $\bar{z}$ & & & & $\begin{array}{c}\text { 23-Nov- } \\
12\end{array}$ & 31-Mar-13 & \\
\hline 5 & $\begin{array}{l}\text { Huong Can comm. } \\
\text { Thanh Son dist., Phu } \\
\text { Tho pro. }\end{array}$ & & & $\begin{array}{l}\text { ThanhCong } \\
\text { limited Co., }\end{array}$ & & & & & $\begin{array}{c}\text { 16-Jan- } \\
13\end{array}$ & 20-Nov-13 & \\
\hline 6 & $\begin{array}{l}\text { Thuong Am comm., } \\
\text { Son Duong dist. } \\
\text { Tuyen Quang pro. }\end{array}$ & & & $\begin{array}{l}\text { Duy Thinh } \\
\text { Co., }\end{array}$ & & & & & & & \\
\hline 7 & $\begin{array}{c}\text { Nhu Khe comm. } \\
\text { Thanh Liem dist., Ha } \\
\text { Nam pro. }\end{array}$ & & & $\begin{array}{l}\text { Thang Loi } \\
\text { cooperative }\end{array}$ & & & & & & & \\
\hline
\end{tabular}


Loan 2391/2392 - VIE: GMS Kunming - Hai Phong Transport Corridor Noi Bai - Lao Cai Highway Project

\begin{tabular}{|c|c|c|c|c|c|c|c|c|c|c|c|}
\hline \multicolumn{12}{|c|}{ QUARRIES } \\
\hline \multirow{2}{*}{$\begin{array}{l}\text { Package } \\
\text { I Quarry } \\
\text { No. }\end{array}$} & \multirow[b]{2}{*}{ Location } & \multirow{2}{*}{$\begin{array}{l}\text { Approved } \\
\text { Area }\left(\mathrm{m}^{2}\right)\end{array}$} & \multirow{2}{*}{$\begin{array}{c}\text { Approved } \\
\text { Volume } \\
\left(\mathrm{m}^{3}\right)\end{array}$} & \multicolumn{2}{|c|}{ Ownership $^{a}$} & \multirow{2}{*}{$\begin{array}{l}\text { Prior Land } \\
\text { Use }^{b}\end{array}$} & \multicolumn{2}{|c|}{ Approval } & \multicolumn{3}{|c|}{ Operation Schedule } \\
\hline & & & & Name & Contact Info & & Date & Agency $^{c}$ & Start & $\begin{array}{c}\text { Estimated } \\
\text { Completion }\end{array}$ & $\begin{array}{c}\text { Actual } \\
\text { Completion }\end{array}$ \\
\hline 8 & $\begin{array}{c}\text { Dan Ha comm., Ky } \\
\text { Son dist., Hoa Binh } \\
\text { pro. } \\
\end{array}$ & & & N/A & & & & & & & \\
\hline 9 & $\begin{array}{l}\text { Doi Can comm. Yen } \\
\text { Son dist. Tuyen } \\
\text { Quang pro. }\end{array}$ & & & $\begin{array}{l}\text { Ha Nam } \\
\text { lime stone } \\
\text { Co., - Mrs }\end{array}$ & & & & & & & \\
\hline 10 & $\begin{array}{l}\text { Ngoc Lap comm. Yen } \\
\text { Lap dist. Phu Tho } \\
\text { pro. }\end{array}$ & & & Tu Lap Co., & & & & & & & \\
\hline 11 & $\begin{array}{c}\text { Ngoc Lap comm. Yen } \\
\text { Lap dist. Phu Tho } \\
\text { pro. }\end{array}$ & & & $\begin{array}{l}\text { Truong An } \\
\text { JSC }\end{array}$ & & & & & 6-Feb-13 & 10-Nov-13 & \\
\hline 12 & $\begin{array}{l}\text { Quang Son comm. } \\
\text { Lap Thach dist. Vinh } \\
\text { Phuc pro. }\end{array}$ & & & $\begin{array}{l}\text { Hung Vi } \\
\text { Co., }\end{array}$ & & & & & & & \\
\hline 13 & $\begin{array}{l}\text { Cao Duong comm. } \\
\text { Luong Son dist. Hoa } \\
\text { Binh pro.. }\end{array}$ & & & $\begin{array}{c}\text { Ngoc Thao } \\
\text { Co., }\end{array}$ & & & & & 1-Apr-13 & 3-Nov-13 & \\
\hline 14 & $\begin{array}{l}\text { Cao Duong comm. } \\
\text { Luong Son dist. Hoa } \\
\text { Binh pro.. } \\
\end{array}$ & & & $\begin{array}{l}\text { Valine Co., } \\
\text { (Hung } \\
\text { Long) } \\
\end{array}$ & & & & & & & \\
\hline
\end{tabular}

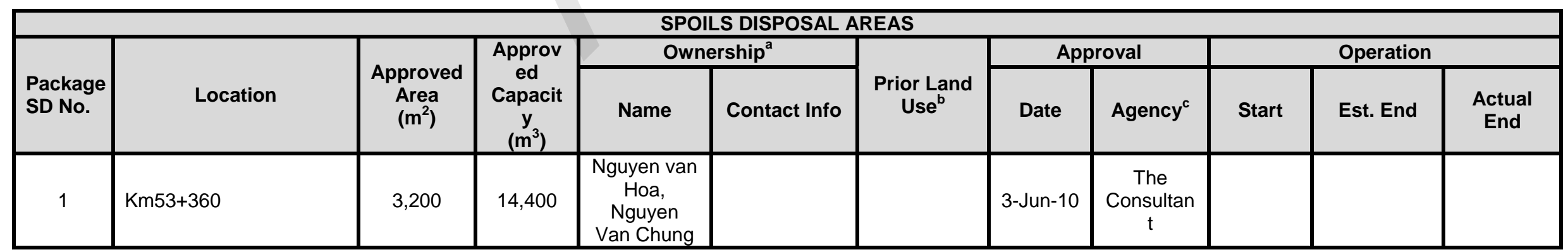


Loan 2391/2392 - VIE: GMS Kunming - Hai Phong Transport Corridor Noi Bai - Lao Cai Highway Project

\begin{tabular}{|c|c|c|c|c|c|c|c|c|c|c|c|}
\hline \multicolumn{12}{|c|}{ SPOILS DISPOSAL AREAS } \\
\hline \multirow[b]{2}{*}{$\begin{array}{l}\text { Package } \\
\text { SD No. }\end{array}$} & \multirow[b]{2}{*}{ Location } & \multirow[b]{2}{*}{$\begin{array}{c}\text { Approved } \\
\text { Area } \\
\left(\mathrm{m}^{2}\right)\end{array}$} & \multirow{2}{*}{$\begin{array}{c}\text { Approv } \\
\text { ed } \\
\text { Capacit } \\
y \\
\left(\mathrm{~m}^{3}\right)\end{array}$} & \multicolumn{2}{|c|}{ Ownership $^{a}$} & \multirow[b]{2}{*}{$\begin{array}{l}\text { Prior Land } \\
\text { Use }^{b}\end{array}$} & \multicolumn{2}{|c|}{ Approval } & \multicolumn{3}{|c|}{ Operation } \\
\hline & & & & Name & Contact Info & & Date & Agency $^{c}$ & Start & Est. End & $\begin{array}{l}\text { Actual } \\
\text { End }\end{array}$ \\
\hline 2 & $\mathrm{Km} 49+500$ & 2,350 & 46,000 & Le Van Ngu & & $\begin{array}{c}\text { Rice field \& } \\
\text { Vegetable } \\
\text { field }\end{array}$ & $\begin{array}{c}\text { 16-Feb- } \\
11\end{array}$ & $\begin{array}{c}\text { The } \\
\text { Consultan } \\
\mathrm{t}\end{array}$ & & & \\
\hline 3 & $\mathrm{Km} 49+600$ & 1,954 & 37,000 & $\begin{array}{l}\text { Nguyen } \\
\text { Tien Dung }\end{array}$ & & $\begin{array}{l}\text { Rice field \& } \\
\text { Vegetable } \\
\text { field }\end{array}$ & $\begin{array}{c}\text { 16-Feb- } \\
11\end{array}$ & $\begin{array}{c}\text { The } \\
\text { Consultan } \\
\mathrm{t}\end{array}$ & & & \\
\hline 4 & Km50+900 & 2,146 & 29,000 & $\begin{array}{l}\text { Le Dinh } \\
\text { Chat }\end{array}$ & & $\begin{array}{l}\text { Rice field \& } \\
\text { Vegetable } \\
\text { field }\end{array}$ & $\begin{array}{c}\text { 16-Feb- } \\
11\end{array}$ & $\begin{array}{c}\text { The } \\
\text { Consultan } \\
\mathrm{t}\end{array}$ & & & \\
\hline 5 & $\mathrm{Km} 51+400$ & 1,940 & 35,000 & $\begin{array}{c}\text { Nguyen Thi } \\
\text { Ly }\end{array}$ & & $\begin{array}{l}\text { Rice field \& } \\
\text { Vegetable } \\
\text { field }\end{array}$ & $\begin{array}{c}\text { 16-Feb- } \\
11\end{array}$ & $\begin{array}{c}\text { The } \\
\text { Consultan } \\
t\end{array}$ & & & \\
\hline 6 & $\mathrm{Km} 52+800$ & 5,690 & 34,000 & $\begin{array}{c}\text { Nguyen Thi } \\
\text { Tuat }\end{array}$ & & $\begin{array}{l}\text { Rice field \& } \\
\text { Vegetable } \\
\text { field }\end{array}$ & $\begin{array}{c}\text { 16-Feb- } \\
11\end{array}$ & $\begin{array}{c}\text { The } \\
\text { Consultan } \\
\mathrm{t}\end{array}$ & & & \\
\hline 7 & Area No. 8 - Hung Lo & 53,489 & 500,000 & $\begin{array}{c}\text { Nguyen } \\
\text { Xuan } \\
\text { Thuong, } \\
\text { Nguyen } \\
\text { Van Sang, } \\
\text { Cao Van } \\
\text { Chinh, Cao } \\
\text { Van Duong, } \\
\text { Cao Van } \\
\text { Minh }\end{array}$ & & & $\begin{array}{c}\text { 22-Mar- } \\
11\end{array}$ & $\begin{array}{c}\text { The } \\
\text { Consultan } \\
\mathrm{t}\end{array}$ & & & \\
\hline 8 & $\mathrm{Km} 52+740$ & 4,114 & 30,000 & $\begin{array}{l}\text { Nguyen } \\
\text { Xuan Hai }\end{array}$ & & $\begin{array}{l}\text { Area No.2 - } \\
\text { Phu Ninh } \\
\text { Commune }\end{array}$ & $\begin{array}{c}\text { 24-Apr- } \\
13\end{array}$ & $\begin{array}{c}\text { The } \\
\text { Consultan } \\
\mathrm{t}\end{array}$ & & & \\
\hline 9 & $\mathrm{Km} 52+840$ & 6,021 & 60,000 & $\begin{array}{l}\text { Nguyen } \\
\text { Van The }\end{array}$ & & $\begin{array}{l}\text { Area No.2 - } \\
\text { Phu Ninh } \\
\text { Commune }\end{array}$ & $\begin{array}{c}\text { 24-Apr- } \\
13\end{array}$ & $\begin{array}{c}\text { The } \\
\text { Consultan } \\
\mathrm{t}\end{array}$ & & & \\
\hline 10 & $\mathrm{Km} 54+020$ & 6,084 & 50,000 & Nguyen & & Area No.5 - & & & & & \\
\hline
\end{tabular}


Loan 2391/2392 - VIE: GMS Kunming - Hai Phong Transport Corridor Noi Bai - Lao Cai Highway Project

\begin{tabular}{|c|c|c|c|c|c|c|c|c|c|c|c|}
\hline \multicolumn{12}{|c|}{ SPOILS DISPOSAL AREAS } \\
\hline \multirow[b]{2}{*}{$\begin{array}{l}\text { Package } \\
\text { SD No. }\end{array}$} & \multirow[b]{2}{*}{ Location } & \multirow[b]{2}{*}{$\begin{array}{c}\text { Approved } \\
\text { Area } \\
\left(\mathrm{m}^{2}\right)\end{array}$} & \multirow{2}{*}{$\begin{array}{c}\text { Approv } \\
\text { ed } \\
\text { Capacit } \\
\text { y } \\
\left(\mathrm{m}^{3}\right)\end{array}$} & \multicolumn{2}{|c|}{ Ownership $^{a}$} & \multirow[b]{2}{*}{$\begin{array}{l}\text { Prior Land } \\
\text { Use }^{b}\end{array}$} & \multicolumn{2}{|c|}{ Approval } & \multicolumn{3}{|c|}{ Operation } \\
\hline & & & & Name & Contact Info & & Date & Agency $^{c}$ & Start & Est. End & $\begin{array}{l}\text { Actual } \\
\text { End }\end{array}$ \\
\hline & & & & Van Bay & & $\begin{array}{l}\text { Phu Ninh } \\
\text { Commune }\end{array}$ & & & & & \\
\hline 11 & $\begin{array}{l}\text { Hop Quan - Phu Ninh } \\
\text { Commune }\end{array}$ & 21,000 & 378,000 & $\begin{array}{l}\text { Phu Ninh } \\
\text { Commune }\end{array}$ & & $\begin{array}{c}\text { Area No. } 10 \\
\text { near Nha } \\
\text { Xe hill } \\
\end{array}$ & $\begin{array}{c}13-\text { Oct- } \\
10\end{array}$ & $\begin{array}{c}\text { The } \\
\text { Consultan } \\
\mathrm{t}\end{array}$ & & & \\
\hline 12 & Tien Kien Commune & 15,724 & 283,032 & $\begin{array}{l}\text { Nguyen } \\
\text { Cong Chuc }\end{array}$ & & $\begin{array}{l}\text { Area No. } 8 \\
\text { \&No.9 }\end{array}$ & $\begin{array}{l}\text { 4-Nov- } \\
11\end{array}$ & $\begin{array}{c}\text { The } \\
\text { Consultan } \\
\mathrm{t}\end{array}$ & & & \\
\hline 13 & $\begin{array}{l}\text { Km56+100 - Phu Ninh } \\
\text { Commune }\end{array}$ & 5,070 & 40,000 & $\begin{array}{l}\text { Nguyen } \\
\text { Truong } \\
\text { Giang }\end{array}$ & & $\begin{array}{l}\text { Area No.10 } \\
\text { - Phu Ninh } \\
\text { Commune }\end{array}$ & $\begin{array}{l}\text { 22-Apr- } \\
11\end{array}$ & $\begin{array}{c}\text { The } \\
\text { Consultan } \\
\mathrm{t}\end{array}$ & & & \\
\hline 14 & $\begin{array}{l}\text { Km55+900 - Phu Ninh } \\
\text { Commune }\end{array}$ & 2,880 & 15,500 & $\begin{array}{l}\text { Nguyen } \\
\text { Van Tai }\end{array}$ & & $\begin{array}{l}\text { Area No.10 } \\
\text { - Phu Ninh } \\
\text { Commune }\end{array}$ & $\begin{array}{l}\text { 24-Apr- } \\
13\end{array}$ & $\begin{array}{c}\text { The } \\
\text { Consultan } \\
\mathrm{t}\end{array}$ & & & \\
\hline 15 & $\begin{array}{l}\text { Ram A1-2 Km00+100 } \\
\text { Phu Ninh Commune }\end{array}$ & 5,736 & 50,000 & $\begin{array}{l}\text { Nguyen } \\
\text { Van Chi }\end{array}$ & & $\begin{array}{l}\text { Area No.8 - } \\
\text { Phu Ninh } \\
\text { Commune }\end{array}$ & $\begin{array}{l}\text { 24-Apr- } \\
13\end{array}$ & $\begin{array}{c}\text { The } \\
\text { Consultan } \\
\mathrm{t}\end{array}$ & & & \\
\hline 16 & $\begin{array}{l}\text { Ram A1-2 Km00+200 - } \\
\text { Phu Ninh Commune }\end{array}$ & 4,072 & 35,000 & $\begin{array}{l}\text { Nguyen Thi } \\
\text { Nhuan }\end{array}$ & & $\begin{array}{l}\text { Area No.4 - } \\
\text { Phu Ninh } \\
\text { Commune }\end{array}$ & $\begin{array}{l}\text { 24-Apr- } \\
13\end{array}$ & $\begin{array}{c}\text { The } \\
\text { Consultan } \\
\mathrm{t}\end{array}$ & & & \\
\hline 17 & $\begin{array}{l}\text { Km53+800 - Phu Ninh } \\
\text { Commune }\end{array}$ & 8,172 & 70,000 & $\begin{array}{l}\text { Phu Ninh } \\
\text { Commune }\end{array}$ & & $\begin{array}{l}\text { Area No.7 - } \\
\text { Phu Ninh } \\
\text { Commune } \\
\end{array}$ & $\begin{array}{l}\text { 24-Apr- } \\
13\end{array}$ & $\begin{array}{c}\text { The } \\
\text { Consultan } \\
\mathrm{t}\end{array}$ & & & \\
\hline 18 & $\begin{array}{l}\text { Km56+300 - Phu Ninh } \\
\text { Commune }\end{array}$ & 6,163 & 50,000 & $\begin{array}{l}\text { Phu Ninh } \\
\text { Commune }\end{array}$ & & $\begin{array}{l}\text { Area No.10 } \\
\text { - Phu Ninh } \\
\text { Commune } \\
\end{array}$ & $\begin{array}{l}\text { 24-Apr- } \\
13\end{array}$ & $\begin{array}{c}\text { The } \\
\text { Consultan } \\
\mathrm{t}\end{array}$ & & & \\
\hline 19 & Phu Ho Commune & 25,000 & 150,000 & $\begin{array}{l}\text { Nguyen } \\
\text { Van Thai }\end{array}$ & & $\begin{array}{l}\text { Area No.5 - } \\
\text { Phu Ho } \\
\text { Commune }\end{array}$ & $\begin{array}{l}\text { 25-Feb- } \\
11\end{array}$ & $\begin{array}{c}\text { The } \\
\text { Consultan } \\
\mathrm{t}\end{array}$ & & & \\
\hline 20 & Van Lung Commune & 11,508 & 69,500 & $\begin{array}{l}\text { Van Lung } \\
\text { Commune }\end{array}$ & & Dui forest & $\begin{array}{l}\text { 13-Oct- } \\
10\end{array}$ & $\begin{array}{c}\text { The } \\
\text { Consultan } \\
\mathrm{t}\end{array}$ & & & \\
\hline
\end{tabular}


Loan 2391/2392 - VIE: GMS Kunming - Hai Phong Transport Corridor Noi Bai - Lao Cai Highway Project

\begin{tabular}{|c|c|c|c|c|c|c|c|c|c|c|c|}
\hline \multicolumn{12}{|c|}{ SPOILS DISPOSAL AREAS } \\
\hline \multirow[b]{2}{*}{$\begin{array}{l}\text { Package } \\
\text { SD No. }\end{array}$} & \multirow[b]{2}{*}{ Location } & \multirow{2}{*}{$\begin{array}{c}\text { Approved } \\
\text { Area } \\
\left(\mathrm{m}^{2}\right)\end{array}$} & \multirow{2}{*}{$\begin{array}{c}\text { Approv } \\
\text { ed } \\
\text { Capacit } \\
y \\
\left(\mathrm{~m}^{3}\right)\end{array}$} & \multicolumn{2}{|c|}{ Ownership $^{a}$} & \multirow[b]{2}{*}{$\begin{array}{c}\text { Prior Land } \\
\text { Use }^{\mathbf{b}}\end{array}$} & \multicolumn{2}{|c|}{ Approval } & \multicolumn{3}{|c|}{ Operation } \\
\hline & & & & Name & Contact Info & & Date & Agency $^{c}$ & Start & Est. End & $\begin{array}{c}\text { Actual } \\
\text { End }\end{array}$ \\
\hline 21 & Vo Lao Commune & 12,850 & 89,950 & $\begin{array}{l}\text { Dinh Tien } \\
\text { Minh }\end{array}$ & & & $\begin{array}{c}\text { 06-Sep- } \\
10\end{array}$ & $\begin{array}{c}\text { The } \\
\text { Consultan } \\
\mathrm{t}\end{array}$ & & & \\
\hline 22 & $\begin{array}{l}\text { Chi Tien \& Hoang } \\
\text { Cuong Commune }\end{array}$ & 15,170 & 106,190 & $\begin{array}{c}\text { Tran Quy } \\
\text { Cuong }\end{array}$ & & & $\begin{array}{c}\text { 19-Oct- } \\
10\end{array}$ & $\begin{array}{c}\text { The } \\
\text { Consultan } \\
\mathrm{t}\end{array}$ & & & \\
\hline 23 & Yen Lap Commune & 4,517 & 90,340 & $\begin{array}{c}\text { Truong } \\
\text { Xuan } \\
\text { Company.,L } \\
\text { TD }\end{array}$ & & & $\begin{array}{c}\text { 27-Jul- } \\
12\end{array}$ & $\begin{array}{c}\text { The } \\
\text { Consultan } \\
\mathrm{t}\end{array}$ & & & \\
\hline
\end{tabular}

\begin{tabular}{|c|c|c|c|c|c|c|c|c|c|c|c|}
\hline \multicolumn{12}{|c|}{ BATCHING PLANTS } \\
\hline \multirow{2}{*}{$\begin{array}{l}\text { Packag } \\
\text { e I SD } \\
\text { No. }\end{array}$} & \multirow[b]{2}{*}{ Location } & \multirow{2}{*}{$\begin{array}{c}\text { Appropriat } \\
\text { e settling } \\
\text { pond }\end{array}$} & \multirow{2}{*}{$\begin{array}{c}\text { Noise } \\
\text { and dust } \\
\text { measure } \\
\text { s }\end{array}$} & \multicolumn{2}{|c|}{ Ownership $^{a}$} & \multirow{2}{*}{$\begin{array}{l}\text { Prior Land } \\
\text { Use }^{b}\end{array}$} & \multicolumn{2}{|c|}{ Approval } & \multicolumn{3}{|c|}{ Operation } \\
\hline & & & & Name & Contact Info & & Date & Agency $^{c}$ & Start & Est. End & $\begin{array}{c}\text { Actual } \\
\text { End }\end{array}$ \\
\hline 1 & $\begin{array}{l}\text { Section } 2-\text { Concrete } \\
\text { batching plant } D\end{array}$ & Yes & Yes & $\begin{array}{l}\text { HEUNG WOO } \\
\text { VINA CO., } \\
\text { LTD }\end{array}$ & $>$ & & & & $\begin{array}{l}\text { 10-Aug- } \\
10\end{array}$ & 31-Dec-13 & \\
\hline 2 & $\begin{array}{l}\text { Section } 7-\text { Concrete } \\
\text { batching plan } t\end{array}$ & Yes & Yes & Evernew & & & & & 8-Dec-12 & 30-Jul-13 & \\
\hline 3 & $\begin{array}{l}\text { IC No.10 bridge - } \\
\text { Concrete } \\
\text { plant }\end{array}$ & Yes & Yes & $\begin{array}{l}\text { Duong Chau } \\
\text { Construction } \\
\text { and Trading } \\
\text { company } \\
\end{array}$ & & & & & $\begin{array}{c}\text { 10-Jan- } \\
13\end{array}$ & 9-Jul-13 & \\
\hline 4 & Phu Ninh - Phu Tho & Yes & Yes & $\begin{array}{c}\text { Song Lo } \\
\text { construction } \\
\text { \&tradinG, JSC }\end{array}$ & & & & & $\begin{array}{l}\text { 14-Sep- } \\
11\end{array}$ & 31-Dec-13 & \\
\hline
\end{tabular}


Loan 2391/2392 - VIE: GMS Kunming - Hai Phong Transport Corridor Noi Bai - Lao Cai Highway Project

\begin{tabular}{|c|c|c|c|c|c|c|c|c|c|c|c|}
\hline \multicolumn{12}{|c|}{ BATCHING PLANTS } \\
\hline \multirow{2}{*}{$\begin{array}{l}\text { Packag } \\
\text { e I SD } \\
\text { No. }\end{array}$} & \multirow[b]{2}{*}{ Location } & \multirow{2}{*}{$\begin{array}{c}\text { Appropriat } \\
\text { e settling } \\
\text { pond }\end{array}$} & \multirow{2}{*}{$\begin{array}{c}\text { Noise } \\
\text { and dust } \\
\text { measure } \\
\text { s }\end{array}$} & \multicolumn{2}{|c|}{ Ownership $^{a}$} & \multirow{2}{*}{$\begin{array}{l}\text { Prior Land } \\
\text { Use }^{b}\end{array}$} & \multicolumn{2}{|c|}{ Approval } & \multicolumn{3}{|c|}{ Operation } \\
\hline & & & & Name & Contact Info & & Date & Agency $^{c}$ & Start & Est. End & $\begin{array}{c}\text { Actual } \\
\text { End }\end{array}$ \\
\hline 5 & $\begin{array}{l}\text { Section } 3-\text { Asphalt } \\
\text { concrete } \\
\text { plant }\end{array}$ & $N / A$ & Yes & SEAHAN & & & & & $\begin{array}{l}\text { 31-Dec- } \\
12\end{array}$ & 3-May-13 & \\
\hline 6 & $\begin{array}{l}\text { Section } 7-\begin{array}{r}\text { Asphalt } \\
\text { concrete } \\
\text { plant }\end{array} \quad \text { batching } \\
\end{array}$ & N/A & Yes & Cienco 116 & & & & & 12-Jul-13 & & \\
\hline
\end{tabular}

\section{Package A4}

\begin{tabular}{|c|c|c|c|c|c|c|c|c|c|c|c|}
\hline \multicolumn{12}{|c|}{ BORROW PITS } \\
\hline \multirow{2}{*}{$\begin{array}{l}\text { Package } \\
\text { /Borrow } \\
\text { Pit No. }\end{array}$} & \multirow[t]{2}{*}{ Location } & \multirow{2}{*}{$\begin{array}{c}\text { Approv } \\
\text { ed } \\
\text { Area } \\
\left(\mathrm{m}^{2}\right)\end{array}$} & \multirow{2}{*}{$\begin{array}{c}\text { Approv } \\
\text { ed } \\
\text { Volume } \\
\left(\mathrm{m}^{3}\right)\end{array}$} & \multicolumn{2}{|c|}{ Ownership $^{a}$} & \multirow{2}{*}{$\begin{array}{l}\text { Prior Land } \\
\text { Use }^{b}\end{array}$} & \multicolumn{2}{|c|}{ Approval } & \multicolumn{3}{|c|}{ Operation Schedule } \\
\hline & & & & Name & Contact Info & & Date & Agency $^{\mathrm{C}}$ & Start & $\begin{array}{c}\text { Estimated } \\
\text { Completio } \\
n\end{array}$ & $\begin{array}{c}\text { Actual } \\
\text { Completio } \\
n\end{array}$ \\
\hline A4/BP1 & 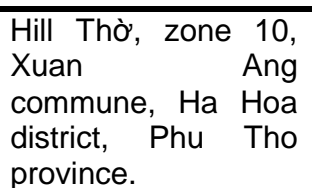 & 39,000 & $\begin{array}{l}473,277 . \\
7\end{array}$ & $\begin{array}{l}\text { Xuan Ang } \\
\text { Commun } \\
\text { e }\end{array}$ & $\begin{array}{l}\text { Mr Tuan. Xuan } \\
\text { Ang President }\end{array}$ & $\begin{array}{l}\text { Artificial } \\
\text { forest land, } \\
\text { farm land... }\end{array}$ & $\begin{array}{l}27 \\
\text { June } \\
2012\end{array}$ & $\begin{array}{l}\text { Phu Tho } \\
\text { Provincial } \\
\text { People's } \\
\text { Committee }\end{array}$ & $\begin{array}{l}27 \\
\text { June } \\
2012\end{array}$ & $\begin{array}{l}4^{\text {th }} \text { Quarter } \\
2013\end{array}$ & \\
\hline A4/BP2 & 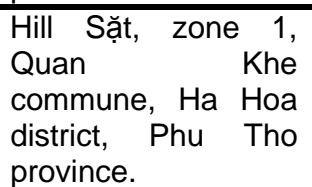 & 34,000 & 93,180 & $\begin{array}{l}\text { Quan } \\
\text { Khe } \\
\text { Commun } \\
\text { e }\end{array}$ & $\begin{array}{l}\text { Mr Tuoc. Quan } \\
\text { Khe president }\end{array}$ & $\begin{array}{l}\text { Artificial } \\
\text { forest land, } \\
\text { farm land... }\end{array}$ & $\begin{array}{l}26 \\
\text { June } \\
2012\end{array}$ & $\begin{array}{l}\text { Phu Tho } \\
\text { Provincial } \\
\text { People's } \\
\text { Committee }\end{array}$ & $\begin{array}{l}26 \\
\text { June } \\
2012\end{array}$ & $\begin{array}{l}4^{\text {th }} \text { Quarter } \\
2013\end{array}$ & \\
\hline A4/BP3 & $\begin{array}{lr}\text { Hill Bóng Đa, zone } \\
3, \quad \text { Quan } & \text { Khe } \\
\text { commune, Ha } & \text { Hoa } \\
\text { district, Phu } & \text { Tho } \\
\text { province. } & \end{array}$ & 36,000 & 193,909 & $\begin{array}{l}\text { Quan } \\
\text { Khe } \\
\text { Commun } \\
\text { e }\end{array}$ & $\begin{array}{l}\text { Mr Tuoc. Quan } \\
\text { Khe president }\end{array}$ & $\begin{array}{l}\text { Artificial } \\
\text { forest land, } \\
\text { farm land... }\end{array}$ & $\begin{array}{l}26 \\
\text { June } \\
2012\end{array}$ & $\begin{array}{l}\text { Phu Tho } \\
\text { Provincial } \\
\text { People's } \\
\text { Committee }\end{array}$ & $\begin{array}{l}26 \\
\text { June } \\
2012\end{array}$ & $\begin{array}{l}4^{\text {th }} \text { Quarter } \\
2013\end{array}$ & \\
\hline A4/BP4 & Quyet & 45,400 & 292,012 & Hien & Nguyen. & Artificial & 26 & Phu & 26 & $4^{\text {th }}$ Quarter & \\
\hline
\end{tabular}


Loan 2391/2392 - VIE: GMS Kunming - Hai Phong Transport Corridor

Noi Bai - Lao Cai Highway Project

\begin{tabular}{|c|c|c|c|c|c|c|c|c|c|c|c|}
\hline & $\begin{array}{l}\text { commune, Ha } \mathrm{Hoa} \\
\text { district, Phu Tho } \\
\text { province. }\end{array}$ & & & $\begin{array}{l}\text { Luong } \\
\text { Commun } \\
\mathrm{e}\end{array}$ & $\begin{array}{l}\text { Hien Luong } \\
\text { president. }\end{array}$ & $\begin{array}{l}\text { forest land, } \\
\text { farm land... }\end{array}$ & $\begin{array}{l}\text { June } \\
2012\end{array}$ & $\begin{array}{l}\text { Provincial } \\
\text { People's } \\
\text { Committee }\end{array}$ & $\begin{array}{l}\text { June } \\
2012\end{array}$ & 2013 & \\
\hline A4/BP5 & $\begin{array}{l}\text { Hill Lau, zone } 5, \text { Vo } \\
\text { Tranh commune, Ha } \\
\text { Hoa district, Phu } \\
\text { Tho province. }\end{array}$ & 16,800 & 156,423 & $\begin{array}{l}\text { Vo Tranh } \\
\text { Commun } \\
\text { e }\end{array}$ & $\begin{array}{l}\mathrm{Mr} \text { Thinh. Vo } \\
\text { Tranh } \\
\text { President }\end{array}$ & $\begin{array}{l}\text { Artificial } \\
\text { forest land, } \\
\text { farm land... }\end{array}$ & $\begin{array}{l}23 \text { Apr } \\
2012\end{array}$ & $\begin{array}{l}\text { Phu Tho } \\
\text { Provincial } \\
\text { People's } \\
\text { Committee }\end{array}$ & $\begin{array}{l}23 \mathrm{Apr} \\
2012\end{array}$ & $\begin{array}{l}4^{\text {th }} \text { Quarter } \\
2013\end{array}$ & \\
\hline A4/BP6 & $\begin{array}{l}\text { Hill Trường, zone 1, } \\
\text { Hien Luong } \\
\text { commune, Ha Hoa } \\
\text { district, Phu Tho } \\
\text { province. }\end{array}$ & 55,000 & 864,270 & $\begin{array}{l}\text { Hien } \\
\text { Luong } \\
\text { Commun } \\
\mathrm{e}\end{array}$ & $\begin{array}{lr}\text { Mr } & \text { Nguyen. } \\
\text { Hien } & \text { Luong } \\
\text { president. }\end{array}$ & $\begin{array}{l}\text { Artificial } \\
\text { forest land, } \\
\text { farm land... }\end{array}$ & $\begin{array}{l}23 \text { Apr } \\
2012\end{array}$ & $\begin{array}{l}\text { Phu Tho } \\
\text { Provincial } \\
\text { People's } \\
\text { Committee }\end{array}$ & $\begin{array}{l}23 \mathrm{Apr} \\
2012\end{array}$ & $\begin{array}{l}4^{\text {th }} \text { Quarter } \\
2013\end{array}$ & \\
\hline A4/BP7 & $\begin{array}{l}\text { Km80+000- } \\
\text { Km82+500 } \\
\text { Hills of Ong Duoc, } \\
\text { Nuong Phe, Nuong } \\
\text { Dieu, Nuong Son, } \\
\text { Nha Vam Go Ca }\end{array}$ & 118.500 & 805.098 & $\begin{array}{l}\text { Thanh } \\
\text { Nga } \\
\text { commune } \\
\text { Khe, Cam } \\
\text { Kistrict. }\end{array}$ & $\begin{array}{l}\text { Thanh Nga } \\
\text { commune, } \\
\text { Cam Khe, } \\
\text { district, Phu } \\
\text { Tho province }\end{array}$ & $\begin{array}{l}\text { Hill land of } \\
\text { forestry tree }\end{array}$ & $\begin{array}{l}24 \text { Aug } \\
2012\end{array}$ & $\begin{array}{l}\text { Phu Tho } \\
\text { Provincial } \\
\text { People's } \\
\text { Committee }\end{array}$ & $\begin{array}{l}\text { Aug } \\
2012\end{array}$ & Aug 2014 & \\
\hline A4/BP8 & $\begin{array}{l}\text { Hill Reo, Dong Cam } \\
\text { commune, Cam Khe } \\
\text { district }\end{array}$ & & 239.443 & $\begin{array}{l}\text { Dong } \\
\text { Cam } \\
\text { commune } \\
\text { Khe, Cam } \\
\text { district. }\end{array}$ & $\begin{array}{ll}\text { Dong } & \text { Cam } \\
\text { commune, } \\
\text { Cam Khe, } \\
\text { district. }\end{array}$ & $\begin{array}{l}\text { Artificial } \\
\text { forest land, } \\
\text { farm land... }\end{array}$ & $\begin{array}{l}02 \text { Oct } \\
2012\end{array}$ & $\begin{array}{l}\text { Phu Tho } \\
\text { Provincial } \\
\text { People's } \\
\text { Committee }\end{array}$ & $\begin{array}{l}02 \text { Oct } \\
2012\end{array}$ & $\begin{array}{ll}02 & \text { Oct } \\
2014 & \end{array}$ & \\
\hline A4/BP9 & $\begin{array}{l}\text { Hill Gieng Chuoi, } \\
\text { Tuy Loc commune, } \\
\text { Cam Khe district }\end{array}$ & 1.600 & 195.872 & $\begin{array}{l}\text { Tuy Loc } \\
\text { commune } \\
\text { Khe, Cam } \\
\text { district. }\end{array}$ & $\begin{array}{l}\text { Tuy Loc } \\
\text { commune, } \\
\text { Cam Khe, } \\
\text { district. }\end{array}$ & $\begin{array}{l}\text { Artificial } \\
\text { forest land, } \\
\text { farm land... }\end{array}$ & $\begin{array}{l}02 \text { Oct } \\
2012\end{array}$ & $\begin{array}{l}\text { Phu Tho } \\
\text { Provincial } \\
\text { People's } \\
\text { Committee }\end{array}$ & $\begin{array}{l}02 \text { Oct } \\
2012\end{array}$ & $\begin{array}{ll}02 & \text { Oct } \\
2014 & \end{array}$ & \\
\hline A4/BP10 & $\begin{array}{l}\text { Hill Gia Gia and Hill } \\
\text { Nuong Trong Phung } \\
\text { Xa commune, Cam } \\
\text { Khe district }\end{array}$ & 2.500 & 99.000 & $\begin{array}{l}\text { Phung Xa } \\
\text { commune } \\
\text { Khe, Cam } \\
\text { district. }\end{array}$ & $\begin{array}{l}\text { Phung } \quad \text { Xa } \\
\text { commune, } \\
\text { Cam Khe, } \\
\text { district. }\end{array}$ & $\begin{array}{l}\text { Artificial } \\
\text { forest land, } \\
\text { farm land... }\end{array}$ & $\begin{array}{l}05 \text { Oct } \\
2012\end{array}$ & $\begin{array}{l}\text { Phu Tho } \\
\text { Provincial } \\
\text { People's } \\
\text { Committee }\end{array}$ & $\begin{array}{l}02 \text { Oct } \\
2012\end{array}$ & $\begin{array}{ll}05 & \text { Oct } \\
2014 & \end{array}$ & \\
\hline
\end{tabular}


Loan 2391/2392 - VIE: GMS Kunming - Hai Phong Transport Corridor

Noi Bai - Lao Cai Highway Project

\begin{tabular}{|c|c|c|c|c|c|c|c|c|c|c|c|}
\hline \multirow{2}{*}{$\begin{array}{l}\text { Package } \\
\text { IQuarry } \\
\text { No. }\end{array}$} & \multirow[t]{2}{*}{ Location } & \multirow{2}{*}{$\begin{array}{c}\text { Approve } \\
\text { d } \\
\text { Area } \\
\left(\mathrm{m}^{2}\right)\end{array}$} & \multirow{2}{*}{$\begin{array}{c}\text { Approve } \\
\text { d } \\
\text { Volume } \\
\left(\mathrm{m}^{3}\right)\end{array}$} & \multicolumn{2}{|c|}{ Ownership ${ }^{a}$} & \multirow{2}{*}{$\begin{array}{l}\text { Prior Land } \\
\text { Use }^{b}\end{array}$} & \multicolumn{2}{|c|}{ Approval } & \multicolumn{3}{|c|}{ Operation Schedule } \\
\hline & & & & Name & Contact Info & & Date & Agencyc $^{c}$ & Start & $\begin{array}{c}\text { Estimated } \\
\text { Completio } \\
\mathbf{n}\end{array}$ & $\begin{array}{c}\text { Actual } \\
\text { Completio } \\
\mathbf{n}\end{array}$ \\
\hline
\end{tabular}

\begin{tabular}{|c|c|c|c|c|c|c|c|c|c|c|c|}
\hline \multicolumn{12}{|c|}{ SPOILS DISPOSAL AREAS } \\
\hline \multirow{2}{*}{$\begin{array}{l}\text { Packag } \\
\text { e / SD } \\
\text { No. }\end{array}$} & \multirow[t]{2}{*}{ Location } & \multirow{2}{*}{$\begin{array}{c}\text { Approve } \\
\text { d } \\
\text { Area } \\
\left(\mathrm{m}^{2}\right)\end{array}$} & \multirow{2}{*}{$\begin{array}{c}\text { Approve } \\
\text { d } \\
\text { Capacity } \\
\left(\mathrm{m}^{3}\right)\end{array}$} & \multicolumn{2}{|c|}{ Ownership $^{a}$} & \multirow[t]{2}{*}{ Prior Land Use ${ }^{b}$} & \multicolumn{2}{|c|}{ Approval } & \multicolumn{3}{|c|}{ Operation } \\
\hline & & & & Name & Contact Info & & Date & Agency $^{\mathrm{C}}$ & Start & Est. End & $\begin{array}{l}\text { Actual } \\
\text { End }\end{array}$ \\
\hline \multicolumn{12}{|c|}{ Xa Minh Coi, Ha Hoa } \\
\hline 1 & $\mathrm{Km} \mathrm{90+080}$ & 1266.2 & 16400 & $\begin{array}{l}\text { Nguyen } \\
\text { Rang }\end{array}$ & $\begin{array}{l}\text { Zone 7, Minh Coi } \\
\text { Communce, Ha } \\
\text { Hoa }\end{array}$ & $\begin{array}{l}\text { Low elevation, } \\
\text { flood area, can not } \\
\text { cultivation }\end{array}$ & $\begin{array}{l}20 \text { Oct. } \\
2010\end{array}$ & $\begin{array}{l}\text { Minh Coi } \\
\text { Communce }\end{array}$ & \begin{tabular}{|l|}
20 Oct. \\
2010
\end{tabular} & $\begin{array}{l}4^{\text {th }} \text { Quarter } \\
2013\end{array}$ & $\begin{array}{l}4^{\text {th }} \text { Quarter } \\
2013\end{array}$ \\
\hline 2 & $\mathrm{Km} \mathrm{90+220}$ & 111.02 & 2500 & Bui Van Nhu & $\begin{array}{l}\text { Zone 7, Minh Coi } \\
\text { Communce, } \mathrm{Ha} \\
\text { Hoa }\end{array}$ & $\begin{array}{l}\text { Low elevation, } \\
\text { flood area, can not } \\
\text { cultivation }\end{array}$ & $\begin{array}{l}20 \text { Oct. } \\
2010\end{array}$ & $\begin{array}{l}\text { Minh Coi } \\
\text { Communce }\end{array}$ & $\begin{array}{l}20 \text { Oct. } \\
2010\end{array}$ & $\begin{array}{l}4^{\text {th }} \text { Quarter } \\
2013\end{array}$ & $\begin{array}{l}4^{\text {th }} \text { Quarter } \\
2013\end{array}$ \\
\hline 3 & $\mathrm{Km} \mathrm{90+220}$ & 637.6 & 12250 & $\begin{array}{ll}\text { Nguyen } & \mathrm{Y} \\
\text { Nguyen } & \end{array}$ & $\begin{array}{l}\text { Zone 7, Minh Coi } \\
\text { Communce, Ha } \\
\text { Hoa }\end{array}$ & $\begin{array}{l}\text { Low elevation, } \\
\text { flood area, can not } \\
\text { cultivation }\end{array}$ & $\begin{array}{l}20 \text { Oct. } \\
2010\end{array}$ & $\begin{array}{l}\text { Minh Coi } \\
\text { Communce }\end{array}$ & $\begin{array}{l}20 \text { Oct. } \\
2010\end{array}$ & $\begin{array}{l}4^{\text {th }} \text { Quarter } \\
2013\end{array}$ & $\begin{array}{l}4^{\text {th }} \text { Quarter } \\
2013\end{array}$ \\
\hline 4 & $\mathrm{Km} \mathrm{90+280}$ & 453.6 & 8200 & $\begin{array}{l}\text { Nguyen } \\
\text { Hung }\end{array}$ & $\begin{array}{l}\text { Zone 7, Minh Coi } \\
\text { Communce, Ha } \\
\text { Hoa }\end{array}$ & $\begin{array}{l}\text { Low elevation, } \\
\text { flood area, can not } \\
\text { cultivation }\end{array}$ & $\begin{array}{l}20 \text { Oct. } \\
2010\end{array}$ & $\begin{array}{l}\text { Minh Coi } \\
\text { Communce }\end{array}$ & $\begin{array}{l}20 \text { Oct. } \\
2010\end{array}$ & $\begin{array}{l}4^{\text {th }} \text { Quarter } \\
2013\end{array}$ & $\begin{array}{l}4^{\text {th }} \text { Quarter } \\
2013\end{array}$ \\
\hline 5 & $\mathrm{Km} \mathrm{91+200}$ & 172.8 & 12000 & Le Quang Thang & $\begin{array}{l}\text { Zone 5, Minh Coi } \\
\text { Communce, Ha } \\
\text { Hoa }\end{array}$ & $\begin{array}{l}\text { Low elevation, } \\
\text { flood area, can not } \\
\text { cultivation }\end{array}$ & $\begin{array}{l}20 \text { Oct. } \\
2010\end{array}$ & $\begin{array}{l}\text { Minh Coi } \\
\text { Communce }\end{array}$ & $\begin{array}{l}20 \text { Oct. } \\
2010\end{array}$ & $\begin{array}{l}4^{\text {th }} \text { Quarter } \\
2013\end{array}$ & $\begin{array}{l}4^{\text {th }} \text { Quarter } \\
2013\end{array}$ \\
\hline 6 & $\mathrm{Km} 92+000$ & 850 & 16369 & Phung Thi Khoa & $\begin{array}{l}\text { Zone 5, Minh Coi } \\
\text { Communce, Ha } \\
\text { Hoa }\end{array}$ & $\begin{array}{l}\text { Low elevation, } \\
\text { flood area, can not } \\
\text { cultivation }\end{array}$ & $\begin{array}{l}20 \text { Oct. } \\
2010\end{array}$ & $\begin{array}{l}\text { Minh Coi } \\
\text { Communce }\end{array}$ & $\begin{array}{l}20 \text { Oct. } \\
2010\end{array}$ & $\begin{array}{l}4^{\text {th }} \text { Quarter } \\
2013\end{array}$ & $\begin{array}{l}4^{\text {th }} \text { Quarter } \\
2013\end{array}$ \\
\hline 7 & $\mathrm{Km} 92+100$ & 702.1 & 11200 & $\begin{array}{l}\text { Nguyen } \\
\text { Giao }\end{array}$ & $\begin{array}{l}\text { Zone 1, Minh Coi } \\
\text { Communce, Ha } \\
\text { Hoa }\end{array}$ & $\begin{array}{l}\text { Low elevation, } \\
\text { flood area, can not } \\
\text { cultivation }\end{array}$ & $\begin{array}{l}20 \text { Oct. } \\
2010\end{array}$ & $\begin{array}{l}\text { Minh Coi } \\
\text { Communce }\end{array}$ & $\begin{array}{l}20 \text { Oct. } \\
2010\end{array}$ & $\begin{array}{l}4^{\text {th }} \text { Quarter } \\
2013\end{array}$ & $\begin{array}{l}4^{\text {th }} \text { Quarter } \\
2013\end{array}$ \\
\hline 8 & $\mathrm{Km} \mathrm{92+510}$ & 504.2 & 6000 & Nguyen & Zone 2, Minh Coi & elevation, & 20 Oct. & Minh & 20 Oct. & $4^{\text {th }}$ Quarter & $4^{\text {th }}$ Quarter \\
\hline
\end{tabular}


Loan 2391/2392 - VIE: GMS Kunming - Hai Phong Transport Corridor

Noi Bai - Lao Cai Highway Project

\begin{tabular}{|c|c|c|c|c|c|c|c|c|c|c|c|}
\hline & & & & Cuong & $\begin{array}{l}\text { Communce, } \mathrm{Ha} \\
\mathrm{Hoa}\end{array}$ & $\begin{array}{l}\text { flood area, can not } \\
\text { cultivation }\end{array}$ & 2010 & Communce & 2010 & 2013 & 2013 \\
\hline 9 & $\mathrm{Km} \mathrm{92+600}$ & 522.2 & 6500 & $\begin{array}{l}\text { Nguyen } \quad \text { Van } \\
\text { Cuong }\end{array}$ & $\begin{array}{l}\text { Zone 2, Minh Coi } \\
\text { Communce, } \mathrm{Ha} \\
\text { Hoa }\end{array}$ & $\begin{array}{l}\text { Low elevation, } \\
\text { flood area, can not } \\
\text { cultivation }\end{array}$ & $\begin{array}{l}20 \text { Oct. } \\
2010\end{array}$ & $\begin{array}{lr}\text { Minh } \quad \text { Coi } \\
\text { Communce }\end{array}$ & $\begin{array}{l}20 \text { Oct. } \\
2010\end{array}$ & $\begin{array}{l}4^{\text {th }} \text { Quarter } \\
2013\end{array}$ & $\begin{array}{l}4^{\text {th }} \text { Quarter } \\
2013\end{array}$ \\
\hline 10 & $\mathrm{Km} \mathrm{92+850}$ & 822.73 & 14300 & Do Thi Nu & $\begin{array}{l}\text { Zone 2, Minh Coi } \\
\text { Communce, } \mathrm{Ha} \\
\text { Hoa }\end{array}$ & $\begin{array}{l}\text { Low elevation, } \\
\text { flood area, can not } \\
\text { cultivation }\end{array}$ & $\begin{array}{l}20 \text { Oct. } \\
2010\end{array}$ & \begin{tabular}{lr|} 
Minh $\quad$ Coi \\
Communce
\end{tabular} & $\begin{array}{l}20 \text { Oct. } \\
2010\end{array}$ & $\begin{array}{l}4^{\text {th }} \text { Quarter } \\
2013\end{array}$ & $\begin{array}{l}4^{\text {th }} \text { Quarter } \\
2013\end{array}$ \\
\hline 11 & $\mathrm{Km} \mathrm{93+050}$ & 376.2 & 6100 & $\begin{array}{l}\text { Nguyen } \quad \text { Van } \\
\text { Thoa }\end{array}$ & $\begin{array}{l}\text { Zone 2, Minh Coi } \\
\text { Communce, } \mathrm{Ha} \\
\text { Hoa }\end{array}$ & $\begin{array}{l}\text { Low elevation, } \\
\text { flood area, can not } \\
\text { cultivation }\end{array}$ & $\begin{array}{l}20 \text { Oct. } \\
2010\end{array}$ & $\begin{array}{l}\text { Minh Coi } \\
\text { Communce }\end{array}$ & $\begin{array}{l}20 \text { Oct. } \\
2010\end{array}$ & $\begin{array}{l}4^{\text {th }} \text { Quarter } \\
2013\end{array}$ & $\begin{array}{l}4^{\text {th }} \text { Quarter } \\
2013\end{array}$ \\
\hline 12 & $\mathrm{Km} \mathrm{93+160}$ & 687.6 & 13400 & $\begin{array}{l}\text { Nguyen Van } \\
\text { Thoa }\end{array}$ & $\begin{array}{l}\text { Zone 2, Minh Coi } \\
\text { Communce, } \mathrm{Ha} \\
\text { Hoa }\end{array}$ & $\begin{array}{l}\text { Low elevation, } \\
\text { flood area, can not } \\
\text { cultivation }\end{array}$ & $\begin{array}{l}20 \text { Oct. } \\
2010\end{array}$ & $\begin{array}{l}\text { Minh Coi } \\
\text { Communce }\end{array}$ & $\begin{array}{l}20 \text { Oct. } \\
2010\end{array}$ & $\begin{array}{l}4^{\text {th }} \text { Quarter } \\
2013\end{array}$ & $\begin{array}{l}4^{\text {th }} \text { Quarter } \\
2013\end{array}$ \\
\hline 13 & $\mathrm{Km} \mathrm{93+100}$ & 326.3 & 5800 & Le Thi Loan & $\begin{array}{l}\text { Zone 2, Minh Coi } \\
\text { Communce, } \mathrm{Ha} \\
\text { Hoa }\end{array}$ & $\begin{array}{l}\text { Fish pond, but not } \\
\text { efficient }\end{array}$ & $\begin{array}{l}20 \text { Oct. } \\
2010\end{array}$ & $\begin{array}{lr}\text { Minh Coi } \\
\text { Communce }\end{array}$ & $\begin{array}{l}20 \text { Oct. } \\
2010\end{array}$ & $\begin{array}{l}4^{\text {th }} \text { Quarter } \\
2013\end{array}$ & $\begin{array}{l}4^{\text {th }} \text { Quarter } \\
2013\end{array}$ \\
\hline 14 & $\mathrm{Km} \mathrm{93+600}$ & 1354.8 & 18200 & Ly Minh Tam & $\begin{array}{l}\text { Zone 2, Minh Coi } \\
\text { Communce, } \mathrm{Ha} \\
\text { Hoa }\end{array}$ & $\begin{array}{l}\text { Low elevation, } \\
\text { flood area, can not } \\
\text { cultivation }\end{array}$ & $\begin{array}{l}20 \text { Oct. } \\
2010\end{array}$ & $\begin{array}{l}\text { Minh Coi } \\
\text { Communce }\end{array}$ & $\begin{array}{l}20 \text { Oct. } \\
2010\end{array}$ & $\begin{array}{l}4^{\text {th }} \text { Quarter } \\
2013\end{array}$ & $\begin{array}{l}4^{\text {th }} \text { Quarter } \\
2013\end{array}$ \\
\hline 15 & $\mathrm{Km} \mathrm{93+700}$ & 650 & 5350 & $\begin{array}{ll}\text { Nguyen } & \mathrm{Ba} \\
\text { Ngoc } & \end{array}$ & $\begin{array}{l}\text { Zone 2, Minh Coi } \\
\text { Communce, } \mathrm{Ha} \\
\text { Hoa }\end{array}$ & $\begin{array}{l}\text { Low elevation, } \\
\text { flood area, can not } \\
\text { cultivation }\end{array}$ & $\begin{array}{l}20 \text { Oct. } \\
2010\end{array}$ & $\begin{array}{lr}\text { Minh } \quad \text { Coi } \\
\text { Communce }\end{array}$ & $\begin{array}{l}20 \text { Oct. } \\
2010\end{array}$ & $\begin{array}{l}4^{\text {th }} \text { Quarter } \\
2013\end{array}$ & $\begin{array}{l}4^{\text {th }} \text { Quarter } \\
2013\end{array}$ \\
\hline 16 & $\mathrm{Km} \mathrm{93+820}$ & 3880 & 85360 & $\begin{array}{l}\text { Nguyen Thanh } \\
\text { Binh }\end{array}$ & $\begin{array}{l}\text { Zone 2, Minh Coi } \\
\text { Communce, } \mathrm{Ha} \\
\text { Hoa }\end{array}$ & $\begin{array}{ll}\begin{array}{l}\text { Steep } \\
\text { unable } \\
\text { farming }\end{array} & \begin{array}{l}\text { slope, } \\
\text { make }\end{array} \\
\end{array}$ & $\begin{array}{l}05 \text { Oct. } \\
2013\end{array}$ & $\begin{array}{l}\mathrm{Ha} \\
\text { District }\end{array}$ & $\begin{array}{l}05 \text { Oct. } \\
2013\end{array}$ & & $\begin{array}{l}18^{\text {th }} \text { June } \\
2013\end{array}$ \\
\hline 17 & $\mathrm{Km} \mathrm{92+300}$ & 900 & 15300 & Nguyen Van Tai & $\begin{array}{l}\text { Zone 2, Minh Coi } \\
\text { Communce, } \mathrm{Ha} \\
\text { Hoa }\end{array}$ & $\begin{array}{l}\text { Not suitable for } \\
\text { farming. }\end{array}$ & $\begin{array}{l}05 \text { Oct. } \\
2013\end{array}$ & $\begin{array}{ll}\mathrm{Ha} & \mathrm{Hoa} \\
\text { District } & \end{array}$ & $\begin{array}{l}18 \\
\text { June. } \\
2013\end{array}$ & & $\begin{array}{l}27 \text { June. } \\
2013\end{array}$ \\
\hline 18 & $\mathrm{Km} \mathrm{91+240}$ & 2718.7 & 46218 & $\begin{array}{ll}\text { Minh } & \text { Coi } \\
\text { Commune } & \end{array}$ & $\begin{array}{l}\text { Minh } \\
\text { Commune }\end{array}$ & $\begin{array}{ll}\text { Valley, } & \text { slopes } \\
\text { areas } & \end{array}$ & $\begin{array}{l}05 \text { Oct. } \\
2013\end{array}$ & $\begin{array}{l}\mathrm{Ha} \\
\text { District }\end{array}$ & $\begin{array}{l}18 \\
\text { June. } \\
2013 \\
\end{array}$ & & $\begin{array}{l}30 \text { August. } \\
2013\end{array}$ \\
\hline \multicolumn{12}{|c|}{ Xa Bang Gia, Ha Hoa } \\
\hline 1 & Bai ui & 3600 & 28800 & $\begin{array}{ll}\text { Bang } & \text { Gia } \\
\text { Communce } & \end{array}$ & $\begin{array}{l}\text { Mr. Thinh } \\
\text { Chairman of Bang } \\
\text { Gia Communce }\end{array}$ & Fish pond & $\begin{array}{l}12 \text { Dec. } \\
2010\end{array}$ & $\begin{array}{lr}\text { Bang Gia } \\
\text { Communce }\end{array}$ & $\begin{array}{l}12 \text { Dec. } \\
2010\end{array}$ & $\begin{array}{l}4^{\text {th }} \text { Quarter } \\
2013\end{array}$ & \\
\hline 2 & Zone 11 & 3800 & 11400 & $\begin{array}{l}\text { Nguyen } \\
\text { Quan }\end{array}$ & $\begin{array}{l}\text { Zone 11, Bang } \\
\text { Gia Communce }\end{array}$ & Fish pond & $\begin{array}{l}19 \text { Nov. } \\
2010\end{array}$ & \begin{tabular}{lr|} 
Bang Gia \\
Communce \\
\end{tabular} & $\begin{array}{l}19 \text { Nov. } \\
2010\end{array}$ & $\begin{array}{l}4^{\text {th }} \text { Quarter } \\
2013\end{array}$ & \\
\hline
\end{tabular}


Loan 2391/2392 - VIE: GMS Kunming - Hai Phong Transport Corridor

Noi Bai - Lao Cai Highway Project

\begin{tabular}{|c|c|c|c|c|c|c|c|c|c|c|c|}
\hline \multicolumn{12}{|c|}{ Xa Vo Tranh, Ha Hoa } \\
\hline 1 & $\begin{array}{l}\text { Cap Tien, } \\
\text { Zone 6, Vo } \\
\text { Tranh }\end{array}$ & 1200 & 3600 & Tran Thien Le & $\begin{array}{l}\text { Zone 6, Cap Tien, } \\
\text { Vo Tranh } \\
\text { Communce }\end{array}$ & Fish pond & $\begin{array}{l}10 \\
\text { January } \\
2011\end{array}$ & $\begin{array}{l}\text { Vo Tranh } \\
\text { Communce }\end{array}$ & \begin{tabular}{|l|}
10 \\
January \\
2011
\end{tabular} & $\begin{array}{l}1^{\text {st }} \text { Quarter } \\
2014\end{array}$ & \\
\hline 2 & $\begin{array}{l}\text { Dong Mai, } \\
\text { Zone } 5\end{array}$ & 1500 & 6000 & $\begin{array}{l}\text { Vo Tranh } \\
\text { Communce }\end{array}$ & $\begin{array}{l}\text { Zone 5, Vo Tranh } \\
\text { Communce }\end{array}$ & Fish pond & $\begin{array}{l}10 \\
\text { January } \\
, 2011\end{array}$ & $\begin{array}{l}\text { Vo Tranh } \\
\text { Communce }\end{array}$ & \begin{tabular}{|l|}
10 \\
January \\
, 2011
\end{tabular} & $\begin{array}{l}4^{\text {th }} \text { Quarter } \\
2013\end{array}$ & \\
\hline \multicolumn{12}{|c|}{ Xa Hien Luong, Ha Hoa } \\
\hline 1 & $\begin{array}{l}\text { Cutural } \\
\text { house }\end{array}$ & 1620 & 3240 & $\begin{array}{l}\text { Mr Nguyen, } \\
\text { Chairman of } \\
\text { Hien Luong } \\
\text { Communce }\end{array}$ & $\begin{array}{l}\text { Hien Luong } \\
\text { Communce }\end{array}$ & $\begin{array}{l}\text { Low elevation, } \\
\text { flood area need to } \\
\text { raise level }\end{array}$ & $\begin{array}{l}17 \text { Dec. } \\
2010\end{array}$ & $\begin{array}{l}\text { Hien Luong } \\
\text { Communce }\end{array}$ & $\begin{array}{l}17 \text { Dec. } \\
2010\end{array}$ & $\begin{array}{l}4^{\text {th }} \text { Quarter } \\
2013\end{array}$ & $\begin{array}{l}4^{\text {th }} \text { Quarter } \\
2013\end{array}$ \\
\hline 2 & Zone 2 & 1200 & 1800 & $\begin{array}{l}\text { Mr Nguyen, } \\
\text { Chairman of } \\
\text { Hien Luong } \\
\text { Communce }\end{array}$ & $\begin{array}{l}\text { Hien Luong } \\
\text { Communce }\end{array}$ & $\begin{array}{l}\text { Low elevation, } \\
\text { flood area need to } \\
\text { raise level }\end{array}$ & $\begin{array}{l}17 \text { Dec. } \\
2010\end{array}$ & $\begin{array}{l}\text { Hien Luong } \\
\text { Communce }\end{array}$ & $\begin{array}{l}17 \text { Dec. } \\
2010\end{array}$ & $\begin{array}{l}4^{\text {th }} \text { Quarter } \\
2013\end{array}$ & $\begin{array}{l}4^{\text {th }} \text { Quarter } \\
2013\end{array}$ \\
\hline 3 & $\begin{array}{l}\text { Pond of } \\
\text { Mrs Hoan, } \\
\text { Zone } 2\end{array}$ & 1200 & 2400 & Mrs Hoan & $\begin{array}{lr}\text { Zone } \quad 2, \quad \text { Hien } \\
\text { Luong Communce }\end{array}$ & Fish pond & $\begin{array}{l}17 \text { Dec. } \\
2010\end{array}$ & $\begin{array}{l}\text { Hien Luong } \\
\text { Communce }\end{array}$ & $\begin{array}{l}17 \text { Dec. } \\
2010\end{array}$ & $\begin{array}{l}4^{\text {th }} \text { Quarter } \\
2013\end{array}$ & $\begin{array}{l}4^{\text {th }} \text { Quarter } \\
2013\end{array}$ \\
\hline 4 & $\begin{array}{l}\text { Old brick } \\
\text { production } \\
\text { area }\end{array}$ & 4000 & 6000 & Dong Trua & $\begin{array}{ll}\mathrm{Au} & \mathrm{Co} \\
\text { Cooperative } & \end{array}$ & $\begin{array}{l}\text { Excavated area for } \\
\text { brick production } \\
\text { needs to be } \\
\text { recovered }\end{array}$ & $\begin{array}{l}17 \text { Dec. } \\
2010\end{array}$ & $\begin{array}{l}\text { Hien Luong } \\
\text { Communce }\end{array}$ & $\begin{array}{l}17 \text { Dec. } \\
2010\end{array}$ & $\begin{array}{l}4^{\text {th }} \text { Quarter } \\
2013\end{array}$ & $\begin{array}{l}4^{\text {th }} \text { Quarter } \\
2013\end{array}$ \\
\hline \multicolumn{12}{|c|}{ Xa Quan Khe, Ha Hoa } \\
\hline 1 & $\begin{array}{l}\text { Fish pond } \\
\text { of Mr. } \\
\text { Cuong's } \\
\text { house }\end{array}$ & 690 & 1244 & $\begin{array}{l}\text { Nguyen Van } \\
\text { Cuong }\end{array}$ & $\begin{array}{l}\text { Zone 1, Quan Khe } \\
\text { Communce, Ha } \\
\text { Hoa }\end{array}$ & $\begin{array}{l}\text { Fish pond, but not } \\
\text { efficient }\end{array}$ & $\begin{array}{l}7 \text { Oct. } \\
2010\end{array}$ & $\begin{array}{l}\text { Quan Khe } \\
\text { Communce }\end{array}$ & \begin{tabular}{|l|}
7 Oct. \\
2010
\end{tabular} & $\begin{array}{l}4^{\text {th }} \text { Quarter } \\
2013\end{array}$ & $\begin{array}{l}4^{\text {th }} \text { Quarter } \\
2013\end{array}$ \\
\hline 2 & $\begin{array}{l}\text { Fish pond } \\
\text { of Mrs. } \\
\text { Oanh's } \\
\text { house, } \\
\text { Zone 1 }\end{array}$ & 900 & 2160 & Do Thi Oanh & $\begin{array}{l}\text { Zone 1, Quan Khe } \\
\text { Communce, Ha } \\
\text { Hoa }\end{array}$ & $\begin{array}{l}\text { Fish pond, but not } \\
\text { efficient }\end{array}$ & $\begin{array}{l}7 \text { Oct. } \\
2010\end{array}$ & $\begin{array}{l}\text { Quan Khe } \\
\text { Communce }\end{array}$ & $\begin{array}{l}7 \text { Oct. } \\
2010\end{array}$ & $\begin{array}{l}4^{\text {th }} \text { Quarter } \\
2013\end{array}$ & $\begin{array}{l}4^{\text {th }} \text { Quarter } \\
2013\end{array}$ \\
\hline 3 & $\begin{array}{l}\text { Fish pond } \\
\text { of } \quad \text { Mr. } \\
\text { Chau's }\end{array}$ & 624 & 1560 & Do Ngoc Chau & $\begin{array}{l}\text { Zone 3, Quan Khe } \\
\text { Communce, Ha } \\
\text { Hoa }\end{array}$ & $\begin{array}{l}\text { Fish pond, but not } \\
\text { efficient }\end{array}$ & $\begin{array}{l}7 \text { Oct. } \\
2010\end{array}$ & $\begin{array}{l}\text { Quan Khe } \\
\text { Communce }\end{array}$ & \begin{tabular}{|l|}
7 Oct. \\
2010
\end{tabular} & $\begin{array}{l}4^{\text {th }} \text { Quarter } \\
2013\end{array}$ & $\begin{array}{l}4^{\text {th }} \text { Quarter } \\
2013\end{array}$ \\
\hline
\end{tabular}


Loan 2391/2392 - VIE: GMS Kunming - Hai Phong Transport Corridor

Noi Bai - Lao Cai Highway Project

\begin{tabular}{|c|c|c|c|c|c|c|c|c|c|c|c|}
\hline & house & & & & & & & & & & \\
\hline 4 & $\begin{array}{l}\text { Pond, Zone } \\
1\end{array}$ & 5788 & 36000 & \begin{tabular}{|lr} 
Mr & Doanh, \\
Chairman & of \\
Quan & Khe \\
Communce & \\
\end{tabular} & $\begin{array}{ll}\text { Quan } & \text { Khe } \\
\text { Communce } & \end{array}$ & $\begin{array}{l}\text { Fish pond, but not } \\
\text { efficient }\end{array}$ & $\begin{array}{l}7 \quad \text { Oct. } \\
2010\end{array}$ & $\begin{array}{l}\text { Quan Khe } \\
\text { Communce }\end{array}$ & $\begin{array}{l}7 \quad \text { Oct. } \\
2010\end{array}$ & $\begin{array}{l}4^{\text {th }} \text { Quarter } \\
2013\end{array}$ & $\begin{array}{l}4^{\text {th }} \text { Quarter } \\
2013\end{array}$ \\
\hline 5 & $\begin{array}{l}\text { Dyke, Zone } \\
1\end{array}$ & 400 & 23152 & $\begin{array}{|lr|}\text { Mr } & \text { Doanh, } \\
\text { Chairman } & \text { of } \\
\text { Quan } & \text { Khe } \\
\text { Communce } & \\
\end{array}$ & $\begin{array}{ll}\text { Quan } & \text { Khe } \\
\text { Communce } & \end{array}$ & $\begin{array}{l}\text { Low elevation, } \\
\text { flood area, can not } \\
\text { cultivation }\end{array}$ & $\begin{array}{l}7 \quad \text { Oct. } \\
2010\end{array}$ & $\begin{array}{l}\text { Quan Khe } \\
\text { Communce }\end{array}$ & $\begin{array}{l}7 \text { Oct. } \\
2010\end{array}$ & $\begin{array}{l}4^{\text {th }} \text { Quarter } \\
2013\end{array}$ & $\begin{array}{l}4^{\text {th }} \text { Quarter } \\
2013\end{array}$ \\
\hline \multicolumn{12}{|c|}{ Xa Son Nga, huyen Cam Khe } \\
\hline 1 & $\mathrm{Km} \mathrm{81+020}$ & 800 & 8000 & 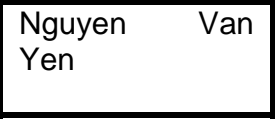 & $\begin{array}{l}\text { Zone 3, Son Nga } \\
\text { Communce }\end{array}$ & $\begin{array}{l}\text { Low elevation, } \\
\text { need to raise level } \\
\text { for cultivation }\end{array}$ & $\begin{array}{l}29 \text { Dec. } \\
2010\end{array}$ & $\begin{array}{l}\text { Son Nga } \\
\text { Communce }\end{array}$ & $\begin{array}{l}29 \text { Dec. } \\
2010\end{array}$ & $\begin{array}{l}4^{\text {th }} \text { Quarter } \\
2013\end{array}$ & $\begin{array}{l}4^{\text {th }} \text { Quarter } \\
2013\end{array}$ \\
\hline 2 & $\mathrm{Km} \mathrm{81+020}$ & 400 & 2400 & 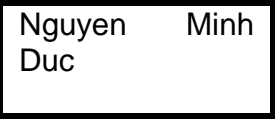 & $\begin{array}{l}\text { Zone 3, Son Nga } \\
\text { Communce }\end{array}$ & $\begin{array}{l}\text { Low elevation, } \\
\text { need to raise level } \\
\text { for cultivation }\end{array}$ & $\begin{array}{l}29 \text { Dec. } \\
2010\end{array}$ & $\begin{array}{lr}\text { Son Nga } \\
\text { Communce }\end{array}$ & $\begin{array}{l}29 \text { Dec. } \\
2010\end{array}$ & $\begin{array}{l}4^{\text {th }} \text { Quarter } \\
2013\end{array}$ & $\begin{array}{l}4^{\text {th }} \text { Quarter } \\
2013\end{array}$ \\
\hline 3 & $\mathrm{Km} \mathrm{81+080}$ & 240 & 960 & Hoangf Van Ba & $\begin{array}{l}\text { Zone 3, Son Nga } \\
\text { Communce }\end{array}$ & $\begin{array}{l}\text { Low elevation, } \\
\text { need to raise level } \\
\text { for cultivation }\end{array}$ & $\begin{array}{l}29 \text { Dec. } \\
2010\end{array}$ & $\begin{array}{l}\text { Son Nga } \\
\text { Communce }\end{array}$ & $\begin{array}{l}29 \text { Dec. } \\
2010\end{array}$ & $\begin{array}{l}4^{\text {th }} \text { Quarter } \\
2013\end{array}$ & $\begin{array}{l}4^{\text {th }} \text { Quarter } \\
2013\end{array}$ \\
\hline 4 & $\mathrm{Km} \mathrm{80+800}$ & 2000 & 20000 & $\begin{array}{|ll|}\text { Hoa } & \text { Mai } \\
\text { Company }\end{array}$ & $\begin{array}{ll}\text { Son } & \mathrm{Nga} \\
\text { Communce } & \\
\end{array}$ & $\begin{array}{l}\text { Backfill for brick } \\
\text { production area }\end{array}$ & $\begin{array}{l}29 \text { Dec. } \\
2010 \\
\end{array}$ & \begin{tabular}{lr|} 
Son Nga \\
Communce \\
\end{tabular} & $\begin{array}{l}29 \text { Dec. } \\
2010 \\
\end{array}$ & $\begin{array}{l}4^{\text {th }} \text { Quarter } \\
2013 \\
\end{array}$ & $\begin{array}{l}4^{\text {th }} \text { Quarter } \\
2013 \\
\end{array}$ \\
\hline \multicolumn{12}{|c|}{ Xa Phung Xa, huyen Cam Khe } \\
\hline 1 & $\mathrm{Km} \mathrm{82+080}$ & 300 & 600 & $\begin{array}{|ll|}\begin{array}{l}\text { Nguyen } \\
\text { Thung }\end{array} & \text { Thi } \\
\end{array}$ & $\begin{array}{l}\text { Zone 2, Phung Xa } \\
\text { Communce }\end{array}$ & $\begin{array}{l}\text { Pond, and low } \\
\text { area, need to }\end{array}$ & $\begin{array}{l}28 \text { Dec. } \\
2010\end{array}$ & $\begin{array}{l}\text { Phung Xa } \\
\text { Communce }\end{array}$ & $\begin{array}{l}28 \text { Dec. } \\
2010\end{array}$ & $\begin{array}{l}4^{\text {th }} \text { Quarter } \\
2013\end{array}$ & $\begin{array}{l}4^{\text {th }} \text { Quarter } \\
2013\end{array}$ \\
\hline 2 & $\mathrm{Km} \mathrm{82+100}$ & 2200 & 8800 & $\begin{array}{|lr|}\text { M. Toa, } & \text { Vice } \\
\text { Chairman } & \text { of } \\
\text { Phung } & \text { Xa } \\
\text { Communce } & \\
\end{array}$ & $\begin{array}{l}\text { Phung } \\
\text { Communce }\end{array}$ & $\begin{array}{l}\text { Fill for stadium of } \\
\text { the communce }\end{array}$ & $\begin{array}{l}28 \text { Dec. } \\
2010\end{array}$ & $\begin{array}{l}\text { Phung Xa } \\
\text { Communce }\end{array}$ & $\begin{array}{l}28 \text { Dec. } \\
2010\end{array}$ & $\begin{array}{l}4^{\text {th }} \text { Quarter } \\
2013\end{array}$ & $\begin{array}{l}4^{\text {th }} \text { Quarter } \\
2013\end{array}$ \\
\hline \multicolumn{12}{|c|}{ Xa Tuy Loc, huyen Cam Khe } \\
\hline 1 & $\mathrm{Km} \mathrm{85+500}$ & 2,424 & 9,396 & \begin{tabular}{|l|} 
Nguyen \\
Hong
\end{tabular} & $\begin{array}{l}\text { Zone 4, Du } \mathrm{Ba} \\
\text { Village, Tuy } \mathrm{Loc} \\
\text { commune, Cam } \\
\text { Khe district }\end{array}$ & Pond & $\begin{array}{l}19 \text { Dec. } \\
2012\end{array}$ & $\begin{array}{lr}\text { Tuy Loc } \\
\text { Communce }\end{array}$ & $\begin{array}{l}1 \quad \text { Nov } \\
2012\end{array}$ & & $\begin{array}{ll}5 & \text { Feb } \\
2013 & \end{array}$ \\
\hline 2 & $\mathrm{Km} \mathrm{85+600}$ & 404 & 1,568 & \begin{tabular}{|l|l|} 
Nguyen & Van \\
Hong &
\end{tabular} & $\begin{array}{l}\text { Zone } 4, \quad \mathrm{Du} \\
\text { Village, Tuy } \\
\text { commune, } \quad \text { Coc } \\
\end{array}$ & Houses's garden & $\begin{array}{l}19 \text { Dec. } \\
2012\end{array}$ & $\begin{array}{lr}\text { Tuy } \quad \text { Loc } \\
\text { Communce }\end{array}$ & $\begin{array}{l}20 \text { Dec } \\
2012\end{array}$ & & $\begin{array}{ll}5 & \text { Feb } \\
2013 & \end{array}$ \\
\hline
\end{tabular}


Loan 2391/2392 - VIE: GMS Kunming - Hai Phong Transport Corridor

Noi Bai - Lao Cai Highway Project

\begin{tabular}{|c|c|c|c|c|c|c|c|c|c|c|c|}
\hline & & & & & Khe district & & & & & & \\
\hline 3 & $\mathrm{Km} \mathrm{85+550}$ & 1934 & 7500 & $\begin{array}{ll}\text { Nguyen } & \text { Van } \\
\text { Hong } & \end{array}$ & $\begin{array}{l}\text { Zone 4, Du } \mathrm{Ba} \\
\text { Village, Tuy } \mathrm{Loc} \\
\text { commune, Cam } \\
\text { Khe district }\end{array}$ & Pond & $\begin{array}{l}19 \text { Dec. } \\
2012\end{array}$ & $\begin{array}{l}\text { Tuy Loc } \\
\text { Communce }\end{array}$ & $\begin{array}{l}20 \text { Dec } \\
2012\end{array}$ & & $\begin{array}{ll}5 & \text { Feb } \\
2013 & \end{array}$ \\
\hline 4 & $\mathrm{Km} \mathrm{85+480}$ & 3112 & 12064 & $\begin{array}{ll}\text { Nguyen } & \text { Van } \\
\text { Hong } & \end{array}$ & $\begin{array}{l}\text { Zone 4, Du } \mathrm{Ba} \\
\text { Village, Tuy } \mathrm{Loc} \\
\text { commune, Cam } \\
\text { Khe district }\end{array}$ & Pond & $\begin{array}{l}19 \text { Dec. } \\
2012\end{array}$ & $\begin{array}{l}\text { Tuy Loc } \\
\text { Communce }\end{array}$ & $\begin{array}{l}1 \quad \text { Nov } \\
2012\end{array}$ & & $\begin{array}{ll}5 & \text { Feb } \\
2013 & \end{array}$ \\
\hline 5 & $\mathrm{Km} \mathrm{85+460}$ & 851 & 3300 & $\begin{array}{ll}\text { Nguyen } & \text { Van } \\
\text { Hong } & \end{array}$ & $\begin{array}{l}\text { Zone 4, Du Ba } \\
\text { Village, Tuy Loc } \\
\text { commune, Cam } \\
\text { Khe district }\end{array}$ & Houses's garden & $\begin{array}{l}19 \text { Dec. } \\
2012\end{array}$ & $\begin{array}{l}\text { Tuy Loc } \\
\text { Communce }\end{array}$ & $\begin{array}{l}20 \text { Dec } \\
2012\end{array}$ & & $\begin{array}{ll}5 & \text { Feb } \\
2013 & \end{array}$ \\
\hline \multicolumn{12}{|c|}{ Xa Tuy Loc, huyen Cam Khe } \\
\hline 1 & $\begin{array}{r}\mathrm{Km80+000} \\
-\mathrm{Km} 82+500\end{array}$ & 4.517 & 100.000 & $\begin{array}{ll}\text { Truong } & \text { Xuan } \\
\text { Co., Ltd. } & \end{array}$ & $\begin{array}{ll}\text { Yen } & \text { Lap } \\
\text { commune, } & \text { Cam } \\
\text { Khe district, } & \text { Phu } \\
\text { Tho province } & \end{array}$ & $\begin{array}{l}\text { Emty land for } \\
\text { storing of brick. }\end{array}$ & $\begin{array}{l}12 / 04 / 2 \\
013\end{array}$ & $\begin{array}{l}\text { Cam Khe } \\
\text { district }\end{array}$ & $\begin{array}{l}\text { April } \\
2013\end{array}$ & Dec 2013 & Dec 2013 \\
\hline
\end{tabular}

\begin{tabular}{|c|c|c|c|c|c|c|c|c|c|c|c|}
\hline \multicolumn{12}{|c|}{ BATCHING PLANTS } \\
\hline \multirow{2}{*}{$\begin{array}{l}\text { Packag } \\
\text { e / SD } \\
\text { No. }\end{array}$} & \multirow[t]{2}{*}{ Location } & \multirow{2}{*}{$\begin{array}{l}\text { Appropriate } \\
\text { settling pond }\end{array}$} & \multirow{2}{*}{$\begin{array}{c}\text { Noise } \\
\text { and dust } \\
\text { measure } \\
\text { s }\end{array}$} & \multicolumn{2}{|c|}{ Ownership $^{a}$} & \multirow{2}{*}{$\begin{array}{l}\text { Prior Land } \\
\text { Use }^{b}\end{array}$} & \multicolumn{2}{|c|}{ Approval } & \multicolumn{3}{|c|}{ Operation } \\
\hline & & & & Name & Contact Info & & Date & Agency $^{c}$ & Start & Est. End & $\begin{array}{l}\text { Actual } \\
\text { End }\end{array}$ \\
\hline $\begin{array}{c}\text { A4/CBP } \\
1\end{array}$ & Ha Hoa Bridge & Yes & Yes & $\begin{array}{l}\text { Bang Gia } \\
\text { Communce }\end{array}$ & $\begin{array}{lr}\text { Mr. } & \text { Long } \\
\text { Chairman } & \text { of } \\
\text { Bang } & \text { Gia } \\
\text { Communce } & \end{array}$ & Pending & $\begin{array}{l}1 \text { Jan. } \\
2012\end{array}$ & $\begin{array}{l}\text { Bang Gia } \\
\text { Communce }\end{array}$ & $\begin{array}{l}1 \text { Jan. } \\
2012\end{array}$ & $\begin{array}{l}1 \text { Jan. } \\
2016\end{array}$ & \\
\hline $\begin{array}{c}\text { A4/CBP } \\
2\end{array}$ & $\begin{array}{l}\text { Zone 4, Minh Coi } \\
\text { commune, Ha Hoa } \\
\text { district }\end{array}$ & Yes & Yes & Ho Van Thai & 01696.643 .932 & farm land & $\begin{array}{l}14 \text { Dec } \\
2012\end{array}$ & $\begin{array}{l}\text { Minh Coi } \\
\text { commune } \\
\text { certified }\end{array}$ & $\begin{array}{l}1^{\text {st }} \\
\text { Quarter } \\
2012\end{array}$ & $\begin{array}{l}4^{\text {th }} \\
\text { Quarter } \\
2013\end{array}$ & $\begin{array}{l}4^{\text {th }} \text { Quarter } \\
2013\end{array}$ \\
\hline & & & & $\begin{array}{l}\text { Nguyen Tien } \\
\text { Loi }\end{array}$ & 01686.352 .890 & farm land & $\begin{array}{l}14 \text { Dec } \\
2012\end{array}$ & $\begin{array}{l}\text { Minh Coi } \\
\text { commune } \\
\text { certified }\end{array}$ & $\begin{array}{l}1^{\text {st }} \\
\text { Quarter } \\
2012\end{array}$ & $\begin{array}{l}4^{\text {th }} \\
\text { Quarter } \\
2013\end{array}$ & $\begin{array}{l}4^{\text {th }} \text { Quarter } \\
2013\end{array}$ \\
\hline & & & & $\begin{array}{l}\text { Nguyen } \\
\text { Tuan Hong }\end{array}$ & 0975.247 .493 & farm land & $\begin{array}{l}14 \text { Dec } \\
2012\end{array}$ & $\begin{array}{l}\text { Minh Coi } \\
\text { commune }\end{array}$ & $\begin{array}{l}1^{\text {st }} \\
\text { Quarter }\end{array}$ & $\begin{array}{l}4^{\text {th }} \\
\text { Quarter }\end{array}$ & $\begin{array}{l}4^{\text {th }} \text { Quarter } \\
2013\end{array}$ \\
\hline
\end{tabular}


Loan 2391/2392 - VIE: GMS Kunming - Hai Phong Transport Corridor Noi Bai - Lao Cai Highway Project

\begin{tabular}{|c|c|c|c|c|c|c|c|c|c|c|c|}
\hline & & & & & & & & certified & 2012 & 2013 & \\
\hline & & & & $\begin{array}{l}\text { Nguyen } \\
\text { Xuan Liem }\end{array}$ & 01689.338 .258 & farm land & $\begin{array}{l}14 \text { Dec } \\
2012\end{array}$ & \begin{tabular}{|l|} 
Minh Coi \\
commune \\
certified
\end{tabular} & $\begin{array}{l}1^{\text {st }} \\
\text { Quarter } \\
2012\end{array}$ & $\begin{array}{l}4^{\text {th }} \\
\text { Quarter } \\
2013\end{array}$ & $\begin{array}{l}4^{\text {th }} \text { Quarter } \\
2013\end{array}$ \\
\hline & & & & $\begin{array}{l}\text { Phung Duc } \\
\text { Thu }\end{array}$ & 01275.168 .096 & farm land & $\begin{array}{l}14 \text { Dec } \\
2012\end{array}$ & $\begin{array}{l}\text { Minh Coi } \\
\text { commune } \\
\text { certified }\end{array}$ & $\begin{array}{l}1^{\text {st }} \\
\text { Quarter } \\
2012\end{array}$ & $\begin{array}{l}4^{\text {th }} \\
\text { Quarter } \\
2013\end{array}$ & $\begin{array}{l}4^{\text {th }} \text { Quarter } \\
2013\end{array}$ \\
\hline & & & & $\begin{array}{ll}\text { Tran } & \text { Van } \\
\text { Nhan } & \end{array}$ & 0210.6291 .937 & farm land & $\begin{array}{l}14 \text { Dec } \\
2012\end{array}$ & \begin{tabular}{|l|} 
Minh Coi \\
commune \\
certified
\end{tabular} & $\begin{array}{l}1^{\text {st }} \\
\text { Quarter } \\
2012\end{array}$ & $\begin{array}{l}4^{\text {th }} \\
\text { Quarter } \\
2013\end{array}$ & $\begin{array}{l}4^{\text {th }} \text { Quarter } \\
2013\end{array}$ \\
\hline & & & & $\begin{array}{l}\text { Nguyen } \\
\text { Hong } \\
\text { Phuong }\end{array}$ & 01678.814 .448 & farm land & $\begin{array}{l}14 \text { Dec } \\
2012\end{array}$ & \begin{tabular}{|l|} 
Minh Coi \\
commune \\
certified
\end{tabular} & $\begin{array}{l}1^{\text {st }} \\
\text { Quarter } \\
2012\end{array}$ & $\begin{array}{l}4^{\text {th }} \\
\text { Quarter } \\
2013\end{array}$ & $\begin{array}{l}4^{\text {th }} \text { Quarter } \\
2013\end{array}$ \\
\hline & & & & $\begin{array}{l}\text { Nguyen Van } \\
\text { Sy }\end{array}$ & 01687.147 .867 & farm land & $\begin{array}{l}14 \text { Dec } \\
2012\end{array}$ & \begin{tabular}{|l|} 
Minh Coi \\
commune \\
certified
\end{tabular} & $\begin{array}{l}1^{\text {st }} \\
\text { Quarter } \\
2012\end{array}$ & $\begin{array}{l}4^{\text {th }} \\
\text { Quarter } \\
2013\end{array}$ & $\begin{array}{l}4^{\text {th }} \text { Quarter } \\
2013\end{array}$ \\
\hline
\end{tabular}

\section{Package A5}

\begin{tabular}{|c|c|c|c|c|c|c|c|c|c|c|c|}
\hline \multicolumn{12}{|c|}{ BATCHING PLANTS } \\
\hline \multirow{2}{*}{$\begin{array}{l}\text { Package I SD } \\
\text { No. }\end{array}$} & \multirow{2}{*}{ Location } & \multirow{2}{*}{$\begin{array}{c}\text { Appropriate } \\
\text { settling pond }\end{array}$} & \multirow{2}{*}{$\begin{array}{l}\text { Noise and } \\
\text { dust } \\
\text { measures }\end{array}$} & \multicolumn{2}{|c|}{ Ownership $^{a}$} & \multirow{2}{*}{$\begin{array}{c}\text { Prior Land } \\
\text { Use }^{\mathrm{b}}\end{array}$} & \multicolumn{2}{|c|}{ Approval } & \multicolumn{3}{|c|}{ Operation } \\
\hline & & & & Name & Contact Info & & Date & Agency $^{c}$ & Start & Est. End & Actual End \\
\hline A5/CBP1 & $\mathrm{Km} \mathrm{124+000}$ & Yes & No & $\begin{array}{l}\text { Song Hong } \\
\text { Concrete } \\
\text { JSC }\end{array}$ & $\begin{array}{c}\text { Tran Yen } \\
\text { district, Yen } \\
\text { Bai province }\end{array}$ & $\begin{array}{l}\text { Side Cut of } \\
\text { idled land }\end{array}$ & $31 / 10 / 201$ & $\begin{array}{l}\text { Tran Yen } \\
\text { GOV }\end{array}$ & $17 / 9 / 2011$ & & \\
\hline A5/CBP2 & $\mathrm{Km} \mathrm{136+000}$ & Yes & No & Licogi 15 & $\begin{array}{c}\text { Van Yen } \\
\text { district, Yen } \\
\text { Bai province }\end{array}$ & grass land & $\begin{array}{c}31 / 10 / 201 \\
1\end{array}$ & $\begin{array}{l}\text { Van Yen } \\
\text { GOV }\end{array}$ & $4 / 12 / 2011$ & & \\
\hline A5/CBP3 & $\mathrm{Km} \mathrm{145+200}$ & Yes & No & $\begin{array}{l}\text { Thanh } \\
\text { Thu-Bao } \\
\text { Tin }\end{array}$ & $\begin{array}{c}\text { Van Yen } \\
\text { district, Yen } \\
\text { Bai province }\end{array}$ & $\begin{array}{l}\text { idled grass } \\
\text { land }\end{array}$ & 27/6/2011 & $\begin{array}{l}\text { Van Yen } \\
\text { GOV }\end{array}$ & $10 / 12 / 2011$ & & \\
\hline
\end{tabular}




\section{Loan 2391/2392 - VIE: GMS Kunming - Hai Phong Transport Corridor} Noi Bai - Lao Cai Highway Project

\begin{tabular}{|c|c|c|c|c|c|c|c|c|c|c|c|}
\hline \multicolumn{12}{|c|}{ BATCHING PLANTS } \\
\hline \multirow{2}{*}{$\begin{array}{l}\text { Package / SD } \\
\text { No. }\end{array}$} & \multirow{2}{*}{ Location } & \multirow{2}{*}{$\begin{array}{l}\text { Appropriate } \\
\text { settling pond }\end{array}$} & \multirow{2}{*}{$\begin{array}{c}\text { Noise and } \\
\text { dust } \\
\text { measures }\end{array}$} & \multicolumn{2}{|c|}{ Ownership $^{a}$} & \multirow{2}{*}{$\begin{array}{c}\text { Prior Land } \\
\text { Use }^{\mathbf{b}}\end{array}$} & \multicolumn{2}{|c|}{ Approval } & \multicolumn{3}{|c|}{ Operation } \\
\hline & & & & Name & Contact Info & & Date & Agency $^{c}$ & Start & Est. End & Actual End \\
\hline A5/CBP dtx & KCN Dam Hong & Yes & No & $\begin{array}{l}\text { Dong Tam } \\
\text { Xanh } \\
\text { Investment } \\
\text { and } \\
\text { Constructio } \\
\text { n JSC }\end{array}$ & $\begin{array}{c}\text { Van Yen } \\
\text { district, Yen } \\
\text { Bai province }\end{array}$ & $\begin{array}{l}\text { commercial } \\
\text { lot }\end{array}$ & $26 / 1 / 2011$ & $\begin{array}{l}\text { Van Yen } \\
\text { GOV }\end{array}$ & $30 / 7 / 2011$ & & \\
\hline A5/CBP 4 & $\mathrm{Km} 145+100$ & Yes & No & Trancosin & $\begin{array}{c}\text { Van Yen } \\
\text { district, Yen } \\
\text { Bai province }\end{array}$ & $\begin{array}{l}\text { commercial } \\
\text { lot }\end{array}$ & $6 / 10 / 2012$ & $\begin{array}{l}\text { Van Yen } \\
\text { GOV }\end{array}$ & $12 / 11 / 2012$ & & \\
\hline A5/CBP 5 & $\mathrm{Km} 122+000$ & Yes & No & Licogi 13 & $\begin{array}{c}\text { Tran Yen } \\
\text { district, Yen } \\
\text { Bai province }\end{array}$ & $\begin{array}{l}\text { commercial } \\
\text { lot }\end{array}$ & $10 / 6 / 2013$ & $\begin{array}{l}\text { Tran Yen } \\
\text { GOV }\end{array}$ & $6 / 5 / 2013$ & & \\
\hline A5/ACBP1 & $\mathrm{Km} 142$ & Yes & No & $\begin{array}{l}123 \\
\text { company }\end{array}$ & $\begin{array}{c}\text { Van Yen } \\
\text { district, Yen } \\
\text { Bai province }\end{array}$ & Private land & $1 / 10 / 2013$ & $\begin{array}{l}\text { Van Yen } \\
\text { GOV }\end{array}$ & $6 / 11 / 2013$ & & \\
\hline A5/ACBP2 & $\mathrm{Km} 119$ & Yes & No & $\begin{array}{l}\text { Asphalt } \\
\text { concrete } \\
\text { batching } \\
\text { plant } \\
\text { Km119 }\end{array}$ & $\begin{array}{c}\text { Tran Yen } \\
\text { district, Yen } \\
\text { Bai province }\end{array}$ & Private land & $\begin{array}{c}11 / 12 / 201 \\
3\end{array}$ & $\begin{array}{l}\text { Tran Yen } \\
\text { GOV }\end{array}$ & $14 / 1 / 2014$ & & \\
\hline A5/ACBP3 & $\mathrm{Km} 135+700$ & Yes & No & $\begin{array}{l}\text { Asphalt } \\
\text { concrete } \\
\text { batching } \\
\text { plant } \\
\text { Km135 }\end{array}$ & $\begin{array}{c}\text { Tran Yen } \\
\text { district, Yen } \\
\text { Bai province }\end{array}$ & $\begin{array}{l}\text { Disposal } \\
\text { areas } \\
\text { Km135 }\end{array}$ & $3 / 1 / 2014$ & $\begin{array}{l}\text { Tran Yen } \\
\text { GOV }\end{array}$ & $15 / 2 / 2014$ & & \\
\hline A5/ACBP4 & $\mathrm{Km} 117$ & No & No & $\begin{array}{l}\text { Asphalt } \\
\text { concrete } \\
\text { batching } \\
\text { plant } \\
\text { Km117 }\end{array}$ & $\begin{array}{c}\text { Tran Yen } \\
\text { district, Yen } \\
\text { Bai province }\end{array}$ & $\begin{array}{l}\text { Service area } \\
\mathrm{Km} 117\end{array}$ & $10 / 1 / 2014$ & $\begin{array}{l}\text { Tran Yen } \\
\text { GOV }\end{array}$ & $2 / 2 / 2014$ & & \\
\hline
\end{tabular}




\section{Loan 2391/2392 - VIE: GMS Kunming - Hai Phong Transport Corridor}

\section{Noi Bai - Lao Cai Highway Project}

\begin{tabular}{|c|c|c|c|c|c|c|c|c|c|c|c|}
\hline \multirow{2}{*}{$\begin{array}{l}\text { Package } \\
\text { SD No. }\end{array}$} & \multirow{2}{*}{ Location } & \multirow{2}{*}{$\begin{array}{c}\text { Approved } \\
\text { Area } \\
\text { (m2) }\end{array}$} & \multirow{2}{*}{$\begin{array}{c}\text { Approved } \\
\text { Capacity } \\
\text { (m3) }\end{array}$} & \multicolumn{2}{|c|}{ Ownershipa } & \multirow{2}{*}{$\begin{array}{c}\text { Prior Land } \\
\text { Useb }\end{array}$} & \multicolumn{2}{|c|}{ Approval } & \multicolumn{3}{|c|}{ Operation } \\
\hline & & & & Name & Contact Info & & Date & Agencyc & Start & Est. End & Actual End \\
\hline A5/SD1 & $\begin{array}{l}\text { Km111+740, Minh } \\
\text { Quan commune, Tran } \\
\text { Yen district, Yen Bai } \\
\text { province }\end{array}$ & 4094 & 14201 & $\begin{array}{l}\text { Song Da } \\
\text { Co., Ltd }\end{array}$ & $\begin{array}{c}\text { Minh Quan } \\
\text { commune, Tran } \\
\text { Yen district, Yen } \\
\text { Bai province }\end{array}$ & $\begin{array}{l}\text { Private } \\
\text { land }\end{array}$ & 17-Sep-2012 & 3-Oct-2012 & 3-Oct-2012 & & \\
\hline A5/SD2 & $\begin{array}{l}\text { Km111+680, Minh } \\
\text { Quan commune, Tran } \\
\text { Yen district, Yen Bai } \\
\text { province }\end{array}$ & 16580 & 59245 & $\begin{array}{l}\text { Song Da } \\
\text { Co., Ltd }\end{array}$ & $\begin{array}{c}\text { Minh Quan } \\
\text { commune, Tran } \\
\text { Yen district, Yen } \\
\text { Bai province }\end{array}$ & $\begin{array}{l}\text { Private } \\
\text { land }\end{array}$ & 17-Sep-2012 & 3-Oct-2012 & 3-Oct-2012 & & \\
\hline A5/SD3 & $\begin{array}{l}\text { Km113+100, Minh } \\
\text { Quan commune, Tran } \\
\text { Yen district, Yen Bai } \\
\text { province }\end{array}$ & 4427 & 29358 & $\begin{array}{l}\text { Song Da } \\
\text { Co., Ltd }\end{array}$ & $\begin{array}{c}\text { Minh Quan } \\
\text { commune, Tran } \\
\text { Yen district, Yen } \\
\text { Bai province }\end{array}$ & $\begin{array}{l}\text { Private } \\
\text { land }\end{array}$ & 17-Sep-2012 & 3-Oct-2012 & 3-Oct-2012 & & \\
\hline A5/SD4 & $\begin{array}{l}\text { Km112+200, Minh } \\
\text { Quan commune, Tran } \\
\text { Yen district, Yen Bai } \\
\text { province }\end{array}$ & 9600 & 43790 & $\begin{array}{l}\text { Song Da } \\
\text { Co., Ltd }\end{array}$ & $\begin{array}{c}\text { Minh Quan } \\
\text { commune, Tran } \\
\text { Yen district, Yen } \\
\text { Bai province }\end{array}$ & $\begin{array}{l}\text { Private } \\
\text { land }\end{array}$ & 17-Sep-2012 & 3-Oct-2012 & 3-Oct-2012 & & \\
\hline A5/SD5 & $\begin{array}{l}\text { Km112+600, Bao } \\
\text { Hung commune, Tran } \\
\text { Yen district, Yen Bai } \\
\text { province }\end{array}$ & 19370 & 60750 & $\begin{array}{l}\text { Song Da } \\
\text { Co., Ltd }\end{array}$ & $\begin{array}{c}\text { Bao Hung } \\
\text { commune, Tran } \\
\text { Yen district, Yen } \\
\text { Bai province } \\
\end{array}$ & Wild land & 17-Sep-2012 & 3-Oct-2012 & 3-Oct-2012 & & \\
\hline A5/SD6 & $\begin{array}{l}\text { Km116+480, Bao } \\
\text { Hung commune, Tran } \\
\text { Yen district, Yen Bai } \\
\text { province }\end{array}$ & 1940 & 12731 & $\begin{array}{l}\text { Song Da } \\
\text { Co., Ltd }\end{array}$ & $\begin{array}{c}\text { Bao Hung } \\
\text { commune, Tran } \\
\text { Yen district, Yen } \\
\text { Bai province }\end{array}$ & $\begin{array}{l}\text { Private } \\
\text { land }\end{array}$ & 17-Sep-2012 & 3-Oct-2012 & 3-Oct-2012 & & \\
\hline A5/SD7 & $\begin{array}{l}\text { Km125+300, Minh } \\
\text { Tien commune, Tran } \\
\text { Yen district, Yen Bai } \\
\text { province }\end{array}$ & 3566 & 8273 & $\begin{array}{c}\text { Licogi } 15 \\
\text { Co., Ltd }\end{array}$ & $\begin{array}{c}\text { Minh Tien } \\
\text { commune, Tran } \\
\text { Yen district, Yen } \\
\text { Bai province }\end{array}$ & $\begin{array}{l}\text { Private } \\
\text { land }\end{array}$ & 17-Sep-2012 & 3-Oct-2012 & 3-Oct-2012 & & \\
\hline A5/SD8 & $\begin{array}{l}\text { Km118+755, Bao } \\
\text { Hung commune, Tran } \\
\text { Yen district, Yen Bai } \\
\text { province }\end{array}$ & 560 & 28528 & $\begin{array}{l}\text { Licogi } 13 \\
\text { Co., Ltd }\end{array}$ & $\begin{array}{l}\text { Bao Hung } \\
\text { commune, Tran } \\
\text { Yen district, Yen } \\
\text { Bai province }\end{array}$ & Wild land & 9-Oct-2012 & $\begin{array}{c}\text { 27-Oct- } \\
2012\end{array}$ & $\begin{array}{c}27-\text { Oct- } \\
2012\end{array}$ & & \\
\hline A5/SD9 & $\begin{array}{l}\text { Km119+6800, Hop } \\
\text { Minh commune, Tran } \\
\text { Yen district, Yen Bai }\end{array}$ & 1560 & 43759 & $\begin{array}{l}\text { Licogi } 13 \\
\text { Co., Ltd }\end{array}$ & $\begin{array}{c}\text { Bao Hung } \\
\text { commune, Tran } \\
\text { Yen district, Yen }\end{array}$ & Wild land & 9-Oct-2012 & $\begin{array}{c}\text { 27-Oct- } \\
2012\end{array}$ & $\begin{array}{c}\text { 27-Oct- } \\
2012\end{array}$ & & \\
\hline
\end{tabular}


Loan 2391/2392 - VIE: GMS Kunming - Hai Phong Transport Corridor

Noi Bai - Lao Cai Highway Project

\begin{tabular}{|c|c|c|c|c|c|c|c|c|c|c|c|}
\hline \multicolumn{12}{|c|}{ SPOILS DISPOSAL AREAS } \\
\hline \multirow{2}{*}{$\begin{array}{l}\text { Package } \\
\text { SD No. }\end{array}$} & \multirow{2}{*}{ Location } & \multirow{2}{*}{$\begin{array}{c}\text { Approved } \\
\text { Area } \\
\text { (m2) }\end{array}$} & \multirow{2}{*}{$\begin{array}{c}\text { Approved } \\
\text { Capacity } \\
\text { (m3) }\end{array}$} & \multicolumn{2}{|c|}{ Ownershipa } & \multirow{2}{*}{$\begin{array}{l}\text { Prior Land } \\
\text { Useb }\end{array}$} & \multicolumn{2}{|c|}{ Approval } & \multicolumn{3}{|c|}{ Operation } \\
\hline & & & & Name & Contact Info & & Date & Agencyc & Start & Est. End & Actual End \\
\hline & province & & & & Bai province & & & & & & \\
\hline A5/SD10 & $\begin{array}{l}\text { Km120+180, Hop } \\
\text { Minh commune, Tran } \\
\text { Yen district, Yen Bai } \\
\text { province }\end{array}$ & & 64699 & $\begin{array}{l}\text { Licogi } 13 \\
\text { Co., Ltd }\end{array}$ & $\begin{array}{c}\text { Bao Hung } \\
\text { commune, Tran } \\
\text { Yen district, Yen } \\
\text { Bai province }\end{array}$ & Wild land & 9-Oct-2012 & $\begin{array}{l}\text { 27-Oct- } \\
2012\end{array}$ & $\begin{array}{c}\text { 27-Oct- } \\
2012\end{array}$ & & \\
\hline A5/SD11 & $\begin{array}{l}\text { Km126+620, Y Kan } \\
\text { commune, Tran Yen } \\
\text { district, Yen Bai } \\
\text { province, }\end{array}$ & & 4721 & $\begin{array}{l}\text { Licogi } 15 \\
\text { Co. Ltd }\end{array}$ & $\begin{array}{c}\text { Y Kan } \\
\text { commune, Tran } \\
\text { Yen district, Yen } \\
\text { Bai province, }\end{array}$ & $\begin{array}{l}\text { Private } \\
\text { land }\end{array}$ & 17-Sep-2012 & $\begin{array}{l}\text { 15-Oct- } \\
2012\end{array}$ & $\begin{array}{c}15-O c t- \\
2012\end{array}$ & & \\
\hline A5/SD12 & $\begin{array}{l}\text { Km126+750, Y Kan } \\
\text { commune, Tran Yen } \\
\text { district, Yen Bai } \\
\text { province }\end{array}$ & & 2448 & $\begin{array}{l}\text { Licogi } 15 \\
\text { Co. Ltd }\end{array}$ & $\begin{array}{c}\text { Y Kan } \\
\text { commune, Tran } \\
\text { Yen district, Yen } \\
\text { Bai province, }\end{array}$ & $\begin{array}{l}\text { Private } \\
\text { land }\end{array}$ & 17-Sep-2012 & $\begin{array}{l}\text { 15-Oct- } \\
2012\end{array}$ & $\begin{array}{c}15-O c t- \\
2012\end{array}$ & & \\
\hline A5/SD13 & $\begin{array}{l}\text { Km129+300, Y Kan } \\
\text { commune, Tran Yen } \\
\text { district, Yen Bai } \\
\text { province }\end{array}$ & & 2427 & $\begin{array}{l}\text { Licogi } 15 \\
\text { Co. Ltd }\end{array}$ & $\begin{array}{c}\text { Y Kan } \\
\text { commune, Tran } \\
\text { Yen district, Yen } \\
\text { Bai province, }\end{array}$ & $\begin{array}{l}\text { Private } \\
\text { land }\end{array}$ & 17-Sep-2012 & $\begin{array}{l}\text { 15-Oct- } \\
2012\end{array}$ & $\begin{array}{c}15-O c t- \\
2012\end{array}$ & & \\
\hline A5/SD14 & $\begin{array}{l}\text { Km130+620, Y Kan } \\
\text { commune, Tran Yen } \\
\text { district, Yen Bai } \\
\text { province }\end{array}$ & 2238 & 11700 & $\begin{array}{l}\text { Licogi } 15 \\
\text { Co. Ltd }\end{array}$ & $\begin{array}{c}\text { Y Kan } \\
\text { commune, Tran } \\
\text { Yen district, Yen } \\
\text { Bai province, }\end{array}$ & $\begin{array}{l}\text { Private } \\
\text { land }\end{array}$ & 17-Sep-2012 & $\begin{array}{l}\text { 15-Oct- } \\
2012\end{array}$ & $\begin{array}{c}\text { 15-Oct- } \\
2012\end{array}$ & & \\
\hline A5/SD15 & $\begin{array}{l}\text { Km131+840, Quy } \\
\text { Mong commune, Tran } \\
\text { Yen district, Yen Bai } \\
\text { province }\end{array}$ & 2158 & 28167 & $\begin{array}{l}\text { Licogi } 15 \\
\text { Co. Ltd }\end{array}$ & $\begin{array}{c}\text { Quy Mong } \\
\text { commune, Tran } \\
\text { Yen district, Yen } \\
\text { Bai province }\end{array}$ & $\begin{array}{l}\text { Private } \\
\text { land }\end{array}$ & 17-Sep-2012 & $\begin{array}{l}\text { 24-Oct- } \\
2012\end{array}$ & $\begin{array}{c}\text { 24-Oct- } \\
2012\end{array}$ & & \\
\hline A5/SD16 & $\begin{array}{l}\text { Km132+440, Quy } \\
\text { Mong commune, Tran } \\
\text { Yen district, Yen Bai } \\
\text { province }\end{array}$ & 2465 & 19720 & $\begin{array}{l}\text { Licogi } 15 \\
\text { Co. Ltd }\end{array}$ & $\begin{array}{c}\text { Quy Mong } \\
\text { commune, Tran } \\
\text { Yen district, Yen } \\
\text { Bai province } \\
\end{array}$ & $\begin{array}{l}\text { Private } \\
\text { land }\end{array}$ & 17-Sep-2012 & $\begin{array}{l}\text { 2-Nov- } \\
2012\end{array}$ & $\begin{array}{c}\text { 2-Nov- } \\
2012\end{array}$ & & \\
\hline A5/SD17 & $\begin{array}{l}\text { Km133+680, Quy } \\
\text { Mong commune, Tran } \\
\text { Yen district, Yen Bai } \\
\text { province }\end{array}$ & 1875 & 18750 & $\begin{array}{l}\text { Licogi } 15 \\
\text { Co. Ltd }\end{array}$ & $\begin{array}{l}\text { Quy Mong } \\
\text { commune, Tran } \\
\text { Yen district, Yen } \\
\text { Bai province }\end{array}$ & $\begin{array}{l}\text { Private } \\
\text { land }\end{array}$ & 17-Sep-2012 & $\begin{array}{l}\text { 2-Nov- } \\
2012\end{array}$ & $\begin{array}{c}\text { 2-Nov- } \\
2012\end{array}$ & & \\
\hline A5/SD18 & Km136+320, Quy & 2175 & 32190 & Licogi 15 & Quy Mong & Wild land & 27-Aug-2012 & 9-Sep- & 9-Sep- & & \\
\hline
\end{tabular}




\section{Loan 2391/2392 - VIE: GMS Kunming - Hai Phong Transport Corridor}

Noi Bai - Lao Cai Highway Project

\begin{tabular}{|c|c|c|c|c|c|c|c|c|c|c|c|}
\hline \multicolumn{12}{|c|}{ SPOILS DISPOSAL AREAS } \\
\hline \multirow{3}{*}{$\begin{array}{l}\text { Package } \\
\text { SD No. }\end{array}$} & \multirow{2}{*}{ Location } & \multirow{2}{*}{$\begin{array}{l}\text { Approved } \\
\text { Area } \\
\text { (m2) }\end{array}$} & \multirow{2}{*}{$\begin{array}{l}\text { Approved } \\
\text { Capacity } \\
\text { (m3) }\end{array}$} & \multicolumn{2}{|c|}{ Ownershipa } & \multirow{2}{*}{$\begin{array}{l}\text { Prior Land } \\
\text { Useb }\end{array}$} & \multicolumn{2}{|c|}{ Approval } & \multicolumn{3}{|c|}{ Operation } \\
\hline & & & & Name & Contact Info & & Date & Agencyc & Start & Est. End & Actual End \\
\hline & $\begin{array}{l}\text { Mong commune, Tran } \\
\text { Yen district, Yen Bai } \\
\text { province }\end{array}$ & & & Co. Ltd & $\begin{array}{l}\text { commune, Tran } \\
\text { Yen district, Yen } \\
\text { Bai province }\end{array}$ & & & 2012 & 2012 & & \\
\hline A5/SD19 & $\begin{array}{l}\text { Km138+000, Hoang } \\
\text { Thang commune, } \\
\text { Tran Yen district, Yen } \\
\text { Bai province }\end{array}$ & & 6003 & $\begin{array}{l}\text { Licogi } 15 \\
\text { Co. Ltd }\end{array}$ & $\begin{array}{c}\text { Quy Mong } \\
\text { commune, Tran } \\
\text { Yen district, Yen } \\
\text { Bai province }\end{array}$ & Wild land & 27-Aug-2012 & $\begin{array}{c}\text { 9-Sep- } \\
2012\end{array}$ & $\begin{array}{c}\text { 9-Sep- } \\
2012\end{array}$ & & \\
\hline A5/SD20 & $\begin{array}{l}\text { Km136+750, Quy } \\
\text { Mong commune, Tran } \\
\text { Yen district, Yen Bai } \\
\text { province }\end{array}$ & 1980 & 8329 & $\begin{array}{l}\text { Licogi } 15 \\
\text { Co. Ltd }\end{array}$ & $\begin{array}{c}\text { Quy Mong } \\
\text { commune, Tran } \\
\text { Yen district, Yen } \\
\text { Bai province }\end{array}$ & Wild land & 27-Aug-2012 & $\begin{array}{c}\text { 9-Sep- } \\
2012\end{array}$ & $\begin{array}{c}\text { 9-Sep- } \\
2012\end{array}$ & & \\
\hline A5/SD21 & $\begin{array}{l}\text { Km137+420, Hoang } \\
\text { Thang commune, } \\
\text { Tran Yen district, Yen } \\
\text { Bai province }\end{array}$ & 5437 & 45891 & $\begin{array}{l}\text { Licogi } 15 \\
\text { Co. Ltd }\end{array}$ & $\begin{array}{c}\text { Hoang Thang } \\
\text { commune, Tran } \\
\text { Yen district, Yen } \\
\text { Bai province }\end{array}$ & $\begin{array}{l}\text { Private } \\
\text { land }\end{array}$ & 27-Aug-2012 & $\begin{array}{c}\text { 9-Sep- } \\
2012\end{array}$ & $\begin{array}{c}\text { 9-Sep- } \\
2012\end{array}$ & & \\
\hline A5/SD22 & $\begin{array}{l}\text { Km137+980, Hoang } \\
\text { Thang commune, } \\
\text { Tran Yen district, Yen } \\
\text { Bai province }\end{array}$ & 1244 & 5980 & $\begin{array}{c}\text { Trancosin } \\
\text { Co. Ltd }\end{array}$ & $\begin{array}{c}\text { Hoang Thang } \\
\text { commune, Tran } \\
\text { Yen district, Yen } \\
\text { Bai province }\end{array}$ & $\begin{array}{l}\text { Private } \\
\text { land }\end{array}$ & 27-Aug-2012 & $\begin{array}{c}\text { 9-Sep- } \\
2012\end{array}$ & $\begin{array}{c}\text { 9-Sep- } \\
2012\end{array}$ & & \\
\hline A5/SD23 & $\begin{array}{l}\text { Km140+140, Xuan Ai } \\
\text { commune, Tran Yen } \\
\text { district, Yen Bai } \\
\text { province }\end{array}$ & & 13940 & $\begin{array}{c}\text { Trancosin } \\
\text { Co. Ltd }\end{array}$ & $\begin{array}{c}\text { Xuan Ai } \\
\text { commune, Tran } \\
\text { Yen district, Yen } \\
\text { Bai province }\end{array}$ & $\begin{array}{l}\text { Private } \\
\text { land }\end{array}$ & 27-Aug-2012 & $\begin{array}{c}\text { 9-Sep- } \\
2012\end{array}$ & $\begin{array}{c}\text { 9-Sep- } \\
2012\end{array}$ & & \\
\hline A5/SD24 & $\begin{array}{l}\text { Km141+160, Xuan Ai } \\
\text { commune, Tran Yen } \\
\text { district, Yen Bai } \\
\text { province }\end{array}$ & & 11681 & $\begin{array}{c}\text { Trancosin } \\
\text { Co. Ltd }\end{array}$ & $\begin{array}{c}\text { Xuan Ai } \\
\text { commune, Tran } \\
\text { Yen district, Yen } \\
\text { Bai province }\end{array}$ & $\begin{array}{l}\text { Private } \\
\text { land }\end{array}$ & 27-Aug-2012 & $\begin{array}{c}\text { 20-Sep- } \\
2012\end{array}$ & $\begin{array}{c}\text { 20-Sep- } \\
2012\end{array}$ & & \\
\hline A5/SD25 & $\begin{array}{l}\text { Km141+240, Xuan Ai } \\
\text { commune, Tran Yen } \\
\text { district, Yen Bai } \\
\text { province }\end{array}$ & & 3599 & $\begin{array}{c}\text { Trancosin } \\
\text { Co. Ltd }\end{array}$ & $\begin{array}{c}\text { Xuan Ai } \\
\text { commune, Tran } \\
\text { Yen district, Yen } \\
\text { Bai province }\end{array}$ & $\begin{array}{l}\text { Private } \\
\text { land }\end{array}$ & 27-Aug-2012 & $\begin{array}{c}\text { 20-Sep- } \\
2012\end{array}$ & $\begin{array}{c}\text { 20-Sep- } \\
2012\end{array}$ & & \\
\hline A5/SD26 & $\begin{array}{l}\text { Km140+520, Xuan Ai } \\
\text { commune, Tran Yen } \\
\text { district, Yen Bai }\end{array}$ & & 6015 & $\begin{array}{c}\text { Trancosin } \\
\text { Co. Ltd }\end{array}$ & $\begin{array}{c}\text { Xuan Ai } \\
\text { commune, Tran } \\
\text { Yen district, Yen }\end{array}$ & $\begin{array}{l}\text { Private } \\
\text { land }\end{array}$ & 27-Aug-2012 & $\begin{array}{c}\text { 20-Sep- } \\
2012\end{array}$ & $\begin{array}{l}\text { 20-Sep- } \\
2012\end{array}$ & & \\
\hline
\end{tabular}




\section{Loan 2391/2392 - VIE: GMS Kunming - Hai Phong Transport Corridor}

Noi Bai - Lao Cai Highway Project

\begin{tabular}{|c|c|c|c|c|c|c|c|c|c|c|c|}
\hline \multicolumn{12}{|c|}{ SPOILS DISPOSAL AREAS } \\
\hline \multirow{2}{*}{$\begin{array}{l}\text { Package } \\
\text { SD No. }\end{array}$} & \multirow{2}{*}{ Location } & \multirow{2}{*}{$\begin{array}{c}\text { Approved } \\
\text { Area } \\
\text { (m2) }\end{array}$} & \multirow{2}{*}{$\begin{array}{c}\text { Approved } \\
\text { Capacity } \\
\text { (m3) }\end{array}$} & \multicolumn{2}{|c|}{ Ownershipa } & \multirow{2}{*}{$\begin{array}{c}\text { Prior Land } \\
\text { Useb }\end{array}$} & \multicolumn{2}{|c|}{ Approval } & \multicolumn{3}{|c|}{ Operation } \\
\hline & & & & Name & Contact Info & & Date & Agencyc & Start & Est. End & Actual End \\
\hline & province & & & & Bai province & & & & & & \\
\hline A5/SD27 & $\begin{array}{l}\text { Km140+860, Xuan Ai } \\
\text { commune, Tran Yen } \\
\text { district, Yen Bai } \\
\text { province }\end{array}$ & & 15826 & $\begin{array}{c}\text { Trancosin } \\
\text { Co. Ltd }\end{array}$ & $\begin{array}{c}\text { Xuan Ai } \\
\text { commune, Tran } \\
\text { Yen district, Yen } \\
\text { Bai province }\end{array}$ & $\begin{array}{l}\text { Private } \\
\text { land }\end{array}$ & 27-Aug-2012 & $\begin{array}{c}\text { 20-Sep- } \\
2012\end{array}$ & $\begin{array}{c}\text { 20-Sep- } \\
2012\end{array}$ & & \\
\hline A5/SD28 & $\begin{array}{l}\text { Km145+000, Yen } \\
\text { Hop Commune, Van } \\
\text { Yen district, Yen Bai } \\
\text { province }\end{array}$ & 4500 & 26286 & $\begin{array}{c}\text { Trancosin } \\
\text { Co. Ltd }\end{array}$ & $\begin{array}{c}\text { Yen Hop } \\
\text { Commune, Van } \\
\text { Yen district, } \\
\text { Yen Bai } \\
\text { province }\end{array}$ & $\begin{array}{l}\text { Private } \\
\text { land }\end{array}$ & 27-Aug-2012 & $\begin{array}{c}\text { 20-Sep- } \\
2012\end{array}$ & $\begin{array}{c}\text { 20-Sep- } \\
2012\end{array}$ & & \\
\hline A5/SD29 & $\begin{array}{l}\text { Km146+250, Yen } \\
\text { Hop Commune, Van } \\
\text { Yen district, Yen Bai } \\
\text { province }\end{array}$ & 3500 & 11584 & $\begin{array}{c}\text { Trancosin } \\
\text { Co. Ltd }\end{array}$ & $\begin{array}{c}\text { Yen Hop } \\
\text { Commune, Van } \\
\text { Yen district, } \\
\text { Yen Bai } \\
\text { province }\end{array}$ & $\begin{array}{l}\text { Private } \\
\text { land }\end{array}$ & 27-Aug-2012 & $\begin{array}{c}\text { 20-Sep- } \\
2012\end{array}$ & $\begin{array}{c}\text { 20-Sep- } \\
2012\end{array}$ & & \\
\hline A5/SD30 & $\begin{array}{l}\text { Km146+720, Yen } \\
\text { Hop Commune, Van } \\
\text { Yen district, Yen Bai } \\
\text { province }\end{array}$ & 1734 & 6937 & $\begin{array}{c}\text { Trancosin } \\
\text { Co. Ltd }\end{array}$ & $\begin{array}{c}\text { Yen Hop } \\
\text { Commune, Van } \\
\text { Yen district, } \\
\text { Yen Bai } \\
\text { province }\end{array}$ & $\begin{array}{l}\text { Private } \\
\text { land }\end{array}$ & 27-Aug-2012 & $\begin{array}{c}\text { 17-Sep- } \\
2012\end{array}$ & $\begin{array}{c}\text { 17-Sep- } \\
2012\end{array}$ & & \\
\hline A5/SD31 & $\begin{array}{l}\text { Km147+200, Yen } \\
\text { Hop Commune, Van } \\
\text { Yen district, Yen Bai } \\
\text { province }\end{array}$ & 1488 & 11583 & $\begin{array}{c}\text { Trancosin } \\
\text { Co. Ltd }\end{array}$ & $\begin{array}{c}\text { Yen Hop } \\
\text { Commune, Van } \\
\text { Yen district, } \\
\text { Yen Bai } \\
\text { province }\end{array}$ & $\begin{array}{l}\text { Private } \\
\text { land }\end{array}$ & 27-Aug-2012 & $\begin{array}{c}\text { 17-Sep- } \\
2012\end{array}$ & $\begin{array}{c}\text { 17-Sep- } \\
2012\end{array}$ & & \\
\hline A5/SD32 & $\begin{array}{l}\text { Km148+300, Yen } \\
\text { Hop commune, Tran } \\
\text { Yen district, Yen Bai } \\
\text { province }\end{array}$ & 1023 & 15000 & $\begin{array}{l}\text { Trancosin } \\
\text { Co. Ltd }\end{array}$ & $\begin{array}{c}\text { Yen Hop } \\
\text { commune, Tran } \\
\text { Yen district, Yen } \\
\text { Bai province } \\
\end{array}$ & $\begin{array}{l}\text { Private } \\
\text { land }\end{array}$ & 27-Aug-2012 & $\begin{array}{c}\text { 17-Sep- } \\
2012\end{array}$ & $\begin{array}{c}\text { 17-Sep- } \\
2012\end{array}$ & & \\
\hline A5/SD33 & $\begin{array}{l}\text { Km111+740, Minh } \\
\text { Quan commune, Tran } \\
\text { Yen district, Yen Bai } \\
\text { province }\end{array}$ & 2184 & 6282 & $\begin{array}{l}\text { Song Da } \\
9 \text { Co. Ltd }\end{array}$ & $\begin{array}{c}\text { Minh Quan } \\
\text { commune, Tran } \\
\text { Yen district, Yen } \\
\text { Bai province }\end{array}$ & $\begin{array}{l}\text { Private } \\
\text { land }\end{array}$ & 28-Nov-2012 & $\begin{array}{c}\text { 15-Dec- } \\
2012\end{array}$ & $\begin{array}{c}\text { 15-Dec- } \\
2012\end{array}$ & & \\
\hline A5/SD34 & Km111+740, Minh & 1280 & 7919 & Song $\mathrm{Da}$ & Minh Quan & Wild land & 28-Nov-2012 & 15-Dec- & 15-Dec- & & \\
\hline
\end{tabular}




\section{Loan 2391/2392 - VIE: GMS Kunming - Hai Phong Transport Corridor}

Noi Bai - Lao Cai Highway Project

\begin{tabular}{|c|c|c|c|c|c|c|c|c|c|c|c|}
\hline \multicolumn{12}{|c|}{ SPOILS DISPOSAL AREAS } \\
\hline \multirow{2}{*}{$\begin{array}{l}\text { Package } \\
\text { SD No. }\end{array}$} & \multirow{2}{*}{ Location } & \multirow{2}{*}{$\begin{array}{l}\text { Approved } \\
\text { Area } \\
\text { (m2) }\end{array}$} & \multirow{2}{*}{$\begin{array}{c}\text { Approved } \\
\text { Capacity } \\
\text { (m3) }\end{array}$} & \multicolumn{2}{|c|}{ Ownershipa } & \multirow{2}{*}{$\begin{array}{l}\text { Prior Land } \\
\text { Useb }\end{array}$} & \multicolumn{2}{|c|}{ Approval } & \multicolumn{3}{|c|}{ Operation } \\
\hline & & & & Name & Contact Info & & Date & Agencyc & Start & Est. End & Actual End \\
\hline & $\begin{array}{l}\text { Quan commune, Tran } \\
\text { Yen district, Yen Bai } \\
\text { province }\end{array}$ & & & 9 Co. Ltd & $\begin{array}{l}\text { commune, Tran } \\
\text { Yen district, Yen } \\
\text { Bai province }\end{array}$ & & & 2012 & 2012 & & \\
\hline A5/SD35 & $\begin{array}{l}\text { Km111+680, Minh } \\
\text { Quan commune, Tran } \\
\text { Yen district, Yen Bai } \\
\text { province }\end{array}$ & 2677 & 6150 & $\begin{array}{l}\text { Song Da } \\
9 \text { Co. Ltd }\end{array}$ & $\begin{array}{c}\text { Minh Quan } \\
\text { commune, Tran } \\
\text { Yen district, Yen } \\
\text { Bai province }\end{array}$ & $\begin{array}{l}\text { Private } \\
\text { land }\end{array}$ & 28-Nov-2012 & $\begin{array}{c}\text { 15-Dec- } \\
2012\end{array}$ & $\begin{array}{c}\text { 15-Dec- } \\
2012\end{array}$ & & \\
\hline A5/SD36 & $\begin{array}{l}\text { Km111+680, Minh } \\
\text { Quan commune, Tran } \\
\text { Yen district, Yen Bai } \\
\text { province }\end{array}$ & 4603 & 5000 & $\begin{array}{l}\text { Song Da } \\
9 \text { Co. Ltd }\end{array}$ & $\begin{array}{c}\text { Minh Quan } \\
\text { commune, Tran } \\
\text { Yen district, Yen } \\
\text { Bai province }\end{array}$ & Wild land & 28-Nov-2012 & $\begin{array}{l}\text { 15-Dec- } \\
2012\end{array}$ & $\begin{array}{c}\text { 15-Dec- } \\
2012\end{array}$ & & \\
\hline A5/SD37 & $\begin{array}{l}\text { Km111+800, Minh } \\
\text { Quan commune, Tran } \\
\text { Yen district, Yen Bai } \\
\text { province }\end{array}$ & 9300 & 48095 & $\begin{array}{l}\text { Song Da } \\
9 \text { Co. Ltd }\end{array}$ & $\begin{array}{c}\text { Minh Quan } \\
\text { commune, Tran } \\
\text { Yen district, Yen } \\
\text { Bai province }\end{array}$ & $\begin{array}{l}\text { Private } \\
\text { land }\end{array}$ & 28-Nov-2012 & $\begin{array}{l}\text { 22-Dec- } \\
2012\end{array}$ & $\begin{array}{c}\text { 22-Dec- } \\
2012\end{array}$ & & \\
\hline A5/SD38 & $\begin{array}{l}\text { Km110+100, Minh } \\
\text { Quan commune, Tran } \\
\text { Yen district, Yen Bai } \\
\text { province }\end{array}$ & 9600 & 43790 & $\begin{array}{l}\text { Song Da } \\
9 \text { Co. Ltd }\end{array}$ & $\begin{array}{c}\text { Minh Quan } \\
\text { commune, Tran } \\
\text { Yen district, Yen } \\
\text { Bai province } \\
\end{array}$ & $\begin{array}{l}\text { Private } \\
\text { land }\end{array}$ & 28-Nov-2012 & $\begin{array}{l}\text { 22-Dec- } \\
2012\end{array}$ & $\begin{array}{l}\text { 22-Dec- } \\
2012\end{array}$ & & \\
\hline A5/SD39 & $\begin{array}{l}\text { Km110+340, Minh } \\
\text { Quan commune, Tran } \\
\text { Yen district, Yen Bai } \\
\text { province }\end{array}$ & 330 & 1650 & $\begin{array}{l}\text { Song Da } \\
9 \text { Co. Ltd }\end{array}$ & $\begin{array}{c}\text { Minh Quan } \\
\text { commune, Tran } \\
\text { Yen district, Yen } \\
\text { Bai province } \\
\end{array}$ & $\begin{array}{l}\text { Private } \\
\text { land }\end{array}$ & 28-Nov-2012 & $\begin{array}{l}\text { 22-Dec- } \\
2012\end{array}$ & $\begin{array}{c}\text { 22-Dec- } \\
2012\end{array}$ & & \\
\hline A5/SD40 & $\begin{array}{l}\text { Km110+360, Minh } \\
\text { Quan commune, Tran } \\
\text { Yen district, Yen Bai } \\
\text { province }\end{array}$ & 7070 & 29100 & $\begin{array}{l}\text { Song Da } \\
9 \text { Co. Ltd }\end{array}$ & $\begin{array}{c}\text { Minh Quan } \\
\text { commune, Tran } \\
\text { Yen district, Yen } \\
\text { Bai province } \\
\end{array}$ & $\begin{array}{l}\text { Private } \\
\text { land }\end{array}$ & 28-Nov-2012 & $\begin{array}{l}\text { 22-Dec- } \\
2012\end{array}$ & $\begin{array}{c}\text { 22-Dec- } \\
2012\end{array}$ & & \\
\hline A5/SD41 & $\begin{array}{l}\text { Km111+670, Minh } \\
\text { Quan commune, Tran } \\
\text { Yen district, Yen Bai } \\
\text { province }\end{array}$ & 12000 & 30000 & $\begin{array}{l}\text { Song Da } \\
9 \text { Co. Ltd }\end{array}$ & $\begin{array}{c}\text { Minh Quan } \\
\text { commune, Tran } \\
\text { Yen district, Yen } \\
\text { Bai province } \\
\end{array}$ & $\begin{array}{l}\text { Private } \\
\text { land }\end{array}$ & 28-Nov-2012 & $\begin{array}{l}\text { 22-Dec- } \\
2012\end{array}$ & $\begin{array}{l}\text { 22-Dec- } \\
2012\end{array}$ & & \\
\hline A5/SD42 & $\begin{array}{l}\text { Km148+300, Yen } \\
\text { Hop Commune, Van } \\
\text { Yen district, Yen Bai }\end{array}$ & & 150000 & $\begin{array}{l}\text { Trancosin } \\
\text { Co. Ltd }\end{array}$ & $\begin{array}{c}\text { Yen Hop } \\
\text { Commune, Van } \\
\text { Yen district, }\end{array}$ & $\begin{array}{l}\text { Private } \\
\text { land }\end{array}$ & 17-Dec-2012 & $\begin{array}{c}\text { 15-Jan- } \\
2013\end{array}$ & $\begin{array}{l}\text { 15-Jan- } \\
2013\end{array}$ & & \\
\hline
\end{tabular}


Loan 2391/2392 - VIE: GMS Kunming - Hai Phong Transport Corridor

Noi Bai - Lao Cai Highway Project

\begin{tabular}{|c|c|c|c|c|c|c|c|c|c|c|c|}
\hline \multicolumn{12}{|c|}{ SPOILS DISPOSAL AREAS } \\
\hline \multirow{2}{*}{$\begin{array}{l}\text { Package } \\
\text { SD No. }\end{array}$} & \multirow{2}{*}{ Location } & \multirow{2}{*}{$\begin{array}{c}\text { Approved } \\
\text { Area } \\
\text { (m2) }\end{array}$} & \multirow{2}{*}{$\begin{array}{c}\text { Approved } \\
\text { Capacity } \\
\text { (m3) }\end{array}$} & \multicolumn{2}{|c|}{ Ownershipa } & \multirow{2}{*}{$\begin{array}{l}\text { Prior Land } \\
\text { Useb }\end{array}$} & \multicolumn{2}{|c|}{ Approval } & \multicolumn{3}{|c|}{ Operation } \\
\hline & & & & Name & Contact Info & & Date & Agencyc & Start & Est. End & Actual End \\
\hline & province & & & & $\begin{array}{l}\text { Yen Bai } \\
\text { province }\end{array}$ & & & & & & \\
\hline A5/SD43 & $\begin{array}{l}\text { Km146+250, Yen } \\
\text { Hop Commune, Van } \\
\text { Yen district, Yen Bai } \\
\text { province }\end{array}$ & & 11584 & $\begin{array}{l}\text { Trancosin } \\
\text { Co. Ltd }\end{array}$ & $\begin{array}{c}\text { Yen Hop } \\
\text { Commune, Van } \\
\text { Yen district, } \\
\text { Yen Bai } \\
\text { province }\end{array}$ & $\begin{array}{l}\text { Private } \\
\text { land }\end{array}$ & 17-Dec-2012 & $\begin{array}{l}\text { 15-Jan- } \\
2013\end{array}$ & $\begin{array}{l}\text { 15-Jan- } \\
2013\end{array}$ & & \\
\hline A5/SD44 & $\begin{array}{l}\text { Km145+000, Yen } \\
\text { Hop Commune, Van } \\
\text { Yen district, Yen Bai } \\
\text { province }\end{array}$ & & 26286 & $\begin{array}{l}\text { Trancosin } \\
\text { Co. Ltd }\end{array}$ & $\begin{array}{c}\text { Yen Hop } \\
\text { Commune, Van } \\
\text { Yen district, } \\
\text { Yen Bai } \\
\text { province }\end{array}$ & $\begin{array}{l}\text { Private } \\
\text { land }\end{array}$ & 17-Dec-2012 & $\begin{array}{l}\text { 15-Jan- } \\
2013\end{array}$ & $\begin{array}{l}\text { 15-Jan- } \\
2013\end{array}$ & & \\
\hline A5/SD45 & $\begin{array}{l}\text { Km126+900, Y Kan } \\
\text { commune, Tran Yen } \\
\text { district, Yen Bai } \\
\text { province }\end{array}$ & & 16084 & $\begin{array}{l}\text { Trancosin } \\
\text { Co. Ltd }\end{array}$ & $\begin{array}{c}\text { Y Kan } \\
\text { commune, Tran } \\
\text { Yen district, Yen } \\
\text { Bai province }\end{array}$ & $\begin{array}{l}\text { Private } \\
\text { land }\end{array}$ & 17-Dec-2012 & $\begin{array}{l}\text { 15-Jan- } \\
2013\end{array}$ & $\begin{array}{l}\text { 15-Jan- } \\
2013\end{array}$ & & \\
\hline A5/SD46 & $\begin{array}{l}\text { Km127+000, Y Kan } \\
\text { commune, Tran Yen } \\
\text { district, Yen Bai } \\
\text { province }\end{array}$ & & 4224 & $\begin{array}{c}\text { Keangna } \\
\mathrm{m} \\
\text { Contracto } \\
\mathrm{r}\end{array}$ & $\begin{array}{c}\text { Y Kan } \\
\text { commune, Tran } \\
\text { Yen district, Yen } \\
\text { Bai province }\end{array}$ & Wild land & 4-Feb-2013 & $\begin{array}{l}\text { 28-Mar- } \\
2013\end{array}$ & $\begin{array}{l}\text { 28-Mar- } \\
2013\end{array}$ & & \\
\hline A5/SD47 & $\begin{array}{l}\text { Km127+000, Y Kan } \\
\text { commune, Tran Yen } \\
\text { district, Yen Bai } \\
\text { province }\end{array}$ & & 5779 & $\begin{array}{c}\text { Keangna } \\
\mathrm{m} \\
\text { Contracto } \\
\mathrm{r}\end{array}$ & $\begin{array}{c}\text { Y Kan } \\
\text { commune, Tran } \\
\text { Yen district, Yen } \\
\text { Bai province }\end{array}$ & Wild land & 4-Feb-2013 & $\begin{array}{l}\text { 28-Mar- } \\
2013\end{array}$ & $\begin{array}{l}\text { 28-Mar- } \\
2013\end{array}$ & & \\
\hline A5/SD48 & $\begin{array}{l}\text { Km120+200, Hop } \\
\text { Minh commune, Tran } \\
\text { Yen district, Yen Bai } \\
\text { province }\end{array}$ & & 7067 & $\begin{array}{c}\text { Keangna } \\
\mathrm{m} \\
\text { Contracto } \\
\mathrm{r}\end{array}$ & $\begin{array}{c}\text { Hop Minh } \\
\text { commune, Tran } \\
\text { Yen district, Yen } \\
\text { Bai province }\end{array}$ & $\begin{array}{l}\text { Private } \\
\text { land }\end{array}$ & 4-Feb-2013 & $\begin{array}{l}\text { 28-Mar- } \\
2013\end{array}$ & $\begin{array}{l}\text { 28-Mar- } \\
2013\end{array}$ & & \\
\hline A5/SD49 & $\begin{array}{l}\text { Km122+100, Hop } \\
\text { Minh commune, Tran } \\
\text { Yen district, Yen Bai } \\
\text { province }\end{array}$ & & 37515 & $\begin{array}{l}\text { Hoang An } \\
\text { Co. Ltd }\end{array}$ & $\begin{array}{c}\text { Hop Minh } \\
\text { commune, Tran } \\
\text { Yen district, Yen } \\
\text { Bai province }\end{array}$ & Wild land & 4-Feb-2013 & $\begin{array}{l}\text { 28-Mar- } \\
2013\end{array}$ & $\begin{array}{l}\text { 28-Mar- } \\
2013\end{array}$ & & \\
\hline A5/SD50 & $\begin{array}{l}\text { Km128+800, Y Kan } \\
\text { commune, Tran Yen }\end{array}$ & & 2558 & $\begin{array}{l}\text { Hoang An } \\
\text { Co. Ltd }\end{array}$ & $\begin{array}{c}\text { Y Kan } \\
\text { commune, Tran }\end{array}$ & $\begin{array}{l}\text { Private } \\
\text { land }\end{array}$ & 17-Sep-2012 & $\begin{array}{l}\text { 3-Nov- } \\
2012\end{array}$ & $\begin{array}{l}\text { 3-Nov- } \\
2012\end{array}$ & & \\
\hline
\end{tabular}


Loan 2391/2392 - VIE: GMS Kunming - Hai Phong Transport Corridor

Noi Bai - Lao Cai Highway Project

\begin{tabular}{|c|c|c|c|c|c|c|c|c|c|c|c|}
\hline \multicolumn{12}{|c|}{ SPOILS DISPOSAL AREAS } \\
\hline \multirow{2}{*}{$\begin{array}{l}\text { Package } \\
\text { SD No. }\end{array}$} & \multirow{2}{*}{ Location } & \multirow{2}{*}{$\begin{array}{c}\text { Approved } \\
\text { Area } \\
\text { (m2) }\end{array}$} & \multirow{2}{*}{$\begin{array}{c}\text { Approved } \\
\text { Capacity } \\
\text { (m3) }\end{array}$} & \multicolumn{2}{|c|}{ Ownershipa } & \multirow{2}{*}{$\begin{array}{l}\text { Prior Land } \\
\text { Useb }\end{array}$} & \multicolumn{2}{|c|}{ Approval } & \multicolumn{3}{|c|}{ Operation } \\
\hline & & & & Name & Contact Info & & Date & Agencyc & Start & Est. End & Actual End \\
\hline & $\begin{array}{l}\text { district, Yen Bai } \\
\text { province }\end{array}$ & & & & $\begin{array}{c}\text { Yen district, Yen } \\
\text { Bai province } \\
\end{array}$ & & & & & & \\
\hline A5/SD51 & $\begin{array}{l}\text { Km129+590, Y Kan } \\
\text { commune, Tran Yen } \\
\text { district, Yen Bai } \\
\text { province }\end{array}$ & & 2784 & $\begin{array}{l}\text { Hoang An } \\
\text { Co. Ltd }\end{array}$ & $\begin{array}{c}\text { Y Kan } \\
\text { commune, Tran } \\
\text { Yen district, Yen } \\
\text { Bai province }\end{array}$ & $\begin{array}{l}\text { Private } \\
\text { land }\end{array}$ & 17-Sep-2012 & $\begin{array}{l}\text { 3-Nov- } \\
2012\end{array}$ & $\begin{array}{l}\text { 3-Nov- } \\
2012\end{array}$ & & \\
\hline A5/SD52 & $\begin{array}{l}\text { Km126+000, Y Kan } \\
\text { commune, Tran Yen } \\
\text { district, Yen Bai } \\
\text { province }\end{array}$ & & 392 & $\begin{array}{c}\text { Keangna } \\
\mathrm{m} \\
\text { Contracto } \\
\mathrm{r}\end{array}$ & $\begin{array}{c}\text { Y Kan } \\
\text { commune, Tran } \\
\text { Yen district, Yen } \\
\text { Bai province }\end{array}$ & $\begin{array}{l}\text { Private } \\
\text { land }\end{array}$ & 5-Feb-2013 & $\begin{array}{l}\text { 29-Mar- } \\
2013\end{array}$ & $\begin{array}{l}\text { 29-Mar- } \\
2013\end{array}$ & & \\
\hline A5/SD53 & $\begin{array}{l}\text { Km125+950, Y Kan } \\
\text { commune, Tran Yen } \\
\text { district, Yen Bai } \\
\text { province }\end{array}$ & & 880 & $\begin{array}{c}\text { Keangna } \\
\mathrm{m} \\
\text { Contracto } \\
\mathrm{r}\end{array}$ & $\begin{array}{c}\text { Y Kan } \\
\text { commune, Tran } \\
\text { Yen district, Yen } \\
\text { Bai province } \\
\end{array}$ & $\begin{array}{l}\text { Private } \\
\text { land }\end{array}$ & 5-Feb-2013 & $\begin{array}{l}\text { 26-Feb- } \\
2013\end{array}$ & $\begin{array}{l}\text { 26-Feb- } \\
2013\end{array}$ & & \\
\hline A5/SD54 & $\begin{array}{l}\text { Km125+600, Y Kan } \\
\text { commune, Tran Yen } \\
\text { district, Yen Bai } \\
\text { province }\end{array}$ & & 2919 & $\begin{array}{c}\text { Keangna } \\
\mathrm{m} \\
\text { Contracto } \\
\mathrm{r}\end{array}$ & $\begin{array}{c}\text { Y Kan } \\
\text { commune, Tran } \\
\text { Yen district, Yen } \\
\text { Bai province } \\
\end{array}$ & $\begin{array}{l}\text { Private } \\
\text { land }\end{array}$ & 5-Feb-2013 & $\begin{array}{l}\text { 26-Feb- } \\
2013\end{array}$ & $\begin{array}{l}\text { 26-Feb- } \\
2013\end{array}$ & & \\
\hline A5/SD55 & $\begin{array}{l}\text { Km125+500, Y Kan } \\
\text { commune, Tran Yen } \\
\text { district, Yen Bai } \\
\text { province }\end{array}$ & & 987 & $\begin{array}{c}\text { Keangna } \\
\mathrm{m} \\
\text { Contracto } \\
\mathrm{r}\end{array}$ & $\begin{array}{c}\text { Y Kan } \\
\text { commune, Tran } \\
\text { Yen district, Yen } \\
\text { Bai province }\end{array}$ & $\begin{array}{l}\text { Private } \\
\text { land }\end{array}$ & 5-Feb-2013 & $\begin{array}{l}\text { 26-Feb- } \\
2013\end{array}$ & $\begin{array}{l}\text { 26-Feb- } \\
2013\end{array}$ & & \\
\hline A5/SD56 & $\begin{array}{l}\text { Km125+780. Y Kan } \\
\text { commune, Tran Yen } \\
\text { district, Yen Bai } \\
\text { province }\end{array}$ & & 2095 & $\begin{array}{c}\text { Keangna } \\
\mathrm{m} \\
\text { Contracto } \\
\mathrm{r}\end{array}$ & $\begin{array}{c}\text { Y Kan } \\
\text { commune, Tran } \\
\text { Yen district, Yen } \\
\text { Bai province } \\
\end{array}$ & $\begin{array}{l}\text { Private } \\
\text { land }\end{array}$ & 5-Feb-2013 & $\begin{array}{l}\text { 26-Feb- } \\
2013\end{array}$ & $\begin{array}{l}\text { 26-Feb- } \\
2013\end{array}$ & & \\
\hline A5/SD57 & $\begin{array}{l}\text { Km125+700, Y Kan } \\
\text { commune, Tran Yen } \\
\text { district, Yen Bai } \\
\text { province }\end{array}$ & & 378 & $\begin{array}{c}\text { Keangna } \\
\mathrm{m} \\
\text { Contracto } \\
\mathrm{r}\end{array}$ & $\begin{array}{c}\text { Y Kan } \\
\text { commune, Tran } \\
\text { Yen district, Yen } \\
\text { Bai province }\end{array}$ & $\begin{array}{l}\text { Private } \\
\text { land }\end{array}$ & 5-Feb-2013 & $\begin{array}{l}\text { 26-Feb- } \\
2013\end{array}$ & $\begin{array}{l}\text { 26-Feb- } \\
2013\end{array}$ & & \\
\hline A5/SD58 & $\begin{array}{l}\text { Km125+700, Y Kan } \\
\text { commune, Tran Yen } \\
\text { district, Yen Bai } \\
\text { province }\end{array}$ & & 622 & $\begin{array}{c}\text { Keangna } \\
\mathrm{m} \\
\text { Contracto } \\
\mathrm{r}\end{array}$ & $\begin{array}{c}\text { Y Kan } \\
\text { commune, Tran } \\
\text { Yen district, Yen } \\
\text { Bai province }\end{array}$ & $\begin{array}{l}\text { Private } \\
\text { land }\end{array}$ & 5-Feb-2013 & $\begin{array}{l}\text { 26-Feb- } \\
2013\end{array}$ & $\begin{array}{l}\text { 26-Feb- } \\
2013\end{array}$ & & \\
\hline
\end{tabular}




\section{Loan 2391/2392 - VIE: GMS Kunming - Hai Phong Transport Corridor}

Noi Bai - Lao Cai Highway Project

\begin{tabular}{|c|c|c|c|c|c|c|c|c|c|c|c|}
\hline \multicolumn{12}{|c|}{ SPOILS DISPOSAL AREAS } \\
\hline \multirow{2}{*}{$\begin{array}{l}\text { Package } \\
\text { SD No. }\end{array}$} & \multirow{2}{*}{ Location } & \multirow{2}{*}{$\begin{array}{c}\text { Approved } \\
\text { Area } \\
\text { (m2) }\end{array}$} & \multirow{2}{*}{$\begin{array}{c}\text { Approved } \\
\text { Capacity } \\
\text { (m3) }\end{array}$} & \multicolumn{2}{|c|}{ Ownershipa } & \multirow{2}{*}{$\begin{array}{l}\text { Prior Land } \\
\text { Useb }\end{array}$} & \multicolumn{2}{|c|}{ Approval } & \multicolumn{3}{|c|}{ Operation } \\
\hline & & & & Name & Contact Info & & Date & Agencyc & Start & Est. End & Actual End \\
\hline A5/SD59 & $\begin{array}{l}\text { Km145+500, Yen } \\
\text { Hop Commune, Van } \\
\text { Yen district, Yen Bai } \\
\text { province }\end{array}$ & 809 & 2000 & $\begin{array}{l}\text { Song Da } \\
9 \text { Co. Ltd }\end{array}$ & $\begin{array}{c}\text { Yen Hop } \\
\text { Commune, Van } \\
\text { Yen district, } \\
\text { Yen Bai } \\
\text { province }\end{array}$ & $\begin{array}{l}\text { Private } \\
\text { land }\end{array}$ & 18-Apr-2013 & $\begin{array}{l}\text { 5-May- } \\
2013\end{array}$ & $\begin{array}{l}\text { 5-May- } \\
2013\end{array}$ & & \\
\hline A5/SD60 & $\begin{array}{l}\text { Km147+680, Yen } \\
\text { Hop Commune, Van } \\
\text { Yen district, Yen Bai } \\
\text { province }\end{array}$ & 2000 & 6000 & $\begin{array}{c}\text { Trancosin } \\
\text { Co. Ltd }\end{array}$ & $\begin{array}{c}\text { Yen Hop } \\
\text { Commune, Van } \\
\text { Yen district, } \\
\text { Yen Bai } \\
\text { province }\end{array}$ & $\begin{array}{l}\text { Private } \\
\text { land }\end{array}$ & 18-Apr-2013 & $\begin{array}{l}\text { 5-May- } \\
2013\end{array}$ & $\begin{array}{l}\text { 5-May- } \\
2013\end{array}$ & & \\
\hline A5/SD61 & $\begin{array}{l}\text { Km148+200, Yen } \\
\text { Hop Commune, Van } \\
\text { Yen district, Yen Bai } \\
\text { province }\end{array}$ & 20000 & 106000 & $\begin{array}{c}\text { Trancosin } \\
\text { Co. Ltd }\end{array}$ & $\begin{array}{c}\text { Yen Hop } \\
\text { Commune, Van } \\
\text { Yen district, } \\
\text { Yen Bai } \\
\text { province }\end{array}$ & Wild land & 18-Apr-2013 & $\begin{array}{l}\text { 5-May- } \\
2013\end{array}$ & $\begin{array}{l}\text { 5-May- } \\
2013\end{array}$ & & \\
\hline A5/SD62 & $\begin{array}{l}\text { Km149+030, Yen } \\
\text { Hop Commune, Van } \\
\text { Yen district, Yen Bai } \\
\text { province }\end{array}$ & 1800 & 4000 & $\begin{array}{c}\text { Trancosin } \\
\text { Co. Ltd }\end{array}$ & $\begin{array}{c}\text { Yen Hop } \\
\text { Commune, Van } \\
\text { Yen district, } \\
\text { Yen Bai } \\
\text { province } \\
\end{array}$ & $\begin{array}{l}\text { Private } \\
\text { land }\end{array}$ & 18-Apr-2013 & $\begin{array}{l}\text { 5-May- } \\
2013\end{array}$ & $\begin{array}{l}\text { 5-May- } \\
2013\end{array}$ & & \\
\hline A5/SD63 & $\begin{array}{l}\text { Km146+700, Yen } \\
\text { Hop Commune, Van } \\
\text { Yen district, Yen Bai } \\
\text { province }\end{array}$ & 1992 & 50000 & $\begin{array}{c}\text { Trancosin } \\
\text { Co. Ltd }\end{array}$ & $\begin{array}{c}\text { Yen Hop } \\
\text { Commune, Van } \\
\text { Yen district, } \\
\text { Yen Bai } \\
\text { province } \\
\end{array}$ & Wild land & 2-Nov-2013 & $\begin{array}{c}\text { 18-Dec- } \\
2013\end{array}$ & $\begin{array}{c}\text { 18-Dec- } \\
2013\end{array}$ & & \\
\hline A5/SD64 & $\begin{array}{l}\text { Km148+000, Yen } \\
\text { Hop Commune, Van } \\
\text { Yen district, Yen Bai } \\
\text { province }\end{array}$ & 2650 & 105000 & $\begin{array}{l}\text { Trancosin } \\
\text { Co. Ltd }\end{array}$ & $\begin{array}{c}\text { Yen Hop } \\
\text { Commune, Van } \\
\text { Yen district, } \\
\text { Yen Bai } \\
\text { province } \\
\end{array}$ & $\begin{array}{l}\text { Private } \\
\text { land }\end{array}$ & 2-Nov-2013 & $\begin{array}{c}\text { 18-Dec- } \\
2013\end{array}$ & $\begin{array}{c}\text { 18-Dec- } \\
2013\end{array}$ & & \\
\hline A5/SD65 & $\begin{array}{l}\text { Km148+500, Yen } \\
\text { Hop Commune, Van } \\
\text { Yen district, Yen Bai } \\
\text { province }\end{array}$ & 2929 & 45000 & $\begin{array}{c}\text { Trancosin } \\
\text { Co. Ltd }\end{array}$ & $\begin{array}{c}\text { Yen Hop } \\
\text { Commune, Van } \\
\text { Yen district, } \\
\text { Yen Bai } \\
\end{array}$ & Wild land & 2-Nov-2013 & $\begin{array}{l}\text { 18-Dec- } \\
2013\end{array}$ & $\begin{array}{c}\text { 18-Dec- } \\
2013\end{array}$ & & \\
\hline
\end{tabular}




\section{Loan 2391/2392 - VIE: GMS Kunming - Hai Phong Transport Corridor} Noi Bai - Lao Cai Highway Project

\begin{tabular}{|c|c|c|c|c|c|c|c|c|c|c|c|}
\hline \multicolumn{12}{|c|}{ SPOILS DISPOSAL AREAS } \\
\hline \multirow{2}{*}{$\begin{array}{l}\text { Package } \\
\text { SD No. }\end{array}$} & \multirow{2}{*}{ Location } & \multirow{2}{*}{$\begin{array}{c}\text { Approved } \\
\text { Area } \\
\text { (m2) } \\
\end{array}$} & \multirow{2}{*}{$\begin{array}{c}\text { Approved } \\
\text { Capacity } \\
\text { (m3) }\end{array}$} & \multicolumn{2}{|c|}{ Ownershipa } & \multirow{2}{*}{$\begin{array}{l}\text { Prior Land } \\
\text { Useb }\end{array}$} & \multicolumn{2}{|c|}{ Approval } & \multicolumn{3}{|c|}{ Operation } \\
\hline & & & & Name & Contact Info & & Date & Agencyc & Start & Est. End & Actual End \\
\hline & & & & & province & & & & & & \\
\hline
\end{tabular}

\begin{tabular}{|c|c|c|c|c|c|c|c|c|c|c|c|}
\hline \multicolumn{12}{|c|}{ BORROW PITS } \\
\hline A5/BP1 & Km111+170 & & 120,000 & $\begin{array}{l}\text { Song Da } 9 \\
\text { sub- } \\
\text { contractor }\end{array}$ & $\begin{array}{c}\text { Tran Yen } \\
\text { district, Yen } \\
\text { Bai province }\end{array}$ & Mountain & & $\begin{array}{ll}\text { Tran } & \text { Yen } \\
\text { GOV } & \end{array}$ & & & \\
\hline A5/BP2 & Km111+540 & & 130,000 & $\begin{array}{l}\text { Song Da } 9 \\
\text { sub- } \\
\text { contractor }\end{array}$ & $\begin{array}{c}\text { Tran Yen } \\
\text { district, Yen } \\
\text { Bai province }\end{array}$ & Mountain & & $\begin{array}{l}\text { Tran } \\
\text { GOV }\end{array}$ & & & \\
\hline A5/BP3 & Km116+600 & & 33,000 & $\begin{array}{l}\text { Song Da } 9 \\
\text { sub- } \\
\text { contractor }\end{array}$ & $\begin{array}{c}\text { Tran Yen } \\
\text { district, Yen } \\
\text { Bai province }\end{array}$ & Mountain & & $\begin{array}{ll}\text { Tran } & \text { Yen } \\
\text { GOV } & \end{array}$ & & & \\
\hline A5/BP4 & Km117+120 & & 37,000 & $\begin{array}{l}\text { Licogi } 13 \\
\text { sub- } \\
\text { contractor }\end{array}$ & $\begin{array}{c}\text { Tran Yen } \\
\text { district, Yen } \\
\text { Bai province }\end{array}$ & Mountain & & $\begin{array}{ll}\text { Tran } & \text { Yen } \\
\text { GOV } & \end{array}$ & & & \\
\hline A5/BP5 & Km117+400 & & 15,000 & $\begin{array}{l}\text { Licogi } 13 \\
\text { sub- } \\
\text { contractor }\end{array}$ & $\begin{array}{c}\text { Tran Yen } \\
\text { district, Yen } \\
\text { Bai province }\end{array}$ & Mountain & & $\begin{array}{ll}\text { Tran } & \text { Yen } \\
\text { GOV }\end{array}$ & & & \\
\hline
\end{tabular}




\section{Loan 2391/2392 - VIE: GMS Kunming - Hai Phong Transport Corridor} Noi Bai - Lao Cai Highway Project

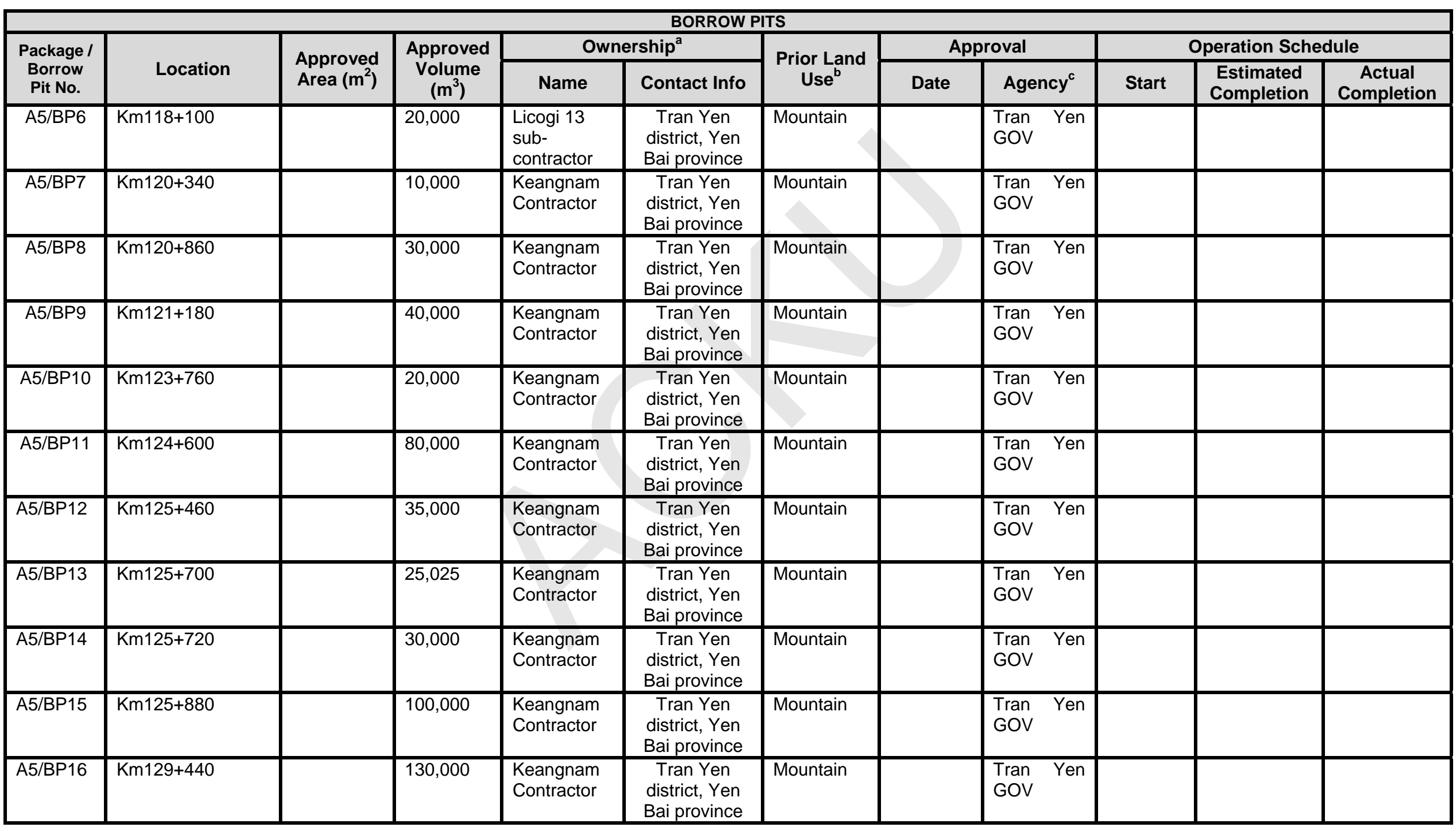




\section{Loan 2391/2392 - VIE: GMS Kunming - Hai Phong Transport Corridor} Noi Bai - Lao Cai Highway Project

\begin{tabular}{|c|c|c|c|c|c|c|c|c|c|c|c|}
\hline \multicolumn{12}{|c|}{ BORROW PITS } \\
\hline \multirow{2}{*}{$\begin{array}{l}\text { Package I } \\
\text { Borrow } \\
\text { Pit No. }\end{array}$} & \multirow[b]{2}{*}{ Location } & \multirow{2}{*}{$\begin{array}{l}\text { Approved } \\
\text { Area }\left(m^{2}\right)\end{array}$} & \multirow{2}{*}{$\begin{array}{c}\text { Approved } \\
\text { Volume } \\
\left(\mathrm{m}^{3}\right)\end{array}$} & \multicolumn{2}{|c|}{ Ownership $^{a}$} & \multirow{2}{*}{$\begin{array}{l}\text { Prior Land } \\
\text { Use }^{b}\end{array}$} & \multicolumn{2}{|c|}{ Approval } & \multicolumn{3}{|c|}{ Operation Schedule } \\
\hline & & & & Name & Contact Info & & Date & Agency $^{c}$ & Start & $\begin{array}{l}\text { Estimated } \\
\text { Completion }\end{array}$ & $\begin{array}{c}\text { Actual } \\
\text { Completion }\end{array}$ \\
\hline A5/BP17 & $\mathrm{Km} 129+240$ & & 70,000 & $\begin{array}{l}\text { Keangnam } \\
\text { Contractor }\end{array}$ & $\begin{array}{c}\text { Tran Yen } \\
\text { district, Yen } \\
\text { Bai province }\end{array}$ & Mountain & & $\begin{array}{ll}\text { Tran } & \text { Yen } \\
\text { GOV } & \end{array}$ & & & \\
\hline A5/BP18 & Km129+160 & & 50,000 & $\begin{array}{l}\text { Keangnam } \\
\text { Contractor }\end{array}$ & $\begin{array}{c}\text { Tran Yen } \\
\text { district, Yen } \\
\text { Bai province }\end{array}$ & Mountain & & $\begin{array}{ll}\text { Tran } & \text { Yen } \\
\text { GOV } & \end{array}$ & & & \\
\hline
\end{tabular}

\section{Package A6}

\begin{tabular}{|c|c|c|c|c|c|c|c|c|c|c|c|}
\hline \multicolumn{12}{|c|}{ BATCHING PLANTS } \\
\hline \multirow{2}{*}{$\begin{array}{l}\text { Package } \\
\text { A6 / SD No. }\end{array}$} & \multirow{2}{*}{ Location } & \multirow{2}{*}{$\begin{array}{l}\text { Appropriate } \\
\text { settling pond }\end{array}$} & \multirow{2}{*}{$\begin{array}{c}\text { Noise and } \\
\text { dust } \\
\text { measures }\end{array}$} & \multicolumn{2}{|c|}{ Ownership $^{a}$} & \multirow{2}{*}{$\begin{array}{l}\text { Prior Land } \\
\text { Use }^{b}\end{array}$} & \multicolumn{2}{|c|}{ Approval } & \multicolumn{3}{|c|}{ Operation } \\
\hline & & & & Name & Contact Info & & Date & Agency $^{c}$ & Start & Est. End & Actual End \\
\hline A6/CBP1 & Km 163 & Yes & No & Vinasan & $\begin{array}{c}\text { Van Yen } \\
\text { district, Yen } \\
\text { Bai province }\end{array}$ & $\begin{array}{l}\text { idled grass } \\
\text { land }\end{array}$ & $\begin{array}{l}\text { 10-Jun- } \\
2010\end{array}$ & $\begin{array}{l}\text { Van Yen } \\
\text { GOV }\end{array}$ & & & \\
\hline A6/CBP2 & Km 165 & Yes & No & $\begin{array}{l}\text { Whitestone } \\
\text { Vina }\end{array}$ & $\begin{array}{c}\text { Van Yen } \\
\text { district, Yen } \\
\text { Bai province }\end{array}$ & $\begin{array}{l}\text { idled grass } \\
\text { land }\end{array}$ & & $\begin{array}{l}\text { Van Yen } \\
\text { GOV }\end{array}$ & & & \\
\hline A6/CBP3 & Km 180 & Yes & No & $\begin{array}{l}\text { Whitestone } \\
\text { Vina }\end{array}$ & $\begin{array}{c}\text { Van Yen } \\
\text { district, Yen } \\
\text { Bai province }\end{array}$ & $\begin{array}{l}\text { idled grass } \\
\text { land }\end{array}$ & $\begin{array}{l}\text { 29-Sep- } \\
2010\end{array}$ & $\begin{array}{l}\text { Van Yen } \\
\text { GOV }\end{array}$ & & & \\
\hline A6/CBP4 & Km 185 & Yes & No & $\begin{array}{l}\text { Whitestone } \\
\text { Vina }\end{array}$ & $\begin{array}{c}\text { Van Yen } \\
\text { district, Yen } \\
\text { Bai province }\end{array}$ & $\begin{array}{l}\text { Side Cut of } \\
\text { idled land }\end{array}$ & $\begin{array}{l}\text { 26-Aug- } \\
2011\end{array}$ & $\begin{array}{l}\text { Van Yen } \\
\text { GOV }\end{array}$ & & & \\
\hline A6/ACBP1 & Km 171 & Yes & No & $\begin{array}{l}\text { Asphalt } \\
\text { Concrete } \\
\text { Batching } \\
\text { Plant Km171 }\end{array}$ & $\begin{array}{l}\text { Van Yen } \\
\text { district, Yen } \\
\text { Bai province }\end{array}$ & $\begin{array}{l}\text { Service area } \\
\text { of Package } \\
\text { A6 }\end{array}$ & $\begin{array}{l}\text { 2-Oct- } \\
2011\end{array}$ & $\begin{array}{l}\text { Van Yen } \\
\text { GOV }\end{array}$ & & & \\
\hline
\end{tabular}




\section{Loan 2391/2392 - VIE: GMS Kunming - Hai Phong Transport Corridor} Noi Bai - Lao Cai Highway Project

\begin{tabular}{|c|c|c|c|c|c|c|c|c|c|c|c|}
\hline \multicolumn{12}{|c|}{ BATCHING PLANTS } \\
\hline \multirow{2}{*}{$\begin{array}{l}\text { Package } \\
\text { A6 / SD No. }\end{array}$} & \multirow{2}{*}{ Location } & \multirow{2}{*}{$\begin{array}{l}\text { Appropriate } \\
\text { settling pond }\end{array}$} & \multirow{2}{*}{$\begin{array}{c}\text { Noise and } \\
\text { dust } \\
\text { measures }\end{array}$} & \multicolumn{2}{|c|}{ Ownership $^{a}$} & \multirow{2}{*}{$\begin{array}{c}\text { Prior Land } \\
\text { Use }^{b}\end{array}$} & \multicolumn{2}{|c|}{ Approval } & \multicolumn{3}{|c|}{ Operation } \\
\hline & & & & Name & Contact Info & & Date & Agency $^{c}$ & Start & Est. End & Actual End \\
\hline A6/ACBP2 & Km 180 & Yes & No & $\begin{array}{l}\text { Asphalt } \\
\text { Concrete } \\
\text { Batching } \\
\text { Plant Km180 }\end{array}$ & $\begin{array}{c}\text { Van Yen } \\
\text { district, Yen } \\
\text { Bai province }\end{array}$ & $\begin{array}{l}\text { idled grass } \\
\text { land }\end{array}$ & $\begin{array}{c}\text { 15-Oct- } \\
2011\end{array}$ & $\begin{array}{l}\text { Van Yen } \\
\text { GOV }\end{array}$ & & & \\
\hline A6/ACBP3 & Km 163 & Yes & No & $\begin{array}{l}\text { Asphalt } \\
\text { Concrete } \\
\text { Batching } \\
\text { Plant Km163 }\end{array}$ & $\begin{array}{l}\text { Van Yen } \\
\text { district, Yen } \\
\text { Bai province }\end{array}$ & $\begin{array}{l}\text { idled grass } \\
\text { land }\end{array}$ & $\begin{array}{l}\text { 1-Jan- } \\
2014\end{array}$ & $\begin{array}{l}\text { Van Yen } \\
\text { GOV }\end{array}$ & & & \\
\hline
\end{tabular}

\begin{tabular}{|c|c|c|c|c|c|c|c|c|c|c|c|}
\hline \multicolumn{12}{|c|}{ SPOILS DISPOSAL AREAS } \\
\hline \multirow{2}{*}{$\begin{array}{l}\text { Package } \\
\text { SD No. }\end{array}$} & \multirow[b]{2}{*}{ Location } & \multirow{2}{*}{$\begin{array}{c}\text { Approved } \\
\text { Area } \\
\left(\mathrm{m}^{2}\right)\end{array}$} & \multirow{2}{*}{$\begin{array}{c}\text { Approved } \\
\text { Capacity } \\
\left(\mathrm{m}^{3}\right)\end{array}$} & \multicolumn{2}{|c|}{ Ownership $^{a}$} & \multirow{2}{*}{$\begin{array}{c}\text { Prior Land } \\
\text { Use }^{b}\end{array}$} & \multicolumn{2}{|c|}{ Approval } & \multicolumn{3}{|c|}{ Operation } \\
\hline & & & & Name & Contact Info & & Date & Agency $^{c}$ & Start & Est. End & $\begin{array}{l}\text { Actual } \\
\text { End }\end{array}$ \\
\hline A6/SD1 & $\begin{array}{l}\text { Km152+600, Tan } \\
\text { Hop commune, Van } \\
\text { Yen district, Yen Bai } \\
\text { province }\end{array}$ & 2,838 & 54,528 & $\begin{array}{l}\text { Quang } \\
\text { Trung., Ltd }\end{array}$ & $\begin{array}{c}\text { Tan Hop } \\
\text { commune, } \\
\text { Van Yen } \\
\text { district, Yen } \\
\text { Bai province }\end{array}$ & Private land & $\begin{array}{l}\text { 27-Mar- } \\
2012\end{array}$ & $\begin{array}{c}\text { 11-April- } \\
2012\end{array}$ & $\begin{array}{c}\text { 16-April- } \\
2012\end{array}$ & & \\
\hline A6/SD2 & $\begin{array}{l}\text { Km152+900, Tan } \\
\text { Hop commune, Van } \\
\text { Yen district, Yen Bai } \\
\text { province }\end{array}$ & 985 & 17971 & $\begin{array}{l}\text { Quang } \\
\text { Trung., Ltd }\end{array}$ & $\begin{array}{c}\text { Tan Hop } \\
\text { commune, } \\
\text { Van Yen } \\
\text { district, Yen } \\
\text { Bai province }\end{array}$ & Private land & $\begin{array}{c}\text { 27-Mar- } \\
12\end{array}$ & $\begin{array}{c}\text { 11-April- } \\
2012\end{array}$ & $\begin{array}{l}\text { 16-April- } \\
2012\end{array}$ & & \\
\hline A6/SD3 & $\begin{array}{l}\text { Km155, Tan Hop } \\
\text { commune, Van Yen } \\
\text { district, Yen Bai } \\
\text { province }\end{array}$ & 1500 & 6000 & $\begin{array}{l}\text { Truong Loc., } \\
\text { Ltd }\end{array}$ & $\begin{array}{c}\text { Tan Hop } \\
\text { commune, } \\
\text { Van Yen } \\
\text { district, Yen } \\
\text { Bai province }\end{array}$ & $\begin{array}{l}\text { Garden of } \\
\text { Mr. Hoa }\end{array}$ & $\begin{array}{l}\text { 19-April- } \\
2012\end{array}$ & $\begin{array}{c}\text { 26-April- } \\
2012\end{array}$ & $\begin{array}{c}\text { 26-April- } \\
2012\end{array}$ & & \\
\hline A6/SD4 & $\begin{array}{l}\text { Km155, Tan Hop } \\
\text { commune, Van Yen } \\
\text { district, Yen Bai }\end{array}$ & 3000 & 12000 & $\begin{array}{l}\text { Truong Loc., } \\
\text { Ltd }\end{array}$ & $\begin{array}{l}\text { Tan Hop } \\
\text { commune, } \\
\text { Van Yen }\end{array}$ & $\begin{array}{l}\text { Garden of } \\
\text { Mr. Dung }\end{array}$ & $\begin{array}{l}\text { 19-April- } \\
2012\end{array}$ & $\begin{array}{c}\text { 26-April- } \\
2012\end{array}$ & $\begin{array}{l}\text { 26-April- } \\
2012\end{array}$ & & \\
\hline
\end{tabular}




\section{Loan 2391/2392 - VIE: GMS Kunming - Hai Phong Transport Corridor}

Noi Bai - Lao Cai Highway Project

\begin{tabular}{|c|c|c|c|c|c|c|c|c|c|c|c|}
\hline \multicolumn{12}{|c|}{ SPOILS DISPOSAL AREAS } \\
\hline \multirow{2}{*}{$\begin{array}{l}\text { Package } \\
\text { SD No. }\end{array}$} & \multirow[b]{2}{*}{ Location } & \multirow{2}{*}{$\begin{array}{c}\text { Approved } \\
\text { Area } \\
\left(\mathrm{m}^{2}\right)\end{array}$} & \multirow{2}{*}{$\begin{array}{c}\text { Approved } \\
\text { Capacity } \\
\left(\mathrm{m}^{3}\right)\end{array}$} & \multicolumn{2}{|c|}{ Ownership $^{a}$} & \multirow{2}{*}{$\begin{array}{l}\text { Prior Land } \\
\text { Use }^{b}\end{array}$} & \multicolumn{2}{|c|}{ Approval } & \multicolumn{3}{|c|}{ Operation } \\
\hline & & & & Name & Contact Info & & Date & Agency $^{c}$ & Start & Est. End & $\begin{array}{l}\text { Actual } \\
\text { End }\end{array}$ \\
\hline & province & & & & $\begin{array}{l}\text { district, Yen } \\
\text { Bai province }\end{array}$ & & & & & & \\
\hline A6/SD5 & $\begin{array}{l}\text { Km155, Tan Hop } \\
\text { commune, Van Yen } \\
\text { district, Yen Bai } \\
\text { province }\end{array}$ & 3000 & 12000 & $\begin{array}{l}\text { Truong Loc., } \\
\text { Ltd }\end{array}$ & $\begin{array}{l}\text { Tan Hop } \\
\text { commune, } \\
\text { Van Yen } \\
\text { district, Yen } \\
\text { Bai province }\end{array}$ & $\begin{array}{l}\text { Garden of } \\
\text { Mr. Thang }\end{array}$ & $\begin{array}{l}\text { 19-April- } \\
2012\end{array}$ & $\begin{array}{l}\text { 26-April- } \\
2012\end{array}$ & $\begin{array}{l}\text { 26-April- } \\
2012\end{array}$ & & \\
\hline A6/SD6 & $\begin{array}{l}\text { Km155+700, Tan } \\
\text { Hop commune, Van } \\
\text { Yen district, Yen Bai } \\
\text { province }\end{array}$ & 1200 & 4800 & $\begin{array}{c}\text { Truong Loc., } \\
\text { Ltd }\end{array}$ & $\begin{array}{l}\text { Tan Hop } \\
\text { commune, } \\
\text { Van Yen } \\
\text { district, Yen } \\
\text { Bai province }\end{array}$ & $\begin{array}{l}\text { Garden of } \\
\text { Mr. Thuc }\end{array}$ & $\begin{array}{l}\text { 19-April- } \\
2012\end{array}$ & $\begin{array}{l}\text { 26-April- } \\
2012\end{array}$ & $\begin{array}{l}\text { 26-April- } \\
2012\end{array}$ & & \\
\hline A6/SD7 & $\begin{array}{l}\text { Km153+700, Tan } \\
\text { Hop commune, Van } \\
\text { Yen district, Yen Bai } \\
\text { province }\end{array}$ & 3000 & 12000 & $\begin{array}{c}\text { Truong Loc., } \\
\text { Ltd }\end{array}$ & $\begin{array}{l}\text { Tan Hop } \\
\text { commune, } \\
\text { Van Yen } \\
\text { district, Yen } \\
\text { Bai province }\end{array}$ & Private land & $\begin{array}{l}\text { 19-April- } \\
2012\end{array}$ & $\begin{array}{l}\text { 26-April- } \\
2012\end{array}$ & $\begin{array}{l}\text { 26-April- } \\
2012\end{array}$ & & \\
\hline A6/SD8 & $\begin{array}{l}\text { Km153+300, Tan } \\
\text { Hop commune, Van } \\
\text { Yen district, Yen Bai } \\
\text { province }\end{array}$ & & 28766 & $\begin{array}{c}\text { Truong Loc., } \\
\text { Ltd }\end{array}$ & $\begin{array}{c}\text { Tan Hop } \\
\text { commune, } \\
\text { Van Yen } \\
\text { district, Yen } \\
\text { Bai province }\end{array}$ & Private land & $\begin{array}{l}\text { 24-May- } \\
2012\end{array}$ & $\begin{array}{l}\text { 12-Jun- } \\
2012\end{array}$ & $\begin{array}{l}\text { 12-Jun- } \\
2012\end{array}$ & & \\
\hline A6/SD9 & $\begin{array}{l}\text { Km154+000, Tan } \\
\text { Hop commune, Van } \\
\text { Yen district, Yen Bai } \\
\text { province }\end{array}$ & 3018 & 15303 & $\begin{array}{c}\text { Truong Loc., } \\
\text { Ltd }\end{array}$ & $\begin{array}{l}\text { Tan Hop } \\
\text { commune, } \\
\text { Van Yen } \\
\text { district, Yen } \\
\text { Bai province }\end{array}$ & Private land & $\begin{array}{l}\text { 27-Dec- } \\
2012\end{array}$ & $\begin{array}{l}\text { 18-Jan- } \\
2013\end{array}$ & $\begin{array}{l}\text { 18-Jan- } \\
2013\end{array}$ & & \\
\hline A6/SD10 & $\begin{array}{l}\text { Km153+520, Tan } \\
\text { Hop commune, Van } \\
\text { Yen district, Yen Bai } \\
\text { province }\end{array}$ & 3380 & 20785 & $\begin{array}{l}\text { Truong Loc., } \\
\text { Ltd }\end{array}$ & $\begin{array}{l}\text { Tan Hop } \\
\text { commune, } \\
\text { Van Yen } \\
\text { district, Yen }\end{array}$ & Private land & $\begin{array}{l}\text { 27-Dec- } \\
2012\end{array}$ & $\begin{array}{l}\text { 18-Jan- } \\
2013\end{array}$ & $\begin{array}{l}\text { 18-Jan- } \\
2013\end{array}$ & & \\
\hline
\end{tabular}




\section{Loan 2391/2392 - VIE: GMS Kunming - Hai Phong Transport Corridor}

Noi Bai - Lao Cai Highway Project

\begin{tabular}{|c|c|c|c|c|c|c|c|c|c|c|c|}
\hline \multicolumn{12}{|c|}{ SPOILS DISPOSAL AREAS } \\
\hline \multirow{2}{*}{$\begin{array}{l}\text { Package } \\
\text { SD No. }\end{array}$} & \multirow[b]{2}{*}{ Location } & \multirow{2}{*}{$\begin{array}{c}\text { Approved } \\
\text { Area } \\
\left(\mathrm{m}^{2}\right)\end{array}$} & \multirow{2}{*}{$\begin{array}{c}\text { Approved } \\
\text { Capacity } \\
\left(\mathrm{m}^{3}\right)\end{array}$} & \multicolumn{2}{|c|}{ Ownership $^{a}$} & \multirow{2}{*}{$\begin{array}{l}\text { Prior Land } \\
\text { Use }^{b}\end{array}$} & \multicolumn{2}{|c|}{ Approval } & \multicolumn{3}{|c|}{ Operation } \\
\hline & & & & Name & Contact Info & & Date & Agency $^{c}$ & Start & Est. End & $\begin{array}{l}\text { Actual } \\
\text { End }\end{array}$ \\
\hline & & & & & Bai province & & & & & & \\
\hline A6/SD11 & $\begin{array}{l}\text { Km155+400, Tan } \\
\text { Hop commune, Van } \\
\text { Yen district, Yen Bai } \\
\text { province }\end{array}$ & 480 & 3638 & $\begin{array}{l}\text { Truong Loc., } \\
\text { Ltd }\end{array}$ & $\begin{array}{c}\text { Tan Hop } \\
\text { commune, } \\
\text { Van Yen } \\
\text { district, Yen } \\
\text { Bai province }\end{array}$ & Private land & $\begin{array}{l}\text { 9-Oct- } \\
2012\end{array}$ & $\begin{array}{l}16-\text {-Oct- } \\
2012\end{array}$ & $\begin{array}{c}\text { 16-Oct- } \\
2012\end{array}$ & & \\
\hline A6/SD12 & $\begin{array}{l}\text { Km155+600, Tan } \\
\text { Hop commune, Van } \\
\text { Yen district, Yen Bai } \\
\text { province }\end{array}$ & 3161 & 18644 & $\begin{array}{l}\text { Truong Loc., } \\
\text { Ltd }\end{array}$ & $\begin{array}{c}\text { Tan Hop } \\
\text { commune, } \\
\text { Van Yen } \\
\text { district, Yen } \\
\text { Bai province }\end{array}$ & Wild land & $\begin{array}{l}\text { 28-Jan- } \\
2013\end{array}$ & $\begin{array}{l}\text { 5-Feb- } \\
2013\end{array}$ & $\begin{array}{l}\text { 5-Feb- } \\
2013\end{array}$ & & \\
\hline A6/SD13 & $\begin{array}{l}\text { Km155+500, Tan } \\
\text { Hop commune, Van } \\
\text { Yen district, Yen Bai } \\
\text { province }\end{array}$ & 448 & 1413 & $\begin{array}{c}\text { Truong Loc., } \\
\text { Ltd }\end{array}$ & $\begin{array}{c}\text { Tan Hop } \\
\text { commune, } \\
\text { Van Yen } \\
\text { district, Yen } \\
\text { Bai province }\end{array}$ & Wild land & $\begin{array}{l}\text { 28-Jan- } \\
2013\end{array}$ & $\begin{array}{l}\text { 5-Feb- } \\
2013\end{array}$ & $\begin{array}{l}\text { 5-Feb- } \\
2013\end{array}$ & & \\
\hline A6/SD14 & $\begin{array}{l}\text { Km155+700, Tan } \\
\text { Hop commune, Van } \\
\text { Yen district, Yen Bai } \\
\text { province }\end{array}$ & 5063 & 100848 & $\begin{array}{c}\text { Truong Loc., } \\
\text { Ltd }\end{array}$ & $\begin{array}{c}\text { Tan Hop } \\
\text { commune, } \\
\text { Van Yen } \\
\text { district, Yen } \\
\text { Bai province } \\
\end{array}$ & Private land & $\begin{array}{l}\text { 28-May- } \\
2013\end{array}$ & $\begin{array}{l}\text { 11-Jun- } \\
2013\end{array}$ & $\begin{array}{l}\text { 11-Jun- } \\
2013\end{array}$ & & \\
\hline A6/SD15 & $\begin{array}{l}\text { Km155+500, Tan } \\
\text { Hop commune, Van } \\
\text { Yen district, Yen Bai } \\
\text { province }\end{array}$ & 2077 & 9347 & Licogi., Ltd & $\begin{array}{c}\text { Tan Hop } \\
\text { commune, } \\
\text { Van Yen } \\
\text { district, Yen } \\
\text { Bai province }\end{array}$ & $\begin{array}{l}\text { Garden of } \\
\text { Mr. Hieu }\end{array}$ & $\begin{array}{l}\text { 19-Apr- } \\
2012\end{array}$ & $\begin{array}{l}\text { 26-Apr- } \\
2012\end{array}$ & $\begin{array}{l}\text { 26-Apr- } \\
2012\end{array}$ & & \\
\hline A6/SD16 & $\begin{array}{l}\text { Tan Hop commune, } \\
\text { Van Yen district, } \\
\text { Yen Bai province }\end{array}$ & 2171 & 9770 & Licogi., Ltd & $\begin{array}{c}\text { Tan Hop } \\
\text { commune, } \\
\text { Van Yen } \\
\text { district, Yen } \\
\text { Bai province }\end{array}$ & $\begin{array}{l}\text { Private land } \\
\text { of Tan Hop's } \\
\text { primary } \\
\text { school }\end{array}$ & $\begin{array}{l}\text { 19-Apr- } \\
2012\end{array}$ & $\begin{array}{l}\text { 26-Apr- } \\
2012\end{array}$ & $\begin{array}{l}\text { 26-Apr- } \\
2012\end{array}$ & & \\
\hline
\end{tabular}




\section{Loan 2391/2392 - VIE: GMS Kunming - Hai Phong Transport Corridor}

Noi Bai - Lao Cai Highway Project

\begin{tabular}{|c|c|c|c|c|c|c|c|c|c|c|c|}
\hline \multicolumn{12}{|c|}{ SPOILS DISPOSAL AREAS } \\
\hline \multirow{2}{*}{$\begin{array}{l}\text { Package } \\
\text { SD No. }\end{array}$} & \multirow[b]{2}{*}{ Location } & \multirow{2}{*}{$\begin{array}{c}\text { Approved } \\
\text { Area } \\
\left(\mathrm{m}^{2}\right) \\
\end{array}$} & \multirow{2}{*}{$\begin{array}{c}\text { Approved } \\
\text { Capacity } \\
\left(\mathrm{m}^{3}\right)\end{array}$} & \multicolumn{2}{|c|}{ Ownership $^{a}$} & \multirow{2}{*}{$\begin{array}{l}\text { Prior Land } \\
\text { Use }^{b}\end{array}$} & \multicolumn{2}{|c|}{ Approval } & \multicolumn{3}{|c|}{ Operation } \\
\hline & & & & Name & Contact Info & & Date & Agency $^{c}$ & Start & Est. End & $\begin{array}{l}\text { Actual } \\
\text { End }\end{array}$ \\
\hline A6/SD17 & $\begin{array}{l}\text { Tan Hop commune, } \\
\text { Van Yen district, } \\
\text { Yen Bai province }\end{array}$ & 6466 & 29097 & Licogi., Ltd & $\begin{array}{c}\text { Tan Hop } \\
\text { commune, } \\
\text { Van Yen } \\
\text { district, Yen } \\
\text { Bai province }\end{array}$ & $\begin{array}{l}\text { Private land } \\
\text { of Tan Hop's } \\
\text { children } \\
\text { school }\end{array}$ & $\begin{array}{c}\text { 19-Apr- } \\
2012\end{array}$ & $\begin{array}{c}\text { 26-Apr- } \\
2012\end{array}$ & $\begin{array}{c}\text { 26-Apr- } \\
2012\end{array}$ & & \\
\hline A6/SD18 & $\begin{array}{l}\text { Tan Hop commune, } \\
\text { Van Yen district, } \\
\text { Yen Bai province }\end{array}$ & 7526 & 33867 & Licogi., Ltd & $\begin{array}{c}\text { Tan Hop } \\
\text { commune, } \\
\text { Van Yen } \\
\text { district, Yen } \\
\text { Bai province }\end{array}$ & $\begin{array}{l}\text { Garden of } \\
\text { Mr. Hien }\end{array}$ & $\begin{array}{c}\text { 19-Apr- } \\
2012\end{array}$ & $\begin{array}{c}\text { 26-Apr- } \\
2012\end{array}$ & $\begin{array}{c}\text { 26-Apr- } \\
2012\end{array}$ & & \\
\hline A6/SD19 & $\begin{array}{l}\text { Tan Hop commune, } \\
\text { Van Yen district, } \\
\text { Yen Bai province }\end{array}$ & 3422 & 15399 & Licogi., Ltd & $\begin{array}{c}\text { Tan Hop } \\
\text { commune, } \\
\text { Van Yen } \\
\text { district, Yen } \\
\text { Bai province }\end{array}$ & $\begin{array}{l}\text { Garden of } \\
\text { Mr. Thong }\end{array}$ & $\begin{array}{c}\text { 19-Apr- } \\
2012\end{array}$ & $\begin{array}{c}\text { 26-Apr- } \\
2012\end{array}$ & $\begin{array}{c}\text { 26-Apr- } \\
2012\end{array}$ & & \\
\hline A6/SD20 & $\begin{array}{l}\text { Tan Hop commune, } \\
\text { Van Yen district, } \\
\text { Yen Bai province }\end{array}$ & 6877 & 60947 & Licogi., Ltd & $\begin{array}{c}\text { Tan Hop } \\
\text { commune, } \\
\text { Van Yen } \\
\text { district, Yen } \\
\text { Bai province }\end{array}$ & $\begin{array}{l}\text { Garden of } \\
\text { Mr. Huong }\end{array}$ & $\begin{array}{c}\text { 19-Apr- } \\
2012\end{array}$ & $\begin{array}{c}\text { 26-Apr- } \\
2012\end{array}$ & $\begin{array}{c}\text { 26-Apr- } \\
2012\end{array}$ & & \\
\hline A6/SD21 & $\begin{array}{l}\text { Tan Hop commune, } \\
\text { Van Yen district, } \\
\text { Yen Bai province }\end{array}$ & 3752 & 18193 & Licogi., Ltd & $\begin{array}{c}\text { Tan Hop } \\
\text { commune, } \\
\text { Van Yen } \\
\text { district, Yen } \\
\text { Bai province }\end{array}$ & Private land & $\begin{array}{l}\text { 5-Jun- } \\
2012\end{array}$ & $\begin{array}{c}\text { 16-Jun- } \\
2012\end{array}$ & $\begin{array}{c}\text { 16-Jun- } \\
2012\end{array}$ & & \\
\hline A6/SD22 & $\begin{array}{l}\text { Tan Hop commune, } \\
\text { Van Yen district, } \\
\text { Yen Bai province }\end{array}$ & 4163 & 30572 & Licogi., Ltd & $\begin{array}{c}\text { Tan Hop } \\
\text { commune, } \\
\text { Van Yen } \\
\text { district, Yen } \\
\text { Bai province }\end{array}$ & Private land & $\begin{array}{c}\text { 5-Jun- } \\
2012\end{array}$ & $\begin{array}{c}\text { 16-Jun- } \\
2012\end{array}$ & $\begin{array}{c}\text { 16-Jun- } \\
2012\end{array}$ & & \\
\hline A6/SD23 & Tan Hop commune, & 2383 & 22253 & Licogi., Ltd & Tan Hop & Private land & 11-Jul- & 16-Jul- & 16-Jul- & & \\
\hline
\end{tabular}




\section{Loan 2391/2392 - VIE: GMS Kunming - Hai Phong Transport Corridor} Noi Bai - Lao Cai Highway Project

\begin{tabular}{|c|c|c|c|c|c|c|c|c|c|c|c|}
\hline \multicolumn{12}{|c|}{ SPOILS DISPOSAL AREAS } \\
\hline \multirow{2}{*}{$\begin{array}{l}\text { Package } \\
\text { SD No. }\end{array}$} & \multirow[b]{2}{*}{ Location } & \multirow{2}{*}{$\begin{array}{c}\text { Approved } \\
\text { Area } \\
\left(\mathrm{m}^{2}\right)\end{array}$} & \multirow{2}{*}{$\begin{array}{c}\text { Approved } \\
\text { Capacity } \\
\left(\mathrm{m}^{3}\right)\end{array}$} & \multicolumn{2}{|c|}{ Ownership $^{a}$} & \multirow{2}{*}{$\begin{array}{l}\text { Prior Land } \\
\text { Use }^{b}\end{array}$} & \multicolumn{2}{|c|}{ Approval } & \multicolumn{3}{|c|}{ Operation } \\
\hline & & & & Name & Contact Info & & Date & Agency $^{c}$ & Start & Est. End & $\begin{array}{l}\text { Actual } \\
\text { End }\end{array}$ \\
\hline & $\begin{array}{l}\text { Van Yen district, } \\
\text { Yen Bai province }\end{array}$ & & & & $\begin{array}{l}\text { commune, } \\
\text { Van Yen } \\
\text { district, Yen } \\
\text { Bai province }\end{array}$ & & 2012 & 2012 & 2012 & & \\
\hline A6/SD24 & $\begin{array}{l}\text { Tan Hop commune, } \\
\text { Van Yen district, } \\
\text { Yen Bai province }\end{array}$ & & 18412 & Licogi., Ltd & $\begin{array}{c}\text { Tan Hop } \\
\text { commune, } \\
\text { Van Yen } \\
\text { district, Yen } \\
\text { Bai province }\end{array}$ & Private land & $\begin{array}{l}\text { 24-Aug- } \\
2012\end{array}$ & $\begin{array}{l}\text { 7-Sep- } \\
2012\end{array}$ & $\begin{array}{l}\text { 7-Sep- } \\
2012\end{array}$ & & \\
\hline A6/SD25 & $\begin{array}{l}\text { Tan Hop commune, } \\
\text { Van Yen district, } \\
\text { Yen Bai province }\end{array}$ & 5502 & 104470 & Licogi., Ltd & $\begin{array}{c}\text { Tan Hop } \\
\text { commune, } \\
\text { Van Yen } \\
\text { district, Yen } \\
\text { Bai province }\end{array}$ & Private land & $\begin{array}{l}\text { 24-Aug- } \\
2012\end{array}$ & $\begin{array}{l}\text { 7-Sep- } \\
2012\end{array}$ & $\begin{array}{l}\text { 7-Sep- } \\
2012\end{array}$ & & \\
\hline A6/SD26 & $\begin{array}{l}\text { Tan Hop commune, } \\
\text { Van Yen district, } \\
\text { Yen Bai province }\end{array}$ & & 23043 & Licogi., Ltd & $\begin{array}{c}\text { Tan Hop } \\
\text { commune, } \\
\text { Van Yen } \\
\text { district, Yen } \\
\text { Bai province }\end{array}$ & Private land & $\begin{array}{l}\text { 24-May- } \\
2012\end{array}$ & $\begin{array}{l}\text { 21-Jun- } \\
2012\end{array}$ & $\begin{array}{l}\text { 21-Jun- } \\
2012\end{array}$ & & \\
\hline A6/SD27 & $\begin{array}{l}\text { Tan Hop commune, } \\
\text { Van Yen district, } \\
\text { Yen Bai province }\end{array}$ & & 22675 & Licogi., Ltd & $\begin{array}{c}\text { Tan Hop } \\
\text { commune, } \\
\text { Van Yen } \\
\text { district, Yen } \\
\text { Bai province }\end{array}$ & Private land & $\begin{array}{l}\text { 24-May- } \\
2012\end{array}$ & $\begin{array}{l}\text { 21-Jun- } \\
2012\end{array}$ & $\begin{array}{l}\text { 21-Jun- } \\
2012\end{array}$ & & \\
\hline A6/SD28 & $\begin{array}{l}\text { Km166+600, Dong } \\
\text { An commune, Van } \\
\text { Yen district, Yen Bai } \\
\text { province }\end{array}$ & & 3258 & An Sinh., Ltd & $\begin{array}{c}\text { Dong An } \\
\text { commune, } \\
\text { Van Yen } \\
\text { district, Yen } \\
\text { Bai province }\end{array}$ & Wild land & $\begin{array}{l}\text { 13-Aug- } \\
2010\end{array}$ & $\begin{array}{l}\text { 16-Aug- } \\
2010\end{array}$ & $\begin{array}{l}\text { 16-Aug- } \\
2010\end{array}$ & & \\
\hline A6/SD29 & $\begin{array}{l}\text { Km167+300, Dong } \\
\text { An commune, Van } \\
\text { Yen district, Yen Bai }\end{array}$ & & 5380 & An Sinh., Ltd & $\begin{array}{l}\text { Dong An } \\
\text { commune, } \\
\text { Van Yen }\end{array}$ & Wild land & $\begin{array}{l}\text { 13-Aug- } \\
2010\end{array}$ & $\begin{array}{l}\text { 16-Aug- } \\
2010\end{array}$ & $\begin{array}{l}\text { 16-Aug- } \\
2010\end{array}$ & & \\
\hline
\end{tabular}




\section{Loan 2391/2392 - VIE: GMS Kunming - Hai Phong Transport Corridor}

Noi Bai - Lao Cai Highway Project

\begin{tabular}{|c|c|c|c|c|c|c|c|c|c|c|c|}
\hline \multicolumn{12}{|c|}{ SPOILS DISPOSAL AREAS } \\
\hline \multirow{2}{*}{$\begin{array}{l}\text { Package } \\
\text { SD No. }\end{array}$} & \multirow[b]{2}{*}{ Location } & \multirow{2}{*}{$\begin{array}{c}\text { Approved } \\
\text { Area } \\
\left(\mathrm{m}^{2}\right)\end{array}$} & \multirow{2}{*}{$\begin{array}{c}\text { Approved } \\
\text { Capacity } \\
\left(\mathrm{m}^{3}\right)\end{array}$} & \multicolumn{2}{|c|}{ Ownership $^{a}$} & \multirow{2}{*}{$\begin{array}{l}\text { Prior Land } \\
\text { Use }^{b}\end{array}$} & \multicolumn{2}{|c|}{ Approval } & \multicolumn{3}{|c|}{ Operation } \\
\hline & & & & Name & Contact Info & & Date & Agency $^{c}$ & Start & Est. End & $\begin{array}{l}\text { Actual } \\
\text { End }\end{array}$ \\
\hline & province & & & & $\begin{array}{l}\text { district, Yen } \\
\text { Bai province }\end{array}$ & & & & & & \\
\hline A6/SD30 & $\begin{array}{l}\text { Km168+700, Dong } \\
\text { An commune, Van } \\
\text { Yen district, Yen Bai } \\
\text { province }\end{array}$ & & 24318 & An Sinh., Ltd & $\begin{array}{c}\text { Dong An } \\
\text { commune, } \\
\text { Van Yen } \\
\text { district, Yen } \\
\text { Bai province }\end{array}$ & Private land & $\begin{array}{l}\text { 13-Aug- } \\
2010\end{array}$ & $\begin{array}{l}\text { 16-Aug- } \\
2010\end{array}$ & $\begin{array}{l}\text { 16-Aug- } \\
2010\end{array}$ & & \\
\hline A6/SD31 & $\begin{array}{l}\text { Km168+000, Dong } \\
\text { An commune, Van } \\
\text { Yen district, Yen Bai } \\
\text { province }\end{array}$ & & 11882 & An Sinh., Ltd & $\begin{array}{c}\text { Dong An } \\
\text { commune, } \\
\text { Van Yen } \\
\text { district, Yen } \\
\text { Bai province }\end{array}$ & Wild land & $\begin{array}{l}\text { 13-Aug- } \\
2010\end{array}$ & $\begin{array}{l}\text { 16-Aug- } \\
2010\end{array}$ & $\begin{array}{l}\text { 16-Aug- } \\
2010\end{array}$ & & \\
\hline A6/SD32 & $\begin{array}{l}\text { Km166+050, Dong } \\
\text { An commune, Van } \\
\text { Yen district, Yen Bai } \\
\text { province }\end{array}$ & & 2819 & An Sinh., Ltd & $\begin{array}{c}\text { Dong An } \\
\text { commune, } \\
\text { Van Yen } \\
\text { district, Yen } \\
\text { Bai province }\end{array}$ & Wild land & $\begin{array}{l}\text { 13-Aug- } \\
2010\end{array}$ & $\begin{array}{l}\text { 16-Aug- } \\
2010\end{array}$ & $\begin{array}{l}\text { 16-Aug- } \\
2010\end{array}$ & & \\
\hline A6/SD33 & $\begin{array}{l}\text { Km165+400, Dong } \\
\text { An commune, Van } \\
\text { Yen district, Yen Bai } \\
\text { province }\end{array}$ & 1317 & 6959 & An Sinh., Ltd & $\begin{array}{l}\text { Dong An } \\
\text { commune, } \\
\text { Van Yen } \\
\text { district, Yen } \\
\text { Bai province }\end{array}$ & Private land & $\begin{array}{l}\text { 1-Jun- } \\
2012\end{array}$ & $\begin{array}{l}\text { 12-Jun- } \\
2012\end{array}$ & $\begin{array}{l}\text { 12-Jun- } \\
2012\end{array}$ & & \\
\hline A6/SD34 & $\begin{array}{l}\text { Km165+400, Dong } \\
\text { An commune, Van } \\
\text { Yen district, Yen Bai } \\
\text { province }\end{array}$ & & 51127 & An Sinh., Ltd & $\begin{array}{c}\text { Dong An } \\
\text { commune, } \\
\text { Van Yen } \\
\text { district, Yen } \\
\text { Bai province }\end{array}$ & Private land & $\begin{array}{l}\text { 1-Jun- } \\
2012\end{array}$ & $\begin{array}{l}\text { 12-Jun- } \\
2012\end{array}$ & $\begin{array}{l}\text { 12-Jun- } \\
2012\end{array}$ & & \\
\hline A6/SD35 & $\begin{array}{l}\text { Km166+487, Dong } \\
\text { An commune, Van } \\
\text { Yen district, Yen Bai } \\
\text { province }\end{array}$ & & 20083 & An Sinh., Ltd & $\begin{array}{l}\text { Dong An } \\
\text { commune, } \\
\text { Van Yen } \\
\text { district, Yen }\end{array}$ & Private land & $\begin{array}{l}\text { 1-Jun- } \\
2012\end{array}$ & $\begin{array}{l}\text { 12-Jun- } \\
2012\end{array}$ & $\begin{array}{l}\text { 12-Jun- } \\
2012\end{array}$ & & \\
\hline
\end{tabular}




\section{Loan 2391/2392 - VIE: GMS Kunming - Hai Phong Transport Corridor}

Noi Bai - Lao Cai Highway Project

\begin{tabular}{|c|c|c|c|c|c|c|c|c|c|c|c|}
\hline \multicolumn{12}{|c|}{ SPOILS DISPOSAL AREAS } \\
\hline & & & & & Bai province & & & & & & \\
\hline A6/SD38 & $\begin{array}{l}\text { Km165+360, Dong } \\
\text { An commune, Van } \\
\text { Yen district, Yen Bai } \\
\text { province }\end{array}$ & 2155 & 3597 & An Sinh., Ltd & $\begin{array}{c}\text { Dong An } \\
\text { commune, } \\
\text { Van Yen } \\
\text { district, Yen } \\
\text { Bai province }\end{array}$ & Private land & $\begin{array}{l}\text { 2-Sep- } \\
2013\end{array}$ & $\begin{array}{l}\text { 17-Sep- } \\
2013\end{array}$ & $\begin{array}{c}\text { 17-Sep- } \\
2013\end{array}$ & & \\
\hline $\mathrm{A6} / \mathrm{SD} 40$ & $\begin{array}{l}\text { Km175+460, Chau } \\
\text { Que Ha commune, } \\
\text { Van Yen district, } \\
\text { Yen Bai province }\end{array}$ & 1090 & 4361 & $\begin{array}{l}\text { Weicovina., } \\
\text { Ltd }\end{array}$ & $\begin{array}{c}\text { Chau Que Ha } \\
\text { commune, } \\
\text { Van Yen } \\
\text { district, Yen } \\
\text { Bai province }\end{array}$ & Private land & $\begin{array}{l}\text { 13-Aug- } \\
2010\end{array}$ & $\begin{array}{l}\text { 16-Aug- } \\
2010\end{array}$ & $\begin{array}{l}\text { 16-Aug- } \\
2010\end{array}$ & & \\
\hline A6/SD41 & $\begin{array}{l}\text { Km175+720, Chau } \\
\text { Que Ha commune, } \\
\text { Van Yen district, } \\
\text { Yen Bai province }\end{array}$ & 2515 & 10059 & $\begin{array}{l}\text { Weicovina., } \\
\text { Ltd }\end{array}$ & $\begin{array}{c}\text { Chau Que Ha } \\
\text { commune, } \\
\text { Van Yen } \\
\text { district, Yen } \\
\text { Bai province }\end{array}$ & Private land & $\begin{array}{l}\text { 13-Aug- } \\
2010\end{array}$ & $\begin{array}{l}\text { 16-Aug- } \\
2010\end{array}$ & $\begin{array}{l}\text { 16-Aug- } \\
2010\end{array}$ & & \\
\hline
\end{tabular}




\section{Loan 2391/2392 - VIE: GMS Kunming - Hai Phong Transport Corridor}

Noi Bai - Lao Cai Highway Project

\begin{tabular}{|c|c|c|c|c|c|c|c|c|c|c|c|}
\hline \multicolumn{12}{|c|}{ SPOILS DISPOSAL AREAS } \\
\hline \multirow{2}{*}{$\begin{array}{l}\text { Package } \\
\text { SD No. }\end{array}$} & \multirow[b]{2}{*}{ Location } & \multirow{2}{*}{$\begin{array}{c}\text { Approved } \\
\text { Area } \\
\left(\mathrm{m}^{2}\right)\end{array}$} & \multirow{2}{*}{$\begin{array}{c}\text { Approved } \\
\text { Capacity } \\
\left(\mathrm{m}^{3}\right)\end{array}$} & \multicolumn{2}{|c|}{ Ownership $^{a}$} & \multirow{2}{*}{$\begin{array}{l}\text { Prior Land } \\
\text { Use }^{b}\end{array}$} & \multicolumn{2}{|c|}{ Approval } & \multicolumn{3}{|c|}{ Operation } \\
\hline & & & & Name & Contact Info & & Date & Agency $^{c}$ & Start & Est. End & $\begin{array}{c}\text { Actual } \\
\text { End }\end{array}$ \\
\hline A6/SD42 & $\begin{array}{l}\text { Km176+200, Chau } \\
\text { Que Ha commune, } \\
\text { Van Yen district, } \\
\text { Yen Bai province }\end{array}$ & 2383 & 9534 & $\begin{array}{l}\text { Weicovina., } \\
\text { Ltd }\end{array}$ & $\begin{array}{c}\text { Chau Que Ha } \\
\text { commune, } \\
\text { Van Yen } \\
\text { district, Yen } \\
\text { Bai province }\end{array}$ & Private land & $\begin{array}{l}\text { 13-Aug- } \\
2010\end{array}$ & $\begin{array}{l}\text { 16-Aug- } \\
2010\end{array}$ & $\begin{array}{l}\text { 16-Aug- } \\
2010\end{array}$ & & \\
\hline A6/SD43 & $\begin{array}{l}\text { Km176+560, Chau } \\
\text { Que Ha commune, } \\
\text { Van Yen district, } \\
\text { Yen Bai province }\end{array}$ & 6939 & 27756 & $\begin{array}{c}\text { Anh Cuong., } \\
\text { Ltd }\end{array}$ & $\begin{array}{c}\text { Chau Que Ha } \\
\text { commune, } \\
\text { Van Yen } \\
\text { district, Yen } \\
\text { Bai province }\end{array}$ & Private land & $\begin{array}{l}\text { 13-Aug- } \\
2010\end{array}$ & $\begin{array}{l}\text { 16-Aug- } \\
2010\end{array}$ & $\begin{array}{l}\text { 16-Aug- } \\
2010\end{array}$ & & \\
\hline A6/SD44 & $\begin{array}{l}\text { Km176+500, Chau } \\
\text { Que Ha commune, } \\
\text { Van Yen district, } \\
\text { Yen Bai province }\end{array}$ & 3333 & 29105 & $\begin{array}{l}\text { Anh Cuong., } \\
\text { Ltd }\end{array}$ & $\begin{array}{c}\text { Chau Que Ha } \\
\text { commune, } \\
\text { Van Yen } \\
\text { district, Yen } \\
\text { Bai province }\end{array}$ & Private land & $\begin{array}{l}\text { 19-Mar- } \\
2012\end{array}$ & $\begin{array}{l}\text { 24-Mar- } \\
2012\end{array}$ & $\begin{array}{c}\text { 24-Mar- } \\
2012\end{array}$ & & \\
\hline A6/SD45 & $\begin{array}{l}\text { Km177+500, Chau } \\
\text { Que Ha commune, } \\
\text { Van Yen district, } \\
\text { Yen Bai province }\end{array}$ & 1054 & 9329 & $\begin{array}{l}\text { Anh Cuong., } \\
\text { Ltd }\end{array}$ & $\begin{array}{c}\text { Chau Que Ha } \\
\text { commune, } \\
\text { Van Yen } \\
\text { district, Yen } \\
\text { Bai province }\end{array}$ & Private land & $\begin{array}{l}\text { 19-Mar- } \\
2012\end{array}$ & $\begin{array}{l}\text { 24-Mar- } \\
2012\end{array}$ & $\begin{array}{c}\text { 24-Mar- } \\
2012\end{array}$ & & \\
\hline A6/SD46 & $\begin{array}{l}\text { Km177+200, Chau } \\
\text { Que Ha commune, } \\
\text { Van Yen district, } \\
\text { Yen Bai province }\end{array}$ & 2422 & 44043 & $\begin{array}{l}\text { Anh Cuong., } \\
\text { Ltd }\end{array}$ & $\begin{array}{c}\text { Chau Que Ha } \\
\text { commune, } \\
\text { Van Yen } \\
\text { district, Yen } \\
\text { Bai province }\end{array}$ & Private land & $\begin{array}{l}\text { 19-Mar- } \\
2012\end{array}$ & $\begin{array}{l}\text { 24-Mar- } \\
2012\end{array}$ & $\begin{array}{c}\text { 24-Mar- } \\
2012\end{array}$ & & \\
\hline A6/SD47 & $\begin{array}{l}\text { Km177+210, Chau } \\
\text { Que Ha commune, } \\
\text { Van Yen district, } \\
\text { Yen Bai province }\end{array}$ & 1071 & 17617 & $\begin{array}{c}\text { Anh Cuong., } \\
\text { Ltd }\end{array}$ & $\begin{array}{c}\text { Chau Que Ha } \\
\text { commune, } \\
\text { Van Yen } \\
\text { district, Yen } \\
\text { Bai province }\end{array}$ & Private land & $\begin{array}{l}\text { 19-Mar- } \\
2012\end{array}$ & $\begin{array}{l}\text { 24-Mar- } \\
2012\end{array}$ & $\begin{array}{c}\text { 24-Mar- } \\
2012\end{array}$ & & \\
\hline A6/SD48 & Km171+200, Chau & 932 & 16888 & Weicovina., & Chau Que Ha & Private land & 19-Mar- & 24-Mar- & 24-Mar- & & \\
\hline
\end{tabular}




\section{Loan 2391/2392 - VIE: GMS Kunming - Hai Phong Transport Corridor}

Noi Bai - Lao Cai Highway Project

\begin{tabular}{|c|c|c|c|c|c|c|c|c|c|c|c|}
\hline \multicolumn{12}{|c|}{ SPOILS DISPOSAL AREAS } \\
\hline \multirow{3}{*}{$\begin{array}{l}\text { Package } \\
\text { SD No. }\end{array}$} & \multirow[b]{2}{*}{ Location } & \multirow{2}{*}{$\begin{array}{c}\text { Approved } \\
\text { Area } \\
\left(\mathrm{m}^{2}\right)\end{array}$} & \multirow{2}{*}{$\begin{array}{c}\text { Approved } \\
\text { Capacity } \\
\left(\mathrm{m}^{3}\right)\end{array}$} & \multicolumn{2}{|c|}{ Ownership $^{a}$} & \multirow{2}{*}{$\begin{array}{c}\text { Prior Land } \\
\text { Use }^{b}\end{array}$} & \multicolumn{2}{|c|}{ Approval } & \multicolumn{3}{|c|}{ Operation } \\
\hline & & & & Name & Contact Info & & Date & Agency $^{c}$ & Start & Est. End & $\begin{array}{l}\text { Actual } \\
\text { End }\end{array}$ \\
\hline & $\begin{array}{l}\text { Que Ha commune, } \\
\text { Van Yen district, } \\
\text { Yen Bai province }\end{array}$ & & & Ltd & $\begin{array}{l}\text { commune, } \\
\text { Van Yen } \\
\text { district, Yen } \\
\text { Bai province }\end{array}$ & & 2012 & 2012 & 2012 & & \\
\hline A6/SD49 & $\begin{array}{l}\text { Chau Que Ha } \\
\text { commune, Van Yen } \\
\text { district, Yen Bai } \\
\text { province }\end{array}$ & & 1211 & $\begin{array}{l}\text { Weicovina., } \\
\text { Ltd }\end{array}$ & $\begin{array}{c}\text { Chau Que Ha } \\
\text { commune, } \\
\text { Van Yen } \\
\text { district, Yen } \\
\text { Bai province }\end{array}$ & Private land & $\begin{array}{l}20-\text { Oct- } \\
2012\end{array}$ & $\begin{array}{c}\text { 31-Oct- } \\
2012\end{array}$ & $\begin{array}{c}\text { 31-Oct- } \\
2012\end{array}$ & & \\
\hline A6/SD50 & $\begin{array}{l}\text { Chau Que Ha } \\
\text { commune, Van Yen } \\
\text { district, Yen Bai } \\
\text { province }\end{array}$ & & 9781 & $\begin{array}{l}\text { Weicovina., } \\
\text { Ltd }\end{array}$ & $\begin{array}{c}\text { Chau Que Ha } \\
\text { commune, } \\
\text { Van Yen } \\
\text { district, Yen } \\
\text { Bai province }\end{array}$ & Private land & $\begin{array}{c}20-\text {-Oct- } \\
2012\end{array}$ & $\begin{array}{l}\text { 31-Oct- } \\
2012\end{array}$ & $\begin{array}{c}\text { 31-Oct- } \\
2012\end{array}$ & & \\
\hline A6/SD51 & $\begin{array}{l}\text { Chau Que Ha } \\
\text { commune, Van Yen } \\
\text { district, Yen Bai } \\
\text { province }\end{array}$ & & 17769 & $\begin{array}{l}\text { Weicovina., } \\
\text { Ltd }\end{array}$ & $\begin{array}{c}\text { Chau Que Ha } \\
\text { commune, } \\
\text { Van Yen } \\
\text { district, Yen } \\
\text { Bai province }\end{array}$ & Private land & $\begin{array}{c}20-\text {-Oct- } \\
2012\end{array}$ & $\begin{array}{c}\text { 31-Oct- } \\
2012\end{array}$ & $\begin{array}{c}31-O c t- \\
2012\end{array}$ & & \\
\hline A6/SD52 & $\begin{array}{l}\text { Km173+540, Chau } \\
\text { Que Ha commune, } \\
\text { Van Yen district, } \\
\text { Yen Bai province }\end{array}$ & & 51276 & $\begin{array}{l}\text { Doosan } \\
\text { Contractor }\end{array}$ & $\begin{array}{c}\text { Chau Que Ha } \\
\text { commune, } \\
\text { Van Yen } \\
\text { district, Yen } \\
\text { Bai province }\end{array}$ & Private land & $\begin{array}{c}20-\text {-Oct- } \\
2012\end{array}$ & $\begin{array}{c}\text { 31-Oct- } \\
2012\end{array}$ & $\begin{array}{c}31-O c t- \\
2012\end{array}$ & & \\
\hline A6/SD53 & $\begin{array}{l}\text { Km173+540, Chau } \\
\text { Que Ha commune, } \\
\text { Van Yen district, } \\
\text { Yen Bai province }\end{array}$ & & 121442 & $\begin{array}{l}\text { Doosan } \\
\text { Contractor }\end{array}$ & $\begin{array}{c}\text { Chau Que Ha } \\
\text { commune, } \\
\text { Van Yen } \\
\text { district, Yen } \\
\text { Bai province }\end{array}$ & Private land & $\begin{array}{c}20-\text {-Oct- } \\
2012\end{array}$ & $\begin{array}{l}\text { 31-Oct- } \\
2012\end{array}$ & $\begin{array}{c}31-\text { Oct- } \\
2012\end{array}$ & & \\
\hline A6/SD54 & $\begin{array}{l}\text { Km178+920, Chau } \\
\text { Que Ha commune, } \\
\text { Van Yen district, }\end{array}$ & 488 & 1220 & $\begin{array}{l}\text { Weicovina., } \\
\text { Ltd }\end{array}$ & $\begin{array}{c}\text { Chau Que Ha } \\
\text { commune, } \\
\text { Van Yen }\end{array}$ & $\begin{array}{l}\text { Garden of } \\
\text { Mrs. Vach }\end{array}$ & $\begin{array}{c}\text { 20-Apr- } \\
2012\end{array}$ & $\begin{array}{l}\text { 5-May- } \\
2012\end{array}$ & $\begin{array}{c}\text { 5-May- } \\
2012\end{array}$ & & \\
\hline
\end{tabular}




\section{Loan 2391/2392 - VIE: GMS Kunming - Hai Phong Transport Corridor}

Noi Bai - Lao Cai Highway Project

\begin{tabular}{|c|c|c|c|c|c|c|c|c|c|c|c|}
\hline \multicolumn{12}{|c|}{ SPOILS DISPOSAL AREAS } \\
\hline \multirow{3}{*}{$\begin{array}{l}\text { Package } \\
\text { SD No. }\end{array}$} & \multirow[b]{2}{*}{ Location } & \multirow{2}{*}{$\begin{array}{c}\text { Approved } \\
\text { Area } \\
\left(\mathrm{m}^{2}\right)\end{array}$} & \multirow{2}{*}{$\begin{array}{c}\text { Approved } \\
\text { Capacity } \\
\left(\mathrm{m}^{3}\right)\end{array}$} & \multicolumn{2}{|c|}{ Ownership $^{a}$} & \multirow{2}{*}{$\begin{array}{l}\text { Prior Land } \\
\text { Use }^{b}\end{array}$} & \multicolumn{2}{|c|}{ Approval } & \multicolumn{3}{|c|}{ Operation } \\
\hline & & & & Name & Contact Info & & Date & Agency $^{c}$ & Start & Est. End & $\begin{array}{l}\text { Actual } \\
\text { End }\end{array}$ \\
\hline & Yen Bai province & & & & $\begin{array}{l}\text { district, Yen } \\
\text { Bai province }\end{array}$ & & & & & & \\
\hline A6/SD55 & $\begin{array}{l}\text { Km179+040, Chau } \\
\text { Que Ha commune, } \\
\text { Van Yen district, } \\
\text { Yen Bai province }\end{array}$ & 1980 & 4950 & $\begin{array}{l}\text { Weicovina., } \\
\text { Ltd }\end{array}$ & $\begin{array}{c}\text { Chau Que Ha } \\
\text { commune, } \\
\text { Van Yen } \\
\text { district, Yen } \\
\text { Bai province }\end{array}$ & $\begin{array}{l}\text { Garden of } \\
\text { Mr. Khoa }\end{array}$ & $\begin{array}{l}\text { 20-Apr- } \\
2012\end{array}$ & $\begin{array}{l}\text { 5-May- } \\
2012\end{array}$ & $\begin{array}{l}\text { 5-May- } \\
2012\end{array}$ & & \\
\hline A6/SD56 & $\begin{array}{l}\text { Km179+040, Chau } \\
\text { Que Ha commune, } \\
\text { Van Yen district, } \\
\text { Yen Bai province }\end{array}$ & 2660 & 6650 & $\begin{array}{l}\text { Weicovina., } \\
\text { Ltd }\end{array}$ & $\begin{array}{c}\text { Chau Que Ha } \\
\text { commune, } \\
\text { Van Yen } \\
\text { district, Yen } \\
\text { Bai province }\end{array}$ & $\begin{array}{l}\text { Garden of } \\
\text { Mr. Thang }\end{array}$ & $\begin{array}{l}\text { 20-Apr- } \\
2012\end{array}$ & $\begin{array}{l}\text { 5-May- } \\
2012\end{array}$ & $\begin{array}{l}\text { 5-May- } \\
2012\end{array}$ & & \\
\hline A6/SD57 & $\begin{array}{l}\text { Km179+700, Chau } \\
\text { Que Ha commune, } \\
\text { Van Yen district, } \\
\text { Yen Bai province }\end{array}$ & 380 & 950 & $\begin{array}{l}\text { Weicovina., } \\
\text { Ltd }\end{array}$ & $\begin{array}{c}\text { Chau Que Ha } \\
\text { commune, } \\
\text { Van Yen } \\
\text { district, Yen } \\
\text { Bai province }\end{array}$ & $\begin{array}{l}\text { Garden of } \\
\text { Mr. Viet }\end{array}$ & $\begin{array}{l}\text { 20-Apr- } \\
2012\end{array}$ & $\begin{array}{l}\text { 5-May- } \\
2012\end{array}$ & $\begin{array}{l}\text { 5-May- } \\
2012\end{array}$ & & \\
\hline A6/SD58 & $\begin{array}{l}\text { Km179+600, Chau } \\
\text { Que Ha commune, } \\
\text { Van Yen district, } \\
\text { Yen Bai province }\end{array}$ & 1275 & 3188 & $\begin{array}{l}\text { Weicovina., } \\
\text { Ltd }\end{array}$ & $\begin{array}{c}\text { Chau Que Ha } \\
\text { commune, } \\
\text { Van Yen } \\
\text { district, Yen } \\
\text { Bai province }\end{array}$ & $\begin{array}{l}\text { Garden of } \\
\text { Mr. Vien }\end{array}$ & $\begin{array}{l}\text { 20-Apr- } \\
2012\end{array}$ & $\begin{array}{l}\text { 5-May- } \\
2012\end{array}$ & $\begin{array}{l}\text { 5-May- } \\
2012\end{array}$ & & \\
\hline A6/SD59 & $\begin{array}{l}\text { Km181+500, Chau } \\
\text { Que Ha commune, } \\
\text { Van Yen district, } \\
\text { Yen Bai province }\end{array}$ & 7785 & 19463 & $\begin{array}{l}\text { Quang } \\
\text { Trung., Ltd }\end{array}$ & $\begin{array}{c}\text { Chau Que Ha } \\
\text { commune, } \\
\text { Van Yen } \\
\text { district, Yen } \\
\text { Bai province }\end{array}$ & $\begin{array}{l}\text { Garden of } \\
\text { Mr. Hanh }\end{array}$ & $\begin{array}{l}\text { 20-Apr- } \\
2012\end{array}$ & $\begin{array}{l}\text { 5-May- } \\
2012\end{array}$ & $\begin{array}{l}\text { 5-May- } \\
2012\end{array}$ & & \\
\hline A6/SD60 & $\begin{array}{l}\text { Km179+520, Chau } \\
\text { Que Ha commune, } \\
\text { Van Yen district, } \\
\text { Yen Bai province }\end{array}$ & 2922 & 7305 & $\begin{array}{l}\text { Weicovina., } \\
\text { Ltd }\end{array}$ & $\begin{array}{l}\text { Chau Que Ha } \\
\text { commune, } \\
\text { Van Yen } \\
\text { district, Yen }\end{array}$ & $\begin{array}{l}\text { Garden of } \\
\text { Mr. Binh }\end{array}$ & $\begin{array}{l}\text { 20-Apr- } \\
2012\end{array}$ & $\begin{array}{l}\text { 5-May- } \\
2012\end{array}$ & $\begin{array}{l}\text { 5-May- } \\
2012\end{array}$ & & \\
\hline
\end{tabular}




\section{Loan 2391/2392 - VIE: GMS Kunming - Hai Phong Transport Corridor}

Noi Bai - Lao Cai Highway Project

\begin{tabular}{|c|c|c|c|c|c|c|c|c|c|c|c|}
\hline \multicolumn{12}{|c|}{ SPOILS DISPOSAL AREAS } \\
\hline \multirow{2}{*}{$\begin{array}{l}\text { Package } \\
\text { SD No. }\end{array}$} & \multirow[b]{2}{*}{ Location } & \multirow{2}{*}{$\begin{array}{c}\text { Approved } \\
\text { Area } \\
\left(\mathrm{m}^{2}\right)\end{array}$} & \multirow{2}{*}{$\begin{array}{c}\text { Approved } \\
\text { Capacity } \\
\left(\mathrm{m}^{3}\right)\end{array}$} & \multicolumn{2}{|c|}{ Ownership $^{a}$} & \multirow{2}{*}{$\begin{array}{l}\text { Prior Land } \\
\text { Use }^{b}\end{array}$} & \multicolumn{2}{|c|}{ Approval } & \multicolumn{3}{|c|}{ Operation } \\
\hline & & & & Name & Contact Info & & Date & Agency $^{c}$ & Start & Est. End & $\begin{array}{c}\text { Actual } \\
\text { End }\end{array}$ \\
\hline & & & & & Bai province & & & & & & \\
\hline A6/SD61 & $\begin{array}{l}\text { Km177+200, Chau } \\
\text { Que Ha commune, } \\
\text { Van Yen district, } \\
\text { Yen Bai province }\end{array}$ & 6700 & 66997 & $\begin{array}{l}\text { Weicovina., } \\
\text { Ltd }\end{array}$ & $\begin{array}{c}\text { Chau Que Ha } \\
\text { commune, } \\
\text { Van Yen } \\
\text { district, Yen } \\
\text { Bai province }\end{array}$ & Wild land & $\begin{array}{c}25-O c t- \\
2012\end{array}$ & $\begin{array}{c}\text { 12-Nov- } \\
2012\end{array}$ & $\begin{array}{c}\text { 12-Nov- } \\
2012\end{array}$ & & \\
\hline A6/SD62 & $\begin{array}{l}\text { Chau Que Ha } \\
\text { commune, Van Yen } \\
\text { district, Yen Bai } \\
\text { province }\end{array}$ & & 14941 & $\begin{array}{c}\text { Quang } \\
\text { Trung., Ltd }\end{array}$ & $\begin{array}{c}\text { Chau Que Ha } \\
\text { commune, } \\
\text { Van Yen } \\
\text { district, Yen } \\
\text { Bai province }\end{array}$ & Private land & $\begin{array}{c}\text { 27-Feb- } \\
2013\end{array}$ & 2-Apr-2013 & $\begin{array}{l}\text { 2-Apr- } \\
2013\end{array}$ & & \\
\hline A6/SD63 & $\begin{array}{l}\text { Chau Que Ha } \\
\text { commune, Van Yen } \\
\text { district, Yen Bai } \\
\text { province }\end{array}$ & & 29846 & $\begin{array}{c}\text { Quang } \\
\text { Trung., Ltd }\end{array}$ & $\begin{array}{c}\text { Chau Que Ha } \\
\text { commune, } \\
\text { Van Yen } \\
\text { district, Yen } \\
\text { Bai province }\end{array}$ & Private land & $\begin{array}{c}\text { 27-Feb- } \\
2013\end{array}$ & 2-Apr-2013 & $\begin{array}{l}\text { 2-Apr- } \\
2013\end{array}$ & & \\
\hline A6/SD64 & $\begin{array}{l}\text { Chau Que Ha } \\
\text { commune, Van Yen } \\
\text { district, Yen Bai } \\
\text { province }\end{array}$ & & 42528 & $\begin{array}{c}\text { Quang } \\
\text { Trung., Ltd }\end{array}$ & $\begin{array}{c}\text { Chau Que Ha } \\
\text { commune, } \\
\text { Van Yen } \\
\text { district, Yen } \\
\text { Bai province }\end{array}$ & Private land & $\begin{array}{c}\text { 27-Feb- } \\
2013\end{array}$ & 2-Apr-2013 & $\begin{array}{l}\text { 2-Apr- } \\
2013\end{array}$ & & \\
\hline A6/SD65 & $\begin{array}{l}\text { Km182+620, Chau } \\
\text { Que Thuong } \\
\text { commune, Van Yen } \\
\text { district, Yen Bai } \\
\text { province }\end{array}$ & 3200 & 4000 & $\begin{array}{c}\text { Quang } \\
\text { Trung., Ltd }\end{array}$ & $\begin{array}{l}\text { Chau Que } \\
\text { Thuong } \\
\text { commune, } \\
\text { Van Yen } \\
\text { district, Yen } \\
\text { Bai province }\end{array}$ & Private land & $\begin{array}{c}\text { 27-Feb- } \\
2013\end{array}$ & 2-Apr-2013 & $\begin{array}{l}\text { 2-Apr- } \\
2013\end{array}$ & & \\
\hline A6/SD66 & $\begin{array}{l}\text { Km184+900, Chau } \\
\text { Que Thuong } \\
\text { commune, Van Yen } \\
\text { district, Yen Bai }\end{array}$ & & 27000 & $\begin{array}{l}\text { Nghe An., } \\
\text { Ltd }\end{array}$ & $\begin{array}{l}\text { Chau Que } \\
\text { Thuong } \\
\text { commune, } \\
\text { Van Yen } \\
\text { district, Yen }\end{array}$ & Private land & $\begin{array}{l}\text { 8-Sep- } \\
2010\end{array}$ & $\begin{array}{l}\text { 16-Sep- } \\
2010\end{array}$ & $\begin{array}{c}\text { 16-Sep- } \\
2010\end{array}$ & & \\
\hline
\end{tabular}


Loan 2391/2392 - VIE: GMS Kunming - Hai Phong Transport Corridor Noi Bai - Lao Cai Highway Project

\begin{tabular}{|c|c|c|c|c|c|c|c|c|c|c|c|}
\hline \multicolumn{12}{|c|}{ SPOILS DISPOSAL AREAS } \\
\hline \multirow{2}{*}{$\begin{array}{l}\text { Package } \\
\text { SD No. }\end{array}$} & \multirow[b]{2}{*}{ Location } & \multirow{2}{*}{$\begin{array}{c}\text { Approved } \\
\text { Area } \\
\left(\mathrm{m}^{2}\right)\end{array}$} & \multirow{2}{*}{$\begin{array}{c}\text { Approved } \\
\text { Capacity } \\
\left(\mathrm{m}^{3}\right)\end{array}$} & \multicolumn{2}{|c|}{ Ownership $^{a}$} & \multirow{2}{*}{$\begin{array}{c}\text { Prior Land } \\
\text { Use }\end{array}$} & \multicolumn{2}{|c|}{ Approval } & \multicolumn{3}{|c|}{ Operation } \\
\hline & & & & Name & Contact Info & & Date & Agency $^{c}$ & Start & Est. End & $\begin{array}{l}\text { Actual } \\
\text { End }\end{array}$ \\
\hline & & & & & Bai province & & & & & & \\
\hline A6/SD67 & $\begin{array}{l}\text { Km185+300, Chau } \\
\text { Que Thuong } \\
\text { commune, Van Yen } \\
\text { district, Yen Bai }\end{array}$ & 2700 & 39286 & $\begin{array}{l}\text { Nghe An., } \\
\text { Ltd }\end{array}$ & $\begin{array}{c}\text { Chau Que } \\
\text { Thuong } \\
\text { commune, } \\
\text { Van Yen } \\
\text { district, Yen } \\
\text { Bai province }\end{array}$ & Private land & $\begin{array}{c}\text { 13-Mar- } \\
2013\end{array}$ & $\begin{array}{l}\text { 20-Mar- } \\
2013\end{array}$ & $\begin{array}{l}\text { 20-Mar- } \\
2013\end{array}$ & & \\
\hline A6/SD68 & $\begin{array}{l}\text { Km185+300, Chau } \\
\text { Que Thuong } \\
\text { commune, Van Yen } \\
\text { district, Yen Bai }\end{array}$ & 5350 & 97066 & $\begin{array}{l}\text { Nghe An., } \\
\text { Ltd }\end{array}$ & $\begin{array}{c}\text { Chau Que } \\
\text { Thuong } \\
\text { commune, } \\
\text { Van Yen } \\
\text { district, Yen } \\
\text { Bai province }\end{array}$ & Private land & $\begin{array}{c}\text { 24-Mar- } \\
2013\end{array}$ & $\begin{array}{l}\text { 3-May- } \\
2013\end{array}$ & $\begin{array}{l}\text { 3-May- } \\
2013\end{array}$ & & \\
\hline A6/SD69 & $\begin{array}{l}\text { Km188+200, Chau } \\
\text { Que Thuong } \\
\text { commune, Van Yen } \\
\text { district, Yen Bai }\end{array}$ & 46690 & 162582 & $\begin{array}{l}\text { Nghe An., } \\
\text { Ltd }\end{array}$ & $\begin{array}{c}\text { Chau Que } \\
\text { Thuong } \\
\text { commune, } \\
\text { Van Yen } \\
\text { district, Yen } \\
\text { Bai province }\end{array}$ & Private land & $\begin{array}{l}\text { 29-Dec- } \\
2010\end{array}$ & $\begin{array}{c}\text { 13-Jan- } \\
2011\end{array}$ & $\begin{array}{c}\text { 13-Jan- } \\
2011\end{array}$ & & \\
\hline A6/SD70 & $\begin{array}{l}\text { Km190+110, Chau } \\
\text { Que Thuong } \\
\text { commune, Van Yen } \\
\text { district, Yen Bai } \\
\text { province }\end{array}$ & 6910 & 17032 & $\begin{array}{l}\text { Nghe An., } \\
\text { Ltd }\end{array}$ & $\begin{array}{c}\text { Chau Que } \\
\text { Thuong } \\
\text { commune, } \\
\text { Van Yen } \\
\text { district, Yen } \\
\text { Bai province }\end{array}$ & Wild land & $\begin{array}{l}\text { 29-Dec- } \\
2010\end{array}$ & $\begin{array}{l}\text { 13-Jan- } \\
2011\end{array}$ & $\begin{array}{c}\text { 13-Jan- } \\
2011\end{array}$ & & \\
\hline A6/SD71 & $\begin{array}{l}\text { Km187+300, Chau } \\
\text { Que Thuong } \\
\text { commune, Van Yen } \\
\text { district, Yen Bai } \\
\text { province }\end{array}$ & 1102 & 15780 & $\begin{array}{l}\text { Nghe An., } \\
\text { Ltd }\end{array}$ & $\begin{array}{c}\text { Chau Que } \\
\text { Thuong } \\
\text { commune, } \\
\text { Van Yen } \\
\text { district, Yen } \\
\text { Bai province }\end{array}$ & Wild land & $\begin{array}{l}\text { 29-Dec- } \\
2010\end{array}$ & $\begin{array}{l}\text { 13-Jan- } \\
2011\end{array}$ & $\begin{array}{c}\text { 13-Jan- } \\
2011\end{array}$ & & \\
\hline
\end{tabular}




\section{Loan 2391/2392 - VIE: GMS Kunming - Hai Phong Transport Corridor}

Noi Bai - Lao Cai Highway Project

\begin{tabular}{|c|c|c|c|c|c|c|c|c|c|c|c|}
\hline \multicolumn{12}{|c|}{ SPOILS DISPOSAL AREAS } \\
\hline \multirow{2}{*}{$\begin{array}{l}\text { Package } \\
\text { SD No. }\end{array}$} & \multirow[b]{2}{*}{ Location } & \multirow{2}{*}{$\begin{array}{c}\text { Approved } \\
\text { Area } \\
\left(\mathrm{m}^{2}\right)\end{array}$} & \multirow{2}{*}{$\begin{array}{c}\text { Approved } \\
\text { Capacity } \\
\left(\mathrm{m}^{3}\right)\end{array}$} & \multicolumn{2}{|c|}{ Ownership $^{a}$} & \multirow{2}{*}{$\begin{array}{l}\text { Prior Land } \\
\text { Use }^{b}\end{array}$} & \multicolumn{2}{|c|}{ Approval } & \multicolumn{3}{|c|}{ Operation } \\
\hline & & & & Name & Contact Info & & Date & Agency $^{c}$ & Start & Est. End & $\begin{array}{l}\text { Actual } \\
\text { End }\end{array}$ \\
\hline A6/SD72 & $\begin{array}{l}\text { Km187+900, Chau } \\
\text { Que Thuong } \\
\text { commune, Van Yen } \\
\text { district, Yen Bai } \\
\text { province }\end{array}$ & 691 & 5404 & $\begin{array}{l}\text { Nghe An., } \\
\text { Ltd }\end{array}$ & $\begin{array}{l}\text { Chau Que } \\
\text { Thuong } \\
\text { commune, } \\
\text { Van Yen } \\
\text { district, Yen } \\
\text { Bai province }\end{array}$ & Private land & $\begin{array}{l}\text { 29-Dec- } \\
2010\end{array}$ & $\begin{array}{l}\text { 13-Jan- } \\
2011\end{array}$ & $\begin{array}{l}\text { 13-Jan- } \\
2011\end{array}$ & & \\
\hline A6/SD73 & $\begin{array}{l}\text { Km189+600, Chau } \\
\text { Que Thuong } \\
\text { commune, Van Yen } \\
\text { district, Yen Bai } \\
\text { province }\end{array}$ & 1146 & 19898 & $\begin{array}{l}\text { Nghe An., } \\
\text { Ltd }\end{array}$ & $\begin{array}{l}\text { Chau Que } \\
\text { Thuong } \\
\text { commune, } \\
\text { Van Yen } \\
\text { district, Yen } \\
\text { Bai province }\end{array}$ & Private land & $\begin{array}{l}\text { 29-Dec- } \\
2010\end{array}$ & $\begin{array}{l}\text { 13-Jan- } \\
2011\end{array}$ & $\begin{array}{l}\text { 13-Jan- } \\
2011\end{array}$ & & \\
\hline A6/SD74 & $\begin{array}{l}\text { Km187+660, Chau } \\
\text { Que Thuong } \\
\text { commune, Van Yen } \\
\text { district, Yen Bai } \\
\text { province }\end{array}$ & 2446 & 13684 & $\begin{array}{l}\text { Nghe An., } \\
\text { Ltd }\end{array}$ & $\begin{array}{l}\text { Chau Que } \\
\text { Thuong } \\
\text { commune, } \\
\text { Van Yen } \\
\text { district, Yen } \\
\text { Bai province }\end{array}$ & Private land & $\begin{array}{l}\text { 14-Oct- } \\
2011\end{array}$ & $\begin{array}{l}\text { 28-Nov- } \\
2011\end{array}$ & $\begin{array}{l}\text { 28-Nov- } \\
2011\end{array}$ & & \\
\hline A6/SD75 & $\begin{array}{l}\text { Km188+400, Chau } \\
\text { Que Thuong } \\
\text { commune, Van Yen } \\
\text { district, Yen Bai } \\
\text { province }\end{array}$ & 995 & 5396 & $\begin{array}{l}\text { Nghe An., } \\
\text { Ltd }\end{array}$ & $\begin{array}{l}\text { Chau Que } \\
\text { Thuong } \\
\text { commune, } \\
\text { Van Yen } \\
\text { district, Yen } \\
\text { Bai province }\end{array}$ & Private land & $\begin{array}{l}\text { 14-Oct- } \\
2011\end{array}$ & $\begin{array}{l}\text { 28-Nov- } \\
2011\end{array}$ & $\begin{array}{l}\text { 28-Nov- } \\
2011\end{array}$ & & \\
\hline A6/SD76 & $\begin{array}{l}\text { Km188+600, Chau } \\
\text { Que Thuong } \\
\text { commune, Van Yen } \\
\text { district, Yen Bai } \\
\text { province }\end{array}$ & 1185 & 4387 & $\begin{array}{l}\text { Nghe An., } \\
\text { Ltd }\end{array}$ & $\begin{array}{l}\text { Chau Que } \\
\text { Thuong } \\
\text { commune, } \\
\text { Van Yen } \\
\text { district, Yen } \\
\text { Bai province }\end{array}$ & Private land & $\begin{array}{l}\text { 14-Oct- } \\
2011\end{array}$ & $\begin{array}{l}\text { 28-Nov- } \\
2011\end{array}$ & $\begin{array}{l}\text { 28-Nov- } \\
2011\end{array}$ & & \\
\hline A6/SD77 & $\begin{array}{l}\text { Km189+600, Chau } \\
\text { Que Thuong }\end{array}$ & 3586 & 14962 & $\begin{array}{l}\text { Nghe An., } \\
\text { Ltd }\end{array}$ & $\begin{array}{l}\text { Chau Que } \\
\text { Thuong }\end{array}$ & Private land & $\begin{array}{l}\text { 14-Oct- } \\
2011\end{array}$ & $\begin{array}{l}\text { 28-Nov- } \\
2011\end{array}$ & $\begin{array}{l}\text { 28-Nov- } \\
2011\end{array}$ & & \\
\hline
\end{tabular}


Loan 2391/2392 - VIE: GMS Kunming - Hai Phong Transport Corridor Noi Bai - Lao Cai Highway Project

\begin{tabular}{|c|c|c|c|c|c|c|c|c|c|c|c|}
\hline \multicolumn{12}{|c|}{ SPOILS DISPOSAL AREAS } \\
\hline \multirow{2}{*}{$\begin{array}{l}\text { Package } \\
\text { SD No. }\end{array}$} & \multirow[b]{2}{*}{ Location } & \multirow{2}{*}{$\begin{array}{c}\text { Approved } \\
\text { Area } \\
\left(\mathrm{m}^{2}\right)\end{array}$} & \multirow{2}{*}{$\begin{array}{c}\text { Approved } \\
\text { Capacity } \\
\left(\mathrm{m}^{3}\right)\end{array}$} & \multicolumn{2}{|c|}{ Ownership $^{a}$} & \multirow{2}{*}{$\begin{array}{c}\text { Prior Land } \\
\text { Use }^{\mathbf{b}}\end{array}$} & \multicolumn{2}{|c|}{ Approval } & \multicolumn{3}{|c|}{ Operation } \\
\hline & & & & Name & Contact Info & & Date & Agency $^{c}$ & Start & Est. End & $\begin{array}{l}\text { Actual } \\
\text { End }\end{array}$ \\
\hline & $\begin{array}{l}\text { commune, Van Yen } \\
\text { district, Yen Bai } \\
\text { province }\end{array}$ & & & & $\begin{array}{c}\text { commune, } \\
\text { Van Yen } \\
\text { district, Yen } \\
\text { Bai province }\end{array}$ & & & & & & \\
\hline A6/SD78 & $\begin{array}{l}\text { Km190+140, Chau } \\
\text { Que Thuong } \\
\text { commune, Van Yen } \\
\text { district, Yen Bai } \\
\text { province }\end{array}$ & 1075 & 18519 & $\begin{array}{l}\text { Nghe An., } \\
\text { Ltd }\end{array}$ & $\begin{array}{c}\text { Chau Que } \\
\text { Thuong } \\
\text { commune, } \\
\text { Van Yen } \\
\text { district, Yen } \\
\text { Bai province }\end{array}$ & Wild land & $\begin{array}{c}14-O c t- \\
2011\end{array}$ & $\begin{array}{l}\text { 28-Nov- } \\
2011\end{array}$ & $\begin{array}{c}\text { 28-Nov- } \\
2011\end{array}$ & & \\
\hline A6/SD79 & $\begin{array}{l}\text { Km188+400, Chau } \\
\text { Que Thuong } \\
\text { commune, Van Yen } \\
\text { district, Yen Bai } \\
\text { province }\end{array}$ & 2439 & 14962 & $\begin{array}{l}\text { Nghe An., } \\
\text { Ltd }\end{array}$ & $\begin{array}{c}\text { Chau Que } \\
\text { Thuong } \\
\text { commune, } \\
\text { Van Yen } \\
\text { district, Yen } \\
\text { Bai province }\end{array}$ & Wild land & $\begin{array}{c}\text { 14-Oct- } \\
2011\end{array}$ & $\begin{array}{c}\text { 28-Nov- } \\
2011\end{array}$ & $\begin{array}{c}\text { 28-Nov- } \\
2011\end{array}$ & & \\
\hline A6/SD80 & $\begin{array}{l}\text { Km188+500, Chau } \\
\text { Que Thuong } \\
\text { commune, Van Yen } \\
\text { district, Yen Bai } \\
\text { province }\end{array}$ & 1945 & 12833 & $\begin{array}{l}\text { Nghe An., } \\
\text { Ltd }\end{array}$ & $\begin{array}{c}\text { Chau Que } \\
\text { Thuong } \\
\text { commune, } \\
\text { Van Yen } \\
\text { district, Yen } \\
\text { Bai province }\end{array}$ & Wild land & $\begin{array}{c}\text { 14-Oct- } \\
2011\end{array}$ & $\begin{array}{c}\text { 28-Nov- } \\
2011\end{array}$ & $\begin{array}{c}\text { 28-Nov- } \\
2011\end{array}$ & & \\
\hline A6/SD81 & $\begin{array}{l}\text { Km189+200, Chau } \\
\text { Que Thuong } \\
\text { commune, Van Yen } \\
\text { district, Yen Bai } \\
\text { province }\end{array}$ & 2148 & 18714 & $\begin{array}{l}\text { Nghe An., } \\
\text { Ltd }\end{array}$ & $\begin{array}{l}\text { Chau Que } \\
\text { Thuong } \\
\text { commune, } \\
\text { Van Yen } \\
\text { district, Yen } \\
\text { Bai province }\end{array}$ & Wild land & $\begin{array}{c}14-\text { Oct- } \\
2011\end{array}$ & $\begin{array}{c}\text { 28-Nov- } \\
2011\end{array}$ & $\begin{array}{c}\text { 28-Nov- } \\
2011\end{array}$ & & \\
\hline A6/SD82 & $\begin{array}{l}\text { Km188+720, Chau } \\
\text { Que Thuong } \\
\text { commune, Van Yen } \\
\text { district, Yen Bai }\end{array}$ & & 58384 & $\begin{array}{l}\text { Nghe An., } \\
\text { Ltd }\end{array}$ & $\begin{array}{l}\text { Chau Que } \\
\text { Thuong } \\
\text { commune, } \\
\text { Van Yen }\end{array}$ & Wild land & $\begin{array}{c}\text { 11-Jan- } \\
2013\end{array}$ & $\begin{array}{c}20-J a n- \\
2013\end{array}$ & $\begin{array}{c}\text { 20-Jan- } \\
2013\end{array}$ & & \\
\hline
\end{tabular}


Loan 2391/2392 - VIE: GMS Kunming - Hai Phong Transport Corridor Noi Bai - Lao Cai Highway Project

\begin{tabular}{|c|c|c|c|c|c|c|c|c|c|c|c|}
\hline \multicolumn{12}{|c|}{ SPOILS DISPOSAL AREAS } \\
\hline \multirow{2}{*}{$\begin{array}{l}\text { Package } \\
\text { SD No. }\end{array}$} & \multirow[b]{2}{*}{ Location } & \multirow{2}{*}{$\begin{array}{c}\text { Approved } \\
\text { Area } \\
\left(\mathrm{m}^{2}\right)\end{array}$} & \multirow{2}{*}{$\begin{array}{c}\text { Approved } \\
\text { Capacity } \\
\left(\mathrm{m}^{3}\right)\end{array}$} & \multicolumn{2}{|c|}{ Ownership $^{a}$} & \multirow{2}{*}{$\begin{array}{c}\text { Prior Land } \\
\text { Use }^{b}\end{array}$} & \multicolumn{2}{|c|}{ Approval } & \multicolumn{3}{|c|}{ Operation } \\
\hline & & & & Name & Contact Info & & Date & Agency $^{c}$ & Start & Est. End & $\begin{array}{l}\text { Actual } \\
\text { End }\end{array}$ \\
\hline & province & & & & $\begin{array}{l}\text { district, Yen } \\
\text { Bai province }\end{array}$ & & & & & & \\
\hline A6/SD83 & $\begin{array}{l}\text { Km186+145, Chau } \\
\text { Que Thuong } \\
\text { commune, Van Yen } \\
\text { district, Yen Bai } \\
\text { province }\end{array}$ & 7231 & 96970 & Cavico., Ltd & $\begin{array}{l}\text { Chau Que } \\
\text { Thuong } \\
\text { commune, } \\
\text { Van Yen } \\
\text { district, Yen } \\
\text { Bai province }\end{array}$ & Wild land & $\begin{array}{l}\text { 26-Nov- } \\
2010\end{array}$ & $\begin{array}{l}\text { 15-Dec- } \\
2010\end{array}$ & $\begin{array}{l}\text { 15-Dec- } \\
2010\end{array}$ & & \\
\hline A6/SD84 & $\begin{array}{l}\text { Km186, Chau Que } \\
\text { Thuong commune, } \\
\text { Van Yen district, } \\
\text { Yen Bai province }\end{array}$ & & 19993 & Cavico., Ltd & $\begin{array}{c}\text { Chau Que } \\
\text { Thuong } \\
\text { commune, } \\
\text { Van Yen } \\
\text { district, Yen } \\
\text { Bai province }\end{array}$ & Wild land & $\begin{array}{l}\text { 26-Nov- } \\
2010\end{array}$ & $\begin{array}{l}\text { 15-Dec- } \\
2010\end{array}$ & $\begin{array}{l}\text { 15-Dec- } \\
2010\end{array}$ & & \\
\hline A6/SD85 & $\begin{array}{l}\text { Km173+300, Chau } \\
\text { Que Ha commune, } \\
\text { Van Yen district, } \\
\text { Yen Bai province }\end{array}$ & & 65350 & $\begin{array}{l}\text { Doosan } \\
\text { Contractor }\end{array}$ & $\begin{array}{c}\text { Chau Que Ha } \\
\text { commune, } \\
\text { Van Yen } \\
\text { district, Yen } \\
\text { Bai province }\end{array}$ & Wild land & $\begin{array}{l}\text { 25-Sep- } \\
2013\end{array}$ & $\begin{array}{l}10-\text { Oct- } \\
2013\end{array}$ & $\begin{array}{l}\text { 25-Sep- } \\
2013\end{array}$ & & \\
\hline A6/SD86 & $\begin{array}{l}\text { Km156+100 - } \\
\text { Km156+300, Tan } \\
\text { Hop commune, } \\
\text { Van Yen district, } \\
\text { Yen Bai province }\end{array}$ & & 9506 & $\begin{array}{l}\text { Doosan } \\
\text { Contractor }\end{array}$ & $\begin{array}{c}\text { Tan Hop } \\
\text { commune, } \\
\text { Van Yen } \\
\text { district, Yen } \\
\text { Bai province }\end{array}$ & Private land & $\begin{array}{l}\text { 25-Sep- } \\
2013\end{array}$ & $\begin{array}{l}10-\text { Oct- } \\
2013\end{array}$ & $\begin{array}{l}\text { 25-Sep- } \\
2013\end{array}$ & & \\
\hline A6/SD87 & $\begin{array}{l}\text { Km185+060, Chau } \\
\text { Que Thuong } \\
\text { commune, Van } \\
\text { Yen district, }\end{array}$ & 5400 & 32900 & $\begin{array}{l}\text { Doosan } \\
\text { Contractor }\end{array}$ & $\begin{array}{l}\text { Chau Que } \\
\text { Thuong } \\
\text { commune, } \\
\text { Van Yen } \\
\text { district, }\end{array}$ & Wild land & $\begin{array}{l}22-\text {-Oct- } \\
13\end{array}$ & $\begin{array}{l}25-O c t- \\
2013\end{array}$ & $\begin{array}{l}\text { 25-Sep- } \\
2013\end{array}$ & & \\
\hline A6/SD88 & $\begin{array}{l}\text { Km152+500 - } \\
\text { Km152+700, Tan } \\
\text { Hop commune, Van }\end{array}$ & 6800 & 29240 & $\begin{array}{l}\text { Doosan } \\
\text { Contractor }\end{array}$ & $\begin{array}{l}\text { Tan Hop } \\
\text { commune, } \\
\text { Van Yen }\end{array}$ & Private land & $\begin{array}{l}29-O c t- \\
13\end{array}$ & $\begin{array}{l}\text { 22-Nov- } \\
2013\end{array}$ & $\begin{array}{l}\text { 22-Nov- } \\
2013\end{array}$ & & \\
\hline
\end{tabular}


Loan 2391/2392 - VIE: GMS Kunming - Hai Phong Transport Corridor Noi Bai - Lao Cai Highway Project

\begin{tabular}{|c|c|c|c|c|c|c|c|c|c|c|c|}
\hline \multicolumn{12}{|c|}{ SPOILS DISPOSAL AREAS } \\
\hline \multirow{2}{*}{$\begin{array}{l}\text { Package } \\
\text { SD No. }\end{array}$} & \multirow[b]{2}{*}{ Location } & \multirow{2}{*}{$\begin{array}{c}\text { Approved } \\
\text { Area } \\
\left(\mathrm{m}^{2}\right)\end{array}$} & \multirow{2}{*}{$\begin{array}{c}\text { Approved } \\
\text { Capacity } \\
\left(\mathrm{m}^{3}\right)\end{array}$} & \multicolumn{2}{|c|}{ Ownership $^{a}$} & \multirow{2}{*}{$\begin{array}{l}\text { Prior Land } \\
\text { Use }^{b}\end{array}$} & \multicolumn{2}{|c|}{ Approval } & \multicolumn{3}{|c|}{ Operation } \\
\hline & & & & Name & Contact Info & & Date & Agency $^{c}$ & Start & Est. End & $\begin{array}{l}\text { Actual } \\
\text { End }\end{array}$ \\
\hline & $\begin{array}{l}\text { Yen district, Yen Bai } \\
\text { province }\end{array}$ & & & & $\begin{array}{l}\text { district, Yen } \\
\text { Bai province }\end{array}$ & & & & & & \\
\hline A6/SD89 & $\begin{array}{l}\text { Km152+830, Tan } \\
\text { Hop commune, Van } \\
\text { Yen district, Yen Bai } \\
\text { province }\end{array}$ & & 15000 & $\begin{array}{l}\text { Doosan } \\
\text { Contractor }\end{array}$ & $\begin{array}{c}\text { Tan Hop } \\
\text { commune, } \\
\text { Van Yen } \\
\text { district, Yen } \\
\text { Bai province }\end{array}$ & Private land & 2-Nov-13 & $\begin{array}{l}\text { 29-Nov- } \\
2013\end{array}$ & $\begin{array}{l}\text { 29-Nov- } \\
2013\end{array}$ & & \\
\hline A6/SD90 & $\begin{array}{l}\text { Km173+540, Chau } \\
\text { Que Ha commune, } \\
\text { Van Yen district, } \\
\text { Yen Bai province }\end{array}$ & & 21442 & $\begin{array}{l}\text { Van Phuc } \\
\text { sub- } \\
\text { contractor }\end{array}$ & $\begin{array}{c}\text { Chau Que Ha } \\
\text { commune, } \\
\text { Van Yen } \\
\text { district, Yen } \\
\text { Bai province }\end{array}$ & Private land & $\begin{array}{l}29-\text {-Oct- } \\
13\end{array}$ & $\begin{array}{l}\text { 22-Nov- } \\
2013\end{array}$ & $\begin{array}{l}\text { 22-Nov- } \\
2013\end{array}$ & & \\
\hline A6/SD91 & $\begin{array}{l}\text { Km173+800, Chau } \\
\text { Que Ha commune, } \\
\text { Van Yen district, } \\
\text { Yen Bai province }\end{array}$ & & 28043 & $\begin{array}{l}\text { Doosan } \\
\text { Contractor }\end{array}$ & $\begin{array}{c}\text { Chau Que Ha } \\
\text { commune, } \\
\text { Van Yen } \\
\text { district, Yen } \\
\text { Bai province }\end{array}$ & Wild land & $\begin{array}{l}22-J a n- \\
14\end{array}$ & $\begin{array}{l}\text { 14-Mar- } \\
2014\end{array}$ & $\begin{array}{l}\text { 14-Mar- } \\
2014\end{array}$ & & \\
\hline
\end{tabular}

Contractor didn't provide any information regarding the quarries used for the construction works in Package A6. In this package, no borrow pits are needed for the construction activities.

\section{Packaqes A7}

\begin{tabular}{|c|c|c|c|c|c|c|c|c|c|c|c|}
\hline \multicolumn{12}{|c|}{ BORROW PITS } \\
\hline \multirow{2}{*}{$\begin{array}{l}\text { Package } \\
\text { /Borrow } \\
\text { Pit No. }\end{array}$} & \multirow[t]{2}{*}{ Location } & \multirow{2}{*}{$\begin{array}{l}\text { Approved } \\
\text { Area }\left(\mathrm{m}^{2}\right)\end{array}$} & \multirow{2}{*}{$\begin{array}{c}\text { Approved } \\
\text { Volume } \\
\left(\mathrm{m}^{3}\right)\end{array}$} & \multicolumn{2}{|c|}{ Ownership $^{\mathrm{a}}$} & \multirow{2}{*}{$\begin{array}{l}\text { Prior Land } \\
\text { Use }^{b}\end{array}$} & \multicolumn{2}{|c|}{ Approval } & \multicolumn{3}{|c|}{ Operation Schedule } \\
\hline & & & & Name & Contact Info & & Date & Agency $^{c}$ & Start & Estimated & Actual \\
\hline
\end{tabular}


Loan 2391/2392 - VIE: GMS Kunming - Hai Phong Transport Corridor Noi Bai - Lao Cai Highway Project

\begin{tabular}{|c|c|c|c|c|c|c|c|c|c|c|}
\hline & & & & & & & & & Completion & Completion \\
\hline A7/BP1 & $\begin{array}{l}\mathrm{Km} 207- \\
\mathrm{Km} 218+040\end{array}$ & 30.000 & $300.000 \mathrm{~m}^{3}$ & $\begin{array}{ll}\text { Cam4- } & \text { Cam } \\
\text { Con } & \\
\text { committee- } \\
\text { Baor Yen } \\
\text { district- Lao } \\
\text { Cai Provice }\end{array}$ & Hill land & $11 / 5 / 2011$ & $\begin{array}{l}\text { DONRE } \\
\text { OF Lao } \\
\text { Cai } \\
\text { Provice }\end{array}$ & $30 / 5 / 2011$ & $11 / 10 / 2011$ & $30 / 10 / 2011$ \\
\hline
\end{tabular}

\begin{tabular}{|c|c|c|c|c|c|c|c|c|c|c|c|}
\hline \multicolumn{12}{|c|}{ QUARRIES } \\
\hline \multirow{2}{*}{$\begin{array}{l}\text { Package } \\
\text { IQuarry } \\
\text { No. }\end{array}$} & \multirow[t]{2}{*}{ Location } & \multirow{2}{*}{$\begin{array}{l}\text { Approved } \\
\text { Area }\left(m^{2}\right)\end{array}$} & \multirow{2}{*}{$\begin{array}{l}\text { Approved } \\
\text { Volume } \\
\left(\mathrm{m}^{3}\right)\end{array}$} & \multicolumn{2}{|c|}{ Ownership $^{a}$} & \multirow{2}{*}{$\begin{array}{l}\text { Prior Land } \\
\text { Use }^{b}\end{array}$} & \multicolumn{2}{|c|}{ Approval } & \multicolumn{3}{|c|}{ Operation Schedule } \\
\hline & & & & Name & Contact Info & & Date & Agency $^{c}$ & Start & $\begin{array}{l}\text { Estimated } \\
\text { Completion }\end{array}$ & $\begin{array}{c}\text { Actual } \\
\text { Completion }\end{array}$ \\
\hline A7/Q1 & \multicolumn{11}{|c|}{ has been provided } \\
\hline
\end{tabular}

\begin{tabular}{|c|c|c|c|c|c|c|c|c|c|c|c|}
\hline \multicolumn{12}{|c|}{ SPOILS DISPOSAL AREAS } \\
\hline \multirow{2}{*}{$\begin{array}{l}\text { Package } \\
\text { I SD No. }\end{array}$} & \multirow[t]{2}{*}{ Location } & \multirow{2}{*}{$\begin{array}{c}\text { Approved } \\
\text { Area } \\
\left(\mathrm{m}^{2}\right) \\
\end{array}$} & \multirow{2}{*}{$\begin{array}{c}\text { Approved } \\
\text { Capacity } \\
\left(\mathrm{m}^{3}\right)\end{array}$} & \multicolumn{2}{|c|}{ Ownership $^{\mathrm{a}}$} & \multirow{2}{*}{$\begin{array}{l}\text { Prior Land } \\
\text { Use }^{b}\end{array}$} & \multicolumn{2}{|c|}{ Approval } & \multicolumn{3}{|c|}{ Operation } \\
\hline & & & & Name & Contact Info & & Date & Agency $^{\mathrm{C}}$ & Start & Est. End & $\begin{array}{l}\text { Actual } \\
\text { End }\end{array}$ \\
\hline A7/SD1 & Km191+600 & 106.000 & 1.060 .000 & $\begin{array}{l}\text { Tan An } \\
\text { committee }\end{array}$ & $\begin{array}{l}\text { Tan An- Van } \\
\text { Ban- Lao Cai }\end{array}$ & $\begin{array}{l}\text { idle farm } \\
\text { lot }\end{array}$ & $19 / 4 / 2010$ & $\begin{array}{l}\text { Contact } \\
\text { between }\end{array}$ & $30 / 4 / 2010$ & $15 / 12 / 2010$ & $30 / 11 / 2010$ \\
\hline A7/SD2 & Km195+800 & 103.000 & 1.030 .000 & $\begin{array}{l}\text { Tan An } \\
\text { committee }\end{array}$ & $\begin{array}{l}\text { Tan An- Van } \\
\text { Ban- Lao Cai }\end{array}$ & $\begin{array}{l}\text { idle farm } \\
\text { lot }\end{array}$ & $19 / 4 / 2010$ & $\begin{array}{l}\text { the } \\
\text { contractor } \\
\text { and land }\end{array}$ & $30 / 4 / 2010$ & $15 / 12 / 2010$ & $30 / 11 / 2010$ \\
\hline A7/SD3 & Km197+200 & 65.000 & 260.000 & $\begin{array}{l}\text { Tan An } \\
\text { committee }\end{array}$ & $\begin{array}{l}\text { Tan An- Van } \\
\text { Ban- Lao Cai }\end{array}$ & $\begin{array}{l}\text { idle farm } \\
\text { lot }\end{array}$ & $19 / 4 / 2010$ & $\begin{array}{l}\text { owner with } \\
\text { confirm of }\end{array}$ & $30 / 4 / 2010$ & $15 / 12 / 2010$ & $30 / 11 / 2010$ \\
\hline A7/SD4 & Km198+400 & 8.000 & 120.000 & $\begin{array}{l}\text { Tan An } \\
\text { committee }\end{array}$ & $\begin{array}{l}\text { Tan An- Van } \\
\text { Ban- Lao Cai }\end{array}$ & rice field & $19 / 4 / 2010$ & $\begin{array}{l}\text { commune } \\
\text { people's } \\
\text { committee }\end{array}$ & $30 / 4 / 2010$ & $15 / 12 / 2010$ & $30 / 11 / 2010$ \\
\hline A7/SD5 & $\mathrm{Km} 203+440$ & 10.000 & 70.000 & $\begin{array}{l}\text { Tran Van } \\
\text { Bang }\end{array}$ & $\begin{array}{l}\text { Khe U- Tan } \\
\text { Thuong- Van } \\
\text { Ban- Lao Cai }\end{array}$ & rice field & $7 / 5 / 2010$ & & $30 / 5 / 2010$ & $31 / 12 / 2011$ & $20 / 10 / 2011$ \\
\hline A7/SD6 & $\mathrm{Km} 203+440$ & 30.000 & 210.000 & $\begin{array}{l}\text { Tran Van } \\
\text { Ngoi }\end{array}$ & $\begin{array}{ll}\text { Khe U- } & \text { Tan } \\
\text { Thuong- } & \text { Van }\end{array}$ & rice field & $7 / 5 / 2010$ & & $30 / 5 / 2010$ & $31 / 12 / 2011$ & $25 / 11 / 2011$ \\
\hline
\end{tabular}


Loan 2391/2392 - VIE: GMS Kunming - Hai Phong Transport Corridor Noi Bai - Lao Cai Highway Project

\begin{tabular}{|c|c|c|c|c|c|c|c|c|c|c|c|}
\hline & & & & & SPOILS DISPO & $\overline{\text { SAL AREAS }}$ & & & & & \\
\hline Package & Location & Approved & Approved & Owr & $\operatorname{ership}^{a}$ & Prior Land & & val & & Operation & \\
\hline & & $\begin{array}{c}\text { Area } \\
\left(\mathrm{m}^{2}\right)\end{array}$ & $\begin{array}{l}\text { Capacity } \\
\left(\mathrm{m}^{3}\right)\end{array}$ & Name & Contact Info & & Date & Agency $^{c}$ & Start & Est. End & $\begin{array}{l}\text { Actual } \\
\text { End }\end{array}$ \\
\hline & & & & & Ban- Lao Cai & & & & & & \\
\hline A7/SD7 & $\mathrm{Km} 206+500$ & 8.000 & 40.000 & $\begin{array}{l}\text { Do Van } \\
\text { Hanh }\end{array}$ & $\begin{array}{l}\text { Ban Ly- Cam } \\
\text { Con- Bao Yen- } \\
\text { Lao Cai }\end{array}$ & $\begin{array}{l}\text { acacia } \\
\text { plantation }\end{array}$ & $10 / 5 / 2010$ & & $25 / 5 / 2010$ & $31 / 12 / 2011$ & $20 / 8 / 2011$ \\
\hline A7/SD8 & Km205+000 & 10897.6 & 54488 & $\begin{array}{l}\text { Nguyen } \\
\text { Van Dong }\end{array}$ & $\begin{array}{l}\text { Ban Ly2- Cam } \\
\text { Con- Bao Yen- } \\
\text { Lao Cai }\end{array}$ & $\begin{array}{l}\text { idle farm } \\
\text { lot }\end{array}$ & $19 / 5 / 2010$ & & $15 / 5 / 2010$ & $31 / 12 / 2011$ & $29 / 9 / 2011$ \\
\hline A7/SD9 & $\mathrm{Km} 206+200$ & 3772.3 & 18861.5 & Ly Van Tu & $\begin{array}{l}\text { Ban Ly1- Cam } \\
\text { Con- Bao Yen- } \\
\text { Lao Cai }\end{array}$ & $\begin{array}{l}\text { idle farm } \\
\text { lot }\end{array}$ & $19 / 5 / 2010$ & & $15 / 5 / 2010$ & $31 / 12 / 2011$ & $29 / 9 / 2011$ \\
\hline A7/SD10 & Km209+280 & 2.848 .5 & 14.242 .5 & $\begin{array}{l}\text { Nguyen } \\
\text { Thi Linh }\end{array}$ & $\begin{array}{l}\text { Bong 1- Cam } \\
\text { Con- Bao Yen- } \\
\text { Lao Cai }\end{array}$ & rice field & $1 / 2 / 2012$ & & $15 / 2 / 2012$ & & \\
\hline A7/SD11 & $\mathrm{Km} 210+360$ & 3.044 .6 & 21.312 .2 & $\begin{array}{l}\text { Tran Van } \\
\text { Su }\end{array}$ & $\begin{array}{l}\text { Tan Tien- Cam } \\
\text { Con- Bao Yen- }\end{array}$ & rice field & $1 / 2 / 2012$ & & $15 / 2 / 2012$ & & $5 / 2012$ \\
\hline A7/SD12 & $\mathrm{Km} 210+360$ & 5.281 .9 & 36.973 .3 & $\begin{array}{l}\text { Hoang Van } \\
\text { Chuc }\end{array}$ & & rice field & $1 / 2 / 2012$ & & $15 / 2 / 2012$ & & $5 / 2012$ \\
\hline A7/SD13 & $\mathrm{Km} 210+360$ & 2.703 .8 & 18.926 .6 & $\begin{array}{l}\text { Nguyen } \\
\text { Thi Tam }\end{array}$ & & rice field & $1 / 2 / 2012$ & & $15 / 2 / 2012$ & & $5 / 2012$ \\
\hline A7/SD14 & $\mathrm{Km} 210+380$ & 3.735 & 26.145 & $\begin{array}{l}\text { Hoang Van } \\
\text { Thong }\end{array}$ & & rice field & $1 / 2 / 2012$ & & $15 / 2 / 2012$ & & $5 / 2012$ \\
\hline A7/SD15 & $\mathrm{Km} 210+380$ & 1.592 .1 & 11.144 .7 & $\begin{array}{l}\text { Nguyen } \\
\text { Van Hai }\end{array}$ & & rice field & $1 / 2 / 2012$ & & $15 / 2 / 2012$ & & $5 / 2012$ \\
\hline A7/SD16 & $\mathrm{Km} 210+400$ & 1.800 & 10.800 & $\begin{array}{l}\text { Tran Van } \\
\text { Be }\end{array}$ & & rice field & $1 / 2 / 2012$ & & $15 / 2 / 2012$ & & $5 / 2012$ \\
\hline A7/SD17 & $\mathrm{Km} 216+260$ & 2.010 .3 & 12.061 .8 & $\begin{array}{l}\text { Pham Van } \\
\text { Thuy }\end{array}$ & $\begin{array}{l}\text { Hong Cam- } \\
\text { Cam Con- Bao }\end{array}$ & rice field & $1 / 2 / 2012$ & & $15 / 2 / 2012$ & & $5 / 2012$ \\
\hline A7/SD18 & $\mathrm{Km} 216+840$ & 5.760 .5 & 34.563 & Vuong & & rice field & $1 / 2 / 2012$ & & $15 / 2 / 2012$ & & $5 / 2012$ \\
\hline
\end{tabular}




\section{Loan 2391/2392 - VIE: GMS Kunming - Hai Phong Transport Corridor} Noi Bai - Lao Cai Highway Project

\begin{tabular}{|c|c|c|c|c|c|c|c|c|c|c|c|}
\hline \multicolumn{12}{|c|}{ SPOILS DISPOSAL AREAS } \\
\hline \multirow{3}{*}{$\begin{array}{l}\text { Package } \\
\text { I SD No. }\end{array}$} & \multirow[t]{2}{*}{ Location } & \multirow{2}{*}{$\begin{array}{c}\text { Approved } \\
\text { Area } \\
\left(\mathrm{m}^{2}\right)\end{array}$} & \multirow{2}{*}{$\begin{array}{c}\text { Approved } \\
\text { Capacity } \\
\left(\mathrm{m}^{3}\right)\end{array}$} & \multicolumn{2}{|c|}{ Ownership $^{\mathrm{a}}$} & \multirow{2}{*}{$\begin{array}{l}\text { Prior Land } \\
\text { Use }^{b}\end{array}$} & \multicolumn{2}{|c|}{ Approval } & \multicolumn{3}{|c|}{ Operation } \\
\hline & & & & Name & Contact Info & & Date & Agency $^{\mathrm{C}}$ & Start & Est. End & $\begin{array}{c}\text { Actual } \\
\text { End }\end{array}$ \\
\hline & & & & $\begin{array}{l}\text { Thanh } \\
\text { Hung }\end{array}$ & & & & & & & \\
\hline A7/SD19 & $\mathrm{Km} 216+980$ & 3.470 .7 & 22.559 .55 & $\begin{array}{l}\text { Pham Van } \\
\text { Truong }\end{array}$ & & rice field & $1 / 2 / 2012$ & & $15 / 2 / 2012$ & & $5 / 2012$ \\
\hline A7/SD20 & $\mathrm{Km} 217+960$ & 1.549 & 10.068 .5 & $\begin{array}{l}\text { Pham Van } \\
\text { Minh }\end{array}$ & & rice field & $1 / 2 / 2012$ & & $15 / 2 / 2012$ & & $5 / 2012$ \\
\hline A7/SD21 & $\mathrm{Km} 207+000$ & 5.887 .3 & 41.211 .1 & $\begin{array}{l}\text { Vu } \quad \text { Van } \\
\text { Khac }\end{array}$ & $\begin{array}{l}\text { Tan Thanh- } \\
\text { Cam Con- Bao } \\
\text { Yen- LC }\end{array}$ & rice field & $1 / 2 / 2012$ & & $20 / 5 / 2012$ & & $6 / 2012$ \\
\hline A7/SD22 & $\mathrm{Km} 209+820$ & 2.282 .5 & 15.977 .5 & $\begin{array}{ll}\text { Le } & \text { Van } \\
\text { Hung } & \end{array}$ & $\begin{array}{l}\text { Tan Tien- Cam } \\
\text { Con- Bao Yen- } \\
\text { LC }\end{array}$ & rice field & $1 / 2 / 2012$ & & $20 / 5 / 2012$ & & $6 / 2012$ \\
\hline A7/SD23 & $\mathrm{Km} 210+740$ & 151.5 & 1.090 .8 & $\begin{array}{ll}\text { Trinh } & \text { Thi } \\
\text { Hien } & \end{array}$ & $\begin{array}{l}\text { Tan Tien- Cam } \\
\text { Con- Bao Yen- }\end{array}$ & rice field & $7 / 5 / 2012$ & & $20 / 5 / 2012$ & & $6 / 2012$ \\
\hline A7/SD24 & $\mathrm{Km} 210+760$ & 1.500 & 14.250 & $\begin{array}{l}\text { Cam Con } \\
\text { committee }\end{array}$ & & rice field & $7 / 5 / 2012$ & & $20 / 5 / 2012$ & & $6 / 2012$ \\
\hline A7/SD25 & $\mathrm{Km} 210+780$ & 145.3 & 1.191 .46 & $\begin{array}{l}\text { Dinh Thi } \\
\text { Mui }\end{array}$ & & rice field & $7 / 5 / 2012$ & & $20 / 5 / 2012$ & & $6 / 2012$ \\
\hline A7/SD26 & $\mathrm{Km} 210+800$ & 1.390 & 8.618 & $\begin{array}{l}\text { Le Nguyen } \\
\text { Hong }\end{array}$ & & rice field & $7 / 5 / 2012$ & & $20 / 5 / 2012$ & & $6 / 2012$ \\
\hline A7/SD27 & $\mathrm{Km} 210+820$ & 1.141 & 8.215 .2 & Tran Cu & & rice field & $7 / 5 / 2012$ & & $20 / 5 / 2012$ & & $6 / 2012$ \\
\hline A7/SD28 & $\mathrm{Km} 211+200$ & 1.490 & 11.026 & $\begin{array}{l}\text { Lam Xuan } \\
\text { Truong }\end{array}$ & $\begin{array}{l}\text { Con2- Cam } \\
\text { Con- Bao Yen- } \\
\text { LC }\end{array}$ & rice field & $7 / 5 / 2012$ & & $20 / 5 / 2012$ & & $6 / 2012$ \\
\hline A7/SD29 & $\mathrm{Km} 216+520$ & 9.127 & 86.706 .5 & $\begin{array}{l}\text { Pham Thi } \\
\text { Cuong }\end{array}$ & $\begin{array}{l}\text { Hong Cam- } \\
\text { Cam Con- Bao }\end{array}$ & rice field & $7 / 5 / 2012$ & & $20 / 5 / 2012$ & & $6 / 2012$ \\
\hline A7/SD30 & $\mathrm{Km} 216+520$ & 7.385 & 66.465 & $\begin{array}{l}\text { Vu Thi } \\
\text { Huong }\end{array}$ & & rice field & $7 / 5 / 2012$ & & $20 / 5 / 2012$ & & $6 / 2012$ \\
\hline
\end{tabular}


Loan 2391/2392 - VIE: GMS Kunming - Hai Phong Transport Corridor Noi Bai - Lao Cai Highway Project

\begin{tabular}{|c|c|c|c|c|c|c|c|c|c|c|c|}
\hline \multicolumn{12}{|c|}{ SPOILS DISPOSAL AREAS } \\
\hline \multirow{2}{*}{$\begin{array}{l}\text { Package } \\
\text { I SD No. }\end{array}$} & \multirow[t]{2}{*}{ Location } & \multirow{2}{*}{$\begin{array}{c}\text { Approved } \\
\text { Area } \\
\left(\mathrm{m}^{2}\right)\end{array}$} & \multirow{2}{*}{$\begin{array}{c}\text { Approved } \\
\text { Capacity } \\
\left(\mathrm{m}^{3}\right)\end{array}$} & \multicolumn{2}{|c|}{ Ownership $^{a}$} & \multirow{2}{*}{$\begin{array}{l}\text { Prior Land } \\
\text { Use }^{b}\end{array}$} & \multicolumn{2}{|c|}{ Approval } & \multicolumn{3}{|c|}{ Operation } \\
\hline & & & & Name & Contact Info & & Date & Agency $^{c}$ & Start & Est. End & $\begin{array}{l}\text { Actual } \\
\text { End }\end{array}$ \\
\hline A7/SD31 & $\mathrm{Km} 216+640$ & 11.075 & 110.750 & $\begin{array}{l}\text { Pham Thi } \\
\text { Lan }\end{array}$ & & rice field & $7 / 5 / 2012$ & & $20 / 5 / 2012$ & & $6 / 2012$ \\
\hline A7/SD32 & $\mathrm{Km} 217+080$ & 14.655 & 131.895 & $\begin{array}{ll}\text { Le } & \text { Van } \\
\text { Hien } & \end{array}$ & & rice field & $7 / 5 / 2012$ & & $20 / 5 / 2012$ & & $6 / 2012$ \\
\hline A7/SD33 & $\mathrm{Km} 217+280$ & 7.865 & 86.515 & $\begin{array}{l}\text { Tran Van } \\
\text { Theo }\end{array}$ & & rice field & $7 / 5 / 2012$ & & $20 / 5 / 2012$ & & $6 / 2012$ \\
\hline A7/SD34 & Km189+700 & 15.555 .56 & 140.000 & $\begin{array}{l}\text { Tran Van } \\
\text { Thanh }\end{array}$ & $\begin{array}{l}\text { Hamlet1- Que } \\
\text { Thuong- Van } \\
\text { Yen- Yen Bai }\end{array}$ & $\begin{array}{l}\text { idle farm } \\
\text { lot }\end{array}$ & $20 / 10 / 2011$ & & $1 / 11 / 2011$ & & $25 / 3 / 2012$ \\
\hline A7/SD35 & $\mathrm{Km} 191+350$ & 15.000 & 120.000 & $\begin{array}{l}\text { Ta Dinh } \\
\text { Hai }\end{array}$ & $\begin{array}{l}\text { Xuan Sang1- } \\
\text { Tan An- Van } \\
\text { Ban- Lao Cai }\end{array}$ & $\begin{array}{l}\text { idle farm } \\
\text { lot }\end{array}$ & $22 / 10 / 2011$ & & $15 / 11 / 2011$ & & $3 / 2012$ \\
\hline A7/SD36 & Km199+100 & 10.769 .23 & 70.000 & $\begin{array}{l}\text { Ly Xuan } \\
\text { Hinh }\end{array}$ & $\begin{array}{l}\text { Cau Thin- Tan } \\
\text { Thuong- Van } \\
\text { Ban- Lao Cai }\end{array}$ & $\begin{array}{l}\text { idle farm } \\
\text { lot }\end{array}$ & $21 / 10 / 2011$ & & $12 / 11 / 2011$ & & $3 / 2012$ \\
\hline A7/SD37 & $\mathrm{Km} 189+700$ & $15,555.56$ & $140,000.00$ & $\begin{array}{l}\text { Tran Van } \\
\text { Thanh }\end{array}$ & $\begin{array}{l}\text { Tan An- Van } \\
\text { Ban- Lao Cai }\end{array}$ & abandoned & $11 / 4 / 2013$ & $\begin{array}{l}\text { These } \\
\text { waste }\end{array}$ & $15 / 6 / 2012$ & $20 / 12 / 2012$ & $31 / 12 / 2012$ \\
\hline A7/SD38 & Km191+350 & $8,000.00$ & $60,000.00$ & $\begin{array}{l}\text { Tran Van } \\
\text { Nhi }\end{array}$ & $\begin{array}{l}\text { Tan An- Van } \\
\text { Ban- Lao Cai }\end{array}$ & $\begin{array}{l}\text { idle farm } \\
\text { lot }\end{array}$ & $11 / 4 / 2013$ & $\begin{array}{l}\text { disposal } \\
\text { have } \\
\text { approved }\end{array}$ & $15 / 6 / 2012$ & $20 / 12 / 2012$ & $31 / 12 / 2012$ \\
\hline A7/SD39 & $\mathrm{Km} 191+350$ & $6,875.00$ & $55,000.00$ & $\begin{array}{l}\text { Pham Van } \\
\text { Thong }\end{array}$ & $\begin{array}{l}\text { Tan An- Van } \\
\text { Ban- Lao Cai }\end{array}$ & $\begin{array}{l}\text { idle farm } \\
\text { lot }\end{array}$ & $11 / 4 / 2013$ & $\begin{array}{l}\text { by } \\
\text { Resource }\end{array}$ & $15 / 6 / 2012$ & $20 / 12 / 2012$ & $31 / 12 / 2012$ \\
\hline A7/SD40 & $\mathrm{Km} 191+350$ & $15,000.00$ & $120,000.00$ & $\begin{array}{ll}\text { Ta } & \text { Dinh } \\
\text { Hai } & \end{array}$ & $\begin{array}{l}\text { Tan An- Van } \\
\text { Ban- Lao Cai }\end{array}$ & $\begin{array}{l}\text { idle farm } \\
\text { lot }\end{array}$ & $11 / 4 / 2013$ & $\begin{array}{l}\text { and } \\
\text { Environme } \\
\text { nt Bureau }\end{array}$ & $15 / 6 / 2012$ & $20 / 12 / 2012$ & $31 / 12 / 2012$ \\
\hline A7/SD41 & Km194+790 & $9,333.33$ & $70,000.00$ & $\begin{array}{l}\text { Dang Van } \\
\text { Thong }\end{array}$ & $\begin{array}{l}\text { Tan An- Van } \\
\text { Ban- Lao Cai }\end{array}$ & abandoned & $11 / 4 / 2013$ & $\begin{array}{l}\text { of Van Ban } \\
\text { district }\end{array}$ & $15 / 6 / 2012$ & 20/12/2012 & $31 / 12 / 2012$ \\
\hline A7/SD42 & Km195+700 & $70,000.00$ & $490,000.00$ & $\begin{array}{l}\text { Some } \\
\text { ownership }\end{array}$ & $\begin{array}{l}\text { Tan An- Van } \\
\text { Ban- Lao Cai }\end{array}$ & abandoned & $11 / 4 / 2013$ & & $15 / 6 / 2012$ & $20 / 12 / 2012$ & $31 / 12 / 2012$ \\
\hline A7/SD43 & Km199+100 & $10,769.23$ & $70,000.00$ & Ly Xuan & Tan Thuong- & abandoned & $11 / 4 / 2013$ & & $15 / 6 / 2012$ & $20 / 12 / 2012$ & $31 / 12 / 2012$ \\
\hline
\end{tabular}


Loan 2391/2392 - VIE: GMS Kunming - Hai Phong Transport Corridor Noi Bai - Lao Cai Highway Project

\begin{tabular}{|c|c|c|c|c|c|c|c|c|c|c|c|}
\hline \multicolumn{12}{|c|}{ SPOILS DISPOSAL AREAS } \\
\hline \multirow{2}{*}{$\begin{array}{l}\text { Package } \\
\text { I SD No. }\end{array}$} & \multirow[t]{2}{*}{ Location } & \multirow{2}{*}{$\begin{array}{c}\text { Approved } \\
\text { Area } \\
\left(\mathrm{m}^{2}\right)\end{array}$} & \multirow{2}{*}{$\begin{array}{c}\text { Approved } \\
\text { Capacity } \\
\left(\mathrm{m}^{3}\right)\end{array}$} & \multicolumn{2}{|c|}{ Ownership $^{a}$} & \multirow{2}{*}{$\begin{array}{c}\text { Prior Land } \\
\text { Use }^{b}\end{array}$} & \multicolumn{2}{|c|}{ Approval } & \multicolumn{3}{|c|}{ Operation } \\
\hline & & & & Name & Contact Info & & Date & Agency $^{\mathrm{c}}$ & Start & Est. End & $\begin{array}{c}\text { Actual } \\
\text { End }\end{array}$ \\
\hline & & & & Hinh & $\begin{array}{l}\text { Van Ban- Lao } \\
\text { Cai }\end{array}$ & & & & & & \\
\hline A7/SD44 & Km199-Km200 & $7,500.00$ & $60,000.00$ & $\begin{array}{l}\text { Nguyen } \\
\text { Thi Bac }\end{array}$ & $\begin{array}{l}\text { Tan Thuong- } \\
\text { Van Ban- Lao } \\
\text { Cai }\end{array}$ & abandoned & $11 / 4 / 2013$ & & $15 / 6 / 2012$ & $20 / 12 / 2012$ & $31 / 12 / 2012$ \\
\hline
\end{tabular}

\begin{tabular}{|c|c|c|c|c|c|c|c|c|c|c|c|}
\hline \multicolumn{12}{|c|}{ BATCHING PLANTS } \\
\hline \multirow{2}{*}{$\begin{array}{l}\text { Package I } \\
\text { SD No. }\end{array}$} & \multirow[t]{2}{*}{ Location } & \multirow{2}{*}{$\begin{array}{l}\text { Appropriate } \\
\text { settling pond }\end{array}$} & \multirow{2}{*}{$\begin{array}{c}\begin{array}{c}\text { Noise and } \\
\text { dust } \\
\text { measures }\end{array} \\
\end{array}$} & \multicolumn{2}{|c|}{ Ownership $^{a}$} & \multirow{2}{*}{$\begin{array}{l}\text { Prior Land } \\
\text { Use }^{b}\end{array}$} & \multicolumn{2}{|c|}{ Approval } & \multicolumn{3}{|c|}{ Operation } \\
\hline & & & & Name & Contact Info & & Date & Agency $^{c}$ & Start & Est. End & Actual End \\
\hline A7/CBP1 & Km191+353 & $\begin{array}{l}\text { Settling pond } \\
\text { had provided }\end{array}$ & $\begin{array}{l}\text { Noise and } \\
\text { dust } \\
\text { measures } \\
\text { had } \\
\text { support } \\
\text { with plant }\end{array}$ & $\begin{array}{l}\text { Khe Sang } \\
\text { BCP }\end{array}$ & $\begin{array}{lr}\text { Xuan } & \text { Sang2- } \\
\text { Tan } & \text { An } \\
\text { commune - Van } \\
\text { Ban } \\
\text { Lao Cai }\end{array}$ & Abandoned & $7 / 9 / 2012$ & $\begin{array}{l}\text { Van Ban } \\
\text { District } \\
\text { people's } \\
\text { committee }\end{array}$ & $18 / 3 / 2011$ & $25 / 3 / 2013$ & $\begin{array}{l}\text { December } \\
2013\end{array}$ \\
\hline A7/CBP2 & Km199+860 & $\begin{array}{l}\text { Settling pond } \\
\text { had provided }\end{array}$ & $\begin{array}{l}\text { Noise and } \\
\text { dust } \\
\text { measures } \\
\text { had } \\
\text { support } \\
\text { with plant }\end{array}$ & $\begin{array}{l}\text { Tan } \\
\text { Thuong } \\
\text { BCP }\end{array}$ & $\begin{array}{l}\text { Khe Quat- Tan } \\
\text { An commune- } \\
\text { Van Ban } \\
\text { District- Lao Cai }\end{array}$ & Abandoned & $7 / 9 / 2012$ & $\begin{array}{l}\text { Van Ban } \\
\text { District } \\
\text { people's } \\
\text { committee }\end{array}$ & $14 / 11 / 2011$ & $25 / 3 / 2013$ & March 2014 \\
\hline A7/CBP3 & Km198+400 & $\begin{array}{l}\text { Settling pond } \\
\text { had provided }\end{array}$ & $\begin{array}{l}\text { Noise and } \\
\text { dust } \\
\text { measures } \\
\text { had } \\
\text { support } \\
\text { with plant }\end{array}$ & $\begin{array}{l}\text { Xom } \\
\text { Danh } \\
\text { BCP }\end{array}$ & $\begin{array}{l}\text { Ngam Thin- Tan } \\
\text { Thuong } \\
\text { commune - Van } \\
\text { Ban District- } \\
\text { Lao Cai }\end{array}$ & rice field & & $\begin{array}{l}\text { Van Ban } \\
\text { District } \\
\text { people's } \\
\text { committee }\end{array}$ & $15 / 1 / 2011$ & $25 / 3 / 2013$ & March 2014 \\
\hline A7/CBP4 & Km209+329 & $\begin{array}{l}\text { Settling pond } \\
\text { had provided }\end{array}$ & $\begin{array}{l}\text { Noise and } \\
\text { dust } \\
\text { measures }\end{array}$ & $\begin{array}{l}\text { Tan Tien } \\
\text { BCP }\end{array}$ & $\begin{array}{lr}\text { Bong1- } & \text { Cam } \\
\text { Con commune - } \\
\text { Bao }\end{array}$ & Hill land & & $\begin{array}{l}\text { Bao Yen } \\
\text { District } \\
\text { people's }\end{array}$ & $25 / 3 / 2011$ & $25 / 3 / 2013$ & July 2013 \\
\hline
\end{tabular}


Loan 2391/2392 - VIE: GMS Kunming - Hai Phong Transport Corridor Noi Bai - Lao Cai Highway Project

\begin{tabular}{|c|c|c|c|c|c|c|c|c|c|c|c|}
\hline \multicolumn{12}{|c|}{ BATCHING PLANTS } \\
\hline \multirow{2}{*}{$\begin{array}{l}\text { Package I } \\
\text { SD No. }\end{array}$} & \multirow[t]{2}{*}{ Location } & \multirow{2}{*}{$\begin{array}{l}\text { Appropriate } \\
\text { settling pond }\end{array}$} & \multirow{2}{*}{$\begin{array}{c}\text { Noise and } \\
\text { dust } \\
\text { measures }\end{array}$} & \multicolumn{2}{|c|}{ Ownership $^{a}$} & \multirow{2}{*}{$\begin{array}{c}\text { Prior Land } \\
\text { Use }^{b}\end{array}$} & \multicolumn{2}{|c|}{ Approval } & \multicolumn{3}{|c|}{ Operation } \\
\hline & & & & Name & Contact Info & & Date & Agency $^{c}$ & Start & Est. End & Actual End \\
\hline & & & $\begin{array}{l}\text { had } \\
\text { support } \\
\text { with plant }\end{array}$ & & District- Lao Cai & & & committee & & & \\
\hline A7/ABP1 & Km195+800 & $\begin{array}{l}\text { Settling pond } \\
\text { had provided }\end{array}$ & $\begin{array}{l}\text { Noise and } \\
\text { dust } \\
\text { measures } \\
\text { had } \\
\text { support } \\
\text { with plant }\end{array}$ & $\begin{array}{l}\text { Trancosin } \\
\text { ABP }\end{array}$ & $\begin{array}{l}\text { Tan Son- Tan } \\
\text { An- Van Ban- } \\
\text { Lao Cai }\end{array}$ & Hill land & $7 / 11 / 2012$ & $\begin{array}{l}\text { Van Ban } \\
\text { District } \\
\text { people's } \\
\text { committee }\end{array}$ & $15 / 11 / 2012$ & $25 / 3 / 2013$ & March 2014 \\
\hline A7/ABP2 & $\mathrm{Km} 203+100$ & $\begin{array}{l}\text { Settling pond } \\
\text { had provided }\end{array}$ & $\begin{array}{l}\text { Noise and } \\
\text { dust } \\
\text { measures } \\
\text { had } \\
\text { support } \\
\text { with plant }\end{array}$ & Trico ABP & $\begin{array}{l}\text { Tan Thuong- } \\
\text { Van Ban- Lao } \\
\text { Cai }\end{array}$ & Hill land & $11 / 10 / 2012$ & $\begin{array}{l}\text { Van Ban } \\
\text { District } \\
\text { people's } \\
\text { committee }\end{array}$ & $14 / 12 / 2012$ & $25 / 3 / 2013$ & March 2014 \\
\hline
\end{tabular}

\section{Packages A8}

\begin{tabular}{|c|c|c|c|c|c|c|c|c|c|c|c|}
\hline \multicolumn{12}{|c|}{ BORROW PITS } \\
\hline \multirow{2}{*}{$\begin{array}{l}\text { Package } \\
\text { IBorrow } \\
\text { Pit No. }\end{array}$} & \multirow[t]{2}{*}{ Location } & \multirow{2}{*}{$\begin{array}{c}\text { Approved } \\
\text { Area }\left(\mathrm{m}^{2}\right)\end{array}$} & \multirow{2}{*}{$\begin{array}{l}\text { Approved } \\
\text { Volume } \\
\left(\mathrm{m}^{3}\right)\end{array}$} & \multicolumn{2}{|c|}{ Ownership $^{a}$} & \multirow{2}{*}{$\begin{array}{l}\text { Prior Land } \\
\text { Use }^{b}\end{array}$} & \multicolumn{2}{|c|}{ Approval } & \multicolumn{3}{|c|}{ Operation Schedule } \\
\hline & & & & Name & Contact Info & & Date & Agency $^{C}$ & Start & $\begin{array}{c}\text { Estimated } \\
\text { Completion }\end{array}$ & $\begin{array}{c}\text { Actual } \\
\text { Completion }\end{array}$ \\
\hline A8/BP1 & Km234- Km235 & $\begin{array}{l}10,5 \mathrm{ha}= \\
105.000\end{array}$ & $\begin{array}{l}500.000 \mathrm{~m}^{3} / \mathrm{y} \\
\text { ear }\end{array}$ & & $\begin{array}{l}\text { Hùng Thắng } \\
\text { and Dong Cam- } \\
\text { Giar Phu } \\
\text { Committee- Bao } \\
\text { Thang District- } \\
\text { Lao Cai Provice }\end{array}$ & Hill land & $10 / 01 / 2011$ & $\begin{array}{l}\text { Lao Cai } \\
\text { Province } \\
\text { people's } \\
\text { committee }\end{array}$ & $31 / 01 / 2011$ & $31 / 01 / 2012$ & $12 / 2011$ \\
\hline
\end{tabular}


Loan 2391/2392 - VIE: GMS Kunming - Hai Phong Transport Corridor Noi Bai - Lao Cai Highway Project

\begin{tabular}{|c|c|c|c|c|c|c|c|c|c|c|c|}
\hline \multicolumn{12}{|c|}{ QUARRIES } \\
\hline \multirow{2}{*}{$\begin{array}{l}\text { Package } \\
\text { IQuarry } \\
\text { No. }\end{array}$} & \multirow[t]{2}{*}{ Location } & \multirow{2}{*}{$\begin{array}{l}\text { Approved } \\
\text { Area }\left(\mathrm{m}^{2}\right)\end{array}$} & \multirow{2}{*}{$\begin{array}{l}\text { Approved } \\
\text { Volume } \\
\left(\mathrm{m}^{3}\right)\end{array}$} & \multicolumn{2}{|c|}{ Ownership $^{a}$} & \multirow{2}{*}{$\begin{array}{l}\text { Prior } \\
\text { Land } \\
\text { Use }\end{array}$} & \multicolumn{2}{|c|}{ Approval } & \multicolumn{3}{|c|}{ Operation Schedule } \\
\hline & & & & Name & Contact Info & & Date & Agency $^{c}$ & Start & $\begin{array}{c}\text { Estimated } \\
\text { Completion }\end{array}$ & $\begin{array}{c}\text { Actual } \\
\text { Completion }\end{array}$ \\
\hline A8/Q1 & & 38800 & $45.000 \mathrm{~m}^{3} /$ year & $\begin{array}{l}\text { Ban Cam } \\
\text { quarry }\end{array}$ & $\begin{array}{l}\text { Ban Cam } \\
\text { committee- Bao } \\
\text { Thang District- } \\
\text { Lao Cai Provice }\end{array}$ & Hill land & $7 / 4 / 2011$ & $\begin{array}{l}\text { Lao Cai } \\
\text { Province } \\
\text { people's } \\
\text { committee }\end{array}$ & April-2011 & $\begin{array}{l}\text { December- } \\
2015\end{array}$ & March-2014 \\
\hline
\end{tabular}

\begin{tabular}{|c|c|c|c|c|c|c|c|c|c|c|c|}
\hline \multicolumn{12}{|c|}{ SPOILS DISPOSAL AREAS } \\
\hline \multirow{2}{*}{$\begin{array}{l}\text { Package } \\
\text { I SD No. }\end{array}$} & \multirow[t]{2}{*}{ Location } & \multirow{2}{*}{$\begin{array}{l}\text { Approved } \\
\text { Area } \\
\left(\mathrm{m}^{2}\right) \\
\end{array}$} & \multirow{2}{*}{$\begin{array}{c}\text { Approved } \\
\text { Capacity } \\
\left(\mathrm{m}^{3}\right) \\
\end{array}$} & \multicolumn{2}{|c|}{ Ownership $^{a}$} & \multirow{2}{*}{$\begin{array}{l}\text { Prior } \\
\text { Land } \\
\text { Use }^{b} \\
\end{array}$} & \multicolumn{2}{|c|}{ Approval } & \multicolumn{3}{|c|}{ Operation } \\
\hline & & & & Name & Contact Info & & Date & Agency $^{\mathrm{C}}$ & Start & Est. End & Actual End \\
\hline A8/SD1 & $\mathrm{Km} 218+500$ & 2.612 & 11.754 & $\begin{array}{l}\text { Tran Van } \\
\text { Chac }\end{array}$ & $\begin{array}{l}\text { An Thang- Son } \\
\text { Ha- Bao Thang- } \\
\text { Lao Cai }\end{array}$ & rice field & $20 / 7 / 2010$ & \multirow{8}{*}{$\begin{array}{l}\text { Contact } \\
\text { between } \\
\text { the } \\
\text { contractor } \\
\text { and land } \\
\text { owner with } \\
\text { confirm of } \\
\text { commune } \\
\text { people's } \\
\text { committee }\end{array}$} & $8 / 2010$ & & $11 / 2010$ \\
\hline A8/SD2 & $\mathrm{Km} 222+500$ & 952 & 1.904 & $\begin{array}{l}\text { Tran Hai } \\
\text { Cuong }\end{array}$ & \multirow{2}{*}{$\begin{array}{l}\text { An Hong- Son } \\
\text { Ha- Bao Thang- } \\
\text { Lao Cai }\end{array}$} & rice field & $20 / 7 / 2010$ & & $8 / 2010$ & & $11 / 2010$ \\
\hline A8/SD3 & $\mathrm{Km} 223+050$ & 1.386 & 3.465 & $\begin{array}{l}\text { Nguyen } \\
\text { Thi Quy }\end{array}$ & & rice field & $20 / 7 / 2010$ & & $8 / 2010$ & & $11 / 2010$ \\
\hline A8/SD4 & $\mathrm{Km} 234+860$ & 10.000 & 120.000 & $\begin{array}{l}\text { Nguyen } \\
\text { Van Duong }\end{array}$ & \multirow{3}{*}{$\begin{array}{l}\text { Tien Loi2- Xuan } \\
\text { Giao- } \quad \text { Bao } \\
\text { Thang- Lao Cai }\end{array}$} & rice field & $10 / 8 / 2010$ & & $8 / 2010$ & & $11 / 2010$ \\
\hline A8/SD5 & $\mathrm{Km} 234+860$ & 2.680 & 8.000 & $\begin{array}{l}\text { Pham Van } \\
\text { Su }\end{array}$ & & rice field & $10 / 8 / 2010$ & & $8 / 2010$ & & $11 / 2010$ \\
\hline A8/SD6 & $\mathrm{Km} 234+840$ & 10.000 & 120.000 & $\begin{array}{l}\text { Nguyen } \\
\text { Van Duong }\end{array}$ & & rice field & $10 / 8 / 2010$ & & $8 / 2010$ & & $11 / 2010$ \\
\hline A8/SD7 & $\mathrm{Km} 237+580$ & 730 & 1.900 & $\begin{array}{l}\text { Nguyen } \\
\text { Thanh Luot }\end{array}$ & $\begin{array}{l}\text { Phu Xuan- Gia } \\
\text { Phu- } \quad \text { Bao } \\
\text { Thang- Lao Cai }\end{array}$ & rice field & $20 / 6 / 2012$ & & $1 / 7 / 2010$ & & $11 / 2010$ \\
\hline A8/SD8 & Km237+195 & 652 & 2.000 & $\begin{array}{l}\text { Do The } \\
\text { Huy }\end{array}$ & $\begin{array}{l}\text { Son Ca- Gia } \\
\text { Phu- Bao }\end{array}$ & rice field & 20/6/2012 & & $1 / 7 / 2010$ & & $11 / 2010$ \\
\hline
\end{tabular}




\section{Loan 2391/2392 - VIE: GMS Kunming - Hai Phong Transport Corridor} Noi Bai - Lao Cai Highway Project

\begin{tabular}{|c|c|c|c|c|c|c|c|c|c|c|c|}
\hline & & & & & SPOILS DISPO & IL AREAS & & & & & \\
\hline Package & Location & Approved & Approved & & 1ership $^{2}$ & Prior & Ap & val & & Operatior & \\
\hline I SD No. & & $\begin{array}{c}\text { Area } \\
\left(\mathrm{m}^{2}\right) \\
\end{array}$ & $\begin{array}{c}\text { Capacity } \\
\left(\mathrm{m}^{3}\right)\end{array}$ & Name & Contact Info & $\begin{array}{l}\text { Land } \\
\text { Use }\end{array}$ & Date & Agency $^{c}$ & Start & Est. End & Actual End \\
\hline A8/SD9 & $\mathrm{Km} 237+160$ & 360 & 1.200 & $\begin{array}{l}\text { Hoang Van } \\
\text { Uyen }\end{array}$ & Thang- Lao Cai & rice field & $3 / 8 / 2010$ & & $15 / 8 / 2010$ & & $11 / 2010$ \\
\hline A8/SD10 & $\mathrm{Km} 237+060$ & 350 & 1.255 & $\begin{array}{l}\text { Pham Van } \\
\text { Tho }\end{array}$ & & rice field & 20/7/2010 & & $15 / 8 / 2010$ & & $11 / 2010$ \\
\hline A8/SD11 & $\mathrm{Km} 237+060$ & 488 & 1.200 & $\begin{array}{l}\text { Nguyen } \\
\text { Ngoc Dinh }\end{array}$ & & rice field & 28/7/2010 & & $15 / 8 / 2010$ & & $11 / 2010$ \\
\hline A8/SD12 & $\mathrm{Km} 238+500$ & 4.900 & 7.350 & $\begin{array}{l}\text { Tran Van } \\
\text { Sinh }\end{array}$ & & rice field & 10/8/2010 & & $15 / 8 / 2010$ & & $11 / 2010$ \\
\hline A8/SD13 & $\mathrm{Km} 238+500$ & 300 & 450 & $\begin{array}{l}\text { Nguyen } \\
\text { Thi Vi }\end{array}$ & & rice field & 10/8/2010 & & $15 / 8 / 2010$ & & $11 / 2010$ \\
\hline A8/SD14 & $\mathrm{Km} 238+500$ & 2.400 & 3.600 & $\begin{array}{l}\text { Dao Van } \\
\text { Nghia }\end{array}$ & & rice field & 10/8/2010 & & 15/8/2010 & & $11 / 2010$ \\
\hline A8/SD15 & $\mathrm{Km} 238+500$ & 3.000 & 7.500 & $\begin{array}{l}\text { Nguyen } \\
\text { Duc Loi }\end{array}$ & Ben Den- Gia & rice field & 10/8/2010 & & $15 / 8 / 2010$ & & $11 / 2010$ \\
\hline A8/SD16 & $\mathrm{Km} 238+500$ & 9.600 & 19.200 & $\begin{array}{l}\text { Pham Van } \\
\text { Thi }\end{array}$ & Thang- Lao Cai & rice field & 10/8/2010 & & $15 / 8 / 2010$ & & $11 / 2010$ \\
\hline A8/SD17 & $\mathrm{Km} 238+500$ & 3.000 & 6.000 & $\begin{array}{ll}\text { Dao } & \text { Thi } \\
\text { Muoi } & \end{array}$ & & rice field & 10/8/2010 & & $15 / 8 / 2010$ & & $11 / 2010$ \\
\hline A8/SD18 & $\mathrm{Km} 238+500$ & 3.000 & 6.000 & $\begin{array}{l}\text { Pham Van } \\
\text { Thu }\end{array}$ & & rice field & 10/8/2010 & & $15 / 8 / 2010$ & & $11 / 2010$ \\
\hline A8/SD19 & $\mathrm{Km} 238+500$ & 4.00 & 8.00 & $\begin{array}{l}\text { Pham Van } \\
\text { Vien }\end{array}$ & & rice field & 10/8/2010 & & $15 / 8 / 2010$ & & $11 / 2010$ \\
\hline
\end{tabular}

\begin{tabular}{|c|c|c|c|c|c|c|c|c|c|c|c|}
\hline \multicolumn{12}{|c|}{ BATCHING PLANTS } \\
\hline \multirow{2}{*}{$\begin{array}{l}\text { Package I } \\
\text { SD No. }\end{array}$} & \multirow[t]{2}{*}{ Location } & \multirow{2}{*}{$\begin{array}{l}\text { Appropriate } \\
\text { settling pond }\end{array}$} & \multirow{2}{*}{$\begin{array}{l}\text { Noise and } \\
\text { dust } \\
\text { measures }\end{array}$} & \multicolumn{2}{|c|}{ Ownership $^{a}$} & \multirow{2}{*}{$\begin{array}{l}\text { Prior Land } \\
\text { Use }\end{array}$} & \multicolumn{2}{|c|}{ Approval } & \multicolumn{3}{|c|}{ Operation } \\
\hline & & & & Name & Contact Info & & Date & Agency $^{c}$ & Start & Est. End & $\begin{array}{l}\text { Actual } \\
\text { End }\end{array}$ \\
\hline
\end{tabular}


Loan 2391/2392 - VIE: GMS Kunming - Hai Phong Transport Corridor

Noi Bai - Lao Cai Highway Project

\begin{tabular}{|c|c|c|c|c|c|c|c|c|c|c|c|}
\hline \multicolumn{12}{|c|}{ BATCHING PLANTS } \\
\hline \multirow{2}{*}{$\begin{array}{l}\text { Package I } \\
\text { SD No. }\end{array}$} & \multirow[t]{2}{*}{ Location } & \multirow{2}{*}{$\begin{array}{l}\text { Appropriate } \\
\text { settling pong }\end{array}$} & \multirow{2}{*}{$\begin{array}{l}\text { Noise and } \\
\quad \text { dust } \\
\text { measures }\end{array}$} & \multicolumn{2}{|c|}{ Ownership $^{a}$} & \multirow{2}{*}{$\begin{array}{l}\text { Prior Land } \\
\text { Use }^{b}\end{array}$} & \multicolumn{2}{|c|}{ Approval } & \multicolumn{3}{|c|}{ Operation } \\
\hline & & & & Name & Contact Info & & Date & Agencyc $^{c}$ & Start & Est. End & $\begin{array}{l}\text { Actual } \\
\text { End }\end{array}$ \\
\hline A8/CBP1 & $\mathrm{Km} 218+040$ & $\begin{array}{l}\text { Settling } \\
\text { pond had } \\
\text { provided }\end{array}$ & $\begin{array}{l}\text { Noise and } \\
\text { dust } \\
\text { measures had } \\
\text { support with } \\
\text { plant }\end{array}$ & $\begin{array}{ll}\text { Suoi } & \text { Nhu } \\
\text { BCp } & \end{array}$ & $\begin{array}{l}\text { An Thang } \\
\text { hamlet, Son Ha } \\
\text { commune, Bao } \\
\text { Thang, Lao Cai }\end{array}$ & Abandoned & $16 / 7 / 2012$ & $\begin{array}{l}\text { Bao Thang } \\
\text { District } \\
\text { people's } \\
\text { committee }\end{array}$ & $1 / 4 / 2011$ & $1 / 8 / 2013$ & July 2013 \\
\hline A8/CBP2 & $\mathrm{Km} 231+889$ & $\begin{array}{l}\text { Settling } \\
\text { pond had } \\
\text { provided }\end{array}$ & $\begin{array}{l}\text { Noise and } \\
\text { dust } \\
\text { measures had } \\
\text { support with } \\
\text { plant }\end{array}$ & $\begin{array}{ll}\text { Suoi } & \text { Trat } \\
\text { BCP } & \end{array}$ & $\begin{array}{l}\text { Giao } \quad \text { Binh } \\
\text { hamlet, Xuan } \\
\text { Giao commune, } \\
\text { Bao Thang, Lao } \\
\text { Cai }\end{array}$ & Hill land & $16 / 7 / 2012$ & $\begin{array}{l}\text { Bao Thang } \\
\text { District } \\
\text { people's } \\
\text { committee }\end{array}$ & $\begin{array}{l}11 / 1 / 201 \\
1\end{array}$ & $1 / 8 / 2013$ & $\begin{array}{l}\text { February } \\
2014\end{array}$ \\
\hline A8/CBP3 & $\mathrm{Km} 238+265$ & $\begin{array}{l}\text { Settling } \\
\text { pond had } \\
\text { provided }\end{array}$ & $\begin{array}{l}\text { Noise and } \\
\text { dust } \\
\text { measures had } \\
\text { support with } \\
\text { plant }\end{array}$ & $\begin{array}{ll}\text { Ngoi } & \text { Bo } \\
\text { BCP } & \end{array}$ & $\begin{array}{l}\text { Ben } \quad \text { Pha } \\
\text { hamlet, Gia Phu } \\
\text { commune, Bao } \\
\text { Thang, Lao Cai }\end{array}$ & Abandoned & $16 / 7 / 2012$ & $\begin{array}{l}\text { Bao Thang } \\
\text { District } \\
\text { people's } \\
\text { committee }\end{array}$ & $\begin{array}{l}24 / 1 / 201 \\
1\end{array}$ & $1 / 8 / 2013$ & May 2013 \\
\hline A8/ABP1 & $\mathrm{Km} 238+265$ & $\begin{array}{l}\text { Settling } \\
\text { pond had } \\
\text { provided }\end{array}$ & $\begin{array}{l}\text { Noise and } \\
\text { dust } \\
\text { measures had } \\
\text { support with } \\
\text { plant }\end{array}$ & $\begin{array}{ll}\text { Ngoi } & \text { Bo } \\
\text { ABP } & \end{array}$ & $\begin{array}{l}\text { Ben Pha } \\
\text { hamlet, Gia Phu } \\
\text { commune, Bao } \\
\text { Thang, Lao Cai }\end{array}$ & Abandoned & $25 / 6 / 2013$ & $\begin{array}{l}\text { Bao Thang } \\
\text { District } \\
\text { people's } \\
\text { committee }\end{array}$ & $\begin{array}{l}29 / 3 / 201 \\
3\end{array}$ & $1 / 8 / 2013$ & $\begin{array}{l}\text { March } \\
2014\end{array}$ \\
\hline A8/ABP2 & $\mathrm{Km} 230+800$ & $\begin{array}{l}\text { Settling } \\
\text { pond had } \\
\text { provided }\end{array}$ & $\begin{array}{l}\text { Noise and } \\
\text { dust } \\
\text { measures had } \\
\text { support with } \\
\text { plant }\end{array}$ & $\begin{array}{l}\text { Son Hai } \\
\text { ABP }\end{array}$ & $\begin{array}{ll}\text { Son } & \text { Hai } \\
\text { commune, } & \text { Bao } \\
\text { Thang, Lao Cai }\end{array}$ & Abandoned & Not yet & Not yet & $\begin{array}{l}20.9 .201 \\
3\end{array}$ & $\begin{array}{l}31.12 .20 \\
13\end{array}$ & $\begin{array}{l}\text { March } \\
2014\end{array}$ \\
\hline
\end{tabular}


Loan 2391/2392 - VIE: GMS Kunming - Hai Phong Transport Corridor Noi Bai - Lao Cai Highway Project

\section{ANNEX 5: SUMMARY TABLE OF IMPOSED PENALTIES}

$12^{\text {th }}$ floor, Ocean Park Building, Dao Duy Anh Street, Dong Da Distric Huu Thu Hamlet, Kim Long Ward, Tam Duong Distric, VinhPhuc Province Calle Ramón de Aguinaga 8, 28028 Madrid, Spain 
Loan 2391/2392 - VIE: GMS Kunming - Hai Phong Transport Corridor Noi Bai - Lao Cai Highway Project 


\section{PACKAGE A1}

\begin{tabular}{|c|c|c|c|}
\hline $\begin{array}{l}\text { DATE/ LETTER } \\
\text { REFERENCE }\end{array}$ & ISSUE & PENALTY IMPOSED & EXECUTION (Y/N) \\
\hline $\begin{array}{l}\text { 22-Nov-2013/GET1- } \\
\text { POS-A1-2317 }\end{array}$ & $\begin{array}{l}\text { Construction } \\
\text { caused landslide on } \\
\text { riversides at Tan Loi (Km } \\
10+695) \text { and Xuan } \\
\text { Phuong (Km } 7+660) \\
\text { Bridges but restoration } \\
\text { works have not been } \\
\text { carried out }\end{array}$ & $\begin{array}{l}\text { Due to the Contractor } \\
\text { didn't take any action } \\
\text { to implement the } \\
\text { requirement of the } \\
\text { Engineer in order to } \\
\text { restore the affected } \\
\text { areas so the Engineer } \\
\text { temporarily retained } \\
\text { VND ten billion } \\
\text { (approximate USD } \\
476,000) \text { from IPC no } \\
38 \text { until the Contractor } \\
\text { finishes restoration } \\
\text { work }\end{array}$ & Yes \\
\hline
\end{tabular}

\section{PACKAGE A2}

\begin{tabular}{|l|l|l|l|}
\hline $\begin{array}{l}\text { DATE/ LETTER } \\
\text { REFERENCE }\end{array}$ & ISSUE & PENALTY IMPOSED & EXECUTION (YIN) \\
\hline \multicolumn{3}{|c|}{ No penalties imposed } \\
\hline
\end{tabular}

\section{PACKAGE A3}

\begin{tabular}{|c|c|c|c|}
\hline $\begin{array}{l}\text { DATEI LETTER } \\
\text { REFERENCE }\end{array}$ & ISSUE & PENALTY IMPOSED & EXECUTION (Y/N) \\
\hline $\begin{array}{l}\text { 18/12/2013/Get4- } \\
\text { Vinocanex- } 912\end{array}$ & $\begin{array}{l}\text { Require to clear the } \\
\text { current flow and clean up } \\
\text { on site - Package } A 8\end{array}$ & $\begin{array}{l}\text { Proposed to keep } \\
\text { payment at next IPC if } \\
\text { the contractor does } \\
\text { not solve this issue } \\
\text { before deadline }\end{array}$ & $\begin{array}{l}\text { The contractor had } \\
\text { improved this issue on } \\
\text { time }\end{array}$ \\
\hline $\begin{array}{l}\text { 29/10/2013/GET2-POS- } \\
\text { A3-2166 }\end{array}$ & $\begin{array}{l}\text { Remind Project Manager } \\
\text { of POSCO E\&C of delay } \\
\text { in solving land slide at } \\
\text { Tien Kien commnue, Lam } \\
\text { Thao district..pdf }\end{array}$ & $\begin{array}{l}\text { Proposed to keep } \\
\text { payment at next IPC if } \\
\text { the contractor does } \\
\text { not solve this issue } \\
\text { before deadline }\end{array}$ & $\begin{array}{l}\text { The contractor had } \\
\text { not yet improved this } \\
\text { issue on time }\end{array}$ \\
\hline $\begin{array}{l}\text { 06/11/2013/GET2-POS- } \\
\text { A3-2180 }\end{array}$ & $\begin{array}{l}\text { Remind Project Manager } \\
\text { of POSCO about solving } \\
\text { environmental matter at } \\
\text { A2 of RRB }\end{array}$ & $\begin{array}{l}\text { Proposed to keep } \\
\text { payment at next IPC if } \\
\text { the contractor does } \\
\text { not solve this issue } \\
\text { before deadline }\end{array}$ & $\begin{array}{l}\text { The contractor had } \\
\text { not yet improved this } \\
\text { issue on time }\end{array}$ \\
\hline 06/11/2013/GET2-POS- & Remind Project Manager & Proposed to & The contractor had \\
\hline
\end{tabular}

Hanoi office:

VinhPhuc office:

Madrid head office: $12^{\text {th }}$ floor, Ocean Park Building, Dao Duy Anh Street, Dong Da Distric

Huu Thu Hamlet, Kim Long Ward, Tam Duong Distric, VinhPhuc Province

Calle Ramón de Aguinaga 8, 28028 Madrid, Spain 
 \\ Loan 2391/2392 - VIE: GMS Kunming - Hai Phong Transport Corridor Noi Bai - Lao Cai Highway Project}

\begin{tabular}{|l|l|l|l|}
\hline $\begin{array}{l}\text { DATEI LETTER } \\
\text { REFERENCE }\end{array}$ & ISSUE PENALTY IMPOSED & EXECUTION (Y/N) \\
\hline A3-2181 & $\begin{array}{l}\text { of POSCO about solving } \\
\text { environmental matter in } \\
\text { Sai Nga commune }\end{array}$ & $\begin{array}{l}\text { payment at next IPC if } \\
\text { the contractor does } \\
\text { not solve this issue } \\
\text { before deadline }\end{array}$ & $\begin{array}{l}\text { improved this issue on } \\
\text { time }\end{array}$ \\
\hline $\begin{array}{l}\text { 12/11/2013/GET2-POS- } \\
\text { A3-2184 }\end{array}$ & $\begin{array}{l}\text { Remind Project Manager } \\
\text { of POSCO E\&C of } \\
\text { solving Environmental } \\
\text { matters in Abutment A2 } \\
\text { of Red River Bridge - }-\end{array}$ & $\begin{array}{l}\text { Proposed to keep } \\
\text { payment at next IPC if } \\
\text { the contractor does } \\
\text { nackage A3 solve this issue } \\
\text { before deadline }\end{array}$ & $\begin{array}{l}\text { The contractor had } \\
\text { not improved this } \\
\text { issue on time }\end{array}$ \\
\hline $\begin{array}{l}\text { Pa/11/2013/GET2-POS- } \\
\text { A3-2193 }\end{array}$ & $\begin{array}{l}\text { Remind Project Manager } \\
\text { of POSCO E\&C of } \\
\text { solving Environmental } \\
\text { matters at Abutment A2 } \\
\text { of Red River Bridge - }-\end{array}$ & $\begin{array}{l}\text { Proposed to keep } \\
\text { payment at next IPC if } \\
\text { Package A3. contractor does } \\
\text { not solve this issue } \\
\text { before deadline }\end{array}$ & $\begin{array}{l}\text { The contractor had } \\
\text { improved this issue on } \\
\text { time }\end{array}$ \\
\hline $26 / 11 / 2013 / G E T 2-P O S-$ & $\begin{array}{l}\text { Remind Project Manager } \\
\text { of POSCO E\&C of delay } \\
\text { in solving landslide in } \\
\text { Tien Kien commune - } \\
\text { Lam Thao district. }\end{array}$ & $\begin{array}{l}\text { Proposed to keep } \\
\text { payment at next IPC if } \\
\text { the contractor does } \\
\text { not solve this issue } \\
\text { before deadline }\end{array}$ & $\begin{array}{l}\text { The contractor had } \\
\text { improved this issue on } \\
\text { time }\end{array}$ \\
\hline
\end{tabular}

\section{PACKAGE A4}

\begin{tabular}{|l|l|l|l|}
\hline $\begin{array}{l}\text { DATEI LETTER } \\
\text { REFERENCE }\end{array}$ & ISSUE & PENALTY IMPOSED & EXECUTION (Y/N) \\
\hline $\begin{array}{l}\text { A4/11/2013/GET2-KEA- } \\
\text { A426 }\end{array}$ & $\begin{array}{l}\text { Remind the Contractor } \\
\text { about disposing the soil } \\
\text { to unregulated area at } \\
\text { Km82+500 - Km82+600 }\end{array}$ & $\begin{array}{l}\text { Proposed to keep } \\
\text { payment at next IPC if } \\
\text { the contractor does } \\
\text { not solve this issue } \\
\text { before deadline }\end{array}$ & $\begin{array}{l}\text { The contractor had } \\
\text { not yet improved this } \\
\text { issue on time }\end{array}$ \\
\hline $\begin{array}{l}\text { 26/11/2013/GET2-KEA- } \\
\text { A4-1427 }\end{array}$ & $\begin{array}{l}\text { Remind the Project } \\
\text { Manager of the } \\
\text { Contractor Keangnam } \\
\text { about not disposing soil } \\
\text { at regulated area at } \\
\text { section 3 and section 6, } \\
\text { Ngoi Van bridge- } \\
\text { Package A4 }\end{array}$ & $\begin{array}{l}\text { Proposed to keep } \\
\text { payment at next IPC if } \\
\text { the contractor does } \\
\text { not solve this issue } \\
\text { before deadline }\end{array}$ & $\begin{array}{l}\text { The contractor had } \\
\text { not yet improved this } \\
\text { issue on time }\end{array}$ \\
\hline 27/12/2013/GET2-KEA- & $\begin{array}{l}\text { Remind PM of the } \\
\text { Contractor of disposal } \\
\text { not following the } \\
\text { regulations at Sec 1, 3, } 6 \\
\text { and Ngoi Van, Ngoi } \\
\text { Gianh bridge }\end{array}$ & $\begin{array}{l}\text { Proposed to keep } \\
\text { payment at next IPC if } \\
\text { the contractor does } \\
\text { not solve this issue } \\
\text { before deadline }\end{array}$ & $\begin{array}{l}\text { The contractor had } \\
\text { not yet improved this } \\
\text { issue on time }\end{array}$ \\
\hline
\end{tabular}

Hanoi office:

VinhPhuc office:

Madrid head office: $12^{\text {th }}$ floor, Ocean Park Building, Dao Duy Anh Street, Dong Da Distric

Huu Thu Hamlet, Kim Long Ward, Tam Duong Distric, VinhPhuc Province

Calle Ramón de Aguinaga 8, 28028 Madrid, Spain 
Loan 2391/2392 - VIE: GMS Kunming - Hai Phong Transport Corridor

Noi Bai - Lao Cai Highway Project

\section{PACKAGE A5}

\begin{tabular}{|c|c|c|c|}
\hline $\begin{array}{l}\text { DATEI LETTER } \\
\text { REFERENCE }\end{array}$ & ISSUE & PENALTY IMPOSED & EXECUTION (Y/N) \\
\hline $\begin{array}{l}\text { Ref. GET3- } \\
\text { KEANGNAM-13-A5-788 } \\
\text { dated on } 15^{\text {th }} \text { October, } \\
2013\end{array}$ & $\begin{array}{l}\text { The Contractor's } \\
\text { construction activities and } \\
\text { material transportation still } \\
\text { are the main factors } \\
\text { causing dusting which } \\
\text { pollute air quality as well } \\
\text { as living, business and } \\
\text { health of local residents at } \\
\text { some stations: Km118, } \\
\text { Km122, Hop Minh My } \\
\text { bridge, NR37 bridge, } \\
\text { Km124, Km142, Km145, } \\
\text { Km148 - Km149. This } \\
\text { situation is causing } \\
\text { serious anger from local } \\
\text { residents living around } \\
\text { project areas. }\end{array}$ & $\begin{array}{l}\text { The Engineer required } \\
\text { the Contractor to apply } \\
\text { measures in order to } \\
\text { solve this problem. If } \\
\text { the situation is not } \\
\text { improved, clause } 2.2 \\
\text { (d) in the section } \\
01700 \text { - environmental } \\
\text { control and protection } \\
\text { (referring to the } \\
\text { Project's technical } \\
\text { specification) will be } \\
\text { immediately applied, } \\
\text { as suspending } \\
\text { payments the works } \\
\text { related with the non } \\
\text { compliance. }\end{array}$ & $\begin{array}{l}\text { The Contractor is } \\
\text { applying some } \\
\text { measures in order to } \\
\text { minimize dusty during } \\
\text { material transportation. } \\
\text { E.g. Some dump trucks } \\
\text { were covered with } \\
\text { canvas during material } \\
\text { transportation, the } \\
\text { Contractor is spraying } \\
\text { water on public roads } \\
\text { and construction site, } \\
\text { dump trucks were } \\
\text { followed the speed } \\
\text { limit. }\end{array}$ \\
\hline $\begin{array}{l}\text { Ref. GET3- } \\
\text { KEANGNAM-13-A5-857 } \\
\text { dated on } 30^{\text {th }} \text { November, } \\
2013\end{array}$ & $\begin{array}{l}\text { At sections: Hop Minh My } \\
\text { bridge's construction site, } \\
\text { Up-box Km123+860, Up- } \\
\text { box Km145+220, } \\
\text { especially on Ngoi Rao } \\
\text { bridge's construction site. } \\
\text { The Contractor's } \\
\text { construction activities and } \\
\text { transportation material are } \\
\text { causing impact to quality } \\
\text { of public roads, difficultly } \\
\text { to vehicles traveling } \\
\text { through these locations }\end{array}$ & $\begin{array}{l}\text { The Engineer required } \\
\text { the Contractor to apply } \\
\text { measures in order to } \\
\text { solve this problem. If } \\
\text { the situation is not } \\
\text { improved, clause } 2.1 \\
\text { (h) in the section } \\
01600 \text { - Maintenance } \\
\text { and protection of traffic } \\
\text { (referring to the } \\
\text { Project's technical } \\
\text { specification) will be } \\
\text { immediately applied, } \\
\text { as suspending } \\
\text { payments the works } \\
\text { related with the non } \\
\text { compliance. }\end{array}$ & $\begin{array}{l}\text { The Contractor is } \\
\text { combining with local } \\
\text { authorities in order to } \\
\text { repair damaged roads. }\end{array}$ \\
\hline $\begin{array}{l}\text { Ref. GET3- } \\
\text { KEANGNAM-13-A5-859 } \\
\text { dated on } 2^{\text {nd }} \text { December, } \\
2013\end{array}$ & $\begin{array}{l}\text { The Contractor delayed } \\
\text { environmental monitoring } \\
\text { activities month (water } \\
\text { quality, air quality, noise } \\
\text { level) }\end{array}$ & $\begin{array}{l}\text { The Engineer requires } \\
\text { the Contractor to } \\
\text { continue implement } \\
\text { environmental } \\
\text { monitoring activities as } \\
\text { Environmental } \\
\text { Monitoring Plan } \\
\text { approved by the } \\
\text { Engineer in order to } \\
\text { ensure the Project's } \\
\text { requirements. If the } \\
\text { situation is not } \\
\text { improved, clause } 2.2 \\
\text { (d) in the section } \\
01700-\text { environmental }\end{array}$ & $\begin{array}{l}\text { The Contractor } \\
\text { continue implemented } \\
\text { environmental } \\
\text { monitoring activities as } \\
\text { Environmental } \\
\text { monitoring plan } \\
\text { approved by the } \\
\text { Engineer. }\end{array}$ \\
\hline
\end{tabular}

Hanoi office:

VinhPhuc office: $12^{\text {th }}$ floor, Ocean Park Building, Dao Duy Anh Street, Dong Da Distric

Huu Thu Hamlet, Kim Long Ward, Tam Duong Distric, VinhPhuc Province

Calle Ramón de Aguinaga 8, 28028 Madrid, Spain 
Loan 2391/2392 - VIE: GMS Kunming - Hai Phong Transport Corridor Noi Bai - Lao Cai Highway Project

\begin{tabular}{|c|c|c|c|}
\hline DATEI LETTER & ISSUE & PENALTY IMPOSED & EXECUTION (Y/N) \\
\hline & & $\begin{array}{l}\text { control and protection } \\
\text { (referring to the } \\
\text { Project's technical } \\
\text { specification) will be } \\
\text { immediately applied, } \\
\text { as suspending } \\
\text { payments the works } \\
\text { related with the non } \\
\text { compliance }\end{array}$ & \\
\hline $\begin{array}{l}\text { Ref. GET3- } \\
\text { KEANGNAM-14-A5-050 } \\
\text { dated on } 26^{\text {th }} \text { February, } \\
2014\end{array}$ & $\begin{array}{l}\text { The Contractor is carrying } \\
\text { out construction for work } \\
\text { items such as bridge, UP } \\
\text { box-culverts, drainage } \\
\text { culverts, irrigation } \\
\text { culverts... at many } \\
\text { locations. During the } \\
\text { construction of these } \\
\text { items the Contractor has } \\
\text { excavated deep holes } \\
\text { such as: foundation } \\
\text { ditches for bridges, } \\
\text { ditches for installation of } \\
\text { drainage and irrigation } \\
\text { culverts, etc. But, } \\
\text { currently safety fences } \\
\text { and signboards still have } \\
\text { not been installed fully } \\
\text { many dangerously areas, } \\
\text { this is unsafe }\end{array}$ & $\begin{array}{l}\text { The Engineer } \\
\text { requested the } \\
\text { Contractor to enhance } \\
\text { safety in order to } \\
\text { ensure the Project's } \\
\text { safety issues during } \\
\text { project } \\
\text { implementation. If the } \\
\text { situation is not } \\
\text { improved, items d; e; f; } \\
\text { g; } \mathrm{h} \text { in section } 2.1 \\
\text { General requirements; } \\
\text { item b-14 in Sub } \\
\text { section } 2.2 \\
\text { Contractor's Safety } \\
\text { Plan; items a; j; } \mathrm{k} \text {; in } \\
\text { section } 2.4 \text { : Special } \\
\text { Requirements for } \\
\text { Safety will be } \\
\text { immediately applied in } \\
\text { order to ensure the } \\
\text { Project's safety issues. }\end{array}$ & $\begin{array}{l}\text { The Contractor are } \\
\text { implementing } \\
\text { measures in order to } \\
\text { solve this problem as } \\
\text { the requirements from } \\
\text { the Consultant. } \\
\text { - Install warning } \\
\text { tape to stop people } \\
\text { and vehicles } \\
\text { passing during } \\
\text { construction; } \\
\text { - Install safety fence } \\
\text { and signboards at } \\
\text { dangerous areas; }\end{array}$ \\
\hline $\begin{array}{l}\text { Ref. GET3- } \\
\text { KEANGNAM-14-A5-096 } \\
\text { dated on } 26^{\text {th }} \text { March, } \\
2014\end{array}$ & $\begin{array}{l}\text { Many workers did not use } \\
\text { fully Personal Protection } \\
\text { Equipment during work on } \\
\text { the site (e.g. helmet, } \\
\text { gloves, safety shoes, etc.) } \\
\text { Up-box Km142, Km137, } \\
\text { Construction site Km142, } \\
\text { Km148, Ngoi Vien } \\
\text { bridge's construction site, } \\
\text { etc. This situation is } \\
\text { causing to affect the } \\
\text { worker's health as well as } \\
\text { safety control of the } \\
\text { project }\end{array}$ & $\begin{array}{l}\text { The Engineer } \\
\text { requested the } \\
\text { Contractor to provide } \\
\text { fully PPE for workers, } \\
\text { and ensure that all } \\
\text { workers are provided } \\
\text { with PPE and that } \\
\text { these are worn at all } \\
\text { times where } \\
\text { necessary. If the } \\
\text { situation is not } \\
\text { improved, items d; e; f; } \\
\text { g; } h \text { in section } 2.1 \\
\text { General requirements; } \\
\text { item b-14 in Sub } \\
\text { section } 2.2 \\
\text { Contractor's Safety } \\
\text { Plan; items a; j; } k \text {; in } \\
\text { section } 2.4: \text { Special } \\
\text { Requirements for }\end{array}$ & $\begin{array}{l}\text { The Contractor } \\
\text { reminded the sub- } \\
\text { contractor about PPE } \\
\text { for worker, but many } \\
\text { workers still are not } \\
\text { using fully PPE during } \\
\text { work on the site. }\end{array}$ \\
\hline
\end{tabular}


Loan 2391/2392 - VIE: GMS Kunming - Hai Phong Transport Corridor Noi Bai - Lao Cai Highway Project

\begin{tabular}{|c|c|c|c|}
\hline DATEI LETTER & ISSUE & PENALTY IMPOSED & EXECUTION (YIN) \\
\hline & & $\begin{array}{l}\text { Safety will be } \\
\text { immediately applied in } \\
\text { order to ensure the } \\
\text { Project's safety issues. }\end{array}$ & \\
\hline $\begin{array}{l}\text { Ref. GET3- } \\
\text { KEANGNAM-14-A5-098 } \\
\text { dated on } 26^{\text {th }} \text { March, } \\
2014\end{array}$ & $\begin{array}{l}\text { Some camps for workers } \\
\text { still are not meeting fully } \\
\text { the Project's requirements } \\
\text { (Ngoi Thu bridge's } \\
\text { construction site, Km127, } \\
\text { Ngoi Gua bridge's } \\
\text { construction site, Km137, } \\
\text { Km140, Asphalt concrete } \\
\text { batching plant Km135), } \\
\text { e.g. no sanitary toilet, } \\
\text { dustbins, first-aid kits, fire- } \\
\text { extinguishers }\end{array}$ & $\begin{array}{l}\text { The Engineer required } \\
\text { the Contractor to } \\
\text { improve living and } \\
\text { working condition at } \\
\text { these locations. If the } \\
\text { situation is not } \\
\text { improved, clause } 2.2 \\
\text { (d) if section } 01700 \\
\text { (referring to the } \\
\text { Project's technical } \\
\text { specification) will be } \\
\text { immediately applied, } \\
\text { as suspending } \\
\text { payments the works } \\
\text { related with the non } \\
\text { compliance }\end{array}$ & $\begin{array}{l}\text { No important changes } \\
\text { done for this work }\end{array}$ \\
\hline
\end{tabular}

\section{PACKAGE A6}

\begin{tabular}{|c|c|c|c|}
\hline $\begin{array}{l}\text { DATE/ LETTER } \\
\text { REFERENCE }\end{array}$ & ISSUE & PENALTY IMPOSED & EXECUTION (YIN) \\
\hline $\begin{array}{l}\text { GET3-DOOSAN-13-A6- } \\
412 \text { dated on } 2^{\text {nd }} \text { July, } \\
2013 \\
\text { GET3-DOOSAN-13-A6- } \\
474 \text { dated on } 6^{\text {th }} \\
\text { August, } 2013 \\
\text { GET3-DOOSAN-13-A6- } \\
609 \text { dated on } 22^{\text {nd }} \\
\text { October, } 2013 \\
\text { GET3-DOOSAN-13-A6- } \\
689 \text { dated on } 18^{\text {th }} \\
\text { December, } 2013 \\
\text { GET3-DOOSAN-14-A6- } \\
\text { 009 dated on } 16^{\text {th }} \\
\text { January, } 2014\end{array}$ & $\begin{array}{l}\text { At station Km166+500, } \\
\text { unsuitable material was } \\
\text { dumped onto the riverbed, } \\
\text { this disposal area was not } \\
\text { approved by the } \\
\text { Engineer, this situation } \\
\text { may cause impact to } \\
\text { water flow and water } \\
\text { quality of the river }\end{array}$ & $\begin{array}{l}\text { The Engineer required } \\
\text { the Contractor to apply } \\
\text { measures in order to } \\
\text { solve this problem. If } \\
\text { the situation is not } \\
\text { improved, clause } 2.2 \\
\text { (d) in the section } \\
\text { 01700- environmental } \\
\text { control and protection } \\
\text { (referring to the } \\
\text { Project's technical } \\
\text { specification) will be } \\
\text { immediately applied, } \\
\text { as suspending } \\
\text { payments the works } \\
\text { related with the non } \\
\text { compliance. }\end{array}$ & $\begin{array}{l}\text { The Contractor is } \\
\text { implementing some } \\
\text { measures in order to } \\
\text { solve this problem } \\
\text { (referring to Report on } \\
\text { Status of the restoration } \\
\text { works in unauthorized } \\
\text { unsuitable material } \\
\text { disposals package A6 - } \\
\text { A7, Bimonthly report of } \\
\text { the Consultant). } \\
\text { Besides, the Contractor } \\
\text { has already submitted } \\
\text { Plan on restoration } \\
\text { works of unauthorized } \\
\text { disposal area } \\
\text { (mentioned in the letter } \\
\text { No.DHIC-13-SET-071) }\end{array}$ \\
\hline $\begin{array}{l}\text { GET3-DOOSAN-13-A6- } \\
630 \text { dated on } 5^{\text {th }} \\
\text { November, } 2013 \\
\text { GET3-DOOSAN-13-A6- } \\
645 \text { dated on } 19^{\text {th }} \\
\end{array}$ & $\begin{array}{l}\text { At Km167+000, Km174, } \\
\text { Km170, The Contractor's } \\
\text { carrying out construction } \\
\text { top ditch and step ditch } \\
\text { unsafe causing risk and } \\
\text { dangerous to people and }\end{array}$ & $\begin{array}{l}\text { The Contractor is } \\
\text { required to } \\
\text { immediately stop the } \\
\text { work of all construction } \\
\text { top ditch and step } \\
\text { ditch teams until safety }\end{array}$ & $\begin{array}{l}\text { The Contractor are } \\
\text { implementing measures } \\
\text { in order to solve this } \\
\text { problem as the } \\
\text { requirements from the }\end{array}$ \\
\hline
\end{tabular}

Hanoi office:

VinhPhuc office: $12^{\text {th }}$ floor, Ocean Park Building, Dao Duy Anh Street, Dong Da Distric

Huu Thu Hamlet, Kim Long Ward, Tam Duong Distric, VinhPhuc Province

Calle Ramón de Aguinaga 8, 28028 Madrid, Spain 


\section{Loan 2391/2392 - VIE: GMS Kunming - Hai Phong Transport Corridor Noi Bai - Lao Cai Highway Project}

\begin{tabular}{|c|c|c|c|}
\hline $\begin{array}{l}\text { DATEI LETTER } \\
\text { REFERENCE }\end{array}$ & ISSUE & PENALTY IMPOSED & EXECUTION (YIN) \\
\hline $\begin{array}{l}\text { November, } 2013 \\
\text { GET3-DOOSAN-13-A6- } \\
652 \text { dated on } 22^{\text {nd }} \\
\text { November, } 2013\end{array}$ & vehicles passing. & $\begin{array}{l}\text { condition of working } \\
\text { improvement. If the } \\
\text { situation is not } \\
\text { improved, items d; e; f; } \\
\text { g; } \mathrm{h} \text { in section } 2.1 \\
\text { General requirements; } \\
\text { item b-14 in Sub } \\
\text { section } 2.2 \\
\text { Contractor's Safety } \\
\text { Plan; items a; j; } \mathrm{k} \text { I in } \\
\text { section } 2.4 \text { : Special } \\
\text { Requirements for } \\
\text { Safety will be } \\
\text { immediately applied in } \\
\text { order to ensure the } \\
\text { Project's safety issues. }\end{array}$ & $\begin{array}{l}\text { Consultant. } \\
\text { - Arrange signal } \\
\text { man and safety } \\
\text { board on working } \\
\text { area; } \\
\text { - Install warning } \\
\text { tape to stop people } \\
\text { and vehicles } \\
\text { passing during } \\
\text { construction; } \\
\text { - All workers have to } \\
\text { use full PPE during } \\
\text { working; }\end{array}$ \\
\hline $\begin{array}{l}\text { GET3-DOOSAN-14-A6- } \\
\text { O39 dated on } 28^{\text {th }} \\
\text { February, } 2014\end{array}$ & $\begin{array}{l}\text { After checking and } \\
\text { reviewing Official } \\
\text { certificate for } \\
\text { environmental monitoring } \\
\text { activities, which were } \\
\text { submitted by the } \\
\text { Contractor, the Engineer } \\
\text { detected that these } \\
\text { Official certificates still } \\
\text { have not been met fully } \\
\text { the requirements of the } \\
\text { Project (mentioned in the } \\
\text { Engineer's letter No. } \\
\text { GET-MISC-390 dated on } \\
10^{\text {th }} \text { January, 2014). }\end{array}$ & $\begin{array}{l}\text { The Engineer strongly } \\
\text { requires the Contractor } \\
\text { to submit official } \\
\text { license of companies } \\
\text { which proved that they } \\
\text { have full } \\
\text { responsibilities under } \\
\text { law to supply services } \\
\text { for environment } \\
\text { monitoring activities. If } \\
\text { Engineer do not } \\
\text { receive fully official } \\
\text { license that proved } \\
\text { they have fully } \\
\text { responsibilities under } \\
\text { law, the Engineer will } \\
\text { proposes to stop } \\
\text { Contract for supplying } \\
\text { services for } \\
\text { environment } \\
\text { monitoring activities } \\
\text { and considers other } \\
\text { company to continues } \\
\text { these services. }\end{array}$ & $\begin{array}{l}\text { The Contractor has } \\
\text { already submitted } \\
\text { fully Official } \\
\text { certificate for } \\
\text { environmental } \\
\text { monitoring activities. }\end{array}$ \\
\hline
\end{tabular}

\section{PACKAGE A7}

\begin{tabular}{|l|l|l|l|}
\hline $\begin{array}{l}\text { DATEI LETTER } \\
\text { REFERENCE }\end{array}$ & ISSUE & PENALTY IMPOSED & EXECUTION (YIN) \\
\hline $\begin{array}{l}16 / 10 / 2013-\text { Ref. GET- } \\
\text { GUA-132 }\end{array}$ & $\begin{array}{l}\text { Notice to correct- } \\
\text { Package A7 }\end{array}$ & $\begin{array}{l}\text { Proposed to keep } \\
1.254 \text { billion if the } \\
\text { contractor not meet } \\
\text { deadline }\end{array}$ & $\begin{array}{l}\text { The contractor not yet } \\
\text { improve }\end{array}$ \\
\hline
\end{tabular}

Hanoi office:

VinhPhuc office:

Madrid head office: $12^{\text {th }}$ floor, Ocean Park Building, Dao Duy Anh Street, Dong Da Distric

Huu Thu Hamlet, Kim Long Ward, Tam Duong Distric, VinhPhuc Province

Calle Ramón de Aguinaga 8, 28028 Madrid, Spain 
 \\ Loan 2391/2392 - VIE: GMS Kunming - Hai Phong Transport Corridor Noi Bai - Lao Cai Highway Project}

\begin{tabular}{|c|c|c|c|}
\hline $\begin{array}{l}\text { DATE/ LETTER } \\
\text { REFERENCE }\end{array}$ & ISSUE & PENALTY IMPOSED & EXECUTION (Y/N) \\
\hline $\begin{array}{l}\text { 19/10/2013 - Ref. GET- } \\
\text { EPMU-2984 }\end{array}$ & $\begin{array}{l}\text { Action takens in IPC28 of } \\
\text { GRBCC due to } \\
\text { Environment non- } \\
\text { compliance }\end{array}$ & $\begin{array}{l}\text { Proposed to 1) has } \\
\text { not certified any } \\
\text { payment for Item } \\
\text { 03100-4 unsuitable } \\
\text { material due to use of } \\
\text { unauthorized disposal } \\
\text { areas } \\
\text { 2) not accepted any } \\
\text { payment for Item } \\
\text { 01100-1 Mobilization } \\
\text { and Demobilization } \\
\text { due to the lack of } \\
\text { Environmental and } \\
\text { Safety specialist } \\
\text { 3) Has been applied } \\
\text { retention } 1.254 \text { bilion } \\
\text { due to the lack of } \\
\text { activityregarding the } \\
\text { unauthorized disposal } \\
\text { area at Km195+500 }\end{array}$ & $\begin{array}{l}\text { The contractor not yet } \\
\text { improve }\end{array}$ \\
\hline $\begin{array}{l}\text { 30/10/2013 - Ref. } \\
\text { GET4-Coreteam- } 225\end{array}$ & $\begin{array}{l}\text { Environment monitoring } \\
\text { quarter III, 2013- Package } \\
\text { A7 }\end{array}$ & $\begin{array}{l}\text { Proposed to core team } \\
\text { to Apply the subitems } \\
\text { e, section } 2.2 \text {, items of } \\
01700 \text { - Protect and } \\
\text { control environment } \\
\text { section } 1 \text { - General } \\
\text { requirements, Volume } \\
3 \text { - General standards } \\
\text { of Contract }\end{array}$ & $\begin{array}{l}\text { The contractor not yet } \\
\text { improve }\end{array}$ \\
\hline $\begin{array}{l}\text { 22/11/2013 - Ref. } \\
\text { GET4-GRBCC-1023 }\end{array}$ & $\begin{array}{l}\text { Require to overcome } \\
\text { Environmental and Safety } \\
\text { problems of Package A7 }\end{array}$ & $\begin{array}{l}\text { Proposed to keep } \\
\text { payment at next IPC if } \\
\text { the contractor not } \\
\text { meet deadline }\end{array}$ & $\begin{array}{l}\text { The contractor not yet } \\
\text { improve }\end{array}$ \\
\hline $\begin{array}{l}\text { 27/11/2013 - Ref. } \\
\text { GET4-GRBCC-1026 }\end{array}$ & $\begin{array}{l}\text { Require to stop dumping } \\
\text { unsuitable material at } \\
\text { Km209+450; Km210+000; } \\
\text { Km210+500 and } \\
\text { Km211+450 }\end{array}$ & $\begin{array}{l}\text { Proposed to has not } \\
\text { certified any payment } \\
\text { for Item } 03100-4 \\
\text { unsuitable material } \\
\text { due to use of } \\
\text { unauthorized disposal } \\
\text { areas }\end{array}$ & $\begin{array}{l}\text { The contractor not yet } \\
\text { improve }\end{array}$ \\
\hline $\begin{array}{l}\text { 18/12/2013 - Ref. } \\
\text { GET4-GRBCC-1045 }\end{array}$ & $\begin{array}{l}\text { Require to clearance the } \\
\text { current flow and cleaning } \\
\text { up on site- Package } A 7\end{array}$ & $\begin{array}{l}\text { Proposed to keep } \\
\text { payment at next IPC if } \\
\text { the contractor not } \\
\text { meet deadline }\end{array}$ & $\begin{array}{l}\text { The contractor not yet } \\
\text { improve }\end{array}$ \\
\hline $\begin{array}{l}\text { 06/01/2014 - Ref. } \\
\text { GET4-GRBCC-1058 }\end{array}$ & $\begin{array}{l}\text { Invitation meeting for } \\
\text { Environment manager } \\
\text { and safety manager of } \\
\text { Package A7 }\end{array}$ & $\begin{array}{l}\text { Propose to Client to } \\
\text { replace } 02 \text { these key } \\
\text { persons above if you } \\
\text { did not follow }\end{array}$ & $\begin{array}{l}\text { The contractor not yet } \\
\text { improve }\end{array}$ \\
\hline
\end{tabular}

Hanoi office:

VinhPhuc office:

Madrid head office: $12^{\text {th }}$ floor, Ocean Park Building, Dao Duy Anh Street, Dong Da Distric

Huu Thu Hamlet, Kim Long Ward, Tam Duong Distric, VinhPhuc Province

Calle Ramón de Aguinaga 8, 28028 Madrid, Spain 
 \\ Loan 2391/2392 - VIE: GMS Kunming - Hai Phong Transport Corridor Noi Bai - Lao Cai Highway Project}

\begin{tabular}{|c|c|c|c|}
\hline $\begin{array}{l}\text { DATEI LETTER } \\
\text { REFERENCE }\end{array}$ & ISSUE & PENALTY IMPOSED & EXECUTION (YIN) \\
\hline & & instruction of Engineer & \\
\hline $\begin{array}{l}\text { 11/02/2014 - Ref. } \\
\text { GET4-GRBCC-1074 }\end{array}$ & $\begin{array}{l}\text { Invitation meeting for } \\
\text { Environment manager } \\
\text { and safety manager of } \\
\text { Package A7- Second time }\end{array}$ & $\begin{array}{l}\text { Propose to Client to } \\
\text { replace } 02 \text { these key } \\
\text { persons above if you } \\
\text { did not follow } \\
\text { instruction of Engineer }\end{array}$ & $\begin{array}{l}\text { The contractor not yet } \\
\text { improve }\end{array}$ \\
\hline $\begin{array}{l}\text { 19/02/2014 - Ref. } \\
\text { GET4-Coreteam- } 284\end{array}$ & $\begin{array}{l}\text { Propose to replace the } \\
\text { Environment Manager } \\
\text { and Safety Manager - } \\
\text { Package A7 }\end{array}$ & $\begin{array}{l}\text { The subitems } \mathrm{d} \text {, } \\
\text { section } 2.4, \text { items of } \\
01700-\text { Protect and } \\
\text { control environment for } \\
\text { Environment manager } \\
\text { and the subitems e, } \\
\text { section } 2.3 \text {, items of } \\
01500-\text { Project safety } \\
\text { for Safety manager }\end{array}$ & $\begin{array}{l}\text { The contractor not yet } \\
\text { improve }\end{array}$ \\
\hline
\end{tabular}

\section{PACKAGE A8}

\begin{tabular}{|l|l|l|l|}
\hline $\begin{array}{l}\text { DATEI LETTER } \\
\text { REFERENCE }\end{array}$ & ISSUE & PENALTY IMPOSED & EXECUTION (Y/N) \\
\hline $\begin{array}{l}\text { 18/12/2013- Ref. } \\
\text { Get4- Vinocanex- } 912\end{array}$ & $\begin{array}{l}\text { Require to clearance } \\
\text { the current flow and } \\
\text { cleaning up on site- } \\
\text { Package A8 }\end{array}$ & $\begin{array}{l}\text { Proposed to keep } \\
\text { payment at next IPC if the } \\
\text { contractor not meet } \\
\text { deadline }\end{array}$ & $\begin{array}{l}\text { The contractor had } \\
\text { improved on time }\end{array}$ \\
\hline $\begin{array}{l}\text { 21/2/2014- Ref. GET- } \\
\text { MISC-395 }\end{array}$ & $\begin{array}{l}\text { Engineer will suspend the } \\
\text { procedure for progress } \\
\text { payments until the } \\
\text { contractor corrects the } \\
\text { defects and secures } \\
\text { normality in the } \\
\text { compliance with saild } \\
\text { requiments }\end{array}$ & $\begin{array}{l}\text { The contractor had } \\
\text { improved on time }\end{array}$ \\
\hline $\begin{array}{l}\text { 18/12/2013- Ref. } \\
\text { Get4- Vinocanex- } 969\end{array}$ & $\begin{array}{l}\text { Ensure safety and } \\
\text { clean on site after } \\
\text { technical open - } \\
\text { Package A8- second } \\
\text { time }\end{array}$ & $\begin{array}{l}\text { If contractor not meet } \\
\text { deadline, Engineer will } \\
\text { not sign IPC35 until the } \\
\text { contractor completed } \\
\text { according to the } \\
\text { Engineer's instructions. }\end{array}$ & $\begin{array}{l}\text { The contractor not yet } \\
\text { improve }\end{array}$ \\
\hline
\end{tabular}

Hanoi office:

VinhPhuc office: $12^{\text {th }}$ floor, Ocean Park Building, Dao Duy Anh Street, Dong Da Distric

Huu Thu Hamlet, Kim Long Ward, Tam Duong Distric, VinhPhuc Province

Calle Ramón de Aguinaga 8, 28028 Madrid, Spain 
Loan 2391/2392 - VIE: GMS Kunming - Hai Phong Transport Corridor Noi Bai - Lao Cai Highway Project

12. ANNEX 6: RESTORATION PLANS AT DISPOSALS 190+420, $195+500$, 208+890 AND 209+800. PACKAGE A7 
Loan 2391/2392 - VIE: GMS Kunming - Hai Phong Transport Corridor Noi Bai - Lao Cai Highway Project 
REPORT ON THE DISPOSAL KM 190+420. RESTORATION PLAN 


\section{CONTENTS}

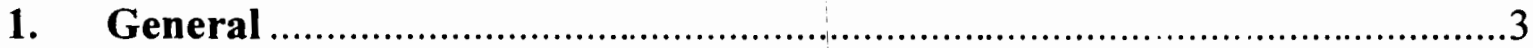

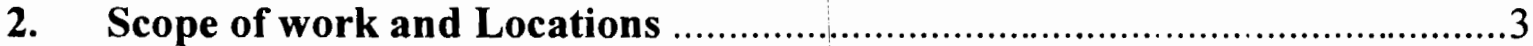

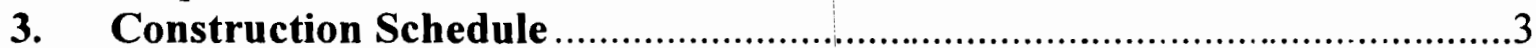

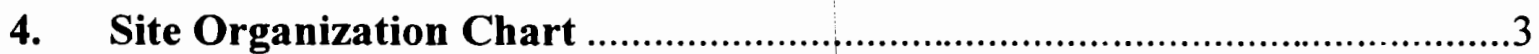

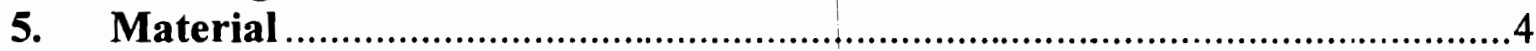

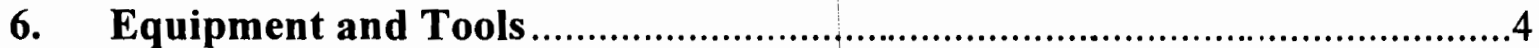

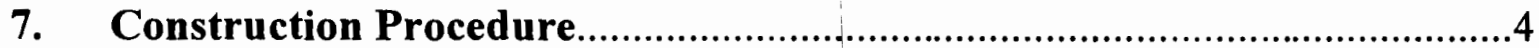

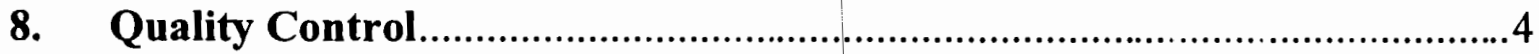

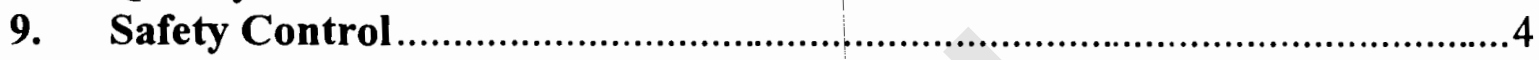

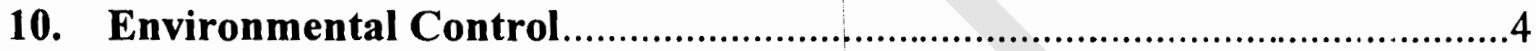




\section{General}

This Method Statement is to describe the work procedures for the construction of Grouted Riprap GR-2. This work item shall be done in accordance with Section 08950-0) of the General Specifications.

\section{Scope of work and Locations}

The scope of work and locations of Grouted Riprap GR-2 are as follows ( As shop drawing approved)

\section{Construction Schedule}

Construction work shall be indicated and updated in monthly and weekly progress.

\section{Site Organization Chart}

Organization Chart for management and construction of Grouted Riprap GR-2 is as follows:

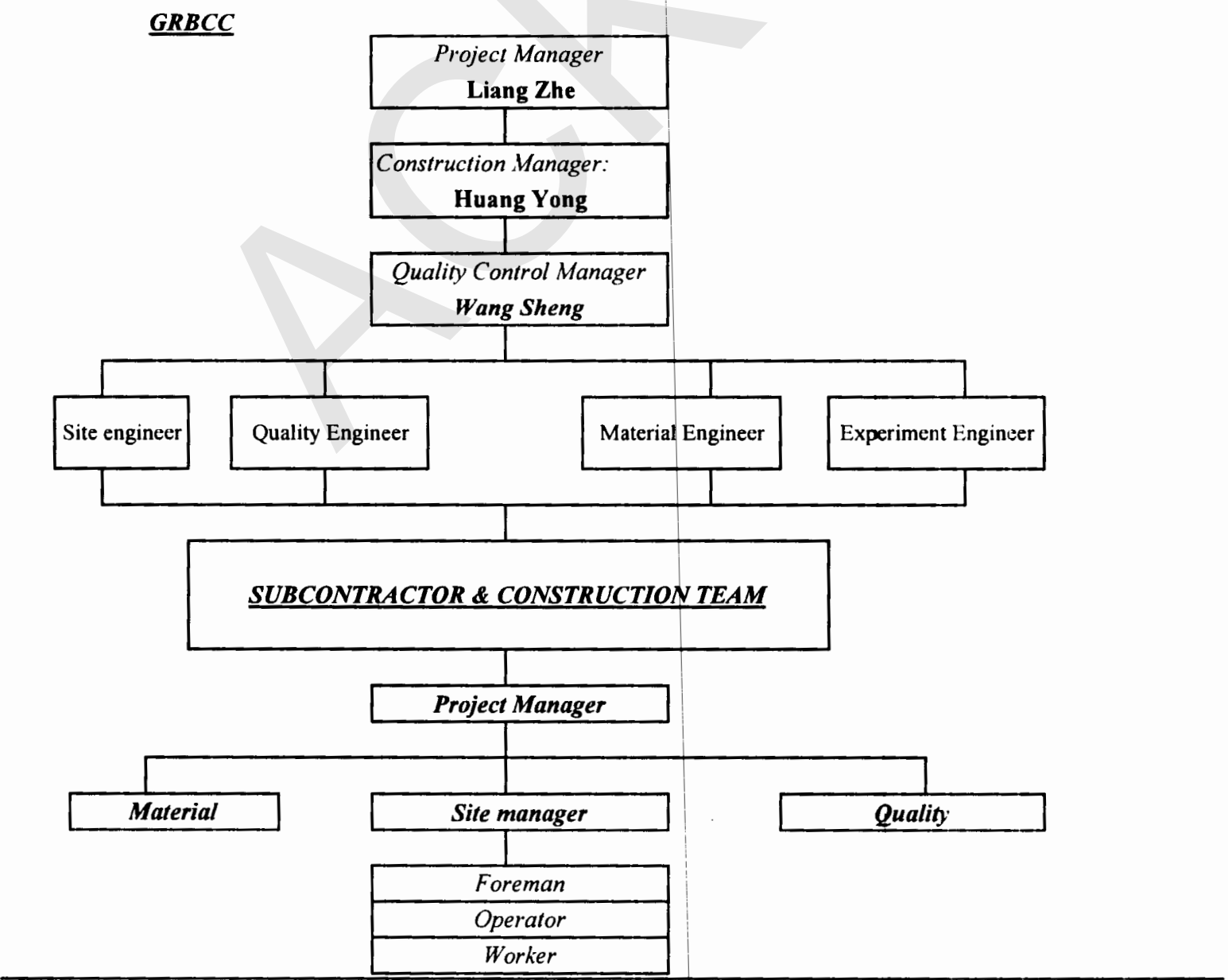




\section{Material}

List of required material for construction is approved by Supervision Consultant:

\section{Equipment and Tools}

List of required equipment and tools for construction is shown below:

\begin{tabular}{|c|l|l|l|}
\hline No. & Equipment/ Tool & \multicolumn{1}{|c|}{ Used for } & Remarks \\
\hline 1 & Excavators & Training cutoff & \\
\hline 2 & $\begin{array}{l}\text { Compacting } \\
\text { machine }\end{array}$ & Compaction and flattening surfaces & \\
\hline 3 & Compactors & Roll on in the construction process & \\
\hline
\end{tabular}

\section{Construction Procedure}

In principle cut areas will be grassed by seeding, and fill slopes will be grassed by sodding, unless there are other instructions from the Engineer.

\section{Seeding Grouted Riprap GR-2}

Surveying and Slope treatment

\section{$>\quad$ Seeding}

Stone shall be distributed and compacted so that the thickness of riprap is not less than that specified or shown on the Drawings. Stone shall be laid with close, broken joints and shall be firmly bedded into the slope and against the adjoining stones. The stones shall be laid perpendicular to the slope with ends in contact. Smaller stones shall be first laid on the slope and larger stones shall be used as surface cover. The riprap shall be thoroughly compacted as construction progresses and the finished surface shall present an even, tight surface. Interstices between stones shall be chinked with spalls firmly rammed into place. Unless otherwise provided, riprap shall be at least $60 \mathrm{~cm}$ in thickness, measured perpendicular to the slope. The surface of riprap shall not vary from the theoretical surface by more than $8 \mathrm{~cm}$ at any point. If the Engineer permits or instructs that stone is placed below the water line then the appropriate working method will be instructed at that time.

\section{Quality Control}

The seeding work and all operations on site shall be in accordance with the Specification requirement and instructions from the Employer and the Engineer.

Any area where Grouted Riprap GR-2 is not well-developed will be repaired the expense of the contractor. The Contractor will be responsible for areas until completion of the Period of Warranty.

\section{Safety Control}

Safety control shall conform to Approved "Project safety control plan" and that method shall be part of this Method Statement. Prior to start the construction work, the following particular matters are to be through to all members working in the construction site in order to complete seeding and construction efficiently without any accident or casualty.

\section{Environmental Control}

Environmental control shall conform to the submitted "Environment control and protection plan". That Method Statement and shall be part of this method statement. Responsibility for surrounding environment during construction work and shall comply with the Condition of 
Contract and Vietnam's National Law on Protection of Environment and other relevant legislation such as: Government Decree No.175/CP, Government Decree on providing Guidance for the Implementation of the Law on Environmental Protection, 1994.

If any other problems occurred in the site, applicable counter measures or prevention action shall be considered immediately and executed as soon as possible.

\section{APPENDIX 1}

\section{Construction Sequence for Grouted Riprap GR-2}

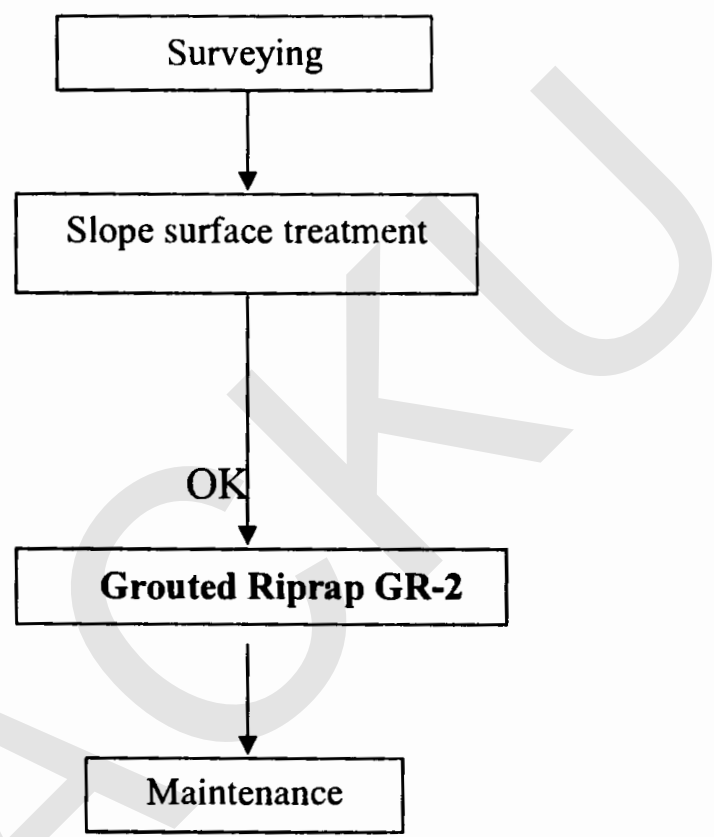

\section{APPENDIX 2}

\section{Typical Drawing}

(1 sheet attached) 


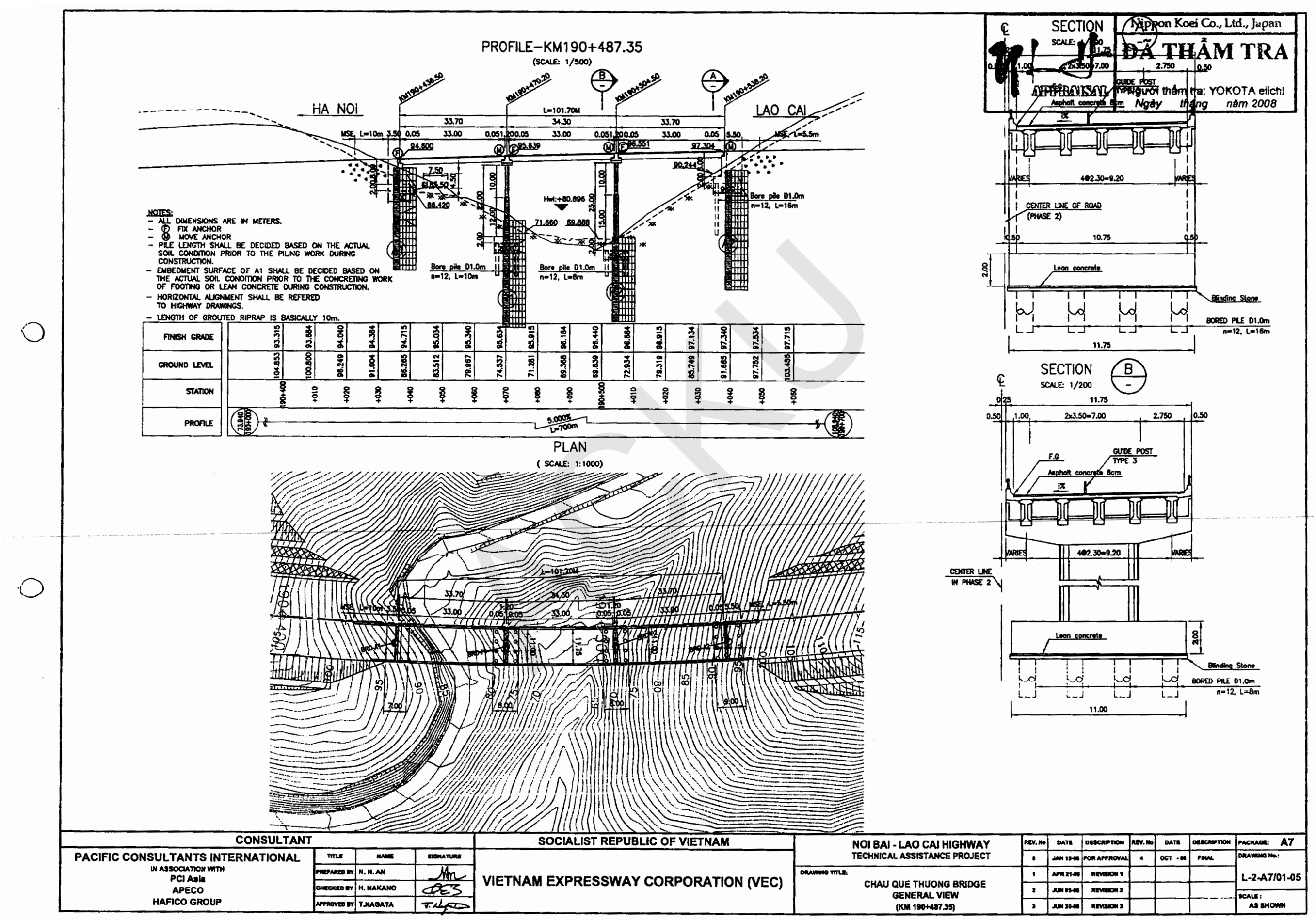




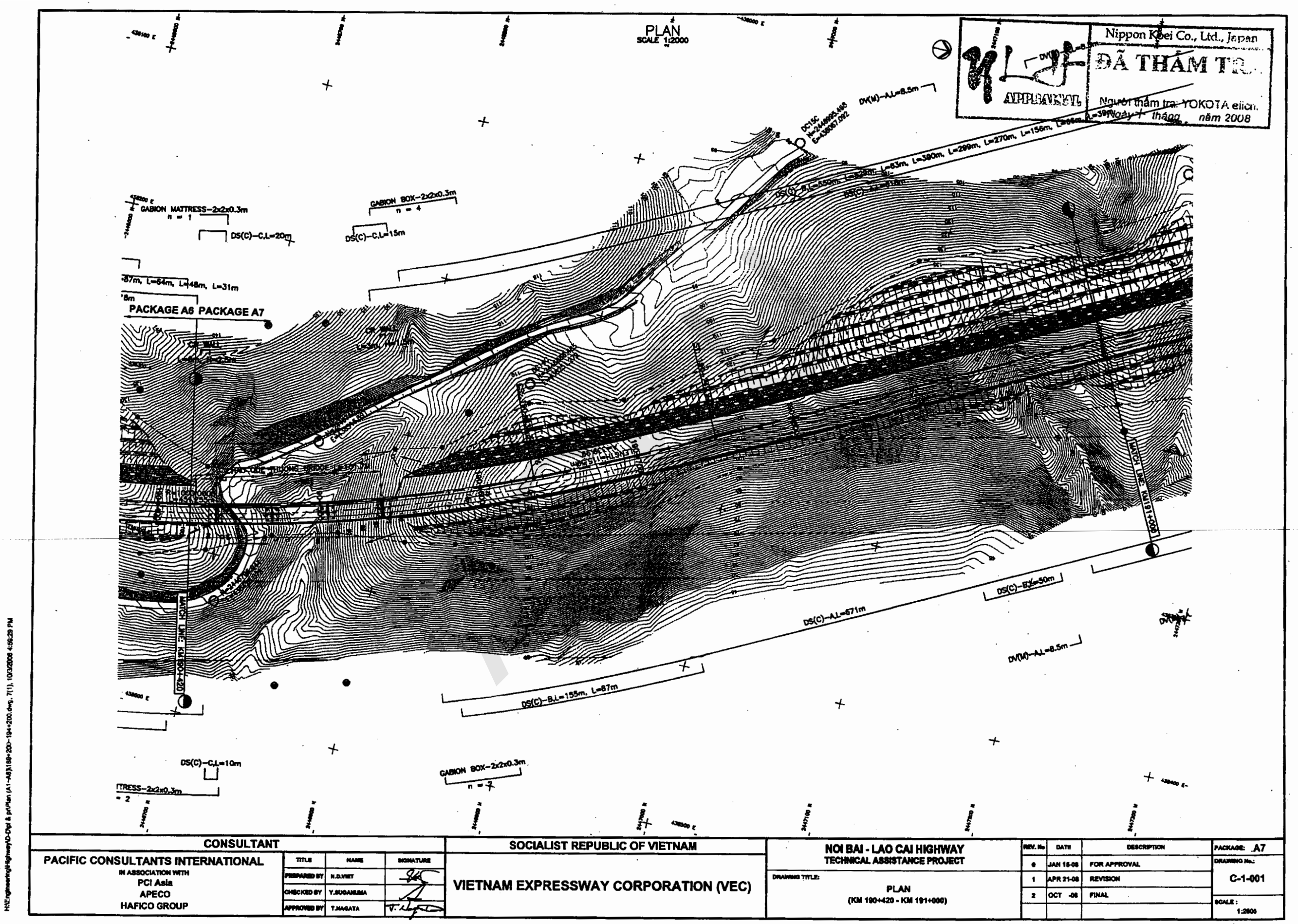




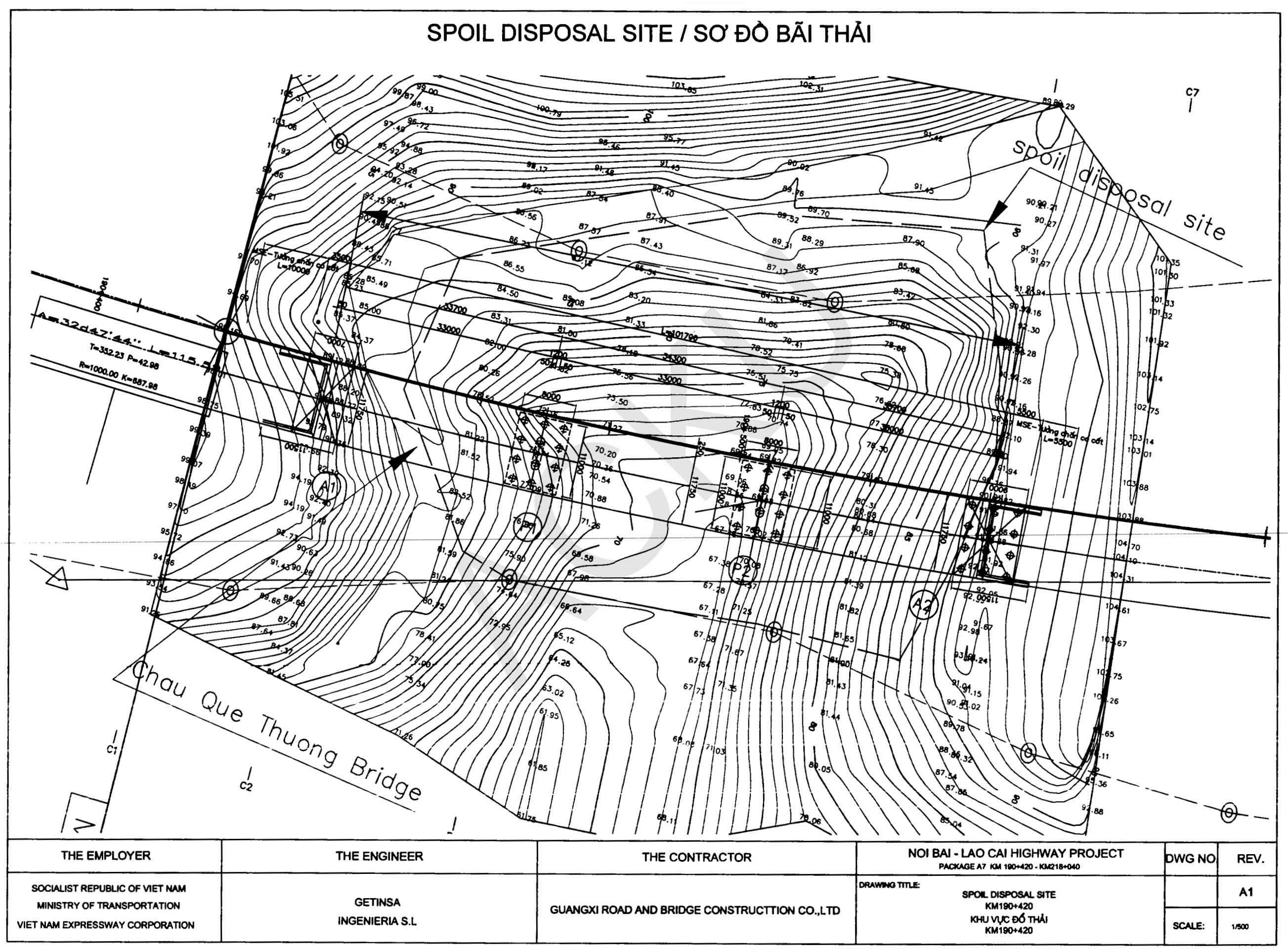


II. SLOPE PROTECTION PLAN AFTER CORRECTING KM190+420 IN MARCH 2014

\begin{tabular}{|c|c|c|c|c|c|c|}
\hline THE EMPLOYER & THE ENGINEER & THE CONTRACTOR & & $\begin{array}{l}\text { AO CAI HIGHWAY PROJECT } \\
\text { EN }\end{array}$ & DWG NO & REV. \\
\hline \multirow{2}{*}{$\begin{array}{l}\text { SOCUNIST REPUBUC OF VET NUM } \\
\text { MNISTRY OF TRUNSPORTATION } \\
\text { VEET MUN EXPRESSWAY CORPORATION }\end{array}$} & \multirow{2}{*}{$\begin{array}{c}\text { GETINSA } \\
\text { INGENIERIA S.L }\end{array}$} & \multirow{2}{*}{ GUANGXI ROAD AND BRIDGE CONSTRUCTTION CO.,LTD } & DRuWWOS TIRE: & \multirow{2}{*}{ 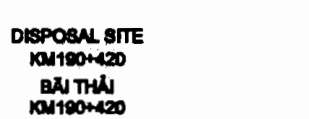 } & & A1 \\
\hline & & & & & SCNE: & \\
\hline
\end{tabular}




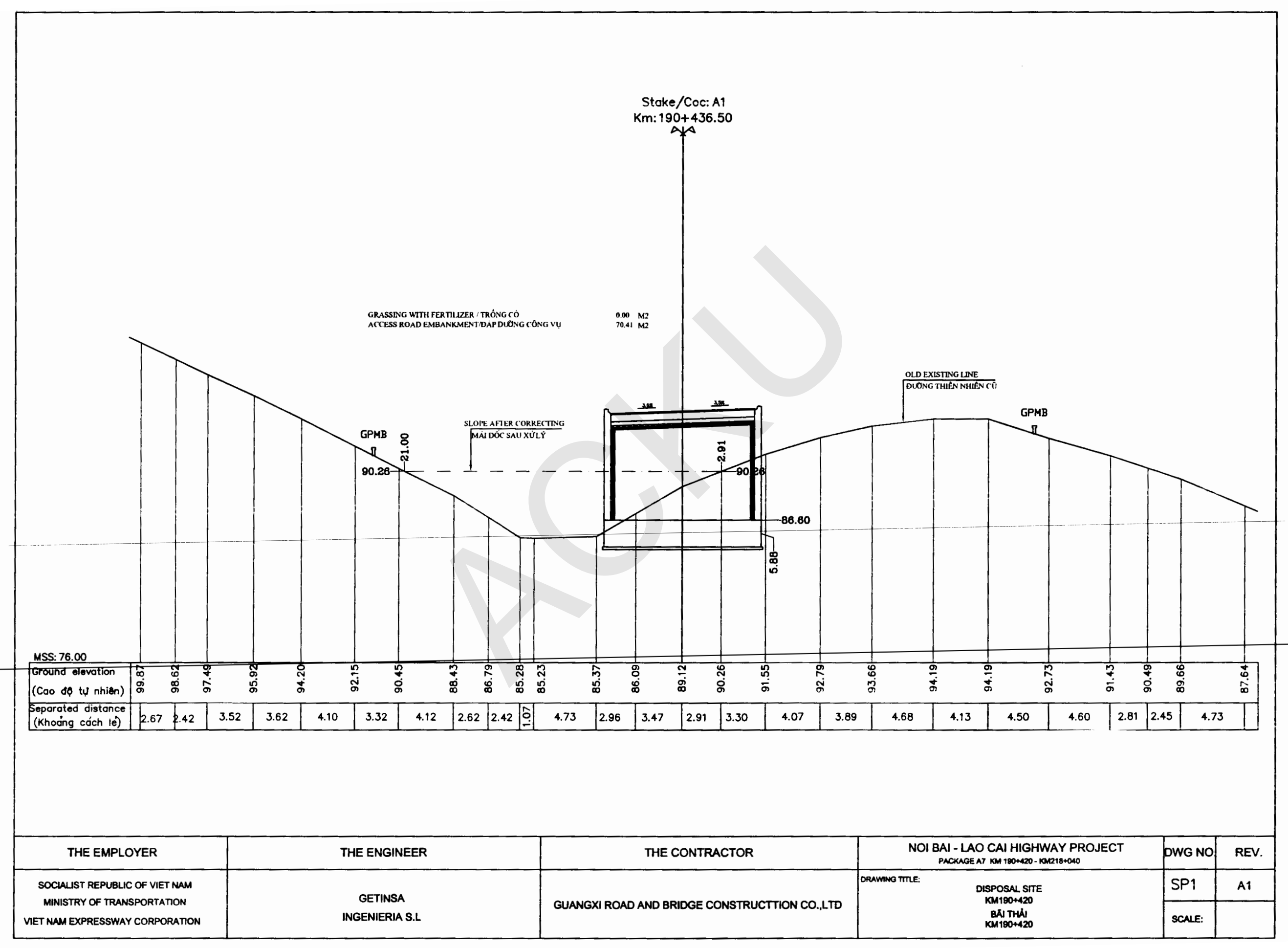




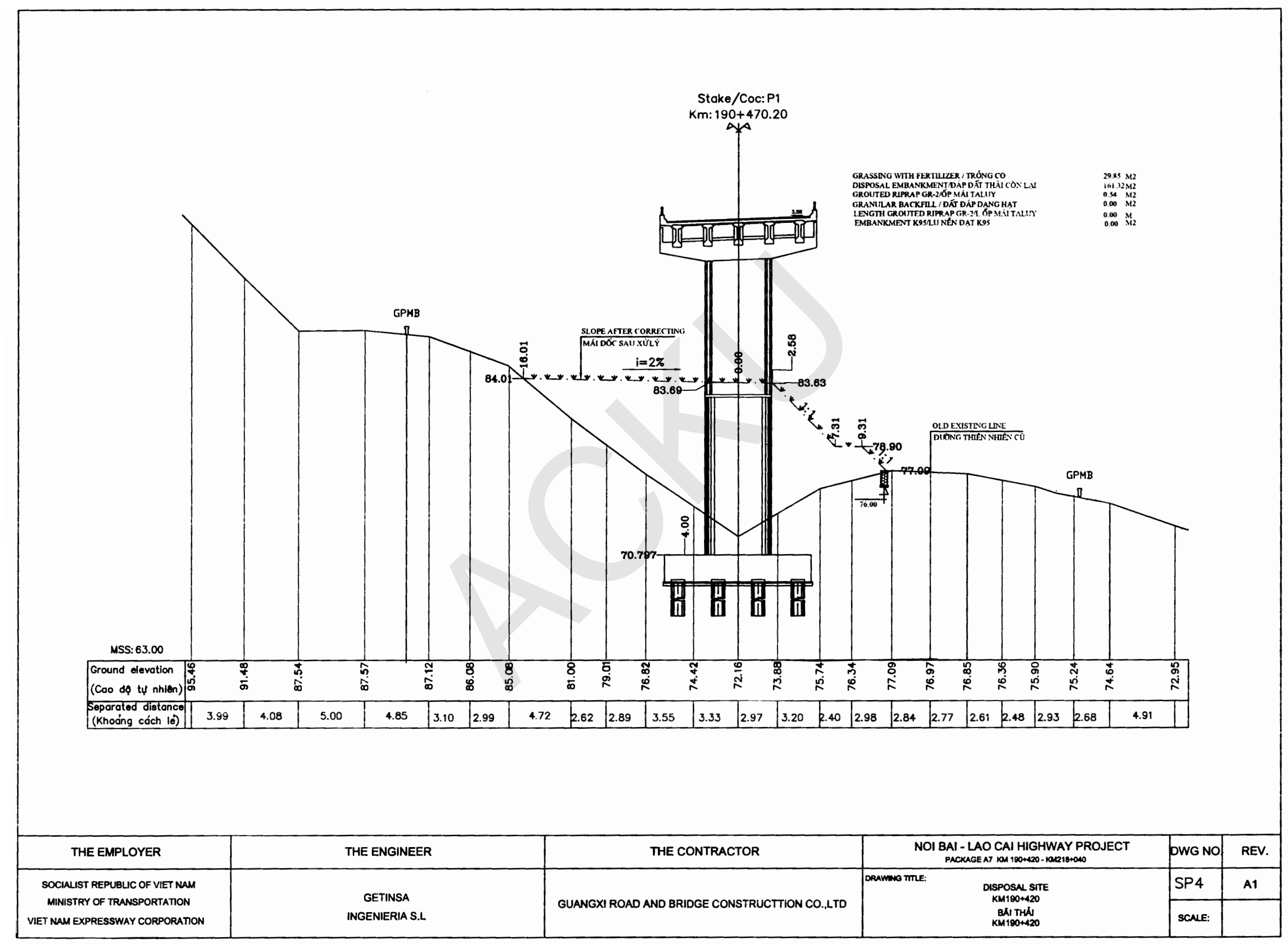




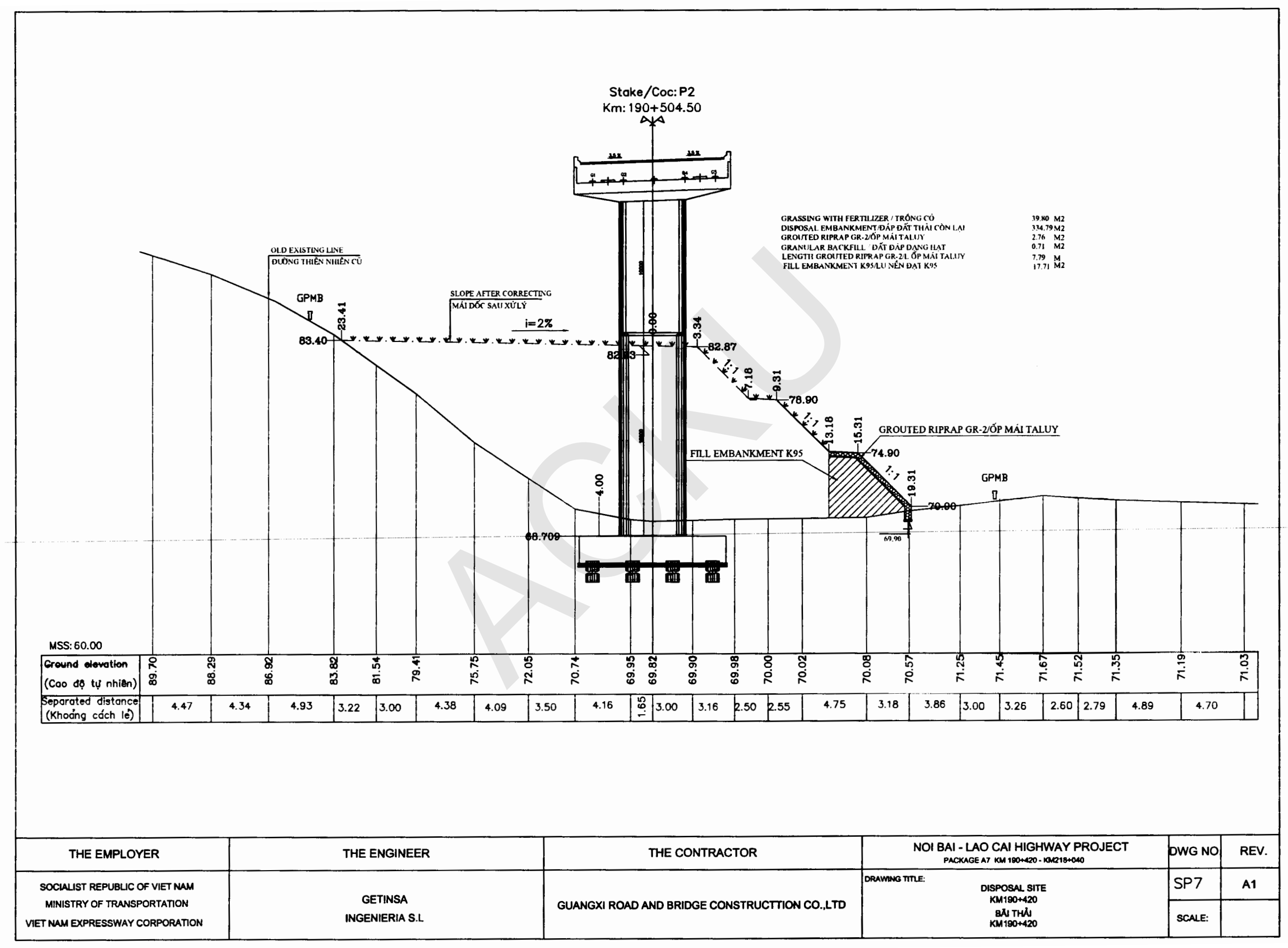



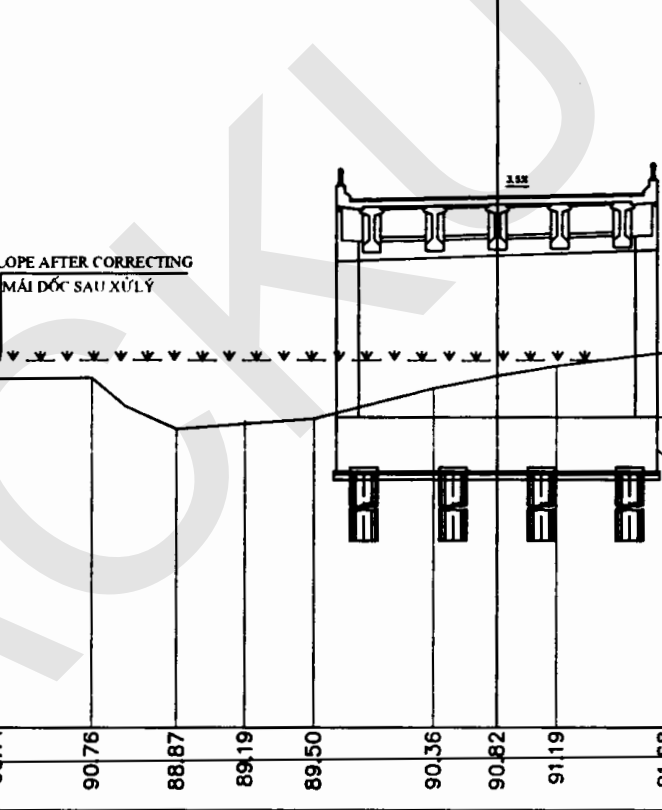

OLD EXISTNG LINE

SLOPE AFTER CORRECTNNO

\section{f)}

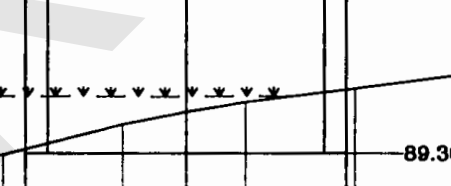

III Ii I i $-89.304$

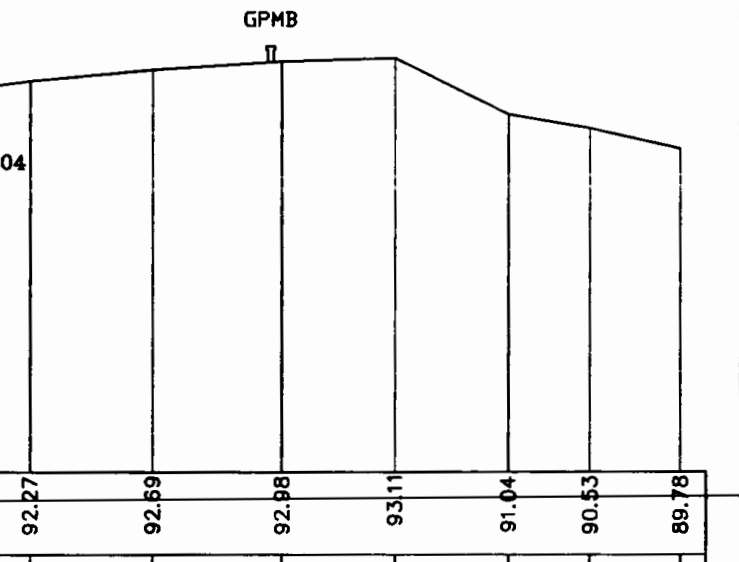

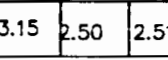

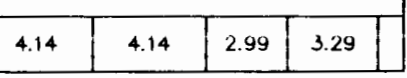

\begin{tabular}{|c|c|c|c|c|c|c|}
\hline THE EMPLOYER & THE ENGINEER & THE CONTRACTOR & & 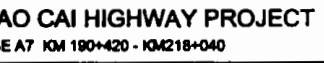 & DWG NO & REV. \\
\hline \multirow{2}{*}{$\begin{array}{l}\text { SOCIALIST REPUBLIC OF VIET NAM } \\
\text { MINISTRY OF TRANSPORTATION } \\
\text { VIET NAM EXPRESSWAY CORPORATION }\end{array}$} & \multirow{2}{*}{$\begin{array}{c}\text { GETINSA } \\
\text { INGENIERIA S.L }\end{array}$} & \multirow{2}{*}{ GUANGXI ROAD AND BRIDGE CONSTRUCTTION CO.,LTD } & \multirow{2}{*}{ 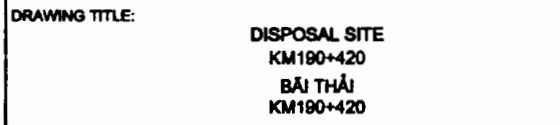 } & \multirow{2}{*}{$\begin{array}{l}\text { DISPOSAL SITE } \\
\text { KM180+420 } \\
\text { BA ITHA } \\
\text { KM180+420 }\end{array}$} & SP9 & A1 \\
\hline & & & & & SCALE: & \\
\hline
\end{tabular}




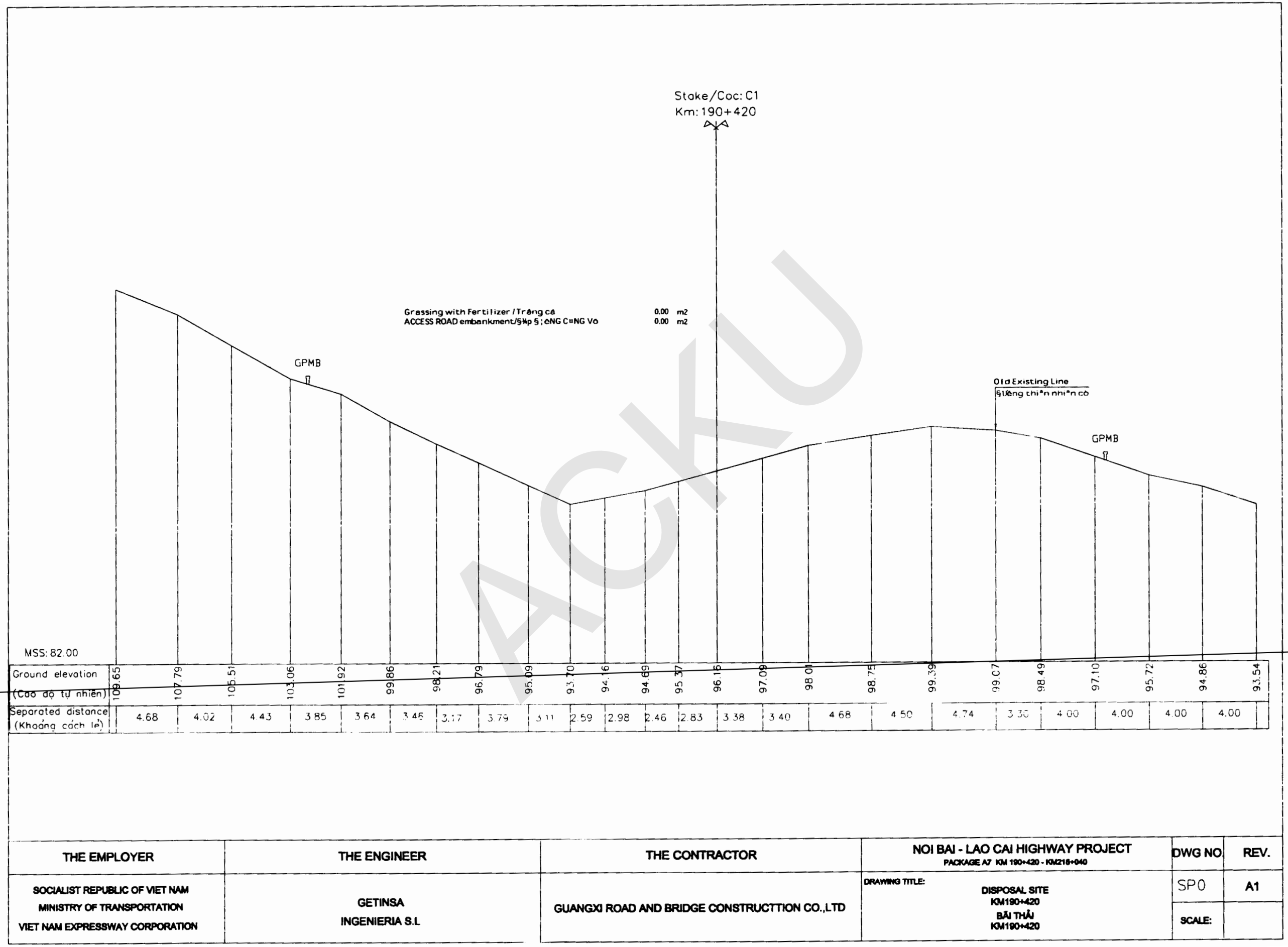




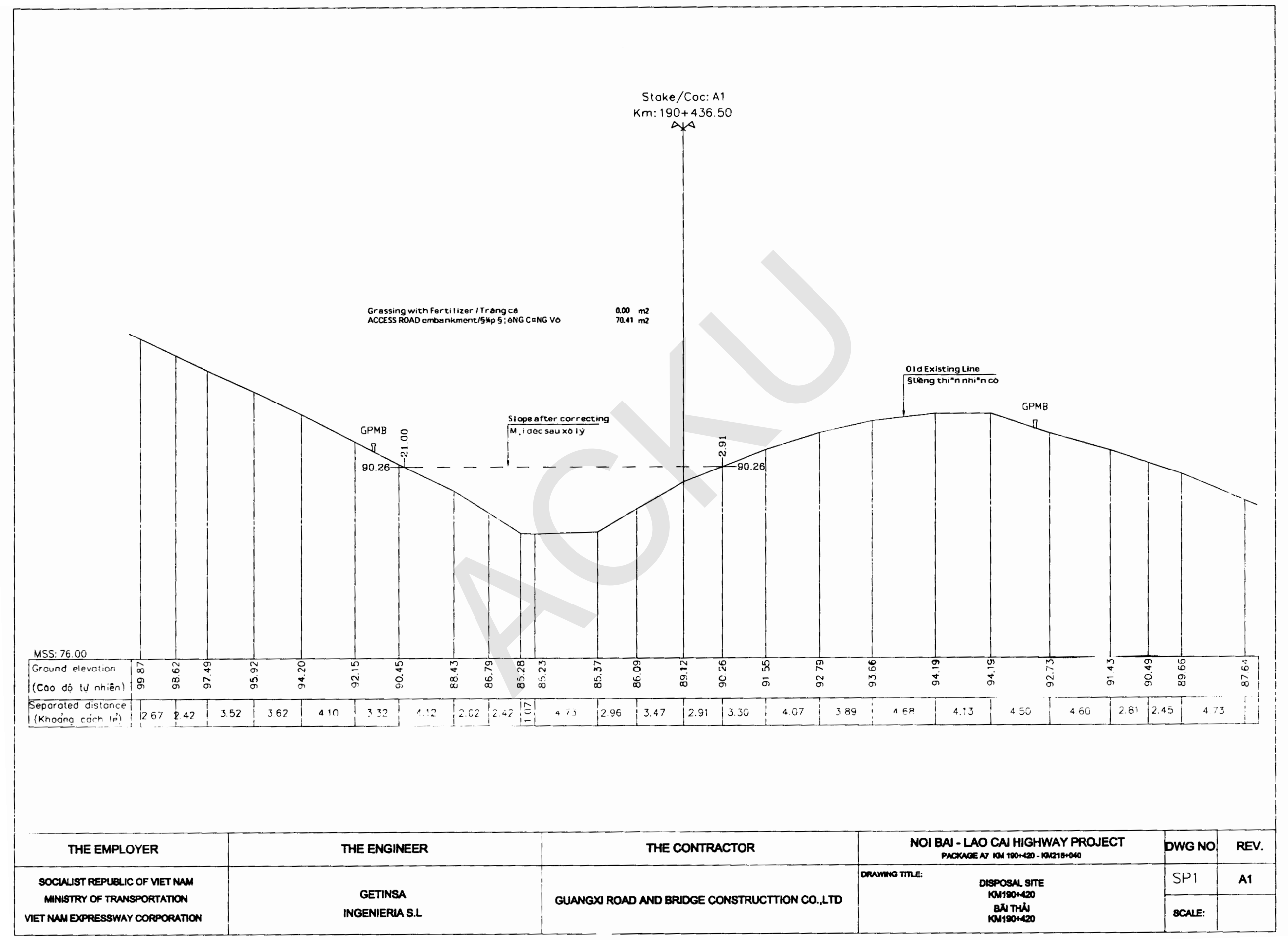




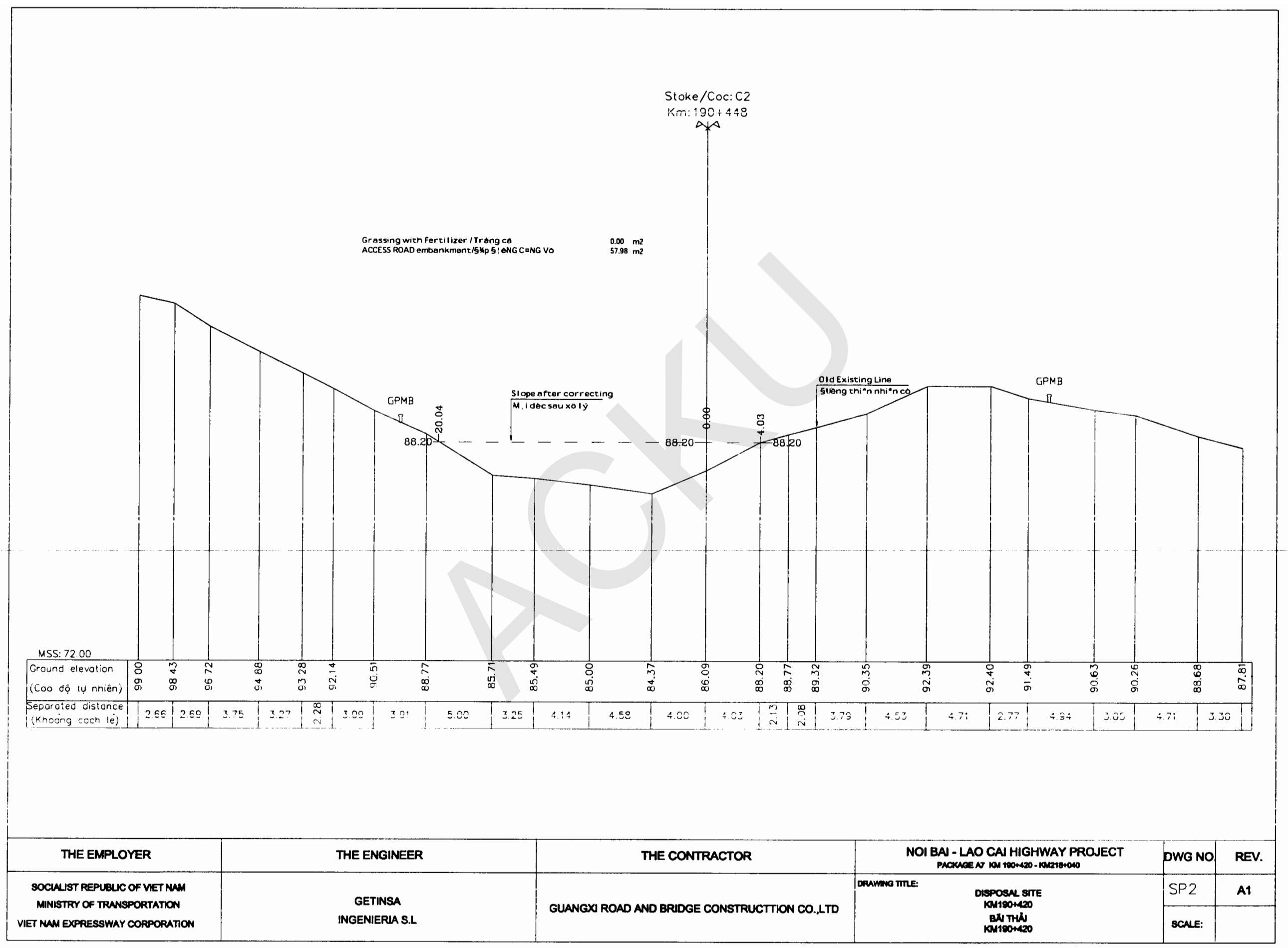




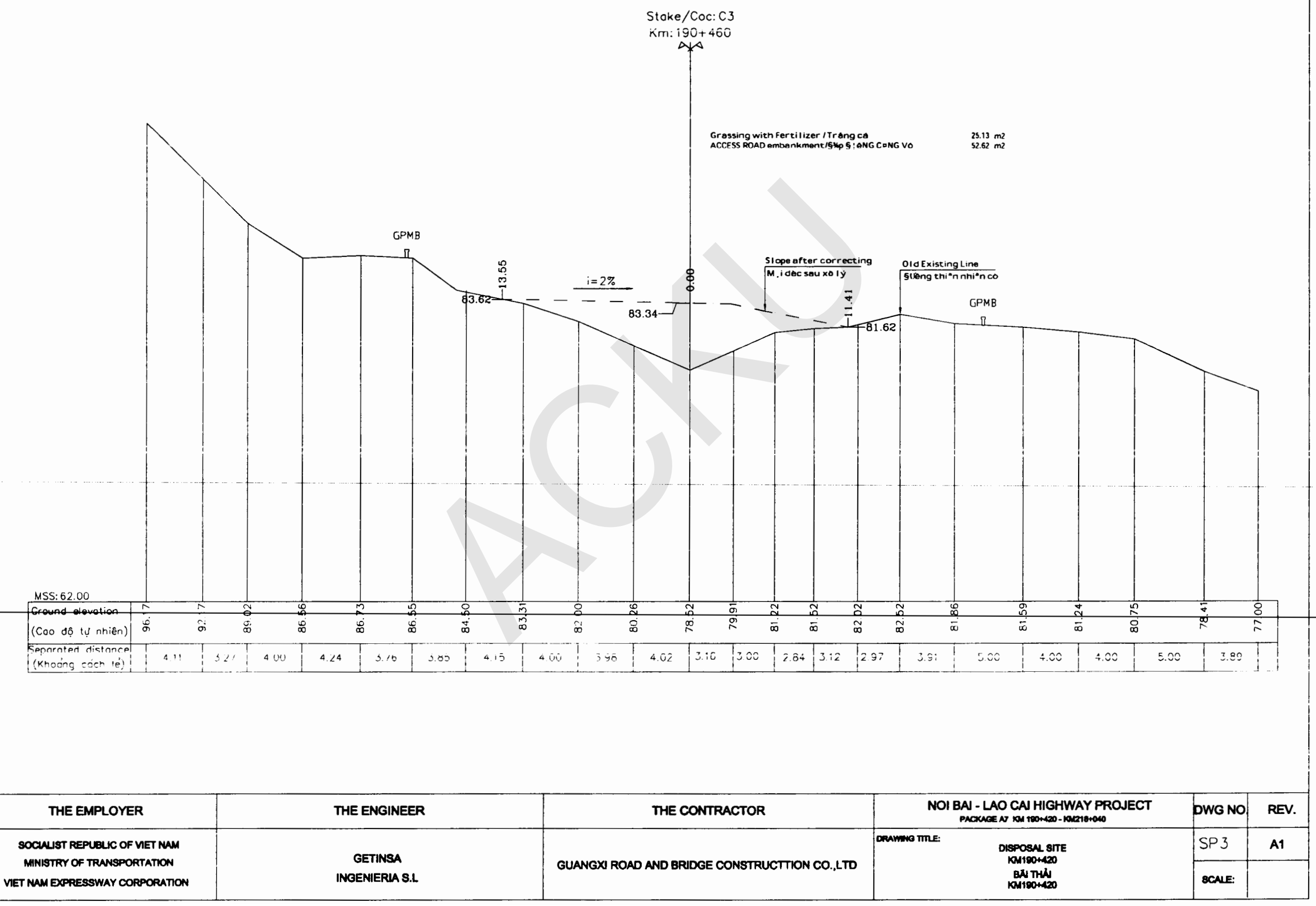




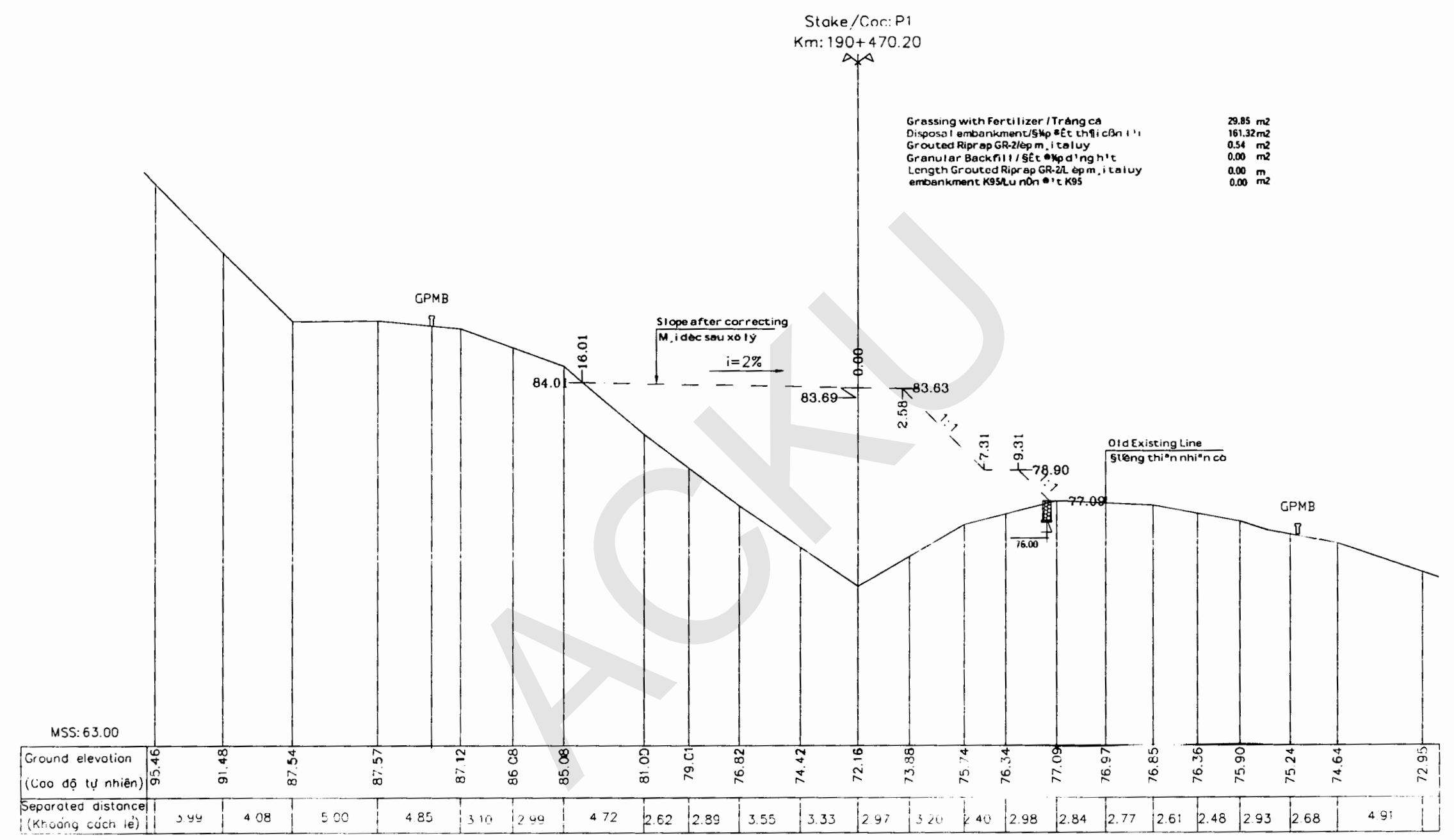

\begin{tabular}{|c|c|c|c|c|c|c|}
\hline THE EMPLOYER & THE ENGINEER & THE CONTRACTOR & & $\begin{array}{l}\text { 10 CA HIGHWAY PROSECT } \\
\text { EN ROM }\end{array}$ & DWG NO & REV. \\
\hline \multirow{2}{*}{$\begin{array}{l}\text { SOCLNIST REPLELIC OF VET NAM } \\
\text { MINISTRY OF TRANSPORTATION } \\
\text { VETT NAM EXPRESSWAY CORPORATION }\end{array}$} & \multirow[b]{2}{*}{$\begin{array}{c}\text { GETINSA } \\
\text { INGENIERA S.L }\end{array}$} & \multirow[b]{2}{*}{ GUANGX ROAD AND BRIDGE CONSTRUCTTION CO.,LTD } & Donumwo The: & \multirow{2}{*}{$\begin{array}{l}\text { DISPOSAL STE } \\
\text { KW180+420 } \\
\text { BN THAN } \\
\text { KN1100+120 }\end{array}$} & SP 4 & A1 \\
\hline & & & & & BCNE: & \\
\hline
\end{tabular}




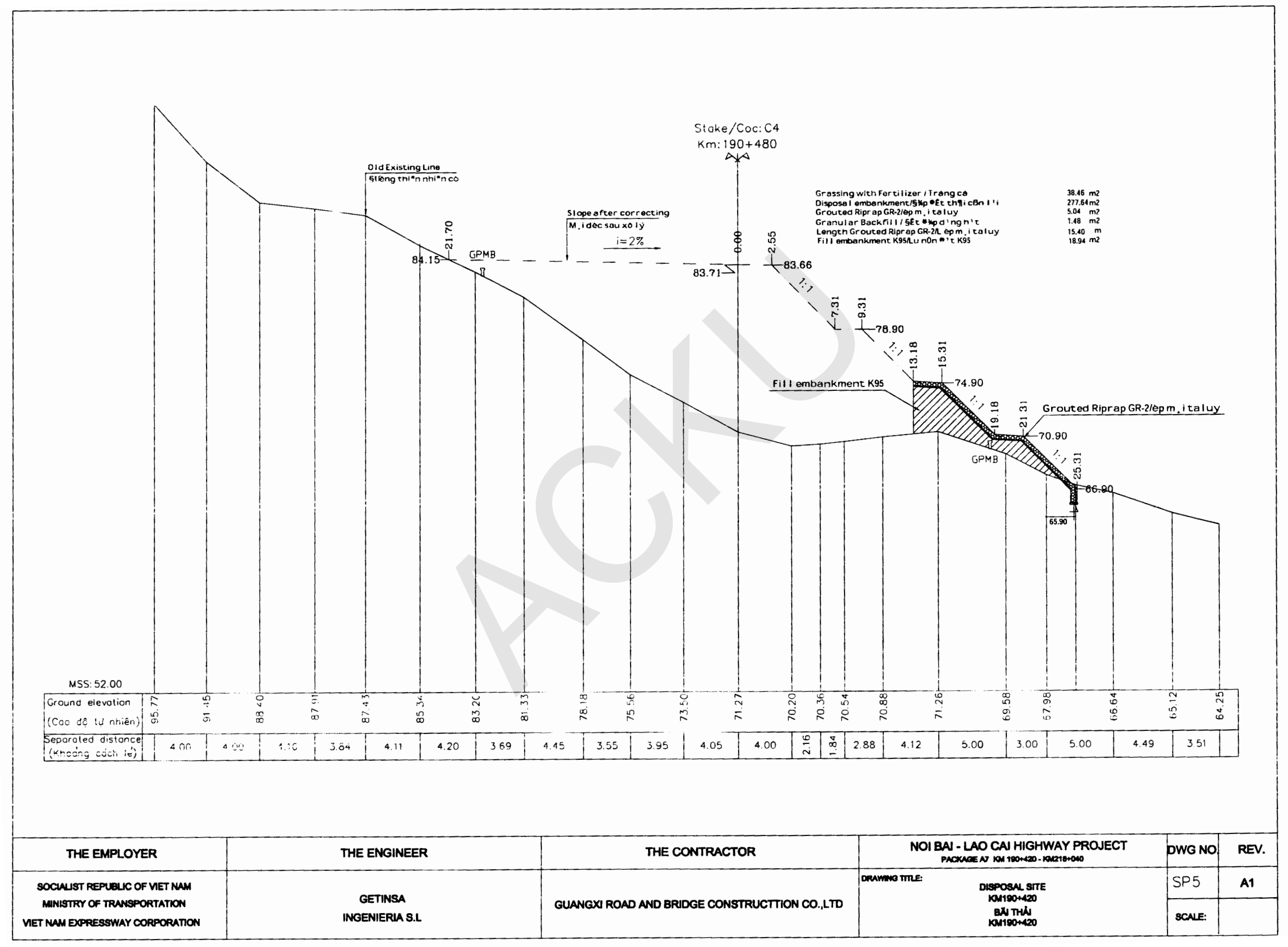




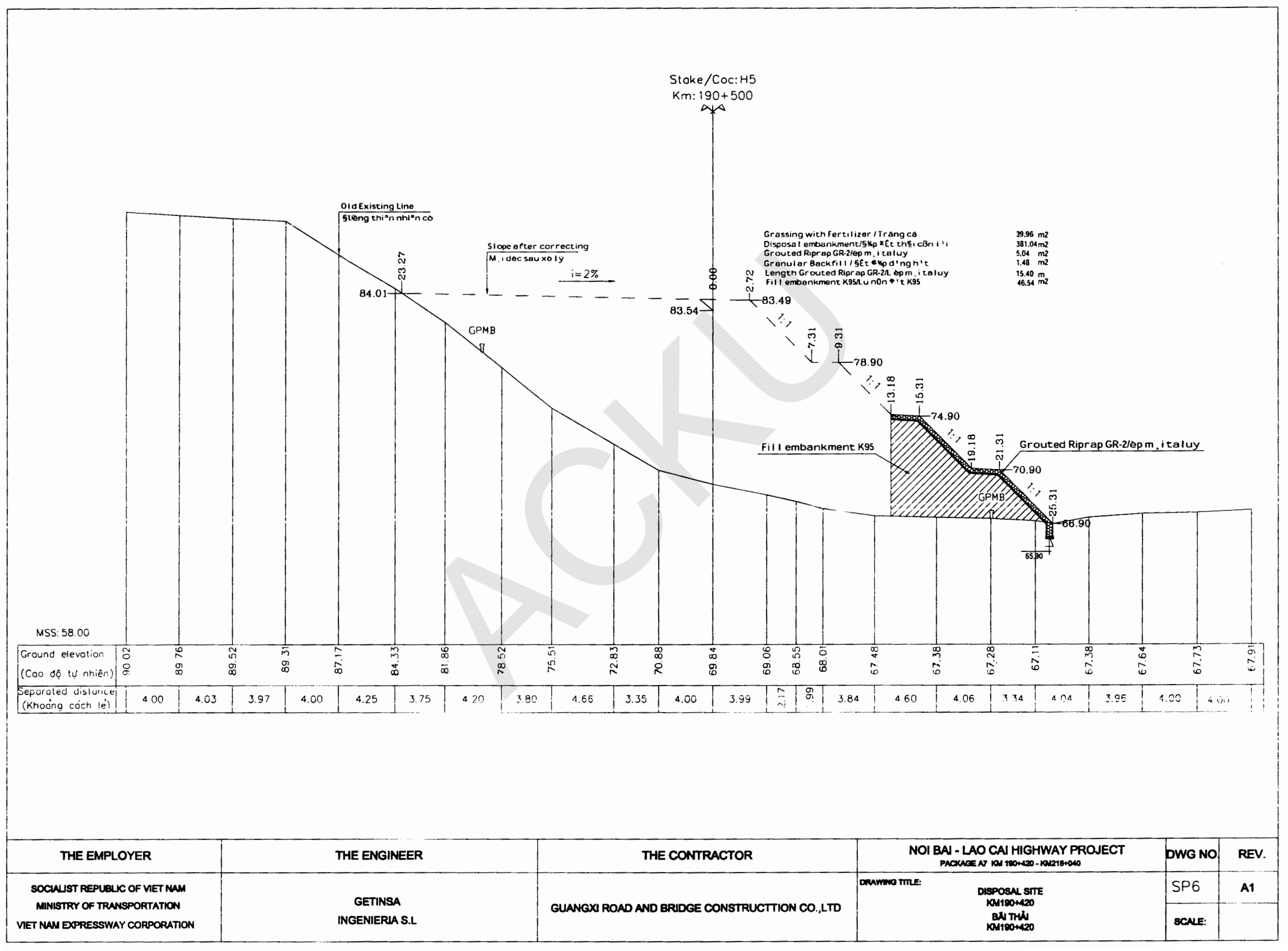




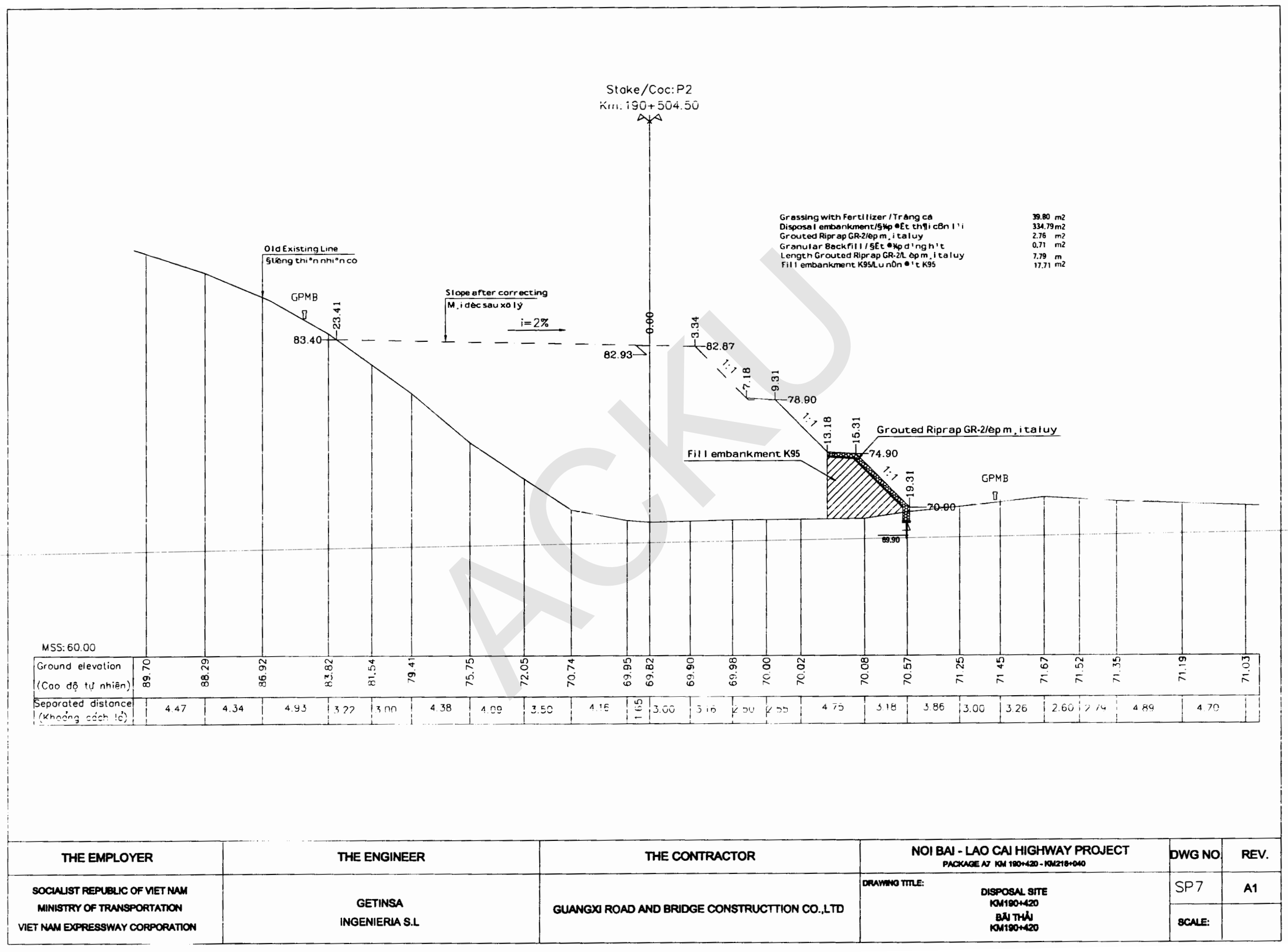




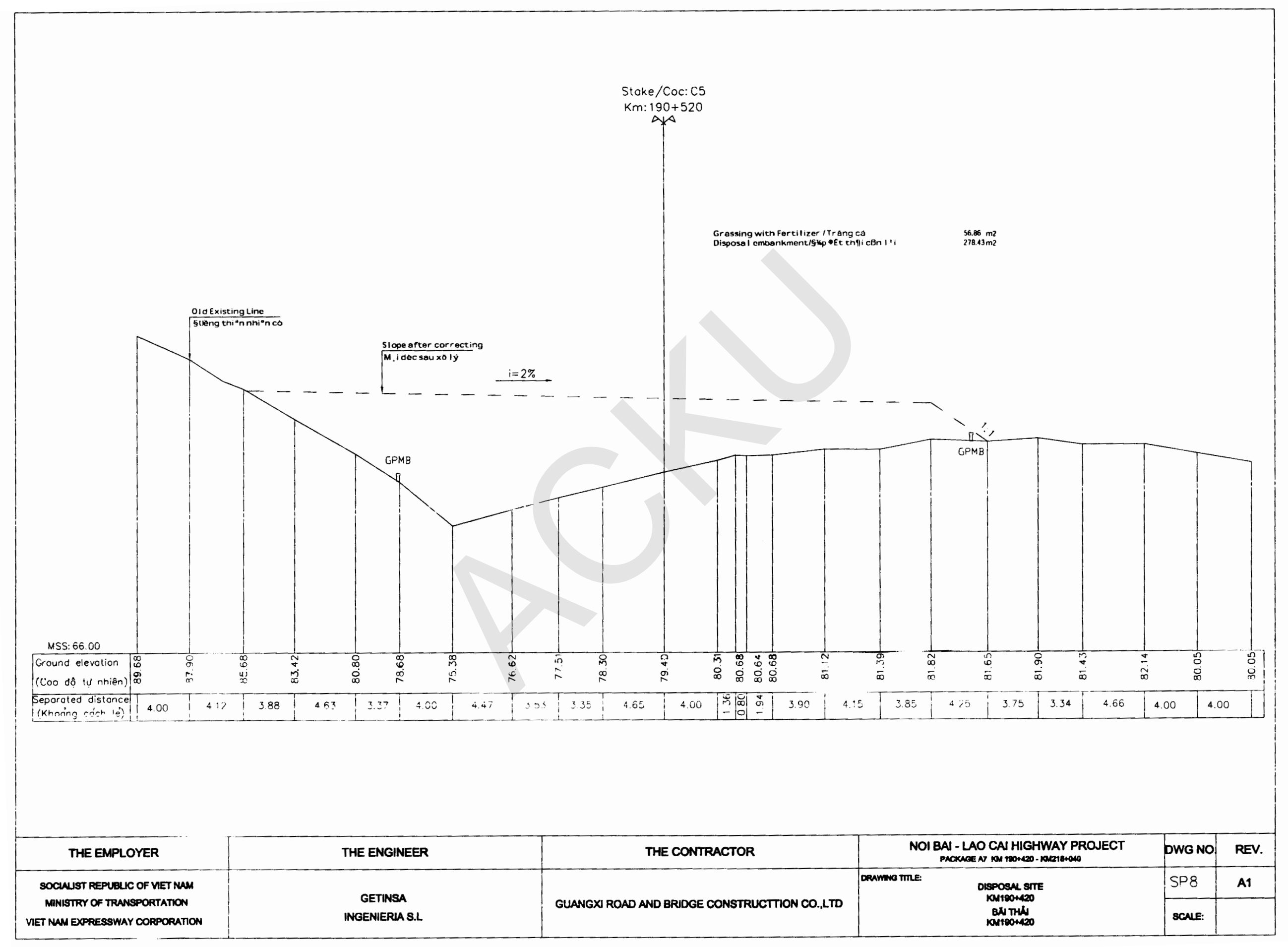




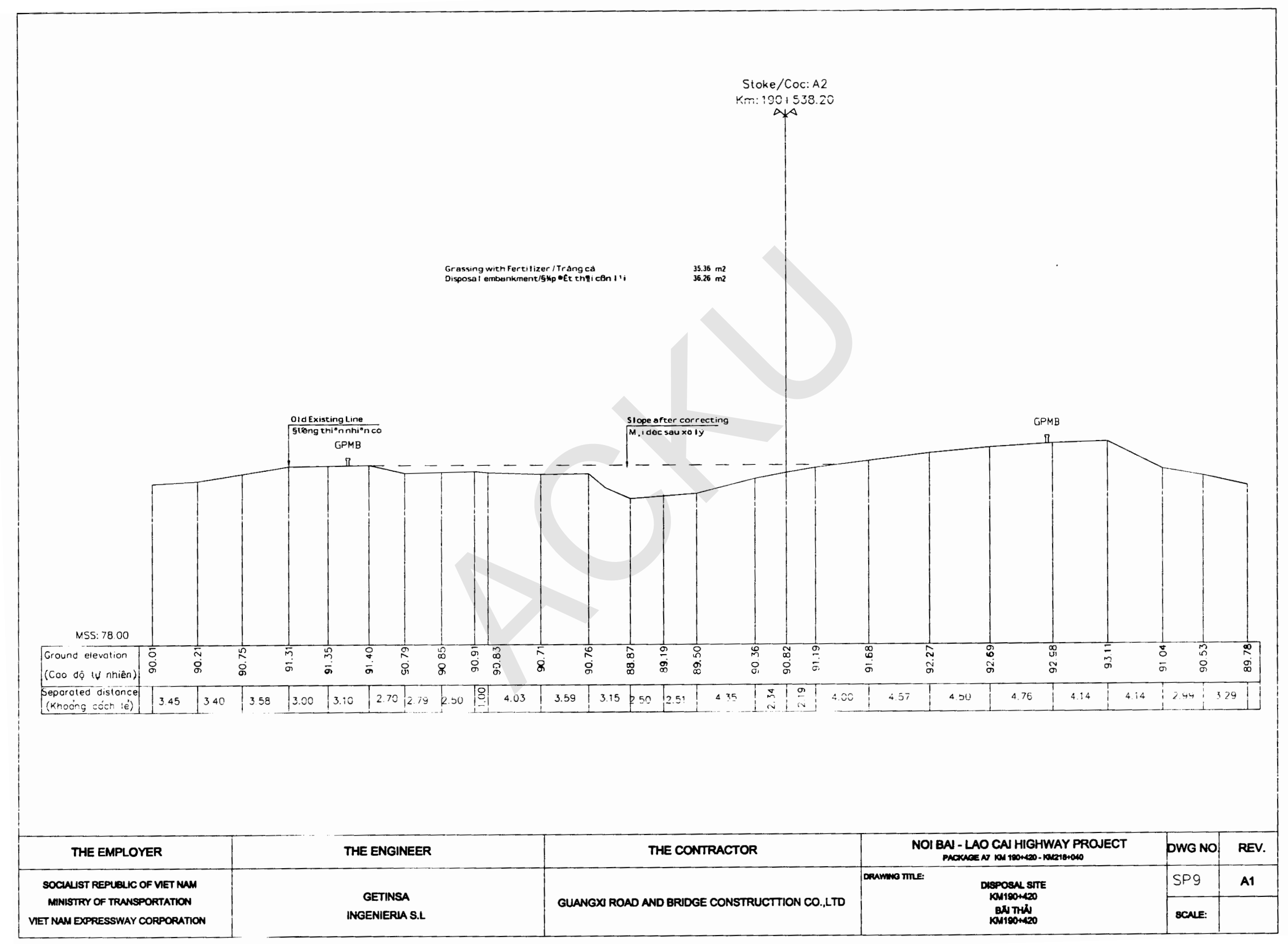




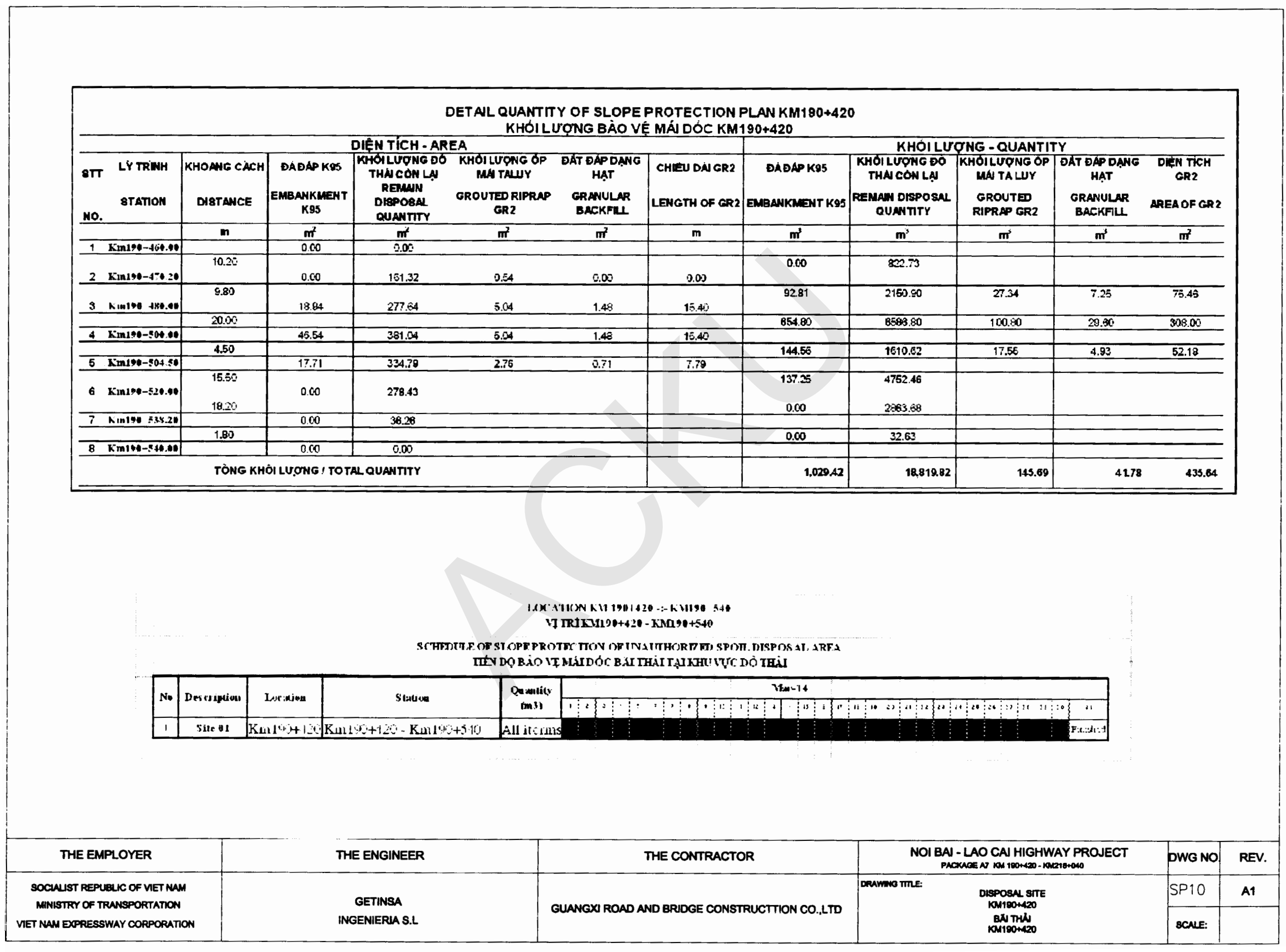


NOI BAI - LAO CAI HIGHWAY PROJECT DỰ ÁN ĐƯờnG CAO TỐC Nộl BÀl - LÀO CAI

PAGKAGE A7 / GÓl THẦU A7: KM 190+420 - KM 218+040

PLANS TO PROCESS AND SLOPE PROTECTION AT SPOIL DISPOSAL AREA KẾ HOẠCH XỬ LÝ̛ VÀ BẢO VỆ MÁl DỐC BÃI THẢI TẠI KHU VựC ĐỔ THẢI SECTION: KM195+500 LÝ TRìNH: KM195+500 
PLANS TO PROCESS AND SLOPE PROTECTION AT SPOIL DISPOSAL AREA Kế hoạch xử lý và bảo vệ mái dốc bãi thải tại khu vực đổ thải

SECTION: KM195+500

Lý trình: Km195+500 


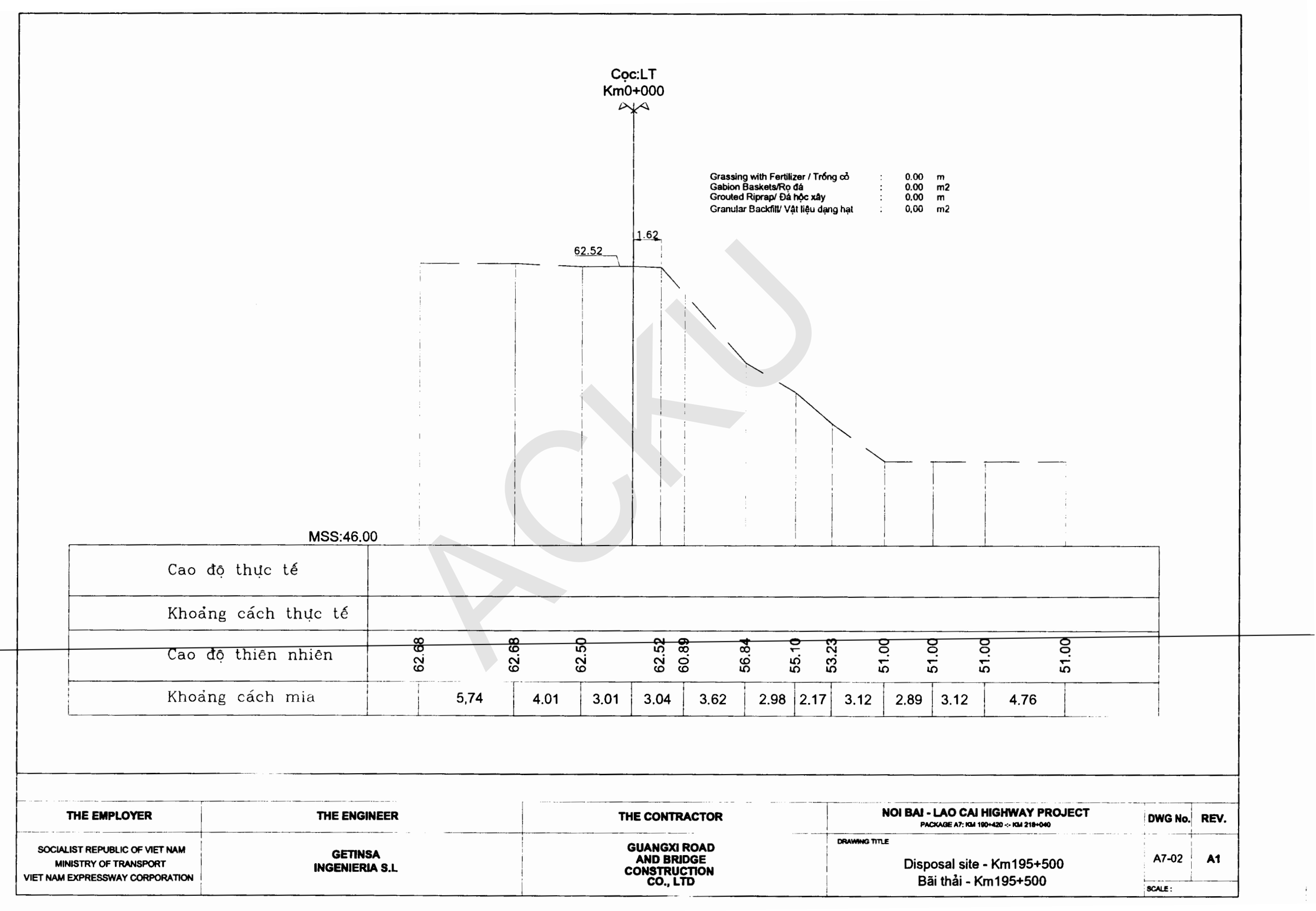




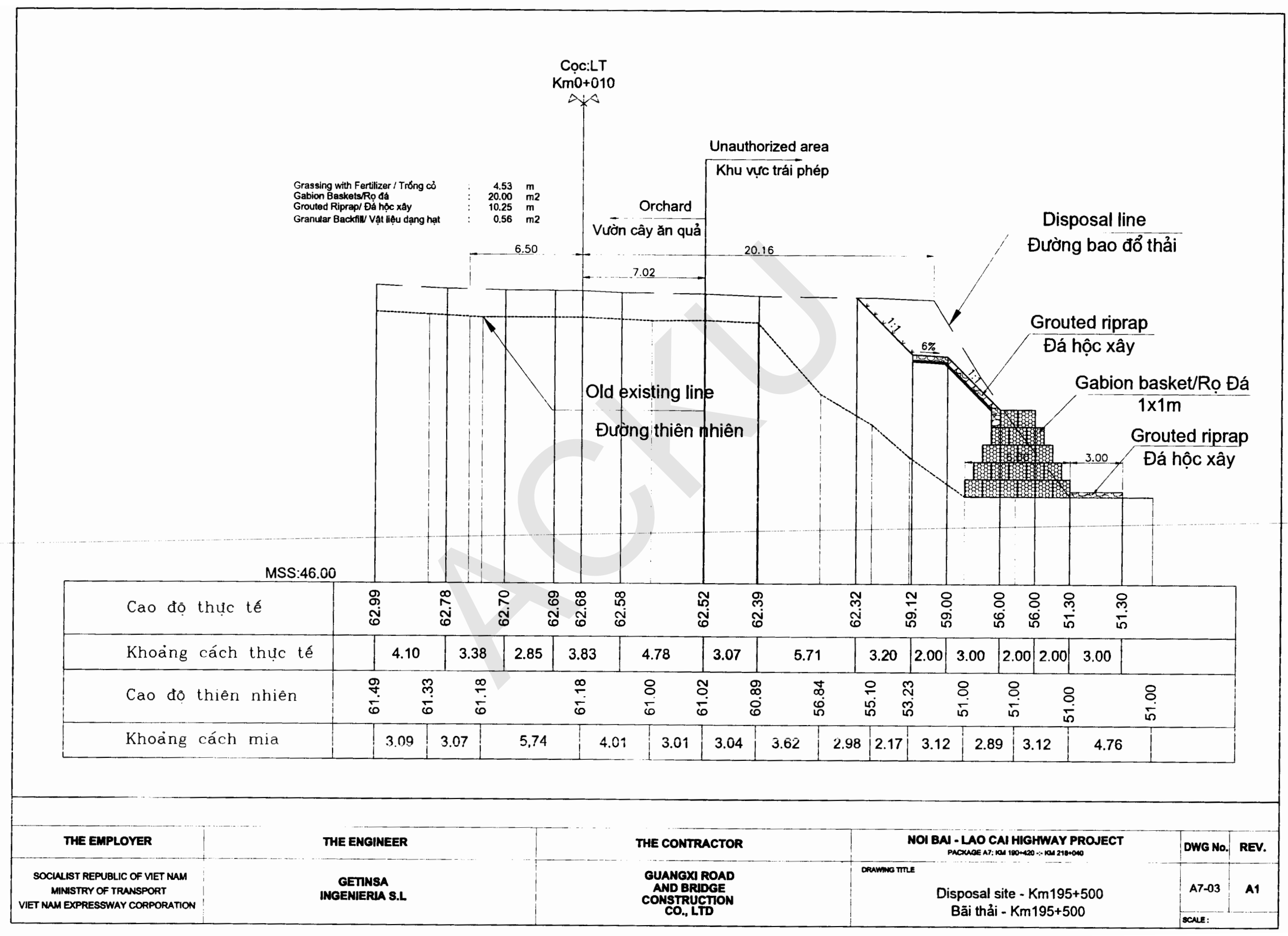




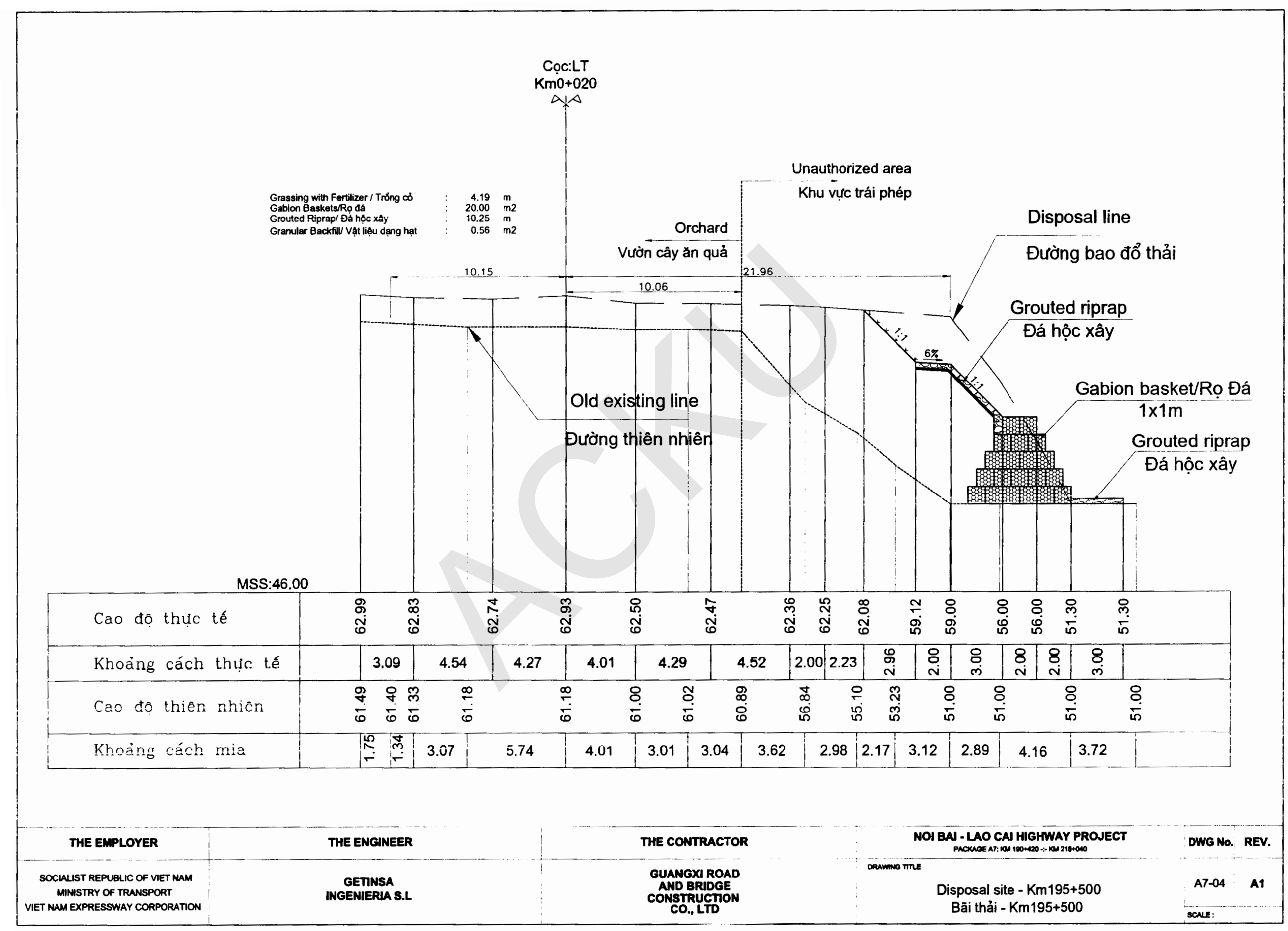




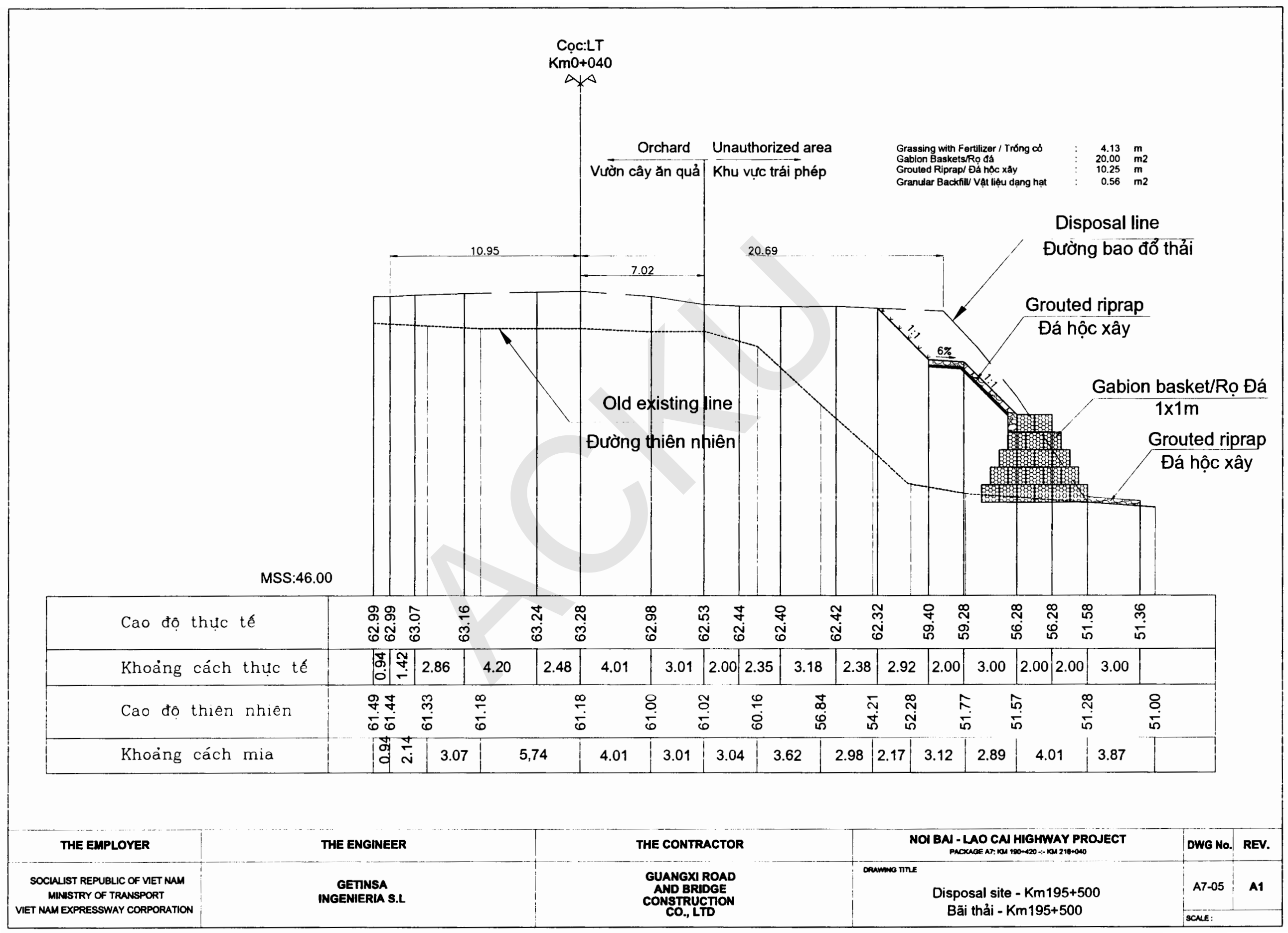




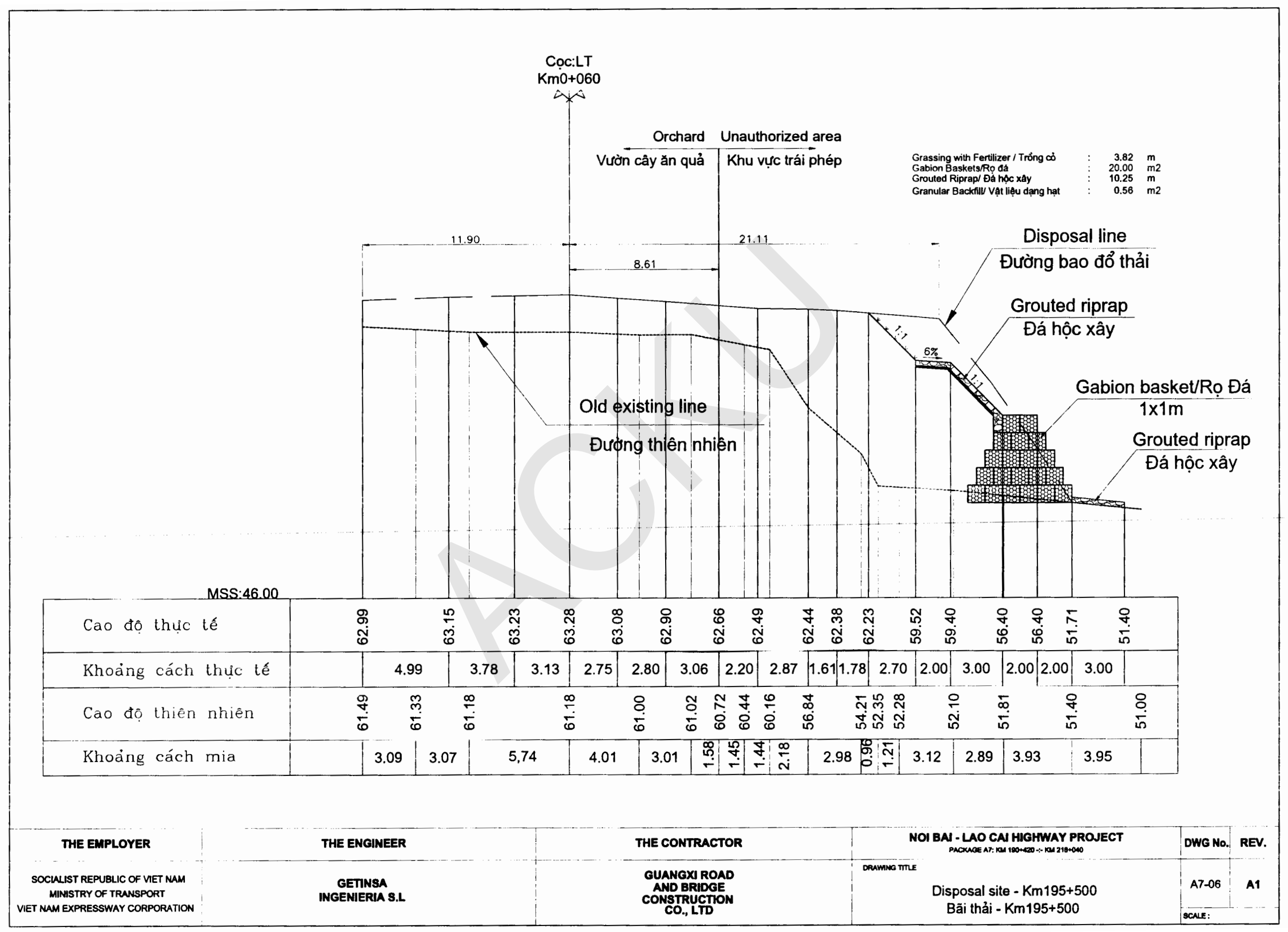




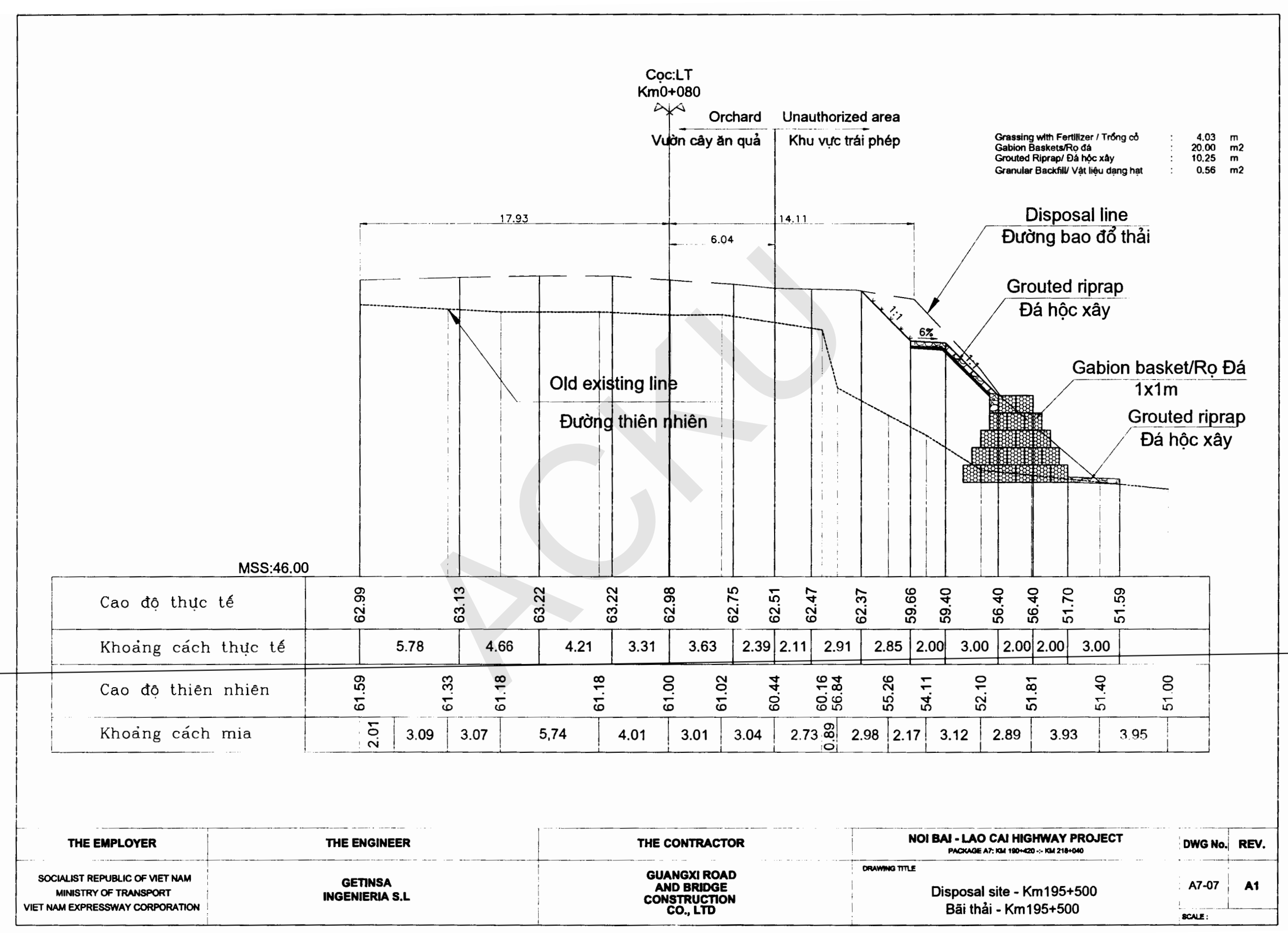




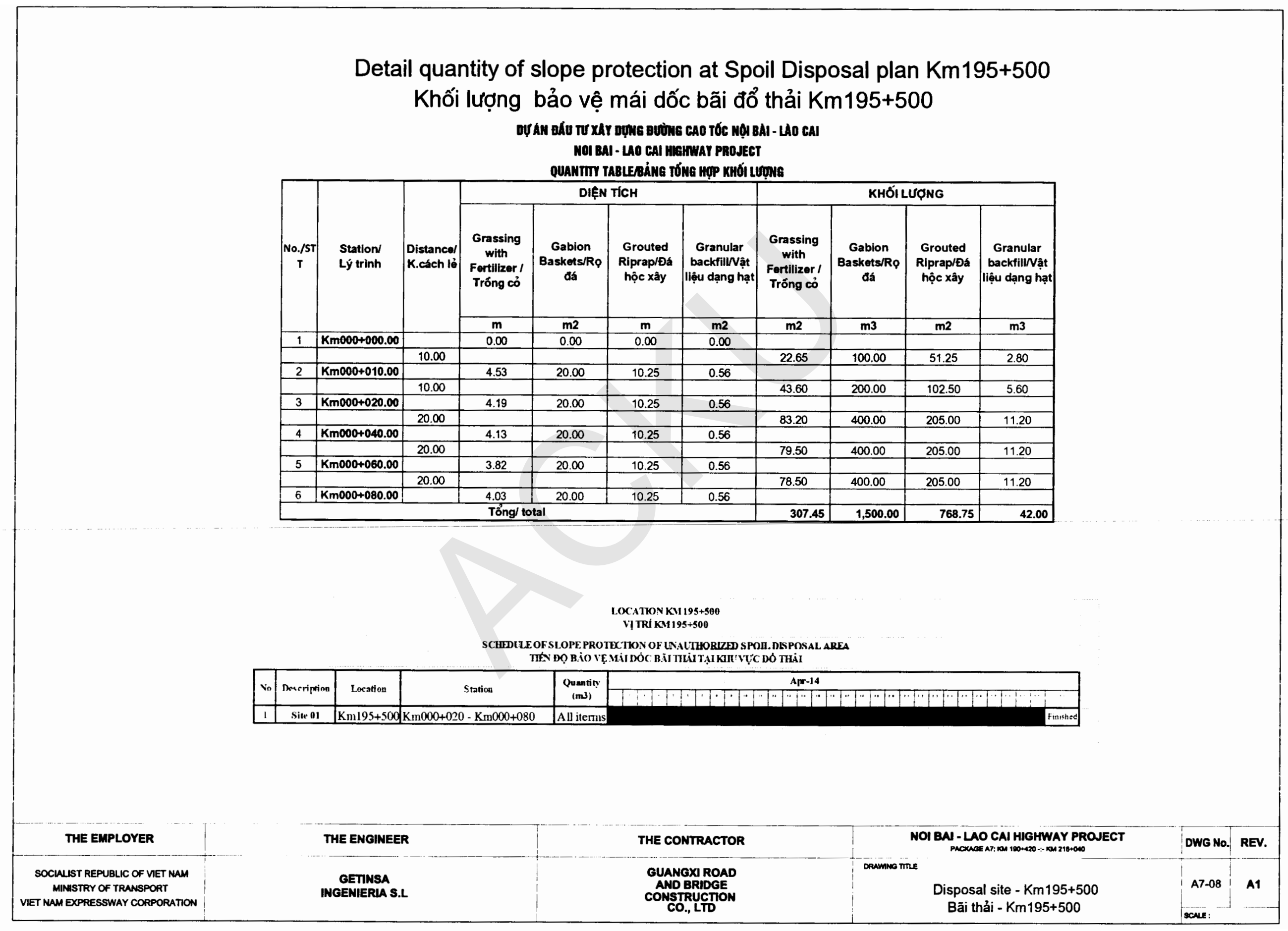




\section{REPOR ON THE DISPOSAL KM208+900 BÁO CÁO VỀ BÃI THẢI KM208+900}

VP điều hành: Km 200+800, đường cao tốc Nội Bài-Lào Cai,

Thôn Tôm Chúc, xã Tân Thượng, huyện Văn Bàn, tỉnh Lào Cai.

ĐT: 020-3799137. Fax: 020- 3799128; ĐTDĐ: 0919434378 \& 0903119968 Email: nblca7@163.com 


\section{REPOR ON THE DISPOSAL KM208+900}

\section{BÁO CÁO VỀ BÃI THẢI KM208+900}

\section{DISPOSAL LOCATION - VI TRÍ BÃI THẢI}

Disposal Km208+900 on the farming area of one householder:

Land code Hg/S-Ia 97 area of 27405.0 m2, owned by Luong Van Ngan.

Bãi thải Km208+900 nằm trên phần diện tích canh tác của một hộ dân:

Mã số địa chính Hg/S-Ia 97, diện tích 27405.0 m², chủ sở hữu là Lương Văn Ngan.

\section{LEGAL PROCEDURES RELATED - CÁC THỦ TỤC PHÁP LÝ LIÊN QUAN}

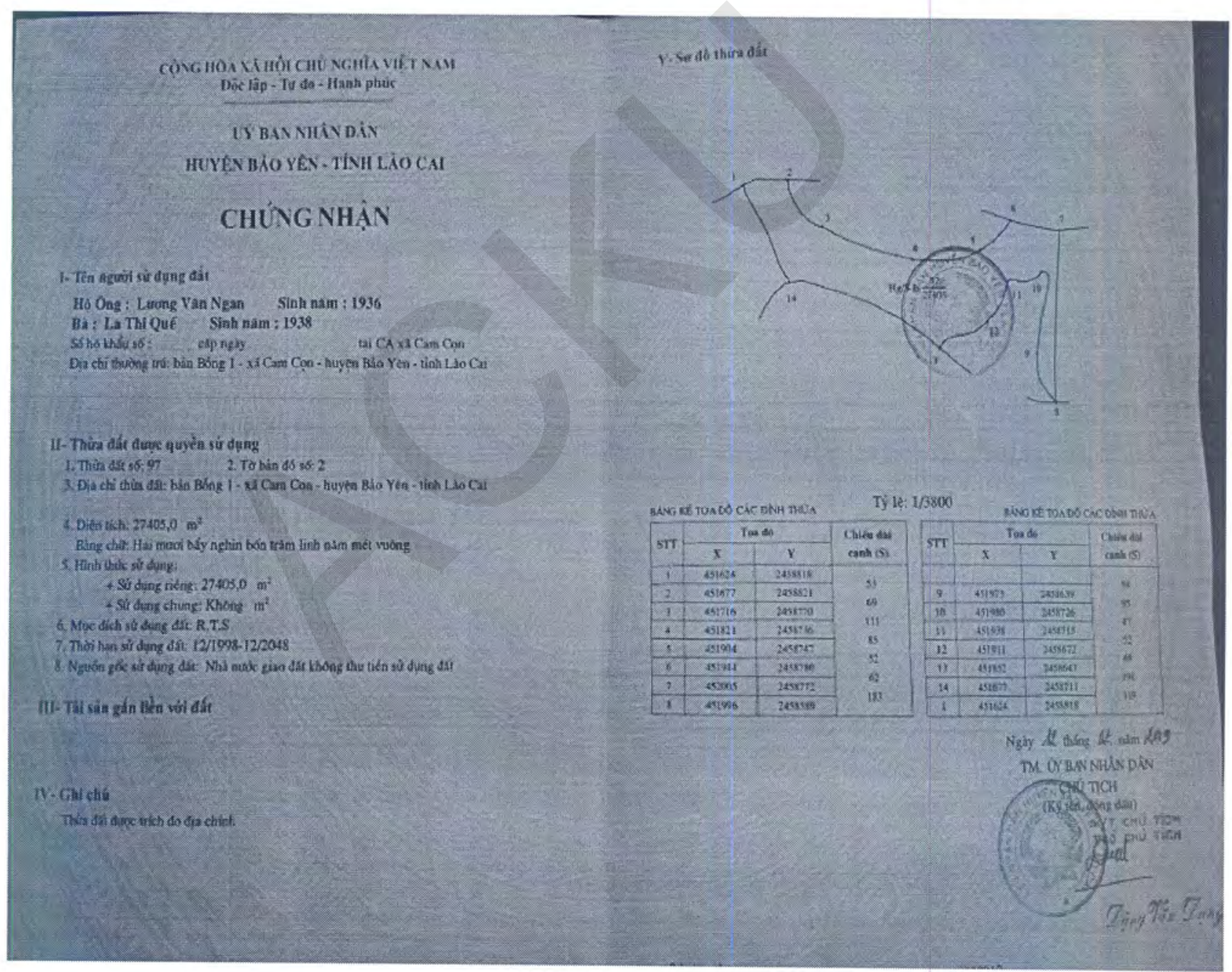

VP điều hành: Km 200+800, đường cao tốc Nội Bài-Lào Cai,

Thôn Tôm Chúc, xã Tân Thượng, huyện Văn Bàn, tỉnh Lào Cai.

ĐT: 020-3799137. Fax: 020- 3799128; ĐTDĐ: 0919434378 \& 0903119968 Email: nblca7@ 163.com 

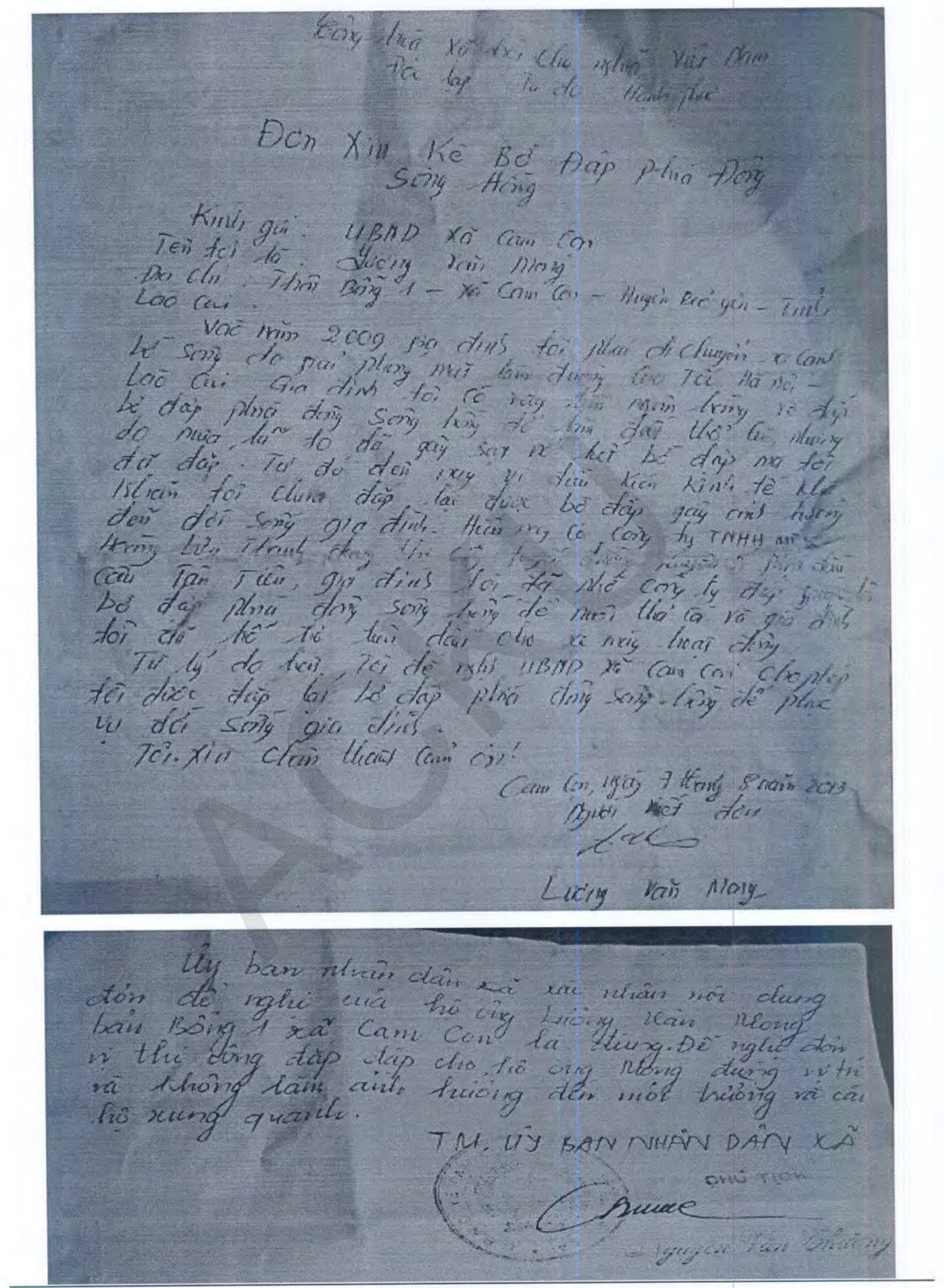

VP điều hành: Km 200+800, đường cao tốc Nội Bài-Lào Cai,

Thôn Tôm Chúc, xã Tân Thượng, huyện Văn Bàn, tỉnh Lào Cai. ĐT: 020-3799137. Fax: 020- 3799128; ĐTDĐ: 0919434378 \& 0903119968 Email: nblca7@ 163.com 


\section{SOCIALIST REPUBLIC OF VIETNAM \\ Independence - Freedom - Happiness}

\section{PETITION ON APPLYING TO EMBANK DAM BANK IN THE EAST OF RED RIVER}

\section{To: Cam Con Commune People's Committee}

My full name: Luong Van Mong

My address: Bong 1 Hamlet - Cam Con Commune - Bao Yen District - Lao Cai

In 2009 my family had to move to near river bank due to land acquisition for construction of Noi Bai - Lao Cai Highway Project. My family borrowed money from bank to embank dam bank in the east of Red River as housing area, but due to rain and flood, it collapse the whole dam bank that was embanked by myself. Up to now due to difficulty in finance, i have not yet re-embanked dam bank. This has affected to my life. Now Hoang Lien Thanh Co., Ltd is constructing Noi Bai - Lao Cai Highway Project at the beginning of Tan Tien bridge, my family had dam bank in the east of Red River embanked by Hoang Lien Thanh to breed fish and my family paid petrol fee to the operation of machineries.

With the above reason, I kindly request Cam Con Commune People's Committee to allow me to re-embank the dam bank in the east of Red River to serve for my family's life.

\section{Your truly,}

Commune People's Committee certified that the content of Luong Van Mong's petition who lives in Bong 1 Hamlet, Cam Con Commune is true and request the construction unit to embank dam for household of Mr. Mong at right position and not affect to environment and surrounding household 


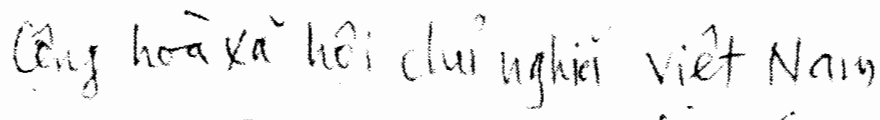

Ate $\operatorname{lap}_{-1}$ To-hant phuc

THIP CAM ON

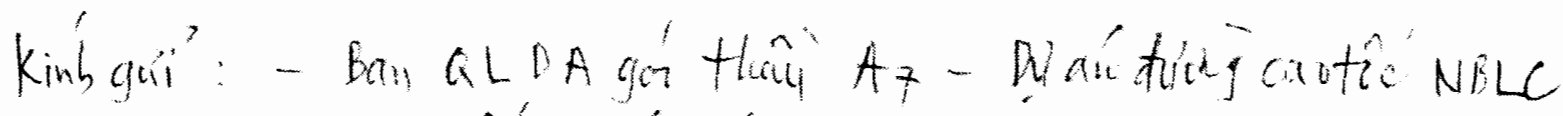

- Tưvaí Giarís sát

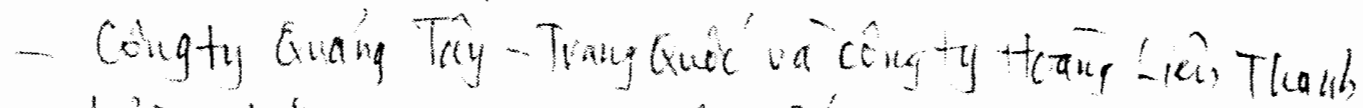

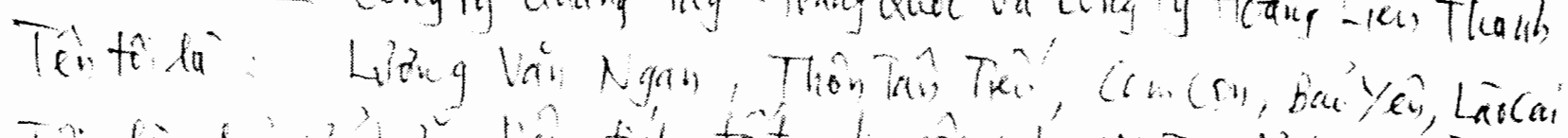

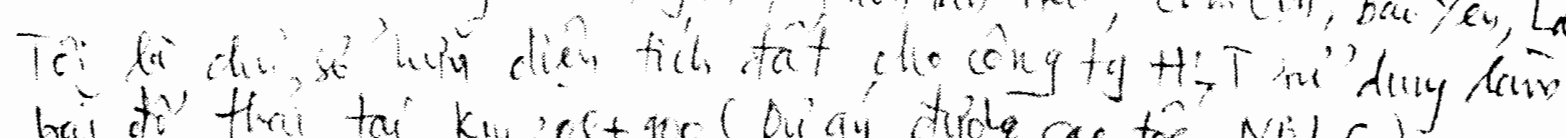

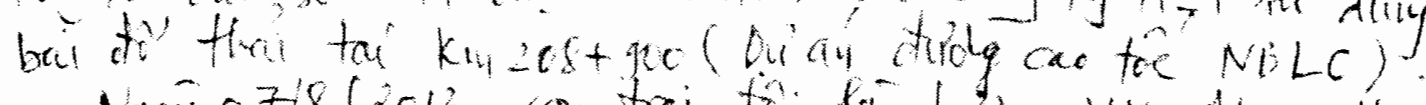

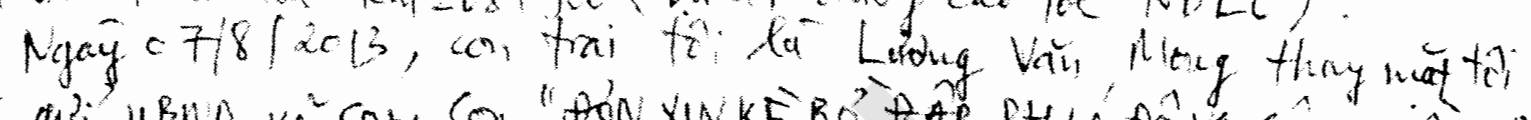

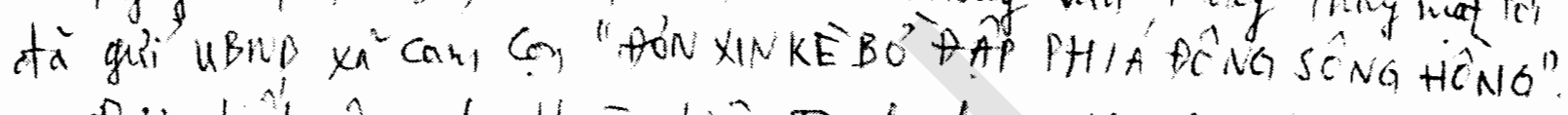

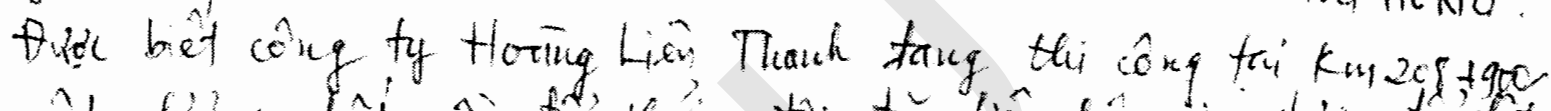

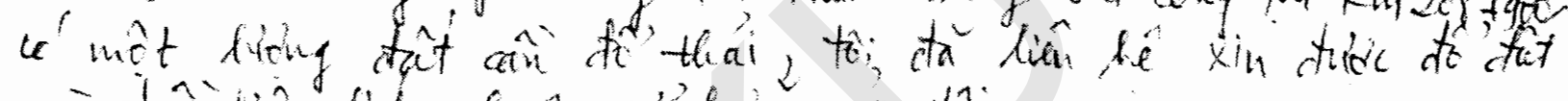

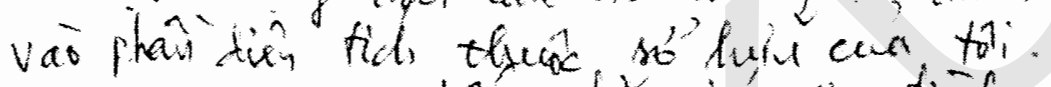

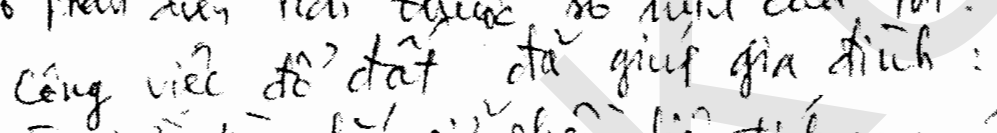

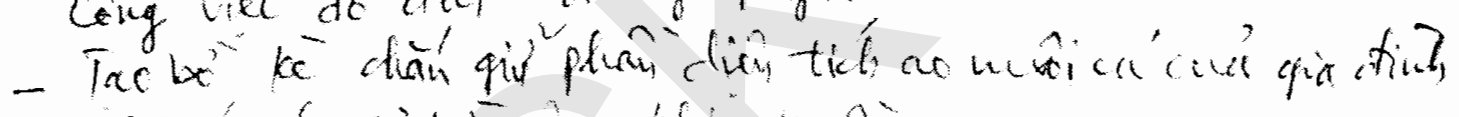

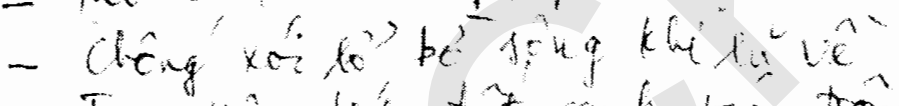

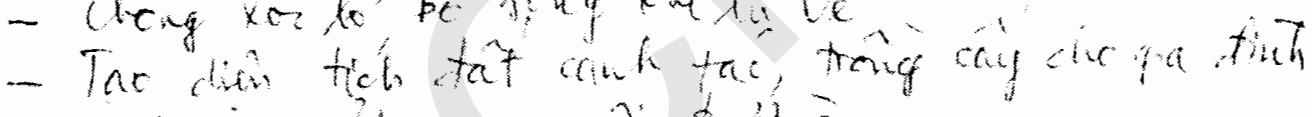

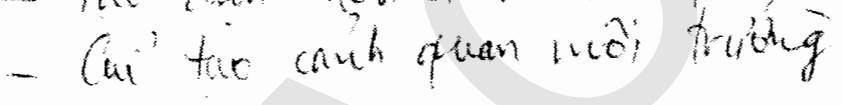

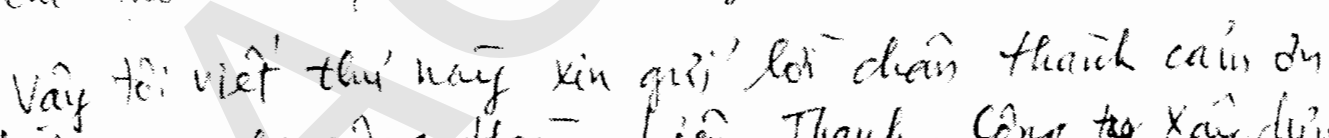

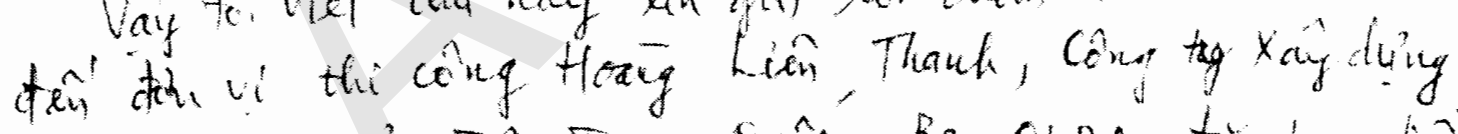

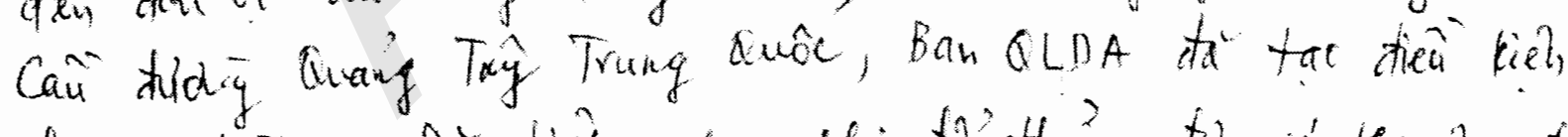

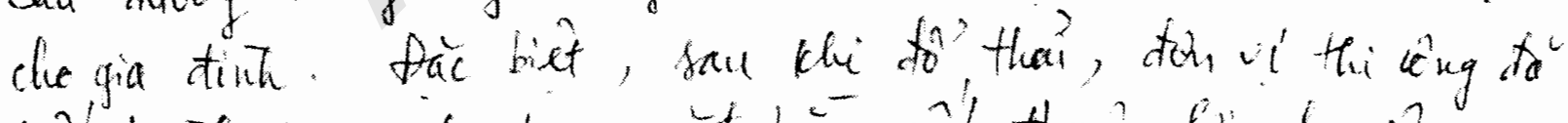

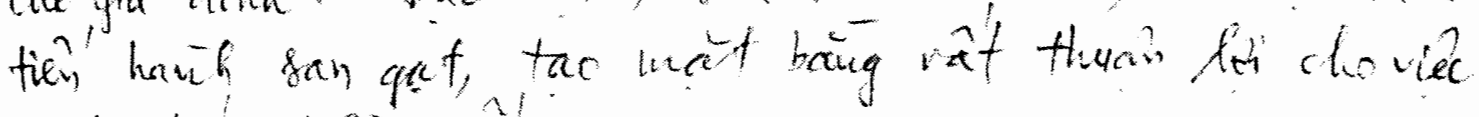
cank tac, tring ain.

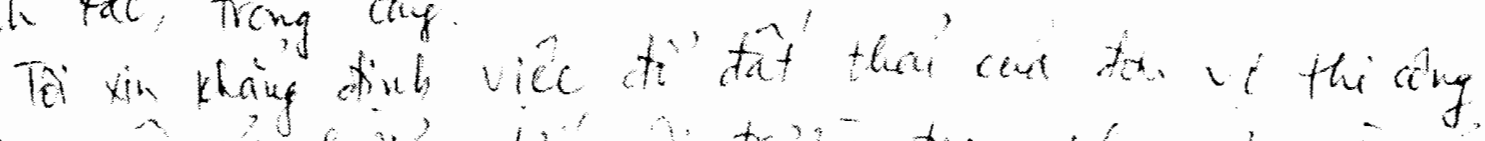

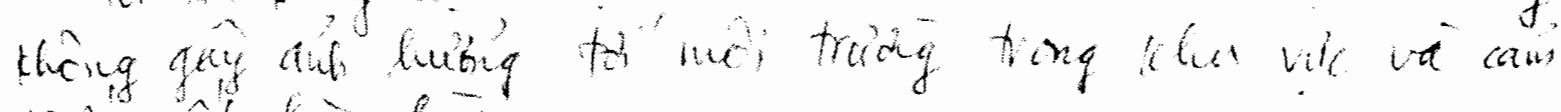
thaig iat hat long

Tax xir chan tranh aw an!

Hogan

Lieng Vau Ngan 


\section{SOCIALIST REPUBLIC OF VIETNAM \\ INDEPENDENCE - FREEDOM - HAPPINESS}

\section{THANKFUL LETTER}

\section{To: Management Board of Package A7}

\section{Supervision Consultant}

GuangXi Road and Bridge Construction Co.,Ltd, Hoang Lien Thanh Company

My full name: Luong Van Ngan

My address: Tan Tien Hamlet - Cam Con Commune - Bao Yen District - Lao Cai Province

I am the land owner with cultivation land area that allow Hoang Lien Thanh Company to use as disposal area at Km208+900 ( Noi Bai - Lao Cai Highway Project. On August 7, 2013, my son, on behalf of me, sent a letter of representation to Cam Con People's Committee on "Applying to embank dam bank of Red River side".

As I know, Hoang Lien Thanh Company is constructing at Km208+900 with a volume of soil that need to dump, I contacted with them to apply to dump spoil on my land

Spoil disposal helped my family as follows:

- Embank to protect my family's fish pond

- Prevent erosion of river bank when floods come

- Create cultivation area for my family

- Improve environment and landscape

By this letter, I would like to send my thanks to Hoang Lien Thanh Company GuangXi Road and Bridge Construction Co.,Ltd whocreated favorable condition for my family. Especially, because the construction units restored the plan after carrying disposal work, this created favorable condition for my family's cultivation.

I commit that dumping spoil in disposal site of construction units does not affect the regional environment and I feel so satisfactory

Your truly,

signed

Luong Van Ngan

VP điều hành: Km 200+800, đường cao tốc Nội Bài-Lào Cai,

Thôn Tôm Chúc, xã Tân Thượng, huyện Văn Bàn, tỉnh Là̀o Cai.

ĐT: 020-3799137. Fax: 020- 3799128; ĐTDĐ: 0919434378 \& 0903119968 Email: nblca7@ 163.com 
III. DESCRIPTION DISPOSAL AREA AND THE SCHEDULE OF RESTORATION OF DISPOSAL AREA - MÔ TẢ KHU VỰC ĐỔ THẢI VÀ TIÉN ĐỘ KHÔI PHỤC BÃI THẢI.

VP điều hành: $\mathrm{Km}$ 200+800, đường cao tốc Nội Bài-Lào Cai,

Thôn Tôm Chúc, xã Tân Thượng, huyện Văn Bàn, tình Lào Cai.

ĐT: 020-3799137. Fax: 020- 3799128; ĐTDĐ: 0919434378 \& 0903119968 Email: nblca7@ 163.com 


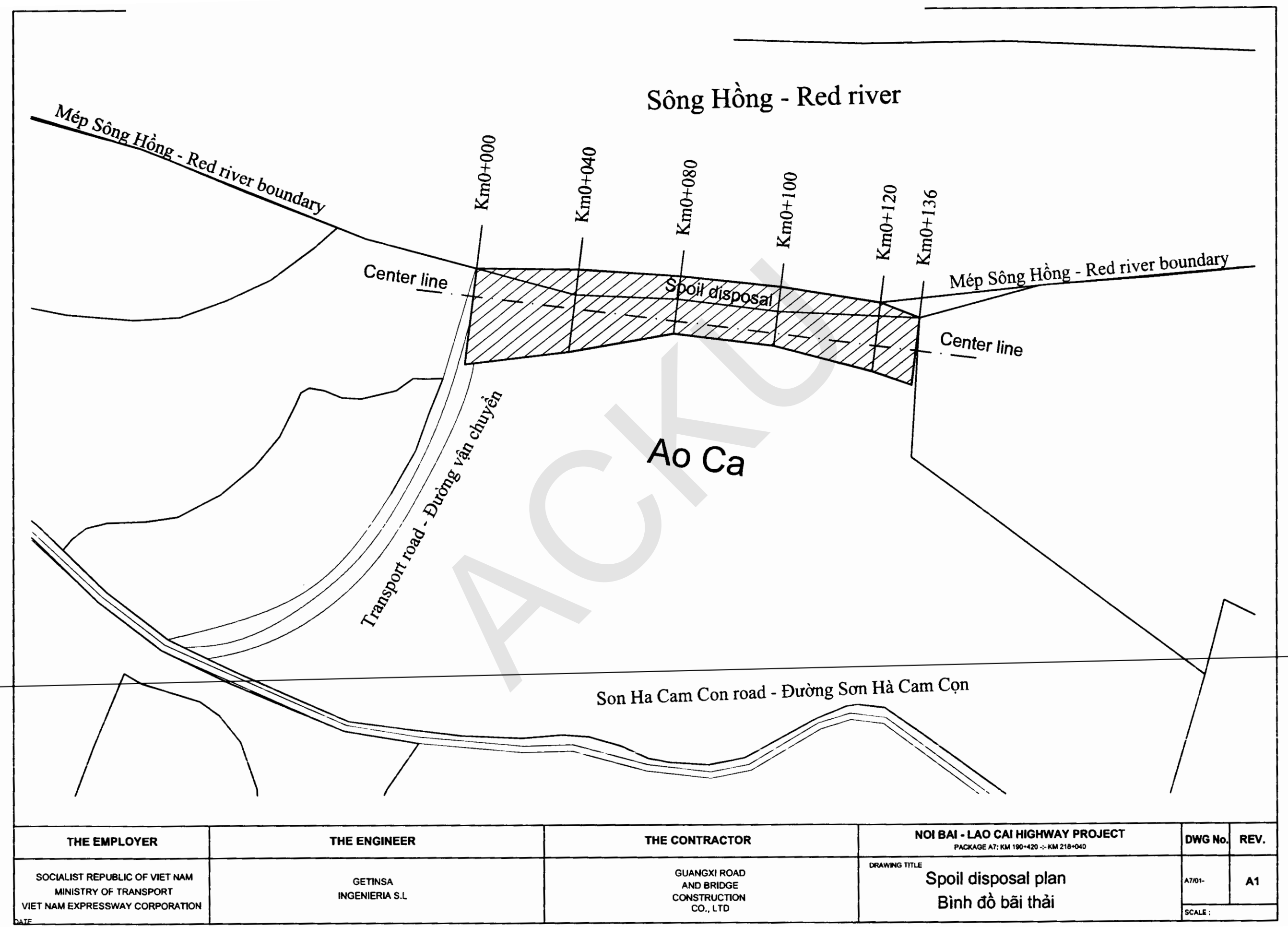




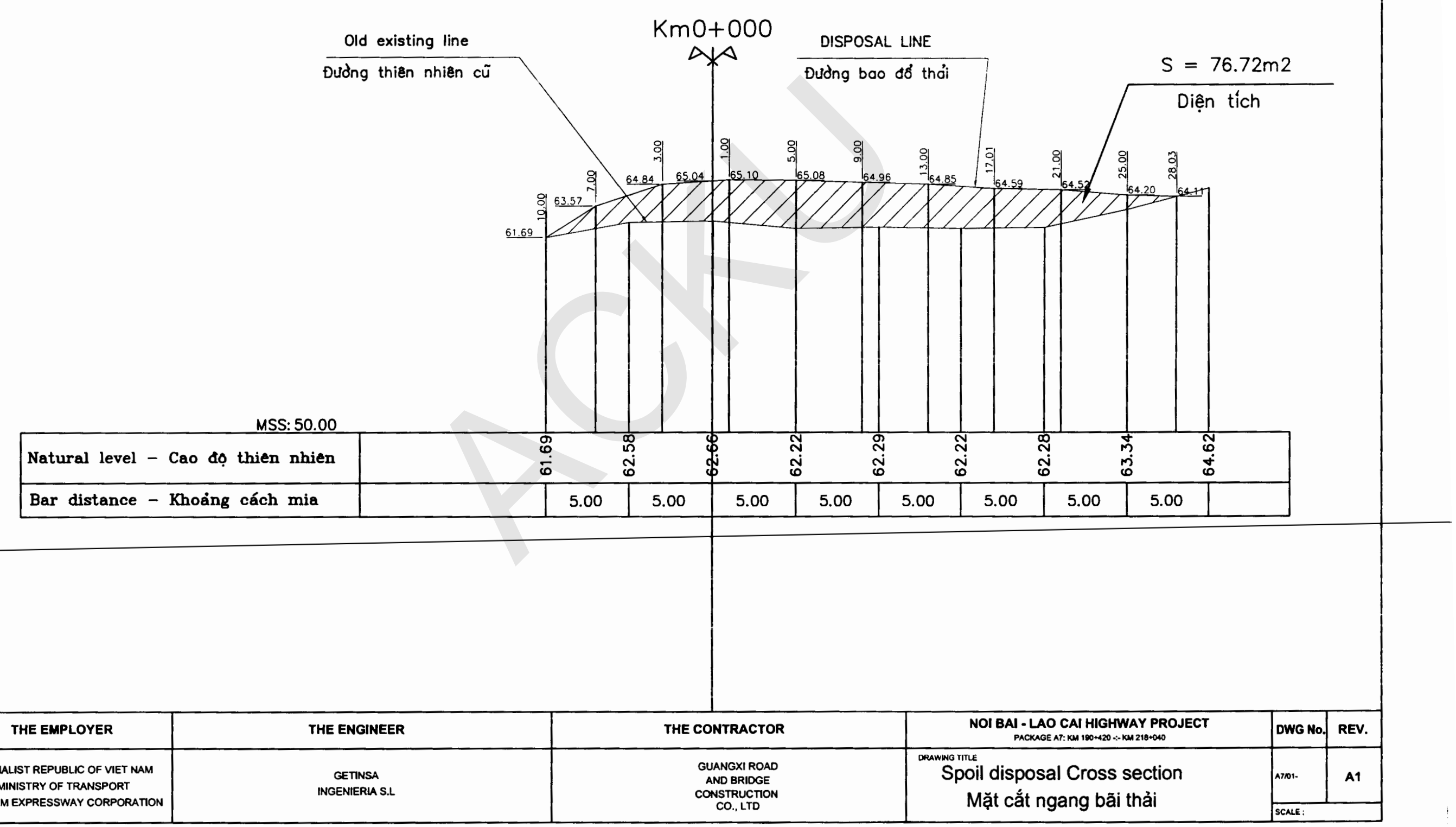




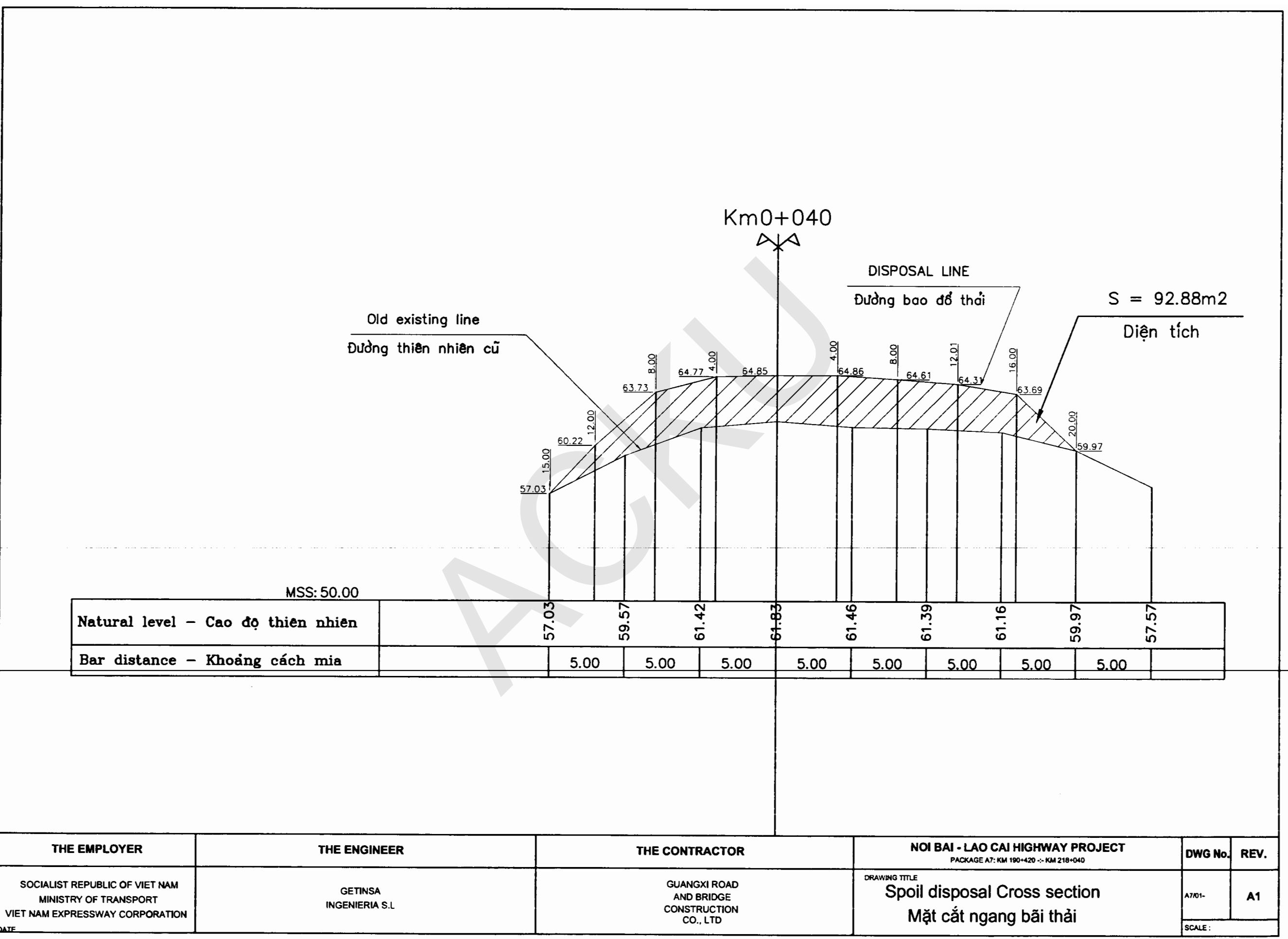




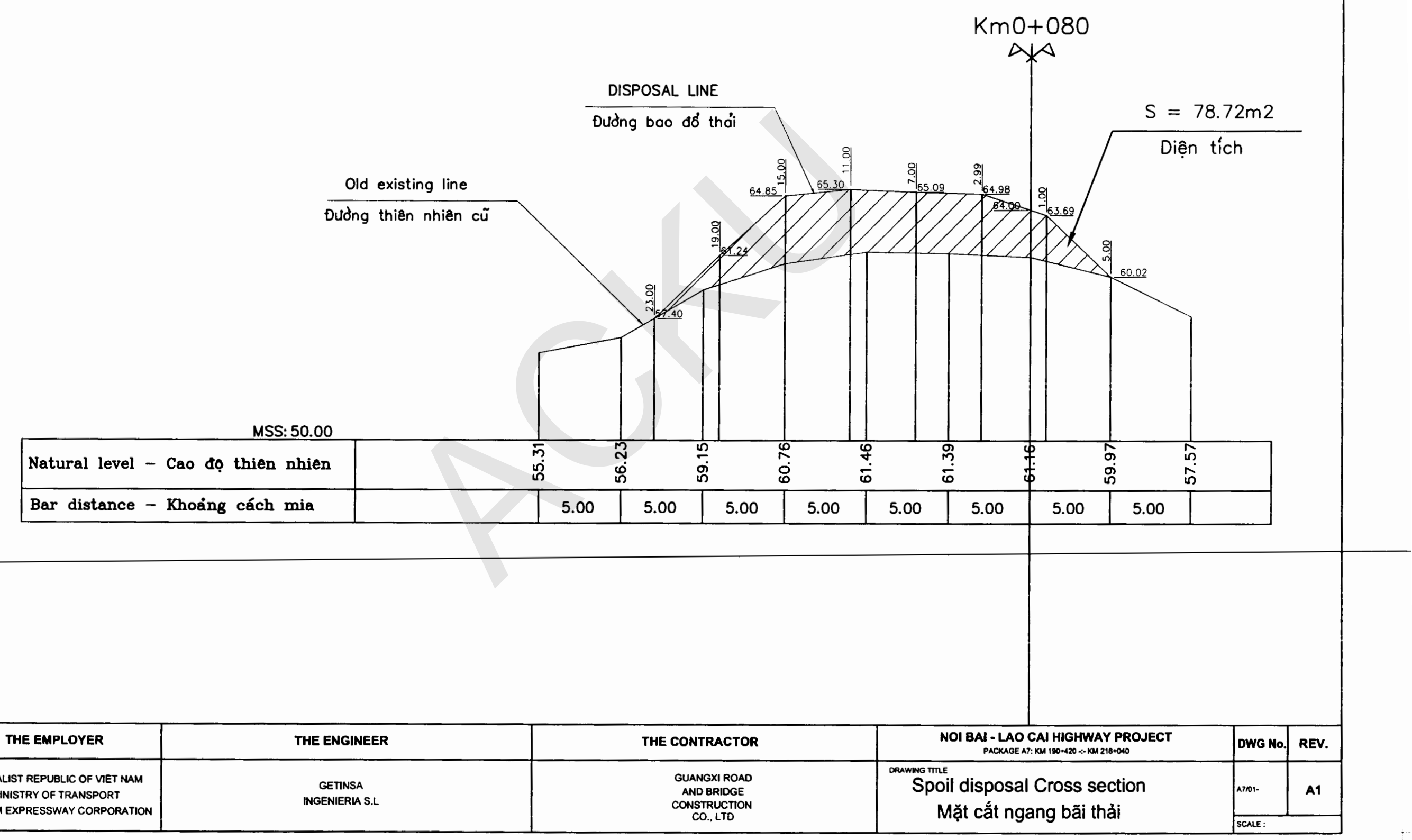




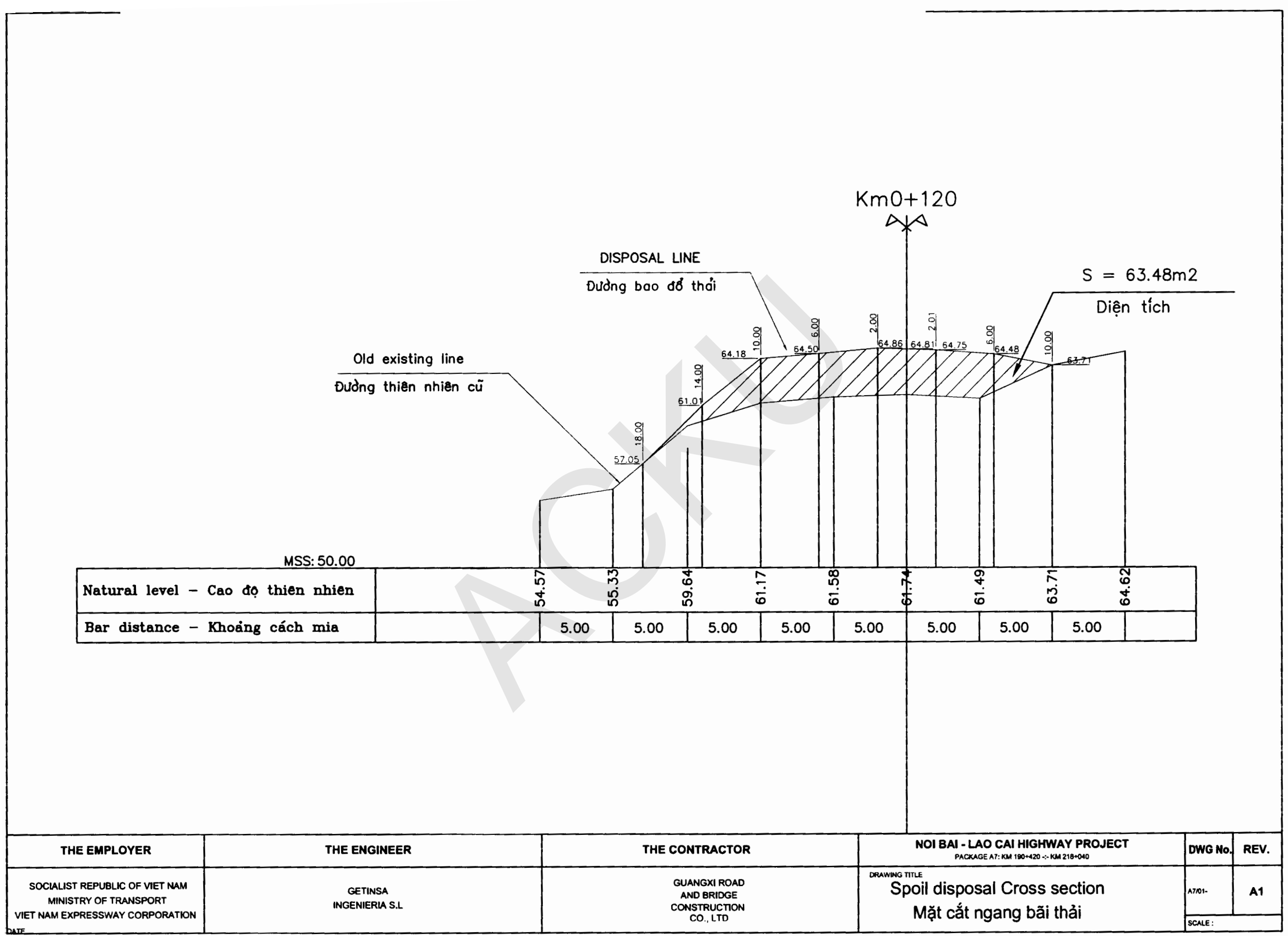




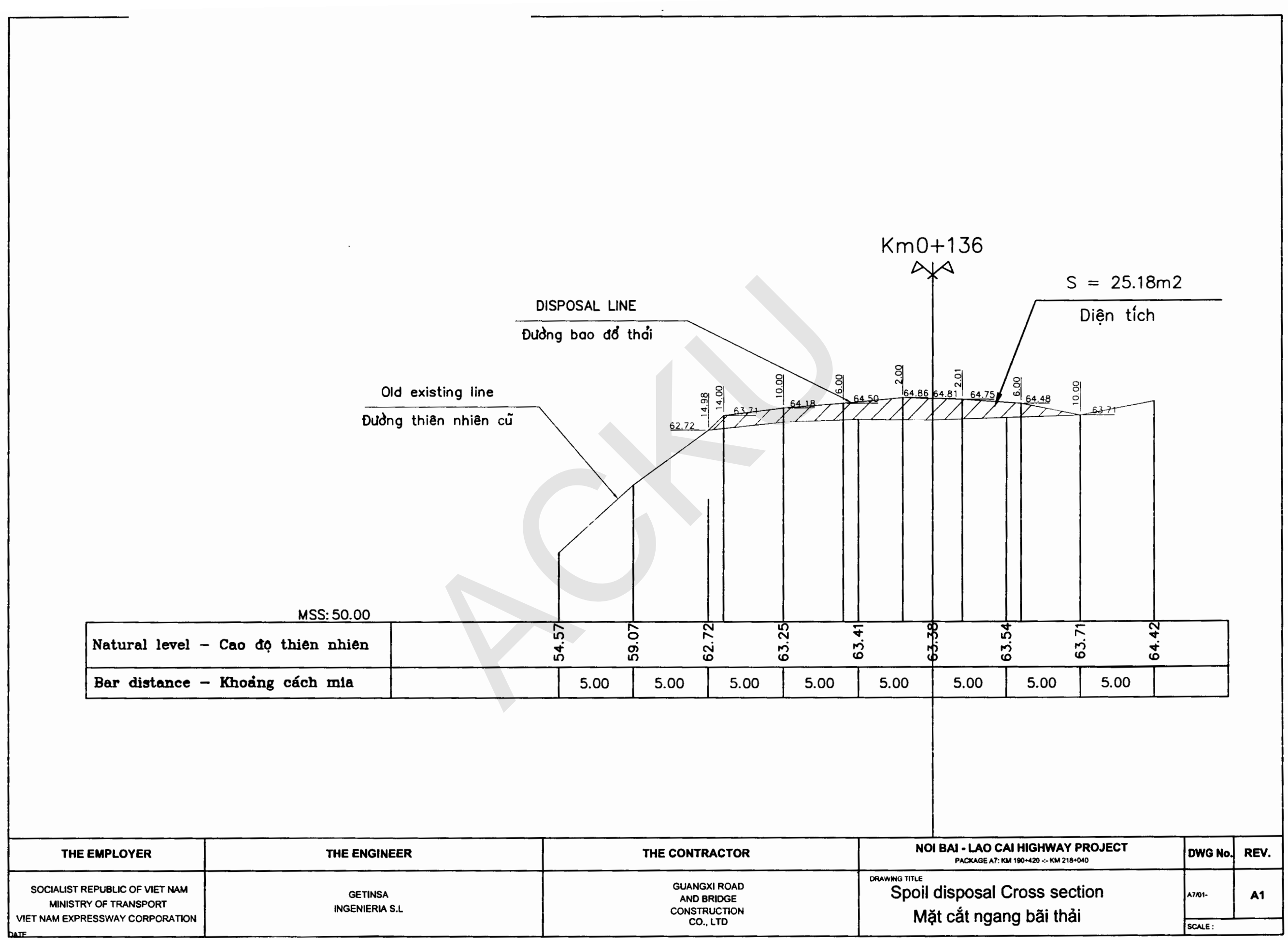




\section{CORRECTIVE MEASURES \\ BIÊNN PHÁP KHĂC PHUUC}

WORK EXECUTION STEPS

The work execution step will be followed below steps:

1. Using excavators to claw make slope 1:1,5. Soil was got up

to above of spoil disposal.

2. Bulldozer be used to plane the spoil disposal sites.

\section{Các bước thực hiện công việc}

Các bước thực hiện công việc như sau:

1. Sử dụng máy xúc vuốt mái tạo độ dốc $1: 1,5$. Đất được đưa lên $\mathrm{m}$ trên của bãi thải.

2. Sử dụng máy ủi để tạo mặt bằng cho bãi thải

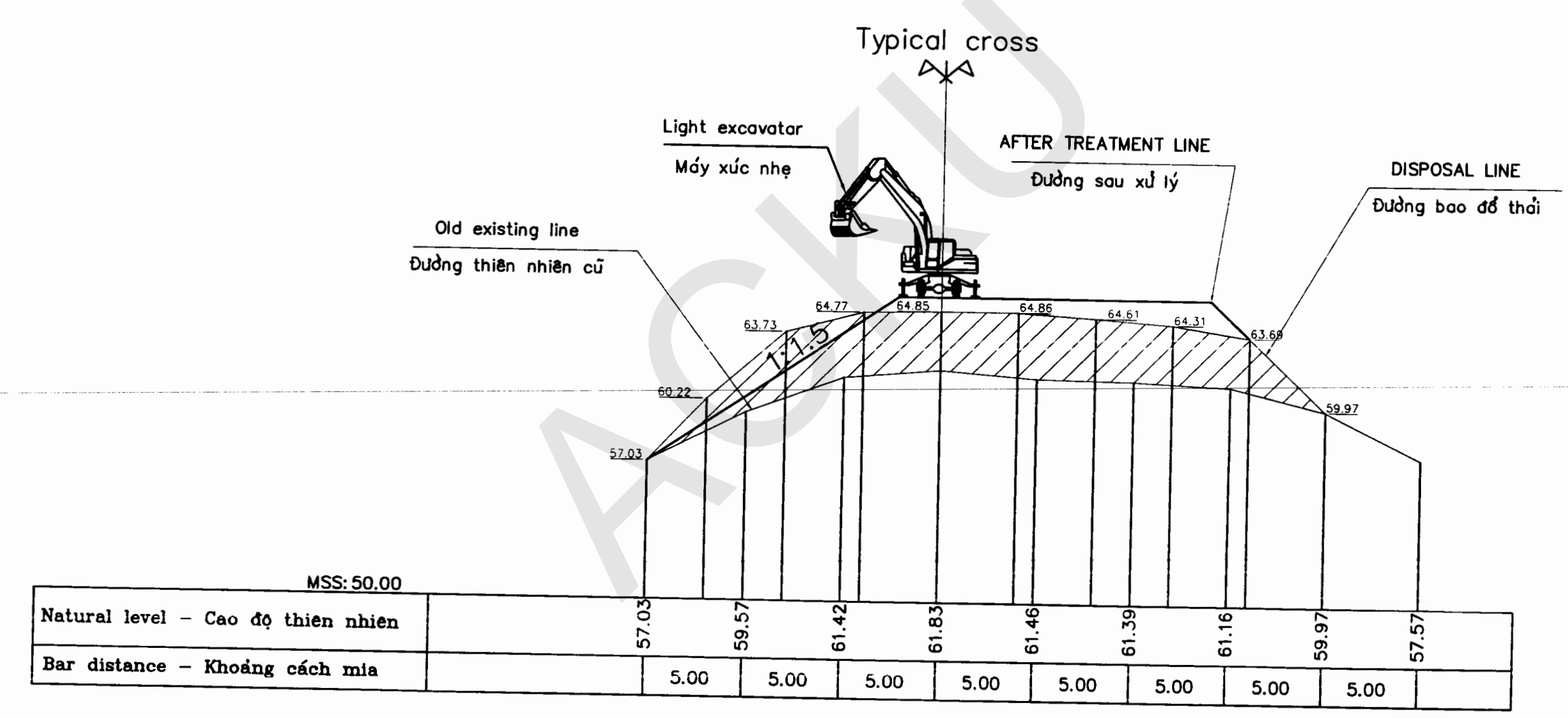

\begin{tabular}{|c|c|c|c|c|c|}
\hline THE EMPLOYER & THE ENGINEER & THE CONTRACTOR & $\begin{array}{c}\text { NOI BAI - LAO CAI HIGHWAY PROJECT } \\
\text { PACKMGE A7: KMM 1800420 } \cdots \mathrm{kM} 218+040\end{array}$ & DWG No. & REV. \\
\hline $\begin{array}{l}\text { SOCLALIST REPUBLIC OF VIET MAM } \\
\text { MINISTRY OF TRANSPORT } \\
\text { VIET NAM EXPRESSWAY CORPORATION } \\
\text { WIIE }\end{array}$ & $\begin{array}{l}\text { GETINSA } \\
\text { INGENIERIA S.L }\end{array}$ & $\begin{array}{l}\text { GUANGXI ROAD } \\
\text { AND BRIOGE } \\
\text { CONSTRUCTON } \\
\text { CO., LTD }\end{array}$ & $\begin{array}{l}\text { Corrective measures } \\
\text { Biện pháp khắc phục }\end{array}$ & aroo. & A1 \\
\hline
\end{tabular}




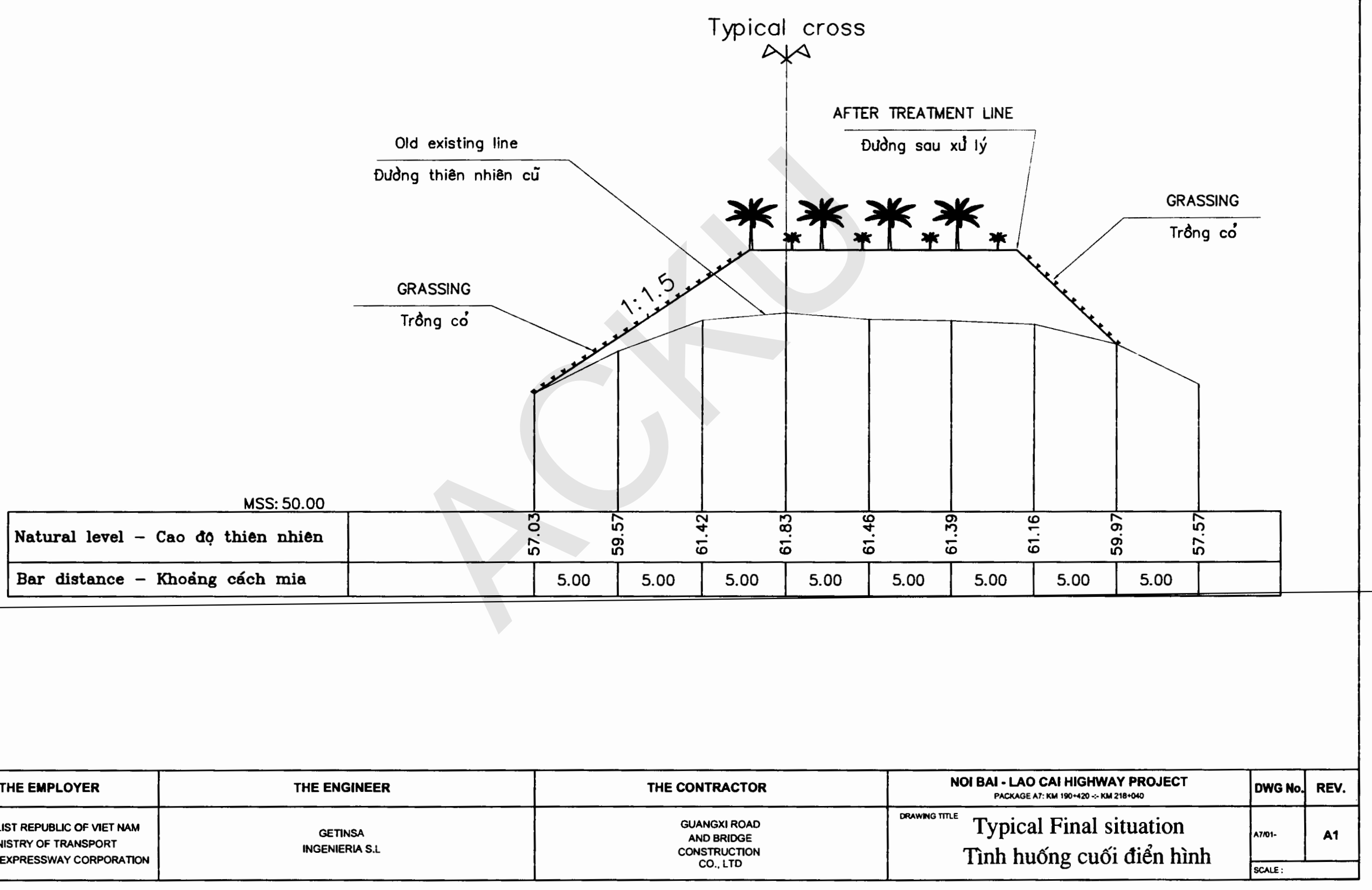


NOI BAI - LAO CAI HIGHWAY PROJECT

PACKAGE A7 - SECTION - LOCATION KMO+000-KMI0+136 (Km 208+900)

GÓI THÁU A7 - PHÂN ĐOẠN - Vị TRI KM0+000 -KM0+136 (Km208+900)

THE SCHEDULE OF RESTORATION OF DISPOSAL AREA

TIÊN ĐỌ PHỤC HỎl ĐẢT THÄI TẠI KHU VỰC ĐÖ THẢI

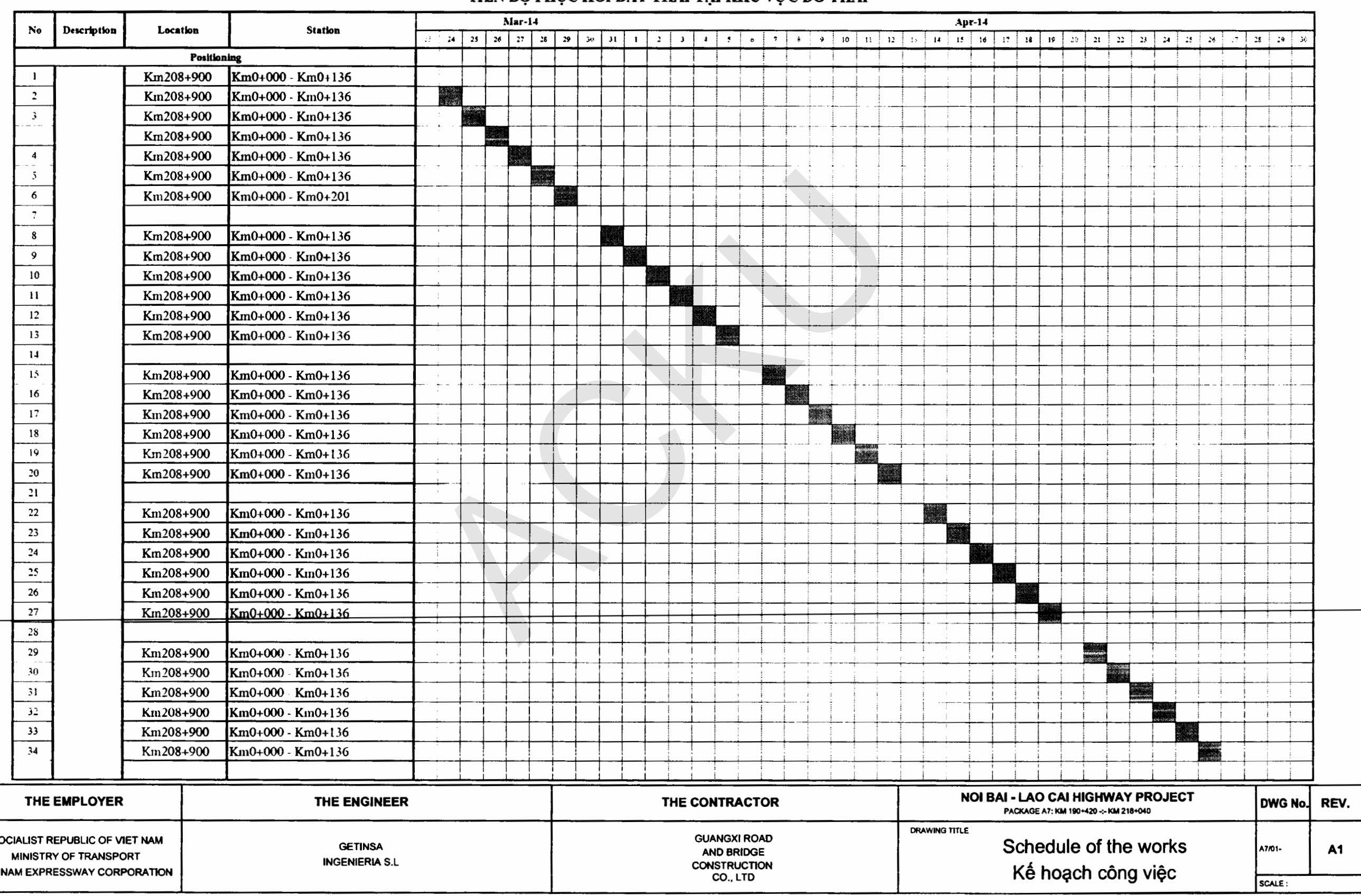




\section{REPOR ON THE DISPOSAL KM209+800 BÁO CÁO VỀ BÃI THẢI KM209+800}

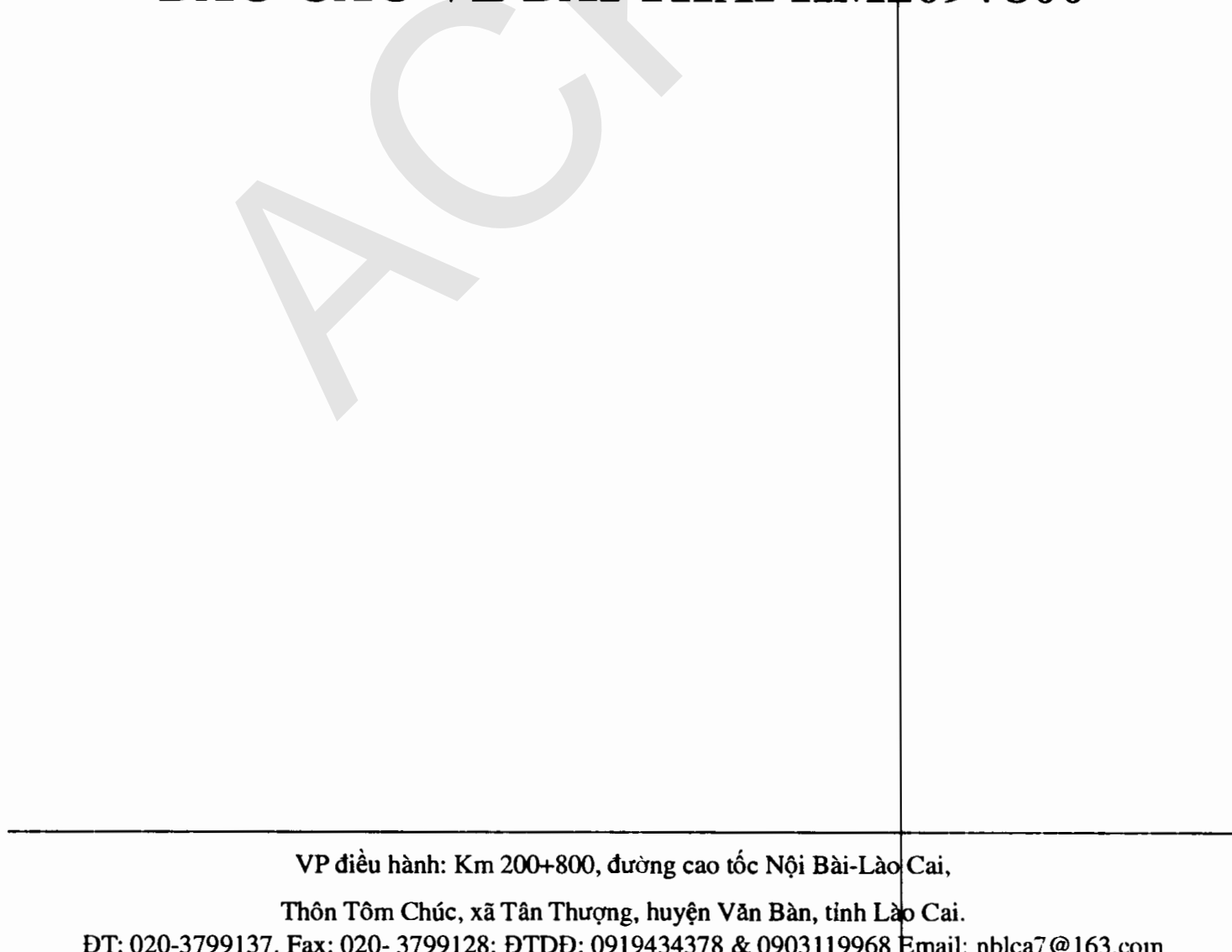

ĐT: 020-3799137. Fax: 020- 3799128; ĐTDĐ: 0919434378 \& 0903119968 Email: nblca7@163.coln 


\section{REPOR ON THE DISPOSAL KM209+800 BÁO CÁO VỂ BÃI THẢI KM209+800}

\section{DISPOSAL LOCATION - VỊ TRÍ BÃI THẢI}

Disposal Km209+800 on the farming area of two householders:

- Plot No.1: Land code HNK62 area of 2169.2 m2, owned by Doan Dinh Dung.

- Plot No.2: Land code HNK109 area of 2048.0 m2, owned by Vu Thi Nu

(Note: Due to Ms. Vu Thi Nu authorize Doan Dinh Dung write letter submissions to Cam Con People's Committee and thank letter to the contractor, so that documents only represent Doan Dinh Dung signed)

Bãi thải Km209+800 nằm trên phần diện tích canh tác của hai hộ dân:

- Thửa số 1: Mã số địa chính HNK62, diện tích 2169.2 m²$^{2}$, chủ sở hữu là Đoàn Đình Dũng.

- Thửa số 2: Mã số địa chính HNK109, diện tích 2048.0 m² , chủ sở hữu là Vũ Thị Nụ (Lưu ý: Do bà Vũ Thị Nu ủy quyền cho ông Đoàn Đình Dũng làm tò̀ trình gửi UBND xã Cam Cọn và Thu Cảm Onn nhà thầu thi công nên trong các giấy tờ trên chỉ có ông Đoàn Đình Dũng đại diện kýtên).

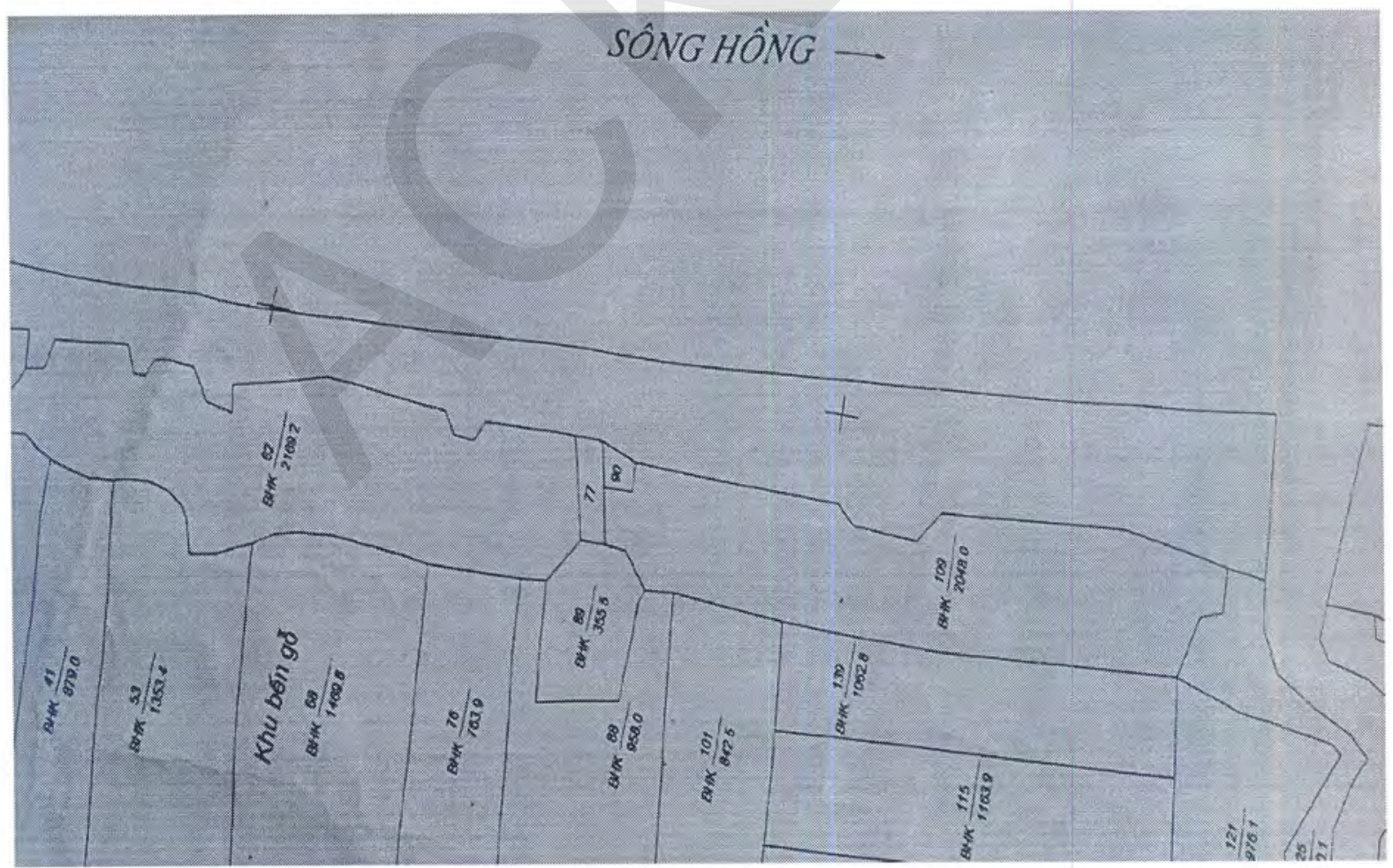

VP điều hành: Km 200+800, đường cao tốc Nội Bài-Lào Cai,

Thôn Tôm Chúc, xã Tân Thượng, huyện Văn Bàn, tỉnh Lào Cai.

ĐT: 020-3799137. Fax: 020- 3799128; ĐTDĐ: 0919434378 \& 0903119968 Email: nblca7@ 163.com 


\section{LEGAL PROCEDURES RELATED - CÁC THỦ TỤC PHÁP LÝ LIÊN QUAN}

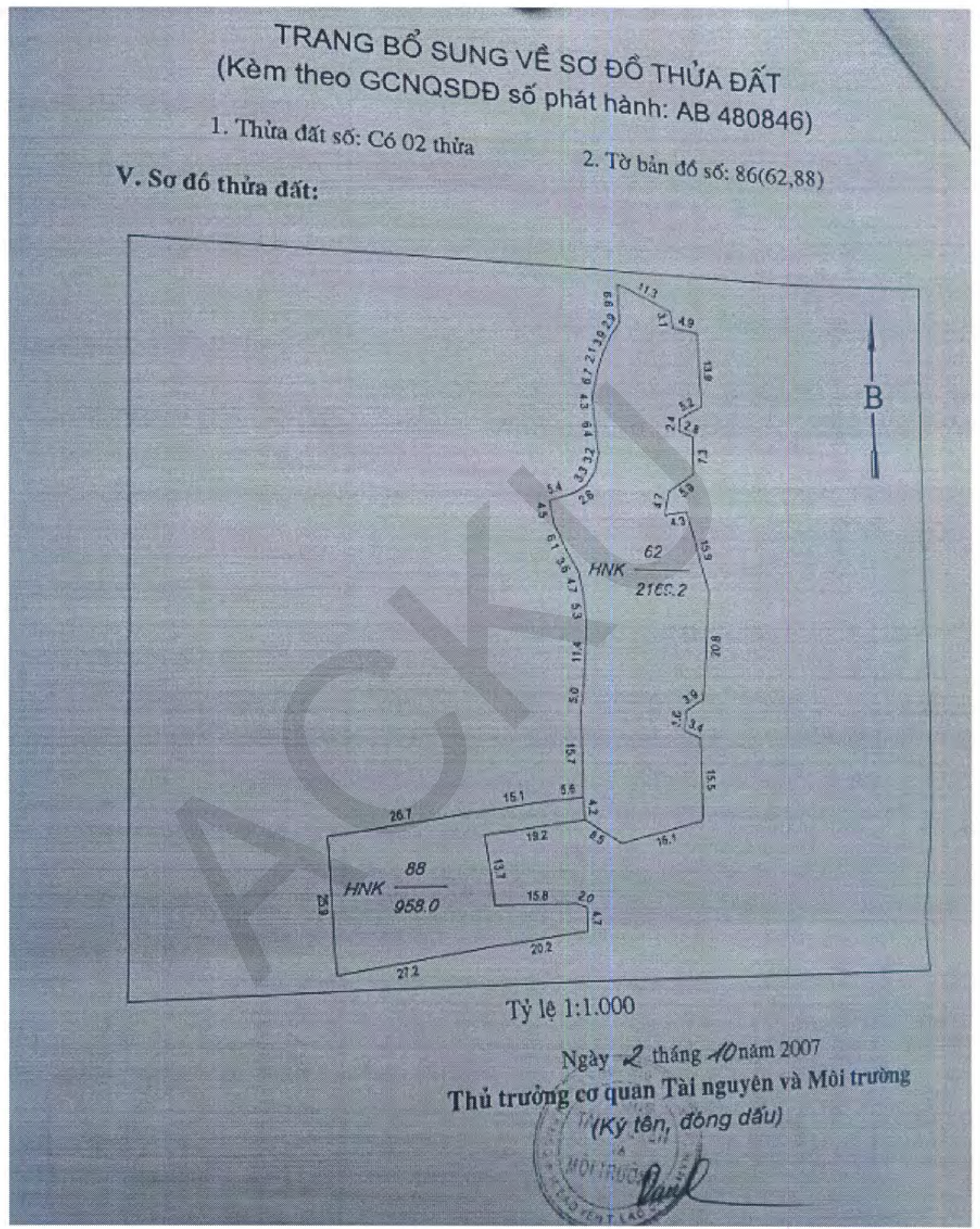

VP điều hành: Km 200+800, đường cao tốc Nội Bài-Lào Cai,

Thôn Tôm Chúc, xã Tân Thượng, huyện Văn Bàn, tỉnh Lào Cai.

ĐT: 020-3799137. Fax: 020- 3799128; ĐTDĐ: 0919434378 \& 0903119968 Email: nblca7@ 163.com 


\section{TRANG BOீ SUNG VÊ SO ĐÓ THƯA ĐÃT (Kèm theo GCNQSDĐ só phát hành: AB 480871)}

1. Thừ dift so: 109

2. Tơ bản đo s6: 86

\section{So dó thira dát:}

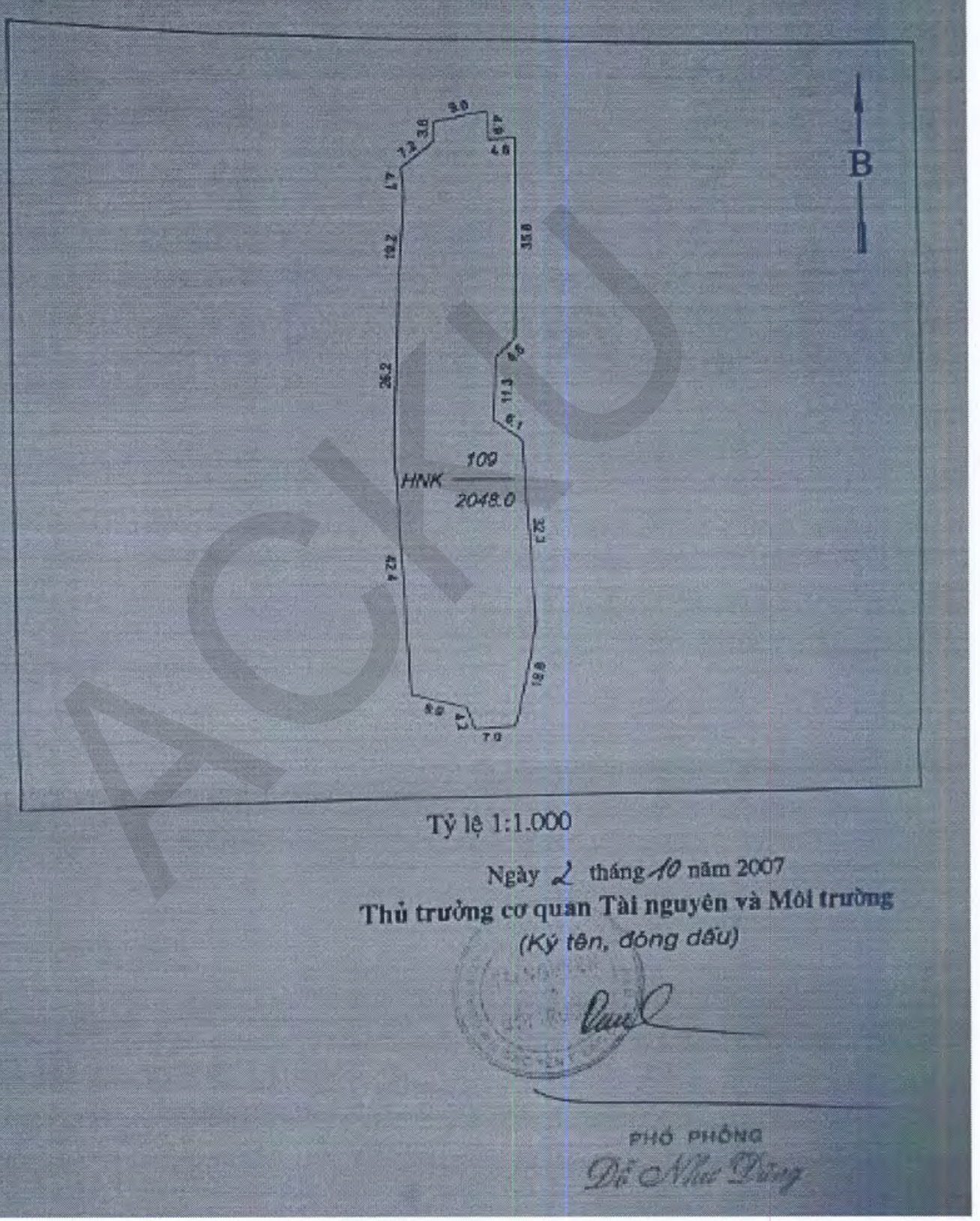

VP điều hành: Km 200+800, đường cao tốc Nội Bài-Lào Cai,

Thôn Tôm Chúc, xã Tân Thượng, huyện Văn Bàn, tỉnh Lào Cai.

ĐT: 020-3799137. Fax: 020- 3799128; ĐTDĐ: 0919434378 \& 0903119968 Email: nblca7@163.com 

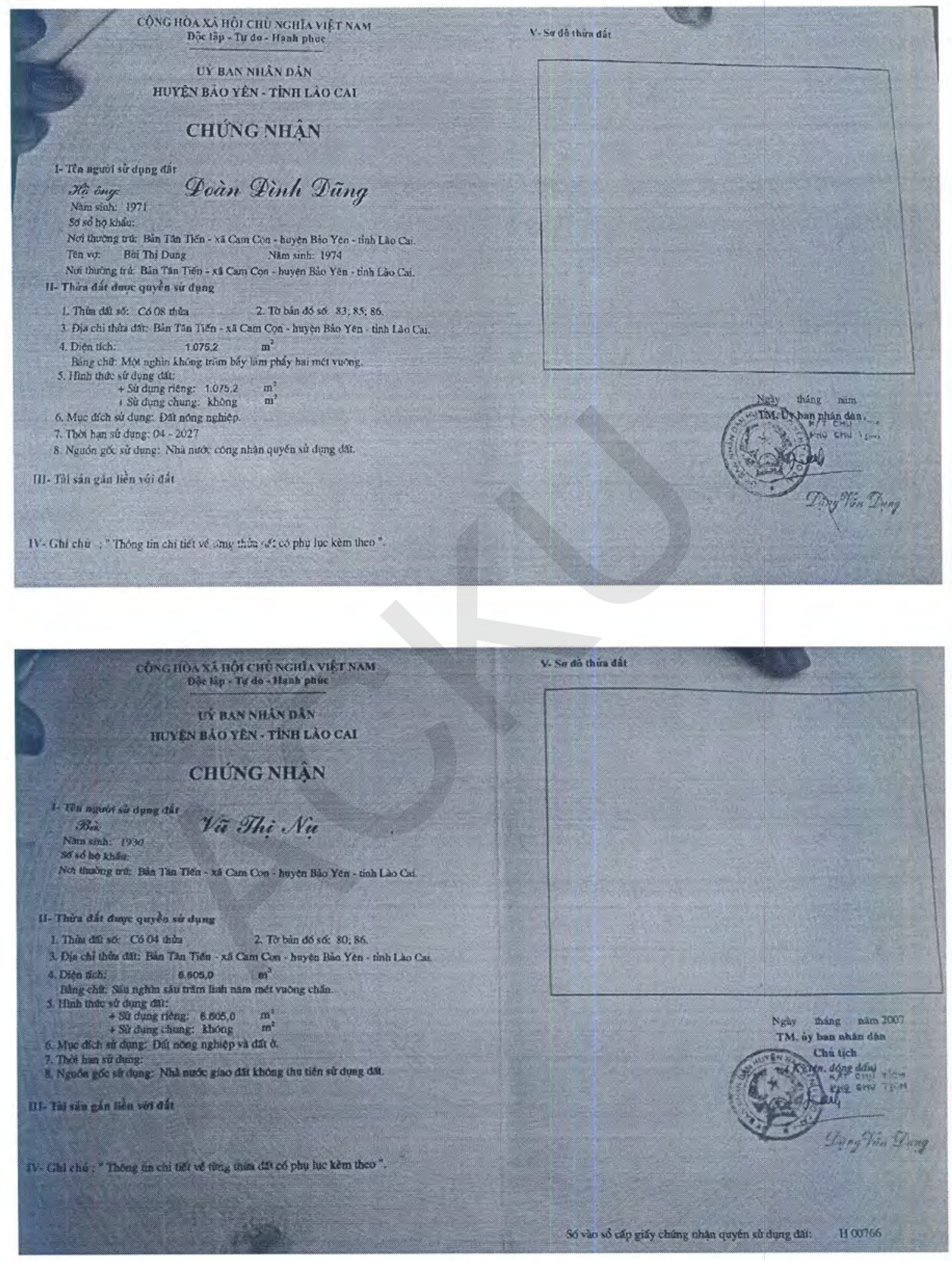

VP điều hành: Km 200+800, đường cao tốc Nội Bài-Lào Cai,

Thôn Tôm Chúc, xã Tân Thượng, huyện Văn Bàn, tỉnh Lào Cai.

ĐT: 020-3799137. Fax: 020- 3799128; ĐTDĐ: 0919434378 \& 0903119968 Email: nblca7@163.com 
BẢN TÂN TIẾN

Số: 01/TTr
CộNG HÒA XÃ HỘI CHỦ NGHÍA VIẸT NAM

Độc lập - Tự do - Hạph Phúc

Tân Tiên, ngày 06 tháng 01 năm 2013

\section{Tờ TRÌnH}

V/v xin đắp đất chống sạt lở ven sông Hồng cho bãi mầu

Kính gửi: - UBND xã Cam Cọn

- Phòng Tài nguyên môi trường huyện Bào Yên

Căn cứ vào tình trạng sạt lở ven sông khu vực đất trồng cây hằng năm của bản Tân Tiến.Trong những năm qua do việc khai thác khoáng sàn trái phép đã làm thay đồi dòng chảy của sông Hồng thuộc địa phận bản Tân Tiến. Diện tích canh tác có nguy cơ bị sạt lờ hoàn toàn khoảng 15 ha chuyên canh các loại cây ngắn ngày như: ngô, đỗ ... và các loại hoa mầu khác là nơi tạo ra sản phầm chính phục vụ chăn nuôi phát triển kinh tế gia đình của bản .

Hiện tại đã lở gần hết khu vực ven sông đang lấn dần vào đất canh tác của dân trong bản. Qua đề nghị và nguyện vọng cua các hộ dân có đất ở ven sông đang rất lo lắng và đề nghị với bản cho đắp một con đê chống sạt lở bảo vệ diện tích đất canh tác.

Nay bản Tân Tiến chúng tôi làm tờ trình đề nghị UBND xã Cam Cọn, phòng Tài nguyên \& Môi trường huyện Bảo Yên, cho phép bàn chúnq tôi được đắp một con đất chống sạt lở để bảo vệ đất canh tác hiện có.

Nhân dân bản Tân Tiến chúng tôi rẩt mong được sự quan tâm tạo điểu kiện giúp đỡ của các cơ quan cấp trên để chúng tôi yên tâm lao động sằn xuát.

\section{TM. NHÂN DÂN BAN TTAN TIEN}

Đoàn Đình Däng 


\begin{tabular}{|l|r|}
\hline $\begin{array}{l}\text { TAN TIEN MOUNTAIN VILLAGE } \\
\text { No. } / 2013 / \text { BB-A7-11 }\end{array}$ & $\begin{array}{r}\text { SOCIALIST REPUBLIC OF VIETNAM } \\
\text { Independence - Freedom - Happiness } \\
\text { T............ }\end{array}$ \\
& TanTien, Januapy 06, 2013 \\
\hline
\end{tabular}

\section{THE LETTER OF REPRESENTATION}

Subject: Applying to embank soil to prevent collapse along Red River for farm land

To: - Com Con Commune People's Committee

- Bao Yen Department of Natural Resource and Environment

Based on the collapse situation along Red River of Tan Tien Mountain Village's yearly cultivation land. In the past years, due to unauthorized mineral exploitation, it changed the flow of Red River under Tan Tien Mountain Village. Cultivation area is in front of risk of being completely collapsed of $15 \mathrm{ha}$ of cultivation land for planting trees such as: maize, bean... and other crop plants that create the main products to serve for breeding to help households to develop home economics.

Now it nearly collapses the whole area along the river, and it is gradually occupying the cultivation land of the people in the mountain village. The local people own the cultivation land along the river are worried about it, and they show aspiration and request to embank a dam to prevent collapse to protect cultivation land.

Now Our Tan Tien Mountain Village make the letter of representation with the reason to request Cam Con Commune People's Committee, Bao Yen Deparment of Natural Resource and Environment to allow us to embank a dam to prevent existing cultivation land.

We, the people of Tan Tien Mountain Village hope to get help and favorable condition creation from authorities at all level so that we keep our mind on our work.

ON THE BEHALF OF TAN TIEN'S PEOPLE signed

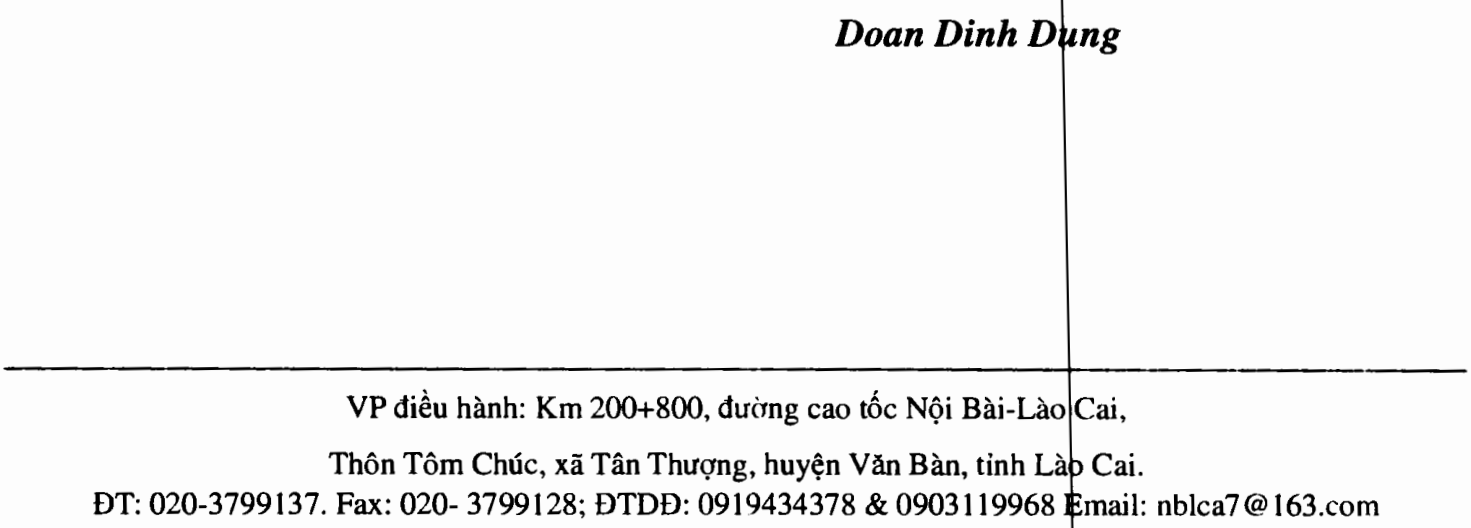




\title{
CÔNG TY Cp ĐÀU TU' VÀ XÂY DỨNG HẠ TÀNG ALPHANAM
}

\author{
Số : A A2/2012/DA \\ $\mathrm{V} / \mathrm{v}$ Đề xuất vị trí đồ đất thải, phục vụ thi \\ công gói thầu $\mathrm{A} 7, \mathrm{Lào} \mathrm{Cai}$
}

Hà Nọi, ngày 01 tháng 12 năm 2012

Kính gừi:

- Ùy ban nhân dân xã Cam Cọn;

- Phòng Tài nguyên Môi trường huyện Bảo Yên;

- Ủy ban nhân dân huyện Bảo Yên.

Công ty $\mathrm{CP}$ ĐT và XD HT ALPHANAM là một trong những nhà thẩu tham gia thi công gói thầu $\mathrm{A} 7$, dự án đường cao tốc Nội Bài - Lào Cai, phân độn $\mathrm{Km} 207+00$-:- $\mathrm{Km} 218+040$. Hiện nay khi công tác đẳp nền đường đã cơ bản hoàn thành, trền tuyến đường đoạn $\mathrm{Km}$ 209-:$\mathrm{Km} 210$ của chúng tôi thi công còn khoàng $200.000 \mathrm{~m} 3$ đất đào đổ thải chưa có vị trí đổ phù hợp.

Trong quá trình thi công tại vị trí trên, chúng tôi quan sát thấy hiện nay bãi trồng hoa màu của bản Tân Tiến - xã Cam Cọn nằm ven Sông Hồng đang sạt lỡ rất nghiêm trọng do hiện tượng xâm thực của dòng chảy Sông Hồng. Thiết nghĩ nếu không cỏ giài pháp ngăn chặn hiện tượng trên, rất có thể trong mùa lũ tới hiện tượng sạt lỡ tiếp tục diễn ra thì toàn bộ diện tích dầt trồng hoa màu của bản Tân Tiến sẽ bị ảnh hương nghiêm trọng, điều đó sẽ gây ảnh hưởng không nhỏ đến đời sống nhân dân khu vực trên.

Sau khi phân tích, đánh giá tình hình chung giữa nhu cầu phục vụ công tác thi công của chúng tôi, biện pháp ngăn chặn hiện tượng sạt lỡ bờ sông của bản Tân Tiến. Chúng tôi đề xuất phương án đề nghị chính quyền địa phương xem xét và để xuất các cấp có thầm quyền cho phép chúng tôi thực hiện như sau:

- Chúng tôi sẽ làm đường công vụ chạy dọc bờ sông đến khu vực sạt lỡ. Toàn bộ khối lượng đất đào thuộc đoạn chúng tồi thi công $\mathrm{Km} 209-:-\mathrm{Km} 210$ sẻ được vận chuyển đến đắp san ủi lu lèn thành đê quai bao bọc khu vực sạt lỡ đó.

- Đường công vụ phục vụ trong quá trình vận chuyển đất sau khi chúng tôi không còn sử dựng sẽ được sửa sang hoàn chỉnh để trở thành con đường phục vụ nhân dân trong việc sản xuât nông nghiệp của khu vực đó.

- Nếu được chấp thuận chủng tôi cam kêt sex không làm ảnh hương đền môi trường ự nhiên, không làm ảnh hường hay hư hại đến diện tích hoa màu cưa nhẩn dàn gieo vờng và chịu chi phi toàn bộ cho công việc trên.

Vì vậy để tạo điều kiện thuận lợi cho chúng tôi đẩy nhanh tiến độ thi công công trinh, đồng thời cưng để bảo vę̣ đất đai của địa phương qua việc ngăán chặn hiện tượng sạt lỡ bờ sông. Kính đề nghị chinh quyển địa phương chấp thuận và đề xuất các cấp có thẩm quyền cho phép chúng tôi thưc hię̂n theo phương án trên.

Rất mong nhận được sự quan tâm giúp đỡ của chính quyền địa phương.

Xin trân trọng cảm ơn ./.

Nơi nhận :

- Nhu kính gữi;

- Mr Hải CV;

- Lư: BDH A7.

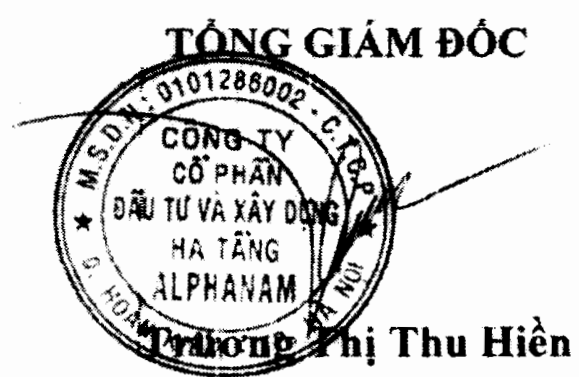




\section{ALPHANALTransport \\ ALPHANAM INFRASTRUCTURE CONSTRUCTION AND INVESTMENT JSC \\ No: $112 / 2012 / D A$ \\ Subject: Propose disposal area, serving for construction \\ of Package A7, Lao Cai}

To:

- Com Con Commune People's Committee

- Bao Yen Department of Natural Resource and Environment

- Bao Yen District People's Committee

During construction at the above position, We realize that now the farm land of Tan Tien Montain Village - Cam Con Comnune along Red River is being seriously collapsed because of erosion of Red River flow. We should think that if it has not the above phenomemon prevention method, the collpase is likely to continue to happen in the next flood season, and the total farm land area of Tan Tien Mountain Village will be seriously affected, this will affect largely to the above region the people's life.

ALPHANAM Infrastructure Construction and Investment JSC is one of units taking part in constructing Package A7- Noi Bai - Lao Cai Highway Project, station Km207+00 $\mathrm{Km} 218+040$. Now the roadbed embankment is basicly finished, on the route of section $\mathrm{Km} 209-210$, it remains more than $200.000 \mathrm{~m} 3$ of spoil without any suitable disposal site.

After analyzing, evaluating general situation of serve demand for our construction of construction unit, collapse prevention method of river bank under Tan Tien Mountain Village and construction unit. We kindly request the local goverment to consider and propose authorities at all levels allow to do as follows:

- We will build the service road along red river to collapse area. The total of excation soil quantity of section $\mathrm{Km} 209-\mathrm{Km} 210$ will be transported to embank compaction turning into coffer-dam to surround the collapse area.

- The service road for transporting soil, after not being used by us, it will be completely repaired to turn into the road serving farmers in agricultural production of the area.

- If it is approved. We commit that we will not affect environment or damage to cultivation area of the local people and bear all cost of the aboye work.

- Therefore, in order to creat favorable conditions for us to speed up construction progress as well as protect land of the local peole by preventing collapse of river bank. We kindly request the local goverment to approve and propose authorities at all levels to allow us to carry out as the above method.

We hope to get help from the local government

Your truly,

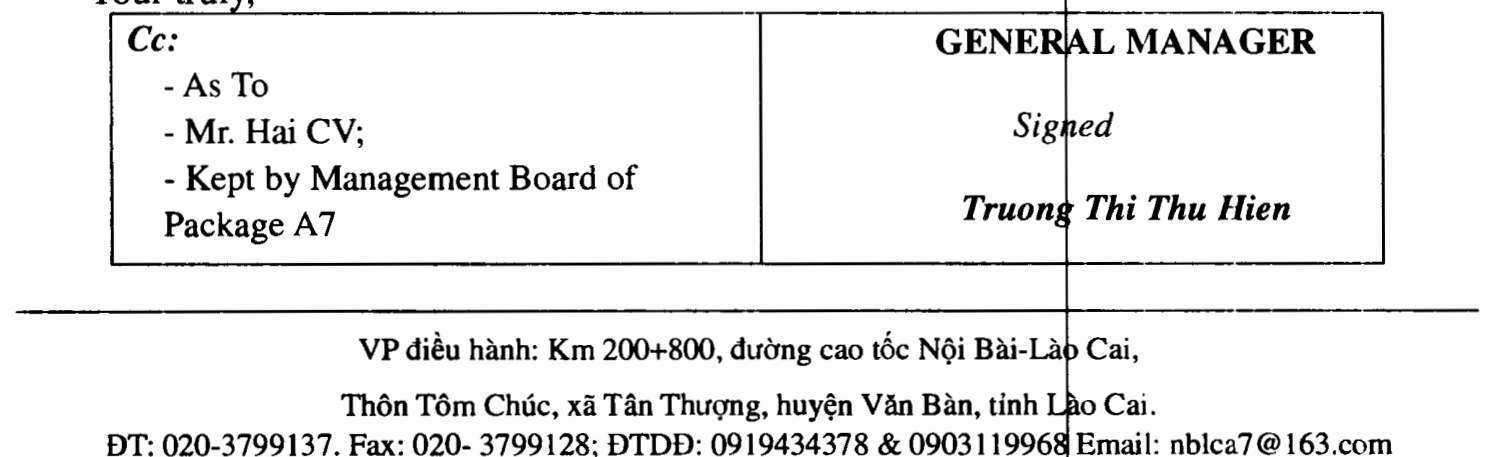

ĐT: 020-3799137. Fax: 020- 3799128; ĐTDĐ: 0919434378 \& 0903119968 Email: nblca7@ 163.com 
ĐOC L IP - TU DO - HANH PHÚC

$* * * * * * * * * * * * *$

Kinh gửi: UBND Huyện Bảo Yên

Cam Cọn: ngay 08 thàng 1 năm 2013

Phòng Tài Nguyên Môi Trường Huyẹn Bảo Yèn

- Căn cứ công văn Số 112/2012/DA của Công ty CP ĐT và XDHT ALPHANAM.

- Căn cứ Tờ trinh về việc thống nhất biện pháp chống sạt lỡ bờ sóng của Bản Tân Tiến - Xã Cam Cọn - Huyện Bảo Yên

- Căn cứ hiện trạng thực tể sạt lỡ bãi trồng hoa màu của Bản Tân Tiên

Chúng tôi nhận thây, hiện nay bãi trồng hoa màu của bản Tân Tiến - Xã Cam Cọn nằm ven Sông Hồng đang sạt lỡ rất nghiêm trọng dọ hiện tượng xâm thực của dòng chảy Sông Hồng. Thiết nghĩ nếu không có giải phảp ngăn chặn hiện tượng trên, rất có thể trong mùa lũ tới hiện tượng sạt lở tiếp tục diễn ra thi toàn bộ diện tich đất trồng hoa màu của bản Tân Tiến sẽ bị ảnh hưởng nghiêm trọng, điều đó sẽ gây ảnh hưởng không nhỏ đên đời sống nhân dân khu vực trên.

Công ty CP ĐT và XDHT ALPHANAM là một trong nhứng đơn vị tham gia thi công gói thâu A7 dự án đường cao tốc Nội Bài - Lào Ca. phân đoạn Km207+00 -:$\mathrm{Km} 218+040$. Hiện nay khi công tác đắp nền đường đã $c o ̛$ bản hoàn thành, trên tuyến đường đoạn $\mathrm{Km} 209-:-\mathrm{Km} 210$ còn khoảng trên $200.000 \mathrm{~m} 3$ đát đào đỗ thải chưa có vị tri đồ phù hợp.

Sau khi phân tích, đánh giá tình hình chung giữa nhu cầu phục vụ công tác thi công của đơn vị thi công, biện pháp ngăn chặn hiện tượng sạt lờ bờ sông của Bản Tân Tiến và đơn vị thi công. Chúng tôi đề nghị các cấp xem xét cho phép đơn vị thi công thực hiện:

- Cho phép Đơn vị thi công làm đường công vụ chạy dọc bờ sông đến khu vực sạt 10̛̃. Toàn bộ khối lượng đất đào thuộc đoạn thi công $\mathrm{Km} 2009--\mathrm{Km} 210$ sẽ được vận chuyển đến đắp san ủi lu lèn thành đê quai bao bọc khu vupc sạt lở đó.

- Mọi chi phí làm đường, chi phi đền bù đất đai hoa mãu cho nhân dán (nếu có) do Đơn vị thi công chi trả

- Đường công vụ phục vụ trong quá trình vận chuyền đất sau khi đơn vị thi công không còn sử dụng sẽ được sứa sang hoàn chỉnh để trớ thành con đường phục vụ nhân dân trong việc sản xuất nông nghiệp của khu vực đo

- Chúng tôi sẽ giám sát Đơn vị thi công không được làm ảnh hướng đến môi trường tự nhiên và không làm ảnh hưởng hay hư hại đến diện tích hoa màu của nhân dân gieo trồng.

Để tạo điều kiện thuận lợi cho đơn vị thi công đẩy nhanh tiến độ thi công cóng trình. Mặt khác cūng để bào vệ đát đai của địa phương qua việc ngăn chặn hiện tượng sạt lở bờ sông. Kính đề nghị các cấp có thẩm quyển xem xét chấp thuận cho phép Đơn vị thi công đường cao tốc thưc hię̣n theo phương án đề xuất.

Xin trân trọng cảm ơn.

THAY MÄT UBND XÃ CAM COQN
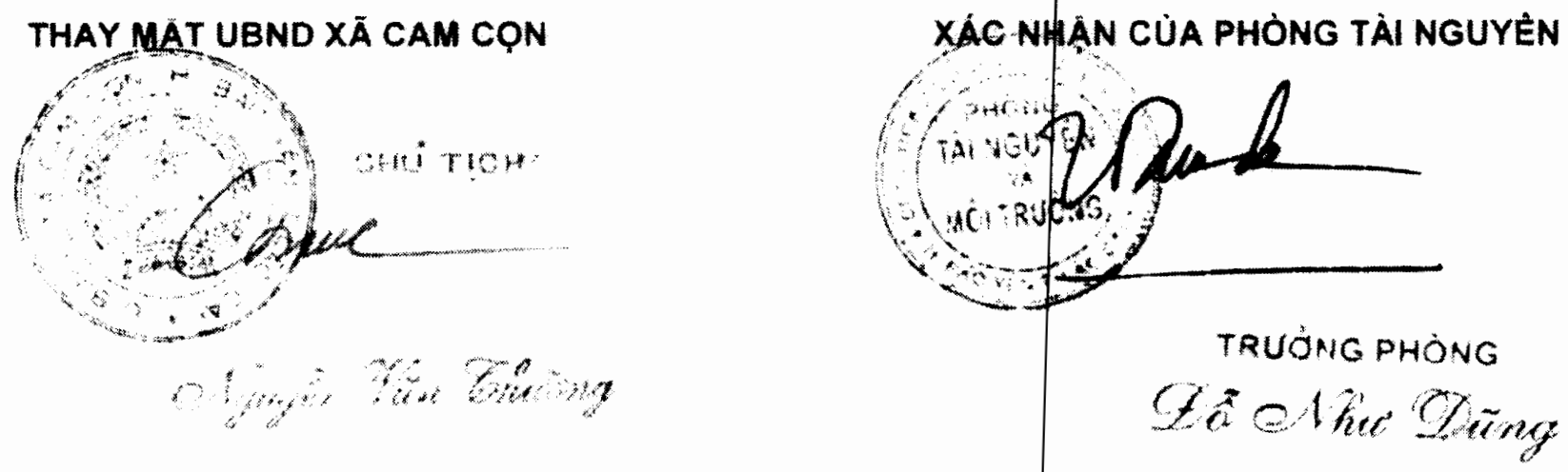


\section{SOCIALIST REPUBLIC OF VIETNAM \\ INDEPENDENCE- FREEDOM- HAPPINESS}

\section{To: Bao Yen District People's Committee}

Cam Con, January 08, 2013

Bao Yen Department of Natural Resource and Environment

- Based on the letter No112/2012/DA of ALPHANAM Infrastructure Construction and Investment JSC.

- Based on the letter of representation on agreeing with collapse prevention method of river bank of Tan Tien MountainVillage - Cam Con Commune - Bao Yen District

- Based on actual collapse status of farm land of Tan Tien Mountain Village

We realize that now the farm land of Tan Tien Montain Village - Cam Con Comnune along Red River is being seriously collapsed because of erosion of Red River flow. We should think that if it has not the above phenomemon prevention method, the collpase is likely to continue to happen in the next flood season, and the total farm land area of Tan Tien Mountain Village will be seriously affected, this will affect largely to the above region the people's life.

ALPHANAM Infrastructure Construction and Investment JSC is one of units taking part in constructing Package A7- Noi Bai - Lao Cai Highway Project, station Km207+00 - Km218+040. Now the roadbed embankment is basicly finished, on the route of section Km209-210, it remains more than $200.000 \mathrm{~m} 3$ of spoil without any suitable disposal site.

After analyzing, evaluating general situation of serve demand for construction of construction unit, collapse prevention method of river bank under Tan Tien Mountain Village and construction unit. We kindly request the goverment at all levels to consider and allow construction units to do:

- Allowing construction units to build the service road along red river to collapse area. The total of excation soil quantity of section $\mathrm{Km} 209-\mathrm{Km} 210$ will be transported to embank compaction turning into coffer-dam to surround the collapse area.

- All cost of buiding the road, farm land compensation for the people (if any) will be paid by constuction uits.

- The service road for transporting soil, after not being used by the unit construction, it will be completely repaired to turn into the road serving farmers in agricultural production of the area

- We will supervise the construction unit so that they would not affect environment or damage to cultivation area of the local people.

- In order to creat favorable conditions for the construction unit to speed up construhction progress. On the other hand, also protect the land of local people by preventing collapse phenomenon of river bank. We kindly request authorities at all leyels to consider for approval to allow construction unit to carry out as proposal method.

ON THE BEHALF OF CAM CON CUMMUNE PEOPLE'S COMMITTEE signed Chairman
Nguyen Van Thuong VERIFIED BY NATURAL
RESOURCE AND ENVIRONMENT
signed
qhief of Department
Do Nhu Dung

VP điều hành: Km 200+800, đường cao tốc Nội Bài-tào Cai,

Thôn Tôm Chúc, xã Tân Thượng, huyện Văn Bàn, tỉnh Lào Cai.

ĐT: 020-3799137. Fax: 020- 3799128; ĐTDĐ: 0919434378 \& 0903119968 Enail: nblca7@ $163 . c o m$ 


\section{CONG HOA XA HOU CHU NGHIA VIET NAM}

Pò lốp - Ty do - Hgah Pliúc

Cam Con, nyèy 25 thaing 9 nâm 2013

Biên bản xác định diện tich và sàn Jựnge

bị ảnh hưỡng do thi cồng đườn Cao tốc - Nọil Bải 1 ào Cai qua

dịa phận bản Tăn Tí́n xả Cam Cọn - Băo Vên 2013;

Căn cư thực lế ảnh hưởng cuia các hộ tại ban Tân Tiến ngày 25 thang 9 năm

I. Dại đię̣̂n đơn vị thi công.

1. Ong: Trịnh Vān Tho

Chíre vụ: Giám dốc dič̀u hanh Phát Đạt

II. Đại diện UBND xă

1. Ong: Nguyễn Vån Thường

Chức vu: Chú tịch UBND xà.

2. Bà: Trịnnh Thị Hiền

Chức vu: $C B$ Địa chinh xã.

III. Đại điện thôn bản.

1. Òng: Doàn Dinh Dũng

Chíc vu: Truơng ban

IV. Đai diện các hô bỉ ành hướng

1. Hộ ông: Đoàn Đinh Dũng

Tiến haình kiém tra hiện truòng tại vị tri đồ thâi cùa Công ty Phát Đạt tố cồng tảc củng kiền tra và thống nhất các họo liệt kể dưới đây bị ảnh hưởng (đất lơ làm thiệt hại một số diện tich ngô chuản bị thu hoạch vư mùa năm 2013).

Diện tich: $1.469,2 \times 0,7 \times 7.000 \times 70 \%=5.039 .000$ đồng

Biên bản đa đượ các bên kièmm tra tại hiện trương các vụ tiếp theo nểu ành hương đơn vị thi công có trách nhięm hơ trơ sân lượng theo vụ, san gạt mạ̃t bằng theo yêu cắu cho hộ gia đỉnl.

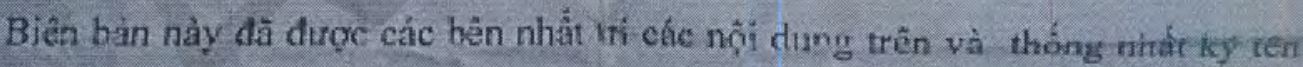
để làm căn cứ cho viẹcc hồ trợ sán lương sau này.

DD HO BAH

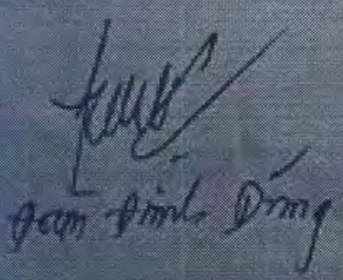

ĐD UBND XÃ

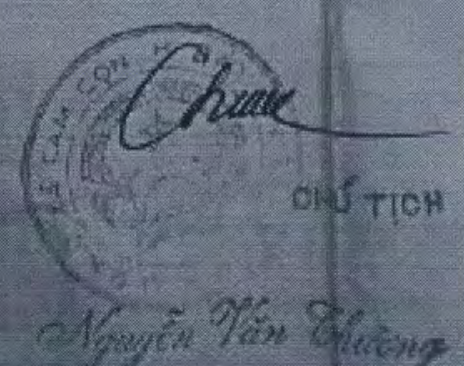

ĐD ĐON VỊ THI CÔNG
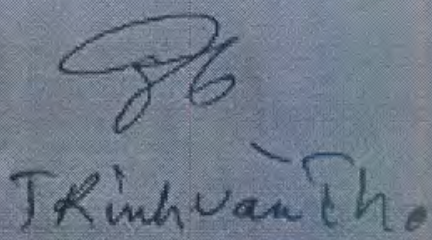

VP điều hành: Km 200+800, đường cao tốc Nội Bài-Lào Cai,

Thôn Tôm Chúc, xã Tân Thượng, huyện Văn Bàn, tỉnh Lào Cai.

ĐT: 020-3799137. Fax: 020- 3799128; ĐTDĐ: 0919434378 \& 0903119968 Email: nblca7@163.com 


\section{SOCIALIST REPUBLIC OF VIETNAM \\ Independence - Freedom - Happiness}

Cam Con, September 25, 2013

Minutes on considering affected area and yield due to construction of Noi Bai - Lao Cai Highway Project under Tan Tien Mountain Village - Cam Con Commune - Bao Yen District.

Based on the actual affect of households at Tan Tien Mountain Village on September 25, 2013

I. Representative of the construction unit

1. Mr. Trinh Van Tho Position: Executive director of Phat Dat Company

II. Representative of Commune People's Committee

1. Mr. Nguyen Van Thuong Position: Chairman of Commune People's Committee

2. Ms. Trinh Thi Hien Position: Land surveyor of Commune

\section{Representative of Mountain Village}
1. Mr. Doan Dinh Dung
Chief of Mountain Village

\section{Representative of affected households}

1. Household of Mr. Doan Dinh Dung

Carrying out site checking at disposal area of Phat Dat Company, work group checked and agreed to list the following affected households ( land erosion caused damage to maize area that would be harvested in crop of year 2013)

Area: $1,469.2 \times 0.7 \times 7,000 \times 70 \%=5,039,000 \mathrm{VND}$

The minutes were checked by other parties on the site is that if next crops are affected, the construction units will take responsibility for assisting crop yield, leveling resettlement as households' requirements

The above content of these minutes are agreed and signed by parties as basis for assisting yield in the future.

\begin{tabular}{|c|c|c|}
\hline $\begin{array}{c}\text { ON THE BEHALF OF } \\
\text { AFFECTED HOUSEHOLD }\end{array}$ & $\begin{array}{c}\text { ON THE BEHALF OF } \\
\text { COMMUNE PEOPLE'S } \\
\text { COMMITTEE } \\
\text { signed }\end{array}$ & $\begin{array}{c}\text { ON THE BEHALF OF } \\
\text { CONSTRUCTION UNIT }\end{array}$ \\
signed & signed \\
Doan Dinh Dung & Nguyen Van Thuong & Trinh Van Tho \\
\hline \multicolumn{2}{|c|}{ VP điều hành: Km 200+800, đường cao tốc Nội Bà-Lào Cai, } \\
Thôn Tôm Chúc, xã Tân Thượng, huỵ̣̂n Văn Bàn, tình Lào Cai. \\
ĐT: 020-3799137. Fax: 020- 3799128; ĐTDĐ: 0919434378 \& 0903119968 Email: nblca7@ 163.com
\end{tabular}




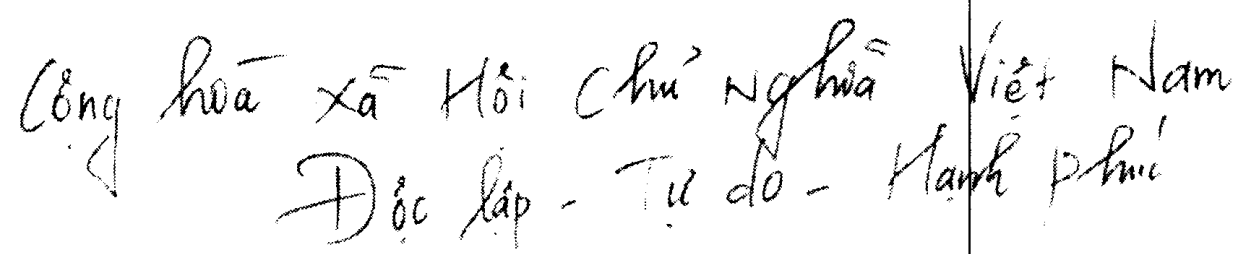

$$
\text { THUCAMON }
$$

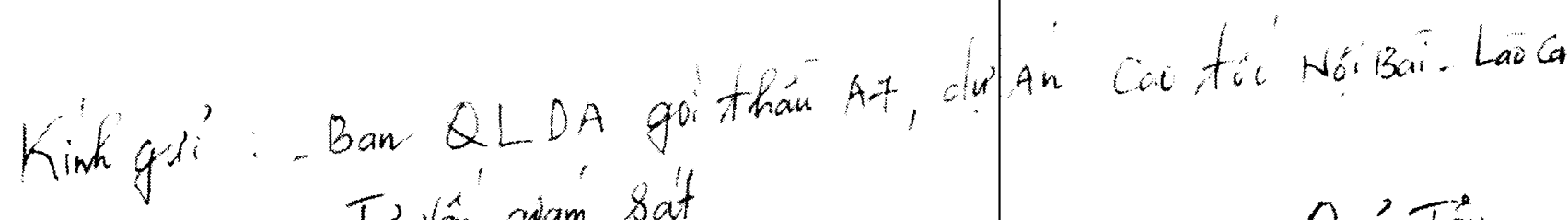

- Tre ván giam sát

- conyty TwHH phat Hat, cony ty TNHH Quara Tay Tén toi lā: Boan - Dinh Dung

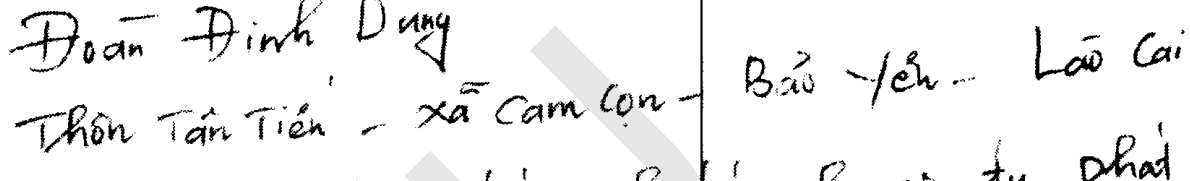

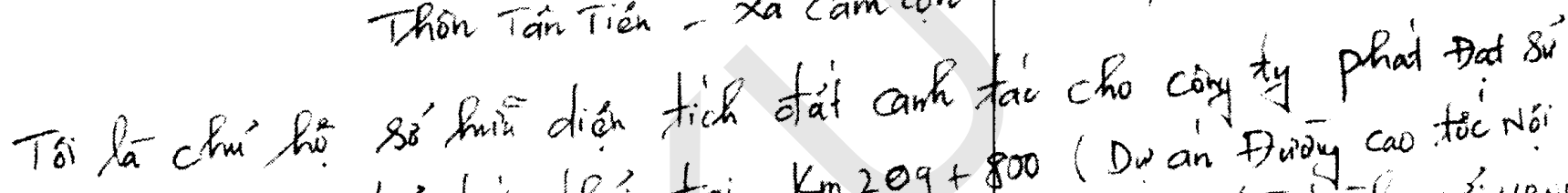

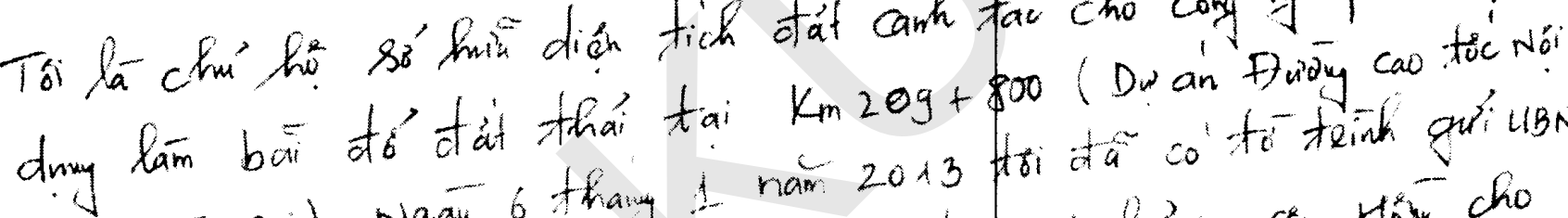

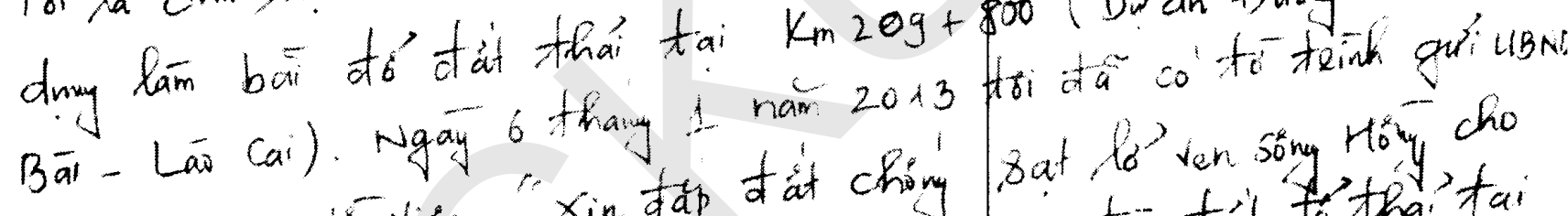

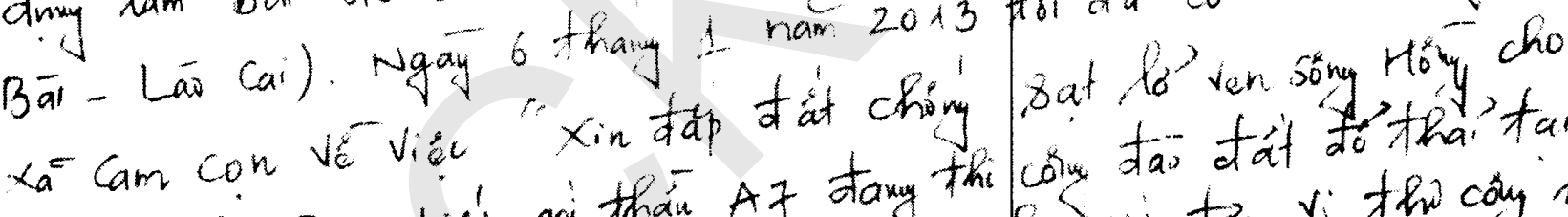

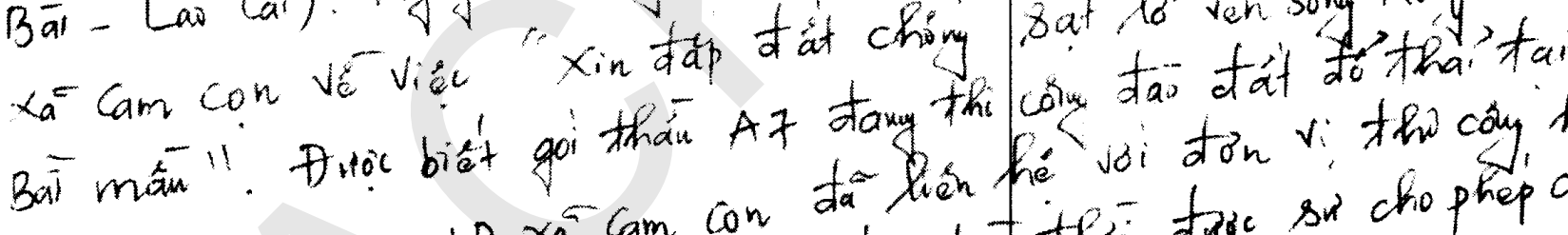

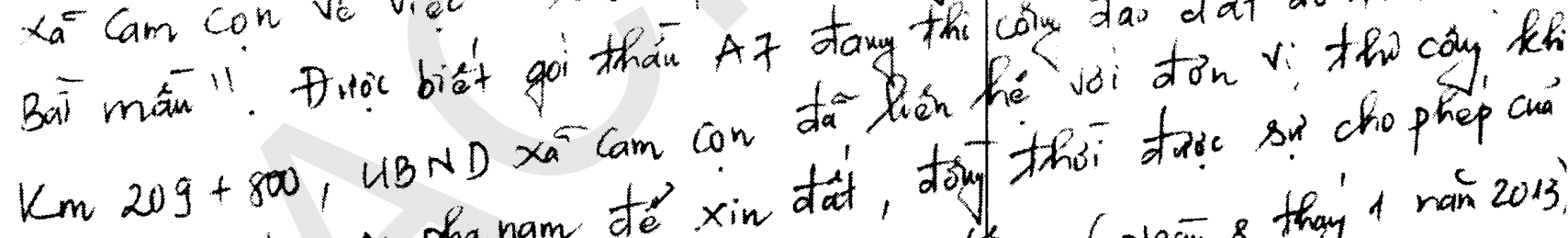

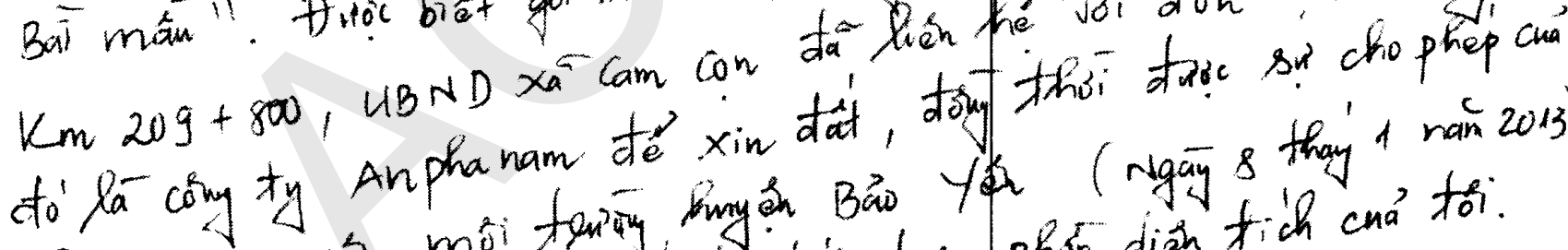

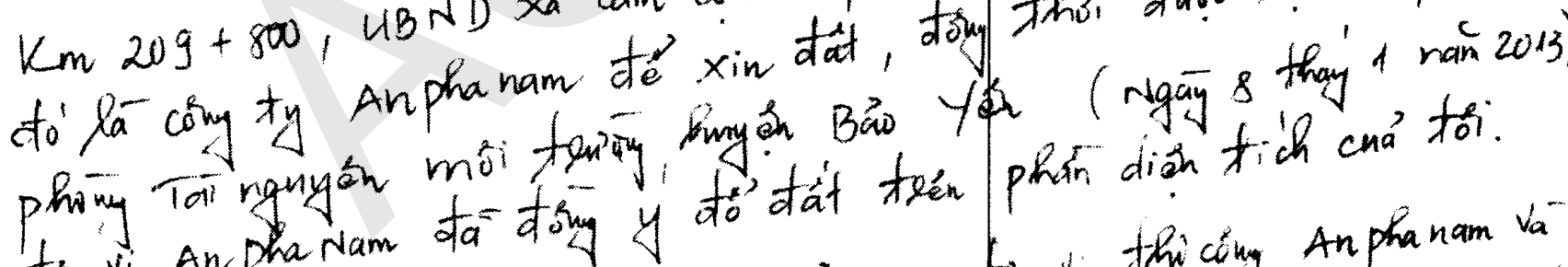

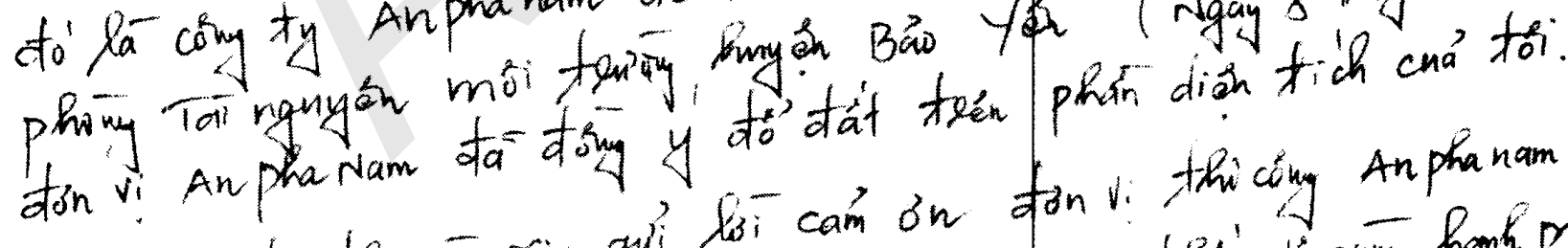

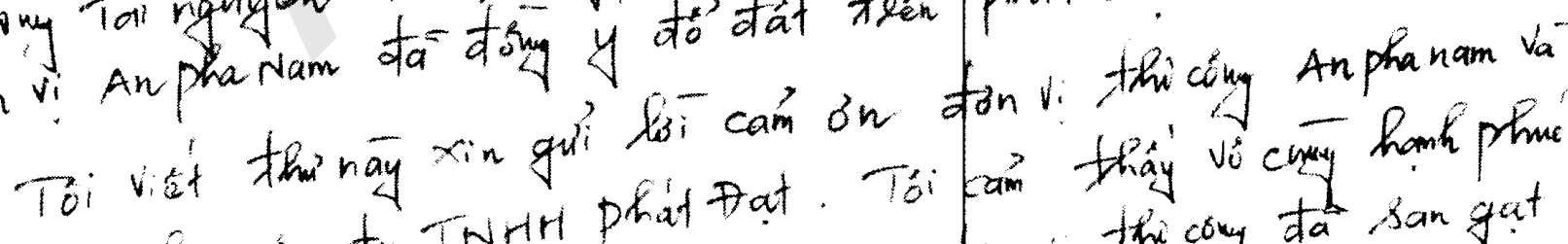

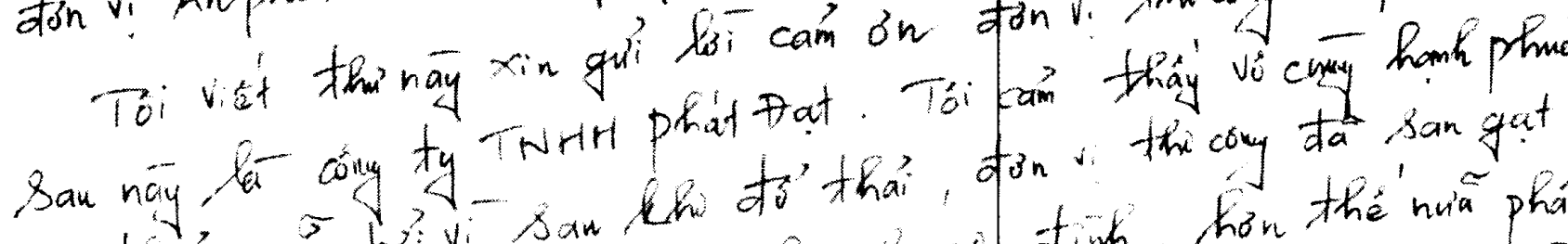

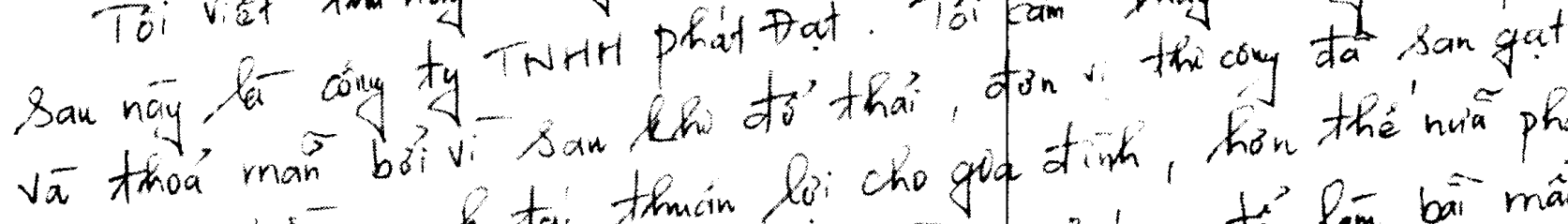

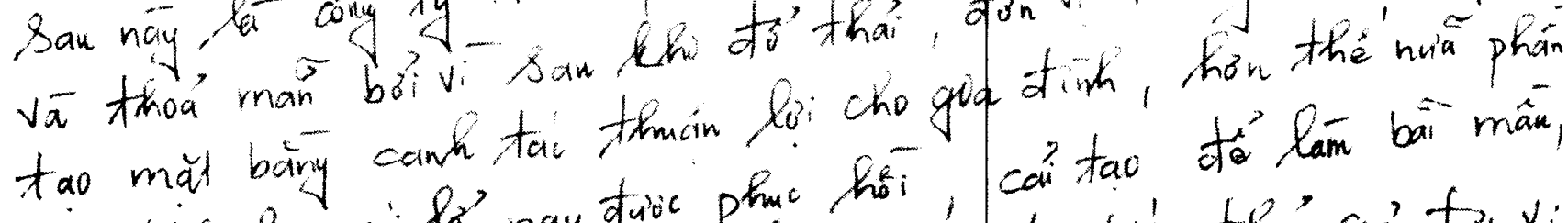

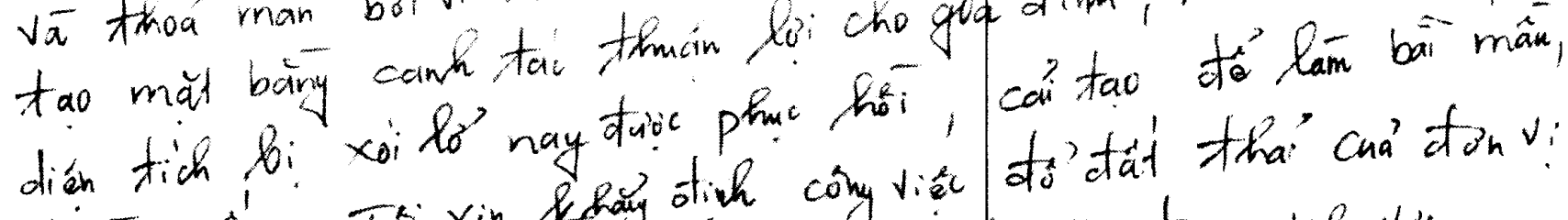

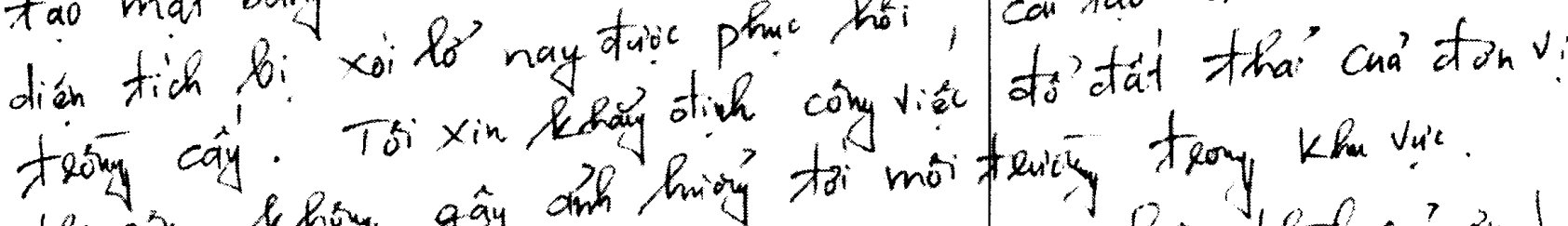

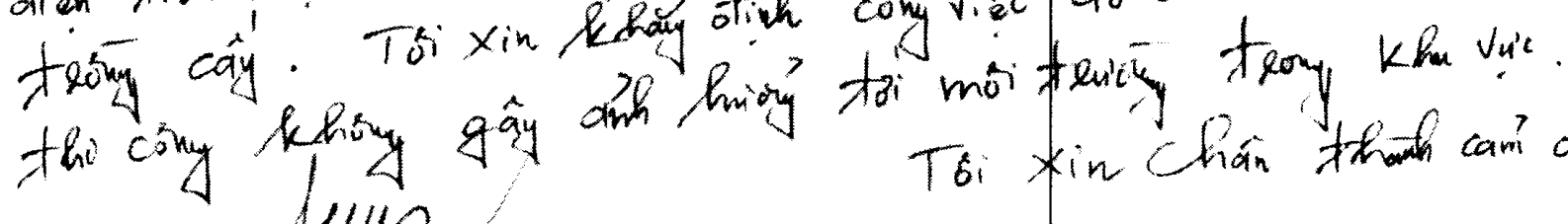

Toi xin Chain thath cam? on!

T)... D T R 


\section{SOCIALIST REPUBLIC OF VIETNAM \\ INDEPENDENCE - FREEDOM - HAPPINESS \\ THANKFUL LETTER \\ Phat Dat Co., Ltd, GuangXi Road and Bridge Construction Co.,Ltd}

To: Management Board of Package A7

Supervision Consultant

My full name: Doan Dinh Dung

My address: Tan Tien Hamlet - Cam Con Commune - Bao Yen District - Lao Cai Province.

I am the land owner with cultivation land area that allow Phat Dat Co.,LTd to use as disposal area at Km209+800 ( Noi Bai - Lao Cai Highway Project. On January 6, 2013, I submitted a letter of representation to Cam Con People's Committee on "Applying to embank soil to prevent erosion for cultivation land bank near Red River". As I know, the disposal excavation of package A7 is being constructed at Km209+800, Cam Con People's Committee contacted with Construction Unit who was Anphanam Company at that time to ask permission of supplying land, at the same time, it got permission from Bao Yen Department of Natural Resource and Environment on January 8, 2013, so Anphanam agreed to dump spoil on my land area.

By this letter, I would like to send my thanks to Anphanam Company and Phat Dat Company thereafter. I feel so happy and satisfactory because the construction units restored the plan after carrying disposal work, this created favorable condition for my family's cultivation, in addition, parts of eroded area are restored and they are improved to be cultivation land. I commit that dumping spoil in disposal site of construction units does not affect the regional environment

Your truly,

signed

Doan Dinh Dung

VP điều hành: Km 200+800, đường cao tốc Nội Bài-Lào Cai,

Thôn Tôm Chúc, xã Tân Thượng, huyện Văn Bàn, tỉnh Lào Cai.

ĐT: 020-3799137. Fax: 020- 3799128; ĐTDĐ: 0919434378 \& $09031199 \$ 8$ Email: nblca7@ 163.com 
III. DESCRIPTION DISPOSAL AREA AND THE SCHEDULE OF RESTORATION OF DISPOSAL AREA - MÔ TẢ KHU VỰC ĐỔ THẢI VÀ TIẾN Độ KHÔI PHỤC BÃI THẢI.

VP điều hành: Km 200+800, đường cao tốc Nội Bài-Lào Cai,

Thôn Tôm Chúc, xã Tân Thượng, huyện Văn Bàn, tỉnh L ho Cai.

ĐT: 020-3799137. Fax: 020- 3799128; ĐTDĐ: 0919434378 \& 0903119968|Email: nblca7@ 163.com 


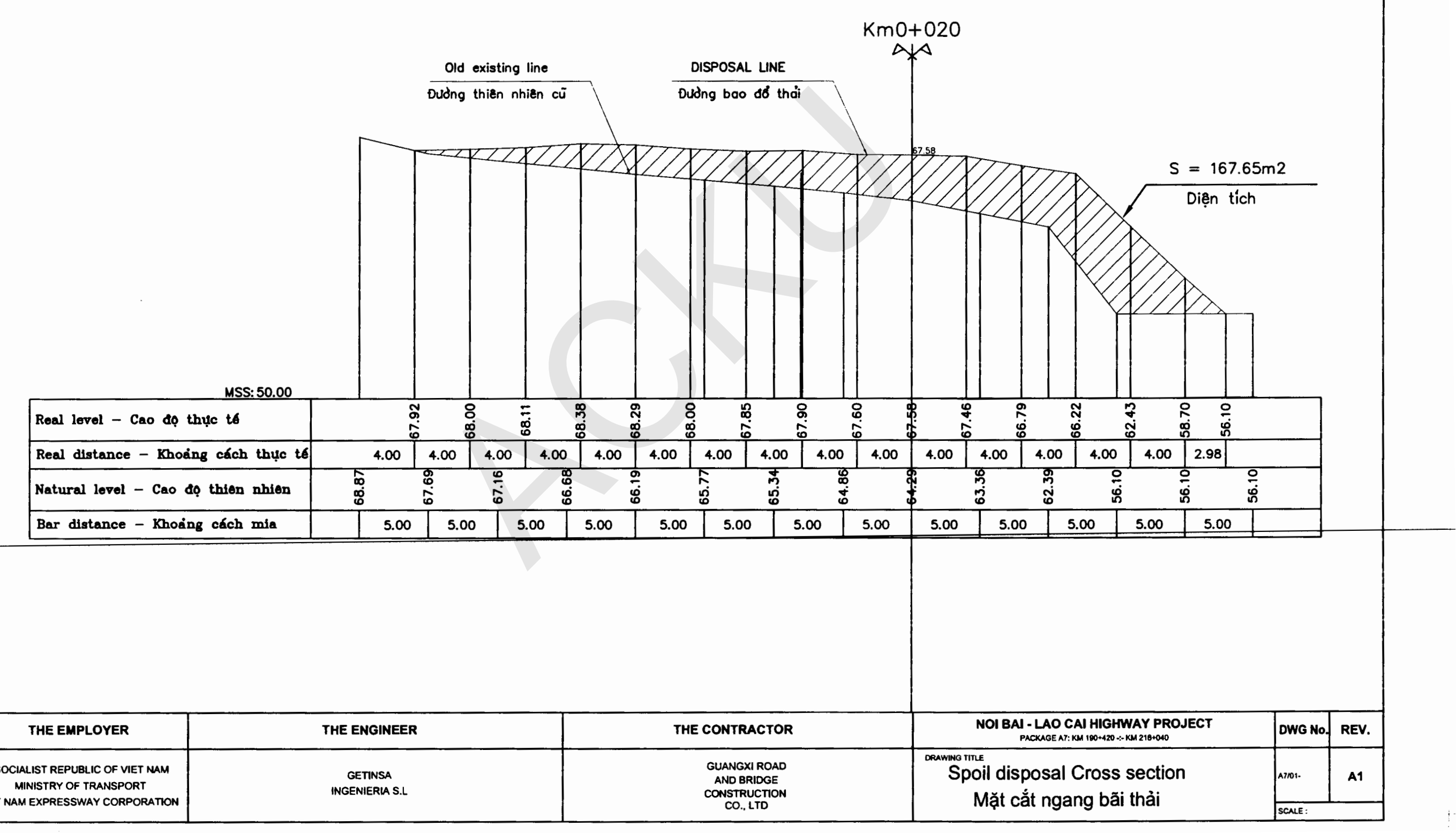




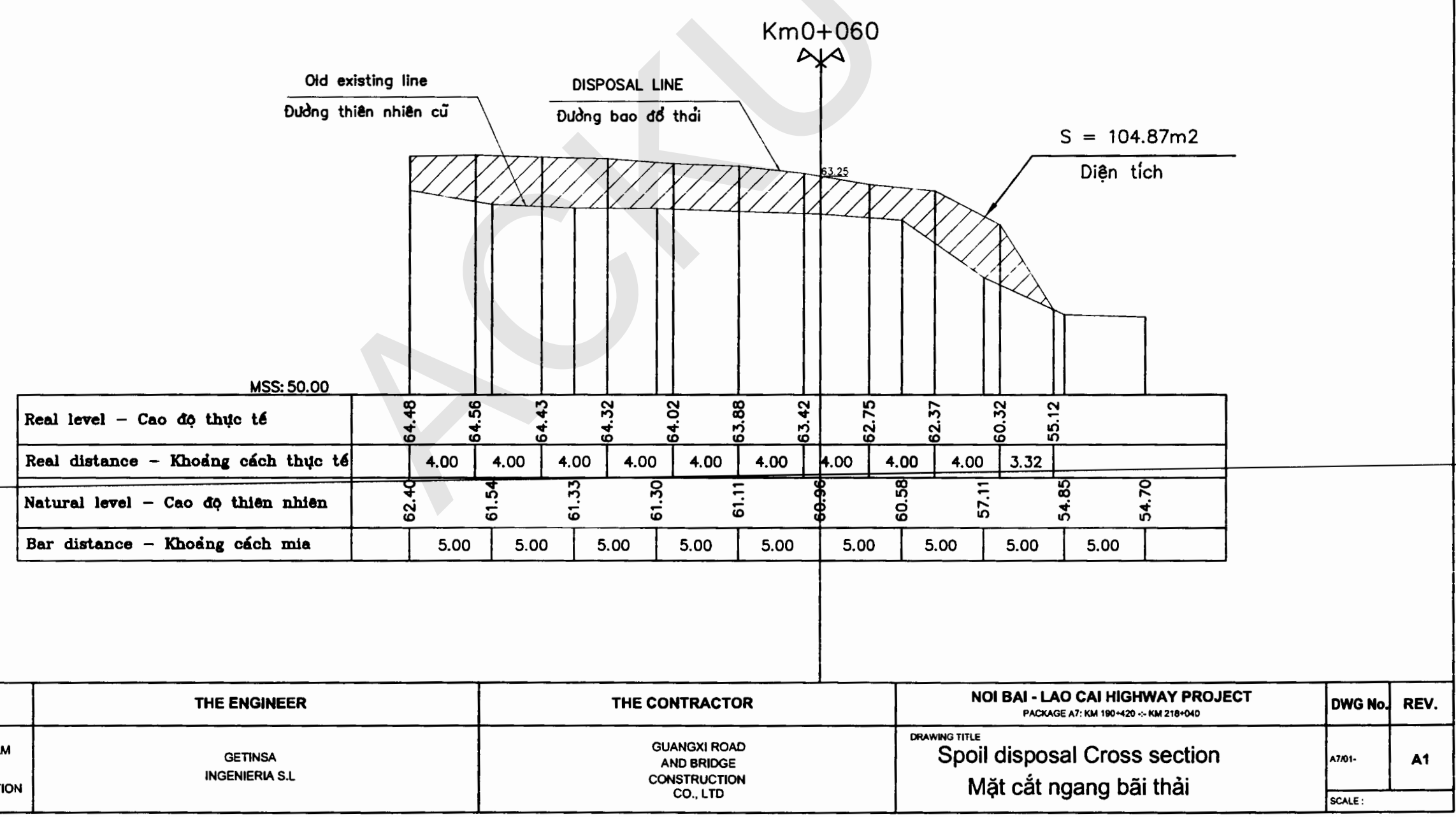




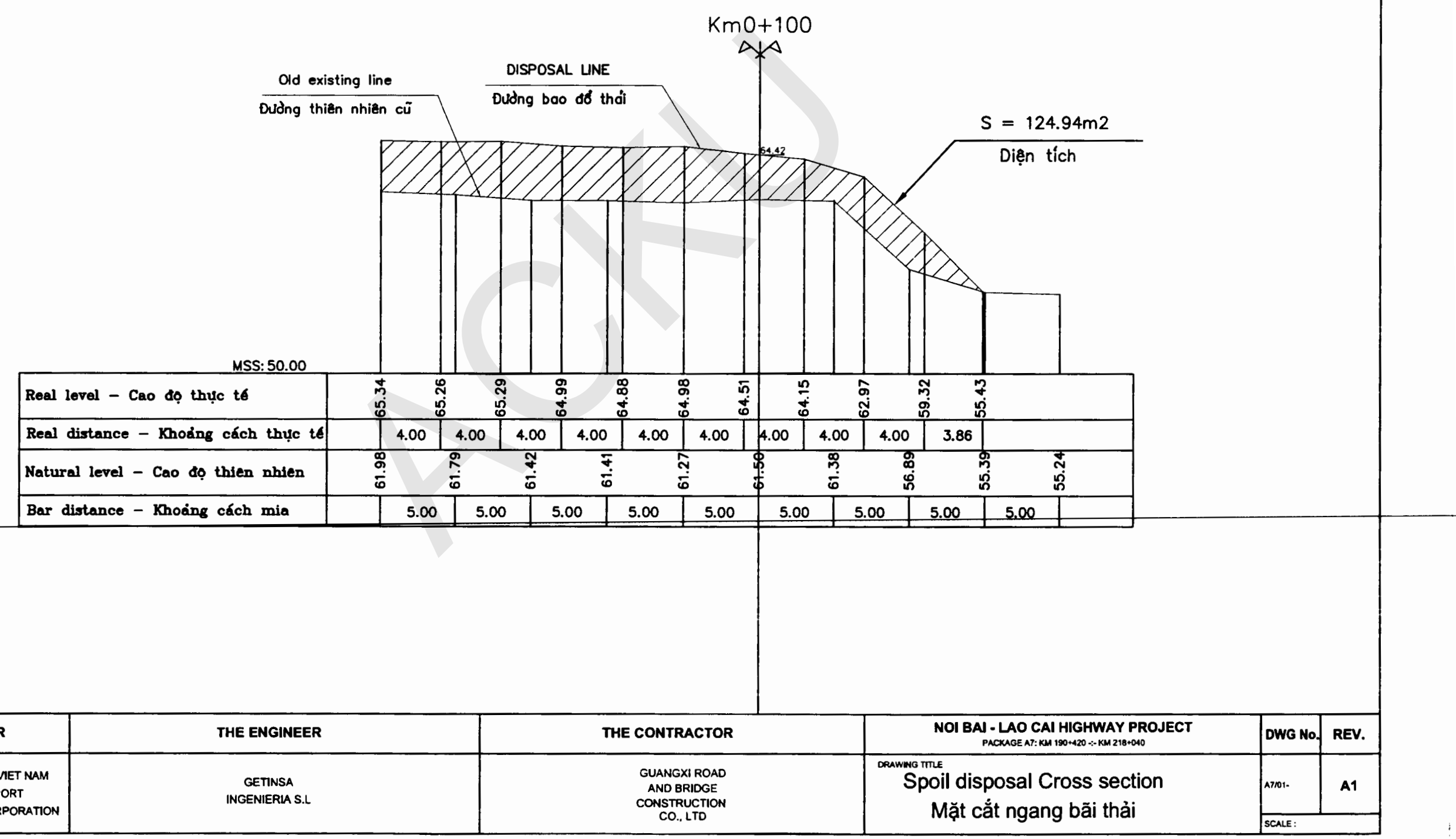




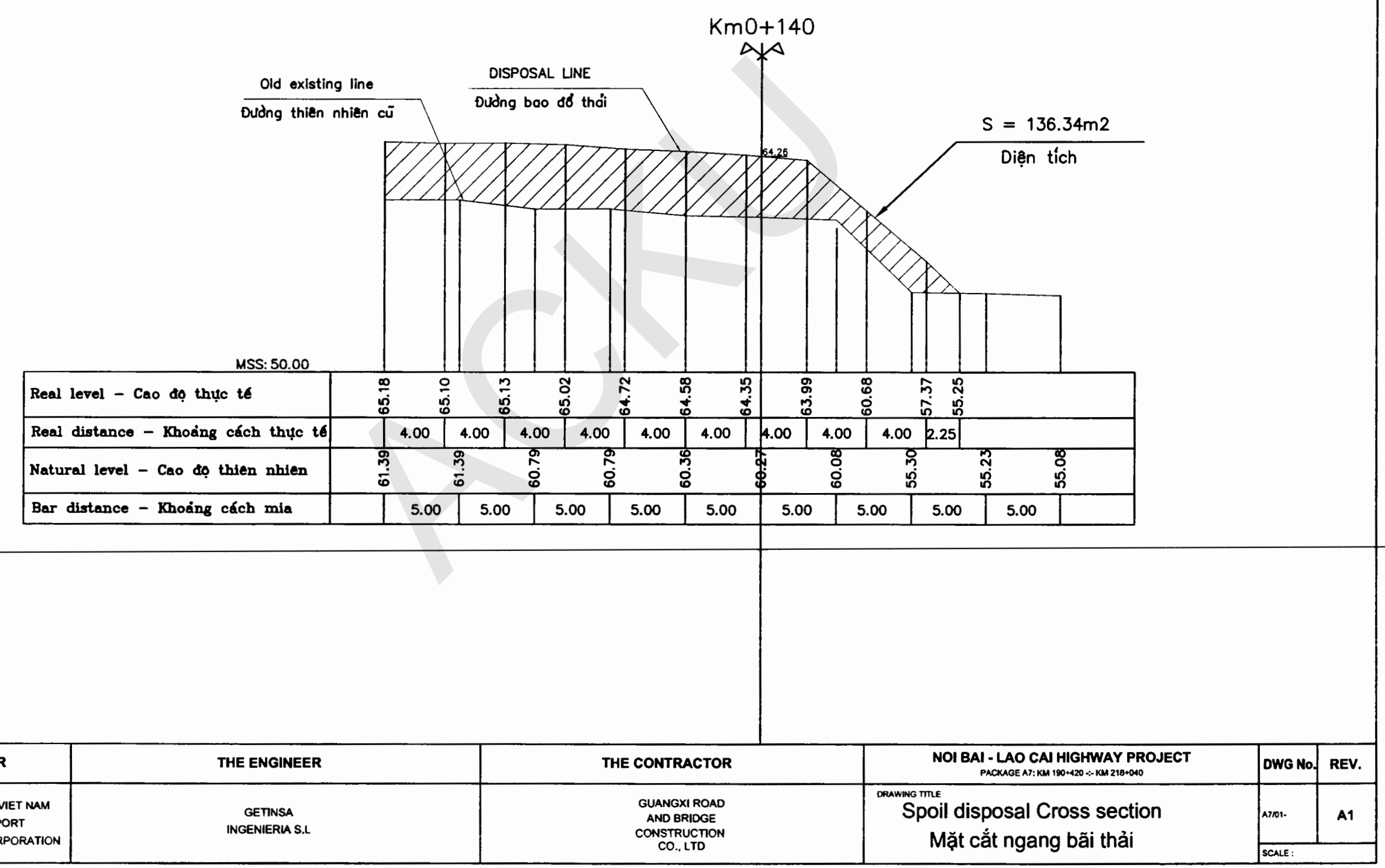




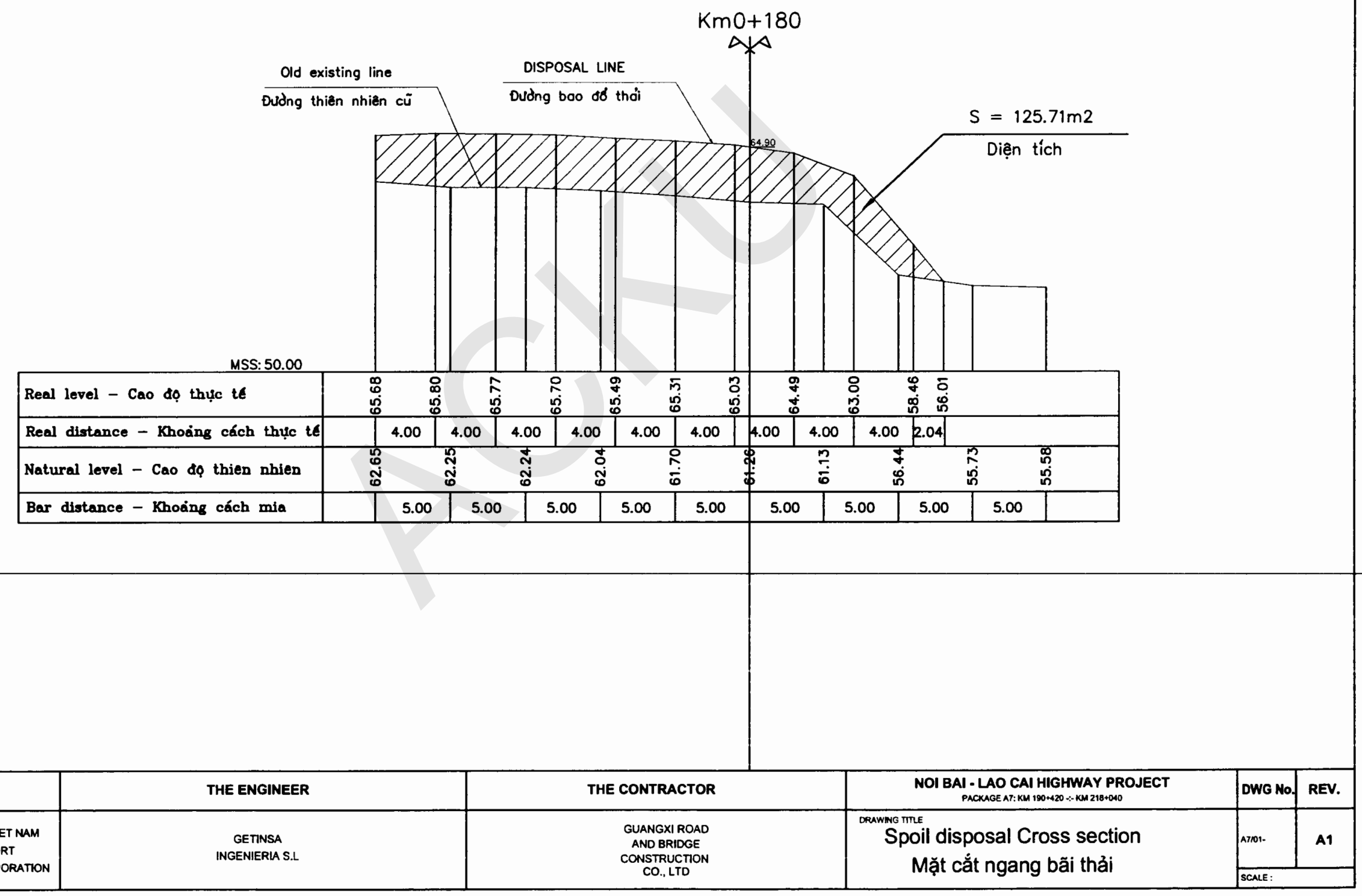




\section{CORRECTIVE MEASURES}

BIÊNN PHÁP KHÁC PHỤC

WORK EXECUTION STEPS

in step will be followed below steps:

1. Using excavators to claw make slope 1:1,5. Soil was got up

2. Bulldozer be used to plane the spoil disposal sites.

Các bước thự hię̣n công vię̣c

Các bước thực hiện công việc như sau :

Sư dụng máy xúc vuốt mải tạo độ dốc I: 1,5. Đất được đưa lên mất trèn của băi thài.

2. Sừ dụng máy ùi đẻ tạo mật bằng cho bẵi thải

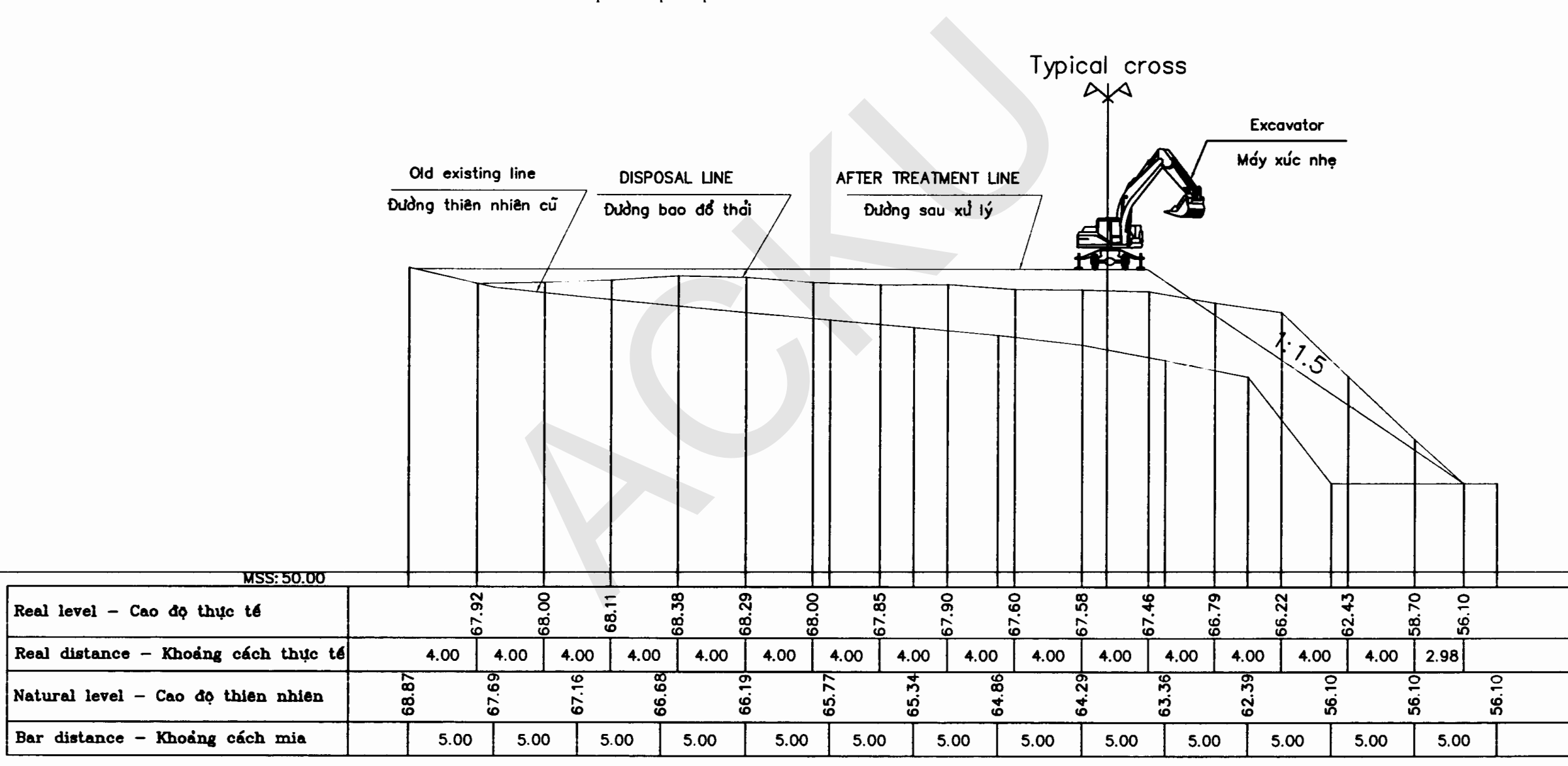

THE EMPLOYER

SOCIALIST REPUBLIC OF VET NAM

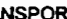
VIET NAM EXPRESSWAY CORPORATION
THE ENGINEER

INGENIERAA S.L
THE CONTRACTOR

GUANGXIROAD

CONSTRUCTION

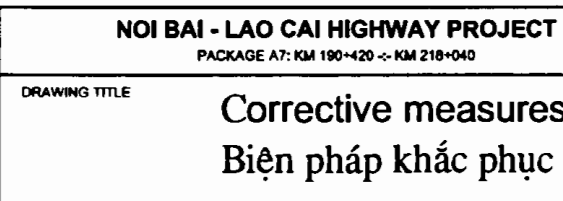

\begin{tabular}{|l|l|}
\hline DWG No. & REV. \\
\hline ATOS. & A1 \\
\hline SCME:
\end{tabular}




\section{BIỆN PHÁP KHẮC PHỤC}

Cultivated crops

Trờng cớy cóc log̣i hoo mày

\section{Typical cross}

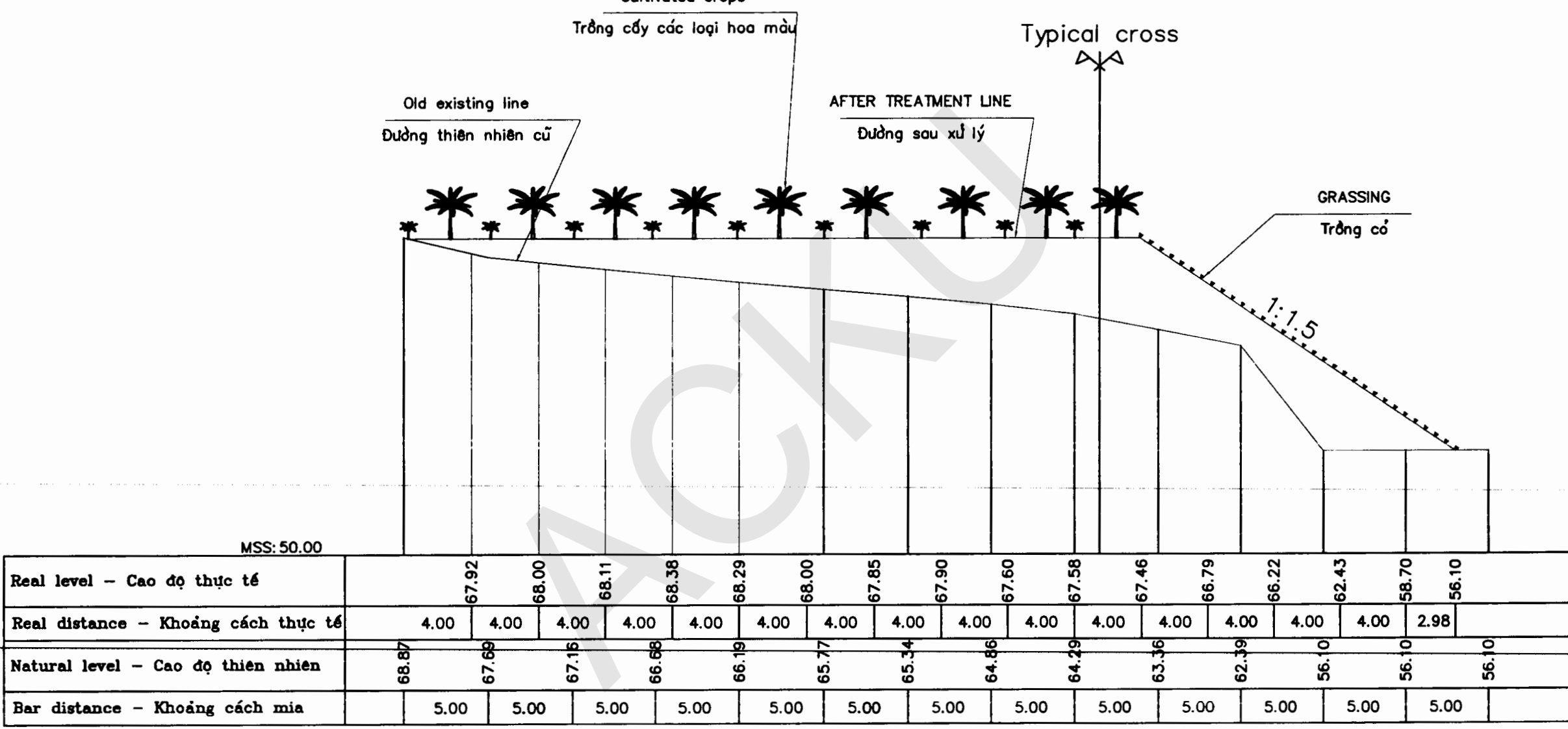

\begin{tabular}{|c|c|c|c|c|c|}
\hline THE EMPLOYER & THE ENGINEER & THE CONTRACTOR & $\begin{array}{l}\text { NOI BAI - LAO CAI HIGHWAY PROJECT } \\
\text { PACKAGE A7: KM } 1800+420 \div-\mathrm{KMM} 218+040\end{array}$ & DWG No. & REV. \\
\hline \multirow[t]{2}{*}{$\begin{array}{l}\text { SOCIALIST REPUBLIC OF VET MAM } \\
\text { MINISTRY OF TRANSPORT } \\
\text { VIET NAM EXPRESSWAY CORPORATION }\end{array}$} & \multirow[t]{2}{*}{$\begin{array}{l}\text { GETINSA } \\
\text { INGENIERIA S.L }\end{array}$} & \multirow[t]{2}{*}{$\begin{array}{l}\text { GUANGXIROAD } \\
\text { AND BRIDGE } \\
\text { CONSTRUCTION } \\
\text { CO.. LTD }\end{array}$} & \multirow[t]{2}{*}{$\begin{array}{l}\text { Typical Final situation } \\
\text { Tình huống cuôi điển hình }\end{array}$} & |A701- & A1 \\
\hline & & & & SCALE: & \\
\hline
\end{tabular}


NOI BAI - LAO CAI HIGHWAY PROJECT

PACKAGE A7 - SECTION - LOCATION KM0+000-KM0+200 (KM1209+800)

GÓI THAU A 7 - PHÂN ĐOAN - VI TRI KM0+000 -KM0+200 (KM209+800)

THE SCHEDULE OF RESTORA TION OF DISPOSAL AREA

TIÉN ĐỌ PHỤC HÒI ĐẢT THẢI TạI KHU VỰC ĐÓ THẢI

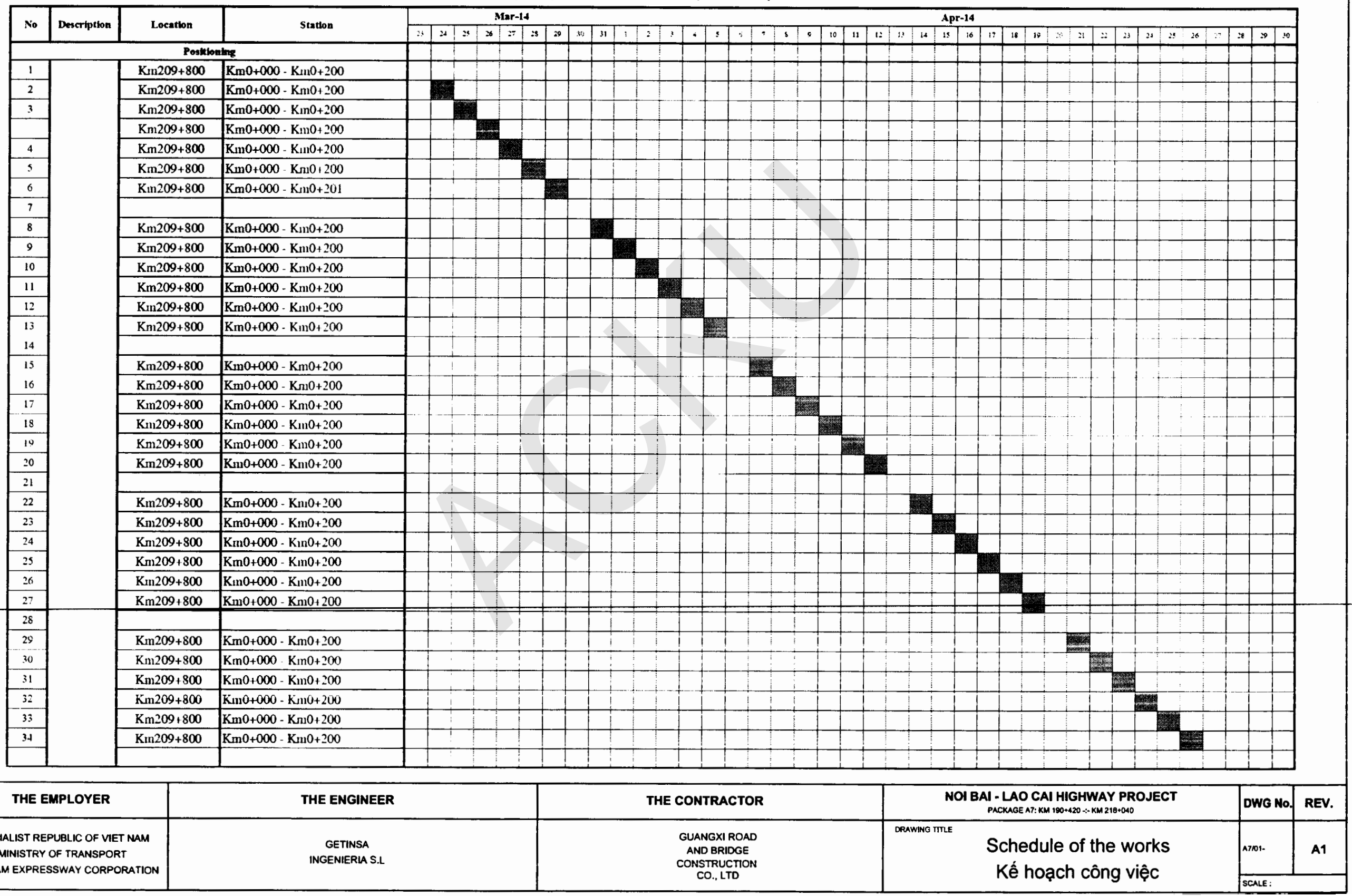


Loan 2391/2392 - VIE: GMS Kunming - Hai Phong Transport Corridor Noi Bai - Lao Cai Highway Project

\section{ANNEX 7: SLOPE PROTECTION AND RESTORATION PLAN AT STRETCH} KM 195+350 - KM 195+500. PACKAGE A7

$12^{\text {th }}$ floor, Ocean Park Building, Dao Duy Anh Street, Dong Da Distric Huu Thu Hamlet, Kim Long Ward, Tam Duong Distric, VinhPhuc Province Calle Ramón de Aguinaga 8, 28028 Madrid, Spain 
Loan 2391/2392 - VIE: GMS Kunming - Hai Phong Transport Corridor Noi Bai - Lao Cai Highway Project 
NOI BAI - LAO CAI HIGHWAY PROJECT DỰ ÁN ĐƯờnG CAO TỐC Nộl BÀl - LÀO CAI

PAGKAGE A7 / Gól THẪU A7: KM 190+420 - KM 218+040

PLANS TO PROCESS AND SLOPE PROTECTION AT SPOIL DISPOSAL AREA KẾ HOẠCH XỬ LÝ VÀ BẢO VÊ MÁl DỐC BÃI THẢI TẠI KHU VỰC BỔ THÁl SECTION: KM195+360-KM195+500 LÝ TRìH: KM195+360-KM195+500 


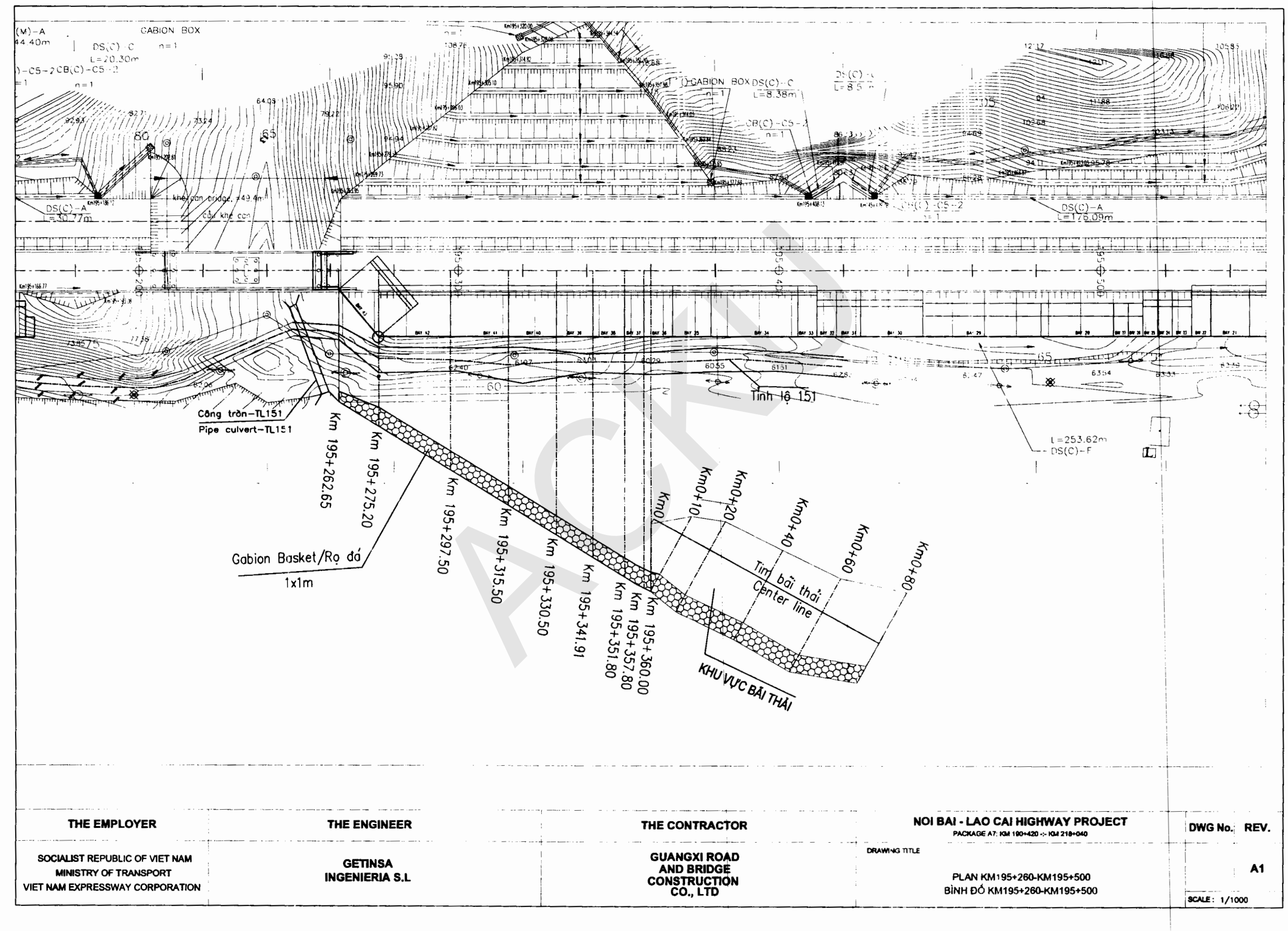




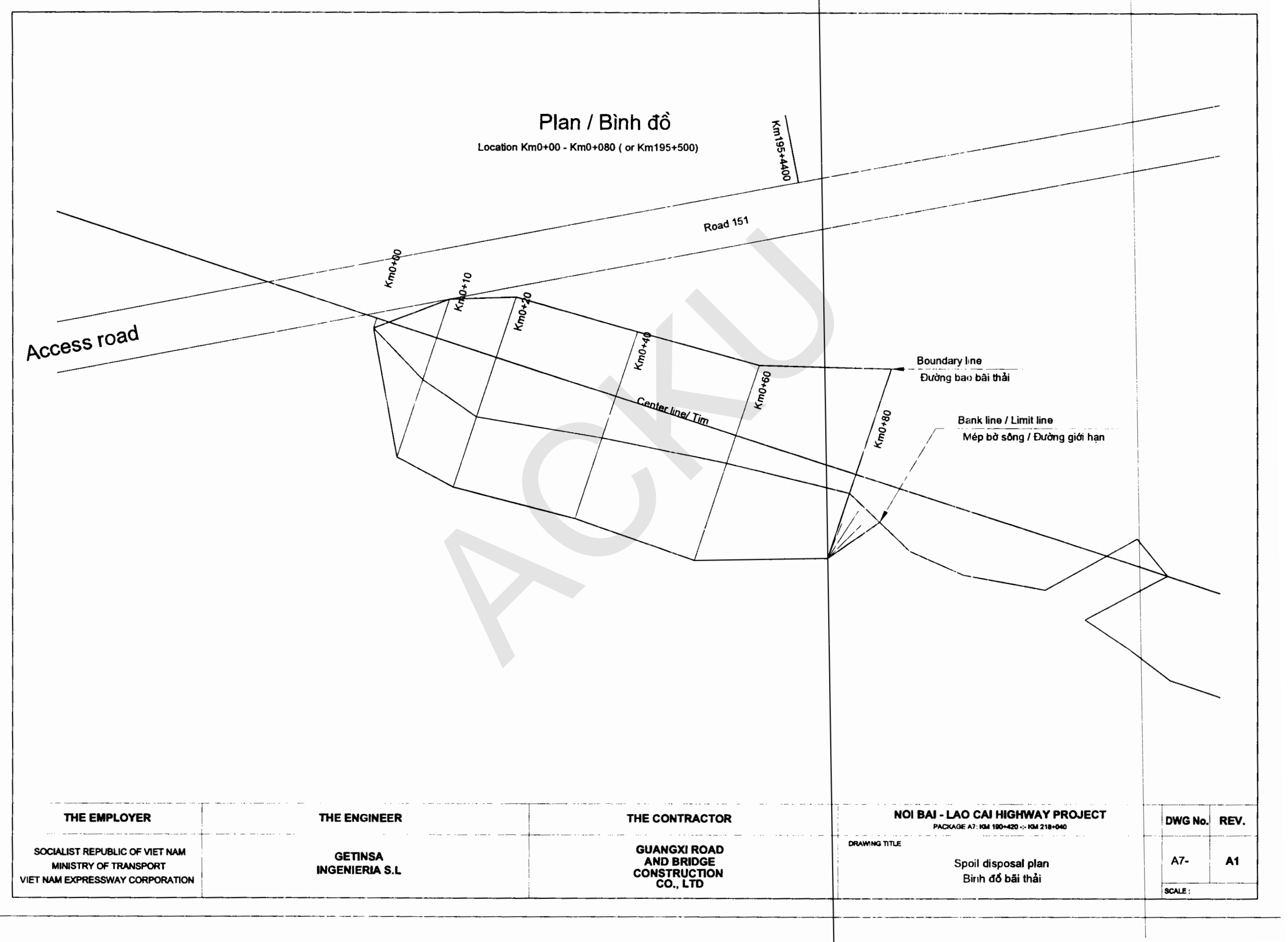




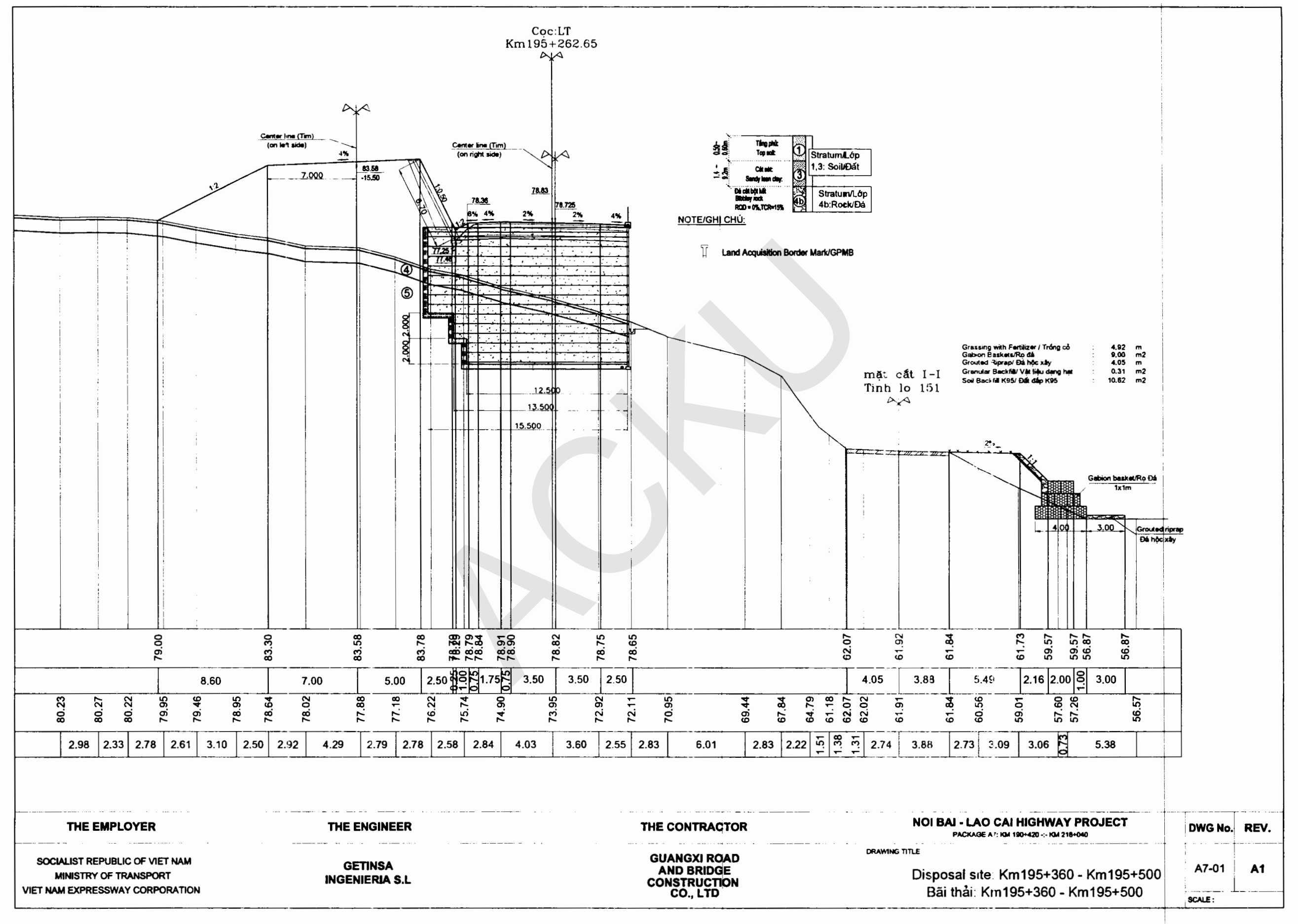




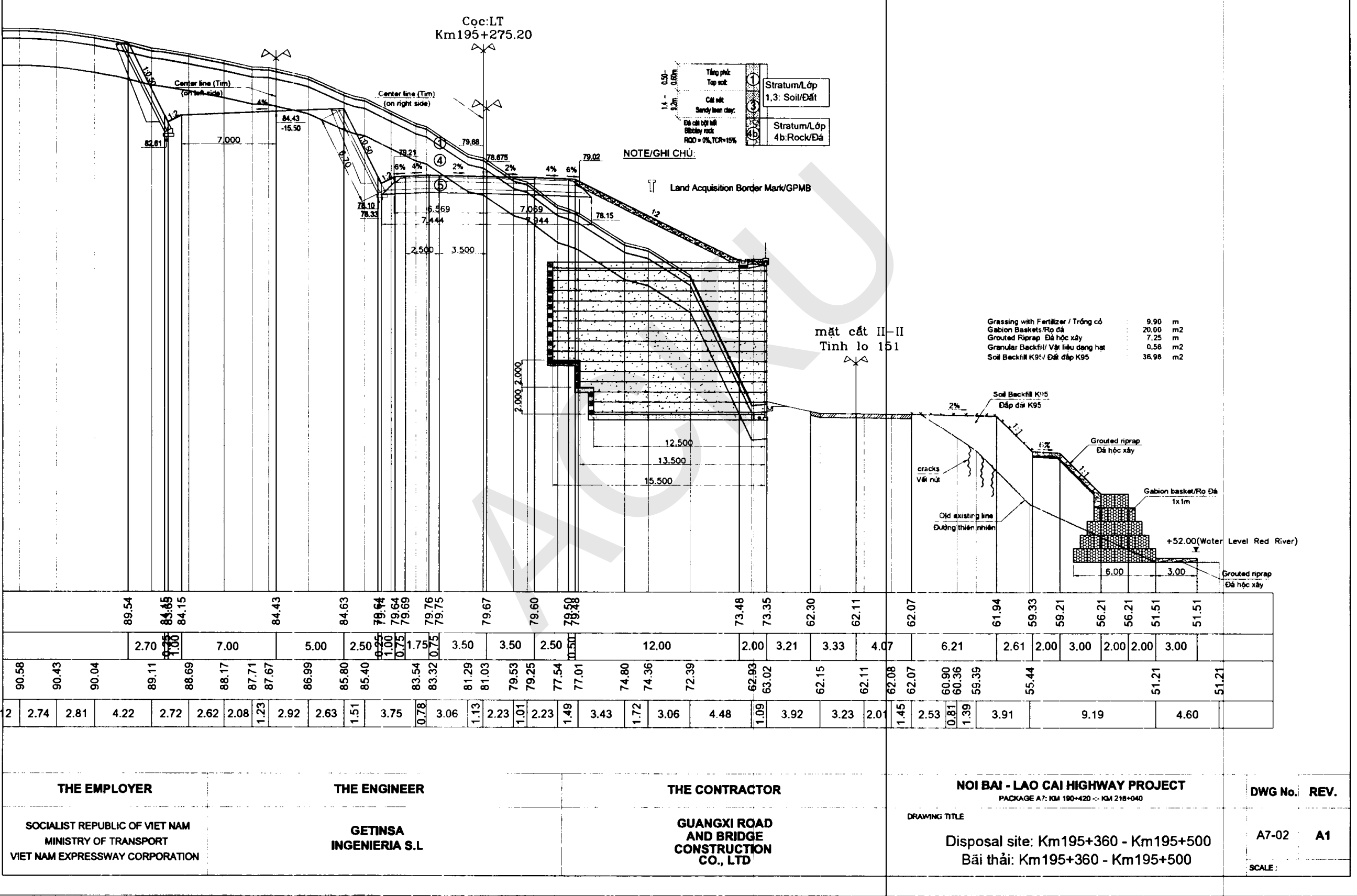




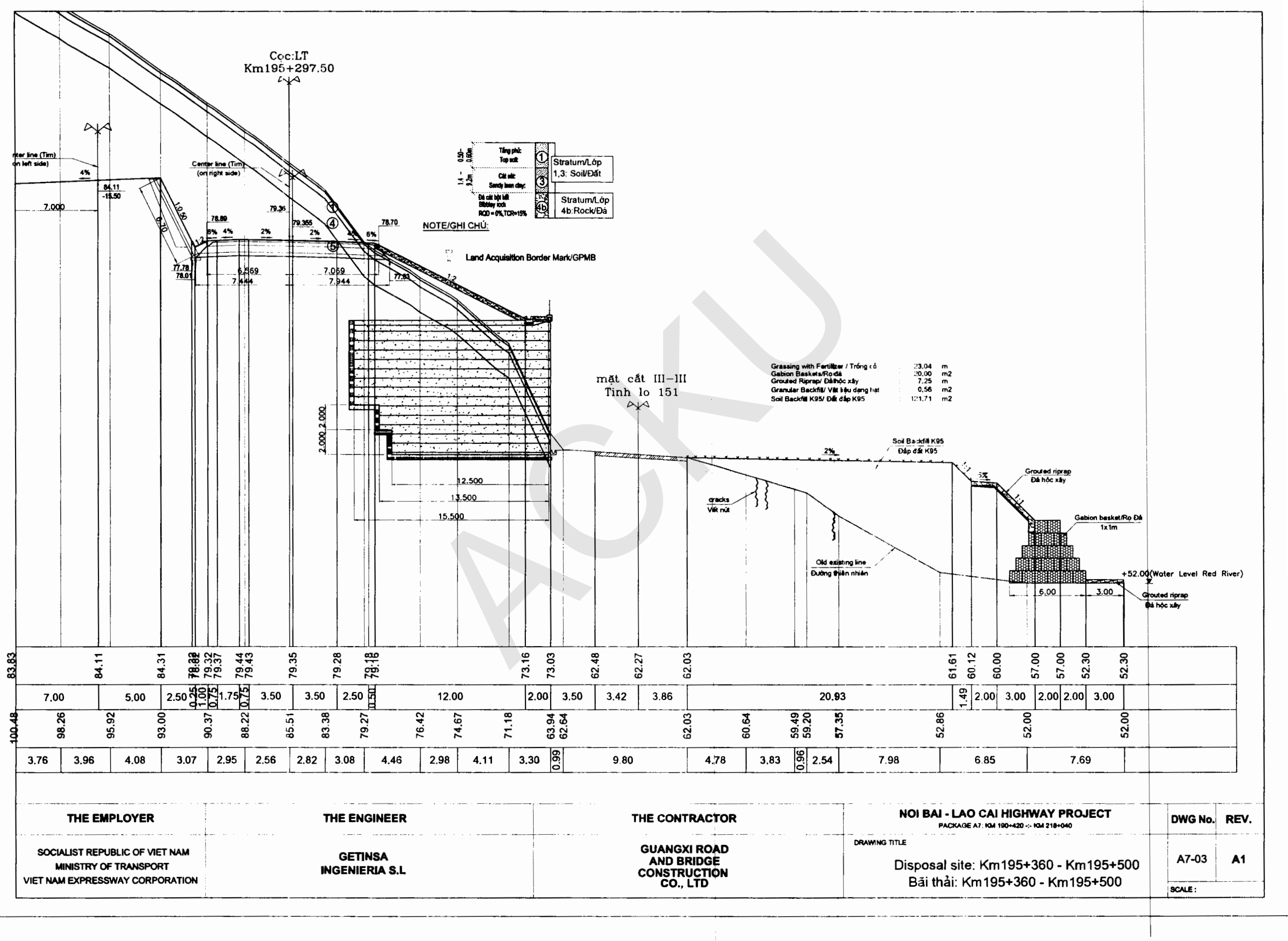




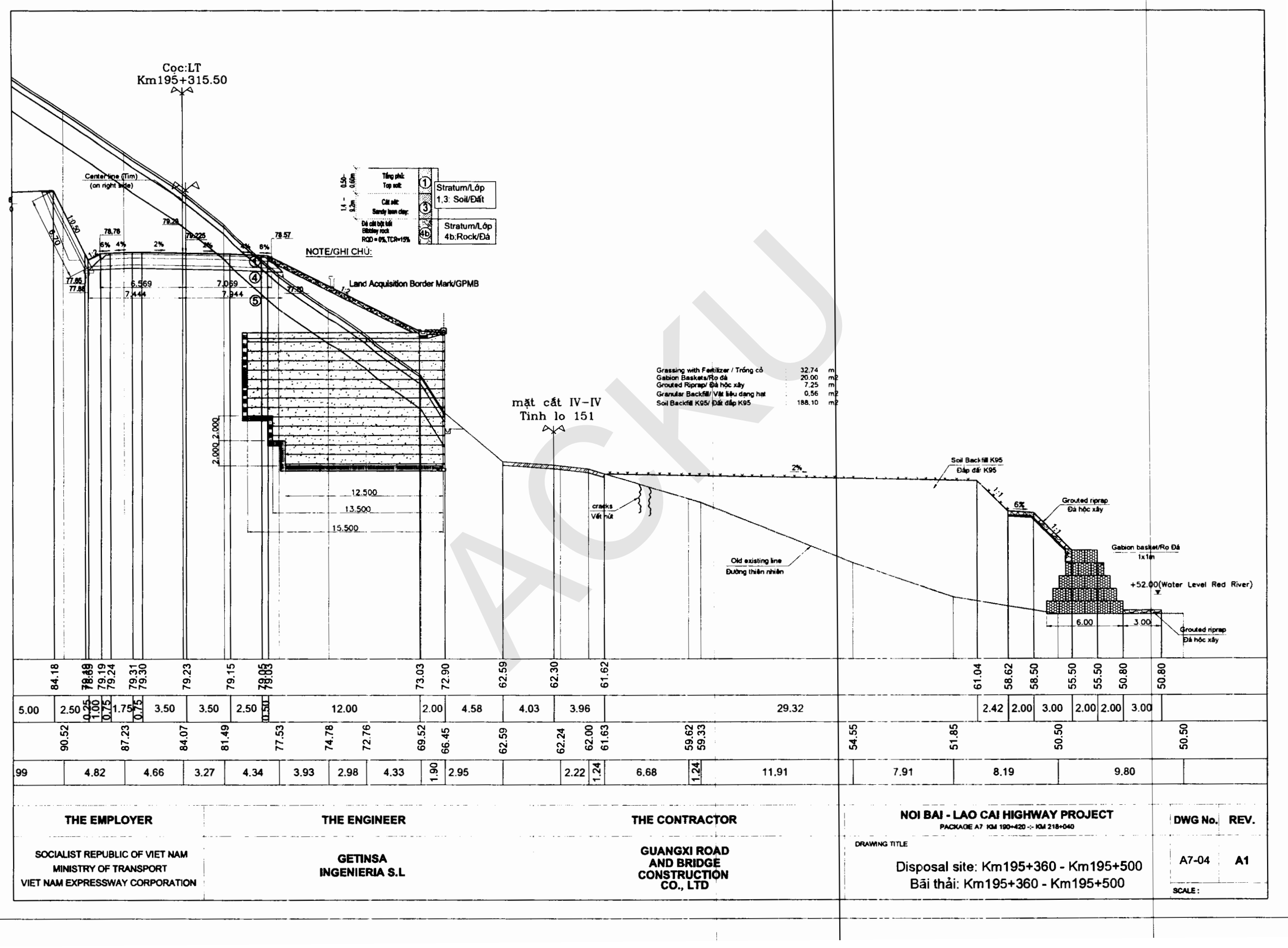




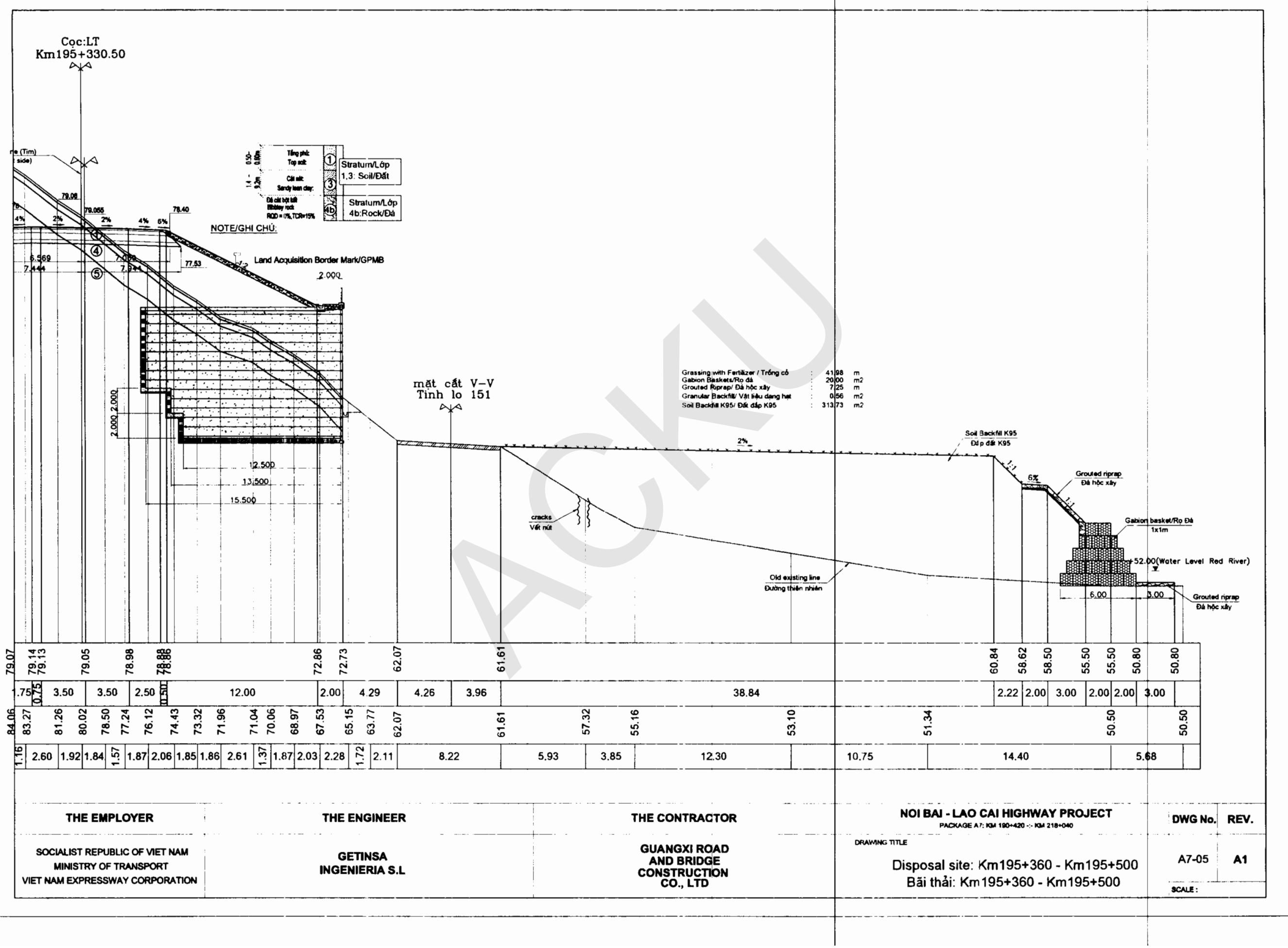




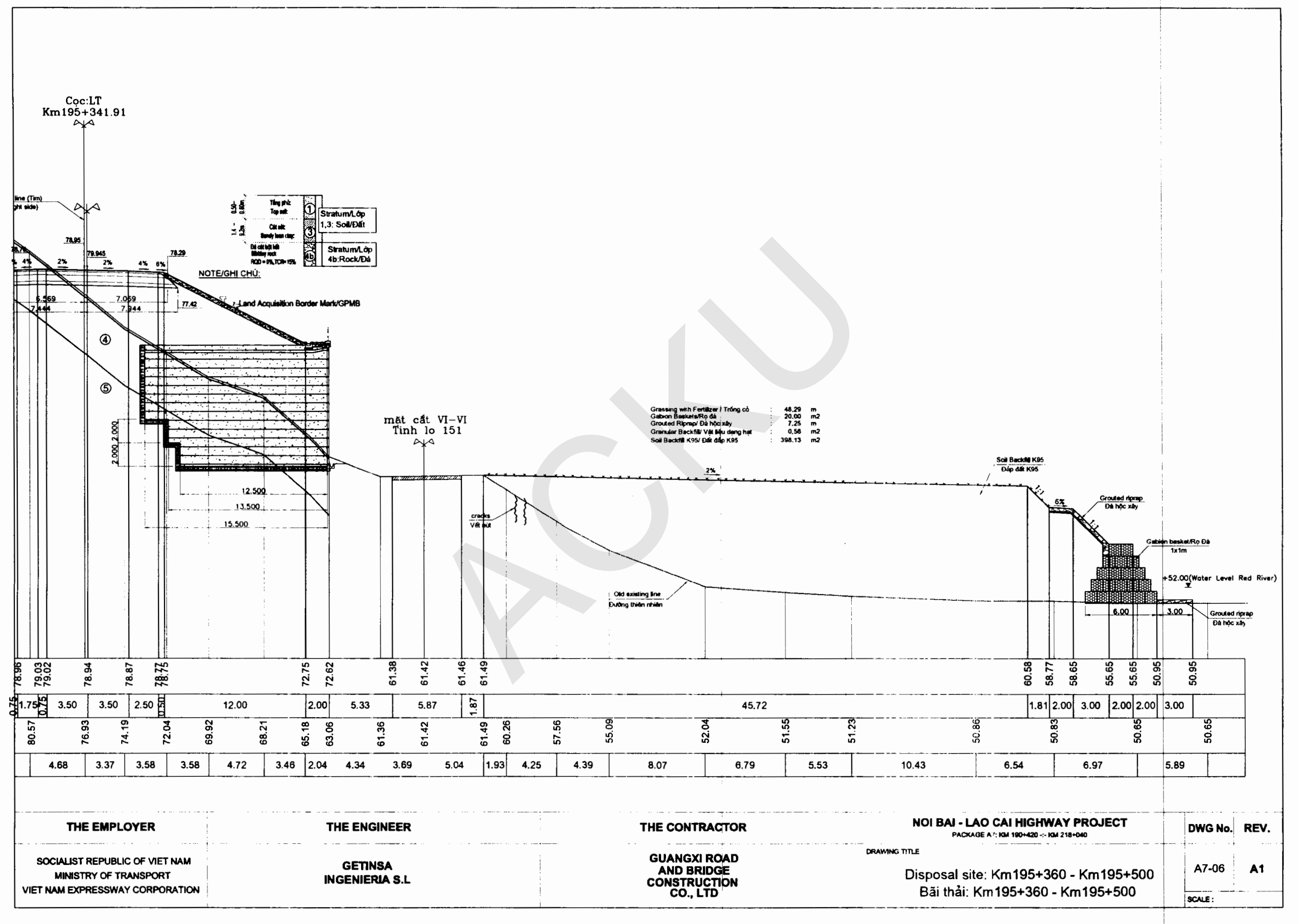




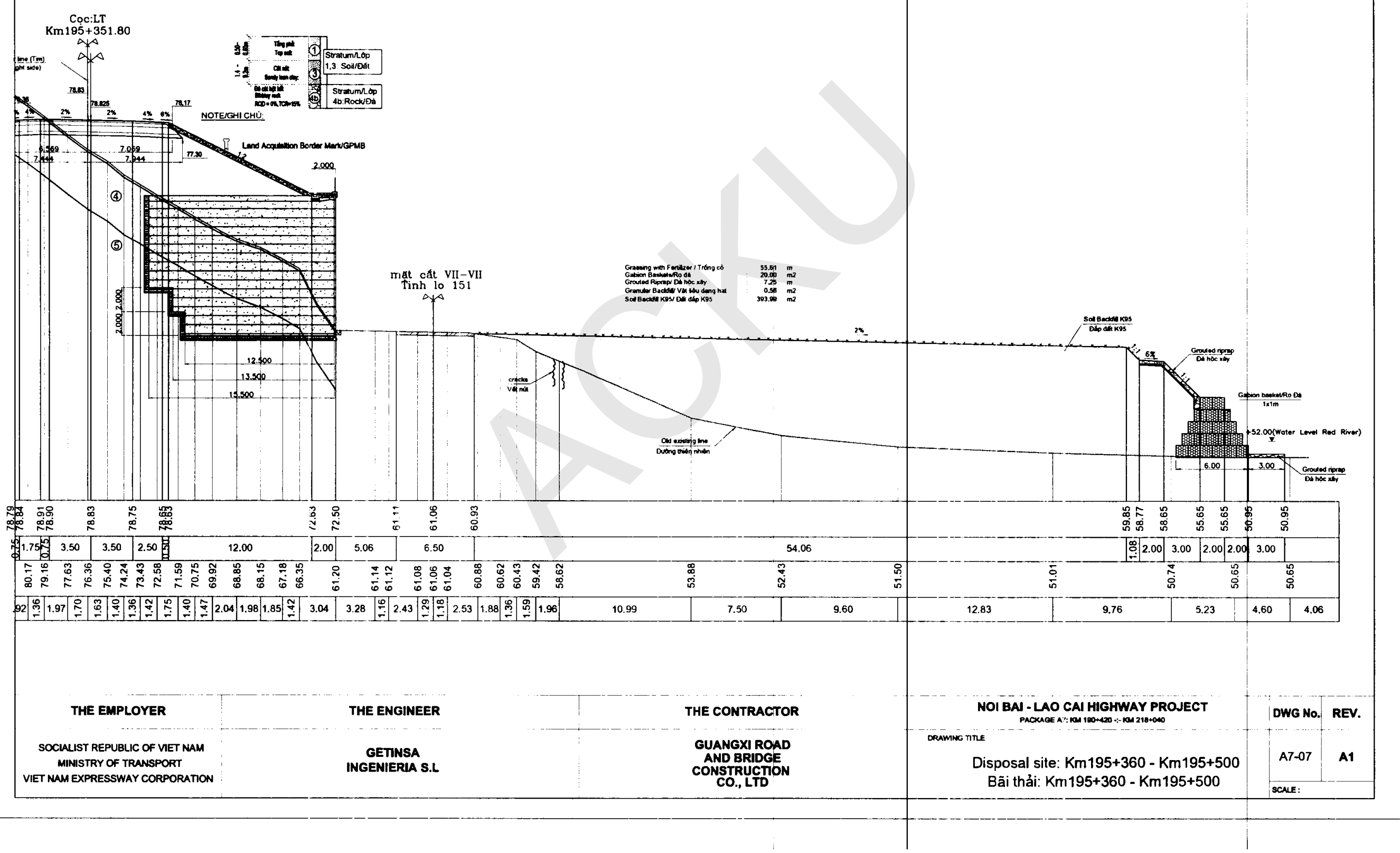




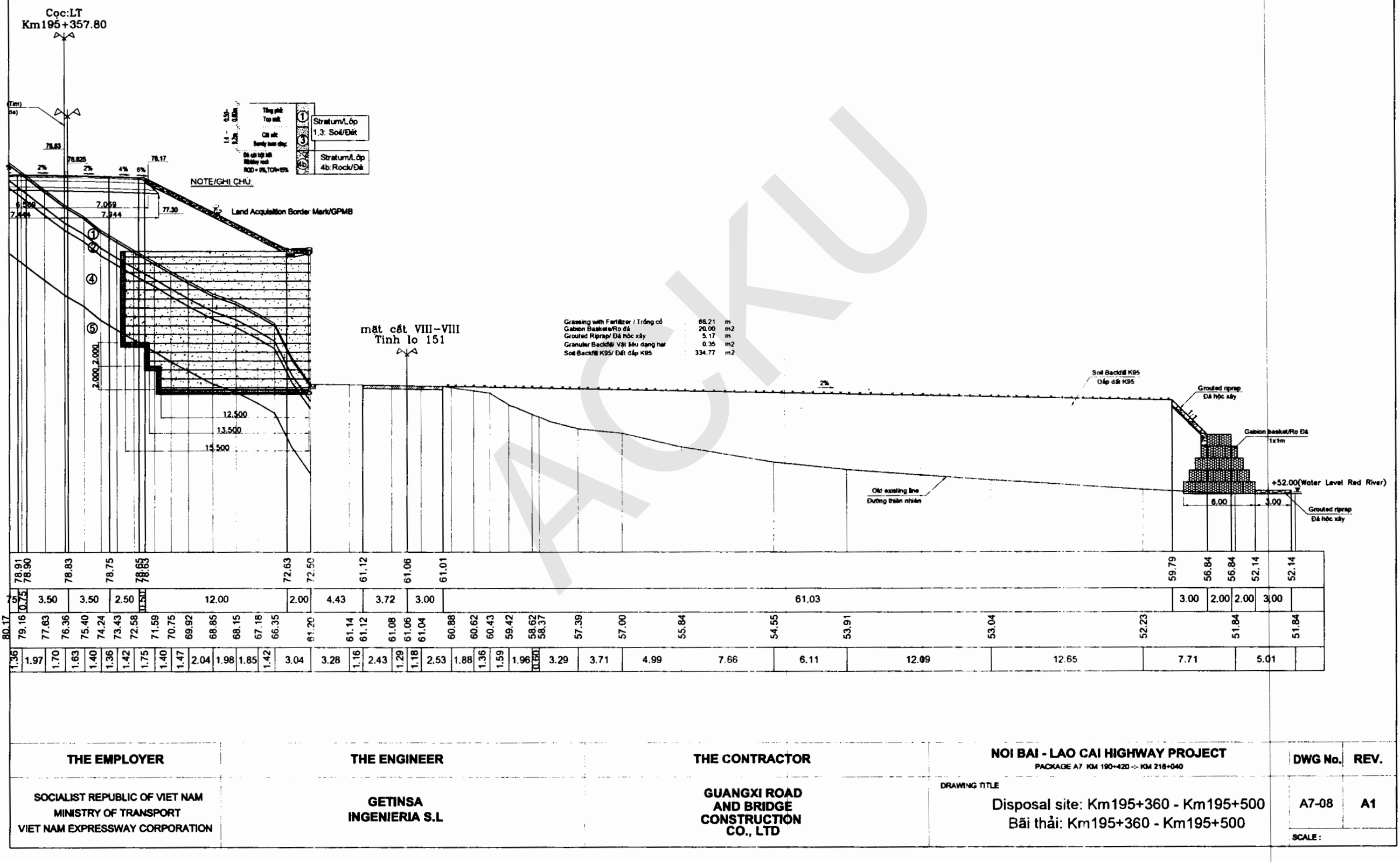




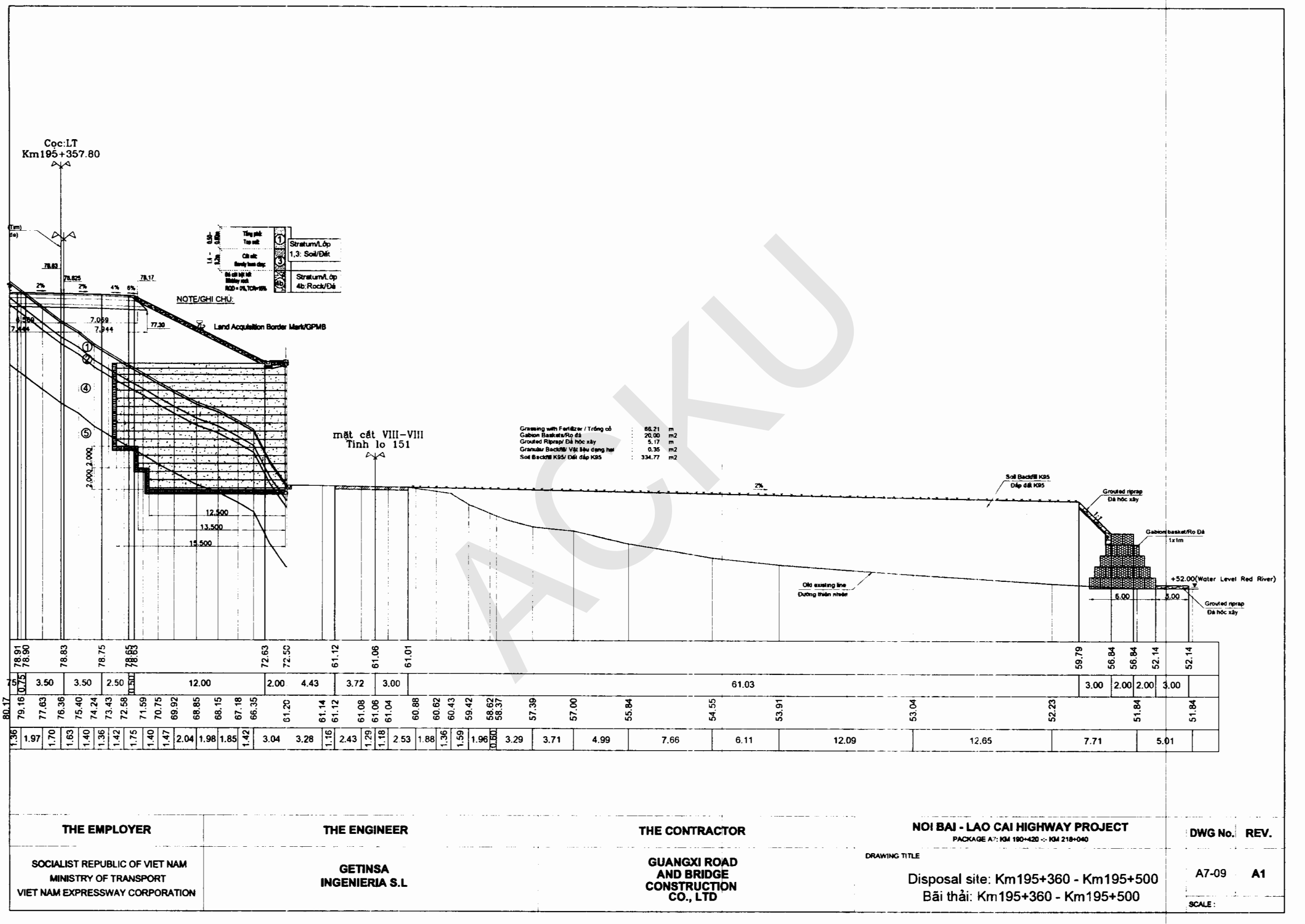




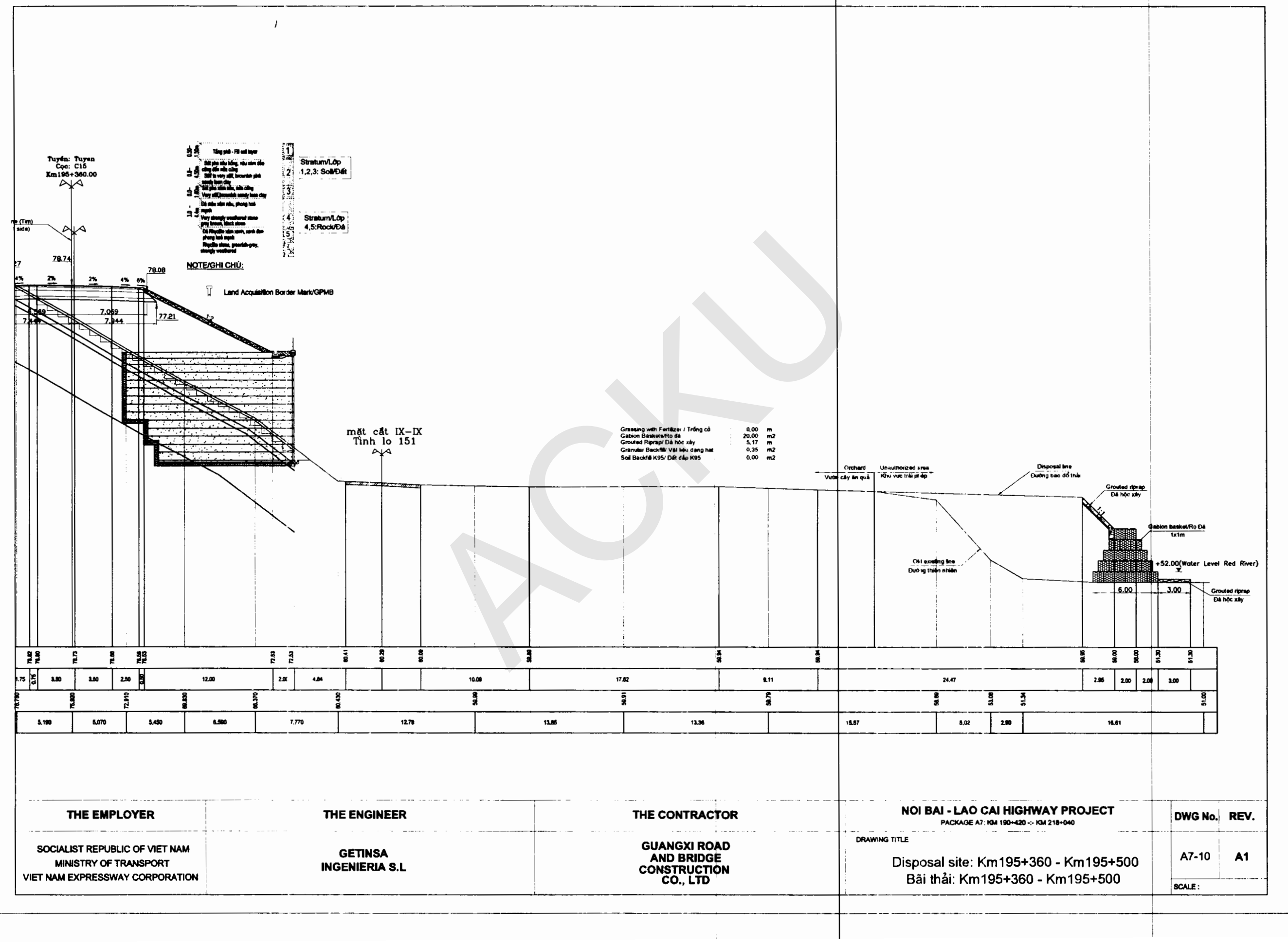




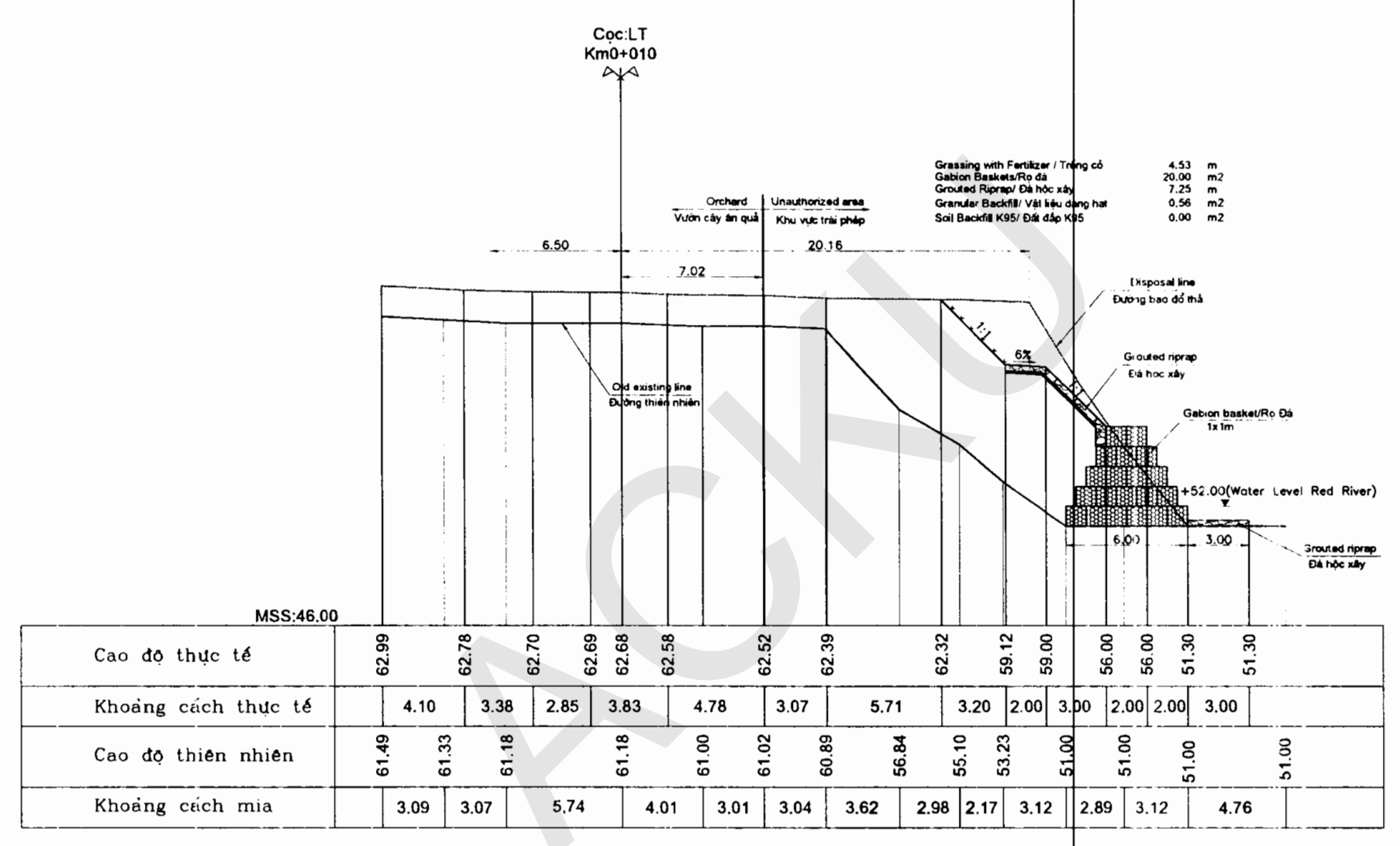

THE EMPLOYER

SOCIALIST REPUBLIC OF VET NAM MINISTRY OF TAWNSPORT
THE ENGINEER GETINSA
INGENIERIA S.
THE CONTRACTOR

GUANGXIROAD

CONSTRUCTEN
NOI BAN - LAO CAI HIGHWAY PROJECT DRAWING TILE

Disposal site: Km195+360 - Km195+500 Bãi thải: Km195+360 - Km195+500
DWG No. REV.

\begin{tabular}{|l|l} 
A7-11 A1 & A1 \\
\hline
\end{tabular} 


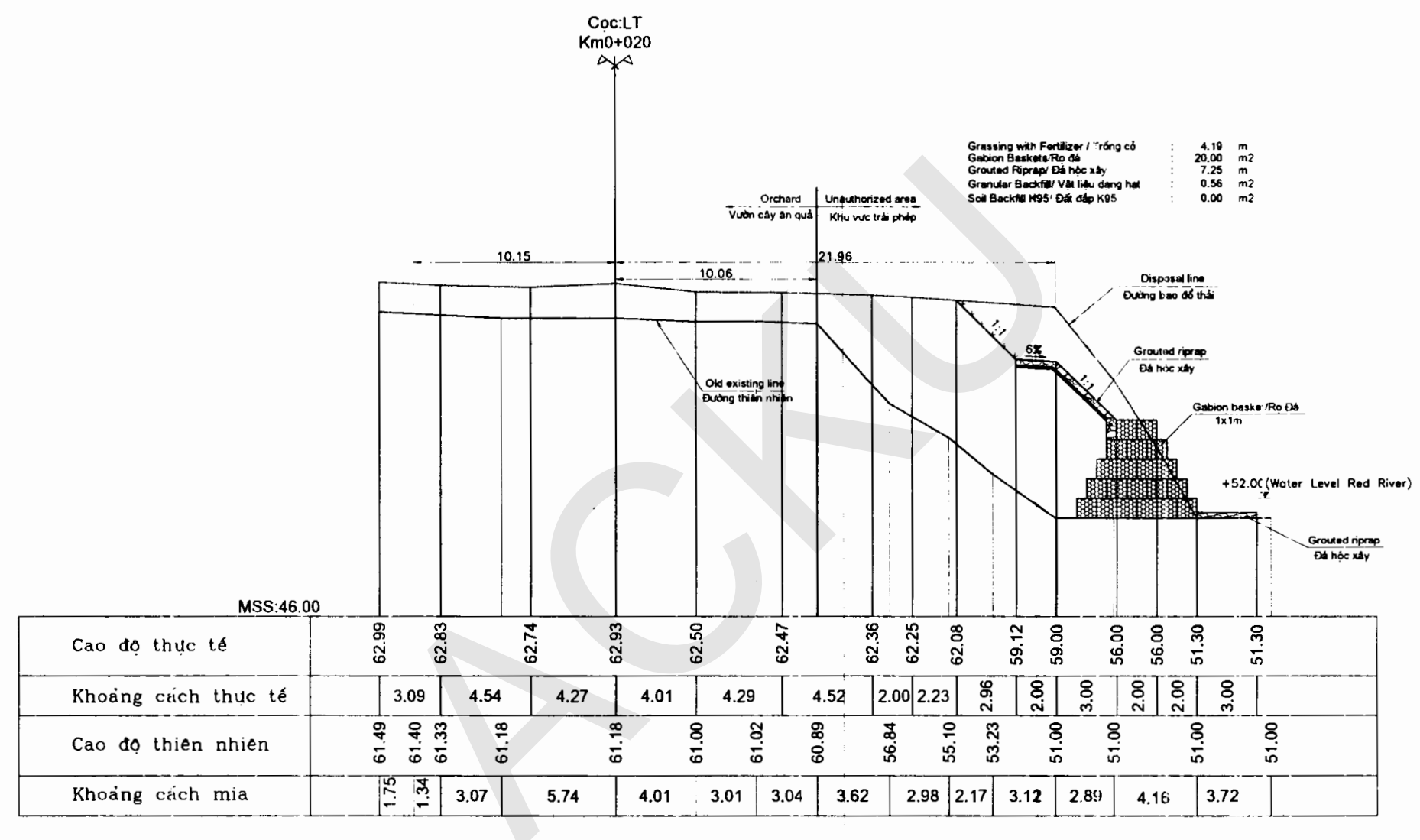

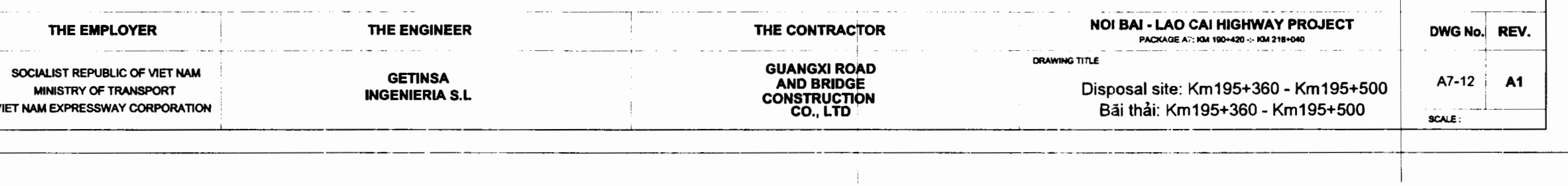




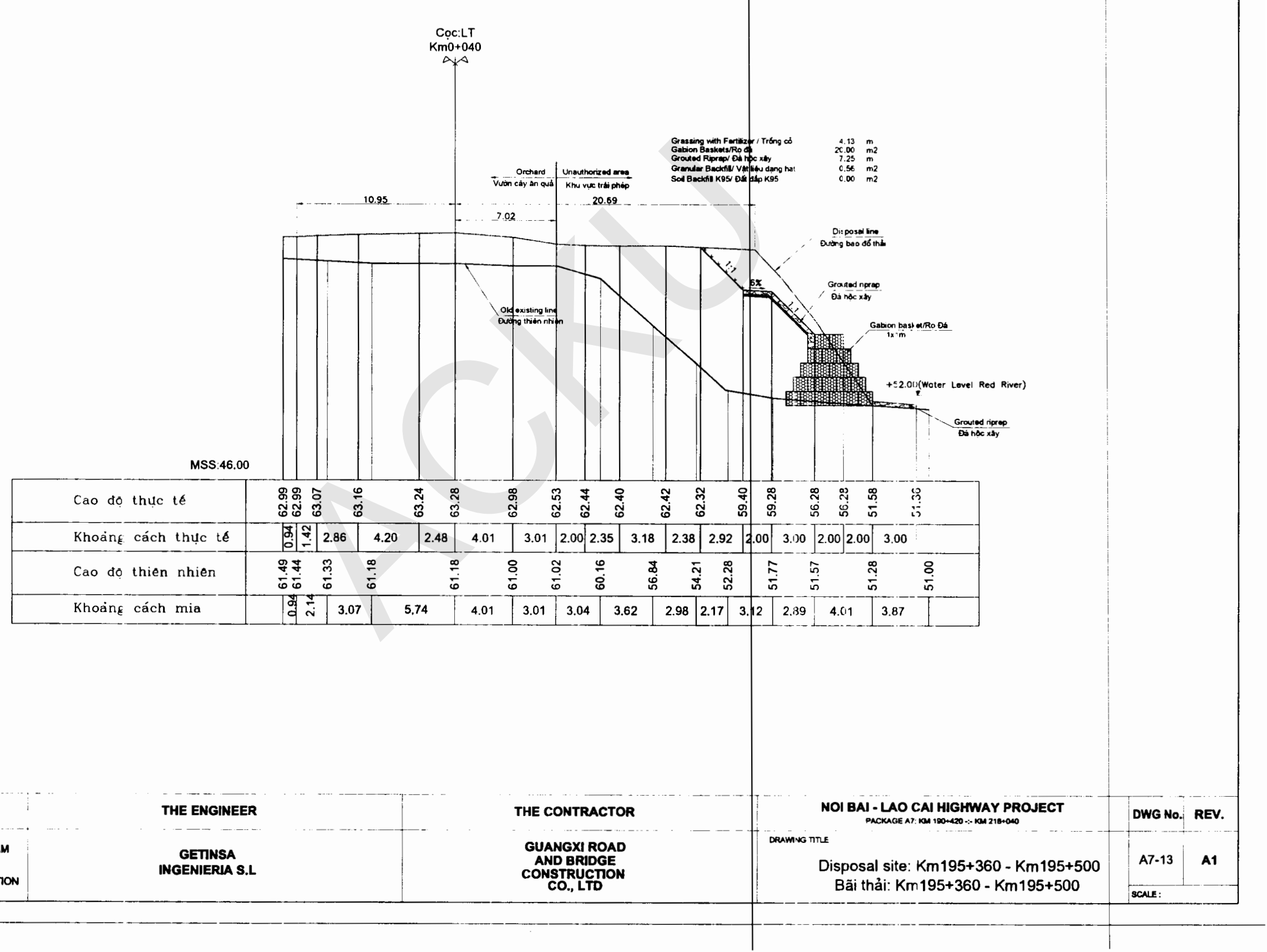




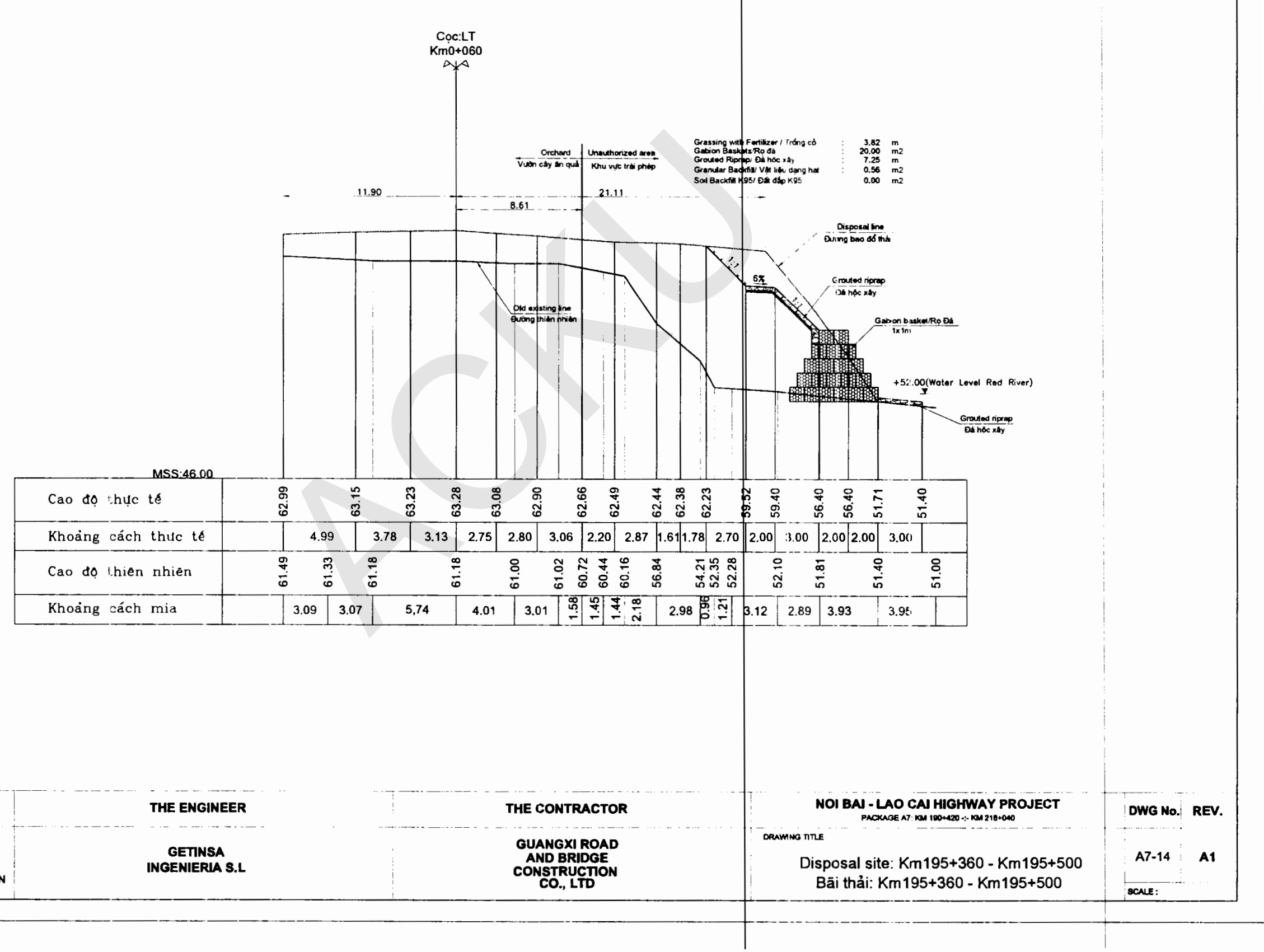




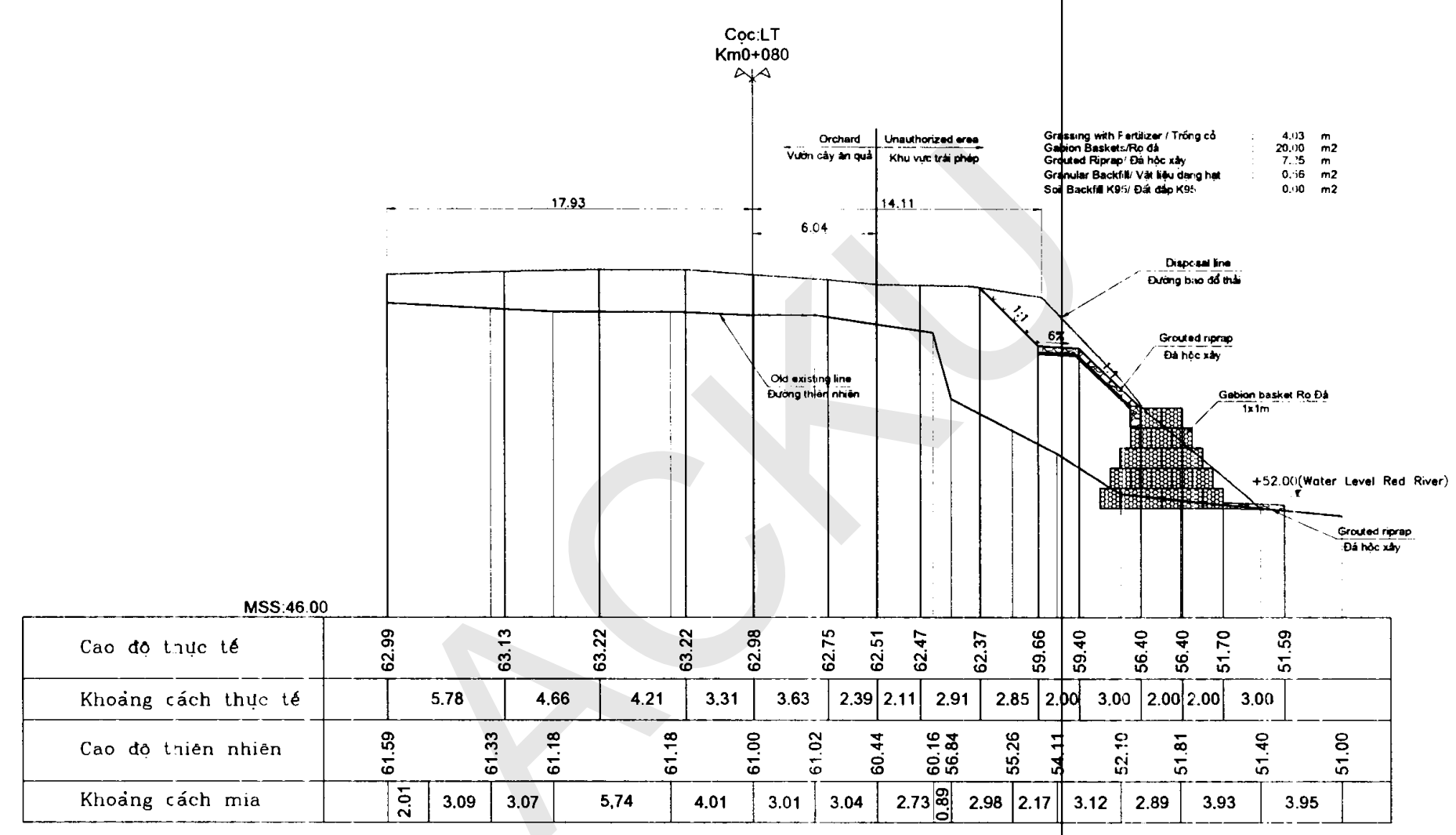

NOI BA - LAO CAI HIGHWAY PROJECT

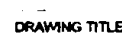

Disposal site: $K m 195+360-K m 195+500$ Bãi thải: Km195+360 - Km195+500
DWG No.| REV.

A7-15: A1 sare: 


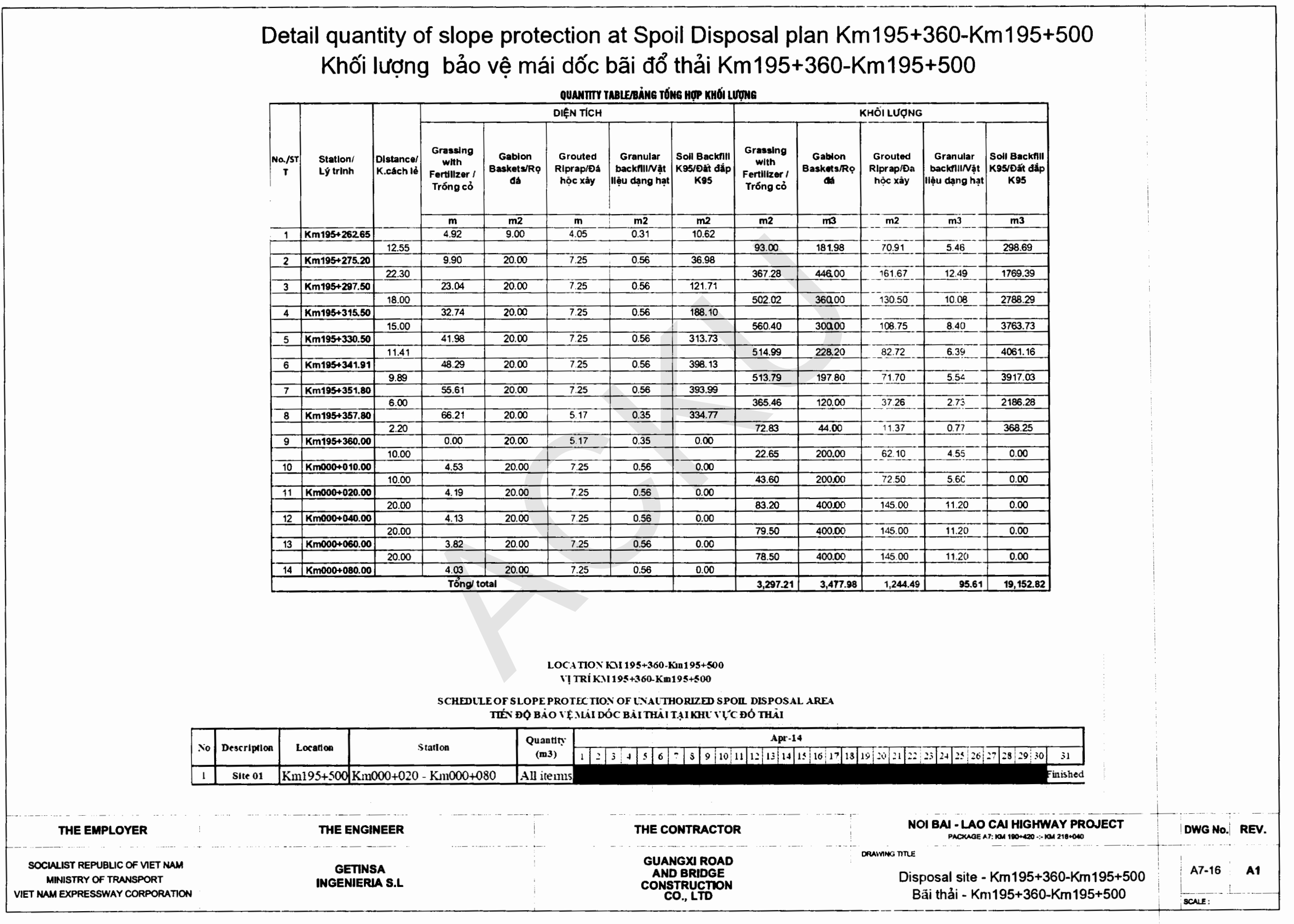


Loan 2391/2392 - VIE: GMS Kunming - Hai Phong Transport Corridor Noi Bai - Lao Cai Highway Project

14. ANNEX 8: RESTORATION PLANS FOR XUAN PHUONG AND TAN LOI RIVERS. SECOND PROPOSAL. PACKAGE A1 
Loan 2391/2392 - VIE: GMS Kunming - Hai Phong Transport Corridor Noi Bai - Lao Cai Highway Project 


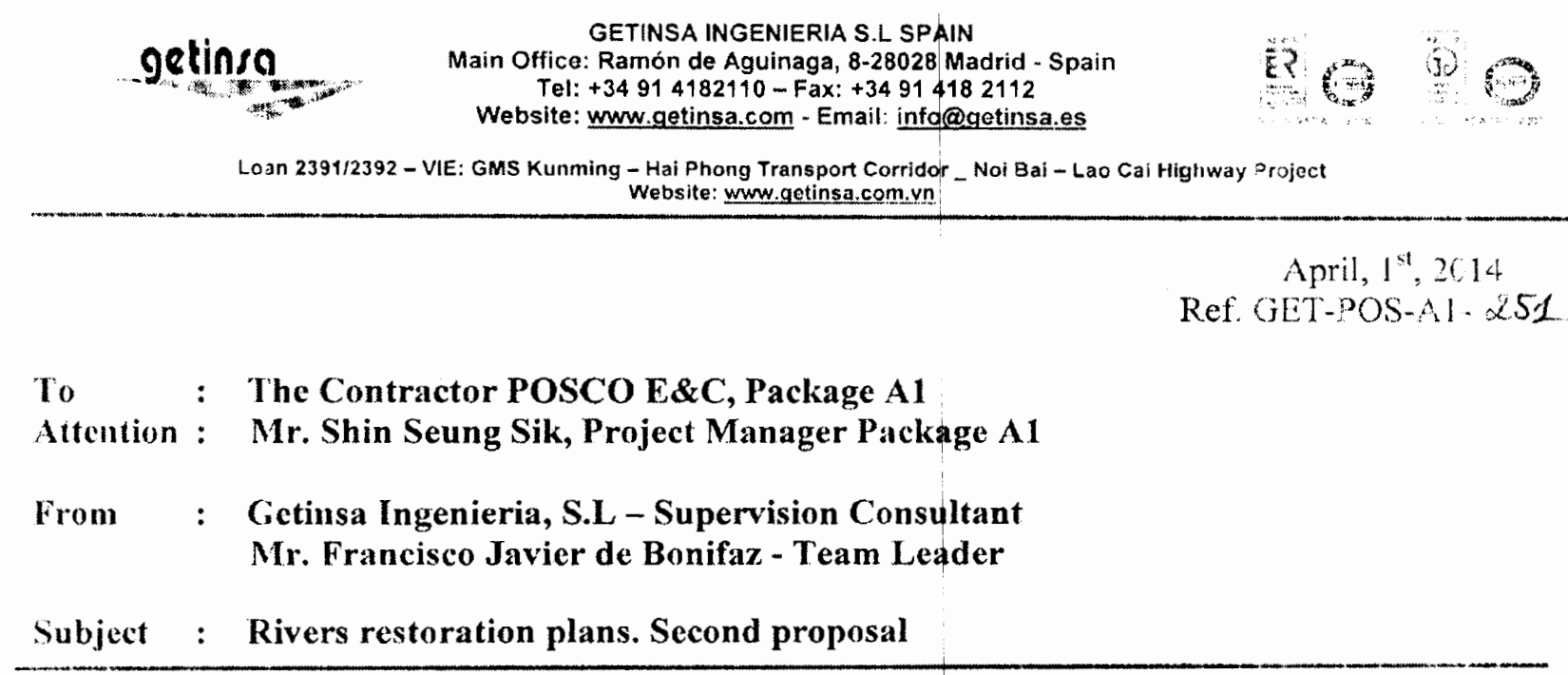

Dear Sir,

According to the following background:

- Letter POS151-2014, dated February 26 2014 , in which POSCO proposcd to modity the already approved restoration plans at Xuan Phuong Bridge and Tan Loi Bridge sites

- Letter GET1/POS/A1/2378, dated March $10^{\text {th }} 2014$, in which the Consultant replied POSCO about that proposal, refusing it as a solution for the restoration works

- $A$ fter the request from POSCO to reconsider the Consultant's decission

The Ingineer, site team 1, didn't approve this new proposal because the construction method was not clear enough . referred to the construction method of gabion baskets.

After reviewing again the proposal, and in order to speed up the restoration works at affected rivers, the Engineer would like to express the following considerations:

- The yabion haskets will be disposed inside a foundation to assure the stabilty

- (jabion baskets will be disposed building a compact wall (see drawing)

- Gabion baskets will reach the normal level of waters. Over them, riprap will be installed for landscaping adaptation, at least until the maximum natural water level (sec drawiag)

- The restoration works will recover the original line of the riverbank, it means, the orignal surface and width at that point

- Over riprap, grass with fertilizer and some trees will be planted

- Only inert earth soils will be dumped for filling, never waste materials, hazardous substances

A handmade drawing is attached showing the modifications that Consultant considers necessary to introduce in the proposal.

According to these considerations and with the commitment to give compliance to the exrressed requirements, the new proposal for restoration works at both riverbanks may be approved. Pltase. 
submit immediately to Consultant, core team, a commitment letter with your arceptance of these requirements and begin to mobilize equipment and material for the works no later than April $15^{\text {th }}$ $2014 \mathrm{At}$ the sane time, you will prepare the final right drawings including our specifications.

Your full cooperation and quick and strict compliance will be highly appreciated.

Sincerely yours,

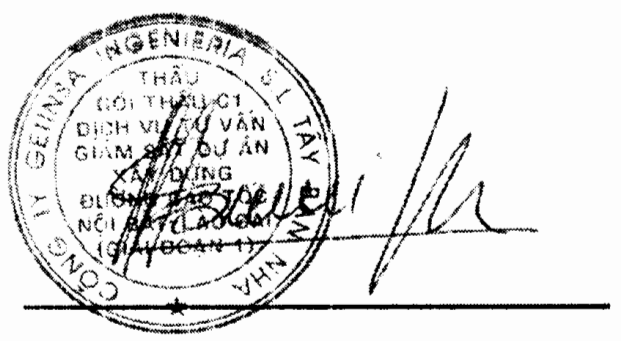

Francisco Javier de Bonifaz,

Team Leader

Supervision Consultant,

Getinsa Ingeniería, S.L - Spain

co: EPML, EPMU1, GETI 


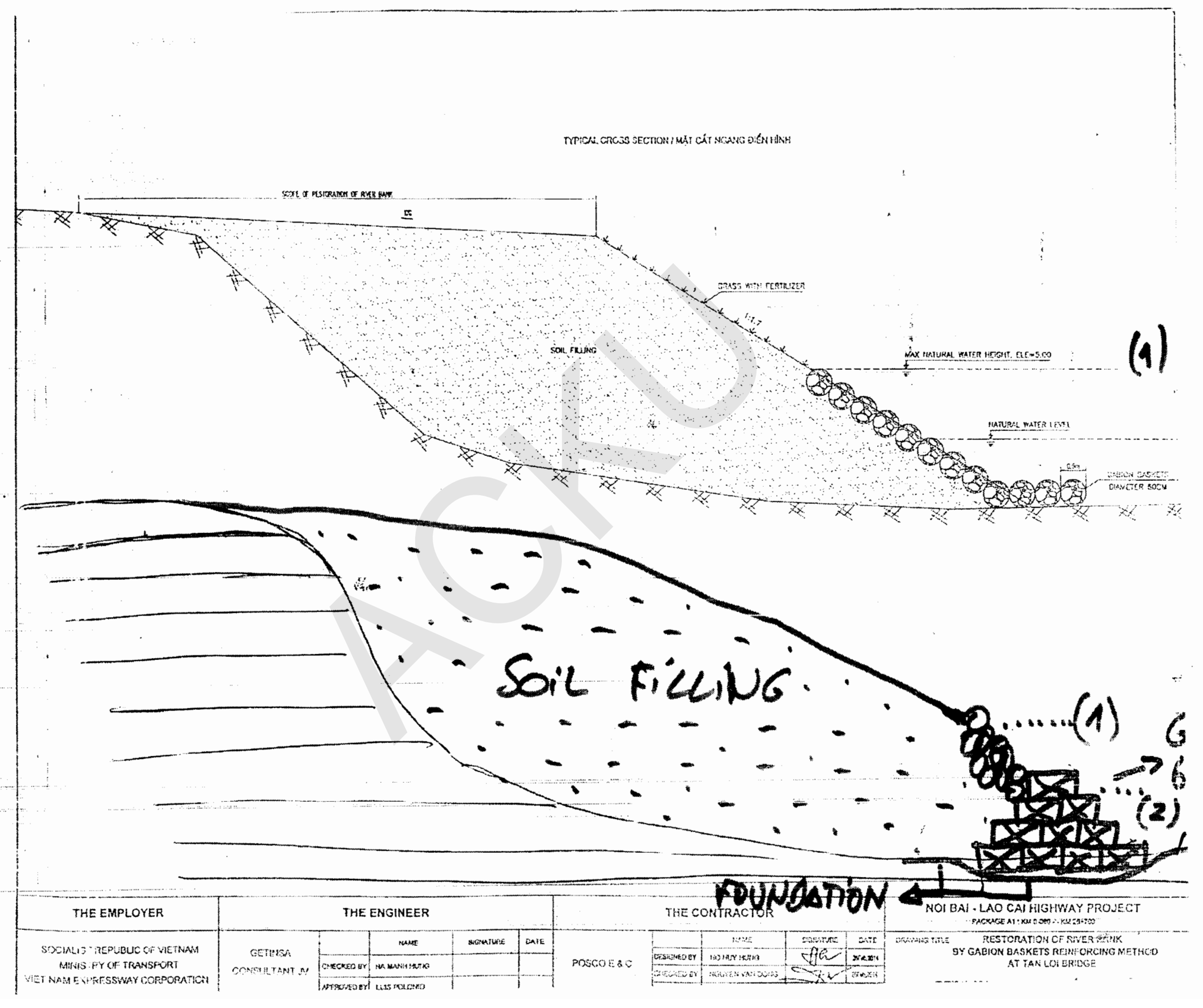




\section{posco \\ E\&C}

www.poscoenc.com
HEAD OFFICE

POSCO E8C Tower 1, 36,

Songdo, Yeonsu

Incheon, 406-840, Korea

Tel: 82-32-748-2114

Fax: 82-32-748-4000
SITE OFFICE

Huu Thu Hamlet, Kim Long Ward,

Tam Duong District, VinhPhuc Province

Tel: 84-211-6265-101

Fax: 84-211-6265-110

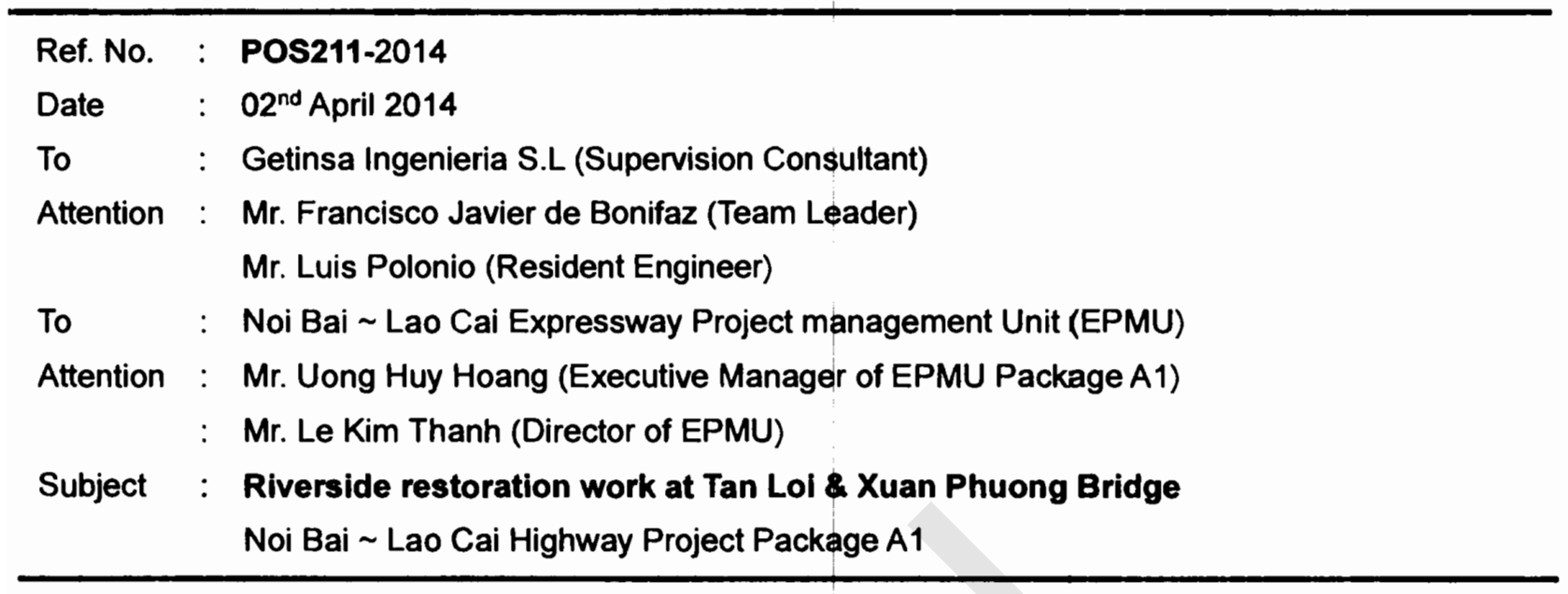

Dear Sir,

With reference to the Engineer's letter Ref.No.GET-POS-A1-251 dated $1^{\text {st }}$ April 2014, the Contractor are pleased to agree with your initiative and shall immediately carry out the restoration work at Site in combination with cleaning work to ensure the smooth flow of the river.

In this regard, your cooperation would be highly appreciated.
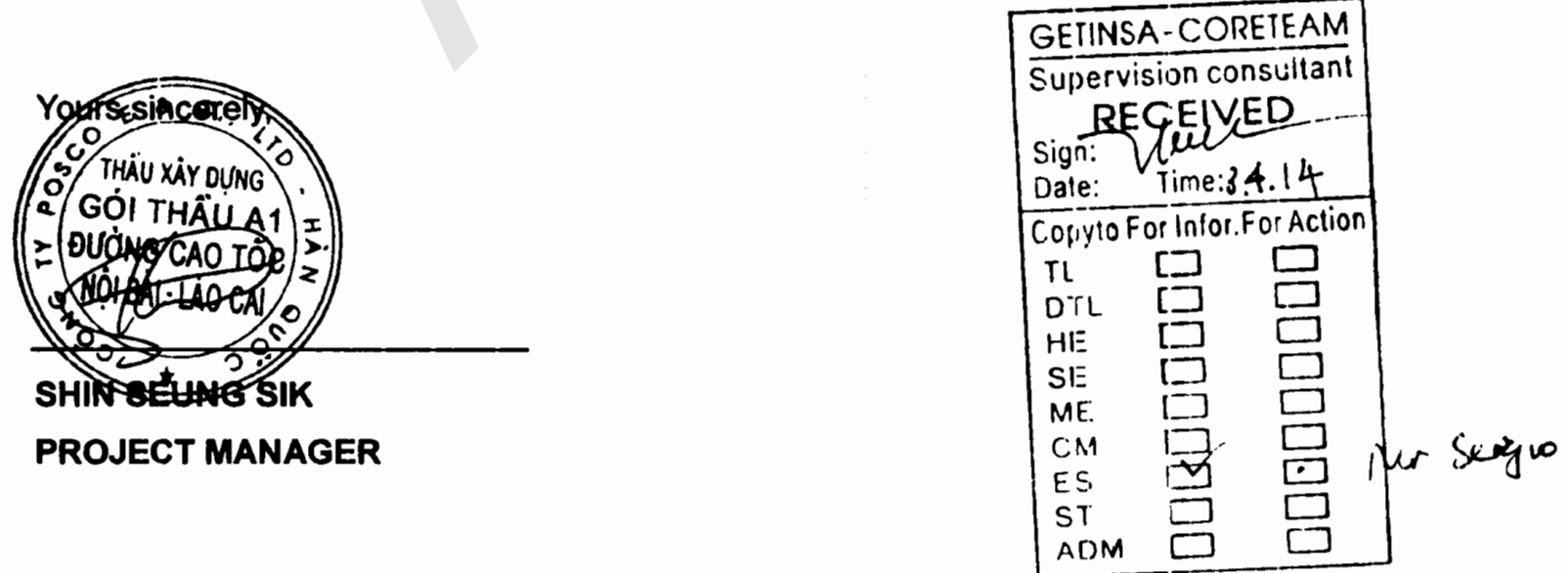
To: $\quad$ POSCO E\&C - PACKAGE A1

Our Ref. GET - POS-A1- 253

Attention: Mr. Shin Seung Shik - Project Manager

From: $\quad$ Getinsa Ingenieria, S.L - Supervision Consultant

Mr. Francisco Javier de Bonifaz - Team Leader

Subject: $\quad$ Approval of Shop drawing for River Bank Restoration using Gabion Baskets at Tan Loi \& Xuan Phuong bridges - package A1

Dear Sir,

With reference to:

- The Contractor's submittal sheet No. POS-A 1-\$S-048/2014 dated April 04 ${ }^{\text {th }}, 2014$;

- The Engineer Site Team 1 submittal No. ST1-CT-070 dated April 07 ${ }^{\text {th }}, 2014$;

Please be informed that after carefully reviewing and studying the method proposed by the Contractor, we have found it to be acceptable and practicable. Therefore, we agree with this shop drawings and hereby instruct the Contractor to proceed the next steps.

Your cooperation would be highly appreciated.

Your faithfully,

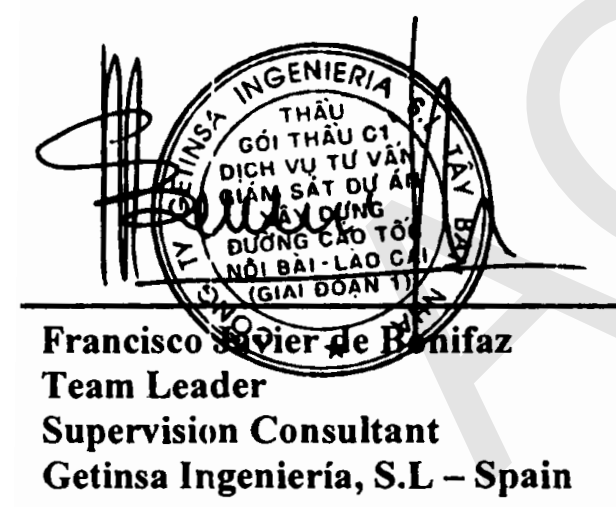

CC: $\quad$ GETI 
NOI BAI - LAO CAI HIGHWAY CONSTRUCTION PROJECT

DỰ ÁN XÂY DỰNG ĐUỜNG CAO TỐC Nộl BÀl - LÀO CAI

PACKAGE A1 / Gól THẦ A1: Km 0-080 -:- KM 26+700

\title{
SHOP DRAWING / BẢN VẼ THI CÔNG
}

\section{NO. A1/8: TAN LOI BRIDGE - KM10+695 RESTORATION OF RIVER BANK BY GABION BASKET METHOD}

\author{
Số A1/8: CẦU TÂN Lộ - KM10+695 \\ KHÔI PHỤC BÒ SÔNG BẰnG BIỆN PHÁP RỌ DÁ
}




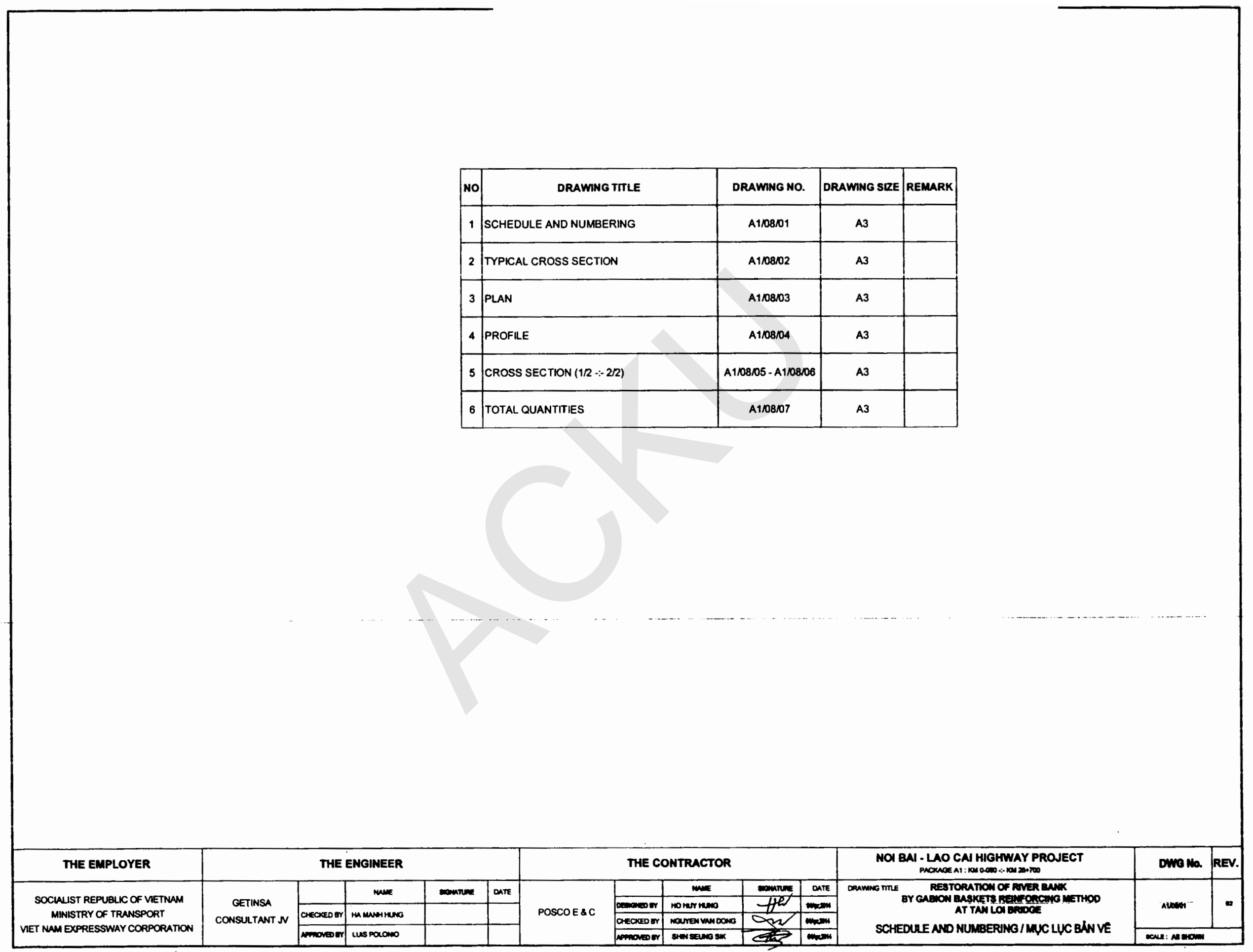




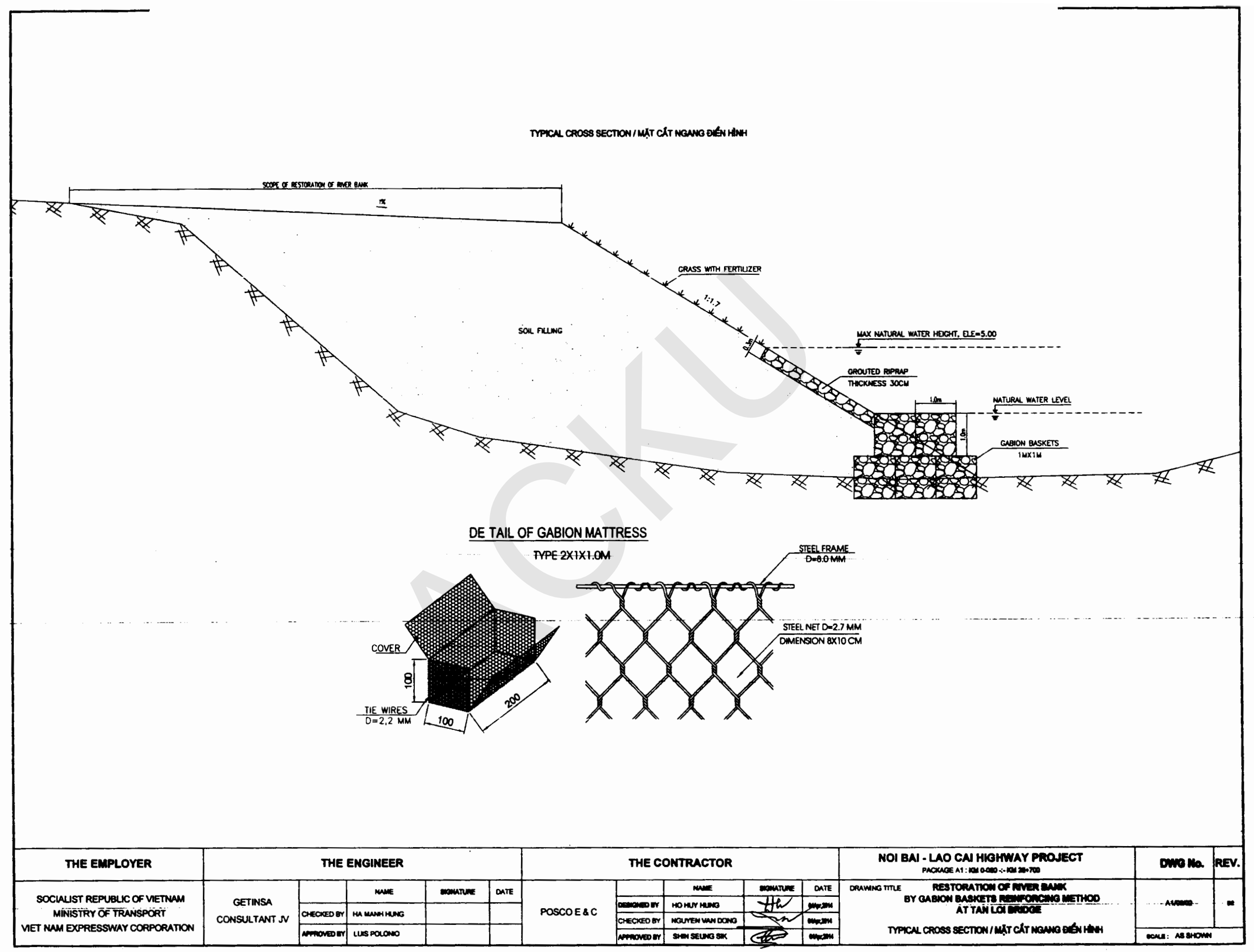




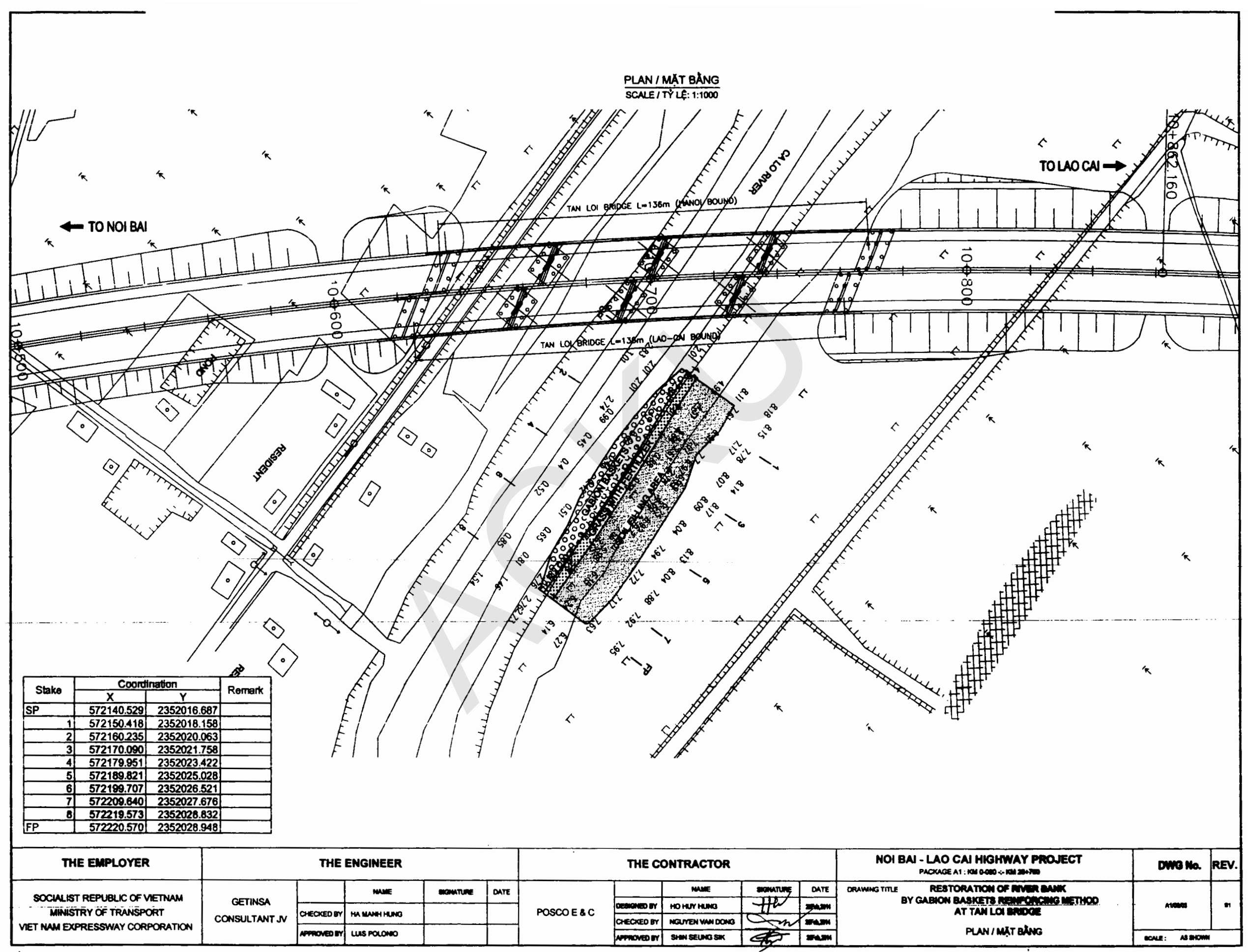




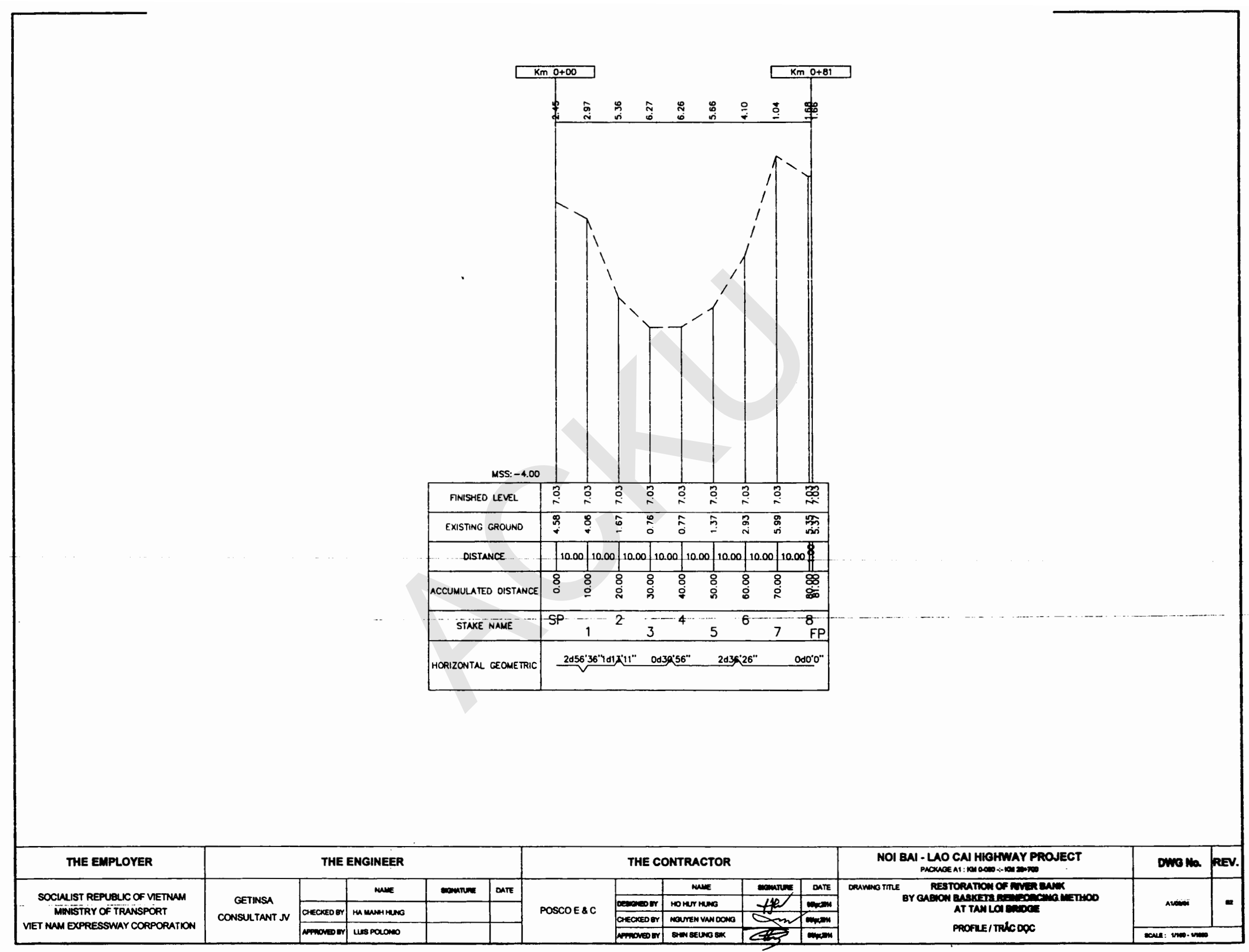




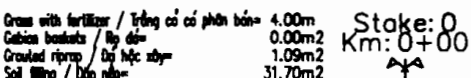

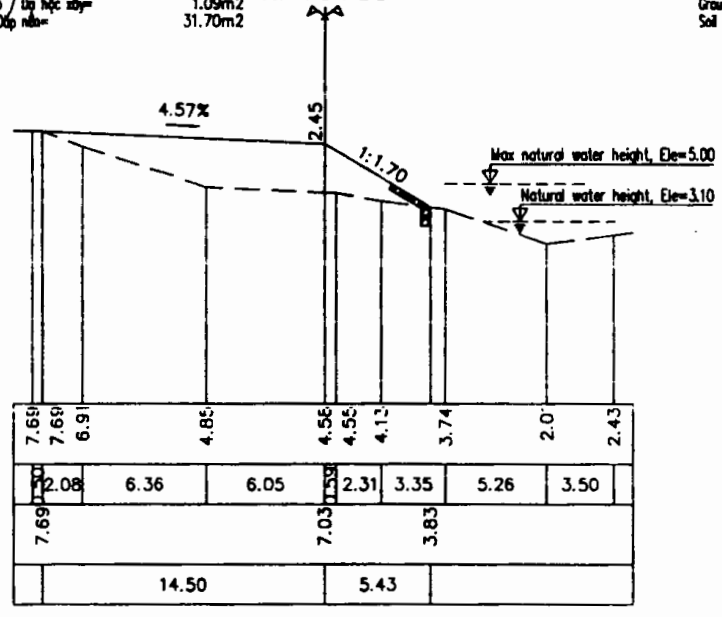

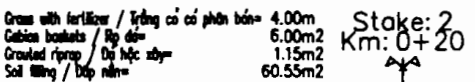

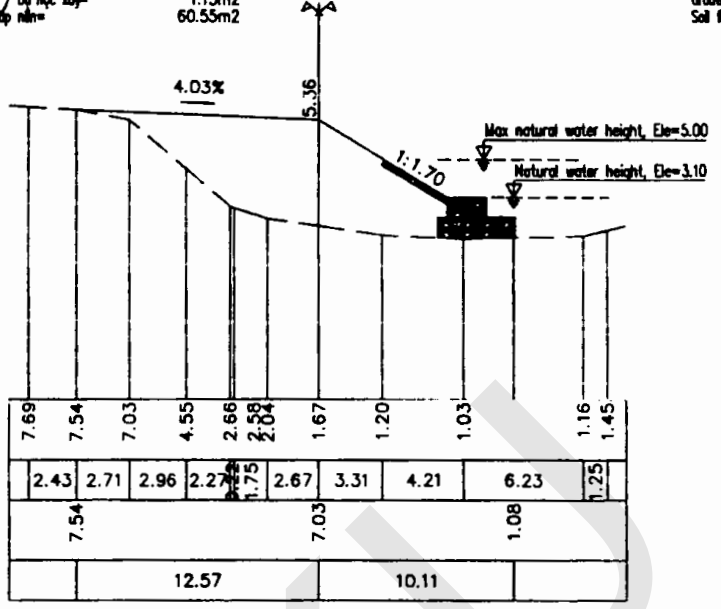

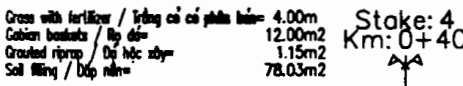

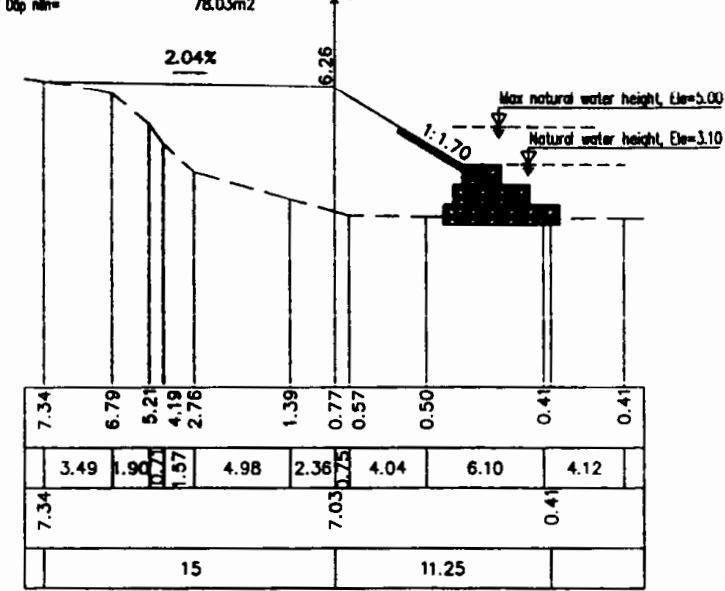

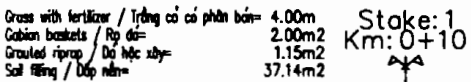

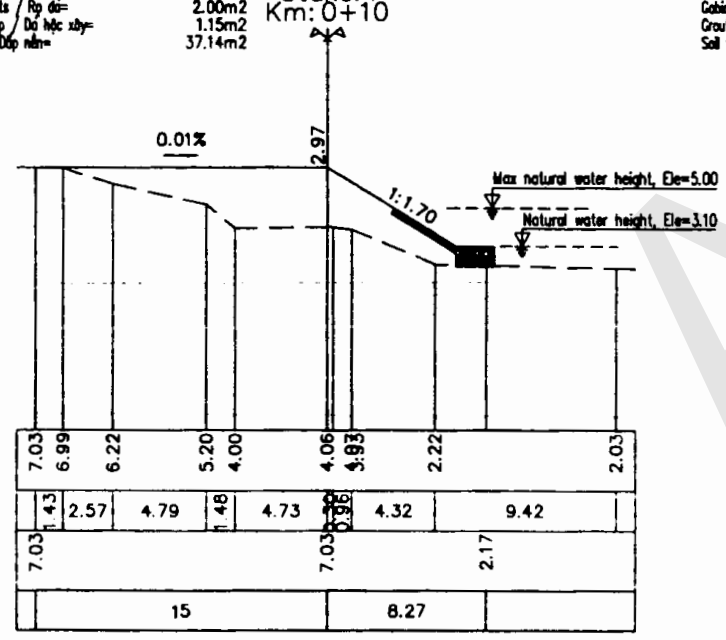

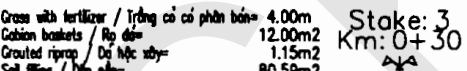
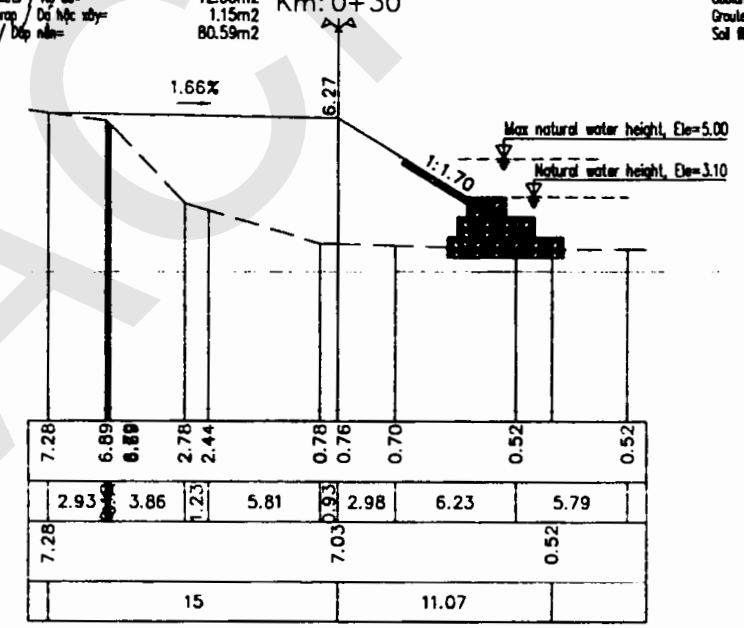

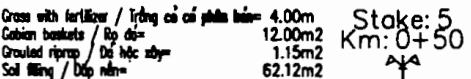

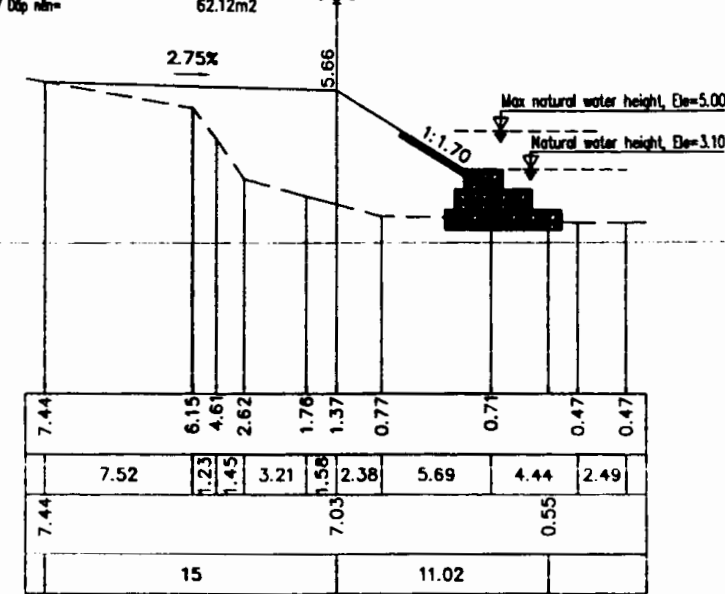

\begin{tabular}{|c|c|c|c|c|c|c|c|c|c|c|c|c|c|}
\hline THE EMPLOYER & \multicolumn{5}{|c|}{ THE ENGINEER } & \multicolumn{5}{|c|}{ THE CONTRACTOR } & NOI BAN - LAO CA MKGHMAY PROJECT & Dwe No. & REV. \\
\hline \multirow{3}{*}{$\begin{array}{l}\text { SOCLNUST REPUBLC OF VETINAM } \\
\text { MIINISTIRY OF TRANSPORT } \\
\text { MET NAM EXPRESSWAY CORPORATION }\end{array}$} & \multirow{3}{*}{ CONSULTANT N } & & mume & monive & DATE & \multirow{3}{*}{ POSCOE \& C } & & nive & manue & DATE & \multirow{3}{*}{ 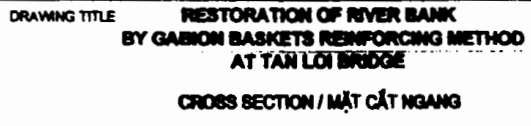 } & & \\
\hline & & CHECKED OY & ma mustringus & & & & 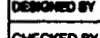 & no havtemes & HW & 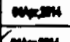 & & Alowor & 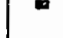 \\
\hline & & Amover of & Lus Polono & & & & \begin{tabular}{|c|c|} 
nemovedor \\
\end{tabular} & Stewstumo swa & $\Rightarrow$ & men & & 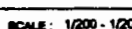 & \\
\hline
\end{tabular}




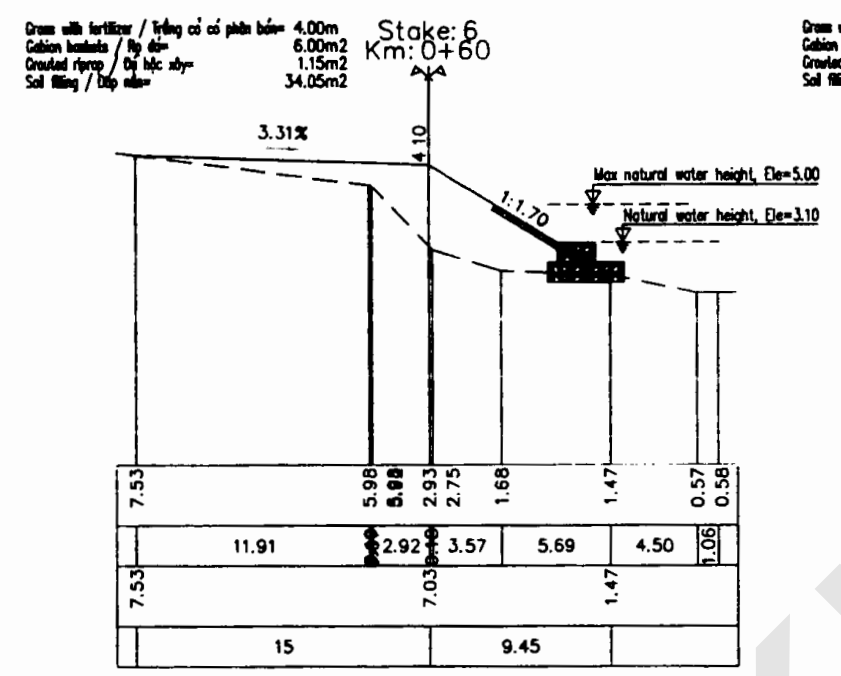

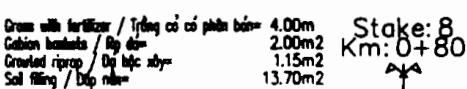

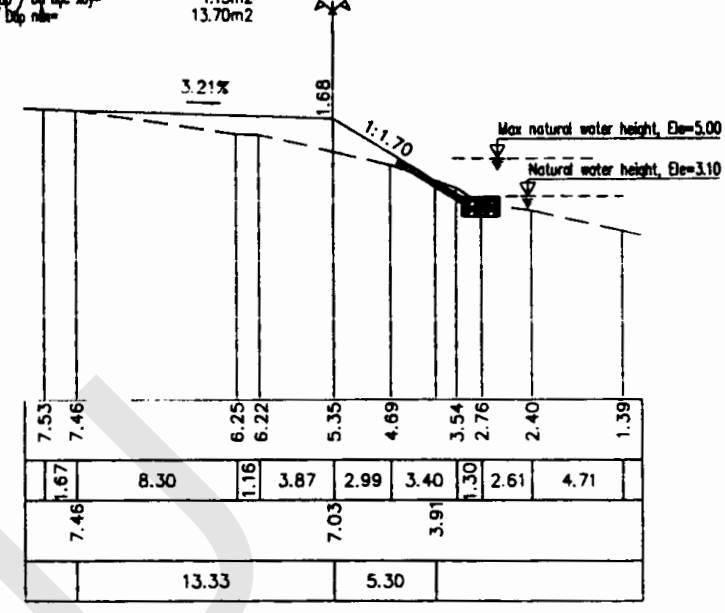

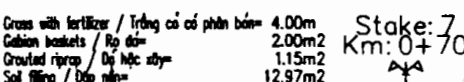

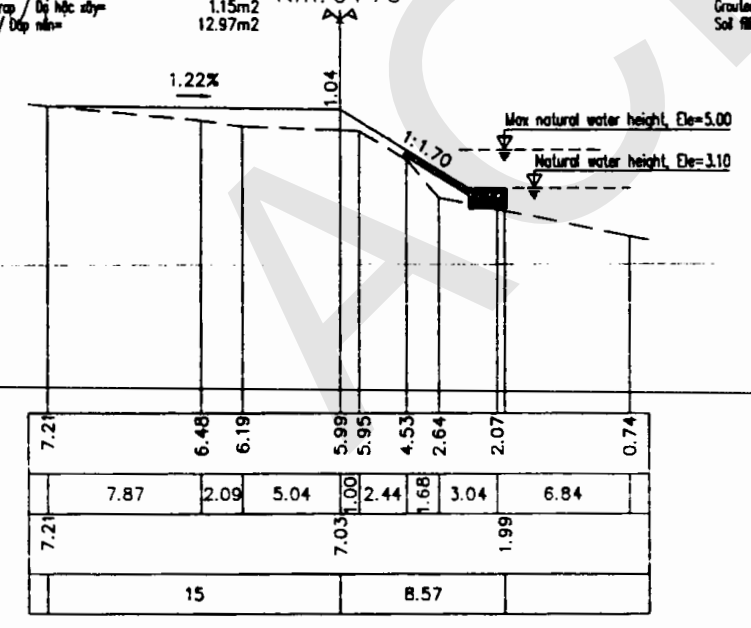

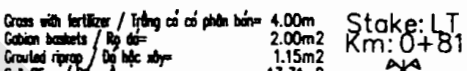

ind

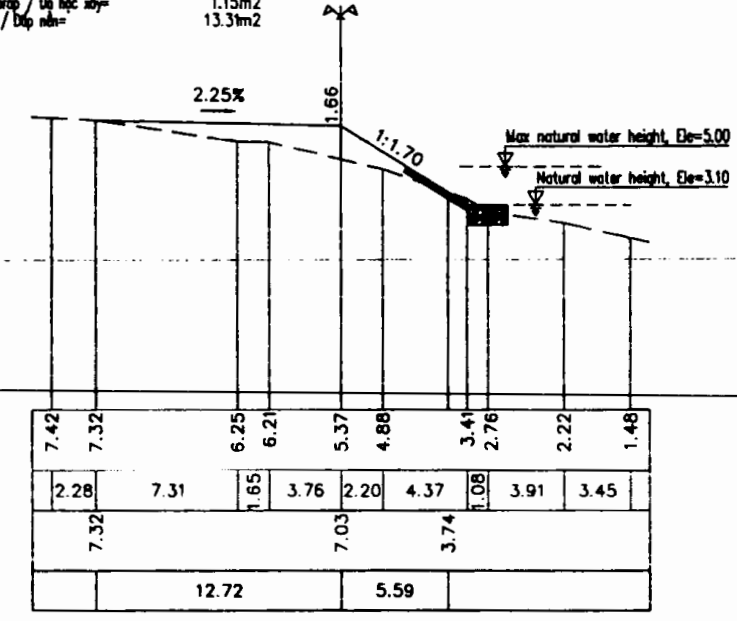

\begin{tabular}{c} 
THE EMPPLOYER \\
\hline $\begin{array}{c}\text { SOCWUUST REPUBLC OF VETUMM } \\
\text { MINISTRY OF"TRANSPORT } \\
\text { MET NAM OXPRESSWAY CORPORATON }\end{array}$
\end{tabular}

GETINSA

THE ENGINEER

THE CONTRACTOR

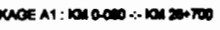
RESTORATOW OF AMER DAN AT TAN LOI BNOJES

CROSS SECTOW/MUT ChT MENG Duro Na. REV.

POSCOE \& C 


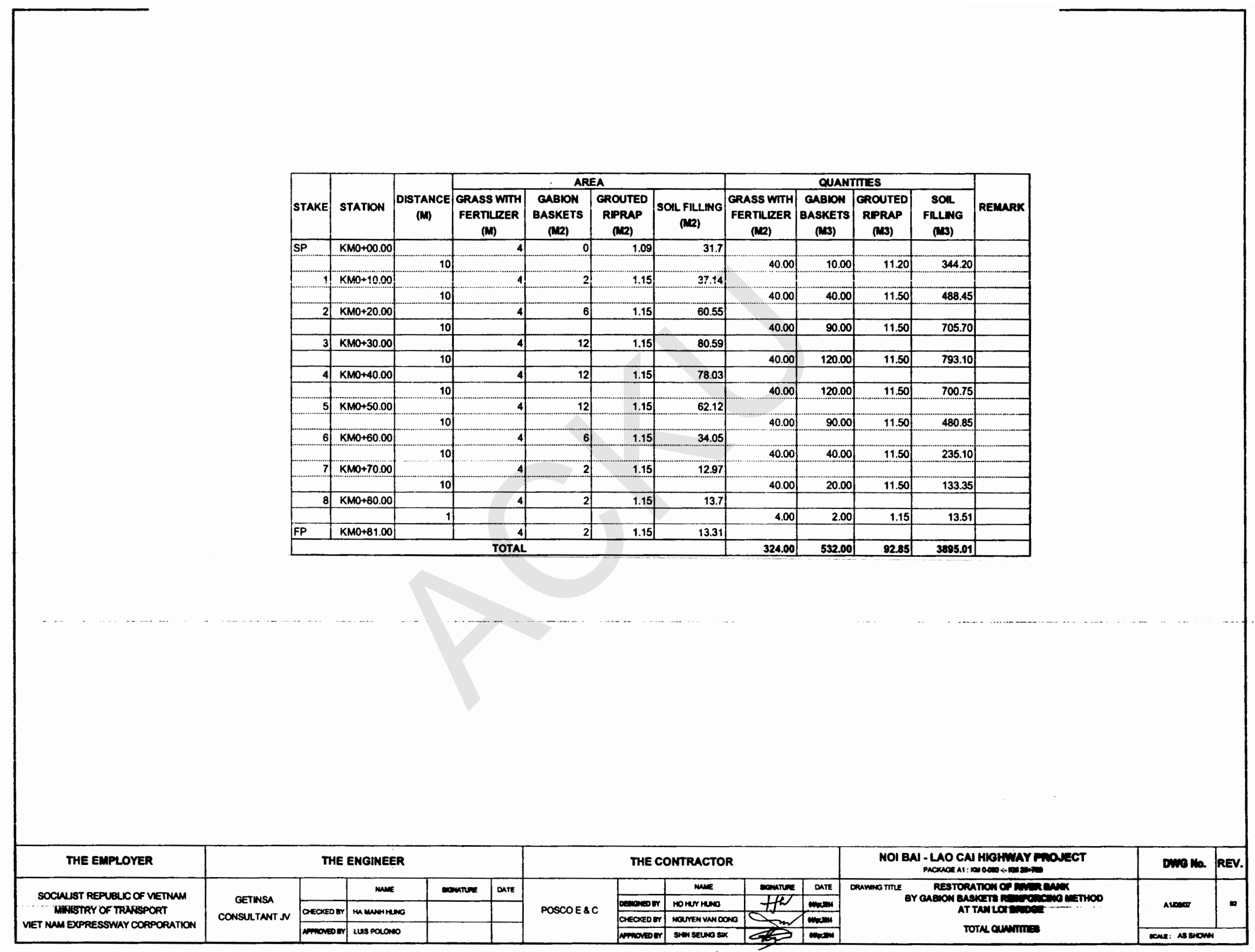


NOI BAI - LAO CAI HIGHWAY CONSTRUCTION PROJECT

DƯ ÁN XÂY DỰNG ĐƯÒNG CAO TỐC NộI BÀI - LÀO CAI

PAGKAGE A1 / GÓl ThẦU A1: KM 0-080 -:- KM $26+700$

\section{SHOP DRAWING / BẢN VẼ THI CÔNG}

\section{NO. A1/05: XUAN PHUONG BRIDGE - KM7+660.05 RESTORATION OF RIVER BANK BY GABION BASKET METHOD}

SỐ A1/05: CẦU XUÂN PHUOUNG - KM7+660.05 KHÔI PHỤC BỜ SÔNG BẰnG BIỆN PHÁP RỌ ĐÁ 


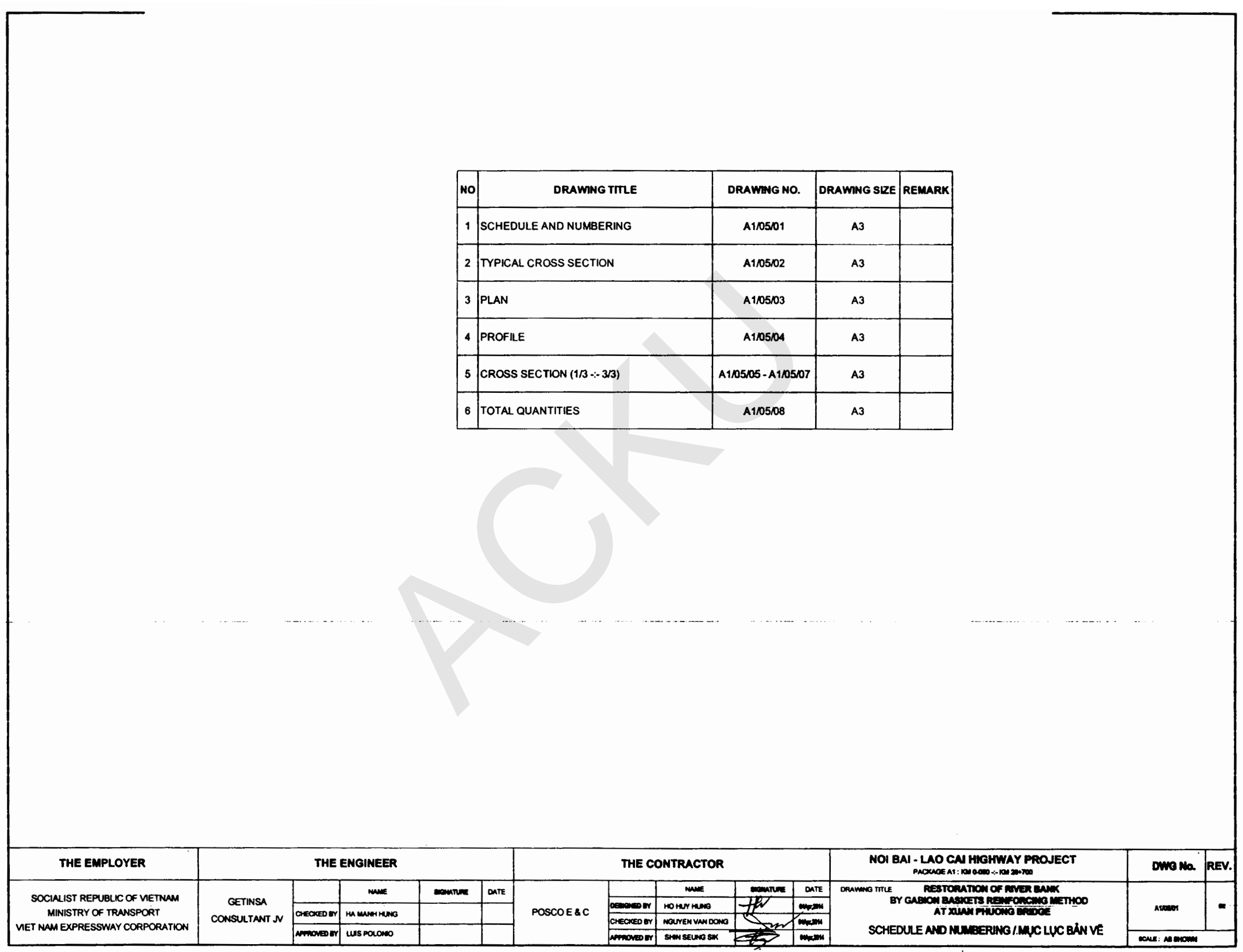




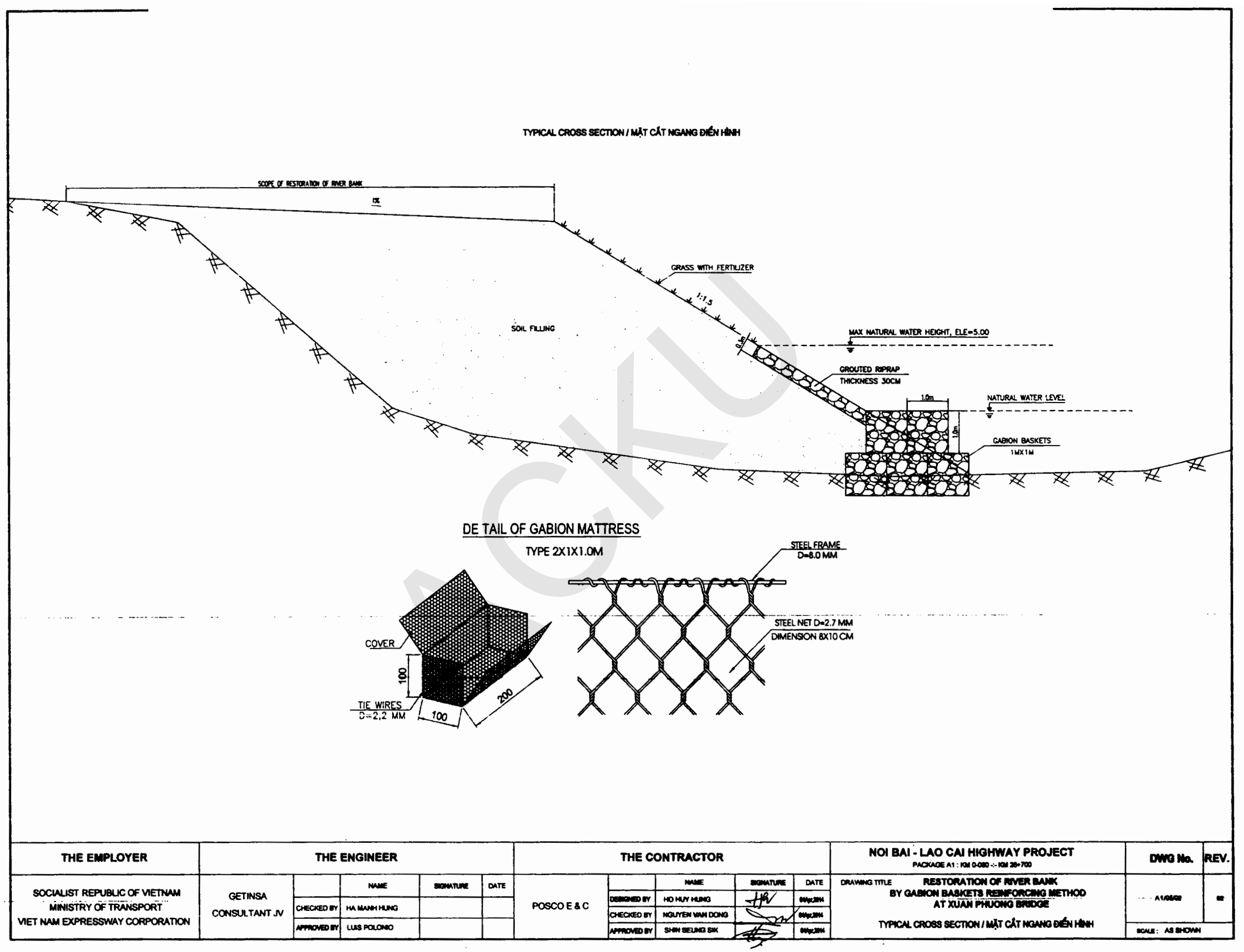




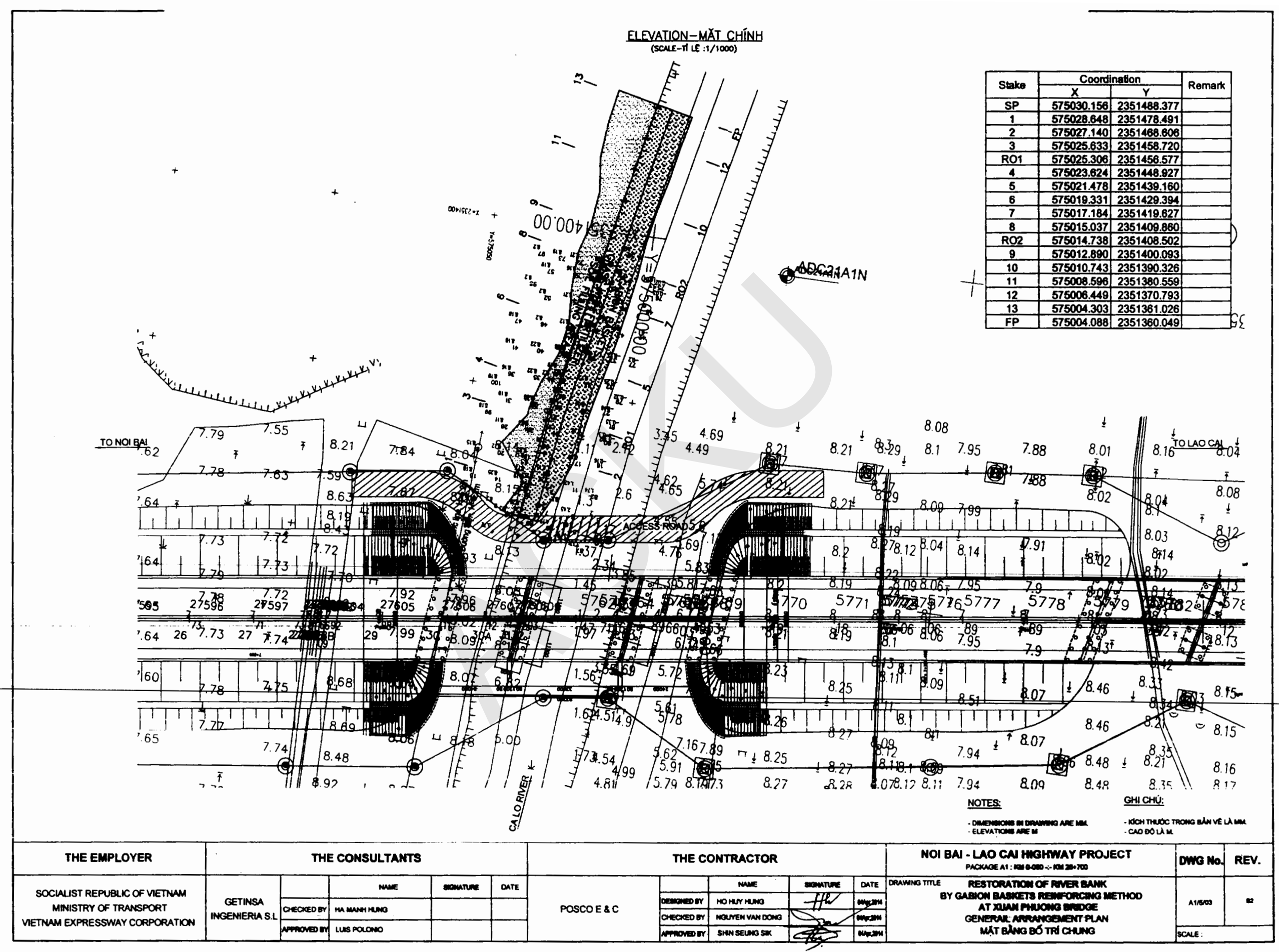




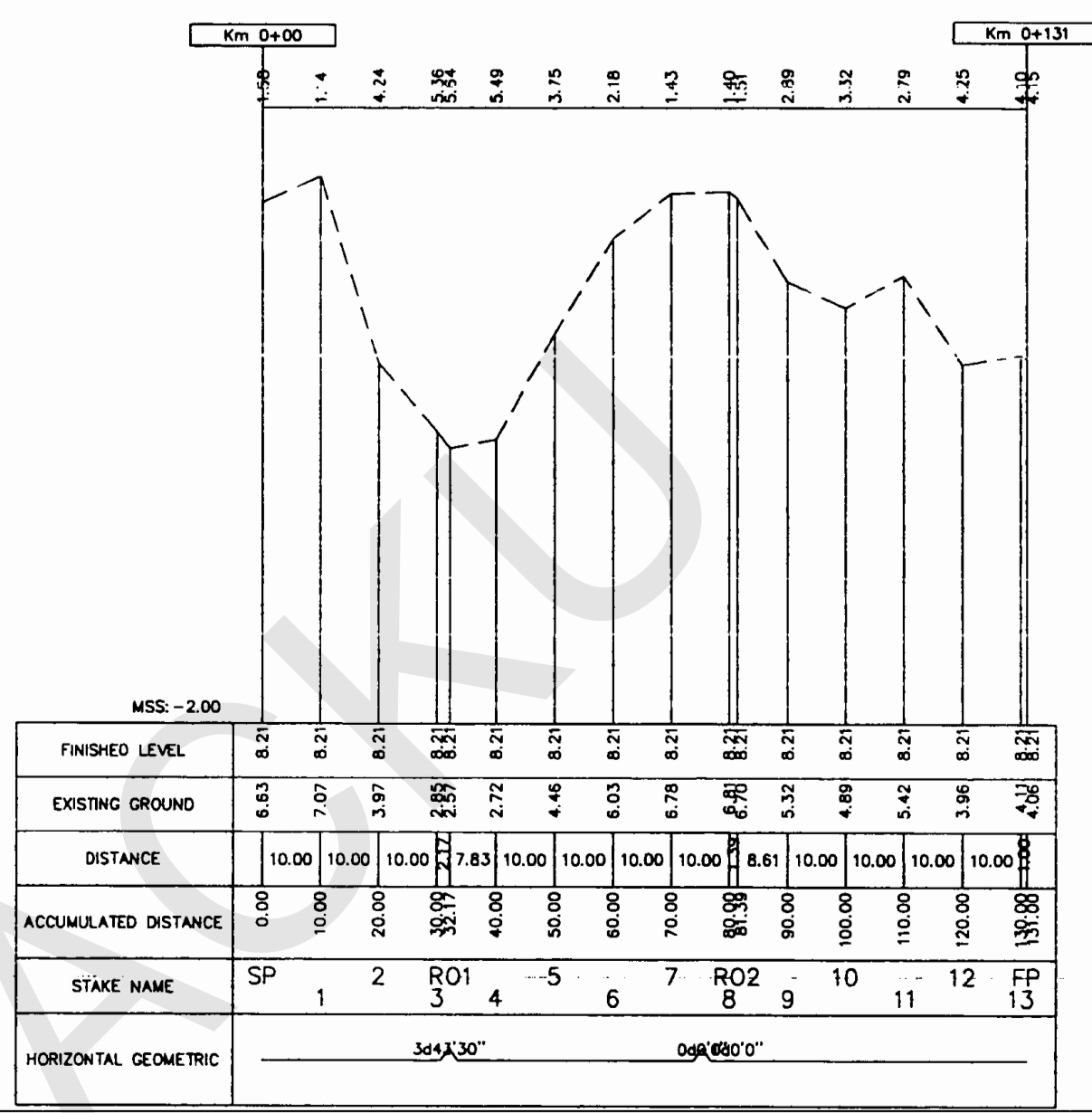

\begin{tabular}{|c|c|c|c|c|c|c|c|c|c|c|c|c|c|}
\hline THE EMPLOYER & \multicolumn{5}{|c|}{ THE ENGINEER } & \multicolumn{5}{|c|}{ THE CONTRACTOR } & NOI BAI - LAO CAI HIGHWAY PROJECT & Dwa na. & REV. \\
\hline \multirow{3}{*}{$\begin{array}{l}\text { SOCLALIST REPUELC OF VETNAM } \\
\text { MINISTRY OF TRANSPORT } \\
\text { MET MAM EXPRESSWAY CORPORATION }\end{array}$} & \multirow{3}{*}{$\begin{array}{c}\text { GETINSA } \\
\text { CONSURTANT NV }\end{array}$} & & muse & somine & OATE & \multirow{3}{*}{ POSCOE\&C } & & muse & momine: & onTE & \multirow{3}{*}{ 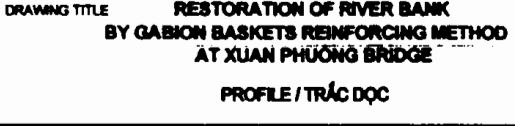 } & \multirow{2}{*}{ המשה } & \multirow{2}{*}{-} \\
\hline & & \multirow{2}{*}{\begin{tabular}{|c|c|} 
arecose or \\
\end{tabular}} & 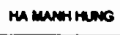 & & & & ChECOED or & 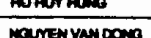 & $71^{\infty}$ & \multirow{2}{*}{$\begin{array}{l}\operatorname{man}_{\operatorname{man}} \\
\max \end{array}$} & & & \\
\hline & & & Lus procomo & & & & Nmoved or & SHEW SEAno SWK & 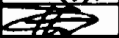 & & & \multicolumn{2}{|l|}{ 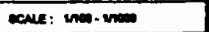 } \\
\hline
\end{tabular}



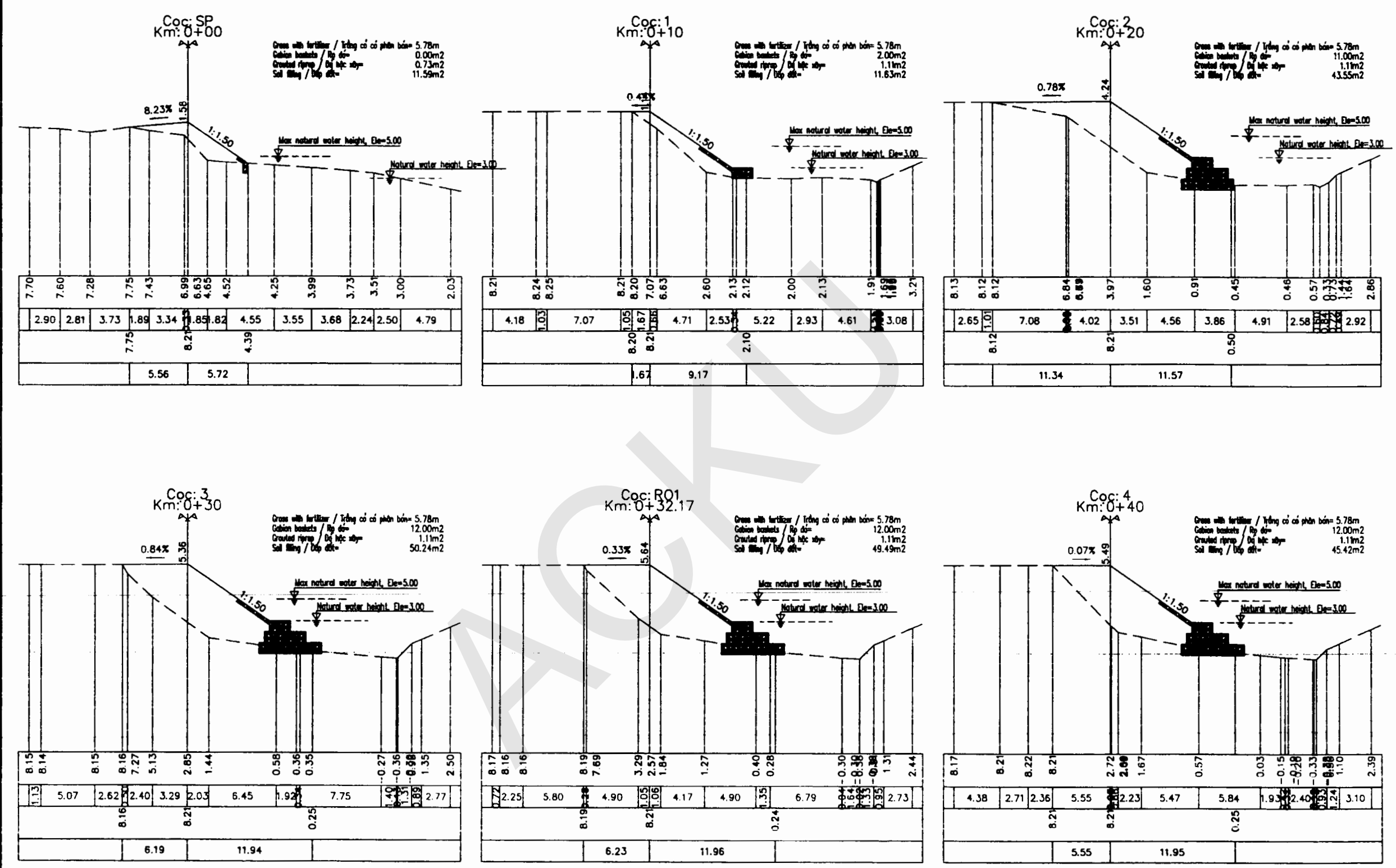

\begin{tabular}{|c|c|c|c|c|c|c|c|c|c|c|c|c|c|}
\hline THE EMPLOYER & \multicolumn{5}{|c|}{ THE ENGINEER } & \multicolumn{5}{|c|}{ THE CONTRACTOR } & NOI BN - LAO CAN HIGHWAY PROJECT & DWo No. & REV. \\
\hline \multirow{3}{*}{$\begin{array}{l}\text { SOCLALIST REPUBLIC OF VETNUM } \\
\text { MNISTRY OF TRANSPORT } \\
\text { MET NAM EXPRESSWAY CORPORATION }\end{array}$} & \multirow{3}{*}{$\begin{array}{c}\text { GETINSA } \\
\text { CONSULTANT SN }\end{array}$} & & mane & momrne & $\overline{\text { onte }}$ & \multirow{3}{*}{ POSCOE \& C } & \multirow{2}{*}{ 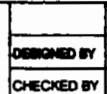 } & \multirow{2}{*}{ 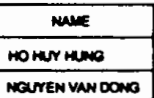 } & Wh & \multirow{2}{*}{\begin{tabular}{|c|} 
onre \\
$\min _{\min }$ \\
\end{tabular}} & \multirow{3}{*}{ 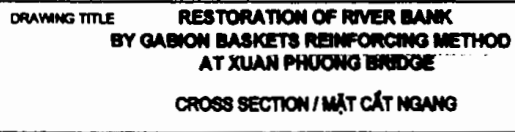 } & \multirow[t]{2}{*}{ Anososos } & \multirow[t]{2}{*}{ - } \\
\hline & & arecose or & 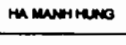 & & & & & & $\cos$ & & & & \\
\hline & & nomover or & Lus pocomo & & & & Nemoved on & 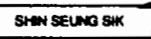 & $x^{20}$ & 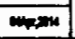 & & Cone: 12000-12000 & \\
\hline
\end{tabular}



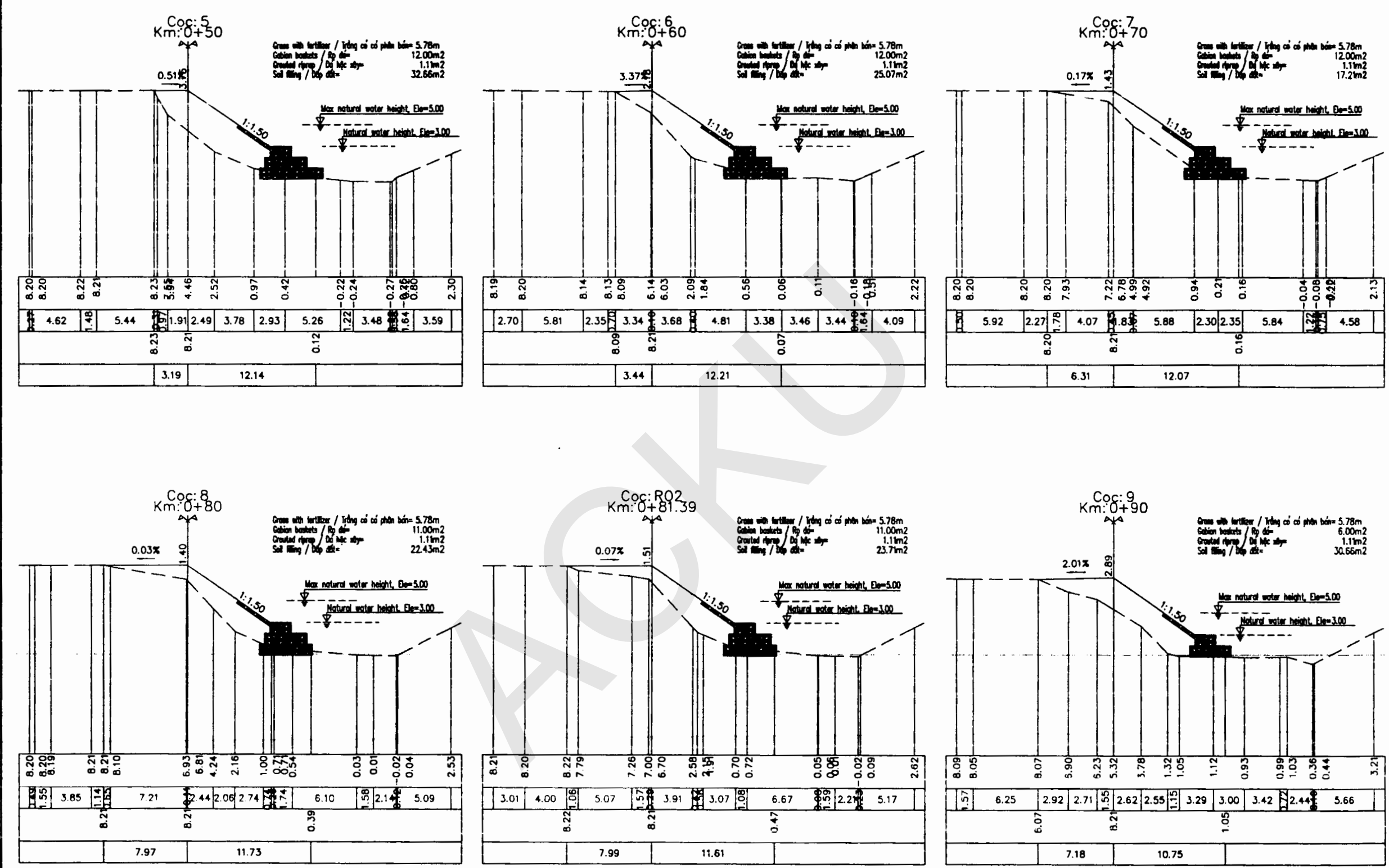

\begin{tabular}{|c|c|c|c|c|c|c|}
\hline THE EMPLOYER & \multicolumn{5}{|c|}{ THE ENGINEER } & \\
\hline \multirow{3}{*}{$\begin{array}{c}\text { SOCMUIST REPUBLIC OF VETNAM } \\
\text { MINISTRY OF TRANSPORT } \\
\text { VET NAM EXPRESSWAY CORPORATION }\end{array}$} & \multirow{3}{*}{$\begin{array}{c}\text { GETINSA } \\
\text { CONSULTANT NN }\end{array}$} & & nume & somirese & oare & \multirow{3}{*}{ POSCOE\&C } \\
\hline & & CHECOED ET & 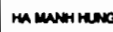 & & & \\
\hline & & Nemoved er & Lus polowo & & & \\
\hline
\end{tabular}

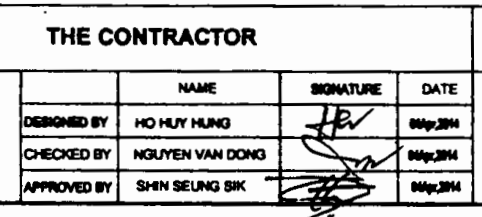

\begin{tabular}{|c|c|c|}
\hline NOI BAI - LAO CAI HIOHWAY PROJECT & DWo Ho. & REV. \\
\hline \multirow{2}{*}{ 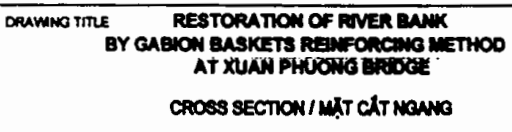 } & A100000 & \\
\hline & \multicolumn{2}{|l|}{ conse: 12000. 10000} \\
\hline
\end{tabular}



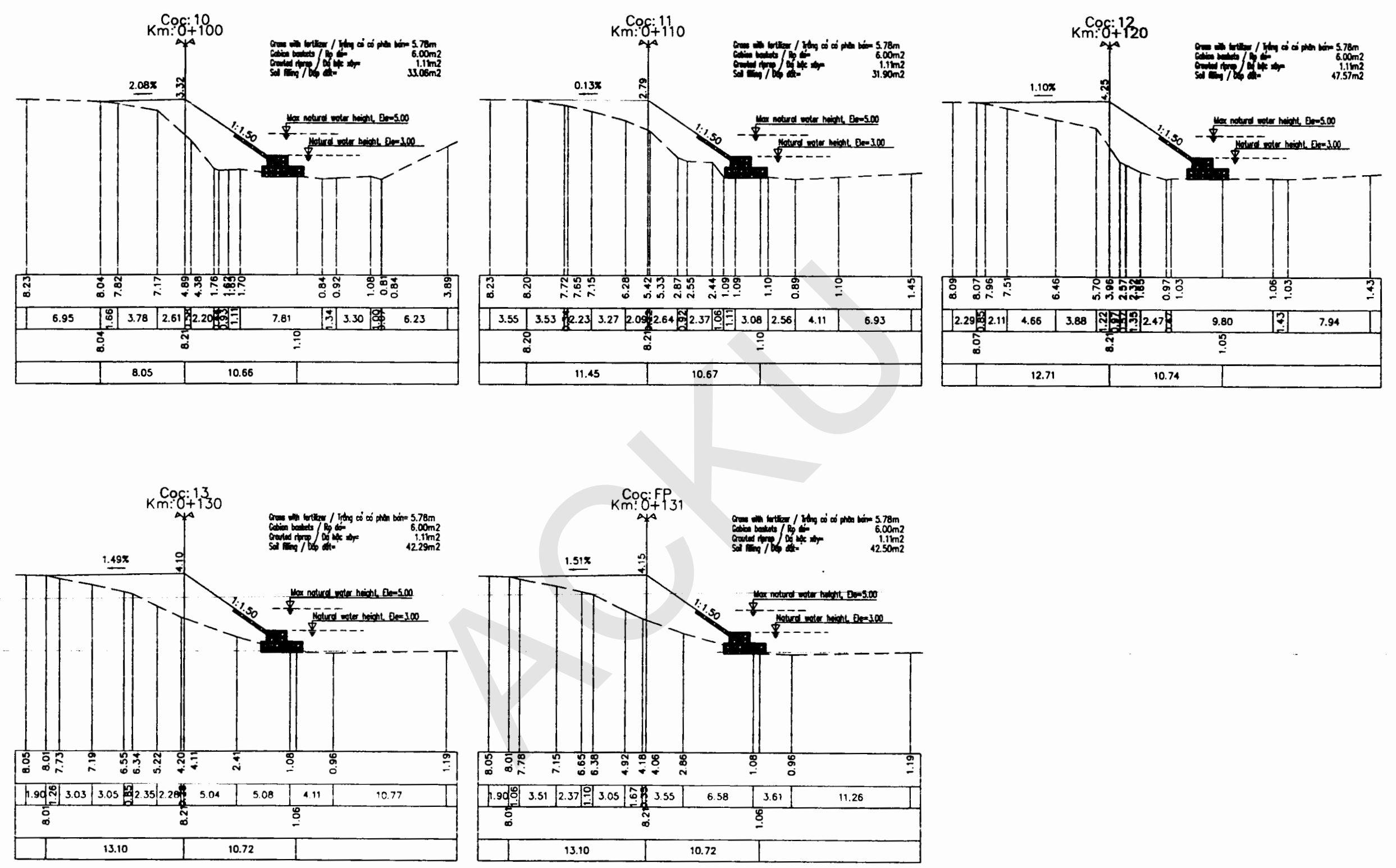

\begin{tabular}{|c|c|c|c|c|c|c|c|c|c|c|c|c|c|}
\hline THE EMPLOYER & \multicolumn{5}{|c|}{ THE ENGINEER } & \multicolumn{5}{|c|}{ THE CONTRACTOR } & NOI BAI - LAO CAN HMGHAYY PROJECT & Dwo Na. & REV. \\
\hline \multirow{3}{*}{$\begin{array}{l}\text { SOCWUIST REPUALC OF VETMAM } \\
\text { MINISTRY OF TRANSPORT } \\
\text { MET MUM EXPRESSWAY CORPORATION }\end{array}$} & \multirow{3}{*}{ CONSULTANT N } & & MUME & sourve & onTE & \multirow{3}{*}{ POSCOE\&C } & & mewe & memirux & onfe & \multirow{3}{*}{ 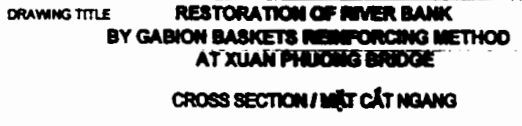 } & \multirow{2}{*}{ A 1,0000 } & \\
\hline & & creexeo or & 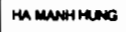 & & & & arcater or & 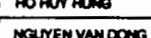 & & $\min \mid$ & & & \\
\hline & & momove or & Lus promo & & & & MAPnovet or & \begin{tabular}{|l|} 
SHWW SELUWG Sim \\
\end{tabular} & 25 & $\operatorname{mon}$ & & ache: $12000 \cdot 1200$ & \\
\hline
\end{tabular}




\begin{tabular}{|c|c|c|c|c|c|c|c|c|c|c|c|}
\hline \multirow[b]{2}{*}{ STAKE } & \multirow[b]{2}{*}{ STATION } & \multirow[b]{2}{*}{$\begin{array}{c}\text { OISTANCE } \\
\text { (M) }\end{array} \mid$} & \multicolumn{4}{|c|}{ AREA } & \multicolumn{4}{|c|}{ QUANTITES } & \multirow[b]{2}{*}{ REMARK } \\
\hline & & & $\begin{array}{c}\text { GRASS WTH } \\
\text { FERTLLEER } \\
\text { (M) }\end{array}$ & $\begin{array}{c}\text { GABION } \\
\text { BASKETS } \\
\text { (112) }\end{array}$ & \begin{tabular}{c|} 
CROUTED \\
RIPRAP \\
(NOA)
\end{tabular} & $\begin{array}{c}\text { SOM } \\
\text { FRLMO } \\
\text { (MR) }\end{array}$ & $\begin{array}{c}\text { CRASS WTH } \\
\text { FERTLZER } \\
\text { (IEZ) }\end{array}$ & \begin{tabular}{|c|} 
GABION \\
BASKETS \\
(MB) \\
\end{tabular} & $\begin{array}{c}\text { GROUTED } \\
\text { RIPRAP } \\
\text { (MB3) }\end{array}$ & $\begin{array}{l}\text { sonk } \\
\text { Fulwo } \\
\text { (Na) }\end{array}$ & \\
\hline \multirow[t]{2}{*}{$S P$} & KMO+00.00 & & 5.78 & 0.00 & 0.73 & 11.59 & & & & & \\
\hline & & 10 & & & & & 57.80 & 10.00 & 920 & 118.10 & \\
\hline \multirow[t]{2}{*}{$\cdots-1$} & $\mathrm{KMOO+10.00}$ & & 5.78 & 2.00 & 1.11 & 11.83 & & & & & \\
\hline & & 10 & & & & & 5780 & 65.00 & 11.10 & 275.90 & \\
\hline \multirow[t]{2}{*}{2} & $\mathrm{KMMO+20.00}$ & & 5.78 & 11.00 & 1.11 & 43.55 & & & & & \\
\hline & & 10 & & & & & 57.80 & 115.00 & 11.10 & 468.95 & \\
\hline \multirow[t]{2}{*}{3 . } & $\mathrm{KMO}+30.00$ & & 5.78 & 1200 & 1.11 & 50.24 & & & & & \\
\hline & & 2.17 & & & & & 12.54 & 26.04 & 2.41 & 10821 & \\
\hline \multirow[t]{2}{*}{ RO1 } & $\mathrm{KMO}+32.17$ & & 5.78 & 12.00 & 1.11 & 49.49 & & & & & \\
\hline & & 7.83 & & & & & 45.26 & 93.96 & 8.69 & 371.57 & \\
\hline \multirow[t]{2}{*}{4} & $K M O+40.00$ & & 5.78 & 12.00 & 1.11 & 45.42 & & & & & \\
\hline & & $10 \mid$ & & & & & 57.80 & 120.00 & 11.10 & 390.40 & \\
\hline \multirow[t]{2}{*}{5} & $K M 0+50.00$ & & 5.78 & 12.00 & 1.11 & 32.66 & & & & & \\
\hline & & 10 & & & & & 57.80 & 120.00 & 11.10 & 288.65 & \\
\hline \multirow[t]{2}{*}{6} & KMO+60.00 & & 5.78 & 12.00 & 1.11 & 25.07 & & & & & \\
\hline & & 10 & & & & & 57.80 & 120.00 & 11.10 & 211.40 & \\
\hline \multirow[t]{2}{*}{7} & $\mathrm{KMOO}+70.00$ & & 5.78 & 1200 & 1.11 & 1721 & & & & & \\
\hline & & 10 & & & & & 57.80 & 115.00 & 11.10 & 198.20 & \\
\hline \multirow[t]{2}{*}{8} & $K M 0+80.00$ & & 5.78 & 11.00 & 1.11 & 22.43 & & & & & \\
\hline & & 139 & & & & & 8.03 & 15.29 & 1.54 & 32.07 & \\
\hline \multirow[t]{2}{*}{$\mathrm{RO} 2$} & KMO+8139 & & 5.78 & 11.00 & 1.11 & 23.71 & & & & & \\
\hline & & 8.61 & & & & & 49.77 & 73.19 & 9.56 & 234.06 & \\
\hline \multirow[t]{2}{*}{9} & $\mathrm{KMO}+90.00$ & & 5.78 & 6.00 & 1.11 & 30.66 & & & & & \\
\hline & & 10] & & & & & 57.80 & 60.00 & 11.10 & 318.60 & \\
\hline \multirow[t]{2}{*}{10} & $\mathrm{KMO}+100.00$ & & 5.78 & 6.00 & 1.11 & 33.06 & & & & & \\
\hline & & 10) & & & & & 57.80 & 60.00 & 11.10 & 324.80 & \\
\hline \multirow[t]{2}{*}{11} & $K M O+110.00$ & & 5.76 & 6.00 & 1.11 & 31.90 & & & & & \\
\hline & & 10 & & & & & 57.80 & 60.00 & 11.10 & 397.35 & \\
\hline \multirow[t]{2}{*}{12} & $\mathrm{KMO}+120.00$ & & 5.78 & 6.00 & 1.11 & 47.57 & & & & & \\
\hline & & 10] & & & & & 57.80 & 60.00 & 11.10 & 449.30 & \\
\hline \multirow[t]{2}{*}{13} & $\mathrm{KMO}+130.00$ & & 5.78 & 8.00 & 1.11 & 4229 & & & & & \\
\hline & & $1]$ & & & & & 5.78 & 6.00 & 1.11 & 42.40 & \\
\hline FP & KMO+131.00 & & 5.78 & 6.00 & 1.11 & 42.50 & & & & & \\
\hline \multicolumn{11}{|c|}{\begin{tabular}{|l|l|l|l|}
757.18 & 1112.48 & 143.51 & 1227.96 \\
\end{tabular}} & \\
\hline
\end{tabular}

\begin{tabular}{|c|c|c|c|c|c|c|c|c|c|c|c|c|c|}
\hline THE EMPLOYER & \multicolumn{5}{|c|}{ THE ENGINEER } & \multicolumn{5}{|c|}{ THE CONTRACTOR } & NOI BNI - LAO CAN HIGHWAY PROJECT & Dwo No. & REV. \\
\hline \multirow{3}{*}{$\begin{array}{l}\text { SOCULUST REPUSUC OF VETNAM } \\
\text { MINISTRY OF TRANSPORT } \\
\text { VET NAM EXPRESSWAY CORPORATKON }\end{array}$} & \multirow{3}{*}{$\begin{array}{c}\text { GETNSA } \\
\text { CONSULTANT NN }\end{array}$} & & mene & momirne & DATE & \multirow{3}{*}{ POSCOE \& C } & & mate & manume & onte & \multirow{3}{*}{ 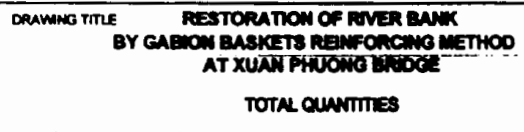 } & \multirow[b]{2}{*}{ Areseon. } & \\
\hline & & \multirow{2}{*}{\begin{tabular}{|l|} 
oreconeo or \\
menove o o \\
\end{tabular}} & Ha mevertons & & & & \multirow{2}{*}{ 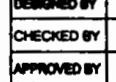 } & \multirow{2}{*}{ 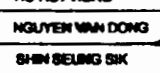 } & \multirow{2}{*}{$\frac{t h}{15}$} & \multirow{2}{*}{$\sum_{m=1}$} & & & " \\
\hline & & & Lus pocomo & & & & & & & & & \multicolumn{2}{|l|}{ cone: is strown } \\
\hline
\end{tabular}


Loan 2391/2392 - VIE: GMS Kunming - Hai Phong Transport Corridor Noi Bai - Lao Cai Highway Project

15. ANNEX 9: DOCUMENTATION RELATED TO COMPLAINTS AND COMPENSATION ACTIVITIES DUE TO SOCIAL IMPACTS 
 \\ Loan 2391/2392 - VIE: GMS Kunming - Hai Phong Transport Corridor Noi Bai - Lao Cai Highway Project}

This report is just a compilation of the current status of the complaints of local people in some packages, related with social impact caused by construction activities, such as landslide over agricultural fields and damages to houses due to vibrations.

It's necessary to clarify that here is included only the available information submitted to the Consultant.

This information, related with packages $\mathrm{A} 3, \mathrm{~A} 4$ and $\mathrm{A} 6$, is presented as summary tables.

Also, it's included a specific chapter with detailed information about the current situation of the complaints and compensation activities at Tien Kien Commune, Lam Thao District, affected by works in Package A4. 


\section{Loan 2391/2392 - VIE: GMS Kunming - Hai Phong Transport Corridor} Noi Bai - Lao Cai Highway Project

\section{COMPENSATION STATUS. SUMMARY TABLES}

\section{PACKAGE A3}

\begin{tabular}{|c|c|c|c|c|c|c|c|c|}
\hline Section & Commune & District & $\begin{array}{l}\text { Subcontrl } \\
\text { Construct } \\
\text { team }\end{array}$ & Location & Current Status & Required & Target & Deadline \\
\hline \multirow{3}{*}{ Section 1} & Hung Lo & \multirow{3}{*}{$\begin{array}{l}\text { Viet Tri } \\
\text { City }\end{array}$} & TGT & $\underset{48+600}{\mathrm{Km}}$ & $\begin{array}{l}\text { TGT and local government discuss } \\
\text { about the compensation list and make } \\
\text { agreement for payment amount }\end{array}$ & \multirow{3}{*}{$\begin{array}{l}\text { Co-operate with local } \\
\text { government to } \\
\text { finalize the total } \\
\text { amount has to pay } \\
\text { for soil sliding } \\
\text { compensation }\end{array}$} & \multirow{3}{*}{$\begin{array}{l}\text { - Meeting with } \\
\text { local government } \\
\text { compensation list } \\
\text { - Make the plan for } \\
\text { payment to } \\
\text { affected people }\end{array}$} & \multirow{3}{*}{$\begin{array}{l}5^{\text {th }} \text { May, } \\
2014\end{array}$} \\
\hline & Kim Đức & & TGT & $\begin{array}{c}\mathrm{Km} \\
50+225 \text { to } \\
\mathrm{Km} \\
50+680\end{array}$ & $\begin{array}{l}\text { TGT still not yet fix the compensation } \\
\text { list and fix the unit price for } \\
\text { compensation }\end{array}$ & & & \\
\hline & $\begin{array}{l}\text { Phuong } \\
\text { Lau }\end{array}$ & & TGT & $\underset{49+145}{K m}$ & $\begin{array}{l}\text { TGT and local government discuss } \\
\text { about the compensation list and make } \\
\text { agreement for payment amount }\end{array}$ & & & \\
\hline \multirow{3}{*}{$\begin{array}{l}\text { Section } 1 \\
\text { Section } \\
2-1\end{array}$} & \multirow{3}{*}{ Phù Ninh } & \multirow{3}{*}{ Phu Ninh } & \multirow{3}{*}{ TGT } & $\begin{array}{c}\mathrm{Km} \\
53+560\end{array}$ & $\begin{array}{l}\text { There is some additional householders } \\
\text { who continue claim for flooding } \\
\text { compensation. POSCO has fix the list } \\
\text { and affective area but local } \\
\text { government not yet confirmed }\end{array}$ & \multirow{3}{*}{$\begin{array}{l}\text { Push to Phu Ninh } \\
\text { people Commitee }\end{array}$} & \multirow{3}{*}{$\begin{array}{l}\text { Solve this mater } \\
\text { before open traffic } \\
\text { date }\left(31^{\text {st }} \text {, March }\right. \\
\text { 2014) }\end{array}$} & \multirow{3}{*}{$\begin{array}{l}5^{\text {th }} \text { May, } \\
2014\end{array}$} \\
\hline & & & & $\begin{array}{l}\mathrm{Km} \\
54+140 \\
\text { (Right } \\
\text { side) }\end{array}$ & $\begin{array}{l}\text { TGT did not discuss with local } \\
\text { government for compensation amount }\end{array}$ & & & \\
\hline & & & & $\begin{array}{c}\mathrm{Km} \\
56+800\end{array}$ & $\begin{array}{l}\text { Calculation the soil sliding } \\
\text { compensation up to } 129 \text { million VND } \\
\text { but TGT did not payment }\end{array}$ & & & \\
\hline
\end{tabular}

\section{Hanoi office:}

$12^{\text {th }}$ floor, Ocean Park Building, Dao Duy Anh Street, Dong Da Distric

VinhPhuc office: Huu Thu Hamlet, Kim Long Ward, Tam Duong Distric, VinhPhuc Province 


\section{getinsa}

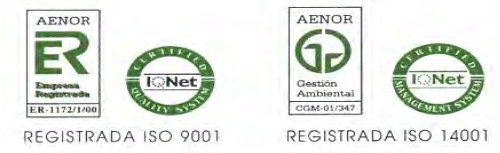

\section{Loan 2391/2392 - VIE: GMS Kunming - Hai Phong Transport Corridor}

Noi Bai - Lao Cai Highway Project

\begin{tabular}{|c|c|c|c|c|c|c|c|c|}
\hline Section & Commune & District & $\begin{array}{c}\text { Subcontrl } \\
\text { Construct } \\
\text { team }\end{array}$ & Location & Current Status & Required & Target & Deadline \\
\hline $\begin{array}{c}\text { Section } \\
2-2\end{array}$ & $\begin{array}{c}\text { Xã } \\
\text { Tiên Kiên }\end{array}$ & $\begin{array}{l}\text { Lam } \\
\text { Thao }\end{array}$ & $\begin{array}{l}\text { Long } \\
\text { Vương }\end{array}$ & $\begin{array}{c}\mathrm{Km} \\
57+300\end{array}$ & $\begin{array}{l}\text { Long Vuong has paid the } \\
\text { compensation to local people but still } \\
\text { remain } 18 \text { householders did not agree } \\
\text { so they did not receive money }\end{array}$ & $\begin{array}{l}\text { Long Vuong will work } \\
\text { again with Tien Kien } \\
\text { PPC and local } \\
\text { people to get the } \\
\text { agreement for } \\
\text { compensation unit } \\
\text { price }\end{array}$ & $\begin{array}{l}\text { Try to pay to local } \\
\text { people. If not Long } \\
\text { Vuong will hand } \\
\text { over the money to } \\
\text { government } \\
\text { instead of local } \\
\text { resident }\end{array}$ & $\begin{array}{c}5^{\text {th }} \text { May, } \\
2014\end{array}$ \\
\hline Section 3 & Phú Hộ & $\begin{array}{c}\text { Phu Tho } \\
\text { Town }\end{array}$ & $\begin{array}{l}\text { Long } \\
\text { Vương }\end{array}$ & $\begin{array}{c}\mathrm{Km} \\
61+400 \\
\text { Cam Phu } \\
\mathrm{Km} \\
61+800\end{array}$ & $\begin{array}{l}\text { - Long Vuong and Heungwoo already } \\
\text { pay the compensation amount of } 2012 \text {. } \\
\text { But local people claim more about } \\
2013 \text { and } 2014 \text {. } \\
\text { - Now POSCO has fixed the total } \\
\text { amount of } 2013 \text { is } 88.046 .557 \text { VND } \\
\text { - Local people continue claim about } \\
2014 \text { compensation }\end{array}$ & $\begin{array}{l}\text { Push Long Vuong to } \\
\text { in charge of pay } \\
\text { compensation at } \mathrm{Km} \\
61+400 \text { and } \mathrm{Km} \\
61+800 \text { with total } \\
\text { amount of } \\
46.406 .934 \mathrm{VND} \\
\text { - POSCO will pay } \\
\text { amount of } \\
41.639 .623 \mathrm{VND}\end{array}$ & $\begin{array}{l}\text { Long Vuong and } \\
\text { POSCO will try to } \\
\text { pay the } \\
\text { compensation } \\
2013 \text { on date } 10^{\text {th }} \\
\text { Mar, } 2014\end{array}$ & $\begin{array}{l}\text { Already } \\
\text { payment } \\
\text { on } 28^{\text {th }} \\
\text { March, } \\
2014\end{array}$ \\
\hline Section 5 & $\begin{array}{l}\text { Xã Đông } \\
\text { Thành }\end{array}$ & $\begin{array}{c}\text { Thanh } \\
\mathrm{Ba}\end{array}$ & Sao Vàng & $\begin{array}{c}\mathrm{Km} \\
69+150\end{array}$ & $\begin{array}{l}\text { There is } 8 \text { householder at Zone } 16 \text { with } \\
\text { total area is } 432,48 m 2 \text {. Work with local } \\
\text { people to unify the unit price and } \\
\text { compensation cost. }\end{array}$ & $\begin{array}{l}\text { Request Sao Vang to } \\
\text { work with local } \\
\text { government to } \\
\text { finalize the } \\
\text { compensation } \\
\text { amount }\end{array}$ & $\begin{array}{l}\text { If Sao Vang did } \\
\text { not pay, POSCO } \\
\text { will be in charge } \\
\text { then deduct from } \\
\text { Sao Vang } \\
\text { retension amount }\end{array}$ & $\begin{array}{c}5^{\text {th }} \text { May, } \\
2014\end{array}$ \\
\hline
\end{tabular}

\section{Hanoi office:}

VinhPhuc office:

Madrid head office: $12^{\text {th }}$ floor, Ocean Park Building, Dao Duy Anh Street, Dong Da Distric

Huu Thu Hamlet, Kim Long Ward, Tam Duong Distric, VinhPhuc Province

Calle Ramón de Aguinaga 8, 28028 Madrid, Spain 


\section{getinsa}

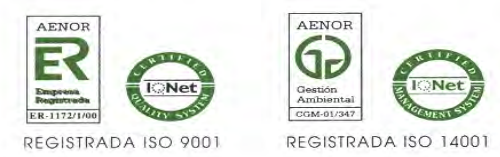

\section{Loan 2391/2392 - VIE: GMS Kunming - Hai Phong Transport Corridor}

Noi Bai - Lao Cai Highway Project

\begin{tabular}{|c|c|c|c|c|c|c|c|c|}
\hline Section & Commune & District & $\begin{array}{c}\text { Subcontrl } \\
\text { Construct } \\
\text { team }\end{array}$ & Location & Current Status & Required & Target & Deadline \\
\hline Section 5 & Xã Võ Lao & & Sao Vàng & $\begin{array}{c}\mathrm{Km} \\
70+907\end{array}$ & $\begin{array}{l}\text { Unify the unit price and cost } \\
\text { estimation. Total amount is } 32.987 .520 \\
\text { VND. However the local people } \\
\text { disagree with this amount. }\end{array}$ & $\begin{array}{l}\text { Request Sao Vang } \\
\text { complete before } 15^{\text {th }} \\
\text { Mar and pay the } \\
\text { compensation cost } \\
\text { before } 31^{\text {st }} \text { Mar, } 2014\end{array}$ & $\begin{array}{l}\text { If Sao Vang did } \\
\text { not pay, POSCO } \\
\text { will be in charge } \\
\text { then deduct from } \\
\text { Sao Vang retesion } \\
\text { amount }\end{array}$ & $25^{\text {th }}$ April \\
\hline Section 6 & $\begin{array}{l}\text { Xã Chí } \\
\text { Tiên }\end{array}$ & & Vinashin & $\begin{array}{c}\mathrm{Km} \\
73 \sim \mathrm{Km} 75\end{array}$ & $\begin{array}{l}\text { Total amount is } 299.349 .000 \text { VND. } \\
\text { Vinashin co-operate with local } \\
\text { government to pay the compensation } \\
\text { cost in twice: First payment will be } \\
100.000 .000 \text { VND. } \\
\text { Vinashin did not pay the second } \\
\text { payment }\end{array}$ & $\begin{array}{l}\text { Push Vinashine pay } \\
\text { the second payment } \\
\text { with total amount of } \\
\text { 199.349.000 VND }\end{array}$ & $\begin{array}{l}\text { Vinashine should } \\
\text { pay before } 15^{\text {th }} \\
\text { Mar. If not, } \\
\text { POSCO will } \\
\text { deduct the } \\
\text { retension amount }\end{array}$ & $25^{\text {th }}$ April \\
\hline
\end{tabular}




\section{Loan 2391/2392 - VIE: GMS Kunming - Hai Phong Transport Corridor Noi Bai - Lao Cai Highway Project}

\section{PACKAGE A4}

\begin{tabular}{|c|c|c|c|c|c|c|c|}
\hline Commune & District & $\begin{array}{c}\text { Subcontrl } \\
\text { Construct } \\
\text { team }\end{array}$ & Location & $\begin{array}{c}\text { Current Status } \\
\left(\text { Rice field area }-\mathrm{m}^{2} \text { ) }\right.\end{array}$ & Required & Target & Deadline \\
\hline Sai Nga & \multirow{4}{*}{ Cam Khe } & KEANGNAM & $\begin{array}{c}\mathrm{Km} 80+000- \\
\mathrm{Km} 80+400\end{array}$ & 550 & \multirow{3}{*}{$\begin{array}{l}\text { The Contractor still fails to } \\
\text { deploy payment }\end{array}$} & \multirow{3}{*}{$\begin{array}{l}\text { Meeting with local } \\
\text { government } \\
\text { compensation list }\end{array}$} & $15^{\text {th }}$ Mar \\
\hline Son Nga & & & $\begin{array}{l}\mathrm{Km} 80+400- \\
\mathrm{Km} 82+500\end{array}$ & $\begin{array}{l}\text { 10,489 } \\
\text { The Contractor paid } \\
15.000 .000 \text { VND at } \\
\text { Km81+700 for local people }\end{array}$ & & & $10^{\text {th }}$ Mar \\
\hline Phung Xa & & KEANGNAM & $\begin{array}{l}\mathrm{Km} 82+500- \\
\mathrm{Km} 83+700\end{array}$ & 1,845 & & & $15^{\text {th }}$ Mar \\
\hline Tuy Loc & & KEANGNAM & $\begin{array}{l}\mathrm{Km85+800-} \\
\mathrm{Km} 88+700\end{array}$ & 10,271 & $\begin{array}{l}\text { The Contractor still fails to } \\
\text { deploy payment }\end{array}$ & $\begin{array}{l}\text { Meeting with local } \\
\text { government } \\
\text { compensation list }\end{array}$ & $31^{\text {st }}$ Mar \\
\hline Minh Coi & \multirow{3}{*}{ Ha Hoa } & KEANGNAM & $\begin{array}{l}\mathrm{Km} 88+700- \\
\mathrm{Km} 94+000\end{array}$ & 65,427 & $\begin{array}{l}\text { The Contractor still fails to } \\
\text { deploy payment }\end{array}$ & $\begin{array}{l}\text { Meeting with local } \\
\text { government } \\
\text { compensation list }\end{array}$ & $31^{\text {st }}$ Mar \\
\hline Van Lang & & & $\begin{array}{l}\mathrm{Km94+000-} \\
\mathrm{Km95+300}\end{array}$ & 11,647 & $\begin{array}{l}\text { The Contractor still fails to } \\
\text { deploy payment }\end{array}$ & $\begin{array}{l}\text { Meeting with local } \\
\text { government } \\
\text { compensation list }\end{array}$ & $15^{\text {st }}$ Mar \\
\hline Bang Gia & & & $\begin{array}{l}\mathrm{Km95+300-} \\
\mathrm{Km96+700}\end{array}$ & 1,315 & $\begin{array}{l}\text { The Contractor still fails to } \\
\text { deploy payment }\end{array}$ & $\begin{array}{l}\text { Meeting with local } \\
\text { government } \\
\text { compensation list }\end{array}$ & $31^{\text {st }}$ Mar \\
\hline
\end{tabular}

\section{Hanoi office:}

$12^{\text {th }}$ floor, Ocean Park Building, Dao Duy Anh Street, Dong Da Distric 
Loan 2391/2392 - VIE: GMS Kunming - Hai Phong Transport Corridor Noi Bai - Lao Cai Highway Project

\begin{tabular}{|c|c|c|c|c|c|c|c|}
\hline Commune & District & $\begin{array}{l}\text { Subcontrl } \\
\text { Construct } \\
\text { team }\end{array}$ & Location & $\begin{array}{c}\text { Current Status } \\
\left(\text { Rice field area }-\mathrm{m}^{2} \text { ) }\right.\end{array}$ & Required & Target & Deadline \\
\hline Vo Tranh & & & $\begin{array}{l}\mathrm{Km96+700-} \\
\mathrm{Km} 99+700\end{array}$ & 3,145 & $\begin{array}{l}\text { The Contractor still fails to } \\
\text { deploy payment }\end{array}$ & $\begin{array}{l}\text { Meeting with local } \\
\text { government } \\
\text { compensation list }\end{array}$ & $31^{\text {st }}$ Mar \\
\hline Quan Khe & & KEANGNAM & $\begin{array}{l}\mathrm{Km} 104+300- \\
\mathrm{Km} 108+200\end{array}$ & $\begin{array}{l}11,342 \\
\text { The Contractor paid } \\
170.000 .000 \text { VND at } \\
\text { Km105+620 for local people }\end{array}$ & $\begin{array}{l}\text { The Contractor still fails to } \\
\text { deploy payment }\end{array}$ & $\begin{array}{l}\text { Meeting with local } \\
\text { government } \\
\text { compensation list }\end{array}$ & $15^{\text {th }} \mathrm{Mar}$ \\
\hline
\end{tabular}

\section{PACKAGE A5}

\begin{tabular}{|c|c|c|}
\hline Location & Commune/District/Province & Status \\
\hline $\mathrm{Km} 109-\mathrm{Km} 115$ & $\begin{array}{c}\text { Minh Quan Commune, Tran Yen District, } \\
\text { Yen Bai Province }\end{array}$ & $\begin{array}{l}\text { The Contractor has already compensated local people for impaction at outside of land } \\
\text { acquisition during protection implementation (e.g. Rice field damage, fish pond } \\
\text { damage, cassava damage, damage to trees, land area damage, etc.). Besides, the } \\
\text { Contractor also combined with local people and local authorities in order to restore } \\
\text { irrigation and traffic system of the region. } \\
\text { The Contractor are applying some measures in order to prevent erosion and landslide } \\
\text { during rainy days at embankment and cutting slope. }\end{array}$ \\
\hline $\mathrm{Km} 115-\mathrm{Km} 118$ & $\begin{array}{c}\text { Bao Hung Commune, Tran Yen District, Yen } \\
\text { Bai Province }\end{array}$ & $\begin{array}{l}\text { The Contractor has already compensated local people for impaction at outside of land } \\
\text { acquisition during protection implementation (e.g. Rice field damage, fish pond } \\
\text { damage, cassava damage, damage to trees, land area damage, etc.). Besides, the } \\
\text { Contractor also combined with local people and local authorities in order to restore } \\
\text { irrigation and traffic system of the region. }\end{array}$ \\
\hline
\end{tabular}

\section{Hanoi office:}

VinhPhuc office:

Madrid head office: $12^{\text {th }}$ floor, Ocean Park Building, Dao Duy Anh Street, Dong Da Distric

Huu Thu Hamlet, Kim Long Ward, Tam Duong Distric, VinhPhuc Province Calle Ramón de Aguinaga 8, 28028 Madrid, Spain 


\section{getinso}

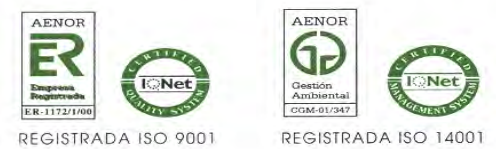

Loan 2391/2392 - VIE: GMS Kunming - Hai Phong Transport Corridor Noi Bai - Lao Cai Highway Project

\begin{tabular}{|c|c|c|}
\hline Location & Commune/District/Province & Status \\
\hline & & $\begin{array}{l}\text { There are some new affected areas related to irrigation system, Rice field damage, } \\
\text { land area damage, traffic condition, this moment, the Contractor is combining with local } \\
\text { people and local authorities in order to solve these problems. }\end{array}$ \\
\hline Km118 - Km123 & Yen Bai city, Yen Bai Province & $\begin{array}{l}\text { The Contractor has already compensated local people for impaction at outside of land } \\
\text { acquisition during protection implementation (e.g. Rice field damage, fish pond } \\
\text { damage, cassava damage, damage to trees, land area damage, etc.). Besides, the } \\
\text { Contractor also combined with local people and local authorities in order to restore } \\
\text { irrigation and traffic system of the region. } \\
\text { There are some new affected areas related to irrigation system, Rice field damage, fish } \\
\text { pond damage, house crack due to the Contractor's construction activities, land area } \\
\text { damage, traffic condition, this moment, the Contractor is combining with local people } \\
\text { and local authorities in order to solve these problems. }\end{array}$ \\
\hline Km123 - Km136 & $\begin{array}{l}\text { Minh Tien Commune, Y Kan Commune, } \\
\text { Quy Mong Commune, Tran Yen District, } \\
\text { Yen Bai Province }\end{array}$ & $\begin{array}{l}\text { The Contractor has already compensated local people for impaction at outside of land } \\
\text { acquisition during protection implementation (e.g. Rice field damage, fish pond } \\
\text { damage, cassava damage, damage to trees, land area damage, etc.). Besides, the } \\
\text { Contractor also combined with local people and local authorities in order to restore } \\
\text { irrigation and traffic system of the region. } \\
\text { The Contractor are applying some measures in order to prevent erosion and landslide } \\
\text { during rainy days at embankment and cutting slope. } \\
\text { There are some new affected areas related to irrigation system, Rice field damage, fish } \\
\text { pond damage, house crack due to the Contractor's construction activities, land area } \\
\text { damage, traffic condition, this moment, the Contractor is combining with local people } \\
\text { and local authorities in order to solve these problems. }\end{array}$ \\
\hline Km136 - Km150 & $\begin{array}{l}\text { Hoang Thang Commune, Xuan Ai } \\
\text { Commune, Yen Hop Commune, An Thinh } \\
\text { Commune, Van Yen District, Yen Bai } \\
\text { Province }\end{array}$ & $\begin{array}{l}\text { The Contractor has already compensated local people for impaction at outside of land } \\
\text { acquisition during protection implementation (e.g. Rice field damage, fish pond } \\
\text { damage, cassava damage, damage to trees, land area damage, etc.). Besides, the } \\
\text { Contractor also combined with local people and local authorities in order to restore } \\
\text { irrigation and traffic system of the region. }\end{array}$ \\
\hline
\end{tabular}

$12^{\text {th }}$ floor, Ocean Park Building, Dao Duy Anh Street, Dong Da Distric

VinhPhuc office: Huu Thu Hamlet, Kim Long Ward, Tam Duong Distric, VinhPhuc Province 


\section{getinso}

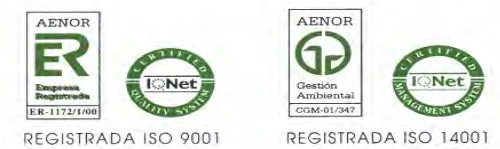

Loan 2391/2392 - VIE: GMS Kunming - Hai Phong Transport Corridor Noi Bai - Lao Cai Highway Project

\begin{tabular}{|c|c|c|}
\hline Location & Commune/District/Province & Status \\
\hline & & $\begin{array}{l}\text { There are some new affected areas related to irrigation system, Rice field damage, } \\
\text { land area damage, traffic condition, this moment, the Contractor is combining with local } \\
\text { people and local authorities in order to solve these problems. }\end{array}$ \\
\hline
\end{tabular}

PACKAGE A6

\begin{tabular}{|c|c|c|}
\hline Location & Commune/District/Province & Status \\
\hline Km150 - Km153 & $\begin{array}{c}\text { An Thinh Commune, Van Yen District, Yen } \\
\text { Bai Province }\end{array}$ & $\begin{array}{l}\text { The Contractor has already compensated local people ( } 29 \text { households) for impaction } \\
\text { at outside of land acquisition during protection implementation (e.g. Rice field } \\
\text { damage, fish pond damage, house crack due to blasting work, cassava damage, } \\
\text { damage to trees, borrowed the access road, land area damage, etc.). Besides, the } \\
\text { Contractor also combined with local people and local authorities in order to restore } \\
\text { irrigation and traffic system of the region. } \\
\text { At Km152+100L. Effected lands couldn't recover, land acquisition board of Van Yen } \\
\text { district has checked on site for additional land acquisition or changing purpose. Now, } \\
\text { the Contractor is waiting the decided from Yen Bai province people's committee. }\end{array}$ \\
\hline Km153 - Km160 & $\begin{array}{c}\text { Tan Hop Commune, Van Yen District, Yen } \\
\text { Bai Province }\end{array}$ & $\begin{array}{l}\text { The Contractor has already compensated local people ( } 99 \text { households) for impaction } \\
\text { at outside of land acquisition during protection implementation (e.g. Rice field } \\
\text { damage, fish pond damage, house crack due to blasting work, cassava damage, } \\
\text { damage to trees, borrowed the access road, land area damage, etc.). } \\
\text { There are some new affected areas related to irrigation system, traffic condition, this } \\
\text { moment, the Contractor is combining with local people and local authorities in order to } \\
\text { solve these problems. } \\
\text { The Contractor are applying some measures in order to prevent erosion and landslide } \\
\text { during rainy days at embankment and cutting slope. } \\
\text { At } \mathrm{Km} 153+300 \mathrm{R} \text {, the Contractor has already compensated and recovered for local }\end{array}$ \\
\hline
\end{tabular}

$12^{\text {th }}$ floor, Ocean Park Building, Dao Duy Anh Street, Dong Da Distric

VinhPhuc office:

Huu Thu Hamlet, Kim Long Ward, Tam Duong Distric, VinhPhuc Province 


\section{getinso}

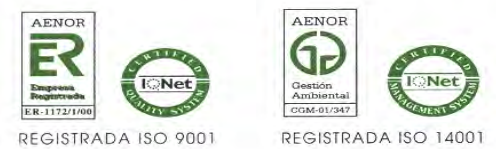

Loan 2391/2392 - VIE: GMS Kunming - Hai Phong Transport Corridor Noi Bai - Lao Cai Highway Project

\begin{tabular}{|c|c|c|}
\hline Location & Commune/District/Province & Status \\
\hline & & $\begin{array}{l}\text { people, local government agreed with result, but the local people has still disagreed } \\
\text { and requested more and more. } \\
\mathrm{Km} 153+700, \mathrm{Km} 156+700, \mathrm{Km} 158+060, \mathrm{Km} 158+600, \mathrm{Km} 158+880 \text {. Effected lands } \\
\text { couldn't recover, land acquisition board of Van Yen district has checked on site for } \\
\text { additional land acquisition or changing purpose. Now, the Contractor is waiting the } \\
\text { decided from Yen Bai province people's committee. }\end{array}$ \\
\hline Km160 - Km168 & $\begin{array}{c}\text { Dong An Commune, Van Yen District, Yen } \\
\text { Bai Province }\end{array}$ & $\begin{array}{l}\text { The Contractor has already compensated local people ( } 132 \text { households) for impaction } \\
\text { at outside of land acquisition during protection implementation (e.g. Rice field } \\
\text { damage, fish pond damage, house crack due to blasting work, cassava damage, } \\
\text { damage to trees, borrowed the access road, land area damage, etc.).. The Contractor } \\
\text { are applying some measures in order to prevent erosion and landslide during rainy } \\
\text { days at embankment and cutting slope. } \\
\text { Besides, At Km179 the Contractor also compensated } 145.000 .000 \mathrm{VND} \text { for remove } 45 \\
\text { tombs which were impacted by the Contractor's construction activities to Ngoc Chau } \\
\text { cemetery. } \\
\text { At Km } 161+900, \mathrm{Km} 162+200, \mathrm{Km} 164+130, \mathrm{Km} 165+960, \mathrm{Km} 166+270, \mathrm{Km} 166+470 \text {, } \\
\mathrm{Km} 166+640, \mathrm{Km} 166+960, \mathrm{Km} 168+430, \mathrm{Km} 168+800 \text {. Effected lands couldn't recover, } \\
\text { land acquisition board of Van Yen district has checked on site for additional land } \\
\text { acquisition or changing purpose. Now, the Contractor is waiting the decided from Yen } \\
\text { Bai province people's committee. } \\
\text { At Km167+300 - Km } 168+600 \text {, the Contractor is combining with local people } \\
\text { authorities in order to compensate to local people. }\end{array}$ \\
\hline Km168 - Km180 & $\begin{array}{c}\text { Chau Que Ha Commune, Van Yen District, } \\
\text { Yen Bai Province }\end{array}$ & $\begin{array}{l}\text { The Contractor has already compensated local people (168 households) for impaction } \\
\text { at outside of land acquisition during protection implementation (e.g. Rice field } \\
\text { damage, fish pond damage, house crack due to blasting work, cassava damage, } \\
\text { damage to trees, borrowed the access road, land area damage, etc.). } \\
\text { There are some new affected areas related to irrigation system, traffic condition, this } \\
\text { moment, the Contractor is combining with local people and local authorities in order to } \\
\text { solve these problems. }\end{array}$ \\
\hline
\end{tabular}

$12^{\text {th }}$ floor, Ocean Park Building, Dao Duy Anh Street, Dong Da Distric

VinhPhuc office:

Huu Thu Hamlet, Kim Long Ward, Tam Duong Distric, VinhPhuc Province 


\section{getinso}

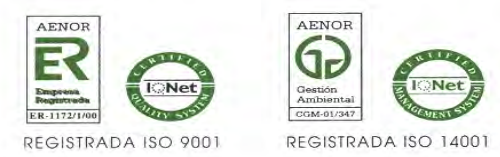

Loan 2391/2392 - VIE: GMS Kunming - Hai Phong Transport Corridor Noi Bai - Lao Cai Highway Project

\begin{tabular}{|c|c|c|}
\hline Location & Commune/District/Province & Status \\
\hline & & $\begin{array}{l}\text { At } \mathrm{Km} 168+920, \mathrm{Km} 170+140, \mathrm{Km} 172+100, \mathrm{Km} 173+260, \mathrm{Km} 176+020, \mathrm{Km} 177+400 \text {, } \\
\mathrm{Km} 179+390, \mathrm{Km} 180+100, \mathrm{Km} 180+920, \mathrm{Km} 168+700 \text {. Effected lands couldn't recover, } \\
\text { land acquisition board of Van Yen district has checked on site for additional land } \\
\text { acquisition or changing purpose. Now, the Contractor is waiting the decided from Yen } \\
\text { Bai province people's committee. }\end{array}$ \\
\hline $\mathrm{Km} 180-\mathrm{Km} 190$ & $\begin{array}{c}\text { Chau Que Thuong Commune, Van Yen } \\
\text { District, Yen Bai Province }\end{array}$ & $\begin{array}{l}\text { The Contractor has already compensated local people (104 households) for impaction } \\
\text { at outside of land acquisition during protection implementation (e.g. Rice field } \\
\text { damage, fish pond damage, house crack due to blasting work, cassava damage, } \\
\text { damage to trees, borrowed the access road, land area damage, etc.). } \\
\text { The Contractor are applying some measures in order to prevent erosion and landslide } \\
\text { during rainy days at embankment and cutting slope. } \\
\text { At } \mathrm{Km} 182+520, \mathrm{Km} 182+680, \mathrm{Km} 183+100, \mathrm{Km} 183+460, \mathrm{Km} 183+885, \mathrm{Km} 184+209 \text {, } \\
\mathrm{Km} 184+840, \mathrm{Km} 185+500, \mathrm{Km} 187+843, \mathrm{Km} 189+075 \text {. Effected lands couldn't recover, } \\
\text { land acquisition board of Van Yen district has checked on site for additional land } \\
\text { acquisition or changing purpose. Now, the Contractor is waiting the decided from Yen } \\
\text { Bai province people's committee. }\end{array}$ \\
\hline
\end{tabular}


Loan 2391/2392 - VIE: GMS Kunming - Hai Phong Transport Corridor

Noi Bai - Lao Cai Highway Project

\section{PROBLEMS CAUSED BY CONSTRUCTION ACTIVITIES OF NBLC HIGHWAY PROJECT IN TIEN KIEN COMMUNE, LAM THAO DISTRICT}

Based on Letter ref. 160/BXD\&GPMB-HC dated 3/9/2013 of Phu Tho Transportation Department about solving problems caused by construction activities of NBLC Project in Tien Kien Commune, Lam Thao District

Based on Working Minutes on 4/9/2013 between Tien Kien Commune People's Committee, Lam Thao District Compensation Council, Posco E\&C and Long VUong Subcontractor;

Based on letters of local residents whose houses were affected by NBLC project in Tien Kien Commune.

Tien Kien Commune People's Committee makes report on implementation status of solving problems caused by construction activities of NBLC Project in Tien Kien Commune, Lam Thao District with the following content:

\section{Area of sliding, flooding of local residents:}

Total area of sliding and flooding is $59,646.4 \mathrm{~m} 2$, in which:

+ Flooding: 30,129.5m2

+ Sliding: 29,516.9m2

On 8 and 9/9/2013 Tien Kien Commune People's Committee cooperated with Lam Thao District Compensation Council to invite construction units to directly check the actual conditions to solve according to letters of local residents.

1. Long Vuong JSC agreed to compensate in October 2013 for 86 households in Hamlet 9, 10, 14, 15 with total area of $40,034.5 \mathrm{~m} 2$, in which:

+ Flooding: 23,124m2

+ Sliding: $16,910.5 \mathrm{~m} 2$

Cost Estimation publicized: 493 million VND

On 25/11/2013, Long Vuong JSC already paid to the households in attached list, however, due to the fact that they agree to compensate 2 crops, only 65 households agreed to receive the compensation, the others do not agree and request to pay according to the publicized cost estimation.

2. Areas agreed by Long Vuong for audit on 8 and 9th September 2013 of 38 households in areas No. 6, 8, 9, 10, 14, 15. With total area $9.710 \mathrm{m2}$. In which: 
+ Flooding: $0 \mathrm{~m} 2$.

+ Sliding: 9,710m2.

(Additional cost estimation dated $31 / 3$ submitted by Lam Thao District People's committee)

- $\quad$ Tien Kien commune people's committee requested Long Vuong to coordinate with Board of Compensation and Assistance and Resettlement of Lam Thao district to agree on the compensation and assistance solutions to the affected people.

3. Flooded and sliding area of $\mathbf{1 6}$ households within Dong De area, hamlet No. 16 (section under the railway flyover) due to construction of railway flyover leading to slides, floods affecting the production activity of people in hamlet No. 16 with total area of $8,008.9 \mathrm{~m} 2$.

+ Flooding: $\quad 7,005.5 \mathrm{~m} 2$

+ Sliding: $\quad 1,003.4 \mathrm{~m} 2$

(List of affected households Dong De area)

- $\quad$ Flooded and sliding area above belongs to construction area of HeungWoo Vina, during bridge construction leading to slide, flood. Commune People's Committee have contacted with the construction unit many times, however, until now, this unit still not coordinate in solving the problems.

4. Actual area affected of households in hamlet 8 (Dong Cham), hamlet 15 (Hoc Mua Ong) há total area of $1,893 \mathrm{~m} 2$.

+ Sliding: 1,893m2

+ Flooding: 0m2.

(List of affected households refusing to register for checking).

- $\quad$ Long Vuong is the unit directly executing the construction causing affect but have not coordinate in solving.

II. TRAFFIC ROADS WITHIN THE AREA AFFECTED BY CONSTRUCTION

1. 325B - Hy Cuong - 32C (section passing Tien Kien Commune):

- Status: Total length of $1.6 \mathrm{~km}$, asphalt concrete pavement width of $6 \mathrm{~m}$, embankment $8 \mathrm{~m}$. As many heavy vehicles travel on the $325 \mathrm{~B}$ during jams, it 
Loan 2391/2392 - VIE: GMS Kunming - Hai Phong Transport Corridor Noi Bai - Lao Cai Highway Project

caused cracks and settlement to the pavements and slides at some sections on the roads with length of $325 \mathrm{~m}$. Degradation proportion of $20 \%$.

- Recommendations: Department of Transport (DoT) and the Construction unit are to assign staffs to check the actual conditions, giving solutions to assist Tien Kien People's Committee in renovating the road system.

2. Frontage road from Mac Sen gate - Thao Binh Hamlet 9:

- Status: Total length $120 \mathrm{~m}$. A slide of $5 \mathrm{~m}$ in Embankment has occurred due to construction of the highway, origin from the canal near Mr. Thinh's house to Thao Binh's household and the drainage system from the service area of the highway go off onto the embankment on frequent basis. When it rains, it makes very difficult for the local people during traveling.

- Recommendation: support to raise the embankment elevation. Embankment width of $10 \mathrm{~m}$, pavement: $7 \mathrm{~m}$, shoulders: $1.5 \mathrm{~m} \times 2$ to ensure travel of local people.

3. Flyover passing hamlet 14 near Mr. Binh household

- Status: due to construction, the local road crossing the highway is diverted from the former one with a section of $45 \mathrm{~m}$, pavement of $5 \mathrm{~m}$. at present, there are 2 turnings not assuring view sight, make it very dangerous during traveling.

- Recommendations: to level and re-divert the embankment to ensure travel of the local people.

4. Underpass box culvert in hamlet 14 near Mr. Gian household

- Status: due to construction, soil slide into the underpass box culvert, make it impossible for running through.

- Recommendations: to level and treat the embankment and BC slabs to ensure travel of local people.

\section{UBC crossing hamlet 9:}

- Status: Both sides of UBC slabs are $30 \mathrm{~cm}$ lower than the living road, so whenever it rains, water can't be drained out.

- Recommendations: construction unit is to take countermeasures.

III. AFFECTED IRRIGATION SYSTEM FOR PRODUCTION AND DAILY ACTIVITIES OF LOCAL PEOPLE

Hanoi office:

VinhPhuc office:

Madrid head office: $12^{\text {th }}$ floor, Ocean Park Building, Dao Duy Anh Street, Dong Da Distric

Huu Thu Hamlet, Kim Long Ward, Tam Duong Distric, VinhPhuc Province

Calle Ramón de Aguinaga 8, 28028 Madrid, Spain 
Loan 2391/2392 - VIE: GMS Kunming - Hai Phong Transport Corridor Noi Bai - Lao Cai Highway Project

1. Canal from bordering point with service area of the highway to Dong Cham:

- Status: Canal bed $1.2 \mathrm{~m}$ wide, $1 \mathrm{~m}$ deep; $200 \mathrm{~m}$ long has been slide totally in the bed.

- Recommendations: Agricultural cooperative and land unit have assigned the Hamlet 9 to dredge the canal but the flow has not been smoothly through until now. It is requested that the construction unit will support with manpower to dredge the canal bed to ensure drainage.

2. Canal from bordering point with service area to Cau Hoai temple:

- Status: Canal bed $1.2 \mathrm{~m}$ wide, $1 \mathrm{~m}$ deep, $800 \mathrm{~m}$ long has been slide totally in the bed.

- $\quad$ Residential area No. 8.9 has called the people who have the fields in lateral sides to dredge the canal themselves, however, until now the flow has not been through. It is requested the construction unit to support with manpower to dredge the canal bed to ensure drainage.

3. Section from foot of UBC near Mr. Thinh household Hamlet 9 to gate of Sen Mac Household:

- Status: Canal bed $1 \mathrm{~m}$ wide, $0.5 \mathrm{~m}$ deep, one section of $170 \mathrm{~m}$ long has been slide totally in the bed.

- It is requested to support dredging to recover the canal bed with original flow.

4. Section from Sen Mac household to Thao Binh household Hamlet 9:

- Status: Canal bed $1.5 \mathrm{~m}$ wide, $1 \mathrm{~m}$ deep, $100 \mathrm{~m}$ long has been slide totally in the bed.

- It is requested to support dredging to recover the canal bed with original flow.

5. Section from Anh Thinh household - to Thao Binh Hamlet 9:

- Status: Canal bed $1 \mathrm{~m}$ wide, $0.7 \mathrm{~m}$ deep, $180 \mathrm{~m}$ long has been slide totally in the bed.

- It is requested to support dredging to run through the flow.

6. Canal passing field of Tuyen Hien household Hamlet 9:

Hanoi office:

VinhPhuc office:

Madrid head office: $12^{\text {th }}$ floor, Ocean Park Building, Dao Duy Anh Street, Dong Da Distric

Huu Thu Hamlet, Kim Long Ward, Tam Duong Distric, VinhPhuc Province

Calle Ramón de Aguinaga 8, 28028 Madrid, Spain 
Loan 2391/2392 - VIE: GMS Kunming - Hai Phong Transport Corridor Noi Bai - Lao Cai Highway Project

- Status: Highway construction unit has constructed the drainage ditch from service area of the highway down to affected rice field, causing slide without any countermeasures.

- Request: Construction unit is to coordinate with locality to get through the canal flow from rice field of Tuyen Hien household to gate of Mr. Mien house ensuring no slide soil into field of the local people. This canal section is $185 \mathrm{~m}$ long, $1.5 \mathrm{~m}$ wide bed, $1 \mathrm{~m}$ deep.

7. Drainage culvert passing highway near Mr. Canh house Hamlet 9:

- Status: Construction unit has placed the drainage culvert crossing the road with dimension $\Phi 150 \mathrm{~cm}$, higher than the house floor level without constructing wall to prevent water running along the flow. At present, water through the culvert run directly to the house area causing flood and mud slide into the house, kitchen, water well affecting daily life of the household.

- Request: Construction unit is to build the culvert wall prevent water from the culvert running through the house, dredge the well to ensure their daily life.

8. Section from Dong Banh from rice field of Tue Dung household hamlet 6 to border with Nghia Quy household hamlet 13

- Status: canal bed $1.5 \mathrm{~m}$ wide, $1 \mathrm{~m}$ deep, $420 \mathrm{~m}$ long has been slide due to the construction fill up the canal bed make impossible for the flow, causing the flow to divert to middle of the field, push the slide mud and soil into rice fields of local people.

- Request: construction unit to support with manpower, clear the slide mud and soil on site of $420 \mathrm{~m}$ long, $1.5 \mathrm{~m}$ wide and $0.7 \mathrm{~m}$ deep. Also, to dig an additional canal section above the highway from Mrs Canh household to the culvert near Son Dung household hamlet 14 with $265 \mathrm{~m}$ long, $2 \mathrm{~m}$ wide and $1 \mathrm{~m}$ deep.

9. Canal section Dong Banh from border with Son Dung household hamlet 14 to rice field of Mrs Tiep, hamlet 13.

- $\quad$ Status: canal bed $2 \mathrm{~m}$ wide, $0.7 \mathrm{~m}$ high, $300 \mathrm{~m}$ long has been slide partially, affecting production activity of local people.

- Request: Agricultural cooperative and power agency of Tien Kien commune have release the flow ensuring drainage for production activities, it is requested to support with expenditures for dredging.

\section{Section from Thao Hieu household - Duc Lo household hamlet 14}

Hanoi office:

VinhPhuc office:

Madrid head office: $12^{\text {th }}$ floor, Ocean Park Building, Dao Duy Anh Street, Dong Da Distric

Huu Thu Hamlet, Kim Long Ward, Tam Duong Distric, VinhPhuc Province

Calle Ramón de Aguinaga 8, 28028 Madrid, Spain 
Loan 2391/2392 - VIE: GMS Kunming - Hai Phong Transport Corridor Noi Bai - Lao Cai Highway Project

- Status: canal bed is $2 \mathrm{~m}$ wide, $1 \mathrm{~m}$ deep, $140 \mathrm{~m}$ long has been slide partially, affecting production activity of households in Dong Lao area.

- Request: to install a new canal lead the flow along the new rice field ensuring drainage at the upstream, if keeping intact the design, drainage will be endangered.

11. Canal section from household of Mrs Tám - Hamlet 15 - Gate of Mrs Chuc house

- Status: canal bed is $3 \mathrm{~m}$ wide, $2 \mathrm{~m}$ deep, $200 \mathrm{~m}$ long. At present, culvert slabs of the highway and the canal bed has been slide with average thickness of $1 \mathrm{~m}$, this canal system is higher than the culvert inlet of the highway constructed, so the water cannot run through.

- Request: to support with manpower to dredge the culvert and the canal of $200 \mathrm{~m}$ long, $3 \mathrm{~m}$ wide and $1 \mathrm{~m}$ long.

12. Canal section from gate of Tuyen Khanh house to Binh Huyen Pond hamlet $\mathbf{1 5}$

- Status: Canal of $190 \mathrm{~m}$ long, $1 \mathrm{~m}$ wide, $0.7 \mathrm{~m}$ deep has been slide totally.

- Request: support in embankment, release the flow to ensure drainage.

13. Section from Ms. Hoa's house-Mr. Ngoc's House Hamlet 16:

- Situation: Due to the construction unit can not maintain the flow, the soil from the hill next to Ms. Hoa's house discharged directly to Ms. Hong and Mr Hieu's pond without any solution.

- Proposal: Create the waterflow along the throughway $185 \mathrm{~m}$ long. $3 \mathrm{~m}$ wide, $1.5 \mathrm{~m}$ deep

14. Section from the flyover next to the railway Song Coi Field:

- Situation: Canal does not ensure the drainage of the existing system but discharge directly to the cropfields of households Hamlet 16.

- Proposal: Create water flow along the throughway from flyover to the cropfield in front of Mr. Hung's house, $200 \mathrm{~m}$ long, $1 \mathrm{~m}$ wide, $0.7 \mathrm{~m}$ deep.

\section{Households complained about house cracking}

In Tien Kien commune, there are 04 households who sent letter of complaint about house cracking caused by construction activities of NBLC Project, such as: Mr. Tuan Ngoc, Ms. Hoa Hamlet 9, Mr. Chau Hamlet 14 and Mr. Tai Hamlet 15. After receiving the letter, CPC

Hanoi office:

VinhPhuc office:

Madrid head office: $12^{\text {th }}$ floor, Ocean Park Building, Dao Duy Anh Street, Dong Da Distric

Huu Thu Hamlet, Kim Long Ward, Tam Duong Distric, VinhPhuc Province

Calle Ramón de Aguinaga 8, 28028 Madrid, Spain 
Loan 2391/2392 - VIE: GMS Kunming - Hai Phong Transport Corridor Noi Bai - Lao Cai Highway Project

cooperated with Lam Thao Resettlement, and compensation committee to check the actual situation, make site minutes and make reports sending to related parties to solve; however, up to now, there is no response from construction unit.

\section{Recommendations}

CPC of Tien Kien Commune make reports requesting related parties to cooperate with the CPC, with Lam Thao Resettlement, and compensation committee to solve completely the damages caused by the construction activities of NBLC Project to avoid letter of complaints and ensure the safety in the commune, create favorable conditions for the residents' lives.

CPC recommends related parties to support financial for CPC to renovate, rebuild the civil structures for the residents' production, including:

+ Build market at Dong Cham to support the works for affected households;

+ Recover the surface of TL325B Tien Kien - Hy Cuong. Build frontage road along both side of NBLC project.

+ Other works related to the sliding and flooding of croplands of households. (request construction unit to recover)

+ Support money to build electricity line J2 at Underpass Box Culvert Hamlet 9

$12^{\text {th }}$ floor, Ocean Park Building, Dao Duy Anh Street, Dong Da Distric Huu Thu Hamlet, Kim Long Ward, Tam Duong Distric, VinhPhuc Province Calle Ramón de Aguinaga 8, 28028 Madrid, Spain 